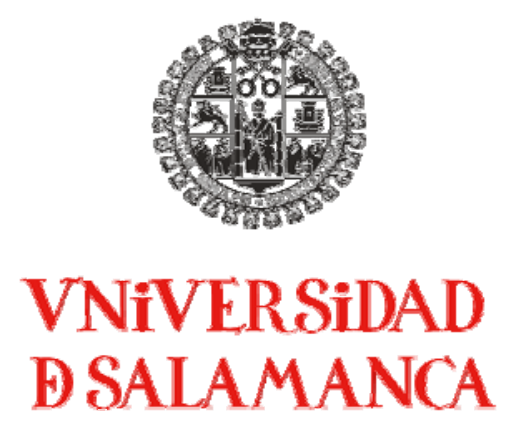

DEPARTAMENTO DE GEOLOGÍA

\title{
Las mineralizaciones magmático-hidrotermales de Sn-W-(Nb-Ta) del distrito de Navasfrías (SO de Salamanca)
}

Tesis Doctoral 



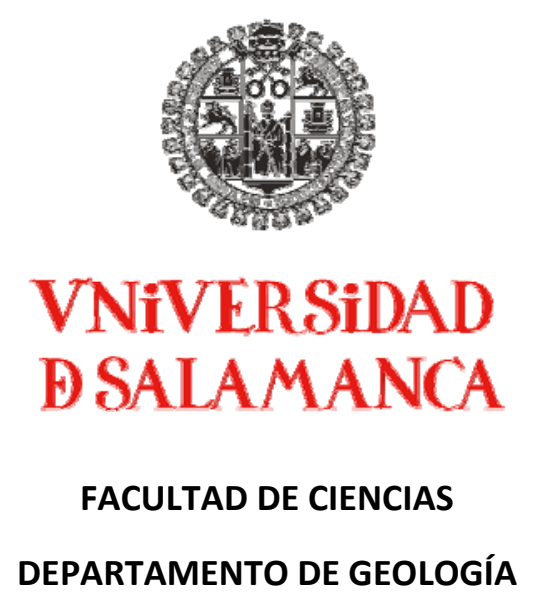

\title{
Las mineralizaciones magmático-hidrotermales de Sn- W-(Nb-Ta) del distrito de Navasfrías (SO de Salamanca)
}

\author{
Teresa Llorens González \\ Memoria presentada para optar al grado de Doctora en Geología. \\ Universidad de Salamanca \\ 2011
}

Tesis doctoral dirigida por la Dra. Ma $\mathbf{a}$ Candelas Moro Benito, Profesora Titular del Departamento de Geología de la Universidad de Salamanca.

$\mathrm{V}^{\circ} \mathrm{B}^{\circ}$ 



\section{AGRADECIMIENTOS}

En este pequeño espacio me gustaría expresar mi más sincero agradecimiento a todas aquellas personas que han contribuido de alguna manera a que este trabajo se haya visto, finalmente, terminado con éxito.

En primer lugar quiero agradecer a mi directora de tesis, Ma Candelas Moro. Su dedicación e interés en este proyecto desde el principio, así como el apoyo incondicional mostrado tanto en los buenos como en los malos momentos, han hecho posible que hoy me sienta orgullosa del trabajo que hemos realizado.

Por supuesto, al alcalde de Navasfrías, D. Celso Ramos, quien siempre facilitó la visita a las minas y la entrada a las galerías. A Luis, cuya ayuda resultó fundamental a la hora de acceder a algunas de ellas. Muchísimas gracias a él y a su mujer por su estupenda hospitalidad. También a Manuel Blanco, por hace más agradable mis estancias en el pueblo y por disfrutar de sus acogedores apartamentos rurales.

Además, quiero agradecer profundamente al profesor Emil Makovicky, del Instituto de Geografía y Geología de la Universidad de Copenhague, y a su mujer Milota por la hospitalidad y el apoyo mostrados durante mi estancia en Dinamarca. Especialmente a Emil, por su supervisión durante mi trabajo allí; su conocimiento de las sulfosales ha permitido una mejor comprensión de estos minerales en el contexto de Navasfrías; por las visitas guiadas al parque natural y por enseñarme a brindar en danés; por permitirme conocer a una de las personas más especiales que han pasado por mi vida, Elisa, sin cuya sincera e incondicional amistad esos dos meses en Dinamarca habrían sido totalmente diferentes y me habría perdido todo lo que ofrece un pequeño pueblo al pie de los Alpes italianos, Marina di Massa. Sin olvidar a Umut, que tanto contribuyó a la mejora de nuestro inglés. A todos ellos, muchísimas gracias.

No podía faltar mi especial agradecimiento a Encarna Roda, o como ella prefiere, Encar. Su ayuda y disposición plena para atender a mis dudas me han permitido adentrarme un poquito en ese complicado mundo de las pegmatitas, enseñándome que los fosfatos son mucho más que un simple apatito.

A Miguel Ángel Fernández, técnico de la microsonda electrónica de Oviedo, por su paciencia y ayuda a la hora de realizar los análisis de mis muestras, por hacer más agradable aún si cabe mi paso por Asturias y por amenizar mis ratos con su música Folk. ¡Eres un artista! A Juan González, del Servicio de Microscopía Electrónica, a Emilio y Marisol, del Servicio de Análisis Químico, a Clemente Recio, del Servicio de Isótopos Estables y a Ángel y Andrés, del Servicio de Preparación de Rocas de la Universidad de Salamanca, por su buena disposición.

No podía faltar mi agradecimiento a Agustina Fernández y Mạ Luisa Cembranos, compañeras durante toda mi trayectoria en el área y una gran ayuda a la hora de resolver dudas y mejorar la presente memoria. Especialmente a Francisco Javier López y Susana Timón, dos grandes apoyos de principio a fin, con los que he pasado buenos y malos momentos y que siempre me han hecho sonreír. 
A Juan Ramón Colmenero, que me ha apoyado desde el principio y ha estado pendiente en todo momento de mi progreso. Igualmente a Gabriel Gutiérrez y Jacinta Talegón, que me han animado constantemente, especialmente durante esta última etapa. A mis compañeros de andadura, Montse, Rubén, Daniel, Eva y Luis Miguel, con los que he compartido impresiones y opiniones $\mathrm{y}$ he pasado buenos momentos.

Una mención especial a mi familia, porque ellos me han sabido apoyar en todo momento, me han levantado cuando caía y me han animado aún más cuando levantaba, interesándose en todo momento por mi bienestar y mi futuro. A mis padres y mi hermano, por entenderme e intentar abrirme siempre el mayor abanico de soluciones posible. A mis tíos/as, por estar ahí para escucharme y para darme un empujón (o una colleja) cuando era necesario. A mis primos y especialmente primas, por interesarse siempre por todo lo que hago, por el paseo, las compras o el refresco de desahogo. Y a Andrea, por supuesto, porque ella es la sal para todas las comidas de la casa.

A mis amigos y amigas, por su apoyo y su confianza incondicional, por esos pinchos en el centro, por la cervecita o el café donde Chuchi, por los paseos en el pueblo, por los primeros pasitos de Emma y por el gabinete psicológico particular.

Y finalmente a mi niño, César, sin el cual esta última etapa de trabajo y de mi vida habrían sido totalmente diferentes. Muchas gracias por la confianza depositada y por los constantes ánimos, por estar ahí y ser tú. Te quiero. 
El presente trabajo ha sido realizado en el Departamento de Geología de la Facultad de Ciencias de la Universidad de Salamanca y financiado por una beca de Formación de Personal Investigador y por los Proyectos de Investigación SA015A06 de la Junta de Castilla y León y 1FD97-0235 de los Fondos Europeos de Desarrollo Regional (FEDER), llevados a cabo por el grupo de investigación de Recursos y Yacimientos Minerales del Área de Cristalografía y Mineralogía bajo la dirección de la Profạ. Mạ Candelas Moro Benito. 



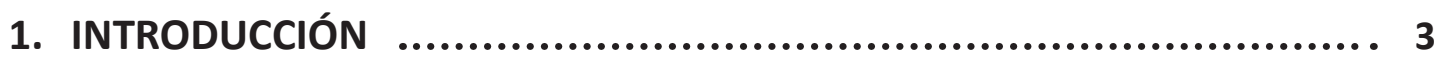

1.1. SITUACIÓN GEOGRÁFICA _...……………………………………………………………... 3

1.2. ANTECEDENTES …………................................................................................................. 4

1.2.1. Antecedentes bibliográficos _......................................................................... 4

1.2.2. Antecedentes mineros _.......................................................................................... 4

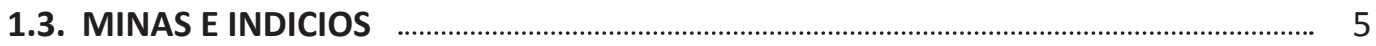

1.3.1. Minas e indicios en el batolito del Jálama ………………………………........... 5

1.3.2. Minas e indicios en el batolito de Cadalso-Casillas de Flores ...................... 7

1.3.3. Minería secundaria ...................................................................................................... 10

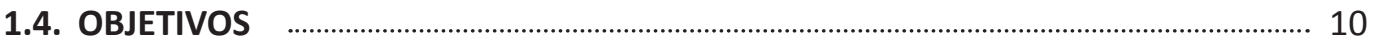

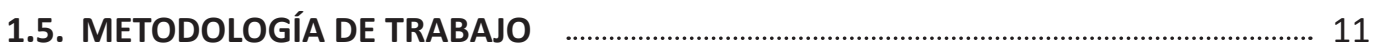

1.5.1. Trabajos de campo ..................................................................................................... 11

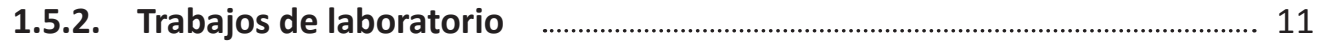

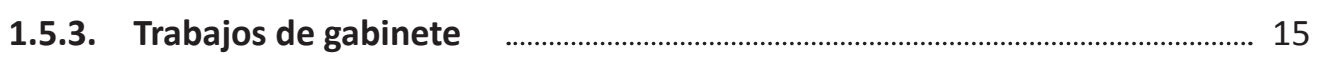

1.6. MINERALIZACIONES DE Sn-W Y METALES RAROS ASOCIADAS A GRANITOS ....... 16

2. ENCUADRE GEOLÓGICO DEL DISTRITO DE NAVASFRÍAS .................. 27

2.1. ROCAS METAMÓRFICAS _.............................................................................................. 27

2.1.1. Unidad Inferior ..................................................................................................... 28

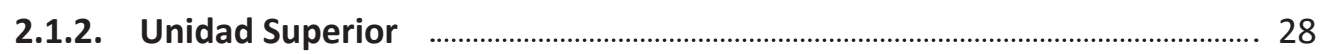

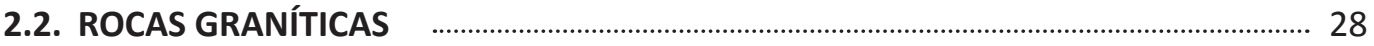

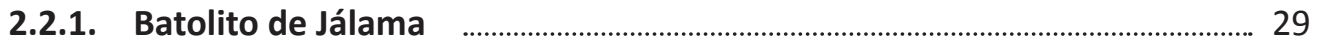

2.2.1.1. La Unidad Externa (UE) _............................................................... 29

2.2.1.2. Monzogranito con sillimanita (MS) ……………………………….... 31

2.2.1.3. Leucogranitos tardíos (LT) _............................................................. 32

2.2.2. Batolito de Cadalso-Casillas de Flores ………............................................. 32

2.2.2.1. Complejo de El Payo ............................................................................. 32

2.2.2.2. Complejo de Peñaparda ......................................................................... 34

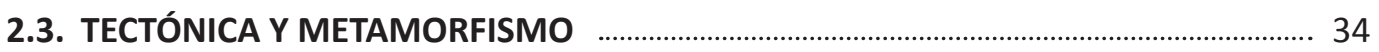

2.3.1. La Orogenia Varisca ...................................................................................... 34

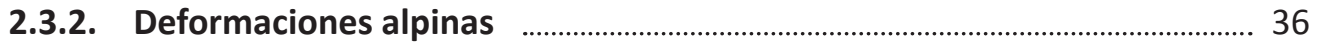




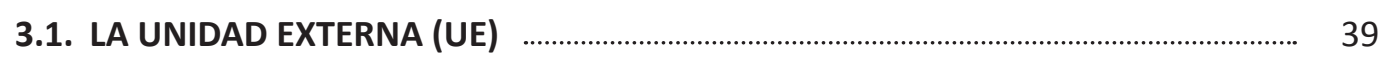

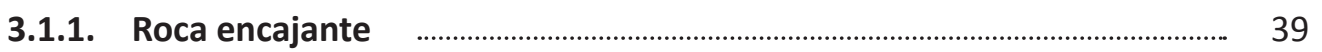

3.1.1.1. Petrografía y química mineral _..................................................... 41

3.1.2. Mineralización _................................................................................................... 55

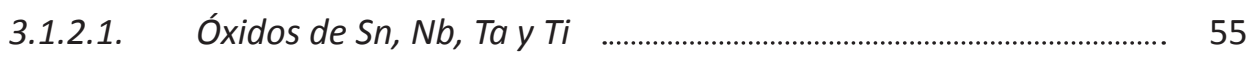

3.2. DIQUES PEGMATÍTICOS INTRA Y PERIBATOLÍTICOS _............................................... 55

3.2.1. Roca encajante .................................................................................................. 56

3.2.1.1. Petrografía y química mineral ............................................................ 62

3.2.2. Mineralización ………………………………………………………………….... 79

3.2.2.1. Casiterita .................................................................................................... 79

3.2.2.2. Minerales del grupo de la columbita .................................................. 80

3.2.2.3. Rutilo y strüverita ............................................................................ 82

3.2.3. Secuencia mineral _................................................................................................. 87

3.3. VENAS DE CUARZO INTRAGRANÍTICAS _............................................................... 89

3.3.1. Caracterización morfológica y estructural .......................................................... 89

3.3.2. Petrografía y química mineral …………….................................................. 94

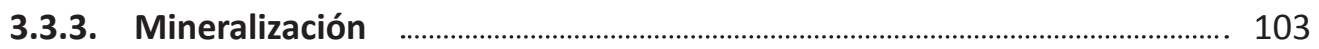

3.3.3.1. Casiterita, wolframita y óxidos de Ti, Nb y Ta ............................... 103

3.3.3.2. Sulfuros y sulfosales ........................................................................ 109

3.3.3.3. Productos de alteración _.................................................................. 128

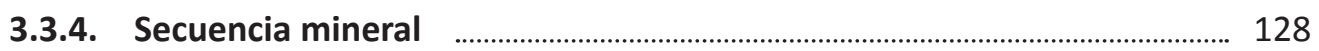

4. MINERALIZACIONES DEL BATOLITO DE CADALSO-CASILLAS DE

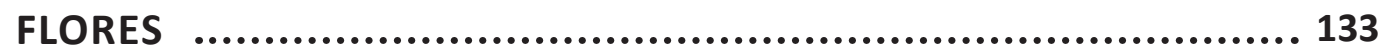

4.1. DIQUES APLÍTICOS Y PEGMATÍTICOS ........................................................................... 133

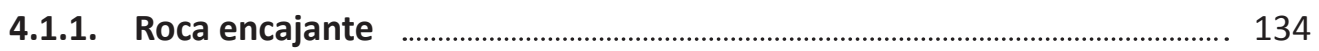

4.1.1.1. Petrografía y química mineral _............................................................ 137

4.1.2. Mineralización ....................................................................................................... 146

4.1.2.1. Minerales del grupo de la columbita y del pirocloro ....................... 146

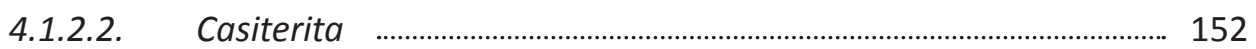

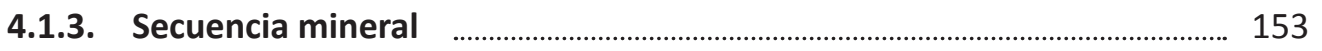

4.2. VENAS DE CUARZO INTRAGRANÍTICAS _....................................................................... 155

4.2.1. Caracterización morfológica y estructural ...................................................... 155

4.2.2. Petrografía y química mineral .................................................................. 158

4.2.3. Mineralización _.................................................................................................... 160

4.2.3.1. Casiterita, wolframita y scheelita ................................................... 160

4.2.3.2. Sulfuros .................................................................................................... 161 
4.2.3.3. Productos de alteración ……................................................................... 165

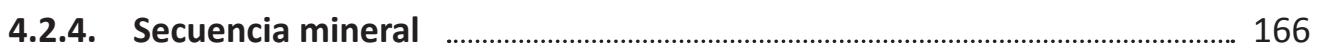

5. INCLUSIONES FLUIDAS Y CARACTERIZACIÓN ISOTÓPICA ............... 169

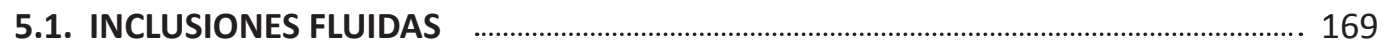

5.1.1. Tipos de inclusiones fluidas …………………................................................. 170

5.1.2. Tipos de fluidos y evolución ............................................................................... 174

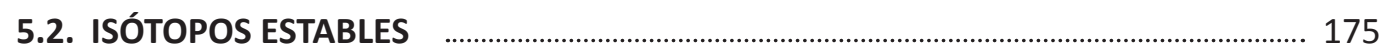

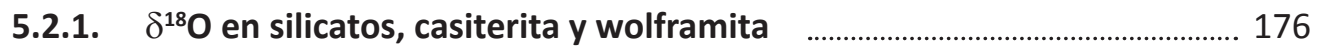

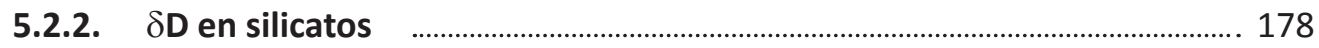

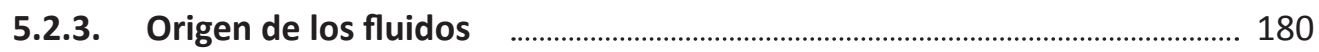

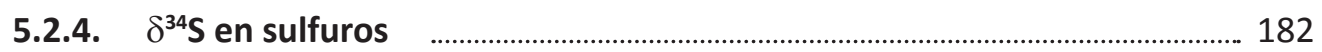

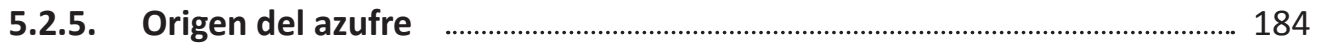

6. CONDICIONES FISICOQUÍMICAS DE FORMACIÓN ......................... 189

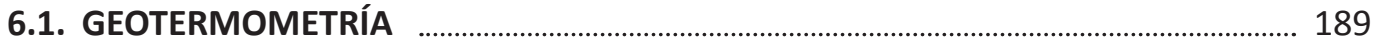

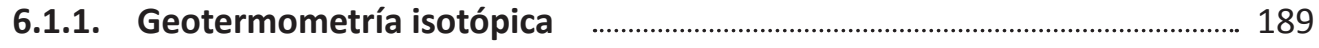

6.1.2. Microtermometría de inclusiones fluidas ………...................................... 190

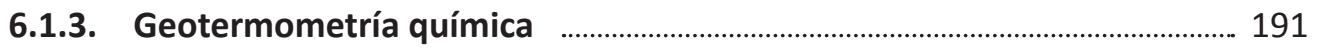

6.1.3.1. Geotermometría de micas ..................................................................... 191

6.1.3.2. Geotermómetro de la arsenopirita ................................................. 193

6.1.3.3. Geotermometría de sulfosales .......................................................... 195

6.1.3.4. Geotermómetro de la clorita ................................................................ 196

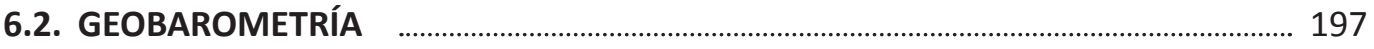

6.2.1. Geobarómetro de la esfalerita ……………………………………………... 198

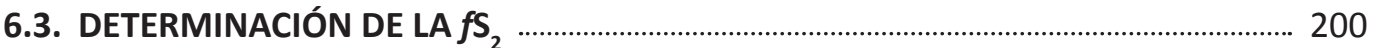

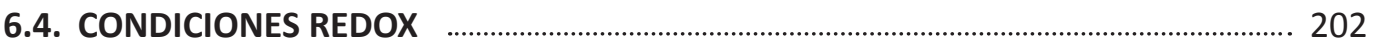

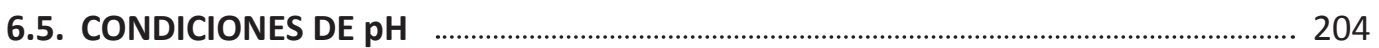

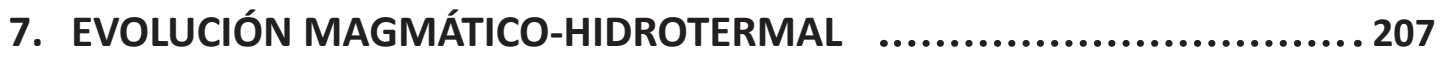

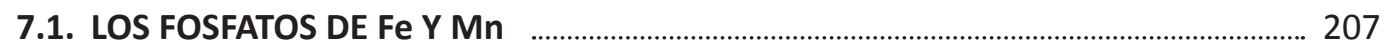

7.1.1. Fraccionamiento del Fe y el Mn ................................................................ 207

7.1.2. Texturas de reemplazamiento ......................................................................... 209

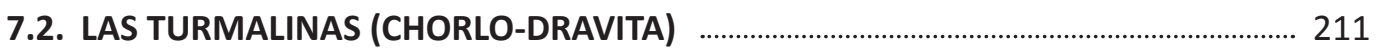

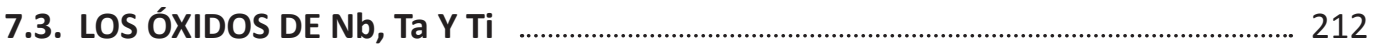


7.3.1. Óxidos de $\mathrm{Nb}$ y $\mathrm{Ta}$ en los diques pegmatíticos

7.3.2. Óxidos de $\mathrm{Ti}$-(Nb-Ta) en las venas de cuarzo

7.4. LAS SULFOSALES DE Bi-Pb-Ag

8. MODELO METALOGENÉTICO Y CONCLUSIONES

9. LINEAS ABIERTAS DE INVESTIGACIÓN

10. BIBLIOGRAFÍA

\section{ANEXOS}

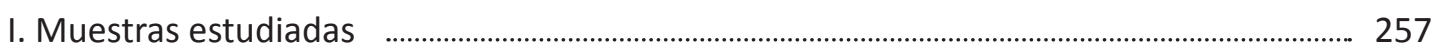

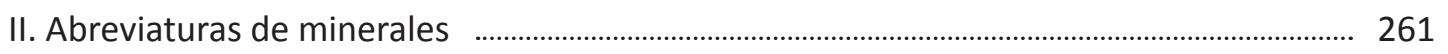

III. Análisis de microsonda electrónica ................................................................................................ 263

IV. Difractogramas de Rayos X ................................................................................................... 345

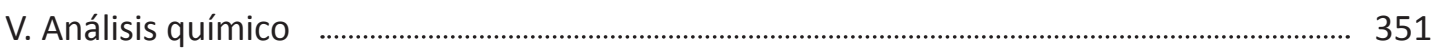

VI. Microtermometría de inclusiones fluidas ……….................................................................... 353 




$$
\begin{array}{r}
\text { capítulo1 } \\
\text { Introducción }
\end{array}
$$





\section{CAPÍTULO 1. INTRODUCCIÓN}

El distrito de Navasfrías es un buen ejemplo de mineralización de Sn-W-(Nb-Ta) asociada a una cúpula granítica peralumínica altamente fraccionada y con elevados contenidos en fósforo. En él están representados, en mayor o menor medida, todos los estadios de mineralización desde las diseminaciones de casiterita en los granitos y aplitas apicales hasta la mineralización de Sn y/o W presente en los diques pegmatíticos y en las venas de cuarzo asociadas.

\subsection{SITUACIÓN GEOGRÁFICA}

El distrito de Navasfrías se sitúa en el sector más suroccidental de la provincia de Salamanca, encuadrado en las hojas topográficas de Fuenteguinaldo 550 (10-22), Valverde del Fresno 572 (9-23) y Gata 573 (10-23) del Mapa Topográfico Nacional a escala 1:50.000 (Fig. 1.1). En este sector afloran el batolito de Cadalso-Casillas de Flores y la parte norte del batolito de Jálama, este último con una extensión aproximada de $220 \mathrm{~km}^{2}$ que ocupa mayoritariamente el norte de la provincia de Cáceres. Geográficamente, esta zona forma parte del sector más occidental de la Sierra de Gata en el Sistema Central Español y presenta importantes desniveles topográficos, siendo el Pico Jálama la parte más elevada del distrito con $1.492 \mathrm{~m}$ de altura. En su entorno nace el río Águeda, que recorre de sur a norte toda la zona occidental de la provincia de Salamanca y que, junto con sus afluentes, entre los que destaca el regato Rubiós, el arroyo Ladrón, el río Perosín o el río Frío, aloja los yacimientos más importantes de oro aluvial del distrito de Navasfrías.

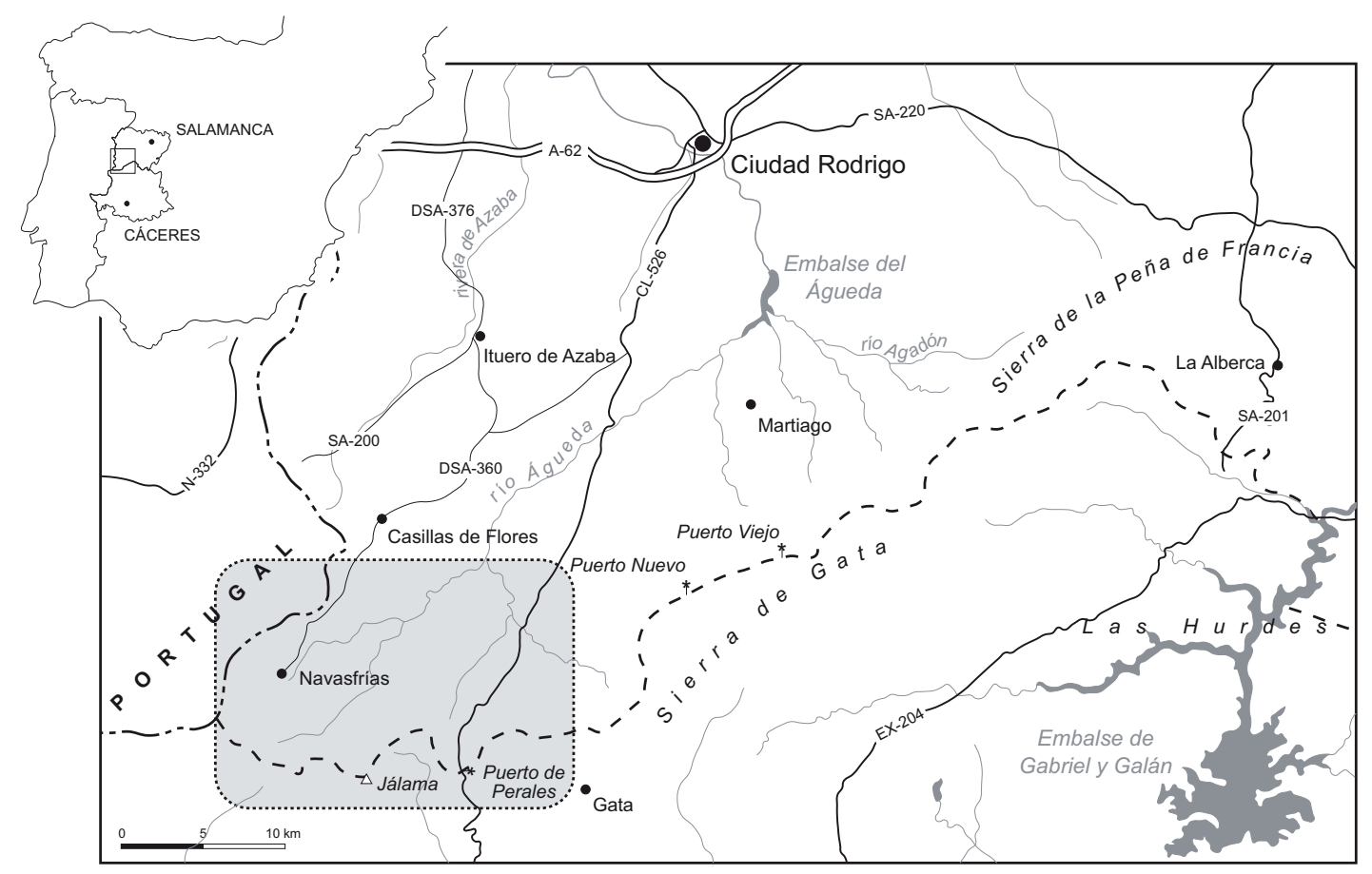

Fig. 1.1. Situación geográfica del distrito de Navasfrías. 


\subsection{ANTECEDENTES}

\subsubsection{Antecedentes bibliográficos}

Los primeros trabajos acerca de los batolitos de Jálama y de Cadalso-Casillas de Flores corresponden a García de Figuerola $(1954,1972)$, quien recoge aspectos sobre las relaciones de campo y el contacto con las rocas metamórficas encajantes en las proximidades de la localidad de Peñaparda, mientras que Saavedra y Pellitero $(1973,1975)$ y Saavedra et al. (1977) aportan datos sobre la petrografía, la geoquímica y aspectos metalogenéticos de los granitoides que componen el batolito de Jálama. Los trabajos más recientes son la tesis doctoral de Ramírez (1996), donde se analiza en profundidad la petrografía y la geoquímica del batolito de Jálama, estableciendo las relaciones genéticas y espaciales entre las diferentes facies graníticas, y la tesis doctoral de Hassan (1996), en la que se analiza en detalle la petrografía y geoquímica de las facies graníticas que componen el batolito de Cadalso-Casillas de Flores, además de las mineralizaciones de $U$ y Th asociadas al mismo. Posteriormente SIEMCALSA (1997) elaboró el Mapa Geológico y Minero de Castilla y León a escala 1:400.000 en el que se recoge la minería del distrito de Navasfrías dividida en dos sectores, la zona del batolito de Jálama y el sector de Villasrubias, asociado al batolito de Cadalso-Casillas de Flores. Estas mineralizaciones fueron de nuevo estudiadas por Moro (2000) a través de un proyecto para el estudio del oro hidrotermal y los metales asociados en Castilla y León, y por Fernández-Leyva (2007), cuya tesis doctoral analiza los potenciales indicadores geoquímicos de las mineralizaciones.

\subsubsection{Antecedentes mineros}

Las citas más antiguas de las que se tienen constancia en el distrito de Navasfrías corresponden con los trabajos de Gil y Maestre (1880), Mallada (1896) y García Puelles (1918), en los que se habla de yacimientos de Sn y W en la comarca y de los posibles criterios de exploración y donde se encuentran las primeras alusiones a la presencia de oro aluvial en el río Águeda.

Durante los años de mayor auge de la actividad minera (1930-1950) no existe más información que la que se recoge en los planes de labores de la Dirección Provincial de Minas. Los elevados precios del Sn y del W impulsaron la actividad minera en la zona, aunque de una manera artesanal, centrándose en el lavado de los placeres y aluviones de los ríos y en el vaciado superficial de los filones más ricos en mineral. La caída de precios que siguió a la etapa de la posguerra obligó al cierre de la mayor parte de las explotaciones, permaneciendo abiertas solamente las más importantes, como es el caso de la mina Salmantina hasta los años 60. Esta y otras minas del área de Navasfrías fueron reabiertas de nuevo en los años 70 tras los estudios de prospección llevados a cabo por el IGME-CGS (1976) dentro del Plan Nacional de Abastecimiento de Materias Primas no Energéticas, y por ENADIMSA (1982) sobre la Concesión Carlos, y debido a un aumento de los precios del Sn, pero su actividad cesó definitivamente en 1983.

Con posterioridad, la Junta de Castilla y León (JCyL, 1985; 1986) estimó las reservas minerales de Sn en este y otros sectores de la Comunidad y se evaluó la posible existencia de yacimientos ricos en Li (JCYL-INTECSA, 1986). Y, por último, JCyL-TAGSA (1987) llevó a cabo una revisión 
de todos los indicios de Sn y W del distrito de Navasfrías, tanto primarios como secundarios, incluyendo el oro aluvial, aunque una vez más se desestimó, por falta de reservas, la posibilidad de una nueva explotación en la región.

Adicionalmente la investigación y exploración minera de $U$ se centró exclusivamente en el sector NW del batolito de Cadalso-Casillas de Flores. Este tipo de mineralizaciones fueron estudiadas por la Junta de la Energía Nuclear (JEN) mediante calicatas, pozos de reconocimiento y varios sondeos.

\subsection{MINAS E INDICIOS}

Las minas e indicios mineros más importantes del distrito de Navasfrías corresponden a las explotaciones de las mineralizaciones primarias de Sn y Sn-W, que se encuentran principalmente en las venas de cuarzo que encajan en las facies graníticas más evolucionadas de los batolitos de Jálama y de Cadalso-Casillas de Flores y en los diques pegmatíticos encajados en la aureola de contacto. Sin embargo, buena parte de los indicios que se encuentran en la zona corresponden también a las exploraciones del Sn y Au detríticos de los materiales aluvionares y coluvionares de los ríos que drenan las rocas del distrito (río Águeda, regato Rubiós, arroyo Ladrón, río Perosín o río Frío). Actualmente tanto la minería primaria como la secundaria están inactivas y prácticamente agotadas en este distrito. No obstante, gracias a los planes de restauración llevados a cabo en algunas de las antiguas explotaciones por los ayuntamientos de los pueblos mineros, la zona está habilitada para el turismo minero y las actividades lúdicas.

Por otra parte, y considerando el gran número de minas e indicios del distrito, resulta conveniente, para su descripción, agruparlos según la roca encajante en la que se encuentran. Las labores mineras en la mayoría de ellas consisten en galerías, pozos y zanjas que siguen la dirección de los diques pegmatíticos y las venas de cuarzo mineralizadas, y cortas de tamaño variable en las facies graníticas mineralizadas. Por su parte, la explotación en los materiales aluvionares de los ríos se llevó a cabo mediante la técnica del bateo. Para la denominación de cada una de las minas e indicios se ha seguido el último trabajo de prospección minera de JCYL-TAGSA (1987).

\subsubsection{Minas e indicios en el batolito de Jálama}

Las minas e indicios asociados al batolito de Jálama son los más importantes del distrito, concentrándose especialmente en la mitad norte de dicho batolito (Fig. 1.2, Anexo I). En función de la naturaleza de la roca encajante se diferencian tres tipos de depósitos: diseminaciones de casiterita en las facies graníticas y aplíticas de borde, diseminaciones de casiterita en los diques pegmatíticos intra y peribatolíticos y venas de cuarzo con casiterita y wolframita.

En el leucogranito y las aplitas con turmalina de la parte norte del batolito de Jálama, con casiterita diseminada, IGME-CGS (1976) llevó a cabo una toma de muestras representativas en las que analizaron los contenidos en $\mathrm{Sn}, \mathrm{W}, \mathrm{Li}, \mathrm{Be}, \mathrm{Nb}$ y Ta, observando que todas ellas presentaban valores bajos en $\mathrm{W}$, Ta y $\mathrm{Nb}$ y, sistemáticamente, más altos en $\mathrm{Sn}$ en los diques 


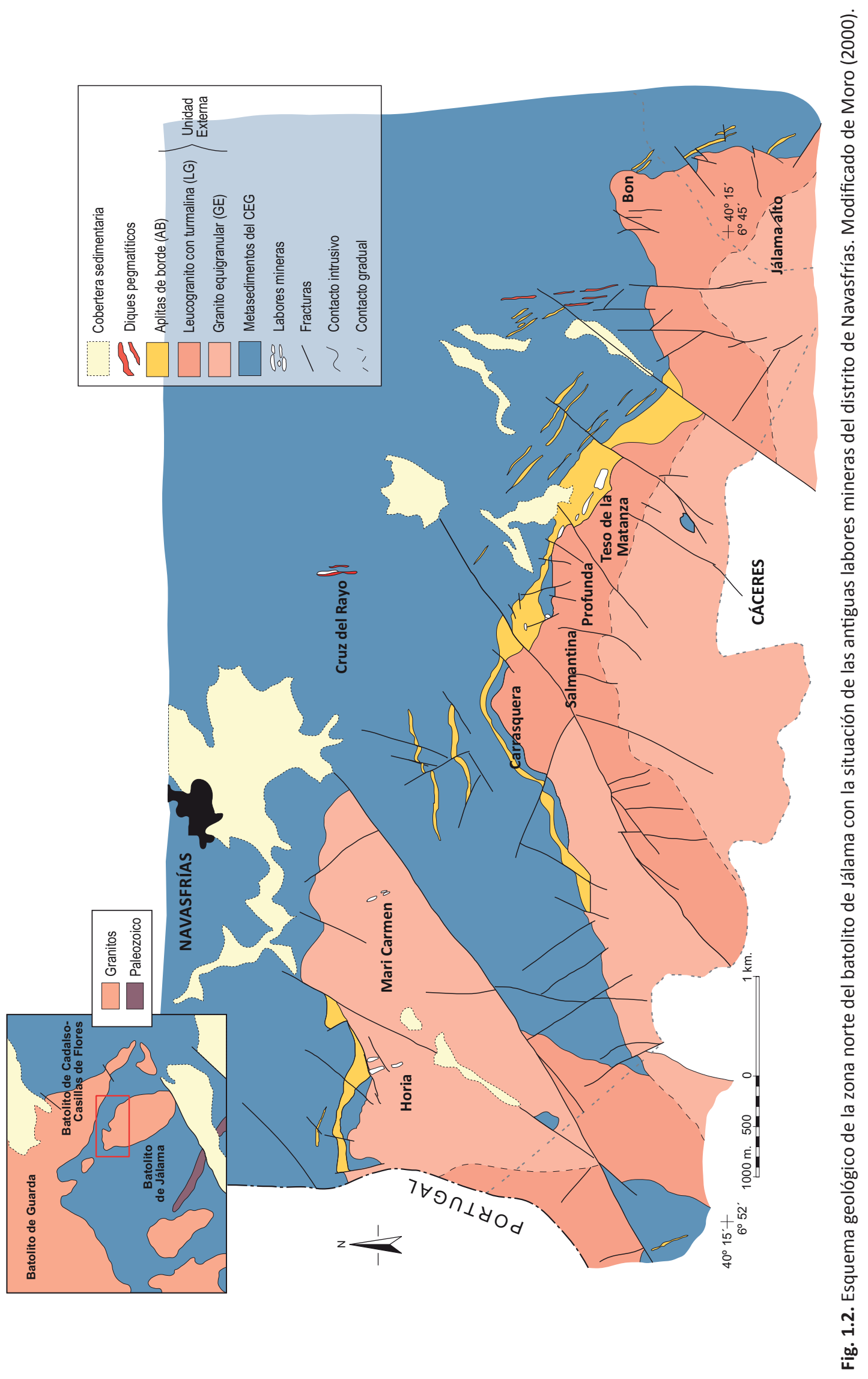


aplíticos (hasta 250 ppm). Los contenidos en Sn de los leucogranitos varían entre 50-100 ppm, salvo algunas de las muestras de caja de las venas de cuarzo mineralizadas que alcanzan hasta 1.000 ppm de Sn debido a la alteración hidrotermal que estas producen. En las zonas en las que el leucogranito está caolinizado (Lám. 1.1a) los contenidos en Sn alcanzan las 400 o 700 ppm cerca de filones mineralizados y en las que está turmalinizado apenas llegan a las $100 \mathrm{ppm}$.

En los diques pegmatíticos peribatolíticos del borde norte del batolito de Jálama, con casiterita diseminada, los contenidos en Sn varían desde 425 ppm en zonas aplíticas hasta 3.820 ppm en zonas pegmatíticas ricas en moscovita (García Sánchez y Gracia Plaza, 1979). Sin embargo, existen solo dos pequeñas explotaciones, la mina San Román en el término municipal de El Payo y de la que no se han podido tomar muestras, y la mina Cruz del Rayo al SE del municipio de Navasfrías (ENADIMSA, 1982; JCyL-TAGSA, 1987) (Fig. 1.2). Los diques pegmatíticos en ambas explotaciones tienen una dirección $\mathrm{N} 150-170^{\circ} \mathrm{E}$. En ninguna de ellas se conservan las labores mineras. En los diques de Cruz del Rayo las muestras tomadas y analizadas por ENADIMSA (1982) dieron valores de hasta 4.800 ppm de Sn, 116 ppm de Nb y menos de 90 ppm de Ta, lo que llevó a un muestreo más exhaustivo de los diques, obteniéndose al final una ley media de 600 ppm de Sn y 22 ppm de Ta, mientras que en los diques de la mina San Román los valores obtenidos son de 2.713 ppm de Sn (JCyL-TAGSA, 1987). Estos diques pegmatíticos también fueron valorados durante el estudio de las posibilidades de minería del Li en Castilla y León (JCyL-INTECSA, 1986), obteniéndose resultados negativos.

$\mathrm{Y}$, por último, las venas de cuarzo intragraníticas, que contienen casiterita, wolframita y sulfuros asociados en el borde norte del batolito de Jálama, han dado lugar a la minería más importante del distrito: por un lado, las minas Horia y Mari Carmen que encajan en un granito equigranular de dos micas con direcciones predominantes $\mathrm{N} 170-\mathrm{N} 180^{\circ} \mathrm{E}$ y buzamientos subverticales (Lám. 1.1b); y por otro, las minas Salmantina, Carrasquera, Profunda, Teso de la Matanza, Bilbao, Bon y Jálama Alto que se encuentran encajadas en un leucogranito y en las aplitas con turmalina con direcciones preferentes que varían entre $\mathrm{N} 80^{\circ} \mathrm{E}-\mathrm{N} 100^{\circ} \mathrm{E}$ (Lám. 1.1c,d,e,f,g,h; Fig. 1.2). De todas ellas, la mina Bilbao se encuentra completamente arrasada por lo que no ha sido posible obtener muestras para efectuar los estudios correspondientes.

En los trabajos de exploración llevados a cabo por ENADIMSA (1982) en la mina Salmantina las muestras analizadas dieron valores en Sn de hasta 277 ppm y en W de hasta 592 ppm, por lo que ampliaron el estudio a las labores de las minas Carrasquera, Profunda y Teso de la Matanza, obteniendo resultados para una ley media de 478 ppm de Sn y 3.343 ppm de W en los filones, y de 785 ppm de Sn y 1.273 ppm de W para el conjunto filones y roca de caja. Además, los análisis geoquímicos llevados a cabo en muestras de las paredes de las catas y de concentrados de cuarzo mineralizado recogidos de las escombreras dieron contenidos de hasta 6.107 ppm de Sn, de 2.800 ppm de W y de Au siempre inferiores a 5 ppb, aunque en algunas de las minas se encontraron hasta 31,6 ppm de Ag (JCyL-TAGSA, 1987).

\subsubsection{Minas e indicios del batolito de Cadalso-Casillas de Flores}

Las mineralizaciones asociadas al batolito de Cadalso-Casillas de Flores son de dos tipos: las de $U$, que se encuentran especialmente concentradas en el sector noroeste del batolito, en 

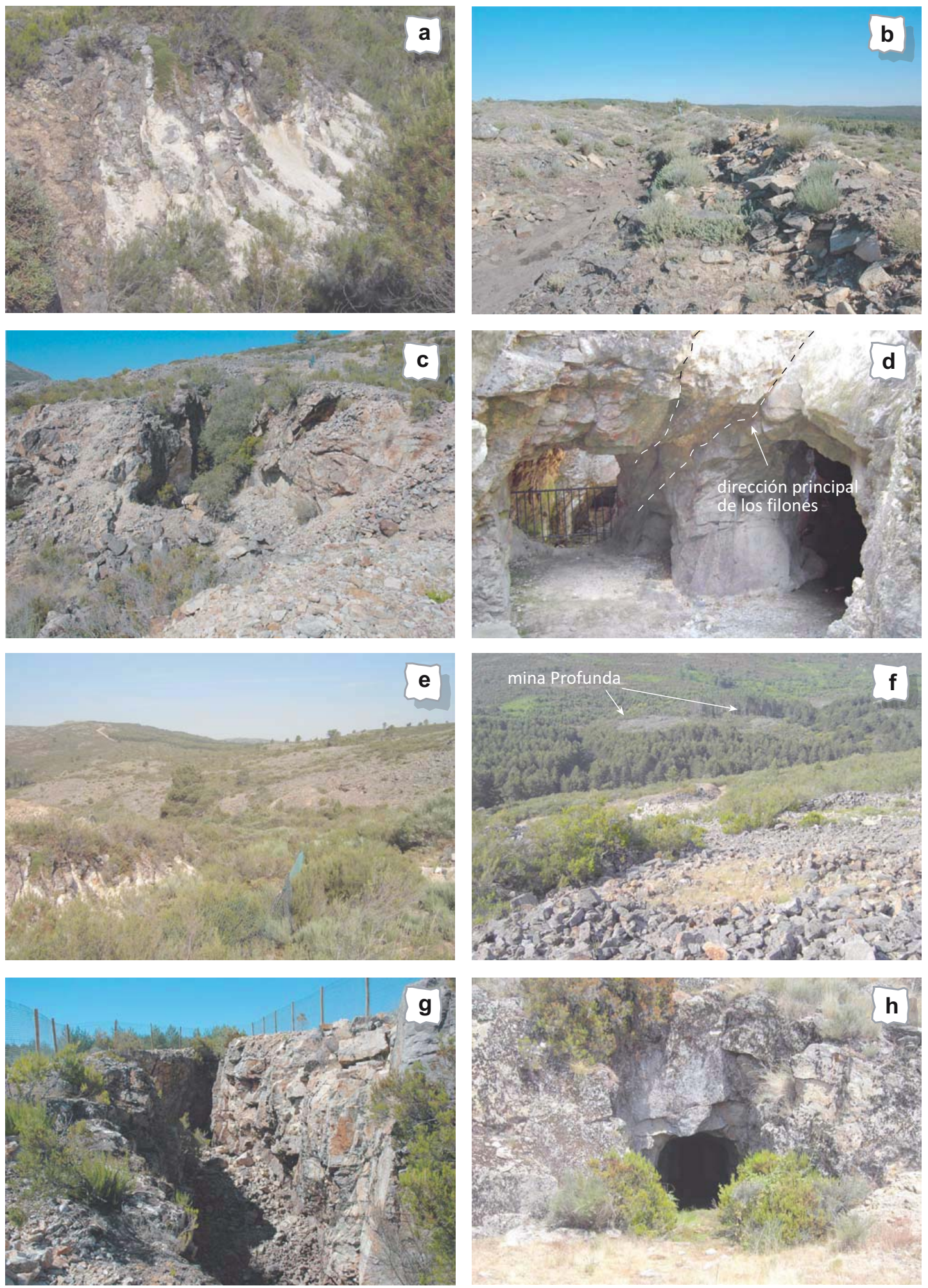

Lám. 1.1. Fotografías de campo de las minas asociadas al batolito de Jálama: a) aspecto del leucogranito con turmalina caolinizado en las zonas apicales del batolito; b) detalle de una de las zanjas excavadas para el vaciado de los filones mineralizados en la mina Horia; c) aspecto de una pequeña corta en la mina Salmantina y restos de escombreras adyacentes; d) detalle de la entrada a una de las galerías de explotación del filón principal en la mina Salmantina; e) panorámica de las zanjas y escombreras en la mina Carrasquera. Obsérvese en el margen inferior izquierdo el leucogranito caolinizado; f) vista general de la mina Profunda desde las escombreras de la mina Salmantina. Separando ambas minas se encuentra el rio Rubiós; $\mathbf{g}$ ) aspecto 


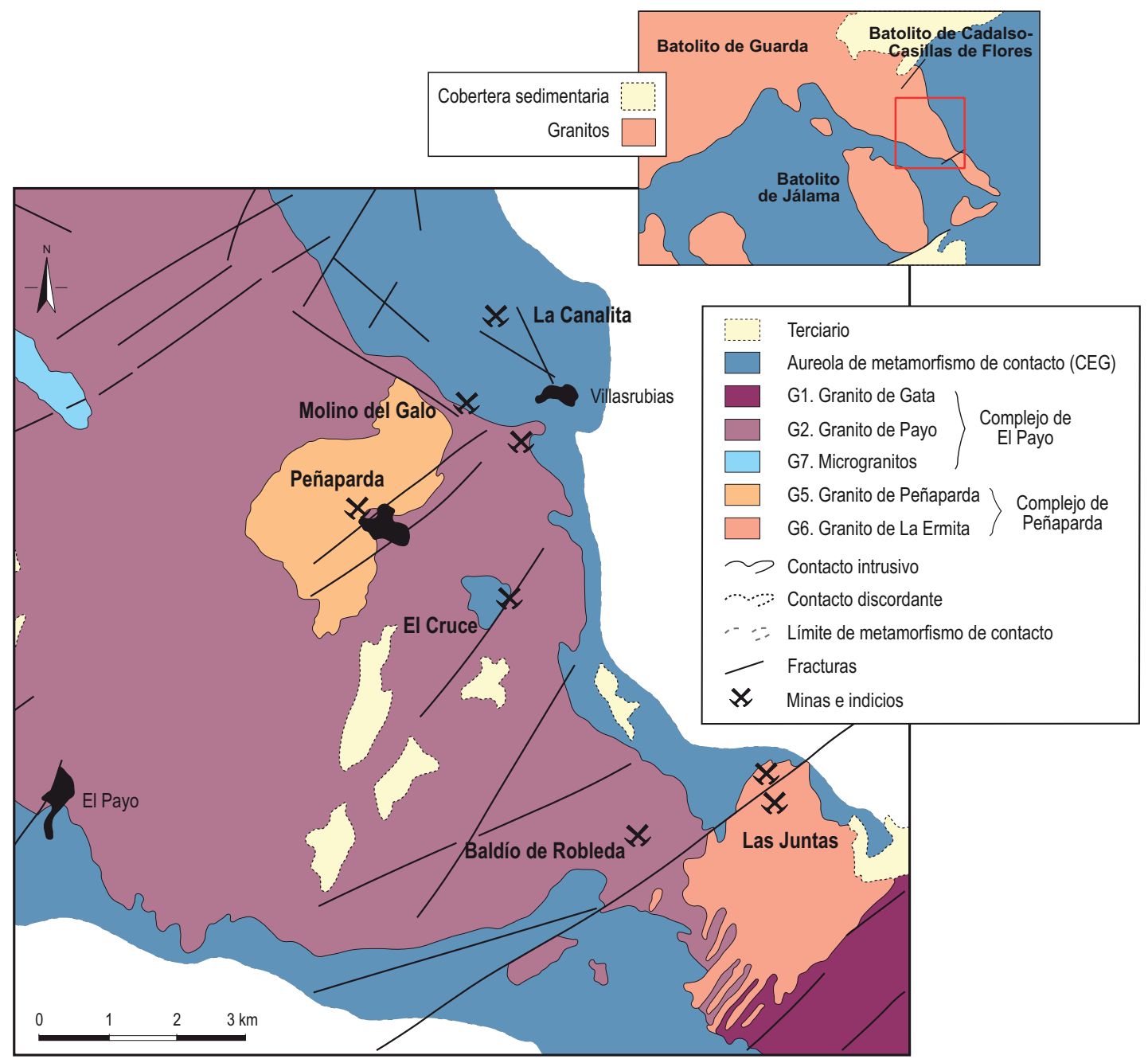

Fig. 1.3. Esquema geológico de la zona central del batolito de Cadalso-Casillas de Flores con la localización de las minas e indicios estudiados. Tomado de Hassan (1996).

las facies graníticas del complejo de El Payo, y que no han sido estudiadas en este trabajo; y las de $\mathrm{Sn} \pm \mathrm{W}$ y sulfuros asociados, concentradas en su zona centro y suroriental y que forman parte del distrito de Navasfrías (Fig. 1.3). Al igual que en el batolito de Jálama, las minas e indicios se han agrupado, en función de la naturaleza de la roca encajante, en diseminaciones de casiterita en diques aplíticos y pegmatíticos peribatolíticos y venas de cuarzo intragraníticas con casiterita y wolframita.

En los diques aplíticos y pegmatíticos que encajan en las rocas metamórficas con dirección predominante $\mathrm{N} 110^{\circ} \mathrm{E}$ a N $150^{\circ} \mathrm{E}$ (JCYL-TAGSA, 1987) se ha reconocido la mina de La Canalita, que es la más importante, en la que se encuentra una serie de diques pegmatíticos ricos en Li en los que se obtuvieron hasta 3.500 ppm de Sn y los indicios de Las Juntas, en el término municipal de Robleda, que actualmente no se conserva y que presentaba valores más bajos

de una de las zanjas principales de la mina Teso de la Matanza; $\mathbf{h}$ ) entrada a la galería principal en la mina Jálama Alto. 
en Sn (1.345 ppm), y el de Molino del Galo, en cuyos informes consultados se indica que contenía diseminaciones de casiterita (JCyL-TAGSA, 1987).

Las venas de cuarzo mineralizadas se localizan en los términos municipales de Peñaparda, Robleda, Villasrubias y en la Dehesa de El Jaque. Los análisis geoquímicos de concentrados obtenidos mediante rozas de las paredes de las catas y de fragmentos de cuarzo mineralizados de las escombreras dan los únicos valores de Au significativos de origen primario, con hasta $50 \mathrm{ppb}$ de Au, hasta $4.000 \mathrm{ppm}$ de $\mathrm{Sn}$ y de W prácticamente nulos. Destacan valores de Ag de hasta 88 ppm, de U hasta 18,7 ppm y de Th hasta 15,12 ppm (JCYL-TAGSA, 1987).

\subsubsection{Minería secundaria}

Si bien el estudio de la minería secundaria no es uno de los objetivos de este trabajo, su importancia en el distrito de Navasfrías requiere una pequeña mención. En el batolito de Jálama las leyes más elevadas se obtuvieron del lavado de material detrítico de las zonas de las minas Horia, Salmantina y Bilbao, con contenidos de hasta 347,23 ppm de Sn y 81,43 ppm de W, mientras que en el término municipal de El Payo, en el batolito de Cadalso-Casillas de Flores, se obtuvieron valores de hasta 149 ppm de Sn y 32,65 ppm de W (JCYL-TAGSA, 1987). Por otro lado, es bien sabida la existencia de pepitas de oro en las arenas de los ríos que drenan las rocas del distrito, especialmente el río Águeda y sus afluentes, como el río de Payo, el regato Rubiós o el arroyo Ladrón. Gil y Maestre (1880) ya relataban el hallazgo de pepitas de gran tamaño por los habitantes de los pueblos del distrito. Los indicios distribuidos en las zonas de Peñaparda, Villasrubias, Navasfrías, Robleda, El Sahugo y Cespedosa de Agadones corresponden a pozos y zanjas que dan hasta $0,175 \mathrm{~g} / \mathrm{cm}^{3}$ de $\mathrm{Au}$, especialmente en zonas de Peñaparda, llegando a obtener 667 pepitas en Robleda y El Sahugo. Existen referencias de pepitas de más de $70 \mathrm{~g}$ de peso, siendo especialmente grandes las encontradas en el arroyo Rubiós.

\subsection{OBJETIVOS}

Los objetivos más importantes planteados en el desarrollo de este trabajo son los siguientes:

- Definir las características morfológicas y estructurales de los distintos tipos de mineralización que se encuentran en el distrito de Navasfrías: diseminada en las facies graníticas y aplíticas de borde, en los diques pegmatíticos intra y peribatolíticos y en las venas de cuarzo intragraníticas.

- Caracterizarlos mineralógica, química e isotópicamente, estableciendo las asociaciones minerales y secuencias paragenéticas de cada uno de los tipos, así como las condiciones físico-químicas de su formación.

- Establecer, con todo ello, un modelo metalogenético que explique espacial y genéticamente las características de estas mineralizaciones en el contexto geológico del sistema magmáticohidrotermal en el que se encuentran facilitando, a la vez, guías y criterios de exploración para futuras investigaciones. 


\subsection{METOdOLOGÍA DE TRABAJO}

A continuación se detallan los trabajos de campo, de laboratorio y de gabinete que se han llevado a cabo para alcanzar los objetivos planteados.

\subsubsection{Trabajos de campo}

Para la realización de los trabajos de campo se utilizaron las cartografías de los batolitos de Jálama (Ramírez, 1996) y de Cadalso-Casillas de Flores (Hassan, 1996), los mapas geológicos de la serie MAGNA correspondientes a este sector, la cartografía digital del terreno facilitada por la Diputación de Salamanca y toda la cartografía minera que se encuentra en los trabajos de exploración de estas mineralizaciones (IGME-CGS, 1976; ENADIMSA, 1982; JCyL, 1985, 1986; JCYL-INTECSA, 1986; JCYL-TAGSA, 1987).

En primer lugar, se realizó un reconocimiento de la geología del distrito, situando cada una de las minas e indicios en su contexto geológico. Seguidamente se reconocieron todas las labores mineras, tanto en superficie como en el interior de las galerías a las que era posible acceder, para identificar los diferentes tipos de rocas y la mineralización que se explotó. Además se realizó el estudio geológico correspondiente con la toma de datos como direcciones y buzamientos, potencias y longitud de los cuerpos mineralizados, fracturas y sistemas de diaclasado.

Posteriormente se llevó a cabo un muestreo, tanto de la roca encajante como de los cuerpos mineralizados, durante el cual se recogieron 229 muestras de las venas de cuarzo intragraníticas que contienen la mineralización principal, pero también de diques pegmatíticos intra y peribatolíticos y, en menor medida, de las facies graníticas y de su encajante metamórfico (Anexo I). En aquellos indicios en los que no ha sido posible el muestreo in situ se tomaron muestras de las escombreras.

\subsubsection{Trabajos de laboratorio}

Las muestras de rocas encajantes y/o mineralizadas tomadas en las minas e indicios del distrito de Navasfrías fueron estudiadas bajo la lupa binocular, realizándose una descripción de las mismas y una selección para su posterior estudio petrográfico, mineralógico y químico. La elaboración de las secciones transparentes-pulidas de las muestras se ha llevado a cabo en el Servicio General de Preparación de Rocas de la Universidad de Salamanca.

\section{Estudio petrográfico, mineralógico y químico}

La caracterización petrográfica, mineralógica y química de las distintas fases minerales se ha realizado a partir de la utilización integrada de microscopía óptica y electrónica de barrido, microsonda electrónica, análisis químico y difracción de rayos $X$.

\section{Microscopía óptica}

Se han utilizado dos microscopios de polarización, un Nikon Eclipse E400 y un Leica DM LP, ambos con cámara de fotos integrada, en el Área de Cristalografía y Mineralogía de la Universidad de Salamanca. 


\section{Microsonda electrónica}

La mayoría de los análisis se han llevado a cabo con una microsonda modelo Cameca SX100 en los Servicios Científico-Técnicos de la Universidad de Oviedo con unas condiciones de análisis de $15 \mathrm{kV}$ de voltaje, $15 \mathrm{nA}$ de corriente y un tiempo de contaje de $10 \mathrm{~s}$ por elemento, $60 \mathrm{~s}$ en el caso del $\mathrm{U}$ y del Rb. Los estándares empleados para los análisis de silicatos y fosfatos fueron: $\mathrm{MgO}$ para el $\mathrm{Mg}, \mathrm{Al}_{2} \mathrm{O}_{3}$ para el $\mathrm{Al}, \mathrm{MnTiO}_{3}$ para $\mathrm{Mn}$ y Ti, andradita para el $\mathrm{Fe}$, vanadinita para el $\mathrm{Cl}$, albita para el $\mathrm{Na}$, $\mathrm{LaF}_{3}$ para $\mathrm{F}, \mathrm{SrF}_{2}$ para el $\mathrm{Sr}, \mathrm{BaSO}_{4}$ para el Ba, $\mathrm{ZnS}$ para el $\mathrm{Zn}$, AsGa para As, ortoclasa para K y Si, apatito para $\mathrm{P}$ y Ca, celestina para $\mathrm{S}, \mathrm{SnO}_{2}$ para el $\mathrm{Sn}, \mathrm{MnWO}_{4}$ para el $\mathrm{W}$, IR-X para el Rb. Para los óxidos de $\mathrm{Sn}, \mathrm{W}, \mathrm{Nb}$, Ta y Ti se emplearon los siguientes: metales para $\mathrm{Ti}, \mathrm{Sn}, \mathrm{W}, \mathrm{Zr}$ y Bi, vanadinita para $\mathrm{V}$, pirita para $\mathrm{Fe}, \mathrm{MnTi}$ para $\mathrm{Mn}$, $\mathrm{Ta}_{2} \mathrm{O}_{5}$ para $\mathrm{Ta}, \mathrm{Nb}_{2} \mathrm{O}_{5}$ para $\mathrm{Nb}$, andradita para $\mathrm{Ca}$, albita para $\mathrm{Na}, \mathrm{Al}_{2} \mathrm{O}_{3}$ para Al, estibnita para $\mathrm{Sb}, \mathrm{PbS}$ para $\mathrm{Pb}, \mathrm{UO}_{2}$ para $\mathrm{U}, \mathrm{NdF}_{3}$ para $\mathrm{F}, \mathrm{HfO}_{2}$ para $\mathrm{Hf}$, Th_glass para Th y MgO para Mg. Para los sulfuros los patrones fueron los siguientes: metales para $\mathrm{Cu}, \mathrm{Ag}, \mathrm{Bi}, \mathrm{Au}, \mathrm{Ni}, \mathrm{Co}, \mathrm{Sn}, \mathrm{Mo} \mathrm{y}$ W, pirita para Fe y S, ZnS para Zn, FeAsS para As, PbS para Pb, estibnita para Sb, CdTe para Cd y $\mathrm{Te}, \mathrm{MnTi}$ para $\mathrm{Mn}, \mathrm{PtSe}_{2}$ para Se y HgS para Hg.

Buena parte de la mineralización metálica de sulfuros y sulfosales se ha analizado en el Laboratorio de Microsonda Electrónica del Instituto de Geología y Geografía de la Universidad de Copenhague, en Dinamarca, empleando una microsonda modelo JEOL JXA8200 Superprobe con unas condiciones de análisis de $15 \mathrm{kV}$ de voltaje y $25 \mathrm{nA}$ de corriente y tiempos de contaje de $10 \mathrm{~s}$ por cada elemento. Los estándares empleados fueron los siguientes: AgBi para Ag y Bi, PbS para Pb, BiSe para Se, CdS para Cd, CuSb para Cu y Sb, FeCrS para Fe, HgS para Hg, AgBiS para S, CuAsS para As, ZnS para Zn, metal para W y Mn y SnS para Sn. Para analizar la arsenopirita se empleó el patrón Asp200 (Kretschmar y Scott, 1976), permitiendo emplear los resultados obtenidos para cálculos geotermométricos.

En total se han realizado 1.704 análisis de las siguientes fases minerales: feldespato potásico (53), albita (111), moscovita (115), lepidolita (2), biotita (15), celadonita (1), clorita (29), turmalina (28), berilo (4), andalucita (2), gahnita (12), escorodita (26), topacio (2), barbosalitalipscombita (6), keckita (5), mitridatita (6), gormanita (8), eosforita-childrenita (34), apatito (91), ambligonita-montebrasita (27), brasilianita (1), goyazita (13), rockbridgeita (21), beraunita (9), zwieselita (1), staněkita (1), xantoxenita (4), alluaudita (11), triplita (10), isokita (3), bermanita (6), fosfosiderita (9), heterosita-ferrisiklerita? (1), arsenopirita (191), esfalerita (53), pirita (78), marcasita (2), pirrotita (38), calcopirita (35), löllingita (1), molibdenita (3), Bi nativo (28), galena (29), matildita (21), argentita (4), ferrokesterita (28), bismutinita (56), homólogos de la pavonita (34), homólogos de la lilianita (156), minerales del grupo de la columbita (91), tapiolita (7), strüverita (1), microlita (7), microlita uranífera (2), rutilo (58), ixiolita (10), casiterita (65) y wolframita (39).

\section{Microscopía electrónica de barrido}

Se han obtenido, además, imágenes de electrones retrodispersados y mapas de rayos- $X$ con un microscopio electrónico de barrido Zeiss DSM-940 con sistema de microanálisis elemental por EDX (Z II de Tracor Northern) en el Servicio General de Microscopía Electrónica de la 
Universidad de Salamanca. Los análisis semicuantitativos han permitido la discriminación de fases minerales en aquellos casos en los que no era posible a través de microsonda. Las abreviaturas empleadas para cada uno de los minerales analizados y su fórmula general se recogen en el Anexo II, mientras que los resultados de su composición química obtenidos por microsonda electrónica y su fórmula calculada están en el Anexo III.

\section{Difracción de Rayos X}

Esta técnica se ha empleado para la identificación de determinadas fases minerales (Anexo IV). Se ha utilizado el equipo de difracción de Rayos $X$ de polvo BRUKER D8 ADVANCE con configuración $\theta-2 \theta$, que opera a $25^{\circ} \mathrm{C}$ de temperatura ambiente bajo unas condiciones de 30 kV y 30 nA que dispone el Servicio de Difracción de Rayos X de la Universidad de Salamanca.

\section{Espectrometría de masas}

Esta técnica fue utilizada para el análisis químico de concentrados de mica blanca previamente separada de muestras de rocas, en el Servicio General de Análisis Químico de la Universidad de Salamanca. Las determinaciones se han realizado en dos Espectrómetros de Emisión de Plasma: ICP-MS modelo Elan 6000 de Perkin-Elmer e ICP-OES modelo ULTIMA 2 de Jobin Yvon. Para la calibración del equipo se ha partido de disoluciones estándar certificadas de los distintos elementos (Panreac), de $1000 \mathrm{mg} / \mathrm{l}$, agrupando todos los estándares en un patrón multielemental. Los elementos mayores analizados, en tanto por ciento del óxido, son $\mathrm{Al}_{2} \mathrm{O}_{3^{\prime}}$, $\mathrm{CaO}, \mathrm{Fe}_{2} \mathrm{O}_{3}, \mathrm{FeO}, \mathrm{K} \mathrm{O}_{2}, \mathrm{MgO}, \mathrm{MnO}, \mathrm{Na}_{2} \mathrm{O}, \mathrm{P}_{2} \mathrm{O}_{5}, \mathrm{SiO}_{2}, \mathrm{TiO}_{2}, \mathrm{LiO}_{2}$ y la materia volátil, mientras que $\mathrm{Ce}, \mathrm{Cr}, \mathrm{Cu}, \mathrm{Nb}, \mathrm{Ni}, \mathrm{Pb}, \mathrm{Sn}, \mathrm{W}$ y $\mathrm{Zn}$ son los elementos traza obtenidos en ppm (Anexo $\mathrm{V}$ ).

Existe una fuerte correlación entre el contenido en $\mathrm{F}$ obtenido por microsonda electrónica en las micas blancas y en $\mathrm{Li}_{2} \mathrm{O}$ obtenido por ICP-OES en las 7 muestras de concentrado de micas blancas analizadas del batolito de Jálama. Por lo tanto, en el resto de las micas los contenidos en Li se han estimado utilizando la ecuación: $\mathrm{Li}_{2} \mathrm{O}=0,320 * \mathrm{~F}-0,049\left(R^{2}=0,929\right)$. Esta correlación es coherente con las relaciones empíricas propuestas por Henderson et al. (1989), Tindle y Webb (1990), Tischendorf et al. (1997), Pesquera et al. (1999) y Roda et al. $(2006,2007)$. También ha sido demostrado experimentalmente en micas de Li trioctahédricas y parcialmente dioctahédricas por Monier y Robert (1986). En el batolito de Cadalso-Casillas de Flores no ha sido posible separar mica blanca y mica de Li de diferentes cuerpos graníticos y pegmatíticos para obtener una correlación similar, por lo que se han empleado las ecuaciones empíricas propuestas por Tischendorf et al. (2004) para el cálculo de los contenidos en Li de las micas analizadas por microsonda electrónica. Para la moscovita la ecuación utilizada es $\mathrm{LiO}_{2}=0,3935 * \mathrm{~F}^{1,326}$, mientras que para la mica de Li la ecuación es $\mathrm{LiO}_{2}=\left(0,289 * \mathrm{SiO}_{2}\right)-9,658$.

\section{Estudio de las inclusiones fluidas}

Para este estudio se emplearon técnicas de microtermometría y microsonda Raman, que permiten una caracterización cualitativa y cuantitativa de los componentes de las inclusiones fluidas sin destruirlas. 


\section{Microtermometría}

A partir de los datos geológicos obtenidos previamente durante los trabajos de campo, y conjuntamente con el estudio de las muestras de mano y el análisis petrográfico de las secciones transparentes-pulidas, se seleccionaron 5 muestras representativas de las mineralizaciones del batolito de Jálama para la elaboración de preparaciones bipulidas.

El estudio petrográfico a temperatura ambiente de estas secciones permitió obtener información acerca de la distribución de las inclusiones en los minerales que componen la muestra así como de sus características físicas, como forma, tamaño, las diferentes fases que componen la inclusión y la estimación volumétrica de cada una de ellas (factor F). Con ello fue posible discriminar entre inclusiones fluidas primarias y secundarias (Roedder, 1984; Shepherd et al., 1985).

Una vez seleccionados grupos o poblaciones de inclusiones fluidas en función de las características previas, la sección bipulida se divide en fragmentos de tamaño adecuado para realizar las medidas microtermométricas. Para ello se empleó una platina calentadorarefrigeradora Chaixmeca con objetivos L32x Leitz Wetzlar y ULWDMS Plan 80x Olympus, instalada en un microscopio petrográfico. Dicha platina consta de una cámara adaptada a la circulación de nitrógeno líquido para el proceso de enfriamiento y una resistencia térmica para calentar la muestra. La temperatura a la que tienen lugar los cambios de fase es registrada en la consola de medida.

El estudio microtermométrico consta de dos etapas. En primer lugar un proceso de enfriamiento hasta $-170^{\circ} \mathrm{C}$, tras el cual se observan los cambios de fase hasta la recuperación de la temperatura ambiente. Las medidas tomadas son: la temperatura eutéctica (Te), temperatura de fusión de la hidrohalita (Tmhh), la temperatura de fusión del hielo (Tmi) y la temperatura de fusión del clatrato (Tmcla). En segundo lugar la muestra es calentada hasta la homogeneización de las fases que componen la inclusión estudiada, obteniendo así la temperatura de homogeneización total (Th) o la temperatura de decrepitación (Td) si la inclusión se rompe. A partir de estos resultados se obtuvieron la composición y la densidad del fluido así como las condiciones de temperatura mínima de atrape del fluido, realizando cálculos y empleando el programa Halwat (Nicholls y Crawford, 1985) para inclusiones acuoso-salinas. Estos resultados se muestran en el Anexo VI.

\section{Microsonda Raman}

Para la determinación de las fases gaseosas presentes en algunas de las inclusiones estudiadas fue empleado un espectrómetro Raman Dilor XY provisto de un microscopio metalográfico Olimpos $\mathrm{BH} 2$, equipado con óptica Nomarski y objetivo de 100x, con posicionamiento focal automático en el Departamento de Física de la Materia Condensada, Cristalografía y Mineralogía de la Universidad de Valladolid. Como fuente de excitación se utilizó la línea espectral de 514,5 nm de longitud de onda, procedente de un láser monocromático de iones de argón, modelo 2020-05 de Spectra Physics, focalizado a través del objetivo del microscopio, lo que permite una resolución espacial inferior a $1 \mu \mathrm{m}$. Las condiciones experimentales 
utilizadas son: dos acumulaciones, tiempos de adquisición de $120 \mathrm{~s}$, rendijas de $250 \mu \mathrm{m}$ y potencia de $250 \mathrm{~mW}$.

\section{Análisis de isótopos estables}

La determinación de las relaciones isotópicas del hidrógeno, oxígeno y azufre se ha llevado a cabo en el Servicio General de Isótopos Estables de la Universidad de Salamanca. Para ello primero se ha procedido a la separación manual de los minerales a analizar empleando una lupa binocular. En total se han realizado 64 análisis de 1 muestra de granito, 9 muestras de pegmatitas y 23 muestras de venas de cuarzo mineralizadas del batolito de Jálama y 3 muestras de venas de cuarzo del batolito de Cadalso-Casillas de Flores. Los minerales analizados han sido cuarzo (20), moscovita (11), turmalina (2), feldespato potásico (1), casiterita (5), wolframita (4), arsenopirita (14), pirita (4) y esfalerita (3), que fueron triturados y molidos en un molino de ágata.

La relación isotópica $\mathrm{D} / \mathrm{H}$ de los minerales hidratados se determinó mediante un espectrómetro de masas VG-Isotech SIRA-II, mientras que la relación ${ }^{18} \mathrm{O} /{ }^{16} \mathrm{O}$ de los minerales hidratados y anhidros se obtuvo mediante la línera de fluorinación según la metodología de Clayton y Mayeda (1963) y empleando $\mathrm{ClF}_{3}$ como reactivo (Borthwick y Harmon, 1982). En este estudio se ha empleado la notación convencional ( $\delta \mathrm{D}$ y $\delta^{18} \mathrm{O}$ respectivamente) y el patrón de referencia empleado es V-SMOW (Viena Standard mean ocean water). Por último, la relación isotópica ${ }^{34} \mathrm{~S} /{ }^{32} \mathrm{~S}\left(\delta^{34} \mathrm{~S}\right)$ de los sulfuros se ha determinado mediante los métodos de Robinson y Kusakabe (1975) y Coleman y Moore (1978), empleando como patrón de referencia V-CDT - Viena Cañon Diablo troilite. Los resultados de estas relaciones se expresan en \%o, siendo la precisión de los datos de $\pm 2 \%$ o $(1 \sigma)$ en todas las medidas.

La diferencia de valores $\delta$ entre determinadas fases minerales se denomina fraccionamiento isotópico y se denota con el símbolo $\Delta$, reflejando el equilibrio isotópico entre determinadas sustancias, que varía en función de las condiciones físico-químicas del sistema. Este fraccionamiento se puede expresar mediante una ecuación del tipo: $\Delta_{A-B}=\delta_{A}-\delta_{B}=1000 \ln \alpha$ $=\mathrm{A}+\mathrm{B} / T+\mathrm{C} / \mathrm{T}^{2}$, donde $\mathrm{A}, \mathrm{B}$ y $\mathrm{C}$ son constantes tabuladas que varían en función del factor de fraccionamiento empleado y $T$ es la temperatura en ${ }^{\circ} \mathrm{K}$ (Bottinga, 1968).

\subsubsection{Trabajos de gabinete}

Con toda la información bibliográfica, los datos geológicos y los resultados de laboratorio se ha llevado a cabo la elaboración de esta memoria mediante la utilización de los siguientes programas: Microsoft Office Excel 2007 para la elaboración de tablas y gráficos y para el cálculo de las fórmulas estructurales; TriDraw 4.5 para crear gráficos triangulares; Macromedia Freehand MX como programa de dibujo; Adobe Photoshop CS2 para el tratamiento de imágenes; y Microsoft Office Word y Adobe InDesign para la edición de esta memoria. Como se mencionó previamente, se ha empleado el programa Halwat (Nicholls y Crawford, 1985) para el tratamiento de los datos microtermométricos de las inclusiones fluidas y el programa CLORITA.EXE (Tornos, 1989) para los cálculos geotermométricos de la clorita. 


\subsection{MINERALIZACIONES DE Sn-W Y METALES RAROS ASOCIADAS A GRANITOS}

Buena parte de los depósitos de estaño, wolframio y metales raros del Cinturón Varisco Europeo se asocian genética y espacialmente a cuerpos graníticos cuya composición inicial se ha visto modificada por diversos factores como la secuencia de cristalización durante el ascenso del magma, las posibles interacciones con la roca encajante o las condiciones de emplazamiento, que hacen que estos granitos sean capaces de concentrar determinados elementos que inicialmente estaban presentes en varias ppm de media hasta formar yacimientos económicamente relevantes de $\mathrm{Li}, \mathrm{Rb}, \mathrm{Cs}, \mathrm{Be}, \mathrm{Cu}, \mathrm{Mo}, \mathrm{Sn}, \mathrm{Zr}, \mathrm{Th}, \mathrm{U}, \mathrm{Nb}, \mathrm{Ta}, \mathrm{W}$, $\mathrm{Au}$ y tierras raras. Estas concentraciones tienen lugar mediante la cristalización fraccionada de los granitos, acumulación en fundidos residuales, intervención de fluidos hidrotermales o por interacción con fluidos procedentes de la roca de caja, por lo que son muy variables. No obstante, en función de las condiciones de emplazamiento y consolidación de los cuerpos graníticos y los procesos subsolidus posteriores se distinguen tres tipos de depósitos (Černý et al., 2005a):

- Mineralización magmática diseminada en granitos.

- Mineralización tardimagmática en pegmatitas.

- Mineralización hidrotermal de tipo greisen y filoniana de cúpula granítica y borde del encajante.

Los granitos que contienen este tipo de mineralizaciones tienen un origen muy variado, procediendo principalmente de la fusión parcial de protolitos ricos en hornblenda, biotita y moscovita de la corteza media a inferior generados en distintos ambientes orogénicos o anorogénicos.

Aunque no hay una clasificación aceptada universalmente para este tipo de rocas, existen diferentes esquemas de clasificación en función de diversos indicadores composicionales. Así, Ishihara (1977) agrupó los granitos pertenecientes a la "serie de la magnetita" o a la "serie de la ilmenita" en función del óxido dominante, mientras que Chappel y White (1974) los clasificaron en función de la naturaleza de la roca fuente de la que proceden, en granitos "tipo $S^{\prime}$ derivados de la fusión parcial de rocas metasedimentarias y granitos "tipo I" que proceden de la fusión de rocas ígneas de composición calco-alcalina. De este último grupo se separan los granitos "tipo A" (Loiselle y Wones, 1979), que engloban un amplio rango de granitos peralcalinos hasta ligeramente peralumínicos. Whalen (1985) denominó granitos "tipo M" a los plagiogranitos y tonalitas derivadas de la fusión o cristalización fraccionada de magmas mantélicos típicos de arcos intraoceánicos. Posteriormente, London (1995) extendió la clasificación de las pegmatitas de elementos raros de Černý (1991a,c) a los granitos de los cuales proceden, distinguiendo entre: granitos LCT (acrónimo procedente de los elementos característicos de esta familia, La, Cs y Ta), de composición mediana a extremadamente peralumínicos y que incluyen los granitos tipo $\mathrm{S}$ e I; granitos NYF (Nb, Y y F), equivalentes a los granitos de tipo A y de composición subalumínica a metalumínica; y los mixtos LCT+NYF. 


\section{Mineralización magmática diseminada en granitos}

Los granitos que contienen las mineralizaciones de metales raros diseminadas representan los últimos diferenciados magmáticos, generalmente ricos en albita y altamente fraccionados, asociados con un magmatismo calco-alcalino. Son típicamente tardiorogénicos o anorogénicos y están normalmente emplazados en niveles altos de la corteza. Normalmente el límite superior de estos cuerpos graníticos con la roca de caja se caracteriza por la presencia de un stockscheider, que se define como el crecimiento de grandes cristales de feldespato con textura plumosa dentro de una matriz granítica de grano fino con bandeado composicional (Černý et al., 2005a). Estos granitos están fuertemente enriquecidos en $\mathrm{F}$ y empobrecidos en $\mathrm{Mg}$, Ti y elementos de transición, presentando contenidos variables de $\mathrm{Sn}, \mathrm{W}, \mathrm{Nb}, \mathrm{Ta}, \mathrm{Rb}, \mathrm{Cs}$, In, Be y Li.

Según la clasificación de Černý et al. (2005a), los granitos de metales raros se agrupan en tres tipos en función de sus características mineralógicas y geoquímicas: peralcalinos $[(\mathrm{Na}+\mathrm{K}) /$ $\mathrm{Al}>1$ ] con contenidos altos en Th, $\mathrm{Sn}, \mathrm{Be}, \mathrm{Rb}$ y $\mathrm{U}$, y muy elevados en $\mathrm{Zr}$, REE, $\mathrm{Y}, \mathrm{Nb}$ y $\mathrm{F}$, y con una mineralización diseminada de $\mathrm{Zr}$, Nb, REE, $\mathrm{U}$ y Th; peralumínicos $[1<\mathrm{Al} /(\mathrm{Na}+\mathrm{K})<1,15]$ con bajo contenido en $\mathrm{P}$ y cantidades intermedias de REE, Y, Zr, Hf y Th, que están asociados con mineralizaciones de $\mathrm{Nb}$, Ta y Sn en ambientes postorogénicos o anorogénicos; y peralumínicos $[\mathrm{Al} /(\mathrm{Na}+\mathrm{K})>1,15]$ con elevado contenido en $\mathrm{P}, \mathrm{Li}, \mathrm{Rb}$ y Sc, generalmente de composición leucocrática y típicamente postorogénicos, que se asocian a mineralizaciones ricas en $\mathrm{Li}$, Ta y Sn.

La mineralización diseminada de metales raros en los granitos se forma por precipitación durante los procesos magmáticos primarios. Estos depósitos pueden estar poco afectados por procesos de alteración subsolidus, como es el caso del granito rico en Li y F de Beauvoir (Raimbault et al., 1995), o pueden presentar una importante alteración hidrotermal que da lugar a la redistribución de los elementos y a la formación de un greisen rico en Li, Sn y W como el que se encuentra en la cúpula de Cínovec (Štemprok y Šulcek, 1969; Johan y Johan, 1994). El enriquecimiento en metales raros en las zonas apicales de las cúpulas graníticas responde a un origen magmático (Černý et al., 2005a) mediante acumulación por procesos de diferenciación fraccionada. Sin embargo, la teoría de un origen metasomático (Beus y Zalashkova, 1964; Hu et al., 1984) explica la mineralización mediante un fuerte enriquecimiento en volátiles combinado con el ascenso de los fluidos postmagmáticos que arrastran los metales desde las partes inferiores del plutón.

\section{Mineralización tardimagmática en pegmatitas}

La hipótesis más aceptada para explicar la formación de las pegmatitas se basa en los procesos de cristalización fraccionada a partir de un magma residual silicatado rico en elementos raros y volátiles, los cuales disminuyen la viscosidad del magma y reducen la temperatura de solidificación. Los elementos raros se comportan como elementos incompatibles que se acumulan progresivamente en el fundido residual de la cristalización de un cuerpo granítico, el cual puede solidificar en la parte apical del mismo formando lo que se llama granito pegmatítico (Černý, 1991a; Wise y Francis, 1992) o, lo que es más frecuente, puede escapar a la roca encajante para formar cuerpos pegmatíticos marginales o exteriores al plutón 
parental. La forma de estos cuerpos depende de la profundidad de emplazamiento y de la temperatura del encajante, de manera que en zonas profundas en las que la temperatura y la presión son elevadas, las pegmatitas presentan formas ovoides o curvadas, mientras que en zonas más superficiales los cuerpos pegmatíticos presentan forma de diques con contactos planares que parecen estar controlados por fracturas (London, 2008).

\section{Clasificación de las pegmatitas graníticas}

La clasificación más reciente (Černý y Ercit, 2005; Černý et al., 2005a) agrupa las pegmatitas en cinco tipos en función de la presión y, en parte, la temperatura de las rocas encajantes (Tabla 1.1). De toda ellas, las que tienen los depósitos de mayor interés económico son las pegmatitas de elementos raros, generadas por la diferenciación magmática de un plutón granítico emplazado a escasa profundidad. Estas pegmatitas se agrupan en tres familias petrogenéticas:

- Familia LCT (Li-Cs-Ta): estas pegmatitas están enriquecidas en Li, Rb, Cs, Be, Sn, Ta>Nb, $B, P$ y $F$ y proceden de granitos sin- a tardiorogénicos de tipo $S$, I o mixtos y de composición peralumínica. Presentan frecuentemente una zonación por diferenciación magmática, promoviendo el enriquecimiento de estos elementos en las facies más evolucionadas.

TABLA 1.1. CLASIFICACIÓN DE LAS PEGMATITAS (Černý et al., 2005a)

\begin{tabular}{|c|c|c|c|c|}
\hline Clase & Elementos menores & $\begin{array}{c}\text { Rocas metamórficas } \\
\text { encajantes }\end{array}$ & $\begin{array}{l}\text { Relación con los } \\
\text { granitos }\end{array}$ & $\begin{array}{l}\text { Características } \\
\text { estructurales }\end{array}$ \\
\hline Abisal & $\begin{array}{c}\text { U, Th, Zr, Nb, Ti, Y, } \\
\text { REE, Mo (Be, B). } \\
\text { Mineralización } \\
\text { pobre }\end{array}$ & $\begin{array}{c}\text { Facies anfibolita a } \\
\text { granulita. } 400-900 \\
\mathrm{MPa}, 700-800^{\circ} \mathrm{C}\end{array}$ & $\begin{array}{c}\text { Ausente, } \\
\text { segregaciones a } \\
\text { partir de } \\
\text { leucosomas } \\
\text { anatécticos }\end{array}$ & $\begin{array}{c}\text { Concordante o } \\
\text { discordante en } \\
\text { venas que cortan las } \\
\text { estructuras }\end{array}$ \\
\hline Moscovita & $\begin{array}{l}\text { Sin mineralización. } \\
\text { Micas y minerales } \\
\text { cerámicos }\end{array}$ & $\begin{array}{c}\text { Facies anfibolitas de } \\
\text { alta presión } 500-900 \\
\text { MPa, } 650-580^{\circ} \mathrm{C}\end{array}$ & $\begin{array}{l}\text { Ausente (cuerpos } \\
\text { anatécticos), } \\
\text { marginales o } \\
\text { exteriores }\end{array}$ & $\begin{array}{l}\text { Ligeramente } \\
\text { concordante o } \\
\text { cortando las } \\
\text { estructuras }\end{array}$ \\
\hline $\begin{array}{l}\text { Moscovita- } \\
\text { elementos raros }\end{array}$ & $\begin{array}{c}\text { Li, Be, Y, REE, Ti, U, } \\
\text { Th, Nb>Ta, (Li, Be). } \\
\text { Mineralización } \\
\text { pobre }\end{array}$ & $\begin{array}{c}\text { Facies anfibolitas de } \\
\text { presión y } \\
\text { temperatura } \\
\text { moderadas a } \\
\text { elevadas, } 300-700 \\
\mathrm{MPa}, 650-520^{\circ} \mathrm{C}\end{array}$ & $\begin{array}{l}\text { Interiores a } \\
\text { exteriores, } \\
\text { pobremente } \\
\text { definidas }\end{array}$ & $\begin{array}{l}\text { Ligeramente } \\
\text { concordante o } \\
\text { cortando las } \\
\text { estructuras }\end{array}$ \\
\hline Elementos raros & $\begin{array}{c}\text { Li, Rb, Cs, Be, Ga, Sn, } \\
\text { Hf, Nb-Ta, B, P, F o } \\
\text { Be, Y, REE, U, Th, } \\
\text { Nb>Ta, F. } \\
\text { Mineralización } \\
\text { pobre a abundante; } \\
\text { gemas y minerales } \\
\text { industriales }\end{array}$ & $\begin{array}{c}\text { Facies anfibolita de } \\
\text { baja presión a } \\
\text { esquistos verdes. } \\
200-400 \mathrm{MPa}, 650- \\
500^{\circ} \mathrm{C}\end{array}$ & $\begin{array}{c}\text { Exteriores, menos } \\
\text { frecuente interiores } \\
\text { o marginales }\end{array}$ & $\begin{array}{l}\text { Ligeramente } \\
\text { concordante o } \\
\text { cortando las } \\
\text { estructuras }\end{array}$ \\
\hline Miarolítica & $\begin{array}{c}\mathrm{Li}, \mathrm{Be}, \mathrm{B}, \mathrm{F}, \mathrm{Ta}>\mathrm{Nb} \text { o } \\
\mathrm{Be}, \mathrm{Y}, \mathrm{REE}, \mathrm{Ti}, \mathrm{U}, \mathrm{Th} \text {, } \\
\mathrm{Zn}, \mathrm{Nb}>\mathrm{Ta} \text {, F. } \\
\text { Mineralización } \\
\text { pobre; gemas }\end{array}$ & $\begin{array}{l}\text { Emplazamiento } \\
\text { superficial a } \\
\text { subvolcánicas }\end{array}$ & $\begin{array}{l}\text { Interiores a } \\
\text { marginales }\end{array}$ & $\begin{array}{l}\text { Lentes interiores } \\
\text { (pods) y diques que } \\
\text { cortan las } \\
\text { estructuras }\end{array}$ \\
\hline
\end{tabular}


Raramente se encuentran en el interior del cuerpo granítico parental formando redes de filones que rellenan fracturas o estructuras generadas tras la consolidación del plutón, siendo lo más común encontrarlas en las rocas metamórficas encajantes del plutón.

- Familia NYF (Nb-Y-F): estas pegmatitas están asociadas a granitos homogéneos de tipo A e I sin- a postorogénicos, escasamente fraccionados y de composición principalmente subalumínica a metalumínica, menos frecuentemente peralumínica y peralcalina. Están enriquecidas en $\mathrm{Nb}>\mathrm{Ta}, \mathrm{Ti}, \mathrm{Y}, \mathrm{Sc}, \mathrm{REE}, \mathrm{Zr}, \mathrm{U}$, Th y $\mathrm{F}$ y proceden de la fusión parcial de materiales mantélicos.

- Familia mixta LCT+NYF: engloba aquellos granitos y pegmatitas que muestran características mineralógicas y geoquímicas mixtas entre las dos familias y que generalmente se explican como producto de contaminación de un magma de tipo NYF por digestión de materiales supracorticales.

Cada una de estas familias se divide en tipos y varias de ellas, además, en subtipos según la mineralogía dominante. Las características y la mineralogía más significativas de cada uno de los tipos y subtipos se recogen en la tabla 1.2.

\section{Mecanismos de formación y zonación regional}

Para explicar la formación de las pegmatitas graníticas existen dos hipótesis enfrentadas históricamente (Černý et al., 2005a y referencias en el interior). La primera y más común aboga por un origen magmático de los diques pegmatíticos a partir de los fundidos residuales diferenciados de intrusiones graníticas. Esta hipótesis está avalada por criterios de campo, geoquímicos y de petrología experimental. La alternativa a esta teoría es la anatexia directa de rocas con una composición química adecuada, como metasedimentos con evaporitas, que tendría lugar alrededor de los plutones en ambientes orogénicos, produciendo magmas pegmatíticos.

Las altas concentraciones de volátiles y agua que presentan estos fundidos pegmatíticos incrementan su fluidez y movilidad, y facilita que sean estables a baja temperatura. Así, la mayor o menor concentración en volátiles y el grado de evolución de los magmas pegmatíticos sería la causa de la mayor o menor distancia de emplazamiento de estos diques respecto del granito parental (Černý, 1991a). En función de esto, se reconocen estructuralmente tres tipos de diques: interiores, marginales y exteriores. Las pegmatitas interiores y marginales son las menos evolucionadas o estériles, y se encuentran dentro o en las zonas marginales del plutón. Sin embargo, las pegmatitas exteriores encajan fuera del plutón, siendo generalmente las más abundantes y mineralógicamente complejas, derivadas de magmas más evolucionados y ricos en volátiles. Estas pertenecen comúnmente a la familia LCT, pudiendo desarrollar una zonación regional en relación con el plutón parental (Černý, 1989b), de manera que los diques menos evolucionados se encuentren más próximos al plutón mientras que los más evolucionados y enriquecidos en elementos raros afloran en zonas más alejadas del mismo (Fig. 1.4). Esta secuencia, desde el cuerpo granítico hacia el exterior, estaría compuesta por pegmatitas: 1) estériles, 2) tipo REE, 3) subtipo berilo-columbita, 4) subtipo berilo-columbitafosfato, 5) subtipo espodumena o petalia, 6) subtipo lepidolita, 7) tipo albita-espodumena y 8) tipo albita. Generalmente, a medida que aumenta la complejidad y el grado de evolución 


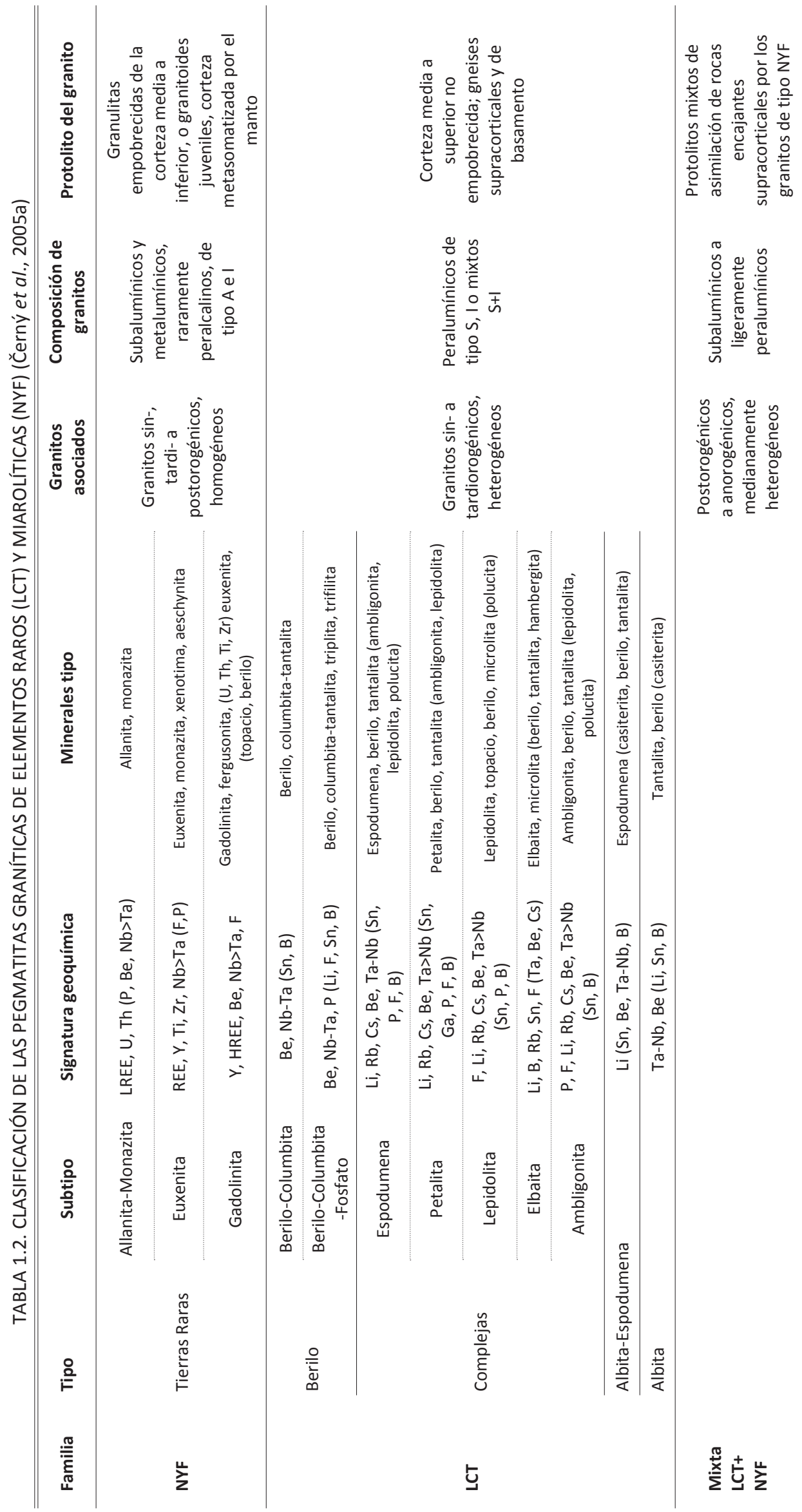




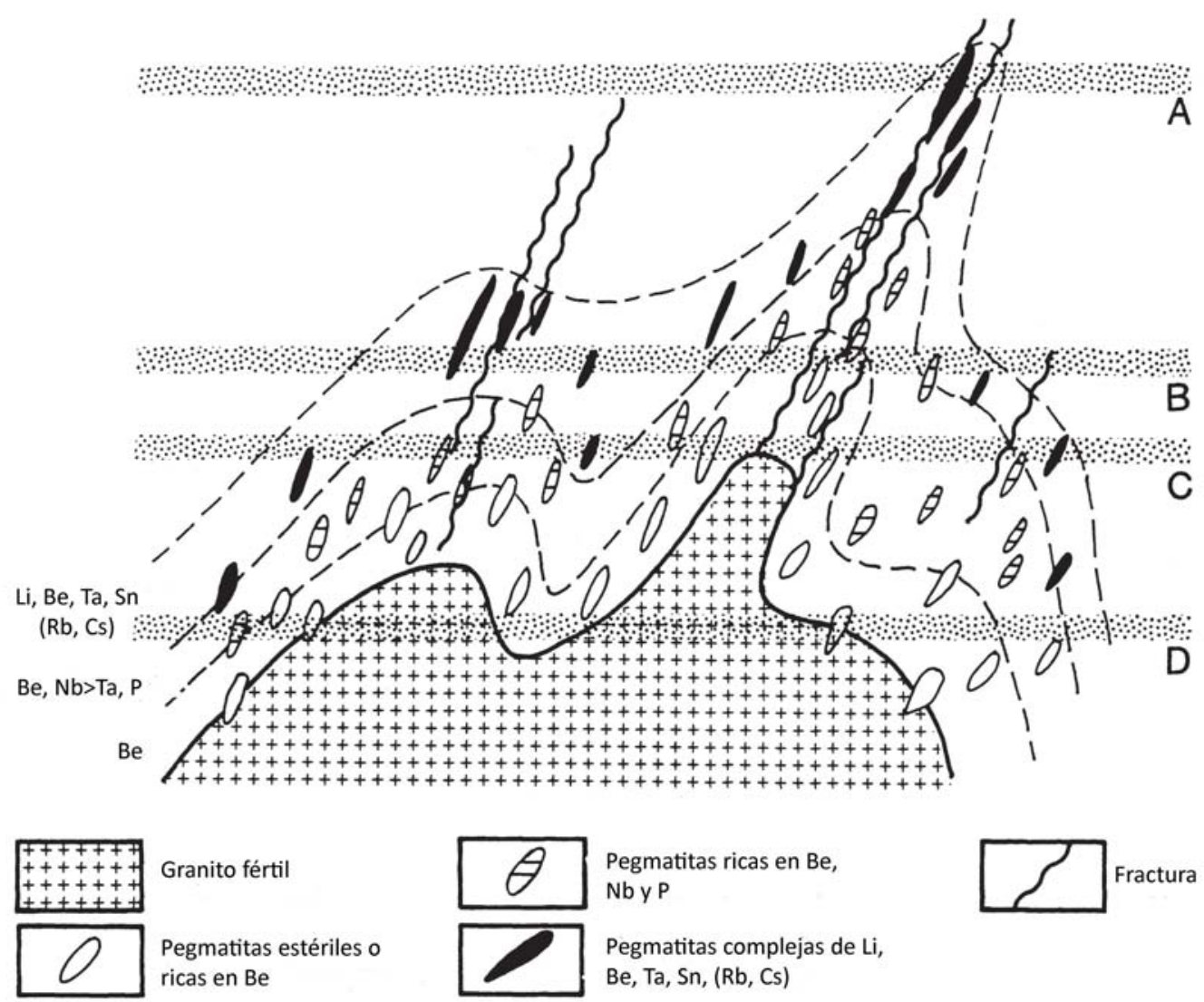

Fig. 1.4. Sección esquemática vertical de un sistema zonado compuesto por granito y pegmatitas. A, B, C y D marcan los niveles potenciales de erosión (modificado de Černý, 1989b).

de las pegmatitas decrece su abundancia. Posteriormente, London (2005) sugirió que una cámara magmática zonada pudo dar lugar a diferentes pulsos de magmas pegmatíticos que causara esta zonación regional.

\section{Zonación y evolución interna de las pegmatitas}

Heinrich (1948) clasificó las pegmatitas, en función de si presentaban zonación o no y si esta era simple o compleja, en tres tipos:

- Pegmatitas simples: presentan una composición y un tamaño de grano homogéneos desde la pared hasta el núcleo y una mineralogía simple.

- Pegmatitas zonadas: muestran una zonación simple constituida por capas más o menos continuas que se denominan zonas y que generalmente se disponen de manera simétrica alrededor de un núcleo, aumentando el tamaño de grano y simplificando la mineralogía desde el borde hasta el interior de los diques.

- Pegmatitas complejas: se denomina así a las pegmatitas zonadas que presentan unidades secundarias de reemplazamiento. Son las más raras aunque las más interesantes económica y mineralógicamente debido a la acumulación de elementos raros o exóticos en estas unidades tardías, que suelen ser irregulares tanto en forma como en distribución (Fig. 1.5). Suelen cortar 


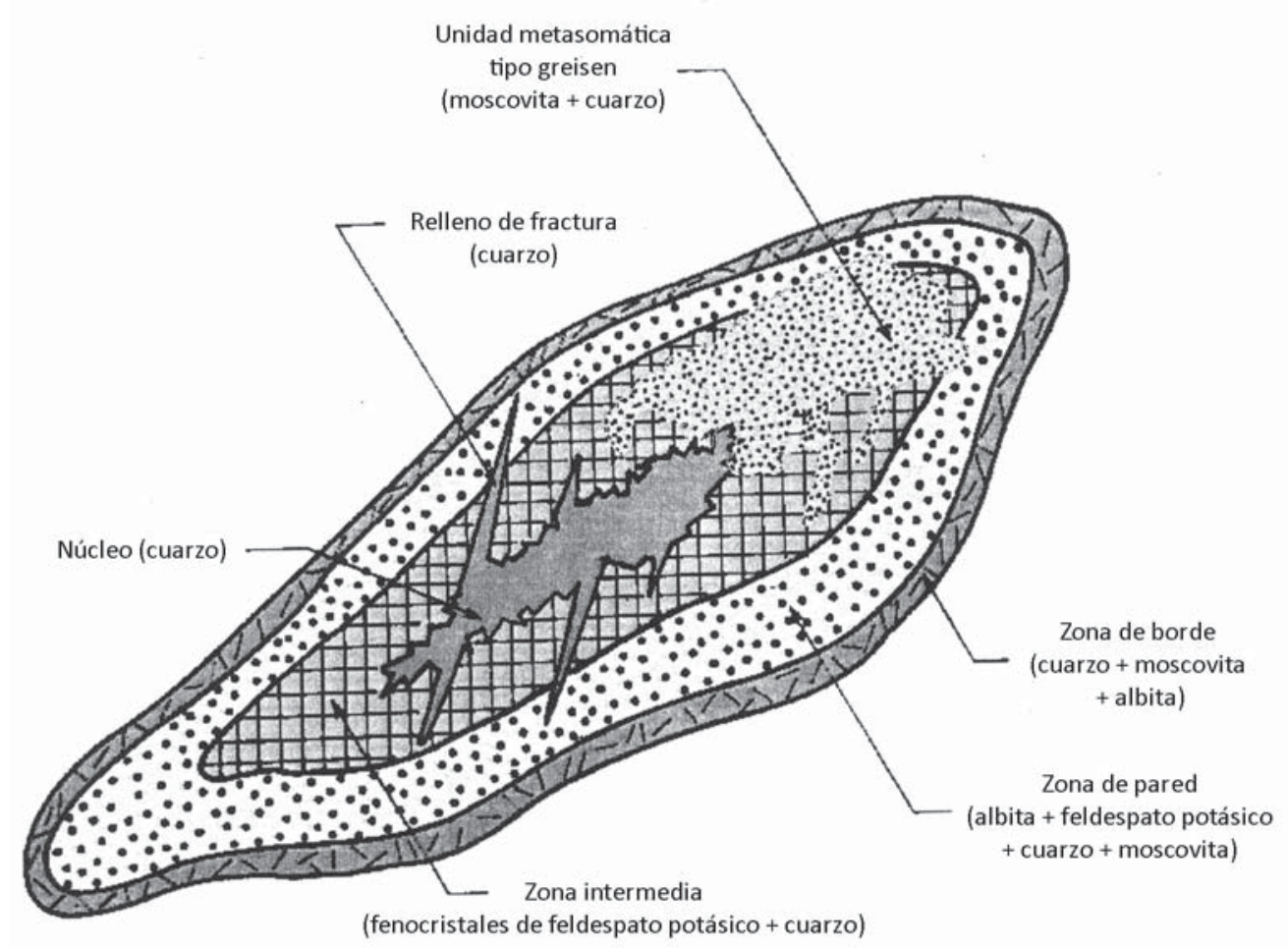

Fig. 1.5. Esquema de la zonación típica de las pegmatitas complejas (tomado de Černý, 1991b).

y superponerse a la zonación primaria llegando, en ocasiones, a destruir completamente el zonado original, y presentan un tamaño de grano muy fino.

La nomenclatura empleada para describir estas zonaciones fue recogida por Cameron et al. (1949), basándose en la distribución interna de los principales minerales que componen la pegmatita y que varían desde el borde de las pegmatitas hasta el núcleo. La composición mineral de una típica pegmatita zonada se muestra en la tabla 1.3.

Esta zonación interna de los diques pegmatíticos es uno de los principales problemas que se ha intentado resolver con los diferentes modelos de evolución interna, entre los que destacan el modelo antiguo de Jahns y Burnham (1969) y el modelo, actualmente más aceptado, de London (Constitutional zone refining; 1992, 2005, 2008). En todos ellos el denominador común es la importancia de los componentes volátiles de los fundidos pegmatíticos.

\section{Mineralización hidrotermal de tipo greisen y filoniana}

La circulación tardi a postmagmática de fluidos exsueltos de leucogranitos peralumínicos o metalumínicos altamente fraccionados durante las últimas etapas de la cristalización magmática produce una alteración hidrotermal en las zonas apicales de los mismos. Esta alteración hidrotermal supone una serie de procesos metasomáticos en los que los álcalis y el $\mathrm{H}^{+}$son especialmente importantes. Así, a medida que aumenta la actividad del $\mathrm{H}^{+} \mathrm{y}$ disminuye la temperatura, las alteraciones que se producen son un metasomatismo alcalino, 
TABLA 1.3. ZONACIÓN TÍPICA DE UNA PEGMATITA (Simmons et al., 2003)

\begin{tabular}{|c|c|c|c|}
\hline Zona & Textura & Minerales principales & Minerales accesorios \\
\hline Zona de borde & Grano fino & $\begin{array}{l}\text { Plagioclasa o microclina, } \\
\text { cuarzo, } \pm \text { moscovita }\end{array}$ & $\begin{array}{c}\text { Chorlo, granate, } \\
\text { magnetita, microclina o } \\
\text { plagioclasa }\end{array}$ \\
\hline Zona de pared & $\begin{array}{c}\text { Grano más grueso que la } \\
\text { anterior }\end{array}$ & $\begin{array}{c}\text { Cuarzo, plagioclasa, } \\
\text { microclina, } \pm \text { moscovita, } \\
\pm \text { biotita }\end{array}$ & $\begin{array}{c}\text { Chorlo, granate, berilo, } \\
\text { apatito }\end{array}$ \\
\hline Zona intermedia exterior & $\begin{array}{l}\text { Aumento progresivo del } \\
\text { tamaño de grano hasta } \\
\text { cristales gigantes; } \\
\text { desarrollo de pockets }\end{array}$ & Microclina, cuarzo & $\begin{array}{c}\text { Chorlo-elbaita, plagioclasa } \\
\text { sódica, moscovita, } \\
\text { fosfatos }\end{array}$ \\
\hline $\begin{array}{l}\text { Zona intermedia interior } \\
\text { (Margen del núcleo) }\end{array}$ & $\begin{array}{l}\text { Grano fino y grueso, } \\
\text { ocasionalmente cristales } \\
\text { gigantes; desarrollo de } \\
\text { pockets }\end{array}$ & $\begin{array}{l}\text { Cuarzo, microclina, } \\
\text { plagioclasa sódica, } \\
\pm \text { moscovita, } \pm \text { biotita }\end{array}$ & $\begin{array}{c}\text { Chorlo-elbaita, berilo, } \\
\text { fosfatos, minerales de } \mathrm{Nb} \text { - } \\
\mathrm{Ta}\end{array}$ \\
\hline Núcleo & & Cuarzo & Berilo, espodumena \\
\hline
\end{tabular}

una moscovitización, greisenización y, por último, alteración argilítica. Otras alteraciones no ligadas a la actividad del $\mathrm{H}^{+}$son la turmalinización y la silicificación.

La mineralización en los depósitos tipo greisen contiene Sn y/o W principalmente en forma de casiterita y wolframita en proporciones variables, a los que se asocian otros elementos como $\mathrm{Mo}, \mathrm{Cu}, \mathrm{Pb}, \mathrm{Zn}, \mathrm{Ag}, \mathrm{F}, \mathrm{U}, \mathrm{In}$, Bey Li en cantidades también variables y, en ocasiones Au (Thompson et al., 1999). Esta mineralización aparece diseminada o bien en lentejones, venas, filones o brechas dentro del plutón (endogreisen), o en la roca encajante del mismo (exogreisen) (Fig. 1.6). Consiste en el reemplazamiento de los minerales primarios del granito por un agregado de cuarzo y moscovita principalmente, al que se asocian otros minerales secundarios como topacio, andalucita, turmalina, berilo y fluorita. La sílice liberada durante la greisenización precipita formando venas individuales 0 agrupadas en haces en todas direcciones (stockwork), o filones encajados en el propio granito o en

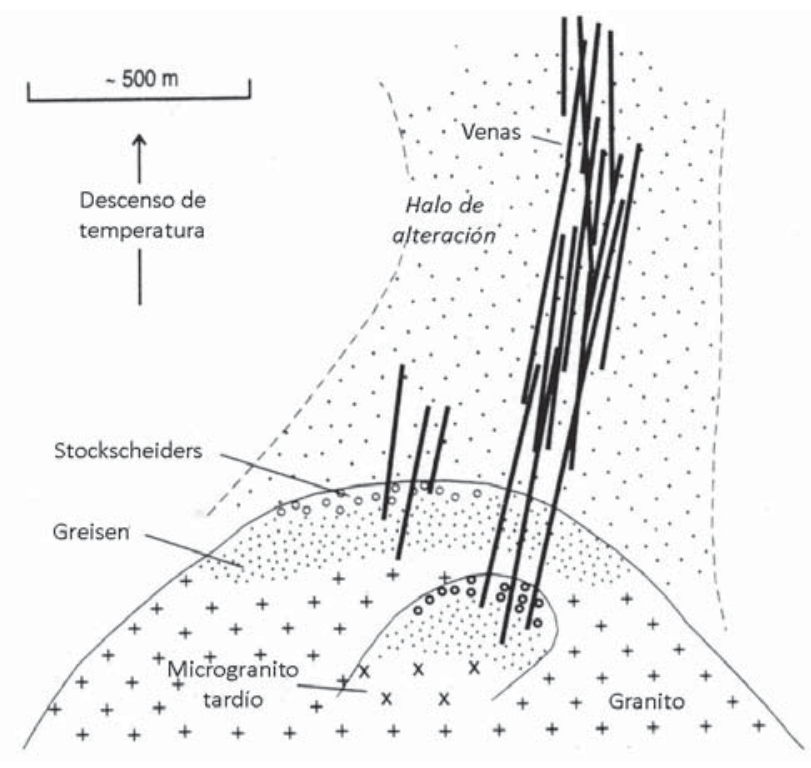

Fig. 1.6. Sección esquemática vertical de un sistema hidrotermal típico de cúpula granítica mineralizada (tomado de Černý et al., 2005a). la roca encajante.

Ejemplos de este tipo de depósitos a lo largo del Cinturón Varisco Europeo son los sistemas de venas de Sn-(W) de Cornwall, en el suroeste de Inglaterra (Charoy, 1986; Willis-Richards y Jackson, 1989), o la mineralización de wolframita y casiterita del granito de Vienne (Bouchot et 
al., 2005; Cuney et al., 2002), en el Macizo Central Francés. En el Macizo Ibérico el yacimiento de wolframita de Panasqueira, en el tercio norte de Portugal (Clark, 1964; Kelly y Rye, 1979; Neiva, 1996, 2008), así como las venas de cuarzo con $\mathrm{S} n \pm$ W de Golpejas y Teba (Mangas y Arribas, 1987) o del distrito de Beariz (Gloaguen, 2006), ligados todos ellos a leucogranitos del norte y oeste de España. 
CAPÍTULO2

Encuadre geológico del distrito de Navasfrías 



\section{CAPÍTULO 2. ENCUADRE GEOLÓGICO DEL DISTRITO DE NAVASFRÍAS}

El distrito de Navasfrías está situado en el Macizo Ibérico (Fig. 2.1) dentro de la denominada Zona Centroibérica de Julivert et al. (1972), que se caracteriza por un basamento gnéisico sobre el que se superpone una potente serie sedimentaria que constituye el Dominio del Complejo Esquisto-Grauváquico (Martínez Catalán et al., 2004), todo ello intruido por un magmatismo sin- o tardicinemático de edad comprendida entre los 300 y los $325 \mathrm{Ma}$ (Bea et al., 2003). En la parte central de este dominio es donde afloran los batolitos de Jálama y de Cadalso-Casillas de Flores, a los que están asociadas la mayoría de las mineralizaciones. Las distintas fases de deformación y fracturación registradas en esta zona condicionan notablemente la orientación de los diques y de las venas de cuarzo mineralizadas.

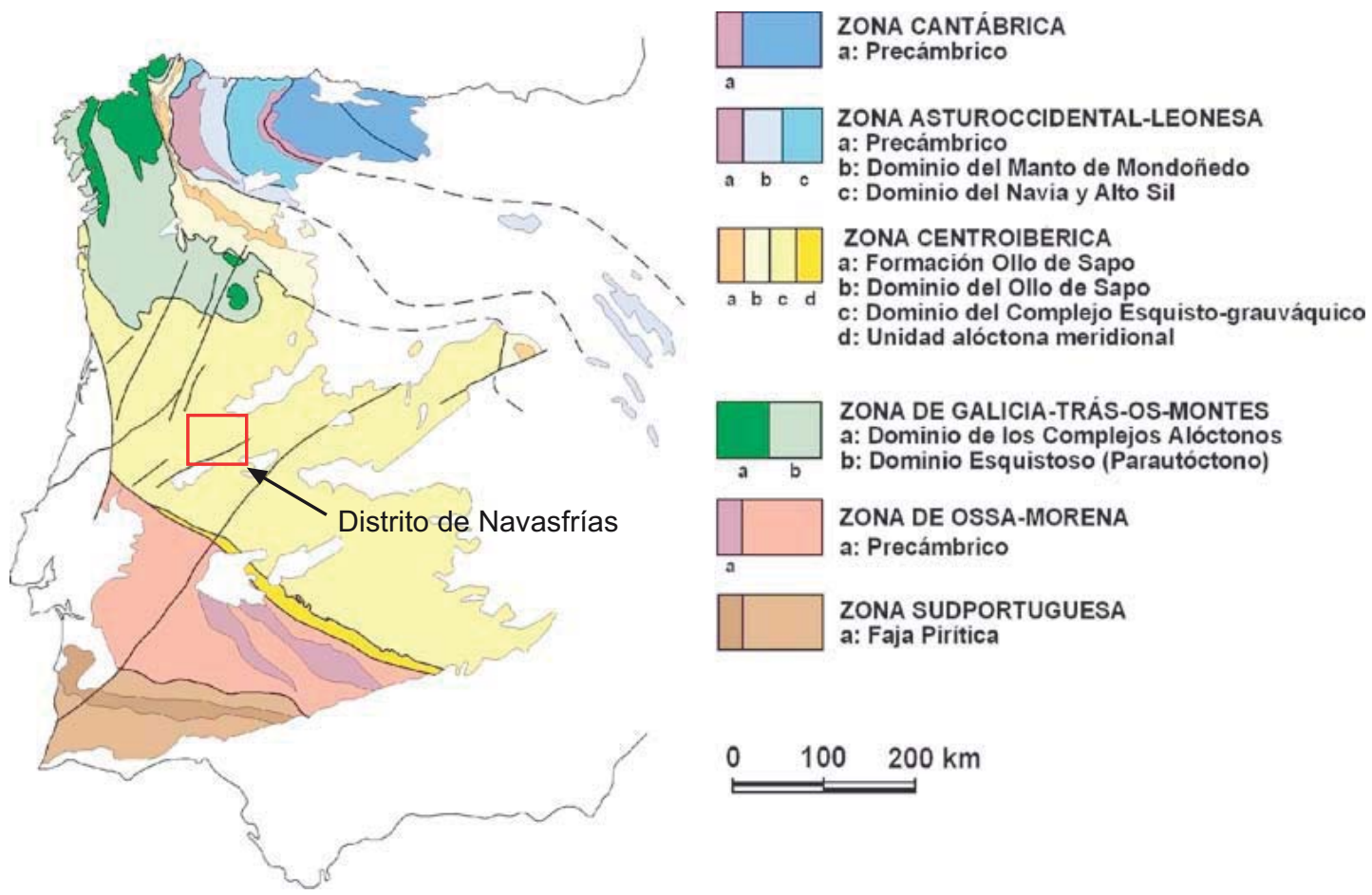

Fig. 2.1. Esquema del Macizo Ibérico con la situación del distrito de Navasfrías (Martínez Catalán et al., 2004).

\subsection{ROCAS METAMÓRFICAS}

En elárea del distrito de Navasfrías pueden considerarse dos grandes unidades litoestratigráficas pertenecientes al Complejo Esquisto-Grauváquico (CEG), la Unidad Inferior y la Unidad Superior (Rodríguez Alonso, 1985; Rodríguez Alonso y Alonso Gavilán, 1995; Valladares et al., 2000), que registran la transición Precámbrico-Cámbrico, quedando relegadas las rocas de edad ordovícica al núcleo de sinclinales alejados de la zona de estudio. Los materiales más recientes corresponden a los sedimentos terciarios y cuaternarios de la Cuenca de Ciudad Rodrigo (Rodríguez Alonso et al., 1990), en el extremo suroccidental de la Cuenca del Duero, y de la Fosa de Moraleja (Alonso Gavilán, 1981), al sur del batolito de Jálama (Fig. 2.2). 
Fig. 2.2. Esquema geológico del distrito de Navasfrías con los afloramientos de la Unidad Superior e Inferior del Complejo Esquisto-Grauváquico y los granitoides variscos. Modificado de Rodríguez Alonso et al. (2004).

\subsubsection{Unidad Inferior}

La Unidad Inferior aflora extensamente en el sector del Sur de Salamanca-Ciudad RodrigoHurdes-Sierra de Gata, donde se ha denominado "Serie Inferior" (Fig. 2.3) y está subdividida en tres unidades (Fig. 2.2) (Ugidos et al., 1997a,b; Valladares et al., 1998, 2000, 2002a). Presenta una sucesión monótona de lutitas y areniscas con intercalaciones conglomeráticas,

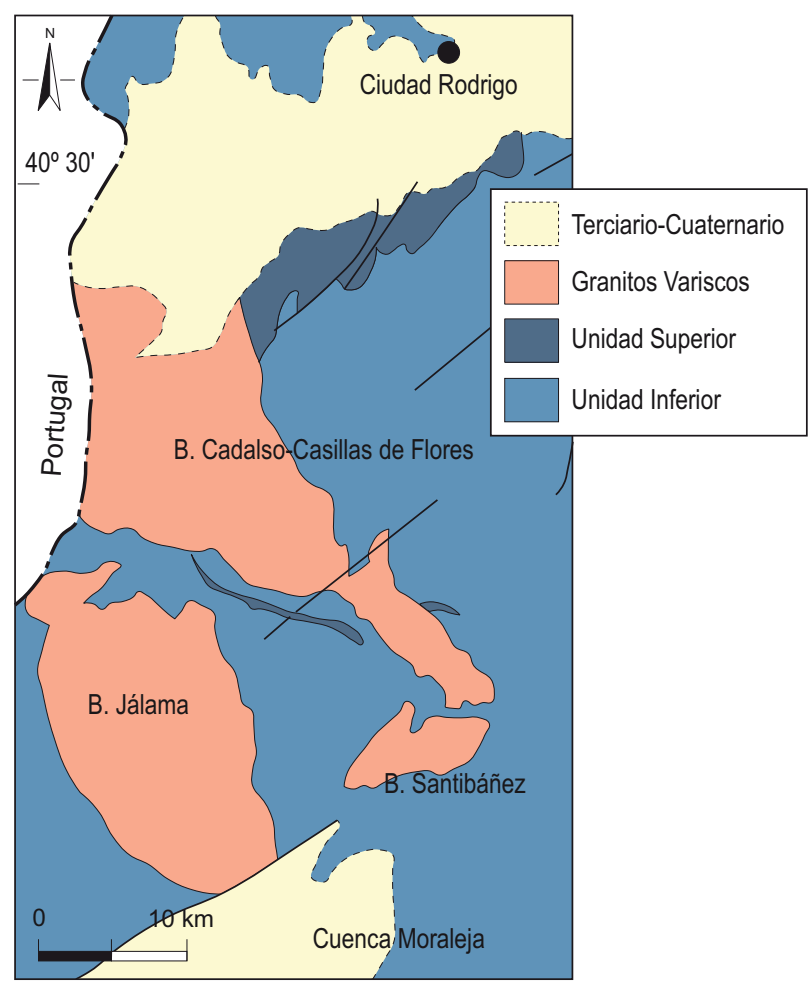
anfibolíticas y vulcanoclásticas muy ocasionales, cuyo límite inferior se desconoce y que se interpreta fundamentalmente como depósitos de turbiditas de abanicos submarinos, taludes y canales (Rodríguez Alonso, 1985; San José et al., 1990; Valladares et al., 2000; Pieren, 2000). La presencia de abundantes microfósiles en algunos lugares permiten datar esta unidad como Vendiense terminal (Palacios, 1989; Vidal et al., 1994a,b).

\subsubsection{Unidad superior}

La Unidad Superior aflora poco en el área de Navasfrías (Fig. 2.2). Correlaciona con las Fm. Monterrubio y Aldeatejada (Díez Balda, 1980, 1986) y con las "Series Intermedia y Superior", subdivididas en nueve unidades (Fig. 2.3) (Ugidos et al., 1997a,b; Valladares et al., 1998, 2000, 2002a). Presenta una mayor variabilidad litológica y es fundamentalmente pelítica, estando compuesta por lutitas negras con intercalaciones de areniscas y conglomerados además de niveles olistostrómicos, calizas, intercalaciones y nódulos fosfatados y niveles vulcanoclásticos ocasionales, que fueron depositados en distintos ambientes paleogeográficos.

\subsection{ROCAS GRANÍTICAS}

Las rocas metamórficas del Complejo Esquisto-Grauváquico fueron intruidas por el batolito de Cadalso-Casillas de Flores al norte (Hassan, 1996) y por el batolito de Jálama (Ramírez, 1996) y el plutón de Santibáñez (García de Figuerola et al., 1985b) al sur. Todos ellos son plutones alóctonos de composición peralumínica y zonados, que desarrollan una aureola de metamorfismo de contacto cuya paragénesis mineral indica una profundidad de emplazamiento somera (Ramírez y Grundvig, 2000). 


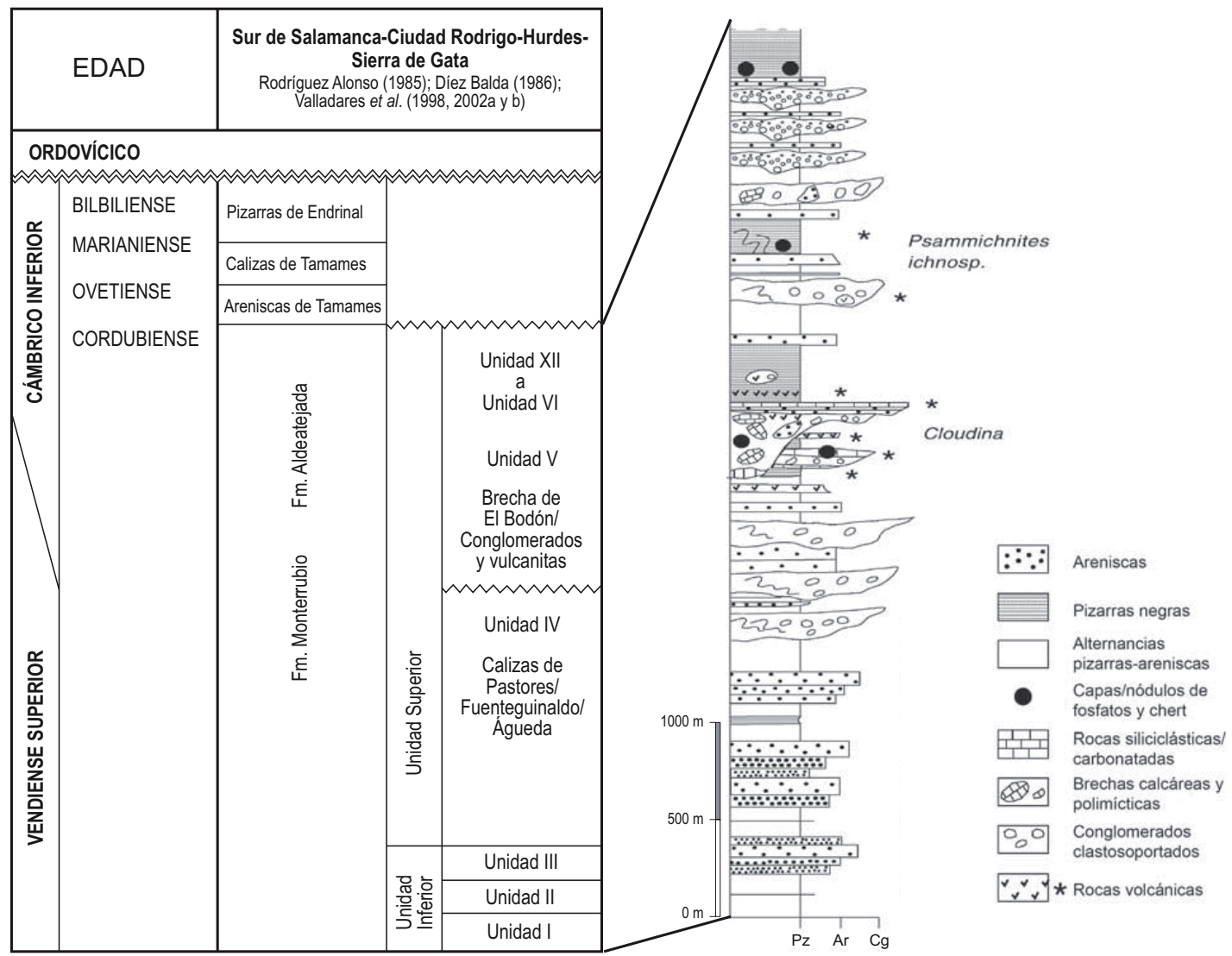

Fig. 2.3. Cuadro cronoestratigráfico de correlación de las distintas Unidades y Formaciones preordovícicas definidas en la zona de Salamanca-Ciudad Rodrigo-Hurdes-Sierra de Gata (Martínez Catalán et al., 2004) y secuencia estratigráfica representativa (Rodríguez Alonso et al., 2004).

\subsubsection{Batolito de Jálama}

El batolito de Jálama es un cuerpo alóctono de aproximadamente $220 \mathrm{~km}^{2}$ que aflora desde la zona centro-este de Portugal hasta el sur de Salamanca y el norte de Cáceres y que presenta una forma elíptica y discordante, con su eje mayor en dirección NNW-SSE. Su emplazamiento tuvo lugar tras las principales fases de deformación Varisca (D1 y D2) a una presión de entre 2-3 kbar, estando datado dicho emplazamiento en $300 \mathrm{Ma}$ mediante el método de Rb/Sr en roca total (Ramírez, 1996).

Presenta una amplia variabilidad litológica y una marcada zonación de las facies graníticas que lo componen, pudiendo considerarse un granito de tipo Araya (Corretgé et al., 1985; Ramírez, 1996; Ramírez y Grundvig, 2000). En este trabajo se emplea la descripción petrográfica de las facies graníticas que componen el batolito de Jálama definida por Ramírez (1996) y Ramírez y Grundvig (2000) (Fig. 2.4).

\subsubsection{La Unidad Externa (UE)}

La Unidad Externa (UE) ocupa la mayor parte del batolito y especialmente la mitad norte. Se compone de tres facies que, desde el centro hacia el margen norte del plutón, son: monzogranito porfídico de dos micas (MP), granito equigranular de dos micas (GE) 
y leucogranito con turmalina (LG), con diques aplíticos de borde ( $A B$ ) y pegmoaplíticos asociados. Dicha Unidad Externa se encuentra localmente cortada por diques pegmatíticos cuya abundancia y complejidad aumenta hacia la margen norte de dicho batolito, al igual que las mineralizaciones de $\mathrm{Sn}$ y $\mathrm{W}$ asociadas a las venas de cuarzo. Estas facies se relacionan entre sí mediante contactos graduales paralelos a los márgenes de la intrusión y su distribución define una zonación en la vertical y en la horizontal del plutón que representa una serie de diferenciación magmática (Ramírez, 1996). En su composición destacan feldespato potásico, plagioclasa, cuarzo, moscovita y biotita como minerales esenciales. Minerales accesorios comunes a las tres facies son apatito y circón, mientras que allanita, thorita y sillimanita se encuentran únicamente en algunas muestras del monzogranito porfídico (Ramírez, 1996), además de arsenopirita, pirita y löllingita que también aparecen en el leucogranito con turmalina y las aplitas de borde. Topacio, ambligonita-montebrasita, trifilita-litiofilita, triplita, uraninita, casiterita, columbita y tapiolita fueron documentados por Ramírez (1996) como exclusivos de las facies de borde.

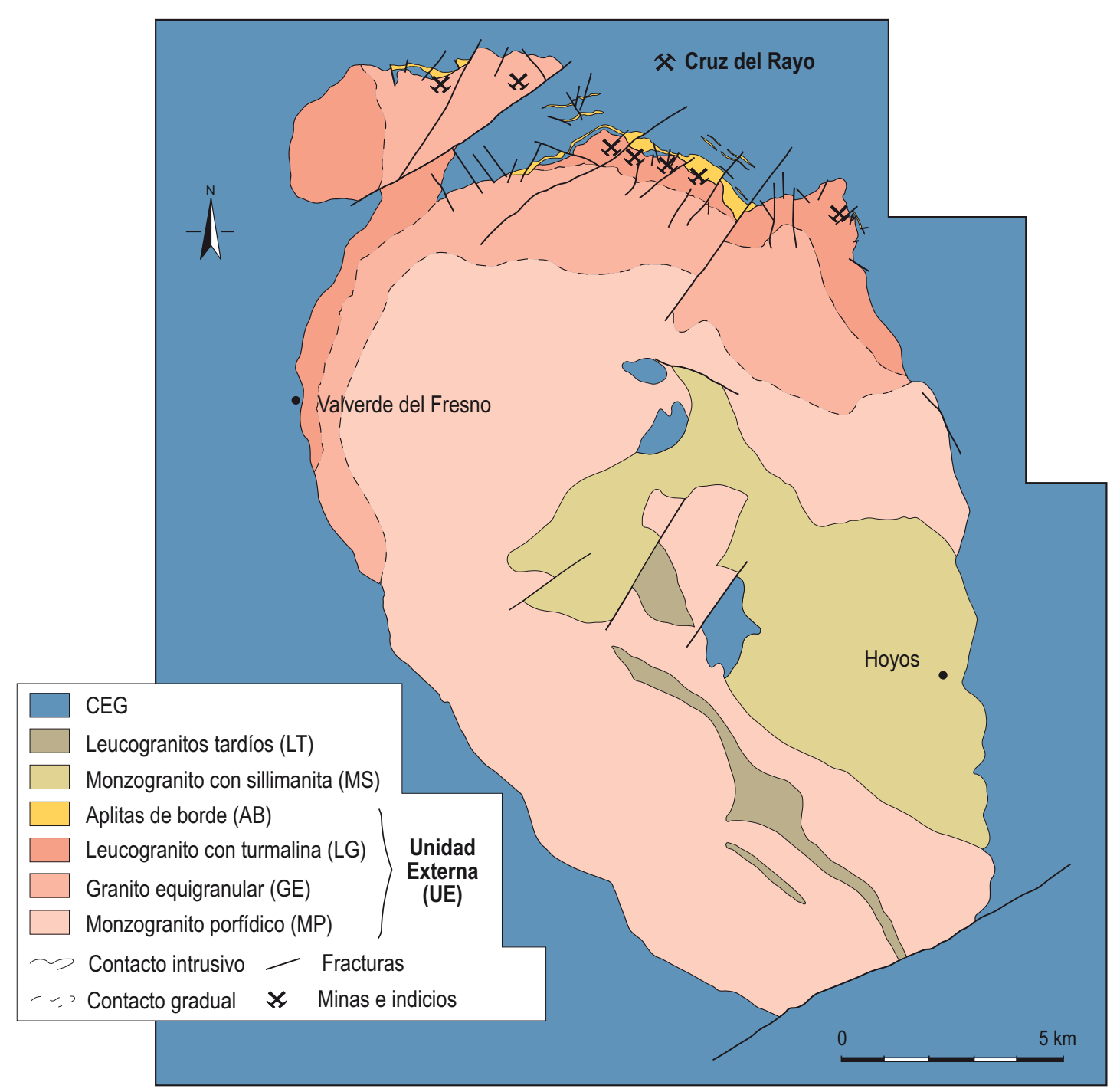

Fig. 2.4. Esquema geológico del batolito de Jálama (modificado de Ramírez, 1996; Ramírez y Grundvig, 2000). 
El monzogranito porfídico de dos micas y grano grueso (MP), ocupa aproximadamente el $50 \%$ de la superficie total del batolito y se caracteriza por la presencia de fenocristales de feldespato potásico de gran tamaño. El granito equigranular de dos micas y grano grueso (GE) presenta la misma mineralogía que el anterior, a excepción de los fenocristales de feldespato potásico, mientras que tanto el leucogranito (LG) como las aplitas de borde ( $A B$ ) son más ricos en moscovita y aparece turmalina en lugar de biotita. Estos diques aplíticos de borde son cuerpos encajados en la aureola de metamorfismo de contacto paralelamente al margen del plutón que pueden alcanzar los $200 \mathrm{~m}$ de ancho, aunque lo normal es que no sobrepasen los $10 \mathrm{~m}$, y que presentan abundante moscovita y turmalina en su composición. Estas tres últimas facies afloran únicamente en el tercio norte del batolito (Fig. 2.4).

Ramírez (1996) distinguió tres tipos de enclaves: microgranulares de morfología elipsoidal y composición tonalítica-granodiorítica, de hasta $10 \mathrm{~m}$ de diámetro; xenolitos de la roca encajante, con formas angulares y de tamaños variables, alcanzando incluso tamaños hectométricos, que se interpretan como restos hundidos del techo de la cámara magmática; y micáceos constituidos principalmente por biotita y de tendencia angulosa o planar.

Las variaciones desde el monzogranito porfídico hasta el leucogranito con turmalina y las aplitas de borde consisten en el progresivo descenso de la cantidad de biotita, feldespato potásico y enclaves granodioríticos y el aumento progresivo de las cantidades de moscovita, turmalina y diques aplíticos y pegmatíticos. Fernández-Leyva (2007) dató la intrusión de la UE en $279 \pm 9$ Ma mediante $\mathrm{Rb} / \mathrm{Sr}$ de roca total.

Las facies que componen la UE, en especial el granito equigranular de dos micas (GE) y el leucogranito con turmalina (LG), experimentan variaciones texturales y mineralógicas causadas por alteraciones tardi- a postmagmáticas, entre las que destacan: un intenso metasomatismo sódico, una moscovitización de la biotita, una greisenización parcial de algunas zonas de borde, especialmente bordes de diques aplíticos y/o pegmatíticos, una turmalinización que se dispone especialmente a lo largo de bandeados en el leucogranito y los diques aplíticos de las zonas de borde, una caolinización local de algunos sectores del leucogranito con turmalina y silicificaciones locales que ocurren de una manera más o menos constante durante la evolución del sistema.

\subsubsection{Monzogranito con sillimanita (MS)}

El monzogranito con sillimanita aflora en la zona central y oriental del plutón formando una ancha banda paralela a la elongación del mismo (Fig. 2.4) y muestra contactos intrusivos con el monzogranito porfídico de la UE, sugiriendo un emplazamiento contemporáneo de ambos tipos de rocas. Es un granito de dos micas de grano fino a medio compuesto por cuarzo, feldespato potásico, plagioclasa, biotita y moscovita como minerales esenciales, con sillimanita, apatito, circón, monacita, allanita y turmalina como accesorios. Contiene dos tipos de enclaves, unos granodioríticos y otros micáceos de entre 1 y $2 \mathrm{~cm}$ de diámetro, estos últimos interpretados como restitas y cuya abundancia marca la existencia de una subfacies rica en restitas y con abundantes megacristales de feldespato potásico y otra pobre en restitas, que presenta una textura granítica (Ramírez, 1996). 


\subsubsection{Leucogranitos tardíos (LT)}

Los leucogranitos tardíos intruyen en las zonas centrales del batolito de Jálama con posterioridad a los monzogranitos, formando diques alargados en la dirección de elongamiento del batolito que intruyen, en algunos casos, a favor de zonas de fracturas (Fig. 2.4). Localmente puede presentar otros diques satélites de menor tamaño. Estos leucogranitos están compuestos esencialmente por cuarzo, plagioclasa, moscovita y feldespato potásico, con apatito, monacita, circón, biotita y uraninita como minerales accesorios, y presentan una textura aplítica o equigranular, similar a los leucogranitos ricos en turmalina de la UE (Ramírez, 1996).

\subsubsection{Batolito de Cadalso-Casillas de Flores}

Los granitoides que constituyen el batolito de Cadalso-Casillas de Flores pertenecen a la prolongación más meridional del batolito de Guarda, en Portugal. Dicho macizo presenta una forma alargada en dirección NO-SE con una longitud aproximada de $34 \mathrm{~km}$. Intruye, en su mayor parte, en los materiales metamórficos preordovícicos del Complejo EsquistoGrauváquico; sin embargo, en el sector NO está cubierto por los sedimentos terciarios y cuaternarios del borde sur de la cuenca de Ciudad Rodrigo (Hassan, 1996).

En este trabajo se ha seguido la descripción de las facies que componen el batolito de CadalsoCasillas de Flores realizada por Hassan (1996), quien diferenció seis facies principales (Fig. 2.5). La asociación paragenética observada en todas las unidades diferenciadas es característica de los granitos peralumínicos del tipo-S, pobres en $\mathrm{CaO}$ y ricos en $\mathrm{P}_{2} \mathrm{O}_{5}$ (Cuney et al., 1979; Cuney y Friedrich, 1987; Bea et al., 1992; London et al., 1989, 1993).

Las relaciones espaciales existentes entre las facies principales sugieren la existencia de dos etapas de intrusión que forman dos complejos graníticos: el complejo de El Payo y el complejo de Peñaparda, siendo ambos el resultado de la fusión parcial de una fuente pelítica (Miller, 1985) y teniendo el segundo un grado de evolución más avanzado al del primer complejo, al que intruye a través de fracturas.

\subsubsection{Complejo de El Payo}

El complejo del Payo ocupa más del $90 \%$ del macizo y está compuesto por las facies G1, G2, G3, G4 y G7, siendo todas ellas el resultado de una cristalización fraccionada continuada desde $\mathrm{G} 1$ hasta $\mathrm{G} 4$, lo que supone un decrecimiento del carácter porfídico y biotítico y de la abundancia de enclaves y un incremento del contenido en moscovita.

El granito biotítico de grano grueso inequigranular y porfídico de Gata (G1) aflora en la parte más suroccidental del batolito (Fig. 2.5). Se compone esencialmente de cuarzo, plagioclasa, fenocristales de feldespato potásico y biotita, con moscovita, clorita, circón, ilmenita, monacita, apatito, allanita, fluorita y sulfuros como minerales accesorios más frecuentes. Es característica la existencia de nidos de biotita asociados a cordierita y de estructuras de flujo. Presenta abundantes enclaves micáceos, restíticos y metamórficos del CEG que pueden superar los $80 \mathrm{~cm}$. Escasos diques aplíticos y aplopegmatíticos en dirección N-S atraviesan la unidad. 


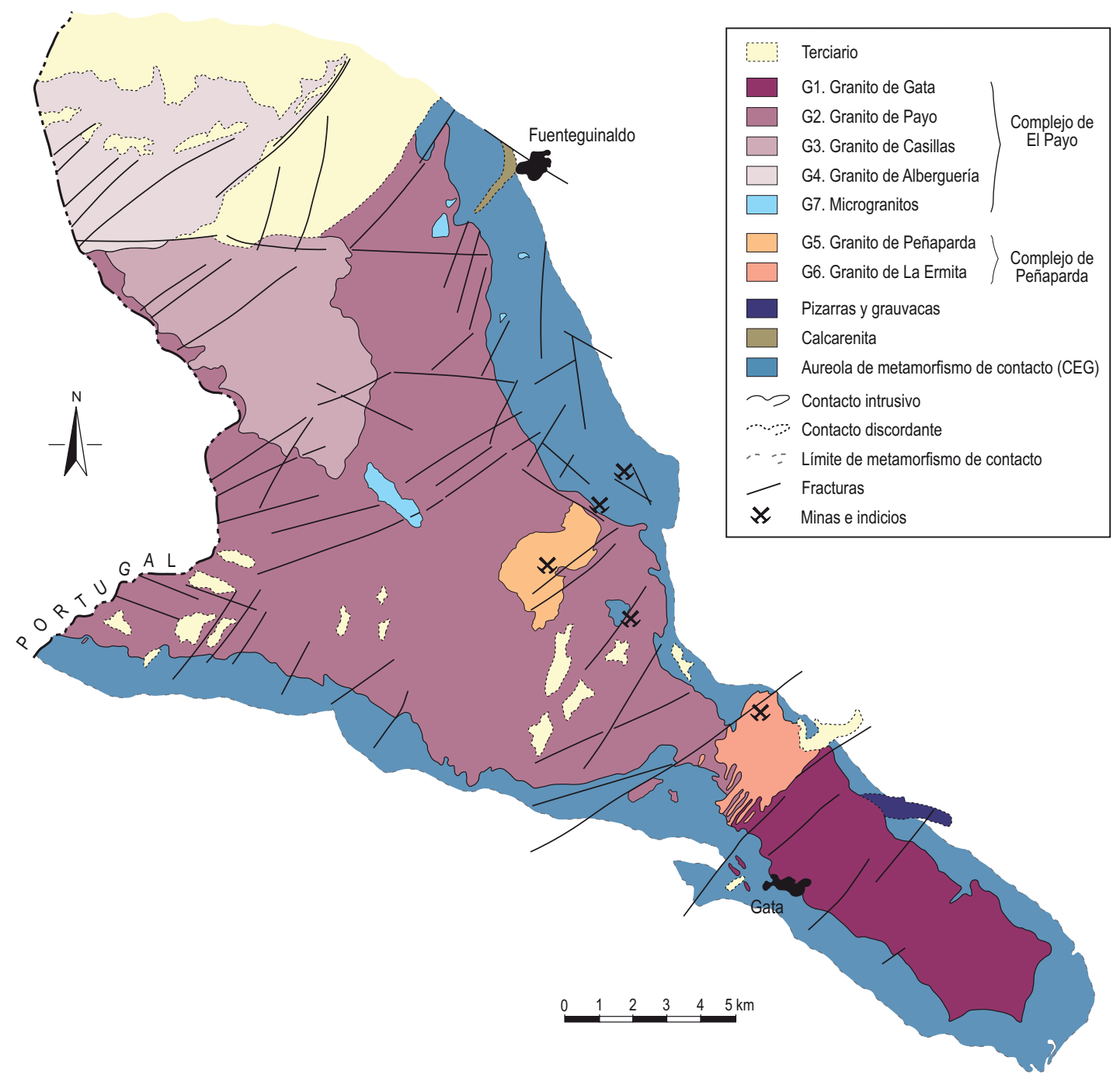

Fig. 2.5. Esquema geológico del batolito de Cadalso-Casillas de Flores (Hassan, 1996).

El granito biotítico de El Payo (G2) es la unidad más extensa que ocupa el batolito (Fig. 2.5) y está formada por una roca de grano grueso a muy grueso, con frecuentes acumulaciones de fenocristales de feldespato potásico de hasta $8 \mathrm{~cm}$ y nidos de biotita menos abundantes que en la facies G1. La moscovita en este caso es también un mineral mayoritario y entre los accesorios, además de los descritos en la facies anterior, destaca la presencia de andalucita, fibrolita, uraninita, rutilo y sulfuros. Se han diferenciado varios tipos de enclaves. Por un lado, enclaves hornfélsicos interpretados como restos del encajante metamórfico no digeridos; enclaves micáceos de hasta $10 \mathrm{~cm}$ de tamaño; enclaves microgranulares y graníticos, muy abundantes y de composición similar al granito que los aloja; y por último, enclaves procedentes de la facies G1, que llegan a superar los $80 \mathrm{~cm}$ de diámetro y que se habrían formado mediante un proceso de stopping. Presenta diques aplíticos y aplopegmatíticos de dirección E-O y otros N-S de escasa potencia, además de venas de turmalina especialmente abundantes en las zonas centrales y orientadas al N o NE y venas de cuarzo en dirección N30$\mathrm{N} 50^{\circ} \mathrm{E}$. 
El granito de dos micas de Casillas de Flores (G3) es una roca de grano medio a grueso, en ocasiones porfídica, con fenocristales de feldespato potásico, en la que biotita y moscovita se encuentran en proporciones similares (Fig. 2.5). Entre los minerales accesorios, además de los descritos en unidades previas, destacan fosfosilicatos de tierras raras ligeras y silicatos de Th como productos de alteración de la monacita. Los enclaves son mucho menos abundantes, diferenciándose los micáceos y los enclaves procedentes del granito encajante de la facies G2. Presenta una red filoniana compuesta por diques aplíticos y aplopegmatíticos de hasta 30 $\mathrm{cm}$ de potencia, diques de cuarzo de potencias inferiores a $60 \mathrm{~cm}$ y no mineralizados y diques básicos, todos ellos orientados al NE, además de venas de turmalina tardías.

El granito moscovítico \pm biotita de La Alberguería (G4) está limitado al norte por los sedimentos terciarios y cuaternarios de la Cuenca de Ciudad Rodrigo (Fig. 2.5). Es un granito equigranular de grano medio a grueso y con cantidades variables de biotita que ocasionalmente presenta fenocristales de feldespato potásico asociados a zonas pegmatíticas, estas últimas más frecuentes en zonas marginales de la unidad o asociadas a diaclasas. Entre los minerales accesorios se encuentran oxi-hidróxidos de Fe con $U$ absorbido y pirita. Es la unidad más evolucionada del complejo de El Payo, con enclaves micáceos o microgranulares y frecuentes estructuras de flujo.

Finalmente, dentro de los microgranitos (G7) se engloban el granito biotítico de grano fino de Villar de Flores y las cúpulas graníticas de grano fino y ricas en moscovita de la Fuente del Espinar, ambos encajados en el granito G2 (Fig. 2.5).

\subsubsection{Complejo de Peñaparda}

El granito biotítico de Peñaparda (G5) es un granito de grano medio y porfídico hacia los bordes de la unidad, donde presenta fenocristales de plagioclasa, disminuyendo el tamaño de grano y la cantidad de fenocristales hacia el interior. Entre los minerales accesorios se encuentran, además, esfalerita, xenotima, fosfatos de Th, fosfatos de Tierras Raras Ligeras y de Fe con U. Aflora en los alrededores y norte de Peñaparda (Fig. 2.5) y contiene enclaves micáceos asociados a nidos de biotita y otros de composición granítica de la facies G2. La red filoniana consta de diques aplíticos y diques de cuarzo orientados en dirección N30-50E.

El granito moscovítico de la Ermita de San Blas (G6) está compuesto por un granito equigranular de grano fino en zonas centrales, a medio en zonas de borde, donde está en contacto con las facies G1 y G2 a las que intruye (Fig. 2.5) y de las que hereda numerosos enclaves y restos de fenocristales de feldespato potásico y plagioclasa, y con los materiales del CEG. La uraninita es un mineral accesorio muy común en esta facies, además de fosfatos de Th y de Tierras Raras Ligeras.

\subsection{TECTÓNICA Y METAMORFISMO}

\subsubsection{La Orogenia Varisca}

La deformación Varisca es la más importante a escala regional, puesto que es la causante del metamorfismo regional y la deformación principal de este sector. En general, es el resultado 
de tres fases de deformación superpuestas (Díez Balda, 1980; Macaya et al., 1991; Díez Balda et al., 1995):

- La primera fase de deformación o D1 dio lugar a un acortamiento inicial debido al desarrollo de grandes pliegues de plano axial vertical o fuertemente inclinado hacia el NE, de dirección NO-SE y con esquistosidad de plano axial (S1). Existe una componente de cizalla simple asociada a movimientos transcurrentes (Aller et al., 1986; Días y Ribeiro, 1991). El metamorfismo regional contemporáneo es de grado muy bajo o bajo y de presión intermedia a baja, con escasa recristalización (López Munguira et al., 1991; Martínez Poyatos et al., 2001), originando biotita, clorita, estaurolita, almandino y sillimanita (Díez Balda et al., 1995).

- La segunda fase de deformación o D2 se interpreta como consecuencia de movimientos extensionales (Díez Balda et al., 1995) que forman pliegues de plano axial subhorizontal que pliegan las estructuras de primera fase, desarrollando una esquistosidad subhorizontal (S2) en zonas de medio a alto grado de metamorfismo (Corretgé y López Plaza, 1976; Díez Balda, 1983) apenas visible en áreas epizonales. Se produce un metamorfismo de menor presión que durante la D1, desarrollando cordierita y andalucita (Díez Balda et al., 1995).

- La tercera fase de deformación o D3 es una fase homoaxial con la D1 cuya consecuencia es el apretamiento de las estructuras formadas durante la primera fase de deformación. Durante esta fase se forman principalmente pliegues de gran longitud de onda y pequeña amplitud de dirección NO-SE, acompañados de pliegues menores con esquistosidad de plano axial asociada (S3) que apenas se aprecia, dado que la S2 en este sector está poco definida (González Lodeiro et al., 1988; Díez Balda et al., 1990; Escuder Viruete, 1998). La paragénesis metamórfica de esta fase se caracteriza por la transformación de biotita en mica blanca y clorita y por reajustes a condiciones de esquistos verdes, lo que indica transición de grado bajo a medio (Díez Balda et al., 1995). Simultáneamente a estas estructuras se generan zonas de cizalla dúctiles subverticales en dos sistemas principales, $\mathrm{N} 70^{\circ} \mathrm{E}$ y $\mathrm{N} 130^{\circ} \mathrm{E}$ (García de Figuerola y Parga, 1968; Iglesias y Ribeiro, 1981; Martínez Catalán y Díez Balda, 1987) y sistemas de fracturas de dirección $\mathrm{N} 115^{\circ} \mathrm{E}$ y $\mathrm{N} 70^{\circ} \mathrm{E}$.

Las deformaciones tardías en este sector están representadas fundamentalmente por dos sistemas de pliegues de muy baja longitud de onda (Martín Herrero et al., 1984): uno de dirección $\mathrm{N} 10-35^{\circ} \mathrm{E}$ con pliegues de plano axial subvertical relacionados con fracturas en la misma dirección y otro de dirección $\mathrm{N} 100-120^{\circ} \mathrm{E}$ con pliegues asimétricos de plano axial buzando $5-20^{\circ} \mathrm{S}$ y asociados a fallas normales.

Por último, la fracturación tardivarisca se observa tanto en los materiales metamórficos del CEG como en las rocas graníticas. Esta desarrolla un sistema principal de fracturas N30$70^{\circ} \mathrm{E}$ con movimiento horizontal senestro que afecta especialmente a los contactos entre las facies graníticas, condicionando los valles más importantes de la región y constituyendo las principales direcciones de relleno de las venas de cuarzo mineralizadas. Otro menos importante de dirección NO-SE y movimiento horizontal dextro es subparalelo a las estructuras regionales variscas (Parga, 1969; Arthaud y Matte, 1975; Ubanell, 1981).

La intrusión de los granitoides variscos posteriormente a la principal fase de deformación Varisca creó una aureola de metamorfismo de contacto en facies de esquistos verdes y 
corneanas hornbléndicas que presenta potencias variables. Por ejemplo, la intrusión del batolito de Jálama generó una aureola de metamorfismo de contacto de hasta $1,5 \mathrm{~km}$ de extensión en la parte occidental, que llega a superar los $5 \mathrm{~km}$ de anchura en zonas del este, probablemente como consecuencia del emplazamiento de otros granitos adyacentes como el de Cadalso-Casillas de Flores o el de Santibáñez (García de Figuerola et al., 1985a,b).

\subsubsection{Deformaciones alpinas}

Durante la deformación alpina se generan una serie de cabalgamientos que condicionan el relieve de las cadenas montañosas en el Sistema Central. En la Sierra de Gata esta deformación corresponde con una elevación del basamento limitada por cabalgamientos de dirección NE-SO que se asocian con fracturas de la misma orientación y cabalgamientos E-O subordinados (Vegas y De Vicente, 2004). Estos movimientos alpinos pudieron superponerse a las estructuras tardivariscas provocando el rejuego de las fracturas en las direcciones predominantes de los cabalgamientos. 
CAPITTULO 3

Mineralizaciones del batolito de Jálama 



\section{CAPÍTULO 3. MINERALIZACIONES DEL BATOLITO DE JÁLAMA}

Las mineralizaciones de $\mathrm{Sn}-\mathrm{W}$-( $\mathrm{Nb}$ - $\mathrm{Ta}$ ) del distrito de Navasfrías que se encuentran en la parte norte del batolito de Jálama encajan en las distintas facies que constituyen la Unidad Externa (UE) de dicho batolito (Fig. 3.1), diferenciándose principalmente tres tipos:

- Casiterita diseminada en las facies de borde de la UE, especialmente en el leucogranito y las aplitas de borde con turmalina.

- Casiterita y óxidos de Nb y Ta diseminados en los diques pegmatíticos intra y peribatolíticos.

- Casiterita y/o wolframita en las venas de cuarzo encajadas en las facies de borde de la UE.

\subsection{LA UNIDAD EXTERNA (UE)}

\subsubsection{Roca encajante}

La mayor parte de la zona norte del batolito de Jálama está constituida por la Unidad Externa (UE), que de acuerdo con Ramírez y Grundvig (2000) se compone, desde las zonas más internas hacia el borde y norte del plutón, por un monzogranito porfídico de grano grueso (MP), un granito equigranular de dos micas (GE) y un leucogranito de grano grueso con turmalina (LG), además de una serie de diques aplíticos de borde ( $A B)$ de carácter también leucocrático y con turmalina (Fig. 3.1, Lám. 3.1). La composición mineralógica de estas facies
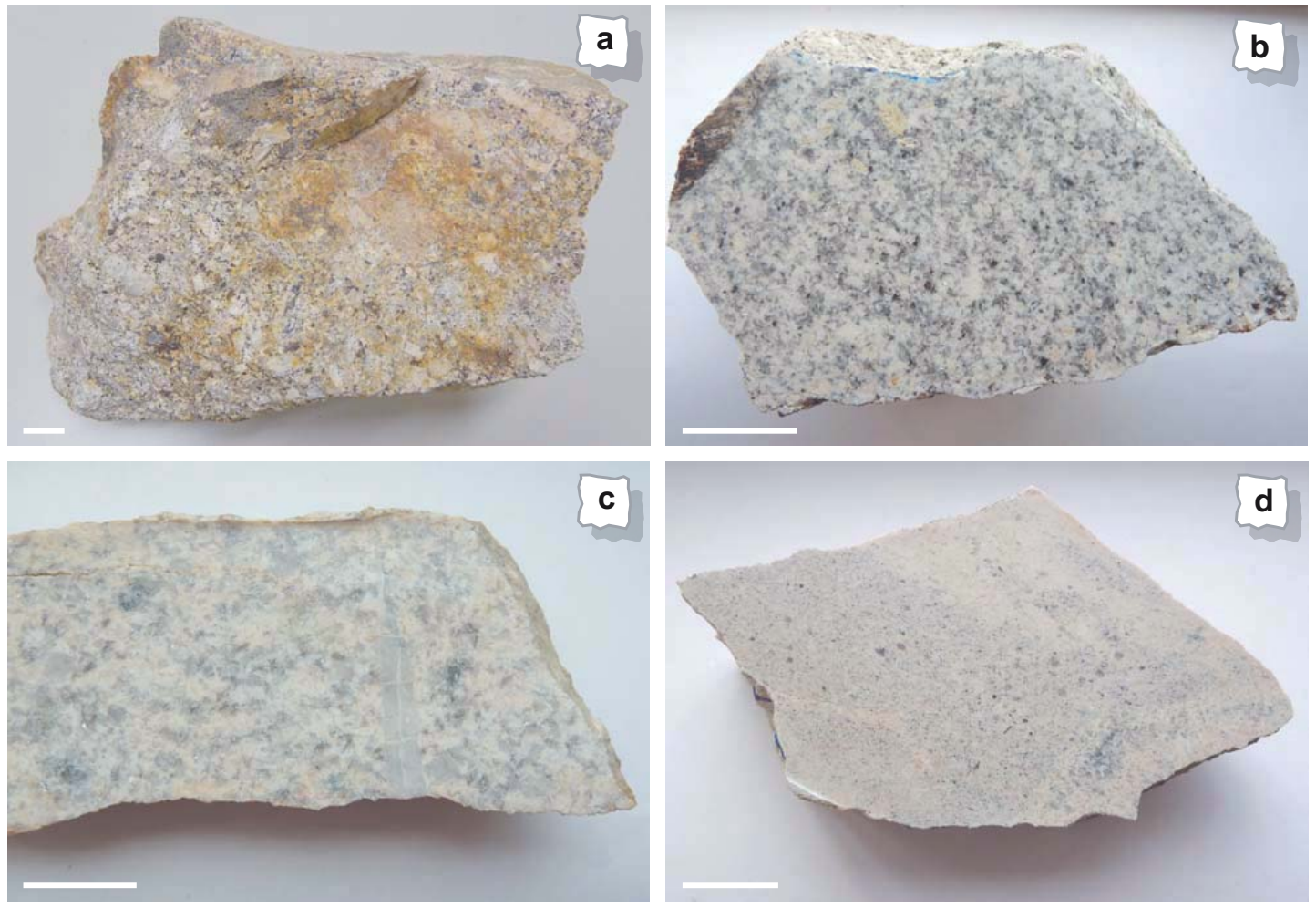

Lám. 3.1. Muestras de rocas representativas de las facies graníticas de la Unidad Externa (UE) del batolito de Jálama: a) monzogranito porfídico (MP); b) granito equigranular de dos micas (GE); c) leucogranito con turmalina (LG); d) aplitas de borde con turmalina (AB). Escala gráfica: $2 \mathrm{~cm}$. 


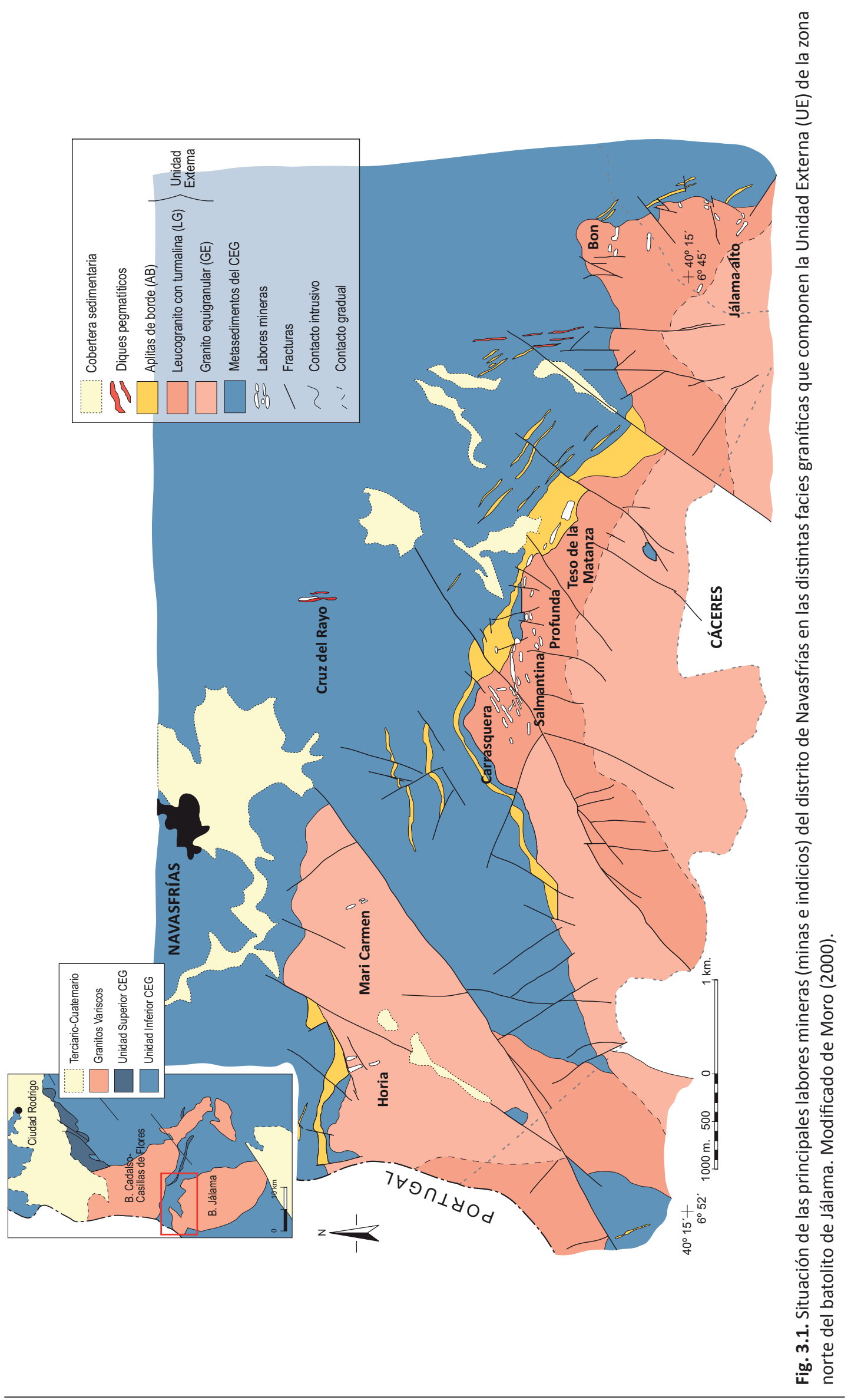


consta fundamentalmente de feldespato potásico, plagioclasa, biotita, mica blanca y cuarzo en diferentes proporciones y su evolución desde las facies menos diferenciadas hasta las más evolucionadas de borde viene marcada por una disminución en las proporciones de feldespato potásico y biotita y por un incremento en el contenido en mica blanca y plagioclasa. De manera accesoria se encuentran turmalina, clorita, fosfatos, sulfuros, circón, andalucita y gahnita.

La mineralización en la UE es muy escasa de manera que únicamente se ha observado casiterita diseminada en el $L G$ y las $A B$ con turmalina. El rutilo es el óxido más abundante mientras que la tantalita-( $\mathrm{Fe})$ se encuentra solo localmente.

\subsubsection{Petrografía y química mineral}

\section{Cuarzo}

En todas las facies de la UE se pueden distinguir principalmente dos generaciones de cuarzo. En primer lugar un cuarzo I que se presenta en cristales de tamaño milimétrico a centimétrico con extinción ondulante y visiblemente deformados, con frecuente crecimiento de subgranos a lo largo de sus bordes, generalmente dentados, y de fracturas. Ocasionalmente adquieren un ligero carácter poiquilítico o se asocian a los feldespatos formando texturas gráficas, especialmente en las facies menos evolucionadas del MP y el GE. De forma subordinada, aunque también abundante, se encuentran cristales de cuarzo II de grano fino con formas poligonales o pseudopoligonales, que muestran extinción débilmente ondulante y que generalmente están asociados a plagioclasa y moscovita también de grano fino.

\section{Feldespatos}

El feldespato potásico en el MP se encuentra en fenocristales sub- a euhedrales de tamaño milimétrico a centimétrico que exhiben normalmente la macla de la microclina y desarrollan frecuentes texturas pertíticas, tanto en venas como en parches (Lám. 3.2a). Presenta una composición $\mathrm{Or}_{93-100} A b_{0-7}$. En el GE aún se encuentran restos de estos fenocristales, aunque de menor tamaño y con texturas rapakivi y antirrapakivi como consecuencia de la alteración a plagioclasa y viceversa (Lám. 3.2b). Localmente se observan texturas gráficas. La composición química de este feldespato es $\operatorname{Or}_{92-95} A_{b_{5-8}}$ mostrando localmente trazas de Ba de hasta 0,29 $\%$ en peso. Por su parte, los restos de feldespato potásico en el LG y en las AB presentan una composición química Or $_{94-98} \mathrm{Ab}_{2-6}$, prácticamente la misma del feldespato euhedral y de color rosado que se forma como producto de la alteración hidrotermal de las venas de cuarzo. El contenido en P de estos feldespatos varía desde $0,16 \%$ en peso de media en el MP y 0,11\% en peso en el GE hasta $0,56 \%$ en peso en el LG, mientras que en las AB muestra los mayores contenidos con hasta $0,76 \%$ en peso de media, aunque puntalmente se llega a superar el 1 $\%$ en peso del óxido.

La plagioclasa es fundamentalmente de tipo albita en todas las facies graníticas de la UE,o bien, localmente, oligoclasa. Suele presentar macla polisintética, menos frecuentemente macla simple y apenas una ligera zonación, más visible en el MP, por la naturaleza más cálcica de los núcleos (frecuentemente sericitizados) y más sódica de los bordes (Lám. 3.2c). Su 

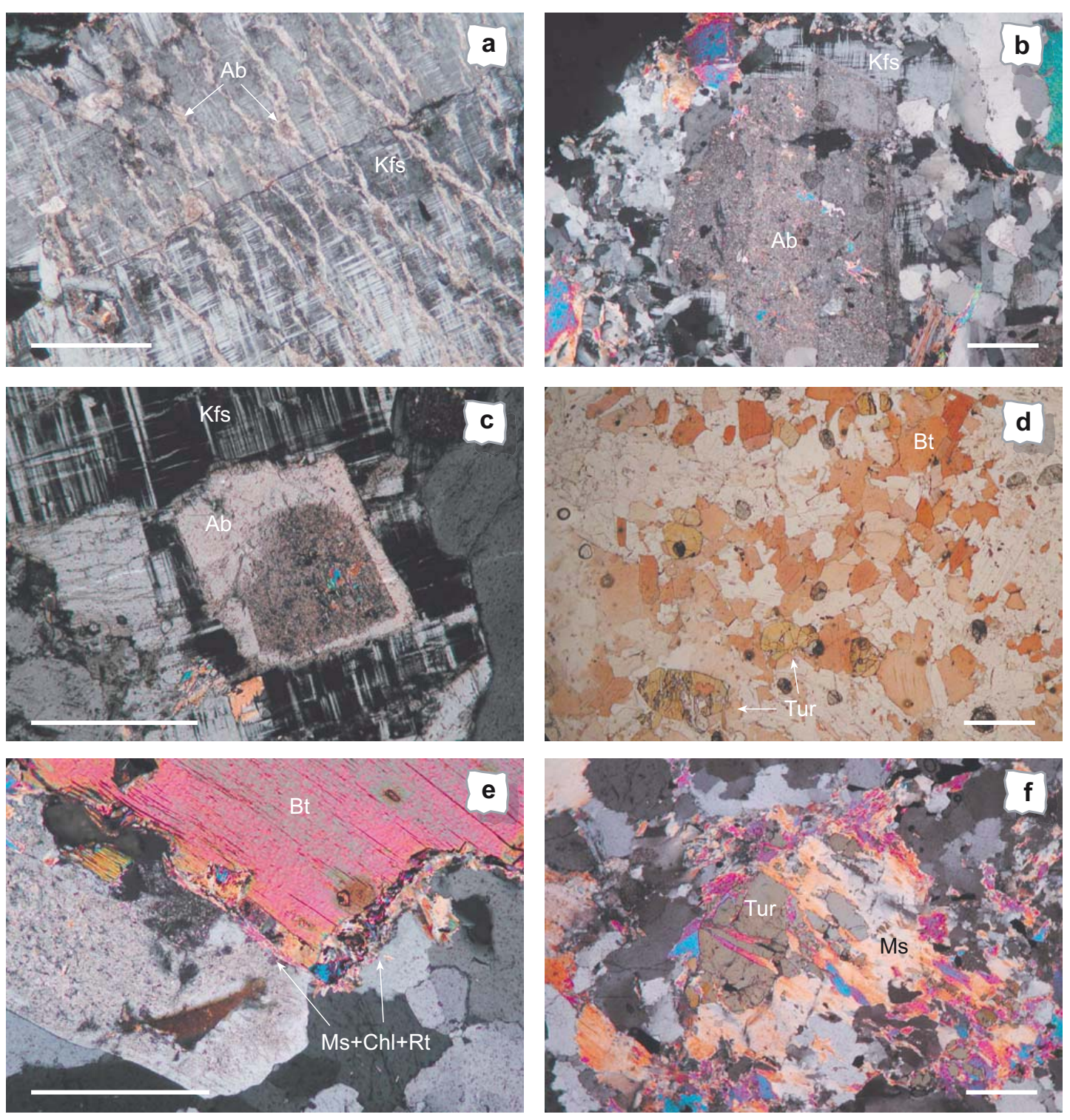

Lám. 3.2. Microfotografías de las facies graníticas de la UE del batolito de Jálama: a) feldespato potásico con venas y parches de albita en el MP, NC; b) textura antirrapakivi de albita con borde de feldespato potásico en el GE, NC; c) plagioclasa zonada dentro de un cristal de feldespato potásico en el MP, NC; d) agregados de biotita y turmalina en el MP, LN; e) agregado de moscovita, clorita y agujas de rutilo en un borde de alteración de la biotita en el GE, NC; f) turmalina reemplazada por moscovita en el LG, NC. Escala gráfica: a) $1 \mathrm{~mm}$; b, c, d, e y f) $500 \mu \mathrm{m}$.

composición en esta facies más interna (MP) es $A b_{81-98} A n_{2-17}$, representando los valores más alejados del polo de la albita (Fig. 3.2a), mientras que en el GE la variación es más restringida $\left(A b_{86-97} A n_{2-12}\right)$. En el GE alterado hidrotermalmente su composición es prácticamente igual que en el $L G$ y las $A B\left(A b_{96-99} A n_{0-2}\right)$. El contenido en $\mathrm{P}_{2} \mathrm{O}_{5}$ de nuevo varía dependiendo de la facies granítica, alcanzando los $0,25 \%$ en peso de media en el MP hasta $0,23 \%$ en peso en el $\mathrm{GE}$ y hasta $0,30 \%$ en peso en las $A B$, mientras que los valores más bajos se encuentran en el LG, con hasta $0,17 \%$ en peso de media. Representando los contenidos en $\%$ en peso de $\mathrm{P}_{2} \mathrm{O}_{5}$ frente al \% en peso de $\mathrm{CaO}$ de las plagioclasas se observa una tendencia positiva más evidente en el LG y las AB (Fig. 3.2b). Por lo tanto, y teniendo en cuenta las frecuentes 
inclusiones de cristales de apatito en las plagioclasas, parece probable que, aunque dicha correlación no sigue la línea del apatito, el contenido en P de las plagioclasas sea debido, en parte, a microinclusiones de apatito (London et al., 1990). Además, si se comparan los contenidos en $\mathrm{P}_{2} \mathrm{O}_{5}$ del feldespato potásico y de la plagioclasa de estas facies, se observa una clara preferencia a su incorporación al feldespato potásico, especialmente en el LG y las AB, mientras que en el GE se incorpora preferentemente a la plagioclasa (Fig. 3.2c)

Monzogranito porfídico (MP)

- Granito equigranular (GE)

- Leucogranito con turmalina (LG)

- Aplitas de borde (AB)
$\mathrm{Ab}$

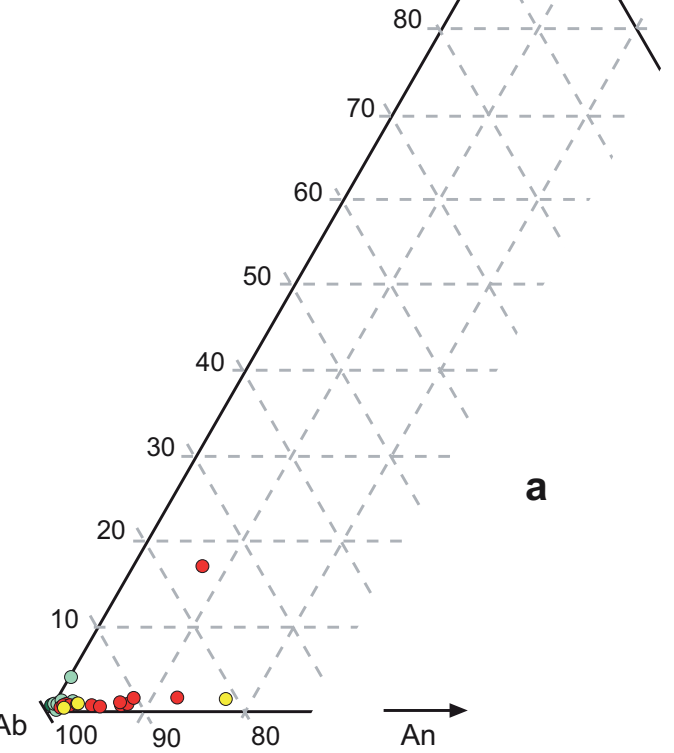

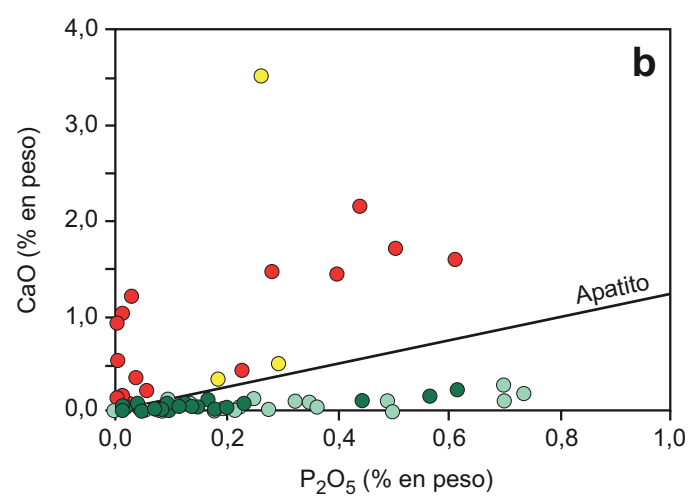

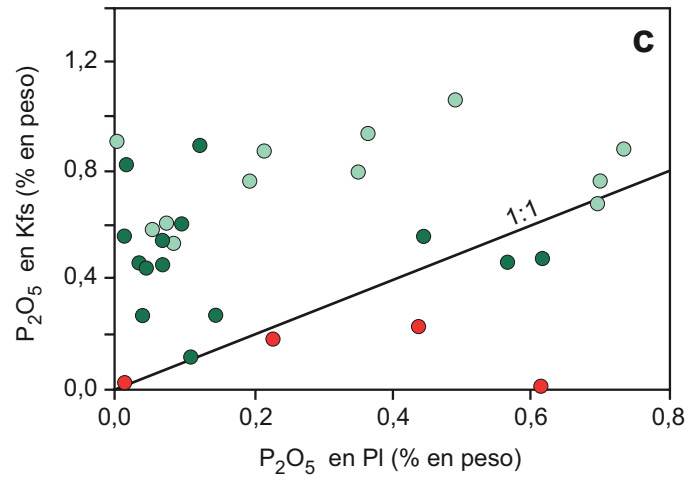

Fig. 3.2. a) Representación de la composición química de los feldespatos analizados en las facies graníticas de la UE en el diagrama triangular Ab-Or-An; b) diagrama de variación de los contenidos de $\mathrm{P}_{2} \mathrm{O}_{5}$ frente a los de $\mathrm{CaO}$ (en \% en peso) en las plagioclasas de las diferentes facies de la UE; c) partición del $\mathrm{P}_{2} \mathrm{O}_{5}$ entre el feldespato potásico (Kfs) y la plagioclasa (PI) en las facies de la UE.

\section{Micas}

La mica negra es muy abundante en el MP donde se encuentra formando agregados de cristales laminares de tamaño inferior a $1 \mathrm{~cm}$ con abundantes inclusiones de circón y apatito y, en ocasiones, parcialmente reemplazada por mica blanca (Lám. 3.2d). La representación de su composición química en el diagrama de clasificación de Tischendorf et al. (2004) se observa que está muy próxima al término de la biotita (Fig. 3.3a,b), con contenidos elevados en Ti (0,33-0,38 apfu) y cantidades significativas de Mn y F, además de contenidos traza de Li (hasta 653 ppm), Sn (hasta 37 ppm) y W (hasta 81 ppm). En el GE esta mica se presenta total o parcialmente alterada a clorita o a mica blanca con abundantes inclusiones de circón, apatito, rutilo e ilmenita (Lám. 3.2e). En este caso la representación de su composición se encuentra en torno al término de la biotita, dentro de la solución sólida annita-flogopita (Fig. 3.3b), con contenidos en Ti que varían entre 0,24 y 0,46 apfu, disminuyendo desde el interior al exterior 

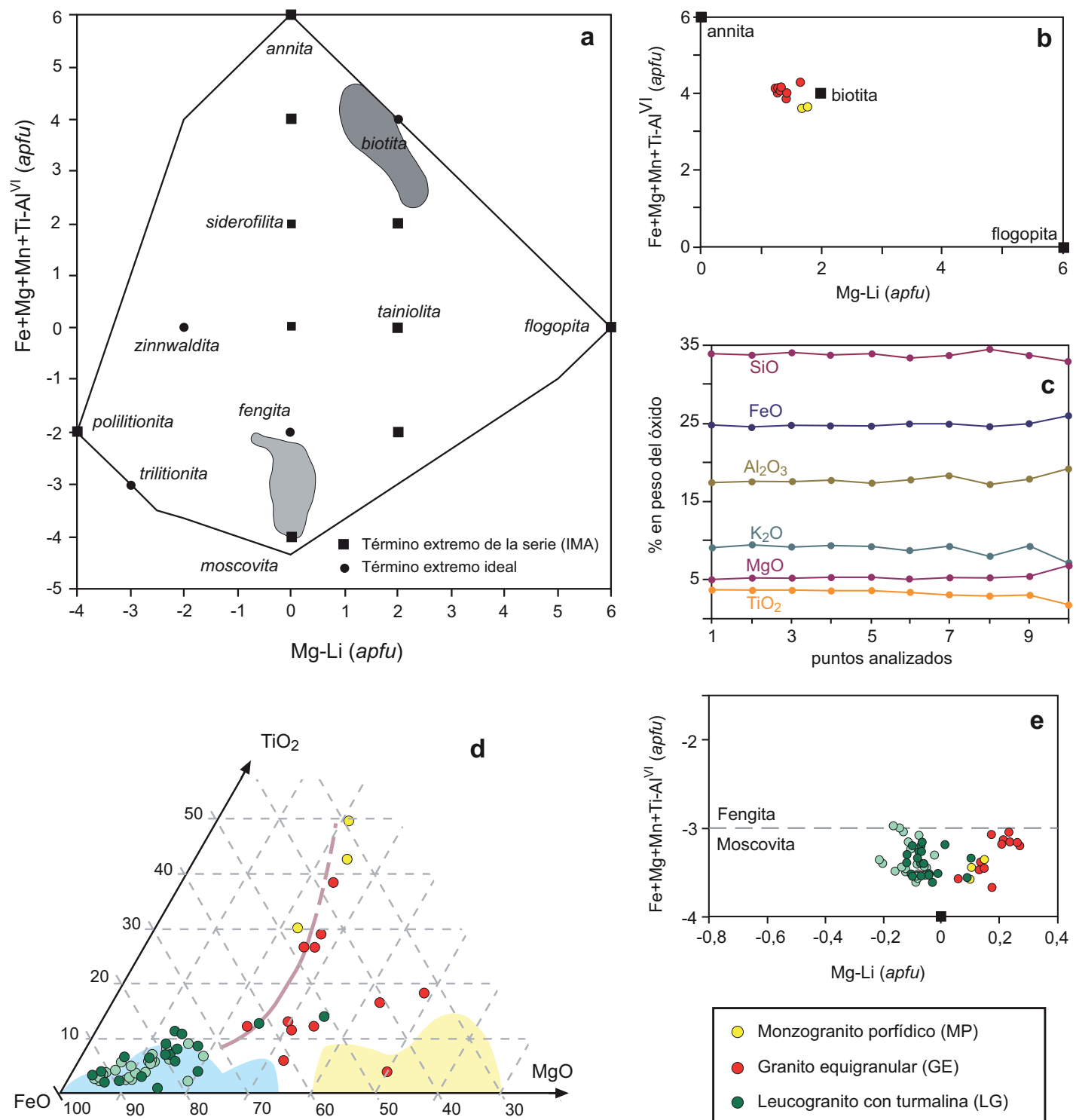

Monzogranito porfídico (MP)
- Granito equigranular (GE)
- Leucogranito con turmalina (LG)
Aplitas de borde con turmalina (AB)

Fig. 3.3. a) Representación de la composición química de la mica blanca y la mica negra analizadas en la UE en el diagrama de clasificación de Tischendorf et al. (2004); b) detalle de la clasificación de la mica negra; c) perfil de la zonación química de un cristal de biotita en el GE; d) Representación de la composición química de la mica blanca analizada en la UE en el diagrama triangular FeO-TiO $-\mathrm{MgO}$ de Monier et al. (1984) expresado en \% del óxido (color rosa: micas de origen tardi- a post-magmático; color azul: micas magmáticas; color amarillo: micas hidrotermales); e) detalle de la clasificación de la mica blanca (Tischendorf et al., 2004).

del cristal (Fig. 3.3c). El contenido en Li es inferior que en el MP, oscilando entre 335 y 847 ppm, aunque el contenido en Sn y, sobre todo, en W es mayor, alcanzando hasta 208 ppm y 1856 ppm respectivamente.

La mica blanca en el MP se encuentra subordinada a la biotita, a la que reemplaza frecuentemente a partir de bordes y planos de exfoliación de los cristales, o como producto de alteración de andalucita o incluso de turmalina. En el GE la moscovita se encuentra en proporciones similares a la biotita. De nuevo, además de los grandes cristales sin apenas inclusiones, con ligera extinción ondulante y de aparente origen primario, con mucha 
frecuencia la mica blanca se encuentra en pequeños cristales como producto de alteración de la biotita y de la plagioclasa, a veces con abundantes inclusiones de rutilo, ilmenita y apatito (Lám. 3.2e). Finalmente, la mica blanca del $L G$ y las $A B$ es fundamentalmente de origen primario, encontrándose también como producto de alteración de plagioclasa y turmalina (Lám. 3.2f) o bien rellenando grietas. En el diagrama triangular FeO-TiO $-\mathrm{MgO}$ (Fig. 3.3d) se observa que las micas del MP y buena parte de las del GE marcan una tendencia de origen tardi- a post-magmático, mientras que las del $L G$ y las $A B$ con turmalina se proyectan dentro del campo de las micas de evolución magmática. Solo algunas de las micas que cristalizan en grietas se encuentran próximas al campo de la alteración hidrotermal.

En la composición química de estas micas se observa un claro enriquecimiento en elementos traza como el Li, el Sn y el W desde las facies menos evolucionadas del MP hasta el LG con turmalina y en las $A B$, donde se alcanzan valores de hasta $2.465 \mathrm{ppm}$ de $L i, 1.020 \mathrm{ppm}$ de Sn y 1.491 ppm de W (Anexo III). El patrón de sustitución principal es de tipo fengítico, aunque influenciado por el vector de sustitución $\mathrm{Si}_{2} \mathrm{LiAl}_{-3}$, como evidencian los diagramas de correlación de la figura 3.4 y el diagrama de clasificación de Tischendorf et al. (2004), en el que se observa a todas ellas en el campo de la moscovita en transición hacia el término fengita, mostrando una clara evolución desde las micas del MP hasta el LG y las AB (Fig. 3.3e). En el GE se observa que las moscovitas de origen primario están más próximas al término ideal de la moscovita, mientras que las que proceden de alteración de la biotita o están en grietas se desvían hacia el campo de la fengita. Al enfrentar los contenidos en $\mathrm{K}$ frente a los de $\mathrm{F}$ se observa que, a pesar de no presentar muy buena correlación, las micas con mayor contenido en $\mathrm{K}$ son las más ricas en $\mathrm{F}$, coincidiendo además con los términos más fengíticos (Fig. 3.4h).

\section{Turmalina}

Es uno de los minerales accesorios más comunes en las facies graníticas de la UE, salvo en el GE donde se muestra totalmente ausente. En el MP la turmalina se encuentra diseminada de manera abundante, mientras que en el $L G$ y las $A B$ se concentra en bandas. Estos cristales muestran a veces una textura poiquilítica debido a que engloban restos de cristales previos, especialmente de cuarzo, lo que sugiere su carácter tardío en la secuencia paragenética. Se presenta, en muestra de mano, en cristales prismáticos alargados de color negro y en secciones triangulares o redondeadas que varían desde tamaños milimétricos a centimétricos. En el MP está asociada con biotita, mientras que en el LG y las AB suele estar reemplazada por moscovita (Lám. 3.2d,f). En luz polarizada normal esta turmalina muestra un fuerte zonado óptico en algunos casos, además de frecuentes inclusiones de circón (Lám. 3.3a).

La fórmula general, de acuerdo con Hawthorne y Henry (1999), se puede expresar $\mathrm{XY}_{3} \mathrm{Z}_{6}\left(\mathrm{~T}_{6} \mathrm{O}_{18}\right)$ $(\mathrm{BO})_{3}\left(\mathrm{H}_{2} \mathrm{O}, \mathrm{F}\right)_{4}$. Calculando por estequiometría los contenidos en $\mathrm{Li}_{2} \mathrm{O}, \mathrm{B}_{2} \mathrm{O}_{3}$ y $\mathrm{H}_{2} \mathrm{O}$ para 24,5 átomos de oxígeno (Anexo $\mathrm{X}$ ), su fórmula media calculada a partir de sus análisis químicos es $\left(\mathrm{Ca}_{0,02} \mathrm{Na}_{0,58} \square_{0,39}\right)_{\Sigma 1}\left(\mathrm{Al}_{0,58} \mathrm{Fe}_{1,91} \mathrm{Ti}_{0,6} \mathrm{Mg}_{0,36} \mathrm{Mn}_{0,02} \mathrm{Li}_{0,05}\right)_{\Sigma 3} \mathrm{Al}_{6}\left(\mathrm{Si}_{5,91} \mathrm{Al}_{0,09}\right)_{\Sigma 6} \mathrm{O}_{18}(\mathrm{BO})_{3}\left[\mathrm{~F}_{0,19}\left(\mathrm{H}_{2} \mathrm{O}\right)_{3,81}\right]_{\Sigma 4^{\prime}}$ que corresponde con las turmalinas del grupo alcalino (Hawthorne y Henry, 1999), aunque con cierta tendencia al de las turmalinas con vacancias (Fig. 3.5a). De acuerdo con la nomenclatura de Selway y Novák (1997), la turmalina presente en el MP es chorlo-dravita (el Mg ocupa hasta el $53 \%$ las posiciones $Y$ ), mientras que en el $L G$ y las $A B$ es chorlo con pequeñas cantidades de 

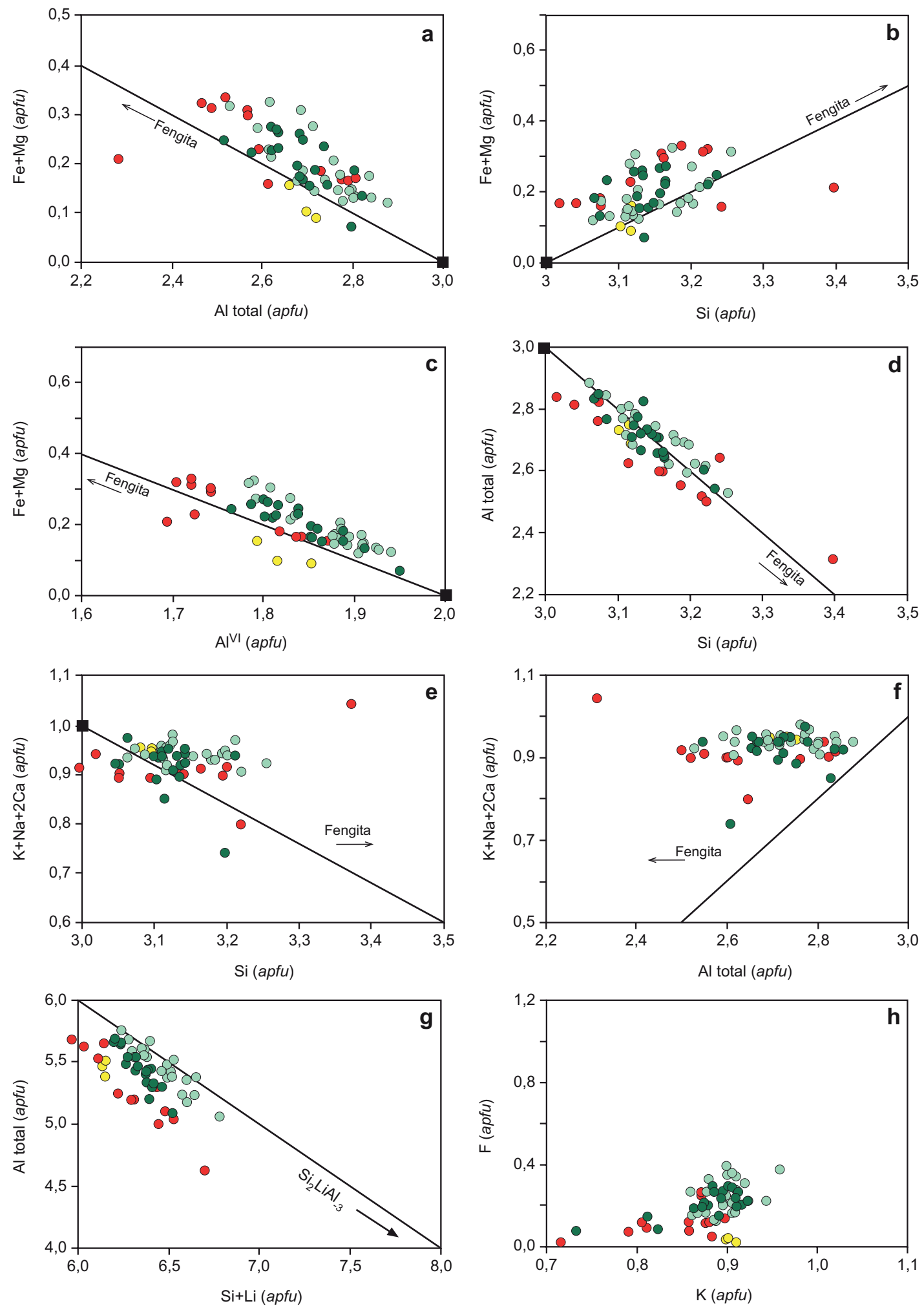

\begin{tabular}{|lll}
\hline Monzogranito porfídico (MP) & Leucogranito con turmalina (LG) \\
Granito equigranular (GE) & $\bigcirc$ Aplitas de borde con turmalina (AB)
\end{tabular}

Fig. 3.4. Diagramas de correlación de la moscovita analizada en las facies graníticas de la UE: a) Al total vs. $\mathrm{Fe}+\mathrm{Mg}$; b) Si vs. $\mathrm{Fe}+\mathrm{Mg}$; c) All ${ }^{\mathrm{vl}}$ vs. $\mathrm{Fe}+\mathrm{Mg}$; d) Si vs. Al total; e) Si vs. $\mathrm{K}+\mathrm{Na}+2 \mathrm{Ca}$; f) Al total vs. $\mathrm{K}+\mathrm{Na}+2 \mathrm{Ca}$; g) $\mathrm{Si}+\mathrm{Li}$ vs. Al total; y h) K vs. F. 
$\mathrm{Mg}$ (hasta un $17 \%$ ) y con un elevado componente de foitita (Fig. 3.5c), proyectándose todas ellas dentro del campo de las rocas graníticas pobres en Li y aplitas y pegmatitas asociadas (Fig. 3.5b). El zonado óptico que presentan se debe a ligeras variaciones composicionales desde el borde hasta el centro del cristal. Estas variaciones en el LG y las AB consisten en una disminución de los contenidos en $(\mathrm{Mg}+\mathrm{Mn}+\mathrm{Fe})$, $\mathrm{Na}$ y Ti y en un incremento en $\mathrm{Al}^{\gamma}+\mathrm{Li}$ hacia el centro de los cristales (Fig. 3.5d).

En el gráfico de la figura 3.5e se observa una clara correlación negativa entre la relación $\mathrm{Fe} /\left(\mathrm{Fe}+\mathrm{Mg}\right.$ ) frente al $\mathrm{Mg}$, lo que sugiere que el vector de intercambio $\mathrm{FeMg}_{-1}$ pudo haber jugado un papel importante en la composición de la turmalina de la serie chorlo-dravita. En el gráfico de la figura 3.5f, que enfrenta los valores de $\mathrm{Na} /(\mathrm{Na}+\mathrm{Vac})$ y $\mathrm{Al}^{\gamma} /\left(\mathrm{Al} \mathrm{l}^{\gamma}+\mathrm{Fe}\right)$, no se representa este vector de sustitución de modo que no se pueden considerar las turmalinas con contenidos en Mg superiores a 1 apfu (Selway et al., 1999). No obstante, al tratarse la mayoría de las turmalinas de miembros de la serie chorlo-dravita más próximos al término rico en Fe es posible emplearlos para la proyección. De esta forma en él se observa, además, cierta influencia de la sustitución chorlo-foitita, cuyo vector de sustitución es $\left[\mathrm{X}_{-1} \mathrm{Al}_{-1}^{\mathrm{Y}} \mathrm{NaFe}\right.$.
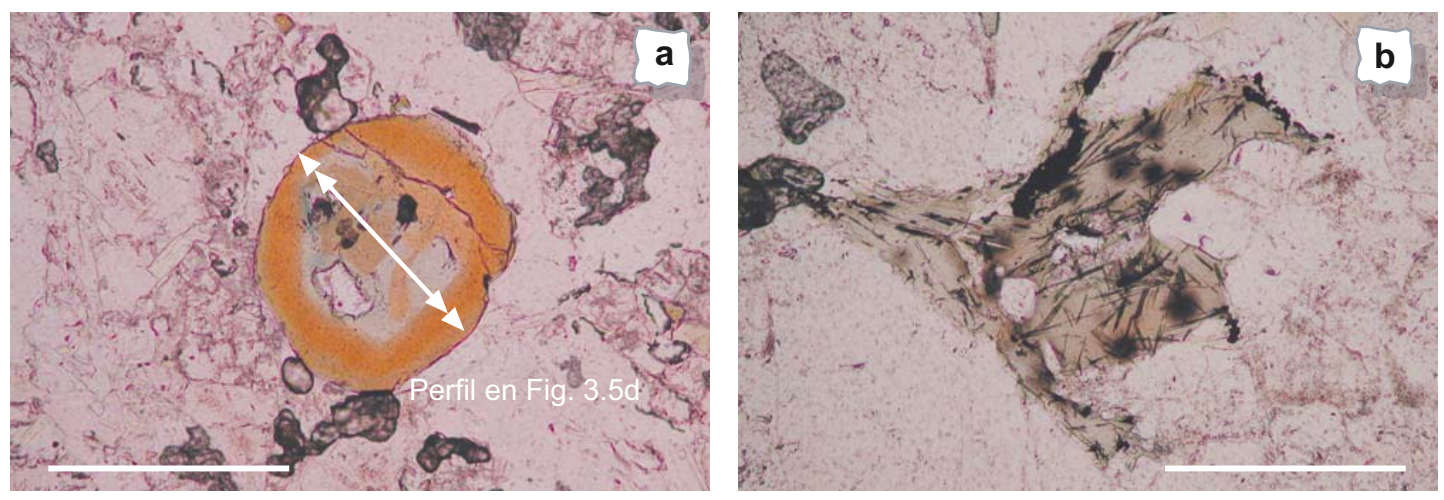

Lám. 3.3. a) Microfotografía de un cristal de turmalina zonado (ver perfil químico en Fig. 3.5d), LN; b) biotita reemplazada totalmente por clorita con agujas de rutilo y cristales de circón en el GE, LN. Escala gráfica: 500 $\mu \mathrm{m}$.

\section{Clorita}

La clorita que se encuentra tanto en el MP como en el GE es un producto de la alteración parcial o total de la biotita y contiene frecuentes inclusiones de rutilo e ilmenita (Lám. 3.3b), mientras que la que se encuentra en el $L G$ y las $A B$ se presenta en cristales o agregados laminares de tamaño micrométrico, rellenando venillas o bien como producto de alteración de fosfatos de la serie childrenita-eosforita. Su composición química en el diagrama de Hey (1954) indica que la clorita que se encuentra en el MP y el GE se clasifica como ripidolita, picnoclorita y brunsvigita (Fig. 3.6a), como chamosita según Bailey (1980) y como clorita de tipo I (Fig. 3.6b) o clorita-Fe según Zane y Weiss (1998). Presenta contenidos en Si inferiores a 3 apfu, de modo que el Al en las posiciones tetraédricas alcanza valores superiores a 1 apfu y, por lo tanto, su contenido en la capa octaédrica disminuye, siendo ocupado por Fe (hasta 3,19 apfu) y Mg (hasta 1,60 apfu) con trazas de Mn y Ti que no dejan lugar a vacancias (Fig. 3.6c). La suma de los cationes interlaminares oscila entre 0,03 y 0,14 apfu, siendo el $\mathrm{K}$ 

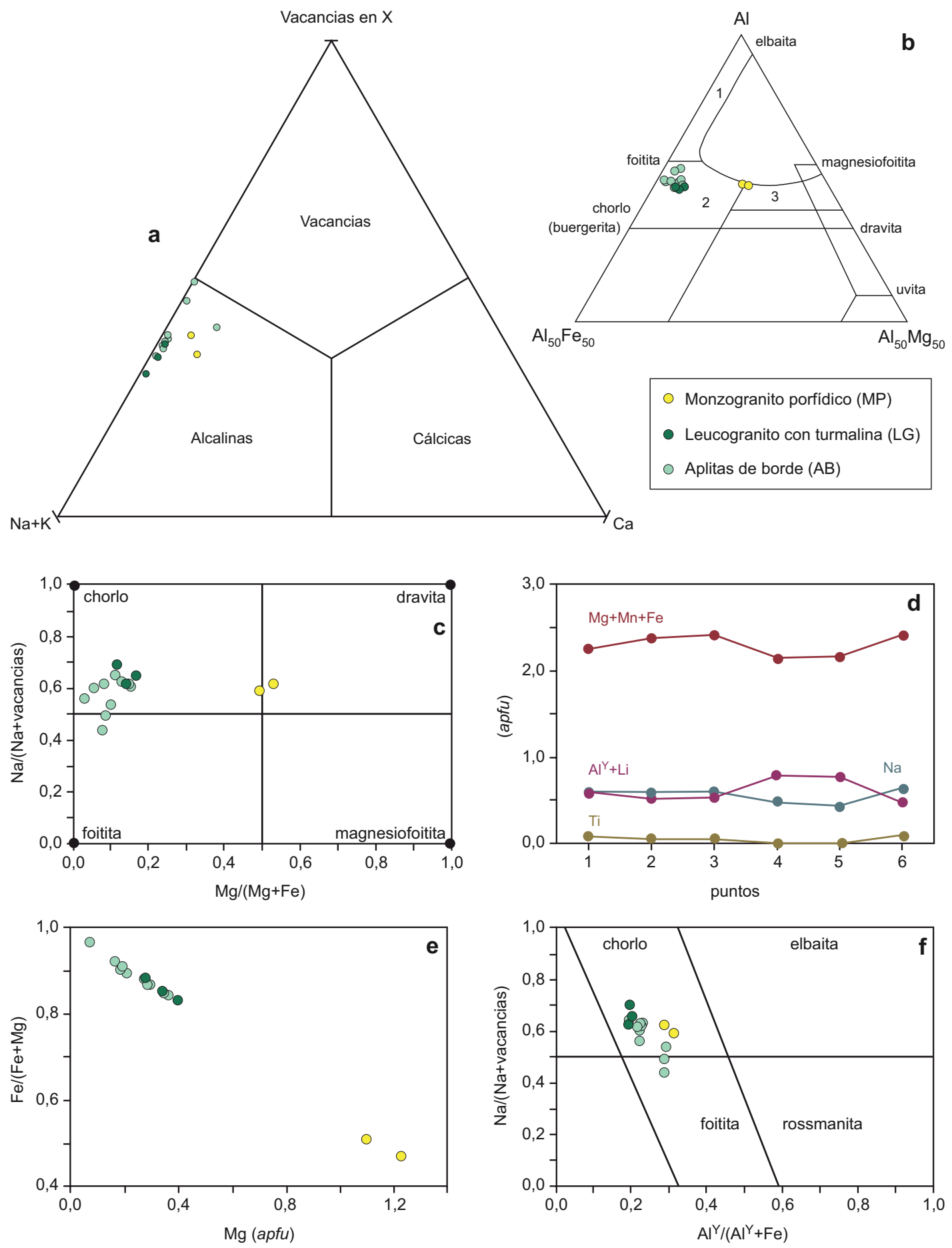

Fig. 3.5. Diagramas triangulares de clasificación de la turmalina: a) en función de la ocupación de las posiciones X según Hawthorne y Henry (1999); y b) en función de las proporciones moleculares de Al$\mathrm{Fe}_{\text {total }} \mathrm{Mg}$ según Henry y Guidotti (1985) (1: pegmatitas y aplitas ricas en Li; 2: rocas graníticas pobres en Li y pegmatitas y aplitas asociadas; 3: metapelitas y metapsamitas coexistiendo con fases alumínicas); c) diagrama de variación de $\mathrm{Na} /(\mathrm{Na}+$ vacancias) en las posiciones $\mathrm{X}$ frente a $\mathrm{Mg} /(\mathrm{Mg}+\mathrm{Fe}$ ) en las posiciones $\mathrm{Y}$ (en apfu); d) perfiles químicos de zonación en un cristal de turmalina. Diagramas de variación de: e) Fe/(Fe+Mg) frente a los contenidos en $\mathrm{Mg}$ en las posiciones $\mathrm{Y}$ (en apfu); y f) $\mathrm{Na} /(\mathrm{Na} a+v a c a n c i a s)$ en las posiciones $\mathrm{X}$ frente a $\mathrm{Al} /(\mathrm{Al}+\mathrm{Fe})$ en las posiciones $\mathrm{Y}$ (en apfu). 
el catión dominante. La relación $\mathrm{Fe} /(\mathrm{Fe}+\mathrm{Mg}$ ) varía entre 0,64 y 0,72 (Fig. 3.6d), valores que coinciden con los que presenta la biotita a partir de la que se forma (Anexo III). Si bien, en este caso, esta relación depende del mineral primario del que procede, que contiene cantidades notables de $\mathrm{Mg}$, también puede influir el quimismo del fluido hidrotermal, enriquecido en Fe más que en $\mathrm{Mg}$, causante de tal alteración.

Por otro lado, la clorita presente en el LG y las AB se clasifica como diabantita y penninita según Hey (1954), también como chamosita según Bailey (1980) y como clorita de tipo II (Fig. 3.6a,b) o clorita-Al según Zane y Weiss (1998). Esta clorita presenta mayores contenidos en Si (hasta 3,90 apfu) que se correlacionan a su vez con mayores contenidos en Al total (hasta 3,72 apfu), indicando una tendencia positiva en el diagrama de la figura 3.6e desde la clorita de las facies más internas (MP) hacia las zonas de borde del batolito. Esta tendencia muestra una pendiente ligeramente superior a 1, de manera que a la sustitución tetraédrica típica de $\mathrm{Si} \leftrightarrow \mathrm{Al}$ habría que añadir la entrada de $\mathrm{P}$ y/o As en sustitución del Si, influenciado probablemente por la composición de los fosfatos y por los fluidos hidrotermales ricos en As que dan lugar a la precipitación de la arsenopirita, lo que indicaría su origen tardío en la secuencia. Por esto, a pesar del incremento del $\mathrm{Si}$, la cantidad de $\mathrm{Al}^{\mathrm{lV}}$ en esta capa es inferior que en la clorita del MP y el GE (Fig 3.6d) aumentando, por tanto, la cantidad de $\mathrm{Al}^{\mathrm{VI}}$ en la capa octaédrica. Esto se traduce en un menor contenido de Fe (entre 0,26 y 2,51 apfu) y, especialmente, de $\mathrm{Mg}$ (hasta 0,06 apfu) de modo que las vacancias calculadas en la capa octaédrica alcanzan hasta 2,57 apfu, mostrando una relación inversa respecto del contenido en $\mathrm{Al}^{\mathrm{IV}}$ (Fig 3.6c). Dada la casi total ausencia de $\mathrm{Mg}$, la relación $\mathrm{Fe} /(\mathrm{Fe}+\mathrm{Mg}$ ) está próxima a 1 y al enfrentarla con el Al total se observa una clara tendencia positiva desde las zonas internas de la UE hacia las facies de borde y, por tanto, una acusada correlación negativa entre el Si y el Fe (Fig 3.6a). Sin embargo, esta tendencia no se aprecia para el Alv (Fig. 3.6d). El hecho de que esta relación sea tan elevada en estas cloritas avala de nuevo la influencia del quimismo del fluido hidrotermal causante de su formación, que está claramente enriquecido en Fe y una menor influencia del mineral precursor de su formación, fundamentalmente fosfatos, en cuya composición domina el Fe y el Mn y, sin embargo, solo el Fe entra a formar parte de la composición de la clorita.

La suma de cationes interlaminares también es muy baja, no superando los 0,15 apfu y apenas se aprecia correlación con el número de vacancias en la capa octaédrica (Fig. 3.6f). Shau et al. (1990) y Jiang et al. (1994) asocian la existencia de estas vacancias en la capa octaédrica a la presencia de capas interestratificadas o inclusiones de otros minerales como micas o arcillas con la clorita; sin embargo, el hecho de que apenas exista correlación entre los cationes interlaminares y las vacancias sugiere que al menos una parte de estas últimas existen realmente en la capa octaédrica.

\section{Sulfuros}

La arsenopirita es el sulfuro más común en las facies graníticas de borde del batolito de Jálama. En el GE se encuentra asociada frecuentemente a calcopirita, pirrotita, pirita y esfalerita en agregados cristalinos que no suelen superar las $50 \mu \mathrm{m}$ de tamaño en los cristales de plagioclasa sericitizados. Solo la pirita se ha observado en cristales aislados de mayor tamaño. La composición química de esta arsenopirita presenta contenidos elevados en As 

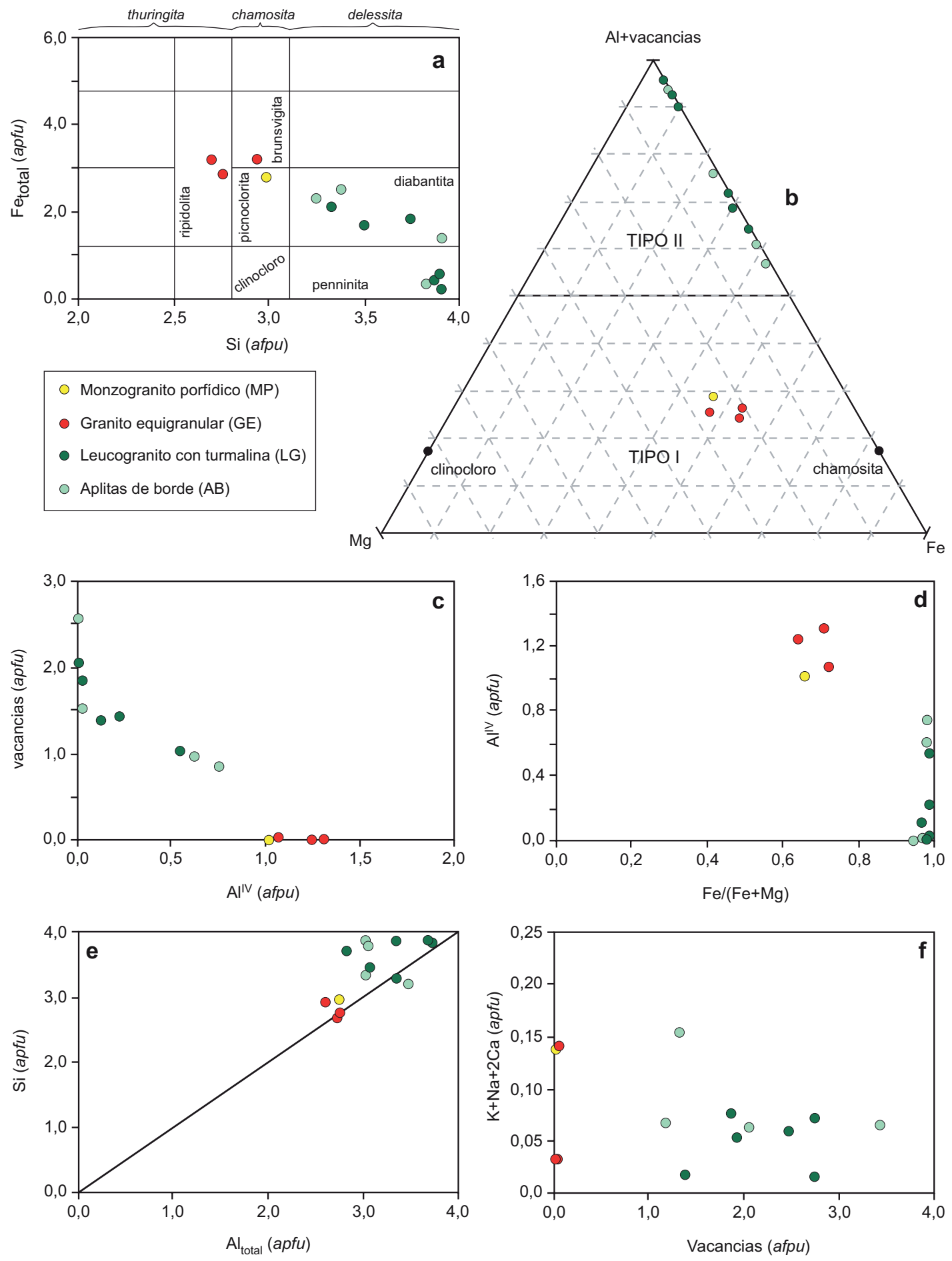

Fig. 3.6. Diagramas de clasificación de la clorita analizada en las facies graníticas de la UE: a) en función de los contenidos en $\mathrm{Fe}_{\text {total }}$ y Si (en apfu) según Hey (1954); y b) en función de los contenidos en $\mathrm{Fe}_{\text {total' }}$ Mg y Al+vacancias (en apfu) según Zane y Weiss (1998). Diagramas de sustitución química de: c) Alv vs. vacancias; d) $\mathrm{Fe} /(\mathrm{Fe}+\mathrm{Mg})$ vs. $\mathrm{Al}^{\mathrm{Iv}}$; e) $\mathrm{Al}_{\text {total }}$ vs. Si; y f) vacancias vs. $\mathrm{K}+\mathrm{Na}+2 \mathrm{Ca}$.

(entre 37,06 y $38,50 \%$ at.) mientras que el Fe está parcialmente sustituido por contenidos significativos de Co (hasta 0,14 apfu) y Ni (hasta 0,08 apfu). Por su parte, la arsenopirita del LG y las $A B$ con turmalina presenta contenidos en As más bajos (entre 34,12 y 34,54 ) y el Fe no 
presenta ninguna sustitución. La löllingita $\left(\mathrm{FeAs}_{2}\right)$ se ha identificado solo en una muestra de aplita en la mina Teso de la Matanza en cristales sub- a euhedrales de tamaño milimétrico y parcialmente reemplazados por arsenopirita, además de molibdenita y minerales del grupo de la estannita que se presentan rellenando grietas. Su composición química muestra hasta 0,12 apfu de $S$ sustituyendo al As y contenidos puntuales de Au que alcanzan el 0,10 \% en peso (Anexo III).

\section{Asociaciones fosfatadas}

Los minerales fosfatados, a pesar de su carácter accesorio, aportan mucha información sobre la evolución composicional y las condiciones físicoquímicas de los fluidos hidrotermales mineralizados. En estas facies de borde de la UE del batolito de Jálama los minerales fosfatados se encuentran diseminados o bien rellenando huecos intersticiales y fracturas tardías únicamente en el LG y las $A B$ con turmalina, agrupándose en dos asociaciones en función de sus características texturales, mineralógicas y químicas (Tabla 3.1) (Llorens y Moro, en prensa).

TABLA 3.1. FOSFATOS DE LAS ASOCIACIONES I Y II

\begin{tabular}{|c|c|c|c|}
\hline \multirow{2}{*}{ Fosfato } & \multirow{2}{*}{ Fórmula general } & \multicolumn{2}{|c|}{ Asociación } \\
\hline & & $\mathbf{I}$ & II \\
\hline Montebrasita & $\mathrm{LiAl}\left(\mathrm{PO}_{4}\right)(\mathrm{OH}, \mathrm{F})$ & & * \\
\hline Goyazita & $\mathrm{SrAl}_{3}\left(\mathrm{PO}_{4}\right)\left(\mathrm{PO}_{3} \mathrm{OH}\right) \cdot(\mathrm{OH})_{6}$ & & * \\
\hline Childrenita-Eosforita & $\left(\mathrm{Fe}^{2+} \mathrm{Mn}^{2+}\right) \mathrm{Al}\left(\mathrm{PO}_{4}\right)(\mathrm{OH})_{2} \cdot 2 \mathrm{H}_{2} \mathrm{O}$ & * & ** \\
\hline Barbosalita-Lipscombita & $\left(\mathrm{Fe}^{2+}, \mathrm{Mn}^{2+}\right) \mathrm{Fe}_{2}^{3+}\left(\mathrm{PO}_{4}\right)_{2}(\mathrm{OH})_{2}$ & ** & \\
\hline Rockbridgeita & $\left(\mathrm{Fe}^{2+}, \mathrm{Mn}^{2+}\right) \mathrm{Fe}_{4}^{3+}{ }_{4}\left(\mathrm{PO}_{4}\right)_{3}(\mathrm{OH})_{5}$ & & *** \\
\hline Mitridatita & $\mathrm{Ca}_{2} \mathrm{Fe}_{3}^{3+} \mathrm{O}_{2}\left(\mathrm{PO}_{4}\right)_{3} \cdot 3 \mathrm{H}_{2} \mathrm{O}$ & ** & \\
\hline Gormanita & $\mathrm{Fe}_{3}^{2+}{ }_{3} \mathrm{Al}_{4}\left(\mathrm{PO}_{4}\right)_{4}(\mathrm{OH})_{6} \cdot 2 \mathrm{H}_{2} \mathrm{O}$ & * & \\
\hline Keckita & $\mathrm{CaMn}\left(\mathrm{Fe}^{3+}, \mathrm{Mn}\right)_{2} \mathrm{Fe}_{2}^{3+}{ }_{2}\left(\mathrm{PO}_{4}\right)_{4}(\mathrm{OH})_{3}\left(\mathrm{H}_{2} \mathrm{O}\right)_{7}$ & ** & \\
\hline Beraunita & $\mathrm{Fe}^{2+} \mathrm{Fe}^{3+}{ }_{5}\left(\mathrm{PO}_{4}\right)_{4}(\mathrm{OH})_{5} \cdot 6 \mathrm{H}_{2} \mathrm{O}$ & & ** \\
\hline Walentaita & $\mathrm{H}\left(\mathrm{Ca}, \mathrm{Fe}^{2+}, \mathrm{Mn}^{2+}\right) \mathrm{Fe}^{3+}{ }_{3}\left(\mathrm{AsO}_{4}, \mathrm{PO}_{4}\right)_{4} \cdot 7 \mathrm{H}_{2} \mathrm{O}$ & * & \\
\hline Apatito & $\mathrm{Ca}_{5}\left(\mathrm{PO}_{4}\right)_{3}(\mathrm{OH}, \mathrm{F}, \mathrm{Cl})$ & $* * *$ & *** \\
\hline
\end{tabular}

Abundancia en cada asociación: ${ }^{* * *}=$ abundante; ${ }^{* *}=$ escaso; ${ }^{*}=$ muy escaso

\section{Asociación 1}

Esta asociación está definida por términos de la serie barbosalita-lipscombita, keckita, mitridatita y fluorapatito, además de gormanita y eosforita ocasionalmente. Su composición química y secuencia de alteración ser recogen en el anexo III y en la figura 3.7a respectivamente. Los fosfatos de la serie barbosalita-lipscombita se presentan en agregados de cristales an- a subhedrales de tamaño milimétrico y de color verde-azul intenso, lo que les confiere una opacidad casi absoluta bajo el microscopio petrográfico y son reemplazados por keckita (Lám. 3.4a). Son fosfatos muy ricos en $\mathrm{Fe}$, la mayor parte en forma de $\mathrm{Fe}^{3+}$ (entre 1,94 y $2 \mathrm{apfu}$ ) y el resto en forma de $\mathrm{Fe}^{2+}$, junto con $\mathrm{Mn}$ y trazas de $\mathrm{Ca}$ y $\mathrm{Zn}$. El bajo contenido en agua de estas fases fosfatadas sugiere que son las más precoces en la secuencia paragenética. Se observan, 

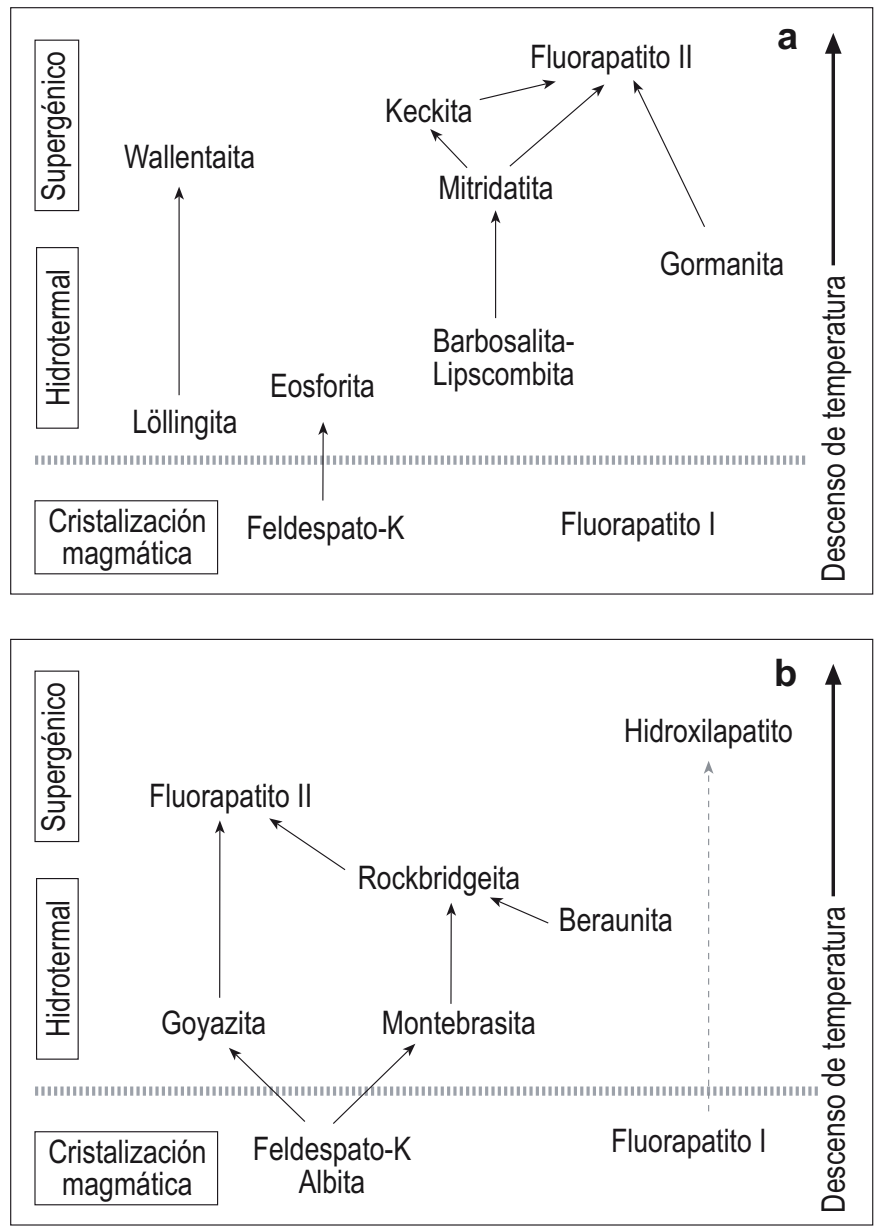

Fig. 3.7. Esquemas de la secuencia de alteración de las asociaciones fosfatadas del LG y las AB con turmalina: a) asociación I; y b) asociación II. además, restos asociados de mitridatita de color rojizo y tamaño micrométrico que tiene también una composición química muy rica en $\mathrm{Fe}^{3+}$ (hasta 2,71 apfu) acompañado de cantidades de $\mathrm{Al}$ y $\mathrm{Mn}^{3+}$ inferiores al 0,5 apfu cada uno. Las posiciones divalentes están totalmente ocupadas por el $\mathrm{Ca}$ (hasta 1,74 apfu), con menos $\mathrm{Fe}^{2+}$ y trazas de Na y Zn. Por su parte, la keckita se presenta en agregados granulares o de aspecto fibrosoradiado de menos de $1 \mathrm{~mm}$ de tamaño, de color verde amarillento y ligeramente pleocroicos, reemplazando tanto a barbosalita-lipscombita como a mitridatita (Lám. 3.4a). Al igual que los fosfatos que altera, su composición química presenta altos contenidos en $\mathrm{Fe}^{3+} \mathrm{e}$ intermedios en $\mathrm{Mn}$ que no llegan a completar la posición $\mathrm{B}$ de la fórmula general $\mathrm{XAB}_{2} \mathrm{C}_{2}(\mathrm{OH})_{3}\left(\mathrm{H}_{2} \mathrm{O}\right)_{7}\left[\mathrm{PO}_{4}\right]_{4}$ (Hochleitner y Fehr, 2010).

Destacan, además, los contenidos en Ca y Na que no ocupan completamente la posición $\mathrm{X}$, siendo esta rellenada también por Mn. Finalmente, el fluorapatito se presenta en cristales subhedrales intersticiales de tamaño milimétrico y origen primario (fluorapatito I), enriquecido en $\mathrm{Mn}$ y F, o reemplazando a fosfatos previos como la gormanita o la keckita (fluorapatito II), con contenidos significativos en Fe y cantidades variables de $\mathrm{OH}$ (Fig. 3.8). Localmente la eosforita se encuentra reemplazando al feldespato potásico mientras que como producto de alteración supergénica de la löllingita se encuentra wallentaita.

\section{Asociación II}

La segunda asociación fosfatada está compuesta fundamentalmente por rockbridgeita, beraunita, fluorapatito, hidroxilapatito y términos intermedios de la serie childrenitaeosforita, además de montebrasita y goyazita localmente. Su composición química y secuencia de alteración se recogen en el anexo III y en la figura 3.7b. La montebrasita es el fosfato más precoz y se encuentra en cristales subhedrales de tamaño inferior a $0,5 \mathrm{~mm}$ asociados a grandes cristales de albita y feldespato potásico, o como producto de alteración de estos. Químicamente el contenido en Li estimado por estequiometría alcanza prácticamente 1 

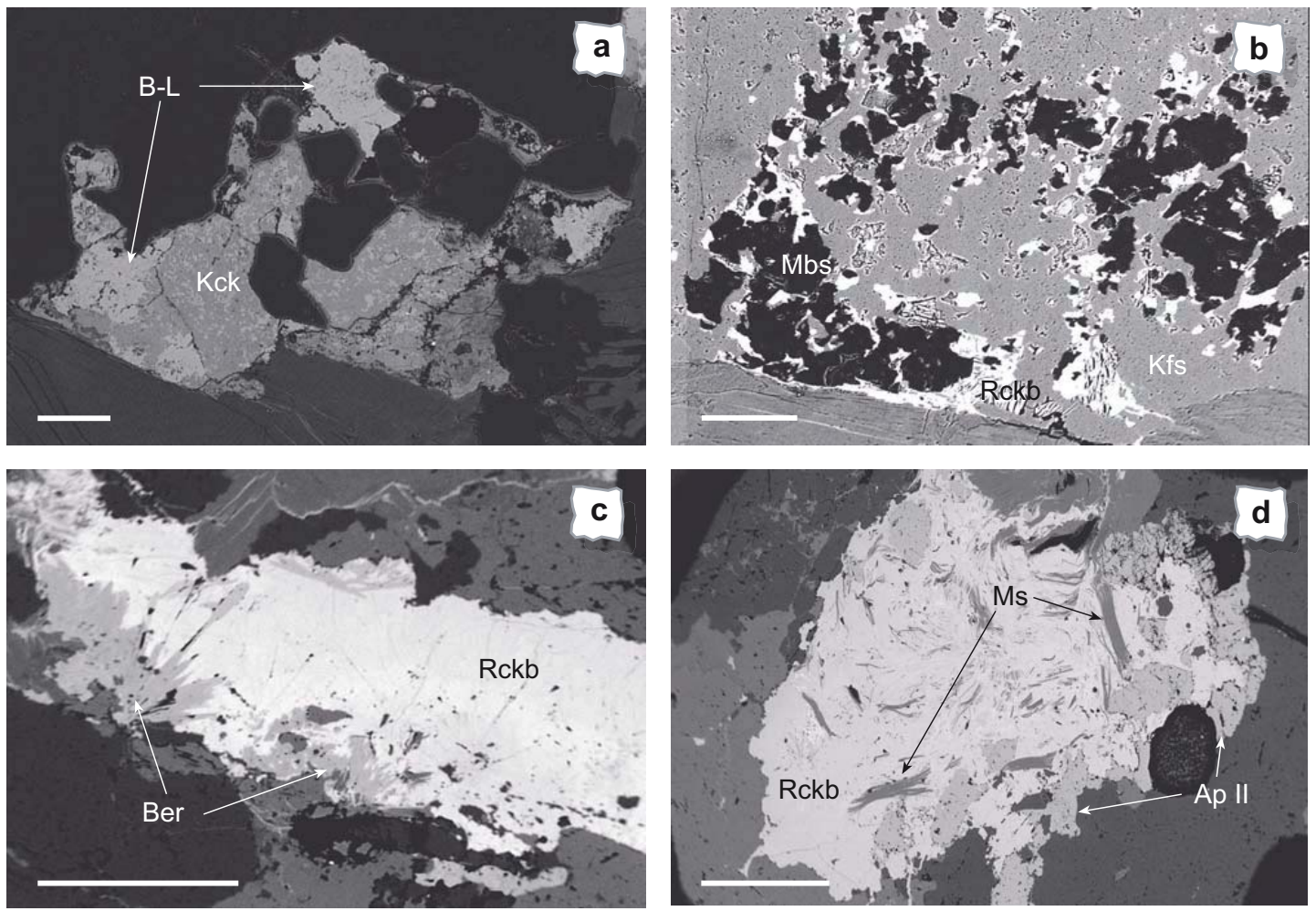

Lám. 3.4. Microfotografías electrónicas de los fosfatos de las asociaciones I y II: a) barbosalita-lipscombita reemplazada por keckita en la facies de $A B$ con turmalina, asociación I; b) feldespato potásico parcialmente reemplazado por montebrasita, que a su vez es posteriormente alterada a rockbridgeita, asociación II; c) agujas de beraunita rellenando una grieta en el LG y parcialmente reemplazados por agregados esferulíticos de rockbridgeita, asociación II; d) agregado de rockbridgeita con moscovita, rodeado de fluorapatito II, asociación II. Escala gráfica: a y b) $100 \mu \mathrm{m}$; c y d) $500 \mu \mathrm{m}$.
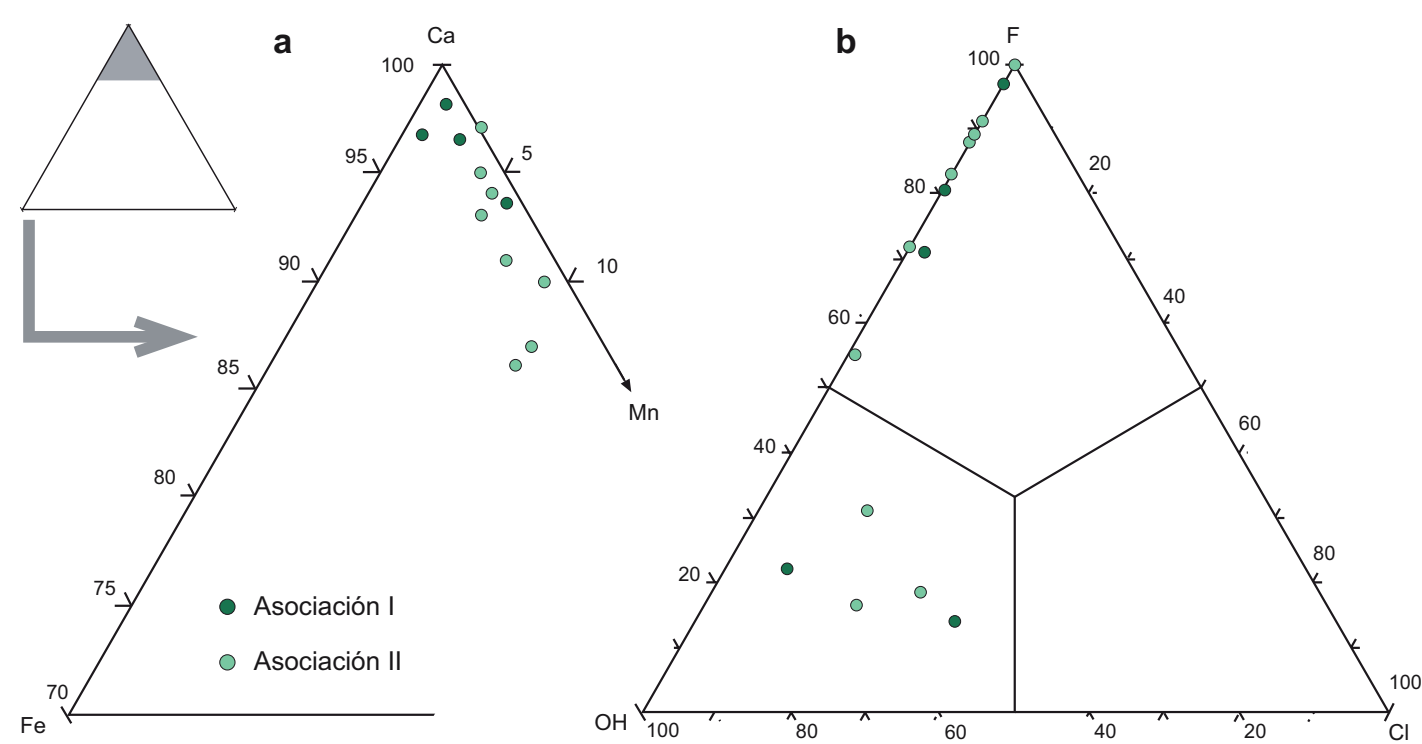

Fig. 3.8. Diagramas triangulares de la composición química del apatito en las asociaciones fosfatadas I y II del LG y las AB con turmalina: a) de los contenidos en Fe, Ca y Mn en las posiciones catiónicas (en apfu); y b) de los contenidos en $\mathrm{OH}, \mathrm{F} \mathrm{y} \mathrm{Cl}$ (en apfu). 


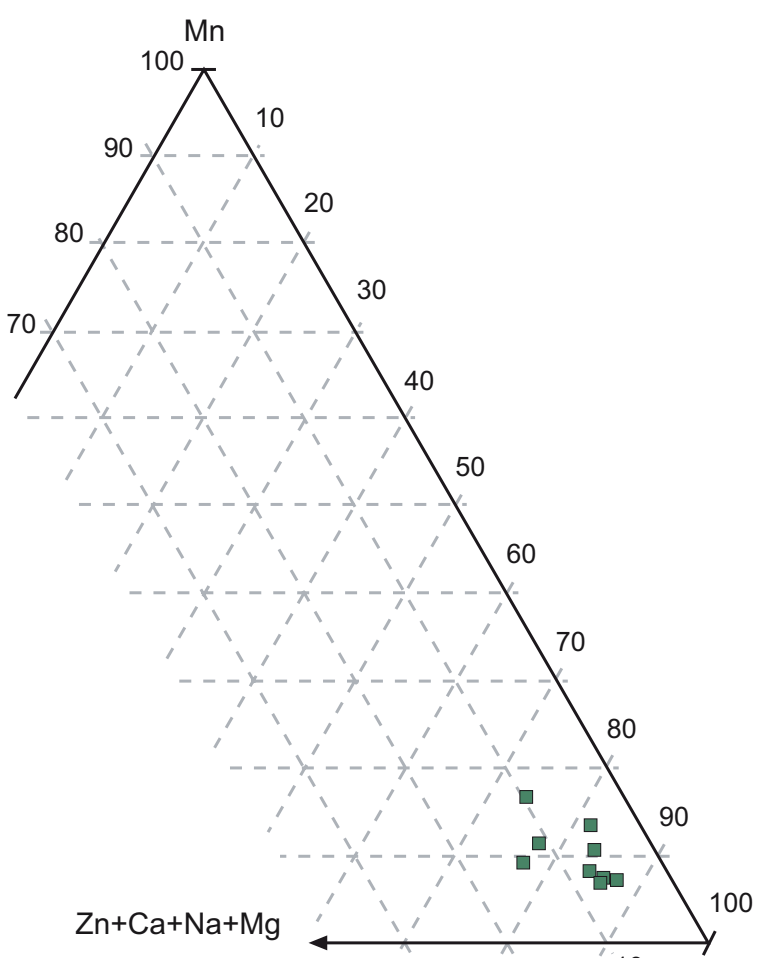

Fig. 3.9. Diagrama triangular $(\mathrm{Zn}+\mathrm{Ca}+\mathrm{Na}+\mathrm{Mg})-\mathrm{Mn}-\mathrm{Fe}$ de las posiciones catiónicas divalentes en proporciones atómicas en la rockbridgeita de la asociación fosfatada II. apfu, con apenas trazas de K, Ca o Fe. La presencia de este último elemento en la montebrasita probablemente es debida a contaminación por la rockbridgeita que la altera (Lám. 3.4b). El contenido en flúor es muy bajo (entre 1,52 y $3,52 \%$ en peso). La beraunita (Lám. 3.4c) forma fibras de hasta $300 \mu \mathrm{m}$ de tono verde a rosado. Presenta una composición química enriquecida en $\mathrm{Fe}$ (hasta 1,97 apfu de $\mathrm{Fe}^{3+}$ y hasta 0,74 apfu de $\mathrm{Fe}^{2+}$ ) con escasas sustituciones de $\mathrm{Mn}, \mathrm{Ca}, \mathrm{Mg}$ o Zn y contenidos relativamente elevados en Al reemplazando al $\mathrm{Fe}^{3+}$ (hasta 0,83 apfu), lo que la asemeja a la beraunita rica en Al del distrito de Krásno (Sejkora et al., 2006). Reemplazando a la fase anterior, a la montebrasita, a los feldespatos o incluso a la turmalina, o bien como relleno de grietas se encuentra la rockbridgeita en esférulos o agregados fibroso-radiados de color

verde oliva a rojo-anaranjado, muy pleocroicos, de hasta $0,5 \mathrm{~cm}$ de longitud (Lám. 3.4b,c,d). En su composición química prácticamente todo el Fe está en forma de $\mathrm{Fe}^{3+}$ ocupando las posiciones trivalentes (entre 3,47 y 3,99 apfu), mientras que el resto del Fe entra en las posiciones divalentes como $\mathrm{Fe}^{2+}$ (Fig. 3.9), con hasta 0,12 apfu de $\mathrm{Mn}$ y trazas de $\mathrm{Ca}, \mathrm{Na}, \mathrm{K}$ y Zn.

La goyazita se presenta localmente en agregados cristalinos de tamaño milimétrico junto con apatito o bien como cristales subhedrales de hasta $200 \mu \mathrm{m}$ incluidos en albita, considerándose un producto de alteración de la misma (Baldwin et al., 2000). Su composición química indica un dominio claro del $\mathrm{Sr}$ (hasta 0,89 apfu), siendo poco significativos los componentes de la crandallita (hasta $38 \%$ ) y gorceixita (hasta $1 \%$ ). El Al presenta escasa sustitución por $\mathrm{Fe}^{3+}$, lo que deja un pequeño déficit atómico comparado con la composición teórica. La cantidad de F es muy baja, ya que apenas llega a 0,15 apfu. Rellenando huecos intersticiales o bien como producto de alteración de la goyazita y de la rockbridgeita, se encuentran agregados cristalinos incoloros de fluorapatito I y || respectivamente (Lám. 3.4d) que muestran altos contenidos en $\mathrm{Mn}$ (hasta 0,37 apfu) sustituyendo al $\mathrm{Ca}$, a veces también $\mathrm{Fe}$, $\mathrm{Sr}$ o $\mathrm{Na}$ (Fig. 3.8a,b). Por otro lado, el hidroxilapatito forma agregados intersticiales de color pardo, probablemente formado a partir de la alteración del apatito magmático previo, aunque no se han observado evidencias texturales. Posee también abundante Mn (hasta 0,39 apfu) pero además contiene altas cantidades de Fe (hasta 0,13 apfu). 


\section{Otros accesorios}

El circón es muy común, se encuentra en todas las facies de la UE generalmente asociado a la biotita en las facies más internas y a la turmalina en el LG y las AB. Se presenta en cristales sub- a euhedrales o redondeados de tamaño micrométrico y con su característico halo pleocroico. En el MP se ha identificado la presencia de andalucita parcialmente alterada a moscovita, mientras que en la zona de la mina Salmantina se han encontrado varios cristales de berilo en el LG, de tamaño hasta centimétrico y asociados generalmente a pockets o bolsadas en las que el tamaño de los cristales aumenta respecto a los adyacentes. Su fórmula media es $\mathrm{Be}_{3}\left(\mathrm{Na}_{0,05} \square_{0,95}\right)_{\Sigma 1}\left(\mathrm{Al}_{1,87} \mathrm{Fe}_{0,03}\right)_{\Sigma 2} \mathrm{Si}_{6} \mathrm{O}_{18}$. Finalmente, en las $\mathrm{AB}$ es frecuente la presencia de gahnita $\left[(\mathrm{Zn}, \mathrm{Fe}) \mathrm{Al}_{2} \mathrm{O}_{4}\right]$ en cristales de tamaño inferior a $1 \mathrm{~mm}$ incluidos en la moscovita. Su composición química presenta entre 52-70 \% mol de componente gahnita y entre 30-42 \% mol de componente hercinita (Anexo III).

\subsubsection{Mineralización}

\subsubsection{1. Óxidos de $\mathrm{Sn}, \mathrm{Nb}, \mathrm{Ta}$ y $\mathrm{Ti}$}

Estos óxidos tienen un carácter muy accesorio, encontrándose fundamentalmente rutilo e ilmenita en pequeños cristales de hábito fibroso tanto dentro de la biotita y la moscovita como en los cristales de clorita derivados de su alteración de biotita. Ocasionalmente aparecen en la matriz como cristales aislados de mayor tamaño. La casiterita se presenta en cristales anhedrales de tamaño milimétrico asociados frecuentemente con moscovita. Ocasionalmente se ha observado la presencia de tantalita-(Fe) diseminada en el LG, cuya fórmula media es $\left(\mathrm{Fe}_{0,76} \mathrm{Mn}_{0,19}\right)_{\Sigma 0,96}\left(\mathrm{Ta}_{1,09} \mathrm{Nb}_{0,8} \mathrm{Ti}_{0,1} \mathrm{Sn}_{0,04}\right)_{\Sigma 2} \mathrm{O}_{6}$ (Anexo III).

Los estudios geoquímicos de roca total llevados a cabo por Ramírez (1996) y FernándezLeyva (2007) en las facies graníticas del Batolito de Jálama ponen de manifiesto los elevados contenidos medios de Sn en todas ellas. Se observa un incremento en el contenido de este elemento en las facies más evolucionadas, probablemente debido a la mayor concentración de casiterita en estas facies (Fig. 3.10a). Comparando los contenidos en Sn de la roca con los de Ta y Li se observa que ocurre lo mismo (Fig. 3.10b,c). Además, los contenidos en Ta son extremadamente bajos, generalmente no superiores a 10 ppm, mientras que los de Li alcanzan las 400 ppm. Finalmente, el comportamiento del Nb respecto al Sn es bastante disperso, no marcando ningún patrón definido con la evolución de las facies (Fig. 3.10d). Estos resultados ponen de manifiesto la escasez o inexistencia de fases ricas en $\mathrm{Nb}$ y $\mathrm{Ta}$ (minerales del grupo de la columbita) y en Li (mica rica en Li) en las rocas analizadas, como se ha reflejado en el estudio petrográfico y mineralógico de los apartados previos.

\subsection{DIQUES PEGMATÍTICOS INTRA Y PERIBATOLÍTICOS}

En las facies de borde del batolito de Jálama se han identificado numerosos diques pegmatíticos que aumentan en número y complejidad, tanto textural como mineralógicamente, desde las facies internas de la UE hacia el LG y las AB con turmalina y las rocas metamórficas del CEG de la aureola de contacto. Sin embargo, la escasa potencia de la mayoría de ellos no ha 

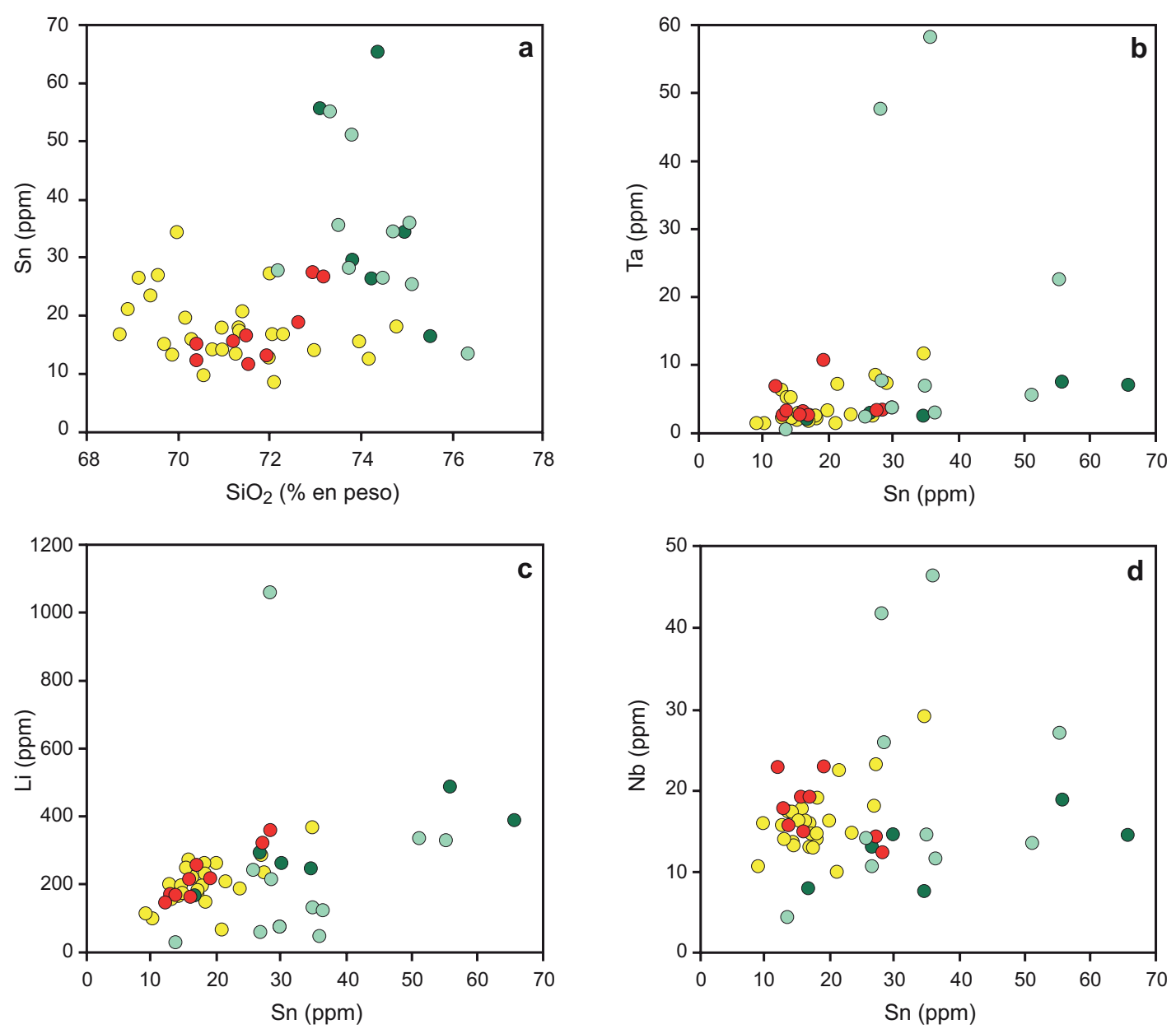

$\bigcirc$ Monzogranito porfídico (MP) $\bigcirc$ Granito equigranular (GE) $\quad$ Leucogranito con turmalina (LG) $\bigcirc$ Aplitas de borde (AB)

Fig. 3.10. Diagramas de correlación de algunos elementos traza analizados en roca total de las facies graníticas de la UE del batolito de Jálama: a) $\mathrm{Sn}$ vs. $\mathrm{SiO}_{2}$; b) Ta vs. Sn; c) Li vs. Sn; y d) Nb vs. Sn. Datos tomados de Ramírez (1996) y Fernández-Leyva (2007).

permitido incluirlos en la cartografía, en la que solo se representan los diques peribatolíticos de Cruz del Rayo (Fig. 3.1).

Generalmente los diques pegmatíticos intragraníticos son estériles, la mayoría de ellos no presentan casiterita o es muy accesoria, mientras que los diques peribatolíticos muestran una importante mineralización diseminada de casiterita y óxidos de $\mathrm{Nb}$ y Ta.

\subsubsection{Roca encajante}

\section{Diques intragraníticos}

Los cuerpos pegmatíticos encajados en el MP, que es la facies más interna del batolito de Jálama y, por tanto, la menos evolucionada, son muy escasos. Estos diques muestran una morfología tabular y potencias no superiores a los $30 \mathrm{~cm}$, con direcciones que varían entre $\mathrm{N} 90^{\circ} \mathrm{E}$ y $\mathrm{N} 120^{\circ} \mathrm{E}$ y buzamientos de entre $45-60^{\circ} \mathrm{S}$. Presentan una mineralogía sencilla, estando compuestos esencialmente por cuarzo, feldespato potásico y mica blanca, con albita 
y turmalina subordinadas. Sin embargo, no ha sido posible tomar muestras de estos diques debido a la intensa alteración que presentan.

Se diferencian varios diques pegmatíticos encajados en el GE en las zonas de las minas Horia y Mari Carmen (Fig. 3.11), cuya intrusión produce una banda de alteración hidrotermal en las rocas graníticas encajantes, generalmente no superior a los $10 \mathrm{~cm}$, en la cual la biotita es reemplazada por mica blanca y clorita.

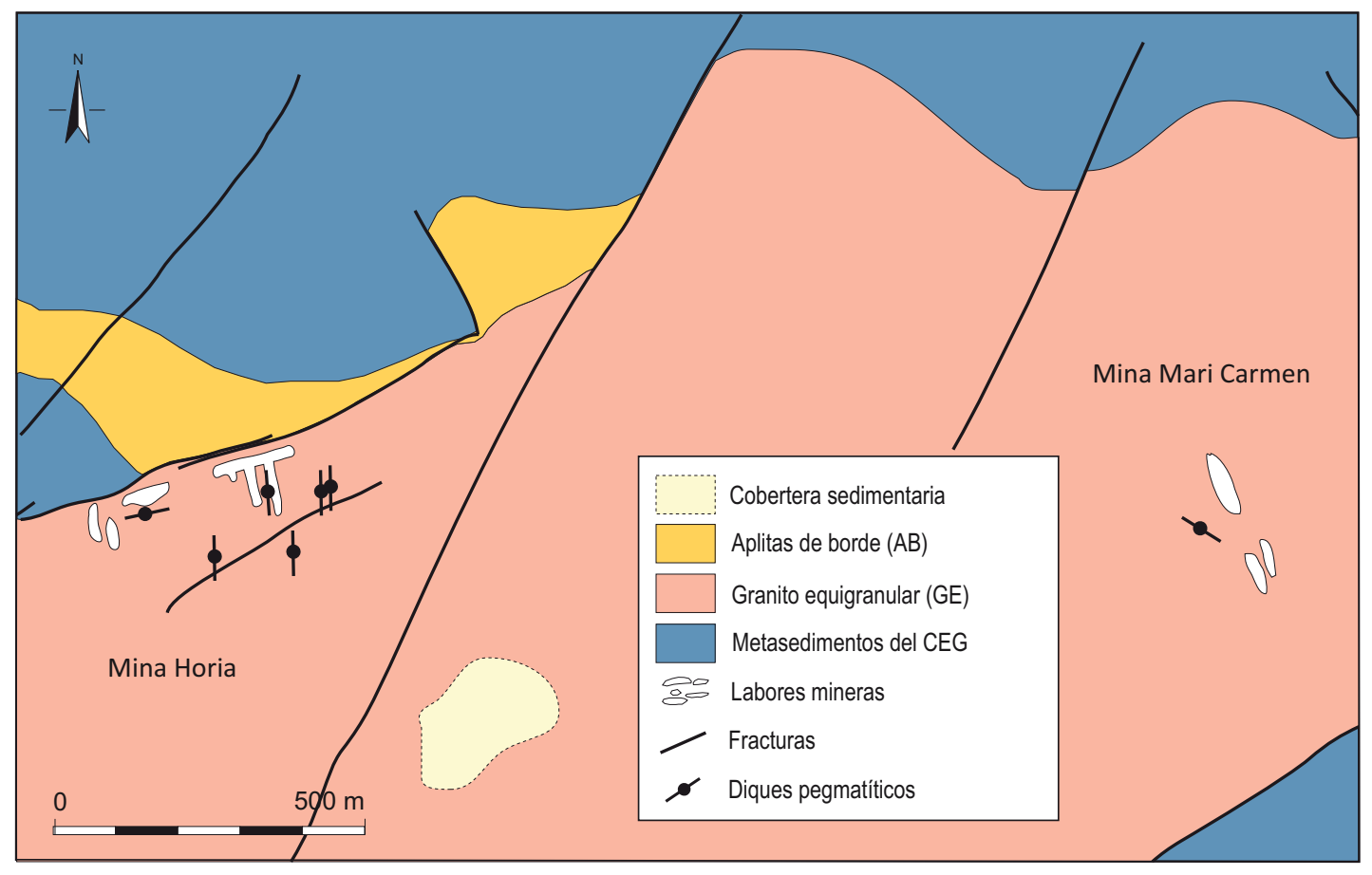

Fig. 3.11. Esquema geológico de la zona de la UE del batolito de Jálama con la situación de las minas Horia y Mari Carmen y los diques pegmatíticos intragraníticos estudiados.

En la mina Horia los diques presentan una dirección principal $\mathrm{N} 170^{\circ} \mathrm{E}-\mathrm{N} 180^{\circ} \mathrm{E}$ con buzamientos aparentemente subverticales y direcciones subordinadas $\mathrm{N}^{\circ} 0^{\circ} \mathrm{E}$ y $\mathrm{N} 120^{\circ} \mathrm{E}$. Su morfología consiste fundamentalmente en cuerpos tabulares o lenticulares de longitudes máximas próximas a los $100 \mathrm{~m}$ y potencias no superiores a los $30 \mathrm{~cm}$. Debido a su escasa potencia estos diques muestran una mineralogía simple, raramente presentan zonación y, cuando esta aparece, es muy grosera y consiste en (Lám. 3.5a): 1) una zona de borde de carácter aplítico o microgranítico compuesta por cuarzo, feldespato potásico, plagioclasa y mica blanca; 2) una zona intermedia de grano medio a grueso con cuarzo y plagioclasa y, en menor proporción, mica blanca y grandes cristales de feldespato potásico creciendo perpendicularmente a los bordes de los diques y hacia el interior de los mismos, además de los fosfatos staněkita, zwieselita y apatito como accesorios; y 3) un núcleo principalmente compuesto por cristales de feldespato potásico y cuarzo intercrecidos y de tamaño centimétrico.

En el área de la mina Mari Carmen aflora un único dique pegmatítico de dirección N140 $\mathrm{E}$ que buza $40^{\circ} \mathrm{SE}$ y alcanza los $100 \mathrm{~m}$ de longitud y los $2 \mathrm{~m}$ de potencia (Lám. 3.5b). De nuevo, la 

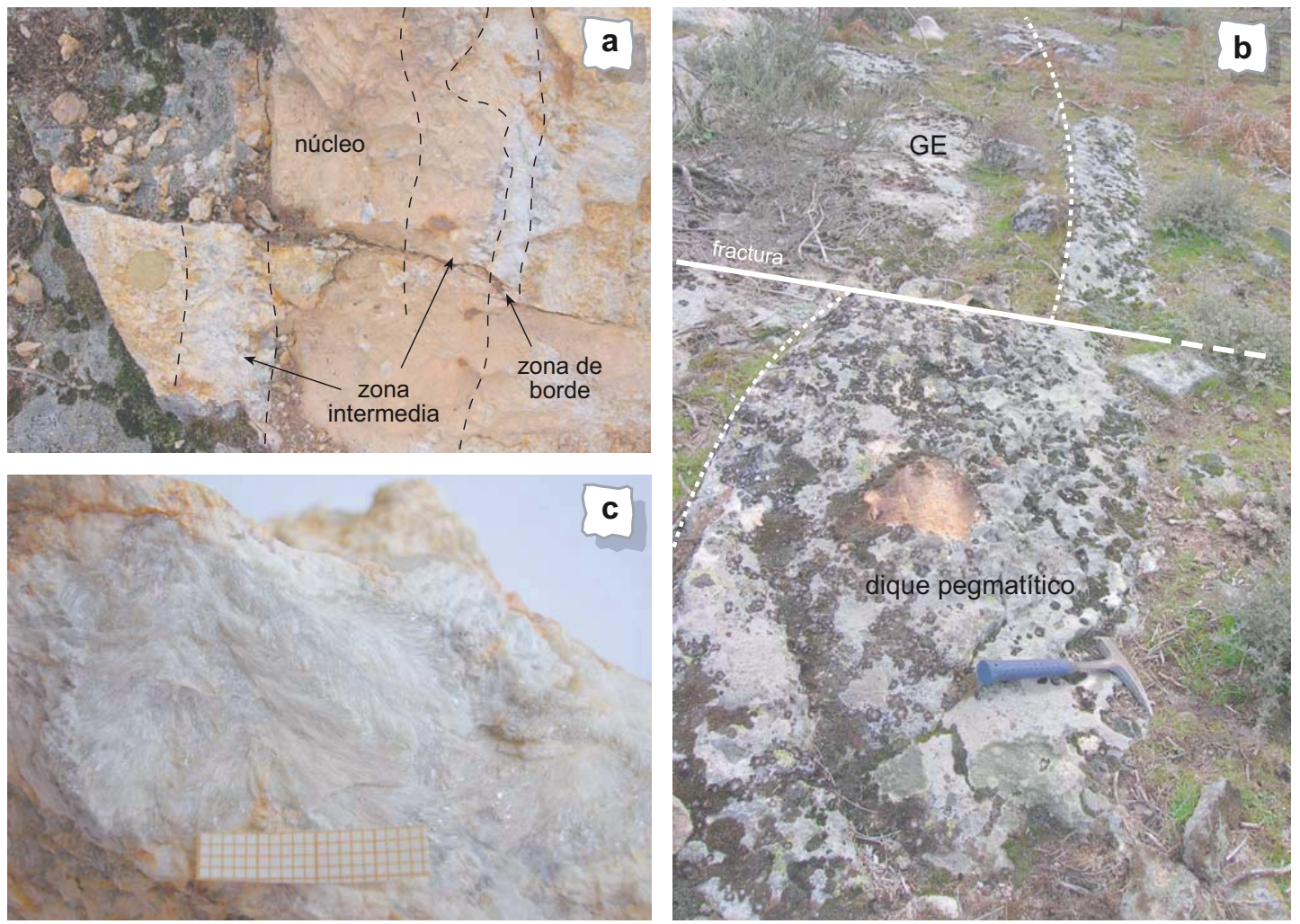

Lám. 3.5. Diques pegmatíticos intragraníticos encajados en el GE: a) zonación grosera de un dique pegmatítico de dirección $\mathrm{N} 180^{\circ} \mathrm{E}$ en la mina Horia; b) afloramiento del dique pegmatítico de dirección $\mathrm{N} 140^{\circ} \mathrm{E}$ en la mina Mari Carmen; c) detalle de los agregados en abanico de la moscovita y el cuarzo en la pegmatita de la mina Mari Carmen.

mineralogía de estos diques es muy sencilla estando compuestos esencialmente por cuarzo, feldespato potásico, moscovita y albita, además de apatito, clorita y arsenopirita como minerales accesorios. Aunque no es posible determinar un patrón de zonación en este dique, sí se define una zona irregular de composición tipo greisen en su borde más oriental, formado esencialmente por cuarzo, mica blanca y albita de grano muy fino. Destacan, además, texturas de intercrecimiento radiales o en abanico entre moscovita y cuarzo (Lám. 3.5c), generalmente asociadas a grietas en el contacto con el granito, indicando un crecimiento inducido por un rápido desequilibrio (London, 1992).

Los diques encajados en el LG y las AB con turmalina de las minas Salmantina, Carrasquera, Teso de la Matanza, Profunda y Bon presentan direcciones que varían entre $\mathrm{N} 130^{\circ} \mathrm{E}$ y N $180^{\circ} \mathrm{E}$, con buzamientos subverticales, siendo menos frecuentes las direcciones $N 40^{\circ} \mathrm{E}$ y $\mathrm{N} 70^{\circ} \mathrm{E}$ (Fig. 3.12). Su morfología varía desde masas irregulares hasta cuerpos tabulares o lenticulares, aunque en ocasiones se presentan en forma de pockets o bolsadas amorfas dentro de la masa granítica. No suelen tener potencias superiores a $1 \mathrm{~m}$, variando generalmente entre los $10 \mathrm{y}$ los $50 \mathrm{~cm}$, lo que les confiere un aspecto bastante homogéneo (Lám. 3.6a). Están compuestos fundamentalmente por cuarzo, feldespato potásico, albita y moscovita, con cantidades variables aunque accesorias de fosfatos de Fe-Mn-(Al-Li) y apatito y menos turmalina, biotita, circón, clorita y sulfuros de Fe y Cu. Además, muchos de estos diques muestran signos claros de deformación como extinción ondulante del cuarzo, kinking o texturas combadas de 


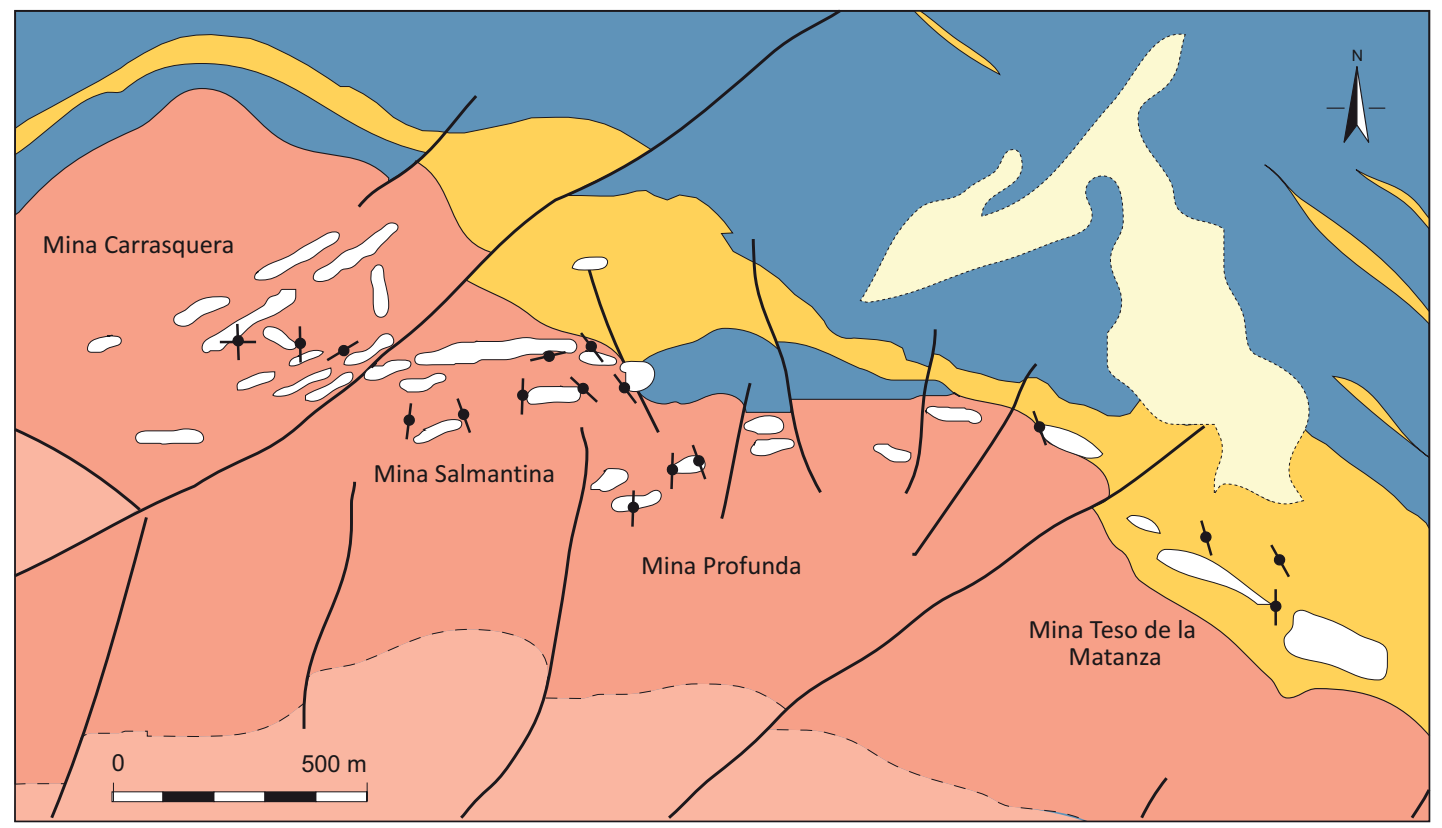

\begin{tabular}{|c|c|c|}
\hline & Cobertera sedimentaria & \multirow{3}{*}{$\begin{array}{l}\text { Unidad } \\
\text { Externa }\end{array}$} \\
\hline & Aplitas de borde (AB) & \\
\hline & Leucogranito con turmalina (LG) & \\
\hline & Granito equigranular (GE) & \\
\hline & Metasedimentos del CEG & \\
\hline$a$ & Diques pegmatiticos & \\
\hline 8 & Labores mineras & \\
\hline 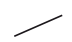 & Fracturas & \\
\hline$\sim$ & Contacto intrusivo & \\
\hline 八 & Contacto gradual & \\
\hline
\end{tabular}

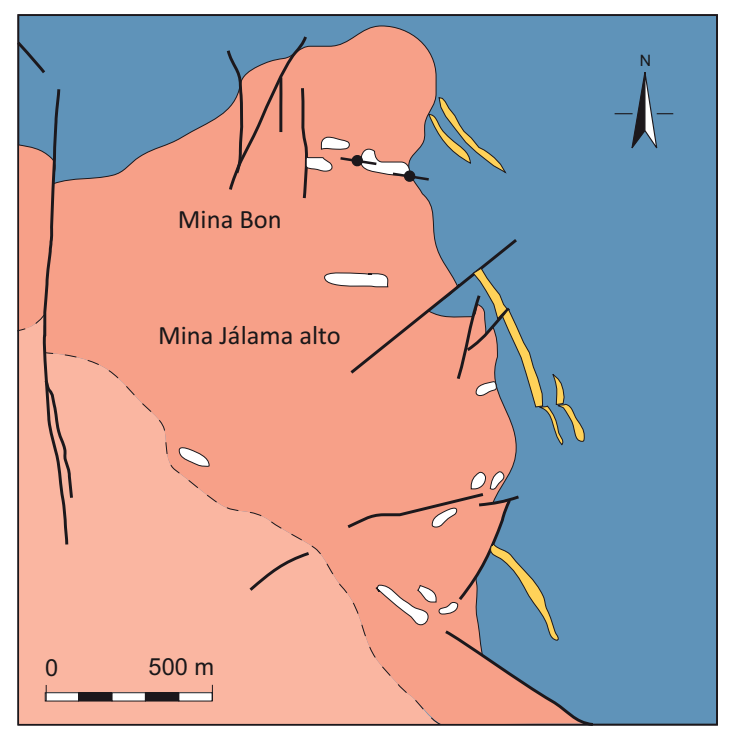

Fig. 3.12. Esquema geológico de la zona de la UE del batolito de Jálama con la situación de las minas Salmantina, Carrasquera, Profunda, Teso de la Matanza, Bon y Jálama Alto y los diques pegmatíticos intragraníticos estudiados.

moscovita y albita y en varios de ellos se puede apreciar una grosera zonación interna (Lám. 3.6b,c). Esta consiste en: 1) una zona de borde de carácter aplítico compuesta por albita, cuarzo y moscovita en diferentes proporciones; 2 ) una zona de pared de idéntica composición mineralógica y grano medio; 3) una zona interna no siempre visible y de tamaño de grano grueso, formada por albita, en ocasiones dispuesta de forma perpendicular a las paredes del dique, moscovita y grandes cristales de feldespato potásico, con cuarzo de manera accesoria (Lám. 3.6d); y 4) un núcleo compuesto por intercrecimientos de cuarzo y feldespato potásico de tamaño hasta centimétrico. Son frecuentes los signos de albitización en estos diques pegmatíticos, especialmente en sus zonas más internas donde se observan agregados masivos blanquecinos de albita sacaroide (Lám. 3.6e). 

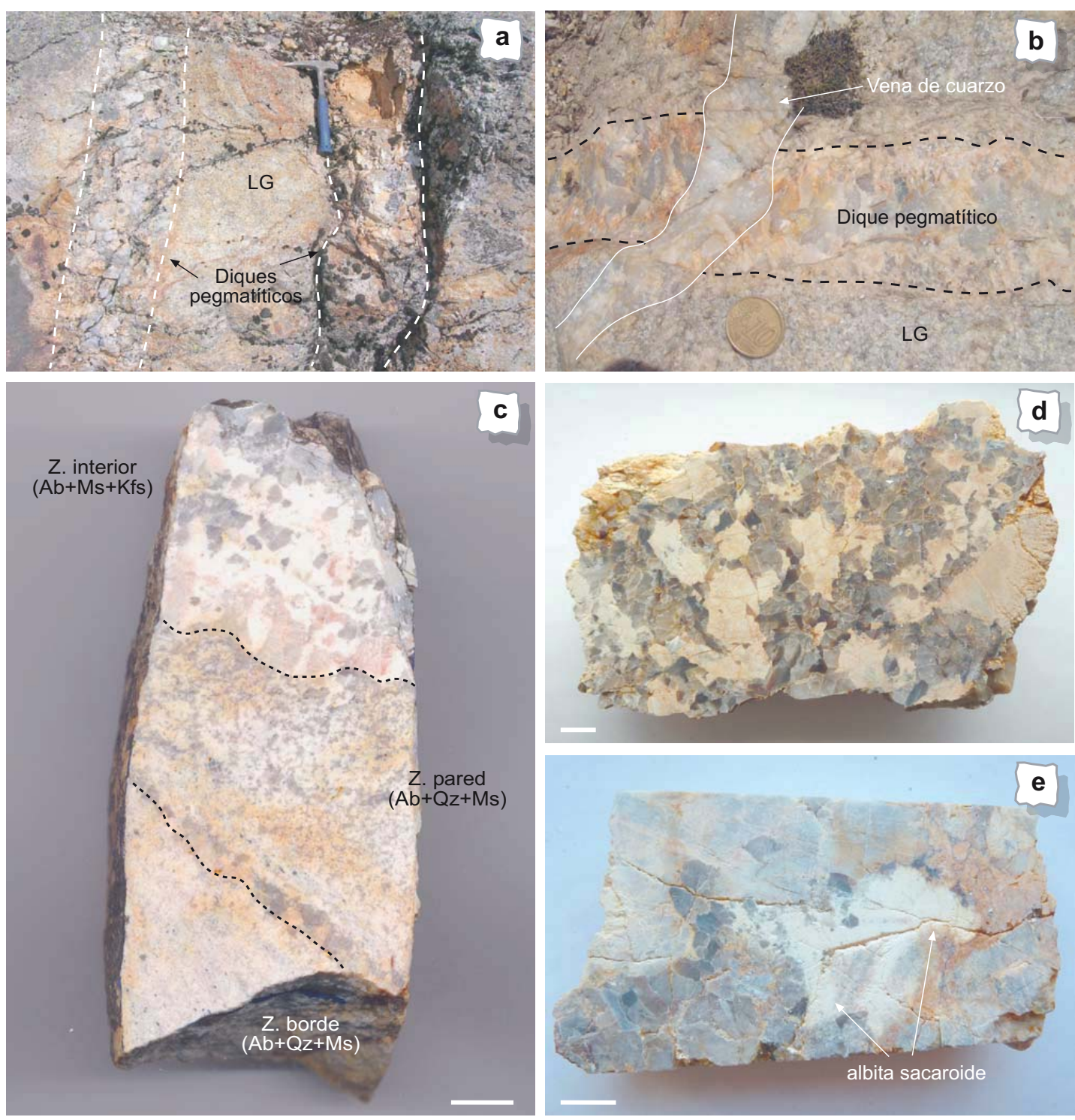

Lám. 3.6. Diques pegmatíticos intragraníticos encajados en el $L G$ y las $A B$ con turmalina: a) diques pegmatíticos $\mathrm{N} 180^{\circ} \mathrm{E}$ y de buzamiento subvertical encajados en el LG de la mina Profunda; b) detalle de un dique pegmatítico de dirección $\mathrm{N} 40^{\circ} \mathrm{E}$ con potencia centimétrica que presenta una ligera zonación interna en el área de la mina Salmantina; c) detalle de la zonación interna que presenta un dique pegmatítico de dirección $\mathrm{N} 180^{\circ} \mathrm{E}$ en la mina Profunda; d) ejemplo de la zona interna de los diques pegmatíticos que afloran en la mina Bon, con dirección $\mathrm{N} 110-115^{\circ} \mathrm{E}$; e) detalle de los agregados de albita sacaroide en la zona interna de los diques, mina Salmantina. Escala gráfica en c, d y e: $1 \mathrm{~cm}$.

\section{Diques peribatolíticos}

Los cuerpos pegmatíticos de Cruz del Rayo que intruyen en los materiales de la aureola de metamorfismo de contacto del CEG (Fig. 3.1), a pesar de no ser muy abundantes, sí son los más importantes a nivel de distrito en cuanto a la mineralización que presentan. De acuerdo con ENADIMSA (1982) este campo pegmatítico constaba de tres diques principales con dirección $\mathrm{N} 170^{\circ} \mathrm{E}$ y buzamiento subvertical, con varias ramificaciones secundarias y algunas fracturas locales con escaso desplazamiento. Dichos diques se acuñan lateralmente hacia ambos lados, 
lo que da una longitud aproximada de casi $300 \mathrm{~m}$ y potencias que varían entre $20 \mathrm{~cm}$ y $1 \mathrm{~m}$. La mena principal que fue explotada es la casiterita, aunque durante el desarrollo de este trabajo se ha puesto de manifiesto la existencia, además, de minerales del grupo de la columbita.

En estos diques se diferencian dos tipos: los de composición granítica y los de composición tipo greisen, ambos con zonación interna (Lám. 3.7a,b).
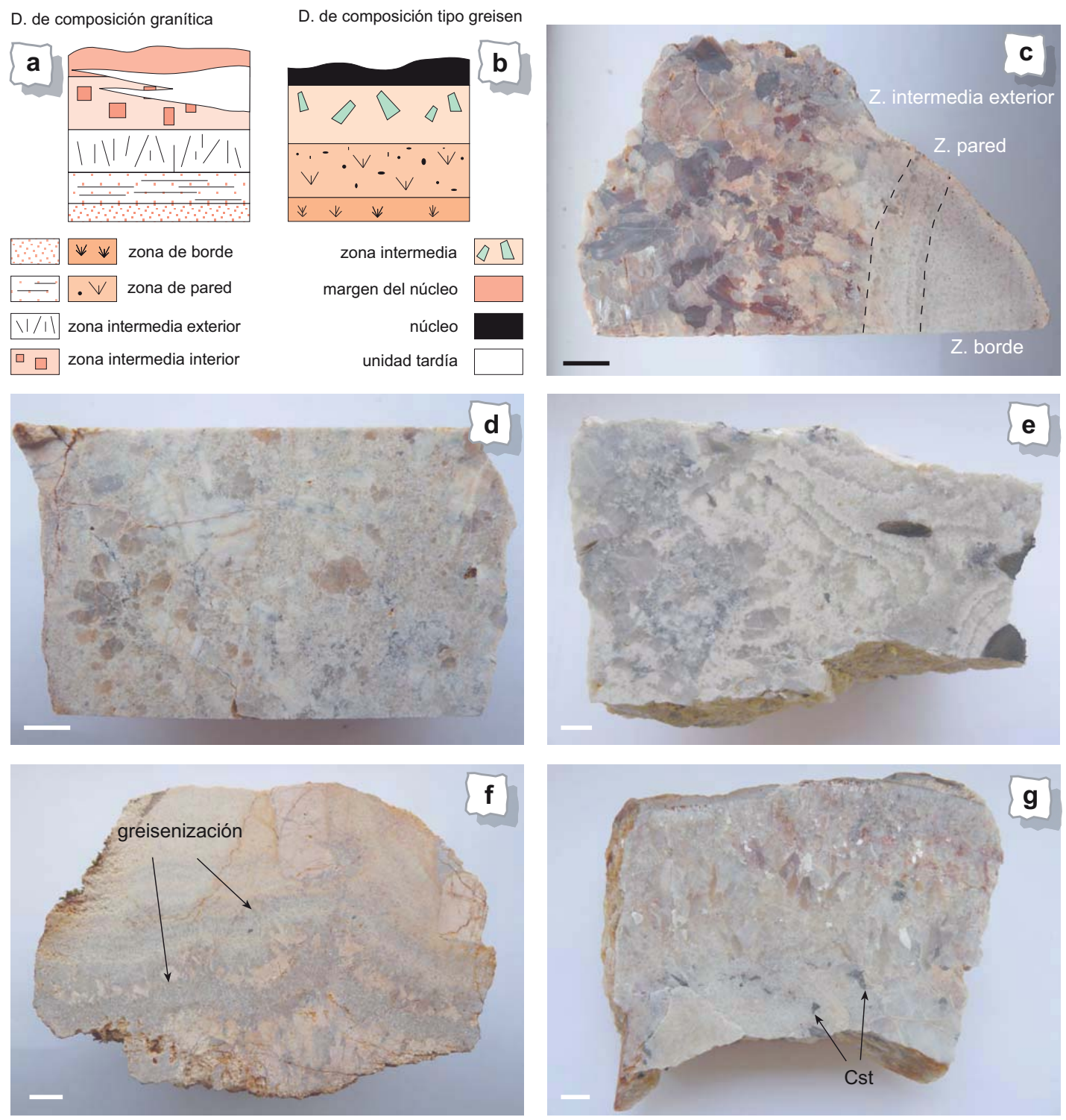

Lám. 3.7. Diques pegmatíticos peribatolíticos del batolito de Jálama; esquemas de la zonación típica que presentan: a) los diques pegmatíticos de composición granítica; y b) los diques pegmatíticos de composición tipo greisen; c) fragmento pegmatítico de composición granítica con estructura zonada; d) detalle de la zona intermedia interior de estos diques donde se aprecian grandes cristales de plagioclasa y de cuarzo en una matriz de tamaño de grano fino; e) fragmento pegmatítico fuertemente albitizado. Obsérvese cómo los agregados cristalinos de albita reemplazan a la roca y cómo posteriormente esta es parcialmente greisenizada; f) detalle de un fragmento de pegmatita de composición granítica parcialmente greisenizado; g) fragmento de un dique de composición tipo greisen en contacto con el encajante metamórfico (parte superior). Obsérvese el crecimiento perpendicular al mismo de los agregados de moscovita. Escala gráfica: $1 \mathrm{~cm}$. 
Los diques de composición granítica constan de: 1) una zona de borde de tamaño milimétrico con textura aplítica de tamaño de grano muy fino, compuesta por abundante albita, cuarzo y mica blanca, con feldespato potásico subordinado; 2) una zona de pared que presenta prácticamente la misma composición que la anterior pero de tamaño de grano un poco más grueso y que muestra un laminado marcado por diferencias en la proporción de los diferentes minerales que la componen; 3 ) la zona intermedia exterior, que presenta un tamaño de grano grueso y consta principalmente de albita de tipo clivelandita, moscovita en agregados con texturas en libro de hasta medio centímetro de tamaño y cuarzo subordinado, todos ellos con signos de deformación. Se aprecia la existencia de agregados microgranudos de cuarzo entre los bordes de los cristales de mayor tamaño; 4) la zona intermedia interior, que se caracteriza por la presencia de grandes cristales de feldespato potásico frecuentemente albitizados en una matriz de grano medio-grueso de cuarzo, albita y moscovita; 5) finalmente, el margen del núcleo está formado por grandes cristales de feldespato potásico y cuarzo (Lám. 3.7a,b,c). No se ha observado la existencia de un núcleo de cuarzo en ninguna de las muestras estudiadas. De manera accesoria se identifican fosfatos como la alluaudita, la mitridatita, la rockbridgeita y el apatito en las zonas más externas de los diques, además de la clorita asociada a grietas y el circón diseminado.

Posteriormente, estos cuerpos pegmatíticos sufren un proceso de metasomatismo de sodio que afecta a varias zonas de las pegmatitas, desarrollando una Unidad Tardía (UT) casi exclusivamente compuesta por albita sacaroide de tamaño de grano fino a muy fino (Lám. 3.7e). Especialmente afectadas se encuentran las zonas intermedias de los cuerpos, donde los megacristales de feldespato potásico se encuentran, en ocasiones, casi totalmente albitizados.

Los diques de composición tipo greisen están compuestos casi exclusivamente por cuarzo y moscovita y presentan una zonación más simple (Lám. 3.7g) con: 1) una zona de borde de grano muy fino compuesto fundamentalmente por cuarzo y moscovita, esta última creciendo en agregados en abanico dispuestos perpendicularmente al margen de los diques y con turmalina y apatito accesorios; 2) la zona de pared está marcada por un aumento en el tamaño de grano, aunque el límite con la anterior es gradual. Domina el cuarzo en grandes cristales, con mica blanca de tamaño hasta centimétrico y fosfatos de la serie ambligonitamontebrasita escasos; 3 ) la zona intermedia presenta una mineralogía similar aunque de mayor tamaño de grano, en la que destacan, además, cristales centimétricos de berilo y abundante ambligonita-montebrasita; $y, 4)$ finalmente, se encuentra un núcleo de cuarzo irregularmente distribuido. La intrusión de estos diques provoca la greisenización parcial de los diques de composición granítica y, especialmente, de la UT (Lám. 3.7e,f) y la turmalinización del encajante metamórfico.

\subsubsection{Petrografía y química mineral}

\section{Cuarzo}

Se pueden distinguir varios tipos de cuarzo en los diques pegmatíticos, siendo el más abundante el cuarzo que se presenta en cristales anhedrales de grano fino a grueso con extinción ondulante, bordes dentados y crecimiento de subgranos en los bordes, claros signos 
de deformación. Un segundo tipo de cuarzo se presenta intercrecido con la plagioclasa en texturas gráficas y mirmequíticas o vermiculares, o en texturas esqueléticas con la moscovita, especialmente en zonas intermedias de los diques (Lám. 3.8a,b). Además, se identifica un cuarzo en cristales subhedrales a euhedrales de grano fino a muy fino y textura granoblástica que se encuentra asociado a grietas y aperturas extensionales de los diques. Finalmente, se encuentran agregados microcristalinos de cuarzo que cristalizan alrededor de los bordes de cristales previos y que están frecuentemente asociados con moscovita, también de tamaño de grano muy fino, constituyendo una textura de tipo greisen que es más común en los diques peribatolíticos de Cruz del Rayo.

\section{Feldespatos}

El feldespato potásico es de tipo microclina y se presenta comúnmente en cristales anhedrales a euhedrales de tamaño milimétrico en las zonas externas de los diques y que aumentan en abundancia y tamaño, hasta centimétricos y decimétricos en algunos casos, hacia las zonas más internas de los mismos. Muestran la típica macla en enrejado y frecuentes texturas pertíticas en venas y parches (Lám. 3.8c). La composición química de estos feldespatos es muy similar tanto en los diques intragraníticos como en los diques peribatolíticos de composición granítica de Cruz del Rayo, variando entre $\operatorname{Or}_{93} \mathrm{Ab}_{7}$ y $\mathrm{Or}_{98} \mathrm{Ab}_{2}$ (Fig. 3.13a). La mayoría de los feldespatos analizados muestran elevados contenidos en $\mathrm{P}_{2} \mathrm{O}_{5}$ que se incrementan con la evolución de los diques pegmatíticos desde $0,72 \%$ en peso de media en los de los diques del GE hasta $0,80 \%$ en peso en los que intruyen en el LG y $0,88 \%$ en peso en los diques peribatolíticos de Cruz del Rayo, con valores puntuales de hasta 1,15\% en peso (Anexos III). En todos los casos los contenidos en $\mathrm{P}_{2} \mathrm{O}_{5}$ son más elevados que los del feldespato potásico de las facies graníticas de la UE.

La plagioclasa de tipo albita es un mineral común a todos los diques pegmatíticos tanto intra como peribatolíticos de composición granítica. Se diferencian tres tipos: por un lado, la albita magmática que se presenta en cristales anhedrales a subhedrales de grano medio a grueso con macla polisintética, en ocasiones combada, frecuentemente con texturas chess-board o en tablero de ajedrez (Lám. 3.8d) y extinción ondulante. En la zona intermedia exterior de los diques de composición granítica de Cruz del Rayo esta albita es de tipo clivelandita y se dispone en agregados arborescentes alargados cuyo maclado polisintético se encuentra combado incluso hasta $30^{\circ}$, lo que demuestra una deformación posterior al emplazamiento (Lám. 3.8e). Por otro lado, se encuentra la albita que forma láminas, venas o parches pertíticos dentro del feldespato potásico. Y por último, se identifican cristales euhedrales de albita de tamaño de grano fino a muy fino, frecuentemente con macla simple y con un claro origen secundario como producto de alteración del feldespato potásico o rellenando fracturas. Su composición química se muestra más o menos constante (Fig. 3.13a) oscilando entre $A b_{97} A n_{3}$ y $A b_{100} A n_{0}$, si bien los valores más elevados de anortita se encuentran en la albita perteneciente a las pegmatitas que intruyen en el GE y en los diques de la mina Bon parcialmente encajados en el LG y en las rocas metamórficas del CEG.

Respecto al contenido en $\mathrm{P}_{2} \mathrm{O}_{5}$ que presenta la albita, al igual que ocurría con el feldespato potásico, este se incrementa desde la de los diques encajados en el GE y en el LG, que contienen $0,25 \%$ y $0,37 \%$ en peso respectivamente, hasta la de los diques que intruyen en 

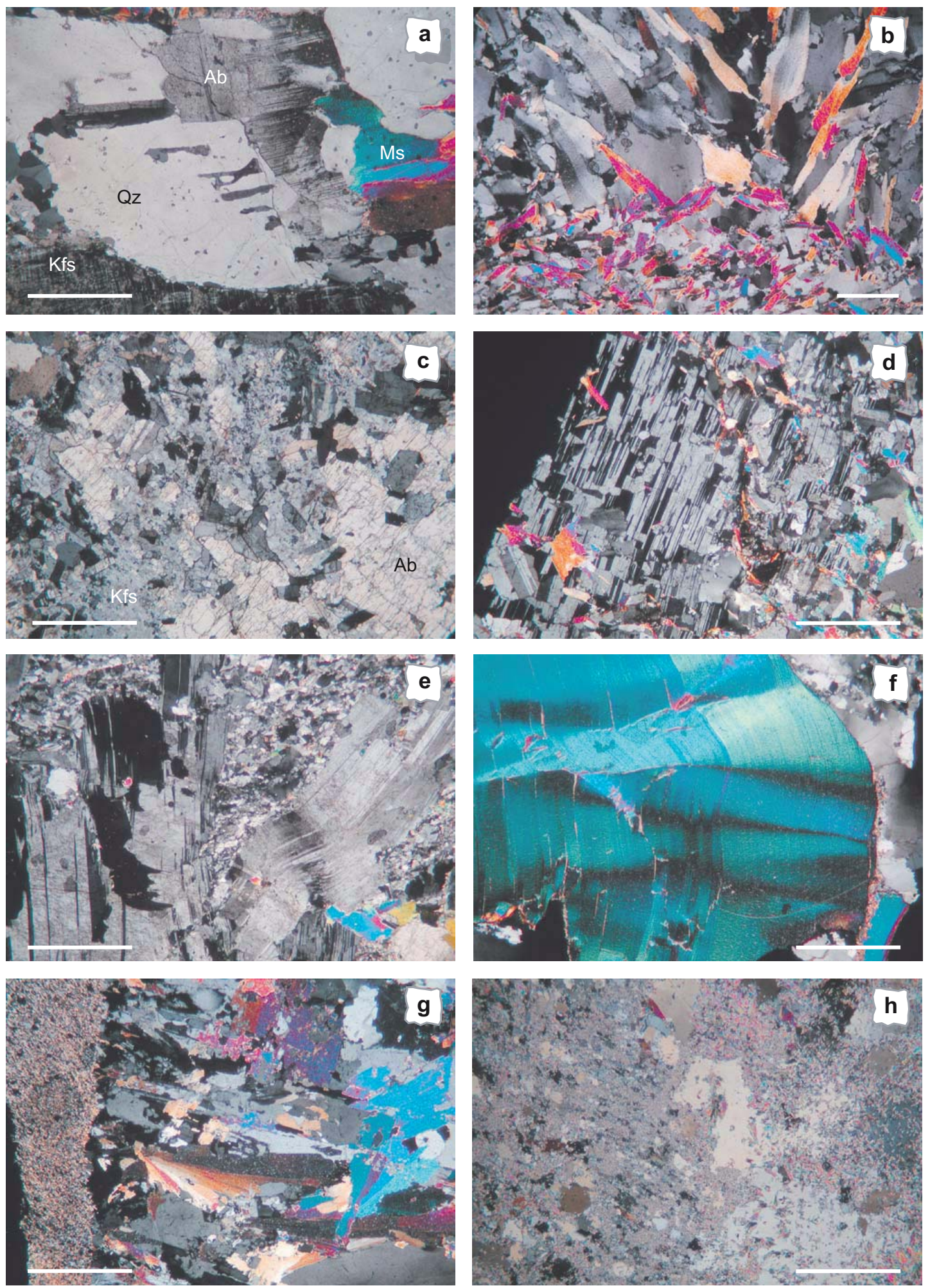

Lám. 3.8. Microfotografías de los aspectos texturales y mineralógicos de los diques pegmatíticos, NC: a) crecimientos gráficos del cuarzo y la albita en las pegmatitas intragraníticas del GE; b) textura esquelética de los agregados de cuarzo y moscovita en el dique pegmatítico intragranítico encajado en el GE, en la mina Mari Carmen; c) feldespato potásico parcialmente albitizado en los diques de composición granítica de Cruz del Rayo, en el CEG; d) textura en tablero de ajedrez de la albita en las pegmatitas intragraníticas del LG y las $A B ;$ e) albita de tipo clivelandita en la zona intermedia exterior de los diques de composición granítica de Cruz del Rayo. Nótese el combamiento de los cristales reflejado en las maclas polisintéticas; f) kinking en 

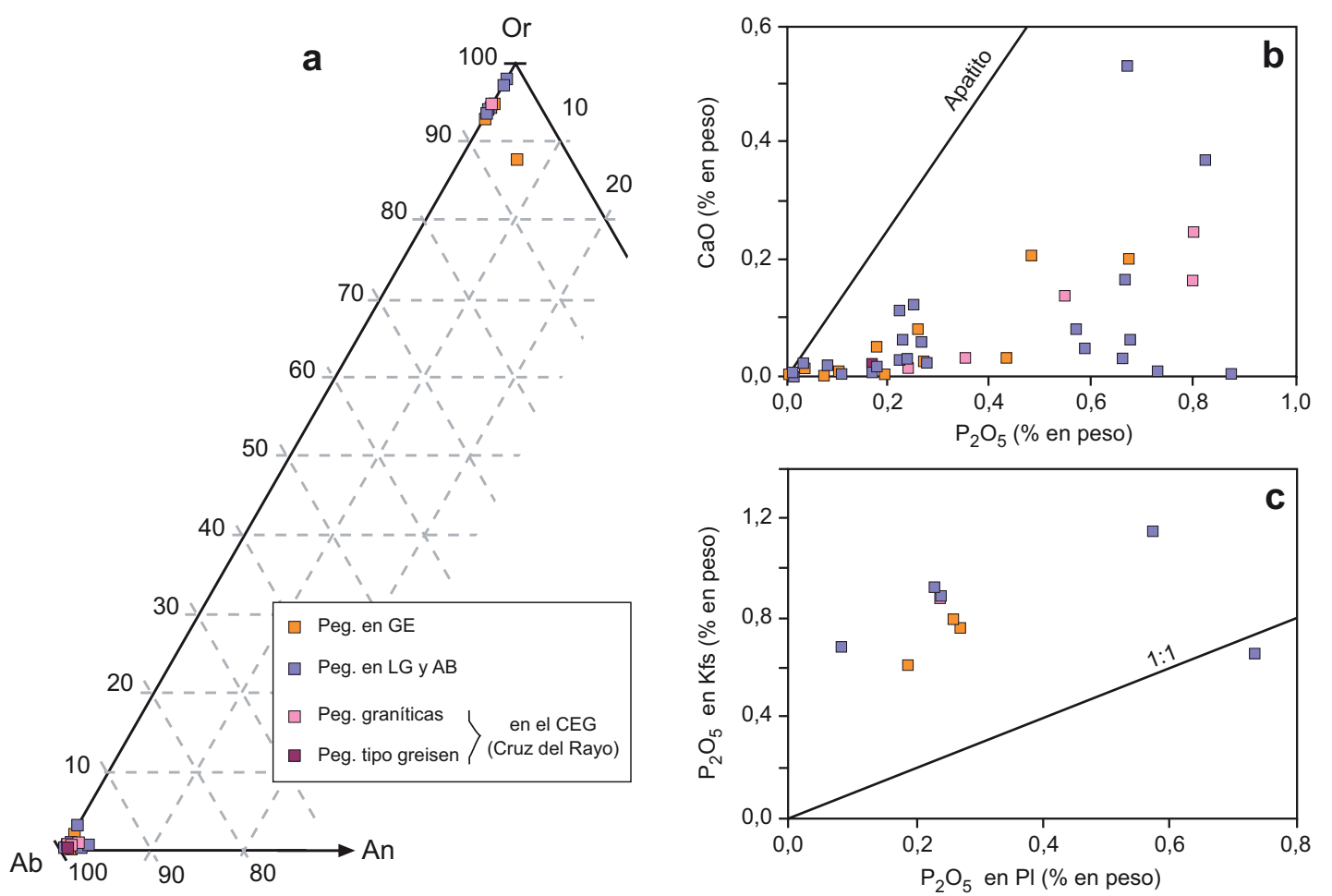

Fig. 3.13. a) Diagrama triangular Ab-Or-An con la representación de los feldespatos analizados en los diques pegmatíticos intra y peribatolíticos; b) diagrama binario de los contenidos en $\mathrm{P}_{2} \mathrm{O}_{5} v s$. CaO (en \% en peso) en las plagioclasas; $c$ ) partición del $\mathrm{P}_{2} \mathrm{O}_{5}$ entre el feldespato potásico (Kfs) y la plagioclasa $(\mathrm{PI})$ en los diques pegmatíticos.

la aureola de metamorfismo, que alcanzan hasta 0,80 \% en peso. Esta albita de los diques más evolucionados es similar, a su vez, a la albita que procede de la alteración del feldespato potásico, que contiene cantidades de $\mathrm{P}_{2} \mathrm{O}_{5}$ elevadas, también en torno a $0,80 \%$ en peso, lo que está probablemente influenciado por la gran cantidad de $\mathrm{P}_{2} \mathrm{O}_{5}$ que presenta el feldespato potásico del que procede. Sin embargo, estos contenidos en $\mathrm{P}_{2} \mathrm{O}_{5}$ disminuyen notablemente en la plagioclasa de la UT de los cuerpos de composición granítica de Cruz del Rayo, alcanzando únicamente hasta $0,17 \%$ en peso de $\mathrm{P}_{2} \mathrm{O}_{5}$.

En el diagrama que relaciona el contenido en $\mathrm{P}_{2} \mathrm{O}_{5}$ con el de $\mathrm{CaO}$ en las plagioclasas (Fig. 3.13b) se observa una grosera correlación positiva más evidente en las pegmatitas encajadas en el GE que las que se encuentran en el LG, que solo presentan contenidos puntualmente muy elevados en $\mathrm{Ca}$. Comparando los contenidos en $\mathrm{P}$ de la plagioclasa con los que presenta feldespato potásico se aprecia, al igual que ocurría en los granitos encajantes, una clara preferencia del fósforo por este último (Fig. 3.13c).

un cristal de moscovita de las pegmatitas de composición granítica de Cruz del Rayo; g) zona de contacto de los diques de tipo greisen con el encajante metamórfico en Cruz del Rayo donde se observa el crecimiento de los agregados laminares de moscovita desde la pared hacia el interior de los diques; $\mathbf{h}$ ) aspecto de una zona greisenizada en los diques pegmatíticos de Cruz del Rayo. Escala gráfica en b) $500 \mu \mathrm{m}$; el resto $1 \mathrm{~mm}$. 


\section{Micas}

Se diferencian dos generaciones de mica blanca en los diques pegmatíticos. La primera se presenta comúnmente en cristales laminares subhedrales de tamaño de grano fino a grueso, incoloras o de color plateado en las zonas más externas de los diques, mientras que en las zonas internas se presentan con tamaños centimétricos en agregados laminares según el eje $c$, con extinción ondulante y texturas tipo kinking (Lám. 3.8f). Una segunda mica blanca presenta texturas fibroso-radiadas y esqueléticas con el cuarzo (Lám. 3.8g), llegando a formar agregados microcristalinos que reemplazan a los cristales previos en las zonas más internas de los diques de composición tipo greisen de Cruz del Rayo (Lám. 3.8h). Adicionalmente, esta mica secundaria se presenta en agregados cristalinos de grano fino a muy fino como producto de la alteración de la albita o bien rellenando fracturas tardías.

En el triángulo composicional $\mathrm{FeO}-\mathrm{TiO}_{2}-\mathrm{MgO}$ de la figura 3.14a se aprecia que prácticamente la totalidad de las micas analizadas en los diques intragraníticos se proyectan en el campo de las micas de evolución magmática. Las micas analizadas en los diques peribatolíticos de Cruz del Rayo se proyectan muy próximas al polo del Fe y sobre la línea que lo une con el polo del $\mathrm{TiO}_{2}$, lo que indicaría que se trata también de micas de evolución magmática extremadamente empobrecidas en Mg. Solamente una de ellas se proyecta sobre el campo de las micas de alteración hidrotermal, que coincide con los agregados microcristalinos de las zonas de greisen.
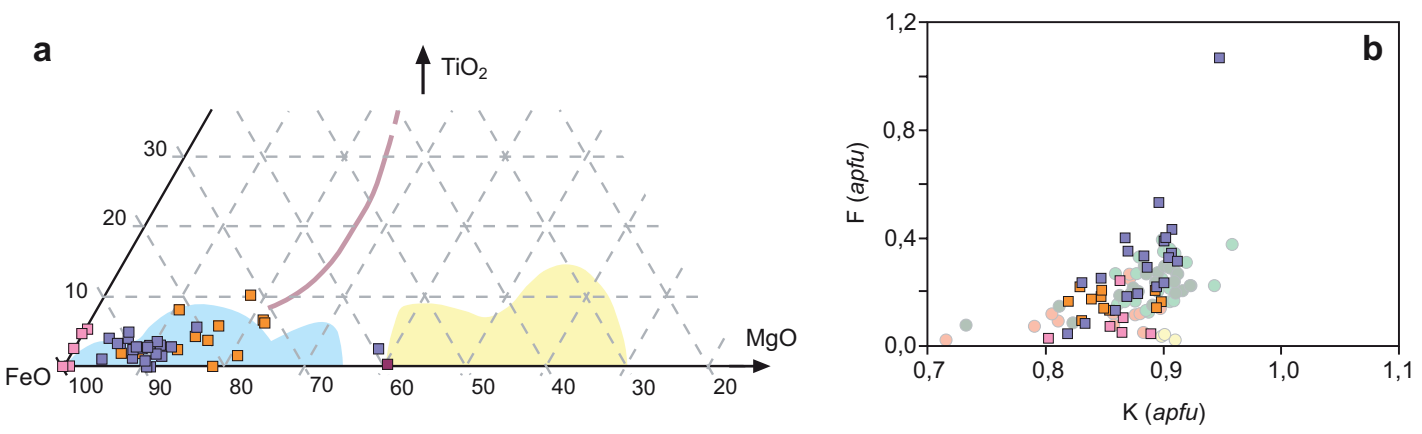

$$
\begin{aligned}
& \square \text { Pegmatitas en el GE } \quad \square \text { Pegmatitas en el LG y las AB } \\
& \square \text { Pegmatitas en el CEG (Cruz del Rayo) }
\end{aligned}
$$

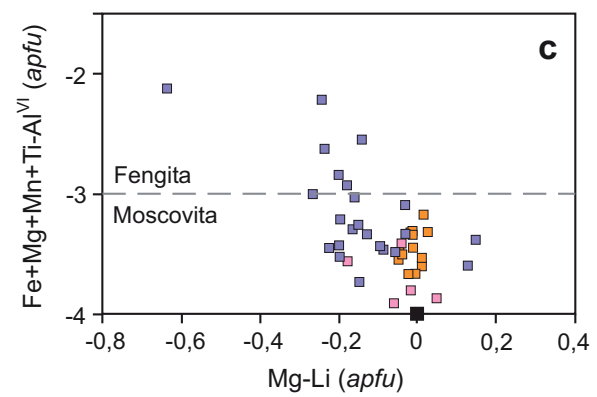

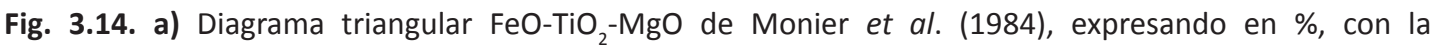
representación de la moscovita analizada en los diques pegmatíticos intra y peribatolíticos (color rosa: micas de origen tardi- a post-magmático; color azul: micas magmáticas; color amarillo: micas de origen hidrotermal); b) diagrama de variación $\mathrm{K}$ vs. F en las micas de los diques, mostrando una tendencia positiva muy similar a la marcada por la moscovita de las facies graníticas (proyectadas de fondo); c) diagrama de clasificación de Tischendorf et al. (2004) donde se han representado las moscovitas analizadas en los diques pegmatíticos. 
En su composición química (Anexo III) destacan también los contenidos significativos en $\mathrm{P} y$, especialmente, en $\mathrm{F}$ (Fig. 3.14b), que son ligeramente superiores en las pegmatitas del LG aunque similares a las del granito encajante, disminuyendo considerablemente en las micas de las pegmatitas de Cruz del Rayo. Las micas que proceden de la alteración de la biotita en algunos de los diques intragraníticos del área de las minas Bon y Salmantina presentan contenidos altos en $\mathrm{F}$ y en $\mathrm{Fe}$, por lo que algunas de ellas no han sido proyectadas en la figura 3.15 por problemas de escala. Cabe destacar, respecto a los elementos traza, un enriquecimiento importante desde las pegmatitas encajadas en el GE hasta las que intruyen en el $L G$ y las $A B$, como se observa en los contenidos en $L i$ que varían desde 1.273 ppm en los diques del GE hasta 6.640 ppm en los del LG. En los contenidos en Sn las variaciones son menores desde 796 ppm hasta 981 ppm. Sin embargo, el contenido en Li y Sn de las micas de los diques más evolucionados de Cruz del Rayo es muy bajo (hasta 1.523 ppm de Li y 553 ppm de Sn).

Al igual que ocurría en las micas de los granitos encajantes, la evolución de estas en los diques pegmatíticos sigue un patrón de sustitución de tipo fengita influenciado, además, por el vector $\mathrm{Si}_{2} \mathrm{LiAl}_{-3}$. Se observa, además, un claro enriquecimiento en $\mathrm{Si}$ y en $\mathrm{Fe}+\mathrm{Mg}$ desde las pegmatitas del GE hacia las del LG y las AB (Fig. 3.15a,b,c,d,e,g). Sin embargo, de nuevo las micas de los diques peribatolíticos de Cruz del Rayo no siguen esta tendencia de enriquecimiento y muestran valores similares a los de las rocas graníticas de la UE y a los de los diques pegmatíticos encajados en ellas. Esto indica que se trata de diques muy poco evolucionados, algo que se demuestra al proyectar su composición en el cuadro de clasificación de Tischendorf et al. (2004) (Fig. 3.14c). En este diagrama se observa que las micas de las pegmatitas encajadas en el GE se encuentran dentro del campo de la moscovita con valores próximos a 0 para el eje de abscisas $\mathrm{Mg}$-Li, mientras que las micas de las pegmatitas del LG y las $A B$ marcan una transición desde el campo de la moscovita hacia el campo de la fengita, mostrando así una clara evolución hacia mayores contenidos en Li. Estas micas más ricas en Si y en Li corresponden con las que proceden de la alteración de la biotita en las pegmatitas de las minas Salmantina y Bon. Sin embargo, al proyectar las micas de los diques de Cruz del Rayo se aprecia que estas se encuentran dentro del campo de la moscovita y muy próximos a 0 debido a los bajos contenidos en Li, menores incluso que los que muestran las pegmatitas intragraníticas.

Por otro lado, la mica negra se encuentra solo localmente en dos diques pegmatíticos encajados en el LG del área de las minas Salmantina y Bon donde aparece en cristales anhedrales a subhedrales de tamaño centimétrico y a veces también en agregados laminares. Sin embargo, la composición química de algunos de estos cristales es la de una biotita total o parcialmente reemplazada por moscovita (Lám. 3.9a). En el diagrama de clasificación de Tischendorf et al. (2004) esta mica pertenece a la serie biotita-flogopita próxima al polo de la biotita (Fig. 3.15h). El contenido en Ti es inferior al de la biotita del GE (hasta $0.21 \mathrm{apfu}$ ), mientras que los contenidos en Mn, Li y F son ligeramente superiores (Anexo III).

\section{Clorita}

La clorita de las pegmatitas intragraníticas se presenta en agregados laminares microcristalinos o esferulíticos de color verde rellenando fracturillas (Lám. 3.9b) o reemplazando a los fosfatos 

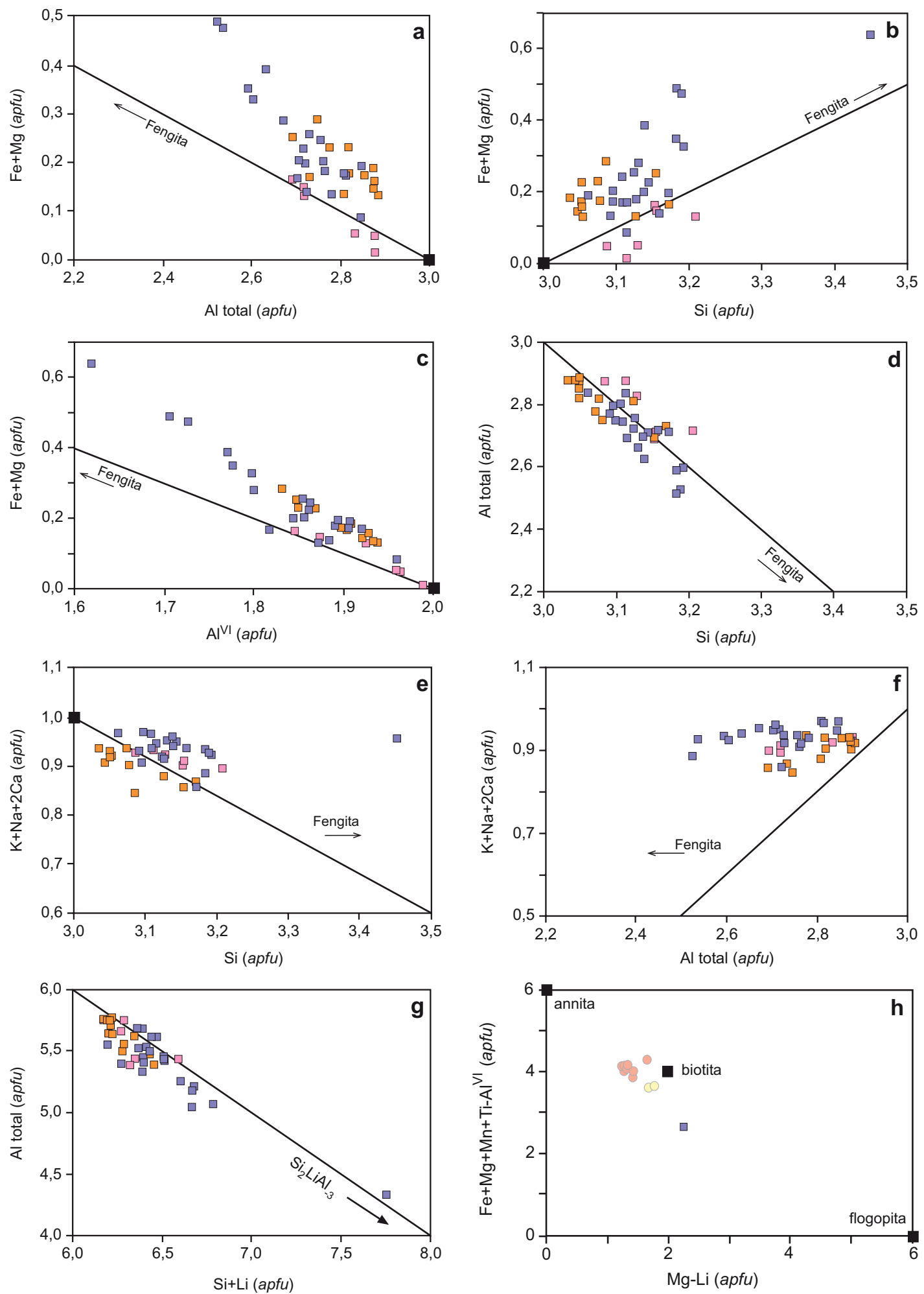

Pegmatitas en GE $\square$ Pegmatitas en LG y AB $\square$ Pegmatitas en el CEG (Cruz del Rayo)

Ms ideal

Fig. 3.15. Diagramas de correlación para la moscovita analizada en los diques pegmatíticos: a) Al total vs. $\mathrm{Fe}+\mathrm{Mg}$; b) Si vs. $\mathrm{Fe}+\mathrm{Mg}$; c) $\mathrm{Al}^{\mathrm{vl}}$ vs. $\mathrm{Fe}+\mathrm{Mg}$; d) Si vs. Al total; e) Si vs. $\mathrm{K}+\mathrm{Na}+2 \mathrm{Ca}$; f) Al total vs. $\mathrm{K}+\mathrm{Na}+2 \mathrm{Ca}$; y g) $\mathrm{Si}+\mathrm{Li}$ vs. Al total. h) Diagrama de clasificación de Tischendorf et al. (2004) con la representación de la biotita de las pegmatitas intragraníticas encajadas en el LG y la AB. De fondo se ha representado la biotita de las facies graníticas de la UE para facilitar su comparación. 

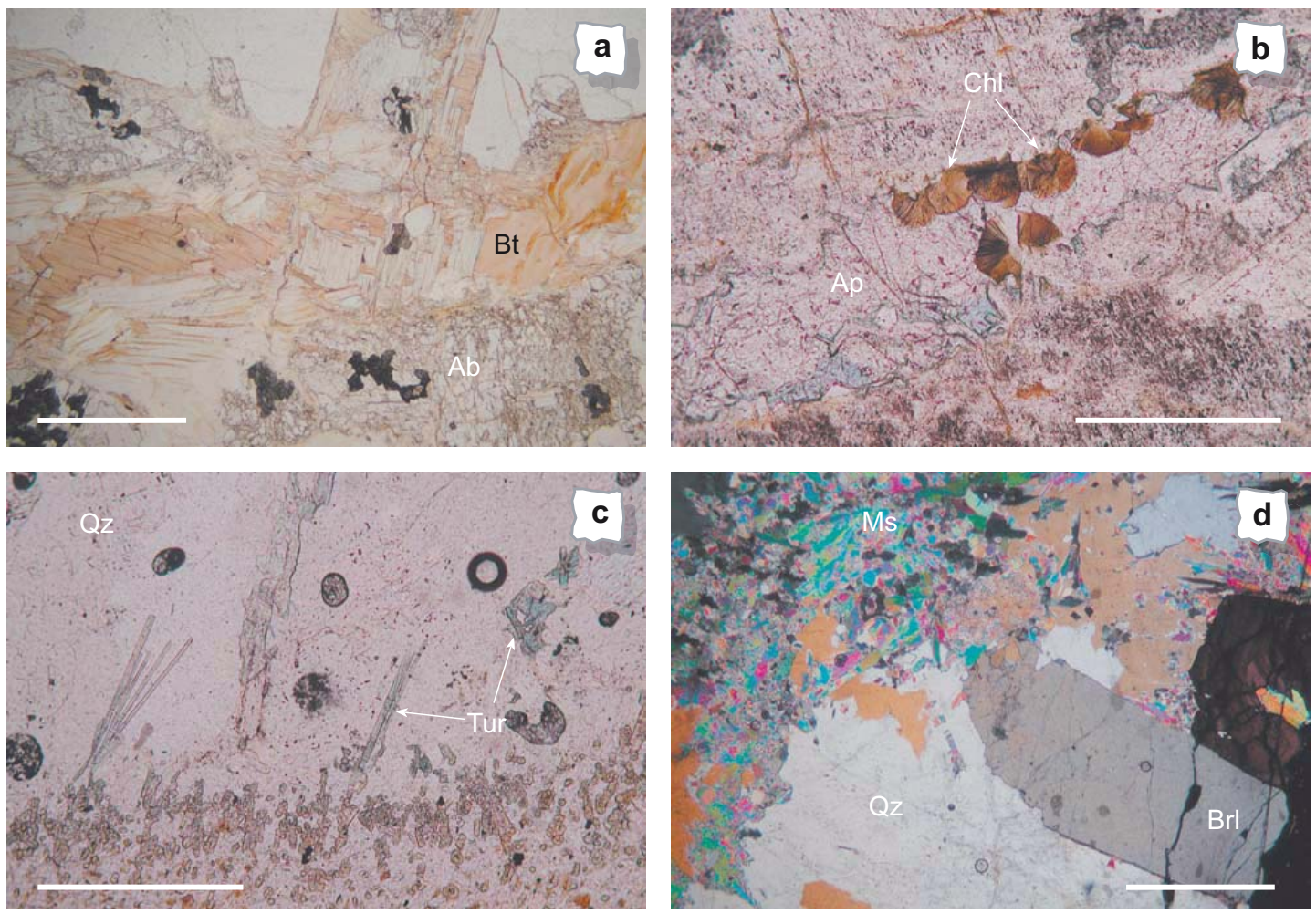

Lám. 3.9. Aspectos microscópicos de los minerales accesorios más comunes en los diques pegmatíticos: a) cristales de biotita parcialmente reemplazados por moscovita en una pegmatita intragranítica encajada en el LG, en la mina Salmantina, LN; b) agregados esferulíticos de clorita junto con cristales subhedrales de hidroxilapatito azul rellenando una grieta tardía en los diques de composición granítica de Cruz del Rayo, LN; c) zona de contacto turmalinizada entre los diques pegmatíticos de la mina Bon y el encajante metamórfico, LN; d) aspecto de un cristal idiomorfo de berilo en los diques de composición tipo greisen de Cruz del Rayo, NC. Escala gráfica: a y d) $1 \mathrm{~mm}$; b y c) $500 \mu \mathrm{m}$.

de la serie childrenita-eosforita, al igual que en las facies graníticas de la UE. Su composición química muestra diferencias incluso dentro del mismo grupo (Fig. 3.16a). Todas ellas se clasifican como chamosita en la clasificación de Bailey (1980), mientras que en la clasificación de Zane y Weiss (1998) se diferencian las cloritas de los diques del GE, en su mayoría de tipo I o cloritas-Fe, y las de los diques del LG y las AB, que son de tipo II o cloritas-Al (Fig. 3.16b).

El contenido en $\mathrm{Si}$, en general, se incrementa desde los diques menos evolucionados hasta los del LG, aumentando también el contenido de Al total (Fig. 3.16c) y, por tanto, de Al ${ }^{\mathrm{VI}}$ que entra en la capa octaédrica. Por el contrario, los elevados contenidos en Fe (hasta 3,3 apfu) y Mg (hasta 0,70 apfu) que se muestran en los diques del GE disminuyen hacia el LG y las $A B$ de modo que se incrementa la cantidad de vacancias calculadas en la capa octaédrica (Fig. 3.16d). De esta manera la relación Fe/(Fe+Mg) oscila entre 0,73 y 0,97 (Fig. 3.16e). Se observan, además, trazas de Zn que superan el $1 \%$ en peso del óxido, especialmente en los diques del LG. La suma de los cationes interlaminares es, generalmente, muy baja.

\section{Turmalina}

La turmalina es un mineral muy accesorio en los diques pegmatíticos, si bien se encuentra mayoritariamente en las zonas turmalinizadas del encajante metamórfico desarrollados por 

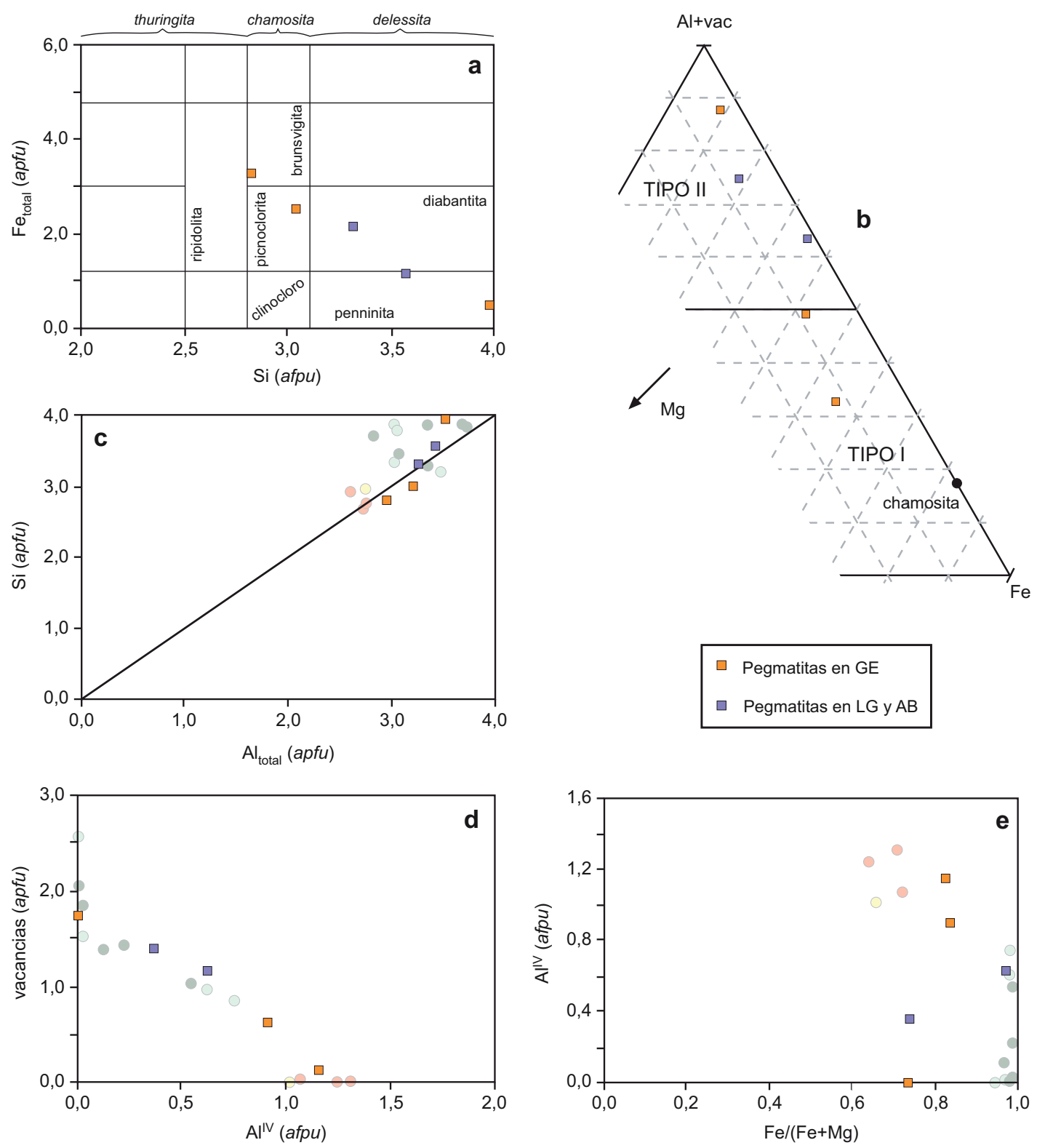

Fig. 3.16. Diagramas de clasificación de la clorita de las pegmatitas intra y peribatolíticas: a) en función de los contenidos en $\mathrm{Fe}_{\text {total }}$ y Si (en apfu) según Hey (1954); y b) en función de los contenidos en $\mathrm{Fe}_{\text {total }}$, Mg y Al+vacancias (en apfu) según Zane y Weiss (1998). Diagramas de sustitución química en la clorita: c) de $\mathrm{Al}_{\text {total }}$ vs. $\mathrm{Si}$; d) de Alv vs. vacancias; y e) de $\mathrm{Fe} /(\mathrm{Fe}+\mathrm{Mg})$ vs. Al'v. De fondo se ha proyectado la clorita analizada en las facies graníticas encajantes de los diques para facilitar su comparación.

la intrusión de los diques peribatolíticos de Cruz del Rayo y, localmente, los de la mina Bon. En las zonas de borde de estos diques, la turmalina se presenta en cristales prismáticos de tamaño milimétrico, incoloros o débilmente azulados en luz natural (Lám. 3.9c). Sin embargo, en los diques intragraníticos del LG y las AB los cristales de turmalina son sub- a euhedrales de tamaño milimétrico a centimétrico, de color negro en muestra de mano y de verdes a marrones y anaranjados en luz natural, similares a los de la roca granítica encajante.

A partir de su composición química (Anexo III) todas estas turmalinas se clasifican como turmalinas alcalinas (Hawthorne y Henry, 1999) en las que el contenido en Ca y en Mg es 
muy bajo o prácticamente nulo (Fig. 3.17a), salvo en las pegmatitas de las minas Bon y Cruz del Rayo, que muestran hasta 0,37 \% en peso de $\mathrm{CaO}$ y hasta 5,25 \% en peso de MgO. Así, según la nomenclatura de Selway y Novák (1997), estas varían desde chorlo con cantidades de $\mathrm{Mg}$ de hasta 10,56 \% hasta chorlo-dravita (56 \% de $\mathrm{Mg}$ ) en la zona de pared de los diques, mientras que presentan valores intermedios cuando encajan en el metamórfico (hasta $39 \%$ $\mathrm{Mg}$ ), proyectándose en zonas intermedias de la serie chorlo-dravita (Fig. 3.17c). La mayoría de ellas están dentro del campo de las rocas graníticas pobres en Li y aplitas y pegmatitas asociadas (Fig. 3.17b), si bien algunas con contenidos más elevados en Al se encuentran en el campo de las pegmatitas y aplitas ricas en $\mathrm{Li}$.

Al igual que en la turmalina de los granitos encajantes, se observa una fuerte correlación negativa entre los valores de $\mathrm{Fe} /(\mathrm{Fe}+\mathrm{Mg}$ ) y $\mathrm{Mg}$ (Fig. 3.17d), lo que indica la influencia del vector de intercambio $\mathrm{FeMg}_{-1}$ en la composición de la turmalina. También se observa un incremento en los contenidos en $\mathrm{Mg}$ desde el encajante granítico hasta los diques pegmatíticos. Del mismo modo, en el gráfico de la figura 3.17e que enfrenta los valores de $\mathrm{Na} /(\mathrm{Na}+\mathrm{vacancias}$ ) y $\mathrm{Al}^{\mathrm{r}} /\left(\mathrm{Al} \mathrm{l}^{\mathrm{\gamma}}+\mathrm{Fe}\right)$, todas ellas se proyectan en el campo del chorlo con cierta tendencia hacia el de la elbaita desde el $L G$ y las $A B$ hasta las pegmatitas tanto intra como peribatolíticas, lo que sugiere una débil influencia del vector de sustitución chorlo-elbaita [LiAlFe ${ }_{-2}$. Los contenidos en $\mathrm{Al}+\mathrm{Li}$ se incrementan gradualmente desde el MP y el LG hacia pegmatitas intra y peribatolíticas a medida que decrece la suma $(\mathrm{Mg}+\mathrm{Fe}+\mathrm{Mn})$, dados los elevados valores de Li calculados para las turmalinas de los diques de Cruz del Rayo, que son los más elevados del distrito, lo que es consistente de nuevo con la sustitución chorlo-elbaita (Fig. 3.17f). Estos elevados contenidos en Li se corresponden con contenidos en $\mathrm{F}$ más bajos, lo que implica además del vector de sustitución chorlo-dravita con cierta influencia del vector chorlo-elbaita [ $\mathrm{LiAlFe}_{-2}$ ], la existencia de un patrón de sustitución $\mathrm{OH}_{-1} \mathrm{~F}_{-1}$.

\section{Berilo}

El berilo se encuentra únicamente en la zona intermedia de los diques pegmatíticos de tipo greisen de Cruz del Rayo. Estos cristales, de morfología prismática y tamaño hasta centimétrico (Lám. 3.9d), presentan una composición química muy sencilla con una fórmula media, calculada en base a 18 átomos de oxígeno y 3 átomos de $\mathrm{Be}, \mathrm{Be}_{3}\left(\mathrm{Na}_{0,17} \square_{0,83}\right)_{\Sigma 1} \mathrm{Al}_{1,91} \mathrm{Si}_{6} \mathrm{O}_{18}$ presentando únicamente cantidades accesorias de Fe y de Na (Anexo III).

\section{Circón}

El circón se encuentra en cristales redondeados o biterminados de tamaño micrométrico junto con apatito y rutilo, incluidos en la biotita, a veces también en la mica blanca, o bien diseminados en los diques pegmatíticos.

\section{Sulfuros}

La arsenopirita ocasionalmente se presenta en cristales anhedrales o agregados granulares de tamaño milimétrico diseminados en los diques pegmatíticos. También se ha identificado de forma puntual eléctrum ( $80 \%$ de $\mathrm{Au}, 11 \%$ de $\mathrm{Ag}$ y algo más de $8 \%$ de $\mathrm{Cu}$ ) en agregados 

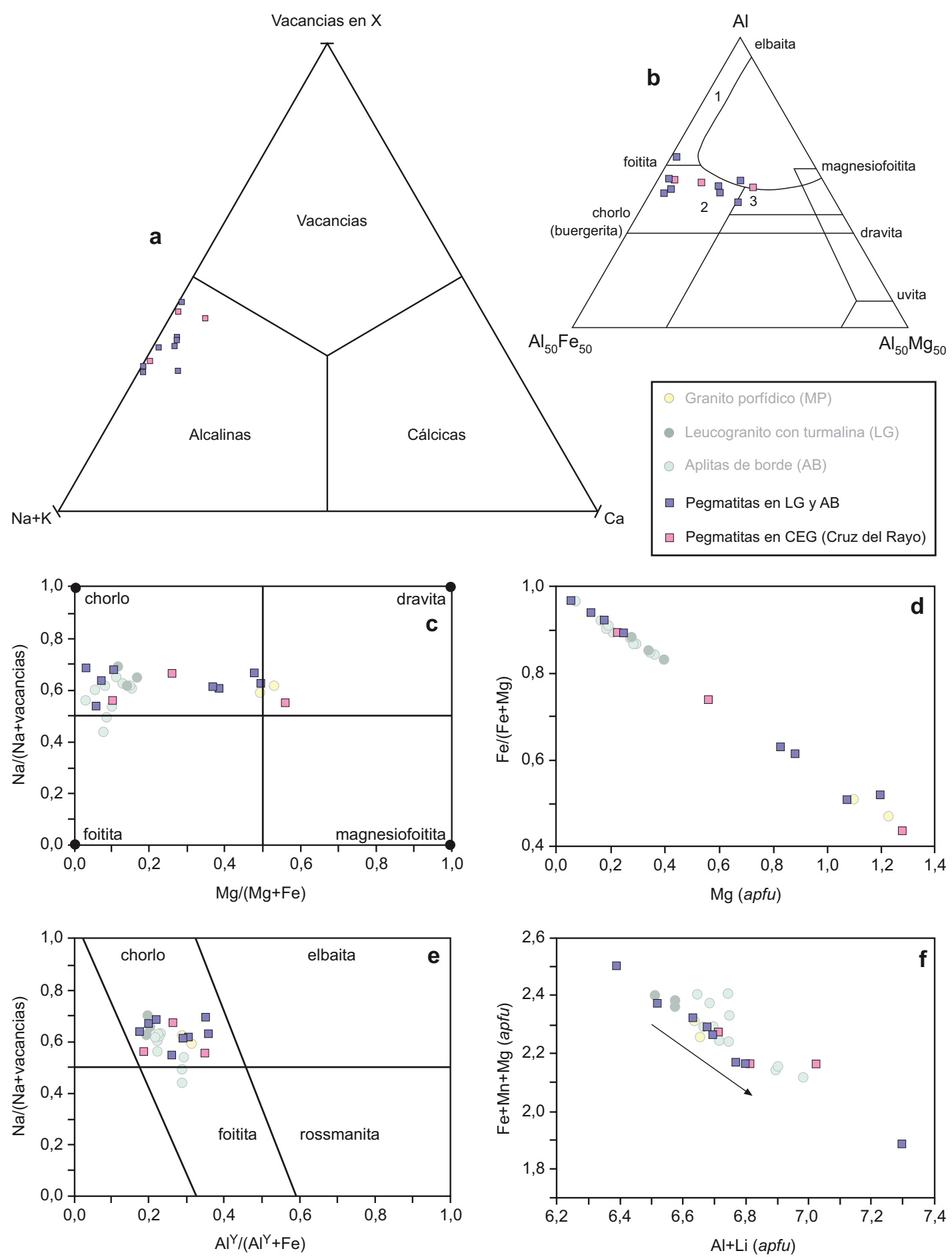

Fig. 3.17. Diagramas triangulares de clasificación de la turmalina: a) en función de la ocupación de las posiciones X según Hawthorne y Henry (1999); y b) en función de las proporciones moleculares de Al-Fe total $^{-}$ Mg en su composición química según Henry y Guidotti (1985) (1: pegmatitas y aplitas ricas en Li; 2: rocas graníticas pobres en Li y pegmatitas y aplitas asociadas; 3: metapelitas y metapsamitas coexistiendo con fases alumínicas). Diagramas de variación química: c) de $\mathrm{Na} /(\mathrm{Na}+\mathrm{vacancias})$ en las posiciones $\mathrm{X}$ vs. $\mathrm{Mg} /$ $(\mathrm{Mg}+\mathrm{Fe}$ ) en las posiciones $\mathrm{Y}$ (en apfu); $\mathrm{d})$ de $\mathrm{Fe} /(\mathrm{Fe}+\mathrm{Mg})$ frente a los contenidos en $\mathrm{Mg}$ en las posiciones $\mathrm{Y}$ (en apfu); e) de $\mathrm{Na} /(\mathrm{Na}+$ vacancias) en las posiciones $\mathrm{X}$ vs. Al/(Al+Fe) en las posiciones $\mathrm{Y}$ (en apfu); y f) de $\mathrm{Fe}+\mathrm{Mn}+\mathrm{Mg}$ vs. Al+Li en las posiciones $\mathrm{Y}$ (en apfu). De fondo se ha proyectado la turmalina analizada en las facies graníticas encajantes de los diques para facilitar su comparación. 

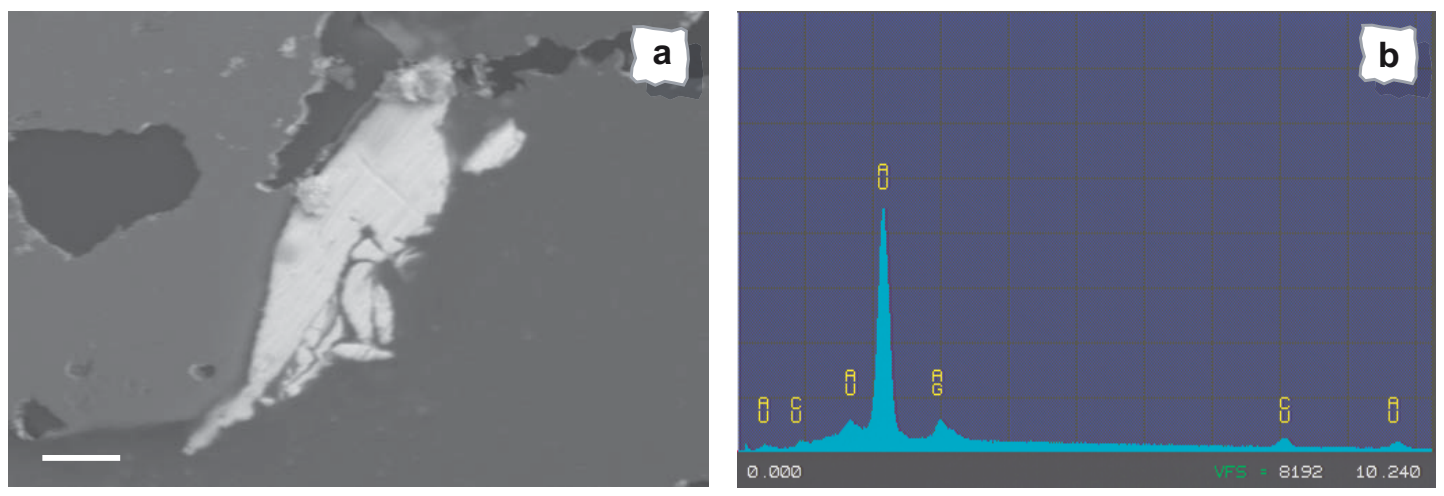

Lám. 3.10. a) Microfotografía electrónica en la que se observa un cristal de eléctrum identificado en el dique pegmatítico de la mina Mari Carmen. Escala gráfica: $5 \mu \mathrm{m}$; b) espectro del eléctrum en el microscopio electrónico de barrido.

anhedrales de tamaño inferior a las $10 \mu \mathrm{m}$, asociados a un cuarzo tardío e hidrotermal en el dique pegmatítico de la mina Mari Carmen (Lám. 3.10a,b).

\section{Asociaciones fosfatadas}

Al igual que ocurría en el LG y las AB estas asociaciones fosfatadas, a pesar de su carácter accesorio, son muy importantes a la hora de interpretar la evolución composicional y fisicoquímica de las mineralizaciones del batolito de Jálama, por lo que se describen por separado y cronológicamente siguiendo la numeración iniciada previamente. Estas asociaciones varían en función del encajante pegmatítico en el que se encuentran, de modo que se tienen asociaciones diferentes en las pegmatitas intragraníticas del GE y del LG y las AB que en los peribatolíticos que encajan en las rocas metamórficas (Llorens y Moro, 2007, 2008, en prensa). La formula general de estos fosfatos se muestra en la tabla 3.2.

TABLA 3.2. FOSFATOS DE LAS ASOCIACIONES III, IV, V Y VI

\begin{tabular}{|c|c|c|c|c|c|}
\hline \multirow{2}{*}{ Fosfato } & \multirow{2}{*}{ Fórmula general } & \multicolumn{4}{|c|}{ Asociación } \\
\hline & & III & IV & $\mathbf{V}$ & VI \\
\hline Triplita- Zwieselita & $\left(\mathrm{Mn}^{2+}, \mathrm{Fe}^{2+} \mathrm{Mg}, \mathrm{Ca}\right)_{2}\left(\mathrm{PO}_{4}\right)(\mathrm{F}, \mathrm{OH})$ & * & & & \\
\hline Staněkita & $\mathrm{Fe}^{3+}\left(\mathrm{Mn}, \mathrm{Fe}^{2+}, \mathrm{Mg}\right) \mathrm{O}\left(\mathrm{PO}_{4}\right)$ & * & & & \\
\hline Alluaudita & $(\mathrm{Na}, \mathrm{Ca},)^{\mathrm{Mn}^{2+}}\left(\mathrm{Fe}^{3+}\right)_{2}\left(\mathrm{PO}_{4}\right)_{3}$ & & ** & * & \\
\hline Montebrasita & $\mathrm{LiAl}\left(\mathrm{PO}_{4}\right)(\mathrm{OH}, \mathrm{F})$ & & * & & *** \\
\hline Childrenita-Eosforita & $\left(\mathrm{Fe}^{2+} \mathrm{Mn}^{2+}\right) \mathrm{Al}\left(\mathrm{PO}_{4}\right)(\mathrm{OH})_{2} \cdot \mathrm{H}_{2} \mathrm{O}$ & & $* * *$ & & \\
\hline Rockbridgeita & $\left(\mathrm{Fe}^{2+}, \mathrm{Mn}^{2+}\right) \mathrm{Fe}^{3+}{ }_{4}\left(\mathrm{PO}_{4}\right)_{3}(\mathrm{OH})_{5}$ & & ** & * & \\
\hline Mitridatita & $\mathrm{Ca}_{2} \mathrm{Fe}_{3}^{3+} \mathrm{O}_{2}\left(\mathrm{PO}_{4}\right)_{3} \cdot 3 \mathrm{H}_{2} \mathrm{O}$ & & * & * & \\
\hline Gormanita & $\mathrm{Fe}^{2+}{ }_{3} \mathrm{Al}_{4}\left(\mathrm{PO}_{4}\right)_{4}(\mathrm{OH})_{6} \cdot 2 \mathrm{H}_{2} \mathrm{O}$ & & ** & & \\
\hline Xantoxenita & $\mathrm{Ca}_{4} \mathrm{Fe}_{2}^{3+}\left(\mathrm{PO}_{4}\right)_{4}(\mathrm{OH})_{2} \cdot 3 \mathrm{H}_{2} \mathrm{O}$ & & ** & & \\
\hline Apatito & $\mathrm{Ca}_{5}\left(\mathrm{PO}_{4}\right)_{3}(\mathrm{OH}, \mathrm{F}, \mathrm{Cl})$ & ** & *** & ** & * \\
\hline
\end{tabular}

Abundancia en cada asociación: ${ }^{* * *}=$ abundante; ${ }^{* *}=$ escaso; ${ }^{*}=$ muy escaso 
Asociación III

La asociación fosfatada que se ha identificado en los diques pegmatíticos encajados en el GE es muy accesoria y consiste en staněkita, zwieselita y fluorapatito. La zwieselita es el fosfato más precoz que forma agregados cristalinos de tamaño inferior a $1 \mathrm{~mm}$ y color pardo o marrón en luz natural (Lám. 3.11a). Su composición química está enriquecida en Fe, con una relación $\mathrm{Fe} /(\mathrm{Fe}+\mathrm{Mn})$ de 0,67 y contenidos en $\mathrm{F}$ de hasta 0,57 apfu (Anexos III). Por otro lado la staněkita se encuentra localmente en cristales anhedrales de hasta $150 \mu \mathrm{m}$, opacos (Lám. 3.11b), con una composición química en la que también domina el Fe sobre el Mn. Además, se diferencian dos generaciones de apatito: el fluorapatito I, que es de origen magmático y se encuentra en cristales de tamaño micrométrico rellenando espacios intergranulares, con contenidos variables en $\mathrm{Mn}$, aunque puede contener algo de $\mathrm{Al}$ y sustituciones del $\mathrm{F}$ por el ión $\mathrm{OH}^{-}$(Fig. 3.18a,b); y el fluorapatito II, que reemplaza a la staněkita y presenta una composición también rica en Mn.

\section{Asociación IV}

Los diques que encajan en el LG y en las $A B$ presentan una asociación fosfatada prácticamente constante desde la zona de borde hasta su interior debido probablemente a su escaso desarrollo. Montebrasita y alluaudita son los fosfatos más precoces en la secuencia de cristalización (Fig. 3.18c), cuya alteración da lugar a todo un cortejo de fosfatos secundarios como xantoxenita, gormanita, mitridatita, rockbridgeita e hidroxilapatito, más abundantes hacia las zonas de borde, o fluorapatito y fosfatos de la serie childrenita-eosforita, especialmente en zonas internas. La montebrasita aparece solo localmente en cristales de tamaño milimétrico asociados a albita y en ocasiones reemplazados parcialmente por rockbridgeita. Presenta escaso contenido en $F(0,21 \mathrm{apfu})$. La alluaudita se presenta en agregados nodulares de tamaño micrométrico y color verde-amarillento que se localizan en microgrietas de los cristales de xantoxenita como restos no alterados por esta en la zona intermedia de los cuerpos pegmatíticos (Lám. 3.11d). Esto sugiere que la alluaudita reemplazaría previamente a una fase primaria no conservada a favor de ciertos planos cristalográficos o fracturas y, posteriormente, esta fase primaria habría sido reemplazada por la xantoxenita en las zonas donde no se produce el reemplazamiento por alluaudita (Roda, com. pers). Su composición química presenta contenidos en $\mathrm{Na}$ y $\mathrm{Mn}$ importantes, mientras que las numerosas vacancias en su fórmula estructural apoyarían la hipótesis de que todo el Fe está en forma de $\mathrm{Fe}^{3+}$ por el mecanismo de sustitución $\mathrm{Mn}^{2+}+2 \mathrm{Fe}^{2+} \rightarrow$ vacancia $+2 \mathrm{Fe}^{3+}$ (Hatert, 2004), por lo que corresponde con una alluaudita muy oxidada con hasta 8,0 apfu de $\mathrm{Fe}^{3+}$. La relación $\mathrm{Fe} /(\mathrm{Fe}+\mathrm{Mn})$ de este fosfato varía entre 0,71 y 0,74 .

La xantoxenita es especialmente abundante en la zona de borde de los diques, donde se encuentra en agregados de cristales an- a subhedrales con tendencia fibroso-radiada y tamaño de hasta $2 \mathrm{~mm}$. En muestra de mano tiene un color marrón amarillento y al microscopio se observa que cristaliza en grietas, lo que confirma su carácter tardío en la secuencia de cristalización (Figs. 3.18c y 3.22), englobando restos de alluaudita, mitridatita, rockbridgeita (Lám. 3.11c,d) y, menos frecuentemente, turmalina. En su composición química los cationes principales son el $\mathrm{Ca}$ (hasta 3,46 apfu) y el Fe ${ }^{3+}$ (hasta 1,84 apfu), mientras que en algunos 

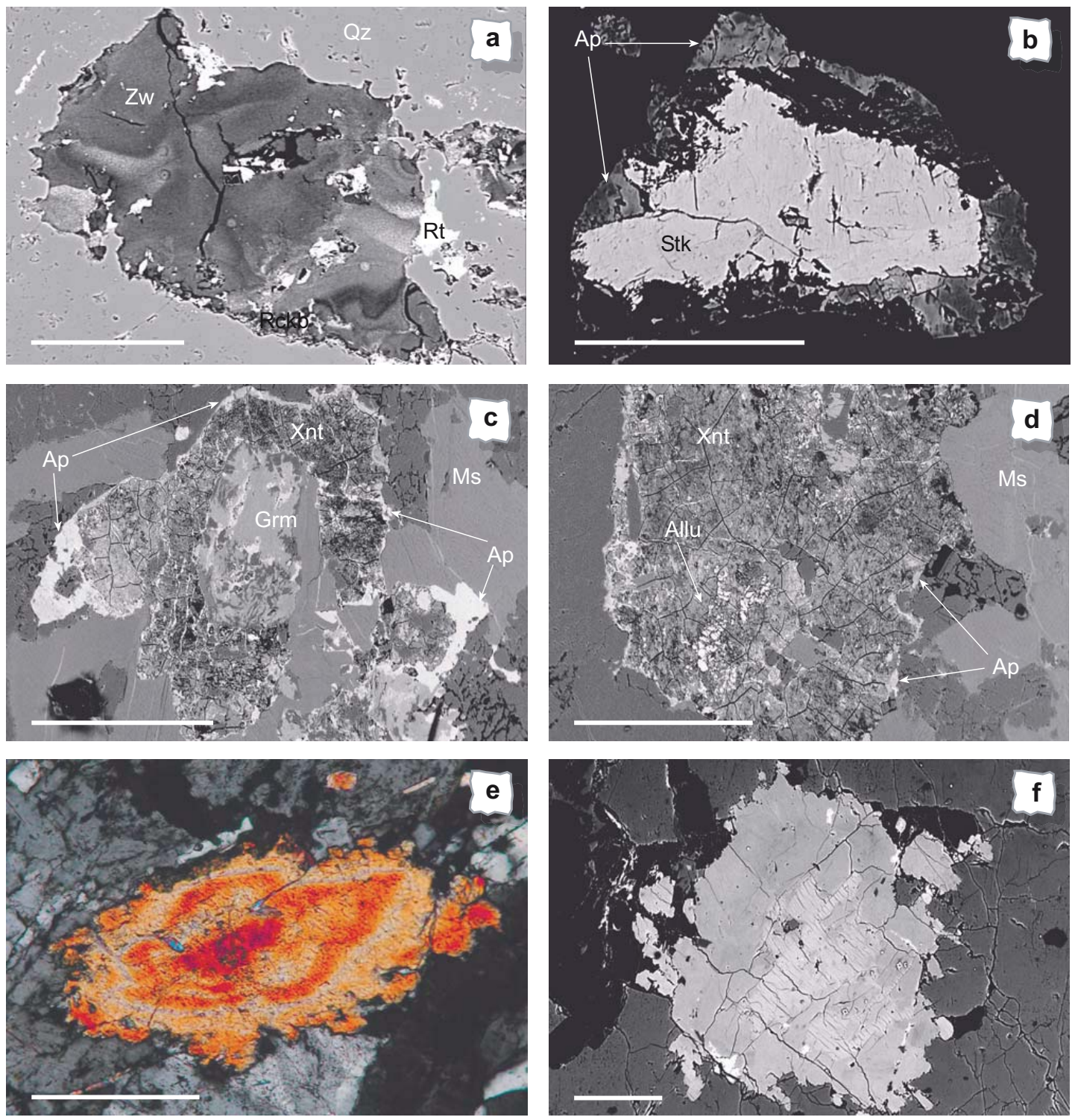

Lám. 3.11. Microfotografías electrónicas ( $a, b, c, d$ y f) y de microscopio petrográfico, en NC, (e) de los fosfatos más representativos de los diques pegmatíticos intragraníticos: a) cristal de zwieselita débilmente alterado, asociación III de los diques encajados en el GE; b) cristal de staněkita alterándose por los bordes a fluorapatito, asociación III de los diques encajados en el GE; c) xantoxenita parcialmente alterada a hidroxilapatito (blanco) con gormanita en su interior, asociación IV de los diques encajados en el LG y las $A B ; d)$ detalle de la asociación anterior en el que se observan restos de alluaudita sin reemplazar por la xantoxenita; e y f) childrenita reemplazando a los cristales de albita, asociación IV de los diques encajados en el LG y las AB. Escala gráfica: a, b, f) $100 \mu \mathrm{m}$; c, d y e) $500 \mu \mathrm{m}$.

cristales se han encontrado hasta $3 \%$ en peso de $\mathrm{MnO}$ o $\mathrm{MgO}$ sustituyendo al catión principal, lo que puede influir en la coloración y extinción con fuertes tonos azules de la xantoxenita (Frondel, 1949). La gormanita forma agregados fibroso-radiados de hasta $0,75 \mathrm{~mm}$ de tamaño y de color marrón claro. Aparece de manera intergranular o como un relleno tardío de grietas junto con moscovita, apatito, xantoxenita y cuarzo (Lám. 3.11c). La composición química muestra vacancias en la posición del Al y el Fe con un escaso componente de souzalita $(0,1-$ 0,6 apfu de Mg). Contiene, además, valores relativamente elevados de $\mathrm{F}$ (hasta 0,57 \% en 

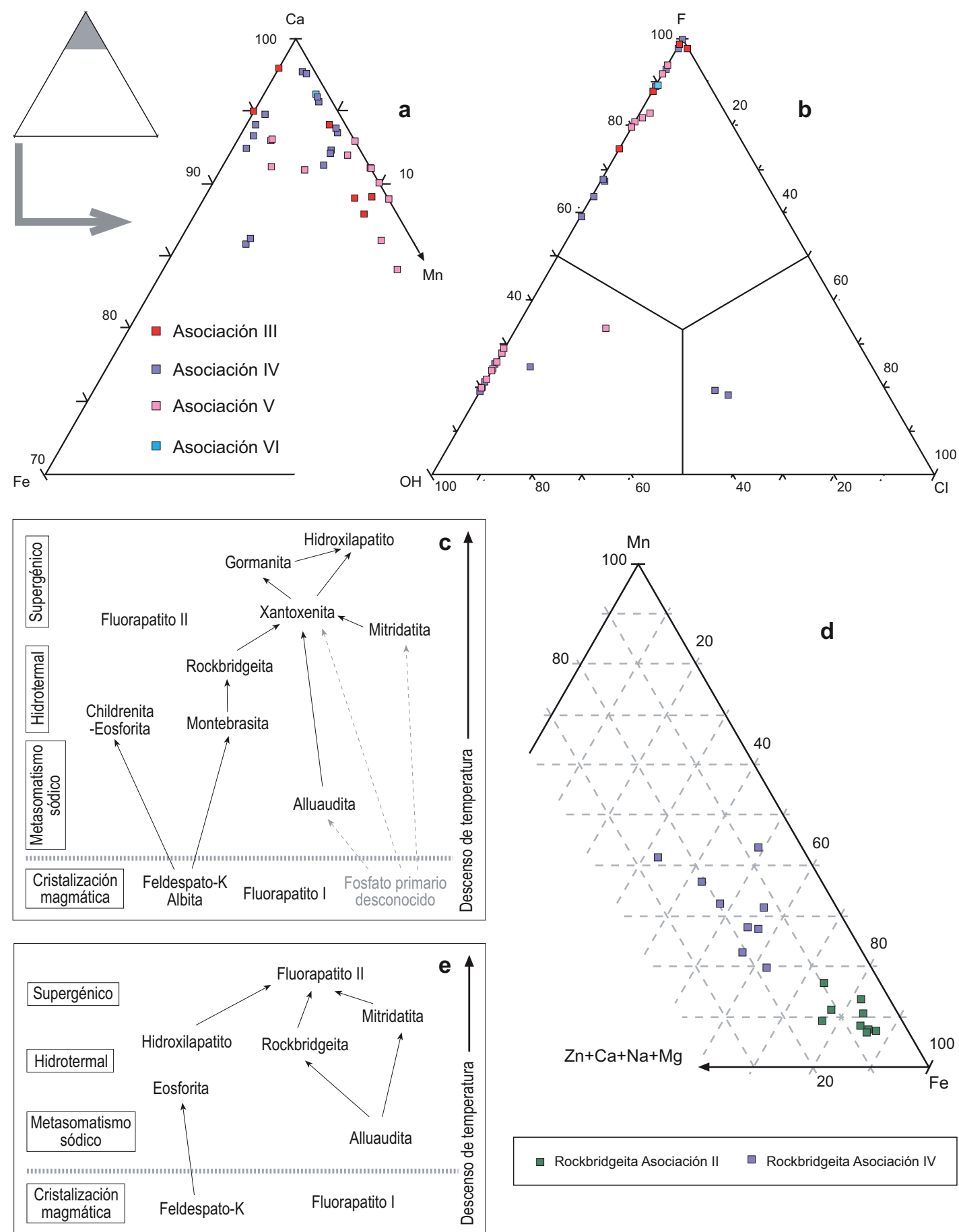

Rockbridgeita Asociación II $\square$ Rockbridgeita Asociación IV

Fig. 3.18. Diagramas triangulares con la composición química del apatito en las asociaciones III, IV, V y VI de los diques pegmatíticos intra y peribatolíticos: a) de los contenidos en $\mathrm{Fe}$, $\mathrm{Ca}$ y $\mathrm{Mn}$ en las posiciones catiónicas (en apfu); y b) de las proporciones de $\mathrm{OH}, \mathrm{Fy} \mathrm{Cl}$ (en apfu). c) Esquema de la secuencia de alteración de la asociación fosfatada IV en las pegmatitas encajadas en el LG y las AB con turmalina; d) diagrama triangular ( $\mathrm{Zn+Ca+Na+Mg)-Mn-Fe} \mathrm{de} \mathrm{las} \mathrm{posiciones} \mathrm{catiónicas} \mathrm{divalentes,} \mathrm{en} \mathrm{proporciones} \mathrm{atómicas,} \mathrm{de} \mathrm{la}$ rockbridgeita de las asociaciones IV y II; e) esquema de la secuencia de alteración de la asociación fosfatada V en los diques de composición granítica de Cruz del Rayo. 
peso). La rockbridgeita aparece en agregados granulares de color verde oliva en luz natural y fuerte pleocroísmo en tonos marrones en el interior de los cristales de xantoxenita como restos sin alterar. Químicamente es una fase mineral muy rica en $\mathrm{Fe}^{3+}$ con hasta 0,12 apfu de Al en sustitución, mientras que las posiciones divalentes se completan con el Fe restante en forma de $\mathrm{Fe}^{2+}$ y menos $\mathrm{Mn}^{2+}$, con trazas de $\mathrm{Mg}, \mathrm{Zn}$, Ca y $\mathrm{Na}$ que no llegan a completar estas posiciones dejando algunas vacancias. Esto indica que pertenecen a términos próximos a la rockbridgeita con escasa sustitución de los grupos $\mathrm{OH}^{-}$por $\mathrm{F}$. En el triángulo de la figura 3.18d los cationes de las posiciones divalentes en la rockbridgeita de la asociación IV se comparan con el mismo mineral de la asociación II del LG y las AB, observándose un claro enriquecimiento en $\mathrm{Mn}$ coherente con la existencia de un fluido hidrotermal ligeramente más evolucionado.

Los fosfatos de la serie childrenita-eosforita son los más abundantes en las pegmatitas intragraníticas estudiadas, encontrándose diseminados desde las zonas de borde hasta su interior. Se presentan en cristales an- a subhedrales frecuentemente maclados y con bordes corroídos que llegan a alcanzar un tamaño máximo de 1,5 mm, y casi siempre se encuentran englobados por, o en contacto con, los feldespatos. Normalmente, los términos más ricos en $\mathrm{Mn}$ suelen ser incoloros y se encuentran incluidos dentro de feldespato potásico, mientras que los más ricos en Fe presentan color amarillo o anaranjado y están incluidos en la albita, lo que avala las observaciones de Fransolet (1980). Muchos cristales reflejan un zonado concéntrico debido a ligeras variaciones en los contenidos en Fe y Mn (Lám. 3.11e,f). Su composición química varía desde términos de childrenita (0,6 apfu de Fe y 0,24 apfu de Mn) hasta eosforita (0,22 apfu de Fe y 0,70 apfu de Mn), siendo las composiciones intermedias y los términos más puros de childrenita los más frecuentes. Presentan, además, trazas de Ca y $\mathrm{Mg}$ y contenidos en $\mathrm{F}$ inferiores a $0,6 \%$ en peso.

En todos los cuerpos pegmatíticos intragraníticos se diferencian, según la composición química y sus características texturales, tres tipos de apatito: el fluorapatito I, de origen magmático tardío, se presenta en cristales an- a subhedrales de tamaño centimétrico y asociados generalmente a moscovita o feldespatos; el fluorapatito II se encuentra en agregados euhedrales rellenando grietas de origen tardío. Ambos tipos son químicamente muy similares con sus posiciones catiónicas ocupadas por el Ca y sustituidas por $\mathrm{Mn}(0,08-0,32 \mathrm{apfu})$ y por Fe (hasta 0,18 apfu), dominando en todos los análisis el Mn frente al Fe, mientras que el $\mathrm{F}$ domina frente al $\mathrm{Cl}$ y el ión $\mathrm{OH}$ (Fig. 3.18a,b); finalmente, el tercer tipo corresponde con hidroxilapatito que se forma por la alteración de la xantoxenita (Lám. 3.11c,d), lo que condiciona su composición química. En este caso el Ca es ampliamente sustituido por Fe (hasta 0,45 apfu), Mg (hasta 0,25 apfu) y $\mathrm{Mn}$ (hasta 0,19 apfu) y predominan el $\mathrm{OH}^{-}$(hasta $0,80 \mathrm{apfu}$ ) y el $\mathrm{Cl}$ (hasta $0,5 \mathrm{apfu}$ ) sobre el $\mathrm{F}$.

Por último, la mitridatita se presenta muy localmente como restos sin alterar de color rojizo dentro de la xantoxenita, al igual que rockbridgeita y alluaudita. Su composición química es muy similar a la que presenta la mitridatita del LG, estando dominada claramente por el $\mathrm{Fe}^{3+}$ (hasta 2,91 apfu) y las posiciones divalentes casi totalmente ocupadas por el Ca (hasta 1,78 apfu). 


\section{Asociación V}

En los diques peribatolíticos de composición granítica de Cruz del Rayo la asociación fosfatada típica se caracteriza por la presencia de restos granulares de tamaño micrométrico de mitridatita y alluaudita, con fluorapatito, hidroxilapatito y rockbridgeita como accesorios en las zonas de pared e intermedia exterior (Fig. 3.18e). La alluaudita de Cruz del Rayo está globalmente más enriquecida en $\mathrm{Mn}$ que la alluaudita de las pegmatitas intragraníticas, alcanzando hasta 0,37 apfu de Mn en las posiciones M2 y hasta 1,00 apfu en la posición $\mathrm{M} 1$, aunque sigue presentando valores elevados de $\mathrm{Fe}$ en forma de $\mathrm{Fe}^{3+}$. La relación $\mathrm{Fe} /$ ( $\mathrm{Fe}+\mathrm{Mn}$ ) varía entre 0,56 y 0,59, lo que demuestra su carácter más evolucionado respecto de la alluaudita de las pegmatitas intragraníticas. Por su parte, la mitridatita forma agregados granulares que alteran a la alluaudita y presenta una composición química muy similar a la mitridatita del LG y de las pegmatitas intragraníticas. Domina el $\mathrm{Fe}^{3+}$ en las posiciones trivalentes (hasta 2,94 apfu) con trazas de $\mathrm{Mn}^{3+}$, mientras que en las posiciones divalentes lo hace el Ca con mayores contenidos que en el LG o en las pegmatitas intragraníticas (hasta 1,97 apfu), completándose estas posiciones con $\mathrm{Fe}^{2+}, \mathrm{Sr}$ y Zn como trazas. Se diferencian de nuevo tres tipos de apatito; el fluorapatito I forma agregados de cristales anhedrales de color pardo con Fe (hasta 0,26 apfu) y Mn (hasta 0,27 apfu) como principales sustitutos del Ca y hasta 0,92 apfu de F (Fig. 3.18a,b); el hidroxilapatito se encuentra en cristales euhedrales y frecuentemente alargados de color azul intenso rellenando grietas junto con clorita en las zonas internas de los diques (Lám. 3.12a). En él, el Mn sustituye hasta en 0,55 apfu al Ca y se encuentran cantidades significativas de $\mathrm{Sr}$ (hasta 0,07 apfu) y contenidos en $\mathrm{OH}^{-}$de hasta 0,80 apfu (Fig. 3.18a,b); finalmente, el fluorapatito II se presenta en cristales anhedrales de color pardo que reemplazan a la mitridatita, la rockbridgeita y el hidroxilapatito previos, con una composición rica en Mn. Por último, la eosforita se forma solo localmente a partir de feldespato potásico.

\section{Asociación VI}

En los diques pegmatíticos de composición tipo greisen de Cruz del Rayo solo se han observado fosfatos de la serie ambligonita-montebrasita (Lám. 3.12b). En la zona de pared de estos
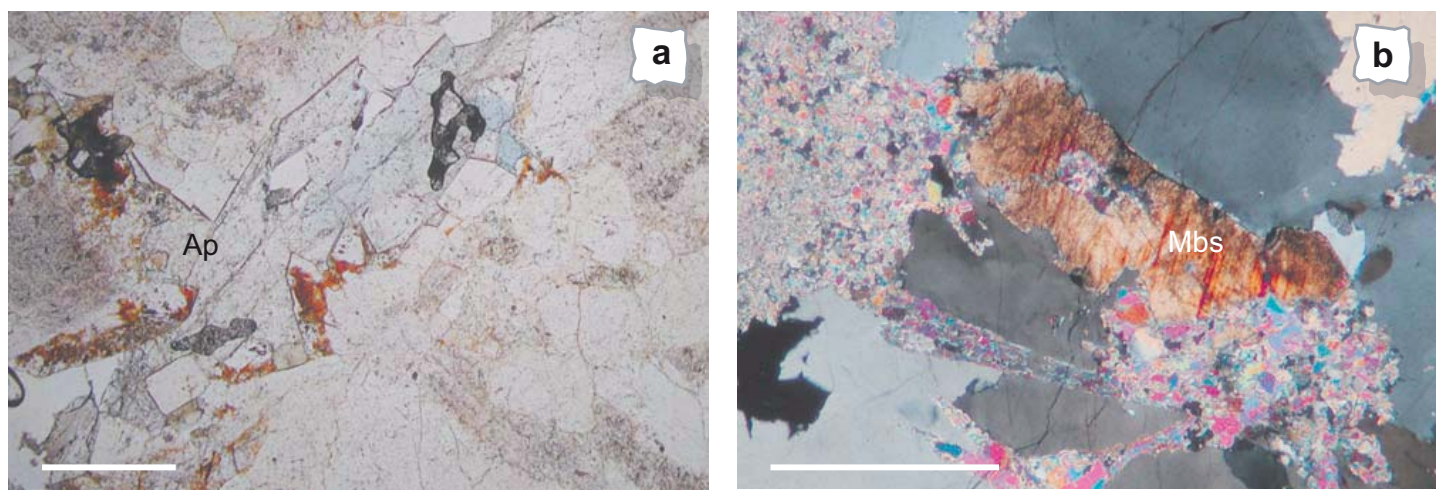

Lám. 3.12. Microfotografías de los fosfatos más representativos de los diques pegmatíticos peribatolíticos: a) hidroxilapatito subhedral de color azul rellenando una fractura tardía, asociación $\mathrm{V}$ de los diques de composición granítica de Cruz del Rayo, LN; b) cristales de montebrasita parcialmente greisenizados, asociación VI de los diques de tipo greisen de Cruz del Rayo, NC. Escala gráfica: a) $500 \mu \mathrm{m}$; b) 1 mm. 
diques son muy accesorios y se presentan en cristales anhedrales de tamaño milimétrico alterándose a un fosfato con textura fibrosa, composición similar al apatito y con contenidos elevados en Al que proceden probablemente de la montebrasita. En la zona intermedia de los diques estos fosfatos son muy abundantes, adquieren formas sub- a euhedrales y presentan contenidos en $\mathrm{F}$ que varían entre 0,16 y 0,53 apfu con trazas de $\mathrm{Na}$ sustituyendo al Li. El fluorapatito, también con altos contenidos en $\mathrm{Mn}$, se encuentra solo de forma accesoria (Fig. 3.18a).

\subsubsection{Mineralización}

La casiterita en los diques pegmatíticos intragraníticos del LG y las $A B$ es muy escasa, siendo el rutilo el óxido dominante, mientras que la strüverita es más accesoria. Por el contrario, en las pegmatitas graníticas peribatolíticas de Cruz del Rayo la casiterita es abundante, especialmente en los diques de composición tipo greisen, junto con minerales del grupo de la columbita (Llorens y Moro, 2010c).

\subsubsection{Casiterita}

La casiterita en los diques pegmatíticos intragraníticos de las facies del LG y las AB se encuentra en cristales an- a euhedrales de tamaño milimétrico asociados frecuentemente con moscovita y con cuarzo. Su composición química es bastante homogénea (Anexo III), de forma que el Sn es el catión principal (entre 0,98-0,99 apfu) sustituido generalmente por hasta 0,01 apfu de $\mathrm{Ti}, \mathrm{Ca}$ y Fe respectivamente. Solo algunos cristales muestran hasta $1,07 \%$ en peso de $\mathrm{Ta}_{2} \mathrm{O}_{5}$ y hasta $0,39 \%$ en peso de $\mathrm{Nb}_{2} \mathrm{O}_{5}$. Por lo general, los contenidos en $\mathrm{Nb}$ son más moderados y constantes, mientras que los de Ta son inexistentes o considerablemente elevados.

La casiterita en los diques pegmatíticos de Cruz del Rayo presenta características similares tanto en los diques de composición granítica, donde se encuentra de manera escasa, como en la Unidad Tardía rica en albita (UT) y en las zonas intermedias de los diques de tipo greisen, donde se encuentra de manera abundante. Esta casiterita se presenta fundamentalmente en cristales an- a subhedrales de tamaño hasta centimétrico diseminados especialmente en las zonas internas de los diques. Bajo el microscopio presenta una textura zonada debido a la alternancia de bandas de color rojizo con otras incoloras (Lám. 3.13a,b) que contienen numerosas inclusiones de minerales del grupo de la columbita. Las bandas de color rojizo contienen más Fe (hasta 0,03 apfu), Nb (hasta 0,04 apfu) y Ta (hasta 0,03 apfu) que las incoloras, en las que la sustitución del $\mathrm{SnO}_{2}$ es inexistente. Destacan, además, contenidos de hasta $0,55 \%$ en peso de $\mathrm{CaO}$ y hasta $0,57 \%$ en peso de $\mathrm{TiO}_{2}$, con trazas de $\mathrm{WO}_{3}$ y $\mathrm{MnO}$.

Proyectando los análisis de todas las casiteritas en el diagrama cuadrilateral de la columbita se observa que la distribución de los puntos no presenta ninguna tendencia (Fig 3.19a). Sin embargo, los análisis varían especialmente en la vertical en función de los contenidos en $\mathrm{Nb}$ y Ta más que en Fe y Mn. Tampoco presentan un patrón definido para la distribución preferente del $\mathrm{Nb}$ y del Ta entre las diferentes bandas de los cristales. No obstante, en el diagrama de la figura 3.19b se observa, a juzgar por la distribución de los análisis sobre la línea 1:1, la existencia de una débil preferencia por el $\mathrm{Nb}$. Además, salvo algunos análisis que se muestran visiblemente más enriquecidos en Ta, varios de estos cristales muestran 

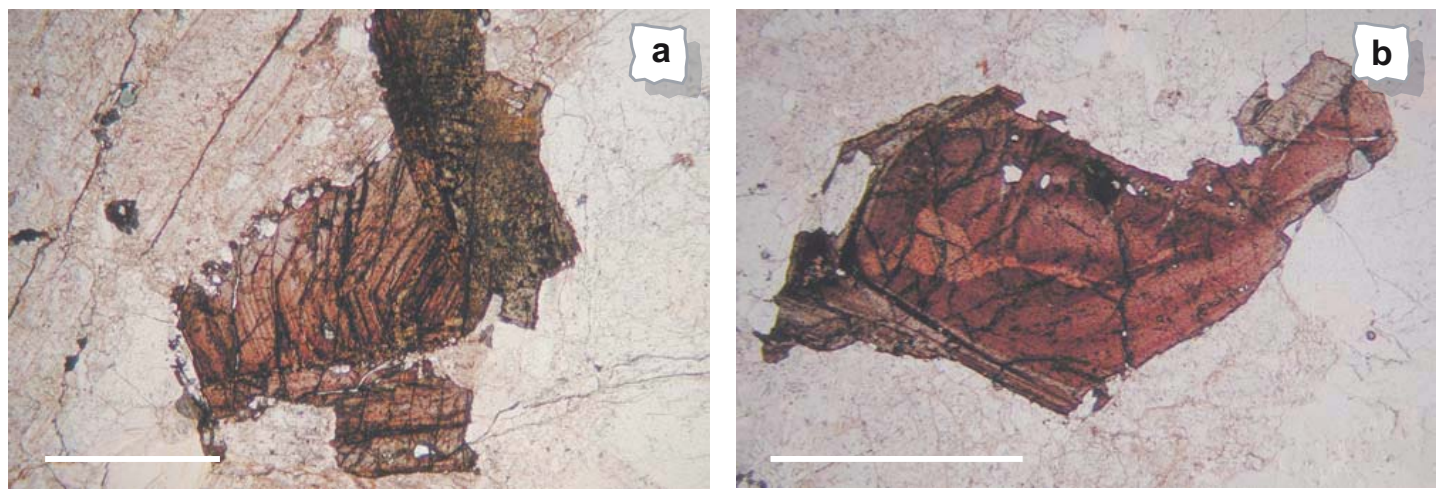

Lám. 3.13. a) Microfotografía de un cristal anhedral de casiterita zonado en los diques pegmatíticos de composición granítica de Cruz del Rayo, LN; b) microfotografía de un cristal subhedral de casiterita zonado en los diques de composición tipo greisen, LN. Escala gráfica: $1 \mathrm{~mm}$.

una tendencia vertical de enriquecimiento casi exclusivo en $\mathrm{Nb}$, por lo que es probable que existan dos mecanismos de enriquecimiento en estos elementos.

El mecanismo más común por el que se produce la entrada de $\mathrm{Nb}$ y Ta en la casiterita es a partir de una sustitución de tipo $(\mathrm{Fe}, \mathrm{Mn})(\mathrm{Ta}, \mathrm{Nb})_{2} \mathrm{O}_{6}$, como se puede apreciar en el triángulo composicional y en el gráfico de las figuras 3.19c y d. En ambos gráficos se observa que los análisis de casiterita en pegmatitas siguen más o menos la línea ideal $(\mathrm{Ta}+\mathrm{Nb}) /(\mathrm{Fe}+\mathrm{Mn})=2$. Solo en la casiterita de los diques intragraníticos el valor de esta relación siempre se encuentra por debajo de 2, lo que significaría que el contenido en Ta y $\mathrm{Nb}$ en la casiterita no estaría exclusivamente controlado por partículas incluidas y exsoluciones de minerales del grupo de la columbita (Möller et al., 1988).

Por otro lado, los contenidos en $\mathrm{TiO}_{2}$ de la casiterita son visiblemente mayores en los diques intragraníticos que en los de Cruz del Rayo, mostrando, además, valores similares para la casiterita que se encuentra en los diques de tipo greisen y en la UT rica en albita (Fig. 3.19e).

\subsubsection{Minerales del grupo de la columbita}

Dada la importancia y la amplia variabilidad que presenta este grupo de minerales en las pegmatitas de Cruz del Rayo, se describen en primer lugar los que se encuentran en los diques de composición granítica y a continuación en los de composición tipo greisen.

\section{Diques de composición granítica}

Los óxidos de $\mathrm{Nb}$ y Ta se limitan a la zona intermedia interior de estos diques donde se identifican dos generaciones de columbita-(Fe), una de origen primario y otra secundaria, mientras que en la UT rica en albita solo se encuentra tantalita-(Fe).

La columbita-(Fe) primaria se presenta en cristales an- a subhedrales de tamaño milimétrico incluidos en casiterita y de color rojo a marrón oscuro en luz natural. Normalmente presenta una textura zonada (Lám. 3.14a) debido a las variaciones en los contenidos de Fe y Mn frente a los de $\mathrm{Nb}$ y $\mathrm{Ta}$, prácticamente constantes, lo que se traduce en una tendencia horizontal en 

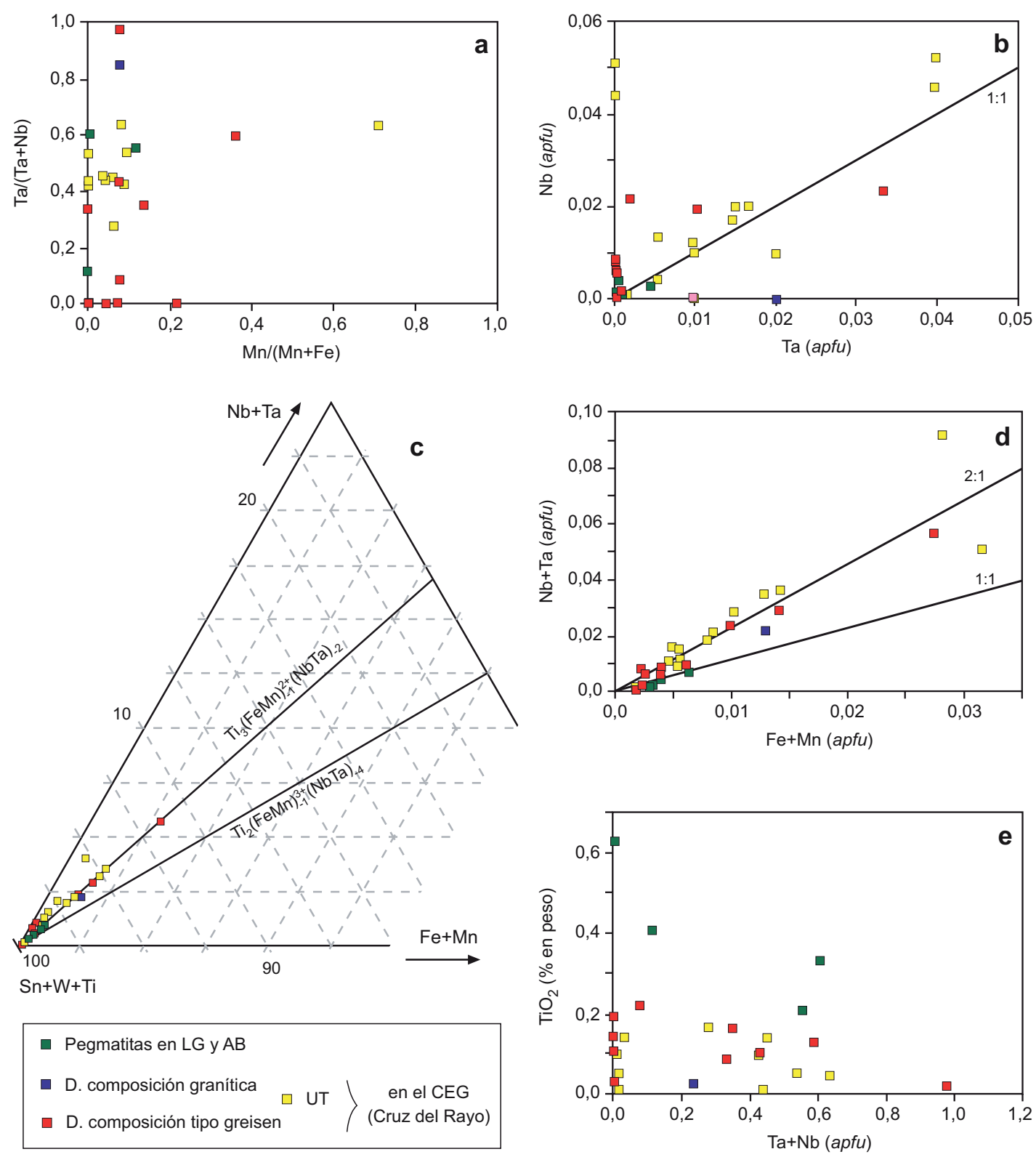

Fig. 3.19. a) Composición de la casiterita (en apfu) de los diques pegmatíticos intra y peribatolíticos y de la UT rica en albita en el diagrama cuadrilateral de la columbita; b) diagrama de variación del Nb y el Ta en la casiterita; $\mathrm{c})$ diagrama triangular $(\mathrm{Sn}+\mathrm{W}+\mathrm{Ti})-(\mathrm{Nb}+\mathrm{Ta})-(\mathrm{Fe}+\mathrm{Mn})$ de ocupación de las posiciones catiónicas en la casiterita, apreciándose el esquema de sustitución química dominante. Diagramas de variación de: d) $\mathrm{Nb}+\mathrm{Ta}$ vs. $\mathrm{Fe}+\mathrm{Mn}$; y e) $\mathrm{TiO}_{2}$ vs. $\mathrm{Ta}+\mathrm{Nb}$ en la casiterita de los diques pegmatíticos.

el diagrama cuadrilateral de la columbita (Fig. 3.20a). Químicamente son fases enriquecidas en $\mathrm{Nb}$ (1,24-1,49 apfu) frente al Ta (0,38-0,62 apfu), con contenidos importantes de Ti (hasta $0,23 \mathrm{apfu}$ ) y trazas de Sn y $\mathrm{W}$ que ocupan la posición $\mathrm{B}$ en su fórmula general $\mathrm{AB}_{2} \mathrm{O}_{6}$ (Von Knorring y Fadipe, 1981). La posición A se encuentra prácticamente en su totalidad ocupada por Fe (entre 0,58 y 0,83 apfu) y Mn (hasta 0,33 apfu) con trazas de Zr. La relación Mn/ ( $\mathrm{Mn}+\mathrm{Fe}$ ) varía ampliamente entre 0,07 y 0,36 debido al zonado de los cristales, mientras que la relación $\mathrm{Ta} /(\mathrm{Ta}+\mathrm{Nb})$ es más limitada $(0,20-0,34)$. 
La columbita-(Fe) secundaria se presenta en cristales euhedrales prismáticos también de tamaño milimétrico, asociados a la casiterita y al cuarzo que con frecuencia la engloba (Lám. 3.14b). Químicamente los contenidos en $\mathrm{Nb}$ y Ta en las posiciones B son similares, hasta 1,05 y 0,94 apfu respectivamente, con cantidades accesorias, en ocasiones importantes, de Sn, W y Ti (hasta 0,3, 0,4 y 0,11 apfu respectivamente), observándose una relación linear entre $\mathrm{Nb}$ y Ta (Fig. 3.20b). La posición A muestra valores similares de Fe (hasta 0,62 apfu) y Mn (hasta 0,45 apfu), mostrando ambos también una relación linear (Fig. 3.20c). La mayoría de estos cristales de columbita- $(\mathrm{Fe})$ muestran valores próximos o iguales a 3 para la suma de las posiciones catiónicas A y B, aunque algunos de ellos pueden alcanzar hasta 3,06 apfu, lo que sugiere la presencia de cationes trivalentes (Ercit, 1994). En este caso las relaciones $\mathrm{Mn} /$ $(\mathrm{Mn}+\mathrm{Fe})$ y $\mathrm{Ta} /(\mathrm{Ta}+\mathrm{Nb})$ muestran valores intermedios y muy similares entre sí, variando entre 0,40-0,48 y entre 0,43-0,49 respectivamente, por lo que se proyectan en zonas intermedias del diagrama de la columbita (Fig.3.20a).

Por último, la tantalita-(Fe) se encuentra en la UT rica en albita en cristales sub- a anhedrales de tamaño micrométrico y con un ligero zonado a composiciones más ricas en Ta hacia el borde de los cristales (Lám. 3.14c). Químicamente las posiciones B se encuentran dominadas por el Ta que alcanza 1,60 apfu, mientras que el Nb llega hasta 0,75 apfu, además de 0,06 apfu de Ti y 0,01 apfu de Sn que completan las posiciones. Por su parte, las posiciones A presentan contenidos intermedios de Fe y $\mathrm{Mn}$, aunque siempre dominando el Fe que alcanza 0,50 apfu, mientas que el Mn llega a 0,42 apfu. Aunque ocasional, destaca hasta 0,01 apfu de $\mathrm{Hf}$ completando estas posiciones, que muestran importantes vacancias. La relación $\mathrm{Mn} /$ ( $\mathrm{Mn}+\mathrm{Fe}$ ) varía entre 0,41 y 0,47 mientras que la relación $\mathrm{Ta} /(\mathrm{Ta}+\mathrm{Nb})$ lo hace entre 0,62 y 0,78 apfu, de manera que muestra los valores más elevados de esta relación en los cuerpos de composición granítica (Fig. 3.20a), variando fundamentalmente en la vertical para valores intermedios de la relación $\mathrm{Mn} /(\mathrm{Mn}+\mathrm{Fe})$.

\section{Diques de composición tipo greisen}

En estos diques la mineralización primaria de $\mathrm{Nb}$ y Ta se encuentra desde la zona de pared hasta la zona intermedia de los mismos (Lám. 3.7b) y puede estar asociada o no a la casiterita. Consiste en columbita-(Fe), columbita-(Mn) y tantalita-(Mn), mientras que la mineralización secundaria está compuesta únicamente por tantalita-(Mn).

La columbita-(Fe) aparece en grupos de exsoluciones anhedrales de tamaño micrométrico en determinadas bandas de los cristales de la casiterita zonada que se encuentran en la zona de pared de los diques. Su composición química está enriquecida en $\mathrm{Nb}(1,25-1,59 \mathrm{apfu})$ frente al Ta (0,27-0,64 apfu), con contenidos importantes en Ti (hasta 0,15 apfu), Sn (hasta 0,10 apfu) y W (hasta $0,03 \mathrm{apfu}$ ) rellenando la posición B. La posición A contiene cantidades variables de Fe (0,51-0,68 apfu) probablemente extraído de la casiterita, con menos $\mathrm{Mn}(0,28-0,46$ apfu) y trazas de $\mathrm{Zr}$. La relación $\mathrm{Mn} /(\mathrm{Mn}+\mathrm{Fe})$ varía entre 0,42 y 0,48 y la de Ta/(Ta+Nb), más restringida, entre 0,18 y 0,22 (Fig. 3.20a).

La columbita-(Mn) es relativamente abundante. Se encuentra generalmente en cristales suba euhedrales de tamaño micrométrico en las zonas de borde de los cristales de casiterita o, localmente, en cristales de hábito prismático asociados al cuarzo o la moscovita. Presentan 

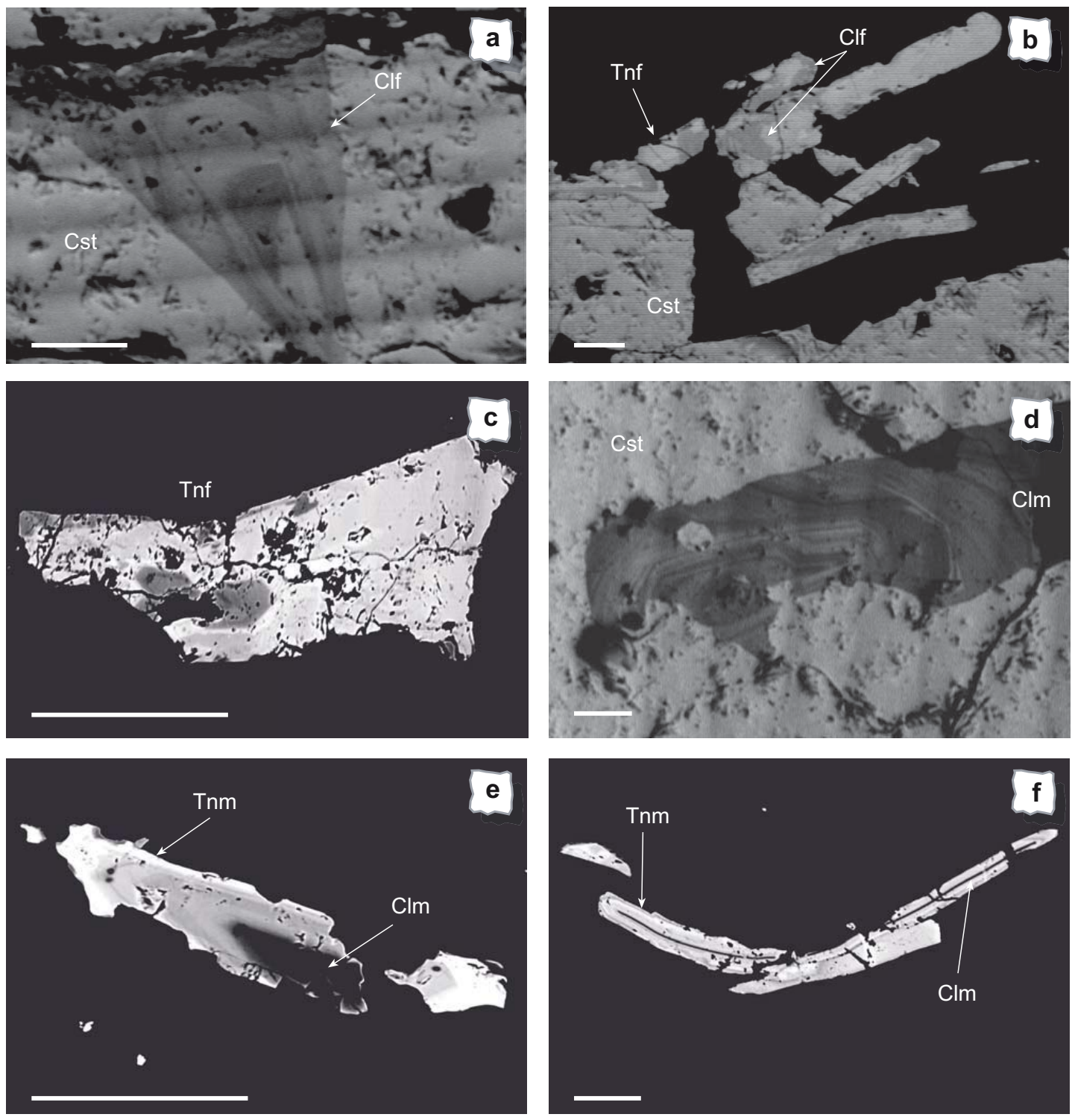

Lám. 3.14. Microfotografías electrónicas de los minerales del grupo de la columbita en los diques pegmatíticos de Cruz del Rayo: a) cristales de columbita-(Fe) primaria con zonado oscilatorio e incluidos en la casiterita de los diques de composición granítica; b) cristales de columbita-(Fe) y tantalita-(Fe) secundarias incluidos en la casiterita y en el cuarzo de los diques de composición granítica; c) cristal de tantalita-(Fe) secundaria zonado debido a pequeñas variaciones en los contenidos de Ta en la UT rica en albita; d) zonado inverso en un cristal de columbita-( $\mathrm{Mn}$ ) primario incluido en casiterita en los diques de composición tipo greisen. Las zonas más claras están enriquecidas en Ta, mientras que las más oscuras lo están en Nb; e) cristal de columbita-(Mn) con un borde de tantalita-( $\mathrm{Mn}$ ) en la zona interna de los diques de composición tipo greisen; f) cristal de tantalita-( $\mathrm{Mn})$ secundaria con un núcleo de columbita-( $\mathrm{Mn}$ ) en los diques de composición tipo greisen. Escala gráfica: a, b y d) $20 \mu \mathrm{m}$; c, e y f) $100 \mu \mathrm{m}$.

una zonación oscilatoria muy marcada debido a las variaciones en los contenidos en Fe-Mn y de $\mathrm{Nb}$-Ta (Fig. 3.20a) (Anderson et al., 1998). En algunos de estos cristales se observa, ocasionalmente, una zonación inversa en la que el borde presenta contenidos en $\mathrm{Nb}$ más altos que las zonas internas (Lám. 3.14d), lo que podría deberse a un reemplazamiento hidrotermal de los óxidos primarios (Černý et al., 1992; Tindle y Breaks, 1998, 2000; Beurlen et al., 2008). Sin embargo, la ausencia de texturas típicas de reemplazamiento y la presencia 

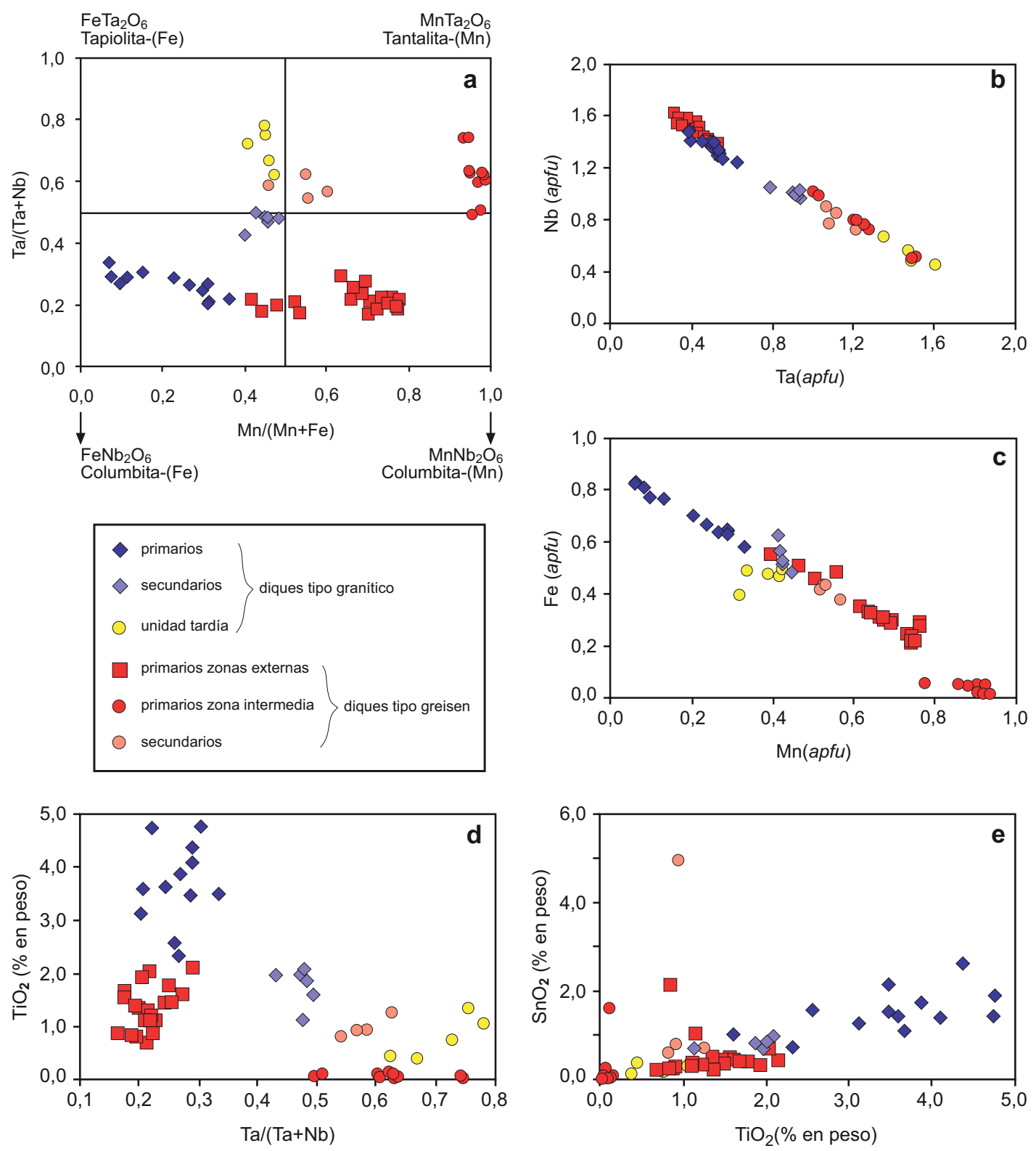

Fig. 3.20. Diagramas de variación en los minerales del grupo de la columbita de los diques pegmatíticos encajados en el CEG de Cruz del Rayo: a) de Ta/(Ta+Nb) vs. Mn/(Mn+Fe), observándose la evolución de estos desde los diques de composición granítica hasta los de tipo greisen; b) de Fe vs. Mn; c) de Nb vs. Ta; d) de $\mathrm{TiO}_{2}$ vs. $\mathrm{Ta} /(\mathrm{Ta}+\mathrm{Nb}) ;$ y e) de $\mathrm{SnO}_{2}$ vs. $\mathrm{TiO}_{2}$.

de planos de crecimiento paralelos a los cambios graduales de composición indican para estos cristales un origen primario. Su composición química muestra contenidos elevados en $\mathrm{Nb}(1,27-1,62 \mathrm{apfu})$ frente al Ta $(0,32-0,64 \mathrm{apfu})$, con Ti y W como trazas más importantes (hasta 0,10 y 0,06 apfu respectivamente) rellenando la posición B. La posición A está ocupada por Mn (entre 0,50-0,76 apfu), Fe (entre 0,21-0,51 apfu) y algunas trazas de Zr. La suma de las posiciones A y B es superior a 3 apfu en algunos de estos cristales (hasta 0,08 apfu más), lo que vuelve a poner de manifiesto la existencia de cationes trivalentes (Ercit, 1994). La relación $\mathrm{Mn} /(\mathrm{Mn}+\mathrm{Fe})$ varía entre 0,52 y 0,78 debido a este zonado oscilatorio, mientras que la relación $\mathrm{Ta} /(\mathrm{Ta}+\mathrm{Nb})$ lo hace entre 0,16 y 0,33. 
La tantalita-(Mn) primaria se encuentra en la zona intermedia de los diques en cristales de tamaño micrométrico asociados, generalmente, a agregados de mica blanca. Son cristales que presentan también una zonación composicional con los bordes más empobrecidos en $\mathrm{Nb}$ (Lám. 3.14e,f). Su composición química está enriquecida en Ta (entre 1 y 1,28 apfu) frente al $\mathrm{Nb}$ (entre 0,51 y 1,01 apfu), con trazas de Ti y $\mathrm{Sn}$ que rellenan las posiciones B, mientras que las posiciones $\mathrm{A}$ están ocupadas por el $\mathrm{Mn}$ hasta 0,93 apfu, de modo que la relación $\mathrm{Mn} /(\mathrm{Mn}+\mathrm{Fe})$ varía entre 0,93 y 0.99 y la $\mathrm{Ta} /(\mathrm{Ta}+\mathrm{Nb})$ entre 0,50 y 0,75 . De esta forma, en el diagrama de la figura 3.20a estos cristales se proyectan próximos al eje vertical para $\mathrm{Mn} /$ $(\mathrm{Mn}+\mathrm{Fe})=1$. La tantalita-(Mn) secundaria es menos frecuente y se presenta en cristales de tamaño micrométrico incluidos en los bordes incoloros de los cristales de casiterita o en torno a cristales previos de columbita, tanto en la zona de pared como en la intermedia. Su composición química está enriquecida en Ta (entre 1,07 y 1,21 apfu) y menos $\mathrm{Nb}(0,72-0,90$ apfu), con hasta 0,7 y 0,3 apfu de Ti y $\mathrm{Sn}$ respectivamente ocupando las posiciones $\mathrm{B}$. Las posiciones A presentan contenidos similares en Fe y $\mathrm{Mn}$ (hasta 0,43 y 0,57 respectivamente), aunque siempre con mayores contenidos en este último y trazas de $\mathrm{Zr}$. La relación $\mathrm{Mn} /(\mathrm{Mn}+\mathrm{Fe})$ varía entre 0,55 y 0,60, mientras que la relación $\mathrm{Ta} /(\mathrm{Ta}+\mathrm{Nb})$ es bastante homogénea $(0,54-$ $0,63)$, por lo que se proyecta en zonas intermedias del diagrama cuadrilateral de la columbita (Fig. 3.20a). El único cristal de tantalita-(Fe) en estas zonas muestra una composición química próxima a la tantalita-(Mn) previa, con valores de $\mathrm{Mn} /(\mathrm{Mn}+\mathrm{Fe})$ y $\mathrm{Ta} /(\mathrm{Ta}+\mathrm{Nb})$ de 0,46 y 0,58 respectivamente.

\section{Sustituciones y evolución de los óxidos}

En el diagrama de la figura 3.20a se puede observar la evolución de los minerales del grupo de la columbita descritos en los diques pegmatíticos de Cruz del Rayo y en la UT rica en albita. En primer lugar se observa una tendencia al enriquecimiento en Mn y, posteriormente, en Ta. En los diques de composición granítica la relación $\mathrm{Mn} /(\mathrm{Mn}+\mathrm{Fe})$ evoluciona desde 0,07 hasta 0,36 para valores más o menos constantes y bajos de la relación $\mathrm{Ta} /(\mathrm{Ta}+\mathrm{Nb})$, lo que representa la mineralización primaria. Los valores más elevados de la relación $\mathrm{Ta} /(\mathrm{Ta}+\mathrm{Nb})$ los presenta la tantalita-(Fe) de la UT rica en albita, dibujando una tendencia ascendente que corresponde con la mineralización secundaria, consecuencia de procesos de reemplazamiento por un metasomatismo de Na que causa la albitización de los diques y la precipitación de esta UT.

Por su parte, en los diques de composición tipo greisen la relación $\mathrm{Mn} /(\mathrm{Mn}+\mathrm{Fe})$ varía desde 0,42 hasta cerca de 1 en las zonas más internas para valores de la relación $\mathrm{Ta} /(\mathrm{Ta}+\mathrm{Nb})$ entre 0,50 y 0,75 . Esta tendencia respondería a la mineralización primaria de estos diques, lo que muestra una evolución hacia composiciones más ricas en Mn y Ta como consecuencia del fraccionamiento de los fundidos que forman los diques pegmatíticos. Finalmente, la mineralización secundaria estaría menos enriquecida en $\mathrm{Mn}$, probablemente debido a la contaminación por fluidos meteóricos y metamórficos enriquecidos en $\mathrm{Fe}$, de modo que la relación $\mathrm{Fe} /(\mathrm{Fe}+\mathrm{Mn})$ presenta contenidos intermedios entre 0,40 y 0,60 para valores de la relación $\mathrm{Ta} /(\mathrm{Ta}+\mathrm{Nb})$ entre 0,56 y 0,74 .

La presencia de contenidos significativos en $\mathrm{Ti}$ en la estructura de estos minerales es notablemente superior en los diques de composición granítica (hasta $4,75 \%$ en peso de $\mathrm{TiO}_{2}$ ) que en los de tipo greisen (hasta $3,26 \%$ en peso de $\mathrm{TiO}_{2}$ ), que llegan a mostrar contenidos 
en $\mathrm{TiO}_{2}$ muy próximos a 0 en las zonas más internas. En el diagrama de la figura $3.20 \mathrm{~d}$ se aprecian las diferencias en los contenidos de $\mathrm{TiO}_{2}$ en ambos tipos de diques, observándose una evolución descendente desde los diques de composición granítica hasta los de tipo greisen para valores bajos de la relación $\mathrm{Ta} /(\mathrm{Ta}+\mathrm{Nb})$, hasta valores muy próximos a 0 en las zonas más internas de los diques de tipo greisen para una relación $\mathrm{Ta} /(\mathrm{Ta}+\mathrm{Nb})$ elevada. Esta tendencia se correspondería con la rama horizontal en el diagrama de la columbita (Fig. 3.20a), que coincide con los minerales primarios de este grupo. Un descenso menos acusado de los valores de $\mathrm{TiO}_{2}$ se dibuja para la mineralización secundaria de ambos tipos de diques y la UT, para valores elevados de la relación $\mathrm{Ta} /(\mathrm{Ta}+\mathrm{Nb})$, lo que refleja el comportamiento normal del Ti en los magmas silicatados. Esto es posible gracias a una doble sustitución 3Ti4 $\leftrightarrow 2(\mathrm{Nb}, \mathrm{Ta})^{5+}+(\mathrm{Fe}, \mathrm{Mn})^{2+}$. El hecho de que la suma de cationes de $\mathrm{Nb}+\mathrm{Ta}+\mathrm{Ti}$ en la posición $\mathrm{B}$ sea ligeramente superior a 2 apfu, confirmaría la actuación de este mecanismo en la mayoría de cristales de este grupo (Ercit, 1994). Al enfrentar los contenidos de $\mathrm{TiO}_{2}$ con los de $\mathrm{SnO}_{2}$ en los óxidos de las pegmatitas de Cruz del Rayo (Fig. 3.20e), se observa una relación positiva 2:1 para Ti:Sn que parece ser la dominante tanto en los diques de composición granítica como en los de tipo greisen y en la UT rica en albita aunque, por lo general, se aprecia una mayor tendencia a incorporar Ti frente al Sn debido probablemente a la menor disponibilidad de este último por la cristalización de la casiterita.

En el gráfico de la figura 3.20c se observa el principal mecanismo de sustitución en la posición A de los minerales del grupo de la columbita. En él se muestran dos poblaciones diferenciadas: por un lado la perteneciente a los diques de composición granítica, que se muestra más enriquecida en Fe (menos de 0,8 apfu); y por otro lado la perteneciente a los diques de composición tipo greisen, claramente enriquecida en Mn (hasta 0,8 apfu), además de los cristales que se encuentran en la UT y los resultantes de procesos de exsolución que muestran composiciones intermedias o más enriquecidas en Fe, probablemente heredadas de la casiterita encajante en el caso de las exsoluciones. Por su parte, en el gráfico $\mathrm{Nb}$ vs. Ta (Fig. 3.20b) se observa el principal mecanismo de sustitución en la posición B. Los datos se proyectan muy próximos a la línea 1:1 que muestra la sustitución isovalente $\mathrm{Ta}^{5+} \leftrightarrow \mathrm{Nb}^{5+}$ aunque, según se aprecia en el triángulo composicional $(\mathrm{Sn}+\mathrm{W}+\mathrm{Ti})-(\mathrm{Nb}+\mathrm{Ta})-(\mathrm{Fe}+\mathrm{Mn})$, la tendencia marcada por los puntos proyectados indica la influencia menor de sustituciones adicionales como Ti, W y Sn (Fig. 3.21).

\subsubsection{Rutilo y strüverita}

El rutilo se encuentra en cristales o agregados granulares de tamaño micrométrico a milimétrico diseminados o en fracturillas junto con moscovita, únicamente en los diques intragraníticos. Químicamente el Ti ocupa la mayor parte de las posiciones catiónicas con hasta 0,94 apfu y está sustituido por $\mathrm{Nb}$ y Fe entre 0,02 y 0,04 apfu y por Ta y Sn hasta 0,02 apfu en total. En la estructura del rutilo el $\mathrm{Nb}$, Ta y Fe entrarían de acuerdo con una sustitución de tipo columbita $(\mathrm{Fe}, \mathrm{Mn})\left(\mathrm{Nb}, \mathrm{Ta}_{2}\right)_{2} \mathrm{Ti}_{-3}$ (Fig. 3.21). Los valores de Al que se encuentran en el rutilo de algunos de los diques pegmatíticos son significativos, llegando a alcanzar hasta 1,72\% en peso de $\mathrm{Al}_{2} \mathrm{O}_{3}$, valores más altos que los obtenidos en el rutilo de la cúpula granítica de Podlesí, en la República Checa (Breiter et al., 2007), considerados hasta la fecha los más enriquecidos. La incorporación de Al al rutilo estaría compensada probablemente por vacancias de oxígeno 
mediante balance de cargas debido a un mecanismo de sustitución de tipo $\mathrm{Al}_{2} \mathrm{Ti}_{-2} \mathrm{O}_{-1}$ (Hata et al., 1996). Finalmente, la strüverita se encuentra muy localmente asociada a la casiterita con una fórmula calculada $\left(\mathrm{Ti}_{0.51} \mathrm{Ta}_{0.24} \mathrm{Nb}_{0.05} \mathrm{Sn}_{0.05} \mathrm{Fe}_{0.16}\right)_{\Sigma 1} \mathrm{O}_{2}$.

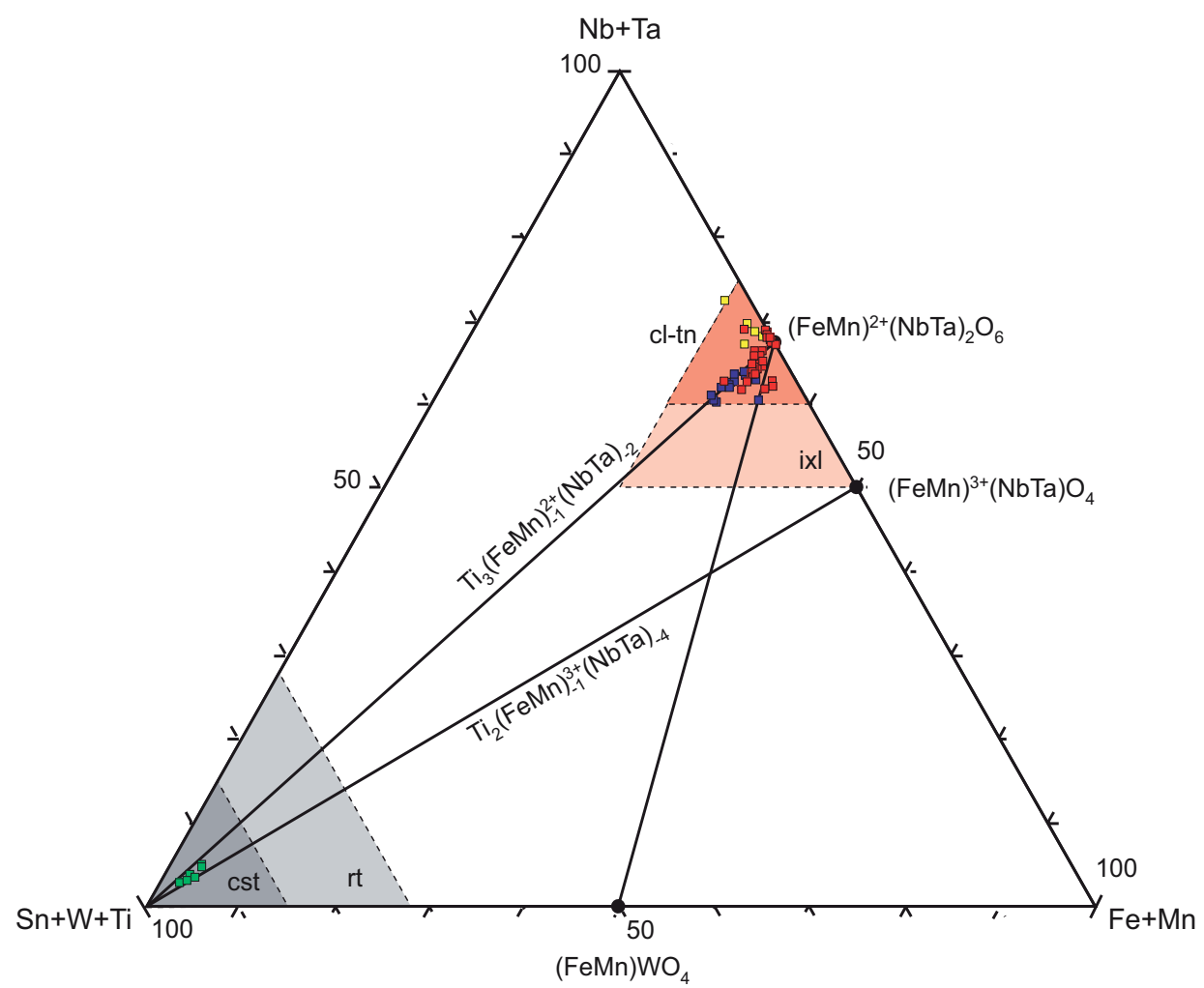

Fig. 3.21. Diagrama triangular $(\mathrm{Sn}+\mathrm{W}+\mathrm{Ti})-(\mathrm{Nb}+\mathrm{Ta})-(\mathrm{Fe}+\mathrm{Mn})$ en el que se representa la composición química del rutilo ( $r t)$ y los minerales del grupo de la columbita (cl-tn) de los diques pegmatíticos con el vector de sustitución dominante.

\subsubsection{Secuencia mineral}

Las pegmatitas intragraníticas del batolito de Jálama están constituidas fundamentalmente por cuarzo, plagioclasa, feldespato potásico y moscovita, con circón y fluorapatito como principales accesorios y biotita y turmalina localmente (Fig. 3.22). Únicamente en las pegmatitas encajadas en el GE se ha identificado la presencia staněkita y zwieselita como fosfatos primarios. Posteriormente son afectadas por un metasomatismo sódico que se manifiesta tanto en la formación de albita secundaria junto con cuarzo, como en la cristalización de alluaudita en las pegmatitas que encajan en el LG y las AB con turmalina. Por su parte, la moscovitización de los feldespatos desencadena la formación de childrenita-eosforita y montebrasita junto con la asociación cuarzo+moscovita. A continuación, la greisenización local en algunos sectores de las pegmatitas intragraníticas da lugar a la formación de agregados de mica blanca y cuarzo de grano muy fino. Asociada a esta alteración se encuentra la mineralización accesoria de casiterita, rutilo y strüverita y, muy puntualmente, la de arsenopirita y eléctrum. Finalmente, la alteración supergénica afecta especialmente a la secuencia fosfatada, formándose la secuencia de alteración que se observa en la figura 3.18c. 


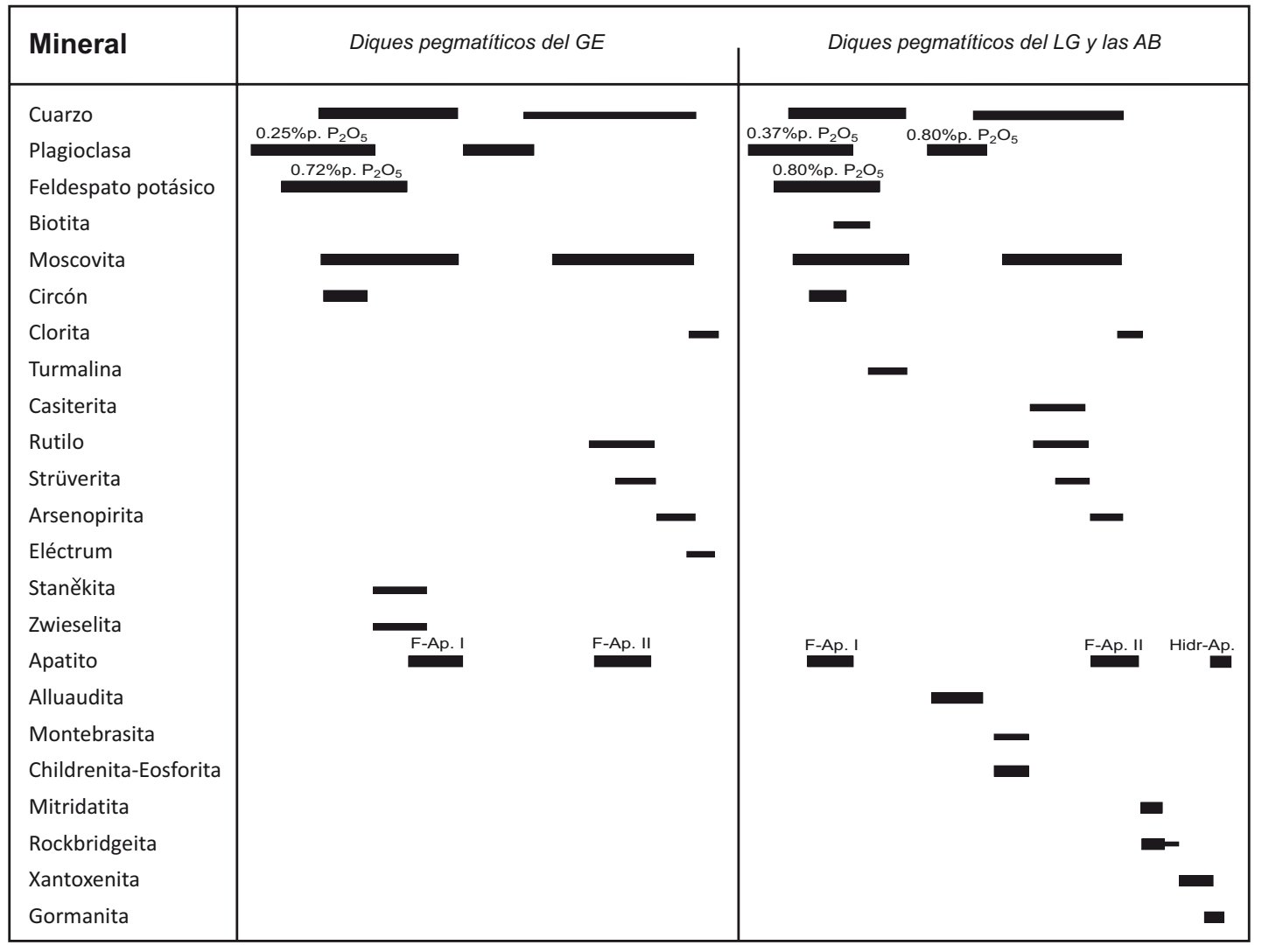

Fig. 3.22. Evolución magmático-hidrotermal de las pegmatitas intragraníticas.

En las pegmatitas peribatolíticas de Cruz del Rayo se diferencian los diques de composición granítica, que presentan una evolución magmático-hidrotermal muy similar a la de las pegmatitas intragraníticas (Fig. 3.23) y en los que el metasomatismo sódico es tan importante que llega a albitizar totalmente algunas zonas de estos diques, especialmente las más internas, formando la denominada Unidad Tardía (UT) rica en albita y cuarzo a la que se asocia la cristalización de la alluaudita y de los minerales secundarios del grupo de la columbita. Posteriormente, tanto los diques de composición granítica como la UT rica en albita son afectados por un proceso de greisenización dando lugar a la formación de los diques de tipo greisen. El berilo y la montebrasita son los principales accesorios, más abundantes hacia zonas internas. Estos diques contienen la mineralización principal de casiterita y minerales del grupo de la columbita, además de arsenopirita muy local. Este proceso da lugar a la alteración de la secuencia fosfatada en los diques de composición granítica, formándose childrenitaeosforita a partir de los feldespatos, rockbridgeita e hidroxilapatito. La alteración supergénica, de nuevo, afecta principalmente a la secuencia fosfatada formándose localmente mitridatita y fluorapatito. 


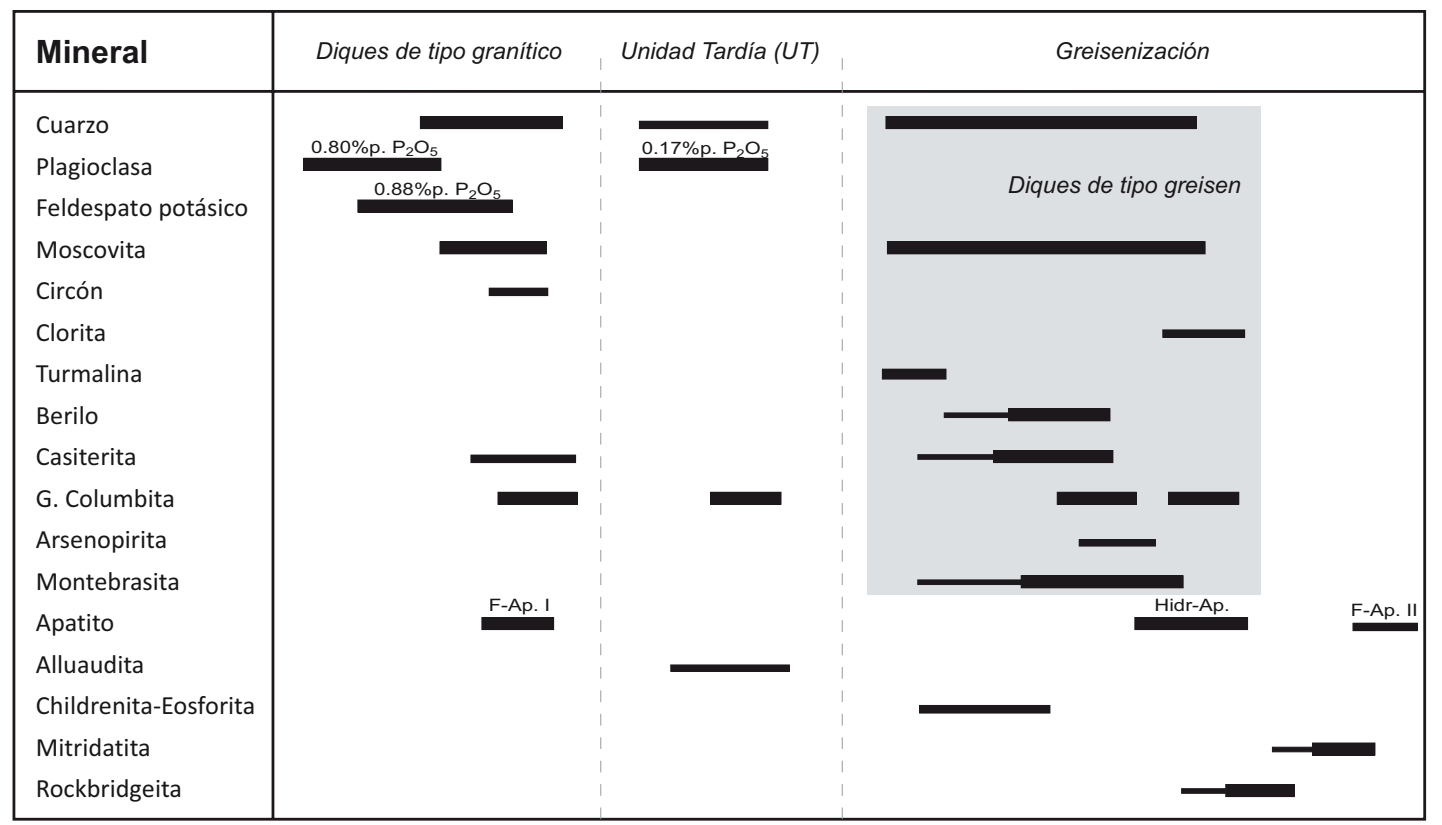

Fig. 3.23. Evolución magmático-hidrotermal de las pegmatitas peribatolíticas de Cruz del Rayo.

\subsection{VENAS DE CUARZO INTRAGRANÍTICAS}

Al igual que ocurría en los diques pegmatíticos, la abundancia y complejidad mineralógica de las venas de cuarzo encajadas en las facies graníticas de la UE del batolito de Jálama aumenta desde las zonas internas hacia las zonas apicales del mismo, mientras que las venas encajadas en las rocas metamórficas del CEG son de escasa entidad y de menor importancia mineralógica. Cronológicamente son posteriores a los diques pegmatíticos, a los que cortan en numerosas ocasiones (Lám. 3.15).

\subsubsection{Caracterización morfológica y estructural}

\section{Venas de cuarzo encajadas en el GE}

En las minas Horia y Mari Carmen la mineralización principal se encuentra en un conjunto de filones distribuidos en haces de dirección principal $\mathrm{N} 170^{\circ} \mathrm{E}-\mathrm{N} 180^{\circ} \mathrm{E}$ y buzamiento subvertical (Fig. 3.24) que presentan una morfología tabular o lenticular y potencias hasta decimétricas (Lám. 3.16a,b). Esta familia de venas es cortada por otra con escasa mineralización de dirección $\mathrm{N}^{\circ} 0^{\circ} \mathrm{E}$ y buzamiento también subvertical, la mayoría de potencia centimétrica, que generalmente tiene gran continuidad lateral. Por último, se aprecia la existencia de un grupo de fracturas de menor entidad con direcciones $\mathrm{N} 40^{\circ} \mathrm{E}, \mathrm{N} 120^{\circ} \mathrm{E}$ y $\mathrm{N} 60^{\circ} \mathrm{E}$ que pueden cortar a las anteriores o chocar contra ellas y desaparecer y que poseen distintos grados de relleno pero que no presentan signos de mineralización.

La intrusión de estas venas de cuarzo mineralizadas genera, ocasionalmente, una salbanda en los contactos con el encajante granítico de unos $2 \mathrm{~cm}$ de potencia máxima (Lám. 3.16b). Cuando está presente, se caracteriza por la presencia de moscovita y cuarzo como minerales esenciales. Por su parte, los minerales de la ganga que constituyen el relleno de la vena son el 


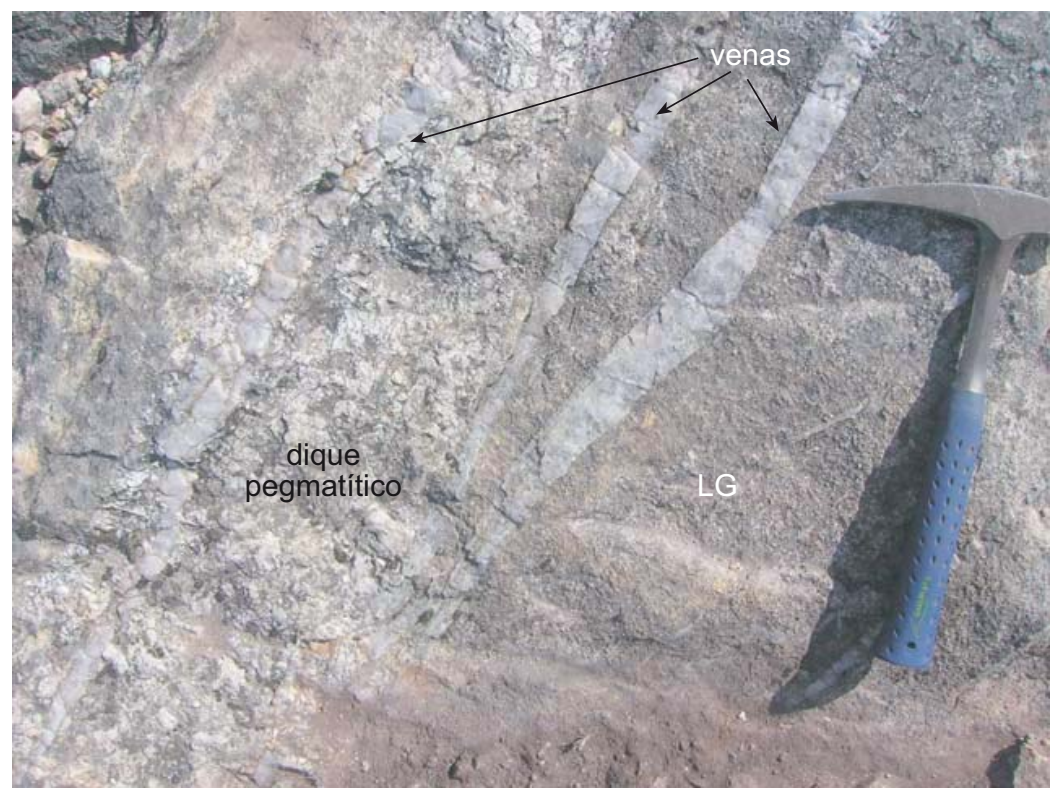

Lám. 3.15. Venas de cuarzo mineralizadas del batolito de Jálama cortando a uno de los diques pegmatíticos en la mina Profunda.

cuarzo principalmente y la moscovita de manera subordinada, con cantidades muy accesorias de clorita y apatito.

La mineralización se localiza mayoritariamente en las zonas internas de las venas asociada principalmente a fracturas y en las zonas más externas de los filones formando agregados

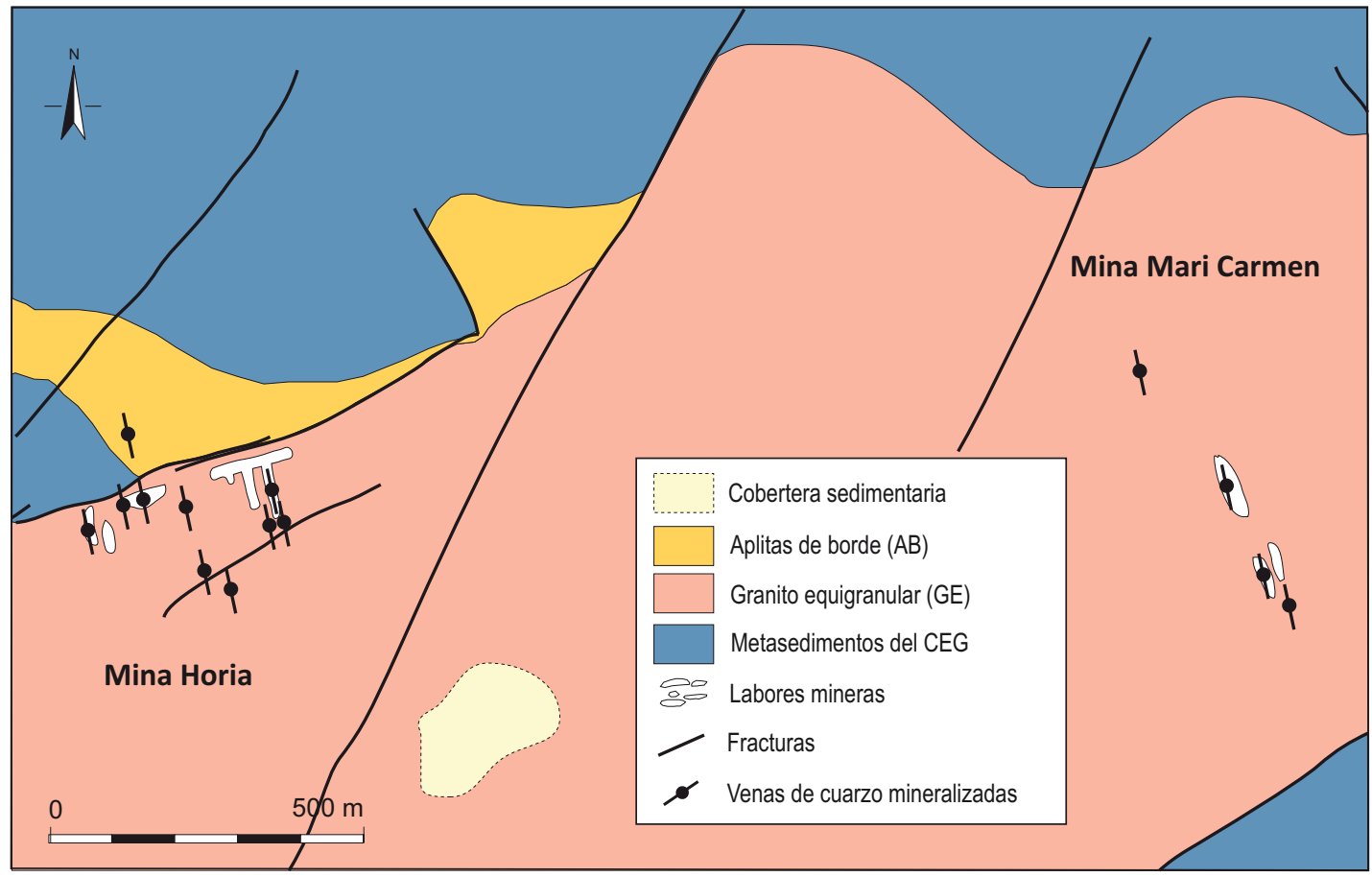

Fig. 3.24. Esquema geológico de la zona de la UE del batolito de Jálama con la situación de las minas Horia y Mari Carmen. Obsérvese las direcciones de las venas de cuarzo con Sn que fueron explotadas. 
cristalinos de grano fino y aspecto masivo en contacto con las salbandas (Lám. 3.16c,d). El mineral principal de la mena es la casiterita, además de la arsenopirita y la esfalerita como sulfuros, con proporciones variables pero claramente inferiores de pirita y calcopirita y cantidades accesorias de rutilo, pirrotita, bismuto nativo, galena, bismutinita, sulfosales de $\mathrm{Bi}-\mathrm{Pb}-\mathrm{Ag}$ y argentita. Los productos de alteración más frecuentes son la escorodita, que reemplaza a la arsenopirita, la covelita y los óxidos de Fe. A pesar de que los informes de la JCYL-TAGSA (1987) e informes previos documentan la existencia de wolframita en estas venas, durante el desarrollo de este trabajo no se ha hallado ningún cristal en vena o escombrera que lo confirme.
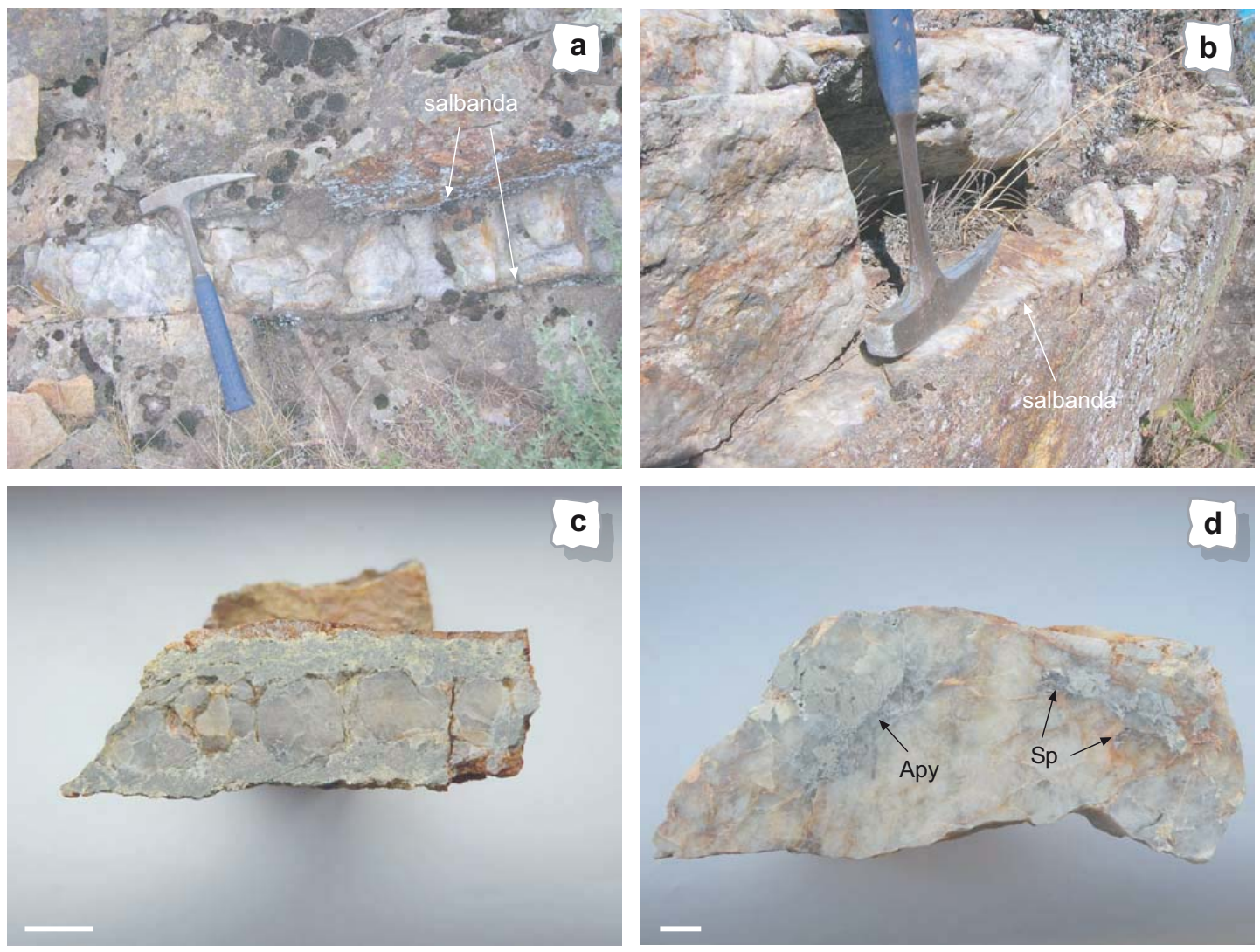

Lám. 3.16. Detalles de algunas de las venas de cuarzo mineralizadas que encajan en el GE de la UE del batolito de Jálama: a) aspecto del afloramiento de las venas de cuarzo mineralizadas con salbanda moscovitizada, dirección $\mathrm{N} 180^{\circ} \mathrm{E}$ y buzamiento subvertical en la mina Horia; b) vena de cuarzo de dirección $\mathrm{N} 180^{\circ} \mathrm{E}$ con salbanda moscovitizada en una zanja de exploración abandonada de la mina Horia; c y d) detalle de la distribución de la mineralización en las venas de cuarzo. Obsérvese los agregados cristalinos de la mena en las salbandas y en el interior de las venas de cuarzo. Escala gráfica en c y d) $1 \mathrm{~cm}$.

\section{Venas de cuarzo encajadas en el LG y las AB}

Las venas de cuarzo mineralizadas encajadas en estas facies de borde son especialmente abundantes en las minas Salmantina, Carrasquera, Profunda, Teso de la Matanza, Bon y Jálama Alto (Fig. 3.25). A diferencia de las venas encajadas en el GE, la mineralización principal aquí se encuentra en los haces de direcciones predominantes $\mathrm{N} 70^{\circ} \mathrm{E}$ a $\mathrm{N} 110^{\circ} \mathrm{E}$ y buzamientos subverticales, que coinciden con las direcciones principales de las labores mineras (Fig. 


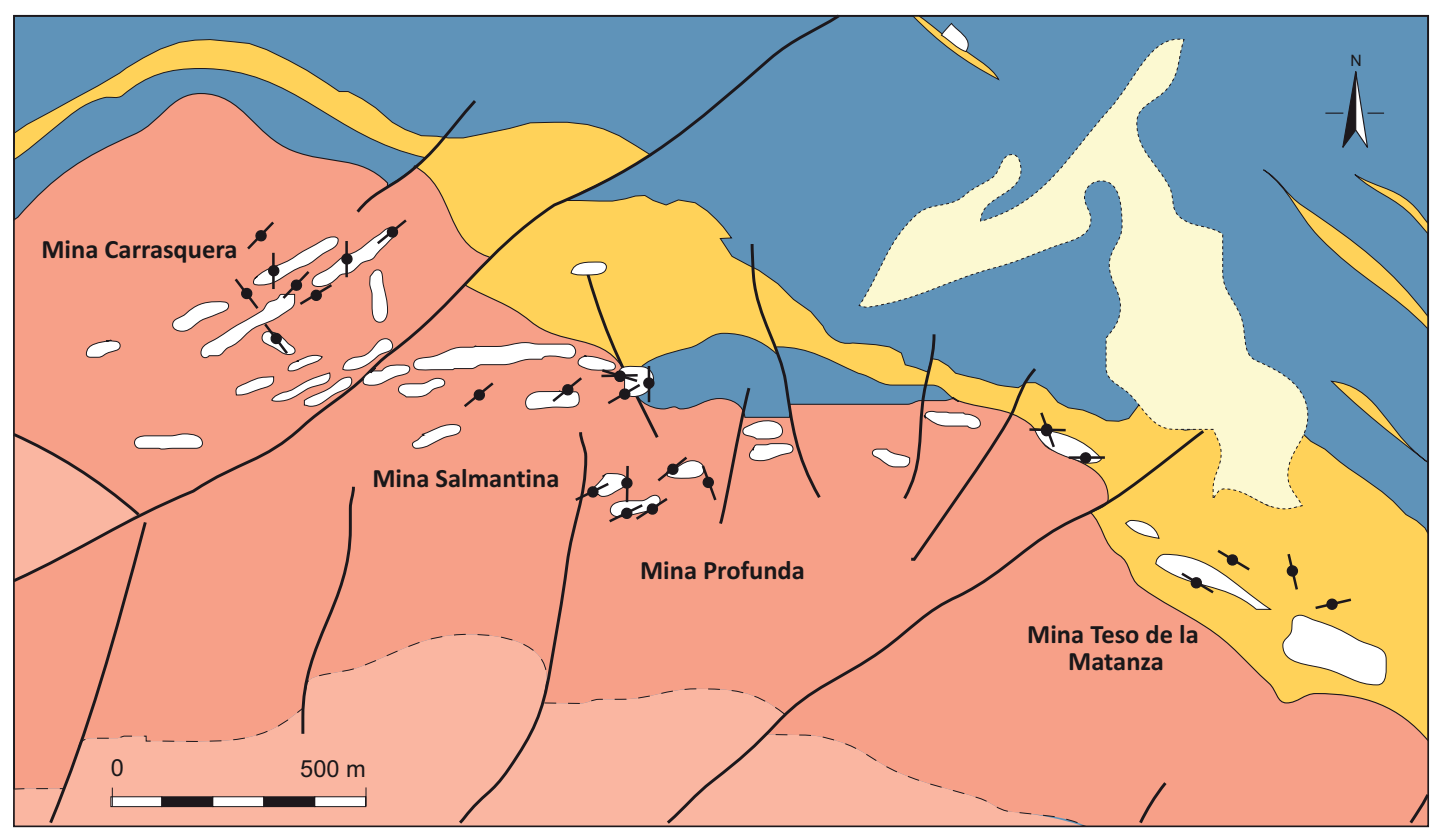

\begin{tabular}{|c|c|c|}
\hline & Cobertera sedimentaria & \multirow{4}{*}{$\begin{array}{l}\text { Unidad } \\
\text { Externa }\end{array}$} \\
\hline & Aplitas de borde (AB) & \\
\hline & Leucogranito con turmalina (LG) & \\
\hline & Granito equigranular (GE) & \\
\hline & Metasedimentos del CEG & \\
\hline a & Venas de cuarzo mineralizadas & \\
\hline 80 & Labores mineras & \\
\hline 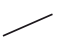 & Fracturas & \\
\hline$\sim$ & Contacto intrusivo & \\
\hline 八 & Contacto gradual & \\
\hline
\end{tabular}

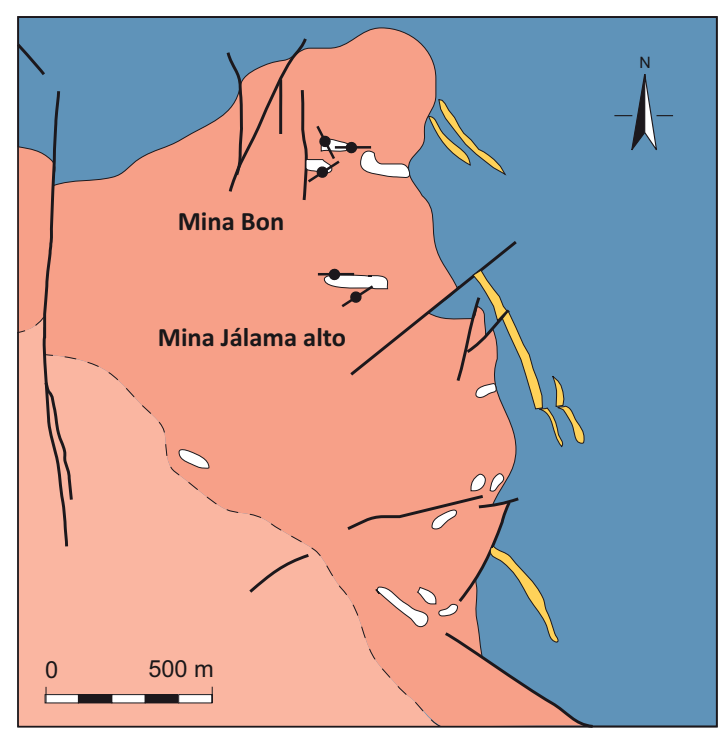

Fig. 3.25. Esquema geológico del sector de la UE del batolito de Jálama con la situación de las minas Salmantina, Carrasquera, Profunda, Teso de la Matanza, Bon y Jálama Alto. Obsérvese las abundantes labores mineras realizadas en ellas y las direcciones de los filones de $\mathrm{S} n \pm \mathrm{W}$ que fueron explotados.

3.25), mientras que las $\mathrm{N} 40^{\circ} \mathrm{E}$ y $\mathrm{N} 60^{\circ} \mathrm{E}$, también con buzamientos subverticales, son menos frecuentes. Sus potencias varían de decímetros a centímetros y muestran una morfología mayoritariamente lenticular (Lám. 3.17a), a veces dispuestas en echelon (Lám. 3.17b), lo que indicaría que se forman como consecuencia de movimientos o fracturas extensionales (Bons, 2000). Menos importantes son las venas que se organizan en haces de direcciones que varían entre $\mathrm{N} 10^{\circ} \mathrm{O}$ y $\mathrm{N} 20^{\circ} \mathrm{E}$ con buzamientos subverticales. Estos presentan gran continuidad lateral con morfologías predominantemente tabulares y lenticulares y potencias máximas de $1,5 \mathrm{~m}$, si bien habitualmente oscilan entre los 30 y los $50 \mathrm{~cm}$. Las continuas variaciones laterales de dirección de las venas generan estructuras de tipo stockwork en algunas zonas del distrito (Lám. $3.17 \mathrm{~b}, \mathrm{c}$ ) en las que las venas no suelen superar los $10 \mathrm{~cm}$. Además, las 

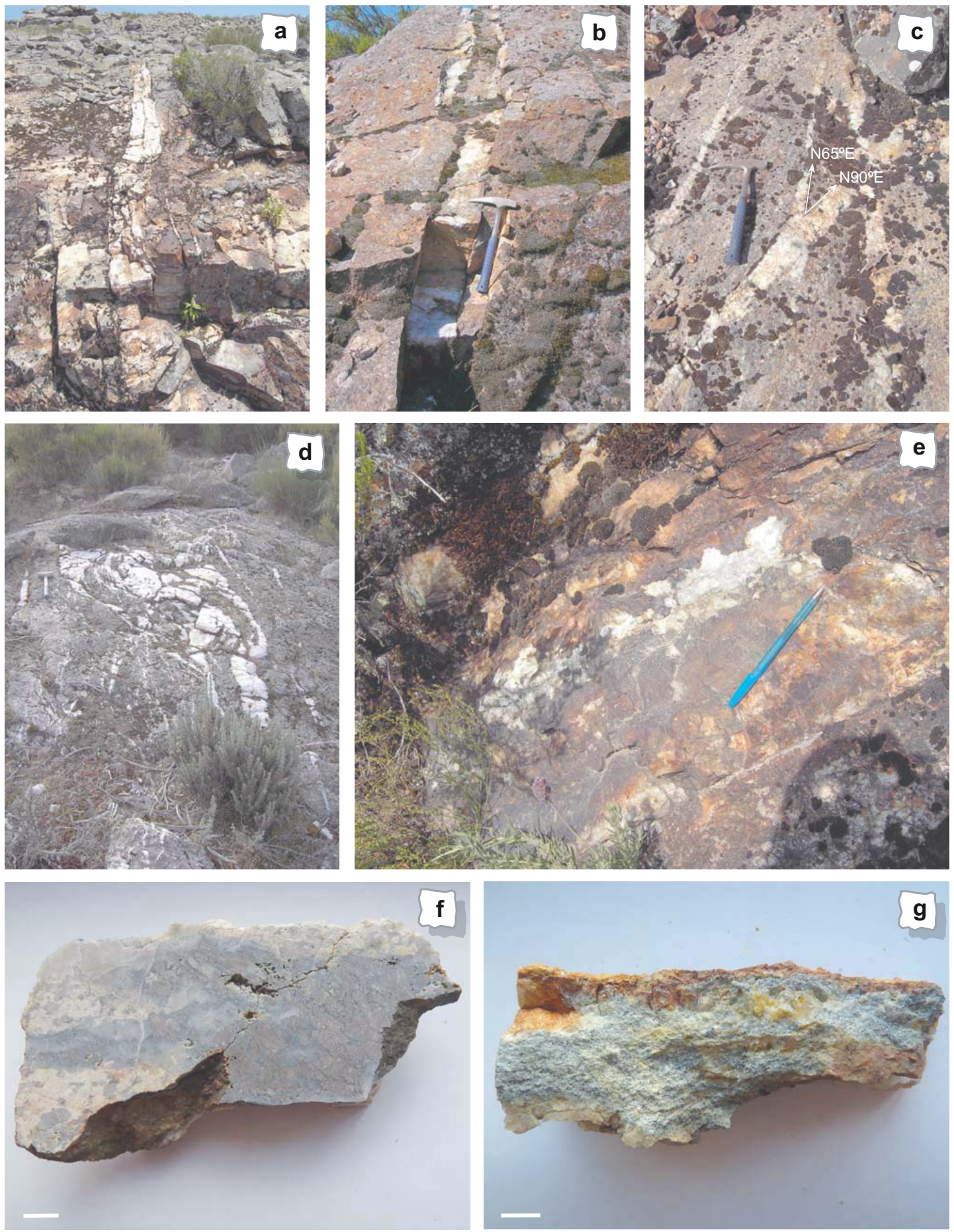

Lám. 3.17. Detalles de los afloramientos de algunas de las venas de cuarzo mineralizadas encajadas en el LG y las AB con turmalina de la UE del batolito de Jálama: a) afloramiento de un potente filón de cuarzo de dirección $\mathrm{N} 170^{\circ} \mathrm{E}$ en la mina Carrasquera; b) venas de cuarzo con dirección N50 ${ }^{\circ} \mathrm{E}$ y estructura en echelon en una de las zanjas de exploración de la mina Salmantina; c) cruce de venas de direcciones $\mathrm{N} 90^{\circ} \mathrm{E}$ y $\mathrm{N} 65^{\circ} \mathrm{E}$ en la mina Salmantina; d) haz de venas amalgamadas y entrecruzadas con dirección general $\mathrm{N} 60^{\circ} \mathrm{E}$ en el entorno de la mina Profunda; e) detalle de la mineralización en una potente vena de cuarzo de dirección $\mathrm{N} 150^{\circ} \mathrm{E}$ en la mina Carrasquera; f) ídem, en muestra de mano, de una vena de cuarzo mineralizada de la mina Salmantina; g) vena de cuarzo con arsenopirita parcialmente alterada a escorodita. Escala gráfica en f y g: $1 \mathrm{~cm}$. 
paredes de los filones se encuentran frecuentemente cizalladas, probablemente debido a movimientos tardíos que provocan el rejuego de las fracturas previas. El grado de relleno de todas estas fracturas es muy variable, siendo el cuarzo el mineral principal de la ganga junto con la moscovita subordinada, además de cantidades accesorias de clorita y todo un cortejo de fosfatos de Ca y Fe.

La mineralización en las venas de los haces principales se localiza tanto en las zonas interiores como hacia las paredes de los filones de cuarzo (Lám. 3.17e,f,g). Los minerales principales de la mena son la casiterita y la wolframita, aunque esta última solo se encuentra en las venas de dirección $\mathrm{N} 70^{\circ} \mathrm{E}-\mathrm{N} 110^{\circ} \mathrm{E}$. Acompañando a estos destaca la presencia abundante de arsenopirita y esfalerita junto con cantidades variables de pirita, pirrotita, calcopirita, rutilo, ixiolita, ferrokesterita, galena, matildita, bismuto nativo, bismutinita y sulfosales de $\mathrm{Bi}-\mathrm{Pb}-\mathrm{Ag}$, además de argentita y molibdenita de manera muy local. Moro (2000) documenta, además, la existencia de granos de Au nativo incluidos en la arsenopirita. De nuevo, la escoroditización y la oxidación de los sulfuros son las alteraciones supergénicas más frecuentes (Lám. 3.17g).

\section{Venas de cuarzo en el CEG}

Son varios los indicios documentados por la JCyL-TAGSA (1987) en los que se describe la existencia de venas de cuarzo mineralizadas encajadas en los materiales metamórficos del CEG en el contacto de la margen $\mathrm{N}$ del batolito de Jálama. Según estos informes los filones de cuarzo, aunque escasos, presentan direcciones entre $\mathrm{N} 110^{\circ} \mathrm{E}$ y $\mathrm{N} 140^{\circ} \mathrm{E}$ con buzamientos subverticales y potencias centimétricas. Son aparentemente estériles o presentan una escasa mineralización de wolframita, además de sulfuros como la arsenopirita y la pirita. Estos filones, en ocasiones, cortan a diques cuarzo-pegmatíticos con abundante feldespato potásico y mineralización de casiterita. Sin embargo, la intensa repoblación forestal llevada a cabo en estos sectores ha llevado a la destrucción completa de todas las labores mineras, por lo que ha sido imposible realizar el estudio correspondiente.

\subsubsection{Petrografía y química mineral}

\section{Cuarzo}

El cuarzo de las venas mineralizadas presenta globalmente una textura que sugiere un crecimiento sintaxial, frecuentemente simétrico, en el que el crecimiento de los cristales tiene lugar a partir de las paredes de las venas hacia el interior (Durney y Ramsay, 1973). Estas características texturales indican que el relleno de la vena tuvo lugar mediante el mecanismo de crack and seal (Ramsay, 1980), de manera que se producen repetidas fracturaciones que seguidamente son selladas por los minerales constituyentes de las venas. En ellas se han identificado cuatro generaciones de cuarzo: un cuarzo I de color blanco lechoso a gris y aspecto masivo en muestra de mano, que microscópicamente está formado por cristales anhedrales de tamaño centimétrico con abundantes inclusiones fluidas y deformados dúctilmente, lo que les confiere una marcada extinción ondulante y texturas en tablero de ajedrez (Lám. 3.18a). Esta deformación provocaría la apertura de grietas de carácter extensional que estarían selladas por la cristalización del cuarzo II, acompañado muy frecuentemente de moscovita de grano fino (Lám. 3.18a,b). Este cuarzo II se presenta en cristales sub- a euhedrales de tamaño 

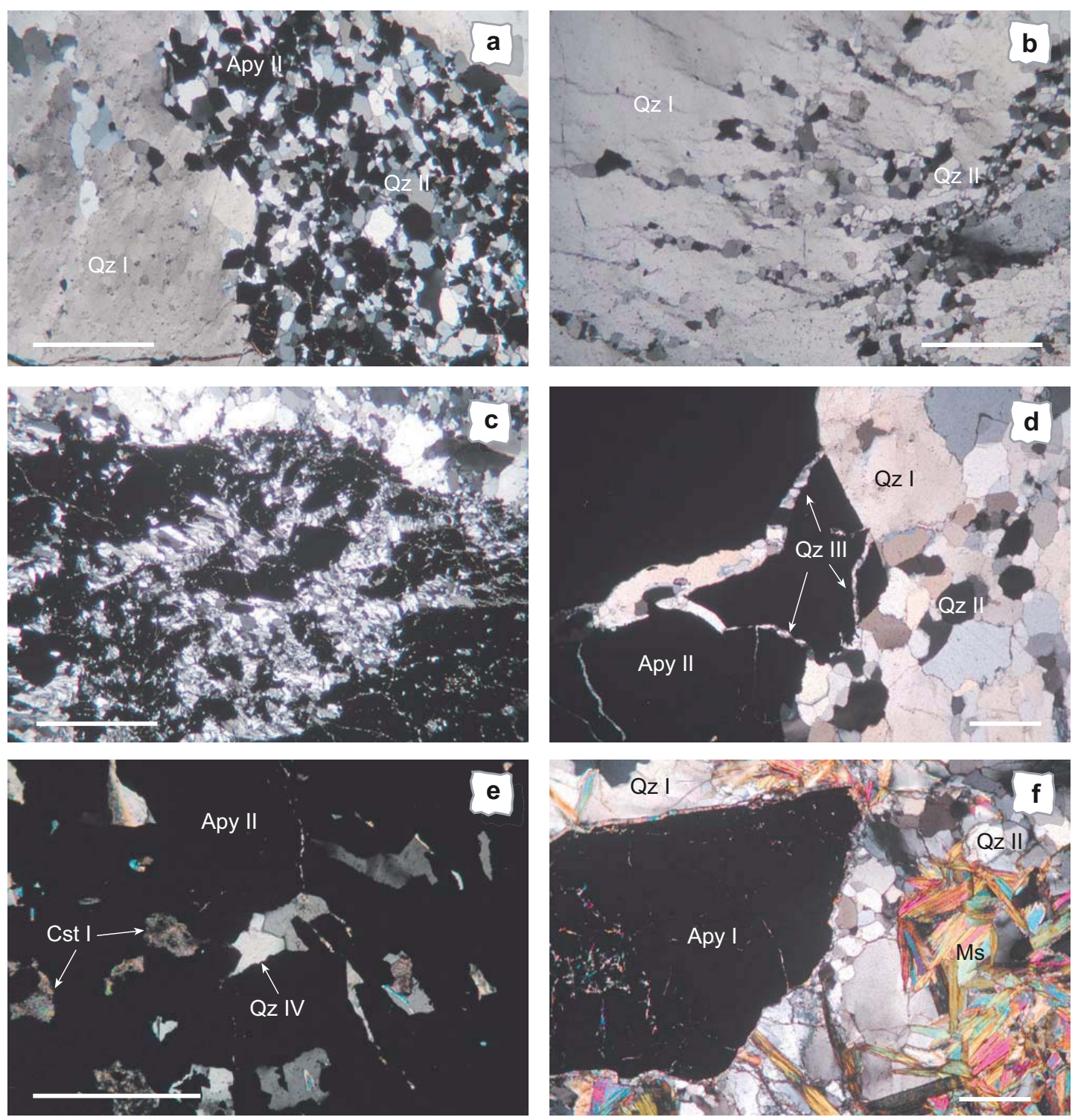

Lám. 3.18. Microfotografías de los aspectos texturales de los diferentes tipos de cuarzo diferenciados en las venas mineralizadas, NC: a) textura en tablero de ajedrez del cuarzo I. Obsérvese también el crecimiento del cuarzo II y de la arsenopirita II debido a la deformación extensional; b) detalle de las aperturas extensionales típicas en el cuarzo I rellenas, a su vez, por cuarzo II; c) agregados cristalinos de cuarzo II y arsenopirita con signos de deformación dúctil; d) cuarzo III con textura granoblástica y en peine rellenando grietas en la arsenopirita I; e) cuarzo IV rellenando huecos en los agregados de cristales de arsenopirita II; f) agregados de moscovita en la salbanda y rellenando grietas en la arsenopirita I. Escala gráfica: a, b, c y d) $1 \mathrm{~mm}$; e y f) $500 \mu \mathrm{m}$.

milimétrico y textura granoblástica, frecuentemente con tendencia poligonal, o bien en fibras alargadas creciendo sobre las caras de menor presión de los sulfuros, fundamentalmente arsenopirita (Lám. 3.18c). A veces presenta también una ligera extinción ondulante y menos inclusiones fluidas que el cuarzo I. El cuarzo III es menos abundante y se presenta principalmente en cristales de hábito fibroso con texturas en peine y tamaño micrométrico, aunque a veces también presenta una textura granoblástica (Lám. 3.18d). Se encuentra rellenando fracturas en minerales previos, con una débil extinción ondulante y sin inclusiones 
fluidas. Y por último, ocasionalmente se identifica un cuarzo IV que se presenta en cristales sub- a euhedrales y de tamaño micrométrico rellenando las cavidades o los huecos tardíos (Lám. 3.18e).

\section{Moscovita}

La moscovita en las salbandas de las venas es el mineral principal y se encuentra en cristales laminares de hasta $5 \mathrm{~mm}$ de tamaño que se disponen mayoritariamente perpendiculares a las paredes de las venas con signos evidentes de deformación, como una fuerte extinción ondulante y kinking (Lám. 3.18f). En el interior de las venas es más accesoria y se presenta en cristales de tamaño de grano fino a muy fino asociados con el cuarzo II y III y con la mineralización metálica.

Químicamente presenta contenidos de hasta 0,43 apfu de Fe y hasta 0,45 apfu de Mg, con una relación $\mathrm{Fe} /(\mathrm{Fe}+\mathrm{Mg})$ que varía entre 0,26 y 0,67. Destacan los contenidos en Li que oscilan entre 850 y 2.171 ppm. Sin embargo, dados los altos contenidos en Mg de esta mica, todas ellas se proyectan en el campo de la moscovita en transición al de la fengita, aunque dominando los valores positivos del eje de abscisas Mg-Li en el diagrama de clasificación de la figura 3.26a. La influencia del vector de sustitución de tipo fengita se intuye también en los diferentes diagramas de sustitución de la figura 3.26, aunque dado el bajo número de análisis de los que se dispone no es posible afirmar esta hipótesis. Se observan, además, contenidos en Sn de hasta 956 ppm, en W hasta 715 ppm y en Rb hasta 2.675 ppm. Los contenidos en F superan el 1,5\% en peso (Anexo III).

\section{Clorita}

La clorita está frecuentemente asociada a fracturas tardías y se presenta bien en agregados microcristalinos similares a la mica blanca, o bien en agregados esferulíticos o fibrosoradiados de color verde, ocasionalmente junto con apatito. Todas ellas se clasifican como penninita en las venas del GE y ripidolita en las del LG y las AB con turmalina según Hey (1954) (Fig. 3.27a) y como chamosita según Bailey (1980), mientras que según Zane y Weiss (1998) la clorita que se presenta en las venas de cuarzo del GE es de tipo II o clorita-Al y la de las venas de cuarzo del LG y las AB son de tipo I o clorita-Fe (Fig. 3.27b). Si bien la cantidad de datos de la que se dispone no es determinante a la hora de afirmar una tendencia de evolución, sí parece que esta es totalmente opuesta a la que se ha descrito en las facies graníticas y pegmatíticas previas, de modo que estas cloritas muestran un descenso del contenido en Si y Al hacia las venas del LG y un incremento considerable en la cantidad de Fe, que llega a rellenar casi completamente las posiciones octaédricas dejando escasas vacancias. Es por ello que la relación $\mathrm{Fe} /(\mathrm{Fe}+\mathrm{Mg}$ ) es muy elevada, pasando de 0,83 en las venas del GE hasta 0,99 en el LG. La capa interlaminar se encuentra prácticamente vacía. En cualquier caso, la tendencia al incremento en la relación $\mathrm{Fe} /(\mathrm{Fe}+\mathrm{Mg})$ sí se mantiene constante desde las venas del GE hacia las del LG. 

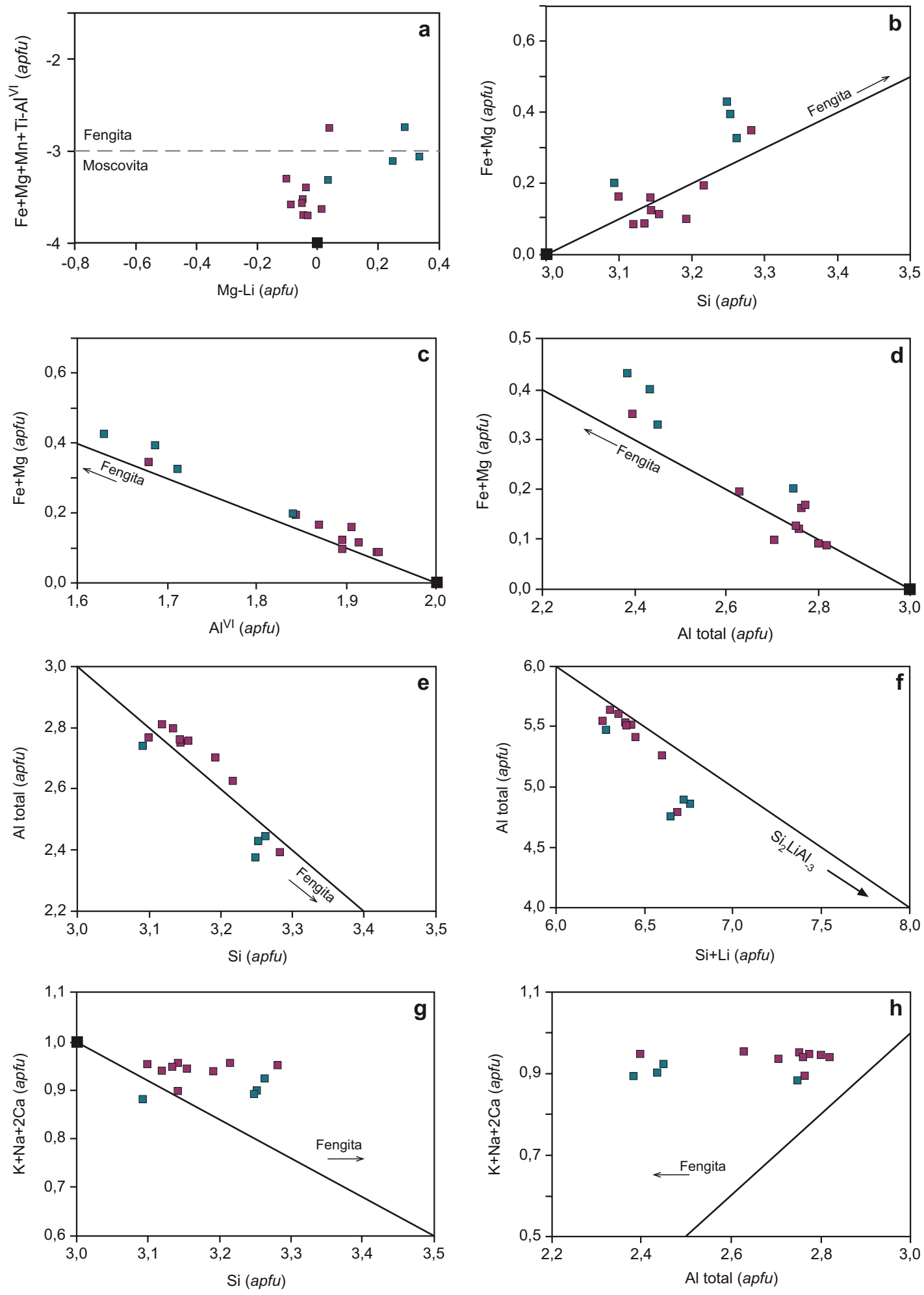

- Venas en el GE $\quad$ Venas en el LG y las AB con turmalina $\quad$ Moscovita ideal

Fig. 3.26. a) Diagrama de clasificación de Tischendorf et al. (2004) donde se ha representado la moscovita analizada en las venas de cuarzo intragraníticas. Diagramas de variación química: b) Si vs. Fe+Mg; c) $\mathrm{Al}^{\mathrm{vI}}$ vs. $\mathrm{Fe}+\mathrm{Mg}$; d) Al total vs. $\mathrm{Fe}+\mathrm{Mg}$; e) Si vs. Al total; f) Si+Li vs. Al total; g) Si vs. K+Na+2Ca; y h) Al total vs. $\mathrm{K}+\mathrm{Na}+2 \mathrm{Ca}$. 


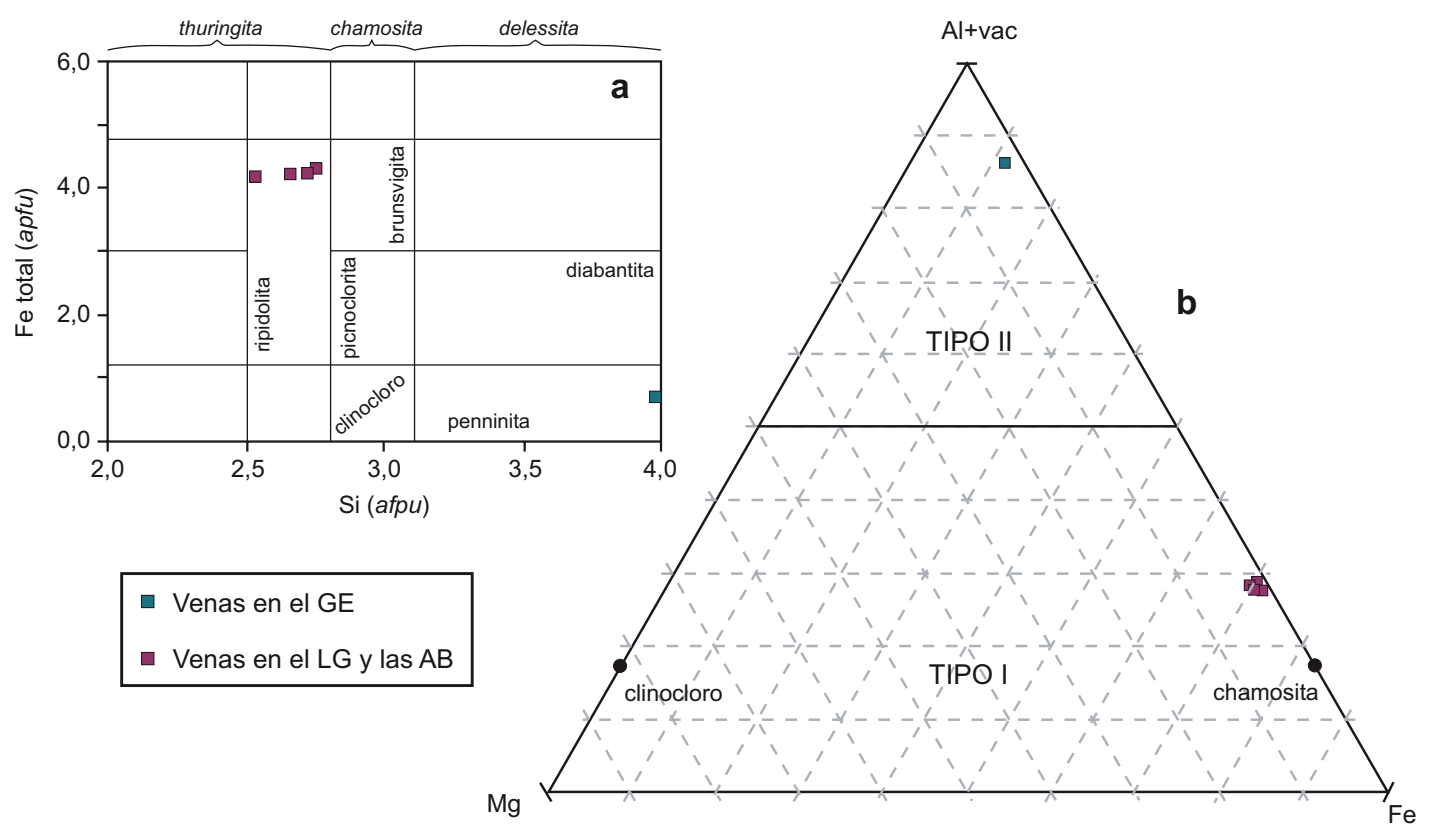

Fig. 3.27. Diagramas de clasificación de la clorita de las venas de cuarzo intragraníticas: a) en función de los contenidos en $\mathrm{Fe}_{\text {total }}$ y Si (en apfu) según Hey (1954); y b) en función de los contenidos en $\mathrm{Fe}_{\text {total }}$, Mg y Al+vacancias (en apfu) según Zane y Weiss (1998).

\section{Asociaciones fosfatadas}

Los minerales fosfatados solo se han identificado en las venas de cuarzo que encajan en el LG y las $A B$ con turmalina de la mina Salmantina donde se han definido, en función de sus características mineralógicas y texturales, dos asociaciones (Tabla 3.3) (Moro y Llorens, 2008; Llorens y Moro, en prensa). En ambas la triplita es el fosfato primario y más común. Las relaciones texturales con la casiterita y la wolframita sugieren que la triplita es contemporánea o ligeramente posterior a ambas, mientras que las fracturas rellenas por cuarzo III parecen indicar que este mineral estaría ligado al final de la cristalización de cuarzo I o al inicio de la del cuarzo II.

\section{Asociación VII}

La triplita de esta asociación fosfatada se encuentra en agregados masivos e irregulares de tamaño centimétrico y color rosado en muestra de mano (Lám. 3.19a,c). Químicamente está enriquecida en $\mathrm{Mn}$ (hasta 1,37 apfu) frente al Fe, considerado todo en forma de $\mathrm{Fe}^{2+}, \mathrm{y}$ al $\mathrm{Mg}$, con solo trazas de $\mathrm{Ca}$, por lo que la relación $\mathrm{Fe} /(\mathrm{Fe}+\mathrm{Mn})$ es de 0,18-0,19. El F es el anión dominante (hasta $0,55 \mathrm{apfu}$ ) junto con el ión $\mathrm{OH}^{-}$calculado por estequiometría. La triplita se encuentra parcialmente alterada a bermanita (Fig. 3.28) que se presenta en agregados cristalinos de tamaño milimétrico y color rojo, apenas perceptibles en muestra de mano (Lám. 3.19c). En su composición química predomina el Mn tanto en forma divalente como trivalente, solo parcialmente sustituido por $\mathrm{Fe}^{2+}$ hasta 0,44 apfu y trazas de $\mathrm{Mg}$ y Ca en las posiciones divalentes, mientras que en las trivalentes se observan abundantes vacancias. La fosfosiderita es el producto de alteración más común de la triplita. Forma esférulos de tamaño milimétrico y color rosado a lila tanto en muestra de mano como al microscopio, que también reemplazan parcialmente a la bermanita y la rockbridgeita (Lám. 3.19c,d) por lo que es un 
TABLA 3.3. FOSFATOS DE LAS ASOCIACIONES VII Y VIII

\begin{tabular}{|c|c|c|c|}
\hline \multirow{2}{*}{ Fosfato } & \multirow{2}{*}{ Fórmula general } & \multicolumn{2}{|c|}{ Asociación } \\
\hline & & VII & VIII \\
\hline Triplita-Zwieselita & $\left(\mathrm{Mn}^{2+}, \mathrm{Fe}^{2+} \mathrm{Mg}, \mathrm{Ca}\right)_{2}\left(\mathrm{PO}_{4}\right)(\mathrm{F}, \mathrm{OH})$ & $* * *$ & $* * *$ \\
\hline Goyazita & $\mathrm{SrAl}_{3}\left(\mathrm{PO}_{4}\right)\left(\mathrm{PO}_{3} \mathrm{OH}\right)(\mathrm{OH})_{6}$ & ** & \\
\hline Rockbridgeita & $\left(\mathrm{Fe}^{2+}, \mathrm{Mn}^{2+}\right) \mathrm{Fe}^{3+}{ }_{4}\left(\mathrm{PO}_{4}\right)_{3}(\mathrm{OH})_{5}$ & ** & \\
\hline Isokita & $\mathrm{CaMg}\left(\mathrm{PO}_{4}\right) \mathrm{F}$ & & ** \\
\hline Beraunita & $\mathrm{Fe}^{2+} \mathrm{Fe}^{3+}{ }_{5}\left(\mathrm{PO}_{4}\right)_{4}(\mathrm{OH})_{5} \cdot 6 \mathrm{H}_{2} \mathrm{O}$ & * & \\
\hline Bermanita & $\mathrm{Mn}^{2+} \mathrm{Mn}_{2}^{3+}\left(\mathrm{PO}_{4}\right)_{2}(\mathrm{OH})_{2} \cdot 4 \mathrm{H}_{2} \mathrm{O}$ & * & \\
\hline Fosfosiderita & $\mathrm{Fe}^{3+} \mathrm{PO}_{4} \cdot 2 \mathrm{H}_{2} \mathrm{O}$ & ** & \\
\hline Escorodita & $\mathrm{Fe}^{3+}\left(\mathrm{AsO}_{4}, \mathrm{PO}_{4}\right) \cdot 2 \mathrm{H}_{2} \mathrm{O}$ & ** & \\
\hline Apatito & $\mathrm{Ca}_{5}\left(\mathrm{PO}_{4}\right)_{3}(\mathrm{OH}, \mathrm{F}, \mathrm{Cl})$ & *** & *** \\
\hline
\end{tabular}

Abundancia en cada asociación: ${ }^{* * *}=$ abundante; ${ }^{* *}=$ escaso; ${ }^{*}=$ muy escaso

fosfato tardío en la secuencia paragenética (Figs. 3.28 y 3.43). Su composición química es muy próxima a la fórmula ideal con hasta 1 apfu de $\mathrm{Fe}^{3+}$, que muestra sustituciones limitadas por Al, $\mathrm{Mn}$ y Ca. Tanto en la bermanita como en la fosfosiderita los contenidos en $\mathrm{P}$ son relativamente elevados respecto a la fórmula ideal y puede estar parcialmente sustituido por As, si bien las líneas de difracción de rayos $\mathrm{X}$ y las características físicas de ambos corrobora la presencia de estos dos fosfatos.

La beraunita se encuentra en fibras de color verde pálido, rosadas o azuladas intercrecidas con la rockbridgeita y solo visibles al microscopio petrográfico. A pesar de que su composición química no presenta $\mathrm{Fe}^{2+}$ en las posiciones divalentes, estos son suplidos con mayores contenidos en $\mathrm{Mn}^{2+}$. Además, los contenidos en $\mathrm{Fe}^{3+}$ son similares a los de la beraunita que aparece en la asociación del LG con turmalina (Anexo III), por lo que podría tratarse de este fosfato. La rockbridgeita se encuentra en agregados masivos de color oscuro y tamaño centimétrico en muestra de mano que tapiza amplias zonas de las venas de cuarzo (Lám. 3.19b) englobando, en ocasiones, a la beraunita. Bajo el microscopio se presenta en esférulos o agregados radiales y en abanico de color verde con pleocroismo a rojo (Lám. 3.19e), a veces con textura crustiforme y maclas en cruz, que frecuentemente se encuentran rellenando fracturas en la arsenopirita junto al cuarzo III. Su

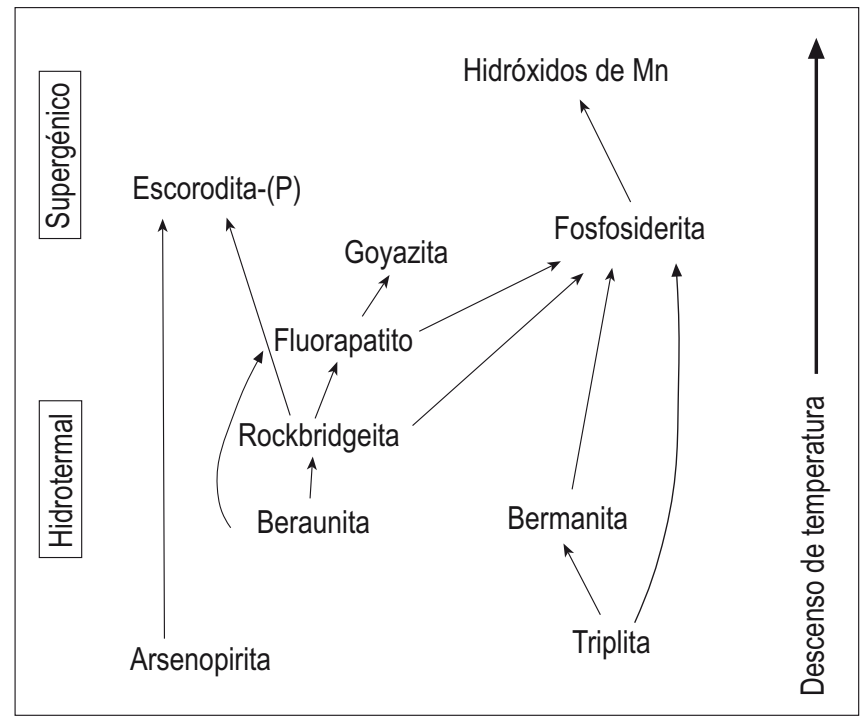

Fig. 3.28. Esquema de la secuencia de alteración de la asociación fosfatada VII de las venas de cuarzo encajadas en el LG y las AB con turmalina. 

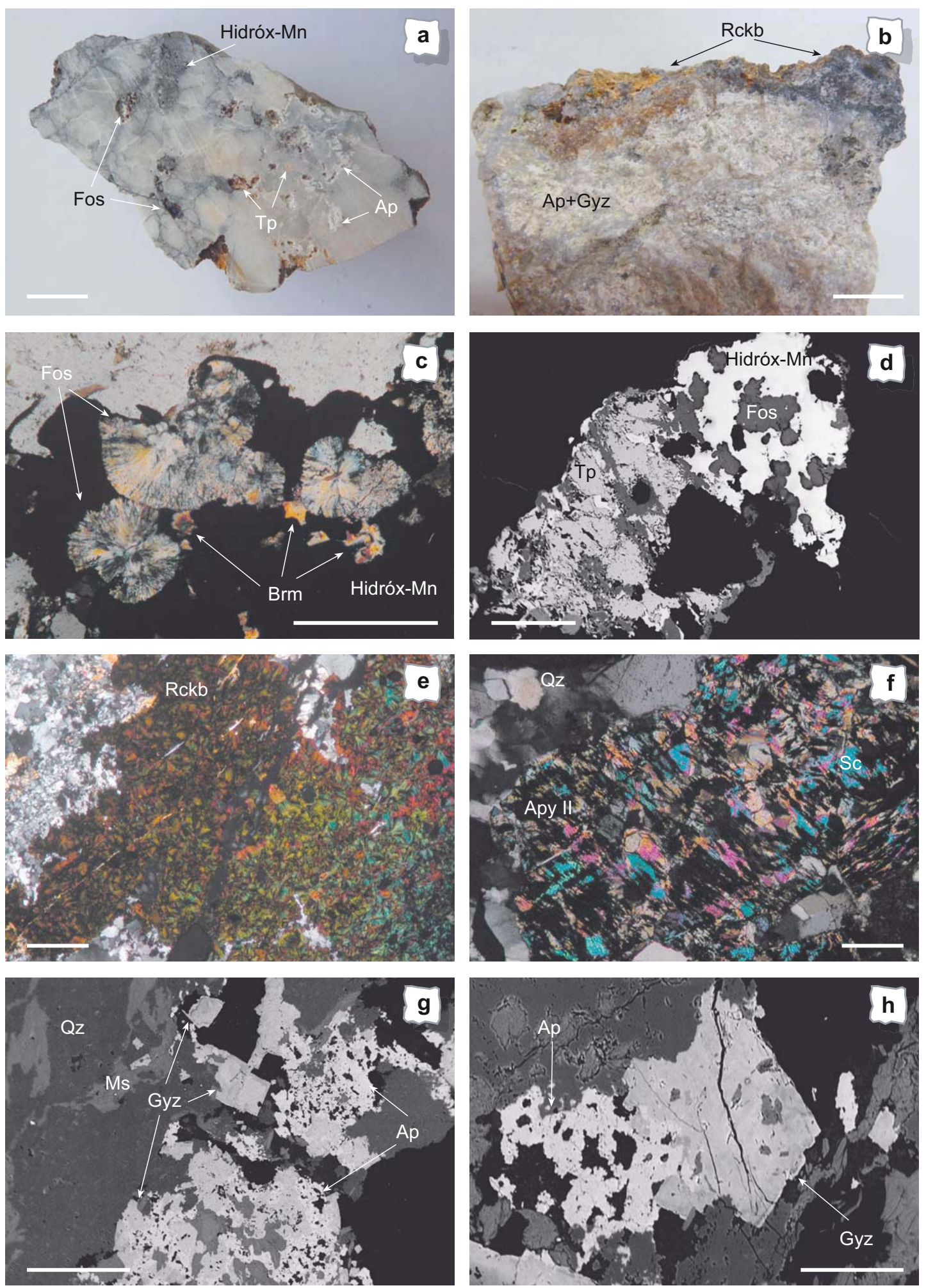

Lám. 3.19. Muestras de mano (a y b), microfotografías electrónicas ( $c, g$ y h) y de microscopio petrográfico ( $d$, e y f) de las venas de cuarzo mineralizadas con los fosfatos de la asociación VI: a) detalle de los restos de triplita parcialmente reemplazados por esferulitos de fosfosiderita de tonos morados e hidróxidos de $\mathrm{Mn}$; b) aspecto pulverulento y oscuro de la rockbridgeita en los bordes de una vena de cuarzo que corta y reemplaza el LG con turmalina, donde cristalizan apatito y goyazita; c) aspecto microscópico de los esferulitos de fosfosiderita y restos de cristales de bermanita, LN; d) triplita parcialmente reemplazada por fosfosiderita. Los hidróxidos de Mn son posteriores y rellenan los huecos tardíos; e) agregados fibroso- 


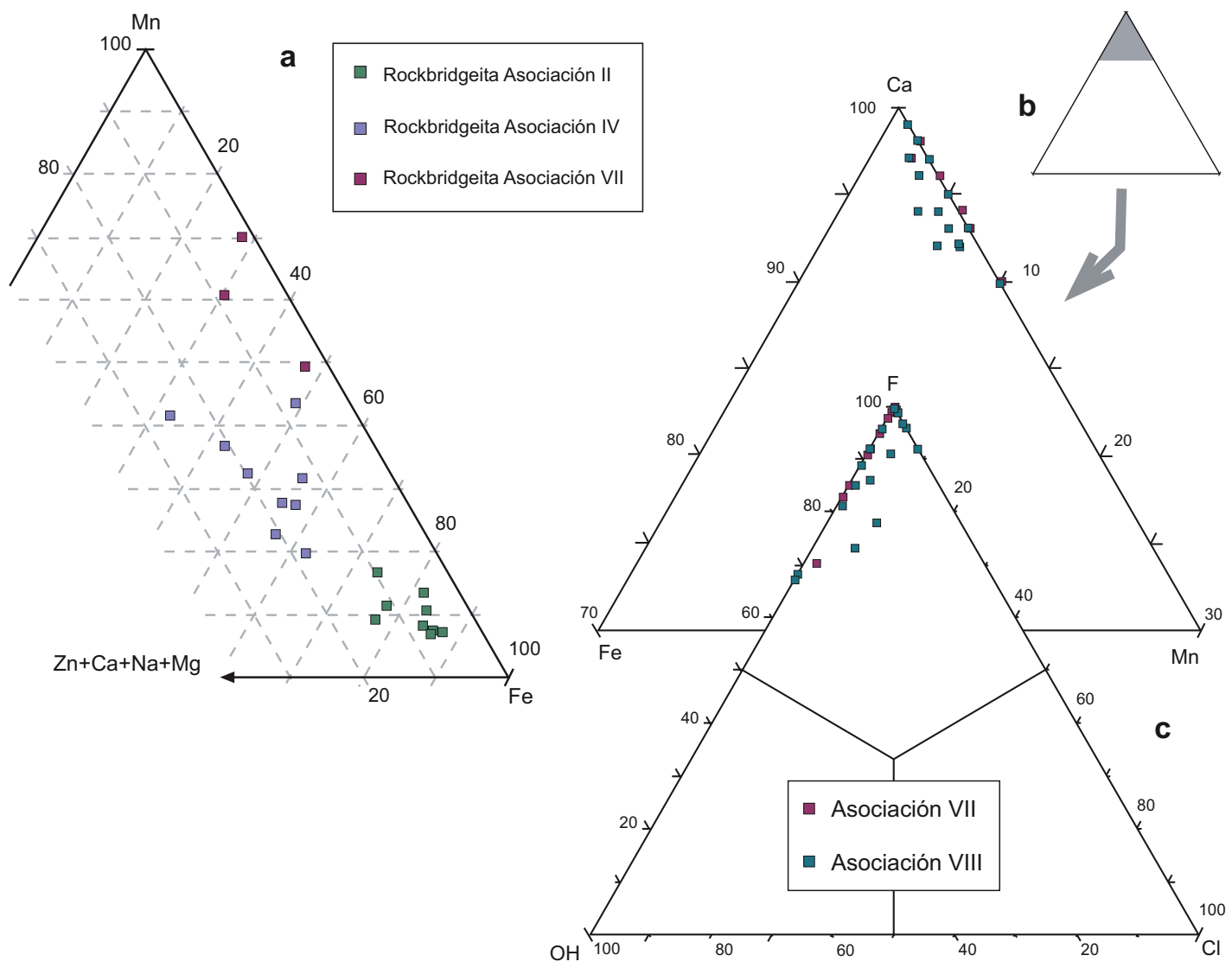

Fig. 3.29. Diagramas triangulares en proporciones atómicas: a) $(\mathrm{Zn}+\mathrm{Ca}+\mathrm{Na}+\mathrm{Mg})-\mathrm{Mn}-\mathrm{Fe}$ de las posiciones catiónicas divalentes en la rockbridgeita de las asociaciones II, IV y VII; b) de los contenidos en Fe, Ca y Mn en las posiciones catiónicas; y c) de los contenidos en $\mathrm{OH}, \mathrm{F}$ y $\mathrm{Cl}$ del apatito en las asociaciones VII y VIII de las venas de cuarzo intragraníticas.

composición química está dominada por el Fe fundamentalmente en forma de $\mathrm{Fe}^{3+}$ (hasta $3,90 \mathrm{apfu}$ ) y menos $\mathrm{Fe}^{2+}$ (hasta 0,54 apfu), aunque presenta mayor sustitución por Mn que la rockbridgeita que se encuentra en las asociaciones del LG y los diques pegmatíticos en él encajados (hasta 0,60 apfu) (Fig. 3.29a). Se encuentra parcialmente reemplazada por una escorodita con hasta $26 \%$ en peso de $\mathrm{P}_{2} \mathrm{O}_{5}$ sustituyendo al As (Lám. 3.19f), por fluorapatito y por fosfosiderita.

El fluorapatito se presenta en agregados cristalinos de tamaño centimétrico y color blanco a verdoso en muestra de mano que engloba a fosfatos como la rockbridgeita y la beraunita y que es reemplazado por fosfosiderita y por una goyazita tardía (Lám. 3.19g,h). Generalmente presenta hasta 0,28 apfu de Mn sustituyendo al Ca, con trazas de Fe (Fig. 3.29b), Na y Sr, consecuencia este último de la contaminación de la goyazita. El F presenta escasa sustitución por $\mathrm{OH}^{-}$(Fig. 3.29c), mientras que el $\mathrm{P}$ de nuevo se ve sustituido por $\mathrm{S}$ hasta 0,20 apfu.

radiados de rockbridgeita, NC; f) cristales euhedrales de escorodita con altos contenidos en $\mathrm{P}$ reemplazando parcialmente a la arsenopirita II, NC; $\mathbf{g}$ $\mathbf{~ h}$ ) cristales an- a euhedrales de goyazita reemplazando al fluorapatito. Nótese la zonación concéntrica de los cristales euhedrales de goyazita. Escala gráfica: a y b) $1 \mathrm{~cm}$; c, d, e, f y g) $500 \mu \mathrm{m}$; h) $100 \mu \mathrm{m}$. 
La goyazita se presenta como un fosfato tardío (Fig. 3.28) ocupando las cavidades de corrosión, formando masas granulares de tamaño centimétrico y color gris blanquecino en muestra de mano. Bajo el microscopio se identifica como agregados cristalinos an- a euhedrales e incoloros con un zonado concéntrico (Lám. 3.19g,h) que responde, químicamente, a variaciones en sus contenidos en $\mathrm{Ca}$ (entre 0,07 y 0,32 apfu) y en $\mathrm{Sr}$ (entre 0,61 y 0,90 apfu). Al igual que en la goyazita de la asociación identificada en el LG y las AB con turmalina (Asociación II), su composición química está dominada por el $\mathrm{Sr}$, con un componente moderado de crandallita (entre 7 y $34 \%$ ) y escaso de gorceixita (hasta $3 \%$ ). El P en este caso está parcialmente sustituido por S (hasta 0,36 apfu), lo que probablemente esté influenciado por la alteración de los sulfuros. Los contenidos en F son superiores a los de la goyazita de la asociación II, llegando a completar hasta 0,57 apfu. Finalmente, lo último en precipitar son hidróxidos de Mn que rellenan los huecos en las venas de cuarzo con formas esferulíticas o botroidales (Lám. 19c,d).

\section{Asociación VIII}

La triplita de la segunda asociación que se encuentra en estas venas de cuarzo muestra un aspecto similar a la anterior, en agregados masivos de color rosado rodeados, en este caso, de una cubierta milimétrica de fluorapatito de color blanco a verdoso en muestra de mano (Lám. 3.20a,b). La composición química de esta triplita está dominada también por Mn (hasta 1.17 apfu) con algo más de Fe y $\mathrm{Mg}$ que en la anterior asociación, por lo que la relación $\mathrm{Fe} /(\mathrm{Fe}+\mathrm{Mn}$ ) es mayor, variando entre 0,30 y 0,43. Esta triplita se altera a fluorapatito con cantidades variables de $\mathrm{Mn}$ (hasta 0,38 apfu), $\mathrm{Na}$ (hasta 0,22 apfu) y Fe (hasta 0,45 apfu) que sustituyen al Ca (Fig. 3.29b,c) y trazas de Sr y Mg (Lám. 3.20b). Finalmente, la isokita se encuentra reemplazando tanto a la triplita como al fluorapatito formando un agregado cristalino de tamaño de grano muy fino no visible en muestra de mano (Lám. 3.20b). Químicamente las posiciones catiónicas se encuentran ocupadas casi totalmente por $\mathrm{Mg}$ y Ca y, además, por trazas de $\mathrm{Fe}, \mathrm{Mn}$ y $\mathrm{Na}$.
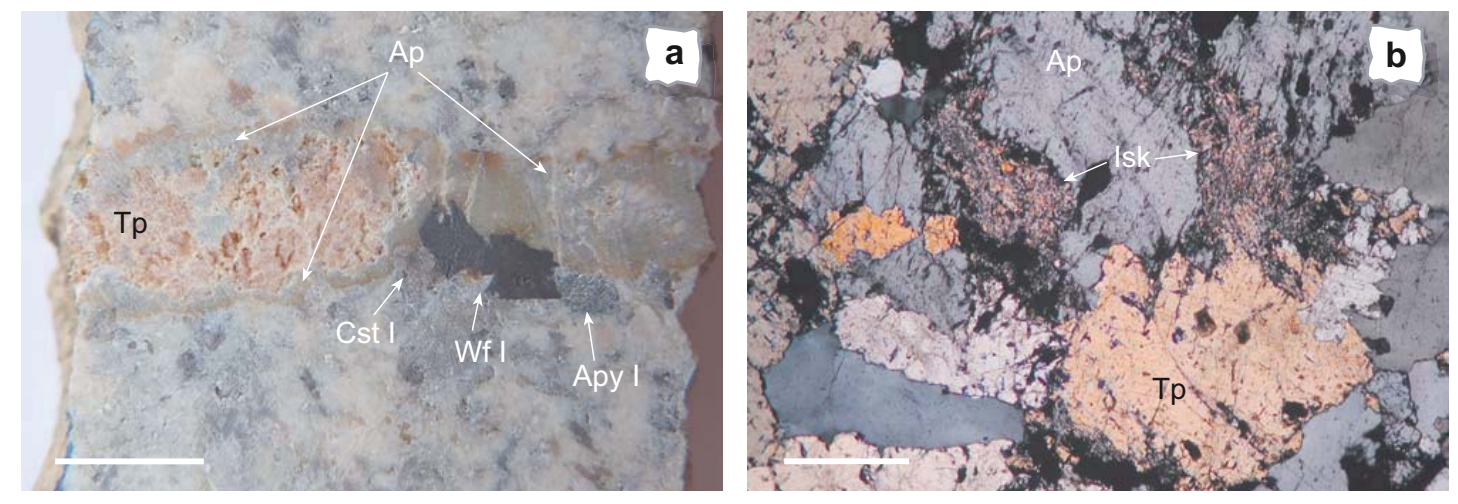

Lám. 3.20. a) Muestra de mano de una vena de cuarzo mineralizada de la mina Salmantina donde se observa la triplita y el fluorapatito de la asociación VII junto con la casiterita I, la wolframita I y arsenopirita I. Escala gráfica: $1 \mathrm{~cm}$; b) microfotografía de la triplita parcialmente sustituida por apatito y ambos por isokita, NC. Escala gráfica: $250 \mu \mathrm{m}$. 


\subsubsection{Mineralización}

\subsubsection{Casiterita, wolframita y óxidos de Ti, Nb y Ta}

\section{Casiterita}

Es el principal mineral de la mena en todas las venas de cuarzo del batolito de Jálama, tanto en el interior de las mismas como, menos frecuentemente, en las salbandas, que aparece en cristales sub- a euhedrales de tamaño micrométrico a centimétrico (hasta $2 \mathrm{~cm}$ de longitud máxima), o bien en agregados cristalinos anhedrales superiores a los 5 cm (Lám. 3.21a). En ambos casos son frecuentes las maclas simples y polisintéticas y menos frecuentes las de pico del estaño. Suelen mostrar, bajo el microscopio, una zonación marcada por la alternancia de bandas cristalinas de color rojo intenso con otras de color claro que, sin embargo, no responde a ningún patrón de zonación químico (Lám. 3.21b). En base a las relaciones paragenéticas se diferencian dos episodios de depósito: la casiterita I, que está asociada con el cuarzo I de la mineralización precoz tanto en el relleno de la vena como en la salbanda (Lám. 3.20a), observándose algunos de estos cristales incluidos en la arsenopirita I, lo que demuestra su carácter precoz en la secuencia paragenética (Fig. 3.43); y la casiterita II, que cristaliza asociada al cuarzo II en el interior de las venas al comienzo de la mineralización principal solapándose, en parte, con la cristalización de la arsenopirita I (Lám. 3.21b,c). En esta son comunes las inclusiones de rutilo de hasta $15 \mu \mathrm{m}$ de tamaño con formas redondeadas.

Químicamente ambas generaciones no muestran diferencias composicionales y se aproximan a la fórmula ideal $\left(\mathrm{SnO}_{2}\right)$, por lo que prácticamente todas las posiciones catiónicas están ocupadas por Sn (0,98-0,99 apfu) con solo contenidos relativamente significativos de Ca (entre 0,50-0,57 \% en peso de $\mathrm{CaO}$ ) y $\mathrm{Ti}$ (hasta $0,73 \%$ en peso de $\mathrm{TiO}_{2}$ ), estos últimos visiblemente superiores a los contenidos en las casiteritas de los diques pegmatíticos. Puede contener trazas de $\mathrm{Fe}, \mathrm{Nb}$ y $\mathrm{W}$, relacionado este último con la existencia de wolframita en las venas. Se observa, además, una correlación positiva entre los contenidos en $\mathrm{Nb}+\mathrm{Ta}$ frente a los de Fe+Mn (Fig. 3.30a).

\section{Wolframita}

La wolframita se encuentra únicamente en las venas de los haces de direcciones $\mathrm{N} 70^{\circ} \mathrm{E}$ a $\mathrm{N} 110^{\circ} \mathrm{E}$ que encajan en el LG y las AB con turmalina, especialmente en las zonas más externas, asociada o no con la casiterita. Se presenta en cristales prismáticos aislados o en agregados cristalinos de tamaño milimétrico a centimétrico que se disponen perpendiculares a las paredes de los filones (Lám. 3.21d). Dos generaciones de wolframita se han identificado en base a criterios texturales y composicionales (Fig. 3.43). La wolframita I, que cristaliza en un primer evento mineralizador, junto con cuarzo I, como único óxido de las venas o asociada a la casiterita I, corresponde mayoritariamente a ferberita aunque en algunas zonas del distrito, como en la mina Teso de la Matanza, esta wolframita primaria está más enriquecida en Mn. La wolframita tardía (wolframita II) cristaliza, junto con el cuarzo II, al inicio del evento hidrotermal responsable del principal depósito de sulfuros y presenta un componente hübnerítico mayoritario (Lám. 3.21e,f). Con frecuencia se observa una disolución parcial de 

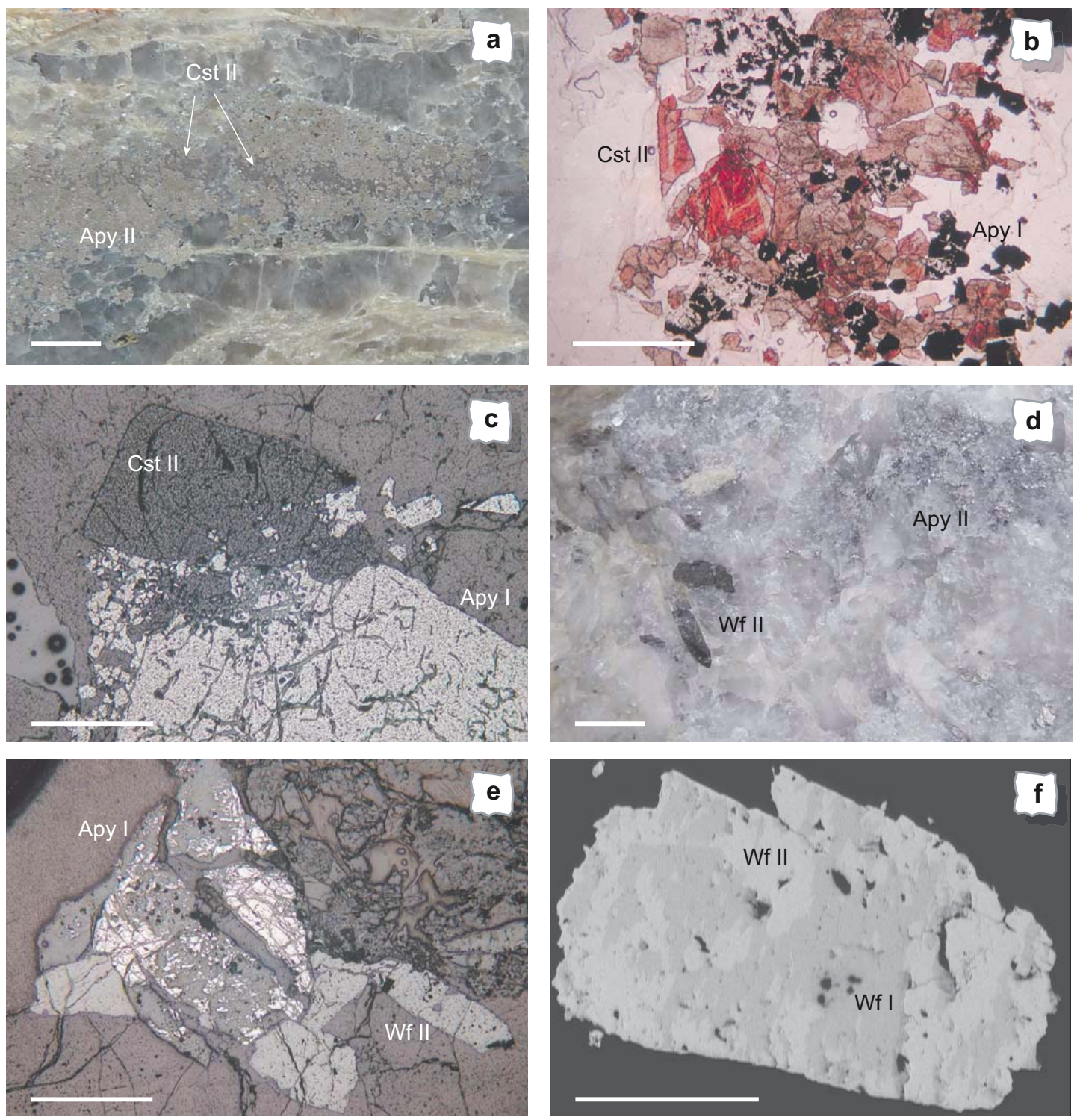

Lám. 3.21. Algunos aspectos de las venas de cuarzo con casiterita y wolframita: a) detalle de los agregados de cristales de casiterita II y arsenopirita II en una vena de cuarzo. Obsérvese la moscovita rellenando las grietas; b) microfotografía de un agregado de cristales zonados de casiterita II junto a la arsenopirita I, LN; c) detalle de la microfotografía anterior en luz reflejada; d) cristales subhedrales de wolframita y agregados cristalinos de arsenopirita en una vena de cuarzo; e) microfotografía de cristales de wolframita II rodeando a una arsenopirita previa parcialmente escoroditizada, luz reflejada; f) microfotografía electrónica en la que se aprecia el parcheado de wolframita II reemplazando a la wolframita I. Escala gráfica: a y d) $0.5 \mathrm{~cm}$; b, c, e y f) $1 \mathrm{~mm}$.

los cristales primarios de ferberita y una precipitación posterior de hübnerita en estas zonas disueltas (Lám. 3.21f).

Químicamente la ferberita responde a la fórmula media $\left(\mathrm{Fe}_{0,61} \mathrm{Mn}_{0,36}\right)_{\Sigma 0,97} \mathrm{WO}_{4^{\prime}}$, donde el $\mathrm{Zr}$ sustituye al W hasta en 0,02 apfu y solo se aprecian trazas de Nb que pueden alcanzar hasta $0,49 \%$ en peso de $\mathrm{Nb}_{2} \mathrm{O}_{5}$. En una de las venas de cuarzo de la mina de Teso de la Matanza la composición es de tipo hübnerita, a pesar de tratarse del mismo evento mineralizador, con una fórmula media $\left(\mathrm{Fe}_{0,41} \mathrm{Mn}_{0,58}\right)_{\Sigma 1} \mathrm{WO}_{4}$. En estas composiciones más ricas en $\mathrm{Mn}$, el $\mathrm{W}$ 

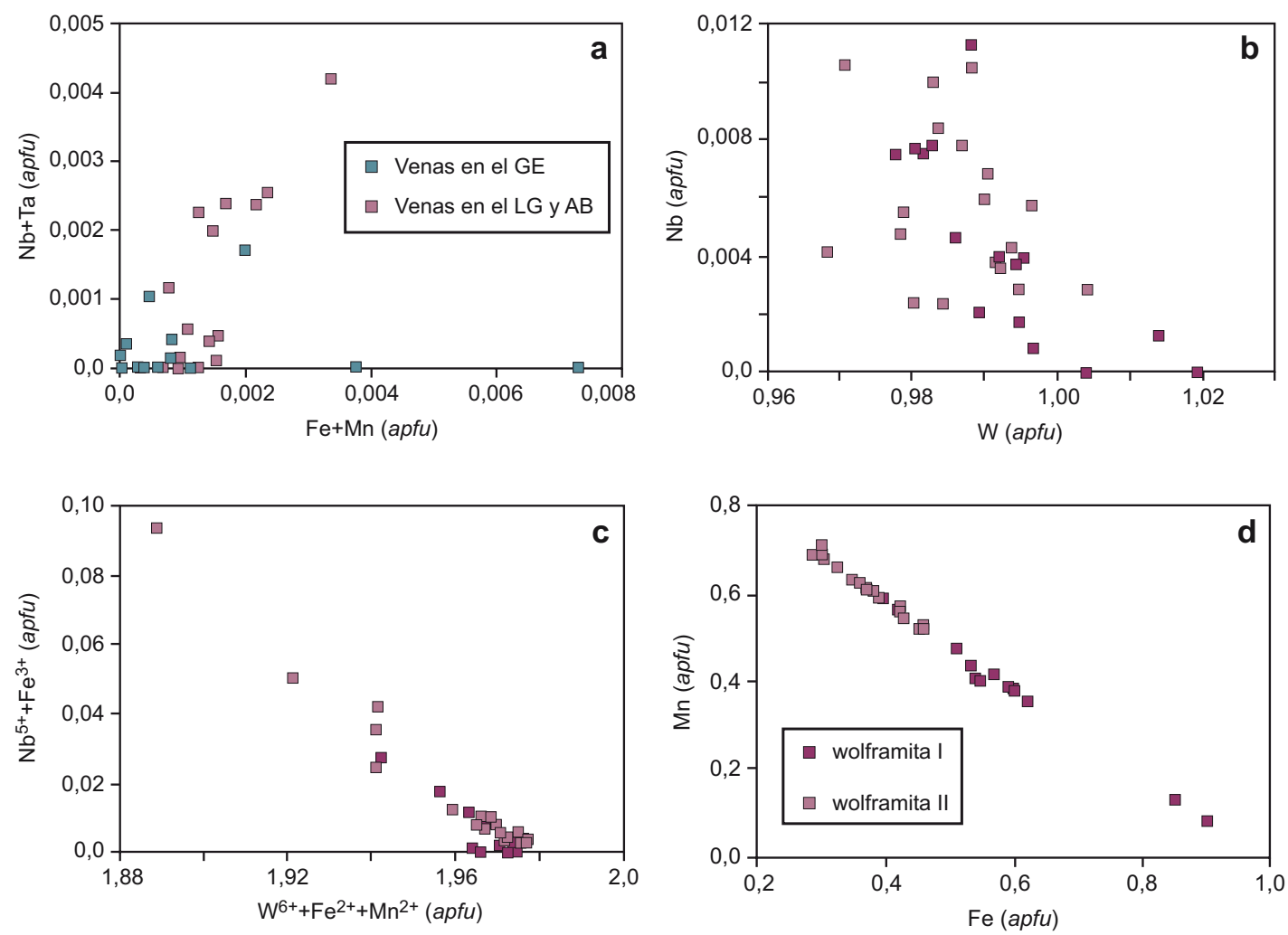

Fig. 3.30. a) Diagrama de variación $\mathrm{Nb}+\mathrm{Ta}$ vs. Fe+Mn en la casiterita de las venas de cuarzo intragraníticas. Diagramas de variación en la wolframita I y II de las venas encajadas en el LG y las AB: b) de Nb vs. W; c) de $\mathrm{Nb}^{5+}+\mathrm{Fe}^{3+}$ vs. $\mathrm{W}^{6+}+\mathrm{Fe}^{2+}+\mathrm{Mn}^{2+} ; \mathrm{y}$ d) de $\mathrm{Mn}$ vs. Fe.

es sustituido por hasta $0.01 \mathrm{apfu}$ de $\mathrm{Nb}$. En cuanto a la wolframita II su fórmula media es $\left(\mathrm{Fe}_{0,37} \mathrm{Mn}_{0,61}\right)_{\Sigma 0,98} \mathrm{WO}_{4}$, con contenidos en $\mathrm{Fe}^{3+}$ superiores a los que presenta la ferberita del primer evento mineralizador.

Los contenidos de $\mathrm{Nb}$ muestran una correlación negativa con los de W (Fig. 3.30b) que, aunque en general no parece depender del contenido en hübnerita de la wolframita, sí se observa que los cristales con mayor componente ferberítico (wolframita I) son los menos enriquecidos en $\mathrm{Nb}$. La fuerte correlación negativa que presenta la composición de estas wolframitas en la figura 3.30c apoya la idea de que el $\mathrm{Nb}$ entra en la wolframita en solución sólida probablemente mediante una sustitución doble de tipo $\left[(\mathrm{Fe}, \mathrm{Mn})^{2+}, \mathrm{W}^{6+}\right]-\left(\mathrm{Fe}^{3+}, \mathrm{Nb}^{5+}\right)$ (Polya, 1988; Neiva, 2008). Esto viene además apoyado por la teoría de que las wolframitas ricas en $\mathrm{Nb}$ poseen mayores parámetros de celda unidad que las desprovistas de este elemento para una composición química similar (Polya, 1988). Este tipo de sustitución se ha observado en otros depósitos wolframíferos como en Panasqueira o Vale das Gatas, en Portugal (Neiva, 2008). En la figura 3.30d se pueden observar las variaciones composicionales entre la wolframita I más rica en Fe y la wolframita II más enriquecida en Mn. Es notable el marcado enriquecimiento en Fe de la wolframita I en una de las labores mineras del borde de la cúpula granítica (mina Bon). Esta wolframita es parcialmente disuelta por fluidos hidrotermales posteriores formando los parches de hübnerita, que se corresponden con los valores más enriquecidos en Mn de la gráfica. 


\section{Rutilo}

En las venas de cuarzo mineralizadas se identifican, textural y composicionalmente, dos tipos de rutilo. El rutilo I se encuentra fundamentalmente en las venas encajadas en el GE en cristales anhedrales de tamaño micrométrico incluidos o asociados especialmente a las bandas incoloras de los cristales zonados de la casiterita I. Químicamente el Ti ocupa la mayor parte de las posiciones catiónicas variando entre 0,89 y 0,95 apfu, con cantidades de $\mathrm{Nb}$ y Ta que alcanzan los 0,04 apfu y 0,01 apfu respectivamente, hasta 0,04 apfu de Fe y hasta 0,03 apfu de $\mathrm{Sn}$, este último probablemente debido a la contaminación por la casiterita. $\mathrm{Nb}$, Ta y Fe entrarían en la estructura del rutilo de acuerdo con una sustitución de tipo columbita $(\mathrm{Fe}, \mathrm{Mn})(\mathrm{Nb}, \mathrm{Ta})_{2} \mathrm{Ti}_{-3}$ (Fig. 3.31a). Como ocurría en algunos diques pegmatíticos intragraníticos, varios cristales de rutilo de estas venas presentan altos contenidos en $\mathrm{Al}$, llegando a alcanzar hasta $1,33 \%$ en peso de $\mathrm{Al}_{2} \mathrm{O}_{3}$ (Anexo III).

El rutilo II se presenta asociado al cuarzo III en el relleno de las venas encajadas en el LG y las $A B$ con turmalina, en cristales sub- a euhedrales de tamaño micrométrico a milimétrico (Lám. 3.22a) y en agregados de cristales rellenando, junto con la ixiolita, los huecos tardíos (Lám. 3.22b). Microscópicamente presenta un zonado oscilatorio más o menos regular, a veces con aspecto parcheado (Lám. 3.22a,c) debido a las variaciones en el contenido en Ti (desde 0,67 apfu en las zonas más claras hasta 0,98 apfu en las zonas más oscuras). Las principales sustituciones del Ti son por $\mathrm{Nb}$ y Ta en proporciones similares hasta 0,12 apfu cada uno (Fig. 3.31b), si bien los bordes de los cristales se presentan generalmente enriquecidos en $\mathrm{Nb}, \mathrm{W}$ y especialmente en Ta, observándose texturas de disolución parcial y reprecipitación (Lám. 3.22d), por lo que existe una buena correlación negativa entre el Ti y el Ta+Nb (Fig. 3.31c). Los contenidos en $\mathrm{WO}_{3}$ no superan normalmente el $3 \%$ en peso, mientras que el $\mathrm{SnO}_{2}$ se mantiene más o menos estable con valores inferiores a 2,50 \% en peso. Presenta bajos contenidos en $\mathrm{Mn}$ y en Fe, este último considerado como $\mathrm{Fe}^{2+}$, que correlacionan con los de $\mathrm{Nb}+\mathrm{Ta}+\mathrm{W}$ (Fig. 3.31d), de manera que en el diagrama cuadrilateral de la columbita el rutilo II se proyecta muy próximo al eje vertical $x=0$ (Fig. 3.31e). Nb, Ta y Fe entrarían en la estructura del rutilo II de acuerdo con una sustitución de tipo columbita cuyo vector está representado por $\mathrm{Ti}_{3}(\mathrm{Fe}, \mathrm{Mn})_{-1}(\mathrm{Nb}, \mathrm{Ta})_{-2}$ (Fig. 3.31a). Los contenidos en Al de varios cristales de rutilo II llegan a alcanzar valores muy elevados de hasta 3,34 \% en peso de $\mathrm{Al}_{2} \mathrm{O}_{3}$ (Anexo III). Su entrada en la estructura del rutilo está probablemente compensada mediante balance de cargas con vacancias de oxígeno (Hata et al., 1996) debido al vector de sustitución $\mathrm{Al}_{2} \square \mathrm{Ti}_{-2} \mathrm{O}_{-1}$. Destacar los valores constantes de $\mathrm{HfO}_{2}$ que varían desde 0,99 hasta $1,98 \%$ en peso.

\section{Ixiolita}

Este mineral ha sido únicamente identificado en las venas de cuarzo encajadas en el LG y las $A B$ de la mina Salmantina. Se presenta en cristales aciculares o agregados de cristales anhedrales rellenando los huecos y fracturas de los sulfuros, especialmente de la arsenopirita, junto con el rutilo II y el cuarzo III (Lám. 3.22e,f). La cristalización de la ixiolita es ligeramente anterior al rutilo II, ya que este último envuelve a algunos de los cristales (Lám. 3.22e). Con frecuencia presenta una textura zonada debido a ligeras variaciones en los contenidos de $\mathrm{Nb}, \mathrm{Ta}$, Ti y $\mathrm{W}$ (Lám. 3.22f). 

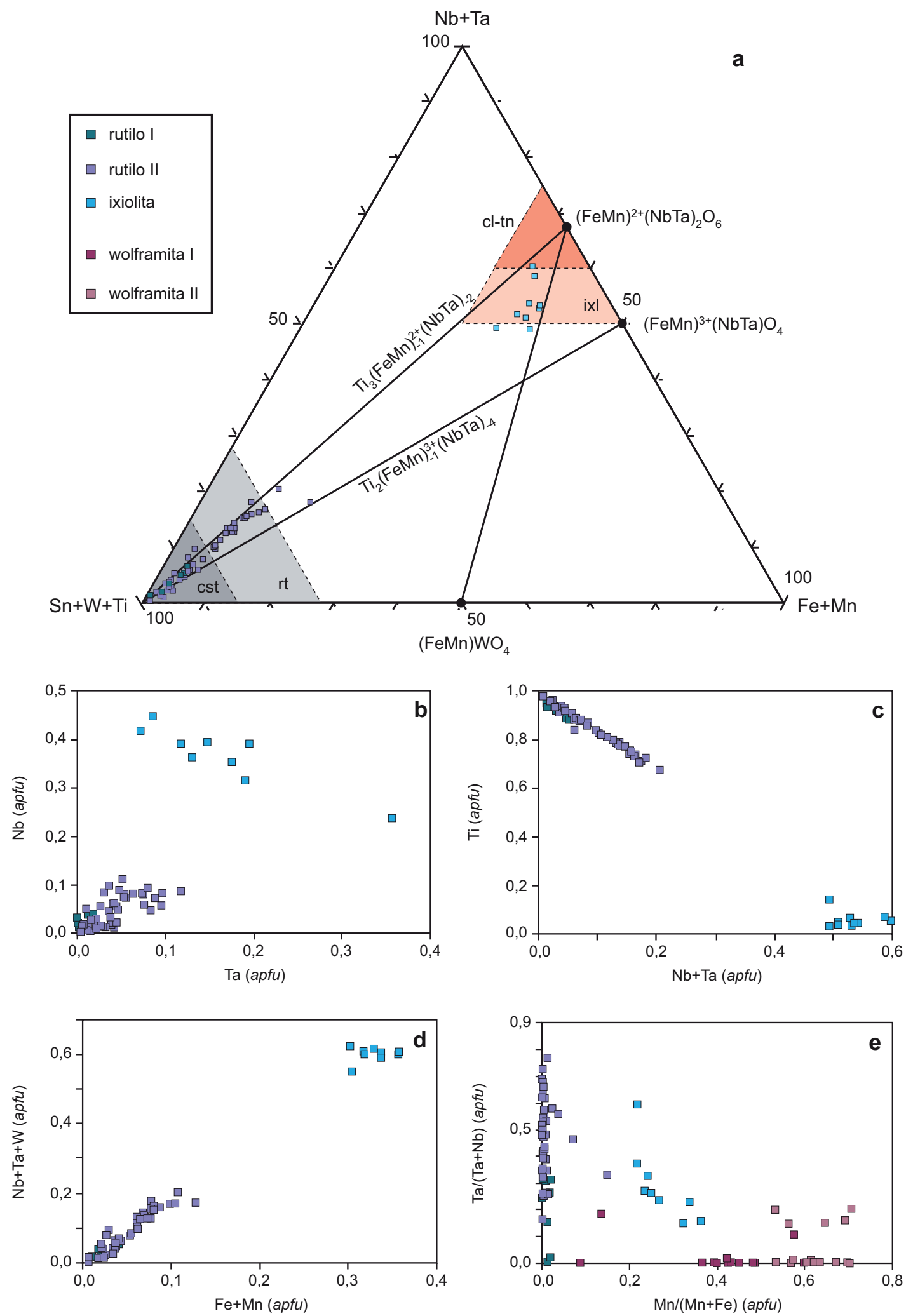

Fig. 3.31. a) Diagrama triangular $(\mathrm{S} n+\mathrm{W}+\mathrm{Ti})-(\mathrm{Nb}+\mathrm{Ta})-(\mathrm{Fe}+\mathrm{Mn})$ en el que se ha representado la composición química del rutilo I y II (rt) y de la ixiolita (ix) de las venas de cuarzo mineralizadas intragraníticas con el vector de sustitución dominante. Diagramas de variación en el rutilo y la ixiolita de las venas de cuarzo intragraníticas: b) Nb vs. Ta; c) Ti vs. $\mathrm{Nb}+\mathrm{Ta}$; y d) Nb+Ta vs. Fe+Mn. e) Diagrama cuadrilateral de la columbita con el rutilo I y II, la ixiolita y la wolframita I y II de las venas de cuarzo intragraníticas, mostrando una evolución hacia composiciones más ricas en Ta. 

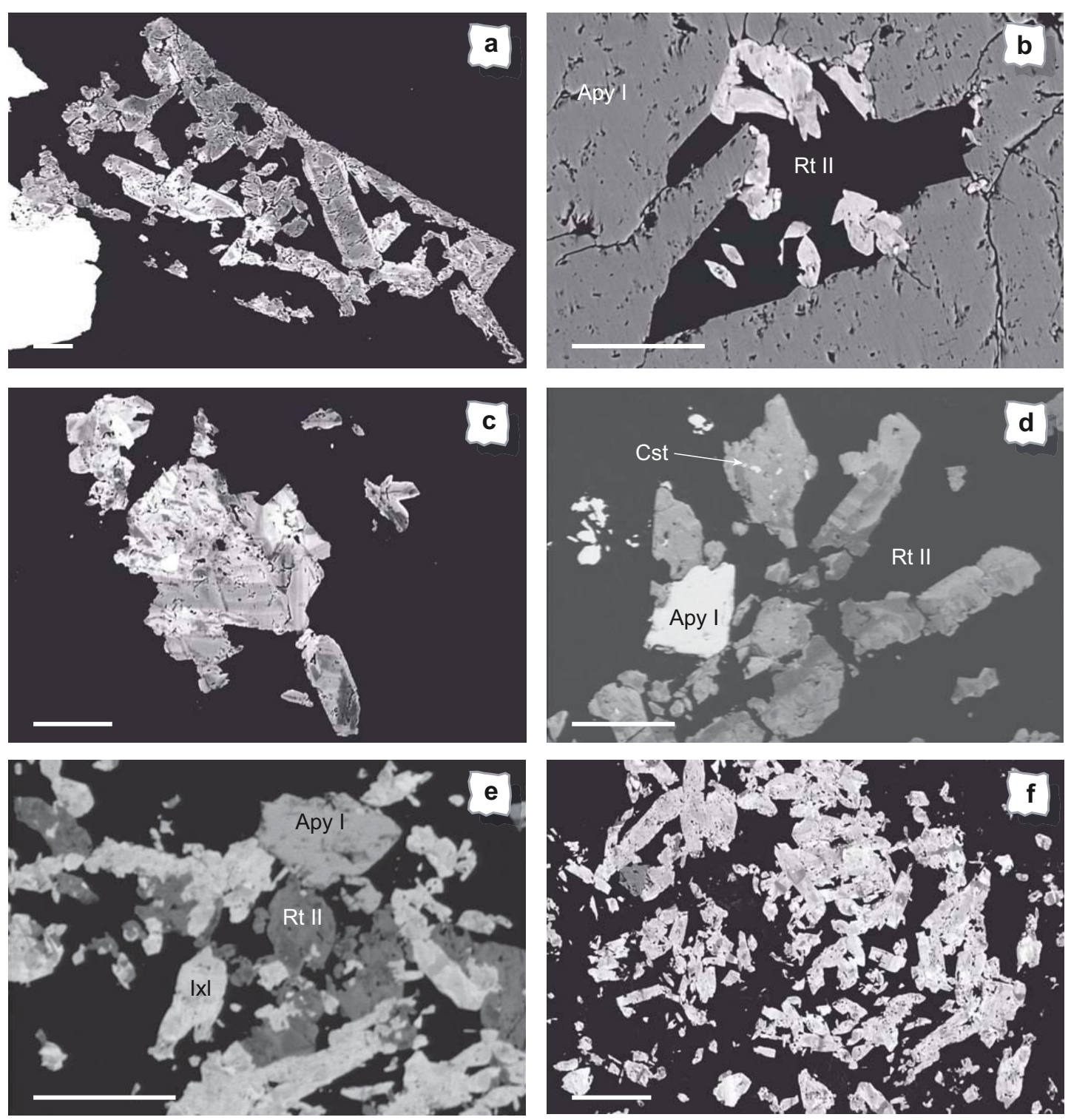

Lám. 3.22. Microfotografías electrónicas de los óxidos de Nb, Ta, Ti y W tardíos en las venas de cuarzo mineralizadas: a) agregado de cristales euhedrales zonados de rutilo II con mayores contenidos en Ti en las zonas interiores (tonos oscuros) y en Ta hacia los bordes (tonos claros); b) agregados subhedrales de rutilo II rellenando huecos de la arsenopirita I; c) agregado cristalino de rutilo II en cuarzo con una zonación exterior y un parcheado en las zonas de interior debido a lamelas de exsolución con diferente contenido en $\mathrm{Nb}$ y Ta; d) cristales de rutilo II con bordes parcialmente disueltos y recristalizados con altos contenidos en Ta; e) agregado de rutilo II bordeando a cristales de ixiolita; f) aspecto de la zonación que presentan los cristales sub- a euhedrales de ixiolita debido a las diferencias en sus contenidos en Nb, Ta, Ti y W. Escala gráfica: 50 $\mu \mathrm{m}$.

Su fórmula general es de tipo rutilo $\left[(\mathrm{Ta}, \mathrm{Nb}, \mathrm{Sn}, \mathrm{Fe}, \mathrm{Mn}) \mathrm{O}_{2}\right]$ en la que destacan los elevados contenidos en $\mathrm{Nb}$ (entre 0.24 y $0.45 \mathrm{apfu}$ ), Ta (entre 0.07 y $0.36 \mathrm{apfu}$ ), W (hasta $0.11 \mathrm{apfu}$ ) y Ti (hasta $0.14 \mathrm{apfu}$ ) y solo contenidos traza en Sn (hasta $0.02 \mathrm{apfu}$ ). En el diagrama de variación $\mathrm{Nb}$ vs. Ta se observa entre ellos una correlación negativa (Fig. 3.31b), si bien ambos elementos son reemplazados por el Ti y por el W (Fig. 3.31c). El W entraría en la estructura de la ixiolita a partir de una sustitución de tipo wolframita mediante el vector de sustitución ( $\mathrm{NbTa})_{4} \mathrm{Fe}$. ${ }_{1} \mathrm{~W}_{-3}$ (Fig. 3.31a). Por otra parte, se observa que la ixiolita está claramente enriquecida en Fe 
(hasta 0,27 apfu) con hasta 0,13 apfu de Mn (Fig. 3.31d) destacando, además, los contenidos traza de $\mathrm{Hf}$, Th y $\mathrm{U}$. Por último, en el diagrama de la figura 3.31e se observan variaciones de la relación $\mathrm{Ta} /(\mathrm{Ta}+\mathrm{Nb})$ entre 0,15 y 0,60 por lo que se proyectan en zonas intermedias.

\section{Uraninita}

La uraninita se ha identificado solamente en un par de muestras de la mina Salmantina ligada a los agregados microcristalinos de cuarzo y mica blanca en la zona de alteración de las venas de cuarzo mineralizadas que encajan en el LG con turmalina. Se presenta en cristales an- a euhedrales de tamaño micrométrico asociados a pirita.

\subsubsection{Sulfuros y sulfosales}

\section{Arsenopirita}

La arsenopirita es el sulfuro más abundante en todas las minas. Por regla general se encuentra en cristales an- a euhedrales de tamaño milimétrico a centimétrico, o bien en agregados granulares de grano fino tanto en el interior de las venas de cuarzo como en las salbandas (Lám. 3.23a,b). Microscópicamente es de color blanco amarillento y muy frecuentemente presenta una textura porosa debido a los abundantes huecos que se conservan agrupados en zonas concretas de los cristales y que mayoritariamente están rellenos por otras fases minerales posteriores o, en ocasiones, están vacíos (Lám. 3.23c,d). Ante las formas cristalinas que presentan algunos de estos huecos (Lám. 3.23e) cabe destacar, para su formación, tres posibles hipótesis: 1) que la arsenopirita durante su cristalización englobe y reemplace casi totalmente a una fase mineral anterior de la que quedan únicamente restos en su interior, como por ejemplo, las inclusiones de pirrotita l; 2) que la arsenopirita durante su cristalización fuerce la disolución total de la pirrotita facilitando el depósito de otras fases minerales en su lugar (lámina 3.23e); y 3) que las fases minerales que engloba la arsenopirita respondan al reemplazamiento de otras fases minerales anteriores. Entre estas últimas se identifican minerales de la ganga o calcopirita, Bi nativo, bismutinita, matildita, argentita y sulfosales de $\mathrm{Bi}-\mathrm{Pb}-\mathrm{Ag}$ de las familias de la lilianita y de la pavonita. Con frecuencia los cristales de arsenopirita se presentan fracturados o brechificados, lo que facilita su alteración parcial o total a escorodita (Lám. 3.23f).

Las relaciones texturales con el resto de minerales paragenéticos y las variaciones composicionales permiten diferenciar dos tipos de arsenopirita (Figs. 3.32a,b y 3.43): la arsenopirita I, que cristaliza junto al cuarzo I y cuyos contenidos en As varían entre 35,00 y $36,25 \%$ at. en las venas del GE, siendo algo inferiores en las del LG y las $A B$ donde varían entre 32,50 y $35,75 \%$ at.; y la arsenopirita II, que cristaliza junto con el cuarzo II y presenta contenidos desde 32,75 a 34,75\% As. en las venas del GE y, de nuevo, inferiores en las venas del $L G$ y las $A B$, variando entre 31,25 y $32,50 \%$ at (Anexo III). Destacan, además, valores significativos de Co (hasta $1.110 \mathrm{ppm}$ ) y Ni (hasta $960 \mathrm{ppm}$ ) especialmente en la arsenopirita de las venas encajadas en el GE, de Se (hasta 3.330 ppm) y de Te (hasta 1.740 ppm), con valores de este último más elevados en las venas del LG y las $A B$. 

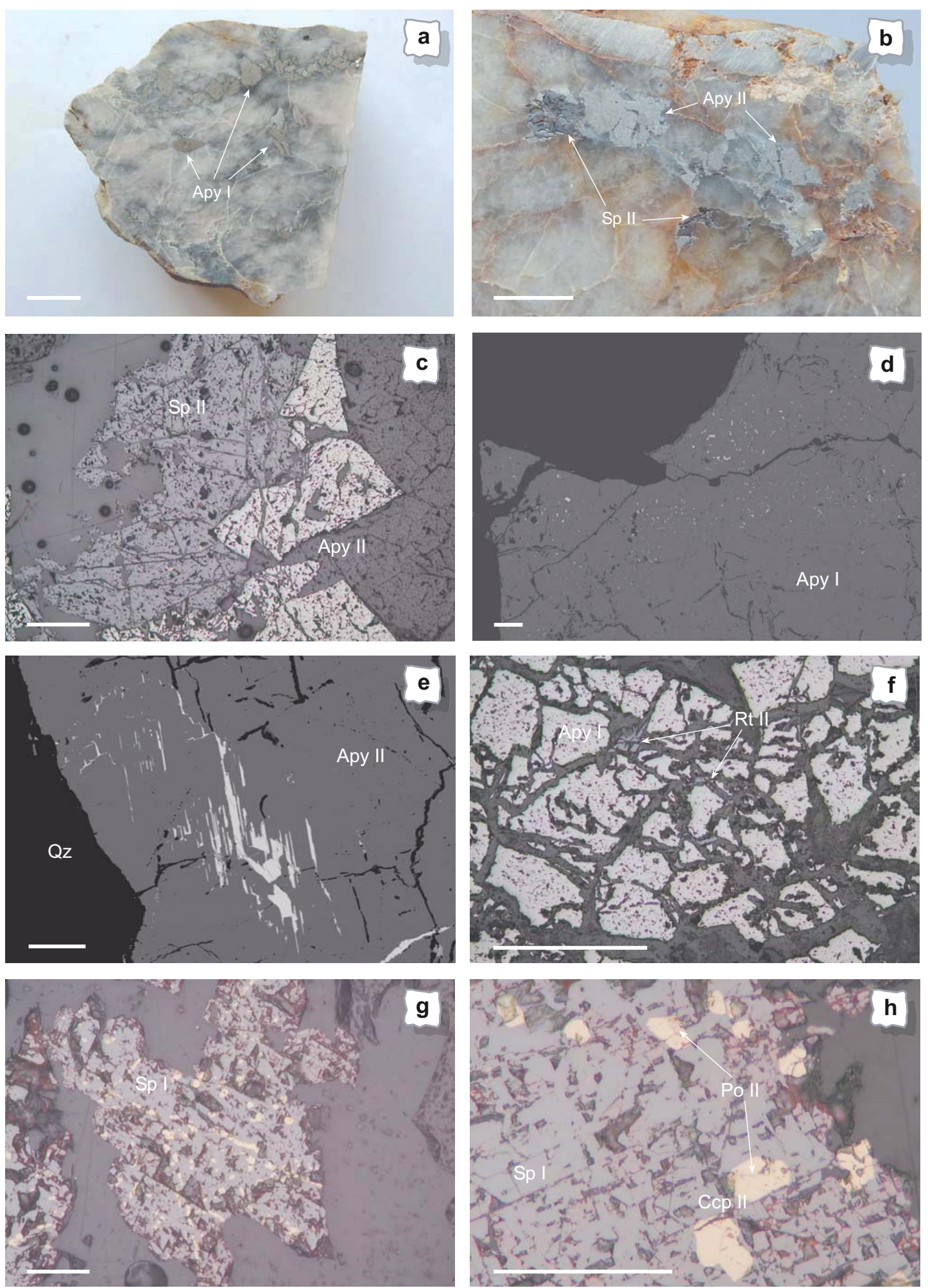

Lám. 3.23. Muestras de mano ( $\mathrm{a}$ y b), microfotografías ópticas en luz reflejada (c, f, g y h) y electrónicas ( $\mathrm{d}$ y e) de las venas de cuarzo mineralizadas: a) aspecto de los agregados de cristales subhedrales de arsenopirita diseminados en las venas de cuarzo de la mina Salmantina; b) detalle de la arsenopirita II junto a la esfalerita Il diseminadas en el cuarzo de las venas de la mina Horia; c) microfotografía de la asociación metálica anterior; d) detalle de la textura microporosa y brechificada que presentan mayoritariamente los cristales de arsenopirita I en la mina Mari Carmen. Las inclusiones identificadas corresponden a sulfosales de $\mathrm{Bi}-\mathrm{Pb}-\mathrm{Ag}$; e) detalle de las sulfosales de $\mathrm{Bi}-\mathrm{Pb}-\mathrm{Ag}$ en los planos cristalográficos de la arsenopirita II en la mina Teso de 

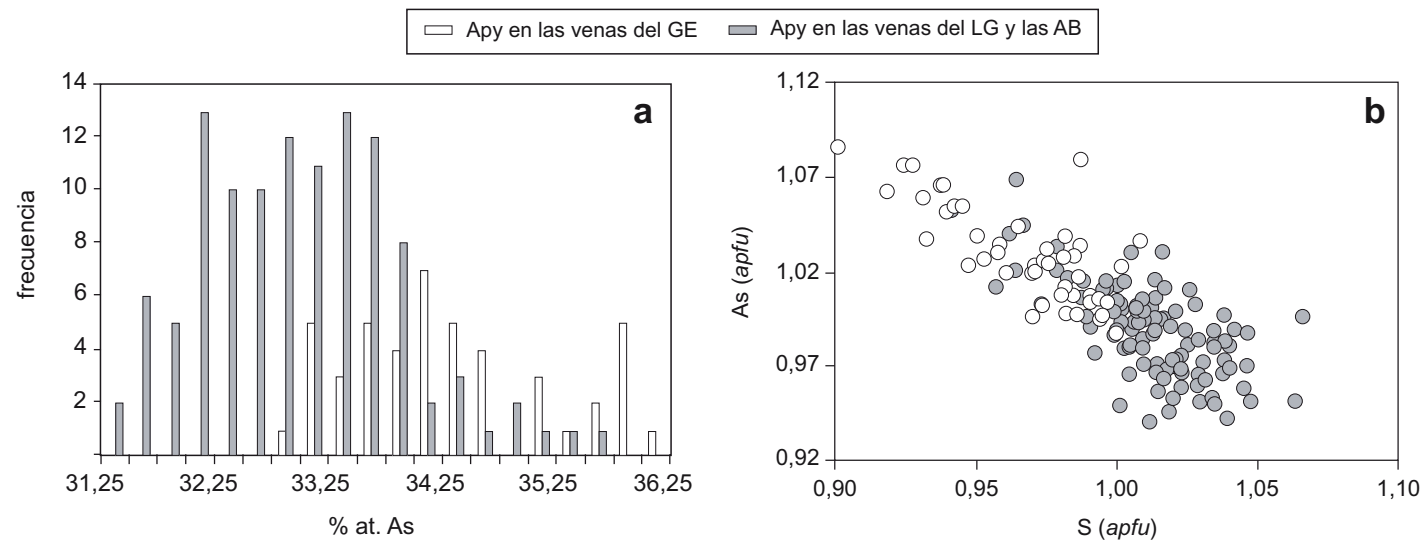

Fig. 3.32. a) Histograma de los contenidos en As (en \% at.); y b) diagrama de variación $\mathrm{S}$ vs. As en las arsenopiritas analizadas observándose, tanto en las venas del GE como en el LG y las AB, dos poblaciones bien diferenciadas.

\section{Esfalerita}

La esfalerita es una fase metálica más escasa en las mineralizaciones estudiadas. Se encuentra en cristales anhedrales o agregados cristalinos de tamaño de grano fino a grueso asociados con la arsenopirita (Lám. 3.23b). Microscópicamente presenta desprendimientos triangulares debido a las dos direcciones preferentes de exfoliación que le dan un aspecto aserrado (Lám. $3.23 \mathrm{~g})$. Tiene un color gris en luz natural y tonos rojizos en nicoles cruzados debido a las abundantes reflexiones internas rojas que presenta. Contiene abundantes inclusiones de calcopirita y pirrotita de tamaño micrométrico en diferentes proporciones (Lám. 3.23g,h) y menos frecuentemente de sulfosales de $\mathrm{Bi}-\mathrm{Pb}-\mathrm{Ag}$, galena y Bi nativo. Esta textura en la que la esfalerita tiene multitud de pequeñas inclusiones de calcopirita y pirrotita es conocida como la "enfermedad de la calcopirita" o chalcopyrite disease (Bente y Doering, 1993). La cristalización de calcopirita necesita un contenido en Cu superior al que la composición de la esfalerita puede contener, por lo que esta textura es consecuencia más de reemplazamiento que de exsolución.

Las relaciones texturales con el resto de minerales paragenéticos y, en particular, con la arsenopirita, sugieren la existencia de dos tipos de esfalerita simultáneos con la cristalización de la arsenopirita I y II (Fig. 3.43). Químicamente también se identifican dos tipos de esfalerita (Fig. 3.33a). La esfalerita I, que es ligeramente anterior a la arsenopirita I, contiene abundantes inclusiones de calcopirita y pirrotita en las venas del GE y presenta contenidos en $\mathrm{Zn}$ que varían entre 0,78 y 0,84 apfu, mientras que en las venas del $L G$ y las $A B$ esta esfalerita I está desprovista de inclusiones y presenta menores contenidos en Zn (entre 0,77 y 0,81 apfu) y elevados contenidos en Fe. Por su parte, la esfalerita II solo se ha diferenciado en las venas

la Matanza; f) aspecto de los cristales de arsenopirita I totalmente brechificados y parcialmente alterados a escorodita en la mina Salmantina. Obsérvese la presencia de rutilo II en las fracturas; $\mathbf{g}$ ) cristal de esfalerita I en la mina Horia reemplazada, a partir de los planos de exfoliación, por una solución sólida intermedia (ssi) de calcopirita II y pirrotita II; h) detalle del reemplazamiento anterior. Escala gráfica: a y b) 1 cm; c, e y f) 500 $\mu \mathrm{m} ; \mathrm{d}, \mathrm{g}$ y h) $100 \mu \mathrm{m}$. 

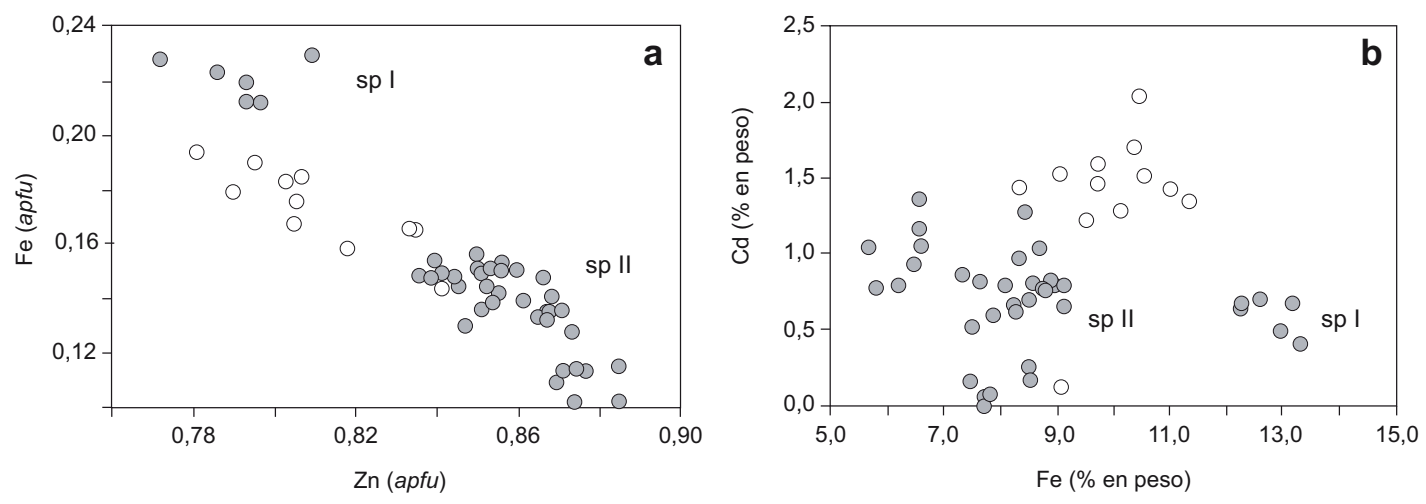

Sp en las venas del GE $\quad \mathrm{Sp}$ en las venas del LG y las $\mathrm{AB}$

Fig. 3.33. Diagramas de variación: a) Fe vs. Zn (en apfu); y b) Cd vs. Fe (en \% en peso) de la esfalerita de las venas del GE y del $L G$ y las $A B$, observándose dos poblaciones.

del $L G$ y las $A B$, con contenidos que varían entre 0,84 y 0,88 apfu de $Z n$ y menores cantidades de Fe que la esfalerita I. Además, los contenidos en Mn pueden alcanzar hasta 0,59\% en peso y los de Cd varían desde $1,51 \%$ en peso de media en la esfalerita I del GE, hasta 0,59\% en peso en la esfalerita I de las venas del LG y las $A B$ y $0,71 \%$ en peso en la esfalerita II (Fig. $3.33 b)$.

\section{Pirita}

La pirita es accesoria en las mineralizaciones estudiadas. Se encuentra tanto en la salbanda como en el interior de la vena, diferenciándose dos tipos: por un lado la pirita I, que se presenta en cristales generalmente cúbicos de tamaño milimétrico y aspecto poroso junto con la arsenopirita I y la esfalerita I (Lám. 3.24a). Localmente forma agregados microcristalinos en la roca granítica encajante alterada rodeando a la uraninita; la pirita II, por otro lado, se

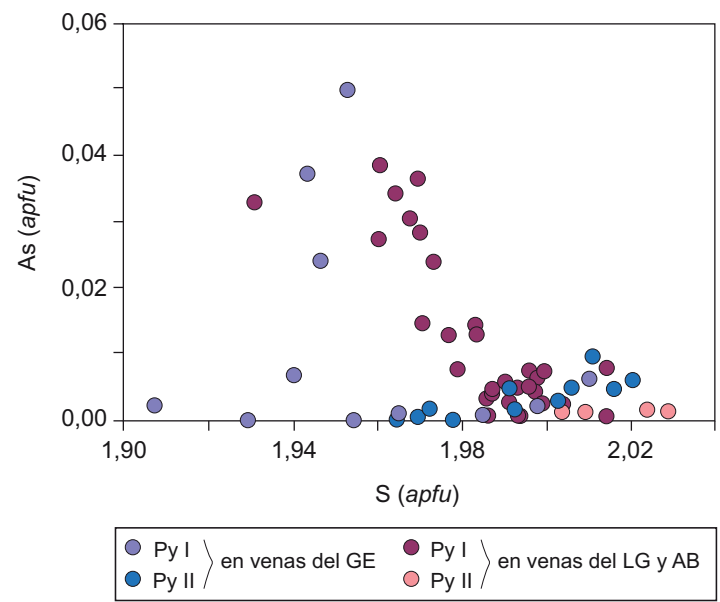

Fig. 3.34. Diagrama de variación As vs. S (en apfu) en las piritas de las venas intragraníticas. Nótese el mayor enriquecimiento en As en la pirita I de ambos tipos de venas. encuentra asociada al cuarzo III rellenando grietas micrométricas tardías en el cuarzo I y II y en los sulfuros anteriores, con formas masivas que en ocasiones llegan a sellar dichas fracturas (Lám. 3.24b). Ocasionalmente, esta pirita II contiene inclusiones irregulares de calcopirita, pirrotita o sulfosales de $\mathrm{Bi}-\mathrm{Pb}-\mathrm{Ag}$.

Su composición química evidencia la existencia de los dos tipos de pirita diferenciados texturalmente, puesto que la pirita I muestra contenidos elevados en As hasta 0,05 apfu, no así la pirita II (Fig. 3.34). Se aprecian, además, trazas de $\mathrm{Cu}, \mathrm{Se}, \mathrm{Te}$, $\mathrm{Hg}$ y $\mathrm{Bi}$ y, en algunas ocasiones, contenidos de Au de hasta 2.200 ppm. 

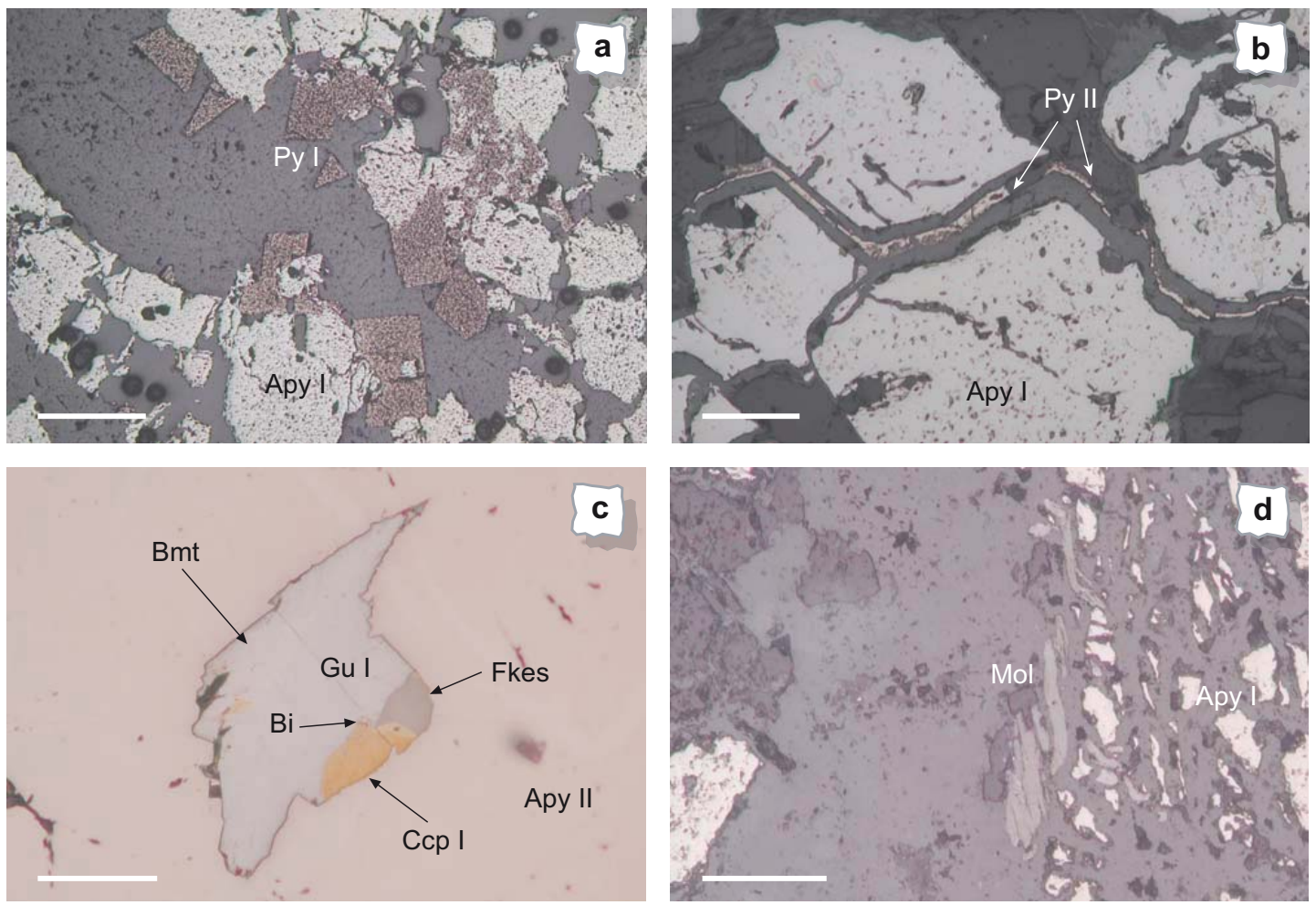

Lám. 3.24. Microfotografías en luz reflejada de: a) cristales euhedrales de pirita I junto con arsenopirita I en la mina Mari Carmen; b) pirita II masiva rellenando las microfracturas de la arsenopirita I en la mina Salmantina; c) cristal de ferrokesterita junto con calcopirita I, Bi nativo, bismutinita y gustavita I en un hueco de la arsenopirita II en la mina Teso de la Matanza; d) cristales fibrosos de molibdenita junto con arsenopirita I fracturada y totalmente alterada en la mina Salmantina. Escala gráfica: a) $500 \mu \mathrm{m}$; b, c y d) $100 \mu \mathrm{m}$.

\section{Calcopirita}

La calcopirita es otro mineral poco frecuente en las mineralizaciones estudiadas. Se diferencian, en base a las relaciones texturales y paragenéticas con el resto de minerales, dos tipos (Fig. 3.43): la calcopirita I, que se presenta en cristales anhedrales rellenando las fracturas o huecos de la arsenopirita junto con las sulfosales de $\mathrm{Bi}-\mathrm{Pb}-\mathrm{Ag}$, Bi nativo $\mathrm{y}$ ferrokesterita; y la calcopirita II, que se encuentra en cristales anhedrales o redondeados de tamaño micrométrico incluidos en esfalerita y asociados a pirrotita (Lám. 3.23g,h), ocasionalmente también a sulfosales de $\mathrm{Bi}-\mathrm{Pb}-\mathrm{Ag}$, galena y Bi nativo. Normalmente estas inclusiones se disponen según las dos direcciones de exfoliación de la esfalerita representando lo que se denomina "enfermedad de la calcopirita" o chalcopyrite disease (Bente y Doering, 1993). Raramente se presentan dispersas sin ningún patrón cristalográfico y varían desde inclusiones microcristalinas dispuestas a lo largo de grietas de los cristales de esfalerita hasta gotas o blebs de $100 \mu \mathrm{m}$ de tamaño. Su composición química es idéntica en ambos tipos de calcopirita y está muy próxima a su composición ideal $\left(\mathrm{Cu}_{1,02} \mathrm{Fe}_{0,98} \mathrm{~S}_{2}\right)$.

\section{Pirrotita}

Texturalmente se distinguen dos generaciones de pirrotita; por un lado la pirrotita I, que se encuentra en cristales redondeados incluidos en la pirita I y en la arsenopirita I, en la que 
se aprecia que los numerosos restos de cristales que se conservan pertenecen a un único cristal de pirrotita parcialmente reemplazado; y por otro lado la pirrotita II, que aparece en inclusiones redondeadas, alargadas o anhedrales de hasta $100 \mu \mathrm{m}$ de tamaño reemplazando a la esfalerita junto con calcopirita, y más localmente con Bi nativo, ferrokesterita y sulfosales de Bi-Pb-Ag (Lám. 3.23h). Químicamente presentan una composición prácticamente idéntica $\left(\mathrm{Fe}_{0,86} \mathrm{~S}\right)$, de modo que las vacancias que se observan están muy próximas a las máximas $(x=0,17)$ calculadas por Fleischer y Mandarino (2004), lo que indica la presencia notable de $\mathrm{Fe}^{3+}$ en la estructura de este mineral al aplicar la sustitución $\mathrm{Fe}^{2+} \rightarrow \mathrm{Fe}^{2+}{ }_{1-3 x}+\mathrm{Fe}^{3+}{ }_{2 x}$.

\section{Minerales del Grupo de la Estannita}

Estas fases minerales solo se han identificado en las venas encajadas en el LG y las AB de las minas Salmantina, Carrasquera y Teso de la Matanza. Normalmente son cristales an-

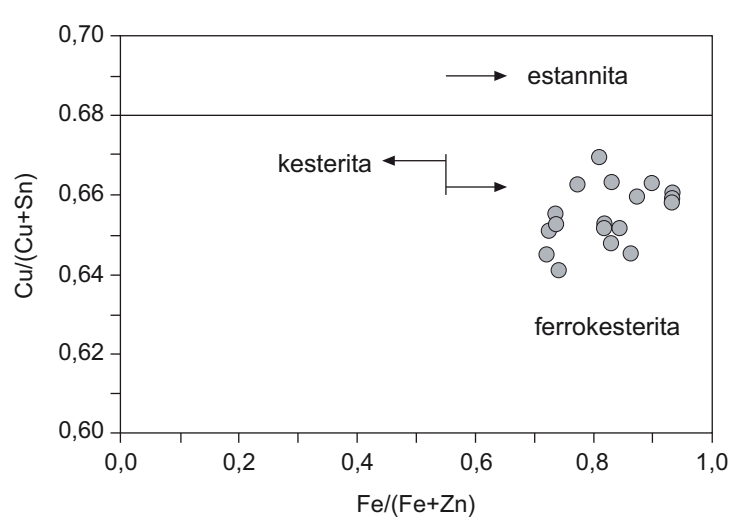

Fig. 3.35. Diagrama de clasificación de Petruk (1973) y Kissin y Owens (1989) con la representación de los minerales del grupo de la estannita analizados. a subhedrales inferiores a $500 \mu \mathrm{m}$ que generalmente rellenan huecos y grietas en la arsenopirita (Lám. 3.24c). Frecuentemente se encuentra asociada con calcopirita y, ocasionalmente, con homólogos de lilianita y pavonita.

Su composición química corresponde al término de la ferrokesterita (Kissin y Owens, 1989), con valores de $\mathrm{Fe} /(\mathrm{Fe}+\mathrm{Zn})$ superiores a 0,70 (Fig. 3.35), por lo que la fórmula media calculada es muy próxima a la ideal $\left[\mathrm{Cu}_{1,91}\left(\mathrm{Fe}_{0,88} \mathrm{Zn}_{0,19}\right) \mathrm{Sn}_{1,01} \mathrm{~S}_{3,97}\right]$. Además, contiene trazas de otros elementos como el $\mathrm{Mn}, \mathrm{Cd}$ o In, mientras que el Se es el principal sustituto del $\mathrm{S}$.

\section{Molibdenita}

Localmente se ha observado la presencia de fibras alargadas de hasta $200 \mu \mathrm{m}$ frecuentemente deformadas de molibdenita rellenando grietas junto con el cuarzo III (Lám. 3.24d) únicamente en las venas que encajan en el LG y las $A B$ con turmalina. Su composición química está muy próxima a la composición ideal, con poco más de 1 apfu de Mo para 2 átomos de $\mathrm{S}$ y destacando únicamente algunas trazas de Fe, W, Hg y Au (hasta 1.106 ppm).

\section{Oro nativo}

Muy localmente se detectó la presencia de cristales de oro nativo de tamaño micrométrico y morfología irregular, incluidos en la arsenopirita (Lám. 3.25 ) (Moro, 2000).

\section{Sulfosales de $\mathrm{Bi} \pm \mathrm{Pb} \pm \mathrm{Ag}$}

En este trabajo se ha identificado la presencia de una gran cantidad de sulfosales de $\mathrm{Bi}-\mathrm{Pb}-\mathrm{Ag}$, algunas de las cuales ya habían sido identificadas con anterioridad (Moro, 2000; Moro et al., 
2001). Entre ellas destacan los homólogos de la lilianita y de la pavonita. A pesar de su carácter accesorio tienen gran importancia para determinar, en base a sus relaciones texturales y a su química mineral, la evolución paragenética de las mineralizaciones estudiadas.

A modo de introducción, cabe destacar que la serie de homólogos de la pavonita está representada por sulfosales cuya estructura cristalina se compone de dos tipos de capas paralelas a (001) (Makovicky

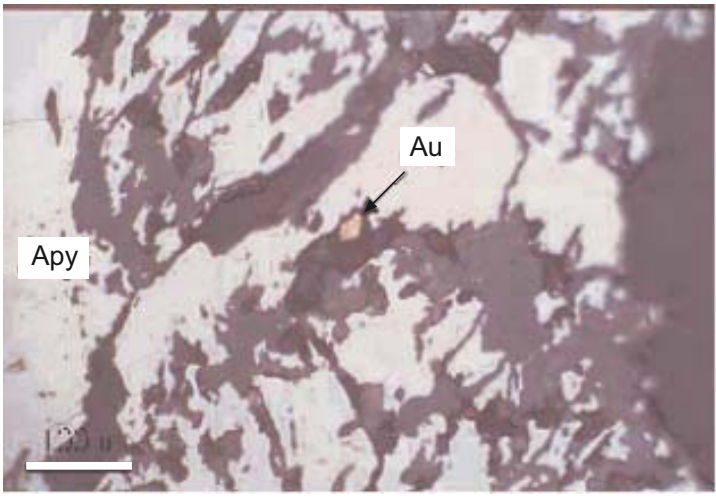

Lám. 3.25. Arsenopirita I fracturada y alterada parcialmente a escorodita con Au nativo en la mina Salmantina, LN. Escala gráfica: $100 \mu \mathrm{m}$. et al., 1977; Makovicky, 2006): por un lado las capas más finas, que contienen un único octaedro con Ag y que alterna con pirámides trigonales de $\mathrm{Bi}\left[\mathrm{Bi}(\mathrm{Pb}) \mathrm{S}_{5}\right]$; y por otro las capas más gruesas, formadas por cadenas paralelas de octaedros tipo galena ligeramente deformadas (Fig. 3.36a). El grosor de esta última capa viene determinado por el número de octaedros en la cadena y se representa con el número $\mathrm{N}$. Así, los homólogos de la pavonita se definen de acuerdo a $\mathrm{N}$ y se denotan como ${ }^{\mathrm{N}} \mathrm{P}$, siendo la pavonita el mineral tipo con $\mathrm{N}=5$. La determinación de este número $\mathrm{N}$ normalmente se basa en la composición química, cuya representación gráfica se muestra en la figura 3.37.

Todas las pavonitas naturales pueden presentar sustitución parcial de $\mathrm{Ag}$ y $\mathrm{Bi}$ por $\mathrm{Pb}$ y Cu (Karup-Møller y Makovicky, 1979). El contenido total de Cu presente en las pavonitas puede dividirse entre $\mathrm{Cu}$ sustitutivo $\left({ }^{\mathrm{s}} \mathrm{Cu}\right)$, que junto con el $\mathrm{Pb}$ sustituye a $\mathrm{Ag}$ y $\mathrm{Bi}$ en la fórmula
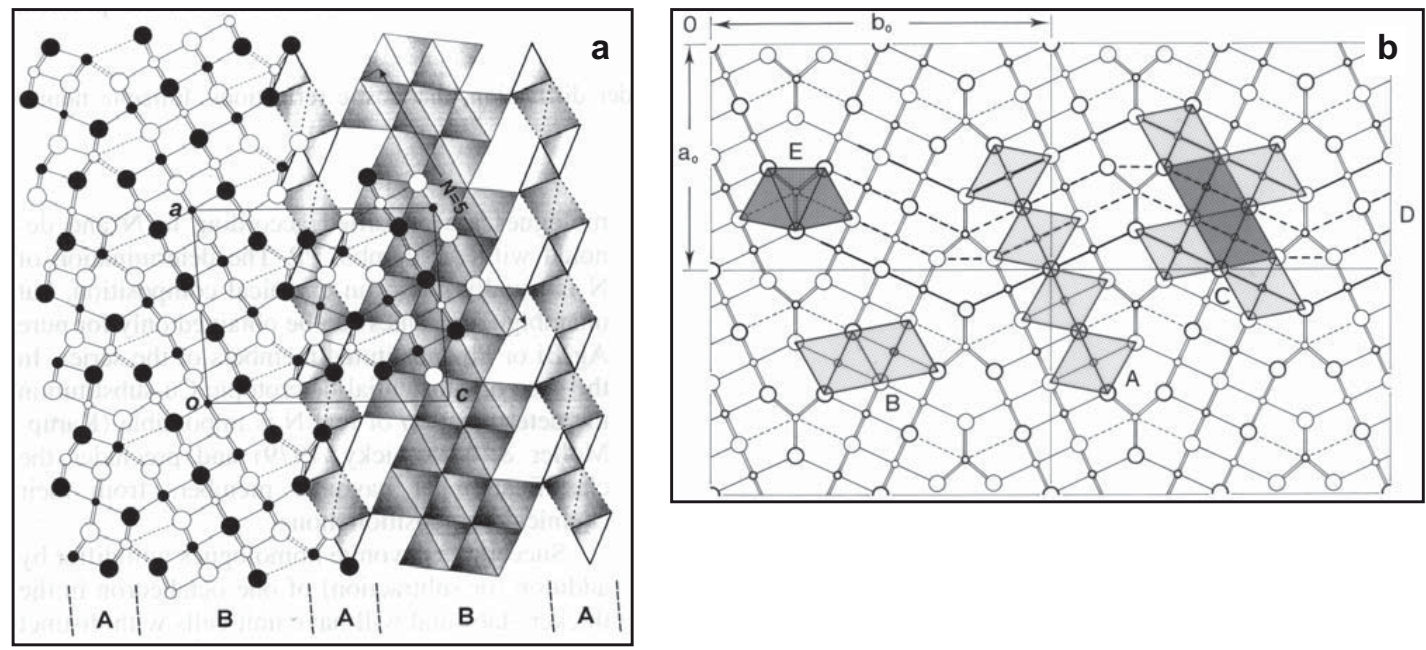

Fig. 3.36. a) Estructura cristalina de la pavonita (Makovicky et al., 1977): (A) capas finas formadas por un octaedro con Ag (línea punteada) alternando con pirámides trigonales de Bi (línea gruesa); y (B) capas gruesas formadas por cadenas paralelas de $\mathrm{N}$ octaedros de $\mathrm{Bi}$ o Ag ligeramente deformadas. b) Elementos de la estructura cristalina de la lilianita (Makovicky y Karup-Møller, 1977a): (A) cadena de N octaedros, (B) capa de octaedros aproximadamente paralelos a (100), (D) cadenas de octaedros en zig-zag a lo largo de (010) definiendo la unidad cristaloquímica (C) y (E) prismas trigonales $\left(\mathrm{PbS}_{6+2}\right)$. 


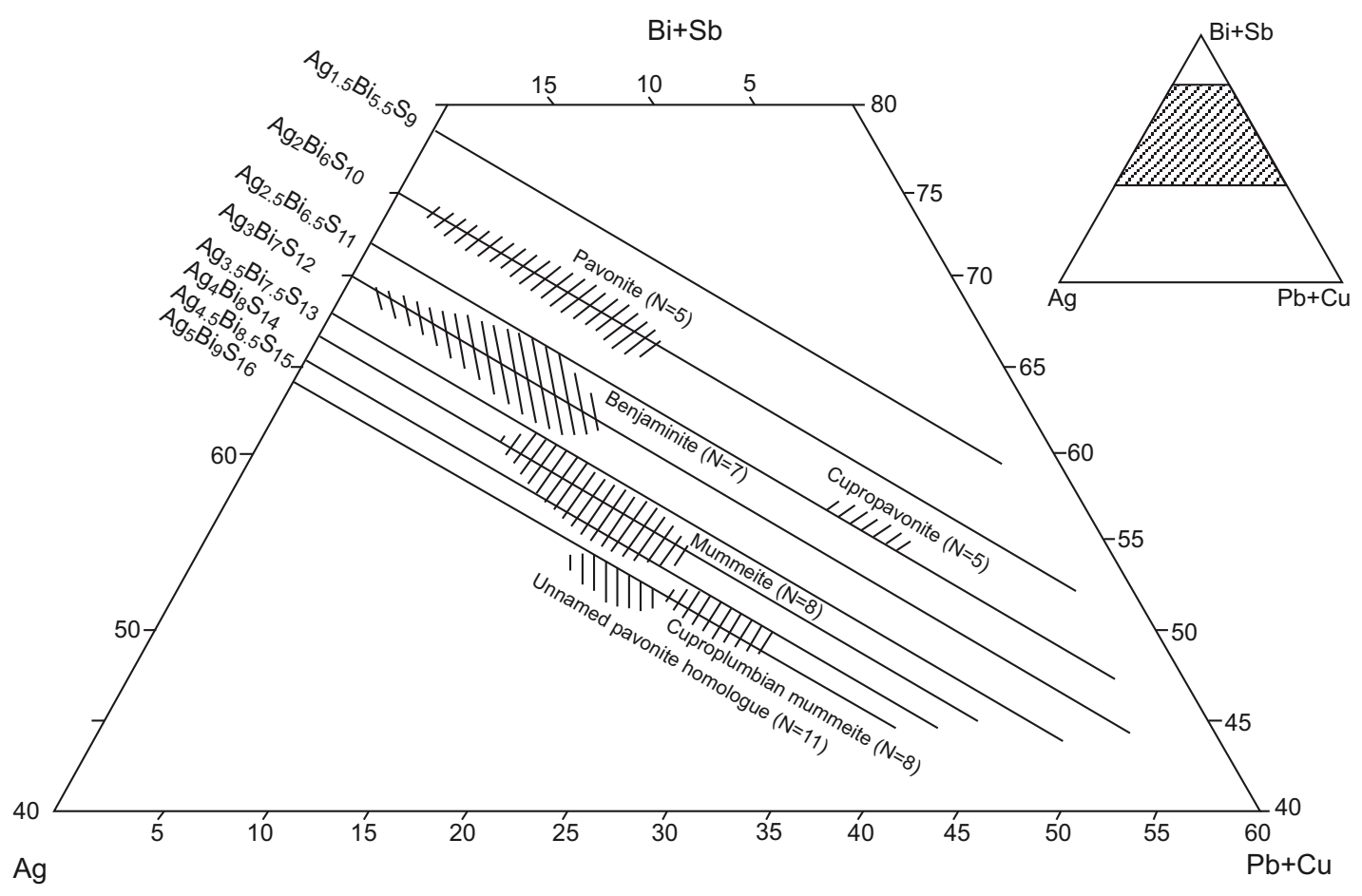

Fig. 3.37. Diagrama triangular Ag-(Bi+Sb)-(Pb+Cu) de Karup-Møller y Makovicky (1992) con la representación gráfica de la composición ideal de los homólogos de la pavonita.

general, y $\mathrm{Cu}$ intersticial (' $\mathrm{Cu}$ ), que rellena posiciones estructurales vacías y se encuentra en exceso en la fórmula. La distribución del Cu total entre uno u otro tipo a la hora de calcular la fórmula estructural depende de la relación entre los resultados analíticos y el NP del mineral. Así, para pavonitas con escaso contenido en $\mathrm{Cu}$ se ha empleado la fórmula que considera todo él como ${ }^{\mathrm{S}} \mathrm{Cu}$ (Karup-Møller y Makovicky, 1979):

$$
N \approx \frac{7-6 B i-3 P b}{2 B i+P b-1}
$$

Mientras que para contenidos significativos de $\mathrm{Cu}$ el mejor resultado se obtiene repartiendo por igual el contenido de $\mathrm{Cu}$ total entre ${ }^{\mathrm{i}} \mathrm{Cu}$ y ${ }^{\mathrm{s}} \mathrm{Cu}$ :

$$
N \approx \frac{7-6 B i-3(P b+1 / 2 C u)}{2 B i+(P b+1 / 2 C u)-1}
$$

La sustitución de $2 \mathrm{~Pb}$ por Ag+Bi preserva el valor químico de $\mathrm{N}$, con lo que las fases varían en la misma línea de igual $\mathrm{N}$. Sin embargo, las fases ricas en $\mathrm{Cu}$ están desplazadas respecto a las líneas de composición ideal al tener valores de $\mathrm{N}$ mayores debido a la sustitución de dos átomos de Cu por cada uno de Bi (ver en Fig. 3.37 el desplazamiento de cupropavonita y mummeita rica en $\mathrm{Cu}$ y $\mathrm{Pb}$ respecto de pavonita y mummeita).

La estructura cristalina de los homólogos de la lilianita (Fig. 3.36b) se compone por una alternancia de capas con estructura tipo galena paralelas a los planos (010) de los cristales y compuestas por átomos de $\mathrm{Pb}, \mathrm{Bi}(\mathrm{Sb})$ y $\mathrm{Ag}$ en coordinación cuasi-octaédrica y otras capas 
discontinuas de átomos de $\mathrm{Pb}$ en coordinación $6+2$ con $\mathrm{S}$, formando prismas trigonales deformados (Makovicky y Karup-Møller, 1977a).

Cada uno de los miembros de la serie de la lilianita se diferencia fundamentalmente en el grosor de la capa tipo galena, compuesta por un número $\mathrm{N}$ de octaedros. La existencia de fases monoclínicas y ortorrómbicas en la serie genera la posibilidad de que haya miembros que pueden formarse por alternancias de dos tipos de capas octaédricas diferentes, $N_{1}$ y $N_{2}$. De esta manera, los diferentes homólogos de la serie se denotan como ${ }^{N} \mathrm{~L}$ cuando las capas

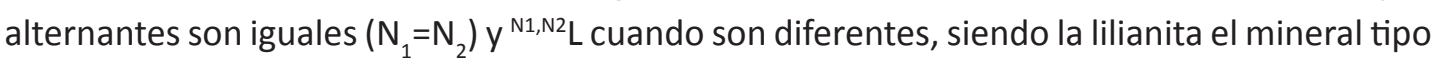
con $\mathrm{N}_{1}=\mathrm{N}_{2}=4$.

El mecanismo principal de sustitución observado en la serie es $\mathrm{Ag}+\mathrm{Bi} \rightarrow 2 \mathrm{~Pb}$, que se denomina "sustitución del tipo gustavita", de modo que las composiciones situadas entre las fases libres de $\mathrm{Ag}$ y las fases ricas en $\mathrm{Ag}+\mathrm{Bi}$, que representan la sustitución total de los octaedros, se proyectan a lo largo de una línea recta que conecta los dos miembros extremos. Cada uno de los homólogos de la lilianita se representa por líneas paralelas entre sí y con la línea de solución sólida galena-matildita, que representa el miembro de la serie de $\mathrm{N}=\infty$ (Fig. 3.38).

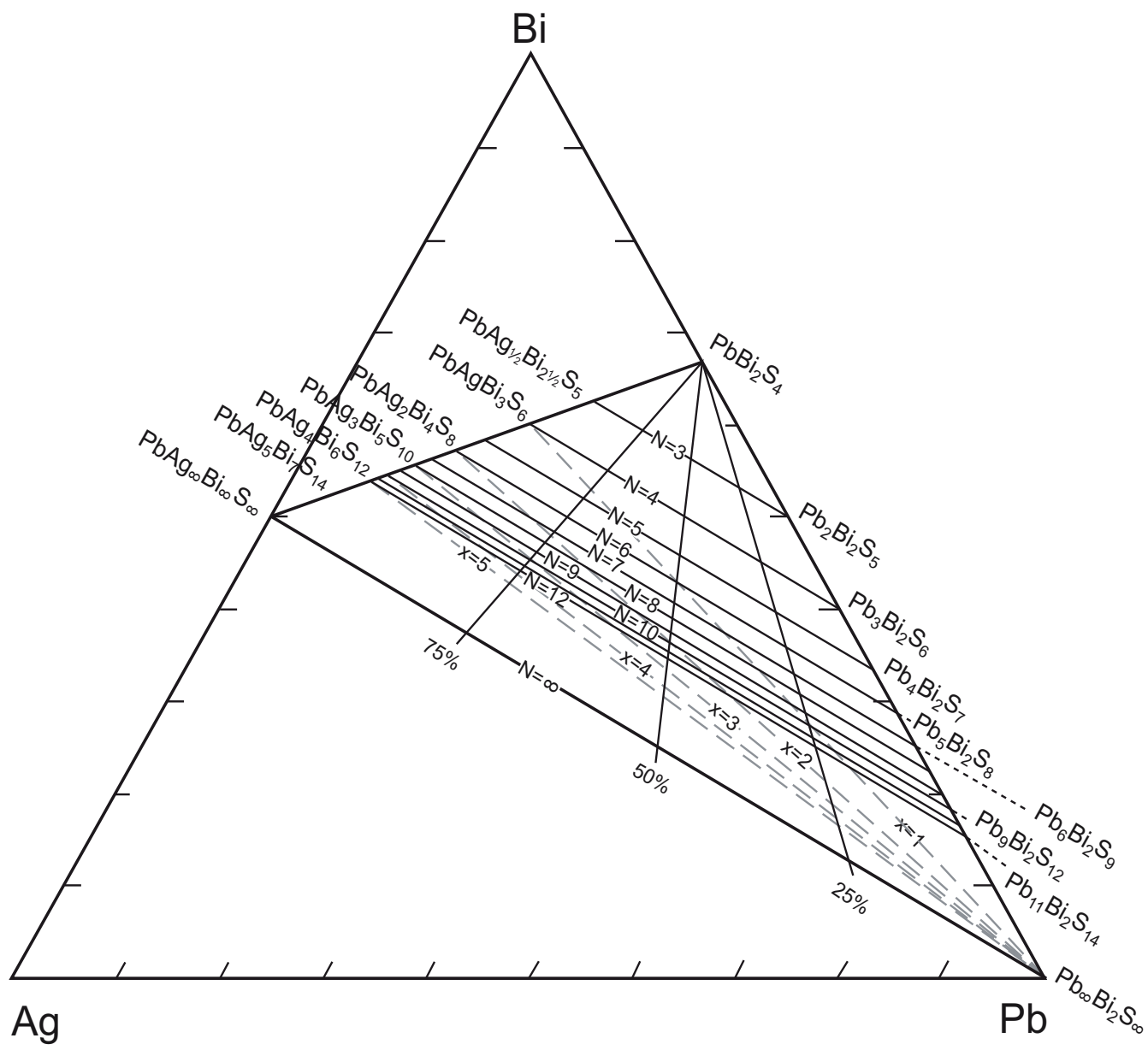

Fig. 3.38. Diagrama triangular Ag-Bi-Pb de Makovicky y Karup-Møller (1977b) para la representación gráfica de los homólogos de la lilianita en el que se observa la fórmula general de cada uno de ellos, la fracción molar del término extremo de la serie y el parámetro de sustitución $x$. 
La mayoría de las lilianitas contienen pequeñas cantidades de $\mathrm{Cu}$ en la estructura que suele ser siempre $\mathrm{Cu}$ en exceso y que no se tiene en cuenta a la hora de calcular la fórmula (ver Makovicky y Karup-Møller, 1977a). El parámetro N se calcula mediante la fórmula:

$$
N=-1+\frac{1}{\left(B i+\frac{P b}{2}-1 / 2\right)}
$$

La fracción molar del término extremo de la serie rico en $\mathrm{Ag}$ y Bi es igual a:

$$
m o l \% A g B i=\frac{(2 B i-P b-1)}{206\left(B i+\frac{P b}{2}-5 / 6\right)}
$$

Yel parámetro de sustitución $x$ para obtener la fórmula $\mathrm{Pb}_{\mathrm{N}-1-2 x} \mathrm{Ag}_{x} \mathrm{Bi}_{2+\mathrm{x}} \mathrm{S}_{\mathrm{N}+2}$ se obtiene mediante:

$$
x=\frac{(m o l \% A g B i) *(N-2)}{200}
$$

La estructura tipo de la pavonita está íntimamente relacionada con la de la lilianita, de modo que la principal diferencia reside en la sustitución del átomo de Bi en las pirámides tetragonales por un átomo de $\mathrm{Pb}$ en coordinación trigonal prismática (Makovicky et al., 1977). La composición química de las pavonitas naturales (Karup-Møller y Makovicky, 1979) y de las lilianitas (Makovicky y Karup-Møller, 1977a) indica un número medio constante de octaedros por capa a lo largo de sus respectivas soluciones sólidas, por lo que en el diagrama triangular $\mathrm{Pb}$-Bi-Ag las líneas que describen ambas soluciones sólidas son paralelas (Fig. 3.38). De hecho, la línea de la benjaminita (1,7 $\mathrm{P}, \mathrm{N}=4)$ continúa en el campo de las lilianitas a lo largo de la línea de la solución sólida lilianita-gustavita $\left({ }^{4,4} \mathrm{~L}, \mathrm{~N}=4\right)$. Sin embargo, la estructura de ambas fases y su composición natural son diferentes por lo que no es posible una solución sólida entre ellas.

Homólogos de la lilianita

Los homólogos de la lilianita son las sulfosales de Bi-Pb-Ag más comunes en el distrito de Navasfrías. Se han identificado términos de la solución sólida gustavita-lilianita, vikingita y heyrovskyita que se presentan en cristales individuales o en agregados de cristales an- a subhedrales de hasta $0.5 \mathrm{~cm}$ de tamaño, incluidos en cuarzo o rellenando grietas y huecos en la arsenopirita I y II (Lám. 3.26).

De todos ellos, la gustavita es la fase más común. Frecuentemente presenta maclas polisintéticas bien desarrolladas, por lo general paralelas a la elongación de los cristales. Muchos de estos cristales son, en realidad, agregados de exsoluciones que representan intercrecimientos de desmezcla de gustavita $\mathrm{Gu}_{60}$ con $\mathrm{Gu}_{95}$. Esta composición corresponde con una composición inicial de aproximadamente $\mathrm{Gu}_{75}$, de alta temperatura. Excepcionalmente estas lamelas de exsolución se disponen siguiendo la dirección de las capas tipo galena, de manera que dibujan claramente la estructura cristalina ordenada de la gustavita (Lám. 3.26) formada por la alternancia de estas capas con otras discontinuas de prismas trigonales de $\mathrm{Pb}$. 


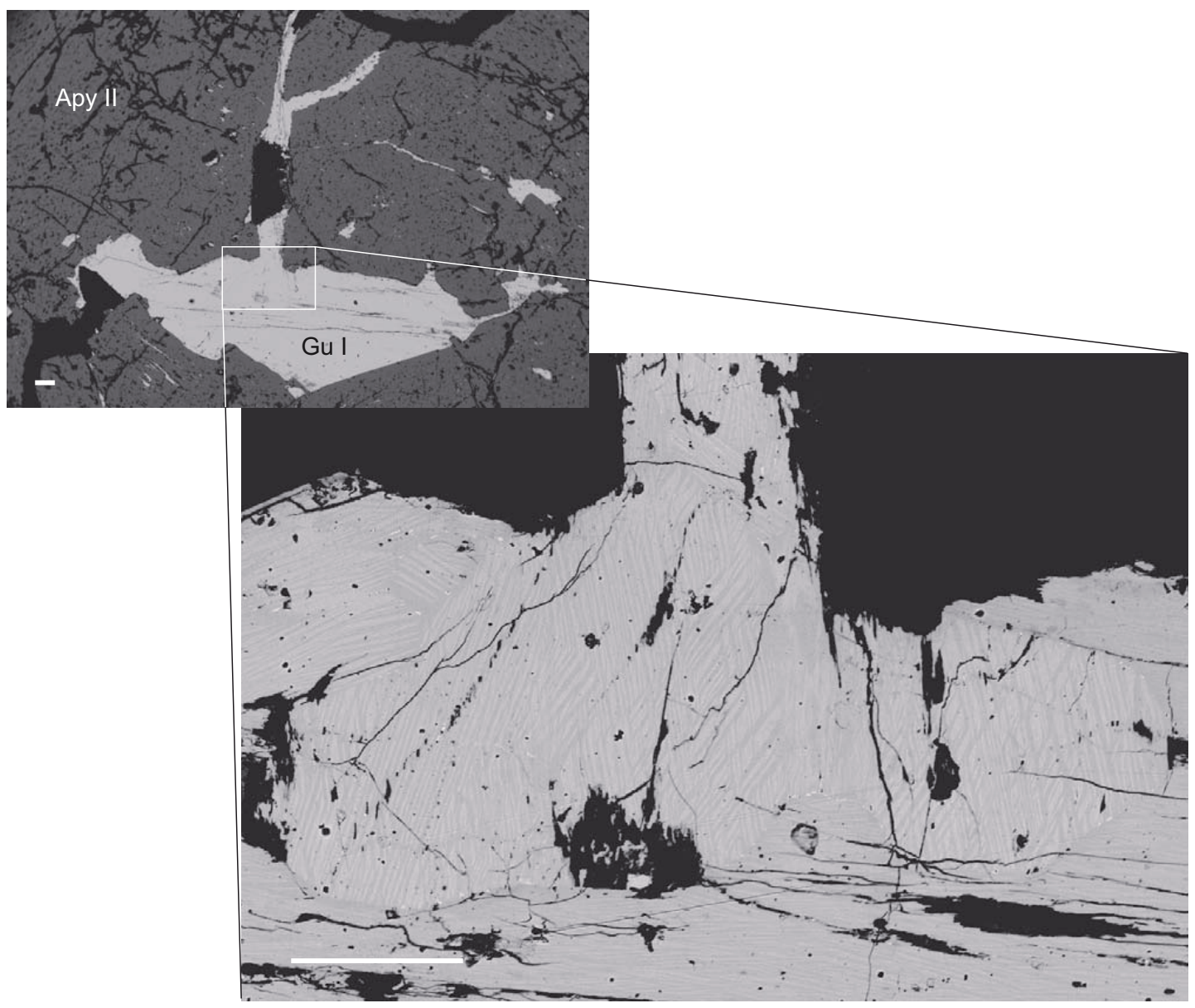

Lám. 3.26. Microfotografías electrónicas de la gustavita I rellenando las fracturas de la arsenopirita II en una vena de cuarzo de la mina Teso de la Matanza. En detalle se aprecian las abundantes lamelas de exsolución de $\mathrm{Gu}_{60}$ (gris claro) con $\mathrm{Gu}_{95}$ (gris oscuro) dibujando la estructura cristalina de la lilianita. Escala gráfica: 100 $\mu \mathrm{m}$.

La gustavita presenta una importante dispersión en torno a la línea de $\mathrm{N}=4$ variando entre ${ }^{3,6} \mathrm{~L}$ y ${ }^{4,7} \mathrm{~L}$, aunque por lo general la mayoría se localizan por encima de $\mathrm{N}=4$. Su composición varía notablemente a lo largo de la línea de igual $\mathrm{N}$, de manera que se compone de 8,21$14,67 \%$ at. de $\mathrm{Pb}, 5,62-9,28 \%$ at. de $\mathrm{Ag}$ y $21,14-27,0 \%$ at. de $\mathrm{Bi}$, con cantidades a veces significativas de $\mathrm{Cu}$ (hasta 1,55 \% at.). El porcentaje de sustitución de la serie varía entre 67 y 100 \% del término extremo de la solución sólida lilianita-gustavita, aunque la mayoría de los análisis se concentran en torno a $\mathrm{Gu}_{90-100}$ (Fig. 3.39a,b,c), que representa la máxima sustitución de $\mathrm{Ag}+\mathrm{Bi} \rightarrow 2 \mathrm{~Pb}$ de la lilianita. A pesar de que el término menos sustituido es de $\mathrm{Gu}_{67}$, seguramente existan términos con una sustitución inferior de lilianita en las muestras ya que, analizando en detalle las zonas de menor sustitución, se aprecia que existe otro patrón adicional de lamelas menores de $1 \mu \mathrm{m}$ (Lám. 3.27a). Este pequeño tamaño hace imposible su caracterización completa, de manera que el resultado obtenido probablemente sea una mezcla de términos con mayor o menor sustitución. La mayoría de los análisis muestran contenidos relativamente elevados en $\mathrm{Sb}$ que suponen hasta $2,4 \% \mathrm{~mol}$ de $\mathrm{Sb} /(\mathrm{Sb}+\mathrm{Bi})$. De esta manera, la fórmula estructural calculada para esta fase varía desde $\mathrm{Pb}_{1,69} \mathrm{Ag}_{0,71} \mathrm{Bi}_{2,71} \mathrm{~S}_{6,11}$ hasta próxima a la fórmula ideal $\mathrm{PbAgBi}_{3} \mathrm{~S}_{6}$. 

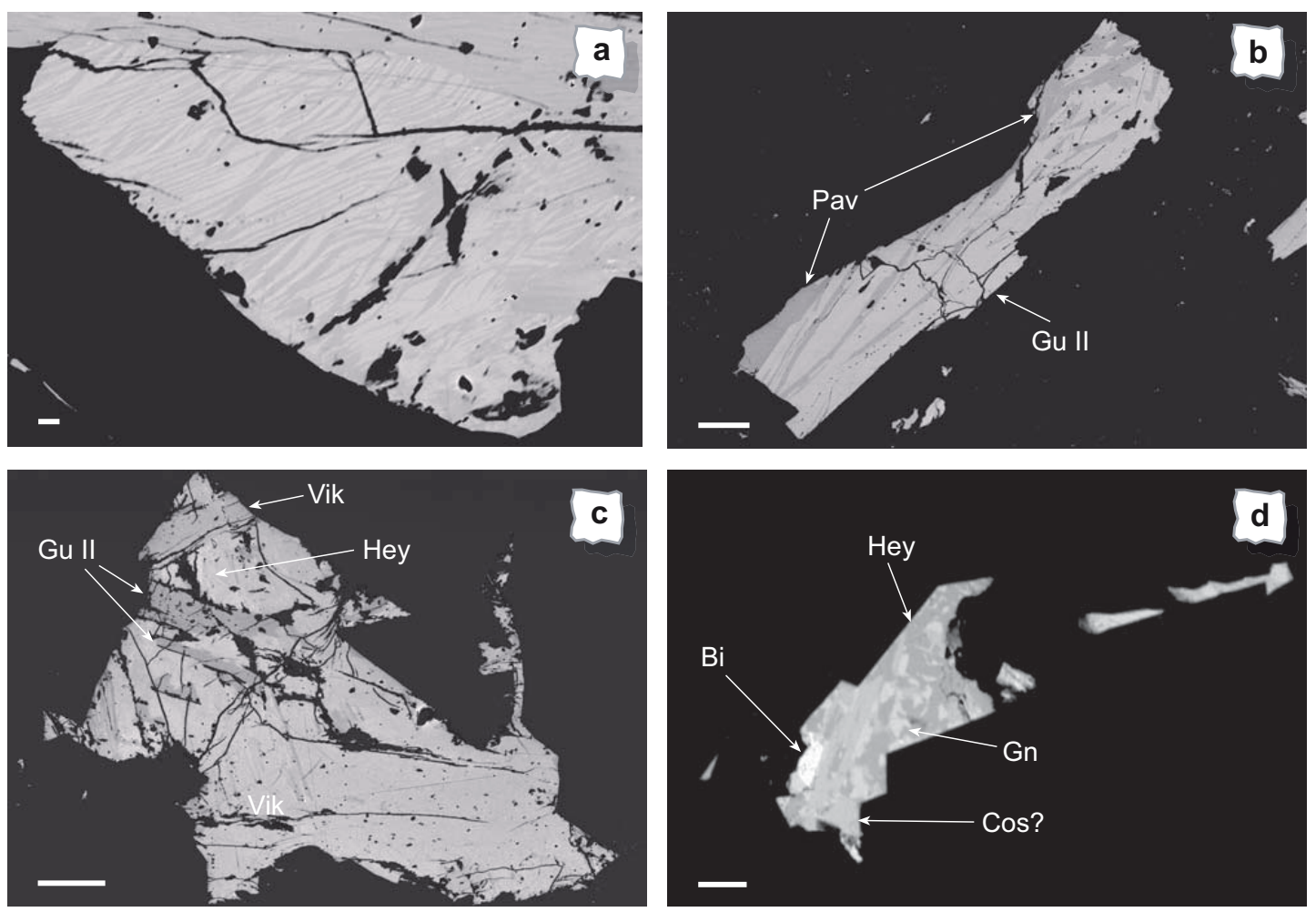

Lám. 3.27. Microfotografías electrónicas de las sulfosales de $\mathrm{Bi}-\mathrm{Pb}-\mathrm{Ag}$ en las venas de cuarzo de las minas Salmantina (d) y Teso de la Matanza ( $a$, b y c): a) detalle de las abundantes lamelas de exsolución de $\mathrm{Gu}_{60}$ (gris claro), en el que se aprecia otro patrón adicional de lamelas de tamaño inferior a $1 \mu \mathrm{m}$, con Gu ${ }_{95}$ (gris oscuro); b) agregado de cristales de pavonita y gustavita II, sin exsoluciones, en los huecos de la arsenopirita II; c) agregado de cristales de gustavita II, vikingita y heyrovskyita en los huecos de la arsenopirita II; d) descomposición de heyrovskyita en galena y cosalita?. Escala gráfica: a y d) $10 \mu \mathrm{m}$; b y c) $100 \mu \mathrm{m}$.

Dada la gran cantidad de datos analíticos que se dispone de estas fases minerales (Anexo III), estas se han proyectado por minas y por cada una de las muestras analizadas. En el triángulo composicional de las lilianitas se observa una serie de sustitución aparentemente continua a lo largo de la línea N=4 (Fig. 3.39a). Sin embargo, Makovicky y Karup-Møller (1977b) demostraron mediante análisis de microsonda y difracción de rayos $X$ sobre muestras naturales que hay un hueco de miscibilidad entre aproximadamente el $60 \%$ at. de sustitución en lilianitas (ortorrómbicas) y aproximadamente el $90 \%$ at. en gustavitas (monoclínicas) a la temperatura en que se produce la deposición hidrotermal. Esto sugiere que los resultados intermedios que se observan en el triángulo de la figura 3.39a representan mezclas o intercrecimientos de exsolución no resueltos en los análisis de microsonda y que el hueco de miscibilidad puede ser menor para temperaturas de formación elevadas. Estos resultados corresponderían, por tanto, a una gustavita I formada a una temperatura relativamente elevada, asociada a los inicios de la cristalización del cuarzo III y que rellena grietas y huecos en la arsenopirita (Lám. 3.26). Por otro lado, buena parte de los resultados se concentran sobre 100-90 \% (gustavita) y algunos se hallan cerca de la composición esperada de lilianita con máxima sustitución (Fig. 3.39b,c), de modo que estaríamos ante una segunda generación de gustavita de menor temperatura que la primera y que cristalizaría durante las últimas fases de precipitación del cuarzo III (Fig. 3.43) rellenando huecos y grietas en la arsenopirita o en cuarzo (Láms. 3.27b,c,d y 3.28). 


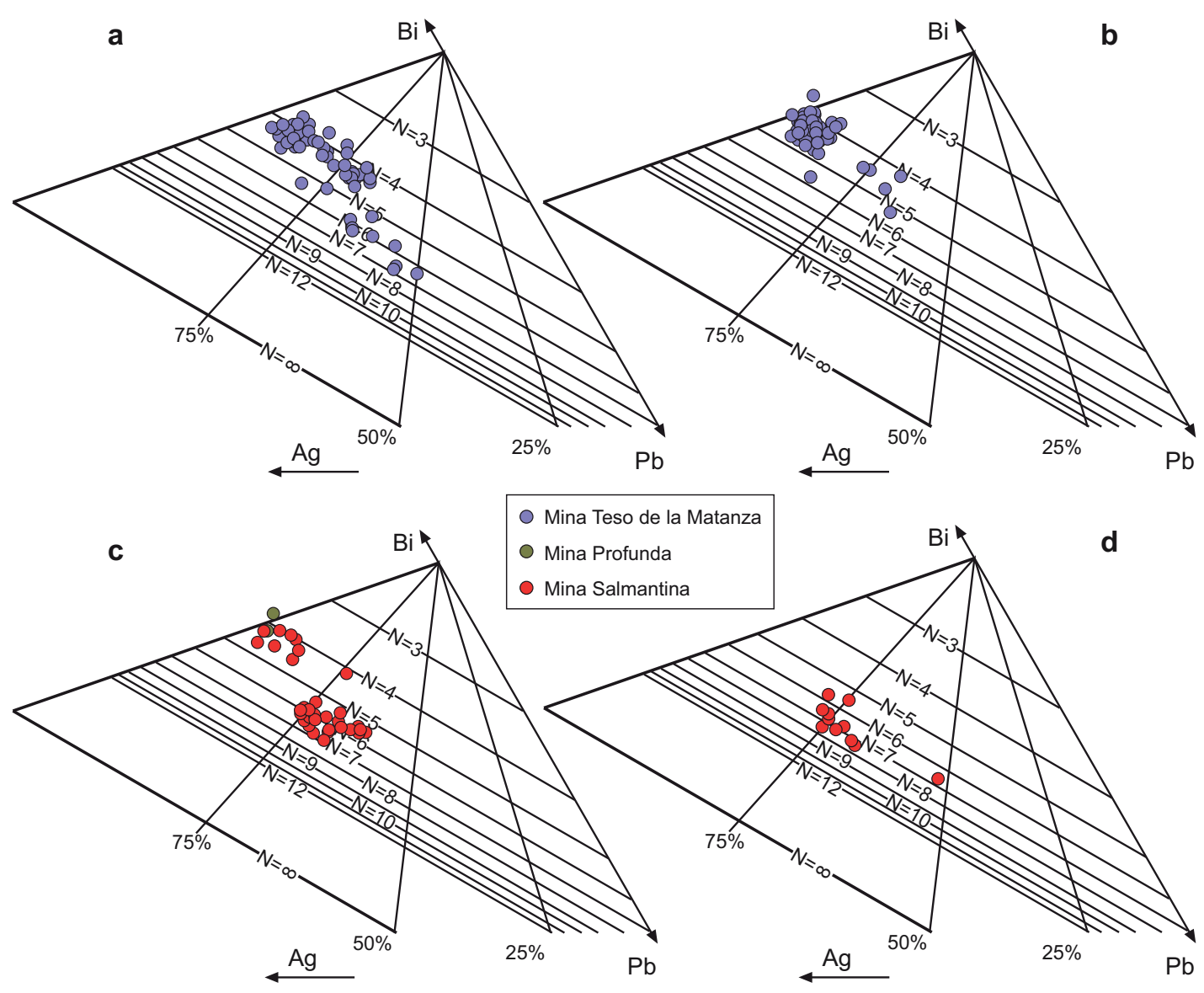

Fig. 3.39. Representación de los diferentes homólogos de la lilianita identificados en las venas intragraníticas encajadas en el LG y las AB con turmalina en las minas Salmantina, Profunda y Teso de la Matanza. Obsérvese la tendencia al enriquecimiento progresivo en $\mathrm{Pb}$ de todas ellas.

Vikingita y heyrovskyita son fases accesorias que normalmente se encuentran asociadas a gustavita, bien en forma de finas lamelas o bien como cristales de mayor tamaño con bordes irregulares y muy difusos respecto a la gustavita II, por lo que las relaciones con esta no están muy claras (Lám. 3.27c) y podrían considerarse más o menos simultáneas (Fig. 3.43). En ocasiones puede darse el caso contrario en que la gustavita es parte accesoria en la asociación mientras que vikingita y heyrovskyita se presentan como cristales aciculares individuales o agregados cristalinos de hasta $2 \mathrm{~mm}$ cuyos bordes a veces muestran signos de disolución parcial por el cuarzo que los rodea.

Los cristales de heyrovskyita analizados corresponden a un término rico en $\mathrm{Ag}$ y $\mathrm{Bi}$ que son muy similares a los analizados por Karup-Møller y Makovicky (1981) y Klomínský et al. (1971). Los valores de $\mathrm{N}$ varían entre 6,40 y 7,44 y existe un rango de sustitución $\mathrm{Bi}+\mathrm{Ag} \rightarrow 2 \mathrm{~Pb}$ de entre 50 y $77 \%$ mol del término final de la serie rico en Ag y Bi. Además, se observan cantidades traza de $\mathrm{Sb}$ en las estructura de este mineral que llegan a suponer hasta un $2 \% \mathrm{~mol}$ de $\mathrm{Sb} /(\mathrm{Sb}+\mathrm{Bi})$. La fórmula media de la heyrovskyita, calculada según Makovicky y Karup-Møller (1977a), es $\mathrm{Pb}_{2,49} \mathrm{Bi}_{3,61} \mathrm{Ag}_{1,61} \mathrm{~S}_{8,72}$. 
Parte de los cristales analizados son homogéneos aunque algunos de ellos, al analizarlos con el microscopio electrónico, se componen principalmente de tres fases. Sin embargo, el reducido tamaño de las distintas fases minerales, a veces inferior a las $50 \mu \mathrm{m}$, ha complicado su identificación aunque los análisis indican que al menos dos de ellas son heyrovskyita y galena. En el triángulo composicional se aprecia cómo algunos de estos análisis se proyectan desplazados hacia el polo del Pb (Fig. 3.39a,c,d), que corresponde con la galena, lo que indica que probablemente se trate de una mezcla de galena con heyrovskyita. Si además se encuentran texturas de reemplazamiento tales como las de la lámina $3.27 \mathrm{~d}$, similares a los descritos por Klomínský et al. (1971), y la galena tiene contenidos significativos de Bi y Ag, como es el caso, es posible que la tercera fase desconocida sea cosalita y que se trate, por tanto, de un reemplazamiento tardío de los cristales de heyrovskyita por cosalita y galena. No obstante, no hay datos químicos acerca de la tercera fase que lo abalen, aunque Klomínský et al. (1971) ya confirmaron que sulfosales del tipo de la heyrovskyita son metaestables a baja temperatura y Godovikov (1972) estableció la temperatura de $400 \pm 25{ }^{\circ} \mathrm{C}$ por debajo de la cual se produce la disociación de heyrovskyita sintética en galena y cosalita.

La vikingita analizada es similar composicionalmente a la estudiada por Makovicky et al. (1992), donde también se asocia con heyrovskyita y gustavita, con lamelas exsueltas de lilianita. Análogamente a lo que se observa en la heyrovskyita, la composición de la vikingita corresponde con un término rico en $\mathrm{Ag}$ y $\mathrm{Bi}$, con lo que la $\mathrm{N}$ calculada para esta fase varía entre $\mathrm{N}=5,2$ y $\mathrm{N}=6,3$. Proyectado en el triángulo composicional (Fig. 3.39a,b.c.d), se observa una variación entre 56 y $78 \%$ mol de sustitución del término final de la serie rico en $\mathrm{Ag} \mathrm{y} \mathrm{Bi}$, de modo que la fórmula media calculada para la vikingita en estas muestras es $\mathrm{Pb}_{2,17} \mathrm{Ag}_{1,21} \mathrm{Bi}_{3,29} \mathrm{~S}_{7,75}$, que se encuentra dentro del rango definido por Makovicky y Karup-Møller (1977b).

De la proyección de estos resultados en los diagramas de la figura 3.39 se deduce una amplia variación composicional de las fases minerales, no solo entre distintas minas del yacimiento sino, incluso, entre diferentes muestras dentro de la misma mina, como ocurre en Teso de la Matanza, donde en unas muestras se encuentra gustavita I junto con vikingita y heyrovskyita menos comunes, mientras que en otras únicamente aparece gustavita II asociada, en este caso, a otros homólogos de la pavonita. Por su parte, en la mina Salmantina son poco frecuentes los términos de gustavita II y, sin embargo, dominan composiciones de vikingita y heyrovskyita que evolucionan hacia el polo del Pb. Esto indicaría la existencia de diferencias composicionales en los fluidos hidrotermales causantes de la mineralización incluso a pequeña escala.

\section{Homólogos de la pavonita}

Son menos abundantes que las lilianitas y se encuentran en cristales an- a subhedrales de hasta $300 \mu \mathrm{m}$ intercrecidos con estas (Láms. 3.27b y $3.28 \mathrm{a}, \mathrm{b}, \mathrm{c}$ ), a veces con bordes parcialmente disueltos. Menos frecuentemente aparecen como pequeños cristales anhedrales en el cuarzo o diseminados en la arsenopirita. Ocasionalmente estas fases también se encuentran en pequeñas inclusiones sub- a euhedrales no superiores a $20 \mu \mathrm{m}$ en la esfalerita. Los homólogos más abundantes son la pavonita $(N=5)$, la dantopaita $(N=6)$ y la benjaminita $(N=7)$, mientras que la mummeita $(\mathrm{N}=9)$ solo aparece de manera puntual. Aunque son más comunes en las 

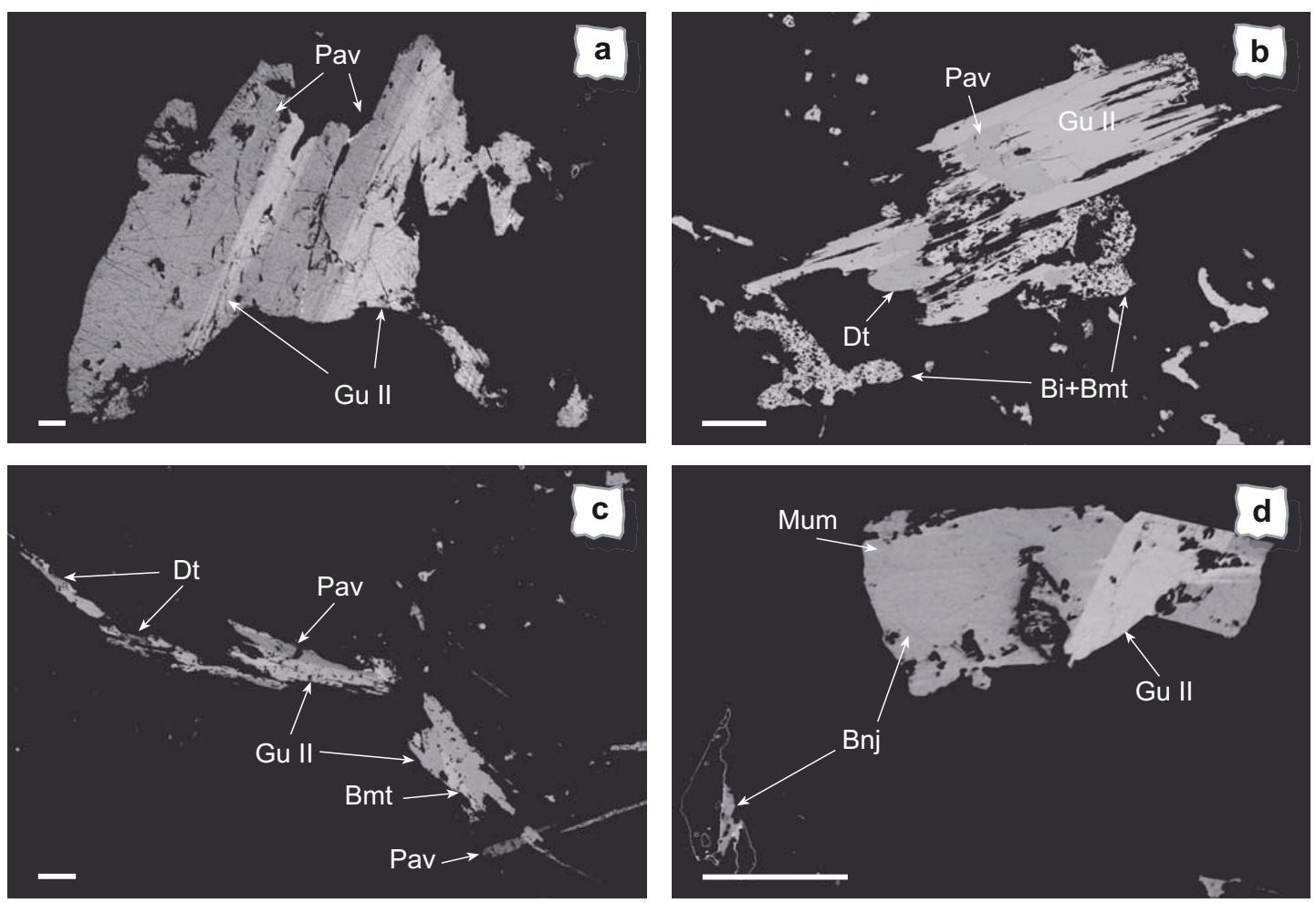

Lám. 3.28. Microfotografías electrónicas de las sulfosales de Bi-Pb-Ag en las venas de cuarzo de la mina Teso de la Matanza: a) intercrecimiento de pavonita con gustavita II en la arsenopirita II; b) asociación de pavonita y dantopaita en el interior de gustavita II. La pérdida de azufre de las anteriores fases da lugar a la cristalización de Bi nativo; c) gustavita II asociada a pavonita y dantopaita en cuarzo. Obsérvese el crecimiento de la gustavita sobre la pavonita, lo que demuestra el carácter precoz de esta última; d) agregado de gustavita II con benjaminita y mummeita en un hueco de arsenopirita II. Escala gráfica: a y c) $10 \mu \mathrm{m} ; \mathrm{b}$ y d) $100 \mu \mathrm{m}$.

venas encajadas en el LG y las AB (minas Salmantina y Teso de la Matanza), algunos de estos cristales se han identificado en las venas del GE.

Las relaciones entre homólogos de la pavonita y de la lilianita no son muy claras. En ocasiones parece que las primeras crecen a lo largo de determinados planos cristalográficos de cristales previos de gustavita (Lám. 3.27b). Sin embargo, en otras muestras se encuentran cristales de gustavita sobreimpuestos a otros anteriores de pavonita (Lám. 3.28c) y se aprecian restos de cristales de pavonita en el interior de agregados de cristales de homólogos de la lilianita, lo que sugiere que esta podría ser anterior a la cristalización de la gustavita II (Fig. 3.43).

La composición química de la pavonita (Anexo III) presenta notables variaciones en las cantidades de $\mathrm{Pb}, \mathrm{Bi}$ y Ag, con contenidos de $\mathrm{Cu}$ que no superan el $2 \%$ en peso. Sin embargo, a pesar del rango de sustitución de $\mathrm{Bi}+\mathrm{Ag}$ por $\mathrm{Pb}+\mathrm{Cu}$, la mayoría de los análisis indican términos de pavonitas próximos a la fórmula ideal $\mathrm{Ag}_{4} \mathrm{Bi}_{12} \mathrm{~S}_{20}\left(\mathrm{Cu}_{0,39} \mathrm{Ag}_{3,60} \mathrm{~Pb}_{0,68} \mathrm{Bi}_{11,62} \mathrm{~S}_{20}\right)$. El rango de variación de la $\mathrm{N}$ calculada para esta fase oscila entre ${ }^{4,6} \mathrm{P}$ y ${ }^{5,4} \mathrm{P}$ (Fig. 3.40).

Varios de estos análisis no se ajustaban bien a la línea $\mathrm{N}=5$, concretamente aquellos cuya $\mathrm{N}$ oscila entre 5,5 y 5,9 que se alejan bastante de la línea de la pavonita y cuya composición difiere notablemente de esta. Recalculando las proporciones atómicas para 22 átomos de 
$\mathrm{S}$ la fórmula química sería $\mathrm{Cu}_{0,40} \mathrm{Ag}_{4,34} \mathrm{~Pb}_{0,60} \mathrm{Bi}_{12,69} \mathrm{~S}_{22}$, lo que corresponde a un homólogo de la pavonita de $\mathrm{N}=6$, que ha sido recientemente aprobado por la IMA, la dantopaita (Makovicky et al., 2010) (Lám. 3.28b,c).

La benjaminita (Lám. 3.28d), al igual que ocurre con la pavonita, presenta un amplio rango de sustitución de $\mathrm{Bi}+\mathrm{Ag}$ por $\mathrm{Pb}+\mathrm{Cu}$. Así, la fórmula para esta fase varía desde $\mathrm{Cu}_{0,01} \mathrm{Ag}_{4,28} \mathrm{~Pb}_{2,93} \mathrm{Bi}_{12,62} \mathrm{~S}_{24}$ a $\mathrm{Cu}_{0,31} \mathrm{Ag}_{5,67} \mathrm{~Pb}_{0,72} \mathrm{Bi}_{13,54} \mathrm{~S}_{24}$. Estas variaciones composicionales se reflejan en el triángulo composicional de la figura 3.40, donde se aprecia que los análisis de este mineral se distribuyen ampliamente a lo largo de la línea $\mathrm{N}=7$ en función del contenido en $\mathrm{Cu}$ y, sobretodo, en $\mathrm{Pb}$ de la benjaminita. El rango de variación de la $\mathrm{N}$ calculada para esta fase es muy pequeño variando entre ${ }^{6,5} \mathrm{P}$ y ${ }^{7,2} \mathrm{P}$ y se ajusta bastante bien al campo definido por Karup-Møller y Makovicky (1992).

La mummeita es muy escasa y de muy pequeño tamaño en estas muestras. Solamente se ha identificado en la mina Teso de la Matanza asociada a benjaminita y a otros homólogos de la lilianita (Lám. 3.28d). Su composición es similar a la de la mummeita identificada por Karup-Møller y Makovicky (1992), aunque en este caso no se han observado exsoluciones de mummeita rica en $\mathrm{Cu}$ y $\mathrm{Pb}$. A pesar de que la $\mathrm{N}$ calculada a partir de los análisis químicos varía entre ${ }^{8} \mathrm{P} \mathrm{y}^{8,9} \mathrm{P}$, la proyección de esta fase en el diagrama triangular (Fig. 3.40) corresponde con el campo de la mummeita descrito por Karup-Møller y Makovicky (1992) y su fórmula media calculada es $\mathrm{Cu}_{1,23} \mathrm{Ag}_{5,30} \mathrm{~Pb}_{2,88} \mathrm{Bi}_{13,34} \mathrm{~S}_{26}$, para $\mathrm{N}=8$ y $\mathrm{Cu}_{1,34} \mathrm{Ag}_{6,05} \mathrm{~Pb}_{3,21} \mathrm{Bi}_{14,06} \mathrm{~S}_{28}$, para $\mathrm{N}=9$.

Frecuentemente la descomposición tanto de pavonitas como de lilianitas provoca la formación de Bi nativo, lo que libera el plomo y la plata necesarios para la precipitación tardía de galena y matildita (Lám. 3.28b).

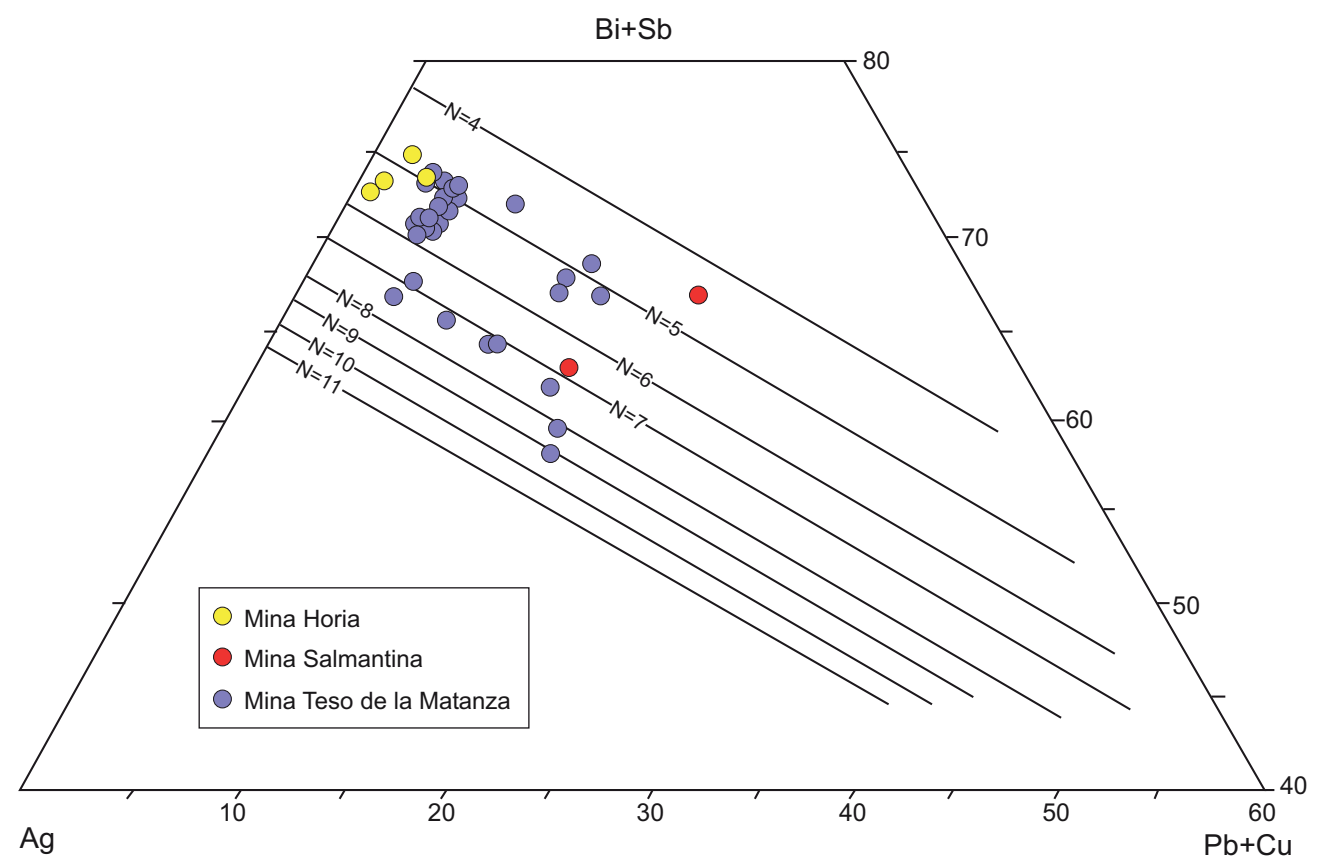

Fig. 3.40. Representación de los homólogos de la pavonita identificados en las venas intragraníticas encajadas en el GE, el LG y las AB con turmalina en las minas Horia, Salmantina y Teso de la Matanza. 

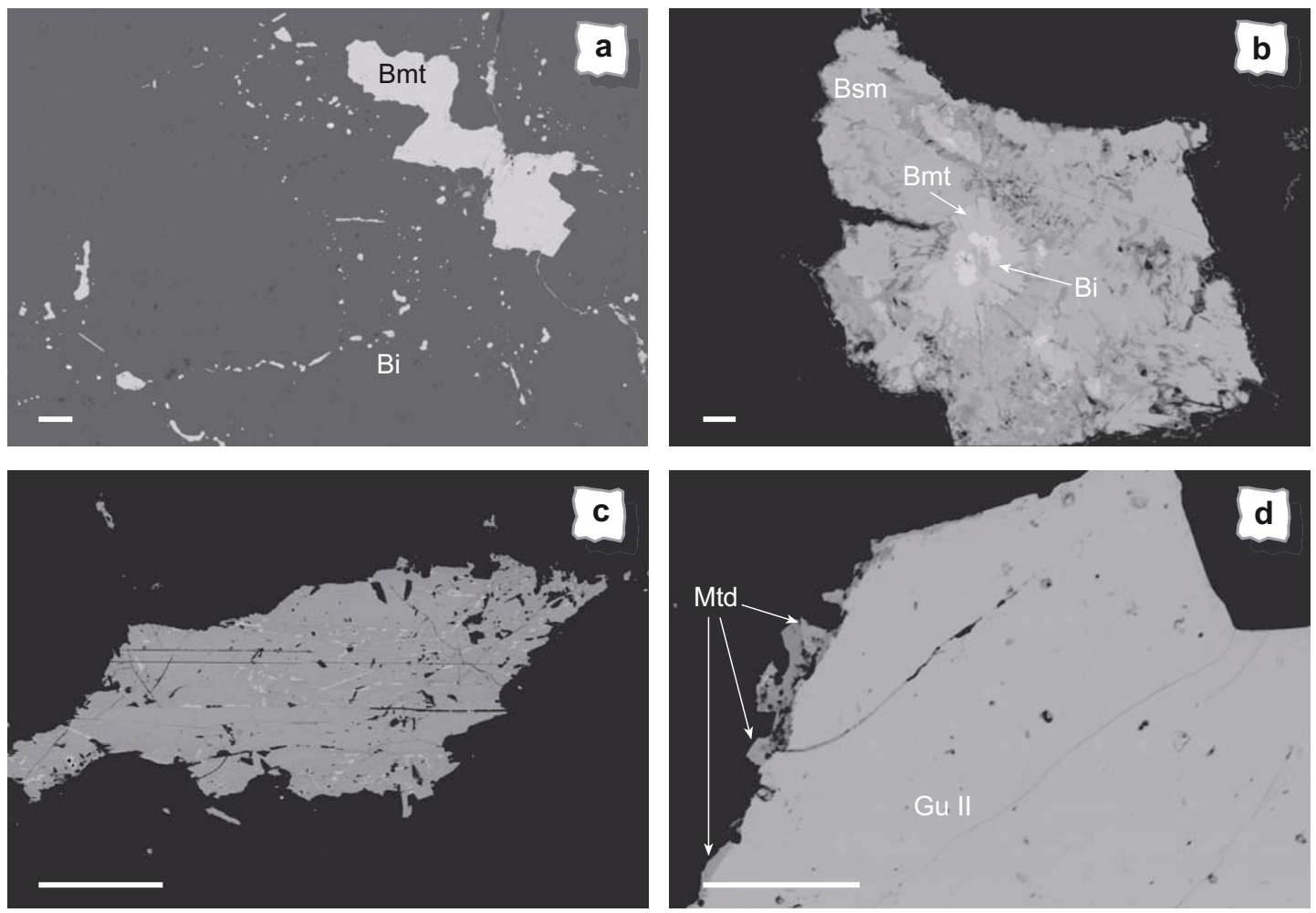

Lám. 3.29. Microfotografías electrónicas de: a) Bi nativo y la bismutinita en las fracturas del cuarzo en la mina Teso de la Matanza; b) detalle de la asociación bismutinita y Bi nativo, este último reemplazado por bismita en la mina Profunda; c) fracturas tardías en los homólogos de la lilianita y la pavonita de la mina Salmantina, ocupadas por galena como producto de descomposición; d) matildita en los borde de alteración de gustavita II en las venas de la mina Teso de la Matanza. Escala gráfica: $100 \mu \mathrm{m}$, salvo b) $10 \mu \mathrm{m}$.

La presencia de Au en la composición de estas fases minerales es poco frecuente, con valores que llegan a superar las 1.000 ppm en algunos cristales de pavonita, mientras que en las lilianitas los valores máximos alcanzados rondan las 4.200 ppm. Sin embargo, el número total de análisis con contenidos en Au por encima de las 600 ppm es inferior a un 10 \% (Anexo III).

\section{Bismuto nativo y bismutinita}

Suelen ser fases tardías que precipitan a lo largo de grietas tanto en el cuarzo como en el interior de cristales de arsenopirita (Lám. 3.29a). El Bi nativo se encuentra mayoritariamente en diminutas gotas o droplets de hasta $50 \mu \mathrm{m}$ de diámetro o con formas anhedrales que a veces presentan bordes dentados. Suele rellenar los pequeños huecos que se encuentran dentro de la arsenopirita y que están distribuidos de forma irregular, tanto en las zonas de borde de los cristales como en las grietas que contienen y, ocasionalmente, también se encuentran en la esfalerita. En ambos casos el Bi nativo está normalmente asociado a calcopirita, pirrotita, argentita, matildita, galena y sulfosales de Bi-Pb-Ag (Lám. 3.23d). También es frecuente encontrar el Bi nativo en grietas del cuarzo I y dentro de inclusiones fluidas secundarias que se encuentran en los cristales de dicho cuarzo, como un sólido, lo que apoyaría su origen tardío (Fig. 3.43). Además de esto, el Bi nativo puede ser el resultado de la alteración de las sulfosales de $\mathrm{Bi}-\mathrm{Pb}-\mathrm{Ag}$ de manera que, a veces, únicamente precipita Bi directamente a partir de gustavita como consecuencia de una disminución de la aS (Lám. 3.28b). Por su parte, la 
bismutinita se encuentra en agregados cristalinos de hasta $300 \mu \mathrm{m}$ de tamaño, asociados frecuentemente al Bi nativo (Lám. 3.29b).

En la composición química del Bi nativo destacan contenidos relativamente elevados de Fe, $\mathrm{Pb}$, As y $\mathrm{S}$ que pueden proceder de contaminación por los minerales que lo contienen, si bien el Fe y el S se correlacionan bastante bien con el Bi (Fig. 3.41a,b) lo que indicaría cierta sustitución del Bi por ambos elementos. Además, se observan contenidos traza de Au (hasta $6.440 \mathrm{ppm}$ ), Ag (hasta $1.880 \mathrm{ppm}$ ), Sb (hasta $2.490 \mathrm{ppm}$ ), Se (hasta $2.500 \mathrm{ppm}$ ) y Te (hasta $2.300 \mathrm{ppm})$.
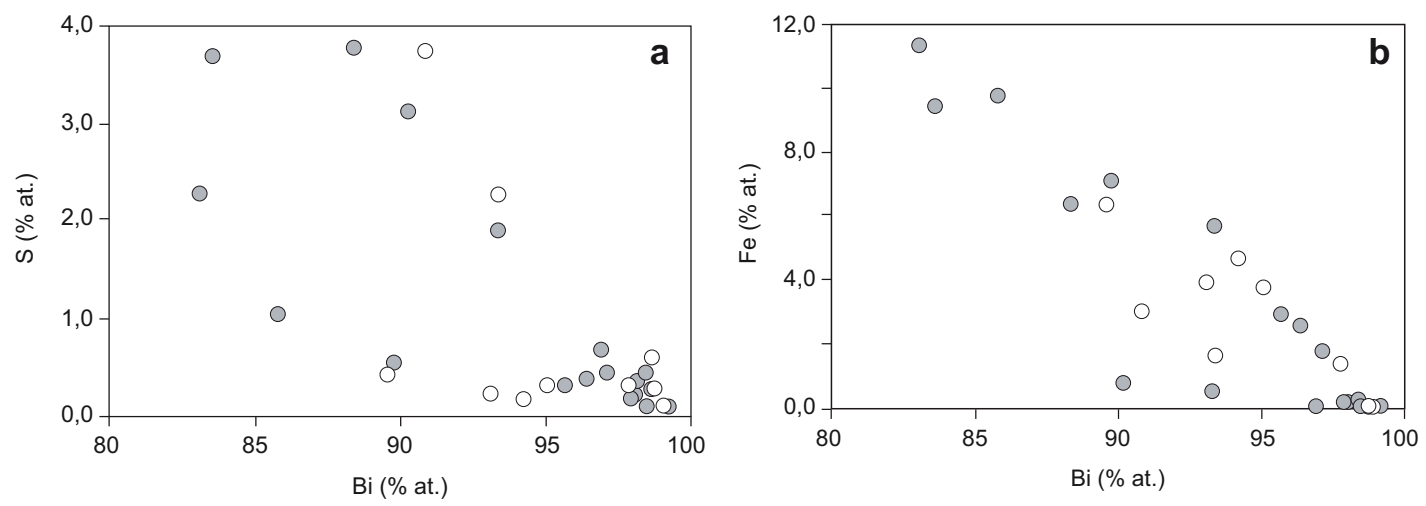

Bi en las venas del GE $\quad$ Bi en las venas del $L G$ y las $A B$

Fig. 3.41. Diagramas de variación de: a) Bi vs. S (en \% at.); y b) Bi vs. Fe (en \% at.) en el Bi nativo de las venas de cuarzo intragraníticas.

Por su parte, la bismutinita corresponde a los términos extremos más ricos en Bi de la solución sólida bismutinita-aikinita con muy poca variabilidad composicional. La fórmula ideal para esta serie es $\mathrm{Cu}_{\mathrm{x}} \mathrm{Pb}_{\mathrm{y}} \mathrm{Bi}_{8-1 / 2(x+y)} \mathrm{S}_{12}$ (Makovicky y Makovicky, 1978) en la que $\mathrm{x} \approx \mathrm{y}$, de manera que el porcentaje del miembro correspondiente de la solución sólida se calcula mediante la fórmula:

$$
n_{\text {aik }}=\frac{25(x+y)}{2}
$$

Los valores de $\mathrm{n}_{\text {aik }}$ calculados son muy bajos en casi todas las muestras analizadas, con lo que la mayoría son términos extremos de bismutinita variando entre $n_{\text {aik }}=0$ y $n_{\text {aik }} \approx 5,4$ (Anexo III). Sin embargo, algún cristal de bismutinita de la mina Teso de la Matanza presenta valores más elevados de hasta $\mathrm{n}_{\text {aik }} \approx 11$, que estarían próximos al término pekoita. La presencia de estas bismutinitas más ricas en $\mathrm{Cu}$ y $\mathrm{Pb}$ coincide, además, con las muestras que contienen los homólogos de pavonita con mayor cantidad de Cu en su composición. Buena parte de los cristales contienen bajas concentraciones de $\mathrm{Se}$ y $\mathrm{Sb}$ y varios de ellos muestran contenidos relativamente elevados de $\mathrm{Fe}$, algunos incluso superiores al $1 \%$ en peso, la mayoría del cual se considera que es necesario por estequiometría en sustitución del $\mathrm{Cu}$, de modo que el exceso de Fe se atribuiría a la presencia de minerales adyacentes ricos en este elemento 
(Makovicky y Mackovicky, 1978), como la pirita y la arsenopirita. Ocasionalmente se observa la presencia de trazas de Au en su composición (hasta 2.370 ppm).

\section{Solución sólida galena-matildita}

Los minerales de esta solución sólida son fases tardías (Fig. 3.43). Es frecuente encontrar la galena sellando microfracturas en los cristales de homólogos de lilianita (Lám. 3.29c) o de pavonita, o bien en inclusiones dentro de la esfalerita. En cambio, la matildita se presenta en cristales anhedrales de tamaño micrométrico incluidos en la arsenopirita I y II de las venas del $L G$ y las $A B$, aunque ocasionalmente puede ser un producto de alteración de gustavita cristalizando a lo largo de grietas o bordes (Lám. 3.29d).

En el triángulo composicional Ag-Bi-Pb (Fig. 3.42) se aprecia una pequeña dispersión de los análisis de matildita en la línea divariante $\mathrm{Ag}-\mathrm{Bi}$, de manera que su composición presenta escasas variaciones respecto de la fórmula ideal, con contenidos en Ag que varían entre 0,90 hasta 1,04 apfu y en $\mathrm{Bi}$ entre 0,91 y 1,10 apfu, mientras que el $\mathrm{Pb}$ solo aparece en trazas inferiores a 0,02 apfu y el Au alcanza hasta 989 ppm.

Por su parte, la galena varía ligeramente sobre la línea $\mathrm{N}=\infty$ de los homólogos de la lilianita (Fig. 3.42) presentado una composición próxima a la ideal en la mayoría de los cristales analizados, con contenidos en $\mathrm{Pb}$ que varían entre 1,64 y 1,95 apfu y con trazas de Ag y $\mathrm{Bi}$. Solamente los cristales de galena que derivan de la descomposición de heyrovskyita en la mina Salmantina presentan mayores contenidos en $\mathrm{Ag}$ (hasta 0,13 apfu) y Bi (hasta 0,10

$\mathrm{Bi}$

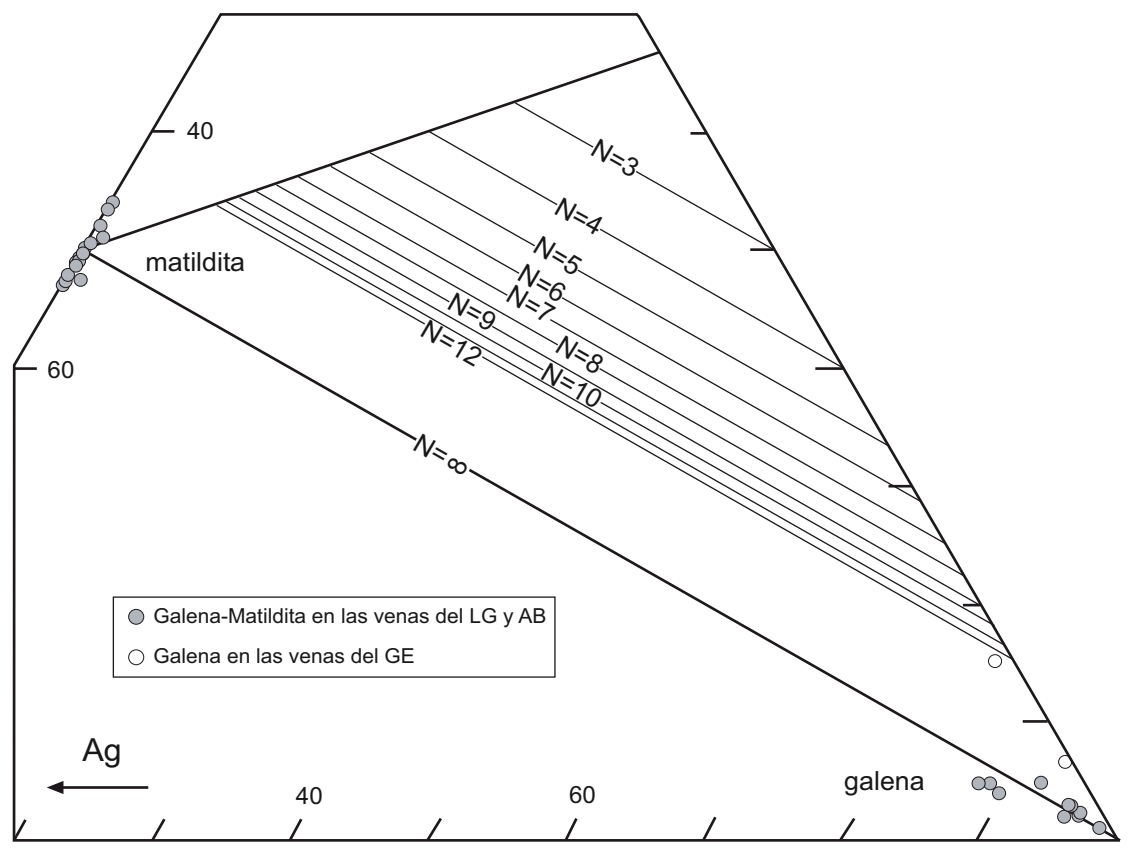

$\mathrm{Pb}$

Fig. 3.42. Diagrama triangular Ag-Bi-Pb de Makovicky y Karup-Møller (1977b) con la representación de la galena y la matildita analizadas a lo largo de la línea $\mathrm{N}=\infty$. 
apfu), mientras que los valores elevados de estos elementos en las venas del GE de la mina Horia son consecuencia de contaminación de los minerales adyacentes. Solo puntualmente se han observado contenidos elevados en Au (3.730 ppm).

\section{Argentita}

Se trata de fases minerales de hasta $6 \mu \mathrm{m}$ de tamaño, generalmente redondeadas, aunque se aprecian caras cristalinas en algunos granos. Al microscopio petrográfico presenta un color gris oscuro con un bajo relieve y se encuentra asociada al Bi nativo o a la pirrotita como una de las múltiples inclusiones dentro de la arsenopirita. Químicamente estas fases contienen entre 1,89 y 1,93 apfu de Ag, salvo uno de los análisis que supera los 2 apfu. Destacan contenidos en Sb de hasta 0,03 apfu sustituyendo al S y en Au de hasta 6.423 ppm.

\subsubsection{Productos de alteración}

La escorodita es el producto de alteración más común de la arsenopirita. Se presenta mayoritariamente en agregados de cristales de tamaño prácticamente criptocristalino y color verde en muestra de mano. En ocasiones los cristales euhedrales de escorodita adquieren un tamaño milimétrico con colores amarillentos o anaranjados bajo el microscopio (Lám. 3.19f). Su composición química depende de la paragénesis a la que se asocie, de manera que los contenidos en $\mathrm{Fe}^{3+}$ pueden variar desde 0,67 hasta más de 1 apfu, con hasta 0,23 apfu de Al como principal sustituto del $\mathrm{Fe}$, mientras que el As puede estar sustituido por hasta 0,65 apfu de $\mathrm{P}$ cuando en la paragénesis se encuentran fosfatos asociados. La covelita es el producto de alteración de la calcopirita y se presenta normalmente en masas coloformes o botroidales de tamaño de grano fino con colores azules muy vivos en luz natural. La bismita $\left(\mathrm{Bi}_{2} \mathrm{O}_{3}\right)$ se presenta como producto de alteración del Bi nativo (Lám. 3.29b) con un aspecto pulverulento de color gris oscuro y muy baja reflectividad en luz natural. Los óxidos e hidróxidos de Fe son el producto de alteración de los sulfuros. Se presentan en masas anhedrales o coloformes, a veces con texturas radiadas reemplazando $y$, ocasionalmente, pseudomorfizando a los sulfuros.

\subsubsection{Secuencia mineral}

La secuencia de precipitación mineral en las venas de cuarzo del batolito de Jálama es difícil de establecer por las relaciones texturales en ocasiones tan contradictorias que se observan en algunas de ellas. Esto es debido a que su formación, en la mayoría de los casos, responde a un proceso polifásico que conlleva la inyección de diferentes fluidos en la misma estructura. No obstante, en la figura 3.43 se establecen las relaciones cronológicas aparentemente existentes entre las distintas fases minerales identificadas en las venas de cuarzo mineralizadas, agrupándolas principalmente en cuatro fases:

Durante la primera fase se desarrolla una mineralización precoz formada principalmente por casiterita I y wolframita I asociadas al cuarzo I, además de rutilo I y pirrotita I en cantidades accesorias y, posteriormente, arsenopirita I, esfalerita I y triplita. A continuación, y tras una deformación dúctil evidente en la mayoría de las venas, se deposita la primera fase de la mineralización principal con la cristalización de casiterita II y wolframita II asociadas al cuarzo 


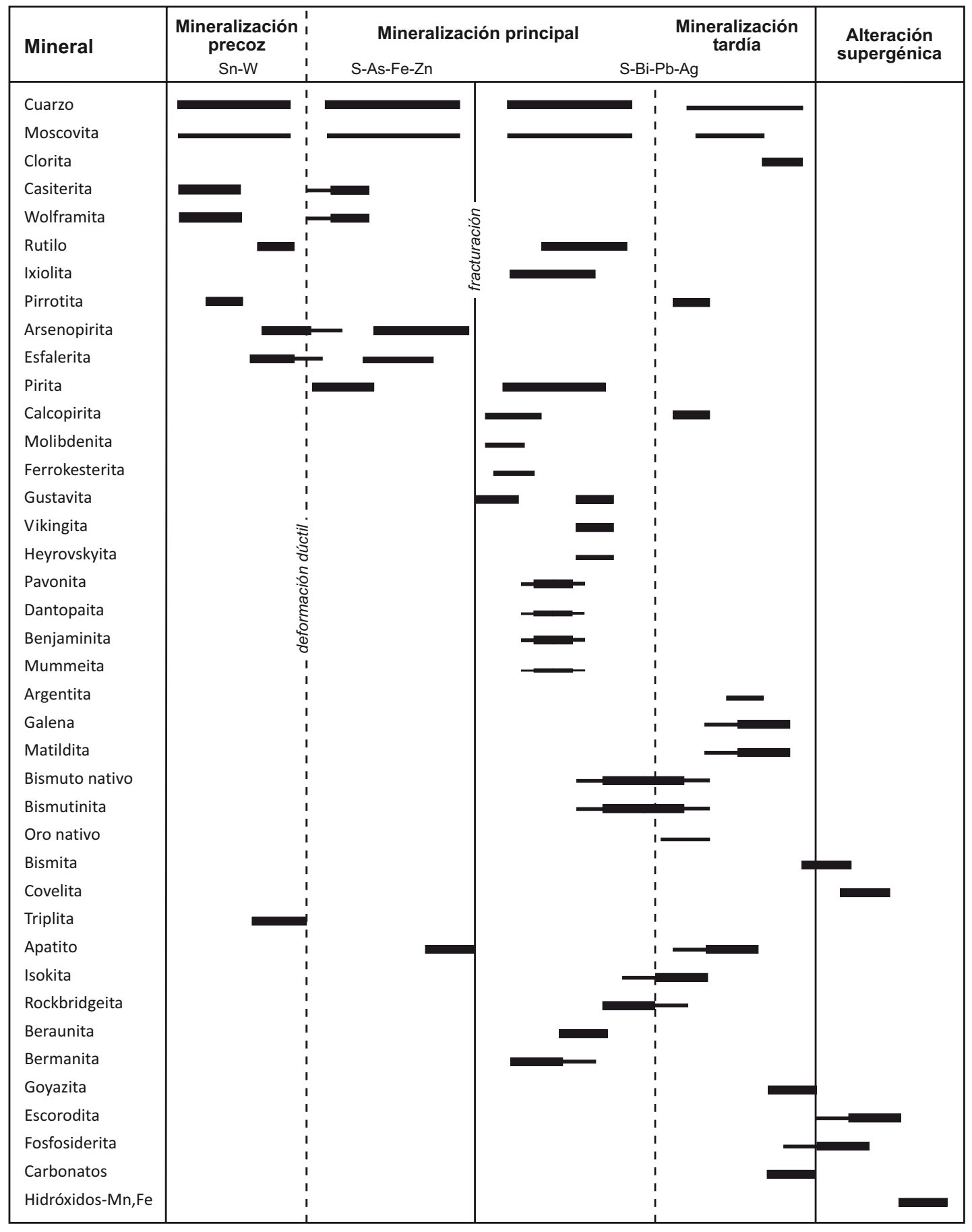

Fig. 3.43. Secuencia mineral de las venas de cuarzo con Sn-W en el batolito de Jálama.

II, seguidas de la pirita I y de la principal deposición de arsenopirita II y esfalerita II junto con el apatito, que es el fosfato que caracteriza este episodio. Seguidamente y tras un proceso de fracturación se deposita la segunda fase de sulfuros asociada al cuarzo III (pirita II, calcopirita I, molibdenita, ferrokesterita), sulfosales de Bi-Pb-Ag (homólogos de la pavonita y la lilianita) y además, la ixiolita, el rutilo II y fosfatos como la rockbridgeita, la beraunita y la bermanita. Por último, y asociada a la deposición del cuarzo IV, la clorita o los carbonatos que rellenan 
los numerosos huecos de las venas, tiene lugar la precipitación del Bi nativo y la bismutinita, además de la galena, la matildita, la argentita, el Au nativo y fosfatos como la isokita, el apatito y la goyazita. 
CAPITTULO 4

Mineralizaciones del batolito de Cadalsor Casillas de Flores 



\section{CAPÍTULO 4. MINERALIZACIONES DEL BATOLITO DE CADALSO-CASILLAS DE FLORES}

Las mineralizaciones de Sn-W asociadas a determinadas facies graníticas del batolito de Cadalso-Casillas de Flores tienen menos entidad que las del batolito de Jálama y, además, el mal estado de conservación de las labores mineras y los afloramientos ha imposibilitado su completa caracterización. Estas mineralizaciones se agrupan en dos tipos principales:

- Casiterita y óxidos de $\mathrm{Nb}$ y Ta diseminados en los diques aplíticos y pegmatíticos peribatolíticos.

- Casiterita y/o wolframita en las venas de cuarzo encajadas en las diferentes facies graníticas del batolito de Cadalso-Casillas de Flores.

\subsection{DIQUES APLÍTICOS Y PEGMATÍTICOS}

En la aureola de metamorfismo de contacto del batolito de Cadalso-Casillas de Flores se han estudiado los diques aplíticos estériles de Molino del Galo y los diques pegmatíticos mineralizados de La Canalita (Fig. 4.1). Las labores mineras realizadas para la explotación de

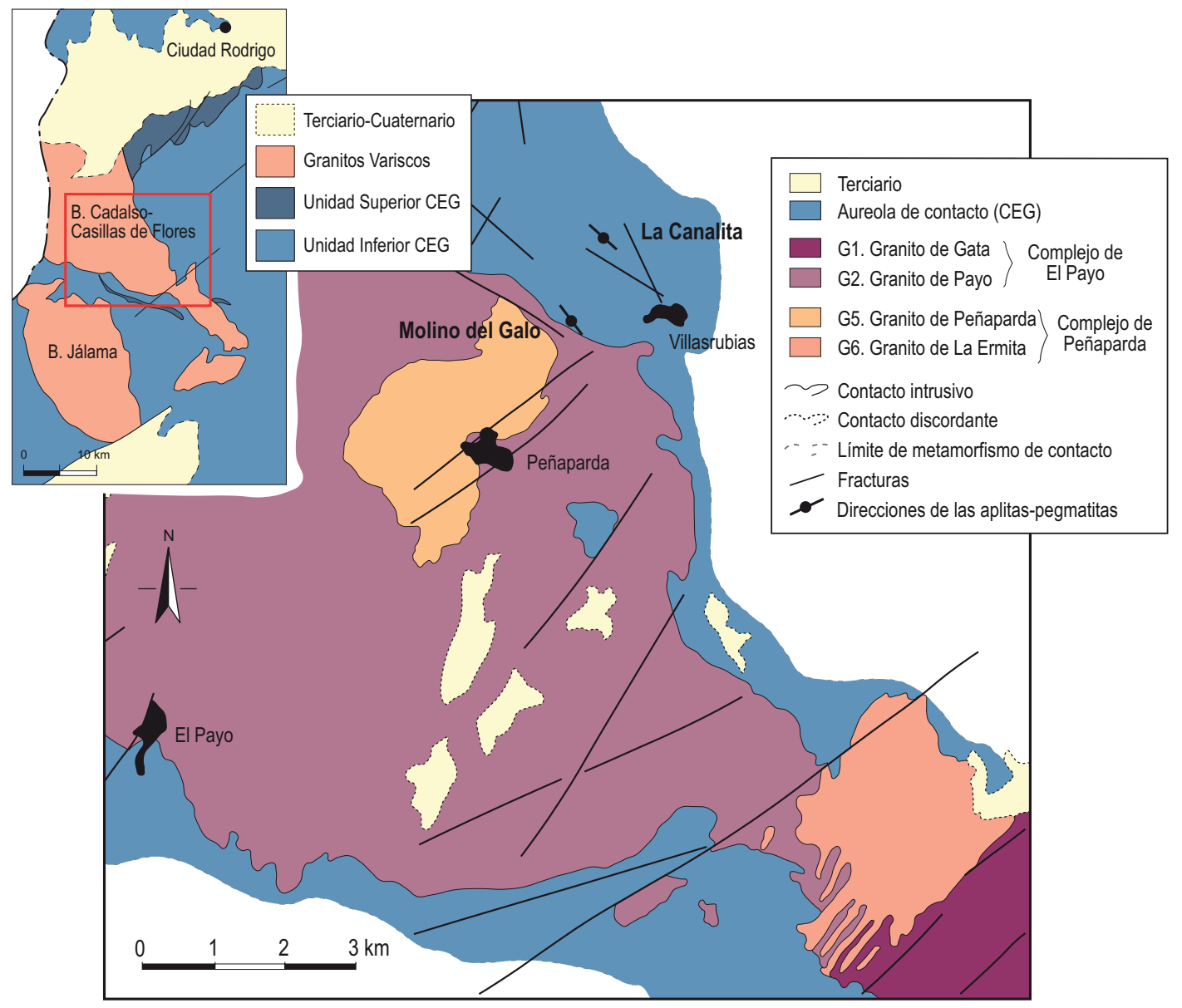

Fig. 4.1. Esquema geológico de la zona central del batolito de Cadalso-Casillas de Flores donde están situados los diques aplíticos y pegmatíticos. Modificado de Hassan (1996). 
estos diques se encuentran totalmente abandonadas e irreconocibles para su levantamiento cartográfico. La mena principal en los diques pegmatíticos de La Canalita fue la casiterita, si bien durante el desarrollo de este trabajo se han identificado abundantes minerales del grupo de la columbita y del pirocloro (Llorens y Moro, 2010a,b). Sin embargo, en los diques aplíticos de Molino del Galo la mineralización de casiterita no ha sido identificada a pesar de que la JCyL-TAGSA (1987) la describió.

\subsubsection{Roca encajante}

Los diques aplíticos de Molino del Galo presentan una dirección N150 E con buzamiento de $75^{\circ}$ al $O$ y potencias que alcanzan los 5 metros (Lám. 4.1a). Su morfología es aparentemente tabular y están frecuentemente cortados por estrechas venas de cuarzo estériles de dirección $\mathrm{N} 60^{\circ} \mathrm{E}$ y de potencia inferior a $10 \mathrm{~cm}$ que contienen localmente agregados de cristales de turmalina en su interior (Lám. 4.1b).
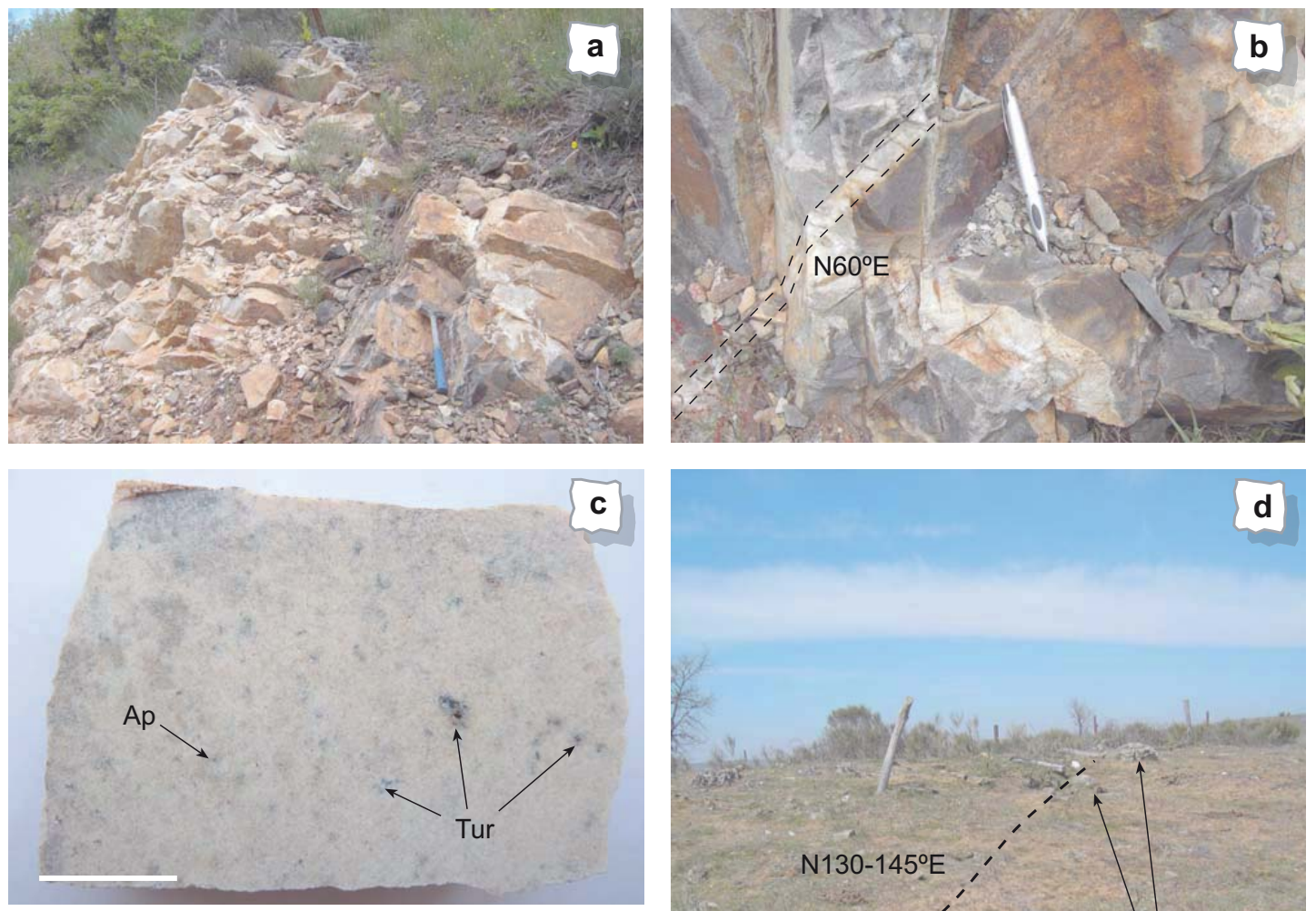

Lám. 4.1. a) Aspecto del afloramiento de los diques aplíticos de Molino del Galo; b) vena de cuarzo estéril con salbanda moscovítica cortando los diques aplíticos; c) muestra de roca de la aplita de los diques. Obsérvense los agregados tardíos de turmalina y de pequeños cristales azules de apatito diseminados en la roca; d) esquema de la dirección $\mathrm{N} 130^{\circ} \mathrm{E}$ de los diques pegmatíticos principales de La Canalita sobre las labores mineras de explotación totalmente restauradas. Escala gráfica en c: $2 \mathrm{~cm}$.

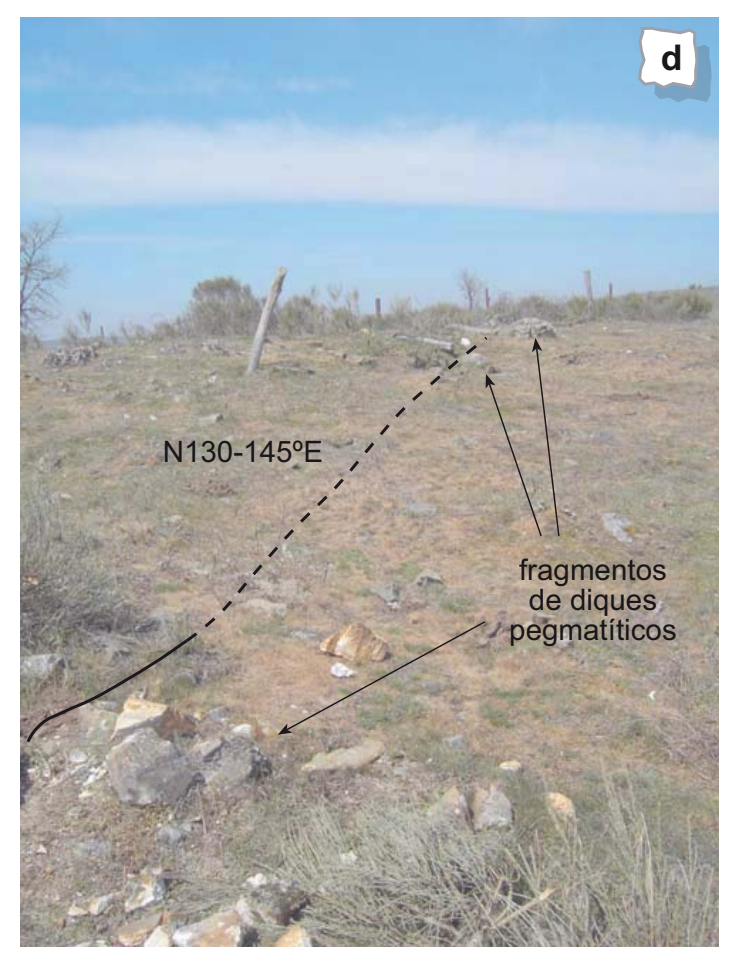


Estos diques se componen esencialmente por cuarzo, plagioclasa y mica blanca, con andalucita, turmalina y fosfatos como el apatito, la alluaudita y la gormanita como minerales accesorios (Lám. 4.1c). Localmente se encuentran circón y gahnita. Ocasionalmente estos diques muestran cierto bandeado causado fundamentalmente por variaciones en los porcentajes de los minerales esenciales en la roca. Además, en uno de los diques aplíticos se ha apreciado un incremento en el tamaño de grano de los cristales en la zona de contacto con el encajante metamórfico, llegando a dimensiones centimétricas, donde se observa la presencia de biotita.

Los diques pegmatíticos de la mina de La Canalita afloran aproximadamente a $1 \mathrm{~km}$ del contacto con el batolito de Cadalso-Casillas de Flores. Presentan una morfología tabular a lenticular con direcciones que varían entre $\mathrm{N} 130^{\circ} \mathrm{E}$ y $\mathrm{N} 145^{\circ} \mathrm{E}$ y buzamientos subverticales (Lám. 4.1d). Su potencia oscila normalmente entre $30 \mathrm{~cm}$ y $1 \mathrm{~m}$ con una longitud superior a los $16 \mathrm{~m}$ y una profundidad indeterminada, aunque según la JCyL-TAGSA (1987) su potencia aumenta en profundidad. Se observa, además, la presencia de venas de cuarzo con una dirección $\mathrm{N}^{\circ} 0^{\circ} \mathrm{E}$ y potencia decimétrica que brechifican e incorporan parte del encajante metamórfico cloritizado y que están asociadas a una banda de óxidos de hierro (Lám. 4.2a). Buena parte de estas venas de cuarzo, aparentemente estériles, aprovechan en ocasiones los planos de debilidad que presentan las diferentes bandas aflorantes de los diques. Los informes de la JCyL-TAGSA (1987) documentan la existencia de varios niveles de óxidos de $\mathrm{Mn}$ de hasta $10 \mathrm{~cm}$ de espesor asociados a estos diques; sin embargo, durante este estudio no se han identificado dichos niveles. Mineralógicamente estos diques están compuestos mayoritariamente por cuarzo, mica blanca y plagioclasa, además de topacio y montebrasita de forma accesoria que en ocasiones llegan a constituir fases mayoritarias. En zonas concretas de las pegmatitas se encuentran lepidolita y feldespato potásico, mientras que el circón aparece solo localmente.

Estos diques pegmatíticos presentan una zonación simétrica en la que se diferencian, desde la zona más externa a la más interna, las siguientes zonas (Fig. 4.2): la zona de borde, que tiene normalmente una potencia milimétrica, composición leucogranítica y tamaño de grano fino a muy fino y que está constituida esencialmente por plagioclasa, cuarzo, mica blanca, topacio y montebrasita en cantidades similares; la zona de pared, que se caracteriza por un tamaño de grano medio a grueso según la potencia de los diques y que está constituida principalmente por plagioclasa y cuarzo, con mica blanca, topacio y montebrasita en cantidades accesorias y ocasionalmente cristales prismáticos de feldespato potásico de tamaño centimétrico parcialmente albitizados (Lám. 4.2b). En esta zona se aprecia un ligero bandeado debido a variaciones en el tamaño de grano de los cristales y en las concentraciones mineralógicas; la presencia casi exclusiva de albita con textura de clivelandita de tamaño centimétrico y dispuesta perpendicularmente a los bordes de los diques caracteriza la zona intermedia exterior (Lám. 4.2c,d). Acompañando a esta albita se encuentran cuarzo y, menos frecuentemente, mica blanca, topacio y montebrasita. Estas bandas suelen presentar abundante casiterita; con textura granítica y tamaño de grano grueso a muy grueso se encuentra la zona intermedia interior, constituida fundamentalmente por plagioclasa, cuarzo, feldespato potásico y lepidolita, además de topacio y montebrasita como minerales accesorios; un aumento 


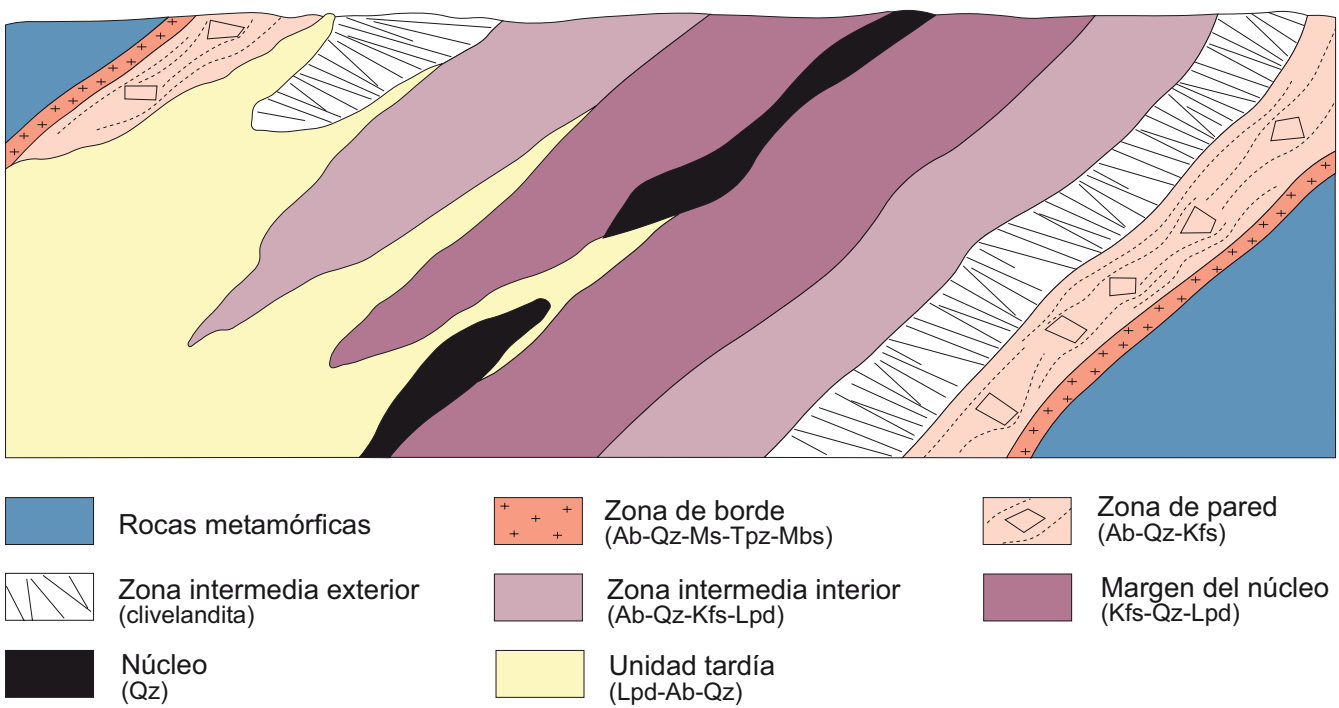

Fig. 4.2. Sección esquemática de los diques pegmatíticos de La Canalita en la que se observa la zonación diferenciada desde la zona de borde hasta el núcleo de cuarzo y la unidad tardía rica en lepidolita y albita.

considerable en el tamaño de grano de los cristales marca el paso al margen del núcleo, compuesto por cristales sub- a euhedrales de feldespato potásico de tamaño centimétrico a decimétrico con parches y venas de plagioclasa, cuarzo y agregados laminares hexagonales de lepidolita de tamaño centimétrico. Topacio y montebrasita aparecen de manera accesoria en cristales de tamaño inferior a 0,5 centímetros; finalmente, el núcleo de cuarzo se presenta de manera irregular y discontinua.

Formando parte de estos cuerpos pegmatíticos se encuentra la denominada unidad tardía rica en lepidolita y albita. Esta unidad presenta un tamaño de grano fino y una estructura bandeada debido a la alternancia de bandas de color lila ricas en lepidolita y cuarzo y bandas de color blanco compuestas esencialmente por albita con textura de clivelandita (Lám. 4.2e). Normalmente varía de centímetros a varios decímetros de potencia y se encuentra comúnmente en el contacto entre las diferentes zonas de los diques con el bandeado interno dispuesto paralelamente a este, lo que en conjunto le confiere una apariencia concordante aunque, ocasionalmente, también presenta un aspecto caótico y brechificado. En algunos casos en la zona de pared de los cuerpos pegmatíticos se observa un combamiento de la laminación y restos de las unidades previas no digeridos, lo que sugiere que estas no estaban totalmente solidificadas en el momento en que cristalizó la unidad tardía.

Por último, estos diques pegmatíticos fueron afectados por una intensa moscovitización, sobre todo en las zonas más externas de los cuerpos, que reemplaza a los cristales de albita e incluso a los de topacio; una greisenización en zonas concretas, especialmente en la unidad tardía, que da lugar a la formación de agregados de grano fino compuestos por cuarzo, mica blanca y topacio (Lám. 4.2f); y, finalmente, una silicificación de manera local. La presencia de agregados microcristalinos de cuarzo y de las venas de cuarzo estériles que cortan a los diques pegmatíticos y se asocian con la precipitación de hidróxidos de hierro sugieren que este último proceso estuvo más o menos activo durante la formación de las pegmatitas. 

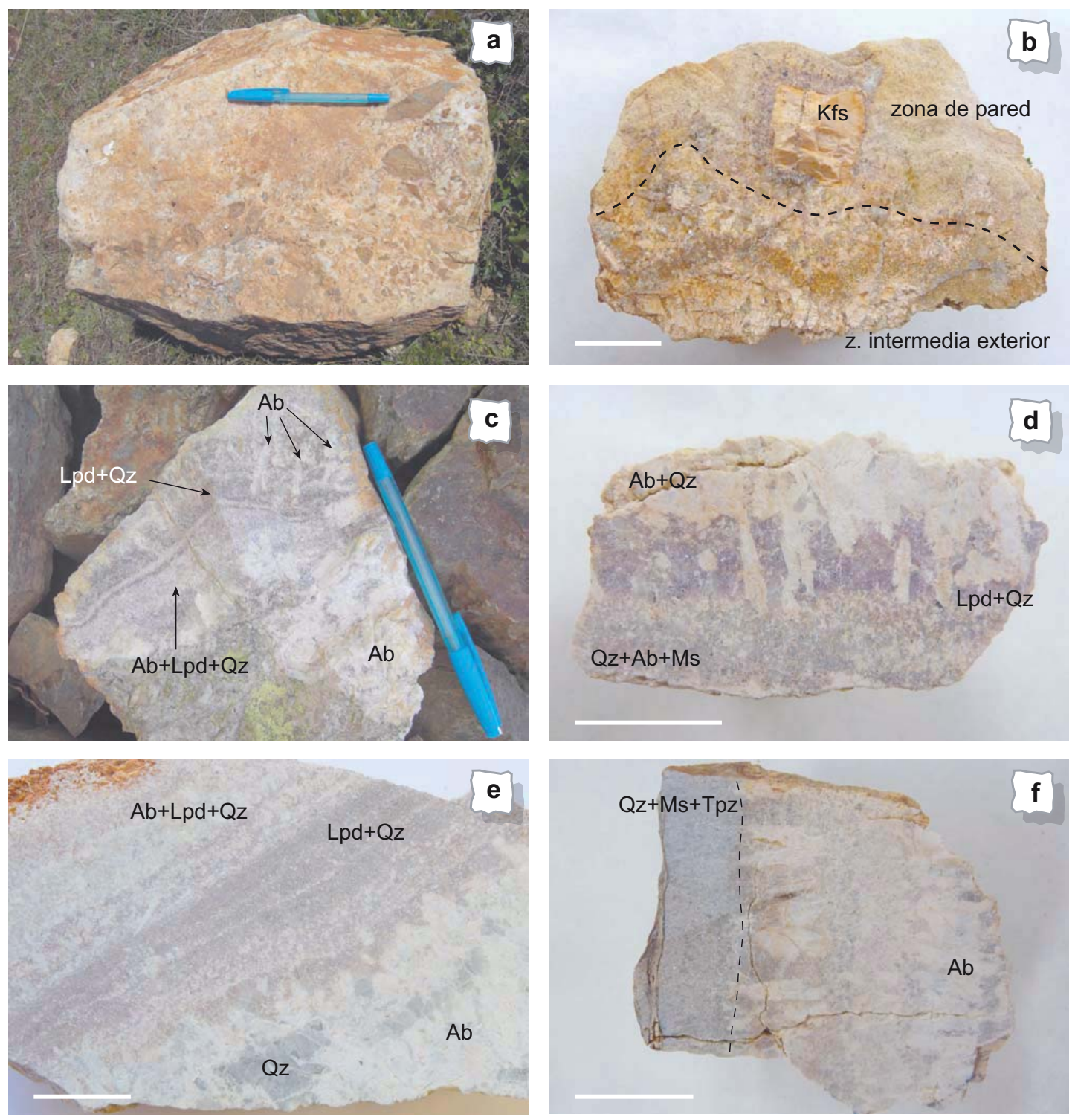

Lám. 4.2. Muestras de mano de los principales tipos de rocas que componen los diques pegmatíticos de La Canalita: a) brecha de cuarzo estéril con fragmentos del encajante metamórfico cloritizado; b) cristal idiomorfo de feldespato potásico de tamaño centimétrico en una matriz aplítica de la zona de pared ligeramente bandeada en contacto con la zona intermedia exterior de los diques; c) ejemplo de cristales de albita de tipo clivelandita creciendo perpendiculares a los bordes de la zona intermedia exterior; d) detalle de los cristales de clivelandita parcialmente reemplazados por un agregado de cuarzo y lepidolita; e) aspecto del bandeado de la unidad tardía formado por la alternancia de bandas de lepidolita y cuarzo con otras de albita; f) zona intermedia exterior parcialmente greisenizada constituida por un agregado de mica blanca y cuarzo de tamaño de grano fino. Escala gráfica: $2 \mathrm{~cm}$.

\subsubsection{Petrografía y química mineral}

\section{Cuarzo}

En las rocas aplíticas y pegmatíticas se diferencian cuatro tipos de cuarzo, de los cuales el más abundante es un cuarzo que se presenta deformado en cristales anhedrales de tamaño hasta centimétrico con extinción ondulante, bordes frecuentemente dentados y texturas en 
tablero de ajedrez. Un segundo tipo de cuarzo en cristales an- a subhedrales de grano fino y de tendencia poligonal se encuentra asociado a microfracturas. En las zonas intermedias de los diques de La Canalita es frecuente un cuarzo vermicular de tamaño de grano muy fino y asociado a la plagioclasa formando texturas mirmequíticas, tanto en los bordes de grandes cristales como en el interior de los de menor tamaño (Lám. 4.3a). Finalmente, en determinadas
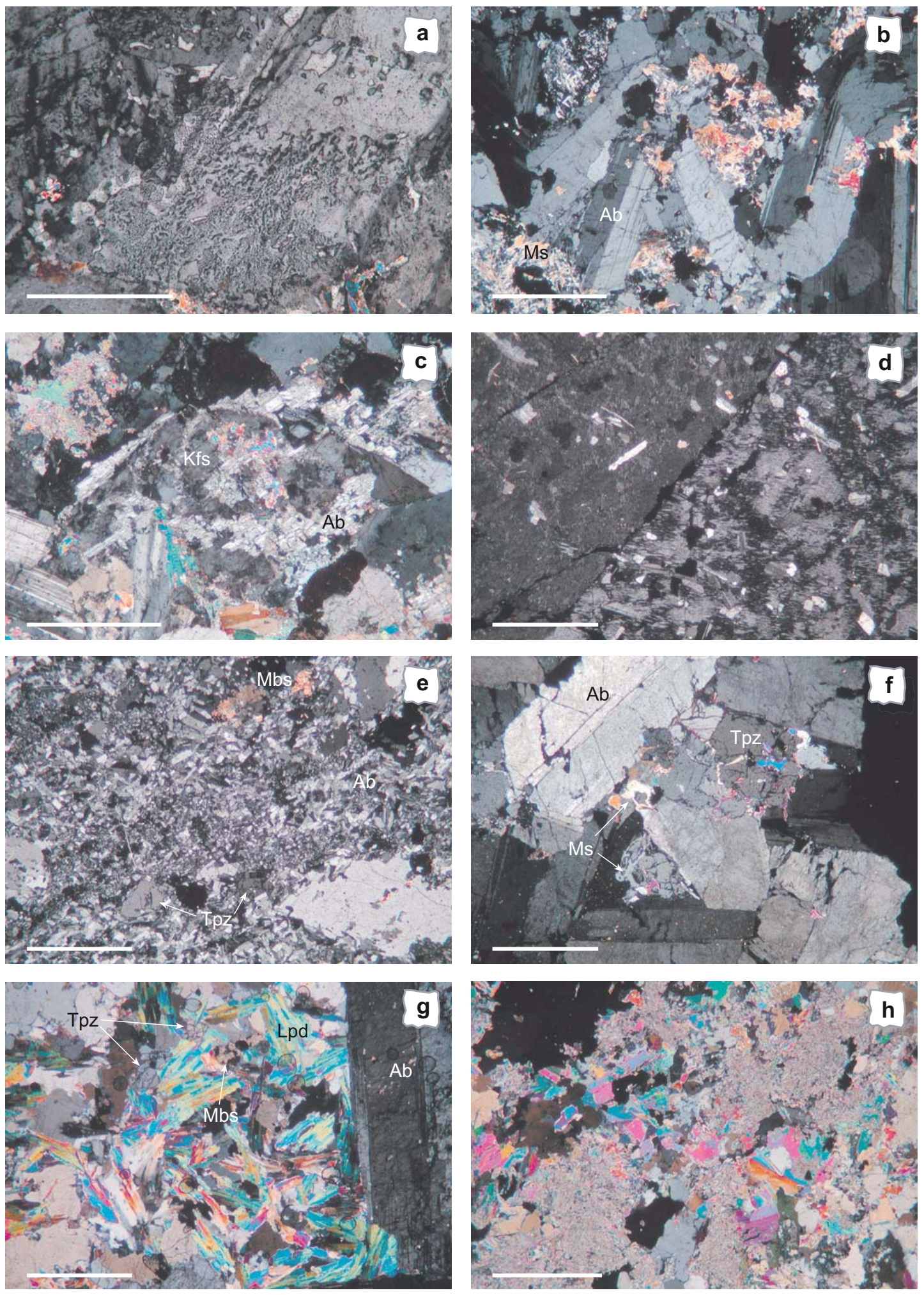
zonas de los diques y como producto de una alteración de tipo greisen, cristalizan agregados microcristalinos de cuarzo asociados a mica blanca y topacio.

\section{Feldespatos}

La plagioclasa de los diques aplíticos de Molino del Galo se presenta en cristales ana subhedrales de tamaño de grano muy fino y con macla polisintética, parcialmente reemplazados por moscovita y por fosfatos como la gormanita. Su composición química es albítica con escaso componente de anortita $\left(\mathrm{Ab}_{98} \mathrm{An}_{1}\right)$ y con contenidos medios en $\mathrm{P}_{2} \mathrm{O}_{5}$ de $0,67 \%$ en peso (Anexo III).

En los diques pegmatíticos de La Canalita la plagioclasa es el feldespato más común. Se encuentra formando cristales anhedrales, generalmente equidimensionales, de grano fino en las zonas más externas de los diques, aumentando de tamaño hasta dimensiones centimétricas hacia el interior de los mismos, donde estos cristales adquieren formas sub- a euhedrales alargadas según el eje $c$, especialmente en la zona intermedia exterior (Lám. 4.3b). En esta zona la plagioclasa muestra una textura de tipo clivelandita que frecuentemente se dispone en agregados arborescentes que a veces se encuentran combados. En ambos casos son comunes las maclas polisintéticas, mientras que la textura en tablero de ajedrez es más frecuente en la plagioclasa de tipo clivelandita y menos frecuentes las venillas y parches que corroen los cristales de feldespato potásico y las pequeñas placas subhedrales con macla simple que cristalizan en su interior (Lám. 4.3c,d). Por su parte, la albita de la unidad tardía consiste en cristales sub- a euhedrales de tamaño milimétrico e incluso mayor con macla simple que forma masas prácticamente monominerálicas reemplazando parcialmente los diques (Lám. 4.3e). Su composición química es muy similar para todas ellas oscilando entre $A b_{98} A n_{2}$ y $A b_{100} A n_{0}$, si bien el contenido medio en $\mathrm{P}_{2} \mathrm{O}_{5}$ se ve incrementado notablemente desde la albita que se encuentra en zonas externas de los diques, donde es prácticamente nulo, hasta la que cristaliza en las zonas más internas, donde se alcanzan valores medios de $0,60 \%$ en peso.

El feldespato potásico en estos diques pegmatíticos no es muy frecuente, encontrándose únicamente en la zona intermedia exterior y el margen del núcleo en cristales generalmente euhedrales de tamaño centimétrico a decimétrico e intensamente albitizados (Lám. 4.3c,d).

Lám. 4.3. Microfotografías de los aspectos texturales y mineralógicos de los diques pegmatíticos de La Canalita, NC: a) textura vermicular de cuarzo y la albita en las zonas intermedia y exterior de los diques; b) cristales de albita de tipo clivelandita parcialmente moscovitizados en la zona intermedia exterior, con agregados de moscovita; c) cristal de feldespato potásico reemplazado parcialmente por albita; d) megacristal de feldespato potásico reemplazado parcialmente por albita en el margen del núcleo de los diques; e) agregados de cristales de albita de grano fino de la unidad tardía; f) cristal de topacio parcialmente reemplazado por moscovita en las zonas externas de los diques pegmatíticos; g) agregado de cristales laminares de lepidolita en las zonas intermedias de los diques; $\mathbf{h}$ ) agregados microcristalinos de mica blanca en una zona greisenizada. Escala gráfica: $1 \mathrm{~mm}$, salvo a) $500 \mu \mathrm{m}$. 


\section{Micas}

En los diques pegmatíticos de La Canalita son comunes dos tipos de mica: por un lado una mica blanca y, por otro, una mica de Li. La mica blanca se presenta en cristales laminares aislados de origen primario y tamaño hasta centimétrico o en agregados formados por el apilamiento de estos cristales según el eje $c$, incoloros o con tonos plateados. La mica blanca de origen secundario se encuentra en agregados de tamaño de grano muy fino, producto de la moscovitización de minerales como la plagioclasa o el topacio (Lám. 4.3f) y también en microfracturas tardías. Por su parte, la mica de Li se encuentra también en cristales laminares de tamaño hasta centimétrico, ocasionalmente con texturas en abanico (Lám. $4.3 \mathrm{~g}$ ) y más frecuentemente en agregados de cristales de morfología hexagonal o aserrada, siempre de color lila. En la unidad tardía esta mica se encuentra comúnmente en agregados microcristalinos junto al cuarzo, como producto de la alteración de tipo greisen (Lám. 4.3h).

Los diques aplíticos de Molino del Galo solo presentan la mica blanca en cristales laminares de grano fino y de origen primario, aunque a veces también se ha identificado como producto de alteración de la andalucita y la gahnita y como relleno de fisuras tardías.

Al proyectar su composición química en el cuadro de clasificación de Tischendorf et al. (2004) (Fig. 4.3a) se observa que las micas de los diques aplíticos de Molino del Galo y de la zonas más
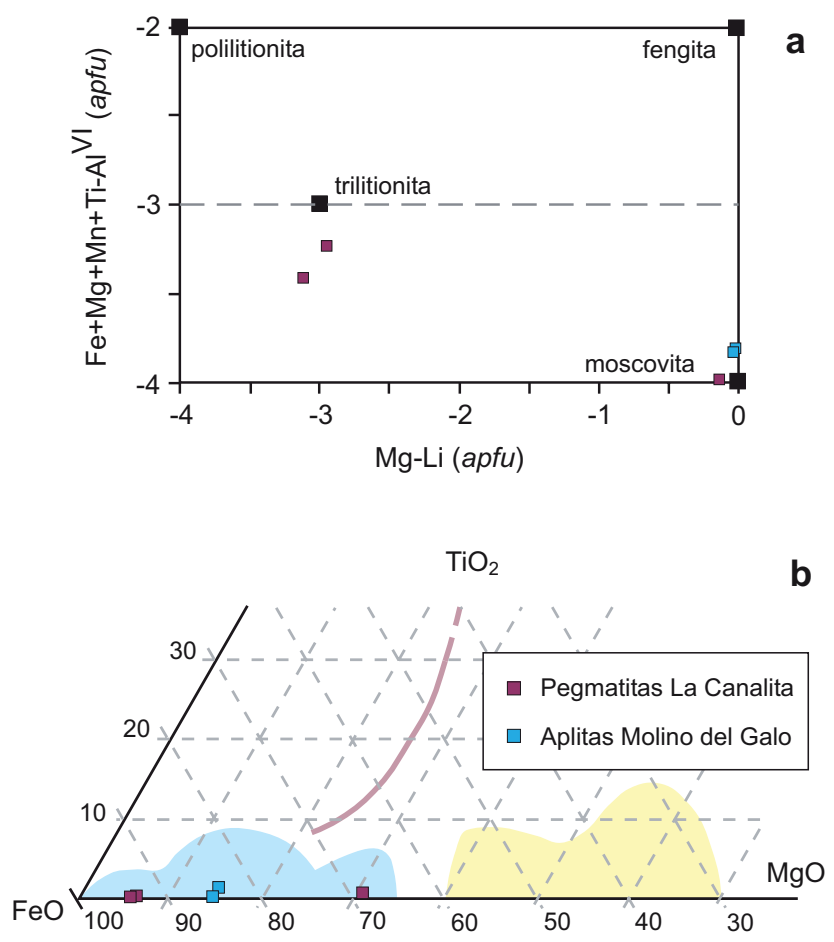

Fig. 4.3. Diagramas con la representación de la mica blanca y la mica de Li analizadas en los diques pegmatíticos de la Canalita y en los diques aplíticos de Molino del Galo: a) de clasificación de Tischendorf et al. (2004); y b) de $\mathrm{FeO}-\mathrm{TiO}_{2}-\mathrm{MgO}$ (en \% en peso) de Monier et al. (1984) (color rosa: micas de origen tardi- a post-magmático; color azul: micas magmáticas; color amarillo: micas hidrotermales). externa de los diques pegmatíticos de La Canalita se encuentran dentro del campo de la moscovita muy próximas a su composición ideal, mientras que la mica de Li de las zonas más internas de los diques de La Canalita se proyecta en el entorno de la trilitionita, indicando un enriquecimiento en $\mathrm{Li}$ desde las zonas externas hacia el interior de estos cuerpos pegmatíticos.

En el triángulo composicional FeO$\mathrm{TiO}_{2}-\mathrm{MgO}$ se observa que tanto la moscovita de las zonas más externas como la trilitionita de las zonas internas de las pegmatitas de La Canalita se encuentran dentro del campo de las micas de evolución magmática, si bien la trilitionita presenta mayores contenidos en Fe que la moscovita, por lo que se proyecta más próxima al polo del FeO (Fig. 4.3b). Lo mismo ocurre con la moscovita 
de los diques aplíticos de Molino del Galo, que se proyecta también en el campo de las micas de evolución magmática.

En su composición química destacan los altos contenidos en $\mathrm{F}$ de la trilitionita, que alcanzan hasta 2,88 apfu, frente a la moscovita de La Canalita y de los diques aplíticos de Molino del Galo, que muestra siempre menos de 0,50 apfu de F (Anexo III). Igualmente, los contenidos en Li calculados a partir de las fórmulas empíricas propuestas por Tischendorf et al. (2004) (ver técnicas analíticas en Capítulo 1) son claramente muy superiores en la trilitionita alcanzando hasta $5,67 \%$ en peso de $\mathrm{LiO}_{2}$. Estos valores son ligeramente superiores a los obtenidos mediante las técnicas de análisis químico, que dan contenidos de hasta 3,63\% en peso de $\mathrm{LiO}_{2}$ en la trilitionita (Anexo V). Por su parte, la moscovita de las zonas externas apenas contiene $0,27 \%$ en peso de $\mathrm{LiO}_{2}$ y en Molino del Galo estos contenidos son casi nulos.

\section{Topacio}

En las zonas externas e intermedias de los diques pegmatíticos de La Canalita el topacio es un mineral muy abundante, mientras que en las aplitas de Molino del Galo está ausente. Se presenta en cristales anhedrales de tamaño micrométrico en las zonas externas o en cristales subhedrales de tamaño centimétrico en las zonas intermedias de los diques (Lám. 4.4a). Se encuentra comúnmente asociado a la montebrasita con la que, en ocasiones, forma crecimientos esqueléticos (Lám. 4.4b). Es frecuente la existencia de agregados microcristalinos
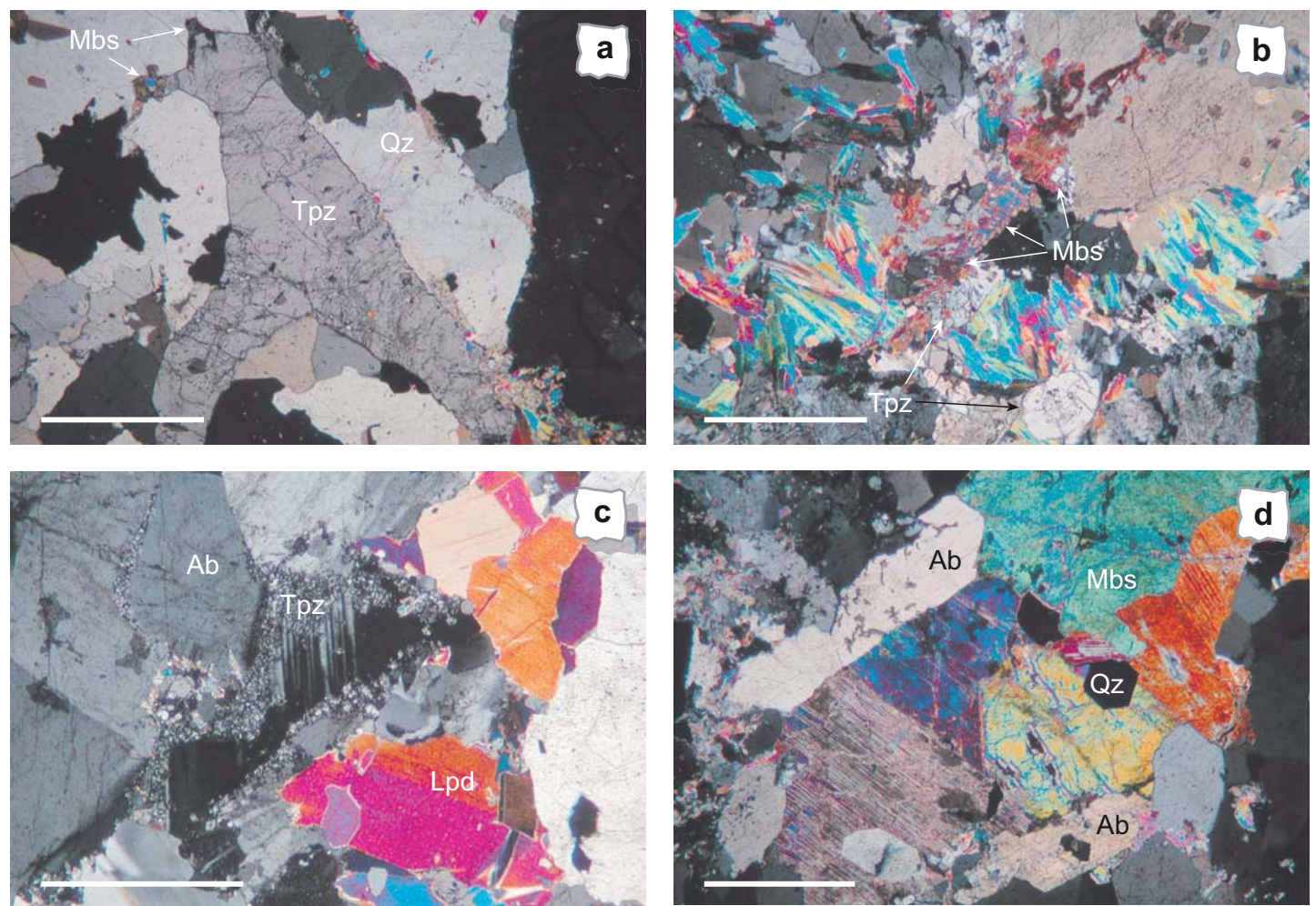

Lám. 4.4. Microfotografías de los aspectos texturales y mineralógicos de los diques pegmatíticos de La Canalita, NC: a) cristal de topacio con agregados de montebrasita en los bordes; b) crecimientos esqueléticos de topacio y montebrasita; c) agregado microcristalino de topacio alrededor de un cristal de albita; d) pequeña cavidad miarolítica rellena de cristales euhedrales de montebrasita y cuarzo. Escala gráfica: $1 \mathrm{~mm}$, salvo c) $500 \mu \mathrm{m}$. 
de topacio entre los bordes de grano de los cristales de los minerales esenciales (Lám. 4.4c). Esto, unido a la presencia de inclusiones de minerales previos en el interior del topacio, le convierte en un mineral tardío en la secuencia de cristalización (Fig. 4.7).

Su composición química se encuentra muy próxima a la ideal para este mineral, con una fórmula estructural media $\mathrm{Al}_{1,76}\left(\mathrm{Si}_{0,91} \mathrm{P}_{0,01}\right) \mathrm{O}_{4} \mathrm{~F}_{0,95} \mathrm{OH}_{1,05}$ en la que se observan algunas vacancias en la posición del Al e incluso en la tetraédrica, donde el Si muestra una escasa sustitución por el $\mathrm{P}$ (Anexo III).

\section{Clorita}

La clorita está presente tanto en los diques pegmatíticos de La Canalita como en los diques aplíticos de Molino del Galo, donde se encuentra comúnmente en agregados masivos rellenando microfracturas.

La representación de su composición química en el diagrama de clasificación de Hey (1954) la define como penninita (Fig. 4.4a), según Bailey (1980) como chamosita y según Zane y Weiss (1998) como clorita de tipo II o clorita-Al (Fig. 4.4b). Presenta contenidos en Si de hasta 3,86 apfu, de modo que el Al en las posiciones tetraédricas es muy escaso ocupando solo hasta 0,44 apfu y su contenido en la capa octaédrica es muy elevado, alcanzando casi los 4 apfu. Las cantidades de Fe y $\mathrm{Mg}$ que entran a rellenar esta capa octaédrica son muy bajas, de modo que la relación $\mathrm{Fe} /(\mathrm{Fe}+\mathrm{Mg})$ varía entre 0,72 y 0,90 y las vacancias calculadas alcanzan hasta 1,72 apfu (Anexo III).

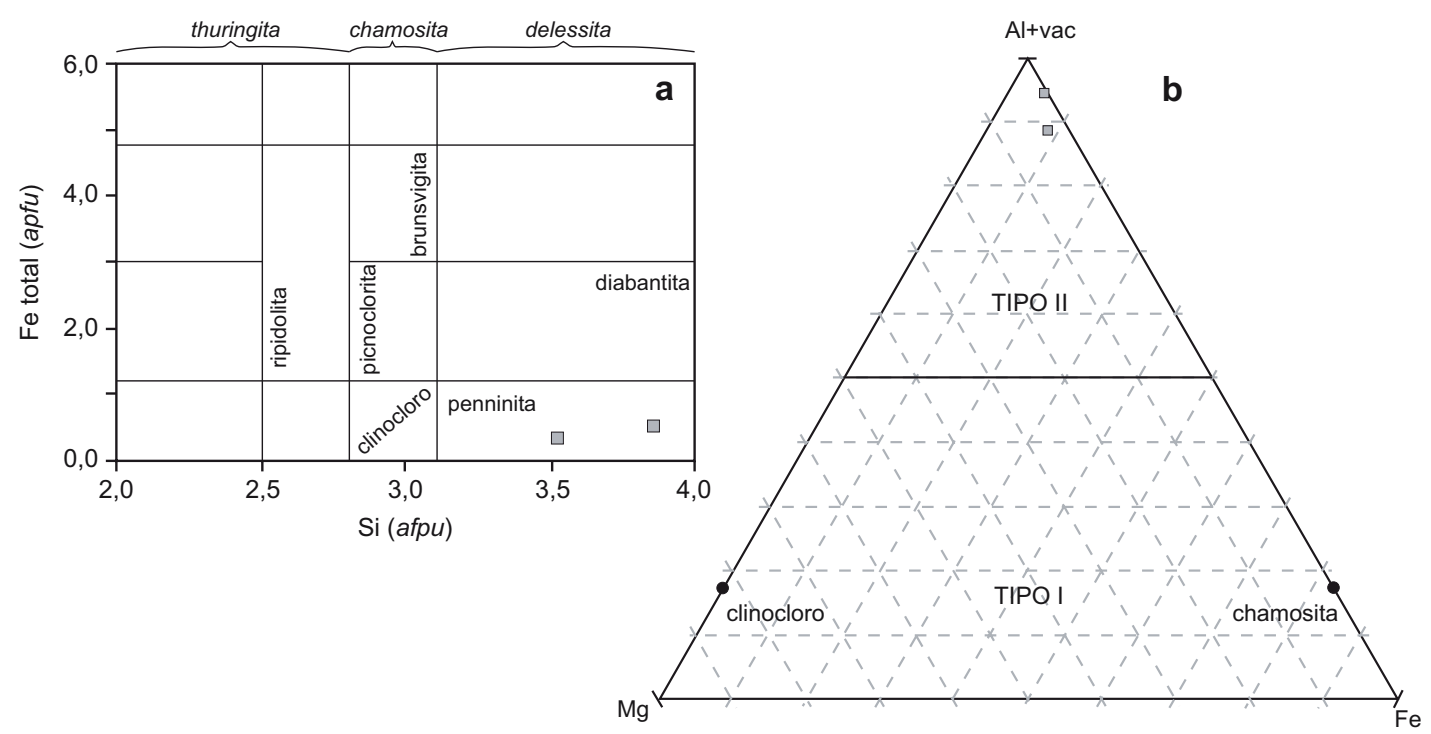

Fig. 4.4. Diagramas de clasificación de la clorita de los diques pegmatíticos de La Canalita: a) en función de los contenidos en $\mathrm{Fe}_{\text {total }}$ y Si (en apfu) según Hey (1954); y b) en función de los contenidos en $\mathrm{Fe}_{\text {total }}, \mathrm{Mg}$ y Al+vacancias (en apfu) según Zane y Weiss (1998). 


\section{Asociaciones fosfatadas}

En las rocas aplíticas y pegmatíticas de los diques de Molino del Galo y La Canalita se ha diferenciado dos asociaciones fosfatadas a las que, siguiendo con la numeración dada en el batolito de Jálama, se le asignan los números IX y X para su denominación. La asociación IX, característica de los diques pegmatíticos de La Canalita, está formada exclusivamente por montebrasita $\mathrm{y}$, localmente, brasilianita, mientras que la asociación $\mathrm{X}$ de los diques aplíticos de Molino del Galo está compuesta por ferrisiklerita-heterosita?, alluaudita, gormanita e hidroxilapatito (Tabla 4.1, Anexo III).

TABLA 4.1. FOSFATOS DE LAS ASOCIACIONES FOSFATADAS IX Y X

\begin{tabular}{lccc}
\hline \hline Fosfato & Fórmula general & \multicolumn{2}{c}{ Asociación } \\
\hline Montebrasita & $\left.(\mathrm{Li}, \mathrm{Na}) \mathrm{Al}(\mathrm{PO})_{4}\right)(\mathrm{OH}, \mathrm{F})$ & $* * *$ & \\
Brasilianita & $\mathrm{NaAl}_{3}\left(\mathrm{PO}_{4}\right)_{2}(\mathrm{OH}, \mathrm{F})_{4}$ & $*$ & \\
Ferrisiklerita & $\mathrm{Li}^{2}\left(\mathrm{Fe}^{3+} \mathrm{Mn}^{2+}\right) \mathrm{PO}_{4}$ & $*$ \\
Heterosita & $\left(\mathrm{Fe}^{3+}, \mathrm{Mn}^{3+}\right) \mathrm{PO}_{4}$ & $*$ \\
Alluaudita & $\left(\mathrm{Na}, \mathrm{Ca}, \mathrm{Mn}^{2+}\left(\mathrm{Fe}^{3+}\right)_{2}\left(\mathrm{PO}_{4}\right)_{3}\right.$ & $*$ \\
Gormanita & $\mathrm{Fe}^{2+}{ }_{3} \mathrm{Al}_{4}\left(\mathrm{PO}_{4}\right)_{4}(\mathrm{OH})_{6} \cdot 2 \mathrm{H}_{2} \mathrm{O}$ & $* *$ \\
Apatito & $\mathrm{Ca}_{5}\left(\mathrm{PO}_{4}\right)_{3}(\mathrm{OH}, \mathrm{F}, \mathrm{Cl})$ & $* *$ \\
\hline \hline
\end{tabular}

\section{Asociación IX}

La montebrasita es un fosfato muy común que aparece, al igual que el topacio, especialmente en las zonas externas e intermedias de los diques pegmatíticos de La Canalita, mientras que en las zonas más internas es únicamente accesorio. Se presenta en cristales anhedrales a subhedrales de tamaño milimétrico o con texturas dendríticas (Lám. 4.4b), incoloros o con un aspecto sucio debido probablemente a una incipiente alteración a brasilianita. En las zonas más internas se ha apreciado la existencia de cavidades o pockets en las que la montebrasita se presenta en cristales euhedrales de tamaño hasta centimétrico y con frecuentes maclas polisintéticas junto con cristales euhedrales de cuarzo (Lám. 4.4d). En las zonas de greisen estos cristales son reemplazados por la mica de Li. La fórmula estructural media de la montebrasita es $\mathrm{Li}_{1} \mathrm{Al}_{0,93}\left(\mathrm{PO}_{4}\right)\left(\mathrm{OH}_{0,84} \mathrm{~F}_{0,16}\right)_{\sum 1}$ y muestra la existencia de algunas vacancias en las posiciones ocupadas por el Al. El contenido en $\mathrm{F}$ de este fosfato es muy bajo y se mantiene más o menos constante desde las zonas de borde hasta las zonas más internas de los diques, variando entre 0,07 y 0,19 apfu, lo que sugiere, por un lado, un origen primario aunque tardío en la secuencia de cristalización (Fig. 4.7) y, por otro, que minerales como el topacio o la lepidolita incorporan el F preferentemente en lugar de la montebrasita.

La brasilianita se encuentra localmente reemplazando a la anterior en las zonas intermedias de los diques pegmatíticos. Sin embargo, se dispone únicamente de un análisis de microsonda de esta fase fosfatada, cuya fórmula estructural calculada con base en 12 átomos de $\mathrm{O}$ y $2 \mathrm{P}$ es $\mathrm{Na}_{0,42} \mathrm{Al}_{2,64}\left(\mathrm{PO}_{4}\right)_{2}\left(\mathrm{OH}_{3,81} \mathrm{~F}_{0,19}\right)_{\sum 4^{\prime}}$ observándose algunas vacancias en las posiciones del $\mathrm{Al} \mathrm{y}$, 
especialmente, en las posiciones ocupadas por el $\mathrm{Na}$. Destacan, además, los bajos contenidos en $\mathrm{F}$, similares a los de la montebrasita a la que reemplaza, por lo que admite elevadas cantidades de $\mathrm{OH}^{-}$calculadas por estequiometría.

\section{Asociación X}

En los diques aplíticos de Molino del Galo la asociación fosfatada identificada es más variada composicionalmente que en La Canalita, si bien el pequeño tamaño de algunas de las fases minerales ha dificultado su completa caracterización. Se han identificado bajo el microscopio restos de cristales de un fosfato de color rojizo y fuertemente pleocroico cuya composición química se asemeja a la de la heterosita o a la ferrisicklerita, con hasta 0,59 apfu de $\mathrm{Fe}^{3+}$ y 0,26 apfu de $\mathrm{Mn}^{3+}$ (si es heterosita) o $\mathrm{Mn}^{2+}$ (si es ferrisicklerita). Junto a esta fase se encuentran también agregados cristalinos de tamaño micrométrico de alluaudita de color marrón verdoso y ligeramente pleocroicos, cuya composición química se caracteriza por elevados contenidos en $\mathrm{Fe}^{3+}$ (hasta 6,73 apfu). Tanto el fosfato anterior, similar a la heterosita o la ferrisiklerita, como la alluaudita tienen una relación $\mathrm{Fe} /(\mathrm{Fe}+\mathrm{Mn})$ prácticamente idéntica de $0,69-0,70$ por lo que ambos pueden corresponder a la alteración de un fosfato primario no preservado.

También se han encontrado agregados de cristales fibrosos de gormanita de tamaño milimétrico que, bajo el microscopio, presentan un color pardo o marrón claro y un intenso pleocroísmo azul. Su fórmula estructural calculada con base en 8 átomos de P está enriquecida especialmente en Fe ${ }^{2+}$ (hasta $4 \mathrm{apfu}$ ) que es sustituido por Mg (hasta $1.01 \mathrm{apfu}$ ) y por $\mathrm{Mn}$ (hasta 0,50 apfu). Esta fase fosfatada se forma por la alteración hidrotermal de las fases anteriores y de la albita (Lám. 4.5a).

Finalmente el hidroxilapatito es el fosfato más común en estas rocas aplíticas y se encuentra en agregados anhedrales de tamaño micrométrico a milimétrico en los espacios intergranulares o bien como producto de alteración de fosfatos previos. Su composición química contiene entre 0,65 y 0,84 apfu de Mn sustituyendo al Ca (Fig. 4.5a) y solo trazas de $\mathrm{Sr}$ (hasta 0,10 apfu) y Fe (hasta 0,06 apfu), mientras que las cantidades del ión $\mathrm{OH}^{-}$calculadas por estequiometría dominan frente al $\mathrm{F} \mathrm{y} \mathrm{al} \mathrm{Cl}$, alcanzando hasta 1,60 apfu (Fig. 4.5b).

\section{Turmalina}

Se encuentra únicamente en los diques aplíticos de Molino del Galo como una fase claramente tardía. Forma agregados cristalinos anhedrales y de tamaño micrométrico a milimétrico rellenando los espacios intergranulares y englobando a los minerales anteriores (Lám. 4.5b). Tiene color negro en muestra de mano, mientras que bajo el microscopio sus colores varían desde el azulado-verdoso al naranja-marrón con un pleocroísmo muy marcado y sin una zonación aparente.

\section{Andalucita}

La andalucita se presenta únicamente en los diques aplíticos de Molino del Galo en cristales de tamaño milimétrico parcialmente moscovitizados (Lám. 4.5c). 

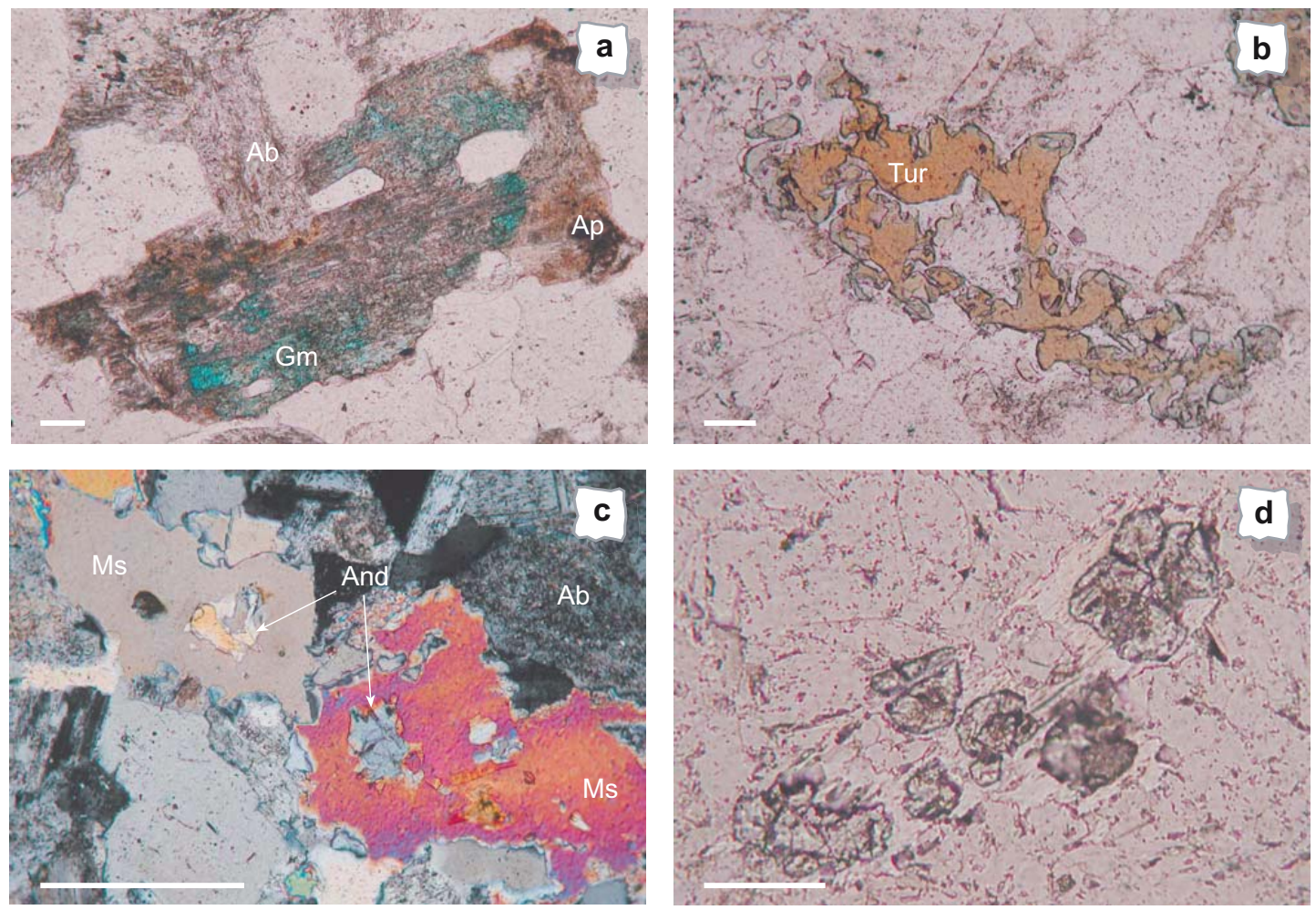

Lám. 4.5. Microfotografías de los aspectos texturales y mineralógicos de los diques aplíticos de Molino del Galo: a) cristal de albita reemplazado parcialmente por gormanita con tonos azulados y posteriormente por apatito, LN; b) turmalina tardía, LN; c) cristal de andalucita moscovitizado, NC; d) cristales subhedrales de gahnita parcialmente moscovitizados, LN. Escala gráfica: $100 \mu \mathrm{m}$, salvo c) $500 \mu \mathrm{m}$.
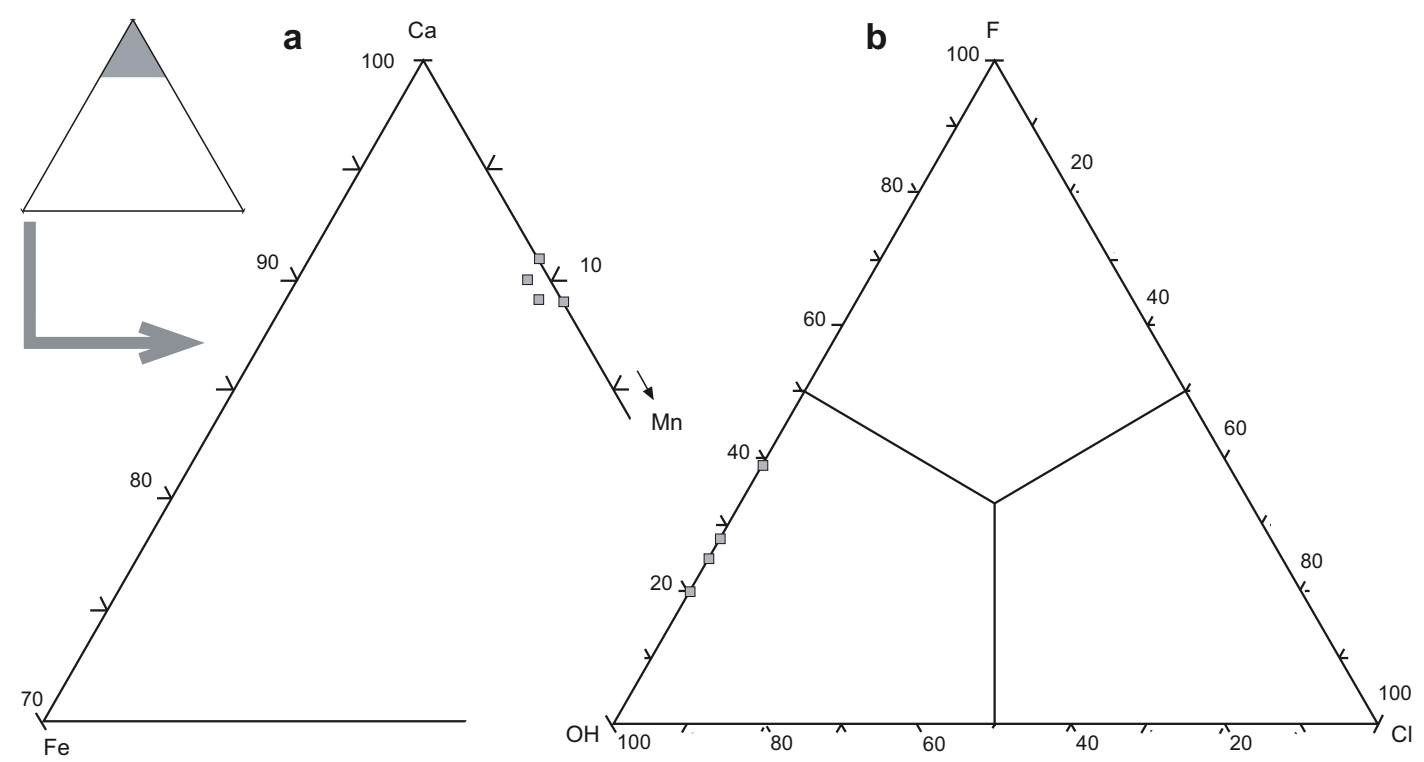

Fig. 4.5. Diagramas triangulares con la representación del apatito analizado en la asociación $\mathrm{X}$ de los diques aplíticos de Molino del Galo: a) de los contenidos en Fe, Ca y Mn en las posiciones catiónicas (en apfu); y b) de los contenidos en $\mathrm{OH}, \mathrm{F} \mathrm{y} \mathrm{Cl}$ (en apfu). 


\section{Gahnita}

La gahnita se encuentra también en los diques aplíticos de Molino del Galo en cristales subhedrales inferiores a $1 \mathrm{~mm}$ de tamaño y parcialmente alterados a mica blanca (Lám. $4.5 \mathrm{~d})$. Su composición química presenta entre $72-79 \% \mathrm{~mol}$ de componente gahnita $\left(\mathrm{ZnAl}_{2} \mathrm{O}_{4}\right)$ y entre $20-26 \%$ mol de hercinita $\left(\mathrm{FeAl}_{2} \mathrm{O}_{4}\right.$ ) (Anexo III).

\section{Circón}

El circón es muy poco frecuente y se encuentra en cristales an- a subhedrales de tamaño micrométrico diseminados e incluidos, generalmente, en la mica blanca.

\subsubsection{Mineralización}

Los diques pegmatíticos de La Canalita son los únicos que están mineralizados. En ellos, las menas más importantes son la casiterita y los minerales del grupo de la columbita, además de la tapiolita y la microlita de forma accesoria. Estos minerales aparecen diseminados en prácticamente todas las zonas diferenciadas de las pegmatitas.

En la secuencia mineral de las pegmatitas de La Canalita se han diferenciado dos asociaciones (Fig. 4.7): una primaria, originada principalmente durante los procesos de cristalización magmática de los diques pegmatíticos; y una secundaria, formada durante la alteración hidrotermal de los mismos y concentrada, por lo tanto, en las zonas intermedias exterior e interior, en la unidad tardía y en las zonas greisenizadas de los diques (Llorens y Moro, 2010a,b).

\subsubsection{Minerales del grupo de la columbita y del pirocloro}

\section{Asociación primaria}

Las principales fases de $\mathrm{Nb}$-Ta de origen primario corresponden a los óxidos del grupo de la columbita-tantalita con altos contenidos en $\mathrm{Mn}$, como la columbita-(Mn) precoz y la tantalita$(\mathrm{Mn})$ un poco más tardía. Además, y puntualmente, se forma una generación de microlita primaria también de carácter tardío. Todas estas fases minerales se encuentran asociadas al topacio, la montebrasita y la mica blanca y, menos comúnmente, a la plagioclasa y la lepidolita de los cuerpos pegmatíticos. Su composición química se recoge en el Anexo III.

La columbita-(Mn) se presenta en cristales de tamaño inferior a un milímetro en las zonas más externas de los diques de pegmatita con tres texturas diferentes: a) núcleo de cristales tabulares; b) cristales irregulares o redondeados incluidos o asociados a la casiterita; y c) exsoluciones de columbita-( $\mathrm{Mn})$ en microlita. Todas ellas son químicamente muy similares y en el diagrama cuadrilateral de la columbita se proyectan a lo largo del extremo más rico en Mn (Fig. 4.6a).

Los cristales tabulares aislados de columbita-( $\mathrm{Mn})$ se encuentran diseminados en la zona de pared de los cuerpos pegmatíticos y muestran un zonado interno composicional con un núcleo rico en $\mathrm{Nb}$ y bordes ricos en Ta (Lám. 4.6a,b y Fig. 4.6b). La composición química de 

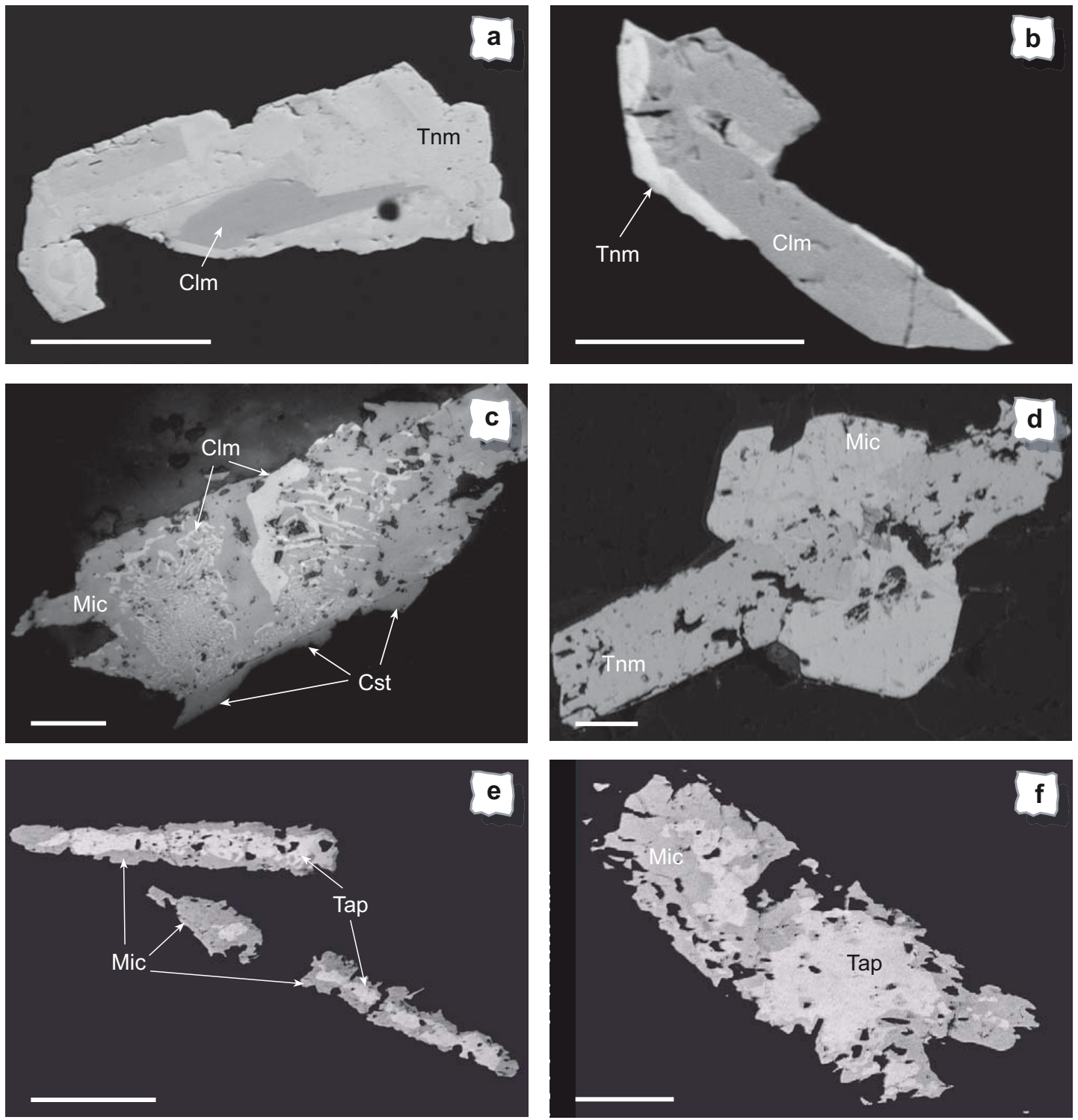

Lám. 4.6. Microfotografías electrónicas ( $a, b, d, e, f)$ y ópticas (c) de la mineralización de Nb y Ta en las pegmatitas de La Canalita: a y b) zonado en los minerales del grupo de la columbita consistente en un núcleo rico en $\mathrm{Nb}$ (gris oscuro), un borde enriquecido en Ta (gris claro) y zonas con variaciones en los contenidos de $\mathrm{Nb}$ y Ta (grises intermedios); c) lamelas de exsolución de columbita-( $\mathrm{Mn}$ ) en una matriz de microlita primaria rodeada de casiterita, LN; d) cristal de microlita secundaria rica en $\mathrm{U}$ reemplazando a tantalita-(Mn); e y f) cristales de tapiolita parcialmente reemplazados por microlita secundaria. Escala gráfica: $50 \mu \mathrm{m}$.

estas zonas más internas de los cristales muestra contenidos elevados en $\mathrm{Nb}$ (1,65-1,70 apfu), con menos Ta (0,34-0,38 apfu) y cantidades traza de W, Sn y Ti en la posición B de su fórmula general $\mathrm{AB}_{2} \mathrm{O}_{6}$ (Von Knorring y Fadipe, 1981). El Mn es el principal catión en la posición $\mathrm{A}$ variando entre 0,76-0,81 apfu, de modo que la relación $\mathrm{Mn} /(\mathrm{Mn}+\mathrm{Fe})$ oscila entre 0,84 y 0,89 mientras que la relación $\mathrm{Ta} /(\mathrm{Ta}+\mathrm{Nb})$ lo hace entre 0,17 y 0,18.

Los cristales de columbita-( $\mathrm{Mn})$ asociados a la casiterita se encuentran diseminados desde la zona de pared hasta la zona intermedia exterior de los cuerpos pegmatíticos. Esta columbita(Mn) es rica en Nb (1,62 apfu) y pobre en Ta (0,32 apfu), con hasta 0,05 apfu de Sn, Ti y W 
en la posición B probablemente debido a la influencia de la casiterita encajante. La posición A está ocupada casi totalmente por 0,90-0,91 apfu de Mn con cantidades de hasta $1 \%$ en peso de FeO. La relación $\mathrm{Mn} /(\mathrm{Mn}+\mathrm{Fe})$ en esta ocasión varía entre 0,90 y 0,95 mientras que la relación $\mathrm{Ta} /(\mathrm{Ta}+\mathrm{Nb})$ es de las más bajas $(0,16-0,18)$.

Por último, las exsoluciones de columbita-( $\mathrm{Mn})$ en microlita dibujan una textura simplectítica de tamaño micrométrico (Lám. 4.6c) que se distribuye homogéneamente en el interior de la microlita primaria de la zona intermedia interior de los diques pegmatíticos. Su composición química es similar a la de la columbita-( $\mathrm{Mn}$ ) asociada a la casiterita, con cantidades ligeramente inferiores de $\mathrm{Nb}\left(1,10-1,47 \mathrm{apfu}\right.$ ) y trazas de $\mathrm{SnO}_{2}$ (hasta $0,38 \%$ en peso) y $\mathrm{WO}_{3}$ (hasta 0,20 $\%$ en peso) ocupando la posición B. Los altos contenidos en $\mathrm{SnO}_{2}$ que presenta uno de estos cristales de columbita-( $\mathrm{Mn}$ ) son probablemente debidos a contaminación de la casiterita. La posición A se encuentra prácticamente en su totalidad ocupada por Mn (hasta 0,93 apfu) y pequeñas cantidades de Fe (hasta 0,02 apfu), de manera que la relación $\mathrm{Mn} /(\mathrm{Mn}+\mathrm{Fe}$ ) varía ligeramente entre 0,98 y 0,99 mientras que la relación $\mathrm{Ta} /(\mathrm{Ta}+\mathrm{Nb})$ lo hace entre 0,27 y 0,42.

La tantalita-(Mn) se presenta en cristales tabulares con un núcleo de columbita-(Mn) diseminados en la zona de pared de los diques pegmatíticos (Lám. 4.6a,b y Fig. 4.6b). Químicamente el borde de estos cristales tabulares está enriquecido en Ta, variando entre 0,99 y 1,07 apfu de Ta y entre 0,94 y 1,04 apfu de $\mathrm{Nb}$ en la posición $\mathrm{B}$ de la fórmula general $\mathrm{AB}_{2} \mathrm{O}_{6}$ (Von Knorring y Fadipe, 1981). La posición A está principalmente ocupada por Mn $(0,77-0,95 \mathrm{apfu}$ ) y hasta 0,16 apfu de Fe, lo que permite la presencia de algunas vacancias en las estructura de este mineral. La relación $\mathrm{Mn} /(\mathrm{Mn}+\mathrm{Fe})$ varía entre 0,83 y 0,99 mientras que la relación $\mathrm{Ta} /(\mathrm{Ta}+\mathrm{Nb}$ ) es elevada, variando entre 0,49 y 0,53 (Fig. 4.6a).

La microlita primaria se encuentra en la zona intermedia interior de dos de los cuerpos pegmatíticos de La Canalita como un mineral tardío en la secuencia de cristalización primaria. Esta microlita precoz forma cristales an- a subhedrales de tamaño milimétrico con exsoluciones de columbita-(Mn) en su interior (Lám. 4.6c), lo que le confiere un color marrónrojizo. Presenta una composición química bastante constante, estando la posición $\mathrm{B}$ de su fórmula general $\mathrm{A}_{2} \mathrm{~B}_{2} \mathrm{O}_{6}(\mathrm{OH}, \mathrm{F})$ (Hogarth, 1977) ocupada principalmente por Ta (1,56-1,67 apfu) y en menor medida por $\mathrm{Nb}(0,31-0,44 \mathrm{apfu})$. La ocupación de la posición A es casi completa, fundamentalmente con $\mathrm{Ca}(0,92-0,95 \mathrm{apfu})$ y $\mathrm{Na}(0,96-0,99 \mathrm{apfu})$ y contenidos variables en otros elementos como el $\mathrm{Mn}$ (hasta 2,3\% en peso de $\mathrm{MnO}$ ) consecuencia, probablemente, de las exsoluciones de columbita-(Mn). Los elevados contenidos en F, de hasta 0,47 apfu, impiden la presencia de altas cantidades de $\mathrm{OH}$ en la estructura de este mineral. Dados su altos contenidos en Ta la relación $\mathrm{Ta} /(\mathrm{Ta}+\mathrm{Nb}$ ) varía entre 0,78 y 0,85 (Fig. 4.6a).

\section{Asociación secundaria}

Las fases minerales secundarias que se han identificado en estos diques pegmatíticos están muy enriquecidas en Ta y presentan diferentes contenidos en Fe y $\mathrm{Mn}$, como la tantalita-(Fe), la columbita-(Fe), la columbita-(Mn), la tantalita-(Mn), la tapiolita, la microlita y la microlita uranífera, formadas todas ellas durante la alteración hidrotermal postmagmática que afecta a los diques pegmatíticos de La Canalita. 

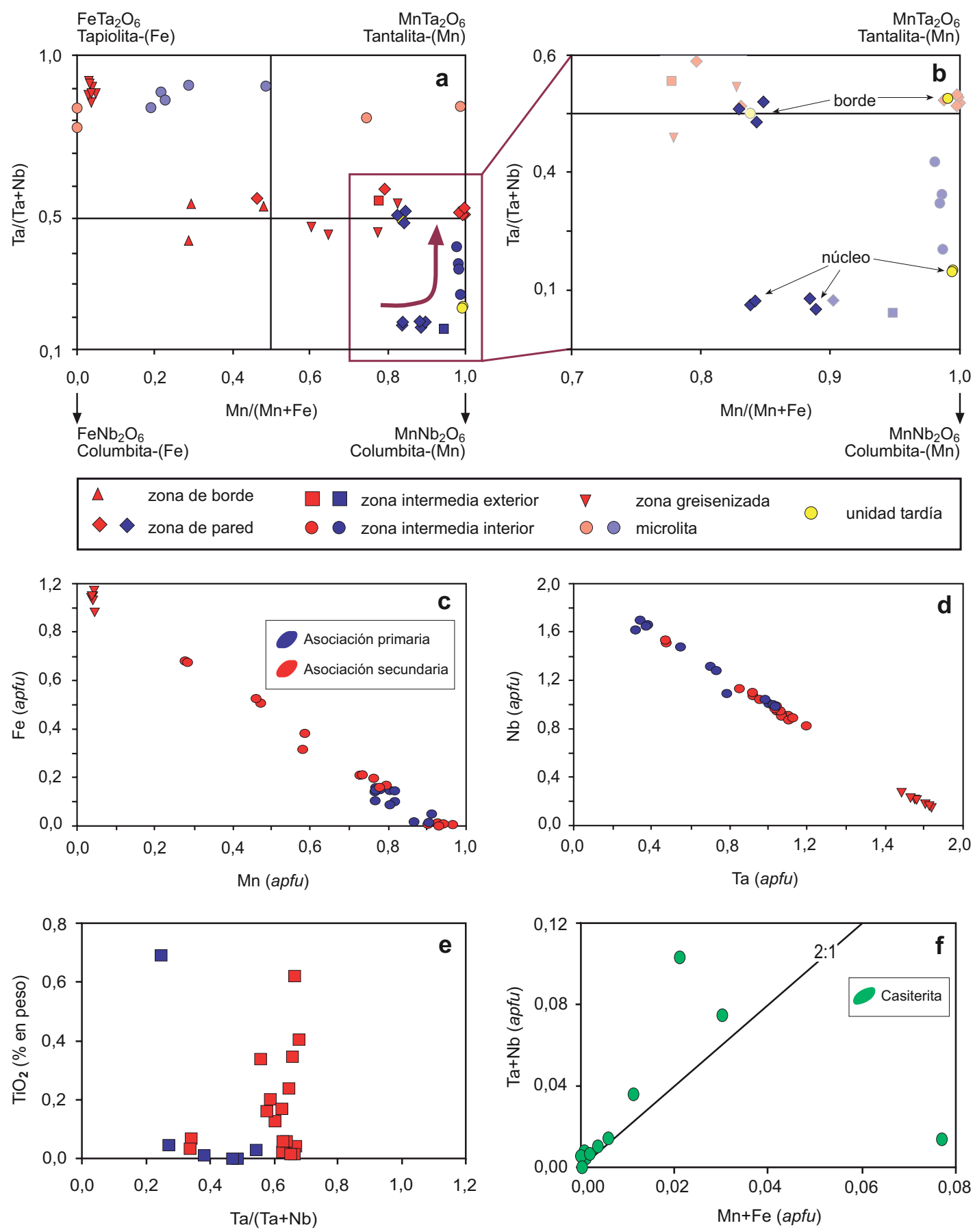

Fig. 4.6. a) Diagrama cuadrilateral de la columbita con la representación de la composición química de los minerales de este grupo en los diques pegmatíticos de La Canalita. Obsérvese la tendencia de evolución de la asociación primaria hacia un enriquecimiento en $\mathrm{Mn}$ y en Ta (flecha); b) detalle del esquema anterior en el que se representan los minerales de la asociación primaria, discriminando entre las zonas de borde y de núcleo de varios de los cristales. Diagramas de variación en los minerales del grupo de la columbita: c) Fe vs. $\mathrm{Mn}$; d) $\mathrm{Nb}$ vs. Ta; y e) $\mathrm{TiO}_{2}$ vs. $\mathrm{Ta} /(\mathrm{Ta}+\mathrm{Nb})$. f) Diagrama de variación $\mathrm{Nb}+\mathrm{Ta}$ vs. Fe+Mn en la casiterita de los diques pegmatíticos en el que se observa un vector de sustitución 2:1. 
La tantalita-(Fe) y la columbita-(Fe) solo se han identificado en la zona de borde y de pared aplítica de uno de los diques pegmatíticos de La Canalita de escasa potencia. Se presentan en cristales tabulares de tamaño milimétrico o bien en pequeñas inclusiones redondeadas dentro de los cristales de casiterita. A pesar de estas diferencias texturales, composicionalmente son muy similares con contenidos en Ta entre 0,85 y $1,11 \mathrm{apfu}$, en Nb entre 0,88 y 1,13 apfu y trazas de $\mathrm{Sn}$ y Ti ocupando la posición B. El Fe y el Mn ocupan proporciones similares en la posición A hasta contenidos de 0,68 apfu y 0,47 apfu respectivamente. Ocasionalmente se aprecian contenidos en Ca poco significativos. La relación $\mathrm{Mn} /(\mathrm{Mn}+\mathrm{Fe})$ varía entre 0,29 y 0,48 mientras que la relación $\mathrm{Ta} /(\mathrm{Ta}+\mathrm{Nb})$ muestra valores intermedios entre 0,43 y 0,56 (Fig. 4.6a).

La columbita-(Mn) en la asociación secundaria forma el núcleo de los cristales irregulares o tabulares de tamaño milimétrico que se encuentran diseminados en la unidad tardía rica en lepidolita y albita. Su composición química es similar a la que se encuentra en las zonas intermedias de los diques pegmatíticos con hasta 0,48 apfu de Ta y 1,53 apfu de $\mathrm{Nb}$ en la posición $\mathrm{B}$ de su fórmula general $\mathrm{AB}_{2} \mathrm{O}_{6}$ (Von Knorring y Fadipe, 1981). La posición A está ocupada casi exclusivamente por $\mathrm{Mn}$ variando entre 0,94 y 0,96 apfu con solo algunas trazas de $\mathrm{Fe}$, de modo que esta columbita se proyecta en el borde más rico en $\mathrm{Mn}$ del diagrama cuadrilateral de la columbita con una relación $\mathrm{Mn} /(\mathrm{Mn}+\mathrm{Fe})$ de 0,99-1,00 y Ta/(Ta+Nb) de 0,24 (Fig. 4.6a).

La tantalita-(Mn) se presenta en cristales tabulares alargados de tamaño milimétrico que se encuentran diseminados en las diferentes zonas de los diques y en las zonas greisenizadas de los cuerpos pegmatíticos. En ambos casos suele aparecen asociada frecuentemente a la microlita secundaria (Lám. 4.6d). Cuando se encuentra en la unidad tardía rica en lepidolita y albita, la tantalita-(Mn) forma el borde de cristales tabulares con un núcleo rico en $\mathrm{Nb}$. Desde el punto de vista químico la ocupación de la posición B oscila entre 0,92 y 1,19 apfu de Ta y entre 0,83 y 1,10 apfu de $\mathrm{Nb}$, con hasta 0,03 apfu de $\mathrm{Sn}$, mientras que la posición A presenta una amplia variabilidad de ocupación mostrando, por lo tanto, un elevado grado de dispersión en el diagrama cuadrilateral de la columbita (Fig. 4.6a). De todas las muestras analizadas los cristales que se encuentran en las zonas greisenizadas son los que tienen los contenidos más altos en Fe (hasta 0,38 apfu). Varios cristales de tantalita-(Mn) secundaria son químicamente muy similares a los bordes de los cristales de columbita-( $\mathrm{Mn}$ ) primarios de las zonas de pared de los diques presentando una relación $\mathrm{Mn} /(\mathrm{Mn}+\mathrm{Fe})$ entre 0,60 y 0,83 , mientras que otros muchos de estos cristales muestran un enriquecimiento extremo en $\mathrm{Mn}$ alcanzando esta relación el valor de 1,00. Este es el caso de los cristales de tantalita-(Mn) diseminados en la zona de pared y de los bordes ricos en Ta de los cristales diseminados en la unidad tardía. Por su parte la relación $\mathrm{Ta} /(\mathrm{Ta}+\mathrm{Nb})$ es muy similar a la que muestra la tanalita(Fe) oscilando entre 0,45 y 0,59 y correspondiendo los valores más bajos a la tantalita de las zonas greisenizadas. A pesar de que algunos de estos valores están próximos al campo de la columbita-(Mn) se considera a todo el conjunto de estos cristales como tantalita-(Mn), lo que facilita su descripción.

La tapiolita es muy accesoria y solo se ha identificado, de manera puntual, en las zonas localmente greisenizadas de la unidad tardía rica en lepidolita y albita. Se presenta en agregados cristalinos que son parcialmente reemplazados por microlita secundaria (Lám. 
4.6e,f). La tapiolita de las pegmatitas de La Canalita presenta una composición química bastante constante, con contenidos en Ta entre 1,69 y 1,84 apfu y de Nb entre 0,15 y 0,28 apfu, de manera que quedan algunas vacancias en la posición $B$ que son ocupadas por trazas de Ti, Sn y Zr. La posición A está casi totalmente ocupada por el Fe (0,89-0,97 apfu) con trazas de $\mathrm{Mn}$ y de $\mathrm{Ca}$, probablemente por contaminación de la microlita que la altera. De este modo la composición de esta tapiolita se acerca bastante a la fórmula teórica $\mathrm{FeTa}_{2} \mathrm{O}_{6}$, proyectándose todas ellas en el vértice rico en Ta y Fe del cuadrilátero de la columbita (Fig. 4.6a). Las relaciones $\mathrm{Mn} /(\mathrm{Mn}+\mathrm{Fe})$ y $\mathrm{Ta} /(\mathrm{Ta}+\mathrm{Nb})$ son las típicas para esta especie mineral, de manera que la primera es muy baja $(0,03-0,04)$ mientras que la segunda varía entre 0,86-0,92.

La microlita secundaria se encuentra en las zonas greisenizadas de los cuerpos pegmatíticos reemplazando a los cristales precoces de tapiolita (Lám. 4.6e,f). Su composición química presenta los mayores contenidos en Ta (1,76 apfu) y los más bajos en $\mathrm{Nb}(0,17-0,22 \mathrm{apfu})$, con trazas de Sn, Ti y Zr y también los mayores contenidos en Ca (1,25-1,32 apfu), ya que es prácticamente el único catión que ocupa las posiciones estructurales $A$ de su fórmula general $\mathrm{A}_{2} \mathrm{~B}_{2} \mathrm{O}_{6}(\mathrm{OH}, \mathrm{F})$ (Hogarth, 1977) debido a que el $\mathrm{Na}$ en esta fase es muy escaso $(0,07-0,12 \mathrm{apfu})$ y otros elementos como Fe y $\mathrm{Mn}$ son poco significativos. Las vacancias en esta posición son las más elevadas de todas las muestras de microlita estudiadas en los diques pegmatíticos de La Canalita, mientras que los contenidos en F son los más bajos (hasta 0,19 apfu), con lo que el contenido en $\mathrm{OH}$ en su estructura es presumiblemente mayor. De acuerdo con esto la relación $\mathrm{Ta} /(\mathrm{Ta}+\mathrm{Nb})$ de esta microlita es la más elevada de todos los minerales de $\mathrm{Nb}$ y $\mathrm{Ta}$ en estos diques $(0,89-0,91)$, lo que indica su carácter más evolucionado y coincide con los valores que muestra la tapiolita a la que reemplaza (Fig. 4.6a). El mismo tipo de reemplazamiento se ha descrito en la pegmatita de Marko, Separation Rapids (Tindle y Breaks, 1998), en las pegmatitas de diversas provincias de África (Von Knorring y Fadipe, 1981) o en la pegmatita de Rubicon, Namibia (Baldwin et al., 2005).

La microlita uranífera se presenta en cristales subhedrales de tamaño milimétrico y color amarillento diseminados o reemplazando a fases precoces de $\mathrm{Nb}$ y $\mathrm{Ta}$ en las zonas intermedias exterior e interior de los cuerpos pegmatíticos (Lám. 4.6d). Tiene contenidos en Ta ligeramente superiores a la microlita primaria mientras que las posiciones $A$ están ocupadas mayoritariamente por Ca que varía entre 0,80 y 0,69 apfu y por $\mathrm{Na}$ (hasta 0,81 apfu), con contenidos en $U$ de hasta de 0,12 apfu, lo que corresponde con algo más del $6 \%$ en peso de $\mathrm{UO}_{2}$, aunque algunos de los cristales analizados semicuantitativamente mediante microscopio electrónico muestran contenidos de hasta $12 \%$ en peso de este óxido. Los contenidos en $\mathrm{F}$ son ligeramente inferiores a los que presenta la microlita primaria lo que permite deducir que el contenido en $\mathrm{OH}$ que puede aceptar estequiométricamente esta microlita es mayor. Debido a su elevado contenido en Ta la relación $\mathrm{Ta} /(\mathrm{Ta}+\mathrm{Nb})$ es de 0,840,86 (Fig. 4.6a). Esta fase es la única de estos cuerpos pegmatíticos que contiene importantes contenidos en uranio y se forma por el reemplazamiento de minerales de $\mathrm{Nb}$ y Ta previos, de acuerdo con Von Knorring y Fadipe (1981).

\section{Sustituciones y evolución de los óxidos}

En el diagrama cuadrilateral de la columbita se observa que la composición química de los minerales del grupo de la columbita se agrupa en dos asociaciones principales (Fig. 4.6a). La 
primera muestra la evolución de estos minerales desde las fases con elevados contenidos en $\mathrm{Nb}$ hasta las fases más enriquecidas en Ta, con una relación $\mathrm{Mn} /(\mathrm{Mn}+\mathrm{Fe})$ entre 0,84 y 0,99 y que muestra una tendencia horizontal seguida de una evolución vertical desde 0,17 hasta 0,42 para la relación $\mathrm{Ta} /(\mathrm{Ta}+\mathrm{Nb})$ debido a un fuerte enriquecimiento en Ta. Esta tendencia representa la cristalización de las fases minerales primarias en los diques pegmatíticos de La Canalita a partir de fundidos que se enriquecen progresivamente en Ta. La segunda asociación refleja contenidos de $\mathrm{Fe} \mathrm{y} \mathrm{Mn}$ variables proyectados de forma dispersa a lo largo del eje $\mathrm{Mn} /(\mathrm{Mn}+\mathrm{Fe})$, que tienen una relación $\mathrm{Ta} /(\mathrm{Ta}+\mathrm{Nb})$ más o menos constante entre 0,43 y 0,59. Este grupo representa la asociación secundaria con altos contenidos en Ta en la secuencia de cristalización de los diques pegmatíticos, cuya variabilidad composicional respecto a los contenidos en Fe y Mn sugiere la influencia de fluidos metamórficos en su composición.

En este diagrama se han proyectado los análisis de la tapiolita en la esquina superior izquierda del diagrama cuadrilateral (Fig. 4.6a), fuera del gap composicional de los minerales del grupo de la columbita, ya que esta está muy enriquecida en Ta y en Fe y además las dos generaciones de microlita, también con elevados valores de la relación $\mathrm{Ta} /(\mathrm{Ta}+\mathrm{Nb})$ : la primaria, con mayores variaciones en los contenidos de Fe y Mn y la secundaria, con contenidos más altos en Fe.

En los gráficos de la figura 4.6c,d se observan los principales mecanismos de sustitución de Fe por $\mathrm{Mn}$ en la posición A y de $\mathrm{Nb}$ por Ta en la posición B en la fórmula general de los minerales del grupo de la columbita. En ambos se aprecian claramente las dos asociaciones de óxidos de $\mathrm{Nb}$ y Ta: la primaria con mayores contenidos en $\mathrm{Nb}$ y en $\mathrm{Mn}$ y la secundaria con valores intermedios o más enriquecidos en Ta y en Fe y Mn. Los datos en ambos casos se muestran muy próximos a la línea 1:1, por lo que se trata principalmente de una sustitución isovalente de $\mathrm{Ta}^{5+}$ por $\mathrm{Nb}^{5+}$ y de $\mathrm{Fe}^{2+}$ por $\mathrm{Mn}^{2+}$, si bien la entrada de otros elementos como el $\mathrm{Sn}$ o el W en su estructura indicaría la influencia de estas sustituciones adicionales.

Además del Sn y el W, el Ti es uno de los elementos traza que frecuentemente aparecen en la composición de los minerales del grupo de la columbita-tantalita, aunque en ningún caso llega a superar el $0.8 \%$ en peso de $\mathrm{TiO}_{2}$. En el diagrama $\mathrm{TiO}_{2}$ vs. $\mathrm{Ta} /(\mathrm{Ta}+\mathrm{Nb})$ (Fig. 4.6e) aparentemente no se aprecia una relación clara entre los puntos aunque parece que, en general, los minerales de la asociación primaria muestran contenidos en $\mathrm{TiO}_{2}$ bajos y constantes (muy próximos a 0) mientras que los minerales de la asociación secundaria muestran contenidos en $\mathrm{TiO}_{2}$ más elevados para valores más altos y más o menos constantes de la relación $\mathrm{Ta} /(\mathrm{Ta}+\mathrm{Nb})$. La suma de los cationes $\mathrm{Ta}+\mathrm{Nb}+\mathrm{Ti}$ en la posición B es ligeramente superior a 2 apfu en la mayoría de estos minerales alcanzando en ocasiones 2,04 apfu, lo que sugiere que la entrada del Ti en su estructura tendría lugar mediante una sustitución de tipo $3 \mathrm{Ti}^{4+} \leftrightarrow 2(\mathrm{Nb}, \mathrm{Ta})^{5+}+(\mathrm{Fe}, \mathrm{Mn})^{2+}($ Ercit, 1994).

\subsubsection{Casiterita}

La casiterita es el óxido más abundante de las pegmatitas de La Canalita y se encuentra diseminada en las diferentes zonas de los diques, sobre todo en la unidad tardía rica en lepidolita y albita, donde se observa que los cristales de casiterita rellenan espacios intergranulares y también en las unidades greisenizadas (Lám. 4.7a,b). La casiterita se presenta en cristales sub- a euhedrales de tamaño inferior a 1 centímetro, a veces biterminados, frecuentemente 

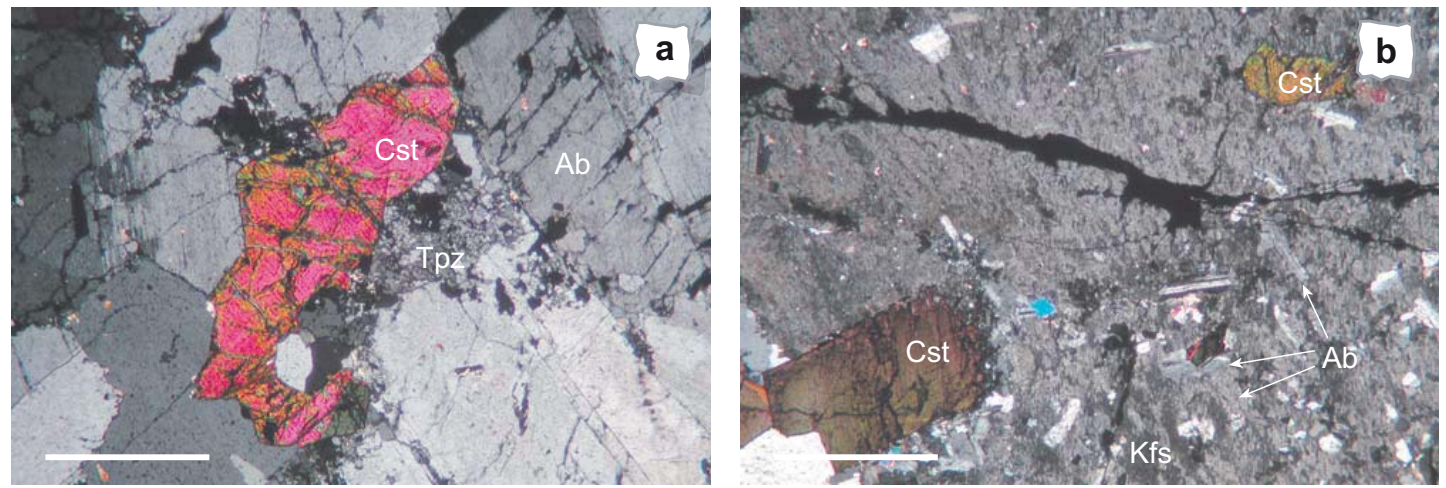

Lám. 4.7. Microfotografías de la casiterita de los diques pegmatíticos de La Canalita, NC: a) asociada a albita y topacio microcristalino; y b) asociada a feldespato potásico albitizado del margen del núcleo. Escala gráfica: $1 \mathrm{~mm}$.

maclados y zonados. Normalmente en estos cristales se observan inclusiones de minerales de $\mathrm{Nb}$ y $\mathrm{Ta}$, lo que prueba el carácter tardío de este óxido tanto en la secuencia primaria de cristalización magmática como en la asociación secundaria de alteración metasomática (Fig. 4.7). Químicamente no se observan diferencias entre la casiterita primaria y la secundaria, donde el Sn ocupa entre 0,88 y 0,99 apfu y el resto está ocupado por trazas de Mn (hasta 1,2 \% en peso de $\mathrm{MnO}$ ), $\mathrm{Fe}$ (hasta 0,3\% en peso de $\mathrm{FeO}$ ) y por contenidos variables en Ta (hasta 0,06 apfu) y Nb (hasta 0,05 apfu). Las casiteritas con contenidos en Ta y Nb más altos corresponden con las que presentan inclusiones de minerales del grupo de la columbita-tantalita, o bien con los análisis de las bandas rojizas de los cristales zonados. Poco significativas son las trazas de otros elementos como el $\mathrm{Al}_{2} \mathrm{O}_{3}, \mathrm{CaO}$ o $\mathrm{WO}_{3}$, que no alcanzan el $1 \%$ en peso (Anexo III).

En el diagrama $\mathrm{Mn}+\mathrm{Fe}$ vs. Ta+Nb (Fig. 4.6f) se observa una tendencia según la relación 2:1 que corresponde con la sustitución doble $3 \mathrm{Sn}^{3+} \rightarrow 2(\mathrm{Nb}, \mathrm{Ta})^{5+}+(\mathrm{Fe}, \mathrm{Mn})^{2+}$. Esta es una relación común en las casiteritas de pegmatitas graníticas, como demuestran Tindle y Breaks (1998). Se observan cantidades más significativas de Ta que de $\mathrm{Nb}$ en alguna de las muestras y un enriquecimiento constante en $\mathrm{Mn}$ sobre el Fe característico de las pegmatitas del subtipo lepidolita o estrechamente relacionadas con estas (Spilde y Shearer, 1992; Raimbault, 1998).

\subsubsection{Secuencia mineral}

En los diques aplíticos de Molino del Galo cristalizan cuarzo, albita y moscovita como minerales esenciales, junto con accesorios como la andalucita, la gahnita, el apatito o el circón (Fig. 4.7). Posteriormente un metasomatismo sódico alteraría a un fosfato primario no conservado, transformándolo en alluaudita y ferrisiklerita-heterosita?. A continuación, las venas de cuarzo que cortan a los diques alterarían hidrotermalmente a estas rocas dando lugar a la moscovitización y cloritización de la albita y de la andalucita y a la formación de la gormanita y el hidroxilapatito a partir de la albita y de los fosfatos previos.

En los diques pegmatíticos de La Canalita cristalizan cuarzo, albita, moscovita, lepidolita, feldespato potásico, topacio y montebrasita en diferentes proporciones según las distintas zonas de los diques (Fig. 4.7). Junto con la mineralización principal de casiterita se forman, además, columbita-(Mn), tantalita-(Mn) y microlita. Posteriormente, un metasomatismo 
sódico da lugar a la cristalización de una unidad tardía rica en albita y lepidolita de tamaño de grano fino, dado que los fundidos residuales extremadamente enriquecidos en Li, F, Ta y Mn estabilizan grandes cantidades de minerales con B, P, Li, F como el topacio, la montebrasita o la lepidolita. En esta cristaliza una segunda generación de columbita-(Mn) y tantalita-(Mn). Posteriormente, la llegada de fluidos hidrotermales produciría la moscovitización de las plagioclasas de las zonas más externas de los cuerpos pegmatíticos y, en menor medida, del topacio de las zonas de borde y de pared liberando parte del Na y el K de las plagioclasas $\mathrm{Y}$ del $\mathrm{F}$ del topacio para dar lugar a agregados de mica blanca y cuarzo de tamaño de grano extremadamente fino (Pirajno, 1992). Como consecuencia del incremento en las actividades de $\mathrm{Na}^{+}, \mathrm{K}^{+}$e $\mathrm{H}^{+} \mathrm{y}$ de los volátiles en el fluido hidrotermal se produce la greisenización parcial de los diques pegmatíticos. El $\mathrm{F}$ liberado durante estos procesos incrementaría la aHF y daría lugar a la formación del topacio y de la mineralización de casiterita junto con tantalita-(Fe), columbita-(Fe), tapiolita, microlita y microlita uranífera (Burt, 1981; Novák y Černý, 1998). Finalmente, la sílice liberada durante las reacciones de greisenización daría lugar a los agregados microcristalinos y venas de cuarzo con hidróxidos de Fe, estos últimos probablemente como consecuencia de contaminación por fluidos metamórficos durante los procesos de alteración supergénica.

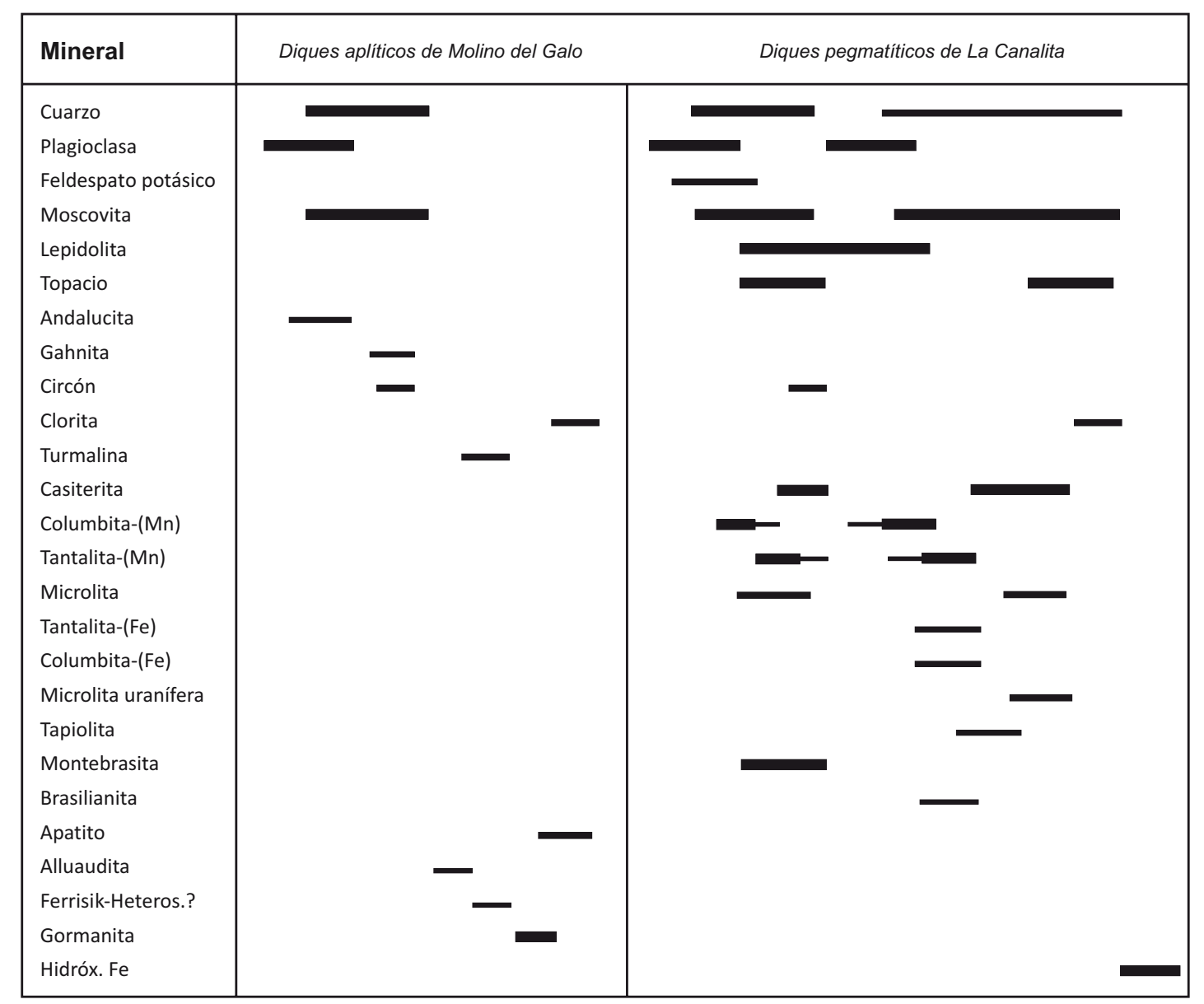

Fig. 4.7. Evolución magmático-hidrotermal de los diques aplíticos de Molino del Galo y pegmatíticos de La Canalita. 


\subsection{VENAS DE CUARZO INTRAGRANÍTICAS}

A diferencia de las venas de cuarzo mineralizadas encajadas en las facies de la UE del batolito de Jálama, las que se encuentran asociadas al batolito de Cadalso-Casillas de Flores tienen menor entidad y su mineralización es escasa. Las venas de cuarzo mineralizadas asociadas al complejo de El Payo se localizan únicamente en la facies intermedia del granito de El Payo (G2), mientras que las que están asociadas al complejo de Peñaparda se encuentran encajadas tanto en la facies del granito de Peñaparda (G5) como en el granito de La Ermita (G6) (Fig. 4.8).

\subsubsection{Caracterización morfológica y estructural}

\section{Venas de cuarzo encajadas en el complejo de El Payo}

El granito de El Payo (G2) ocupa la mayor parte de la superficie aflorante del batolito de Cadalso-Casillas de Flores (Fig. 2.5). En él encaja la mayor parte de los indicios mineros, como el que se encuentra en la zona de Villasrubias, muy próximo al contacto con el encajante metamórfico, en Baldío de Robleda, próximo al contacto con el granito de La Ermita, y en El Cruce, próximo a la localidad de Peñaparda (JCyL-TAGSA, 1987) (Fig. 4.8). De todos ellos el

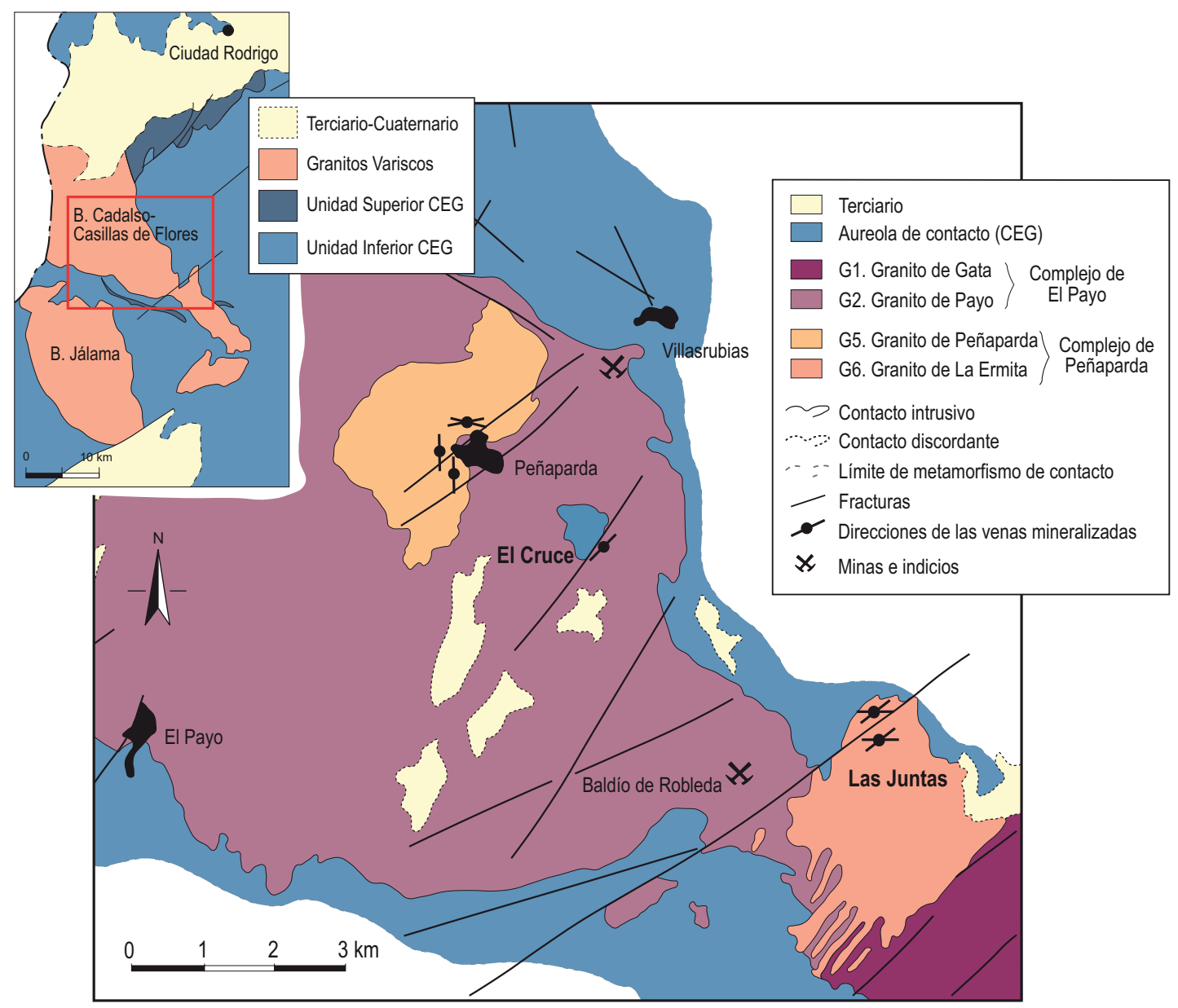

Fig. 4.8. Esquema geológico de la zona central del batolito de Cadalso-Casillas de Flores con la situación de las minas e indicios estudiados. Modificado de Hassan (1996). 
único en el que se han podido describir sus filones mineralizados ha sido en El Cruce, ya que en el resto las labores de restauración y reforestación los han ocultado por completo (Lám. $4.8 \mathrm{a}, \mathrm{b})$.

En la zona de El Cruce el granito encajante se encuentra totalmente fracturado y parcialmente alterado. Se diferencian fracturas de direcciones $\mathrm{N}-\mathrm{S}$ y $\mathrm{N} 40^{\circ} \mathrm{E}$ que lo cortan y que contienen la mineralización que consiste en abundantes sulfuros diseminados. Se conserva únicamente un potente filón de cuarzo de dirección $\mathrm{N} 40^{\circ} \mathrm{E}$ y buzamiento de $70^{\circ}$ al $\mathrm{NO}$ de potencia y longitud superior a $1 \mathrm{~m}$ y $3 \mathrm{~m}$ respectivamente (Lám. 4.8c). El cuarzo es el principal mineral que rellena estas venas junto con moscovita y clorita de manera muy subordinada. En estas venas de cuarzo la mineralización se presenta en agregados cristalinos masivos diseminados en su interior (Lám. 4.8d) y está constituida por abundante arsenopirita, pirita y esfalerita, cantidades accesorias de calcopirita y galena y covelita, marcasita, escorodita y óxidos de Fe como productos de alteración.
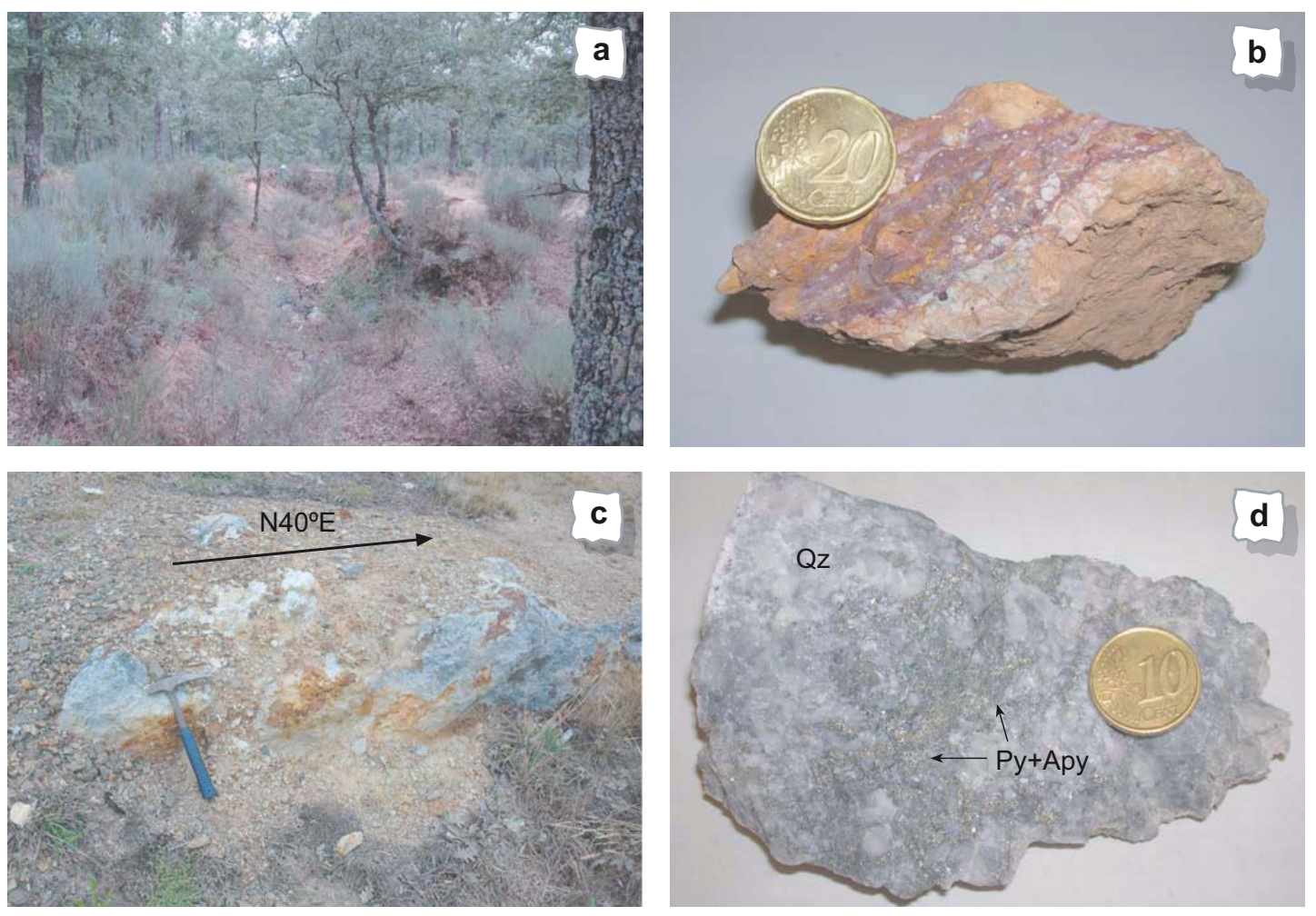

Lám. 4.8. Afloramientos de las venas de cuarzo mineralizadas en el complejo de El Payo: a) aspecto de las labores mineras abandonadas en la localidad de Villasrubias; b) fragmento de brecha mineralizada y muy oxidada en la zona de Villasrubias; c) aspecto del filón de cuarzo mineralizado de dirección N40E en El Cruce de Peñaparda; d) detalle de una muestra de cuarzo mineralizada del filón anterior.

\section{Venas de cuarzo encajadas en el complejo de Peñaparda}

Las venas de cuarzo mineralizadas encajadas en el granito de Peñaparda presentan una dirección principal $\mathrm{N} 170^{\circ} \mathrm{E}$ y buzamiento subvertical (Fig. 4.8), con morfología tabular y 
potencias inferiores a $1 \mathrm{~m}$ (Lám. 4.9a). Menos frecuentes son los haces de venas de direcciones $\mathrm{N} 20^{\circ} \mathrm{E}$ y $\mathrm{N} 80^{\circ} \mathrm{E}-\mathrm{N} 120^{\circ} \mathrm{E}$ y buzamientos también subverticales, que presentan una morfología lenticular, potencias que oscilan entre los 20 y los $30 \mathrm{~cm}$ y una longitud visible de hasta $5 \mathrm{~m}$. El cuarzo es el mineral principal del relleno de estas venas, además de clorita y moscovita subordinadas. La mineralización se suele localizar en las zonas más internas de los filones en agregados masivos o cristalinos ocupando gran parte del relleno de la vena (Lám. 4.9b). En ella se han identificado ocasionalmente casiterita y wolframita, localizada esta última en las zonas de borde de los filones. Los sulfuros principales son la arsenopirita y la pirita, además de esfalerita, galena y calcopirita de forma accesoria. La covelita y la escorodita destacan como los principales minerales de alteración de estos sulfuros, además de abundantes óxidos de Fe.

Por otro lado las venas de cuarzo mineralizadas encajadas en el granito de La Ermita se localizan en la dehesa de El Jaque (Fig. 4.8). Se presentan en haces con direcciones de $\mathrm{N} 50^{\circ} \mathrm{E}$ a $\mathrm{N} 80^{\circ} \mathrm{E}$ y buzamientos subverticales, con potencias inferiores a $1 \mathrm{~m}$. Actualmente estas venas apenas son visibles debido a las labores de repoblación forestal llevadas a cabo en esta zona. El mineral principal de la ganga es el cuarzo con moscovita muy accesoria, mientras que entre los de la mena destaca la presencia de wolframita diseminada hacia las zonas de borde de las venas (Lám. 4.9c). Se encuentra, además, arsenopirita como sulfuro principal y pirita, esfalerita, calcopirita y galena como accesorios.
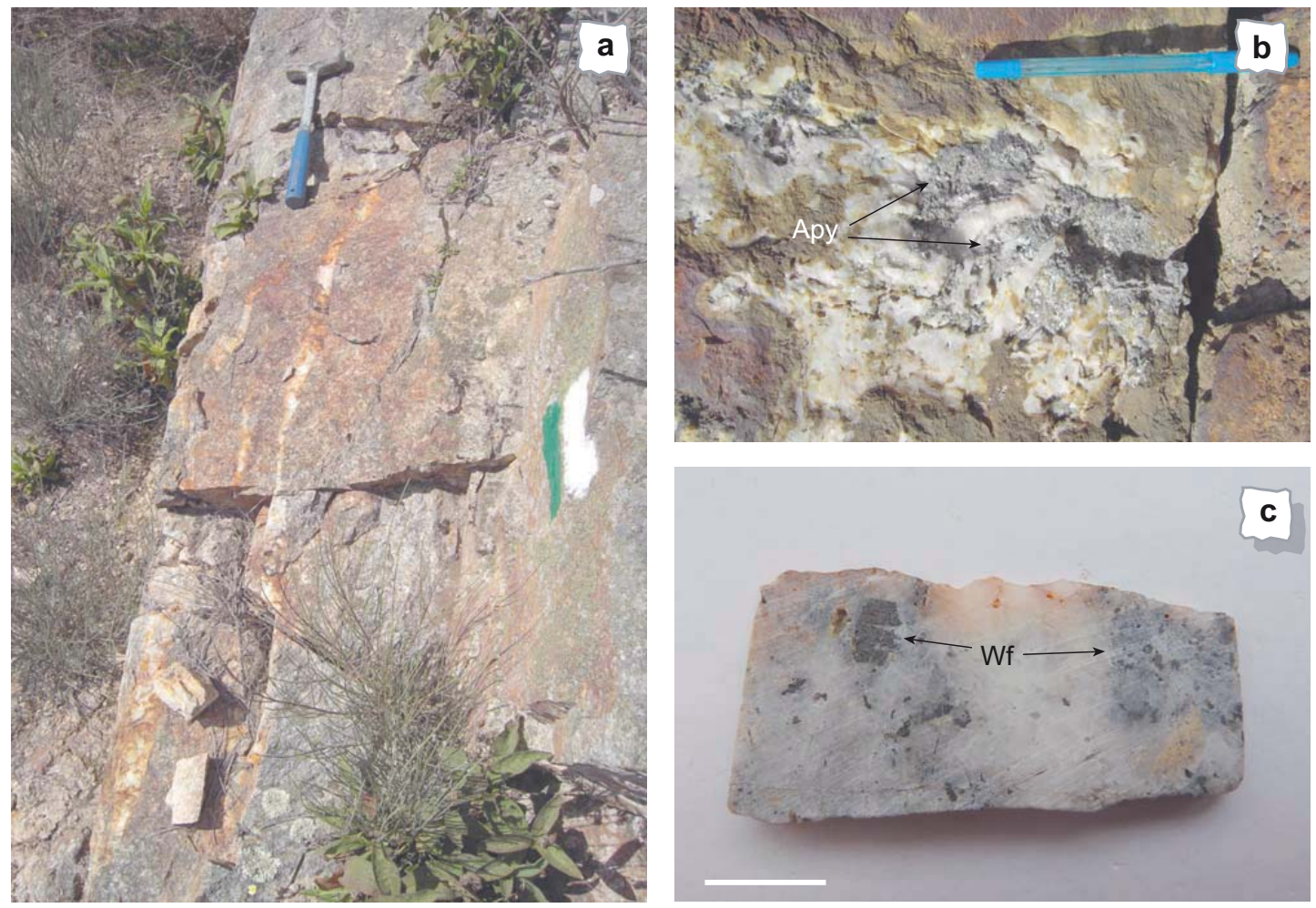

Lám. 4.9. Afloramientos de las venas de cuarzo mineralizadas en el complejo de Peñaparda: a) venas de cuarzo mineralizadas de dirección $\mathrm{N} 170^{\circ} \mathrm{E}$ en la localidad de Peñaparda; b) agregados de arsenopirita parcialmente alterados a escorodita en el interior de las venas de cuarzo de Peñaparda; c) detalle de las venas de cuarzo de El Jaque encajadas en el granito de La Ermita, donde se observa la presencia de cristales de wolframita en las zonas de bordes de los filones. Escala gráfica en c) $1 \mathrm{~cm}$. 


\subsubsection{Petrografía y química mineral}

\section{Cuarzo}

Las características texturales del cuarzo de las venas mineralizadas del batolito de CadalsoCasillas de Flores indican que el relleno tuvo lugar mediante el mecanismo de crack and seal (Ramsay, 1980), produciéndose repetidas fracturaciones que son a continuación selladas por los minerales constituyentes de la vena. Tres generaciones de cuarzo se han identificado: el cuarzo I, que se presenta en cristales sub- a euhedrales de tamaño centimétrico en los que se aprecian las caras de crecimiento cristalino y una fuerte fracturación (Lám. 4.10a), con extinción ondulante y texturas dentadas en los bordes de los cristales (Lám. 4.10b). A este cuarzo I se asocia la cristalización de la mineralización precoz como la casiterita o la wolframita (Fig. 4.13); el cuarzo II es menos abundante y se presenta en cristales sub- a euhedrales de tamaño milimétrico, a veces con tendencia poligonal o con texturas en peine (Lám. 4.10a,c) rellenando las fracturas en el cuarzo I. A este cuarzo II se asocia la cristalización de los sulfuros principales como la arsenopirita y la esfalerita (Fig. 4.13); finalmente, el cuarzo III se presenta en agregados de cristales anhedrales de tamaño micrométrico que rellenan las últimas fracturas producidas en las venas (Lám. $4.10 \mathrm{~d}$ ) y que se asocian a la cristalización de sulfuros tardíos como la pirita (Fig. 4.13).

\section{Moscovita}

La moscovita es un mineral accesorio que se presenta bien en cristales laminares de tamaño milimético asociados al cuarzo I y II (Lám. 4.10e), o bien en agregados criptocristalinos asociados al cuarzo III (Lám. 4.10f) rellenando grietas tardías y tapizando a minerales previos. Su composición química proyectada en el diagrama de clasificación de Tischendorf et al. (2004) se muestra próxima al término ideal de la moscovita y en zonas de transición a la fengita (Fig. 4.9a), lo que indica escasos o nulos contenidos en Li (hasta 0,50 \% en peso de $\mathrm{Li}_{2} \mathrm{O}$ ). Sin embargo, los contenidos en Fe y en $\mathrm{Mg}$ son relativamente altos (hasta 0,82 y 0,22 apfu respectivamente) por lo que la relación $\mathrm{Fe} /(\mathrm{Fe}+\mathrm{Mg})$ se mantiene más o menos constante entre 0,74 y 0,79 . Destacan además los altos contenidos en $F$ que alcanzan hasta 0,53 apfu (Anexo III).
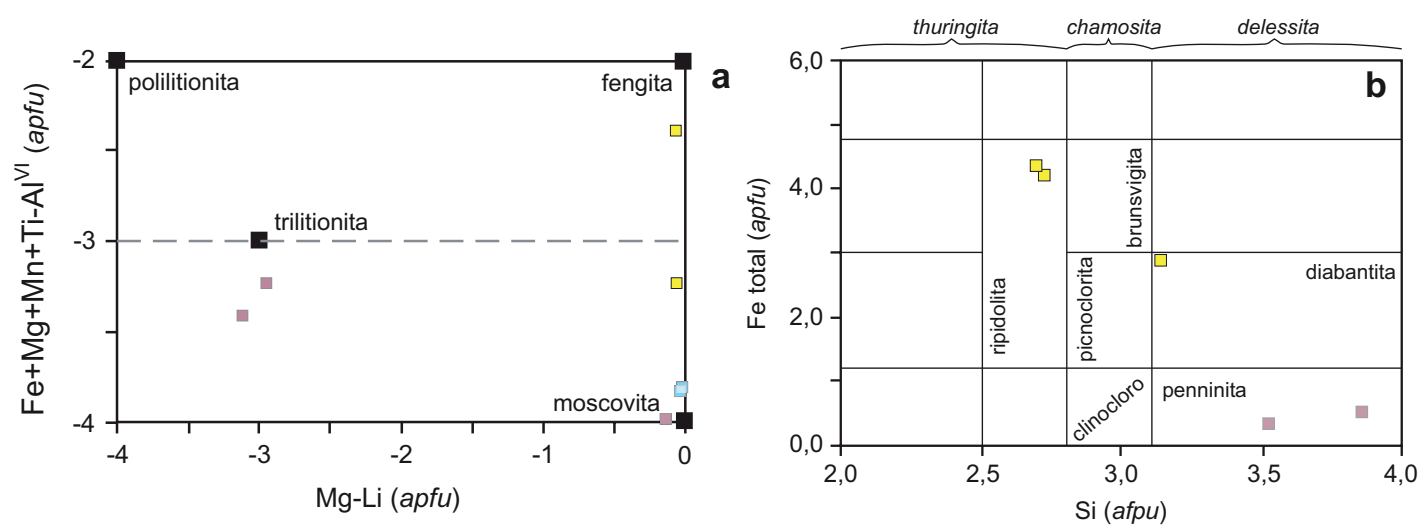

Fig. 4.9. a) Diagrama de clasificación de Tischendorf et al. (2004) con la representación de la composición química de la mica blanca en las venas de cuarzo mineralizadas (amarillo) comparada con la de los diques pegmatíticos y aplíticos; b) diagrama de clasificación de la clorita de las venas de cuarzo según Hey (1954). 

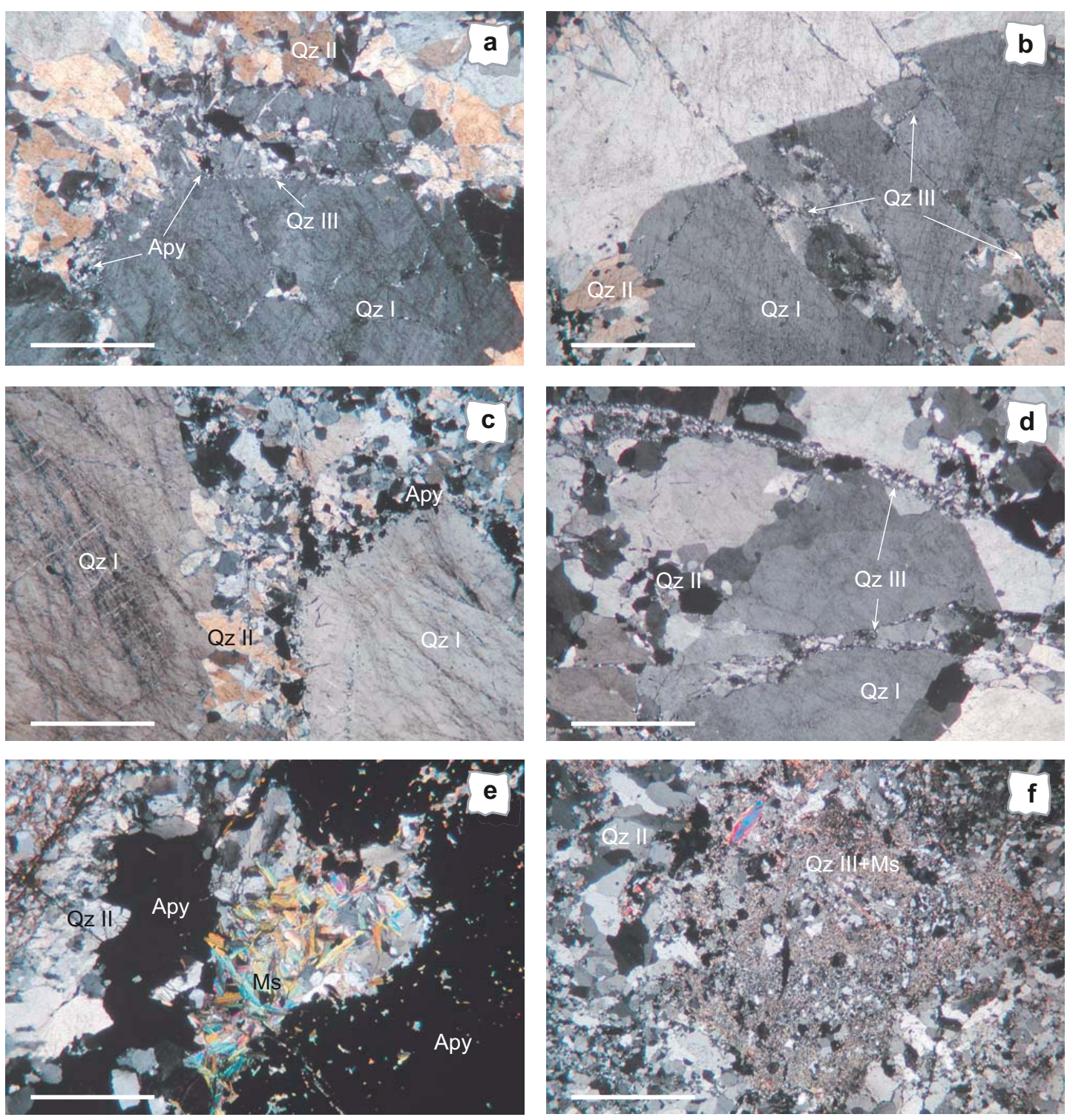

Lám. 4.10. a) Aspecto microscópico de los cristales euhedrales de cuarzo I fracturados junto al cuarzo II y la arsenopirita, El Cruce, NC; b) cristales euhedrales de cuarzo I fracturados, El Cruce, NC; c) fractura en el cuarzo I sellada por cuarzo II y arsenopirita, El Cruce, NC; d) fracturas tardías en el cuarzo I y II selladas por agregados microcristalinos de cuarzo III, El Cruce, NC; e) agregados de mica blanca asociados a la arsenopirita y al cuarzo II, Peñaparda, NC; f) agregados microcristalinos de mica blanca de origen tardío y cuarzo III, Peñaparda, NC. Escala gráfica: $1 \mathrm{~mm}$.

\section{Clorita}

La clorita en estas venas de cuarzo se encuentra asociada a fracturas tardías donde cristaliza de forma masiva en agregados fibroso-radiados y esferulíticos de color verde pálido ligeramente pleocroicos en luz natural (Lám. 4.11a), o como producto de alteración de la moscovita. Según la clasificación de Hey (1954) se clasifica como ripidolita y diabantita (Fig. 4.9b), según la de Bailey (1980) como chamosita y según la de Zane y Weiss (1998) como clorita-Fe que varía entre los tipos I y II al mostrar variaciones en el contenido en Fe y Al+vacancias. En su composición química destacan los contenidos relativamente elevados en $\mathrm{P}$ que sustituyen al 
Si en algunas cloritas, alcanzando hasta 0,25 apfu, lo que coincide con menores contenidos en Fe de este mineral. El contenido en Mg también es muy bajo del orden de 0,12 apfu, de modo que la relación $\mathrm{Fe} /(\mathrm{Fe}+\mathrm{Mg})$ en todas ellas es muy elevada entre 0,97 y 0,99. La capa interlaminar se encuentra prácticamente vacía, únicamente con contenidos traza en $\mathrm{Ca}, \mathrm{Na}$, especialmente, $\mathrm{K}$ (Anexo III).

\section{Turmalina}

Este mineral es muy escaso en las venas de cuarzo. Únicamente se ha identificado en la salbanda y en el interior de las venas asociada al cuarzo I en la zona de Villasrubias. Se encuentra en cristales an- a subhedrales frecuentemente prismáticos o en agregados cristalinos de tamaño hasta centimétrico y color negro en muestra de mano (Lám. 4.11b).
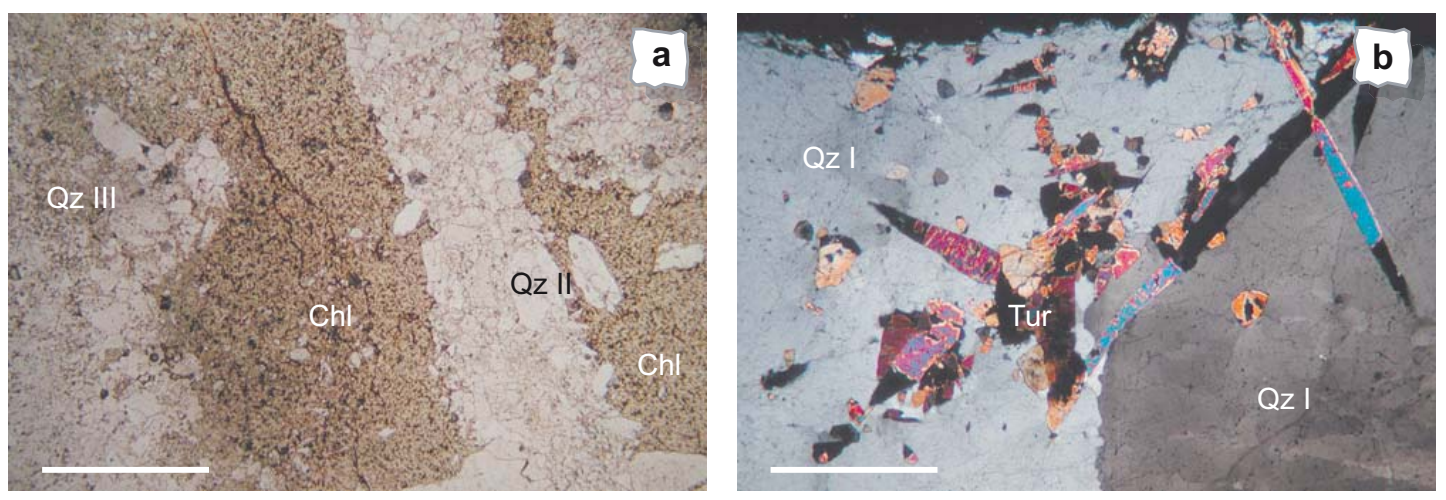

Lám. 4.11. a) Agregados microcristalinos de clorita y cuarzo III rellenando fracturas tardías de las venas, Peñaparda, LN; b) cristales de turmalina asociados al cuarzo I, Villasrubias, NC. Escala gráfica: 1 mm.

\subsubsection{Mineralización}

\subsubsection{Casiterita, wolframita y scheelita}

\section{Casiterita}

La casiterita es un óxido muy escaso en las venas de cuarzo del batolito de Cadalso-Casillas de Flores, únicamente identificado en las venas encajadas en el granito de Peñaparda (G5). En ellas este óxido se presenta en agregados cristalinos de tamaño milimétrico incluidos en cristales de arsenopirita, lo que demuestra su carácter precoz en la secuencia mineral (Fig. 4.13).

Su composición química se encuentra próxima a la fórmula ideal $\left(\mathrm{SnO}_{2}\right)$, con las posiciones catiónicas ocupadas por Sn entre 0,94 y 0,99 apfu (Anexo III) y solo escasas sustituciones de Nb (hasta 0,02 apfu) y Ti (hasta 0,02 apfu). Se observa, además, la preferencia a la incorporación de Fe y Mn frente a Nb y Ta en la casiterita de las venas (Fig. 4.10a), a diferencia de la de las pegmatitas de La Canalita que tendían a incorporar preferentemente $\mathrm{Nb}$ y Ta. 


\section{Wolframita}

Únicamente se ha identificado en las venas de cuarzo mineralizadas asociadas al granito de La Ermita (G6) y al granito de Peñaparda (G5). Esta wolframita se presenta asociada al cuarzo I en cristales an- a subhedrales de tamaño hasta centimétrico en las zonas de borde, alterándose parcialmente a óxidos de Fe y a scheelita (Lám. 4.12a). Su composición química es dominantemente ferberítica con hasta 0,84 apfu de $\mathrm{Fe}^{2+}$ y hasta 0,12 apfu de $\mathrm{Fe}^{3+}$, este último calculado por balance de cargas, con un escaso componente hübnerítico (hasta 0,19 apfu de $\mathrm{Mn}$ ), salvo uno de los cristales analizados que muestra contenidos en Fe y Mn intermedios (Anexo III). En el diagrama binario de Fe vs. Mn se observa una relación de sustitución isovalente 1:1 (Fig. 4.10b).
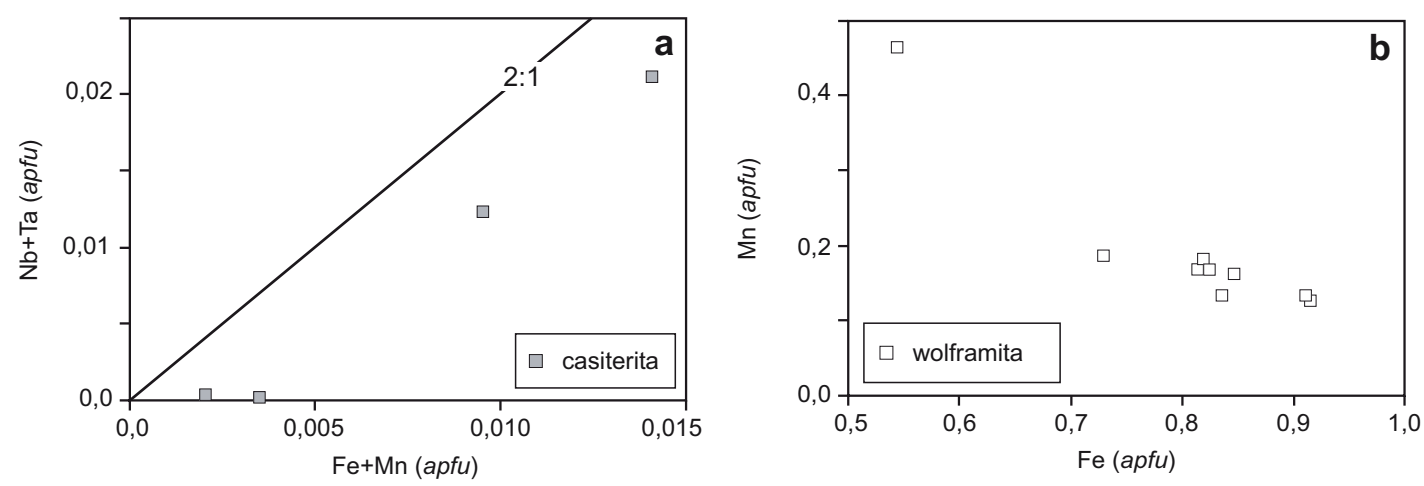

Fig. 4.10. Diagramas de variación: a) Nb+Ta vs. Fe+Mn (en apfu) en la casiterita; y b) Mn vs. Fe (en apfu) en la wolframita de las venas de cuarzo mineralizadas.

\section{Scheelita}

Se ha identificado únicamente en las venas de cuarzo encajadas en el granito de La Ermita (G6) como producto de alteración en las grietas y fracturas de la wolframita.

\section{Rutilo}

El rutilo es un mineral muy tardío que se presenta en agregados cristalinos anhedrales de tamaño micrométrico a milimétrico en fracturas de minerales más precoces junto con agregados microcristalinos de mica blanca y cuarzo. Su composición química se aproxima a la fórmula ideal, donde el Ti ocupa la mayor parte de las posiciones catiónicas variando entre 0,97 y 0,98 apfu, con escasos contenidos en Sn, Fe o, incluso, W (hasta 0,01 apfu).

\subsubsection{Sulfuros}

\section{Arsenopirita}

La arsenopirita es, junto con la pirita, el mineral más abundante en las venas de cuarzo mineralizadas del batolito de Cadalso-Casillas de Flores. Se presenta en cristales an- a subhedrales de color blanco-amarillento bajo el microscopio y de tamaño milimétrico (Lám. 4.12b) o, más frecuentemente, en agregados cristalinos o granulares de aspecto masivo en el 

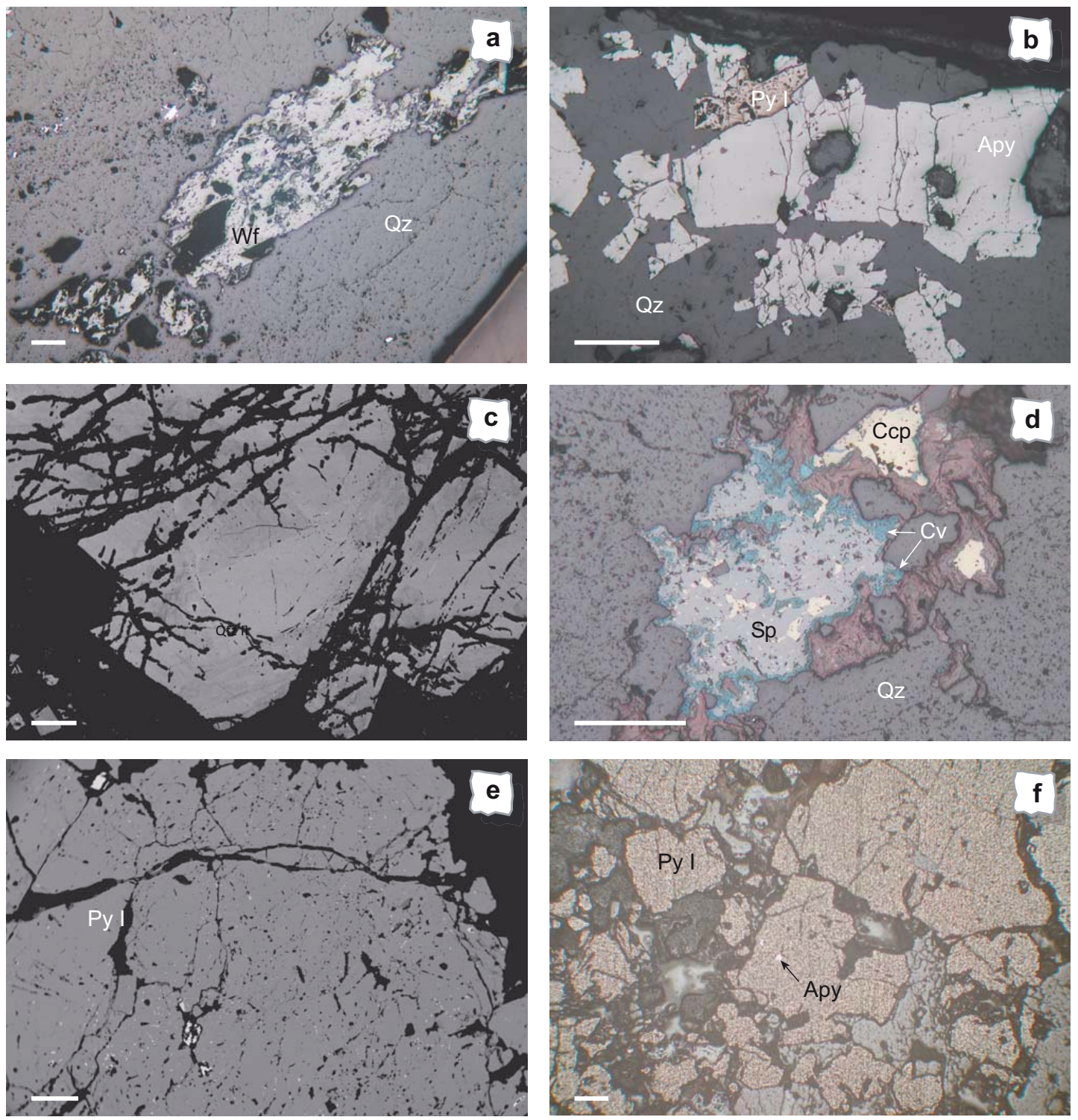

Lám. 4.12. Microfotografías ópticas en luz reflejada ( $a, b, d, f)$ y electrónicas (c, e) de: a) los cristales de wolframita en las venas de cuarzo de la zona de El Jaque, LN; b) cristales subhedrales de arsenopirita y pirita I, El Cruce, LN; c) zonado aparente en la arsenopirita de El Cruce; d) esfalerita con inclusiones de calcopirita parcialmente reemplazadas por covelita, Peñaparda, LN; e) pequeñas inclusiones de calcopirita y galena en la pirita I masiva, El Cruce; f) agregados de cristales de pirita I con inclusiones de arsenopirita en las venas de Peñaparda, LN Escala gráfica: a, b, d, e,f) $250 \mu \mathrm{m}$; c) $100 \mu \mathrm{m}$.

interior de las venas de cuarzo. Normalmente los cristales de arsenopirita están fracturados o brechificados y parcialmente alterados a escorodita.

Su composición química y las relaciones texturales y paragenéticas con el resto de minerales indican la cristalización de una arsenopirita asociada al cuarzo II. Este episodio de cristalización se deduce, además, de la distribución más o menos homogénea de los análisis según una campana gaussiana con un único pico de frecuencia en el histograma de la figura 4.11a y en el diagrama de distribución del As y el S (Fig. 4.11b). Destacan en su composición los bajos contenidos en Sb (hasta 0,40 \% en peso), en Ni (hasta 690 ppm), en Co (hasta 810 ppm), en Se (3.530 ppm) y en Te (hasta 350 ppm) (Anexo III). 

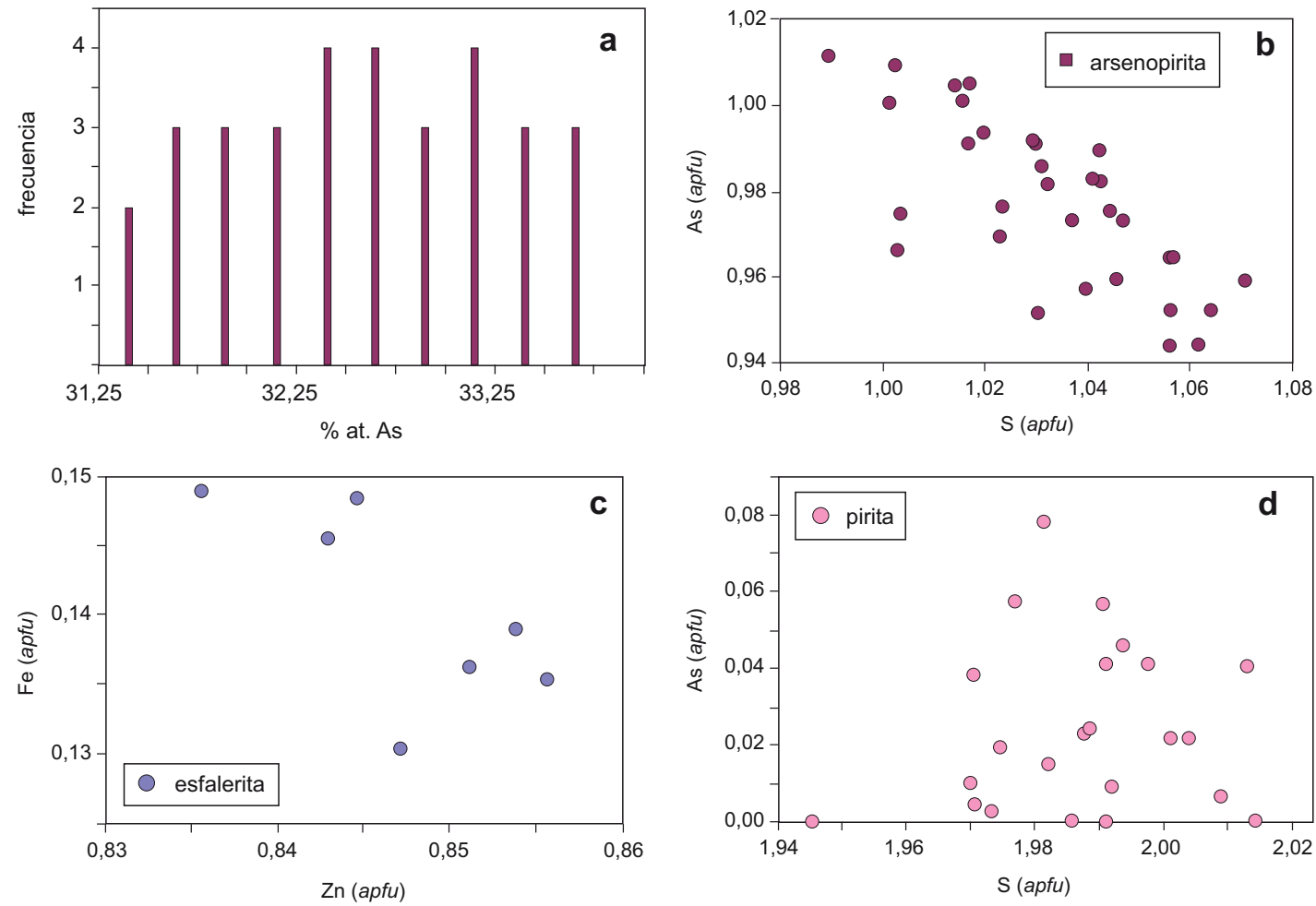

Fig. 4.11. a) Histograma de los contenidos en As (en \% at.); y b) diagrama de variación As vs. S (en apfu) en la arsenopirita de las venas de cuarzo. Diagramas de variación: c) Fe vs. Zn (en apfu) en la esfalerita; y d) As vs. S (en apfu) en la pirita de las venas de cuarzo.

Bajo el microscopio electrónico alguno de estos cristales de arsenopirita presenta una textura zonada (Lám. 4.12c) debido a que el núcleo está enriquecido en As (33,00-33,65 \% at.) y los bordes ligeramente empobrecidos (31,50-32,75\% at. As). Sin embargo, esta aparente zonación podría deberse a una diferente incorporación de As y $S$ en las distintas caras del cristal. Según Vesselinov y Kerestedjian (1995) si la tasa de crecimiento del cristal es suficientemente elevada puede que no reequilibre su composición, con lo que cada cara tendría una relación $\mathrm{S} /$ As determinada. En este caso la relación $\mathrm{S} / \mathrm{As}$ que muestra esta arsenopirita varía entre 0,99 y 1,12 , correspondiendo con una tasa de crecimiento cristalino elevada por lo que dicha zonación estaría causada por una diferente incorporación de S y, por lo tanto, de As en cada una de sus caras.

\section{Esfalerita}

Este mineral se presenta en agregados cristalinos masivos de tamaño milimétrico y de color marrón oscuro frecuentemente reemplazados por calcopirita (Lám. 4.12d). Las relaciones texturales con el resto de minerales de la secuencia mineral sugieren que este sulfuro es ligeramente anterior a la cristalización de la arsenopirita (Fig. 4.13) ya que frecuentemente esta última la incluye.

Químicamente las esfaleritas analizadas en los diferentes indicios del batolito de CadalsoCasillas de Flores son iguales (Anexo III). Los contenidos en Zn varían entre 0,84 y 0,86 apfu y pueden estar sustituidos por hasta 0,15 apfu de $\mathrm{Fe}$, existiendo entre ambos una grosera 
correlación negativa (Fig. 4.11c). Destacan, además, contenidos significativos en Cd (hasta $0,28 \%$ en peso) que son ligeramente más altos en las venas de El Cruce que en el resto, y más bajos en $\mathrm{Mn}$ (hasta 0,14 \% en peso).

\section{Pirita}

Se han diferenciado dos generaciones de pirita en las venas de cuarzo mineralizadas: la pirita I, que se presenta en masas anhedrales o agregados de cristales euhedrales de tamaño micrométrico a centimétrico y que puede contener numerosas inclusiones de sulfuros anteriores (Láms. 4.12b,e,f), cristalizando junto con el cuarzo Il y alterándose ocasionalmente a marcasita (Lám. 4.13a); y la pirita II, que se presenta en agregados granulares masivos y de tamaño micrométrico asociados al cuarzo III en las fracturas de minerales previos (Fig. 4.13).
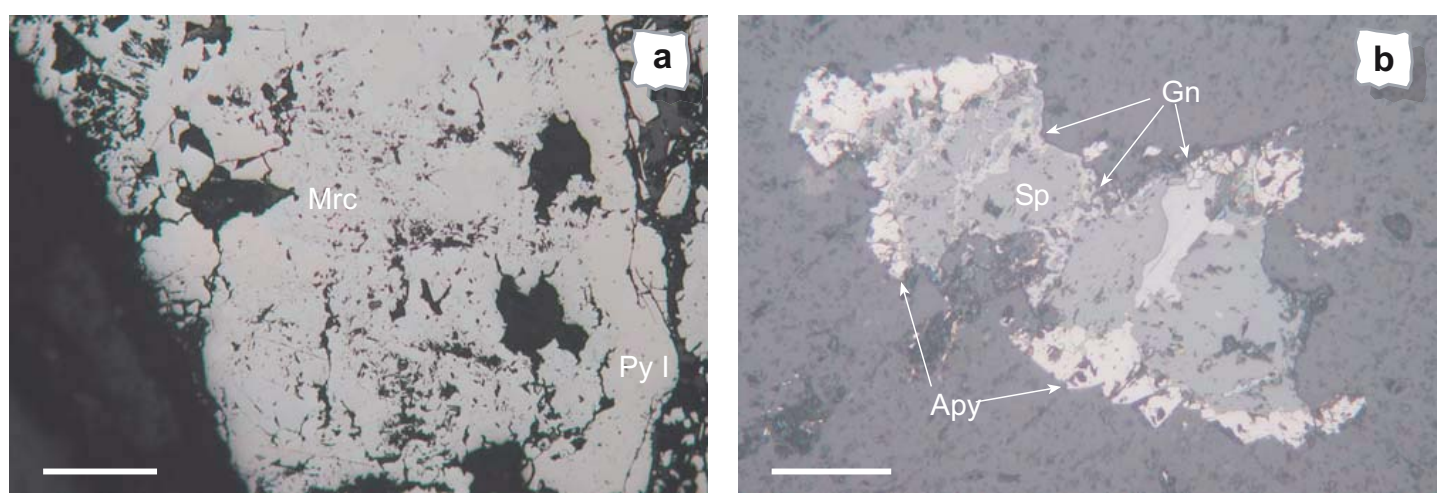

Lám. 4.13. Microfotografías ópticas en luz reflejada de: a) pirita I reemplazada parcialmente por marcasita, El Cruce, LN; b) galena rellenando las fracturas tardías en la esfalerita y la arsenopirita, El Cruce, LN. Escala gráfica: a) $250 \mu \mathrm{m}$; b) $100 \mu \mathrm{m}$.

La composición química de ambos tipos es muy similar con contenidos en As de hasta 0,26 $\%$ at. (Fig. 4.11d) y contenidos significativos en Se, Bi e, incluso, hasta 2.190 ppm de Au en algunas ocasiones. $\mathrm{El} \mathrm{Cu}, \mathrm{Sb}, \mathrm{Ni}$ o $\mathrm{Co}$ se encuentran únicamente en contenidos traza en algunos de los cristales analizados (Anexo III).

\section{Calcopirita}

La calcopirita se encuentra en cristales anhedrales de tamaño micrométrico a milimétrico asociados al cuarzo III, en fracturas, en los huecos de la arsenopirita y la pirita I o bien reemplazando a la esfalerita (Lám. 4.12d). Su composición química es muy próxima a la composición ideal de la calcopirita, con una fórmula estructural media $\mathrm{Cu}_{1,07} \mathrm{Fe}_{0,96} \mathrm{~S}_{1,96}$ además de contenidos traza de $\mathrm{Bi}$, Se o $\mathrm{Zn}$, este último probablemente como consecuencia de contaminación de la esfalerita a la que reemplaza.

\section{Pirrotita}

La pirrotita es un sulfuro precoz en la secuencia de cristalización de las venas (Fig. 4.13). Se encuentra en cristales an- a subhedrales incluidos en la pirita I junto con calcopirita y galena, 
especialmente en las venas de cuarzo de El Cruce. Su composición química es muy próxima a la ideal con una fórmula estructural media $\mathrm{Fe}_{0,87} \mathrm{~S}$ en la que las vacancias en la posición que ocupa el Fe están por debajo del máximo de 0,17 calculado por Fleischer y Mandarino (2004), lo que indica la escasa o nula presencia de $\mathrm{Fe}^{3+}$ en su estructura. Destacan cantidades traza de elementos como el $\mathrm{Zn}$ (hasta 0,15\% en peso) o el In (hasta 0,17 \% en peso), mientras que los elevados contenidos en $\mathrm{Cu}$ de algunos de los análisis probablemente sean consecuencia de contaminación por la calcopirita.

\section{Galena}

Al igual que la calcopirita, la galena es una fase tardía en la secuencia mineral de estas venas de cuarzo (Fig. 4.13). Se encuentra en masas anhedrales de tamaño milimétrico y de color blanco frecuentemente rellenando fracturas y huecos tardíos (Lám. 4.13d). Su composición química en el triángulo composicional Ag-Bi-Pb está representada, con ligeras variaciones, sobre la línea de solución sólida galena-matildita con cantidades de Pb ente 1,64 y 1,93 apfu (Fig. 4.12). En general, los contenidos en $\mathrm{Ag}$, $\mathrm{Bi}$ y Fe que sustituyen al $\mathrm{Pb}$ son muy bajos, no superando en total los 0,5 apfu. Parte de los cristales de galena analizados tienen contenidos en Au por encima del límite de detección (Anexo III), con hasta 3.730 ppm en las venas de EI Jaque y hasta 4.820 ppm en las venas de El Cruce.

$\mathrm{Bi}$

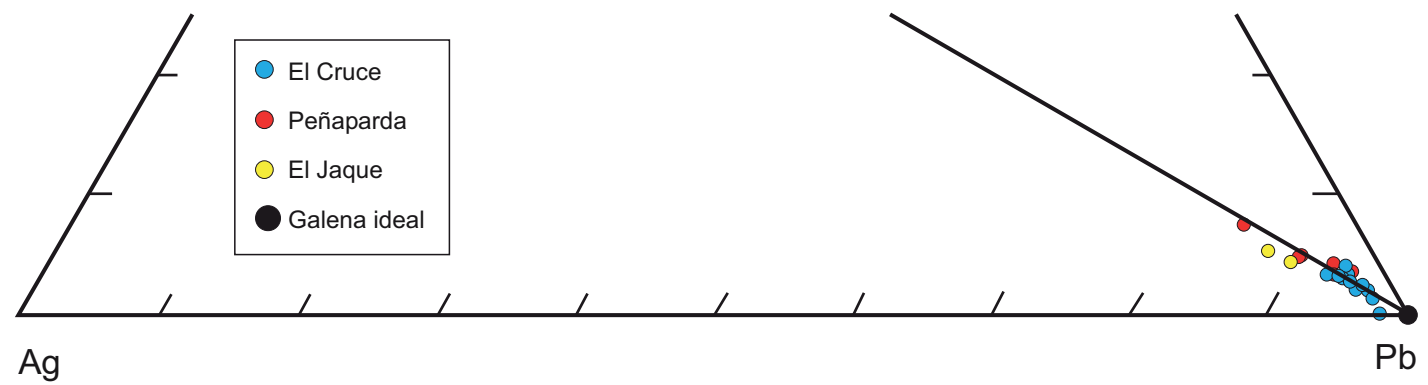

Fig. 4.12. Diagrama triangular Ag-Bi-Pb de Makovicky y Karup-Møller (1977b) con la representación de la composición química de la galena a lo largo de la línea de solución sólida galena-matildita $\mathrm{N}=\infty$.

\section{Sulfosales de $\mathrm{Bi}-\mathrm{Pb}-\mathrm{Ag}$}

Únicamente se han identificado en las venas de cuarzo de la zona de El Jaque como partículas de tamaño micrométrico incluidas en la arsenopirita junto con galena. Sin embargo, el reducido tamaño que presentan ha impedido su correcta caracterización.

\subsubsection{Productos de alteración}

La covelita se encuentra en agregados granulares y botroidales de tamaño micrométrico y de color azul intenso como producto de alteración de la calcopirita en las zonas de oxidación de las venas de cuarzo (Lám. 4.12d). La marcasita se presenta en agregados cristalinos sub- a 
euhedrales de tamaño hasta centimétrico reemplazando a la pirita I en las venas mineralizadas de El Cruce (Lám. 4.13a). Su composición química no difiere de la de la pirita a la que reemplaza. La escorodita se forma como producto de alteración de la arsenopirita y se puede encontrar formando cristales euhedrales de tamaño milimétrico y de color verde azulado en muestra de mano que cristalizan en pequeñas cavidades o en fracturas. Su composición química está enriquecida en P que llega a sustituir al As en hasta 0,31 apfu. Por último, los óxidos-hidróxidos de Fe se presentan como masas anhedrales o coloformes reemplazando total o parcialmente a los sulfuros, especialmente a la pirita, y rellenando grietas tardías.

\subsubsection{Secuencia mineral}

La secuencia mineral que caracteriza la formación de las venas de cuarzo mineralizadas en el batolito de Cadalso-Casillas de Flores se puede agrupar en tres fases (Fig. 4.13). Durante la primera fase cristaliza el cuarzo I y la moscovita y la turmalina accesorias junto con la mineralización precoz de casiterita, wolframita y pirrotita. Posteriormente, y tras una fracturación importante que es precedida en algunos sectores del batolito por una ligera deformación dúctil, tiene lugar la cristalización de la mineralización principal de la arsenopirita, la esfalerita y la pirita I, todas ellas asociadas al cuarzo II. A continuación, y después de un nuevo proceso de deformación frágil, cristaliza el cuarzo III junto a la clorita asociados a una mineralización tardía de pirita II junto con calcopirita, galena y sulfosales de Bi-Pb-Ag rellenando las fracturas y los huecos. Además, se forma scheelita a partir de la wolframita, marcasita a partir de la pirita I y rutilo. Por último, la alteración supergénica de estas mineralizaciones da lugar a la formación de escorodita, covelita y óxidos e hidróxidos de Fe.

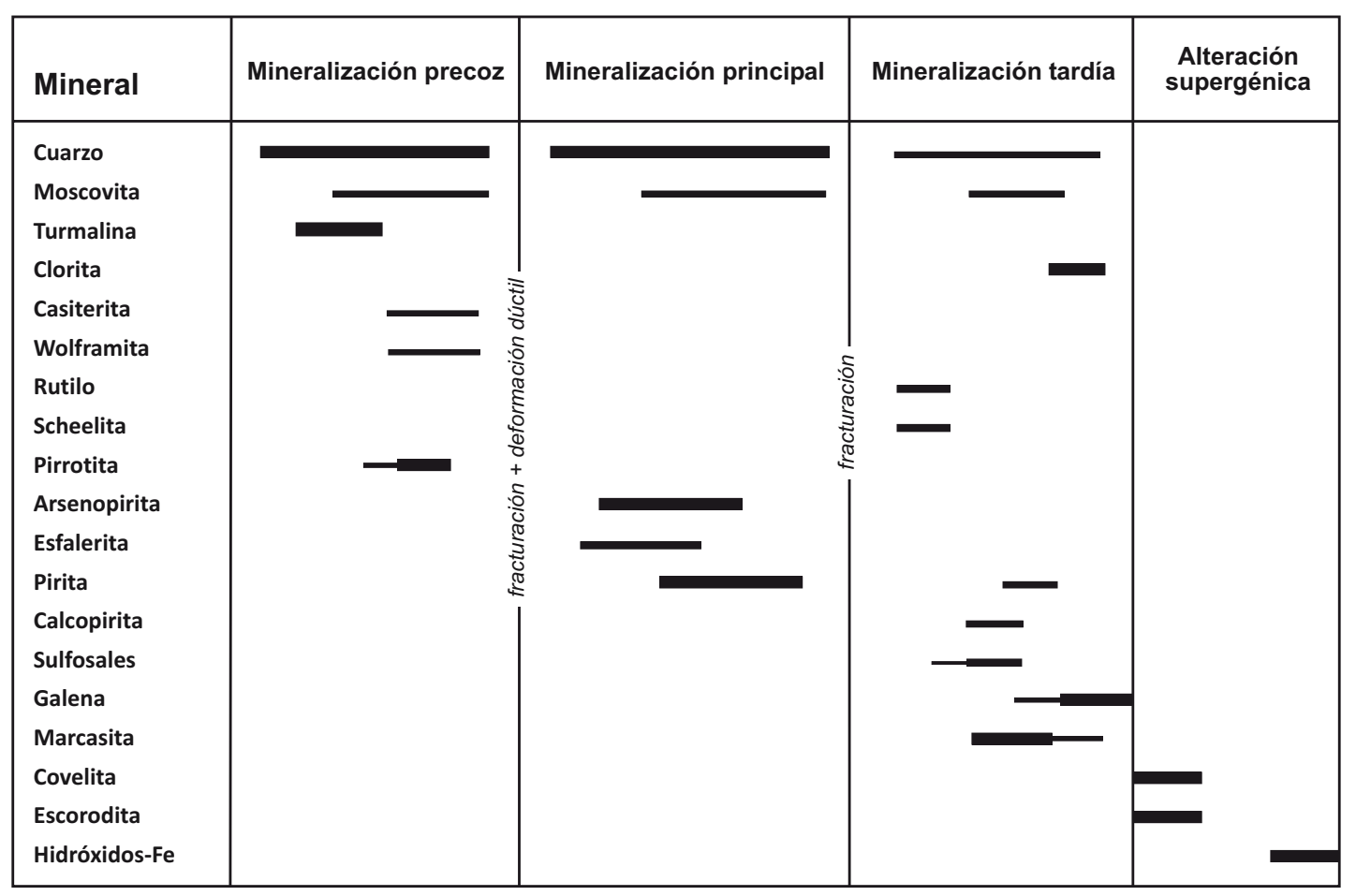

Fig. 4.13. Secuencia mineral de las venas de cuarzo con Sn-W en el batolito de Cadalso-Casillas de Flores. 



\section{CAPÍTULO 5. INCLUSIONES FLUIDAS Y CARACTERIZACIÓN ISOTÓPICA}

\subsection{INCLUSIONES FLUIDAS}

El estudio de las inclusiones fluidas se llevó a cabo en 5 muestras mineralizadas del batolito de Jálama pertenecientes a diferentes venas de cuarzo que encajan en las distintas facies de la UE. Así, se han estudiado: una muestra de vena de cuarzo de la mina Horia encajada en el GE; tres muestras de venas de cuarzo de las minas Salmantina, Teso de la Matanza y Bon encajadas en el $L G$ y las $A B$ con turmalina; y una muestra de los diques pegmatíticos de Cruz del Rayo encajados en los materiales metamórficos del CEG. En todas ellas se estudiaron las inclusiones fluidas atrapadas en el cuarzo I. En las pegmatitas de Cruz del Rayo se analizaron, además, las inclusiones atrapadas en la casiterita de los diques de composición tipo greisen (Lám. 5.1a,b) (Fernández et al., 2001a,b).
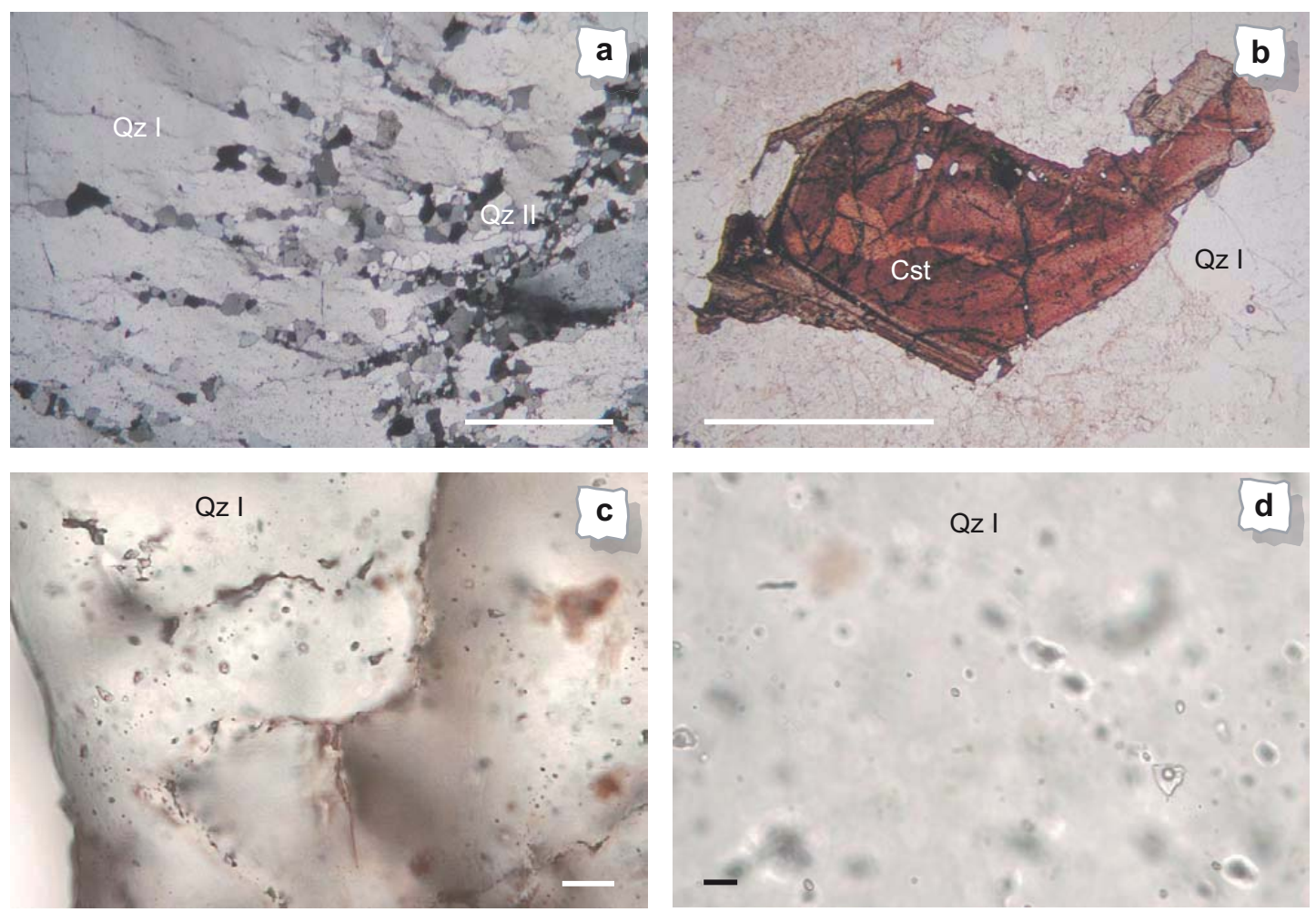

Lám. 5.1. a) Microfotografía de los cristales de cuarzo I en las venas mineralizadas en las que se han estudiado las inclusiones fluidas, NC; b) cristal de casiterita en los diques de composición tipo greisen de Cruz del Rayo, LN; c) inclusiones primarias en los planos de crecimiento del cuarzo I en las venas de la mina Horia, LN; y d) inclusiones fluidas pseudosecundarias en planos de fractura en el cuarzo de las venas de la mina Salmantina, LN. Escala: a y b) $1 \mathrm{~mm}$; c) $40 \mu \mathrm{m}$; d) $20 \mu \mathrm{m}$.

La mayoría de las inclusiones son de origen primario y únicamente un número reducido de ellas se consideran pseudosecundarias (Lám. 5.1c,d). Muestran una morfología variada desde irregulares, redondeadas, ovaladas hasta formas hexagonales, de cristal negativo. Todas ellas son inclusiones bifásicas, con una fase líquida y otra fase vapor. El grado de relleno se ha estimado a partir de las tablas de Roedder (1984) y Shepherd et al. (1985). 


\subsubsection{Tipos de inclusiones fluidas}

El estudio microtermométrico ha permitido diferenciar dos tipos de inclusiones fluidas atendiendo a su composición: las de tipo I son inclusiones acuosas de salinidad baja que pertenecen al sistema $\mathrm{H}_{2} \mathrm{O}-\mathrm{NaCl} \pm \mathrm{CaCl}_{2}$; las de tipo II son inclusiones acuoso-carbónicas complejas del sistema $\mathrm{H}_{2} \mathrm{O}-\mathrm{NaCl}-\mathrm{CO}_{2}$ y otros volátiles $\left(\mathrm{CH}_{4}-\mathrm{N}_{2}\right)$ (Anexo $\mathrm{VI}$ ).

\section{Tipo I: Inclusiones acuosas de salinidad baja $\left(\mathrm{H}_{2} \mathrm{O}-\mathrm{NaCl} \pm \mathrm{CaCl}_{2}\right)$}

Las inclusiones de tipo I se encuentran en todas las muestras de cuarzo y casiterita estudiadas tanto de las venas como de los diques pegmatíticos. Su tamaño varía entre 5 y $18 \mu \mathrm{m}$, presentando la mayoría un grado de relleno que oscila entre 0,5 y 0,9 (Lám. 5.2a,b,c,f).

En el estudio microtermométrico únicamente se ha podido observar una fusión eutéctica (Te) en un número reducido de inclusiones fluidas con valores comprendidos entre -47 y $-51^{\circ} \mathrm{C}$, seguida de la fusión de la hidrohalita (Tmhh) entre -29 y $-21{ }^{\circ} \mathrm{C}$ (Tabla 5.1 y Fig. 5.1a). Estos
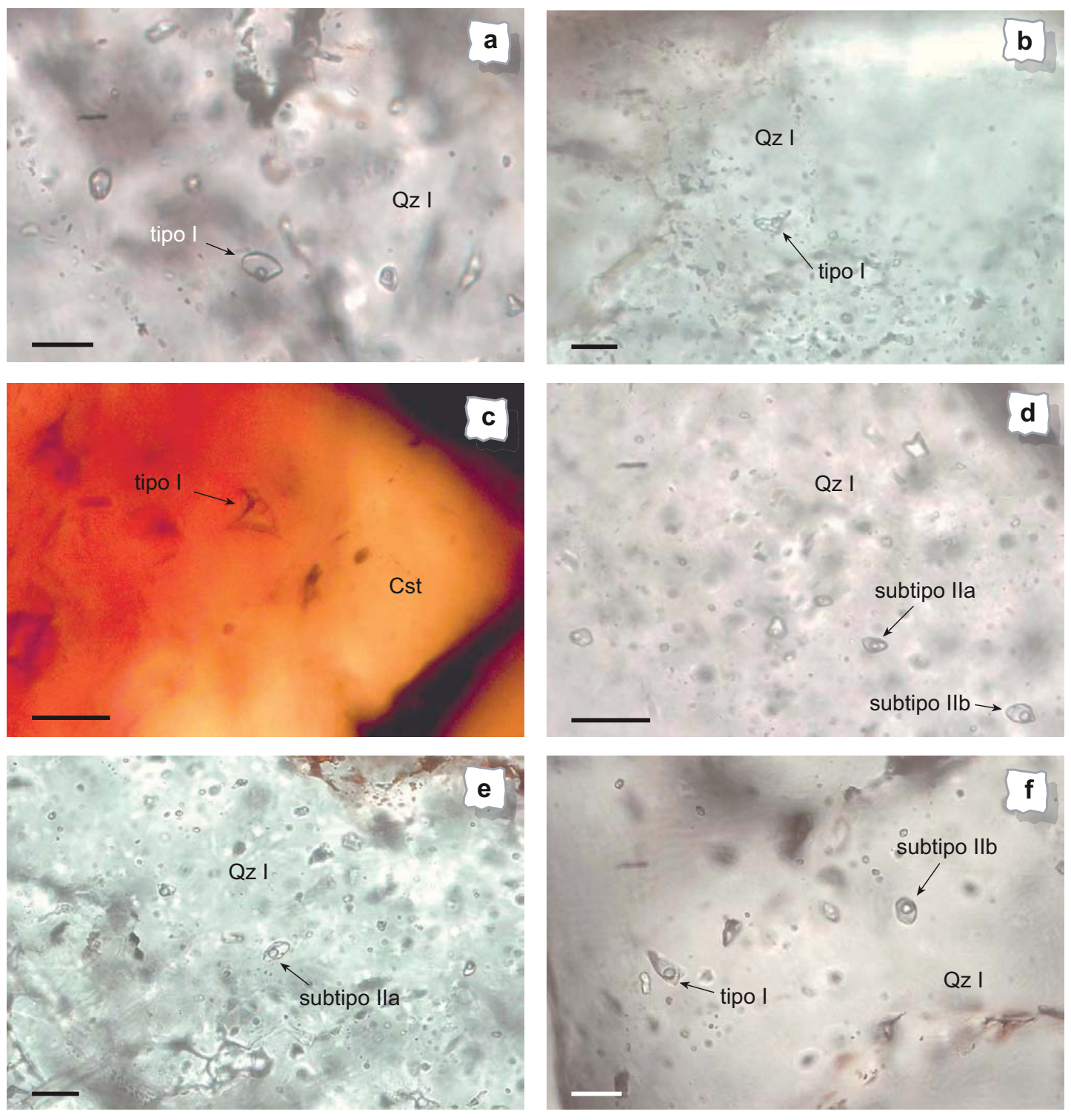
CAPÍTULO 5. Inclusiones fluidas y caracterización isotópica

TABLA 5.1. TIPOS DE INCLUSIONES FLUIDAS

\begin{tabular}{lcccccccc}
\hline \hline Tipo de Roca & \multicolumn{2}{c}{ Diques pegmatíticos } & \multicolumn{2}{c}{ Venas de cuarzo en el GE } & \multicolumn{3}{c}{ Venas de cuarzo en el LG } \\
\hline Mineral & Qz & Cst & Qz & Qz & Qz & Qz & Qz \\
Tipo de inclusión & Tipo I & Tipo I & Tipo I & Tipo Ila & Tipo Ilb & Tipo I & Tipo Ila & Tipo Ilb \\
\hline Tamaño $(\mu \mathrm{m})$ & $5 / 18$ & $8 / 18$ & $7 / 12$ & $6 / 20$ & $10 / 14$ & $6 / 18$ & $6 / 17$ & $5 / 28$ \\
Grado de Relleno & $0,6 / 0,8$ & $0,6 / 0,8$ & $0,5 / 0,9$ & $0,7 / 0,8$ & $0,7 / 0,8$ & $0,5 / 0,9$ & $0,6 / 0,9$ & $0,5 / 0,9$ \\
Tmi $\left({ }^{\circ} \mathrm{C}\right)$ & $-4,1 /-8,3$ & $-2,4 /-3,6$ & $-6,7 /-2,5$ & $-5,9 /-3,0$ & $-6,2 /-3,7$ & $-4,6 /-1,4$ & $-5,2 /-1,9$ & $-7 /-1,9$ \\
Tmcla $\left({ }^{\circ} \mathrm{C}\right)$ & - & - & - & $6,2 / 8,9$ & $10 / 12,7$ & - & $5 / 9,4$ & $10,5 / 14,3$ \\
Th $\left({ }^{\circ} \mathrm{C}\right)$ & $257 / 345$ & $265 / 278$ & $233 / 317$ & $255 / 323$ & $252 / 287$ & $220 / 290$ & $215 / 313$ & $227 / 385$ \\
T atrape $\left({ }^{\circ} \mathrm{C}\right)$ & $500 / 600$ & $450 / 550$ & $475 / 575$ & $475 / 570$ & $450 / 540$ & $420 / 510$ & $450 / 540$ & $420 / 525$ \\
Salinidad $(\%$ eq. $\mathrm{NaCl})$ & $6,4 / 12,0$ & $4,0 / 5,9$ & $4,2 / 10,1$ & $2,2 / 7,1$ & $6 / 9,5 *$ & $2,4 / 7,3$ & $1,2 / 9,1$ & $3,2 / 10,5 *$ \\
Densidad media $\left(\mathrm{g} / \mathrm{cm}^{3}\right)$ & 0,8 & 0,81 & 0,81 & 0,77 & 0,84 & 0,84 & 0,79 & 0,81 \\
$X_{\text {NaCl }}$ & 0,3 & 0,15 & 0,2 & 0,1 & 0,2 & 0,18 & 0,15 & 0,20 \\
$X_{\text {H2O }}$ & 0,7 & 0,85 & 0,8 & 0,9 & 0,8 & 0,82 & 0,85 & 0,80 \\
\hline *Valores de salinidad máxima & & & & & & & &
\end{tabular}

valores de la Tmhh por debajo del eutéctico del sistema $\mathrm{H}_{2} \mathrm{O}-\mathrm{NaCl}$ indicarían la presencia, además de $\mathrm{NaCl}$, de otra sal. Teniendo en cuenta los valores de la Te obtenida se puede considerar la participación de pequeñas cantidades de $\mathrm{CaCl}_{2}$ en el sistema (Crawford, 1981; Bodnar, 2003). Finalmente, la temperatura de fusión del hielo (Tmi) oscila entre $-8,3$ y $-1,4^{\circ} \mathrm{C}$, con la mayoría de los valores en torno a -6 y $-3^{\circ} \mathrm{C}$ (Fig. 5.1b), de modo que la salinidad media calculada de acuerdo con la ecuación de Bodnar (1993) varía desde 8,2\% eq. peso $\mathrm{NaCl}$ en el cuarzo de las pegmatitas, hasta $7,4 \%$ en las venas encajadas en el GE y $5,6 \%$ en las venas encajadas en el LG y las AB con turmalina (Tabla 5.1). Estas inclusiones homogeneizaron a líquido a temperaturas comprendidas entre 220 y $345{ }^{\circ} \mathrm{C}$ (Th), correspondiendo las temperaturas más elevadas al cuarzo de las pegmatitas de Cruz del Rayo (Fig. 5.1C).

A partir de estas medidas microtermométricas se calcularon la densidad de las inclusiones y la fracción molar del $\mathrm{NaCl}\left(X_{\mathrm{NaCl}}\right)$ y del $\mathrm{H}_{2} \mathrm{O}\left(X_{\mathrm{H} 2 \mathrm{O}}\right)$ empleando el programa Halwat (Nicholls y Crawford, 1985) y a partir de los datos de Potter y Brown (1977). La densidad media obtenida varía entre 0,80 y $0,84 \mathrm{~g} / \mathrm{cm}^{3}$, mientras que la $X_{\mathrm{NaCl}}$ presenta un valor medio de 0,20 y la $X_{\mathrm{H} 20}$ de 0,80 .

Tipo II: Inclusiones acuoso-carbónicas complejas $\left[\mathrm{H}_{2} \mathrm{O}-\mathrm{NaCl}-\left(\mathrm{CO}_{2} \pm \mathrm{CH}_{4} \pm \mathrm{N}_{2}\right)\right]$

Dentro de este tipo de inclusiones se han diferenciado, en función de la temperatura de fusión de los clatratos (Tmcla), dos subtipos: el subtipo lla, perteneciente al sistema $\mathrm{H}_{2} \mathrm{O}-\mathrm{NaCl}-\mathrm{CO}_{2}$, y el subtipo IIb, al sistema $\mathrm{H}_{2} \mathrm{O}-\mathrm{NaCl}-\left(\mathrm{CO}_{2}-\mathrm{CH}_{4}-\mathrm{N}_{2}\right)$. Las inclusiones de tipo II se identifican en el cuarzo de todas las muestras de las venas, aunque en la mina Bon las de subtipo Illb son inexistentes. El tamaño es similar a las anteriores, variando entre 5 y $28 \mu \mathrm{m}$ y con un grado de relleno entre 0,5 y 0,9 (Lám. 5.2 d,e,f).

Lám. 5.2. Microfotografías de los tipos de inclusiones fluidas estudiadas, LN: a) inclusión fluida de tipo I en el cuarzo I de las venas de la mina Horia; b) inclusión de tipo I en el cuarzo I de las pegmatitas de Cruz del Rayo; c) inclusión fluida de tipo I en los cristales de casiterita de los diques pegmatíticos tipo greisen de Cruz del Rayo; d) inclusiones fluidas de subtipo lla y llb en el cuarzo I de las venas de la mina Salmantina; e) detalle de una inclusión de subtipo lla en el cuarzo I de las venas de la mina Horia; y f) inclusiones fluidas de tipo I y de subtipo Ilb en el cuarzo I de las venas de la mina Horia. Escala: $20 \mu \mathrm{m}$. 


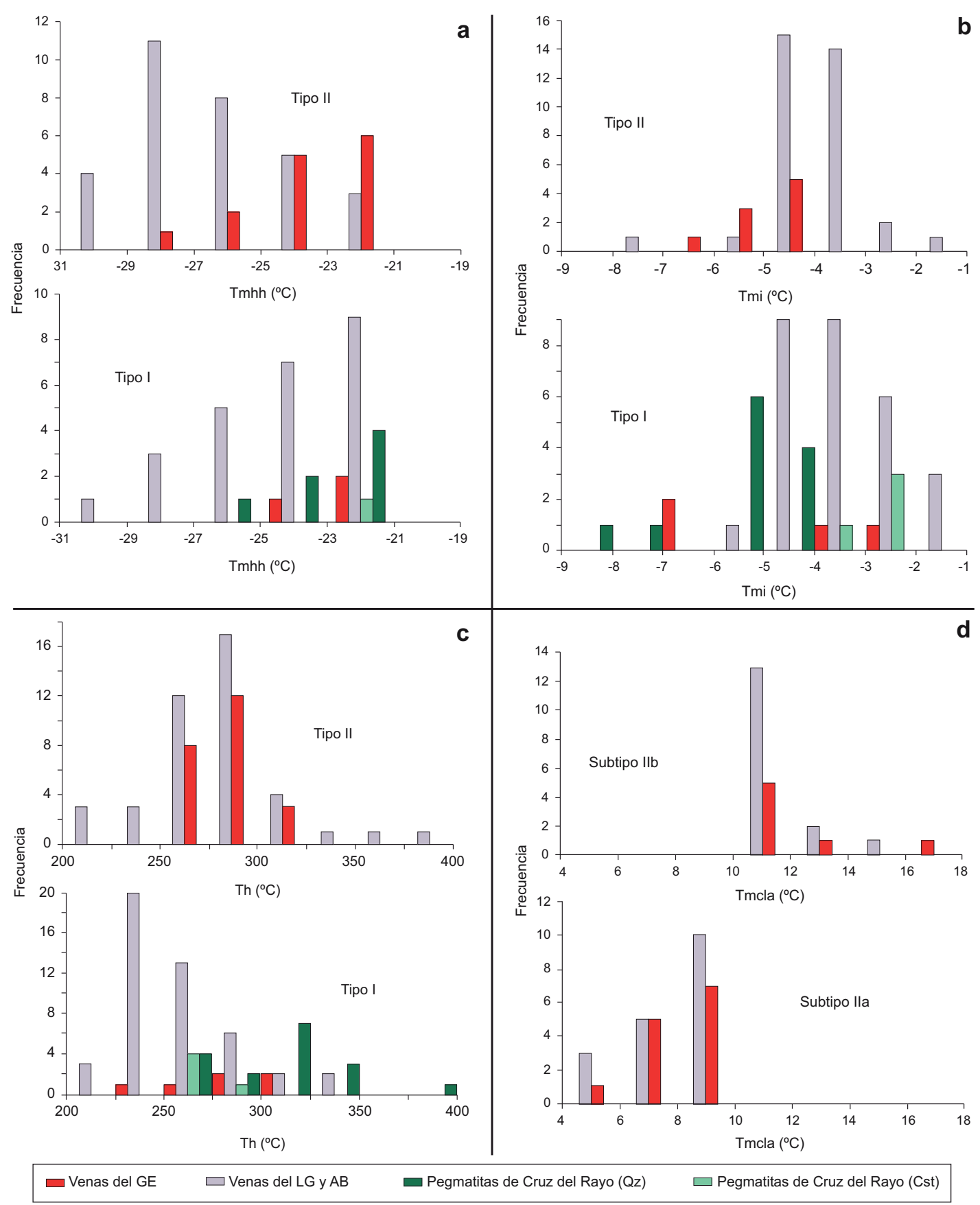

Fig. 5.1. Histogramas de a) la Tmhh; b) la Tmi; c) la Th; y d) la Tmcla de los distintos tipos de inclusiones fluidas estudiadas en el cuarzo I y en la casiterita.

Durante el estudio microtermétrico únicamente en un reducido número de inclusiones fluidas de las minas Horia y Teso de la Matanza se ha identificado un primer eutéctico en torno a los $-56,6{ }^{\circ} \mathrm{C}$ que corresponde con la temperatura de fusión del $\mathrm{CO}_{2}\left(\mathrm{TmCO}_{2}\right)$ con una ligera desviación, especialmente en las del tipo Illb, con respecto del punto triple de este gas puro, por lo que se considera la existencia de otros gases en la mezcla. La fusión de la hidrohalita tiene lugar a temperaturas que oscilan entre $-30,8$ y $-20,8{ }^{\circ} \mathrm{C}(\mathrm{Tmhh})$, de nuevo inferiores al eutéctico del sistema $\mathrm{H}_{2} \mathrm{O}-\mathrm{NaCl}$ (Fig. 5.1a), lo que sugiere la presencia de otra sal en la fase acuosa que probablemente es, como en el caso anterior, $\mathrm{CaCl}_{2}$ dados los valores obtenidos 
de la temperatura de primera fusión en la fase acuoso-salina (Te de $48,7^{\circ} \mathrm{C}$ de media). La Tmi muestra un rango de variación entre -7 y $-1,9^{\circ} \mathrm{C}$ (Tabla 5.1 y Fig. $5.1 \mathrm{~b}$ ).

La fusión de los clatratos (Tmcla) en el subtipo lla tiene lugar entre 5 y $9,4{ }^{\circ} \mathrm{C}$, con una moda situada en el intervalo de 8 a $9,4{ }^{\circ} \mathrm{C}$ (Fig. 5.1d). Estas temperaturas son inferiores a $10^{\circ} \mathrm{C}$, lo que confirmaría la presencia de $\mathrm{CO}_{2}$ como fase dominante en la mezcla gaseosa. En cambio, en el subtipo Ilb la Tmcla es superior a $10{ }^{\circ} \mathrm{C}$ (Fig. 5.1d), oscilando normalmente entre 10 y $14,3{ }^{\circ} \mathrm{C}$, lo que sugiere la presencia de otros gases en la mezcla además del $\mathrm{CO}_{2}$ (Shepherd et al., 1985). Para confirmarlo estas inclusiones fueron estudiadas mediante microsonda Raman, lo que puso de manifiesto la escasa concentración de $\mathrm{CO}_{2}$ y la presencia de bajas concentraciones de $\mathrm{CH}_{4}$ y $\mathrm{N}_{2}$ en la mezcla, prácticamente inexistentes en las de subtipo lla y superiores a las del $\mathrm{CO}_{2}$ en el subtipo Ilb. (Fig. 5.2a,b,c). A partir de los espectros Raman se ha obteniendo una relación de los constituyentes gaseosos $\mathrm{CO}_{2} / \mathrm{CH}_{4}$ que varía entre 5,7 y 44,5 y $\mathrm{CO}_{2} / \mathrm{N}_{2}$ entre 2 y 11,6 para las del subtipo Ila, mientras que en las IIb lo hace entre 0,4 y 0,9 y entre 0,2 y 9,0 respectivamente. La salinidad en las inclusiones del subtipo lla obtenida a partir de la Tmcla utilizando la fórmula de Bozzo et al. (1973), es baja variando entre 1,2 y $10,6 \%$ eq. peso $\mathrm{NaCl}$. En las del subtipo Ilb la imposibilidad de observar
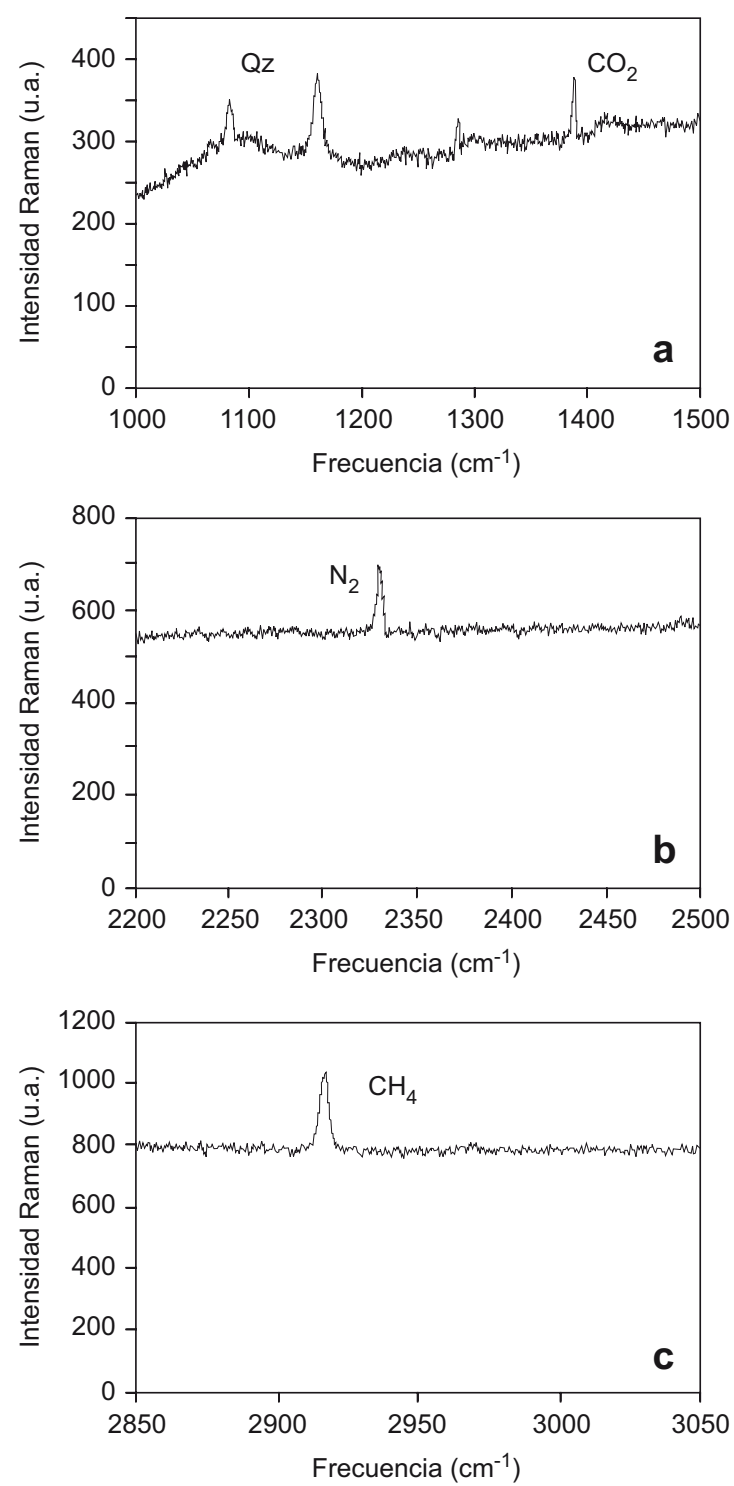

Fig. 5.2. Espectros de a) $\mathrm{CO}_{2}$, b) $\mathrm{N}_{2}$ y c) $\mathrm{CH}_{4}$ de las inclusiones fluidas de subtipo Ilb en el cuarzo I de las venas. temperaturas de homogeneización y de calcular las concentraciones de los gases minoritarios, en especial del $\mathrm{CO}_{2}$, no ha permitido calcular la salinidad correctamente de manera que, dada la escasa representatividad de este tipo de inclusiones, se ha empleado la salinidad máxima obtenida a partir de la ecuación de Bodnar (1993), que varía entre 3,2 y 10,5\% eq. peso $\mathrm{NaCl}$ (Tabla 5.1).

La temperatura de homogeneización de la fase gaseosa a líquido se sitúa entre 215 y $323^{\circ} \mathrm{C}$ (Th) en las inclusiones del subtipo lla y está comprendida entre 227 y $385^{\circ} \mathrm{C}$ en las del subtipo Ilb, con una moda que se sitúa entre 250 y $300^{\circ} \mathrm{C}$ para todas ellas (Fig. 5.1c). 
Dada la escasa concentración de $\mathrm{CO}_{2}, \mathrm{CH}_{4}$ y $\mathrm{N}_{2}$ en la fase gaseosa de ambos subtipos, se ha empleado el programa Halwat para el cálculo de la densidad media y la fracción molar de las sales, oscilando la densidad entre 0,76 y $0,83 \mathrm{~g} / \mathrm{cm}^{3}$ en los dos subtipos, mientras que la $X_{\text {Nacl }}$ y la $X_{\mathrm{H} 2 \mathrm{O}}$ tienen un valor medio de 0,14 y 0,86 respectivamente en el subtipo lla y de 0,20 y 0,80 respectivamente en el subtipo Ilb.

\subsubsection{Tipos de fluidos y evolución}

El cálculo de las isocoras en ambos tipos de inclusiones se ha llevado a cabo mediante el programa Halwat para inclusiones acuoso salinas (Nicholls y Crawford, 1985), que utiliza los datos de Potter y Brown (1977), dada la escasa concentración de $\mathrm{CO}_{2}, \mathrm{CH}_{4}$ y $\mathrm{N}_{2}$ que presentan las de tipo II (Fig. 5.3a,b). La temperatura de atrape en cada uno de los tipos de inclusiones, tanto en los diques pegmatíticos de Cruz del Rayo como en las venas mineralizadas del GE y del LG y las AB con turmalina, se ha obtenido a partir de la intersección de las isocoras con la presión de emplazamiento del batolito de Jálama, que se encuentra entre 2 y 3 kbar (Ramírez y Grundvig, 2000). Dadas las pequeñas diferencias que presentan los distintos tipos de inclusiones fluidas en los valores obtenidos en el estudio microtermométrico, para el cálculo de las isocoras se han tomado las medias de las Th de todo el conjunto de inclusiones fluidas estudiadas en los distintos sectores analizados del batolito de Jálama (Tabla 5.1 y Fig. 5.3a,b).
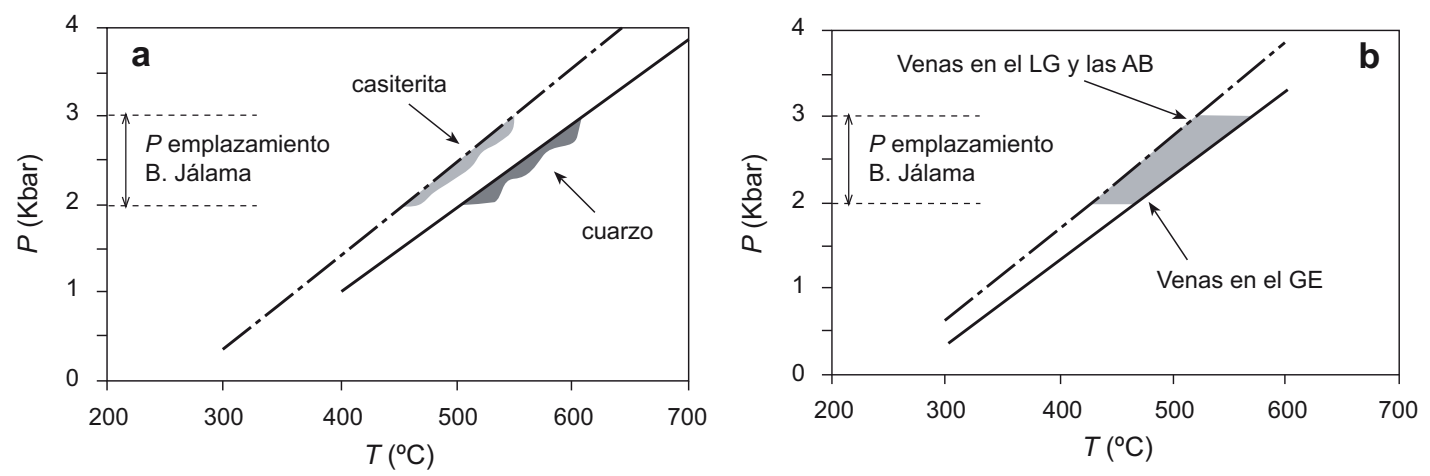

Fig. 5.3. Diagramas $P-T$ en el que se muestran las isocoras calculadas a partir de a) las inclusiones fluidas de tipo I en la casiterita y el cuarzo de los diques pegmatíticos del CEG (Cruz del Rayo); y b) las inclusiones fluidas de tipo I y II en el cuarzo de las venas mineralizadas encajadas en el GE y en el LG y las AB con turmalina.

En las pegmatitas de Cruz del Rayo la temperatura de atrape varía entre 500 y $600{ }^{\circ} \mathrm{C}$ en el cuarzo I y entre 450 y $550^{\circ} \mathrm{C}$ en la casiterita del greisen (Fig. 5.3a). El fluido causante de su formación es fundamentalmente acuoso con una salinidad baja en el cuarzo $(8,2 \%$ eq. peso $\mathrm{NaCl}$ ) y menor en la casiterita (4,8\% eq. peso $\mathrm{NaCl})$.

En las venas de cuarzo las temperaturas de atrape del fluido son, por lo general, más elevadas en las venas de la mina Horia, encajadas en el GE (entre 460 y $560^{\circ} \mathrm{C}$ ), que en el resto de las venas del $L G$ y las $A B$ con turmalina (entre 430 y $530^{\circ} \mathrm{C}$ ). Temperaturas similares de entre 400 y $550^{\circ} \mathrm{C}$ se han documentado en mineralizaciones de Sn-W de Cornwall (Sawkins, 1966) y en Panasqueira (Kelly y Rye, 1979). En este caso, el fluido responsable de la cristalización del 
cuarzo I en las venas es fundamentalmente acuoso, con una salinidad baja, generalmente no superior a $10 \%$ eq. peso $\mathrm{NaCl}$, y escasa o nula concentración de $\mathrm{CO}_{2}, \mathrm{CH}_{4}$ y $\mathrm{N}_{2}$.

En el diagrama de salinidad vs. Th (Fig. 5.4) se recoge la evolución térmica y composicional de la fase precoz del sistema magmático-hidrotermal del borde norte del batolito de Jálama. En él se observa que durante la cristalización de las pegmatitas de Cruz del Rayo los fluidos son ligeramente más salinos que en las venas de cuarzo, presentando una Th también superior. Se aprecia, por tanto, una evolución del sistema magmático-hidrotermal hacia una disminución de la salinidad de los fluidos con el descenso de la temperatura, lo que representa un proceso de dilución natural de los mismos a medida que se enfría el sistema (Wilkinson, 2001), bien debido a

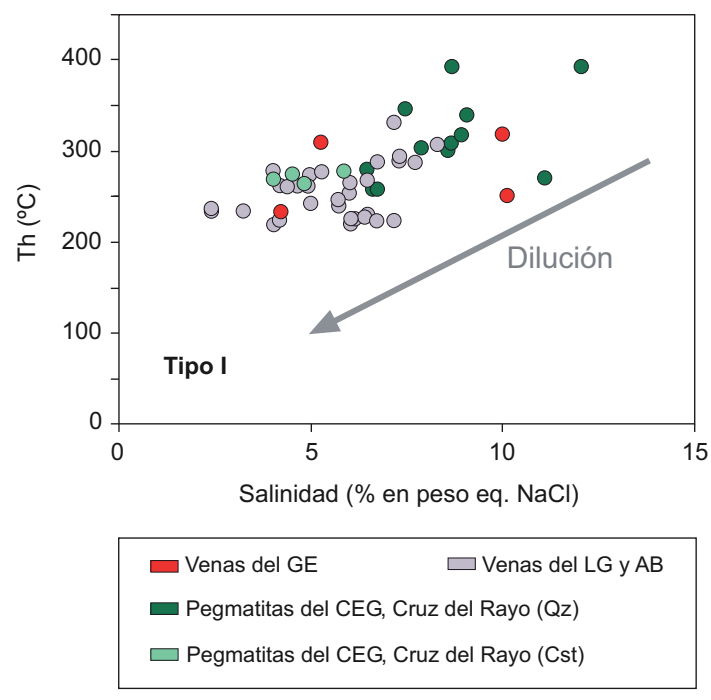

Fig. 5.4. Diagrama de variación de la Th vs. salinidad de las inclusiones fluidas de tipo I estudiadas. una dispersión del calor, a una mezcla del fluido hidrotermal con aguas meteóricas o a una combinación de ambos factores, de manera similar a como ocurre en otros depósitos de Sn y/o W variscos como en Teba o San Finx (Mangas y Arribas, 1987), en el Monte St. Michael's, Cornwall (Moore y Moore, 1979) o en Panasqueira, Portugal (Kelly y Rye, 1979; Noronha et al., 1992).

La fuente del escaso $\mathrm{CO}_{2}, \mathrm{CH}_{4}$ y $\mathrm{N}_{2}$ que presentan los fluidos mineralizadores puede estar en el propio batolito peralumínico de Jálama, ya que estos gases se restringen típicamente a los magmas residuales de tipo S (Graney y Kesler, 1995; Lowenstern, 2001) que tienen un fuerte componente cortical en su composición y una baja $\mathrm{fO}_{2}$ (Chappell y White, 2001). Sin embargo, la presencia de $\mathrm{CH}_{4}$ y $\mathrm{N}_{2}$ podría proceder del lavado de los materiales metasedimentarios del CEG en los que encaja el granito por los fluidos hidrotermales, lo que confirmaría la intervención de fluidos externos al sistema (metamórficos o meteóricos).

\subsection{ISÓTOPOS ESTABLES}

La caracterización isotópica de las mineralizaciones del distrito de Navasfrías se ha llevado a cabo mediante el análisis isotópico del $\mathrm{O}$ y $\mathrm{D}$ de los silicatos, del $\mathrm{O}$ de la casiterita y la wolframita y del $\mathrm{S}$ de los sulfuros hidrotermales de la mineralización. En el batolito de Jálama se han analizado: 1 muestra del LG con turmalina procedente de la mina Salmantina; 2 muestras de los diques pegmatíticos y 8 de las venas de cuarzo mineralizadas del GE en las minas Horia y Mari Carmen; 5 muestras de los diques pegmatíticos y 15 de las venas de cuarzo mineralizadas del LG y las AB con turmalina en las minas Salmantina, Carrasquera, Profunda, Teso de la Matanza y Bon; y, por último, 2 muestras de los diques pegmatíticos peribatolíticos en la mina Cruz del Rayo. En el batolito de Cadalso-Casillas de Flores se han 
analizado 1 muestra de las venas de cuarzo mineralizadas de El Cruce encajadas en el granito de El Payo y 2 de las venas de Peñaparda encajadas en el granito de Peñaparda.

\subsection{1. $\delta^{18} \mathrm{O}$ en silicatos, casiterita y wolframita}

Los valores isotópicos de $\delta^{18} \mathrm{O}_{\text {smow }}$ del cuarzo, la moscovita, la turmalina y el feldespato potásico del LG con turmalina se recogen en la tabla 5.2. Se observa que la $\delta^{18} \mathrm{O}$ más elevada pertenece al cuarzo $(13,3 \%)$ y la más baja a la moscovita $(10,9 \%)$, mientras que la turmalina y el feldespato potásico presentan valores isotópicos intermedios que alcanzan el 12 \%o (Fig. 5.5).

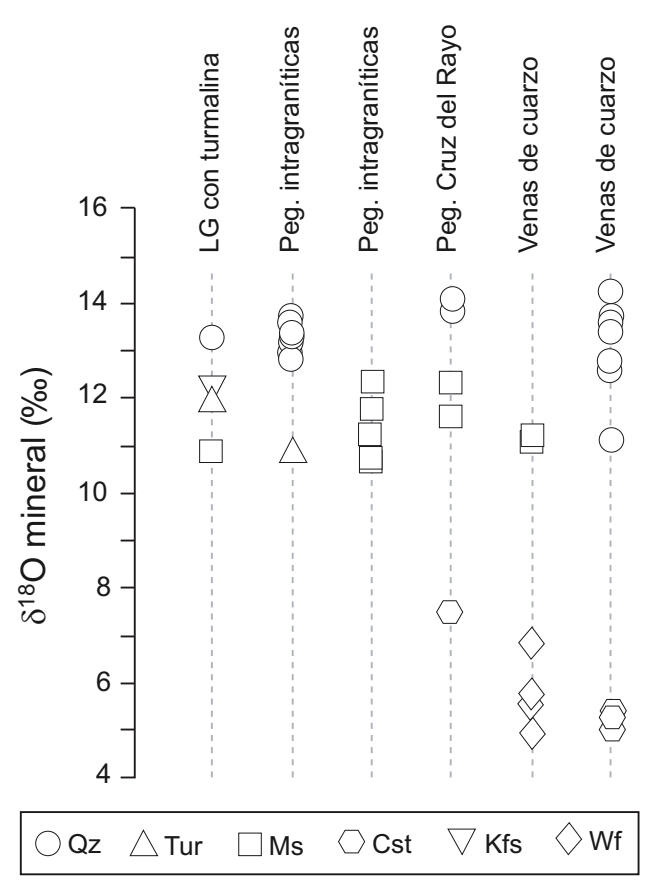

Fig. 5.5. Rango de valores de $\delta^{18} \mathrm{O}$ de los silicatos, la casiterita y la wolframita estudiados.
Los valores isotópicos de $\delta^{18} \mathrm{O}_{\text {smow }}$ en el cuarzo, la moscovita y, localmente, en la turmalina $y$ la casiterita de los diques pegmatíticos intra y peribatolíticos se recogen en la tabla 5.2. Los valores obtenidos para el cuarzo varían entre 12,8 y $14,1 \%$, para la moscovita entre 10,8 y $12,4 \%$, para la turmalina de los diques encajados en el $L G$ y las $A B$ se obtiene un valor de $10,8 \%$, mientras que para la casiterita de los diques peribatolíticos de Cruz del Rayo es de 7,5\%. Estos valores son similares a los que se encuentran en el LG con turmalina (Fig. 5.5), pudiéndose establecer una secuencia desde los valores más pesados hasta los más ligeros: cuarzo $(13,4 \%$ de media) $\rightarrow$ feldespato potásico $(12,2 \%) \rightarrow$ moscovita $(11,4 \%$ o de media). Esta secuencia corresponde con la esperada para el fraccionamiento isotópico de un magma félsico (Taylor, 1978; Taylor y Shepard, 1986).

Respecto a los valores isotópicos de $\delta^{18} \mathrm{O}_{\text {smow }}$ obtenidos para el cuarzo de las venas mineralizadas (Tabla 5.2 y Fig. 5.5) se observa que son muy similares a los de los cuerpos pegmatíticos, variando entre 11,1 y $14,3 \%$. Los valores de $\delta^{18} \mathrm{O}$ más bajos los presenta el cuarzo de las venas encajadas en el GE, mientras que los más elevados los muestra el de las venas encajadas en el $L G$ y las $A B$ con turmalina. También se observa que las dos muestras de moscovita analizadas presentan valores muy similares a los de la moscovita del LG y sus diques pegmatíticos, variando entre 11,1 y $11,2 \%$ (Fig. 5.5). Los valores de $\delta^{18} \mathrm{O}$ de la casiterita de las venas de cuarzo presentan un rango de variación muy restringido entre 5 y $5,35 \%$, mucho más ligeros que los de la casiterita de los diques pegmatíticos peribatolíticos de Cruz del Rayo. Los valores de $\delta^{18} \mathrm{O}$ de la wolframita de estas venas son similares a los de la casiterita, variando entre 5 y 6,9 \%o (Fig. 5.5).

Para calcular la $\delta^{18} \mathrm{O}$ del fluido en equilibrio con los silicatos, la casiterita y la wolframita se han empleado los factores de $\Delta_{\mathrm{Qz}-\mathrm{H} 2 \mathrm{O}}$ de Bottinga y Javoy (1975) y Clayton et al. (1972), de $\Delta_{\text {Tur-H2O }}$ 
CAPÍTULO 5. Inclusiones fluidas y caracterización isotópica

TABLA 5.2. ISÓTOPOS ESTABLES DE O Y D (\%)

\begin{tabular}{|c|c|c|c|c|c|c|c|c|}
\hline Muestra & Localización & Mineral & $T\left({ }^{\circ} \mathrm{C}\right)$ & $\% \mathrm{H}_{2} \mathrm{O}$ & $\delta^{18} O_{\min }$ & $\delta D_{\min }$ & $\delta^{18} \mathrm{O}_{\text {fluido }}$ & $\delta D_{\text {fluido }}$ \\
\hline \multicolumn{9}{|c|}{ Leucogranito con turmalina (LG) } \\
\hline \multirow{4}{*}{1055} & \multirow{4}{*}{ Salmantina } & Qz & \multirow{4}{*}{$620-700$} & & 13,3 & & $11,9 / 12,7$ & \multirow{4}{*}{$-66,9 /-69,3$} \\
\hline & & Ms & & 4,2 & 10,9 & $-83,7$ & $11,8 / 12,3$ & \\
\hline & & Tur & & 2,7 & 12,0 & $-87,2$ & $12,4 / 12,6$ & \\
\hline & & Kfs & & & 12,2 & & $11,8 / 12,1$ & \\
\hline \multicolumn{9}{|c|}{ Diques pegmatíticos intragraníticos } \\
\hline \multirow{2}{*}{1769} & \multirow{2}{*}{ Horia } & Qz & \multirow{14}{*}{$500-600$} & & 13,3 & & $10,1 / 11,6$ & \\
\hline & & Ms & & 4,6 & 11,75 & $-46,0$ & $11,7 / 12,5$ & $-33,5 /-41,6$ \\
\hline \multirow{2}{*}{1776} & \multirow{2}{*}{ Mari Carmen } & Qz & & & 12,8 & & $9,6 / 11,1$ & \\
\hline & & Ms & & 4,3 & 12,4 & $-44,8$ & $12,3 / 13,2$ & $-33,2 /-41,3$ \\
\hline \multirow{2}{*}{809} & \multirow{2}{*}{ Salmantina } & Qz & & & 13,7 & & $10,5 / 12,0$ & \\
\hline & & Tur & & 2,6 & 10,8 & $-86,8$ & $10,7 / 11,1$ & $-60,3 /-65,7$ \\
\hline \multirow{2}{*}{1787} & \multirow{2}{*}{ Carrasquera } & $\mathrm{Qz}$ & & & 13,6 & & $10,4 / 11,9$ & \\
\hline & & Ms & & 3,7 & 10,8 & -75 & $10,7 / 11,6$ & $-61,7 /-69,8$ \\
\hline \multirow{2}{*}{789} & \multirow{2}{*}{ Profunda } & Qz & & & 13,1 & & $9,9 / 11,4$ & \\
\hline & & Ms & & 4,1 & 10,8 & $-75,9$ & $10,7 / 11,6$ & \\
\hline \multirow{2}{*}{1796} & \multirow{2}{*}{ Teso de la Matanza } & Qz & & & 13,75 & & $10,6 / 12,1$ & \\
\hline & & Ms & & 4,4 & 11,3 & $-43,3$ & $11,2 / 12,1$ & \\
\hline \multirow{2}{*}{795} & Bon & Qz & & & 13,0 & & $9,8 / 11,3$ & \\
\hline & Bon & Ms & & 4,2 & 10,9 & $-64,5$ & $10,8 / 11,7$ & $-51,1 /-59,2$ \\
\hline Diques pe & atíticos peribatolíticos & & & & & & & \\
\hline 807 & & Qz & & & 14,1 & & $10,9 / 12,4$ & \\
\hline 802 & & Ms & & 4,5 & 11,6 & $-42,4$ & $11,5 / 12,4$ & $-29,7 /-37,8$ \\
\hline & Cruz del Rayo & Qz & $500-600$ & & 13,8 & & $10,6 / 12,1$ & \\
\hline 1894 & & Ms & & 4,2 & 12,3 & $-53,1$ & $12,2 / 13,1$ & \\
\hline & & Cst & & & 7,5 & & $11,7 / 11,7$ & \\
\hline Venas de & zo encajadas en el GE & & & & & & & \\
\hline & & Qz & & & 12,8 & & $9,9 / 10,6$ & \\
\hline 1040 & & Ms & & 3,8 & 11,2 & $-58,9$ & $10,7 / 11,7$ & \\
\hline & Horla & Qz & & & 13,6 & & $10,7 / 11,4$ & \\
\hline 1711 & & Cst & $460-560$ & & 5,3 & & 9,5 & \\
\hline 1046 & & Qz & & & 12,6 & & $9,7 / 10,4$ & \\
\hline 1046 & Mari Carmen & Cst & & & 5,0 & & 9,2 & \\
\hline 1775 & & $\mathrm{Qz}$ & & & 12,8 & & $9,9 / 10,6$ & \\
\hline Venas de & zo encajadas en el LG & as $A B$ & & & & & & \\
\hline & & Qz & & & 12,6 & & $9,2 / 9,9$ & \\
\hline 1059 & & $W f$ & & & 6,9 & & $9,8 / 10,1$ & \\
\hline & Salmantina & Qz & & & 13,7 & & $10,3 / 11,0$ & \\
\hline 1161 & & Cst & & & 5,35 & & $9,5 / 9,6$ & \\
\hline & & Qz & & & 13,4 & & $10,0 / 10,7$ & \\
\hline 1690 & & Cst & & & 5,0 & & 9,2 & \\
\hline & & Qz & $430-530$ & & 11,1 & & $7,7 / 8,4$ & \\
\hline 783 & Profunda & $W f$ & & & 5,6 & & $8,5 / 8,8$ & \\
\hline & & Qz & & & 14,3 & & $10,9 / 11,6$ & \\
\hline 1790 & Ieso de la Matanza & $W f$ & & & 5,8 & & $8,7 / 9,0$ & \\
\hline & & Qz & & & 13,4 & & $10 / 10,7$ & \\
\hline 2279 & Bon & Ms & & 4,4 & 11,1 & $-57,5$ & $10,1 / 11,3$ & \\
\hline & & Wf & & & 5,0 & & $7,9 / 8,2$ & \\
\hline
\end{tabular}

de Zheng (1993), de $\Delta_{\text {Ms-H2O }}$ de O'Neil y Taylor (1969), de $\Delta_{\text {Wf-H2O }}$ de Zheng (1992) y $\Delta_{\text {Cst-H2O }}$ de Zheng (1991). La temperatura a la que se han realizado estos cálculos ha sido: entre 620 y 700 ${ }^{\circ} \mathrm{C}$ para el LG con turmalina, tomada de Ramírez y Grundvig (2000) por saturación de circón y geoquímica de tierras raras; entre 500 y $600^{\circ} \mathrm{C}$ para los diques pegmatíticos; entre 460 y 560 
${ }^{\circ} \mathrm{C}$ para las venas de cuarzo mineralizadas encajadas en el GE; y entre 430 y $530{ }^{\circ} \mathrm{C}$ para las venas encajadas en el $L G$ y las $A B$ (Tabla 5.2). Estos tres últimos rangos de temperatura han sido establecidos a partir del estudio de las inclusiones fluidas.

El fluido en equilibrio con los silicatos del LG con turmalina muestra valores de $\delta^{18} O$ prácticamente idénticos que oscilan entre 11,8 y $12,7 \%$ indicando una cristalización conjunta (Tabla 5.2 y Fig. 5.6). El fluido en equilibrio con los silicatos y la casiterita de los diques pegmatíticos intra y peribatolíticos muestra un rango de variación más amplio entre 9,6 y $13,2 \%$, especialmente condicionado por la $\delta^{18} \mathrm{O}$ del cuarzo y de la moscovita que marcan los valores más extremos. La $\delta^{18} \mathrm{O}$ del fluido en equilibrio con la casiterita y la turmalina muestra valores intermedios de $11,7 \%$ y entre 10,7 y $11,1 \%$ respectivamente, si bien la turmalina es isotópicamente más ligera que en el LG (Tabla 5.2). Finalmente, la composición isotópica del fluido de las venas de cuarzo mineralizadas es la más variable, oscilando la $\delta^{18} \mathrm{O}$ entre 7,7 y $11,7 \%$, especialmente debido a la $\delta^{18} \mathrm{O}$ del cuarzo. El fluido en equilibrio con la moscovita y la casiterita muestra valores de $\delta^{18} \mathrm{O}$ más ligeros que en el LG y en las pegmatitas (entre $10,2-11,7 \%$ y entre $9,2-9,6 \%$ respectivamente), mientras que el fluido en equilibrio con la wolframita presenta los valores más bajos de $\delta^{18} \mathrm{O}$ (entre 7,9-10,1\%) y una cierta zonalidad regional que se traduce en un fluido más enriquecido en el isótopo pesado en el sector occidental del distrito (mina Salmantina) mientras que en la zona oriental (mina Bon) está más empobrecido. Se observa, por tanto, una tendencia general al empobrecimiento en $\delta^{18} \mathrm{O}$ del fluido desde el LG con turmalina hasta las venas de cuarzo mineralizadas (Fig. 5.6).

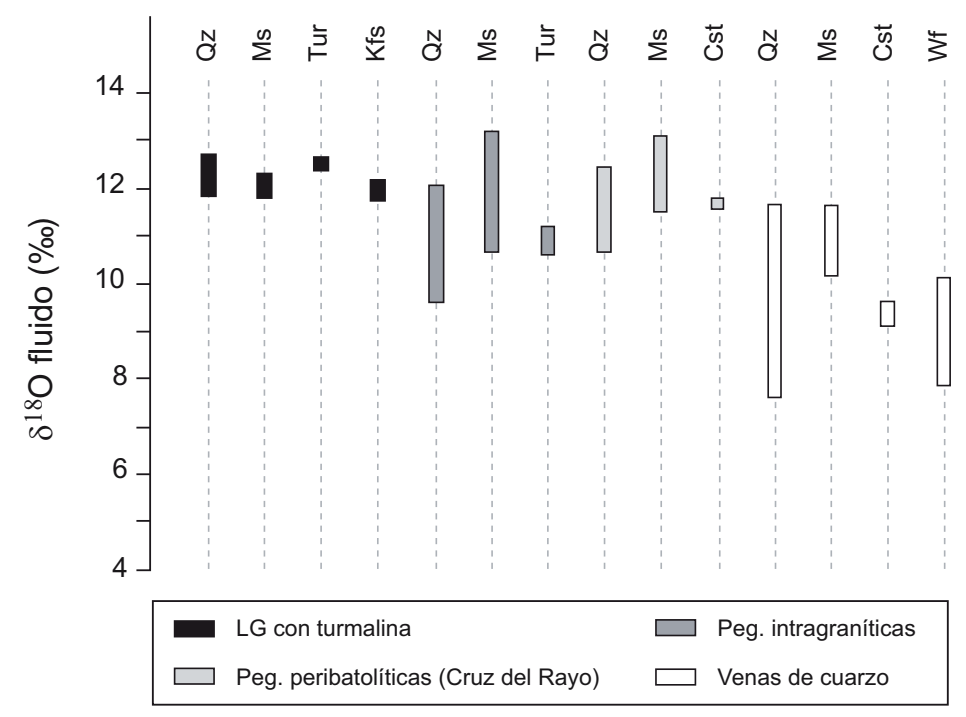

Fig. 5.6. Rango de valores de $\delta^{18} \mathrm{O}$ del fluido en equilibrio con los minerales estudiados.

\subsection{2. $\delta \mathrm{D}$ en silicatos}

Los valores de $\delta \mathrm{D}_{\text {SMow }}$ de la moscovita y la turmalina analizados se recogen en la tabla 5.2. La moscovita del LG con turmalina presenta los valores de $\delta \mathrm{D}$ más ligeros con $-83,7 \%$, variando entre $-44,8$ y $-46,0 \%$ en los diques pegmatíticos intragraníticos encajados en el GE, entre 
$-43,3$ y $-75,9$ en los diques pegmatíticos encajados en el LG con turmalina y entre $-53,1$ y $-42,4$ en las pegmatitas peribatolíticas de Cruz del Rayo. Así, se observa que, en general, los valores isotópicos de la moscovita sufren un enriquecimiento en $D$ desde el granito hacia los diques pegmatíticos (Fig. 5.7a). Teniendo en cuenta que la composición química de todas ellas es muy similar, parece más probable que el amplio rango de composición isotópica que muestran sea debido a variaciones en la $\delta D$ del fluido a partir del cual se formaron $o$ equilibraron. Por otro lado, los valores de $\delta \mathrm{D}$ de la moscovita de las venas de cuarzo varían entre $-57,5$ y $-58,9 \%$, estando más enriquecida en el isótopo pesado que la moscovita del LG (Fig. 5.7a). Finalmente, los valores de $\delta \mathrm{D}$ de la turmalina del LG $(-87,2 \%$ ) son muy similares a las de las pegmatitas intragraníticas $(-86,8 \%$ o).

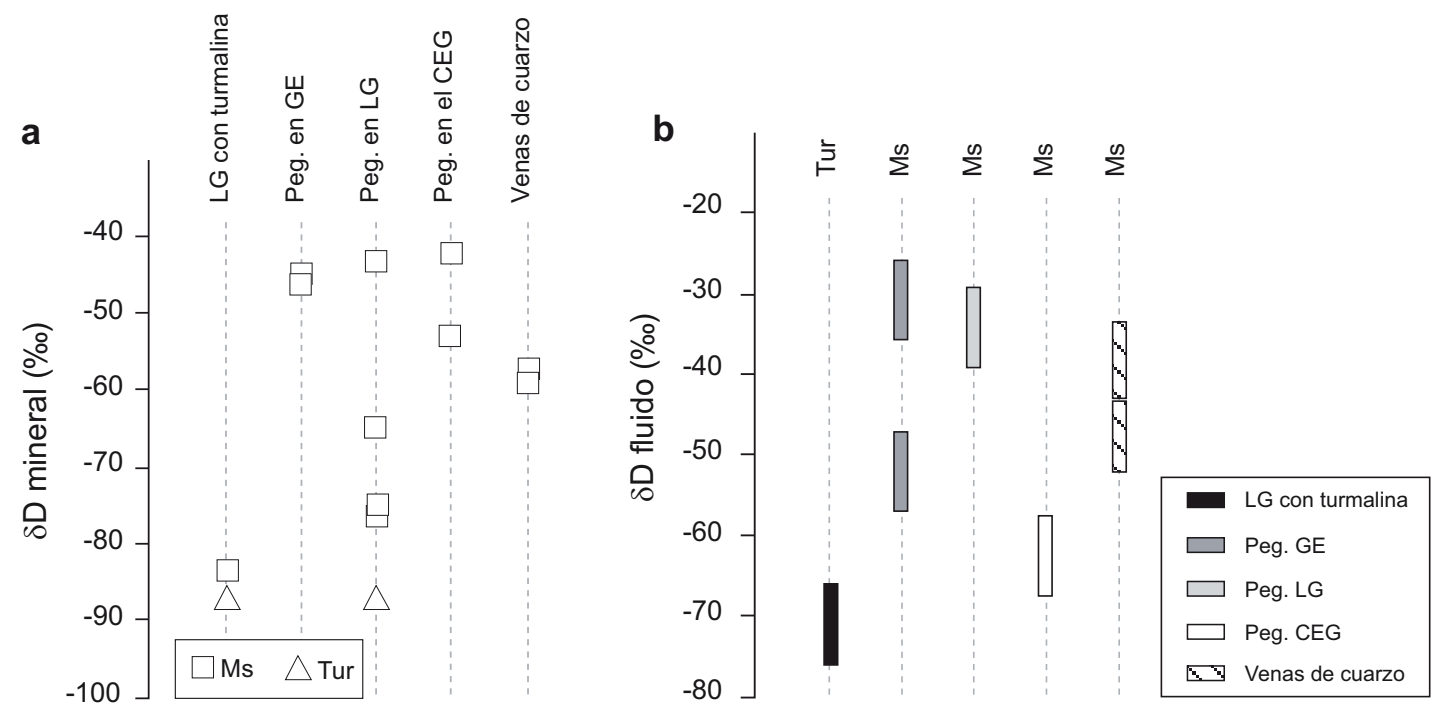

Fig. 5.7. Rango de valores de $\delta D$ de a) la turmalina y la moscovita estudiadas; y b) del fluido en equilibrio con estos minerales.

La composición isotópica de $\delta \mathrm{D}$ del fluido en equilibrio con la moscovita y la turmalina se ha calculado utilizando los factores de $\Delta_{\text {Tur-H2O }}$ de Kotzer et al. (1993) y de $\Delta_{\text {Ms-H2O }}$ de Suzuoki y Epstein (1976) para el mismo rango de temperaturas establecido previamente (Tabla 5.2). El fluido en equilibrio con la turmalina muestra un ligero enriquecimiento en $\delta D$ desde el LG (entre $-66,9$ y -69,3\%o) hasta las pegmatitas intragraníticas (entre $-60,3$ y -65,7\%o) (Fig. 5.7b). La $\delta D$ del fluido en equilibrio con la moscovita es muy pesado en los diques pegmatíticos encajados en el GE (entre $-33,2$ y $-41,6 \%$ ), muestra valores mucho más ligeros y variables en los encajados en el $L G$ y la $A B$ con turmalina (entre $-51,1$ y $-69,8 \%$ ) y está muy enriquecido en el isótopo pesado en los diques peribatolíticos de Cruz del Rayo (entre -29,7 y -37,8 $\%$ ). Por último, los valores de $\delta \mathrm{D}$ del fluido en equilibrio con la moscovita de las venas de cuarzo mineralizadas encajadas en el GE varían entre $-43,1$ y $-52,5 \%$ y en las encajadas en el $L G$ y las $A B$ entre $-33,0$ y $-43,6 \%$. En general, la tendencia del $\delta D$ del fluido es hacia un enriquecimiento desde el LG hacia los diques pegmatíticos más evolucionados y las venas de cuarzo (Fig. 5.7b). 


\subsubsection{Origen de los fluidos}

En el diagrama de la figura 5.8 se proyecta la composición isotópica de $\delta^{18} \mathrm{O}$ y $\delta \mathrm{D}$ del fluido en equilibrio con el LG con turmalina y los diques pegmatíticos, observándose que en prácticamente todas las ocasiones se sobrepasa el límite de $10 \%$ de $\delta^{18} \mathrm{O}$ que marca el campo de las aguas magmáticas primarias de Sheppard (1986), si bien se proyectan dentro del campo de los magmas peralumínicos definido por Ohomoto (1986), típico del batolito de Cornwall en Inglaterra y de otros cuerpos graníticos variscos (Sheppard, 1977). Igualmente se observa que los fluidos en equilibrio con los diques pegmatíticos encajados en el GE y los de Cruz del Rayo están más enriquecidos en $\delta \mathrm{D}$, proyectándose en transición hacia el campo de las aguas metamórficas debido a que los últimos fundidos de diferenciación magmática podrían estar enriquecidos en $\delta \mathrm{D}$ por el fraccionamiento positivo de los isótopos de $\mathrm{D}$ entre fluido-mineral a la temperatura a la que se forman las pegmatitas (Suzuoki y Epstein, 1976). Sin embargo, el hecho de que esto solo ocurra en los diques pegmatíticos que muestran signos de una alteración importante (como moscovitización o greisenización) sugiere que este enriquecimiento en $\delta \mathrm{D}$ está causado por un proceso posterior a la cristalización que no afecta al fundido inicial a partir del cual se forman los diques. Por último, el fluido en

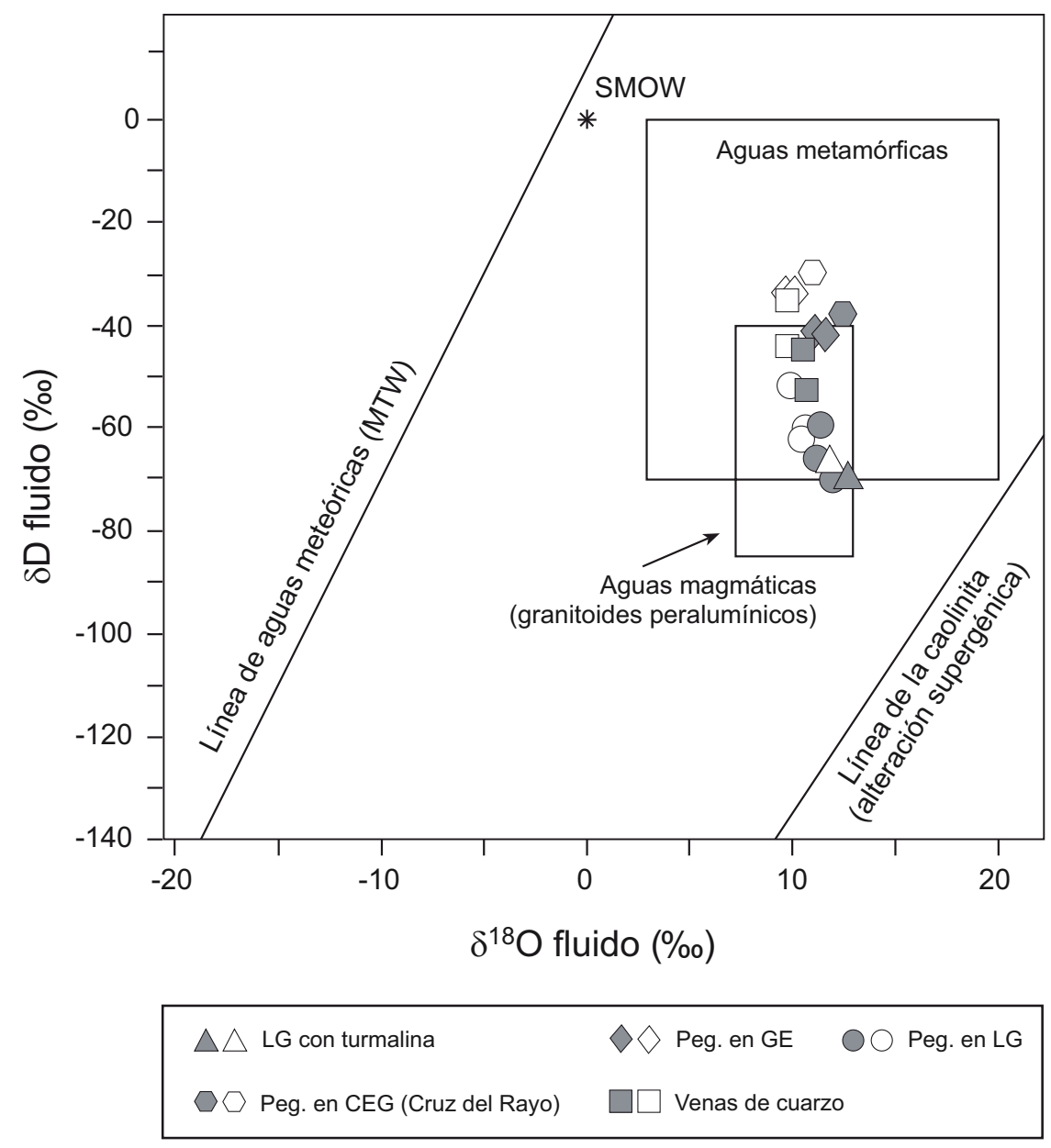

Fig. 5.8. Diagrama de $\delta \mathrm{D}$ vs. $\delta^{18} \mathrm{O}$ para las muestras estudiadas en el rango de temperaturas dado. En blanco se representa la composición isotópica a la $T$ mínima y en gris a la $T$ máxima. SMOW: Standard Mean Ocean Water. Datos de referencia: Sheppard (1986), Ohmoto (1986) y Craig (1961). 
equilibrio con las venas de cuarzo mineralizadas se proyecta también principalmente dentro del campo de los magmas peralumínicos (Ohomoto, 1986) (Fig. 5.8). Los valores isotópicos de $\delta^{18} \mathrm{O}$ del fluido en equilibrio con el cuarzo de las venas que se observan en la tabla 5.2 confirmarían también la procedencia magmática de estos fluidos.

En la figura 5.6 se observa la tendencia hacia composiciones más ligeras de $\delta^{18} O$ de los fluidos hidrotermales residuales derivados de la cristalización del batolito de Jálama, como cabría esperar en un sistema magmático-hidrotermal (Sheppard, 1986), aunque el amplio rango isotópico que muestra el fluido en equilibrio con el cuarzo junto con los valores más pesados de $\delta^{18} \mathrm{O}$ y el amplio rango de variación del $\Delta_{\mathrm{Qz}^{-\mathrm{Ms}} \mathrm{s}^{\prime}}$ entre otros, indican la existencia de un desequilibrio isotópico. Dicho desequilibrio se refleja igualmente en el gráfico de la figura 5.9, donde se enfrentan las composiciones isotópicas de $\delta^{18} \mathrm{O}$ del cuarzo y de la moscovita coexistentes tanto en el LG con turmalina como en los diques pegmatíticos intra y peribatolíticos y en las venas de cuarzo mineralizadas. En él se corrobora que buena parte de los valorse isotópicos de estos cuerpos se proyectan a temperaturas elevadas y que, además, no muestran una disposición paralela a las isotermas lo que sería, de nuevo, un indicador de desequilibrio.

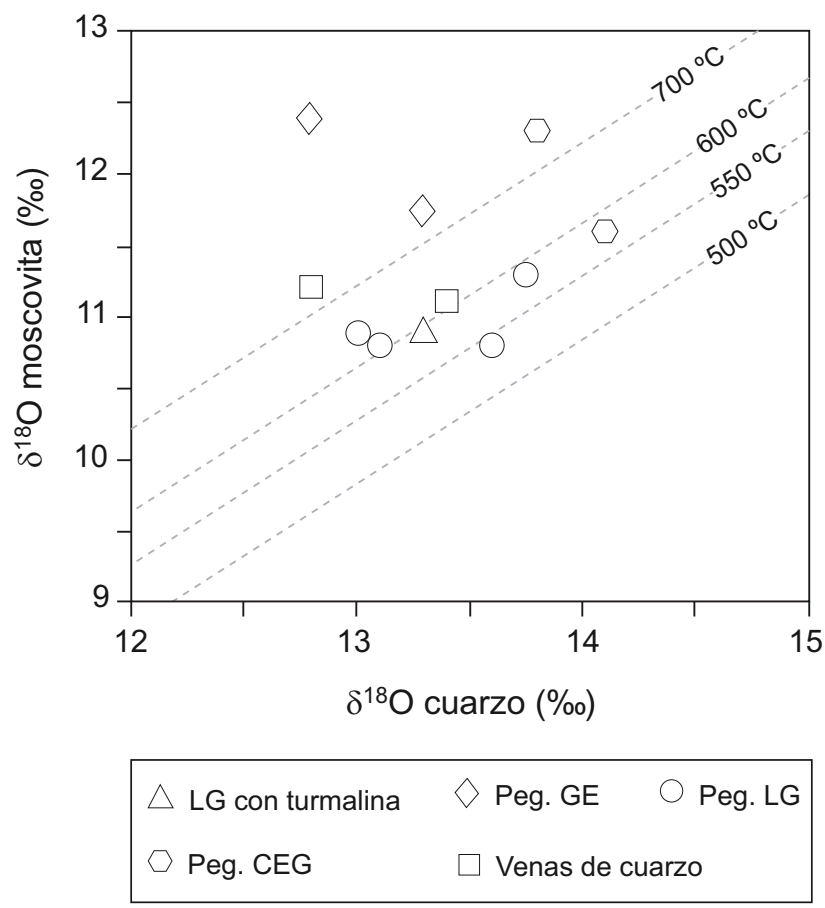

Fig. 5.9. Diagrama de $\delta^{18} \mathrm{O}$ del cuarzo frente a los de $\delta^{18} \mathrm{O}$ de la moscovita de las muestras estudiadas con la representación de las isotermas calculadas mediante el $\Delta_{\mathrm{Qz}-\mathrm{Ms}}$.

Este desequilibrio podría producirse durante la cristalización de los minerales, como ocurre en los diques pegmatíticos de Cruz del Rayo que intruyen en las rocas metamórficas del CEG más frías (hasta $300-400{ }^{\circ} \mathrm{C}$ menos), lo que supone un fuerte contraste de temperatura y, por tanto, un factor de desequilibrio isotópico en el momento de su cristalización (London, 2005, 2008; Sirbescu et al., 2008). Esta interacción entre los diques pegmatíticos y la roca encajante, 
evidente por la cristalización de abundante turmalina rica en Fe en los metasedimentos del CEG y en la zona de borde de los diques, podría favorecer la entrada de un fluido enriquecido en $\delta^{18} \mathrm{O}$ y $\delta \mathrm{D}$. Por otro lado, la intrusión de los diques intragraníticos en la UE no supone un fuerte contraste de temperaturas, por lo que se podría considerar que el equilibrio isotópico en ellos se habría mantenido (Černý, 1991b; London, 2008). Una segunda causa para este desequilibrio sería un intercambio isotópico posterior a la cristalización, que podría producirse como consecuencia de los procesos de metasomatismo sódico en los que, además de albita, cristaliza una moscovita paragenéticamente tardía a partir de un fluido más enriquecido en $\delta^{18} \mathrm{O}$ y en $\delta \mathrm{D}$ que el original, o bien por la interacción de fluidos metamórficos y/o meteóricos durante la evolución hidrotermal del sistema, lo que estaría avalado por todo el cortejo de fosfatos secundarios y de alteración supergénica ricos en $\mathrm{Fe}, \mathrm{Mg}$ y Ca que se encuentran en los diques pegmatíticos intra y peribatolíticos.

En las venas de cuarzo mineralizadas la importancia de esta entrada de fluidos externos al sistema se hace evidente, al igual que en los diques pegmatíticos, por la existencia de abundantes fosfatos de $\mathrm{Ca}$, Fe y $\mathrm{Mg}$ en estas rocas, que necesariamente requieren de la mezcla de fluidos metamórficos \pm meteóricos con los hidrotermales de origen magmático dando lugar a que los minerales reequilibren, por lo que estos muestran composiciones isotópicas enriquecidas en $\delta^{18} \mathrm{O}$ y $\delta \mathrm{D}$. Este hecho también se constata mediante la composición compleja de las inclusiones de tipo lla y llb en las venas de cuarzo, que contienen pequeñas cantidades de $\mathrm{CO}_{2}, \mathrm{CH}_{4}$ y $\mathrm{N}_{2}$.

Valores isotópicos similares se obtienen en otros depósitos de Sn y W, como los yacimientos de Teba y La Parrilla en el oeste español (Mangas y Pérez-Torrado, 1995), en Panasqueira en Portugal (Polya et al., 2000), en el batolito de Cornwall de Inglaterra (Sheppard, 1986), en el Complejo de Naxos en Grecia (Matthews et al., 2003) y en cuerpos graníticos del macizo de Bohemia, el macizo Armoricano y el Macizo Central Francés (Sheppard, 1986).

\subsection{4. $\delta^{34} \mathrm{~S}$ en sulfuros}

Un total de 21 muestras de sulfuros (arsenopirita, pirita y esfalerita) han sido analizadas, de las cuales 18 pertenecen a las venas de cuarzo mineralizadas del batolito de Jálama (minas Horia y Mari Carmen en el GE y minas Salmantina, Carrasquera, Profunda, Teso de la Matanza y Bon en el LG y AB con turmalina) y 3 a las del batolito de Cadalso-Casillas de Flores (El Cruce y Peñaparda), cuyos resultados se recogen en la tabla 5.3.

En las venas encajadas en el GE del batolito de Jálama, los valores de $\delta^{34} S_{C D T}$ son muy similares para la arsenopirita (entre 4,4 y $4,9 \%$ ), pirita (entre 4,3 y $5,9 \%$ ) y esfalerita $(4,1 \%$ ), mientras que en las encajadas en el LG y las $A B$ con turmalina la $\delta^{34} S$ es más pesada, presentando un amplio rango de variabilidad en la arsenopirita (entre 1,4 y $-3,1 \%$ ) y la esfalerita (entre $-0,8$ y $-4,0 \%$ ) (Fig. 5.10a y Tabla 5.3). Por otro lado, en las venas de cuarzo del batolito de Cadalso-Casillas de Flores la $\delta^{34} \mathrm{~S}$ varía ampliamente desde la pirita $(-3,1 \%)$ hasta la mezcla arsenopirita+pirita $(4,1 \%)$ en las venas encajadas en el granito de Peñaparda, mientras que la arsenopirita de El Cruce muestra valores intermedios $(1,4 \%)$. 
TABLA 5.3. ISÓTOPOS ESTABLES DE S EN SULFUROS (\%)

\begin{tabular}{|c|c|c|c|c|c|}
\hline Muestra & Localización & Mineral & $T\left({ }^{\circ} \mathrm{C}\right)$ & $\delta^{34} S_{\min }$ & $\delta^{34} S_{\text {fluido }}$ \\
\hline \multicolumn{6}{|c|}{ Batolito de Jálama } \\
\hline \multicolumn{6}{|c|}{ Venas en el GE } \\
\hline 1040 & Horia & Apy & \multirow{7}{*}{$460-560$} & 4,8 & $4,1 / 4,2$ \\
\hline 1041 & Horia & Py & & 5,9 & $5,2 / 5,3$ \\
\hline $1042 \mathrm{~A}$ & Horia & Apy & & 4,9 & $4,2 / 4,3$ \\
\hline 1044 & Horia & Py & & 5,5 & $4,8 / 4,9$ \\
\hline 1048 & Mari Carmen & $\mathrm{Sp}$ & & 4,1 & $3,4 / 3,5$ \\
\hline 1775 & Mari Carmen & Apy & & 4,4 & $3,7 / 3,8$ \\
\hline 1775 & Mari Carmen & Py & & 4,3 & $3,6 / 3,7$ \\
\hline \multicolumn{6}{|c|}{ Venas en el $L G$ y las $A B$ con turmalina } \\
\hline 1050 & Salmantina & Apy & \multirow{11}{*}{$430-530$} & 1,4 & $0,6 / 0,8$ \\
\hline $1051 \mathrm{~A}$ & Salmantina & Apy & & $-3,1$ & $-3,9 /-3,7$ \\
\hline 1052 & Salmantina & Apy & & 0 & $-0,8 /-0,6$ \\
\hline 1060 & Salmantina & Apy & & $-0,3$ & $-1,1 /-0,9$ \\
\hline 1161 & Salmantina & Apy & & $-2,3$ & $-3,1 /-2,9$ \\
\hline 1181 & Salmantina & $\mathrm{Sp}$ & & -4 & $-4,8 /-4,6$ \\
\hline 1781 & Carrasquera & Apy & & $-1,6$ & $-2,4 /-2,2$ \\
\hline 781 & Profunda & Apy & & $-2,1$ & $-2,9 /-2,7$ \\
\hline 1790 & Teso de la Matanza & Apy & & $-2,4$ & $-3,2 /-3,0$ \\
\hline 1056 & Bon & Apy & & 0,2 & $-0,6 /-0,4$ \\
\hline 1058 & Bon & $\mathrm{Sp}$ & & $-0,8$ & $-1,6 /-1,4$ \\
\hline \multicolumn{6}{|c|}{ Batolito de Cadalso-Casillas de Flores } \\
\hline \multicolumn{6}{|c|}{ Venas en el granito de EI Payo } \\
\hline 808 & El Cruce & Apy & $400-500$ & 1,4 & $0,5 / 0,7$ \\
\hline \multicolumn{6}{|c|}{ Venas en el granito de Peñaparda } \\
\hline 1893 & Peñaparda & Apy+Py & $400-500$ & 4,1 & $3,2 / 3,4$ \\
\hline 1725 & Peñaparda & Py & & $-3,1$ & $-4,0 /-3,8$ \\
\hline
\end{tabular}

Para el cálculo del $\delta^{34} \mathrm{~S}$ del fluido $\left(\mathrm{H}_{2} \mathrm{~S}\right)$ en equilibrio con estos sulfuros se han utilizado los factores de $\Delta_{\text {Py-H2S }}$ y $\Delta_{\text {Sp-H2S }}$ de Ohmoto y Rye (1979) para los intervalos de $T 460-560{ }^{\circ} \mathrm{C}$ en las venas del GE y $430-530^{\circ} \mathrm{C}$ en las venas del $L G$ y las $A B$, obtenidas ambas mediante las inclusiones fluidas y $400-500^{\circ} \mathrm{C}$ en las venas de El Cruce y Peñaparda, obtenidas en este caso por geotermometría de las micas. Dado que no existen datos en la literatura sobre el $\Delta_{\text {Apy-H2S }}$ no es posible calcular la composición isotópica del fluido a partir de la $\delta^{34} \mathrm{~S}$ de la arsenopirita. Sin embargo, en vista de la similitud de su composición isotópica con la de la pirita y la esfalerita, se puede suponer un escaso fraccionamiento entre estos sulfuros que precipitan a partir del mismo fluido, de modo que todos ellos presentan un comportamiento isotópico similar respecto del fluido y las condiciones de pH y reducción-oxidación (Kerrich y Fyfe, 1988). Por ello en este estudio se consideran los cálculos de la $\delta^{34} S$ del fluido a partir de la arsenopirita.

La $\delta^{34} S$ del fluido es ligeramente inferior a la de los sulfuros analizados y apenas varía para el intervalo de temperatura considerado (Tabla 5.3). En el batolito de Jálama se observa una clara diferencia entre el fluido en equilibrio con los sulfuros de las venas de cuarzo encajadas en el GE (entre 3,6 y $5,3 \%$ ) y el de las venas del LG y las $A B$ con turmalina $(-3,8$ y $0,8 \%$ ), isotópicamente más ligero (Fig. 5.10b). Esta fuerte diferencia estaría fundamentalmente relacionada con las condiciones redox, lo que se refleja también en cambios en la composición química de los minerales de que están constituidas (Capítulo 3). Los valores más pesados de las minas Horia y Mari Carmen indican un ambiente reductor en el que la $\mathrm{fO}_{2}$ está limitada. 


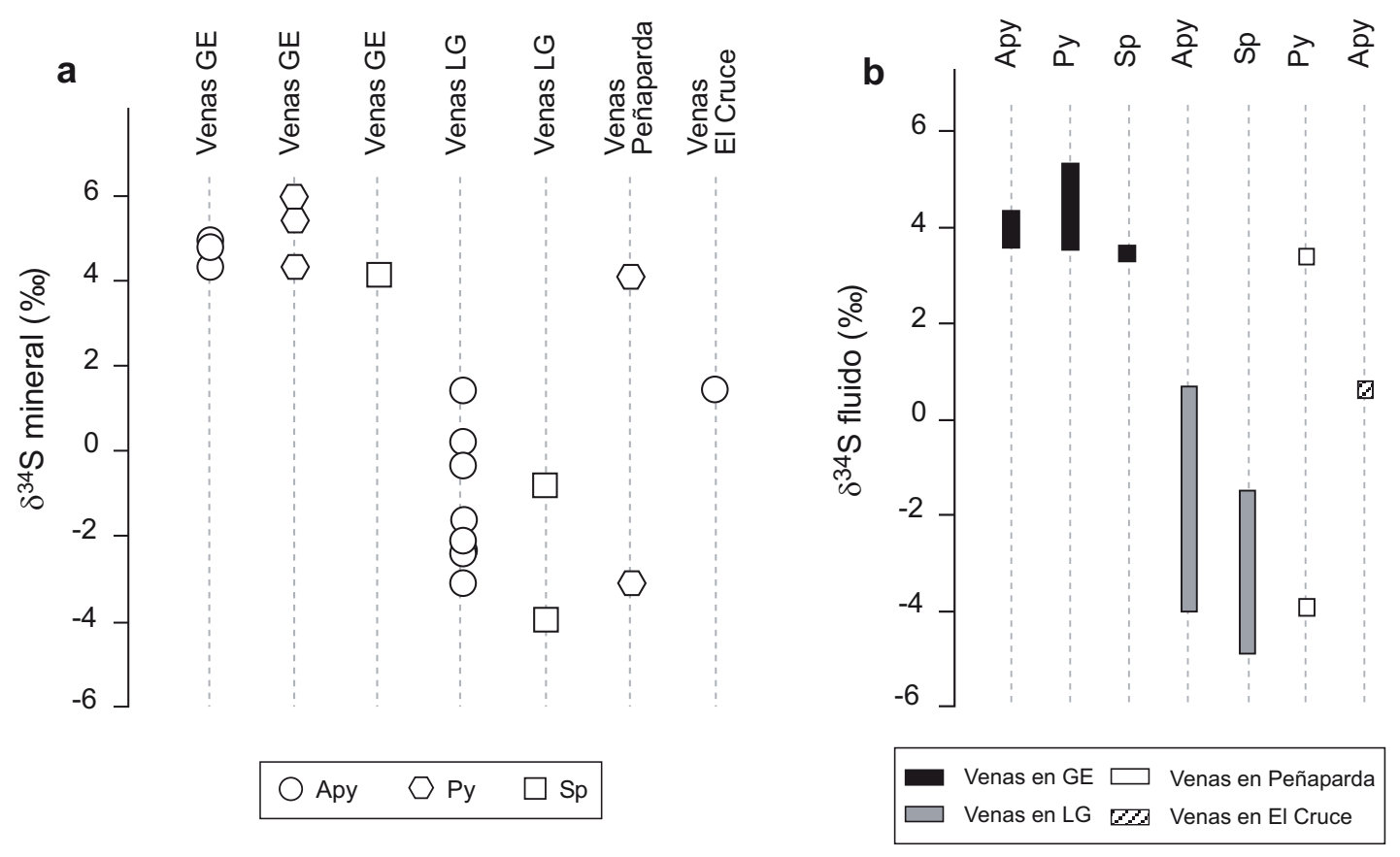

Fig. 5.10. Rango de valores de $\delta^{34} S$ de a) los sulfuros estudiados; y b) el fluido en equilibrio con estos.

Estas condiciones redox son típicas de los yacimientos de $\mathrm{Sn}$ asociados a granitoides de tipo S (Ohmoto, 1986). Sin embargo, la signatura isotópica más ligera del fluido de las venas encajadas en el LG y las AB con turmalina supone un ambiente más oxidante. En vista de los resultados del estudio isotópico de $\delta^{18} \mathrm{O}$ y $\delta \mathrm{D}$ y de las inclusiones fluidas, lo más probable es que el fluido mineralizador haya sufrido una contaminación por fluidos metamórficos procedentes de los metasedimentos encajantes del batolito de Jálama que estuvieran más enriquecidos en gases como $\mathrm{CH}_{4}, \mathrm{H}_{2} \mathrm{~S}_{\text {o }} \mathrm{H}_{2}$ produciendo un ligero incremento de la $\mathrm{fO}_{2} \mathrm{y}$ dando lugar a la cristalización de estos sulfuros con una $\delta^{34} \mathrm{~S}$ más ligera.

En el batolito de Cadalso-Casillas de Flores la $\delta^{34} S$ del fluido varía entre $-4,0 \%$ y $3,4 \%$ en las venas encajadas en el granito de Peñaparda y entre 0,3 y $0,7 \%$ en las venas de El Cruce (Tabla 5.3 y Fig. $5.10 \mathrm{~b}$ ). La contaminación por fluidos metamórficos también podría explicar las diferencias isotópicas de $\delta^{34}$ S en estas venas; sin embargo, dada la ausencia de estudios de inclusiones fluidas e isótopos de $\mathrm{O}$ y $\mathrm{D}$ no es posible confirmar dicha interacción.

\subsubsection{Origen del azufre}

El fraccionamiento isotópico entre el $\mathrm{H}_{2} \mathrm{~S}$ y los sulfuros en el fundido magmático es insignificante, de modo que se puede considerar que la $\delta^{34} S$ de los fluidos magmáticos derivados de magmas graníticos de tipo $\mathrm{S}$ a una $\mathrm{P}_{\mathrm{H} 2 \mathrm{O}}$ superior a 100 bar, es idéntica a la del magma y, a su vez, igual a la de los metasedimentos encajantes. De esta manera, los sulfuros de los yacimientos asociados con estas rocas magmáticas adquieren la signatura isotópica de las rocas de las que proceden (Ohmoto, 1986). En general, la composición isotópica de los sulfuros de procedencia magmática se sitúa entre -5 y $+5 \%$ de $\delta^{34} S$ (Ohomoto y Rye, 1979) (Fig. 5.11). Dada la composición isotópica de $\delta^{34} S$ de los sulfuros y la afiliación isotópica de los 


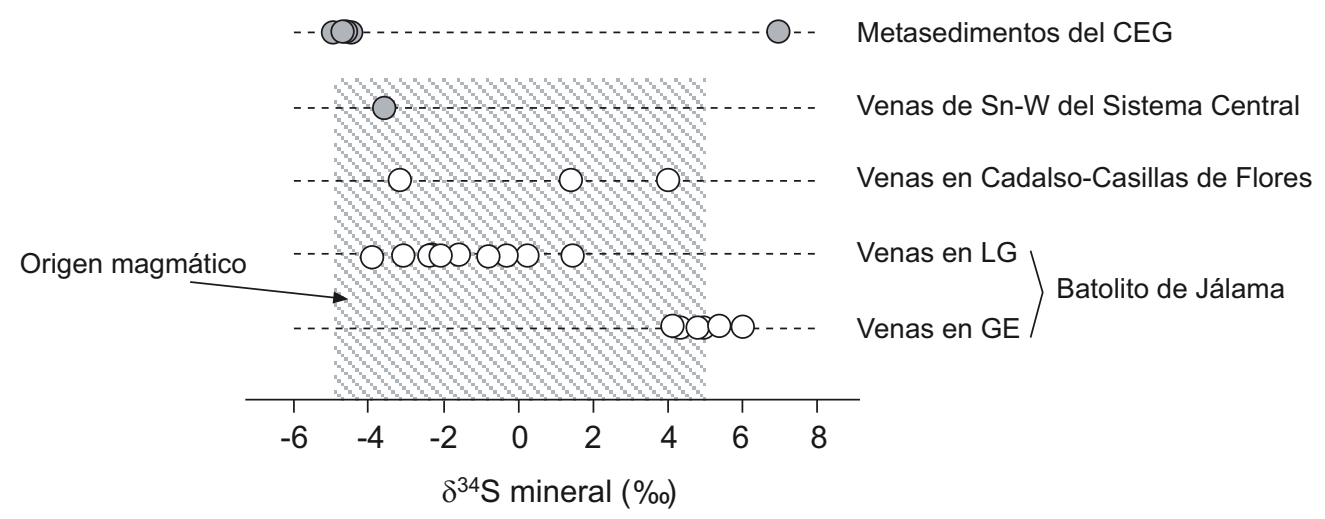

Fig. 5.11. Representación de $\delta^{34} S$ de los sulfuros estudiados en Navasfrías comparado con la composición isotópica de otros sulfuros en venas de cuarzo con $\mathrm{S} \pm \mathrm{W}$ del Sistema Central (Tornos et al., 2000) y en los metasedimentos del CEG (Recio et al., 1991). Campo de los sulfuros de origen magmático de Ohmoto y Rye (1979).

fluidos en las venas de cuarzo mineralizadas del distrito de Navasfrías, se puede considerar que el azufre proviene de una fuente magmática. Así los resultados obtenidos en este estudio son coherentes con los datos de composición isotópica obtenidos por Recio et al. (1991) para los sulfuros de los metasedimentos del CEG en zonas próximas al distrito de Navasfrías. Valores similares de $\delta^{34} S$ se encuentran también en sulfuros asociados a otros depósitos de venas con Sn y/o W asociados a los granitoides del Sistema Central Español (Tornos et al., 2000) (Fig. 5.11). 

CAPÍTULO 6

Condiciones fisicoquímicas deformación 



\section{CAPÍTULO 6. CONDICIONES FISICOQUÍMICAS DE FORMACIÓN}

Para determinar las condiciones fisicoquímicas de formación de las mineralizaciones estudiadas se han utilizado la paragénesis y la química mineral de las diferentes facies graníticas y pegmatíticas y de las venas de cuarzo mineralizadas, así como los resultados microtermométricos y de geotermometría isotópica.

\subsection{GEOTERMOMETRÍA}

\subsubsection{Geotermometría isotópica}

La composición isotópica de minerales paragenéticos y en equilibrio textural permite obtener su $T$ de formación. En este estudio se ha utilizado la composición isotópica de los siquientes pares de minerales que pertenecen a las facies graníticas y pegmatíticas y a las venas de cuarzo mineralizadas del batolito de Jálama: Qz-Ms, Qz-Tur, Qz-Cst, Ms-Cst y Qz-Kfs. Las expresiones termométricas empleadas se obtienen a partir de los factores de fraccionamiento isotópico que se utilizaron en el Capítulo 5.

Cuarzo-moscovita: el fraccionamiento entre el cuarzo y la moscovita $\left(\Delta_{\mathrm{Qz}-\mathrm{Ms}}\right)$ del LG con turmalina es de $2,4 \%$, que corresponde a una temperatura de equilibrio isotópico (Teq.) de $609{ }^{\circ} \mathrm{C}$ (Tabla 6.1), valor que es coherente con los calculados por Ramírez (1996) para esta facies. En algunos de los diques pegmatíticos el $\Delta_{\mathrm{Qz}-\mathrm{Ms}}$ varía entre 2,4 y 2,8 \%o, mientras que en las venas de cuarzo mineralizadas es $2,3 \%$, a los que corresponden Teq. entre 538 y $599^{\circ} \mathrm{C}$ y de $469^{\circ} \mathrm{C}$ respectivamente que coinciden con las establecidas por el estudio de inclusiones fluidas. Sin embargo, algunas de las temperaturas obtenidas en pegmatitas y venas de cuarzo son superiores a los $600{ }^{\circ} \mathrm{C}$ y $870^{\circ} \mathrm{C}$ por lo que no se consideran válidas ya que no están en equilibrio (Tabla 6.1).

Cuarzo-feldespato potásico: en el LG con turmalina encajante de las venas de cuarzo mineralizadas de la mina Salmantina se ha obtenido un $\Delta_{\text {Qz-kfs }}$ de 1,1\%o, correspondiéndole una Teq. de $612{ }^{\circ} \mathrm{C}$ que coincide prácticamente con la calculada a partir del par Qz-Ms (Tabla 6.1).

Cuarzo-turmalina: el $\Delta_{\mathrm{Qz}-\mathrm{Tur}}$ en las pegmatitas intragraníticas es de 2,9\%, obteniendo una temperatura de cierre isotópico de $510^{\circ} \mathrm{C}$, mientras que en el LG con turmalina es de 1,3\%。 y la Teq. calculada alcanza los $689^{\circ} \mathrm{C}$ (Tabla 6.1). Ambas coinciden con los rangos obtenidos por Ramírez y Grundvig (2000) en el LG y por el estudio de las inclusiones fluidas.

Cuarzo-casiterita: el $\Delta_{\mathrm{Qz}-\mathrm{cst}}$ en los diques pegmatíticos de Cruz del Rayo es de 6,3\%, al que corresponde una Teq. de $566{ }^{\circ} \mathrm{C}$, mientras que en las venas de cuarzo este valor varía entre 7,6 y $8,4 \%$, obteniéndose temperaturas de cierre isotópico relativamente bajas entre 388 y $430{ }^{\circ} \mathrm{C}$ (Tabla 6.1), coincidiendo solo esta última con el estudio de inclusiones fluidas.

Cuarzo-wolframita: el $\Delta_{\mathrm{Qz}-\mathrm{wf}}$ en dos de las muestras de las venas de cuarzo encajadas en el LG y las $A B$ con turmalina varía entre 5,5 y 5,7\%, correspondiéndole Teq. entre 476 y $492^{\circ} \mathrm{C}$ que 
TABLA 6.1. GEOTERMOMETRÍA DE ISÓTOPOS ESTABLES

\begin{tabular}{|c|c|c|c|c|}
\hline Muestra & Localización & Tipo de roca & $\Delta_{\min -\min }(\%)$ & Teq. $\left({ }^{\circ} \mathrm{C}\right)$ \\
\hline \multicolumn{5}{|c|}{ Cuarzo-Moscovita } \\
\hline 1055 & Salmantina & LG & 2,4 & 609 \\
\hline 1769 & Horia & Pegmatita en GE & 1,55 & 851 \\
\hline 1776 & Mari Carmen & Pegmatita en GE & 0,4 & $<2001$ \\
\hline 1787 & Carrasquera & Pegmatita en LG & 2,8 & 538 \\
\hline 789 & Profunda & Pegmatita en LG & 2,3 & 629 \\
\hline 795 & Bon & Pegmatita en LG & 2,1 & 675 \\
\hline 1796 & Teso de la Matanza & Pegmatita en LG & 2,45 & 599 \\
\hline 1894 & \multirow{2}{*}{ Cruz del Rayo } & Pegmatita en CEG & 1,5 & 872 \\
\hline 802 & & Pegmatita en CEG & 2,5 & 589 \\
\hline 1040 & Horia & Vena de cuarzo en GE & 1,6 & 675 \\
\hline 2279 & Bon & Vena de cuarzo en LG & 2,3 & 469 \\
\hline \multicolumn{5}{|c|}{ Cuarzo-Feldespato potásico } \\
\hline 1055 & Salmantina & LG & 1,1 & 612 \\
\hline \multicolumn{5}{|c|}{ Cuarzo-Turmalina } \\
\hline 809 & \multirow{2}{*}{ Salmantina } & Pegmatita en LG & 2,9 & 510 \\
\hline 1055 & & LG & 1,3 & 689 \\
\hline \multicolumn{5}{|c|}{ Cuarzo-Casiterita } \\
\hline 1711 & Horia & Vena de cuarzo en GE & 8,3 & 393 \\
\hline 1046 & Mari Carmen & Vena de cuarzo en GE & 7,6 & 430 \\
\hline 1161 & \multirow{2}{*}{ Salmantina } & Vena de cuarzo en LG & 8,35 & 390 \\
\hline 1690 & & Vena de cuarzo en LG & 8,4 & 388 \\
\hline 1894 & Cruz del Rayo & Pegmatita en CEG & 6,3 & 566 \\
\hline \multicolumn{5}{|c|}{ Cuarzo-Wolframita } \\
\hline 1059 & Salmantina & Vena de cuarzo en LG & 5,7 & 476 \\
\hline 783 & Profunda & Vena de cuarzo en LG & 5,5 & 492 \\
\hline 1790 & Teso de la Matanza & Vena de cuarzo en LG & 8,5 & 304 \\
\hline 2279 & Bon & Vena de cuarzo en LG & 8,4 & 309 \\
\hline \multicolumn{5}{|c|}{ Moscovita-Casiterita } \\
\hline 1894 & Cruz del Rayo & Pegmatita en CEG & 4,8 & 456 \\
\hline
\end{tabular}

son coherentes con el estudio de las inclusiones fluidas, mientras que los valores superiores a 8,0 \% de algunas de ellas corresponden con temperaturas próximas a los $300{ }^{\circ} \mathrm{C}$ que están muy por debajo de los rangos calculados (Tabla 6.1).

Moscovita-casiterita: el $\Delta_{\text {Ms-cst }}$ en los diques pegmatíticos de Cruz del Rayo es de 4,8 \%, obteniéndose una Teq. de $456{ }^{\circ} \mathrm{C}$ que encaja con el estudio de las inclusiones fluidas (Tabla 6.2).

\subsubsection{Microtermometría de inclusiones fluidas}

En el estudio microtermométrico de las inclusiones fluidas del cuarzo y la casiterita de los diques pegmatíticos de Cruz del Rayo se han obtenido unas temperaturas de homogeneización (Th) entre $257-391{ }^{\circ} \mathrm{C}$ y entre $265-278{ }^{\circ} \mathrm{C}$ respectivamente que, corregidas a la presión de 2-3 kbar a la que se produce el emplazamiento del batolito de Jálama (Ramírez y Grundvig, 2000), corresponden con una temperatura de formación entre 500 y $600{ }^{\circ} \mathrm{C}$ para el cuarzo y de 450 a $550{ }^{\circ} \mathrm{C}$ para la casiterita.

Igualmente, para el cuarzo I de las venas mineralizadas encajadas en el GE las Th obtenidas varían entre 233 y $323^{\circ} \mathrm{C}$, mientras que en las venas encajadas en el LG y las $A B$ con turmalina 
lo hacen entre 215 y $385^{\circ} \mathrm{C}$. Aplicando la misma corrección de presión se obtiene una temperatura de formación del cuarzo I entre 460 y $560{ }^{\circ} \mathrm{C}$ en las venas encajadas en el GE y entre 430 y $530^{\circ} \mathrm{C}$ en las venas encajadas en el LG y las $A B$.

\subsubsection{Geotermometría química}

\subsubsection{Geotermometría de las micas}

La composición química de la biotita y la moscovita analizadas en los diferentes tipos de rocas de los batolitos de Jálama y de Cadalso-Casillas de Flores puede ser utilizada como geotermómetro a partir del diagrama de Monier y Robert (1986).

\section{Batolito de Jálama}

La biotita en las facies graníticas de la UE del batolito de Jálama se forma a una temperatura elevada, generalmente en torno a los $800{ }^{\circ} \mathrm{C}$ en el monzogranito porfídico (MP), que es la facies más interna y entre 800 y $700{ }^{\circ} \mathrm{C}$ para el granito equigranular (GE) (Fig. 6.1a). Para la moscovita las temperaturas de cristalización oscilan entre los $650^{\circ} \mathrm{C}$ y los $450^{\circ} \mathrm{C}$ (Fig. $6.1 \mathrm{a}, \mathrm{b}, \mathrm{c})$, todas ellas dentro de los rangos calculados por Ramírez y Grundvig (2000). Algunas de estas temperaturas, de acuerdo a estos autores, son demasiado bajas lo que puede ser debido a la existencia de otros componentes, como los volátiles, que reduzcan la temperatura de cristalización del magma. La importancia de los volátiles en estos magmas ya fue puesta de manifiesto por Ramírez (1996) debido a la presencia de turmalina, topacio, berilo y fosfatos de Li en las facies más evolucionadas de la UE y a la existencia de facies aplíticas y pegmatíticas de borde del batolito y de mineralizaciones de Sn y W.

Las moscovitas en los diques pegmatíticos del GE se forman en torno a los $600-650{ }^{\circ} \mathrm{C}$, disminuyendo progresivamente hasta los $600{ }^{\circ} \mathrm{C}$ y los $500{ }^{\circ} \mathrm{C}$ hacia los diques del LG y las $A B$ y las pegmatitas de Cruz del Rayo (Fig. 6.1d,e), lo que concuerda con las temperaturas microtermométricas e isotópicas.

En las venas de cuarzo mineralizadas la mayoría de las moscovitas analizadas se formaron en torno a los $400{ }^{\circ} \mathrm{C}$ en el GE y entre $500-550^{\circ} \mathrm{C}$ en el $L G$ y las $A B$ con turmalina (Fig. 6.1f). Estas últimas coinciden con las obtenidas mediante el estudio de las inclusiones fluidas, de manera que las micas de las venas del $L G$ y las AB pertenecen a la mineralización precoz mientras que las temperaturas más bajas de las venas del GE corresponderían a una más tardía.

\section{Batolito de Cadalso-Casillas de Flores}

La moscovita de los diques aplíticos de Molino del Galo cristaliza en torno a los $650{ }^{\circ} \mathrm{C}$, mientras que la de las pegmatitas de La Canalita lo hace a $600{ }^{\circ} \mathrm{C}$ (Fig. $6.1 \mathrm{~g}$ ), temperatura que coincide con los valores estimados por London (2008) para la formación de pegmatitas graníticas de la familia LCT a la que pertenece el subtipo lepidolita, dentro de la clase de elementos raros. El resto de las micas analizadas en los diques pegmatíticos corresponden con una mica de Li que no es válida para estimar la temperatura de formación. 

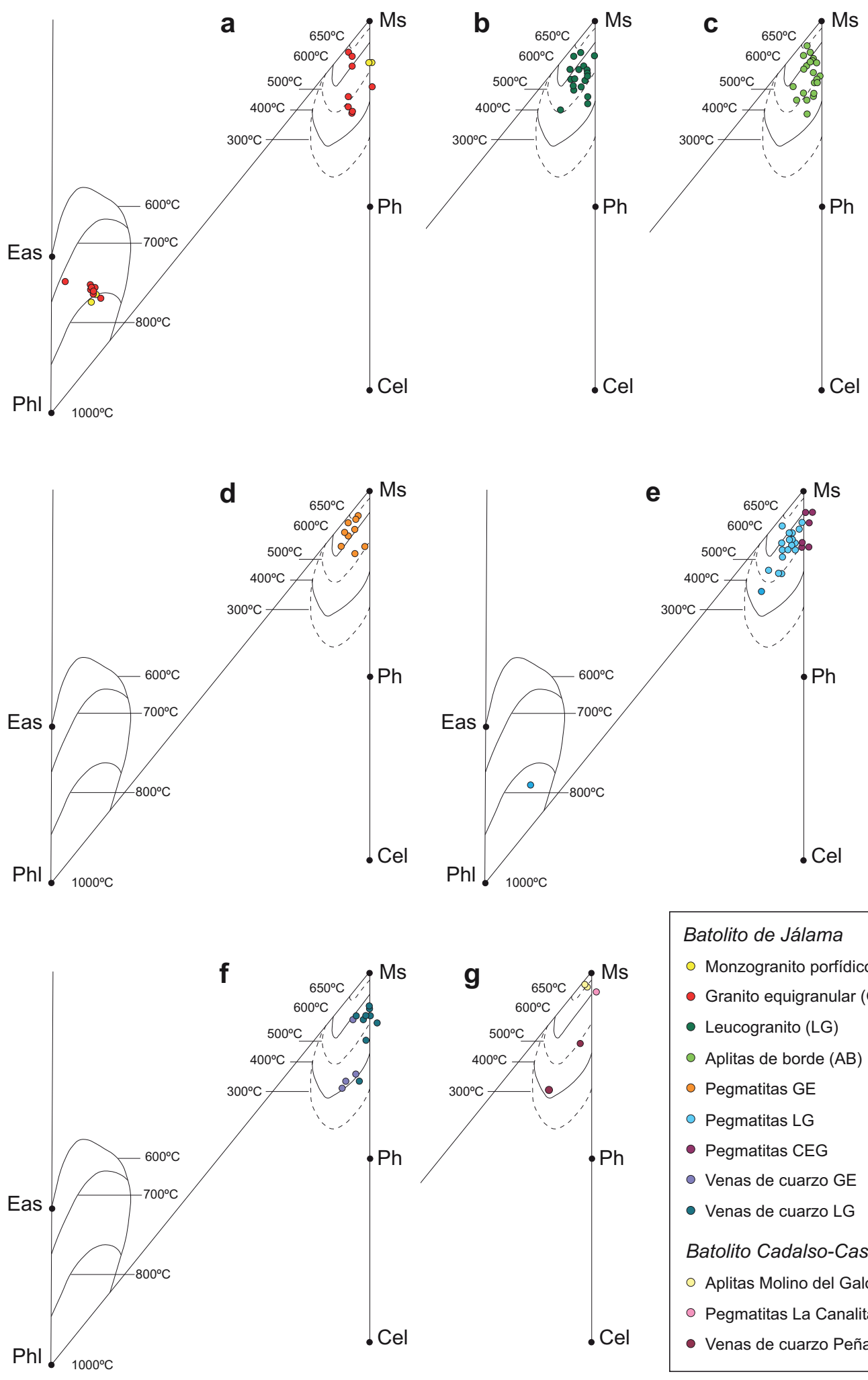

Batolito de Jálama

- Monzogranito porfídico (MP)

- Granito equigranular (GE)

- Leucogranito (LG)

- Aplitas de borde (AB)

- Pegmatitas GE

- Pegmatitas LG

- Pegmatitas CEG

- Venas de cuarzo GE

- Venas de cuarzo LG

Batolito Cadalso-Casillas

- Aplitas Molino del Galo

- Pegmatitas La Canalita

- Venas de cuarzo Peñaparda

Fig. 6.1. Representación de la composición de la moscovita y la biotita de las diferentes facies graníticas (a, b y c) y pegmatíticas ( $\mathbf{d}$, e y $\mathbf{g}$ ) y de las venas de cuarzo mineralizadas ( $\mathbf{f}$ y $\mathbf{g}$ ) de los batolitos de Jálama y de Cadalso-Casillas de Flores en el sistema $\mathrm{M}^{2+}-\mathrm{Al}$-Si que delimita los campos de su temperatura de formación (Monier y Robert, 1986). Eas: eastonita; Phl: flogopita; Ms: moscovita; Ph: fengita; Cel: celadonita. 
Por su parte, la moscovita de las venas de cuarzo mineralizadas que se encuentra asociada al granito de Peñaparda se proyecta entre los 400 y los $500{ }^{\circ} \mathrm{C}$ (Fig. 6.1g), coincidiendo con las venas mineralizadas del batolito de Jálama.

\subsubsection{Geotermómetro de la arsenopirita}

Se han analizado varios tipos de arsenopirita tanto en el batolito de Jálama como en las venas de cuarzo asociadas al batolito de Cadalso-Casillas de Flores, algunas de ellas utilizando el estándar Asp200 (Kretschmar y Scott, 1976) y otras empleando otro estándar (ver Capítulo 1, apartado de metodología), siendo puntos de interés los bordes en contacto con pirita y/o löllingita así como las zonas centrales de los cristales. Comparando los resultados obtenidos con ambos estándares se observó que eran idénticos, por lo que todos ellos se han empleado en los cálculos geotermométricos.

\section{Batolito de Jálama}

Asociada a las facies de la UE de dicho batolito se encuentran dos tipos de arsenopirita: la primera, con contenidos elevados en As (entre 37,06 y $38,50 \%$ at.), se encuentra como pequeñas inclusiones en los silicatos junto con otros sulfuros. La ausencia de löllingita en la asociación acota su cristalización en torno a los $620-680{ }^{\circ} \mathrm{C}$, con una $\mathrm{fS}_{2}$ entre $10^{-4,2}$ y $10^{-3,2}$ bar aproximadamente (Fig. 6.2a). Esta temperatura coincide con la de formación de estas facies graníticas (Ramírez y Grundvig, 2000), aunque los contenidos traza en Co y Ni de esta arsenopirita obligan a tomar estos resultados con reservas; el segundo tipo de arsenopirita se encuentra diseminada en las $A B$ y presenta contenidos intermedios en As entre 34,00 y $34,50 \%$ at., estando precedida de la cristalización de löllingita. Teniendo en cuenta la reacción del paso de löllingita a arsenopirita y la inexistencia de Bi nativo en esta asociación, su temperatura de formación oscila entre 440 y $480^{\circ} \mathrm{C}$, con una $\mathrm{fS}_{2}$ acotada entre $10^{-8,5}$ y $10^{-7,0}$ bar, por lo que se trata de una arsenopirita de origen hidrotermal (Fig. 6.2a).

En cuanto a la arsenopirita de las venas de cuarzo mineralizadas se han definido dos episodios de formación tanto en las venas encajadas en el GE como en las venas encajadas en el LG y las $A B$ con turmalina. No se ha identificado la presencia de löllingita, pero la arsenopirita se encuentra precedida en la secuencia de cristalización por pirrotita I y, posteriormente, hay una generación de pirita que la rodea. Además, ambas generaciones de arsenopirita están asociadas con sendas generaciones de esfalerita que contiene inclusiones tanto de pirrotita II como de calcopirita II. Así, en las venas del GE se han diferenciado: la Apy I, que contiene entre 35,00 y $36,25 \%$ at. As y cuya temperatura de formación oscila entre los 560 y los 610 ${ }^{\circ} \mathrm{C}$, con una $f \mathrm{~S}_{2}$ de entre $10^{-4,0}$ y $10^{-3,5}$ bar; y la Apy II, que contiene entre 33,00 y $34,75 \%$ at. As y que cristaliza entre los 490 y los $560^{\circ} \mathrm{C}$, con una $f S_{2}$ de entre $10^{-4,7}$ y $10^{-4,0}$ bar (Fig. 6.2a). Respecto a las dos generaciones de arsenopirita de las venas encajadas en el LG y las AB con turmalina, estas presentan menores contenidos en As. Así, la Apy I varía entre 32,50 y 34,00 $\%$ at. As $y$, teniendo en cuenta la reacción $\mathrm{Apy} \rightarrow \mathrm{Po}+\mathrm{L}$ como límite superior, su temperatura de formación oscila entre 460 y $530^{\circ} \mathrm{C}$ aproximadamente, con una fS ${ }_{2}$ acotada entre $10^{-5,2}$ y $10^{-4,2}$ bar. La Apy II, con entre 31,50 y 32,50 \% at. As, está controlada por la reacción de estabilidad $\mathrm{Po} \rightarrow \mathrm{Apy}+\mathrm{Py}$ que limita su temperatura de formación entre 400 y $460{ }^{\circ} \mathrm{C}$ y la $f \mathrm{~S}_{2}$ entre $10^{-7,0} \mathrm{y}$ $10^{-5,0}$ bar (Fig. 6.2b). 


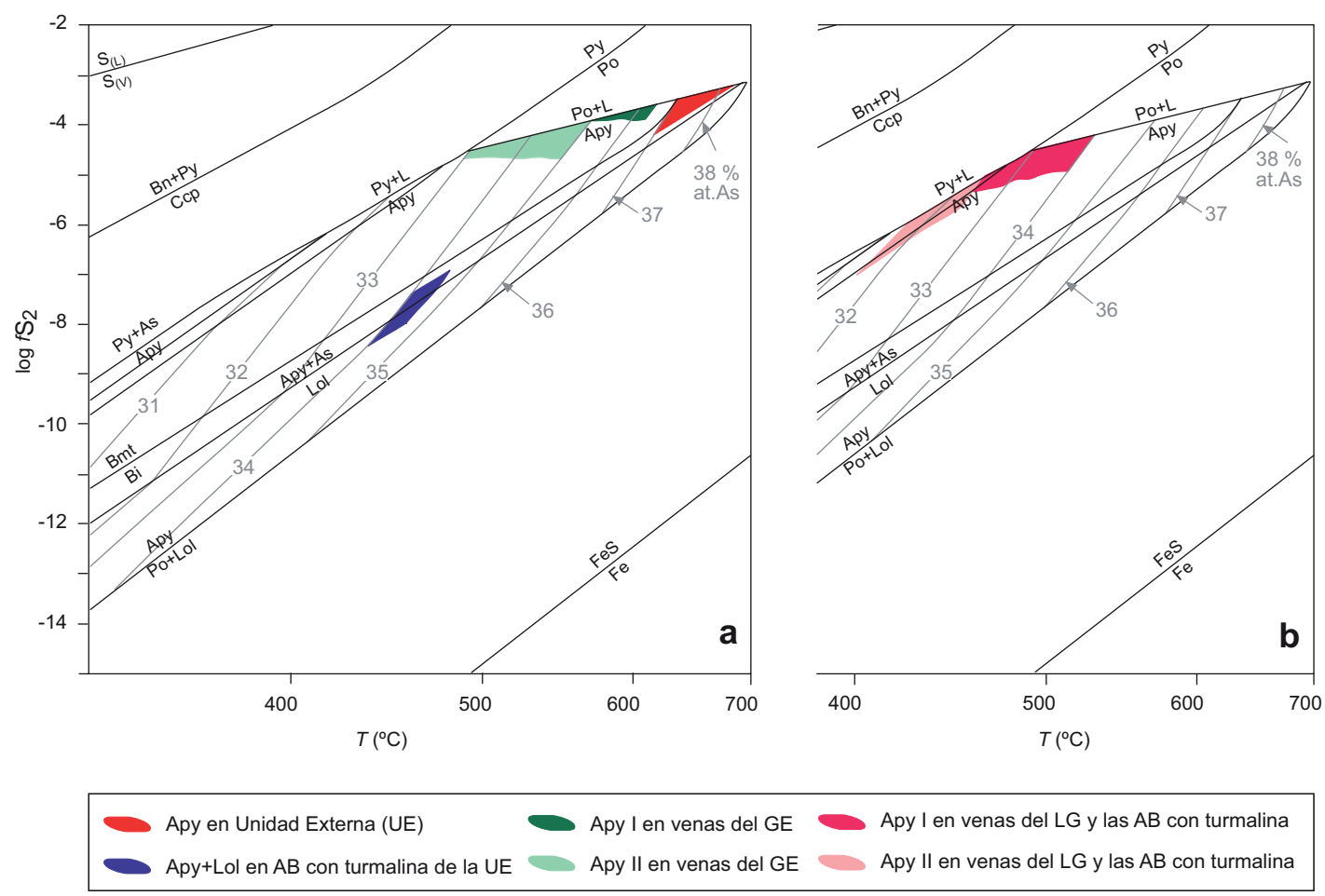

Fig. 6.2. Diagrama de $\log f S_{2}$ vs. $T$ para la arsenopirita (Kretschmar y Scott, 1976; Scott, 1983) en el que se ha proyectado la composición de los diferentes tipos de arsenopirita, en \% at. de As: a) de las facies del GE, las $A B$ con turmalina y las venas de cuarzo mineralizadas encajadas en el GE; y b) de las venas de cuarzo encajadas en el LG y las AB con turmalina del batolito de Jálama.

En resumen, la arsenopirita de las facies más evolucionadas del batolito de Jálama se forma entre $620-680^{\circ} \mathrm{C}$, con la excepción de la arsenopirita asociada a löllingita de las $A B$, que es de origen hidrotermal y cristaliza entre $440-480^{\circ} \mathrm{C}$. La arsenopirita de las venas de cuarzo encajadas en el GE cristaliza en torno a $560-610^{\circ} \mathrm{C}$ durante el primer evento mineralizador y entre $490-560^{\circ} \mathrm{C}$ durante el segundo, mientras que en las venas de cuarzo encajadas en el LG con turmalina lo hace entre $460-530^{\circ} \mathrm{C}$ y entre $400-460{ }^{\circ} \mathrm{C}$ respectivamente.

\section{Batolito de Cadalso-Casillas de Flores}

La arsenopirita asociada a las venas de cuarzo de El Cruce, encajadas en el granito de El Payo, presenta una zonación marcada en cuanto a sus contenidos en As y $\mathrm{S}$, como se describió en el Capítulo 4, con los núcleos ricos en As (33,00-33,65 \% at.) y los bordes empobrecidos (31,50-32,75\% at. As), por lo que no se puede emplear como geotermómetro. Por otro lado, la arsenopirita de las venas de cuarzo encajadas en el granito de La Ermita está generalmente asociada a esfalerita y galena y está precedida por la cristalización de pirrotita, al igual que ocurría en el batolito de Jálama. Sus contenidos en As oscilan entre 31,50 y 33,25\% at., encontrándose su campo de estabilidad entre las reacciones $\mathrm{Po} \rightarrow \mathrm{Apy}+\mathrm{Py}$ y $\mathrm{Apy} \rightarrow \mathrm{Py}+\mathrm{L}$ lo que indica una temperatura de formación en torno a los $400-500^{\circ} \mathrm{C}$ y una $f \mathrm{~S}_{2}$ que oscila ampliamente entre $10^{-7,0}$ y $10^{-4,5}$ bar (Fig. 6.3). Esta temperatura coincide con la obtenida en los gráficos de composición de la moscovita de Monier y Robert (1986). 


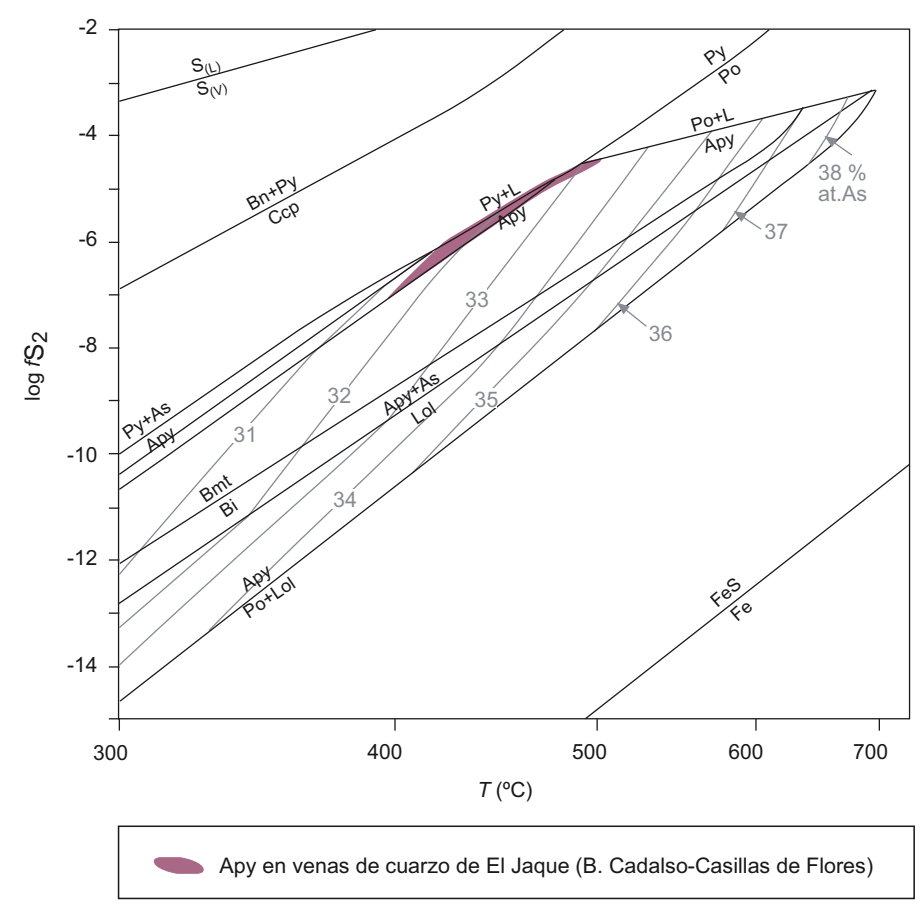

Fig. 6.3. Diagrama de $\log f S_{2} v s . T$ para la arsenopirita (Kretschmar y Scott, 1976; Scott, 1983) en el que se ha proyectado su composición, en \% at. de As, en las venas de cuarzo mineralizadas de El Jaque, encajadas en el granito de la Ermita del batolito de Cadalso-Casillas de Flores.

\subsubsection{Geotermometría de sulfosales}

Las sulfosales son unas especies minerales que tienden a cristalizar después de los sulfuros (Kostov y Minčeva-Stefanova, 1982) y que son muy sensibles a los cambios de $T$, Eh-pH, $\mathrm{fO}_{2}$ y $\mathrm{fS}_{2}$. Los minerales formados en el sistema $\mathrm{Pb}-\mathrm{Bi}-\mathrm{Ag}-(\mathrm{Cu})-\mathrm{S}$ son muy buenos indicadores de la $T \mathrm{y}$, en general, exhiben un progresivo enriquecimiento en $\mathrm{Pb}$ y/o Ag a medida que esta disminuye (Karup-Møller, 1977; Foord et al., 1988). Estos datos fueron comprobados con los estudios de la serie de la lilianita-gustavita y las sulfosales relacionadas (Ontoyev et al., 1982; Foord et al., 1988).

Chang et al. (1988) identificaron diferentes tipos de soluciones sólidas en el sistema $\mathrm{Ag}_{2} \mathrm{~S}-$ $\mathrm{Cu}_{2} \mathrm{~S}-\mathrm{PbS}-\mathrm{Bi}_{2} \mathrm{~S}_{3}$ a $500{ }^{\circ} \mathrm{C}$ de temperatura que representan las sustituciones acopladas entre $\mathrm{Ag}(\mathrm{Cu})+\mathrm{Bi}-2 \mathrm{~Pb}$ y la sustitución simple de $\mathrm{Ag}-\mathrm{Cu}$ y $\mathrm{Bi}-\mathrm{Pb}(\mathrm{Cu})$, además de la adición intersticial de $\mathrm{Cu}$ en la estructura. Una característica común a todas estas fases es la existencia de intercrecimientos lamelares complejos que resultan de la desestabilización de la solución sólida debido a que se produce una inmiscibilidad causada por el descenso de la temperatura (Van Hook, 1960; Craig, 1967; Foord et al., 1988; Foord y Shawe, 1989). Los datos de equilibrio de fases de Craig (1967), inclusiones fluidas e isótopos estables (Nedachi et al., 1973; Foord y Shawe, 1989) indican que estas fases minerales formadas a partir del sistema Ag-(Cu)-Pb-Bi-S cristalizan a temperaturas entre 200 y $400{ }^{\circ} \mathrm{C}$ y que la solución sólida es estable por encima de los $400^{\circ} \mathrm{C}$ y hasta los $500^{\circ} \mathrm{C}$. 
En el distrito de Navasfrías únicamente se encuentran sulfosales de Bi-Pb-Ag en las venas de cuarzo del batolito de Jálama, concretamente en aquellas que están encajadas en el LG y las $A B$ con turmalina. De ellas, las especies más abundantes son las que pertenecen a la solución sólida lilianita-gustavita, de la que se diferencian dos generaciones: la gustavita I (Gu I), con frecuentes lamelas de exsolución y que rellena las fracturas y los huecos en la arsenopirita II; y la gustavita II (Gu II), que no muestra dichas lamelas. De acuerdo con las observaciones de los autores previamente citados, las lamelas de exsolución que muestra la gustavita I (Gu I) indicarían que se formó por encima de los $400{ }^{\circ} \mathrm{C}$ y que fue sometida a un enfriamiento prolongado, mientras que la inexistencia de las mismas en la Gu II revelaría su cristalización por debajo de esta temperatura.

Igualmente, las texturas de reemplazamiento que se observan en los cristales de heyrovskyita por galena y otra fase mineral, que probablemente es cosalita (ver Capítulo 3), sugieren que la heyrovskyita es metaestable y que a cierta temperatura se produce su disociación en las dos fases minerales mencionadas (Klomínský et al., 1971). Este proceso estaría avalado, además, por los contenidos significativos de Bi y Ag que presenta la galena asociada. Godovikov (1972) estableció la temperatura de $400 \pm 25{ }^{\circ} \mathrm{C}$ por debajo de la cual se produce la disociación de heyrovskyita sintética en galena y cosalita, de modo que dicha temperatura se puede considerar la mínima para su formación.

Partiendo de la base de que estas sulfosales forman parte de la mineralización principal rica en $\mathrm{Bi}-\mathrm{Pb}-\mathrm{Ag}$ posterior a la cristalización de la arsenopirita I y II, cuyo límite inferior de temperatura se sitúa en torno a los $450{ }^{\circ} \mathrm{C}$ de media, se puede estimar una temperatura de formación para la gustavita I entre los $450-400^{\circ} \mathrm{C}$, seguida de las sulfosales de la familia de la pavonita a temperaturas ligeramente inferiores. Posteriormente, la gustavita II y el resto de sulfosales de la familia de la lilianita se formarían por debajo de esa temperatura y hasta los $300{ }^{\circ} \mathrm{C}$ aproximadamente.

Otro indicador de temperatura es la relación $\mathrm{Sb} / \mathrm{Bi}$ en las sulfosales. Rangos bajos de dicha relación indicarían un ambiente de formación a temperaturas relativamente elevadas y a una profundidad considerable (Foord y Shawe, 1989), lo que concuerda de nuevo con las condiciones de formación propuestas.

La desestabilización de estas sulfosales da lugar, además, a la pérdida de S y a la formación de Bi nativo. Teniendo en cuenta la temperatura del eutéctico Bi-bismutinita y la cristalización de los droplets de Bi nativo en la arsenopirita, la temperatura de la mayor parte de la mineralización tardía en las venas de cuarzo asociadas al batolito de Jálama estaría por debajo de los $271^{\circ} \mathrm{C}$.

\subsubsection{Geotermómetro de la clorita}

La composición química de las cloritas, o más exactamente el contenido en Alv en posición tetraédrica y la relación $\mathrm{Fe} /(\mathrm{Fe}+\mathrm{Mg})$ combinada con los minerales con los que se encuentra en equilibrio en la asociación paragenética puede aporta su temperatura de formación (Whalse y Solomon, 1981; Cathelineau y Nieva, 1985). Las limitaciones de estos modelos han llevado a la introducción de diversas correcciones para ampliar el rango de aplicación de 
este geotermómetro (Whalse, 1986; Kranidiotis y MacLean, 1987; Cathelineau, 1988; Jowet, 1991; Zang y Fyfe, 1995); sin embargo, a pesar de los numerosos intentos, ninguno de ellos ha resultado satisfactorio por completo (Caritat et al., 1993). Tornos (1989) puso de manifiesto que los modelos de Whalse y Solomon (1981) y Whalse (1986) son los que proporcionan los valores de temperatura más precisos, aunque siempre dentro del rango de aplicación de los $170-260^{\circ} \mathrm{C}$.

Para el cálculo de las temperaturas de formación de las cloritas del último evento mineralizador analizadas se ha empleado el programa CLORITA.EXE (Tornos, 1989). En las venas encajadas en el $L G$ y las $A B$ con turmalina del batolito de Jálama las temperaturas de formación calculadas a partir de los modelos de Whalse y Solomon (1981) y Whalse (1986) se encuentran dentro del rango de aplicación establecido o muy próximo a este, con una media de 242,0 y $273,9^{\circ} \mathrm{C}$ respectivamente (Tabla 6.2). Temperaturas similares, aunque ligeramente inferiores, se obtienen según Kranidiotis y MacLean (1987), mientras que empleando el resto de los modelos la temperatura se encuentra por encima de los $300^{\circ} \mathrm{C}$ por lo que no se tienen en consideración. Como se observa en la tabla 6.2, las temperaturas calculadas según Cathelineau (1988) y Jowet (1991) son prácticamente idénticas y están muy sobreestimadas.

Por su parte, la temperatura de formación calculada para la clorita presente en las venas de cuarzo encajadas en el granito de Peñaparda (batolito de Cadalso-Casillas de Flores) varía entre 205,4 (Whalse y Solomon, 1981 ) y $240,3^{\circ} \mathrm{C}$ (Whalse, 1986). Al igual que en el caso anterior, el resto de las temperaturas son superiores variando desde los $290,4^{\circ} \mathrm{C}$ según Cathelineau y Nieva (1985) hasta los $355,6^{\circ} \mathrm{C}$ tan elevados de Jowet (1991), por lo que tampoco se tienen en cuenta (Tabla 6.2).

TABLA 6.2. TEMPERATURAS DE FORMACIÓN DE LAS CLORITAS $\left({ }^{\circ} \mathrm{C}\right)^{*}$

\begin{tabular}{lcccccc}
\hline \hline Muestra & $\begin{array}{c}\text { Cathelineau \& } \\
\text { Nieva (1985) }\end{array}$ & $\begin{array}{c}\text { Cathelineau } \\
(1988)\end{array}$ & $\begin{array}{c}\text { Whalse \& } \\
\text { Solomon (1981) }\end{array}$ & $\begin{array}{c}\text { Whalse } \\
(1986)\end{array}$ & $\begin{array}{c}\text { Jowet } \\
(1991)\end{array}$ & $\begin{array}{c}\text { Kranidiotis \& } \\
\text { MacLean (1987) }\end{array}$ \\
\hline Venas en el batolito de Jálama & & & & & 21,3 \\
1693.1 & 289,3 & 350,2 & 246,2 & 321,2 & 356,3 & 243,6 \\
1693.2 & 329,6 & 411,4 & 248,6 & 344,4 & 424,5 & 213,7 \\
1693.3 & 282,9 & 340,6 & 239,2 & 230 & 331,4 & 226,9 \\
1693.4 & 304,2 & 372,7 & 234 & 200 & 371,3 & 226,4 \\
Media & 301,5 & 368,7 & 242,0 & 273,9 & 370,9 & 304,4 \\
\hline Venas en el batolito de Cadalso-Casillas de Flores & & & & 307,14 \\
1725.1 & 293,6 & 356,7 & 177,8 & 289,6 & 368,4 & 305,77 \\
1725.2 & 287,2 & 347 & 233 & 191 & 342,9 & 355,64 \\
\hline Media & 290,4 & 351,85 & 205,4 & 240,3 & 304 \\
\hline \hline
\end{tabular}

*Calculadas con el programa CLORITAS.EXE (Tornos, 1989).

\subsection{GEOBAROMETRÍA}

Las condiciones de $P$ de un depósito hidrotermal son más complicadas de estimar puesto que en estos sistemas la estabilidad de las diferentes asociaciones minerales es más sensible a los cambios de temperatura. Ramírez y Grundvig (2000) estimaron una presión de emplazamiento del batolito de Jálama de entre 2-3 kbar en función de las asociaciones minerales de las facies 
de metamorfismo de contacto. Valores más precisos de $P$ se pueden obtener a partir de la composición de la esfalerita.

\subsubsection{Geobarómetro de la esfalerita}

A pesar de que la composición química de la esfalerita se mantiene invariable a temperaturas comprendidas entre los 300 y los $600{ }^{\circ} \mathrm{C}$, el contenido en Fe de la misma depende de la $\mathrm{fS}_{2} \mathrm{y}$ de la $P$ (Scott y Barnes, 1971; Scott, 1974; Vaughan y Craig, 1997). Así, los valores de $P$ pueden obtenerse a partir del contenido en Fe de este sulfuro, siempre que no haya sufrido reacciones de retrogradación que hayan variado su composición, mientras que la $\mathrm{fS}_{2}$ se calcula a partir de la combinación del contenido en FeS de la esfalerita con los diferentes campos de estabilidad de los minerales asociados (Scott, 1983; Toulmin et al., 1991). En el estudio de la esfalerita se han analizado los bordes de los cristales en contacto con pirita, las zonas centrales de cristales desprovistos de inclusiones y aquellas zonas ricas en inclusiones de pirrotita y calcopirita para comprobar posibles pérdidas de Fe.

Como se apuntó en el Capítulo 3, la esfalerita presente en las venas de cuarzo mineralizadas del GE en el batolito de Jálama muestra contenidos variables entre 14,5 y $20,0 \% \mathrm{~mol}$ FeS que no llegan a interaccionar con el campo de estabilidad de la Apy I ni la Apy II, de manera que ambos minerales probablemente no estuvieran en equilibrio (Fig. 6.4a). Teniendo en cuenta

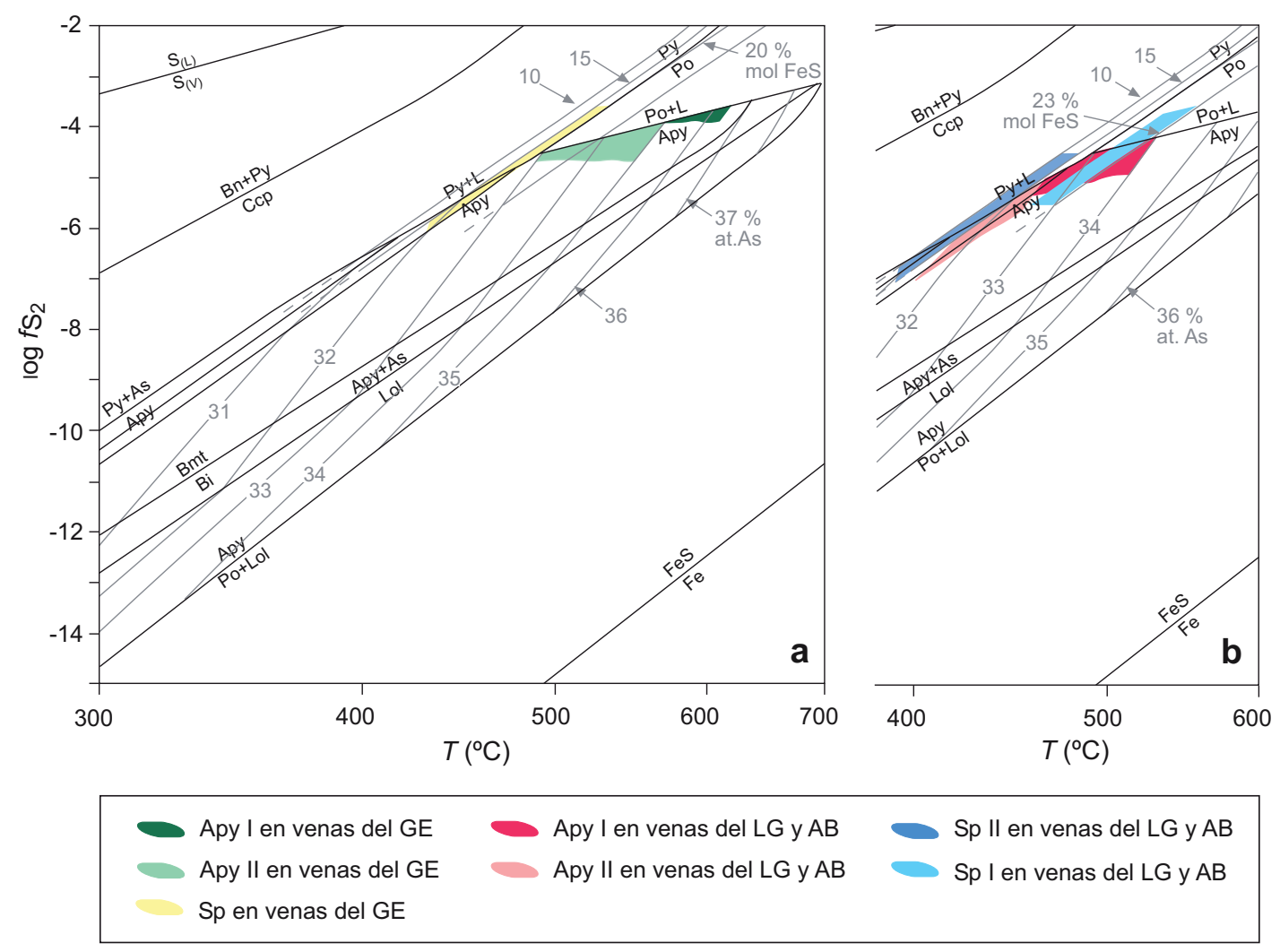

Fig. 6.4. Diagramas de log $\mathrm{fS}_{2}$ vs. $T$ (Kretschmar y Scott, 1976; Scott, 1983) en el que se han proyectado la composición de los diferentes tipos de arsenopirita, en \% at. de As y las isopletas de la composición de la esfalerita, en \% mol de FeS: a) en las venas de cuarzo mineralizadas encajadas en el GE; b) en el LG y las AB con turmalina del batolito de Jálama. 
que esta esfalerita contiene cerca de un $10 \%$ de inclusiones de pirrotita y que suele presentar un importante reemplazamiento por calcopirita II y pirrotita II, la composición de la esfalerita resultaría empobrecida en Fe al sustraer hasta el 20 \% del FeS de su composición original (Barton y Bethke, 1987; Kojima y Sugaki, 1987), cayendo bruscamente de un posible original de 30-35\% mol. FeS, por lo que no se puede emplear como geobarómetro. En las venas del LG y las AB con turmalina existen dos generaciones de esfalerita: la Sp I con contenidos en FeS que varían entre 21,0 y $22,8 \%$ mol que llegan a interaccionar con el campo de estabilidad de la Apy I, por lo que ambos minerales estarían en equilibrio (Fig. 6.4b). A pesar de ello, estos contenidos de FeS son superiores a los establecidos por Scott (1973) y Craig y Vaughan (1994) como indicadores de las condiciones de $P$, por lo que tampoco son útiles como geobarómetro; y, finalmente, la Sp II con contenidos que oscilan entre 10,3 y 15,5\% mol. FeS, que también interacciona con el campo de la Apy II (Fig. 6.4b). Sin embargo, ocurre algo similar a lo que se observa en el primer caso y es que el intenso reemplazamiento por calcopirita II y pirrotita II hacen disminuir fuertemente los contenidos en FeS en su composición y la $P$ obtenida es erróneamente alta, por lo que tampoco puede emplearse como geobarómetro (Hutchinson y Scott, 1980; Lusk et al., 1993).

Finalmente, la esfalerita de las venas de El Cruce y El Jaque, en el batolito de Cadalso-Casillas de Flores, presenta abundantes inclusiones de calcopirita II de reemplazamiento mostrando contenidos en FeS que varían entre 13,0 y 15,0 \% mol. Como se desprende del gráfico de la figura 6.5, en este caso también llega a interaccionar con el campo de estabilidad de la arsenopirita, por lo que ambas se encuentran en equilibrio. Sin embargo, al igual que ocurría

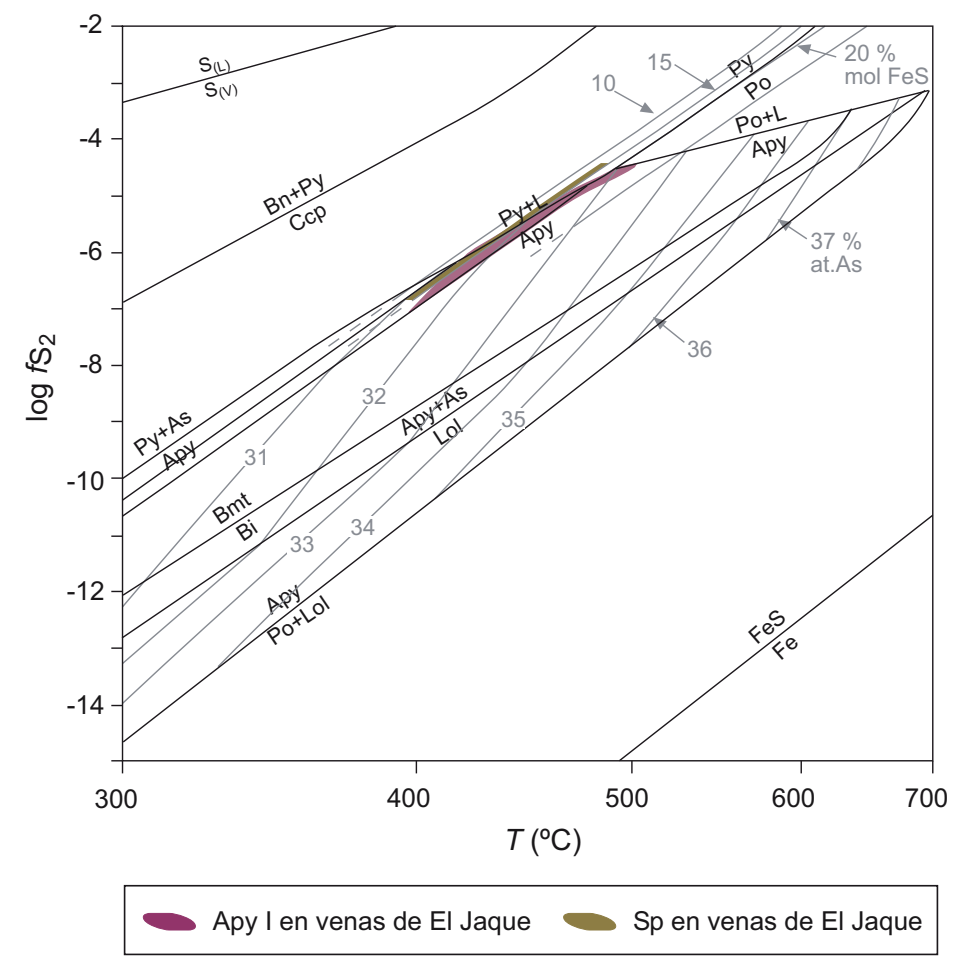

Fig. 6.5. Diagrama de log $f S_{2} v s . T$ (Kretschmar y Scott, 1976; Scott, 1983) con la composición de la arsenopirita, en $\%$ at. de As, y las isopletas de la composición de la esfalerita, en \% mol de FeS, en las venas de cuarzo mineralizadas de El Jaque, encajadas en el granito de la Ermita del batolito de Cadalso-Casillas de Flores. 
en las venas del batolito de Jálama, el reemplazamiento por calcopirita II ha sustraído importantes cantidades de Fe de la esfalerita quedando esta empobrecida en FeS, de modo que los valores de $P$ estimados a partir de ella serían también demasiado elevados y no se puede emplear como geobarómetro.

\subsection{DETERMINACIÓN DE LA fS}

La fugacidad del azufre $\left(f S_{2}\right.$ ) se puede cuantificar con los diagramas de estabilidad $f S_{2}-T$ del geotermómetro de la arsenopirita combinando las diferentes reacciones de estabilidad de los minerales que se encuentran en la secuencia paragenética en cada evento de depósito.

En las facies más evolucionadas del batolito de Jálama es frecuente que los feldespatos tengan inclusiones de arsenopirita, calcopirita o pirita, lo que sugiere que el fundido estaba saturado en azufre durante la cristalización de los silicatos (Ohomoto, 1986), traduciéndose en una elevada $f S_{2}$ entre $10^{-4.2}$ y $10^{-3.2}$ bar (1 en Fig. 6.6).

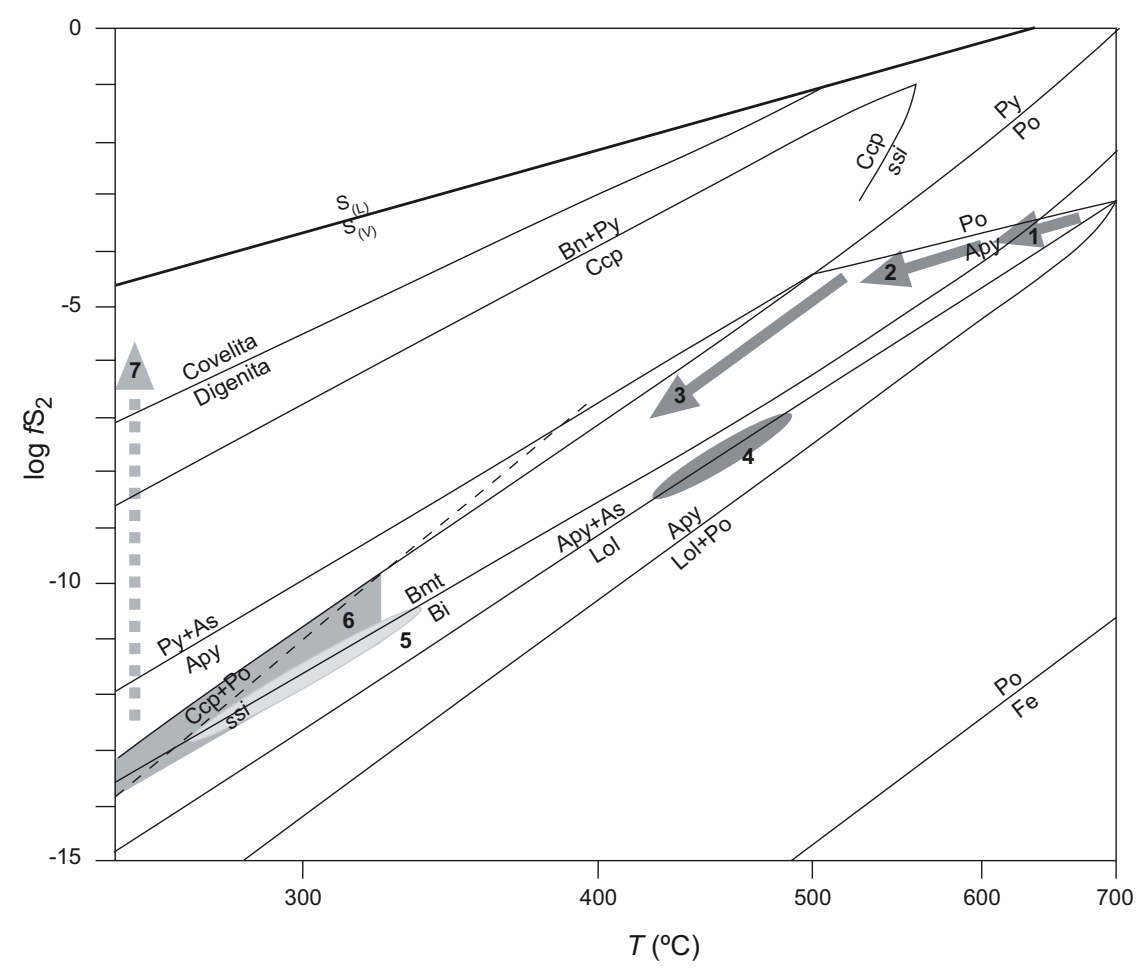

Fig. 6.6. Diagrama de log $f_{2}$ vs. $T$ de Barton y Skinner (1979) con la trayectoria de precipitación de los sulfuros en las mineralizaciones del batolito de Jálama. 1: en la UE; 2: mineralización principal en las venas de cuarzo del GE; 3: mineralización principal en las venas de cuarzo del LG y las AB con turmalina; 4: löllingita en las $A B$ con turmalina; 5: mineralización tardía rica en $\mathrm{Bi}$; 6: reemplazamiento de esfalerita por calcopirita II y pirrotita II; y 7: alteración supergénica de la calcopirita a covelita.

En las venas de cuarzo mineralizadas la asociación Apy-Sp-Py comienza a cristalizar bajo unas condiciones de $T$ y de $f S_{2}$ elevadas entre $10^{-4,7}$ y $10^{-3,5}$ bar en las venas de cuarzo encajadas en el GE (2) y continúa en las que intruyen en el LG y las AB con turmalina (3) hasta los 450 ${ }^{\circ} \mathrm{C}$ aproximadamente y una $f S_{2}$ que ha disminuido a $10^{-7,0}$ bar. Localmente, la arsenopirita 
formada a partir de la desestabilización de löllingita en las $A B$, dentro del mismo rango de temperaturas, muestra un descenso de la $f \mathrm{~S}_{2}$ hasta $10^{-8,5}$ bar (4). Posteriormente, a temperaturas inferiores a $400{ }^{\circ} \mathrm{C}$ tiene lugar el depósito de una mineralización rica en $\mathrm{Bi}$, en la que destacan abundantes sulfosales de $\mathrm{Bi}-\mathrm{Pb}$-Ag seguidas del Bi nativo y la bismutinita (5) y el reemplazamiento de la esfalerita por calcopirita II y pirrotita II que se forman a partir de la desestabilización de una solución-sólida intermedia (ssi), lo que acota la temperatura máxima a la que se produce la alteración hidrotermal de la esfalerita a $325^{\circ} \mathrm{C}$ y una $f \mathrm{~S}_{2}$ de $10^{-10,0}$ bar (6) que sigue disminuyendo a medida que baja la temperatura. Esta temperatura es coherente con la hipótesis de Yund y Kullerud (1966), que proponen una temperatura de formación inferior a $334 \pm 17^{\circ} \mathrm{C}$ para las inclusiones de la esfalerita. Finalmente, la presencia de covelita reemplazando a la calcopirita supone un proceso de sulfidación durante las últimas etapas de alteración del depósito, probablemente en condiciones supergénicas (7) (Fig. 6.6).

Respecto a las venas de cuarzo mineralizadas del batolito de Cadalso-Casillas de Flores, la evolución es muy similar, partiendo de la cristalización de arsenopirita y esfalerita seguidas de pirita a temperaturas entre 400 y $500^{\circ} \mathrm{C}$ bajo condiciones de $f S_{2}$ intermedias, que varían entre $10^{-7,0}$ y $10^{-4,5}$ bar (1 en la Fig. 6.7). La precipitación de calcopirita II a partir de una solución sólida intermedia (ssi) reemplazando a la esfalerita y rellenando los huecos de la pirita junto con galena (2) marca el depósito de la mineralización tardía a una temperatura que oscila entre los 325 y los $400^{\circ} \mathrm{C}$. Teniendo en cuenta la inexistencia de pirrotita junto a la calcopirita

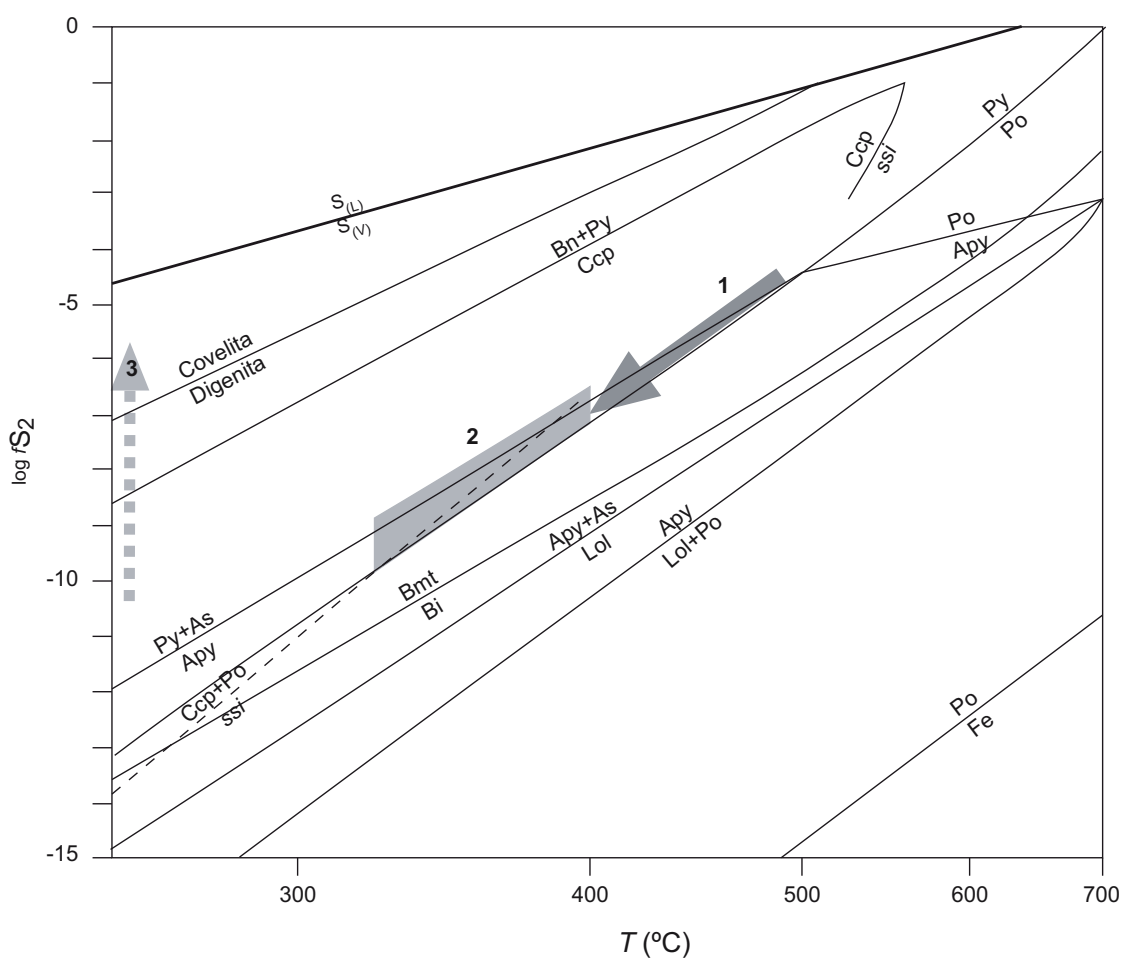

Fig. 6.7. Diagrama de $\log \mathrm{fS}_{2}$ vs. $T$ de Barton y Skinner (1979) con la trayectoria de precipitación de los sulfuros en las mineralizaiones del batolito de Cadalso-Casillas de Flores. 1: mineralización principal; 2: reemplazamiento tardío de la esfalerita por calcopirita II; y 3: alteración supergénica de la calcopirita a covelita. 
de reemplazamiento, las condiciones de $f \mathrm{~S}_{2}$ son mayores que las estimadas para las venas del batolito de Jálama, puesto que nos encontramos a la izquierda del tampón Po-Py, lo que indica variaciones de la $f_{2}$ de entre $10^{-10,0}$ y $10^{-7,0}$ bar. Finalmente y al igual que en las venas del batolito de Jálama, la presencia de covelita reemplazando a la calcopirita indica un aumento de la $f_{2}$ durante la etapa de alteración supergénica (3).

\subsection{CONDICIONES REDOX}

En el batolito de Jálama únicamente ha sido posible calcular las condiciones de $\mathrm{fO}_{2}$ en las facies graníticas que contienen biotita a partir de la relación $\mathrm{Fe} /(\mathrm{Fe}+\mathrm{Mg})$. En las venas de cuarzo mineralizadas se ha estimado la $\mathrm{fO}_{2}$ en la mineralización precoz a partir de la relación $\mathrm{CO}_{2} / \mathrm{CH}_{4}$ de las inclusiones fluidas, mientras que en los últimos estadíos de depósito se ha hecho a partir de la oxidación del Bi nativo a bismita.
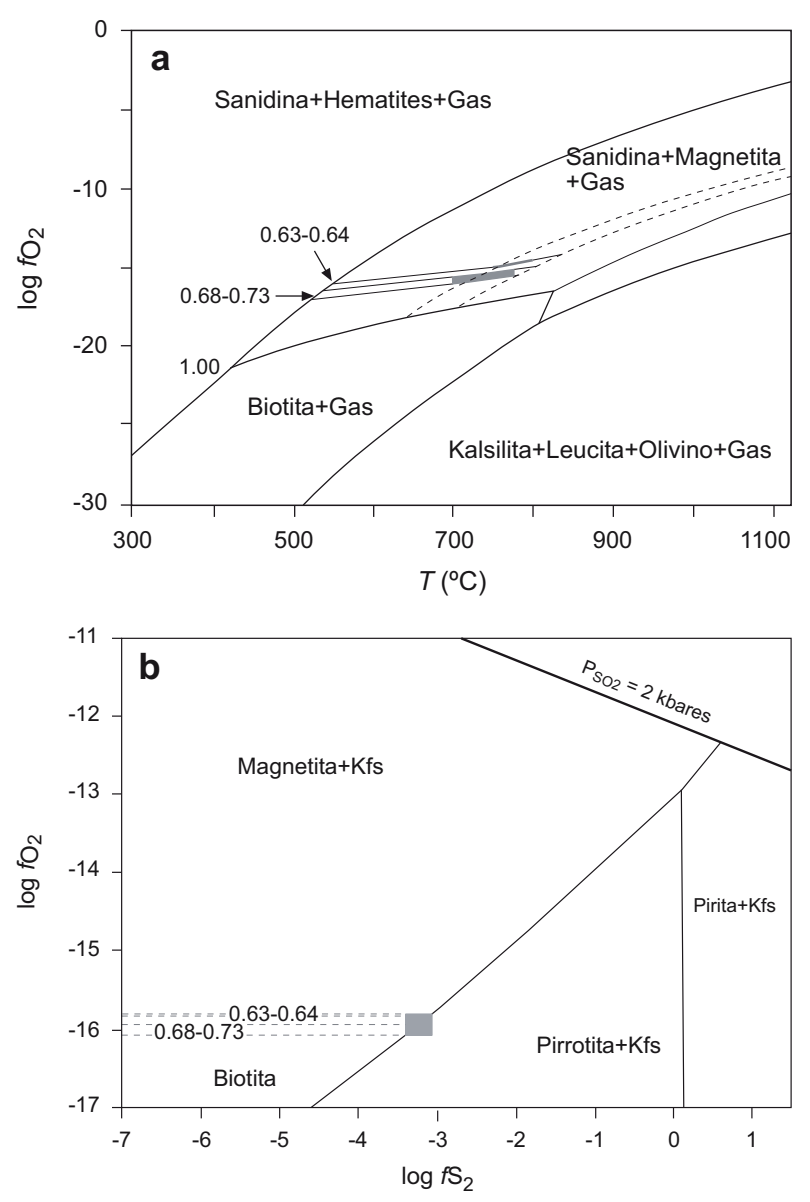

Fig. 6.8. a) Diagramas de $\log \mathrm{fO}_{2}$ vs. $T$ de Wones y Eugster (1965) a 2 kbar; y b) de $\log f \mathrm{O}_{2}$ vs. $\log f \mathrm{~S}_{2}$, a $700{ }^{\circ} \mathrm{C}$ y 2 kbar, en los que se ha proyectado la relación $\mathrm{Fe} /(\mathrm{Fe}+\mathrm{Mg})$ de las biotitas analizadas en las facies de la UE del batolito de Jálama.
La composición de la biotita en las facies más externas del batolito de Jálama ha sido utilizada para obtener las condiciones de $\mathrm{fO}_{2}$ durante la cristalización del fundido, proyectando la relación $\mathrm{Fe} /(\mathrm{Fe}+\mathrm{Mg})$ en el diagrama $T$-log $f_{2}$ de Wones y Eugster (1965) (Fig. 6.8a). Esta relación varía desde 0,63-0,64 en el monzogranito porfídico (MP) hasta 0,68-0,73 en la facies del granito equigranular (GE). Proyectando estos valores en el diagrama de la figura 6.8a a la temperatura de formación de estas facies, en torno a 800-750 ${ }^{\circ} \mathrm{C}$ para el MP y entre $775-700^{\circ} \mathrm{C}$ para el GE (Ramírez y Grundvig, 2000), se puede obtener una aproximación del valor de la $\mathrm{fO}_{2}$. Se observa que las isopletas de la relación $\mathrm{Fe} /(\mathrm{Fe}+\mathrm{Mg})$ se mantienen casi invariables para las temperaturas de formación de estas facies, de manera que la $\mathrm{fO}_{2}$ estaba en torno a $10^{-15}$ bar durante la cristalización del MP, disminuyendo ligeramente hasta $10^{-16}$ bar durante la formación del GE.

Teniendo en cuenta el cálculo de la $\mathrm{fS}_{2}$ que se obtuvo mediante la composición atómica del As en la 
arsenopirita de las facies graníticas en la UE del batolito de Jálama se puede comprobar la validez de los valores de la $\mathrm{fO}_{2}$ en el diagrama de la figura 6.8b. En este diagrama, en el que se ha tomado una temperatura media de $700^{\circ} \mathrm{C}$ y 2 kbar de $P$, se pueden proyectar las isopletas de la relación $\mathrm{Fe} /(\mathrm{Fe}+\mathrm{Mg})$ de la biotita. Asumiendo la estabilidad de la biotita con feldespato potásico y pirrotita en el $\mathrm{GE}$, los valores de $\mathrm{fO}_{2}$ que se obtienen se encuentran en torno a $10^{-}$ 16,0 bar, lo que coincide con los valores de la $\mathrm{fS}_{2}$ calculados, que varían entre $10^{-4,0}$ y $10^{-3,2}$ bar.

Comparando estos valores de $\mathrm{fO}_{2}$ de las facies graníticas en el diagrama de $T$-log $\mathrm{fO}_{2}$ de Burnham y Ohmoto (1980), se observa que son típicos de los magmas de tipo S (Fig. 6.9). A partir de la relación $\mathrm{CO}_{2} / \mathrm{CH}_{4}$ de las inclusiones fluidas del cuarzo asociado a la mineralización precoz de las venas (entre 0,4 y 44,5 ), se deduce que el sistema hidrotermal se encontraba en ese momento en la transición $\mathrm{CH}_{4} \rightarrow \mathrm{CO}_{2}$, como es típico de los depósitos de $\mathrm{Sn}-\mathrm{W}$ (Dubessy et al., 1987), de manera que se pueden estimar unas condiciones de $f \mathrm{O}_{2}$ de entre $10^{-23}$ y $10^{-24}$ bar para una temperatura media de $500^{\circ} \mathrm{C}$ (Fig. 6.9). Estos valores se encuentran entre los tampones cuarzo-fayalita-magnetita (QFM) y Ni-NiO (NNO), dentro de los valores estimados para este tipo de depósitos (Dubessy et al., 1987; Wood y Samson, 2000).

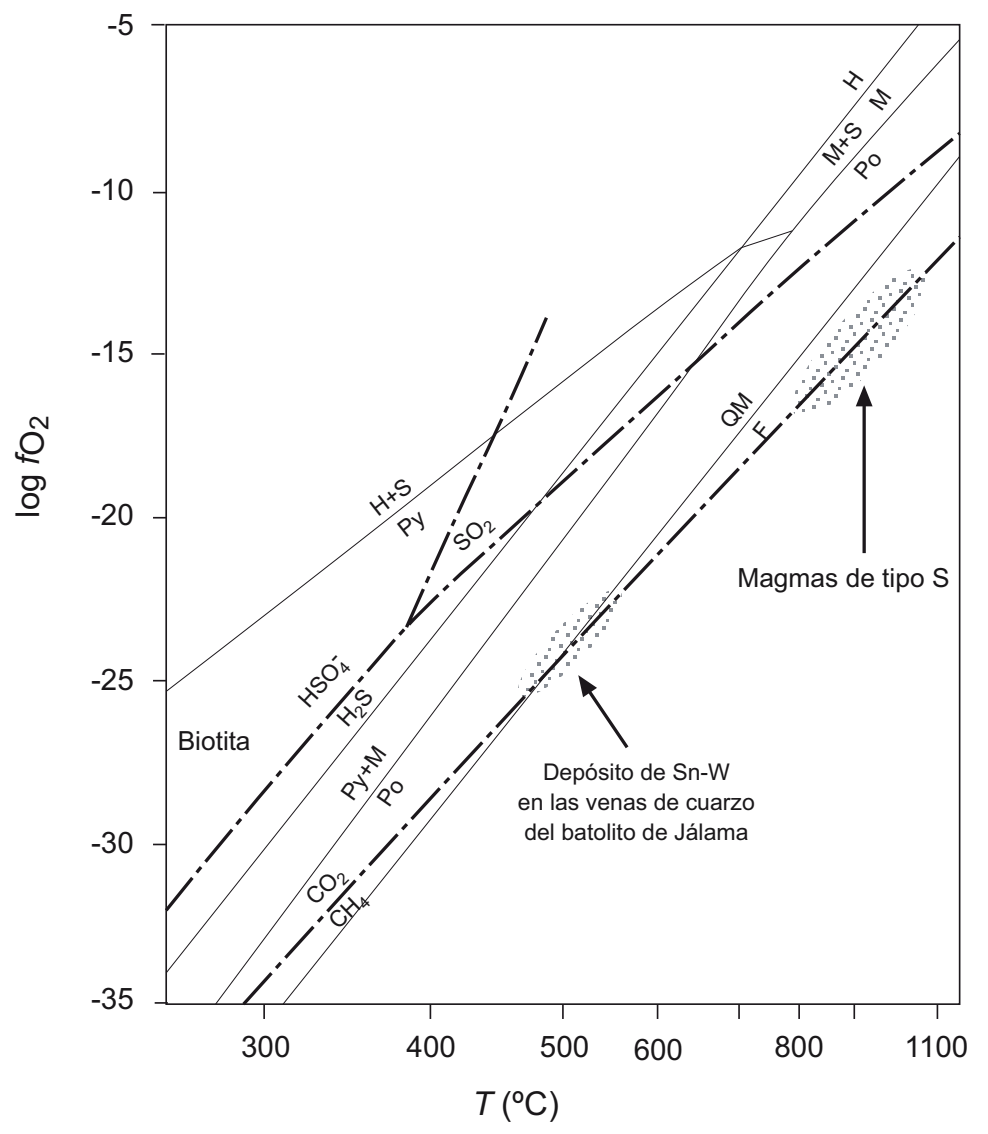

Fig. 6.9. Diagrama de $\log \mathrm{fO}_{2}$ vs. $T$ de Burnham y Ohmoto (1980) en el que se ilustran las condiciones redox de los magmas de tipo $S$ y las condiciones estimadas de depósito para la mineralización de las venas de cuarzo del batolito de Jálama. 
Durante las etapas finales de la mineralización se pudieron alcanzar las condiciones adecuadas para la formación de bismita, que es atribuida habitualmente a un proceso de alteración de minerales de $\mathrm{Bi}$. El bismuto es susceptible a los cambios químicos, lo que significa que a temperaturas inferiores a su punto eutéctico, por debajo de $271{ }^{\circ} \mathrm{C}$, la $f \mathrm{O}_{2}$ habría alcanzado valores de hasta $10^{-25,0}$ bar al menos localmente, dado que este es el valor en el que se inicia la oxidación de $\mathrm{Bi}$ en $\mathrm{Bi}_{2} \mathrm{O}_{3}$ (Afifi et al., 1988; Simon y Essene, 1996).

\subsection{CONDICIONES DE pH}

Las estimaciones de $\mathrm{pH}$ en depósitos ricos en $\mathrm{Sn}$ y $\mathrm{W}$ se basan frecuentemente en el equilibrio entre fases minerales, comúnmente entre moscovita y feldespato potásico, que indican unas condiciones de $\mathrm{pH}$ del fluido que varían de neutro a moderadamente ácido. En el caso de los depósitos de $\mathrm{W}$, las estimaciones de pH indican valores que oscilan entre 4 y 6 (Wood y Samson, 2000 y referencias en el interior), mientras que la presencia de casiterita indica que el pH fue superior a 5 en el momento de depósito (Jackson y Helgeson, 1985) ya que la precipitación de casiterita requiere de un proceso de neutralización de la acidez del fluido, entre otros factores (Heinrich, 1990). 
CAPITULOF

Evolución

magmático-hidrotermal 



\section{CAPÍTULO 7. EVOLUCIÓN MAGMÁTICO-HIDROTERMAL}

Algunas de las asociaciones minerales descritas en los yacimientos e indicios mineros del distrito de Navasfrías pueden aportar mucha información, en cuanto a la evolución química del sistema magmático-hidrotermal mineralizado de los batolitos de Jálama y Cadalso-Casillas de Flores. Entre estas asociaciones destacan la de los fosfatos de Fe-Mn que se encuentran en todos los tipos de mineralizaciones del distrito y que incorporan a su composición elementos de origen magmático, hidrotermal y/o metamórfico; las turmalinas pertenecientes a la serie chorlo-dravita de las facies graníticas, aplíticas y pegmatíticas; los óxidos de $\mathrm{Nb}$, Ta y Ti de los diques pegmatíticos más evolucionados y de las venas de cuarzo mineralizadas; y las sulfosales de $\mathrm{Bi}-\mathrm{Pb}-\mathrm{Ag}$ que constituyen la fase tardía de la mineralización en las venas de cuarzo. La mayoría de estas fases minerales contienen importantes cantidades de $\mathrm{F}, \mathrm{Cl}, \mathrm{B}$ y $\mathrm{P}$ que van a condicionar fuertemente los procesos de cristalización fraccionada, la evolución de la fase fluida y la alteración hidrotermal asociada.

\subsection{LOS FOSFATOS DE Fe-Mn}

La gran variabilidad composicional y textural de los fosfatos estudiados en las facies graníticas y pegmatíticas así como en las venas de cuarzo mineralizadas asociadas al batolito de Jálama indica que el $\mathrm{P}$ ha sido un elemento importante en la evolución magmática e hidrotermal de todo el borde norte del batolito (Llorens y Moro, en prensa).

El apatito está ampliamente distribuido en las facies graníticas, donde los bajos contenidos en CaO y la baja concentración de REE (Ramírez y Menéndez, 1999) sugieren que la incorporación del $\mathrm{P}$ al fundido residual se debe a la elevada solubilidad del apatito en el fundido original (London et al., 1990; Pichavant et al., 1992; Bea et al., 1992; Wolf y London, 1994). Así, el $\mathrm{P}$ se convertiría en un elemento incompatible que aumenta su concentración con el fraccionamiento, de modo que en los fundidos residuales que forman los diques pegmatíticos incrementa su actividad lo suficiente como para desplazar el equilibrio de los aluminosilicatos de litio en favor de la cristalización de ambligonita-montebrasita + cuarzo (London y Burt, 1982), o del granate en favor de los fosfatos de Fe-Mn. En las venas de cuarzo que contienen triplita, apatito y otros fosfatos de Fe y $\mathrm{Mn}$, el $\mathrm{P}$ es aportado por la alteración sericítica y argilítica de los feldespatos (London et al., 1999).

\subsubsection{Fraccionamiento del Fe y el $\mathrm{Mn}$}

El grado de fraccionamiento del Fe y el $\mathrm{Mn}$ es un factor determinante de la amplia variabilidad composicional de los fosfatos, en cuanto que la relación $\mathrm{Fe} /(\mathrm{Fe}+\mathrm{Mn})$ de los más precoces pone de manifiesto su evolución en el fundido y/o fluidos responsables de la formación de las rocas encajantes donde se encuentran. Así, los términos más enriquecidos en Fe de la serie triplita-zwieselita se encuentran en las pegmatitas intragraníticas encajadas en el GE (asociación III), donde presentan una relación $\mathrm{Fe} /(\mathrm{Fe}+\mathrm{Mn}$ ) de 0,67. Por su parte, el término de esta serie más rico en $\mathrm{Mn}$, la triplita, es muy frecuente en las venas de cuarzo mineralizadas que se emplazan en el LG y las AB con turmalina, donde es reemplazada por la bermanita 
y la fosfosiderita (asociación VII) y presenta una relación Fe/(Fe+Mn) entre 0,18 y 0,19, o bien por el fluorapatito y la isokita (asociación VIII), en cuyo caso esta relación varía entre 0,30 y 0,43. En ambos casos estos valores son visiblemente menores que los de la zwieselita de las pegmatitas intragraníticas, observándose un enriquecimiento en Mn (Fig. 7.1), lo que indicaría que los fluidos causantes de la formación de estos fosfatos en las venas de cuarzo son más evolucionados (Llorens y Moro, en prensa). Además, la tendencia al enriquecimiento no solo en Mn sino también en Mg que supone la cristalización de la triplita de la asociación VIII (Fig. 7.1) sugiere la interacción del fluido hidrotermal mineralizador de origen primario con otro externo enriquecido en $\mathrm{Mg}$, lo que es coherente con el estudio de las inclusiones fluidas.

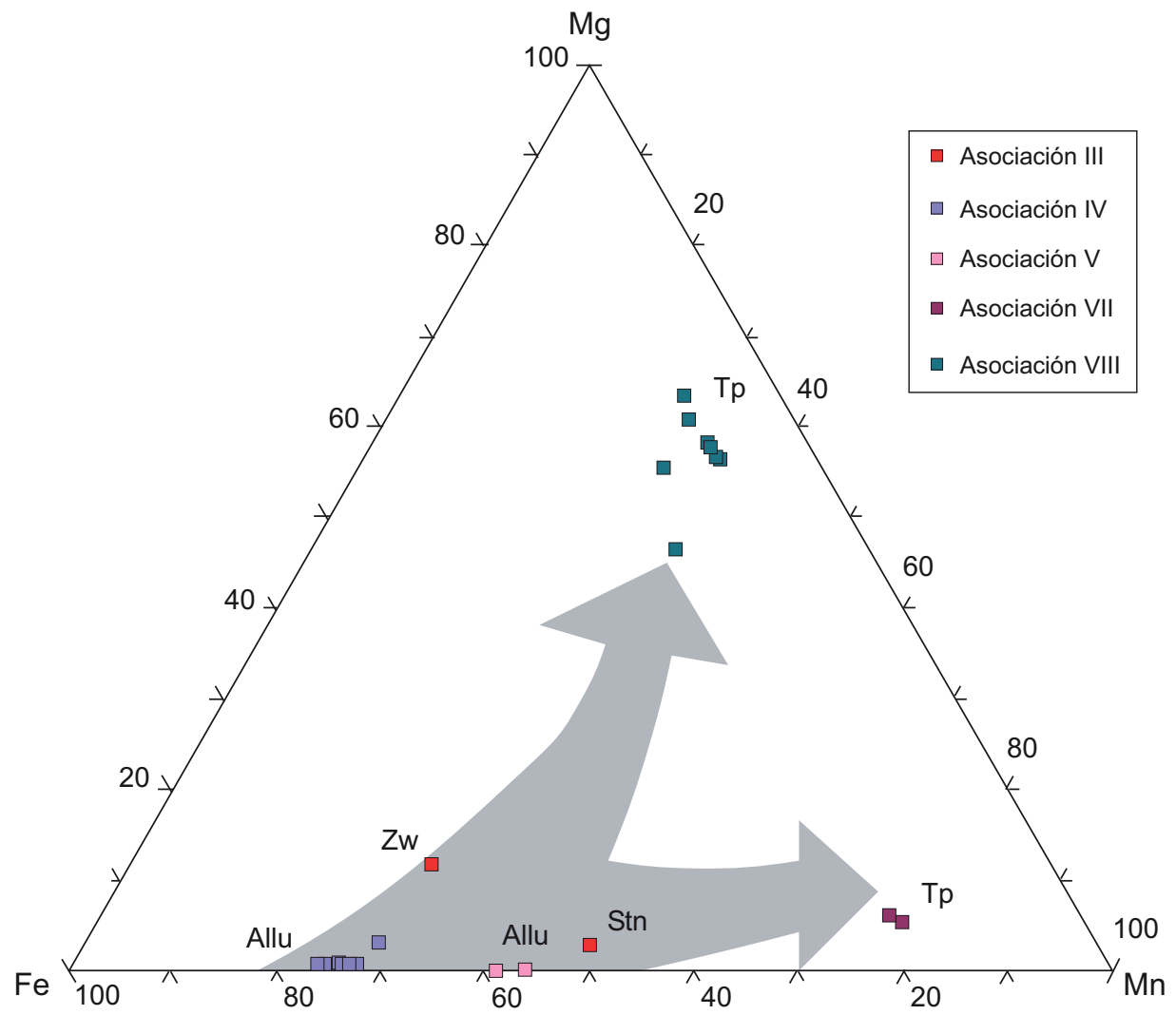

Fig. 7.1. Diagrama triangular de Fe total, $M g$ y $M n$ (en apfu) con la representación de la composición química de los fosfatos más tempranos analizados en las asociaciones fosfatadas definidas en las distintas mineralizaciones del batolito de Jálama. Obsérvense dos tendencias de enriquecimiento desde la cristalización de los diques pegmatíticos intragraníticos hasta las venas de cuarzo; una en Mn y otra en Mn y $\mathrm{Mg}$.

Lo mismo ocurre con la alluaudita, que se encuentra en las pegmatitas encajadas en el LG y las $A B$ con turmalina (asociación IV) con una relación $\mathrm{Fe} /(\mathrm{Fe}+\mathrm{Mn}$ ) de 0,71-0,76, mientras que en las pegmatitas de Cruz del Rayo (asociación V), encajadas en rocas metamórficas, el mismo mineral está más enriquecido en $\mathrm{Mn}$ y por tanto su relación $\mathrm{Fe} /(\mathrm{Fe}+\mathrm{Mn})$ varía entre 0,56 y 0,58, lo que indica que los fundidos a partir de los cuales cristalizaron estas últimas eran más evolucionados (Fig. 7.1). El hecho de que en las pegmatitas intragraníticas la alluaudita aparezca formando agregados granulares de pequeño tamaño sugiere un carácter 
secundario (Huvelin et al., 1972; Keller y Von Knorring, 1989; Roda et al., 1996; Hatert et al., 2006). Además, según Hatert et al. (2006) la alluaudita rica en Mn cristaliza a menor temperatura que la rica en Fe, lo que de nuevo apoya la hipótesis de que este mineral es de origen secundario, probablemente consecuencia de un metasomatismo sódico que afecta a los fosfatos primarios (Moore, 1971) y al feldespato potásico.

\subsubsection{Texturas de reemplazamiento}

Respecto a la variabilidad textural, cabe destacar la importancia de las texturas de reemplazamiento en la secuencia de alteración de las asociaciones fosfatadas, influenciadas notablemente por la interacción de fluidos metamórficos y/o meteóricos en el sistema magmático-hidrotermal (Llorens y Moro, en prensa). Los fosfatos de la serie ambligonitamontebrasita y childrenita-eosforita que se encuentran en las facies del LG y las $A B$ con turmalina de la UE $\mathrm{y}$, especialmente, en las zonas internas de los diques pegmatíticos encajados en ellas, parecen ser el resultado de reemplazamientos hidrotermales de los feldespatos alcalinos por soluciones ricas en $\mathrm{P}$, de los cuales toman el Al necesario para su precipitación (Fransolet, 1980; Fransolet et al., 1986) (Fig. 7.2). Lo mismo ocurre con la goyazita, producto de la alteración de las plagioclasas del LG con turmalina, que se encuentra de manera muy accesoria en la asociación II (Fig. 7.2). El Sr se comporta como un elemento compatible durante la diferenciación magmática de la UE del batolito de Jálama, de modo que sus contenidos disminuyen desde 121 ppm en el MP hasta 19 ppm en el LG con turmalina (Ramírez y Grundvig, 2000). Sin embargo, durante la albitización este elemento puede ser redistribuido (Charoy et al., 2003) y la posterior moscovitización de las plagioclasas proporcionaría el Sr necesario para la formación de la goyazita.

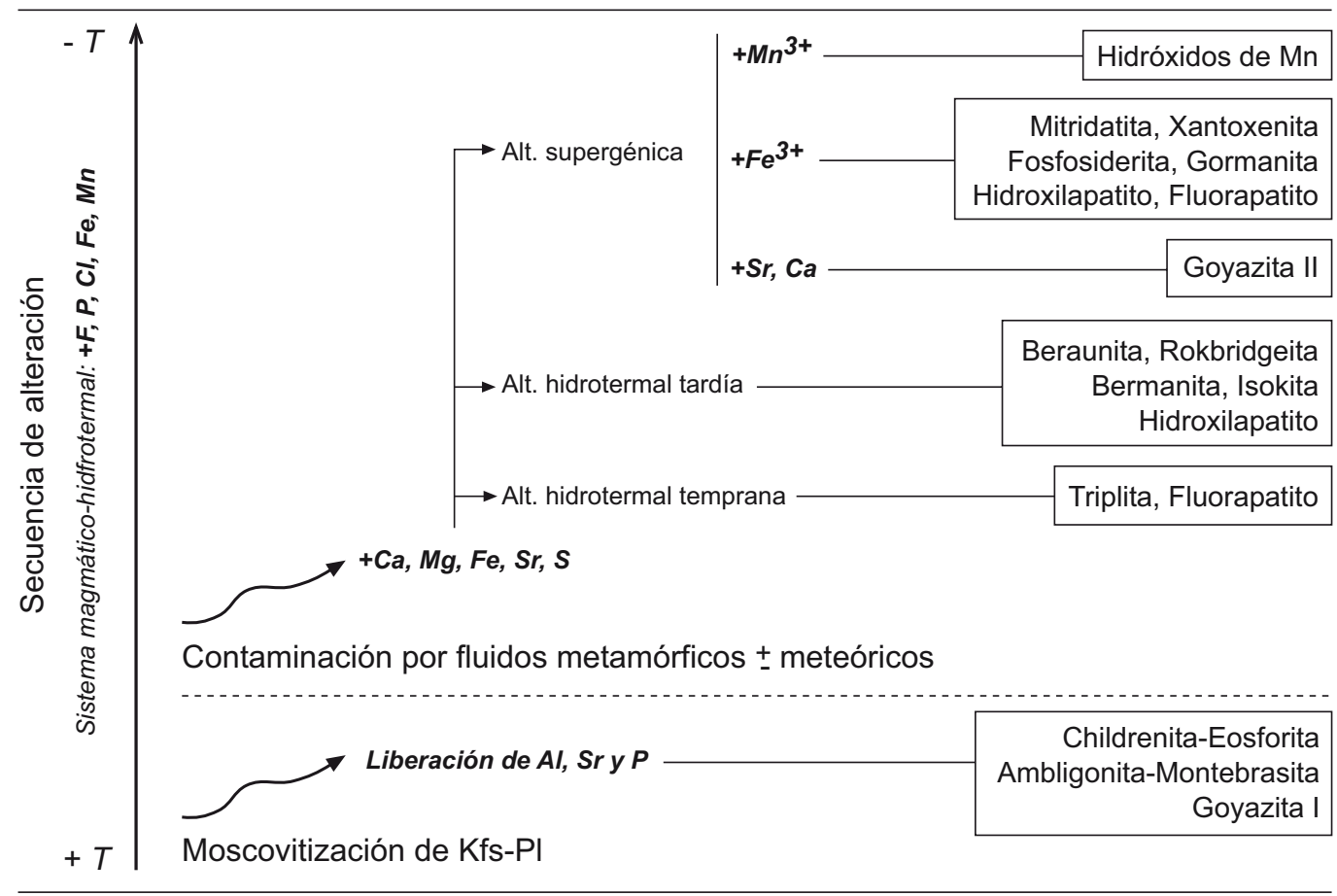

Fig. 7.2. Esquema de la secuencia de alteración hidrotermal y supergénica de los fosfatos de las mineralizaciones del batolito de Jálama. 
Respecto a la secuencia de alteración triplita-fluorapatito-isokita de las venas de cuarzo mineralizadas, esta sugiere la circulación de fluidos ricos en $\mathrm{Ca}, \mathrm{Mg}$ y $\mathrm{F}$ a través de fisuras, que incrementan la $a \mathrm{Ca}$, la $a \mathrm{Mg}$ y la $a \mathrm{~F}$ durante la cristalización de la triplita, enriquecida en Mg, pero también durante los estadios tardíos de la alteración hidrotermal (Lottermoser y Lu, 1997) para la formación de fluorapatito e isokita (Fig. 7.2). Teniendo en cuenta que en granitos peralumínicos la solubilidad del Mg es muy baja (Puziewicz y Johannes, 1988) se hace necesaria la entrada de este elemento en el sistema por fluidos procedentes de las rocas metamórficas encajantes del propio batolito. De esta manera, el Fe y el $\mathrm{Mn}$ liberados durante estas reacciones de reemplazamiento podrían entrar a formar parte de otros minerales originados por la alteración supergénica de las asociaciones fosfatadas descritas previamente.

En la secuencia de alteración triplita-bermanita-fosfosiderita de las venas de cuarzo mineralizadas de la mina Salmantina, juega un papel importante la mineralización metálica de forma similar a lo descrito por Colombo et al. (2007). En estas venas de cuarzo con abundantes sulfuros la triplita es el fosfato más precoz y uno de los más estables, de modo que solo parte de esta se alteraría hidrotermalmente en un ambiente oxidante y a baja temperatura $\left(<250^{\circ} \mathrm{C}\right)$, como sugiere la abundancia de $\mathrm{Fe}^{3+}$ y de moléculas de $\mathrm{H}_{2} \mathrm{O}$ en la estructura de la fosfosiderita o la rockbridgeita formadas a partir de la triplita (Moore, 1973; Lottermoser y Lu, 1997) (Fig. 7.2). La oxidación de los sulfuros produciría un descenso del pH y una estabilización de las fases que cristalizan a pH ácido (Reale, et al., 2003; Delacourt et al., 2004), como la fosfosiderita, que es uno de los productos más comunes de alteración de la triplita. Según Fransolet (2007), a medida que la temperatura disminuye el comportamiento del Fe y del Mn tiende a ser cada vez más independiente el uno del otro, de modo que el Fe, fundamentalmente $\mathrm{Fe}^{3+}$, se incorpora todavía a minerales fosfatados tardíos, como ocurre con la rockbridgeita o la fosfosiderita, mientras que el Mn entra en la estructura de los óxidos e hidróxidos de morfología coloforme (Fig. 7.2). Por lo tanto, las condiciones de pH y Eh generadas por la alteración de la arsenopirita y los sulfuros asociados de las venas, junto con las concentraciones y la movilidad de los distintos iones, condicionan fuertemente la mineralogía de la secuencia de alteración.

La existencia de una segunda generación de goyazita, mucho más abundante que la primera, identificada en el relleno de huecos tardíos del granito alterado adyacente a las venas de cuarzo, reemplazando al fluorapatito previo, sugiere para el $\mathrm{Sr}$ un aporte externo ya que el liberado durante la desestabilización de las plagioclasas no explicaría por sí solo la cristalización tardía de este mineral. En este reemplazamiento la percolación de aguas meteóricas con una $\mathrm{fO}_{2}$ elevada y las altas concentraciones de $\mathrm{F}$ en el sistema podrían jugar un papel importante (Fig. 7.2) movilizando los álcalis y los elementos no móviles como el Al y las REE, incorporándolos a estos minerales (Lottermoser y Lu, 1997) que son estables a $T$ inferiores a $250^{\circ} \mathrm{C}$ (Charoy et al., 2003). El aporte externo de $\mathrm{Sr}$ al sistema hidrotermal permitiría la entrada de otros elementos como el $\mathrm{Ca}, \mathrm{Fe}, \mathrm{Mg}, \mathrm{Ba}, \mathrm{Cl}$ y $\mathrm{S}$ del lavado de las rocas metamórficas encajantes y explicaría, por tanto, la cristalización de los fosfatos tardíos de origen supergénico que se encuentran tanto en el granito (mitridatita, keckita) como en las pegmatitas (xantoxenita, gormanita y mitridatita en la zona de borde de los diques pegmatíticos intragraníticos o mitridatita e hidroxilapatito en los diques peribatolíticos de Cruz del Rayo) y las venas de cuarzo mineralizadas (fosfosiderita, fluorapatito) (Fig. 7.2). De esta manera, la presencia de 
mitridatita se debería a un incremento en la $\mathrm{fO}_{2}$ del fluido durante este estadio tardío de la mineralización, de modo que el $\mathrm{Mn}^{2+}$ es completamente oxidado a $\mathrm{Mn}^{4+}$ (Pieczka, 2007). La cristalización de apatito rico en $\mathrm{OH}$ o $\mathrm{Cl}$ en grietas, en parches, alrededor de otros fosfatos (xantoxenita, gormanita, rockbridgeita...) o incluso de un fluorapatito previo, indicaría la alteración supergénica del fosfato anterior inducido por estos fluidos tardíos enriquecidos en $\mathrm{OH}$ o Cl (Pieczka, 2007), que se ve favorecida por el incremento del pH del fluido y el descenso de la temperatura (Ekström, 1973).

\subsection{LAS TURMALINAS (CHORLO-DRAVITA)}

La turmalina es un mineral común en las rocas graníticas, especialmente en el MP, el LG y las $A B$. Su presencia o ausencia en la paragénesis así como su composición química permiten conocer la evolución de los fundidos durante la cristalización. Así, por ejemplo, desde el punto de vista de su composición química la existencia de vacancias en la posición que debería ocupar el $\mathrm{Na}$ indica la preferencia de este elemento a incorporarse a la albita coexistente con la turmalina, o bien, que esta cristalizó a partir de fundidos empobrecidos en álcalis como consecuencia de la precipitación previa de la albita. Al igual que en los fosfatos con la relación $\mathrm{Fe} /(\mathrm{Fe}+\mathrm{Mn})$, en las turmalinas la relación $\mathrm{Fe} /(\mathrm{Fe}+\mathrm{Mg})$ determina el mayor o menor fraccionamiento del fundido en los diferentes cuerpos graníticos y pegmatíticos estudiados. Así, esta relación evoluciona desde 0,47 en el MP hasta 0,88 en el LG y 0,97 en las $A B$ y las pegmatitas intragraníticas, indicando un mayor fraccionamiento del fundido en esta dirección. Sin embargo algunas turmalinas de los diques pegmatíticos parcial o totalmente peribatolíticos de las minas Bon y Cruz del Rayo presentan valores relativamente bajos $(0,44)$, lo que indicaría que son un producto del metasomatismo de B producido por la intrusión de los diques pegmatíticos en el encajante metamórfico. La relación $\mathrm{Fe} /(\mathrm{Fe}+\mathrm{Mg})$ también depende de la partición del Fe y del Mg entre la turmalina y otros minerales coexistentes ricos en Fe y $\mathrm{Mg}$, como la biotita en el caso del MP o los fosfatos en las facies graníticas, aplíticas y en las pegmatitas, lo que puede explicar la ausencia de una evolución clara y definida desde el MP hasta las pegmatitas y el solape de los campos de las distintas turmalinas proyectadas (Fig. 7.3).

Respecto a la ausencia casi total de la turmalina en los diques pegmatíticos intra y peribatolíticos, donde abundan las asociaciones de fosfatos de Fe y Mn, esta puede deberse a: 1) que la cantidad de $B$ en el fundido era insuficiente para llegar al nivel de saturación necesario para la cristalización de la turmalina; 2) que todo o buena parte del B se perdió previamente a la cristalización de los fosfatos; y 3) que la presencia del P disminuye la estabilidad de la turmalina al disminuir la aAl en el fundido (Gan y Hess, 1992; Wolf y London, 1994), lo que favorece la formación de fosfatos a expensas de la turmalina. Teniendo en cuenta la gran variedad de fases fosfatadas descritas en las pegmatitas intragraníticas, una combinación de la primera y la tercera posibilidad podría ser la causa de la ausencia de turmalina en la mayor parte de los diques, ya que cuando esta cristaliza se encuentra en las zonas de borde o intermedias, pero nunca en zonas internas.

Por otra parte, la presencia exclusiva de turmalina en el contacto turmalinizado de las pegmatitas peribatolíticas de Cruz del Rayo y Bon con el encajante indica que la segunda opción 


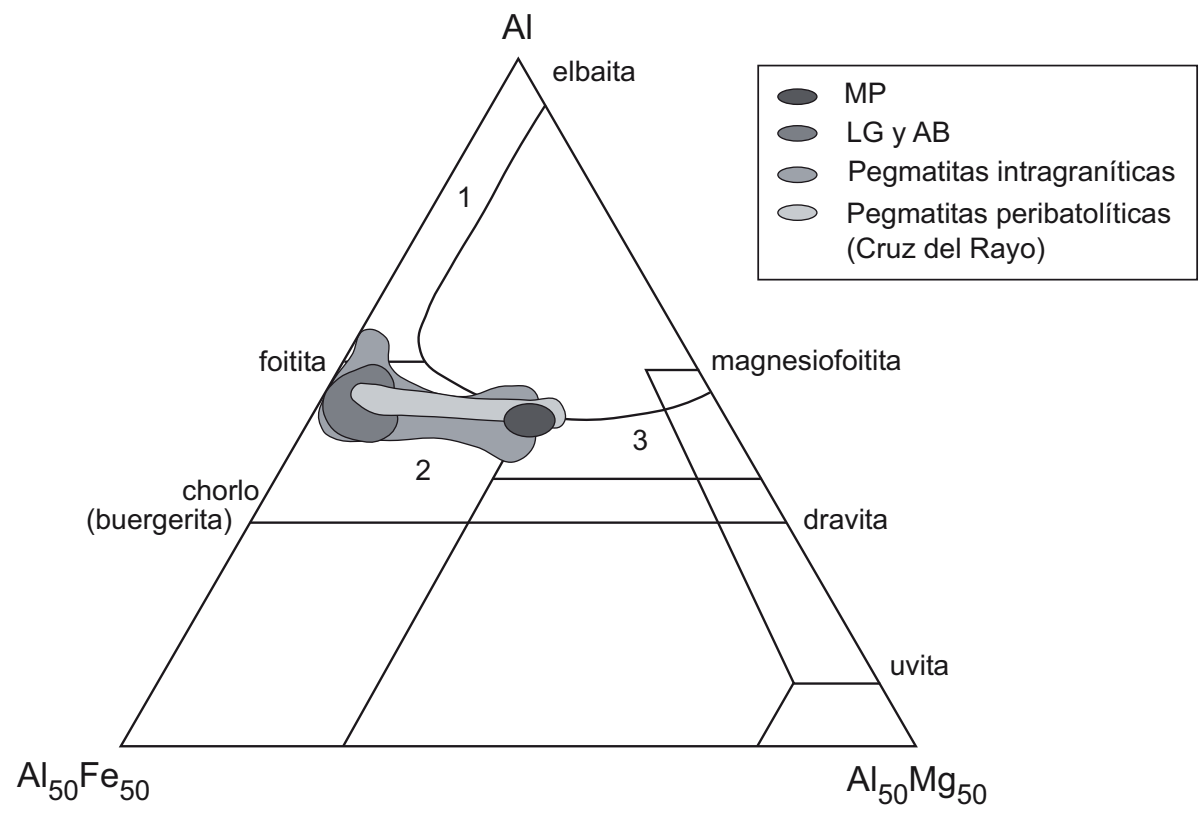

Fig. 7.3. Diagrama triangular de clasificación de la turmalina, en función de las proporciones moleculares de $\mathrm{Al}-\mathrm{Fe}_{\text {total }}-\mathrm{Mg}$, de Henry y Guidotti (1985). Obsérvese el solapamiento de los campos de las turmalinas estudiadas. 1) Pegmatitas y aplitas ricas en Li; 2) rocas graníticas pobres en Li y pegmatitas y aplitas asociadas; y 3) metapelitas y metapsamitas coexistiendo con fases alumínicas.

jugó un papel importante durante su formación y que esta turmalina pudo haber cristalizado a partir del fundido por subenfriamiento en los márgenes pegmatíticos o por difusión del Fe desde la roca encajante hasta un fundido pegmatítico rico en B. Las causas señaladas para la abundancia de turmalina de origen metasomático alrededor de las pegmatitas de Bon y Cruz del Rayo serían, por tanto, la ausencia de componentes adecuados, como el Fe, $\mathrm{Mg}$, Mn o Li en cantidades suficientes en el fundido pegmatítico para su formación, junto con la escasa volatilidad del B (London, 1997), lo que impide que las reacciones de formación de la turmalina tengan lugar en el fundido pegmatítico y provoca que el resto del B que pudiera existir se vaya a la roca metamórfica encajante que constituye un ambiente adecuado para la formación de la turmalina (London et al., 1996).

\subsection{LOS ÓXIDOS DE Nb, Ta y Ti}

\subsection{1. Óxidos de $\mathrm{Nb}$ y $\mathrm{Ta}$ en los diques pegmatíticos}

En los óxidos de $\mathrm{Nb}$ y Ta estudiados, tanto en las pegmatitas de Cruz del Rayo como en La Canalita, se observa un incremento de las relaciones $\mathrm{Mn} /(\mathrm{Mn}+\mathrm{Fe})$ y $\mathrm{Ta} /(\mathrm{Ta}+\mathrm{Nb})$ con el fraccionamiento de los fluidos. La evolución de estas relaciones durante la cristalización de ambos tipos de pegmatitas permite conocer la composición del fundido original y de los fluidos mineralizadores. Así, el incremento de la relación $\mathrm{Ta} /(\mathrm{Ta}+\mathrm{Nb})$ con la evolución de los fundidos se puede explicar por una baja solubilidad de los términos ricos en $\mathrm{Nb}$ del grupo de la columbita en magmas peralumínicos (Linnen y Keppler, 1997). Sin embargo, el incremento de la relación $\mathrm{Mn} /(\mathrm{Mn}+\mathrm{Fe})$ con el fraccionamiento es más complicado de explicar debido a que, según Linnen $(2004 a, b)$, la solubilidad en el fundido de los términos del grupo de la columbita 
ricos en Fe es mayor que la de los más ricos en Mn. Esta tendencia de fraccionamiento podría estar controlado por dos factores: uno, por otros minerales de Fe que se hayan formado durante la evolución de la pegmatita (London et al., 2001); y otro, por el incremento en la $a \mathrm{~F}$ con el fraccionamiento del fluido (Černý, 1989a). Ambos factores condicionan las diferencias en la evolución de los óxidos en las pegmatitas de Cruz del Rayo y de La Canalita.

En los diques pegmatíticos de composición granítica de Cruz del Rayo, asociados al batolito de Jálama, la tendencia general de los óxidos de $\mathrm{Nb}$ y Ta es a un enriquecimiento en $\mathrm{Mn}$, que continúa con la formación de los diques de tipo greisen, seguido posteriormente de un incremento de los contenidos en Ta hacia las fases finales de la mineralización (Fig. 7.4) (Llorens y Moro, 2010c). En los diques de composición granítica existe, aunque escasa, una asociación de fosfatos de Fe y Fe-Mn, como la alluaudita en una fase más temprana, o la mitridatita en procesos tardíos, lo que condicionaría la mineralización de los óxidos. Por su parte, la ausencia de minerales ricos en Fe en los diques de tipo greisen indicaría que el factor que controla la mineralización es el incremento de la $a \mathrm{~F}$, lo que provocaría que las fases más enriquecidas en Ta y en $\mathrm{Mn}$ se presenten en los últimos estadios de consolidación de estos cuerpos pegmatíticos o, incluso, como consecuencia de reemplazamientos posteriores. Esto sugiere que los diques de composición granítica tienen contenidos intermedios en $\mathrm{F}$ que se incrementan ligeramente con el fraccionamiento del magma hacia los diques de tipo greisen, lo que es evidente, además, por el escaso contenido en $\mathrm{F}$ que presentan el apatito, ya que la mayoría es hidroxilapatito y los fosfatos de la serie ambligonita-montebrasita, que solo ocasionalmente presenta más de $7 \%$ en peso de $\mathrm{F}$.

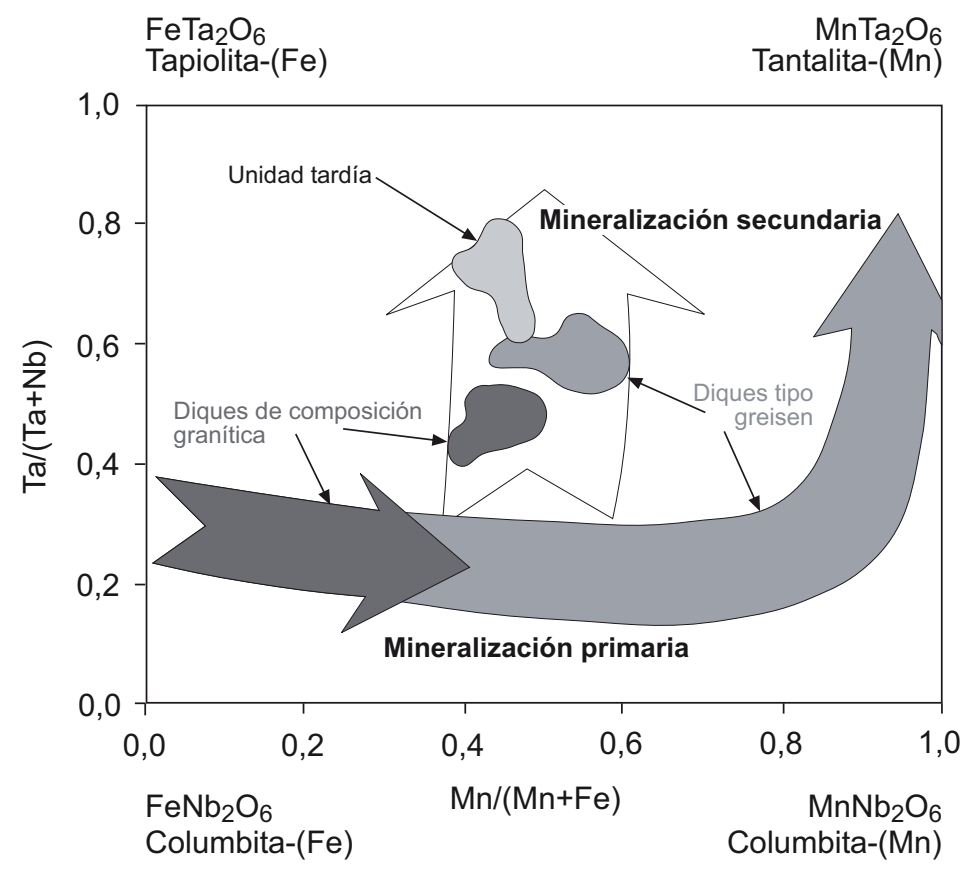

Fig. 7.4. Diagrama cuadrilateral de la columbita en el que se observa la evolución de la mineralización primaria hacia un enriquecimiento en $\mathrm{Mn}$ y Ta desde los diques de composición granítica hasta los diques de composición tipo greisen de Cruz del Rayo (flechas grises), y hacia un enriquecimiento en Ta en la mineralización secundaria (flecha blanca). 
Por tanto, la abundancia de minerales del grupo de la columbita enriquecidos en Fe y con fuertes variaciones en los contenidos de Fe y Mn revela el escaso grado de evolución de los fundidos responsables de la formación de estos diques. En ambos casos, el fraccionamiento del fundido que origina los cuerpos pegmatíticos es el responsable de la tendencia primaria al enriquecimiento en $\mathrm{Mn}$ y, posteriormente, en Ta mientras que la influencia de fluidos metamórficos y meteóricos sobre los fundidos pegmatíticos residuales daría lugar a la mineralización secundaria más rica en Fe (Fig. 7.4). A pesar del extremo enriquecimiento en $\mathrm{Mn}$ de los minerales del grupo de la columbita que cristalizan en las zonas internas de los diques de tipo greisen, la mineralogía de estos diques es característica de las pegmatitas de elementos raros de subtipo berilo-columbita-fosfato (Černý, 1989a, 1992a). Tendencias similares están representadas por el grupo norte del campo pegmatítico de Cross Lake (Černý y Ercit, 1985), Greer Lake (Černý et al., 1986), Los Chilenitos, en Argentina (Sosa et al., 2002) o Cap de Creus, en España (Alfonso et al., 1995).

En los diques pegmatíticos de La Canalita, asociados al batolito de Cadalso-Casillas de Flores, la evolución general de los minerales del grupo de la columbita en la asociación primaria responde a un progresivo enriquecimiento de los fundidos formadores de estos cuerpos en Ta a medida que las fases más ricas en Nb cristalizan (Fig. 7.5) (Llorens y Moro, 2010a,b). Esta tendencia es un rasgo típico de las pegmatitas de elementos raros del subtipo lepidolita (Černý y Ercit, 1985; Černý, 1989a; Raimbault, 1998; Huang et al., 2002). En este tipo de pegmatitas este enriquecimiento en Ta está precedido habitualmente por una progresiva pérdida en Fe y un enriquecimiento en $\mathrm{Mn}$. Sin embargo, la composición química de los óxidos de $\mathrm{Nb}$ y Ta en estas pegmatitas muestran una relación $\mathrm{Mn} /(\mathrm{Mn}+\mathrm{Fe})$ con variaciones muy restringidas. Esta observación, junto con la evidente falta de minerales ricos en Fe en los cuerpos pegmatíticos, revela la prevalencia del $\mathrm{Mn}$ sobre el Fe en el fundido responsable de la cristalización de estas pegmatitas y, por tanto, su naturaleza altamente evolucionada, a diferencia de lo que ocurría en las pegmatitas de Cruz del Rayo.

Por otro lado, la asociación secundaria rica en Ta y con contenidos variables en Fe y Mn es muy similar a la evolución que muestra el complejo de Chvalovice (Moldanubicum) en la República Checa (Novák y Černý, 1998). Además, se aprecia que varios de estos cristales de columbita-( $\mathrm{Mn})$ de la unidad tardía rica en lepidolita y albita muestran una composición similar a la columbita primaria de las zonas intermedias de los diques. Este enriquecimiento en $\mathrm{Nb}$ que se observa en la unidad de reemplazamiento sugiere que el fundido no estaba completamente empobrecido en este elemento durante la cristalización de la asociación primaria, sino que se concentró en los fluidos residuales finales llevando a la cristalización de cristales con un núcleo de columbita-( $\mathrm{Mn}$ ) en la unidad tardía. Además, los minerales que componen esta asociación secundaria muestran variables y elevados contenidos en Ti, lo que sugiere una contaminación por el influjo de fluidos hidrotermales metamórficos (Černý y Němec, 1995; Tindle et al., 1998; Pal et al., 2007) de una manera similar a la contaminación por Fe durante la cristalización de los últimos agregados de cuarzo.

En estos diques, la solubilidad de la columbita-(Mn) y la tantalita-(Mn) podría haberse incrementado debido a la abundancia de Li. No obstante, Linnen (1998) demostró que los magmas alcanzarían el grado de saturación en Ta para valores más bajos de Li y F en el magma, 


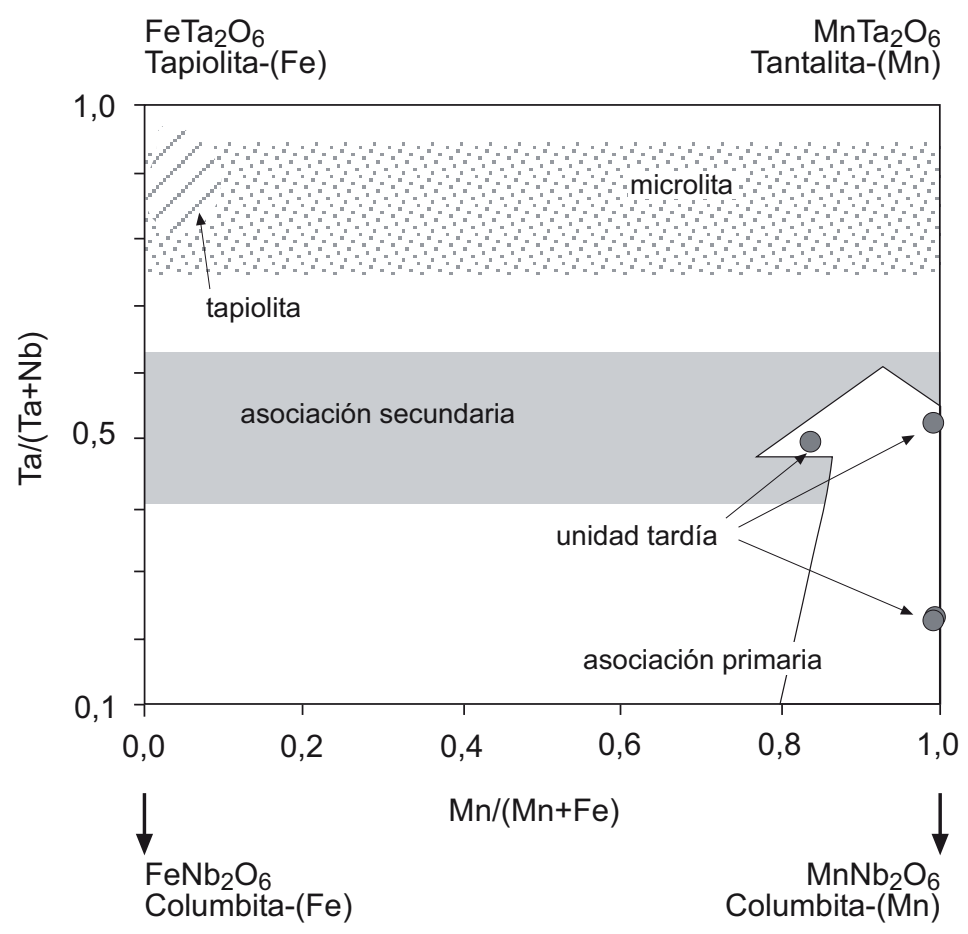

Fig. 7.5. Diagrama cuadrilateral de la columbita de la mineralización de los diques pegmatíticos de La Canalita. Obsérvese la evolución de la asociación primaria hacia un enriquecimiento en Mn y en Ta y la de la asociación secundaria con un enriquecimiento variable en Fe y $\mathrm{Mn}$.

por lo que la formación de esta mineralización rica en Ta requiere la cristalización previa de fases como la montebrasita y el topacio, que extraigan cantidades significativas de Li, F y P del fundido si se trata de los óxidos de la asociación primaria, o del fluido metasomático si se trata de la asociación secundaria (Charoy y Noronha, 1996). Este hecho se refleja en las zonas externas de los diques, donde cristalizan abundantes cantidades de lepidolita, montebrasita y topacio durante estadios tempranos de cristalización, que van disminuyendo hacia las zonas internas de los diques condicionando la cristalización de los óxidos de $\mathrm{Nb}$ y Ta en el mismo sentido.

Černý y Ercit (1985) demostraron que un enriquecimiento en $\mathrm{F}$ provoca la precipitación de mica de Li tardía que, a su vez, promueve el fraccionamiento de $\mathrm{Nb}$ /Ta y el enriquecimiento extremo en $\mathrm{Mn}$, lo que modifica la mineralogía de las fases de $\mathrm{Nb}$ y Ta en favor de la microlita (Černý, 1989a). Este es un mineral típico de las unidades ricas en albita y lepidolita de las pegmatitas graníticas (Von Knorring y Fadipe, 1981; Taylor y Fryer, 1983), aunque también se puede considerar un producto de alteración metasomática de minerales del grupo de la columbita previos en zonas internas de los cuerpos pegmatíticos (Ewing, 1975). La microlita muestra un fuerte enriquecimiento en Ta y una amplia variación en la relación $\mathrm{Mn} /(\mathrm{Mn}+\mathrm{Fe})$, lo que sugiere que podría haber cristalizado tarde en la secuencia mineralógica como consecuencia de la cristalización magmática (microlita primaria) y mediante procesos metasomáticos (microlita secundaria y microlita uranífera). Aunque no hay evidencias texturales que determinen que la microlita primaria cristalizó a partir de tantalita primaria, sí está demostrado que la microlita secundaria se formó como consecuencia de la entrada de fluidos hidrotermales que causaron el reemplazamiento de la tantalita-(Mn) por microlita secundaria rica en $U$ 
en las zonas intermedias de los diques. Además, estos fluidos hidrotermales dieron lugar a una greisenización parcial de la unidad tardía rica en albita y lepidolita, formando microlita secundaria que reemplaza a la tapiolita (Von Knorring y Fadipe, 1981) con una relación Ta/ $(\mathrm{Ta}+\mathrm{Nb})$ heredada de esta, lo que corrobora la escasa movilidad del Ta y del Nb durante la alteración hidrotermal a baja temperatura (Novák et al., 2004; Černý et al., 2004).

\subsection{2. Óxidos de $\mathrm{Ti}-(\mathrm{Nb}-\mathrm{Ta})$ en las venas de cuarzo}

El rutilo tiene un elevado potencial como indicador geoquímico en multitud de depósitos hidrotermales, puesto que es una fase accesoria muy común y es capaz de albergar multitud de sustituciones por elementos menores y traza en su composición, como $\mathrm{Fe}, \mathrm{Cr}, \mathrm{V}, \mathrm{Nb}$ y $\mathrm{Ta}$ (Clark y Williams-Jones, 2009). Dada la influencia de los volátiles como el F en la movilidad del Ti (Ryzhenko et al., 2006), la cristalización de minerales con F, como el fluorapatito, provocaría la saturación en Ti y la precipitación de rutilo (Rapp et al., 2010), lo que se hace evidente con la presencia de rutilo en asociaciones fosfatadas con apatito y otros fosfatos con $\mathrm{F}$ tanto en los diques pegmatíticos como en las facies graníticas del batolito de Jálama.

En las venas de cuarzo la abundancia de rutilo II en las últimas etapas de depósito podría deberse no solo a la cristalización del fluorapatito y la isokita sino, además, a un enriquecimiento previo en Ti probablemente debido al lavado de las rocas metamórficas. Este rutilo tardío presenta elevados contenidos en elementos traza como $\mathrm{Nb}$, Ta e, incluso, W y se encuentra precedido por la cristalización de la ixiolita. Esta evolución hidrotermal representa un enriquecimiento en Ti y en Fe especialmente a expensas de $\mathrm{Mn}$, lo que podría considerarse una tendencia inversa (Tindle y Breaks, 1998; Beurlen et al., 2008) comparada con la evolución normal de enriquecimiento en Mn y Ta observada en los minerales del grupo de la columbita de Cruz del Rayo. De hecho, esta tendencia anómala se puede observar desde la cristalización de la wolframita a mayor temperatura, aunque no es del todo completa puesto que sí se observa un incremento en el contenido en Ta con el paso de ixiolita a rutilo (Fig. 7.6). Además, los altos contenidos en Ti de algunos de los cristales de ixiolita indicarían condiciones de co-cristalización con el rutilo a bajas temperaturas (Černý et al., 1998; Carruzo et al., 2006). Si se tienen en cuenta la ausencia de texturas de reemplazamiento de la ixiolita por el rutilo y la existencia de límites más o menos netos entre ambos minerales, paralelos a las zonaciones composicionales de ambos, parece que se trata de una textura de origen primario que estaría causada por cambios en la composición del fluido mineralizador, probablemente consecuencia de una mezcla con fluidos metamórficos y/o meteóricos que están enriquecidos en Ti y Fe.

Linnen y Keppler (1997) señalaron la preferencia de las fases accesorias a incorporar $\mathrm{Nb}$ frente al Ta, como ocurre en la ixiolita, de modo que la relación $\mathrm{Nb} / \mathrm{Ta}$ decrece en el fluido residual a medida que avanza el fraccionamiento. Además, el incremento en la concentración del F aumenta la solubilidad de complejos ricos en Ta (Linnen, 1998), lo que retrasa su incorporación en la estructura del rutilo hasta las últimas fases de la cristalización. El hecho de que se formen a partir de un fluido acuoso puede favorecer, además, la separación del Nb y del Ta (Dostal y Chatterjee, 2000; Novák et al., 2003). 


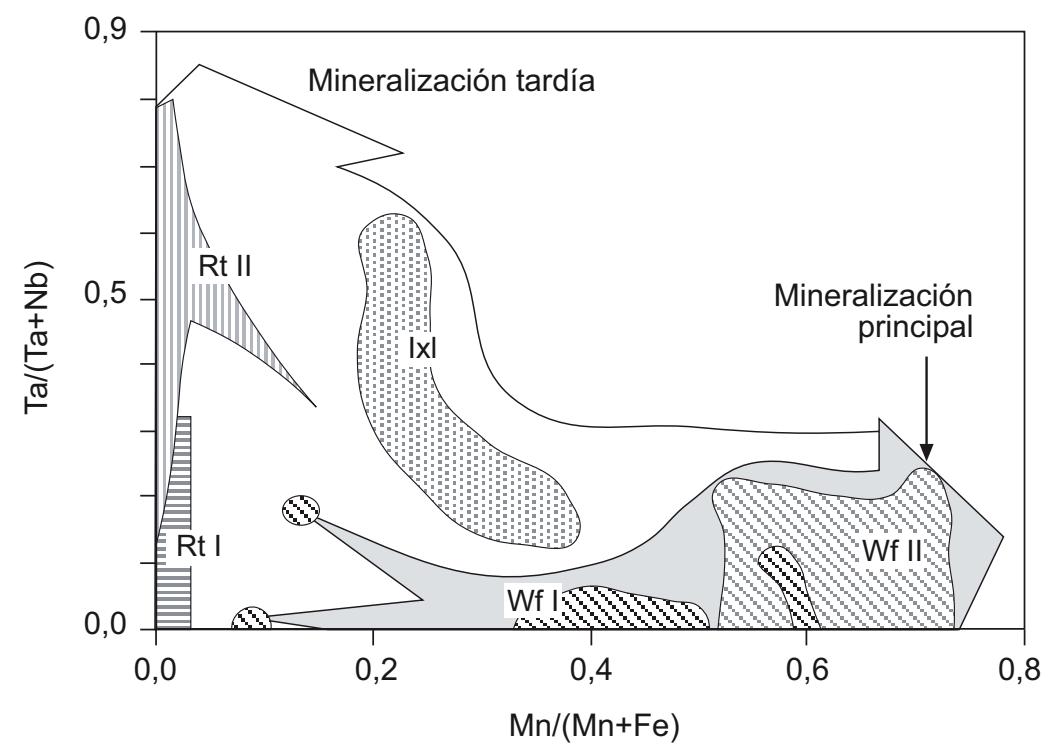

Fig. 7.6. Diagrama cuadrilateral de la columbita en el que se observan dos tendencias de evolución: una normal hacia un enriquecimiento en $\mathrm{Mn}$ de la wolframita I y II de la mineralización principal en las venas de cuarzo del batolito de Jálama (flecha gris); y otra inversa hacia un enriquecimiento en Fe y Ta de la ixiolita y el rutilo II durante la mineralización tardía (flecha blanca).

\subsection{LAS SULFOSALES DE Bi-Pb-Ag}

Una gran variedad de sulfosales de $\mathrm{Bi}-\mathrm{Pb}$ - $\mathrm{Ag}$ han sido descritas en las mineralizaciones asociadas al batolito de Jálama, observándose que su composición química varía ampliamente de unas minas a otras del distrito, como se puede observar en las figuras 3.39 y 3.40 , en las que destaca la presencia exclusiva de homólogos de la pavonita en las venas encajadas en el GE, mientras que las lilianitas dominan en las venas encajadas en el LG y las AB con turmalina, con la solución sólida lilianita-gustavita especialmente abundante en la mina de Teso de la Matanza, mientras que vikingita y heyrovskyita se encuentran preferentemente en la zona de la Salmantina. Esta variabilidad composicional no se aprecia únicamente a nivel de distrito sino también a escala de mina encontrándose diferentes tipos de sulfosales, como en Teso de la Matanza, donde en la misma vena de cuarzo se encuentran gustavita I (Gu I) o gustavita II (Gu II) según la zona de la vena estudiada, e incluso a escala cristalina donde se han observado diferentes tipos de pavonitas intercrecidas con el mismo cristal de gustavita. Todo esto sugiere, por un lado, una gran variabilidad composicional de los fluidos hidrotermales mineralizadores que contienen diferentes concentraciones de $\mathrm{Ag}$-Bi frente a $\mathrm{Pb}$; y por otro, unas condiciones fisicoquímicas de los fluidos también cambiantes a muy pequeña escala.

No hay una asociación definida entre la aparición de los homólogos de la pavonita con los de la lilianita aunque parecen responder al mismo vector de sustitución. En el triángulo de las lilianitas se observan dos tendencias de evolución (Fig. 7.7). Por un lado, el paso de la Gu I a la Gu II a lo largo de la línea de $\mathrm{N}=4$, que supone un enriquecimiento en Bi de la asociación con el descenso de la temperatura; y por otro, una clara tendencia que se puede marcar con una línea paralela al borde $\mathrm{Bi}-\mathrm{Pb}$, en la que la mineralización evoluciona desde la Gu II casi completamente sustituida hacia fases más ricas en $\mathrm{Pb}$, como son la vikingita y la heyrovskyita, 


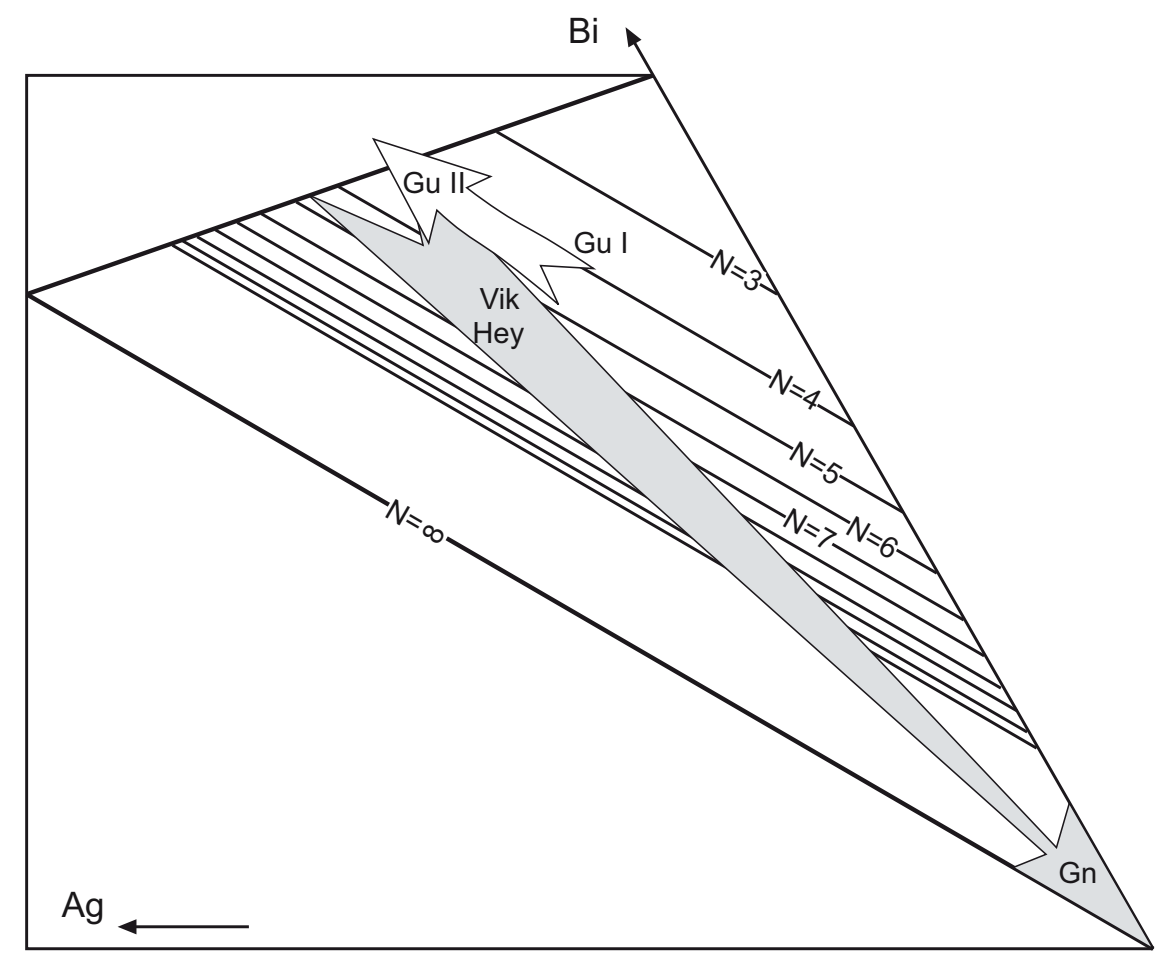

$\mathrm{Pb}$

Fig. 7.7. Diagrama triangular Ag-Bi-Pb de Makovicky y Karup-Møller (1977b) en el que se observa el enriquecimiento inicial en $\mathrm{Bi}$ y posterior en $\mathrm{Pb}$ de los diferentes homólogos de la lilianita estudiados en las venas de cuarzo del batolito de Jálama.

especialmente en sectores más occidentales del batolito de Jálama (Fig. 7.7). Esta línea se prolonga hasta la galena tardía coexistente con estas fases, con cantidades variables de Ag y Bi que rellena microfracturas y que constituye un producto de la disociación de las sulfosales previas, lo que sugiere que el sistema ha evolucionado hacia fases más estables de $\mathrm{Pb}$, como ocurre en los depósitos de Sn y W de Monteneme, en España (Gouanvic y Babkine, 1985). 
CAPÍTULO 8

Modelo metalogenético y conclusiones 



\section{CAPÍTULO 8. MODELO METALOGENÉTICO Y CONCLUSIONES}

Las mineralizaciones magmático-hidrotermales de $\mathrm{Sn}-\mathrm{W}-(\mathrm{Nb}-\mathrm{Ta})$ del distrito de Navasfrías responden a un modelo de cúpula granítica altamente fraccionada de edad tardi-varisca. Las facies graníticas que componen la UE del batolito de Jálama son el resultado de la cristalización fraccionada de un magma que procede de la fusión parcial de rocas metamórficas de grado bajo, peralumínicas y composicionalmente heterogéneas (Ramírez, 1996; Ramírez y Grundvig, 2000). El desarrollo de células convectivas como consecuencia del emplazamiento del magma da lugar a una distribución térmica relativamente homogénea dentro de la cámara magmática (Worster et al., 1990) y a la concentración del fundido residual más ligero y enriquecido en $F$, $\mathrm{Cl}, \mathrm{P}$ y $\mathrm{B}$ hacia las zonas apicales de la misma (Fig. 8.1). El exceso de la presión en la cámara magmática provocado por la cristalización fraccionada da lugar a la expulsión de los fundidos residuales ( \pm fluidos) hacia zonas proximales estructuralmente más débiles, cristalizando in situ en algunos casos los diques pegmatíticos intragraníticos que contienen casiterita diseminada, o hacia zonas más distales formando los diques peribatolíticos de composición granítica encajados en las rocas metamórficas del CEG (Cruz del Rayo) y que contienen igualmente casiterita diseminada y minerales del grupo de la columbita (Fig. 8.1). Muchos de los diques de pegmatitas intragraníticas estudiados presentan formas elipsoidales o irregulares a modo de pockets en el propio leucogranito, observándose una transición gradual entre el tamaño de grano de los minerales esenciales del LG y de las pegmatitas lo que sugiere que estas corresponden a la cristalización in situ de segregaciones residuales locales de los fundidos pegmatíticos (Černý et al., 2005b). La composición peralumínica de las rocas magmáticas y de sus fundidos residuales dio lugar a la cristalización de una serie de fosfatos primarios raramente conservados como la zwieselita en los diques pegmatíticos del GE (Llorens y Moro, 2007, en prensa).

Los fundidos residuales de la cristalización de estas pegmatitas en la parte superior de la cámara magmática estarían altamente enriquecidos en volátiles y, por lo tanto, en Na lo que provocaría, a una temperatura elevada, un metasomatismo sódico especialmente evidente en las facies del LG y las AB con turmalina y en los diques pegmatíticos encajados en estas, donde el feldespato potásico es ampliamente reemplazado por albita y un fosfato primario por alluaudita. Esto es debido al incremento de las actividades del $\mathrm{Na}$, del $\mathrm{H}^{+} \mathrm{y}$ del $\mathrm{HF}$ del fundido residual que provoca un aumento de la acidez del medio que desestabiliza esencialmente al feldespato potásico y, en menor medida, a la mica y la plagioclasa (Pollard, 1983). Sin embargo, en los diques pegmatíticos peribatolíticos de composición granítica de Cruz del Rayo el efecto de esta alteración es más intenso. Tras su cristalización, la saturación en vapor del fundido residual daría lugar a la formación de la Unidad Tardía rica en albita especialmente en las zonas internas, lo que se atribuye a una pérdida de componentes volátiles como B o F que restan viscosidad al fundido residual o que pueden inhibir la cristalización de las fases silicatadas normales (London et al., 1989).

La cristalización de este fundido residual rico en Na liberaría grandes cantidades de fluido acuoso junto con el exceso de boratos o fluoruros alcalinos previos, los cuales migran hacia las zonas apicales y las márgenes superiores del batolito provocando un incremento de la 


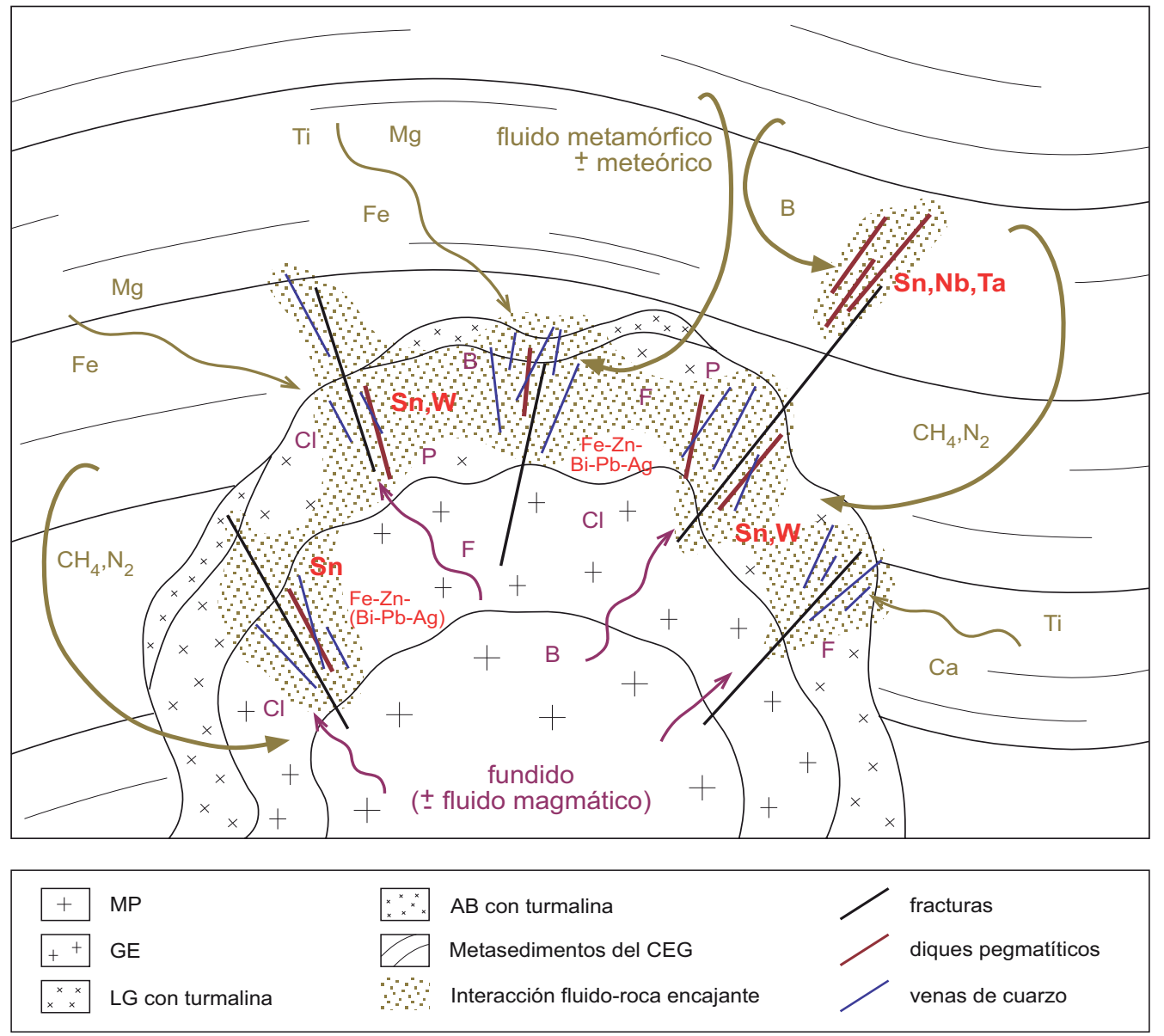

Fig. 8.1. Modelo esquemático del sistema magmático-hidrotermal de las mineralizaciones del batolito de Jálama.

presión de los fluidos y, como consecuencia, una intensa fracturación hidráulica que facilita la circulación de los fluidos hidrotermales y la formación de las venas de cuarzo mineralizadas. La reacción de estos fluidos con las masas graníticas produce una moscovitización que favorece el reemplazamiento de los feldespatos por mica blanca, cuarzo y fosfatos como la goyazita, montebrasita y childrenita-eosforita y una greisenización (Burt, 1981; London y Burt, 1982) preferentemente dentro de (o adyacente a) los diques pegmatíticos (Llorens y Moro, en prensa). Esta última es especialmente importante en los de composición granítica encajados en el CEG (Cruz del Rayo), lo que da lugar a la formación de los diques de composición tipo greisen que, de acuerdo con Llorens y Moro (2010c), pertenecen al grupo de elementos raros dentro de la familia LCT, subtipo berilo-columbita (Černý, 1989a, 1992a). Tanto la moscovitización como la greisenización provocan la expulsión de elementos incompatibles como el $\mathrm{Sn}, \mathrm{Nb}$, Ta y $\mathrm{W}$ de la estructura cristalina de los minerales magmáticos pudiéndose incorporar en los minerales secundarios o bien precipitar en forma de casiterita, wolframita y minerales del grupo de la columbita en los diques pegmatíticos o en las venas de cuarzo junto con la sílice liberada durante las reacciones de greisenización. La intensa fracturación hidráulica probablemente facilitó el influjo de fluidos metamórficos \pm meteóricos con escasos contenidos de $\mathrm{CH}_{4}$ y $\mathrm{N}_{2}$ (Fig. 8.1) que provocaron en los fluidos primarios una dilución y un 
incremento del pH lo que, junto con el descenso de la temperatura, originó el depósito de la mineralización.

Como en otros depósitos de Sn y W, la concentración de los metales en el fluido magmáticohidrotermal estuvo controlada por la evolución de las concentraciones de $\mathrm{H}_{2} \mathrm{O}, \mathrm{Cl}$ y $\mathrm{F}$ en el fundido durante los procesos de cristalización fraccionada y exsolución de fluidos. Así, los fluidos responsables de la mineralización en las venas de cuarzo encajadas en el GE (minas Horia y Mari Carmen) estarían relativamente enriquecidos en $\mathrm{Cl}$, lo que favorecería el transporte del Sn (Fig. 8.1). En cambio, los fluidos responsables de la mineralización en las venas del $L G$ y las $A B$ con turmalina presentarían un temperatura y unas proporciones relativas de $\mathrm{Cl}$ menores dada la mayor concentración de $\mathrm{F}$ en el mismo por la diferenciación (Webster y Holloway, 1990), por lo que son capaces de transportar no solo Sn, sino también W. Durante esta fase, además de formarse la mineralización precoz de casiterita y wolframita en las venas de cuarzo, tiene lugar la precipitación de fosfatos como la triplita y de los sulfuros, lo que acidifica la solución lo suficiente como para iniciar un nuevo procesos de alteración de la roca encajante, ya sean las facies graníticas de la UE o los diques pegmatíticos intra y peribatolíticos. La neutralización de la acidez provoca un nuevo episodio de depósito en las venas de cuarzo favorecido por una deformación dúctil que abre grietas distensivas en las que se forma la mineralización metálica principal de S-As-Fe-Zn. La intensa fracturación tardi-varisca provoca la brechificación de los sulfuros previos y la precipitación de una mineralización tardía rica en $\mathrm{Bi}-\mathrm{Pb}-\mathrm{Ag}$ y menos Fe-Cu de relleno y reemplazamiento (Fig. 8.1).

Finalmente, la mezcla de fluidos metamórficos \pm meteóricos con los fluidos hidrotermales residuales durante los procesos tardíos de depósito de la mineralización sería la responsable, en parte, de la amplia variedad de fases fosfatadas estudiadas, especialmente ricas en Fe y $\mathrm{Mn}$ pero también en $\mathrm{Mg}$ y Ca tanto en las facies graníticas y pegmatíticas (barbosalitalipscombita, rockbridgeita) como en las propias venas de cuarzo (bermanita, rockbridgeita, isokita). La percolación de aguas meteóricas al sistema bajo condiciones de elevada $\mathrm{fO}_{2}$ permitiría la movilización e incorporación de elementos como el $\mathrm{Sr}$, $\mathrm{Fe}, \mathrm{Ca}$ y $\mathrm{Cl}$ a los fosfatos que se forman como consecuencia de la alteración supergénica de las asociaciones previas junto con el Fe y el Mn liberados de reemplazamientos anteriores, cristalizando así gormanita, beraunita, mitridatita, xantoxenita, walentaita, keckita o apatito rico en $\mathrm{OH}$ y $\mathrm{Cl}$ en los granitos y pegmatitas, mientras que en las venas de cuarzo precipitan goyazita, fosfosiderita e hidróxidos de Mn (Llorens y Moro, 2008, en prensa).

La evolución magmático-hidrotermal del batolito de Cadalso-Casillas de Flores es muy similar, con las diferencias propias de la distinta mineralogía de las venas de cuarzo y los diques pegmatíticos. En este caso los fundidos residuales de su cristalización estarían altamente enriquecidos en $\mathrm{F}$ y $\mathrm{Li}$, además de $\mathrm{Rb}, \mathrm{Cs}$, B y $\mathrm{P}$ que aumentan la solubilidad del $\mathrm{H}_{2} \mathrm{O}$, lo que se traduce en una reducción extrema de la viscosidad del fundido favoreciendo suficientemente su movilidad como para escapar fuera del granito aprovechando los sistemas de fracturas (Černý, 1992b) y cristalizando, en los metasedimentos del CEG, los diques aplíticos de Molino del Galo y las pegmatitas de La Canalita que, de acuerdo con Llorens y Moro (2010), pertenecen al grupo de las pegmatitas complejas dentro de la clase de elementos raros de la familia LCT, subtipo lepidolita (Černý, 1989a, 1992a) con contenidos anómalamente elevados en P 
(Raimbault et al., 1991). En estas, el incremento en las actividades de KF y LiF en un ambiente con una acidez relativamente baja estabilizaría la lepidolita a expensas de los aluminosilicatos de litio anhidros (Černý, 1992a). Además, un incremento de la aHF estabilizaría la asociación lepidolita+topacio (London, 1987) y la presencia de montebrasita como una fase común indica una elevada $a \mathrm{PFO}_{2}$ (Burt y London, 1982). La influencia de fluidos externos al sistema durante los últimos eventos de alteración metasomática estaría avalada por la presencia de cantidades variables de Fe en las asociaciones de minerales secundarios, como la tantalita(Fe) o la tapiolita, sugiriendo una mezcla de los fluidos primarios exsueltos de los fundidos residuales con otros procedentes del encajante metamórfico.

La influencia de los procesos de metasomatismo sódico y greisenización se hace evidente en la formación de la unidad tardía rica en albita y de zonas greisenizadas en los diques, lo que pudo facilitar las condiciones adecuadas para la precipitación de la mineralización de $\mathrm{Sn}, \mathrm{W}, \mathrm{Nb}$ y Ta tanto en los diques pegmatíticos como en las venas de cuarzo. Además, la transformación de wolframita en scheelita indica un aumento de la aCa que apoya de nuevo la hipótesis de una interacción con fluidos metamórficos y meteóricos durante las fases tardías de la mineralización. 


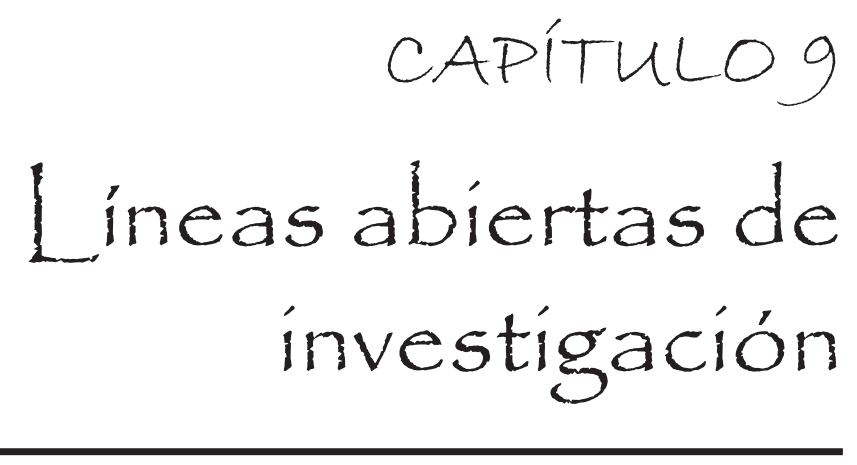





\section{LÍNEAS ABIERTAS DE INVESTIGACIÓN}

Todas las investigaciones realizadas en el distrito de Navasfrías llevan a plantear, como una de las líneas prioritarias de investigación a desarrollar en los próximos años, el conocer el origen, aún desconocido, del Au detrítico que se encuentra en el distrito. Como yacimientos primarios se sugieren los originados a partir de fundidos \pm fluidos ricos en $\mathrm{Bi}$ que dan lugar a las abundantes sulfosales de $\mathrm{Bi}-\mathrm{Pb}-\mathrm{Ag}$ que se encuentran en las venas de cuarzo mineralizadas del distrito, cuya descomposición y posterior lavado da lugar a su acumulación en las arenas de los ríos y arroyos que drenan el distrito. Es conocida la capacidad de las soluciones ricas en Bi para extraer el Au de los fundidos subsaturados en este elemento a temperaturas superiores al punto de fusión del $\mathrm{Bi}\left(271^{\circ} \mathrm{C}\right)$ y $f \mathrm{~S}_{2}$ por debajo de tampón Po-Py, por lo que el fraccionamiento de estos fundidos supone un buen mecanismo de depósito del Au en yacimientos de afiliación magmática (Douglas et al., 2000; Ciobanu et al., 2005; Wagner, 2007; Tooth et al., 2008). A pesar de ello sorprende, teniendo en cuenta una asociación tan rica en $\mathrm{Bi}$, no encontrar Au nativo en los depósitos primarios del distrito más que de forma accidental, como ocurre también en otros distritos mineros (Ciobanu et al., 2002).

No obstante, cabe destacar los elevados contenidos que presentan algunas de las sulfosales de $\mathrm{Bi}-\mathrm{Pb}-\mathrm{Ag}$ de la familia de la lilianita y de la pavonita, así como la solución sólida galenamatildita, Bi nativo y derivados de la bismutinita que se encuentran en las venas de cuarzo mineralizadas asociadas al batolito de Jálama. Así, se han detectado contenidos en Au de hasta 1.000 ppm en algunos cristales de pavonita, de 2.370 ppm en los de bismutinita y de 4.000 ppm en los de lilianita. Los contenidos más altos se han encontrado en cristales de Bi nativo con hasta 6.640 ppm de Au, mientras que los más bajos están en cristales de matildita que no superan las 990 ppm. Destacan, además, los cristales de galena con hasta 0,10 apfu de Bi en su composición que presentan contenidos de hasta 3.730 ppm en Au. Si bien la Ag no parece influir en la solubilidad del Au, sí que podría facilitar su incorporación a las sulfosales, dado que mayores contenidos en $\mathrm{Ag}$ se correlacionan con mayores cantidades de oro (Ciobanu et al., 2009). Para explicar el atrape del Au en estos minerales, los autores anteriormente citados proponen dos modelos: uno, disolución de una fase previa rica en Au (aunque escaso hay evidencias de la presencia de eléctrum en el distrito); y otro, removilización a partir de discontinuidades de la estructura cristalina de determinadas fases minerales y reprecipitación como nanopartículas en otras.

Por todo ello, y para avanzar en el conocimiento del origen del oro primario del distrito, se propone continuar en primer lugar con el estudio petrológico, mineralógico y químico de las muestras mineralizadas que contengan las asociaciones minerales de $\mathrm{Bi}-\mathrm{Pb}$-Ag mediante todas las técnicas disponibles que permitan conocer cómo y dónde se encuentra el oro primario del distrito de Navasfrías. Entre estas técnicas cabe destacar la Espectrometría de Masas con Fuente de Plasma de Acoplamiento Inductivo mediante Ablación Láser (LA-ICP-MS), que determina los contenidos en elementos con rango de masa atómica entre 7 y 250 , esto es desde el Li hasta el $U$, con un rango de detección de ppb, lo que facilitaría el análisis de los contenidos en Au y otros elementos traza en las sulfosales de Bi-Pb-Ag. También se utilizarían 
la Microscopía Electrónica de Transmisión de Alta Resolución (HRTEM), para identificar las nanopartículas de Au y obtener imágenes de la estructura cristalina a escala atómica, y la Microsonda lónica de Alta Sensibilidad y Resolución (SHRIMP), para obtener la distribución espacial de los contenidos en Au y los valores del isótopo ${ }^{197}$ Au que permitan conocer la edad de estas mineralizaciones tardías ricas en $\mathrm{Bi}-\mathrm{Pb}-\mathrm{Ag}$ con una precisión muy elevada. 
CAPITTULO 10

Bibliografía 



\section{CAPÍTULO 10. BIBLIOGRAFÍA}

AfIFI, A.M., Kelly, W.C. Y ESSENE, E.J. (1988): Phase relations among tellurides, sulfides, and oxides. I. Thermochemical data and calculated equilibria. Econ. Geol., 83, 377-394.

Alfonso, P., Corbella, M. y Melgarejo, J.-C. (1995): Nb-Ta-minerals from the Cap de Creus pegmatite field, eastern Pyrenees: distribution and geochemical trends. Miner. Petrol., 55, 53-69.

Aller, J., Bastida, F., Ortega, E. y Pérez-Estaún, A. (1986): Aportación al conocimiento estructural del Sinclinal de Almadén. Bol. Geol. Min., 97, 608-621.

Alonso GAVILÁN, G. (1981): Estratigrafía y sedimentología del Paleógeno en el borde suroccidental de la cuenca del Duero (provincia de Salamanca). Tesis Doctoral, Univ. de Salamanca, $438 \mathrm{p}$.

ANDERSON, S.D., ČERnÝ, P., HALDEN, N.M., ChAPMAN, R. Y UHER, P. (1998): The YITT-B pegmatite swarm at Bernic Lake, southeastern Manitoba: a geochemical and paragenetic anomaly. Can. Mineral., 36, 283-301.

ARTHAUd, F. y MATTE, PH. (1975): Les décrochements tardihercyniens du Sud-Ouest de l'Europe. Géometrie et essai de reconstitution des conditions de la déformation. Tectonophysics, 25, 139-171.

BAILEY, S.W. (1980): Summary of recommendation of AIPEA Nomenclature Committee on clay minerals. Am. Mineral., 65, 1-7.

BAldWIN, J.R., HILl, P.G., FINCH, A.A., Von KNORRING, O. y Oliver, G.J.H. (2005): Microlitemanganotantalite exsolution lamellae: evidence from rare-metal pegmatite, Karibib, Namibia. Mineral. Mag., 69, 917-935.

BALdWIN, J.R., HILl, P.G., VON KNORRING, O. Y Oliver, G.J.H. (2000): Exotic aluminium phosphates, natromontebrasite, brazilianite, goyazite, gorceixite and crandallite from rareelement pegmatites in Namibia. Mineral. Mag., 64, 1147-1164.

BARTON, P.B.JR. Y BethKe, P.M. (1987): Chalcopyrite disease in sphalerite: Pathology and epidemiology. Am. Mineral., 72, 451-467.

BARTON, P.B.JR. Y SKINNER, J. (1979): Sulfide mineral stabilities. En: Geochemistry of Hydrothermal Ore Deposits (H.L. Barnes, Ed.). New York, Wiley. 278-403.

BeA, F., Fershtater, G. y Corretgé, L.G. (1992): The geochemistry of phosphorus in granitic rocks and the effect of aluminium. Lithos, 29, 43-56.

BEA, F., MONTERO, P. Y ZINGER, T. (2003): The nature and origin of the granite source layer of Central Iberia: Evidence from trace elements, $\mathrm{Sr}$ and $\mathrm{Nd}$ isotopes, and zircon age patterns. Jour. Geol., 107, 399-419. 
BENTE, K. Y DOERING, T. (1993): Solid-state diffusion in sphalerites: an experimental verification of the "chalcopyrite disease". Eur. J. Mineral., 5, 465-478.

Beurlen, H., DA Silva, M.R.R., Thomas, R., SOAReS, D.R. y Olivier, P. (2008): Nb-Ta-(Ti-Sn) oxide mineral chemistry as tracer of rare-element granitic pegmatite fractionation in the Borborema Province, Northeastern Brazil. Miner. Deposita, 43, 207-228.

BEUS, A.A. Y ZALASHKOVA, N.Y. (1964): Postmagmatic high temperature metasomatic processes in granitic rocks. Int. Geol. Rev., 6, 668-681.

BODNAR, R.J. (1993): Revised equation and table for determining the freezing point depression of $\mathrm{H}_{2} \mathrm{O}-\mathrm{NaCl}$ solutions. Geochim. Cosmochim. Acta, 57, 683-684.

BODNAR, R.J. (2003): Introduction to aqueous-electrolyte fluid inclusions. En: Fluid Inclusions. Analysis and Interpretation (I. Samson, A. Anderson y D. Marshall ,Eds.). Mineral. Assoc. Canada, Short Course, 32, 81-100.

BONS, P.D. (2000): The formation of veins and their microstructures. En: Stress, Strain and Structure - A volume in honour of W.D. Means (M.W. Jessell y J.L. Urai, Eds.). J. Virtual Expl., 2.

BORTHWICK, J. Y HARMON, R.S. (1982): A note regarding $\mathrm{ClF}_{3}$ as an alternative to $\mathrm{BrF}_{5}$ for oxygen isotope analysis. Geochim. Cosmochim. Acta, 46, 1665-1668.

BotTINGA, Y. (1968): Calculation of fractionation factors for carbon and oxygen isotopic exchange in the system calcite-carbon dioxide-water. Jour. Phys. Chem., 72, 800-808.

BotTINGA, Y. Y JAVOY, M. (1975): Oxygen isotope partitioning among the minerals in igneous and metamorphic rocks. Rev. Geophys. Space Phys., 13, 255-263.

Bouchot, V., Ledru, P., Lerouge, C., Lescuyer, J.-L. Y MilésI, J.-P. (2005): Late-Variscan mineralizing systems related to orogenic processes: the French Massif Central. Ore Geol. Rev. 27, 169-197.

BozZo, A.T., CHEN, H.S., KASS, J.R. Y BARDUHN, A.J. (1973): The properties of the hydrates of chloride and carbon dioxide. En: $4^{\text {th }}$ Int. Symp. On Fresh Water from the sea (A. Delyannis y E. Delyannis, Eds.), 3, 437-451.

BREITER, K., ŠKODA, R. y UHER, H. (2007): Nb-Ta-Ti-W-Sn-oxide minerals as indicators of peraluminous P- and F-rich granitic system evolution: Podlesí, Czech Republic. Miner. Petrol., 91, 225-248.

BuRnhaM, C.W. y OHмото, H. (1980): Late stage processes of felsic magmatism. Soc. Minning Geol. Japan, Special Issue, 8, 1-11.

BURT, D.M. (1981): Acidity-salinity diagrams. Application to greisen and porphyry deposits. Econ. Geol., 76, 832-843. 
BURT, D.M. Y LONDON, D. (1982): Subsolidus equilibria. Mineral. Assoc. Canada, Short Course Handbook, 8, 329-346.

CAMERON, E.N., JAHNS, R.H., McNaIR, A.H. y PAGE, L.R. (1949): Internal structure of granitic pegmatites. Econ. Geol. Monograph, 2. 115 p.

CARITAT, P., HUtCHEON, I. Y WALSHE, J.L. (1993): Chlorite goethermometry; a review. Clay Clay Miner., 41, 219-239.

Carruzzo, S., Clarke, D.B., Pelrine, K.M. y MacDonald, M.A. (2006): Texture, composition and origin of rutile in the South Mountain batholith, Nova Scotia. Can. Mineral., 44, 715-729.

Cathelineau, M. (1988): Cation site occupancy in chlorites and illites as a function of temperature. Clay Miner., 23, 471-485.

Cathelineau, M. y Nieva, D. (1985): A chlorite solid solution geothermometer. The Los Azufres (Mexico) geothermal system. Contrib. Miner. Petrol., 91, 235-244.

ČERNÝ, P. (1989a): Characteristics of pegmatite deposits of tantalum. En: Lanthanides, Tantalum and Niobium (P. Möller, P. Černý y F. Saupé, Eds.). SGA Special Publication, 7, 195239. Springer-Verlag.

ČERNÝ, P. (1989b): Exploration strategy and methods for pegmatite deposits of tantalum. En: Lanthanides, Tantalum and Niobium (P. Möller, P. Černý y F. Saupé, Eds.). SGA Special Publication, 7, 274-302. Springer Verlag.

ČERNÝ, P. (1991a): Rare element granitic pegmatites. Part I: Anatomy and internal evolution of pegmatite deposits. Geosci. Can., 18, 49-67.

ČERNÝ, P. (1991b): Rare-element granitic pegmatites. Part II. Regional to global environments and petrogenesis. Geosci. Can., 18, 68-81.

ČERNÝ, P. (1991c): Fertile granites of Precambrian rare-element pegmatite fields: is geochemistry controlled by tectonic setting or source lithologies? Precambrian Res., 51, 429468.

ČERNÝ, P. (1992a): Geochemical and petrogenetic features of mineralization in rare-element granitic pegmatites in the light of current research. Appl. Geochem., 7, 393-416.

ČERNÝ, P. (1992b): Regional zoning of pegmatite populations and its interpretation. Mitt. Österr. Mineral. Ges., 137, 99-107.

ČERNÝ, P. Y ERCIT, S. (1985): Some recent advances in the mineralogy and geochemistry of $\mathrm{Nb}$ and Ta in rare-element granitic pegmatites. Bull. Minéral., 108, 499-532.

ČERNÝ, P. Y ERCIT, T.S. (2005): The classification of granitic pegmatites revisited. Can. Mineral., 43, 2005-2026. 
ČERNÝ, P. Y NĚMEC, D. (1995): Pristine vs. contamined trends in Nb,Ta-oxide minerals of the Jihlava pegmatite district, Czech Republic. Miner. Petrol., 55, 117-207.

ČeRnÝ, P., BLeVIN, P.L., CUNEY, M. Y LONDON, D. (2005a): Granite-related ore deposits. Econ. Geol. 100 th Anniversary Volume, 337-370.

Černý, P., ChAPMAN, R., FerReIRA, K. y SMEdS, S.-A. (2004): Geochemistry of oxide minerals of $\mathrm{Nb}, \mathrm{Ta}, \mathrm{Sn}$, and $\mathrm{Sb}$ in the Varuträsk granitic pegmatite, Sweden: The case of an "anomalous" columbite-tantalite trend. Am. Mineral., 89, 505-518.

ČennÝ, P., ERCIT, T.S., WISE, M.A., ChAPMAN, R. y BUCK, M. (1998): Compositional, structural and phase relationships in titanian ixiolite and titanian columbite-tantalite. Can. Mineral., 36, 574-561.

ČERnÝ, P., GoAD, B.E., HAWTHORNE, C. Y CHAMPAN, R. (1986): Fractionation trends of the Nband Ta-bearing oxide minerals in the Greer Lake pegmatitic granite and its pegmatite aureole, southeastern Manitoba. Am. Mineral., 71, 501-517.

ČennÝ, P., Masau, M., GoAd, B.E. y Ferreira, K. (2005b): The Greer Lake leucogranite, Manitoba, and the origin of lepidolite-subtype granitic pegmatites. Lithos, 80, 305-321.

ČERNÝ, P., NOVAK, M. Y CHAPMAN, P. (1992): Effects of sillimanite-grade metamorphism and shearing on $\mathrm{Nb}$-Ta-oxide minerals in granitic pegmatites: Marsikov, Northern Moravia, Czechoslovakia. Can. Mineral., 30, 699-718.

ChANG, L.L.Y., WU, D. Y KNOWLES, C.R. (1988): Phase relations in the system $\mathrm{Ag}_{2} \mathrm{~S}-\mathrm{Cu}_{2} \mathrm{~S}-\mathrm{PbS}-$ $\mathrm{Bi}_{2} \mathrm{~S}_{3}$. Econ. Geol., 83, 405-418.

CHAPPeLL, B.W. Y White, A.J.R. (1974): Two contrasting granite types. Pacific Geol., 8, 173-174.

ChAPPELL, B.W. Y WHITE, A.J.R. (2001): Two contrasting granite types: 25 years later. Austr. Jour. Earth Sci., 48, 489-499.

CHAROY, B. (1986): The genesis of the Cornubian batholith (southwest England): the example of the Carnmenellis pluton. J. Petrol., 27, 571-604.

Charoy, B. Y NORONhA, F. (1996): Multistage growth of a rare-element, volatile-rich microgranite at Argemela (Portugal). J. Petrol., 37, 73-94.

Charoy, B., Chaussidon, M., le Carlier De Veslud, C. y Duthou, J.l. (2003): Evidence of Sr mobility in and around the albite-lepidolite-topaz granite of Beauvoir (France): an in-situ ion and electron probe study of secondary Sr-rich phosphates. Contrib. Mineral. Petr., 145, 673690.

CIOBANU, C.L., CoOK, N.J. Y PRING, A. (2005): Bismuth tellurides as gold scavenger. En: Mineral deposit research: meeting the global challenge (J.W. Mao y F.P. Bierlen, Eds.). Springer, BerlinHeidelberg-New York, 1383-1386. 
Ciobanu, C.L., Cook, N.J., Pring, A., Brugger, J., Danyushevsky, L.V. y ShimizU, M. (2009): "Invisible gold" in bismuth chalcogenides. Geochim. Cosmochim. Acta, 73, 1970-1999.

Ciobanu, C.L., Cook, N.J. y SUndblad, K. (2002): Genetic insights from exotic trace mineral associations at Orijarvi and lilijarvi, SW Finland. Metallogeny of Precambrian Shields, Ky'iv, Ukraine, 13-26 Sept. Abstract volume, 41-45

CLARK, A. H. (1964): Preliminary study of the temperatures and confining pressures of granite emplacement and mineralization, Panasqueira, Portugal. Inst. Mining Metallurgy, Trans., 73, 813-824.

CLARK. J.R. Y WILLIAMS-JONES, A.E. (2009): Compositional variability of rutile in hydrothermal ore deposits. Am. Geophys. Union, Spring Meeting 2009, abstract \#V14A-01.

CLAYTON, R.N. Y MAYEDA, T.K. (1963): The use of bromine pent fluoride in the extraction of oxygen from oxides and silicates for isotopic analysis. Geochim. Cosmochim. Acta, 27, 43-52.

CLAYTON, R.N., O'NEIL, J.R. y MAYEDA, T.K. (1972): Oxygen isotope exchange between quartz and water. J. Geophys. Res., 77, 3057-3067.

COLEMAN, M.L. y MoORE, M.P. (1978): Direct reduction of sulfates to sulfur-dioxide for isotopic analysis. Anal. Chem., 50, 1594-1595.

Colombo, F., PAnnunzio-Miner, E.V., GAY, H.D., LIRA, R. y DorAIS, M.J. (2007): Barbosalita y lipscombita en Cerro Blanco, Córdoba (Argentina): descripción y génesis de fosfatos secundarios en pegmatitas con triplita y apatita. Rev. Mex. Cienc. Geol., 24, 120-130.

Corretgé, L.G. Y López PlAzA, M. (1976): Geología del área granítica y metamórfica al oeste de Ciudad Rodrigo (Salamanca): I- El complejo esquisto-grauváquico: estratigrafía, metamorfismo y deformación. Stud. Geol., XI, 122-149.

CORRETGÉ, L.G., BEA, F. y SUÁREZ, O. (1985). Las características geoquímicas del batolito de Cabeza de Araya (Cáceres, España): implicaciones petrogenéticas. Trab. Geol. Univ. Oviedo, 15, 219-238.

CRAIG, H. (1961): Isotopic variations in meteoric waters. Science, 133, 1702-03.

CRAIG, J.R. (1967): Phase relations and mineral assemblages in the Ag-Bi-Pb-S system. Miner. Deposita, 1, 278-306.

CRAIG, J.R. Y VAUGHAN, D.J. (1994): Ore Microscopy and Ore Petrography. $2^{\text {nd }}$ Ed., New York, Wiley-Interscience.

CRAWFORD, M.L. (1981): Phase equilibria in aqueous fluid inclusions. En: Short Course in Fluid Inclusions: Applications to Petrology (L.S. Hollister y M.L. Crawford, Eds.) Mineral. Assoc. Can. Short Course Handbook, 6, 75-100. 
CUney, M. Y Friedrich, M. (1987): Physico-chemical and crystalochemical controls on accessory mineral paragenesis in granitoids: implications of uranium metallogenesis. Bull. Mineral., 110, 235-247.

Cuney, M., Alexandrov, P., le Carlier, C., Cheilletz, A., Raimbault, L. y Ruffet, G. (2002): The Sn-W-rare metals mineral deposits of Western Variscan chain in their orogenic setting: The case of the Limousin area (French Massif Central). Geol. Soc. London, Special Publication, 206, 213-228.

Cuney, M., LeRoY, J. y PAGeL, M. (1979): Comportement de l'uranium et du thorium dans les granites uraniferes Français. Sci. de la Terre, Série "Informatique Géologique", 13, 57-63.

Delacourt, C., Wurm, C., Reale, P., Morcrette, M. y MAsquelier, C. (2004): Low temperature preparation of optimized phosphates for Li-battery applications. Solid State Ionics, 173, 113118.

DíAS, R. Y RIBEIRO, A. (1991): Finite strain analysis in a transpressive regime (Variscan autochthon, northeast Portugal). Tectonophysics, 191, 389-397.

DíEz BALDA, M.A. (1980): La sucesión del Complejo-esquisto-grauváquico al Sur de Salamanca. Est. Geol., 36, 131-138.

DíEZ BALDA, M.A. (1983): Características del elipsoide de deformación finita ligado a la segunda fase hercínica en áreas meso y catazonales del Sur de la provincia de Salamanca. Stud. Geol. Salmantina, 18, 65-80.

DíEz BALDA, M.A. (1986): El Complejo Esquisto-Grauváquico, las series paleozoicas y la estructura hercínica al Sur de Salamanca. Acta Salmant. Ser. Ciencias, 52, 162 p.

Díez Balda, M.A., García Casquero, J.L., Monteserín lópez, V., Nozal Martín, F., Pardo ALONSO, M.V. Y RoBles CASAS, R. (1990): Cizallamientos subverticales posteriores a la segunda fase de deformación hercínica al sur de Salamanca. Rev. Soc. Geol. España, 3, 117-125.

Díez Balda, M.A., Martínez Catalán, J.R. y Ayarza Arribas, P. (1995): Syn-collisional extensional collapse parallel to the orogenic trend in a domain of steep tectonics: the Salamanca Detachment Zone (Central Iberian Zone, Spain). Jour. Struct. Geol., 17, 163-182.

Dostal J. y Chatterjee A. K. (2000) Contrasting behavior of $\mathrm{Nb} / \mathrm{Ta}$ and $\mathrm{Zr} / \mathrm{Hf}$ ratios in a peraluminous granitic pluton (Nova Scotia, Canada). Chem. Geol. 163, 207-218.

Douglas, N., Mavrogenes, J., HaCK, A. y England, R. (2000): The liquid bismuth collector model: an alternative gold deposition mechanism. AGC Abstracts, 59, 135.

Dubessy, J., Ramboz, C., nguyen-Trung, C., Cathelineau, M., Charoy, B., Cuney, M., Leroy, J., Poty, B. Y WEISBROD, A. (1987): Physical and chemical controls (fO, T, pH) of the opposite behavior of $U$ and Sn-W as exemplified by hydrothermal deposits in France and Great Britain, and solubility data. Bull. Minéral., 110, 261-281. 
DURNEY, D.W. Y RAMSAY, J. G. (1973): Incremental strains measured by syntectonic crystal growths. En: Gravity and Tectonics (K. A. De Jong y R. Scholten, Eds.), 67-96.

EKSTRÖM, T.K. (1973): Synthetic and natural chlorine-bearing apatite. Contrib. Mineral. Petr., 38, 329-338.

ENADIMSA (1982): Investigación de la concesión "Carlos". Navasfrías (Salamanca). Inédito.

ERCIT, T.S. (1994): The geochemistry and crystal chemistry of columbite-group minerals from granitic pegmatites, southwestern Grenville Province, Canadian Shield. Can. Mineral., 32, 421-438.

ESCUder VIRUete, J. (1998): Relationships between structural units in the Tormes Gneiss Dome (NW Iberian Massif, Spain): geometry, structure and kinematics of contractional and extensional Variscan deformation. Geol. Rundschau, 87, 165-179.

EWING, R. C. (1975): Alteration of metamictic, rare-earth, $\mathrm{AB}_{2} \mathrm{O}_{6}$-type $\mathrm{Nb}$-Ta-Ti oxides. Geochim. Cosmochim. Acta, 39, 521-530.

Fernández, A., Moro, M.C., Prieto, C., Villar, P., Fadón, O. y Cembranos, M.L. (2001a): Datos geotermobarométricos de las mineralizaciones de $\mathrm{Sn}-\mathrm{W}$ de Navasfrías (SO de Salamanca). Bol. Soc. Esp. Mineral., 24A, 159-160.

Fernández, A., Moro, M.C., Prieto, C., Villar, P., Fadón, O. y Cembranos, M.L. (2001b): Fluid inclusions study in the tungsten-tin deposits from Navasfrías district (Salamanca, Spain). XVI ECROFI, Abstracts, Memória (F. Noronha, A. Dória y A. Guedes, Eds.), 7, 153-156. Porto 2001.

FERNÁNDEZ-LEYVA, C. (2007): Estudio metalogenético del batolito de Jálama y su entorno. Tesis Doctoral. Univ. Politéctnica de Madrid, Madrid, 188 p.

FLEISCHER, M. Y MANDARINO, J.A. (2004): Fleischer's Glossary of Mineral Species 2004. Mineral. Rec., Tucson, $310 \mathrm{p}$.

FOORD E.E. YSHAWE, D.R. (1989): The Pb-Bi-Ag-Cu-(Hg) chemistry of galena and some associated sulphosalts: a review and some new data from Colorado, California and Pennsylvania. Can. Mineral., 27, 363-382.

FOORD, E.E., SHAWE, D.R. Y CONKLIN, N.M. (1988): Coexisting galena, $\mathrm{PbS}_{\mathrm{ss}}$ and sulphosalts: evidence for multiple episodes of mineralization in the Round Mountain and Manhattan gold districts, Nevada. Can. Mineral., 26, 355-376.

Fransolet, A.M. (1980): The Eosphorite-Childrenite series associated with the Li-Mn-Fe phosphate minerals from the Buranga pegmatite, Rwanda. Mineral. Mag., 43, 1015-1023.

FRANSOLET, A.M. (2007): Phosphate associations in the granitic pegmatites: the relevant significance of these accessory minerals. Granitic Pegmatites: The State of the Art. Memórias, 8, 7-8. Porto, Portugal (abst). 
Fransolet, A.M., Keller, P. y Fontan, F. (1986): The phosphate mineral associations of the Tsaobismund pegmatite, Namibia. Contrib. Mineral. Petr., 92, 502-517.

Frondel, C. (1949): Wolfeite, xanthoxenite, and whitlockite from the Palermo mine, New Hampshire. Am. Mineral., 34, 692-705.

GAN, H. Y HESS, P.C. (1992): Phosphate speciation in potassium aluminosilicate glasses. Am. Mineral., 77, 495-506.

García de Figuerola, L.C. (1954): Contacto entre el granito y facies de los esquistos verdes. Notas y Com. IGME, 33, 27-55.

García de Figuerola, L.C. (1972): Memoria explicativa de la Hoja Geológica $n^{\circ}$ 451, E. 1:50.000. IGME, Spain.

García de Figuerola, L.C. y PARGA, J.R. (1968): Sobre los ortoneises de Traguntia-Juzbado (Salamanca) y su significación tectónica. Acta Geol. Hisp., III, 69-72.

García Figuerola, L.C., BAscones AlviRA, L. y Martín Herrero, D. (1985a): Mapa geológico de España, E. 1:50.000. Hoja 572 (Valverde del Fresno). IGME.

García Figuerola, L.C., Rodríguez Alonso, M.D., Bascones Alvira, L. y Martín Herrero, D. (1985b): Mapa geológico de España, E. 1:50.000. Hoja 573 (Gata). IGME.

García Puelles, E. (1918): Estudio industrial de los yacimientos wolframíferos y estanníferos de la provincia de Salamanca. Bol. Oficial Minas y Metal., 11, 12 y 13.

García SÁncheZ, A. y GraCia PlAZA, A.S. (1979): Aspectos mineralógicos y geoquímicos de las mineralizaciones (Sn, W, Ta) de la zona norte del plutón del Jálama (Salamanca). Anu. Cent. Edafol. y Biol. Apl. Salamanca, V, 279-288.

GIL y MAESTRE, A. (1880): Descripción física, geológica y minera de la provincia de Salamanca. Mem. de la Com. del Mapa Geológico de España. Madrid.

Gloaguen, E. (2006): Apports d'une étude intégrée sur les realtions entre granites et minéralisations filoniennes (Au et Sn-W) en contexte tardi orogénique (Chaîne Hercynienne, Galice centrale, Espagne). Tesis Doctoral. Univ. de Orleans, Francia, 572 p.

GodoviKov, A.A. (1972): Bismuth sulphosalts: their chemical composition, synthesis and classification. En: Peculiarities of the chemical composition, synthesis, classification. Nauka, Moscow, Russia (en ruso). 303 p.

González lodeiro, F., Martínez Catalán, J.R., Macaya, J. y Álvarez, F. (1988): Sobre la estructura del Antiforme de El Cardoso y el Sinforme de Majaelrayo y su relación con la Falla de Berzosa. Geogaceta, 4, 11-14.

GoUANVIC, Y. Y BABKINE, J. (1985): Metallogenie du gisement à tunstène-etain de Monteneme (N.W. Galice, Espagne). Miner. Deposita, 20, 8-15. 
GRANEY, J.R. Y KESLER, S.E. (1995): Gas composition of inclusion fluid in ore deposits: is there a relation to magmas? En: Magmas, Fluids, and Ore Deposits (J.F.H. Thompson, Ed.). Mineral. Assoc. Can. Short Course Series, 23, 221-245.

HASSAN, A. (1996): Estudio de los granitos uraníferos del macizo de Cadalso-Casillas de Flores (Salamanca-Cáceres, España). Tesis Doctoral. Univ. Complutense de Madrid, 318 p.

HATA, K., HiguchI, M., TAKAHASHI, J. Y KodaiRA, K. (1996): Floating zone growth and characterization of aluminium-doped rutile single crystals. J. Cryst. Growth, 163, 279-284.

HATERT, F. (2004): Etude cristallochimique et synthèse hydrothermale des alluaudites: contribution nouvelle au problem génétique des phosphates de fer et de manganèse dans les pegmatites granitiques et, partant, à celui de l'évolution de ces gisements. Mém. Acad. Royale Sci. Belgique, Cl. Sci., Coll. In-8, 3ème série XXI: 96 p.

Hatert, F., Fransolet, A.M. y MAResch, W.V. (2006): The stability of primary alluaudites in granitic pegmatites: an experimental investigation of the $\mathrm{Na}_{2}\left(\mathrm{Mn}_{2-2 x}\right)\left(\mathrm{PO}_{4}\right)_{3}$ system. Contrib. Mineral. Petr., 152, 399-419.

HAWTHORNE, F.C. Y HENRY, D.J. (1999): Classification of the minerals of the tourmaline group. Eur. J. Mineral., 11, 201-215.

HEINRICH, C.A. (1990): The chemistry of hydrothermal tin(-tungsten) ore deposition. Econ. Geol., 85, 457-481.

HeinRICH, E.W. (1948): Pegmatites of the Eight Mile Park, Fremont County, Colorado. Am. Mineral., 33, 550-587.

Henderson, C.M.B., Martin, J.S. y Mason, R.A. (1989): Compositional relations in Li-micas from S.W England and France: an ion- and electron-microprobe study. Mineral. Mag., 53, 427-449.

HENRY, D.J. Y GUIDOTTI, C.V. (1985): Tourmaline as a petrogenetic indicator mineral: an example from the staurolite-grade metapelites of NW Maine. Am. Mineral., 70, 1-15.

HEY, M.H. (1954): A new review of the chlorites. Mineral. Mag., 30, 277-298.

HOGARTH, D.D. (1977): Classification and nomenclature of the pyrochlore group. Am. Mineral., 62, 403-410.

HOCHLEITNER, R. y FEHR, K.T. (2010): The keckite problem and its bearing on the crystal chemistry of the jahnsite group; Mössbauer and electron-microprobe studies. Can. Mineral., 48, 1445-1453

HU, S., SUN, M., YAN, Z., XU, J., CAO, X. Y YE, Y. (1984): An important metallogenetic model for $\mathrm{W}, \mathrm{Sn}$ and rare granitophile elements ore deposits related to metasomatically altered granites. Geology of Granites and their Metallogenetic Relations, International Symposium, Proceedings, 519-537. Nanjing University, Nanjing, 1982. 
HuANG, X.L., WANG, R.C., Chen, X.M., HU, H. Y LIU, C.S. (2002): Vertical variations in the mineralogy of the Yichun topaz-lepidolite granite, Jiangxi province, southern china. Can. Mineral., 40, 1047-1068.

HUTCHINSON, M. N. Y SCOTT, S. D. (1980): Sphalerite geobarometry applied to metamorphosed sulfide ores of the Swedish Caledonides and U.S. Appalachians. Norges Geol. Unders., 360, 59-71.

HuVELIN, P., ORLIAC, M. y PERMINGEAT, F. (1972): Ferrialluaudite calcifère de Sidi Bou Othomane (Jelibet, Maroc). Notes Serv. Géol. Maroc, 241, 35-49.

IGLESIAS, M. Y RIBEIRO, A. (1981): La zone de cisaillement ductile de Juzbado (Salamanca) Penalva do Castelo (Viseu): un linéament ancien réactivé pendant l'orogénie hercynienne? Com. Serv. Geol. Portugal, LXVII, 89-93.

IGME-CGS (1976): Fase intermedia de prospección de Estaño y Wolframio. Área de El PayoVillamiel (Cáceres-Salamanca). Inédito. IGME, Informe 10313.

ISHIHARA, S. (1977): The magnetite-series and ilmenite-series granitic rocks. Mining Geol., 27, 293-305.

JACKSON, K.J. Y HELGESON, H.C. (1985): chemical and thermodynamic constraints on the hydrothermal transport and deposition of tin: I. Calculation of the solubility of cassiterite at high pressures and temperatures. Geochim. Cosmochim. Acta, 49, 1-22.

JAHNS, R.H. Y BURNHAM, W.C. (1969): Experimental studies of pegmatite genesis. 1. A model for the derivation and crystallization of granitic pegmatites. Econ. Geol., 64, 843-864.

JCYL (1985): Estimación de reservas minerales de estaño en las provincias de Salamanca, Segovia y Ávila. Inédito. Consejería de Industria, Energía y Trabajo de la Junta de Castilla y León.

JCYL (1986): Estudio de las mineralizaciones de rocas pegmatíticas en Castilla y León. Inédito. Dirección General de Política Industrial de la Consejería de Industria, Energía y Trabajo de la Junta de Castilla y León. Proyecto 6/85.

JCYL-INTECSA (1986): Estudio de las posibilidades de minería de Litio en Castilla y León. Inédito. Dirección General de Política Industrial de la Consejería de Industria, Energía y Trabajo de la Junta de Castilla y León. Proyecto 9/85.

JCYL-TAGSA (1987): Estudio de prospección geoquímica de la vertiente norte de la Sierra de Gata (Salamanca). Inédito. Dirección General de Política Industrial de la Consejería de Fomento de la Junta de Castilla y León. Proyecto 2/86.

JIANG, W.W., PEACOR, D.R. Y BUSECK, P.R. (1994): Chlorite geothermometry; contamination and apparent octahedral vacancies. Clay Clay Miner., 42, 593-6052. 
JOHAN, V. Y JOHAN, Z. (1994): Accessory minerals of the Cínovec (Zinnwald) granite cupola, Czech Republic. Part 1: Nb-, Ta- and Ti-bearing oxides. Miner. Petrol., 51, 323-343.

JOWET, E.C. (1991): Fitting iron and magnesium into de hydrothermal chlorite geothermometer. Join Ann. Meet. Geol. Assoc. Can., Toronto, Abstracts, 16, 62 p.

Julivert, M., Fontboté, J.M., RibeiRo, A. y NABAIS-Conde, L.E. (1972): Mapa tectónico de la Península Ibérica y Baleares a escala 1:1.000.000. IGME, Memoria explicativa, $113 \mathrm{p}$.

KARUP-MøLLER, S. (1977): Mineralogy of some Ag-(Cu)-Pb-Bi sulphide associations. Bull. Geol. Soc. Denmark, 26, 41-68.

KARUP-MØLLER, S. Y MAKOVICKY, E. (1979): On pavonite, cupropavonite, benjaminite and "oversubstituted" gustavite. Bull. Minéral., 102, 351-367.

KARUP-MØLLER, S. Y MAKOVICKY, E. (1981): Ag- and Bi-rich Heyrovskyite from the Bi-W-Mo mineralization at Castelgar, British Columbia. Can. Mineral., 19, 349-353.

KARUP-MøLLER, S. Y MAKOVICKY, E. (1992): Mummeite - A new member of the pavonite homologous series from Alaska Mine, Colorado. N. Jb. Miner. Abh., 12, 555-576.

Keller, P. y Von KNorring, O. (1989): Pegmatites at the Okatjimukuju farm, Karibib, Namibia. Part I: Phosphate mineral associations of Clementine II pegmatite. Eur. J. Mineral., 1, 567-593.

KeLLY, W. C. Y RYE, R. O. (1979): Geologic, fluid inclusion, and stable isotope studies of the tintungsten deposits of Panasqueira, Portugal. Econ. Geol., 74, 1721-1822.

KERRICH, R. Y FYFE, W.S. (1988): The formation of gold deposits with particular reference to Archean greenstone belts and Yellowknife. Source of hydrothermal fluids, alteration patterns and genetic models. En: Contribution to the Geology of the Northwest territories. NWT Geology Division, INAC, Yellowknife, 63-95.

KISSIN, S.A. Y OWENS, DE A.R. (1989): The relatives of stannite in the light of new data. Can. Mineral., 27, 673-688.

KLomínskÝ, J., RIEdeR, M., KIEFT, C. y MRÁz, L. (1971): Heyrovskyite, $6\left[\mathrm{~Pb}_{0.86} \mathrm{Bi}_{0.08}(\mathrm{Ag}, \mathrm{Cu})_{0.04}\right]$ $\mathrm{S} \cdot \mathrm{Bi}_{2} \mathrm{~S}_{3}$ from Hůrky, Czechoslovakia, a New Mineral of Genetic Interest. Miner. Deposita, 6, 133-147.

KOJIMA, S. Y SUGAKI, A. (1987): An experimental study on chalcopyritisation of sphalerite induced by hydrothermally metasomatic reactions. Mining Geol., 37, 373-380.

Kostov, I. y Minčeva-Stefanova, J. (1982): Sulphide minerals. Crystal Chemistry, Parageneses and Systematics. E. Schweizerbartsche Verlagsbuchhandlung, $211 \mathrm{p}$.

KOTZER, T.G., KYESER, T.K., KING, R.W. Y KERRICH, R. (1993): An empirical oxygen- and hydrogenisotope geothermometer for quartz-tourmaline and tourmaline-water. Geochim. Cosmochim. Acta, 57, 3421-3126. 
KRANIDIOTIS, P. Y MACLEAN, W.H. (1987): Systematics of chlorite alteration and the Phelps Dodge massive sulfide deposit. Matagami, Quebec. Econ. Geol., 82, 1898-1992.

KRETSCHMAR, U. Y SCOTT, S. (1976): Phase relations involving arsenopyrite in the system FeAs-S and their application. Can. Mineral., 14, 364-386.

KRETZ, R. (1983): Symbols of rock-forming minerals. Am. Miner., 68, 277-279.

LINNEN, R.L. (1998): The solubility of Nb-Ta-Zr-Hf-W in granitic melts with Li and Li+F: Constraints for mineralization in rare metal granites and pegmatites. Econ. Geol., 93, 10131025.

LINNEN, R.L. (2004a): PIG comments and questions, reply. http://www.minsocam.org/MSA/ Special/Pig/Pig_CQ/PIG_CQ/Kjellman.html.

LINNEN, R.L. (2004b): Ferrocolumbite-manganotantalite trends in granites and pegmatites: experimental and natural constraints. Geol. Soc. Amer. Progr. Abstr., 36, 115.

LINNEN, R.L. Y KEPPLER, H. (1997): Columbite stability in granitic melts: consequences for the enrichment and fractionation of $\mathrm{Nb}$ and Ta in the Earth crust. Contrib. Mineral. Petr., 128, 213-227.

LLORENS, T. Y MORO, M.C. (2007): Preliminary study of intragranitic pegmatites in the Sn-W(Au) District of Navasfrías (SW of Salamanca, Spain). Granitic Pegmatites: the State of the Art. Memórias, 8, 56-57. Porto, Portugal (abst).

LLORENS, T. Y MORO, M.C. (2008): Fosfatos de Al-Fe-Mn en las pegmatitas intragraníticas del distrito de Navasfrías (SO Salamanca). Macla, 8, 145-146. Zaragoza (abst).

LLORENS, T. Y MORO, M.C. (2010a): Microlite and tantalite in the LCT granitic pegmatites of La Canalita, Navasfrías Sn-W District, Salamanca, Spain. Can. Mineral., 48, 549-564.

LLORENS, T. Y MORO, M.C. (2010b): Nb-Ta-oxide minerals in the LCT granitic pegmatites of La Canalita, SW Salamanca, Spain. IMA2010. Acta Miner.-Petro., Abstract Series, 6, 167. Budapest, Hungría.

LLORENS, T. Y Moro, M.C. (2010c): Columbite-group minerals in the Cruz del Rayo pegmatite dikes, SW Salamanca, Spain. IMA2010. Acta Miner.-Petro., Abstract Series, 6, 167. Budapest, Hungría.

LLORENS, T. Y MORO, M.C. (en prensa): Fe-Mn phosphate associations as indicators of the magmatic and hydrothermal evolution of the Jálama batholith in the Navasfrías Sn-W District, Salamanca, Spain. Mineral. Mag.

LOISELLE, M.C. Y WONES, D.R. (1979): Characteristics and origin of anorogenic granites. Geol. Soc. America, Abstracts with Programs, 11, 468. 
LONDON, D. (1987): Internal differentiation of rare-element pegmatites: Effects of boron, phosphorous, and fluorine. Geochim. Cosmochim. Acta, 51, 403-420.

LONDON, D. (1992): The application of experimental petrology to the genesis and crystallization of granitic pegmatites. Can. Mineral., 30, 499-540.

LONDON, D. (1995): Geochemical features of peraluminous granites, pegmatites, and rhyolites as sources of lithophile metal deposits. Mineral. Assoc. Canada, Short Course Series, 23, 175202.

LONDON, D. (1997): Estimating abundances of volatile and other mobile components in evolved silicic melts through mineral-melt equilibria. J. Petrol., 38, 1691-1706.

LONDON, D. (2005): Granitic pegmatites: an assessment of current concepts and direction for the future. Lithos, 80, 281-303.

London, D. (2008): Pegmatites. Can. Mineral., Special Publication, 10, 347 p.

LONDON, D. Y BURT, D.M. (1982): Chemical models for lithium aluminosilicate stabilities in pegmatites and granites. Am. Mineral., 67, 494-509.

LONDON, D., CeRný, P., LOOMIS, J.L. Y PAN, J.J. (1990): Phosphorous in alkali feldspars of rareelement granitic pegmatites. Can. Mineral., 28, 771-786.

London, D., GeORGE, B.M., HAROLD, A.B. Y JeNNIFER, L.L. (1993): Behaviour and effects of phosphorus in the system $\mathrm{Na}_{2} \mathrm{O}-\mathrm{K}_{2} \mathrm{O}-\mathrm{Al}_{2} \mathrm{O}_{3}-\mathrm{SiO}_{2}-\mathrm{P}_{2} \mathrm{O}_{5}-\mathrm{H}_{2} \mathrm{O}$ at $200 \mathrm{MPa}\left(\mathrm{H}_{2} \mathrm{O}\right)$. Contrib. Mineral. Petr., 113, 450-465.

LONDON, D., MORGAN, G.B. Y HERVIG, R.L. (1989): Vapor-undersaturated experiments with Macusani glass $+\mathrm{H}_{2} \mathrm{O}$ at $200 \mathrm{MPa}$, and the internal differentiation of granitic pegmatites. Contrib. Mineral. Petr., 102, 1-17.

LONDON, D., MORGAN, G.B., VI Y WoLf, M.B. (1996): Boron in granitic rocks and their contact aureoles. En: Boron: Mineralogy, Petrology and Geochemistry (E.S. Grew y L.M. Anovitz, Eds.) Rev. Mineral., 33, 299-330.

LONDON, D., MoRgan VI, G.B. Y Wolf, M.B. (2001): Amblygonite-montebrasite solid solutions as monitors of fluorine in evolved granitic and pegmatitic melts. Am. Mineral., 86, 225-233.

LONDON, D., Wolf, M.B., MoRgan VI G.B. Y Gallego GaRRIDO, M. (1999): Experimental SilicatePhosphate equilibria in peraluminous granitic magmas, with a case study of the Alburquerque Batholith at Tres Arroyos, Badajoz, Spain. J. Petrol., 40, 215-240.

lópez Munguira, A., Nieto, F., Sebastián Pardo, E. y Velilla, N. (1991): The composition of phyllosilicates in Precambrian low-grade metamorphic, clastic rocks from the Southern Hesperian Massif (Spain) used as an indicator to metamorphic conditions. Precambrian Res., 53, 267-279. 
LotTermoser, M.G. Y LU, J. (1997): Petrogenesis of rare-element pegmatites in the Olary Block, South Australia, part 1. Mineralogy and chemical evolution. Miner. Petrol., 59, 1-19.

LOWENSTERN, J.B. (2001): Carbon dioxide in magmas and implications for hydrothermal systems. Miner. Deposita, 36, 490, 502.

LUSK, J., SCOTT, S.D. Y FORD, C.E. (1993): Phase relations in the Fe-Zn-S system to 5 kbars and temperatures between $325^{\circ}$ and $150^{\circ} \mathrm{C}$. Econ. Geol., 88, 1880-1903.

macaya, J., González lodeiro, F., Martínez Catalán, J.R. y Álvarez, F. (1991): Continuous deformation ductile trhusting and backfolding of cover and basament in the Sierra de Guadarrama Hercynian orogen of central Spain. Tectonophysics, 191, 291-309.

MAKovickY, E. (2006): Crystal structures of sulfides and other chalcogenides. En: Sulfide mineralogy and geochemistry (D.J. Vaughan, Ed.). Rev. Mineral. Geochem., 61, 7-125.

MAKOVICKY, E. Y KARUP-MøLLER, S. (1977a): Chemistry and crystallography of the lillianite homologous series. Part I. N. Jb. Miner. Abh., 130, 264-287.

MAKOVICKY, E. Y KARUP-MøLLER, S. (1977b): Chemistry and crystallography of the lillianite homologous series. Part II. N. Jb. Miner. Abh., 131, 56-82.

MAKOVICKY, E. Y MAKOVICKY, M. (1978): Representation of compositions in the bismuthiniteaikinite series. Can. Mineral., 16, 405-409.

MAKOVICKY, E., MUMme, G. W. Y MAdSEN, I. C. (1992): The crystal structure of vikingite. N. Jb. Miner. Abh., 10, 454-468.

MAKovickY, E., G. MUMme, W. Y WATTS, J. A. (1977): The crystal structure of synthetic pavonite, $\mathrm{AgBi}_{3} \mathrm{~S}_{5}$, and the definition of the pavonite homologous series. Can. Mineral., 15, 339-348.

MAKovicky, E., PAAR, W.H., PUTZ, H. Y ZAGLeR, G. (2010): Dantopaite, $\mathrm{Ag}_{5} \mathrm{Bi}_{13} \mathrm{~S}_{22}$, the ${ }^{6} \mathrm{P}$ natural member of the pavonite homologous series, from Erzwies, Austria. Can. Mineral., 48, 467481.

MalladA, L. (1896): Explicación del Mapa Geológico de España. Com. del Mapa Geológico, Memorias T.2. Madrid.

MANGAS, J. Y ARRIBAS, A. (1987): Fluid inclusion study in different types of tin deposits associated with the hercynian granites of western Spain. Chem. Geol., 61, 193-208.

MANGAS, J. Y PÉREZ-ToRRADo, F.J. (1995): Fluid inclusion and stable isotope studies in Sn-W deposits of western Spain. Mineral Deposits: From their origin to their environmental impacts. Proceedings of the third biennial SGA Meeting (J. Pašava, B. Kříbek y K. Žák, Eds.), Prague, Czech Republic, 473-476.

Martín Herrero, D., Bascones Alvira, L. y García de Figuerola, L.C. (1984): Mapa Geológico de España a escala 1:50.000. Hoja 596 (Moraleja). Memoria explicativa. IGME. 
MARTínez CATALÁN, J.R. y DíEZ BALDA, M.A. (1987): Structural pattern and ascent model in the Central Extremadura batholith, Hercynian belt, Spain: Discussion. J. Struct. Geol., 9, 381-382.

Martínez Catalán, J.R., Martínez Poyatos, D. y BeA, F. (2004): Zona Centroibérica. En: Geología de España (J.A. Vera, Ed.). SGE-IGME, Madrid, España, 68-133.

MARtínez Poyatos, D., Nieto, F., AZOR, A. y SimAnCAS, J.F. (2001): Relationships between very low-grade metamorphism and tectonic deformation: examples from the southern Central Iberian Zone (Iberian Massif, Variscan Belt). Jour. Geol. Soc. (London), 158, 953-968.

Matthews, A., Putlitz, B., Hamiel, Y. y Hervig, R.L. (2003): Volatile transport during the crystallization of anatectic melts: oxygen, boron and hydrogen stable isotope study on the metamorphic complex of Naxos, Greece. Geochim. Cosmochim. Acta, 67, 3145-3163.

MiLLER, C.F. (1985): Are strongly peraluminous magmas derived from pelitic sedimentary sources?. J. Geol., 93, 673-689.

MONIER, G. Y ROBERT, J.L. (1986): Evolution of the miscibility gap between muscovite and biotite solid solutions with increasing lithium content: an experimental study in the system $\mathrm{K}_{2} \mathrm{O}-\mathrm{Li}_{2} \mathrm{O}-\mathrm{MgO}-\mathrm{FeO}-\mathrm{Al}_{2} \mathrm{O}_{3}-\mathrm{SiO}_{2}-\mathrm{H}_{2} \mathrm{O}-\mathrm{HF}$ at $600^{\circ} \mathrm{C}, 2$ kbar $\mathrm{PH}_{2} \mathrm{O}$ : comparison with natural lithium micas. Mineral. Mag., 50, 641-651.

Monier, G., Mergoli-Daniel, J. y Labernardiere, H. (1984): Générations succesives de muscovites et feldspaths potassiques dans les leucogranites du massif de Milevaches (Massif Central Français). Bull. Mineral., 105, 55-68.

Moore, J. Y MoORE, D.J. (1979): Fluid inclusion study of mineralization at St. Michael's Mount, Cornwall. Trans. Instn. Mining Metall., 88B, 57-60.

MoorE, P.B. (1971): Crystal chemistry of the alluaudite structure type: contribution to the paragenesis of pegmatite phosphate giant crystals. Am. Mineral., 56, 1955-1975.

Moore, P.B. (1973): Pegmatite phosphates: descriptive mineralogy and crystal chemistry. Mineral. Rec., 4, 103-130.

Moro, M.C. (2000): Estudio de las mineralizaciones hidrotermales de oro y metales asociados de Castilla y León (España). Proyecto FEDER (1FD97-0235).

Moro, M.C., Villar, P., Fadón, O., Fernández, A., Cembranos, M.L. y Crespo, J.L. (2001): Bismutinita, pavonita, gustavita y homólogos de lillianita en los depósitos de $\mathrm{Sn}$-W del distrito de Navasfrías (SO de Salamanca). Bol. Soc. Esp. Mineral., 24-A, 161-162.

MoRo, M.C. y LLORENS, T. (2008): Triplita-apatito-isokita en las venas de cuarzo intragraníticas con Sn-W de La Salmantina (Navasfrías, SO de Salamanca). Macla, 9, 167-168 (abst). Zaragoza.

MÖlleR, P., DULSKI, P., SZACKI, W., MALOW, G. y RIEDEL, E. (1988): Substitution of tin in cassiterite by tantalum, niobium, tungsten, iron and manganese. Geochim. Cosmochim. Acta, 52, 14971503. 
Nedachi, M., TAKeuchi, T., Yamaoka, K. y TANiguchi, M. (1973): Bi-Ag-Pb-S minerals from Agenosawa mine, Akita Prefecture, northeastern Japan. Tohoku Univ., Sci. Rep., Third Ser, 12, 69-80.

NeIVA, A.M.R. (1996): Geochemistry of cassiterite and its inclusions and exsolution products from tin and tungsten deposits in Portugal. Can. Mineral., 34, 745-768.

NeIVA, A.M.R. (2008): Geochemistry of cassiterite and wolframite from tin and tungsten quartz veins in Portugal. Ore Geol. Rev., 33, 221-238.

NiCHOLLS, J. Y CRAWFORD, M.L. (1985): Fortran programs for calculation of fluids properties from microthermometric data on fluid inclusions. Comput. Geosci., 11, 619-645.

NORONhA, F., DoriA, A., DuBESSY, J. y ChAROY, B. (1992): Characterization and timing of the different types of fluids present in the barren and ore-veins of the W-Sn deposit of Panasqueira, Central Portugal. Miner. Deposita, 27, 72-79.

NovÁK, M. Y ČERNÝ, P. (1998): Niobium-Tantalum oxide minerals from complex granitic pegmatites in the Moldanubicum, Czech Republic: primary versus secondary compositional trends. Can. Mineral., 36, 659-672.

NOVÁK, M., ČERNÝ, P. Y UHER, P. (2003): Extreme fractionation and apparent reversal of Nb-Ta fractionation in columbite-group minerals from the Scheibengraben beryl-columbite granitic pegmatite, Maršíkov, Czech Republic. Eur. J. Mineral., 15, 565-574.

NovÁK, M., ČERnÝ, P., CEMPÍREK, J., ŠREIN, V. Y FILIP, J. (2004): Ferrotapiolite as a pseudomorph of stibiotantalite from the Lastovičky lepidolite pegmatite, Czech Republic: an example of hydrothermal alteration at constant Ta/(Ta+Nb). Can. Mineral., 42, 1117-1128.

O'NEIL, J.R. Y TAYLOR, H.P., JR. (1969): Oxygen isotope equilibrium between muscovite and water. J. Geophys. Res., 74, 6012-6022.

Онмото, Н. (1986): Stable isotope geochemistry ore deposits. En: Stable isotopes in high temperature geological processes (J.W. Valley, H.P. Taylor, Jr. y J.R. O’Neil, Eds.). Rev. Mineral., 16, 491-556.

Онмото, H. Y RYE, R.O. (1979): Isotopes of sulfur and carbon. En: Geochemistry of hydrothermal ore deposits (J. Wiley and Sons, Eds.). New York, 509-567.

OntoyeV, D.O., Druzhinin, A.V., TSEPIN, A.I., Vyal'sov, L.N. y Basova, G.V. (1982): Minerals of the gustavite-lillianite series from the Kti-Teberda deposit (northern Caucasus). Int. Geol. Review, 24, 659-670.

PAL, D.C., MishrA, B. y BERnhARDT, H.-J. (2007): Mineralogy and geochemistry of pegmatitehosted Sn-, Ta-Nb-, and Zr-Hf-bearing minerals from the southeastern part of the BastarMalkangiri pegmatite belt, Central India. Ore Geol. Rev., 30, 30-55. 
PALACIOS, T. (1989): Microfósiles de pared orgánica del Proterozoico Superior (región central de la Península Ibérica). Mem. Museo Paleont. Univ. Zaragoza, 3, 1-91.

PARGA, M. (1969): Sistemas de fracturas tardihercínicas del Macizo Hespérico. Trabajos Lab. Geol. Laxe, 37, 1-15.

Pesquera, A., Torres-Ruiz, J., Gil-Crespo, P.P. y Velilla, N. (1999): Chemistry and genetic implications of tourmaline and Li-F-Cs micas from the Valdeflores area (Cáceres, Spain). Am. Mineral., 84, 55-69.

Petruk, W. (1973): Tin sulphides from the deposit of Bunswick Tin Mines Limited. Can. Mineral., 12, 46-54.

PIChaVANT, M., Montel, J.-M. y RIChARD, L.R. (1992): Apatite solubility in peraluminous liquids: Experimental data and an extension of the Harrison-Watson model. Geochim. Cosmochim. Acta, 56, 3855-3861.

PIECZKA, A. (2007): Beusite and an unusual Mn-rich apatite from the Szklary granitic pegmatite, Lower Silesia, Southwestern Poland. Can. Mineral., 45, 901-914.

Pieren, A. (2000): Las sucesiones anteordovícicas de la región oriental de la provincia de Badajoz y área contigua de la de Ciudad Real. Tesis Doctoral, Univ. Complutense de Madrid, $379 \mathrm{p}$.

Pirajno, F. (1992): Hydrothermal mineral deposits. Principles and fundamental concepts for the exploration geologist. Berlin, Springer-Verlag, 709 p.

POLLARD, P.J. (1983): Magmatic and postmagmatic processes in the formation of rocks associated with rare-element deposits. Trans. Inst. Min. Metall., 92, B1-B9.

PolYA, D.A. (1988): Compositional variation in wolframites from the Barroca Grande mine, Portugal: evidence for fault-controlled ore formation. Mineral. Mag., 52, 497-503.

Polya, D.A., Foxford, K.A., StuARt, F., BoyCe, A. y FAllick, A.E. (2000): Evolution and paragenetic context of low $\delta D$ hydrothermal fluids from the Panasqueira W-Sn deposits, Portugal: New evidence from microthermometric stable isotope, noble gas and halogen analyses of primary fluid inclusions. Geochim. Cosmochim. Acta, 64, 3357-3371.

POTTER, R.W. Y BROWN, D.L. (1977): The volumetric properties of aqueous sodium chloride solutions from $0{ }^{\circ} \mathrm{C}$ to $500{ }^{\circ} \mathrm{C}$ and pressures up to 2000 bars based on a regression of available data in the literature. U.S. Geol. Survey Bull., 1421, 36 p.

PUZIEWICZ, J. Y JohANNES, W. (1988): Phase equilibria and composition of Fe-Mg-Al minerals and melts in water-saturated peraluminous granitic system. Contrib. Mineral. Petr., 100, 156168. 
RaIMBaULt, L. (1998): Composition of complex lepidolite-type granitic pegmatites and of constituent columbite-tantalite, Chèdeville, Massif Central, France. Can. Mineral., 36, 563583.

Raimbault, L., Charoy, B., Cuney, M. y Pollard, P.J. (1991): Comparative geochemistry of Tabearing granites. En: Source, Transport and Deposition of Metals (M. Pagel y J. Leroy, Eds.). Balkema, Rotterdam, The Netherlands. 793-796.

Raimbault, L., Cuney, M., Azencott, C., Duthou, J.L. Y Joron, J.L. (1995): Geochemical evidence for a multistage magmatic genesis of Ta-Sn-Li mineralization in the Granite at Beauvoir, French Massif Central. Econ. Geol., 90, 548-576.

RAMírez, J.A. (1996): Estudio petrológico, geoquímico e isotópico del Batolito de Jálama (Norte de Extremadura). Tesis Doctoral, Univ. Granada, 201 p.

RAMíREZ, J.A. Y MENÉNDEZ, L.G. (1999): A geochemical study of two peraluminous granites from south-central Iberia: the Nisa-Albuquerque and Jálama batholiths. Mineral. Mag. 63, 85-104.

RAMíREZ, J.A. Y GRUNDVIG, S. (2000): Causes of geochemical diversity in peraluminous granitic plutons: the Jálama pluton, Central-Iberian Zone (Spain and Portugal). Lithos, 50, 171-190.

RAMSAY, J. G. (1980): The crack-seal mechanism of rock deformatiom. Nature, 284, 135-139.

RAPP, J.F., KLEMME, S., BUTLER, I.B. Y HARLEY, S.L. (2010): Extremely high solubility of rutile in chloride and fluoride-bearing metamorphic fluids: an experimental investigation. Geology, 38, 323-326.

Reale, P., Scrosati, B., Delacourt, C., Wurm, C., Morcrette, M. y Masquelier, C. (2003): Synthesis and thermal behavior of crystalline hydrated iron (III) phosphates of interest as positive electrodes in Li batteries. Chem. Mater., 15, 2021-5058.

RECIO, C., FALLICK, A.E. Y UGIDOS, J.M. (1991): Sulphur isotope systematic of granitoids and associated rocks from the Ávila-La Alberca area (Western Sistema Central, Spain). Rev. Soc. Geol. España, 4, 371-381.

ROBINSON, B. W. Y KUSAKABE, M. (1975): Quantitative separation of sulphur dioxide for ${ }^{34} \mathrm{~S} /{ }^{32} \mathrm{~S}$ analyses from sulphides by combustion with cuprous oxide. Anal. Chem., 47, 1179-1181.

Roda, E., Fontan, F., Pesquera, A. y Velasco, F. (1996): The phosphate mineral association of the granitic pegmatites of the Fregeneda area (Salamanca, Spain). Mineral. Mag., 60, 767778.

RodA, E., Keller, P., PesquerA, A. y FontAN, F. (2007): Micas of the muscovite-lepidolite series from the Karibib pegmatites, Namibia. Mineral. Mag., 71, 41-62. 
RodA, E., Pesquera, A., Gil-Crespo, P.P., Torres-Ruiz, J. y de PArseval, P. (2006): Mineralogy and geochemistry of micas from the Pinilla de Fermoselle pegmatite (Zamora, Spain). Eur. J. Mineral., 18, 369-377.

Rodríguez Alonso, M.D. (1985): El Complejo Esquisto-Grauwáquico y el Paleozoico en el Centro-Oeste español. Acta Salamant., 51, 1-174.

Rodríguez Alonso, M.D. y Alonso GAVILÁn, G. (Eds.) (1995): Neoproterozoic-Lower Cambrian in the Central-Western part of the Iberian Peninsula. Spain-Portugal. Post-Confer. Field guide, XIII Geol. Meet. West of the Iberian Peninsula, 120 p.

Rodríguez Alonso, M.A., García de Figuerola, L.C., Bascones Alvira, L., Robles Casas, R., Álvarez nava de OÑate, M. y Picart Boira, J. (1990): Mapa geológico de España, Escala 1:50.000, Hoja 550 (Fuenteguinaldo). IGME, Memoria explicativa, 71 p.

Rodríguez Alonso, M.D., Peinado, M., lópez Plaza, M., Franco, P., Carnicero, A. y Gonzalo, J.C. (2004): Neoproterozoic-Cambrian synsedimentary magmatism in the Central Iberian Zone (Spain): Geology, petrology and geodynamic significance. Int. Jour. Earth. Sci., 93, 897-920.

Roedder, E. (1984): Fluid inclusions. Rev. Mineral., 12. Mineral. Soc. Amer., 644 p.

RYZHENKo, B., Kovalenko, N. Y PRISYAgINA, N. (2006): Titanium complexation in hydrothermal systems. Geochem. Int., 44, 879-895.

SAaVedra, J. y Pellitero, A. (1973): Estudio geoquímico de rocas ígneas del norte de la provincia de Cáceres. Stud. Geol., VI, 49-63.

SAAVedrA, J. y Pellitero, A. (1975): Factores geoquímicos en la génesis de los yacimientos de Sn y W asociado a rocas plutónicas ácidas. Aplicación al granito de Jálama. Tecniterrae, 8-15.

SaAvedra, J., Pellitero, P., García, A. y Madruga, F. (1977): Estudio del granito mineralizado del Jálama, Salamanca-Cáceres, España. Bol. Geol. Min., 88, 333-344.

San José, M.A., Pieren, A., García hidalgo, F.J., Vilas, L., Herranz, P., Peláez, J.R. y Perejón, A. (1990): Central Iberian Zone. Ante-Ordovician Stratigraphy. En: Pre-Mesezoic Geology of Iberia (R.D. Dallmayer y E. Martínez García, Eds.), Springer-Verlag, Berlín, 147-159.

SAWKINS, F.J. (1966): Preliminary fluid inclusion studies of the mineralisation associated with the Hercynian granites of Southewst England. Trans. Inst. Min. Metall., 75, B109-B112.

SejkorA, J., ŠKodA, R., Ondruš, P, BerAn, P. y SüSSER, C. (2006): Mineralogy of phosphate accumulations in the Huber stock, Krásno ore district, Slavkovský les area, Czech Republic. J. Czech Geol. Soc., 51, 103-147.

ScotT, S. D. (1973): Experimental calibration of the Sphalerite Geobarometer. Econ. Geol., 68, 466-474. 
SCOTT, S.D. (1974): Experimental methods in sulfide synthesis. En: Sulfide Mineralogy (P.H. Ribbe, Ed.). Washington, D.C., Mineral. Soc. Am. Rev. Mineral., 1, 1-38.

SCOTT, S.D. (1983): Chemical behavior of sphalerite and arsenopyrite in hydrothermal and metamorphic environments. Mineral. Mag., 47, 427-435.

SCOTT, S.D. Y BARNES, H.L. (1971): Sphalerite geothermometry and geobarometry. Econ. Geol., 66, 653-669.

SELWAY, J.B. Y NOVÁK, M. (1997): Experimental conditions, normalization procedures and used nomenclature for tourmaline. En: Tourmaline, 1997. Field Trip Guidebook (M. Novák y J.B. Selway, Eds.). Morav Museum, Brno, 19-21.

Selway, J.B., Novák, M., Cerný, P. y Hawthorne, C. (1999): Compositional evolution of tourmaline in lepidolite-subtype pegmatites. Eur. J. Mineral., 11, 569-584.

SHAU, Y.-H., PEACOR, D., Y ESSENE, E. (1990): Corrensite and mixed-layer chlorite/corrensite in metabasalt from northern Taiwan: TEM/AEM, EMPA, XRD and optical studies. Contrib. Miner. Petrol., 13, 487-498.

SHEPHERD, T.J., RANKIN, A.H. Y ALDERTON, D.H.M. (1985): A practical guide to fluid inclusions studies. Blackie and Sons, Glasgow and London, $239 \mathrm{p}$.

SHEPPARD, S.M.F. (1977): The Cornubian batholiths, S.W. England: D/H and ${ }^{18} \mathrm{O} /{ }^{16} \mathrm{O}$ studies of kaolinite and other alteration minerals. J. Geol. Soc., 133, 573-591.

SHEPPARD, S.M.F. (1986): Characterization and isotopic variations in natural waters. En: Stable Isotopes in High Temperature Geological Processes (J.W. Valley, H.P. Taylor, Jr. y J.R. O'Neil, Eds.). Rev. Mineral., 16, 165-183.

SIEMCALSA (1997): Mapa Geológico y Minero de Castilla y León, Escala 1:400.000. Junta de Castilla y León.

Simmons, W. "SkiP", Webber, K.L., Falster, A.U. y Nizamoff, J.W. (2003): Pegmatology: Pegmatite Mineralogy, Petrology and Petrogenesis. Rubellite Press, New Orleans, LA. 176 p.

SIMON, G. y ESSENE, E.J. (1996): Phase relations among Selenides, Sulfides, Tellurides and Oxides: I. Thermodynamic properties and calculated equilibria. Econ. Geol., 91, 1183-1208.

SIRBESCU, M.-L.C., HARTWICK, E.E. Y StUdent, J.J. (2008): Rapid crystallization of the Animikie Red Ace Pegmatite, Florence County, northeastern Wisconsin: inclusion microthermometry and conductive-cooling modeling. Contrib. Miner. Petrol., 156, 289-305.

SosA, G.M., Augsburger, M.S. y PedregosA, J.C. (2002): Columbite-group minerals from raremetal granitic pegmatites of the Sierra de San Luis, Argentina. Eur. J. Mineral., 14, 627-636.

SPEAR, F.S. (1993): Metamorphic Phase Equilibria and Pressure-Temperature-Time Paths. Monograph 1, Mineral. Soc. Am., Chantilly, Virginia. 
SPILDE, M.N. Y SHEARER, C.K. (1992): A comparison of tantalum-niobium oxide assemblages in two mineralogically distinct rare-element granitic pegmatites, Black Hills, South Dakota. Can. Mineral., 30, 719-737.

ŠTEMPROK, M. Y ŠULCEK, Z. (1969): Geochemical profile through an ore bearing lithium granite. Econ. Geol., 64, 392-404.

SUZUOKI, T. Y EPSTEIN, S. (1976): Hydrogen isotope fractionation between OH-bearing minerals and water. Geochimi. Cosmochim. Acta, 40, 1229-1240.

TAYLOR, H.P. JR. (1978): Oxygen and hydrogen isotope studies of plutonic granitic rocks. Earth Planet. Sc. Lett., 338, 177-210.

TAYLOR, H.P. JR. Y SHEPPARD, S.M.F. (1986): Igneous rocks. I. Processes of isotopic fractionation and isotope systematic. En: Stable Isotopes in High Temperature Geological Processes (J.W. Valley, H.P. Taylor, Jr. y J.R. O’Neil, Eds.). Rev. Mineral., 16, 227-272.

TAYLOR, R.P. Y FRYER, B.J. (1983): Rare earth element lithogeochemistry of granitoid mineral deposits. Can. Inst. Miner. Metal., Bull., 76, 74-84.

Thompson, J.F.H., Sillitoe, R.H., BAKER, T., LANG, J.R. y MoRTenSEN, J.K. (1999): Intrusionrelated gold deposits associated with tungsten-tin provinces. Miner. Deposita, 34, 323-334.

TINDLE, A.G. Y WEBB, P.C. (1990): Estimation of lithium contents in trioctahedral micas using microprobe data: application to micas from granitic rocks. Eur. J. Mineral., 5, 595-610.

TINDLE, A.G. Y BREAKS, F.W. (1998): Oxide minerals of the Separation Rapids rare-element granitic pegmatite group, northwestern Ontario. Can. Mineral., 36, 609-635.

TINDLE, A.G. Y BREAKS, F.W. (2000): Columbite-tantalite mineral chemistry from rare-element granitic pegmatites: Separation Lake area, NW Ontario, Canada. Miner. Petrol., 70, 165-198.

TINDLE, A.G., BREAKS, F.W. Y WEBB, P.C. (1998): Wodginite-group minerals from the Separation Rapids rare-element granitic pegmatite group, northwestern Ontario. Can. Mineral., 36, 637658.

TISCHENDORF, G., GOTTESMANN, B., FORSTER, H.J. Y TRUMBULL, R.B. (1997): On Li-bearing micas: estimating Li from electron microprobe analysis and an improved diagram for graphical representation. Mineral. Mag., 61, 809-834.

Tischendorf, G., Rieder, M., Förster, H.-J., Gottesmann, B. y Guidotti, Ch.V. (2004): A new graphical presentation and subdivision of potassium micas. Mineral. Mag., 68, 649-667.

TOOTH, B., BRUgGeR, J., CIOBANU, C. Y LIU, W. (2008): Modeling of gold scavenging by bismuth melts coexisting with hydrothermal fluids. Geology, 36, 815-818. 
ToRnos, F. (1989): Los skarns y mineralizaciones asociadas del Sistema Central Español. Modelo de caracterización petrológica, geoquímica y metalogénica. Tesis Doctoral, Univ. Complutense de Madrid, $487 \mathrm{p}$.

Tornos, F., Delgado, A., CAsquet, C. y Galindo, C. (2000): 300 Million years of episodic hydrothermal activity: stable isotope evidence form hydrothermal rocks of the Eastern Iberian Central System. Miner. Deposita, 35, 551-569.

TOULMIN, P., BARTON, P.B. Y WIGgINS, L.B. (1991): Commentary on the spahlerite geothermometer. Am. Mineral., 76, 1038-1051.

UbanelL, A.G. (1981): Características principales de la fracturación tardihercínica en un segmento del Sistema Central Español. Cuad. Geol. Ibérica, 7, 591-606.

Ugidos, J.M., Armenteros, I., Barba, P., Valladares, M.I. y Colmenero, J.R. (1997a): Geochemistry and petrology of recycled orogen-derived sediments: a case study from Upper Precambrian siliciclastic rocks of the Central Iberian Zone, Iberian Massif, Spain. Precamb. Res., 84, 163-180.

Ugidos, J.M., Valladares, M.I., Recio, C., Rogers, G., Fallick, A.E. y Stephens, W.E. (1997b): Provenance of Upper Precambrian-Lower Cambrian shales in the Central Iberian Zone, Spain: evidence from a chemical and isotopic study. Chem. Geol., 136, 55-70.

Valladares, M.I., Barba, P., Colmenero, J.R., Armenteros, I. y Ugidos, J.M. (1998): La sucesión sedimentaria del Precámbrico superior-Cámbrico inferior en el sector central de la Zona Centro-Ibérica: litoestratigrafía, geoquímica y facies sedimentarias. Rev. Soc. Geol. España, 11, 271-283.

VAlLAdARES, M.I., BARBA, P. Y UGIDOS, J.M. (2002a): Precambrian. En: The Geology of Spain (W. Gibbons y T. Moreno, Eds.), Geol. Soc. (London), 7-16.

Valladares, M.I., Barba, P., Ugidos, J.M., Colmenero, J.R. y ARmenteros, I. (2000): Upper Neoproterozoic-Lower Cambrian shales in the Central Iberian Zone: Chemical features and implications for other peri-Gondwanan areas. J. Conf. Abstracts, 4, Annual Meeting of IGCP Project 376, 1021-1022.

VAlladARes, M.I., Ugidos, J.M., BARBA, P. y Colmenero, J.R. (2002b): Contrasting geochemical features of the Central Iberian Zone shales (Iberian Massif, Spain): Implications for the evolution of Neoproterozoic-Lower Cambrian sediments and their sources in other PeriGondwana areas. Tectonophysics, 352, 121-132.

VAN Hook, H.J. (1960): The ternary system $\mathrm{Ag}_{2} \mathrm{~S}_{-} \mathrm{Bi}_{2} \mathrm{~S}_{3}-\mathrm{PbS}$. Econ. Geol., 55, 759-788.

VAUGHAN, D.J. Y CRAIG, J.R. (1997): Sulfide ore mineral stabilities, morphologies, and intergrowth textures. En: Geochemistry of Hydrothermal Ore Deposits (H.L. Barnes, Ed.), 367434. 
VeGAS, R. y DE VICENTE, G. (2004): Sierra de Gata-Peña de Francia. En: Geología de España (J.A. Vera, Ed.), SGE-IGME, Madrid, 626-627.

VESSELINOV, I. Y KERESTEDJIAN, T. (1995): Kinetec aspects of sector zoning in arsenopyrite: a case study. Miner. Petrol., 52, 85-106.

VIDAL, G., JeNSEN, S. y PALACIOS, T. (1994a): Neoproterozoic (Vendian) ichnofossils from Lower Alcudian strata in central Spain. Geol. Mag., 131, 169-179.

Vidal, G., Palacios, T., Gámez-Vintaned, J.A., Díez Balda, M.A. y Grant, S.W.F. (1994b): Neoproterozoic-early Cambrian geology and palaeontology of Iberia. Geol. Mag., 131, 729 765.

Von KNORRING, O. Y FADIPE, A. (1981): On the mineralogy and geochemistry of niobium and tantalum in some granite pegmatites and alkali granites of Africa. Bull. Minéral., 104, 496507.

WAGNER, T. (2007): Thermodynamic modeling of Au-Bi-Te melt precipitation from hightemperature hydrothermal fluids: Preliminary results. En: Mineral Exploration and Research: Digging Deeper. Proc. 9th Biennial SGA meeting (C.J. Andrew, Ed.). Dublin, 769-772.

WEBSTER, J.D. Y HOLLOWAY, J.R. (1990): Partitioning of $F$ and Cl between magmatic hydrothermal fluids and highly evolved granitic magmas. Geol. Soc. Am. Special Paper, 246, 21-34.

WhALEN, J.B. (1985): Geochemistry of an island-arc plutonic suite: the Uasilay-Yau Yau Complex, New Britain, P.N.G. J. Petrol., 26, 603-632.

WHALSE, J.L. (1986): A six component chlorite solid solution model and the conditions of chlorite formation in hydrothermal and geothermal systems. Econ. Geol., 81, 681-703.

WHALSE, J.L. Y SOLOMON, M. (1981): An investigation into de environment of formation of the volcanic hosted Mt. Lyell copper deposits using geology, mineralogy, stable isotopes and a six component chlorite solid solution model. Econ. Geol., 76, 246-284.

WHITNEY, D.L. Y EVANS, B.W. (2010): Abbreviations for names of rock-forming minerals. Am. Mineral., 95, 185-187.

WILKINSON, J.J. (2001): Fluids in hydrothermal ore deposits. Lithos, 55, 229-272.

WISE, M.A. Y FRANCIS, C.A. (1992): Distribution, classification and geological setting of granitic pegmatites in Maine. Northeastern Geol., 14, 82-93.

WILLIS-RICHARDS, J. Y JACKSON, N.J. (1989): Evolution of the Cornubian ore field, southwest England: Part 1. Batholith modeling and ore distribution. Econ. Geol., 84, 1078-1100.

WolF, M.B. Y LoNDON, D. (1994): Apatite dissolution into peraluminous haplogranitic melts: an experimental study of solubilities and mechanisms. Geochim. Cosmochim. Acta, 58, 41274145. 
WONES, D.R. Y EUGSTER, H.P. (1965): Stability of biotite: experiment, theory, and application. Am. Mineral., 50, 1228-1272.

WOOD, S.A. Y SAMSON, I.M. (2000): The hydrothermal geochemistry of tungsten in granitoid environments: I. Relative solubilities of ferberite and scheelite as a function of T, P, pH and $\mathrm{mNaCl}$. Econ. Geol., 95, 143-182.

WORSTER, M.G., HUPPERT, H.E. Y SPARKS, R.S.J. (1990): Convection and crystallization in magma cooled from above. Earth Planet. Sc. Lett., 101, 78-89.

YUND, R.A. Y KULLERUD, G. (1966): Thermal stability of assemblages of the Cu-Fe-S system. J. Petrol., 7, 454-488.

ZANE, A. Y WEISS, Z. (1998): A procedure for classification of rock-forming chlorites based on microprobe data. Rend. Fis. Accad. Lincei, 9, 51-56.

ZANG, W. Y FYFE, W.S. (1995): Chloritization of the hydrothermally altered bedrocks at the Igarapé Bahia fold deposit, Carajás, Brazil. Miner. Deposita., 30, 30-38.

ZHENG, Y.-F. (1991): Calculation of oxygen isotope fractionation in metal oxides. Geochim. Cosmochim. Acta, 55, 2299-2307.

ZHENG, Y.-F. (1992): Oxygen isotope fractionation in wolframite. Eur. J. Mineral., 4, 1331-1335.

ZHENG, Y.-F. (1993): Calculation of oxygen isotope fractionation in hydroxyl-bearing silicates. Earth Planet. Sc. Lett., 120, 247-263. 
Anexos 

San Martín de Trevejo

807 Monzogranito porfídico (MP)

\section{Mina Horia}

\begin{tabular}{llll}
\hline 1040 & Vena de Qz con Apy & 1703 & Vena de Qz con Apy y Py \\
1041 & Vena de Qz con Apy & 1706 & Vena de Qz con Apy, Py y Cst \\
1042 & Vena de Qz con Apy & 1707 & Vena de Qz con Apy, Py y Cst \\
1043 & Vena de Qz con Apy & 1708 & Vena de Qz con Apy, Py y Ap \\
1044 & Vena de Qz con Apy & 1709 & Vena de Qz con Apy \\
1681 & GE con venas de Qz y Apy & 1711 & Vena de Qz con sulfuros y Cst \\
1682 & Granito equigranular (GE) & 1723 & Vena de Qz N170E \\
1686 & Dique Qz-pegmatítico con Apy y Ap & 1724 & Vena de Qz N170E con Apy \\
1687 & Dique Qz-pegmatítico con Apy, Cst y Ap & 1725 & Vena de Qz N170E con Apy \\
1694 & Vena de Qz con Apy y Cst & 1766 & Vena de Qz N170E con Apy \\
1695 & Vena de Qz con Apy, Py y Sp & 1767 & Vena de Qz N170E con Apy \\
1696 & Vena de Qz con Apy, Py y Ap & 1768 & Vena de Qz N170E con Apy \\
1697 & Vena de Qz con Cst y Apy & 1769 & Pegmatita N170E \\
1698 & Vena de Qz con Apy y Cst & 1770 & Vena de Qz N170E \\
1700 & Vena de Qz con Apy & 1771 & Pegmatita N60E \\
1702 & Vena de Qz con Apy & 1773 & Vena de Qz N170E con Apy \\
\hline & & &
\end{tabular}

Mina Mari Carmen

\begin{tabular}{llll}
\hline 1045 & Vena de Qz con Apy & 1718 & Vena de Qz con sulfuros \\
1046 & Vena de Qz con Apy y Cst & 1720 & Vena de Qz con sulfuros \\
1047 & Vena de Qz con Apy & 1774 & Vena de Qz N170E con Apy \\
1048 & Vena de Qz con Apy & 1775 & Vena de Qz N170E con Apy y Py \\
1715 & Vena de Qz con sulfuros oxidados & 1776 & Pegmatita N140E \\
\hline
\end{tabular}

Mina Salmantina

\begin{tabular}{|c|c|c|c|}
\hline 1049 & Vena de Qz con Apy y Cst & 1684 & AB con Apy diseminada \\
\hline 1050 & Vena de Qz con Apy & 1685 & AB con turmalina \\
\hline 1051 & Vena de Qz con Apy & 1688 & LG con Apy diseminada \\
\hline 1052 & Leucogranito (LG) con Apy & 1689 & LG con venas $\mathrm{N} 60^{\circ} / \mathrm{N} 20^{\circ}$ \\
\hline 1053 & Brecha silícea con óxidos & 1690 & Vena de Qz N80E con Apy y Cst \\
\hline 1054 & AB con turmalina y fosfatos & 1691 & Venas de Qz $\mathrm{N} 90^{\circ} \mathrm{E} / \mathrm{N} 65^{\circ} \mathrm{E}$ con Wf y Cst \\
\hline 1055 & LG con turmalina y fosfatos & 1692 & LG alterado \\
\hline 1059 & Vena de Qz con Apy y Wf & 1693 & Vena de Qz N50E con sulfuros \\
\hline 1060 & Vena de Qz con Apy y Cst & 1699 & Vena de Qz N60 E con Apy y Cst \\
\hline 1152 & Aplita con vena de Qz, Apy y Wf & 1701 & Vena de Qz N170E con Apy \\
\hline 1153 & Vena de Qz con Apy & 1704 & Vena de Qz N170 ${ }^{\circ}$ con sulfuros y Cst \\
\hline 1154 & Vena de Qz con Apy y Wf & 1705 & Vena de Qz N40E con Apy \\
\hline 1155 & Vena de Qz con sulfuros & 1710 & Vena de Qz N40E con Ap \\
\hline 1156 & Vena de Qz con Apy & 1712 & Vena de Qz con sulfuros y Cst \\
\hline 1157 & LG con Cst, Wf y Apy & 1713 & Vena de Qz N180E \\
\hline 1158 & Vena de Qz con Wf & 1714 & Vena de Qz N180 E con sulfuros y Cst \\
\hline 1159 & Vena de Qz con sulfuros & 1716 & Vena de Qz N180E con sulfuros \\
\hline 1160 & Vena de Qz con sulfuros & 1717 & Pegmatita $\mathrm{N} 140^{\circ} \mathrm{E}$ con fosfatos \\
\hline 1161 & LG con turmalina & 1719 & Pegmatita $\mathrm{N} 130^{\circ} \mathrm{E}$ \\
\hline 1162 & Vena de Qz con Apy & 1721 & Pegmatita $\mathrm{N} 170^{\circ} \mathrm{E}$ con fosfatos \\
\hline 1180 & Vena de Qz con Apy y Cst & 1722 & Pegmatita $\mathrm{N} 140^{\circ} \mathrm{E}$ \\
\hline 1181 & Vena de Qz con sulfuros y fosfatos & 1772 & Pegmatita $\mathrm{N} 180^{\circ} \mathrm{E}$ con fosfatos \\
\hline 1182 & Metasedimentos con sulfuros & 1798 & Vena de Qz con sulfuros en CEG \\
\hline 1183 & Vena de Qz con fosfatos & 809 & Pegmoaplita con turmalina \\
\hline 1184 & Vena de Qz con Apy y Wf & 825 & Aplita de borde (AB) \\
\hline 1185 & Vena de Qz con Apy y sulfosales & 833 & Vena de Qz N90 $\mathrm{E}$ con sulfuros y fosfatos \\
\hline 1186 & Metasedimentos con sulfuros & 834 & Vena de Qz $\mathrm{N} 90^{\circ} \mathrm{E}$ con sulfuros y fosfatos \\
\hline 1187 & Vena de Qz con sulfuros & 835 & Vena de Qz con fosfatos y uraninita \\
\hline 1188 & Vena de Qz con sulfuros y Wf & 843 & Vena de Qz con fosfatos \\
\hline 1189 & LG con Apy diseminada & 845 & Vena de Qz con fosfatos \\
\hline 1190 & $\mathrm{AB}$ alterada & 846 & Vena de Qz con Apy, Wf y fosfatos \\
\hline 1191 & Vena de Qz con Apy, Py y Cst & 847 & Vena de Qz con Apy, Wf y fosfatos \\
\hline 1683 & LG con turmalina & 848 & Vena de Qz con Apy, Wf y fosfatos \\
\hline
\end{tabular}


Mina Carrasquera

\begin{tabular}{llll}
\hline 1777 & AB con Apy diseminada & 1783 & Vena de Qz N60E con Apy \\
1778 & AB con Apy diseminada & 1784 & Vena de Qz N160 ${ }^{\circ}$ con Apy \\
1779 & Salbanda de vena N150 ${ }^{\circ} \mathrm{E}$ & 1785 & Vena de Qz N150 ${ }^{\circ}$ con sulfuros y Cst \\
1780 & LG parcialmente moscovitizado & 1786 & Pegmatita N40 E con fosfatos \\
1781 & Vena de Qz N40 ${ }^{\circ}$ E con Apy & 1787 & Pegmatita subhorizontal con fosfatos \\
1782 & Vena de Qz N30 ${ }^{\circ}$ E con Apy & & \\
\hline
\end{tabular}

Mina Profunda

\begin{tabular}{llll}
\hline 778 & AB con turmalina & 785 & Pegmoaplita con Apy y Cst \\
779 & Vena de Qz con Apy & 786 & Vena de Qz con sulfuros en LG \\
780 & LG & 787 & Pegmatita con turmalina \\
781 & Vena de Qz con Apy en AB & 788 & Vena de Qz con sulfuros en LG/AB \\
782 & Vena de Qz con Apy en LG & 789 & Pegmatita \\
783 & Vena de Qz con Apy y Wf en LG & 790 & AB con fostatos \\
784 & Vena de Qz oxidada & & \\
\hline
\end{tabular}

Mina Teso de la Matanza

\begin{tabular}{llll}
\hline 1061 & LG con Wf y Apy & 1788 & LG con turmalina \\
1062 & LG con vena de Qz & 1789 & LG con turmalina \\
1063 & LG con Apy & 1790 & Venas de Qz N150 /N80E con Wf y Apy \\
1172 & Vena de Qz con sulfuros y sulfosales & 1791 & Vena de Qz N70E con Apy \\
1173 & Vena de Qz con Apy, Wf y sulfosales & 1792 & Vena de Qz N90E con Apy y Cst \\
1174 & Vena de Qz con sulfuros y sulfosales & 1793 & Vena de Qz N120E con sulfuros en LG \\
1175 & Vena de Qz con Apy y Cst & 1794 & Vena de Qz N170E con feldespatos \\
1176 & Vena de Qz con Apy y Cst & 1795 & Vena de Qz N180E en AB \\
1177 & Vena de Qz con Apy y sulfosales en AB & 1796 & Pegmatita N160 16 con fosfatos \\
1179 & Vena de Qz con Apy y Wf en AB & 1797 & Pegmatita N150 15 con fosfatos \\
\hline
\end{tabular}

Mina Bon y Jálama Alto

\begin{tabular}{llll}
\hline 791 & LG con turmalina & 1058 & Vena de Qz con Apy, Py, Wf \\
792 & Vena de Qtz con Apy y sulfosales & 2270 & Pegmatita con Rt y Cst \\
793 & Vena de Qtz con Apy & 2271 & Vena de Qz con Wf \\
794 & Pegmatita encajada en metamórfico & 2272 & Pegmatita con Rt y Cst \\
795 & Pegmatita con Bt & 2273 & Vena de Qz con Apy en LG \\
796 & AB con bolsadas pegmatíticas & 2274 & Vena de Qz en LG \\
836 & LG de la galería principal & 2276 & Vena de Qz con sulfuros en LG \\
837 & Vena de Qz en LG & 2277 & Vena de Qz brechificada \\
838 & Vena de Qz N40 ${ }^{\circ}$ & 2278 & Vena de Qz con sulfuros en LG \\
839 & Vena de Qz con Wf & 2279 & Vena de Qz \\
840 & Vena de Qz & 2280 & LG con turmalina y clorita \\
841 & Vena de Qz y brecha cloritizada & 2281 & Vena de Qz brechificada con Cst \\
842 & Vena de Qz con turmalina & 2718 & Vena de Qz con sulfuros y Cst \\
844 & LG greisenizado con Apy y Cst & 2719 & Vena de Qz con sulfuros y sulfosales \\
1056 & Vena de Qz con Apy & 2720 & Vena de Qz con sulfuros y sulfosales \\
1057 & Vena de Qz con Apy y Py & & \\
\hline
\end{tabular}

Mina Cruz del Rayo

\begin{tabular}{llll}
\hline 802 & Pegmatita tipo granítico & 1894 & Pegmatita tipo greisen con Cst \\
803 & Pegmatita con fosfatos & 1895 & Pegmatita tipo greisen con Cst \\
804 & Pegmatita de tipo granítico & 2297 & Pegmatita tipo greisen con Cst \\
805 & Pegmatita de tipo granítico & 2298 & Pegmatita tipo greisen con Cst y Brl \\
806 & Pegmatita de tipo granítico & & \\
\hline
\end{tabular}


Mina La Canalita

\begin{tabular}{llll}
\hline 810 & Pegmatita con lepidolita & 816 & Pegmatita con lepidolita \\
811 & Pegmatita con lepidolita & 817 & Pegmatita con lepidolita \\
812 & Pegmatita con lepidolita & 818 & Pegmatita con lepidolita \\
813 & Pegmatita con lepidolita & 819 & Pegmatita con lepidolita \\
814 & Pegmatita con lepidolita & 1066 & Pegmatita con fosfatos y topacio \\
815 & Pegmatita con lepidolita & & \\
\hline
\end{tabular}

\section{Molino del Galo}

\begin{tabular}{|c|c|c|c|}
\hline 820 & Dique aplítico con andalucita y fosfatos & 823 & Dique aplítico con vena de Qz \\
\hline 821 & Dique aplítico con vena de Qz & 824 & Bolsada pegmatítica \\
\hline 822 & Encajante metamórfico & & \\
\hline \multicolumn{4}{|c|}{ Peñaparda } \\
\hline 797 & G5 con andalucita y turmalina & 1725 & Vena de Qz con Py y Chl \\
\hline 798 & Vena de $Q z$ con sulfuros & 1892 & Vena de Qz con sulfuros y Cst \\
\hline 799 & Vena de Qz con sulfuros & 1893 & Vena de Qz con sulfuros \\
\hline 1799 & Vena de Qz con sulfuros & & \\
\hline \multicolumn{4}{|c|}{ El Cruce } \\
\hline 776 & Vena de Qz con sulfuros & 832 & Granito G2 \\
\hline 777 & Vena de Qz con sulfuros & 1064 & Vena de Qz con sulfuros \\
\hline 800 & Vena de Qz con sulfuros & 1065 & Vena de Qz con sulfuros \\
\hline 801 & Vena de Qz con sulfuros & 1192 & Vena de Qz con sulfuros \\
\hline 808 & Vena de Qz con sulfuros & & \\
\hline
\end{tabular}

\begin{tabular}{ll} 
El Jaque & \\
\hline 1068 & Vena de Qz brechoide con Apy \\
1069 & Vena de Qz con sulfuros y Wf \\
1070 & Vena de Qz brechoide con Apy \\
\hline
\end{tabular}





\begin{tabular}{|c|c|c|}
\hline Albita & $A b$ & $\mathrm{NaAlSi}_{3} \mathrm{O}_{8}$ \\
\hline Alluaudita & Allu & $(\mathrm{Na}, \mathrm{Ca}, \square) \mathrm{Mn}^{2+}\left(\mathrm{Fe}^{3+}\right)_{2}\left(\mathrm{PO}_{4}\right)_{3}$ \\
\hline Andalucita & And & $\mathrm{Al}_{2} \mathrm{SiO}_{5}$ \\
\hline Anortita & An & $\mathrm{CaAl}_{2} \mathrm{Si}_{2} \mathrm{O}_{8}$ \\
\hline Apatito & Ap & $\mathrm{Ca}_{5}\left(\mathrm{PO}_{4}\right)_{3}(\mathrm{OH}, \mathrm{F}, \mathrm{Cl})$ \\
\hline Arsenopirita & Apy & FeAsS \\
\hline Barbosalita & $B-L$ & $\left(\mathrm{Fe}^{2+}, \mathrm{Mn}^{2+}\right) \mathrm{Fe}_{2}^{3+}\left(\mathrm{PO}_{4}\right)_{2}(\mathrm{OH})_{2}$ \\
\hline Benjaminita & Bnj & $\mathrm{Ag}_{3} \mathrm{Bi}_{7} \mathrm{~S}_{12}$ \\
\hline Beraunita & Ber & $\mathrm{Fe}^{2+} \mathrm{Fe}_{5}^{3+}\left(\mathrm{PO}_{4}\right)_{4}(\mathrm{OH})_{5} \cdot 6 \mathrm{H}_{2} \mathrm{O}$ \\
\hline Berilo & $\mathrm{Brl}$ & $\mathrm{Be}_{3} \mathrm{Al}_{2}\left(\mathrm{SiO}_{3}\right)_{6}$ \\
\hline Bermanita & Brm & $\mathrm{Mn}^{2+} \mathrm{Mn}_{2}^{3+}\left(\mathrm{PO}_{4}\right)_{2}(\mathrm{OH})_{2} \cdot 4 \mathrm{H}_{2} \mathrm{O}$ \\
\hline Biotita & $\mathrm{Bt}$ & $\mathrm{K}\left(\mathrm{Mg}, \mathrm{Fe}^{2+}\right)_{3}\left(\mathrm{Al}, \mathrm{Fe}^{3+}\right) \mathrm{Si}_{3} \mathrm{O}_{10}(\mathrm{OH}, \mathrm{F})_{2}$ \\
\hline Bismita & Bsm & $\mathrm{Bi}_{2} \mathrm{O}_{3}$ \\
\hline Bismutinita & $\mathrm{Bmt}$ & $\mathrm{Bi}_{2} \mathrm{~S}_{3}$ \\
\hline Bismuto nativo & $\mathrm{Bi}$ & $\mathrm{Bi}$ \\
\hline Calcopirita & Ccp & $\mathrm{CuFeS}_{2}$ \\
\hline Casiterita & Cst & $\mathrm{SnO}_{2}$ \\
\hline Clorita & Chl & $(\mathrm{Mg}, \mathrm{Fe})_{5} \mathrm{Al}_{2} \mathrm{Si}_{3} \mathrm{O}_{18} \mathrm{H}_{2}$ \\
\hline Columbita-(Fe) & Clf & $\mathrm{FeNb}_{2} \mathrm{O}_{6}$ \\
\hline Columbita-(Mn) & $\mathrm{Clm}$ & $\mathrm{MnNb}_{2} \mathrm{O}_{6}$ \\
\hline Cosalita & Cos & $\mathrm{Pb}_{2} \mathrm{Bi}_{2} \mathrm{~S}_{5}$ \\
\hline Covelita & $\mathrm{Cv}$ & CuS \\
\hline Cuarzo & Qz & $\mathrm{SiO}_{2}$ \\
\hline Dantopaita & $\mathrm{Dt}$ & $\mathrm{Cu}_{1.06} \mathrm{Ag}_{4.24} \mathrm{~Pb}_{0.9} \mathrm{Bi}_{12.23} \mathrm{~S}_{21.89} \mathrm{Te}_{0.11}$ \\
\hline Escorodita & Sc & $\mathrm{Fe}^{3+}\left(\mathrm{AsO}_{4}, \mathrm{PO}_{4}\right) \cdot 2 \mathrm{H}_{2} \mathrm{O}$ \\
\hline Esfalerita & Sp & $(\mathrm{Zn}, \mathrm{Fe}) \mathrm{S}$ \\
\hline Feldespato potásico & Kfs & $\mathrm{KAISi}_{3} \mathrm{O}_{8}$ \\
\hline Ferrokesterita & Fkes & $\mathrm{Cu}_{2}(\mathrm{Fe}, \mathrm{Zn}) \mathrm{SnS}_{4}$ \\
\hline Fosfosiderita & Fos & $\mathrm{Fe}^{3+} \mathrm{PO}_{4} \cdot 2 \mathrm{H}_{2} \mathrm{O}$ \\
\hline Galena & Gn & $\mathrm{PbS}$ \\
\hline Gormanita & Grm & $\mathrm{Fe}^{2+}{ }_{3} \mathrm{Al}_{4}\left(\mathrm{PO}_{4}\right)_{4}(\mathrm{OH})_{6} \cdot 2 \mathrm{H}_{2} \mathrm{O}$ \\
\hline Goyazita & Gyz & $\mathrm{SrAl}_{3}\left(\mathrm{PO}_{4}\right)\left(\mathrm{PO}_{3} \mathrm{OH}\right)(\mathrm{OH})_{6}$ \\
\hline Gustavita & $\mathrm{Gu}$ & $\mathrm{PbAgBi}_{3} \mathrm{~S}_{6}$ \\
\hline Heyrovskyita & Hey & $\mathrm{Pb}_{6} \mathrm{Bi}_{2} \mathrm{~S}_{9}$ \\
\hline Isokita & Isk & $\mathrm{CaMg}\left(\mathrm{PO}_{4}\right) \mathrm{F}$ \\
\hline Ixiolita & $|x|$ & $(\mathrm{Ta}, \mathrm{Nb}, \mathrm{Sn}, \mathrm{Fe}, \mathrm{Mn}) \mathrm{O}_{2}$ \\
\hline Keckita & Kck & $\mathrm{CaMn}\left(\mathrm{Fe}^{3+} \mathrm{Mn}\right)_{2} \mathrm{Fe}^{3+}{ }_{2}\left[\mathrm{PO}_{4}\right]_{4}(\mathrm{OH})_{3}\left(\mathrm{H}_{2} \mathrm{O}\right)_{7}$ \\
\hline Lepidolita & Lpd & $\mathrm{K}(\mathrm{Li}, \mathrm{Al})_{3}(\mathrm{Al}, \mathrm{Si})_{4} \mathrm{O}_{10}(\mathrm{~F}, \mathrm{OH})_{2}$ \\
\hline Löllingita & Lo & $\mathrm{FeAsS}_{2}$ \\
\hline Marcasita & Mrc & $\mathrm{FeS}_{2}$ \\
\hline Matildita & Mtd & $\mathrm{AgBiS}_{2}$ \\
\hline Microlita & Mic & $(\mathrm{Na}, \mathrm{Ca})_{2} \mathrm{Ta}_{2} \mathrm{O}_{6}(\mathrm{O}, \mathrm{OH}, \mathrm{F})$ \\
\hline Molibdenita & Mol & $\mathrm{MoS}_{2}$ \\
\hline Montebrasita & Mbs & $\mathrm{LiAl}\left(\mathrm{PO}_{4}\right)(\mathrm{OH}, \mathrm{F})$ \\
\hline Moscovita & Ms & $\mathrm{KAl}_{2}\left(\mathrm{Si}_{3} \mathrm{Al}\right) \mathrm{O}_{10}(\mathrm{OH}, \mathrm{F})_{2}$ \\
\hline Mummeita & Mum & $\mathrm{Cu}_{0.5} \mathrm{Ag}_{2.3} \mathrm{~Pb}_{0.4} \mathrm{Bi}_{6.8} \mathrm{~S}_{12}$ \\
\hline Ortoclasa & Or & $\mathrm{KAISi}_{3} \mathrm{O}_{8}$ \\
\hline Pavonita & Pav & $\mathrm{Cu}_{0.27} \mathrm{Ag}_{0.78} \mathrm{~Pb}_{0.33} \mathrm{Bi}_{2.78} \mathrm{~S}_{5}$ \\
\hline Pirita & Py & $\mathrm{FeS}_{2}$ \\
\hline Pirrotita & Po & $\mathrm{Fe}_{1-x} \mathrm{~S}$ \\
\hline Rockbridgeita & Rckb & $\left(\mathrm{Fe}^{2+}, \mathrm{Mn}^{2+}\right) \mathrm{Fe}_{4}^{3+}\left(\mathrm{PO}_{4}\right)_{3}(\mathrm{OH})_{5}$ \\
\hline Rutilo & Rt & $\mathrm{TiO}_{2}$ \\
\hline Staněkita & Stk & $\mathrm{Fe}^{3+}\left(\mathrm{Mn}, \mathrm{Fe}^{2+}, \mathrm{Mg}\right) \mathrm{O}\left(\mathrm{PO}_{4}\right)$ \\
\hline Tantalita-(Fe) & Tnf & $(\mathrm{Fe}, \mathrm{Mn}) \mathrm{Ta}_{2} \mathrm{O}_{6}$ \\
\hline Tantalita-(Mn) & Tnm & $\mathrm{MnTa}_{2} \mathrm{O}_{6}$ \\
\hline Tapiolita & Tap & $\mathrm{FeTa}_{2} \mathrm{O}_{6}$ \\
\hline Topacio & Tpz & $\mathrm{Al}_{2} \mathrm{SiO}_{4}(\mathrm{OH}, \mathrm{F})_{2}$ \\
\hline Triplita-Zwieselita & $T p-Z w$ & $\left(\mathrm{Mn}^{2+}, \mathrm{Fe}^{2+} \mathrm{Mg}, \mathrm{Ca}\right)_{2}\left(\mathrm{PO}_{4}\right)(\mathrm{F}, \mathrm{OH})$ \\
\hline Turmalina & Tur & $\mathrm{Na}\left(\mathrm{Fe}^{2+}\right)_{3} \mathrm{Al}_{6}\left(\mathrm{Si}_{6} \mathrm{O}_{18}\right)\left(\mathrm{BO}_{3}\right)_{3}(\mathrm{OH})_{3}(\mathrm{OH})$ \\
\hline Vikingita & Vik & $\mathrm{Pb}_{8} \mathrm{Ag}_{5} \mathrm{Bi}_{13} \mathrm{~S}_{20}$ \\
\hline Wolframita & $W f$ & $\left(\mathrm{Fe}^{2+}, \mathrm{Mn}\right) \mathrm{WO}_{4}$ \\
\hline Xantoxenita & Xnt & $\mathrm{Ca}_{4} \mathrm{Fe}_{2}{ }_{2}\left(\mathrm{PO}_{4}\right)_{4}(\mathrm{OH})_{2} \cdot 3 \mathrm{H}_{2} \mathrm{O}$ \\
\hline
\end{tabular}

Según Kretz (1983), Spear (1993) y Whitney y Evans (2010) 

Anexo III. Análisis de microsonda electrónica

\begin{tabular}{|c|c|c|c|c|c|c|c|c|c|c|c|c|c|c|c|c|c|c|c|c|c|c|c|}
\hline \multirow{2}{*}{$\begin{array}{l}\text { Mina/Zona } \\
\text { Roca }\end{array}$} & \multicolumn{2}{|c|}{ San Martín } & \multicolumn{4}{|c|}{ Horia } & \multicolumn{3}{|c|}{ Salmantina } & \multicolumn{3}{|c|}{ Carrasquera } & \multicolumn{10}{|c|}{ Teso de la Matanza } & \multirow{2}{*}{$\begin{array}{c}\text { Salm. } \\
A B\end{array}$} \\
\hline & MP & $\mathrm{MP}$ & GE & GE & $\mathrm{GE}$ & GE & LG & LG & LG & LG & LG & LG & LG & LG & LG & LG & LG & LG & LG & LG & LG & LG & \\
\hline Muestra & 807 & 807 & $1682 \mathrm{~A}$ & $1682 \mathrm{~A}$ & $1682 \mathrm{~A}$ & $1682 \mathrm{~A}$ & $1690 \mathrm{~B}$ & $1690 \mathrm{~B}$ & 1055 & 1781 & 1781 & 1781 & 1788 & 1788 & 1788 & $1791 \mathrm{~A}$ & $1791 \mathrm{~A}$ & 1791A & 1791A & 1794 & 1794 & 1794 & 1684 \\
\hline Análisis & 5.1 & 5.3 & 1.1 & 2.1 & 2.2 & 6.2 & 4.1 & 9.1 & 5.9 & 2.1 & 2.3 & 4.2 & 4.1 & 5.2 & 6.2 & 1.1 & 3.1 & 4.2 & 5.1 & 2.2 & 3.1 & 4.1 & 1.1 \\
\hline $\mathrm{SiO}_{2}$ & 65,03 & 65,50 & 63,49 & 64,25 & 65,09 & 64,25 & 64,72 & 64,57 & 65,44 & 64,51 & 64,47 & 63,74 & 64,79 & 64,91 & 64,31 & 64,39 & 62,37 & 65,16 & 67,26 & 65,35 & 65,76 & 64,65 & 64,95 \\
\hline $\mathrm{P}_{2} \mathrm{O}_{5}$ & 0,29 & 0,03 & 0,18 & 0,02 & 0,00 & 0,22 & 0,82 & 0,91 & 0,09 & 0,57 & 0,55 & 0,47 & 0,28 & 0,45 & 0,84 & 0,47 & 0,46 & 0,12 & 0,11 & 0,28 & 0,00 & 0,57 & 0,61 \\
\hline $\mathrm{Al}_{2} \mathrm{O}_{3}$ & 18,04 & 17,86 & 19,04 & 18,12 & 18,45 & 19,09 & 18,14 & 18,20 & 17,91 & 19,03 & 18,98 & 18,59 & 18,27 & 18,85 & 18,92 & 18,68 & 18,50 & 18,74 & 17,91 & 18,14 & 17,82 & 18,55 & 18,70 \\
\hline $\mathrm{Na}_{2} \mathrm{O}$ & 0,80 & 0,02 & 0,83 & 0,61 & 0,52 & 0,73 & 0,63 & 0,33 & 0,24 & 0,33 & 0,34 & 0,59 & 0,63 & 0,26 & 0,58 & 0,46 & 0,53 & 0,18 & 0,21 & 0,15 & 0,18 & 0,62 & 0,17 \\
\hline $\mathrm{K}_{2} \mathrm{O}$ & 15,10 & 16,55 & 15,52 & 15,42 & 15,87 & 15,68 & 15,61 & 15,91 & 16,01 & 15,96 & 15,95 & 15,54 & 15,44 & 15,69 & 15,58 & 15,47 & 15,52 & 16,11 & 15,00 & 16,24 & 15,91 & 15,70 & 15,94 \\
\hline $\mathrm{CaO}$ & 0,00 & 0,00 & 0,04 & 0,01 & 0,00 & 0,03 & 0,00 & 0,00 & 0,00 & 0,00 & 0,00 & 0,00 & 0,00 & 0,00 & 0,00 & 0,00 & 0,00 & 0,00 & 0,00 & 0,00 & 0,00 & 0,00 & 0,00 \\
\hline $\mathrm{MgO}$ & 0,00 & 0,01 & 0,00 & 0,00 & 0,00 & 0,00 & 0,00 & 0,00 & 0,00 & 0,00 & 0,00 & 0,00 & 0,00 & 0,02 & 0,00 & 0,00 & 0,00 & 0,00 & 0,00 & 0,00 & 0,01 & 0,00 & 0,00 \\
\hline $\mathrm{MnO}$ & 0,04 & 0,04 & 0,00 & 0,00 & 0,02 & 0,03 & 0,00 & 0,00 & 0,00 & 0,00 & 0,01 & 0,00 & 0,01 & 0,00 & 0,01 & 0,03 & 0,00 & 0,00 & 0,00 & 0,01 & 0,00 & 0,01 & 0,00 \\
\hline $\mathrm{FeO}$ & 0,00 & 0,03 & 0,00 & 0,01 & 0,01 & 0,02 & 0,04 & 0,00 & 0,11 & 0,00 & 0,09 & 0,01 & 0,00 & 0,02 & 0,04 & 0,00 & 0,02 & 0,00 & 0,02 & 0,00 & 0,00 & 0,00 & 0,00 \\
\hline $\mathrm{TiO}_{2}$ & 0,02 & 0,01 & 0,01 & 0,01 & 0,00 & 0,01 & 0,00 & 0,00 & 0,00 & 0,00 & 0,01 & 0,00 & 0,04 & 0,00 & 0,00 & 0,01 & 0,03 & 0,00 & 0,00 & 0,01 & 0,00 & 0,00 & 0,01 \\
\hline SrO & 0,00 & 0,00 & 0,00 & 0,00 & 0,00 & 0,00 & 0,00 & 0,00 & 0,00 & 0,00 & 0,00 & 0,00 & 0,00 & 0,00 & 0,00 & 0,00 & 0,00 & 0,00 & 0,00 & 0,00 & 0,00 & 0,00 & 0,00 \\
\hline $\mathrm{BaO}$ & 0,05 & 0,05 & 0,29 & 0,08 & 0,09 & 0,04 & 0,00 & 0,01 & 0,00 & 0,08 & 0,00 & 0,10 & 0,20 & 0,00 & 0,00 & 0,07 & 0,01 & 0,04 & 0,10 & 0,00 & 0,05 & 0,04 & 0,12 \\
\hline $\mathrm{ZnO}$ & 0,03 & 0,00 & 0,02 & 0,02 & 0,00 & 0,00 & 0,06 & 0,08 & 0,07 & 0,04 & 0,10 & 0,12 & 0,03 & 0,02 & 0,09 & 0,09 & 0,08 & 0,09 & 0,05 & 0,03 & 0,07 & 0,00 & 0,00 \\
\hline $\mathrm{As}_{2} \mathrm{O}_{3}$ & 0,01 & 0 , & 0, & 0,00 & 0,00 & 0,00 & 0,03 & 0,01 & 0,00 & 0,00 & 0,00 & 0,00 & 0,00 & 0,00 & 0,00 & 0,00 & 0,00 & 0,00 & 0,01 & 0,00 & 0,06 & 0,04 & 0,00 \\
\hline $\mathrm{Rb}_{2} \mathrm{O}$ & 0,02 & 0,02 & 0,01 & 0,01 & 0,01 & 0,01 & 0,01 & 0,01 & 0,03 & 0,01 & 0,01 & 0,01 & 0,01 & 0,01 & 0,01 & 0,01 & 0,01 & 0,01 & 0,01 & 0,03 & 0,03 & 0,03 & 0,01 \\
\hline $\mathrm{Cl}$ & 0,01 & 0,02 & 0,01 & 0,11 & 0,01 & 0,02 & 0,01 & 0,10 & 0,00 & 0,00 & 0,00 & 0,00 & 0,00 & 0,02 & 0,00 & 0,01 & 0,00 & 0,00 & 0,00 & 0,02 & 0,01 & 0,01 & 0,00 \\
\hline $\mathrm{F}$ & 0,00 & 0,04 & 0,00 & 0,10 & 0,00 & 0,00 & 0,02 & 0,04 & 0,00 & 0,05 & 0,00 & 0,01 & 0,05 & 0,04 & 0,01 & 0,01 & 0,00 & 0,00 & 0,01 & 0,00 & 0,00 & 0,00 & 0,00 \\
\hline Total & 99,44 & 100,22 & 99,45 & 98,76 & 100,06 & 100,13 & 100,09 & 100,17 & 99,90 & 100,57 & 100,50 & 99,19 & 99,73 & 100,29 & 100,39 & 99,71 & 97,53 & 100,47 & 100,71 & 100,26 & 99,92 & 100,23 & 100,51 \\
\hline \multicolumn{24}{|c|}{ Número de iones con base a 320} \\
\hline Si & 12,02 & 12,09 & 11,82 & 12,02 & 12,01 & 11,85 & 11,91 & 11,89 & 12,08 & 11,84 & 11,83 & 11,86 & 11,98 & 11,91 & 11,80 & 11,89 & 11,81 & 11,97 & 12,21 & 12,03 & 12,13 & 11,89 & 11,90 \\
\hline Al & 3, & 3,89 & 4 & 3,99 & 4 & 4,15 & & 3,95 & 3 & 4,11 & 11 & 4,08 & 98 & 4,08 & 09 & 4,07 & 13 & 4,06 & 83 & 3,93 & ,87 & 4,02 & 4,04 \\
\hline $\mathrm{Fe}$ & 0,00 & 0,00 & 0,00 & 0,00 & 0,00 & 0,00 & 0,01 & 0,00 & 0,02 & 0,00 & 0,01 & 0,00 & 0,00 & 0,00 & 0,01 & 0,00 & 0,00 & 0,00 & 0,00 & 0,00 & 0,00 & 0,00 & 0,00 \\
\hline Ti & 0,00 & 0,00 & 0,00 & 0,00 & 0,00 & 0,00 & 0,00 & 0,00 & 0,00 & 0,00 & 0,00 & 0,00 & 0,01 & 0,00 & 0,00 & 0,00 & 0,00 & 0,00 & 0,00 & 0,00 & 0,00 & 0,00 & 0,00 \\
\hline Mg & 0,00 & 0 , & 0, & 0,0 & 0, & 0,0 & 0 , & 0, & & 0,00 & & 0,00 & 0,00 & 0,01 & 0,00 & 0,00 & 0,00 & 0,00 & 0,00 & 0,00 & 0,00 & 0,00 & 0,00 \\
\hline $\mathrm{Na}$ & 0,29 & 0,01 & 0,30 & 0,22 & 0,19 & 0,26 & 0,22 & 0,1 & 0 , & 0,1 & 0 & 0,21 & 0,23 & 0,09 & 0,21 & 0,17 & 0,20 & 0,06 & 0,08 & 0,05 & 0,06 & 0,22 & 0,06 \\
\hline $\mathrm{Ca}$ & 0,00 & 0,00 & 0,01 & 0,00 & 0,00 & 0,01 & 0,00 & 0,00 & 0,00 & 0,00 & 0,00 & 0,00 & 0,00 & 0,00 & 0,00 & 0,00 & 0,00 & 0,00 & 0,00 & 0,00 & 0,00 & 0,00 & 0,00 \\
\hline & & & & & & & & & & & & 3,69 & & 3,6 & & 3,64 & & 3,7 & 47 & & 74 & 3,68 & 3,73 \\
\hline $\mathrm{Mn}$ & 0,01 & 0 , & 0, & 0,00 & 0, & 0,0 & & 0,00 & 0 , & 0,00 & 0 & 0,00 & 0 & 0,00 & 00 & 0,01 & 00 & 0,00 & 0,00 & 0,00 & 0,00 & 0,00 & 0,00 \\
\hline & 0,04 & 0,00 & 0,03 & 0,00 & 0,00 & 0,03 & 0 , & 0,14 & 0 , & 0,09 & 0,09 & 0,07 & 0,04 & 0,07 & 0,13 & 0,07 & 0,07 & 0,02 & 0,02 & 0,04 & 0,00 & 0,09 & 0,09 \\
\hline $\mathrm{Ba}$ & 0,00 & & & & & & & & & & & & & 0, & & & & 0,00 & 01 & & 00 & 0,00 & 0,01 \\
\hline $\mathrm{Sr}$ & 0,00 & & 0, & $0,0 c$ & 0 , & 0 , & 0 , & 0,0 & 0 , & 0,00 & 0 & 0,00 & 00 & 0,00 & 0,00 & 0,00 & 0,00 & 0,00 & 0,00 & 0,00 & 0,00 & 0,00 & 0,00 \\
\hline $\mathrm{Zn}$ & 0,00 & & 0, & 0,0 & 0, & 0, & & 0, & & 0, & & 0,02 & 0 & 0,00 & 0,01 & 0,01 & 0,01 & 0,01 & 0,01 & 0,00 & 0,01 & 0,00 & 0,00 \\
\hline As & 0,00 & 0 & & 0 & & & & 0 , & & 0,00 & & 0,00 & & 0,00 & 00 & 0,00 & 00 & 0,00 & 0,00 & 0,00 & 0,01 & 0,00 & 0,00 \\
\hline $\mathrm{Rb}$ & 0,00 & 0,00 & 0,00 & 0,00 & 0,00 & 0,00 & 0,00 & 0,00 & 0,00 & 0,00 & 0,00 & 0,00 & 0,00 & 0,00 & 0,00 & 0,00 & 0,00 & 0,00 & 0,00 & 0,00 & 0,00 & 0,00 & 0,00 \\
\hline$\% \mathrm{~mol}$ & 92,54 & 99,85 & 92,29 & 94,28 & 95,26 & 93,19 & 94,26 & 96,96 & 97,80 & 96,97 & 96,87 & 94,58 & 94,17 & 97,54 & 94,62 & 95,65 & 95,04 & 98,33 & 97,88 & 98,58 & 98,31 & 94,30 & 98,39 \\
\hline$\% \mathrm{~mol}$ & 7,46 & 0,15 & 7,53 & 5,67 & 4,74 & 6,64 & 5,74 & 3,04 & 2,20 & 3,03 & 3,13 & 5,42 & 5,83 & 2,46 & 5,38 & 4,35 & 4,96 & 1,67 & 2,12 & 1,42 & 1,69 & 5,70 & 1,61 \\
\hline$\%$ mol $A n$ & 0,00 & 0,00 & 0,18 & 0,05 & 0,00 & 0,17 & 0,00 & 0,00 & 0,00 & 0,00 & 0,00 & 0,00 & 0,00 & 0,00 & 0,00 & 0,00 & 0,00 & 0,00 & 0,00 & 0,00 & 0,00 & 0,00 & 0,00 \\
\hline
\end{tabular}


Feldespato potásico (continuación)

Anexo III. Análisis de microsonda electrónica

\begin{tabular}{|c|c|c|c|c|c|c|c|c|c|c|c|c|c|c|c|c|c|c|c|c|c|c|c|}
\hline \multirow{2}{*}{$\begin{array}{l}\text { Mina/Zona } \\
\text { Roca }\end{array}$} & \multicolumn{5}{|c|}{ Salmantina } & \multicolumn{6}{|c|}{ Carrasquera } & \multicolumn{4}{|c|}{ Teso de la Matanza } & \multicolumn{4}{|c|}{ Profunda } & \multicolumn{2}{|c|}{ Mari Carmen } & \multirow{2}{*}{\begin{tabular}{|l|} 
Horia \\
Peg. GE
\end{tabular}} & \multirow{2}{*}{$\begin{array}{l}\text { Carr. } \\
\text { Peg. LG }\end{array}$} \\
\hline & $A B$ & $A B$ & $A B$ & $A B$ & $A B$ & $A B$ & $A B$ & $A B$ & $A B$ & $A B$ & $A B$ & $A B$ & $A B$ & $A B$ & $A B$ & $A B$ & $A B$ & LG & LG & $\begin{array}{l}\text { Peg. GE } \\
\end{array}$ & $\begin{array}{l}\text { Peg. GE } \\
\end{array}$ & & \\
\hline Muestra & 1684 & 1684 & 1685 & 1685 & 1685 & 1777 & 1777 & 1777 & 1778 & 1778 & 1778 & 1790 & 1790 & 1790 & 1790 & $783 B$ & $783 \mathrm{~B}$ & 788 & 788 & $1776 \mathrm{~A}$ & $1776 \mathrm{~A}$ & $1769 \mathrm{C}$ & 1786 \\
\hline Análisis & 3.2 & 4.2 & 2.1 & 2.3 & 3.1 & 1.2 & 4.3 & 5.2 & 1.1 & 1.3 & 2.2 & 1.3 & 5.1 & 6.2 & 8.1 & 1.1 & 1.2 & 3.2 & 4.1 & 2.1 & 4.1 & 5.1 & 1.3 \\
\hline $\mathrm{SiO}_{2}$ & 64,89 & 63,68 & 63,72 & 64,62 & 64,66 & 63,82 & 59,47 & 63,17 & 64,82 & 64,11 & 63,96 & 63,78 & 64,11 & 63,97 & 64,02 & 64,81 & 64,50 & 64,33 & 64,77 & 63,68 & 64,28 & 64,75 & 63,82 \\
\hline $\mathrm{P}_{2} \mathrm{O}_{5}$ & 0,76 & 0,68 & 0,54 & 0,33 & 0,22 & 0,89 & 0,87 & 1,06 & 0,76 & 0,79 & 0,80 & 0,94 & 0,83 & 0,91 & 0,88 & 0,58 & 0,84 & 0,61 & 0,49 & 0,79 & 0,76 & 0,61 & 1,15 \\
\hline $\mathrm{Al}_{2} \mathrm{O}_{3}$ & 18,16 & 18,99 & 17,98 & 17,84 & 18,30 & 18,73 & 18,28 & 18,23 & 18,15 & 18,60 & 18,80 & 18,40 & 19,08 & 18,74 & 18,79 & 18,36 & 18,98 & 18,54 & 18,11 & 19,35 & 19,02 & 18,98 & 18,95 \\
\hline $\mathrm{Na}_{2} \mathrm{O}$ & 0,55 & 0,31 & 0,62 & 0,39 & 0,49 & 0,52 & 0,57 & 0,24 & 0,63 & 0,26 & 0,57 & 0,64 & 0,25 & 0,56 & 0,56 & 0,41 & 0,45 & 0,49 & 0,48 & 0,56 & 0,72 & 0,78 & 0,23 \\
\hline $\mathrm{K}_{2} \mathrm{O}$ & 16,03 & 15,75 & 15,97 & 16,02 & 15,84 & 15,75 & 15,72 & 16,21 & 15,79 & 16,37 & 15,63 & 15,24 & 15,67 & 15,40 & 15,78 & 15,69 & 15,99 & 15,52 & 15,82 & 15,92 & 15,60 & 15,65 & 15,72 \\
\hline $\mathrm{CaO}$ & 0,00 & 0,00 & 0,00 & 0,00 & 0,00 & 0,00 & 0,00 & 0,00 & 0,00 & 0,00 & 0,00 & 0,00 & 0,00 & 0,00 & 0,00 & 0,00 & 0,00 & 0,00 & 0,00 & 0,00 & 0,00 & 0,00 & 0,00 \\
\hline $\mathrm{MgO}$ & 0,00 & 0,00 & 0,02 & 0,03 & 0,00 & 0,00 & 0,00 & 0,00 & 0,00 & 0,00 & 0,01 & 0,00 & 0,01 & 0,01 & 0,00 & 0,01 & 0,00 & 0,00 & 0,00 & 0,00 & 0,00 & 0,00 & 0,00 \\
\hline $\mathrm{MnO}$ & 0,02 & 0,00 & 0,00 & 0,00 & 0,04 & 0,00 & 0,04 & 0,00 & 0,00 & 0,00 & 0,00 & 0,00 & 0,01 & 0,00 & 0,00 & 0,01 & 0,00 & 0,00 & 0,02 & 0,01 & 0,00 & 0,00 & 0,00 \\
\hline $\mathrm{FeO}$ & 0,04 & 0,04 & 0,00 & 0,01 & 0,00 & 0,01 & 0,04 & 0,01 & 0,02 & 0,03 & 0,01 & 0,01 & 0,00 & 0,03 & 0,04 & 0,03 & 0,01 & 0,00 & 0,00 & 0,00 & 0,00 & 0,01 & 0,00 \\
\hline $\mathrm{TiO}_{2}$ & 0,00 & 0,00 & 0,02 & 0,01 & 0,00 & 0,02 & 0,00 & 0,00 & 0,00 & 0,00 & 0,00 & 0,01 & 0,00 & 0,00 & 0,00 & 0,00 & 0,00 & 0,00 & 0,00 & 0,00 & 0,00 & 0,00 & 0,00 \\
\hline SrO & 0,00 & 0,00 & 0,00 & 0,00 & 0,00 & 0,00 & 0,00 & 0,00 & 0,00 & 0,00 & 0,00 & 0,00 & 0,00 & 0,00 & 0,00 & 0,00 & 0,00 & 0,00 & 0,00 & 0,00 & 0,00 & 0,00 & 0,00 \\
\hline $\mathrm{BaO}$ & 0,00 & 0,06 & 0,00 & 0,00 & 0,12 & 0,04 & 0,00 & 0,00 & 0,10 & 0,00 & 0,00 & 0,00 & 0,00 & 0,00 & 0,00 & 0,01 & 0,00 & 0,07 & 0,01 & 0,03 & 0,08 & 0,00 & 0,08 \\
\hline $\mathrm{ZnO}$ & 0,03 & 0,03 & 0,04 & 0,00 & 0,09 & 0,03 & 0,04 & 0,04 & 0,00 & 0,03 & 0,01 & 0,04 & 0,00 & 0,05 & 0,06 & 0,00 & 0,00 & 0,07 & 0,00 & 0,03 & 0,00 & 0,00 & 0,08 \\
\hline $\mathrm{As}_{2} \mathrm{O}_{3}$ & 0,04 & 0,00 & 0,00 & 0,01 & 0,05 & 0,05 & 0,00 & 0,00 & 0,00 & 0,00 & 0,06 & 0,00 & 0,01 & 0,00 & 0,01 & 0,02 & 0,02 & 0,02 & 0,06 & 0,01 & 0,00 & 0,00 & 0,00 \\
\hline $\mathrm{Rb}_{2} \mathrm{O}$ & 0,01 & 0,01 & 0,01 & 0,01 & 0,01 & 0,01 & 0,01 & 0,01 & 0,01 & 0,01 & 0,01 & 0,01 & 0,01 & 0,02 & 0,01 & 0,03 & 0,03 & 0,03 & 0,03 & 0,01 & 0,01 & 0,01 & 0,01 \\
\hline $\mathrm{Cl}$ & 0,00 & 0,01 & 0,01 & 0,00 & 0,01 & 0,01 & 0,01 & 0,02 & 0,01 & 0,01 & 0,00 & 0,00 & 0,00 & 0,00 & 0,00 & 0,01 & 0,00 & 0,01 & 0,00 & 0,00 & 0,01 & 0,01 & 0,01 \\
\hline $\mathrm{F}$ & 0,06 & 0,02 & 0,01 & 0,00 & 0,04 & 0,03 & 0,00 & 0,00 & 0,00 & 0,01 & 0,01 & 0,03 & 0,04 & 0,02 & 0,00 & 0,00 & 0,00 & 0,00 & 0,00 & 0,02 & 0,00 & 0,01 & 0,04 \\
\hline Total & 100,59 & 99,58 & 98,94 & 99,28 & 99,87 & 99,91 & 95,04 & 98,99 & 100,29 & 100,22 & 99,86 & 99,11 & 100,03 & 99,72 & 100,15 & 99,99 & 100,83 & 99,69 & 99,79 & 100,43 & 100,49 & 100,87 & 100,10 \\
\hline \multicolumn{24}{|c|}{ Número de iones con base a 320} \\
\hline Si & 11,91 & 11,79 & 11,91 & 12,01 & 11,97 & 11,79 & 11,62 & 11,79 & 11,92 & 11,82 & 11,80 & 11,83 & 11,79 & 11,80 & 11,79 & 11,93 & 11,79 & 11,89 & 11,96 & 11,71 & 11,79 & 11,83 & 11,74 \\
\hline Al & 3,93 & 4,15 & 3,96 & 3,91 & 3,99 & 4,08 & 4,21 & 4,01 & 3,93 & 4,04 & 4,09 & 4,02 & 4,14 & 4,08 & 4,08 & 3,98 & 4,09 & 4,04 & 3,94 & 4,19 & 4,11 & 4,09 & 4,11 \\
\hline $\mathrm{Fe}$ & 0,01 & 0,01 & 0,00 & 0,00 & 0,00 & 0,00 & 0,01 & 0,00 & 0,00 & 0,00 & 0,00 & 0,00 & 0,00 & 0,00 & 0,01 & 0,01 & 0,00 & 0,00 & 0,00 & 0,00 & 0,00 & 0,00 & 0,00 \\
\hline $\mathrm{Ti}$ & 0,00 & 0,00 & 0,00 & 0,00 & 0,00 & 0,00 & 0,00 & 0,00 & 0,00 & 0,00 & 0,00 & 0,00 & 0,00 & 0,00 & 0,00 & 0,00 & 0,00 & 0,00 & 0,00 & 0,00 & 0,00 & 0,00 & 0,00 \\
\hline $\mathrm{Mg}$ & 0,00 & 0,00 & 0,00 & 0,01 & 0,00 & 0,00 & 0,00 & 0,00 & 0,00 & 0,00 & 0,00 & 0,00 & 0,00 & 0,00 & 0,00 & 0,00 & 0,00 & 0,00 & 0,00 & 0,00 & 0,00 & 0,00 & 0,00 \\
\hline $\mathrm{Na}$ & 0,19 & 0,11 & 0,22 & 0,14 & 0,17 & 0,19 & 0,22 & 0,09 & 0,22 & 0,09 & 0,20 & 0,23 & 0,09 & 0,20 & 0,20 & 0,15 & 0,16 & 0,18 & 0,17 & 0,20 & 0,26 & 0,28 & 0,08 \\
\hline $\mathrm{Ca}$ & 0,00 & 0,00 & 0,00 & 0,00 & 0,00 & 0,00 & 0,00 & 0,00 & 0,00 & 0,00 & 0,00 & 0,00 & 0,00 & 0,00 & 0,00 & 0,00 & 0,00 & 0,00 & 0,00 & 0,00 & 0,00 & 0,00 & 0,00 \\
\hline K & 3,75 & 3,72 & 3,81 & 3,80 & 3,74 & 3,71 & 3,92 & 3,86 & 3 , & 3,85 & 3,68 & 3,61 & 3,68 & 3,62 & 3,71 & 3,69 & 3,73 & 3,66 & 3,73 & 3,74 & 3,65 & 3,65 & 3,69 \\
\hline $\mathrm{Mn}$ & 0,00 & 0,00 & 0,00 & 0,00 & 0,01 & 0,00 & 0,01 & 0,00 & 0,00 & 0,00 & 0,00 & 0,00 & 0,00 & 0,00 & 0,00 & 0,00 & 0,00 & 0,00 & 0,00 & 0,00 & 0,00 & 0,00 & 0,00 \\
\hline$P$ & 0,12 & 0,11 & 0,08 & 0,05 & 0,04 & 0,14 & 0,14 & 0,17 & 0,12 & 0,12 & 0,12 & 0,15 & 0,13 & 0,14 & 0,14 & 0,09 & 0,13 & 0,10 & 0,08 & 0,12 & 0,12 & 0,09 & 0,18 \\
\hline Ba & 0,00 & 0,00 & & 0,00 & & 0,00 & & & & & $0,0 c$ & 0,00 & 0, & & 0,00 & 0,00 & 0,00 & 0,00 & 0,00 & 0,00 & 0,01 & 0,00 & 0,01 \\
\hline Sr & 0,00 & 0,00 & 0,00 & 0,00 & 0,00 & 0,00 & 0,00 & 0,00 & 0,00 & 0,00 & 0,00 & 0,00 & 00 & 0,00 & 0,00 & 0,00 & 0,00 & 0,00 & 0,00 & 0,00 & 0,00 & 0,00 & 0,00 \\
\hline $\mathrm{Zn}$ & 0,00 & 0,00 & 0,01 & 0,00 & 0,01 & 0,00 & 0,01 & 0,01 & 0,00 & 0,00 & 0,00 & 0,01 & 0,00 & 0,01 & 0,01 & 0,00 & 0,00 & 0,01 & 0,00 & 0,00 & 0,00 & 0,00 & 0,01 \\
\hline As & 0,00 & 0,00 & 0,00 & 0,00 & 0,01 & 0,01 & 0,00 & 0,00 & 0,00 & 0,00 & 0,01 & 0,00 & 0,00 & 0,00 & 0,00 & 0,00 & 0,00 & 0,00 & 0,01 & 0,00 & 0,00 & 0,00 & 0,00 \\
\hline $\mathrm{Rb}$ & 0,00 & 0,00 & 0,00 & 0,00 & 0,00 & 0,00 & 0,00 & 0,00 & 0,00 & 0,00 & 0,00 & 0,00 & 0,00 & 0,00 & 0,00 & 0,00 & 0,00 & 0,00 & 0,00 & 0,00 & 0,00 & 0,00 & 0,00 \\
\hline$\% \mathrm{molo}$ & 95,07 & 97,13 & 94,46 & 96,40 & 95,54 & 95,19 & 94,80 & 97,76 & 94,28 & 97,62 & 94,77 & 93,97 & 97,60 & 94,75 & 94,88 & 96,14 & 95,86 & 95,41 & 95,60 & 94,94 & 93,60 & 92,91 & $\overline{97,84}$ \\
\hline$\% \mathrm{~mol} A b$ & 4,93 & 2,87 & 5,54 & 3,60 & 4,46 & 4,81 & 5,20 & 2,24 & 5,72 & 2,38 & 5,23 & 6,03 & 2,40 & 5,25 & 5,12 & 3,86 & 4,14 & 4,59 & 4,40 & 5,11 & 6,54 & 7,04 & 2,16 \\
\hline$\%$ mol $A n$ & 0,00 & 0,00 & 0,00 & 0,00 & 0,00 & 0,00 & 0,00 & 0,00 & 0,00 & 0,00 & 0,00 & 0,00 & 0,00 & 0,00 & 0,00 & 0,00 & 0,00 & 0,00 & 0,00 & 0,06 & 0,00 & 0,05 & 0,00 \\
\hline
\end{tabular}


Feldespato potásico (continuación)

\begin{tabular}{|c|c|c|c|c|c|c|c|}
\hline \multirow{2}{*}{$\begin{array}{l}\text { Mina/Zona } \\
\text { Roca }\end{array}$} & \multicolumn{3}{|c|}{ Carrasquera } & \multicolumn{3}{|c|}{ Teso de la Matanza } & \multirow{2}{*}{$\begin{array}{l}\text { Cruz Ray } \\
\text { Peg. CEG }\end{array}$} \\
\hline & Peg. LG & $\begin{array}{ll}\text { Peg. LG } \\
\end{array}$ & $\begin{array}{l}\text { Peg. LG } \\
\end{array}$ & $\begin{array}{ll}\text { Peg. LG } \\
\end{array}$ & $\begin{array}{ll}\text { Peg. LG } \\
\end{array}$ & $\begin{array}{l}\text { Peg. LG } \\
\end{array}$ & \\
\hline Muestra & 1787 & 1787 & 1787 & 1797 & 1797 & 1797 & 803 \\
\hline Análisis & 1.1 & 4.3 & 5.3 & 1.1 & 4.1 & 5.1 & 4.4 \\
\hline $\mathrm{SiO}_{2}$ & 63,64 & 63,97 & 63,58 & 64,01 & 63,62 & 65,15 & 65,40 \\
\hline $\mathrm{P}_{2} \mathrm{O}_{5}$ & 0,92 & 0,89 & 0,72 & 0,58 & 0,69 & 0,66 & 0,88 \\
\hline $\mathrm{Al}_{2} \mathrm{O}_{3}$ & 18,59 & 18,71 & 19,02 & 18,42 & 18,37 & 18,20 & 18,64 \\
\hline $\mathrm{Na}_{2} \mathrm{O}$ & 0,67 & 0,63 & 0,30 & 0,74 & 0,67 & 0,68 & 0,55 \\
\hline $\mathrm{K}_{2} \mathrm{O}$ & 15,44 & 15,62 & 16,00 & 15,76 & 15,62 & 15,63 & 15,26 \\
\hline $\mathrm{CaO}$ & 0,00 & 0,00 & 0,00 & 0,00 & 0,00 & 0,00 & 0,00 \\
\hline $\mathrm{MgO}$ & 0,01 & 0,01 & 0,01 & 0,00 & 0,00 & 0,00 & 0,01 \\
\hline $\mathrm{MnO}$ & 0,00 & 0,00 & 0,00 & 0,01 & 0,00 & 0,05 & 0,00 \\
\hline $\mathrm{FeO}$ & 0,01 & 0,01 & 0,00 & 0,00 & 0,00 & 0,00 & 0,02 \\
\hline $\mathrm{TiO}_{2}$ & 0,01 & 0,00 & 0,00 & 0,00 & 0,00 & 0,00 & 0,00 \\
\hline SrO & 0,00 & 0,00 & 0,00 & 0,00 & 0,00 & 0,00 & 0,00 \\
\hline $\mathrm{BaO}$ & 0,00 & 0,04 & 0,00 & 0,00 & 0,13 & 0,00 & 0,00 \\
\hline $\mathrm{ZnO}$ & 0,06 & 0,06 & 0,04 & 0,00 & 0,00 & 0,03 & 0,10 \\
\hline $\mathrm{As}_{2} \mathrm{O}_{3}$ & 0,06 & 0,00 & 0,02 & 0,02 & 0,00 & 0,00 & 0,03 \\
\hline $\mathrm{Rb}_{2} \mathrm{O}$ & 0,01 & 0,01 & 0,01 & 0,02 & 0,01 & 0,02 & 0,04 \\
\hline $\mathrm{Cl}$ & 0,00 & 0,00 & 0,02 & 0,00 & 0,00 & 0,00 & 0,01 \\
\hline & 0,01 & 0,00 & 0,03 & 0,00 & 0,00 & 0,01 & 0,01 \\
\hline Total & 99,43 & 99,97 & 99,76 & 99,57 & 99,12 & 100,43 & 100,94 \\
\hline \multicolumn{8}{|c|}{ Número de iones con base a 320} \\
\hline Si & 11,79 & 11,79 & 11,77 & 11,87 & 11,85 & 11,94 & 11,89 \\
\hline $\mathrm{Al}$ & 4,06 & 4,07 & 4,15 & 4,02 & 4,03 & 3,93 & 3,99 \\
\hline $\mathrm{Fe}$ & 0,00 & 0,00 & 0,00 & 0,00 & 0,00 & 0,00 & 0,00 \\
\hline $\mathrm{Ti}$ & 0,00 & 0,00 & 0,00 & 0,00 & 0,00 & 0,00 & 0,00 \\
\hline $\mathrm{Mg}$ & 0,00 & 0,00 & 0,00 & 0,00 & 0,00 & 0,00 & 0,00 \\
\hline $\mathrm{Na}$ & 0,24 & 0,23 & 0,11 & 0,26 & 0,24 & 0,24 & 0,19 \\
\hline $\mathrm{Ca}$ & 0,00 & 0,00 & 0,00 & 0,00 & 0,00 & 0,00 & 0,00 \\
\hline K & 3,65 & 3,67 & 3,78 & 3,73 & 3,71 & 3,66 & 3,54 \\
\hline $\mathrm{Mn}$ & 0,00 & 0,00 & 0,00 & 0,00 & 0,00 & 0,01 & 0,00 \\
\hline P & 0,14 & 0,14 & 0,11 & 0,09 & 0,11 & 0,10 & 0,14 \\
\hline $\mathrm{Ba}$ & 0,00 & 0,00 & 0,00 & 0,00 & 0,01 & 0,00 & 0,00 \\
\hline Sr & 0,00 & 0,00 & 0,00 & 0,00 & 0,00 & 0,00 & 0,00 \\
\hline $\mathrm{Zn}$ & 0,01 & 0,01 & 0,01 & 0,00 & 0,00 & 0,00 & 0,01 \\
\hline As & 0,01 & 0,00 & 0,00 & 0,00 & 0,00 & 0,00 & 0,00 \\
\hline $\mathrm{Rb}$ & 0,00 & 0,00 & 0,00 & 0,00 & 0,00 & 0,00 & 0,00 \\
\hline$\% \mathrm{~mol}$ Or & 93,82 & 94,18 & 97,27 & 93,37 & 93,91 & 93,76 & 94,78 \\
\hline 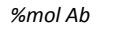 & 6,18 & 5,82 & 2,73 & 6,63 & 6,09 & 6,24 & 5,22 \\
\hline$\%$ mol $A n$ & 0,00 & 0,00 & 0,00 & 0,00 & 0,00 & 0,00 & 0,00 \\
\hline
\end{tabular}

Anexo III. Análisis de microsonda electrónica Horia

\begin{tabular}{|c|c|c|c|c|c|c|c|c|c|c|c|c|c|c|}
\hline \multirow{2}{*}{$\begin{array}{l}\text { Mina/Zona } \\
\text { Roca }\end{array}$} & \multicolumn{3}{|c|}{ San Martin Trevejo } & \multicolumn{11}{|c|}{ Horia } \\
\hline & MP & MP & MP & GE & GE & GE & GE & GE & $\mathrm{GE}$ & GE & GE & GE & GE & GE \\
\hline Muestra & 807 & 807 & 807 & $1682 \mathrm{~A}$ & $1682 \mathrm{~A}$ & $1682 \mathrm{~A}$ & $1682 \mathrm{~A}$ & $1682 \mathrm{~A}$ & $1682 A$ & $1682 \mathrm{~A}$ & $1682 \mathrm{~A}$ & $1682 A$ & $1682 A$ & $1682 \mathrm{~A}$ \\
\hline Análisis & 3.1 & 5.2 & 5.4 & 1.2 & 1.3 & 2.3 & 2.4 & 6.1 & 7.1 & 7.2 & 7.3 & 7.5 & 9.1 & 9.2 \\
\hline $\mathrm{SiO}_{2}$ & 64,17 & 69,87 & 68,19 & 67,45 & 66,22 & 67,96 & 66,02 & 66,95 & 69,30 & 63,65 & 66,15 & 66,68 & 66,23 & 44,91 \\
\hline $\mathrm{P}_{2} \mathrm{O}_{5}$ & 0,26 & 0,18 & 0,29 & 0,23 & 0,40 & 0,01 & 0,61 & 0,44 & 0,00 & 0,03 & 0,50 & 0,00 & 0,28 & 0,02 \\
\hline $\mathrm{Al}_{2} \mathrm{O}_{3}$ & 21,68 & 19,20 & 19,60 & 20,80 & 21,45 & 20,92 & 21,55 & 22,43 & 20,34 & 25,16 & 21,61 & 20,94 & 21,38 & 36,50 \\
\hline $\mathrm{Na}_{2} \mathrm{O}$ & 9,08 & 11,08 & 10,79 & 10,94 & 10,49 & 10,78 & 10,32 & 8,13 & 10,20 & 7,88 & 10,40 & 11,07 & 10,59 & 2,69 \\
\hline $\mathrm{K}_{2} \mathrm{O}$ & 0,24 & 0,06 & 0,13 & 0,14 & 0,13 & 0,09 & 0,11 & 0,21 & 0,11 & 2,69 & 0,23 & 0,08 & 0,08 & 9,72 \\
\hline $\mathrm{CaO}$ & 3,50 & 0,32 & 0,49 & 0,42 & 1,44 & 1,01 & 1,58 & 2,12 & 0,51 & 1,20 & 1,69 & 0,91 & 1,46 & 0,04 \\
\hline $\mathrm{MgO}$ & 0,00 & 0,01 & 0,00 & 0,00 & 0,00 & 0,01 & 0,00 & 0,02 & 0,00 & 0,07 & 0,00 & 0,00 & 0,00 & 0,05 \\
\hline $\mathrm{MnO}$ & 0,01 & 0,00 & 0,00 & 0,01 & 0,01 & 0,00 & 0,00 & 0,00 & 0,00 & 0,01 & 0,00 & 0,00 & 0,02 & 0,01 \\
\hline $\mathrm{FeO}$ & 0,02 & 0,00 & 0,00 & 0,00 & 0,00 & 0,00 & 0,00 & 0,01 & 0,02 & 0,11 & 0,00 & 0,03 & 0,04 & 0,37 \\
\hline $\mathrm{TiO}_{2}$ & 0,01 & 0,00 & 0,00 & 0,00 & 0,00 & 0,01 & 0,00 & 0,02 & 0,00 & 0,00 & 0,00 & 0,00 & 0,00 & 0,06 \\
\hline Sro & 0,00 & 0,00 & 0,00 & 0,00 & 0,00 & 0,00 & 0,00 & 0,00 & 0,00 & 0,00 & 0,00 & 0,00 & 0,00 & 0,00 \\
\hline $\mathrm{BaO}$ & 0,09 & 0,04 & 0,04 & 0,00 & 0,00 & 0,00 & 0,00 & 0,00 & 0,03 & 0,00 & 0,07 & 0,05 & 0,01 & 0,01 \\
\hline $\mathrm{ZnO}$ & 0,00 & 0,03 & 0,03 & 0,05 & 0,03 & 0,03 & 0,00 & 0,00 & 0,02 & 0,00 & 0,01 & 0,02 & 0,00 & 0,02 \\
\hline $\mathrm{As}_{2} \mathrm{O}_{3}$ & 0,00 & 0,00 & 0,04 & 0,00 & 0,00 & 0,01 & 0,02 & 0,02 & 0,01 & 0,00 & 0,01 & 0,01 & 0,03 & 0,03 \\
\hline $\mathrm{Rb}_{2} \mathrm{O}$ & 0,02 & 0,02 & 0,02 & 0,00 & 0,00 & 0,00 & 0,00 & 0,00 & 0,00 & 0,00 & 0,00 & 0,00 & 0,00 & 0,00 \\
\hline $\mathrm{Cl}$ & 0,00 & 0,01 & 0,02 & 0,00 & 0,01 & 0,00 & 0,01 & 0,03 & 0,01 & 0,01 & 0,01 & 0,01 & 0,00 & 0,39 \\
\hline $\mathrm{F}$ & 0,04 & 0,00 & 0,00 & 0,00 & 0,04 & 0,02 & 0,01 & 0,05 & 0,00 & 0,00 & 0,03 & 0,04 & 0,05 & 0,10 \\
\hline
\end{tabular}

Total $\quad \begin{array}{lllllllllllllll}99,41 & 101,00 & 99,78 & 100,08 & 100,25 & 100,88 & 100,25 & 100,56 & 100,62 & 100,84 & 100,74 & 99,86 & 100,31 & 95,02\end{array}$

\begin{tabular}{|c|c|c|c|c|c|c|c|c|c|c|c|c|c|c|}
\hline \multicolumn{15}{|c|}{ Número de iones con base en 320} \\
\hline Si & 11,41 & 12,07 & 11,94 & 11,77 & 11,58 & 11,78 & 11,53 & 11,59 & 11,98 & 11,15 & 11,53 & 11,71 & 11,59 & 8,78 \\
\hline Al & 4,54 & 3,91 & 4,04 & 4,28 & 4,42 & 4,28 & 4,43 & 4,58 & 4,14 & 5,19 & 4,44 & 4,33 & 4,41 & 8,41 \\
\hline $\mathrm{Fe}$ & 0,00 & 0,00 & 0,00 & 0,00 & 0,00 & 0,00 & 0,00 & 0,00 & 0,00 & 0,02 & 0,00 & 0,00 & 0,01 & 0,06 \\
\hline $\mathrm{Ti}$ & 0,00 & 0,00 & 0,00 & 0,00 & 0,00 & 0,00 & 0,00 & 0,00 & 0,00 & 0,00 & 0,00 & 0,00 & 0,00 & 0,01 \\
\hline $\mathrm{Mg}$ & 0,00 & 0,00 & 0,00 & 0,00 & 0,00 & 0,00 & 0,00 & 0,01 & 0,00 & 0,02 & 0,00 & 0,00 & 0,00 & 0,01 \\
\hline $\mathrm{Na}$ & 3,13 & 3,71 & 3,66 & 3,70 & 3,55 & 3,62 & 3,49 & 2,73 & 3,42 & 2,68 & 3,51 & 3,77 & 3,59 & 1,02 \\
\hline $\mathrm{Ca}$ & 0,67 & 0,06 & 0,09 & 0,08 & 0,27 & 0,19 & 0,30 & 0,39 & 0,09 & 0,23 & 0,31 & 0,17 & 0,27 & 0,01 \\
\hline K & 0,05 & 0,01 & 0,03 & 0,03 & 0,03 & 0,02 & 0,03 & 0,05 & 0,02 & 0,60 & 0,05 & 0,02 & 0,02 & 2,42 \\
\hline $\mathrm{Mn}$ & 0,00 & 0,00 & 0,00 & 0,00 & 0,00 & 0,00 & 0,00 & 0,00 & 0,00 & 0,00 & 0,00 & 0,00 & 0,00 & 0,00 \\
\hline P & 0,04 & 0,03 & 0,04 & 0,03 & 0,06 & 0,00 & 0,09 & 0,06 & 0,00 & 0,00 & 0,07 & 0,00 & 0,04 & 0,00 \\
\hline Ba & 0,01 & 0,00 & 0,00 & 0,00 & 0,00 & 0,00 & 0,00 & 0,00 & 0,00 & 0,00 & 0,00 & 0,00 & 0,00 & 0,00 \\
\hline Sr & 0,00 & 0,00 & 0,00 & 0,00 & 0,00 & 0,00 & 0,00 & 0,00 & 0,00 & 0,00 & 0,00 & 0,00 & 0,00 & 0,00 \\
\hline $\mathrm{Zn}$ & 0,00 & 0,00 & 0,00 & 0,01 & 0,00 & 0,00 & 0,00 & 0,00 & 0,00 & 0,00 & 0,00 & 0,00 & 0,00 & 0,00 \\
\hline As & 0,00 & 0,00 & 0,00 & 0,00 & 0,00 & 0,00 & 0,00 & 0,00 & 0,00 & 0,00 & 0,00 & 0,00 & 0,00 & 0,00 \\
\hline $\mathrm{Rb}$ & 0,00 & 0,00 & 0,00 & 0,00 & 0,00 & 0,00 & 0,00 & 0,00 & 0,00 & 0,00 & 0,00 & 0,00 & 0,00 & 0,00 \\
\hline$\%$ mol or & 1,39 & 0,36 & 0,76 & 0,8 & 0,7 & 0,5 & 0,7 & 1,4 & 0,7 & 17,0 & 1,5 & 0,5 & 0,5 & 68,5 \\
\hline$\%$ mol $A b$ & 81,29 & 98,07 & 96,82 & 97,1 & 92,3 & 94,5 & 91,5 & 85,9 & 96,6 & 75,7 & 90,5 & 95,1 & 92,4 & 28,9 \\
\hline$\%$ mol $A n$ & 17,31 & 1,57 & 2,42 & 2,1 & 7,0 & 5,0 & 7,8 & 12,6 & 2,7 & 7,4 & 8,1 & 4,4 & 7,3 & 2,4 \\
\hline
\end{tabular}


Plagioclasa (continuación)

Anexo III. Análisis de microsonda electrónica

\begin{tabular}{|c|c|c|c|c|c|c|c|c|c|c|c|c|c|c|c|c|c|c|c|c|c|c|c|}
\hline \multirow{2}{*}{$\begin{array}{l}\text { Mina/Zona } \\
\text { Roca }\end{array}$} & \multicolumn{5}{|c|}{ Horia } & \multicolumn{4}{|c|}{ Salmantina } & \multicolumn{5}{|c|}{ Carrasquera } & \multicolumn{3}{|c|}{ Profunda } & \multicolumn{6}{|c|}{ Teso de la Matanza } \\
\hline & GE & GE & GE & GE & GE & LG & LG & LG & LG & LG & LG & LG & LG & LG & LG & LG & LG & LG & LG & LG & LG & LG & LG \\
\hline Muestra & 1770 & 1770 & 1770 & 1770 & 1770 & $1690 \mathrm{~B}$ & $1690 \mathrm{~B}$ & $1690 \mathrm{~B}$ & $1690 B$ & 1781 & 1781 & 1781 & 1781 & 1779 & $788 \mathrm{~A}$ & $788 \mathrm{~A}$ & $788 \mathrm{~A}$ & 1788 & 1788 & 1788 & 1788 & $1791 \mathrm{~A}$ & $1791 \mathrm{~A}$ \\
\hline Análisis & 1.1 & 2.1 & 2.2 & 2.3 & 3.1 & 1.1 & 2.1 & 4.2 & 9.2 & 1.1 & 2.2 & 3.2 & 4.1 & 2.1 & 2.3 & 3.3 & 4.2 & 2.2 & 3.3 & 4.2 & 5.1 & 1.2 & 2.1 \\
\hline $\mathrm{SiO}_{2}$ & 69,02 & 69,13 & 68,65 & 67,56 & 69,39 & 69,24 & 69,69 & 69,32 & 68,40 & 67,77 & 67,82 & 68,82 & 69,32 & 68,91 & 69,76 & 70,03 & 68,87 & 69,37 & 68,52 & 69,60 & 67,37 & 67,30 & 67,42 \\
\hline $\mathrm{P}_{2} \mathrm{O}_{5}$ & 0,01 & 0,03 & 0,05 & 0,00 & 0,01 & 0,13 & 0,17 & 0,02 & 0,12 & 0,03 & 0,44 & 0,07 & 0,03 & 0,08 & 0,20 & 0,09 & 0,62 & 0,09 & 0,23 & 0,04 & 0,04 & 0,57 & 0,18 \\
\hline $\mathrm{Al}_{2} \mathrm{O}_{3}$ & 20,08 & 19,84 & 20,12 & 20,28 & 19,69 & 19,24 & 19,41 & 19,32 & 18,93 & 19,97 & 19,75 & 19,01 & 19,64 & 19,23 & 19,21 & 18,84 & 19,60 & 19,76 & 20,12 & 19,69 & 19,86 & 20,03 & 19,95 \\
\hline $\mathrm{Na}_{2} \mathrm{O}$ & 11,07 & 10,86 & 10,79 & 11,03 & 11,02 & 11,39 & 11,09 & 11,05 & 11,55 & 11,71 & 11,70 & 11,81 & 11,31 & 10,76 & 10,94 & 10,99 & 10,84 & 11,07 & 10,89 & 10,85 & 11,35 & 11,07 & 11,22 \\
\hline $\mathrm{K}_{2} \mathrm{O}$ & 0,09 & 0,12 & 0,08 & 0,07 & 0,11 & 0,09 & 0,10 & 0,12 & 0,19 & 0,07 & 0,20 & 0,13 & 0,07 & 0,11 & 0,08 & 0,07 & 0,13 & 0,07 & 0,04 & 0,12 & 0,09 & 0,14 & 0,10 \\
\hline $\mathrm{CaO}$ & 0,10 & 0,32 & 0,20 & 0,12 & 0,13 & 0,03 & 0,12 & 0,03 & 0,09 & 0,06 & 0,10 & 0,04 & 0,02 & 0,00 & 0,04 & 0,02 & 0,23 & 0,07 & 0,10 & 0,04 & 0,01 & 0,17 & 0,04 \\
\hline $\mathrm{MgO}$ & 0,00 & 0,00 & 0,00 & 0,01 & 0,00 & 0,00 & 0,00 & 0,02 & 0,01 & 0,00 & 0,01 & 0,02 & 0,00 & 0,02 & 0,01 & 0,00 & 0,00 & 0,01 & 0,00 & 0,00 & 0,00 & 0,01 & 0,01 \\
\hline $\mathrm{MnO}$ & 0,00 & 0,01 & 0,01 & 0,00 & 0,00 & 0,01 & 0,05 & 0,00 & 0,00 & 0,04 & 0,03 & 0,00 & 0,01 & 0,00 & 0,00 & 0,00 & 0,00 & 0,00 & 0,00 & 0,00 & 0,02 & 0,01 & 0,00 \\
\hline $\mathrm{FeO}$ & 0,00 & 0,00 & 0,01 & 0,01 & 0,03 & 0,00 & 0,02 & 0,00 & 0,06 & 0,04 & 0,01 & 0,06 & 0,03 & 0,00 & 0,00 & 0,04 & 0,01 & 0,00 & 0,02 & 0,00 & 0,00 & 0,02 & 0,00 \\
\hline $\mathrm{TiO}_{2}$ & 0,01 & 0,00 & 0,00 & 0,01 & 0,02 & 0,00 & 0,00 & 0,00 & 0,00 & 0,00 & 0,03 & 0,00 & 0,00 & 0,00 & 0,01 & 0,01 & 0,00 & 0,00 & 0,01 & 0,00 & 0,00 & 0,00 & 0,00 \\
\hline SrO & 0,00 & 0,00 & 0,00 & 0,00 & 0,00 & 0,00 & 0,00 & 0,00 & 0,00 & 0,00 & 0,00 & 0,00 & 0,00 & 0,00 & 0,00 & 0,00 & 0,00 & 0,00 & 0,00 & 0,00 & 0,00 & 0,00 & 0,00 \\
\hline $\mathrm{BaO}$ & 0,00 & 0,00 & 0,05 & 0,02 & 0,02 & 0,05 & 0,00 & 0,01 & 0,04 & 0,00 & 0,00 & 0,01 & 0,00 & 0,03 & 0,03 & 0,00 & 0,00 & 0,00 & 0,04 & 0,00 & 0,11 & 0,05 & 0,00 \\
\hline $\mathrm{ZnO}$ & 0,00 & 0,00 & 0,00 & 0,02 & 0,05 & 0,05 & 0,03 & 0,05 & 0,04 & 0,02 & 0,09 & 0,12 & 0,08 & 0,13 & 0,00 & 0,03 & 0,00 & 0,03 & 0,02 & 0,05 & 0,00 & 0,18 & 0,15 \\
\hline $\mathrm{As}_{2} \mathrm{O}_{3}$ & 0,00 & 0,01 & 0,00 & 0,00 & 0,00 & 0,03 & 0,03 & 0,03 & 0,00 & 0,00 & 0,00 & 0,02 & 0,00 & 0,01 & 0,00 & 0,00 & 0,00 & 0,00 & 0,00 & 0,00 & 0,05 & 0,00 & 0,00 \\
\hline $\mathrm{Rb}_{2} \mathrm{O}$ & 0,02 & 0,02 & 0,27 & 0,28 & 0,27 & 0,00 & 0,00 & 0,00 & 0,00 & 0,00 & 0,00 & 0,00 & 0,00 & 0,00 & 0,02 & 0,02 & 0,02 & 0,00 & 0,00 & 0,00 & 0,00 & 0,00 & 0,00 \\
\hline $\mathrm{Cl}$ & 0,00 & 0,00 & 0,00 & 0,00 & 0,00 & 0,00 & 0,01 & 0,01 & 0,01 & 0,00 & 0,02 & 0,01 & 0,01 & 0,01 & 0,01 & 0,00 & 0,01 & 0,01 & 0,00 & 0,01 & 0,00 & 0,00 & 0,00 \\
\hline $\mathrm{F}$ & 0,01 & 0,00 & 0,00 & 0,03 & 0,00 & 0,00 & 0,01 & 0,03 & 0,00 & 0,05 & 0,04 & 0,00 & 0,00 & 0,00 & 0,00 & 0,01 & 0,00 & 0,00 & 0,01 & 0,02 & 0,09 & 0,00 & 0,01 \\
\hline Total & 100,43 & 100,35 & 100,28 & 99,48 & 100,84 & 100,53 & 100,72 & 100,08 & 99,64 & 99,81 & 100,31 & 100,23 & 100,56 & 99,39 & 100,32 & 100,16 & 100,35 & 100,58 & 100,02 & 100,51 & 99,25 & 99,83 & 99,09 \\
\hline \multicolumn{24}{|c|}{ Número de iones con base en 320} \\
\hline Si & 11,97 & 12,00 & 11,95 & 11,88 & 12,02 & 12,04 & 12,05 & 12,07 & 12,02 & 11,89 & 11,85 & 12,02 & 12,02 & 12,07 & 12,09 & 12,16 & 11,94 & 12,02 & 11,93 & 12,05 & 11,90 & 11,81 & 11,88 \\
\hline Al & 4,10 & 4,06 & 4,13 & 4,20 & 4,02 & 3,94 & 3,96 & 3,97 & 3,92 & 4,13 & 4,07 & 3,91 & 4,01 & 3,97 & 3,92 & 3,85 & 4,01 & 4,03 & 4,13 & 4,02 & 4,13 & 4,14 & 4,14 \\
\hline $\mathrm{Fe}$ & 0,00 & 0,00 & 0,00 & 0,00 & 0,00 & 0,00 & 0,00 & 0,00 & 0,01 & 0,01 & 0,00 & 0,01 & 0,00 & 0,00 & 0,00 & 0,01 & 0,00 & 0,00 & 0,00 & 0,00 & 0,00 & 0,00 & 0,00 \\
\hline $\mathrm{Ti}$ & 0,00 & 0,00 & 0,00 & 0,00 & 0,00 & 0,00 & 0,00 & 0,00 & 0,00 & 0,00 & 0,00 & 0,00 & 0,00 & 0,00 & 0,00 & 0,00 & 0,00 & 0,00 & 0,00 & 0,00 & 0,00 & 0,00 & 0,00 \\
\hline $\mathrm{Mg}$ & 0,00 & 0,00 & 0,00 & 0,00 & 0,00 & 0,00 & 0,00 & 0,00 & 0,00 & 0,00 & 0,00 & 0,01 & 0,00 & 0,01 & 0,00 & 0,00 & 0,00 & 0,00 & 0,00 & 0,00 & 0,00 & 0,00 & 0,00 \\
\hline $\mathrm{Na}$ & 3,72 & 3,65 & 3,64 & 3,76 & 3,70 & 3,84 & 3,72 & 3,73 & 3,94 & 3,98 & 3,96 & 4,00 & 3,80 & 3,65 & 3,68 & 3,70 & 3,64 & 3,72 & 3,67 & 3,64 & 3,89 & 3,76 & 3,84 \\
\hline $\mathrm{Ca}$ & 0,02 & 0,06 & 0,04 & 0,02 & 0,02 & 0,01 & 0,02 & 0,00 & 0,02 & 0,01 & 0,02 & 0,01 & 0,00 & 0,00 & 0,01 & 0,00 & 0,04 & 0,01 & 0,02 & 0,01 & 0,00 & 0,03 & 0,01 \\
\hline K & 0,02 & 0,03 & 0,02 & 0,01 & 0,03 & 0,02 & 0,02 & 0,03 & 0,04 & 0,02 & 0,04 & 0,03 & 0,02 & 0,02 & 0,02 & 0,02 & 0,03 & 0,02 & 0,01 & 0,03 & 0,02 & 0,03 & 0,02 \\
\hline $\mathrm{Mn}$ & 0,00 & 0,00 & 0,00 & 0,00 & 0,00 & 0,00 & 0,01 & 0,00 & 0,00 & 0,01 & 0,00 & 0,00 & 0,00 & 0,00 & 0,00 & 0,00 & 0,00 & 0,00 & 0,00 & 0,00 & 0,00 & 0,00 & 0,00 \\
\hline$P$ & 0,00 & 0,01 & 0,01 & 0,00 & 0,00 & 0,02 & 0,02 & 0,00 & 0,02 & 0,01 & 0,07 & 0,01 & 0,01 & 0,01 & 0,03 & 0,01 & 0,09 & 0,01 & 0,03 & 0,01 & 0,01 & 0,08 & 0,03 \\
\hline Ba & 0,00 & & & & & & & & & 0,00 & 0,00 & & 0,00 & 0,00 & 0,00 & 0,00 & 0,00 & 0,00 & 0,00 & 0,00 & 0,01 & 0,00 & 0,00 \\
\hline Sr & 0,00 & 0,00 & 0,00 & 0,00 & 0,00 & 0,00 & 0,00 & 0,00 & 0,00 & 0,00 & 0,00 & oo & 0,00 & 0,00 & 0,00 & 0,00 & 0,00 & 0,00 & 0,00 & 0,00 & 0,00 & 0,00 & 0,00 \\
\hline $\mathrm{Zn}$ & 0,00 & 0,00 & 0,00 & 0,00 & 0,01 & 0,01 & 0,0 & 0,01 & 0,00 & 0,00 & 0,01 & 0,02 & 0,01 & 0,02 & 0,00 & 0,00 & 0,00 & 0,00 & 0,00 & 0,01 & 0,00 & 0,02 & 0,02 \\
\hline As & 0,00 & 0,00 & 0,00 & 0,00 & 0,00 & 0,00 & 0,00 & 0,00 & 0,00 & 0,00 & 0,00 & oo & 0,00 & 0,00 & 0,00 & 0,00 & 0,00 & 0,00 & 0,00 & 0,00 & 0,01 & 0,00 & 0,00 \\
\hline $\mathrm{Rb}$ & 0,00 & 0,00 & 0,03 & 0,03 & 0,03 & 0,00 & 0,00 & 0,00 & 0,00 & 0,00 & 0,00 & 0,00 & 0,00 & 0,00 & 0,00 & 0,00 & 0,00 & 0,00 & 0,00 & 0,00 & 0,00 & 0,00 & 0,00 \\
\hline$\% \mathrm{molo}$ & 0,5 & 0,7 & 0,6 & 0,4 & 0,7 & 0,5 & 0,6 & 0,7 & 1,1 & 0,4 & 1,1 & 0,7 & 0,4 & 0,7 & 0,5 & 0,4 & 0,8 & 0,4 & 0,3 & 0,7 & 0,7 & 0,9 & 0,6 \\
\hline$\%$ mol $A b$ & 99,0 & 97,7 & 98,5 & 98,9 & 98,5 & 99,3 & 98,8 & 99,2 & 98,5 & 99,2 & 98,3 & 98,8 & 99,4 & 99,2 & 99,2 & 99,3 & 98,1 & 99,2 & 99,1 & 99,1 & 99,4 & 98,3 & 99,2 \\
\hline$\%$ mol $A n$ & 0,5 & 1,6 & 1,1 & 0,7 & 0,8 & 0,2 & 0,6 & 0,1 & 0,4 & 0,6 & 0,7 & 0,5 & 0,3 & 0,2 & 0,3 & 0,3 & 1,2 & 0,4 & 0,6 & 0,2 & 0,1 & 1,0 & 0,2 \\
\hline
\end{tabular}


Plagioclasa (continuación)

Anexo III. Análisis de microsonda electrónica

\begin{tabular}{|c|c|c|c|c|c|c|c|c|c|c|c|c|c|c|c|c|c|c|c|c|c|c|c|}
\hline \multirow{2}{*}{$\begin{array}{l}\text { Mina/Zona } \\
\text { Roca }\end{array}$} & \multicolumn{5}{|c|}{ Teso de la Matanza } & \multicolumn{6}{|c|}{ Salmantina } & \multicolumn{5}{|c|}{ Carrasquera } & \multicolumn{4}{|c|}{ Profunda } & \multicolumn{3}{|c|}{ Teso de la Matanza } \\
\hline & LG & LG & LG & LG & $\begin{array}{l}\text { LG } \\
\end{array}$ & $A B$ & $A B$ & $A B$ & $A B$ & $A B$ & $A B$ & $A B$ & $A B$ & $A B$ & $A B$ & $A B$ & $A B$ & $A B$ & $A B$ & $A B$ & $A B$ & $A B$ & $A B$ \\
\hline Muestra & $1791 \mathrm{~A}$ & 1791A & 1794 & 1794 & 1794 & 1684 & 1684 & 1684 & 1684 & 1685 & 1685 & 1777 & 1777 & 1777 & 1778 & 1778 & 783 & 783 & $781 B$ & $781 \mathrm{~B}$ & 1790 & 1790 & 1790 \\
\hline nálisis & 3.2 & 4.1 & 1.1 & 2.1 & 4.2 & 2.2 & 5.2 & 6.1 & 6.4 & 2.2 & 4.1 & 1.3 & 2.2 & 5.3 & 1.2 & 2.3 & 1.3 & 3.2 & 1.3 & 3.2 & 1.2 & 3.3 & 4.2 \\
\hline $\mathrm{SiO}_{2}$ & 69,29 & 68,52 & 69,51 & 69,10 & 70,05 & 69,11 & 68,33 & 68,85 & 70,18 & 68,08 & 69,44 & 66,04 & 69,16 & 69,09 & 66,51 & 69,69 & 69,05 & 68,81 & 68,81 & 69,06 & 69,07 & 67,51 & 69,28 \\
\hline $\mathrm{P}_{2} \mathrm{O}_{5}$ & 0,07 & 0,11 & 0,01 & 0,14 & 0,01 & 0,07 & 0,19 & 0,70 & 0,08 & 0,08 & 0,13 & 0,73 & 0,09 & 0,49 & 0,70 & 0,35 & 0,05 & 0,25 & 0,50 & 0,22 & 0,36 & 0,32 & 0,28 \\
\hline $\mathrm{O}_{3}$ & 19,36 & 19,86 & 19,23 & 19,53 & 18,98 & 19,16 & 18,67 & 20,37 & 19,18 & 19,17 & 19,17 & 20,73 & 19,10 & 19,34 & 20,58 & 19,51 & 19,22 & 19,49 & 19,64 & 19,16 & 19,55 & 19,99 & 19,89 \\
\hline $\mathrm{Na}_{2} \mathrm{O}$ & 11,18 & 11,35 & 10,82 & 11,18 & 11,25 & 10,57 & 11,81 & 10,32 & 10,80 & 11,49 & 10,72 & 11,47 & 11,72 & 11,38 & 11,70 & 10,68 & 10,98 & 11,02 & 10,65 & 10,82 & 11,07 & 11,54 & 10,12 \\
\hline${ }_{2}^{2} \mathrm{O}$ & 0,11 & 0,12 & 0,10 & 0,11 & 0,11 & 0,12 & 0,16 & 0,13 & 0,07 & 0,08 & 0,12 & 0,13 & 0,11 & 0,09 & 0,11 & 0,10 & 0,11 & 0,13 & 0,60 & 0,11 & 0,17 & 0,11 & 0,16 \\
\hline 0 & 0,02 & 0,05 & 0,06 & 4 & 0,01 & 11 & 0,03 & 29 & 0,02 & 0,02 & 0,08 & 0,21 & 0,14 & 0,13 & 0,13 & 0,10 & 0,04 & 0,14 & 0,01 & 0,04 & 0,06 & 0,11 & 0,05 \\
\hline MgO & 0,01 & 0,02 & 0,00 & 0,00 & 0,00 & 0,00 & 0,00 & 0,00 & 0,00 & 0,01 & 0,00 & 0,00 & 0,00 & 0,01 & 0,00 & 0,00 & 0,02 & 0,00 & 0,00 & 0,00 & 0,00 & 0,01 & 0,00 \\
\hline Ino & 0,00 & 0,00 & 0,00 & 0,00 & 0,01 & 0,01 & 0,00 & 0,02 & 0,00 & 0,00 & 0,03 & 0,00 & 0,01 & 0,00 & 0,03 & 0,00 & 0,03 & 0,01 & 0,00 & 0,00 & 0,01 & 0,00 & 0,00 \\
\hline 0 & 0,00 & 0,00 & 0,01 & 0,00 & 0,00 & 0,02 & 0,01 & 0,01 & 0,00 & 0,04 & 0,00 & 0,01 & 0,07 & 0,00 & 0,02 & 0,01 & 0,04 & 0,00 & 0,00 & 0,02 & 0,01 & 0,00 & 0,00 \\
\hline $\mathrm{O}_{2}$ & 0,00 & 0,00 & 0,00 & 0,01 & 0,00 & 0,00 & 0,00 & 0,00 & 0,00 & 0,00 & 0,00 & 0,00 & 0,00 & 0,00 & 0,00 & 0,00 & 0,02 & 0,00 & 0,00 & 0,00 & 0,00 & 0,00 & 0,02 \\
\hline ro & 0,00 & 0,00 & 0,00 & 0,00 & 0,00 & 0,00 & 0,00 & 0,00 & 0,00 & 0,00 & 0,00 & 0,00 & 0,00 & 0,00 & 0,00 & 0,00 & 0,00 & 0,00 & 0,00 & 0,00 & 0,00 & 0,00 & 0,00 \\
\hline $\mathrm{BaO}$ & 0,09 & 0,00 & 0,00 & 12 & 0,03 & 0,04 & 0,06 & 0,00 & 0,00 & 0,00 & 0,05 & 0,06 & 0,02 & 0,00 & 0,01 & 0,01 & 0,05 & 0,00 & 0,10 & 0,00 & 0,00 & 0,02 & 0,00 \\
\hline no & 0,06 & 0,02 & 0,09 & 0,00 & 0,05 & 0,01 & 0,00 & 0,01 & 0,00 & 0,04 & 0,04 & 0,03 & 0,00 & 0,02 & 0,00 & 0,00 & 0,00 & 0,00 & 0,07 & 0,11 & 0,00 & 0,00 & 0,00 \\
\hline $\mathrm{s}_{2} \mathrm{O}_{3}$ & 0,00 & 0 & 0,00 & 0 & 0,00 & 0,00 & 0,05 & 00 & 0,00 & 0,06 & 0,00 & 0,00 & 0,00 & 0,03 & 0,00 & 0,03 & 0,00 & 0,03 & 0,00 & 0,03 & 0,00 & 0,00 & 0,04 \\
\hline $\mathrm{Rb}_{2} \mathrm{O}$ & 0,00 & 0,00 & 0,02 & 0,02 & 0,02 & 0,00 & 0,00 & 0,00 & 0,00 & 0,00 & 0,00 & 0,00 & 0,00 & 0,00 & 0,00 & 0,00 & 0,02 & 0,02 & 0,02 & 0,02 & 0,00 & 0,00 & 0,00 \\
\hline & 0,01 & 0,00 & 0,00 & 0,00 & 0,01 & 0,00 & 0,00 & 0,01 & 0,00 & 0,01 & 0,00 & 0,01 & 0,00 & 0,01 & 0,01 & 0,00 & 0,00 & 0,01 & 0,01 & 0,00 & 0,00 & 0,00 & 0,01 \\
\hline & 0,00 & 0,00 & 0,04 & 0,02 & 0,00 & 0,05 & 0,00 & 0,05 & 0,02 & 0,00 & 0,04 & 0,00 & 0,02 & 0,02 & 0,00 & 0,00 & 0,05 & 0,00 & 0,09 & 0,02 & 0,02 & ,00 & 0,00 \\
\hline Total & 100,21 & 100,14 & 99,89 & 100,19 & 100,54 & 99,31 & 99,61 & 100,80 & 100,61 & 99,22 & 99,89 & 99,45 & 100,56 & 100,65 & 99,96 & 100,67 & 99,80 & 99,96 & 100,50 & 99,63 & 100,44 & 99,66 & 99,95 \\
\hline \multicolumn{24}{|c|}{ Número de iones con base en 320} \\
\hline $\mathrm{Si}$ & 12,05 & 11,95 & 12,11 & 12,02 & 12,13 & 12,11 & 12,03 & 11,87 & 12,14 & 12,00 & 12,10 & 11,63 & 12,03 & 11,97 & 11,66 & 12,04 & 12,07 & 12,00 & 11,95 & 12,06 & 11,99 & 11,84 & 12,03 \\
\hline & & & 3,95 & & 3,8 & 3,96 & 3,87 & & 3,91 & 88 & 3,94 & 30 & 3,92 & & 4,25 & 3,97 & 3,96 & 4,00 & 4,02 & 3,94 & 4,00 & 13 & 4,07 \\
\hline & 0,00 & 0,00 & 0,00 & 0,00 & 0,00 & 0,00 & 0,00 & 0,00 & 0,00 & 0,01 & 0,00 & 0,00 & 0,01 & 0,00 & 0,00 & 0,00 & 0,01 & 0,00 & 0,00 & 0,00 & 0,00 & 0,00 & 0,00 \\
\hline & 0,00 & 0,00 & 0,00 & 0,00 & 0,00 & 0,00 & 0,00 & 0,00 & 0,00 & 0,00 & 0,00 & 0,00 & 0,00 & 0,00 & 0,00 & 0,00 & 0,00 & 0,00 & 0,00 & 0,00 & 0,00 & 0,00 & 0,00 \\
\hline Ig & 0,00 & & 0,0 & & 0,0 & 0 , & 0,0 & 0 , & $0, c$ & 0, & 0,0 & 0,00 & 0,00 & 0,00 & 0,00 & 0,00 & 0,01 & 0,00 & 0,00 & 0,00 & 0,00 & 0,00 & 0,00 \\
\hline & 3,77 & & & & & & 4,0 & & & & 3,6 & 3, & 3,95 & & 3,98 & & 3,72 & 3,72 & 3,59 & 3,66 & 3,73 & 3,92 & 3,41 \\
\hline a & 0,00 & $0, c$ & 0,01 & 1 & 0,00 & 0,00 & 0,01 & 55 & $0, c$ & 00 & 0,02 & 04 & 0,03 & 02 & 0,02 & 0,02 & 0,01 & 0,03 & 0,00 & 0,01 & 0,01 & 0,02 & 0,01 \\
\hline & & & & & & & & & & & & & & & & & & & & & 0,04 & & 0,04 \\
\hline & & & & & & & & & & & & & 0 & & 0 , & & 0,00 & & 0,00 & 00 & 0,00 & 00 & 0,00 \\
\hline & 0,01 & 0,02 & 0,0 & 0, & 0,00 & $0, C$ & 0,0 & .0 & 0,0 & 01 & 0,02 & 0,11 & 0,01 & .07 & 0,10 & 0,05 & 0,01 & 0,04 & 0,07 & 0,03 & 0,05 & 0,05 & 0,04 \\
\hline & & & & & & & & & & & & & & & & & & 0 & & 00 & 0,00 & 00 & 0,00 \\
\hline & 0, & 0, & & & & 0 , & & & & 0 , & & 00 & & Do & 0 & Do & 0,00 & 00 & 0,00 & 00 & 0,00 &, 00 & 0,00 \\
\hline & 0,01 & & $0, c$ & & 0,0 & & $0, \mathrm{C}$ & & & & & & 0, & & & & 0,00 & 0,00 & 0,01 & 0,01 & 0,00 & 0,00 & 0,00 \\
\hline & 0,00 & & 0,00 & & & & & & & & & & $0, c$ & & $0, C$ & & 0,00 & 0,00 & 0,00 & 00 & 0,00 & 0,00 & 0,00 \\
\hline & 0,00 & 0,00 & 0,00 & 0,00 & 0,00 & 0,00 & 0,00 & 0,00 & 0,00 & 0,00 & 0,00 & 0,00 & 0,00 & 0,00 & 0,00 & 0,00 & 0,00 & 0,00 & 0,00 & 0,00 & 0,00 & 0,00 & 0,00 \\
\hline & 0,8 & 0,7 & 0,6 & 0,7 & 0,7 & 0,7 & 0,9 & 0,8 & 0,5 & 0,4 & 0,7 & 0,9 & 0,6 & 0,5 & 0,6 & 0,6 & 0,7 & 0,8 & 3,7 & 0,6 & 1,0 & 0,7 & 1,0 \\
\hline & 99,2 & 99,0 & 99,0 & 99,1 & 99,3 & 99,2 & 99,0 & 97,6 & 99,5 & 99,5 & 98,9 & 98,2 & 98,5 & 98,8 & 98,7 & 98,8 & 98,8 & 98,5 & 96,4 & 99,1 & 98,7 & 98,8 & 98,6 \\
\hline & . & & . & & & & & 15 & & 01 & 0.4 & 10 & & & & & & 08 & 01 & 03 & 04 & 06 & \\
\hline
\end{tabular}


Plagioclasa (continuación)

Anexo III. Análisis de microsonda electrónica Mina/Zona

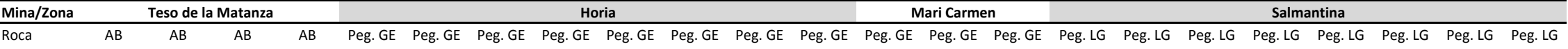

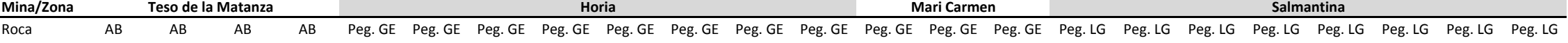

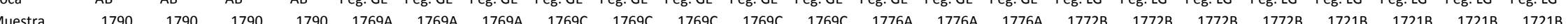

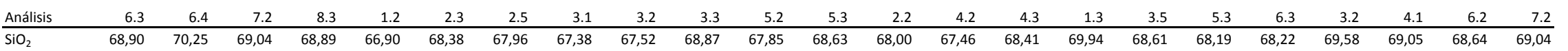

$\begin{array}{rrrrrrrrrrrrrrrrrrrrrrrr}\mathrm{SiO}_{2} & 68,90 & 70,25 & 69,04 & 68,89 & 66,90 & 68,38 & 67,96 & 67,38 & 67,52 & 68,87 & 67,85 & 68,63 & 68,00 & 67,46 & 68,41 & 69,94 & 68,61 & 68,19 & 68,22 & 69,58 & 69,05 & 68,64 & 69,04 \\ \mathrm{P}_{2} \mathrm{O}_{5} & 0,00 & 0,00 & 0,18 & 0,22 & 0,68 & 0,00 & 0,48 & 0,07 & 0,10 & 0,04 & 0,19 & 0,43 & 0,26 & 0,27 & 0,18 & 0,01 & 0,67 & 0,22 & 0,18 & 0,01 & 0,25 & 0,22 & 0,11\end{array}$

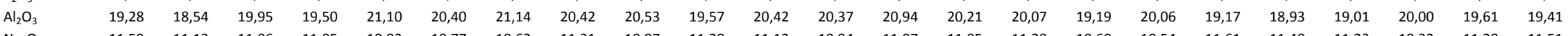

$\begin{array}{rrrrrrrrrrrrrrrrrrrrrrrrr}\mathrm{Na}_{2} \mathrm{O} & 11,59 & 11,13 & 11,06 & 11,05 & 10,82 & 10,77 & 10,62 & 11,31 & 10,97 & 11,28 & 11,12 & 10,94 & 11,07 & 11,05 & 11,20 & 10,60 & 10,54 & 11,61 & 11,40 & 11,23 & 10,32 & 11,28 & 11,51\end{array}$

$\begin{array}{lllllllllllllllllllllllllll}\mathrm{K}_{2} \mathrm{O} & 0,10 & 0,09 & 0,12 & 0,12 & 0,07 & 0,11 & 0,07 & 0,09 & 0,08 & 0,08 & 0,13 & 0,14 & 0,36 & 0,09 & 0,13 & 0,11 & 0,05 & 0,11 & 0,09 & 0,07 & 0,10 & 0,10 & 0,09 \\ \mathrm{CaO} & 0,01 & 0,02 & 0,03 & 0,02 & 0,20 & 0,01 & 0,21 & 0,00 & 0,01 & 0,01 & 0,00 & 0,03 & 0,08 & 0,02 & 0,05 & 0,01 & 0,17 & 0,03 & 0,02 & 0,00 & 0,12 & 0,11 & 0,01\end{array}$

$\begin{array}{llllllllllllllllllllllll}\mathrm{MgO} & 0,00 & 0,00 & 0,00 & 0,00 & 0,00 & 0,01 & 0,00 & 0,00 & 0,01 & 0,00 & 0,00 & 0,00 & 0,00 & 0,01 & 0,00 & 0,00 & 0,01 & 0,00 & 0,00 & 0,00 & 0,02 & 0,00 & 0,02\end{array}$

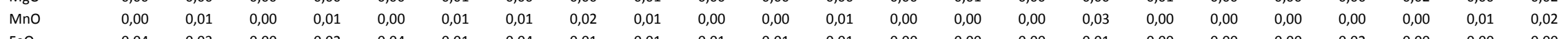

$\begin{array}{lllllllllllllllllllllllll}\mathrm{FeO} & 0,04 & 0,03 & 0,00 & 0,02 & 0,04 & 0,01 & 0,04 & 0,01 & 0,01 & 0,01 & 0,01 & 0,01 & 0,00 & 0,00 & 0,00 & 0,01 & 0,00 & 0,00 & 0,00 & 0,02 & 0,00 & 0,00 & 0,00 \\ \mathrm{TiO}_{2} & 0,00 & 0,00 & 0,01 & 0,00 & 0,00 & 0,00 & 0,00 & 0,00 & 0,00 & 0,00 & 0,00 & 0,00 & 0,00 & 0,00 & 0,00 & 0,00 & 0,00 & 0,00 & 0,00 & 0,00 & 0,00 & 0,00 & 0,00\end{array}$

$\begin{array}{lllllllllllllllllllllllll}\mathrm{TH}_{2} & 0,00 & 0,00 & 0,01 & 0,00 & 0,00 & 0,00 & 0,00 & 0,00 & 0,00 & 0,00 & 0,00 & 0,00 & 0,00 & 0,00 & 0,00 & 0,00 & 0,00 & 0,00 & 0,00 & 0,00 & 0,00 & 0,00 & 0,00 \\ \mathrm{Sro} & 0,00 & 0,00 & 0,00 & 0,00 & 0,00 & 0,00 & 0,00 & 0,00 & 0,00 & 0,00 & 0,00 & 0,00 & 0,00 & 0,00 & 0,00 & 0,00 & 0,00 & 0,00 & 0,00 & 0,00 & 0,00 & 0,00 & 0,00\end{array}$

$\begin{array}{llllllllllllllllllllllll}\mathrm{BaO} & 0,00 & 0,09 & 0,05 & 0,00 & 0,00 & 0,01 & 0,04 & 0,02 & 0,00 & 0,00 & 0,00 & 0,00 & 0,00 & 0,00 & 0,00 & 0,00 & 0,00 & 0,00 & 0,00 & 0,00 & 0,00 & 0,00 & 0,00 \\ \mathrm{BaO} & 0,00 & 0,02 & 0,03 & 0,00 & 0,00 & 0,00 & 0,04 & 0,05 & 0,01 & 0,10 & 0,06 & 0,09 & 0,01 & 0,00 & 0,00\end{array}$

$\begin{array}{llllllllllllllllllllllllllll}\mathrm{ZnO} & 0,00 & 0,03 & 0,00 & 0,00 & 0,03 & 0,00 & 0,00 & 0,01 & 0,00 & 0,00 & 0,03 & 0,02 & 0,00 & 0,03 & 0,01 & 0,06 & 0,02 & 0,00 & 0,00 & 0,06 & 0,08 & 0,02 & 0,08\end{array}$

$\begin{array}{lllllllllllllllllllllllll}\mathrm{As}_{2} \mathrm{O}_{3} & 0,02 & 0,01 & 0,04 & 0,01 & 0,00 & 0,00 & 0,00 & 0,00 & 0,01 & 0,00 & 0,00 & 0,00 & 0,00 & 0,00 & 0,00 & 0,00 & 0,00 & 0,00 & 0,05 & 0,03 & 0,00 & 0,00 & 0,01\end{array}$

$\begin{array}{lllllllllllllllllllllllll}\mathrm{Rb}_{2} \mathrm{O} & \mathrm{O} & 0,00 & 0,00 & 0,00 & 0,00 & 0,00 & 0,00 & 0,01 & 0,00 & 0,00 & 0,00 & 0,00 & 0,00 & 0,00 & 0,00 & 0,00 & 0,00 & 0,00 & 0,00 & 0,00 & 0,00 & 0,00 & 0,00 & 0,00 \\ \mathrm{Cl} & 0,00 & 0,00 & 0,01 & 0,01 & 0,00 & 0,01 & 0,00 & 0,00 & 0,00 & 0,01 & 0,01 & 0,01 & 0,01 & 0,00 & 0,01 & 0,01 & 0,01 & 0,01 & 0,00 & 0,00 & 0,00 & 0,00 & 0,00\end{array}$

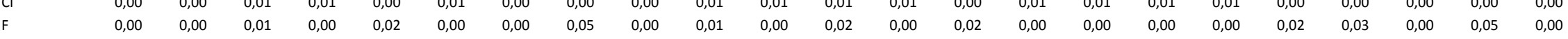

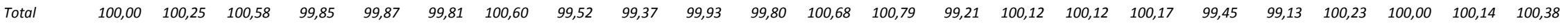

\begin{tabular}{|c|c|c|c|c|c|c|c|c|c|c|c|c|c|c|c|c|c|c|c|c|c|c|c|}
\hline \multicolumn{24}{|c|}{ Número de iones con base en 320} \\
\hline $\mathrm{Si}$ & 12,03 & 12,20 & 11,97 & 12,01 & 11,68 & 11,93 & 11,76 & 11,84 & 11,85 & 12,01 & 11,86 & 11,87 & 11,79 & 11,86 & 11,92 & 12,15 & 11,90 & 11,98 & 12,03 & 12,11 & 11,99 & 11,97 & 12,01 \\
\hline $\mathrm{Al}$ & 3,97 & 3,80 & 4,07 & 4,01 & 4,34 & 4,20 & 4,31 & 4,23 & 4,25 & 4,02 & 4,21 & 4,15 & 4,28 & 4,19 & 4,12 & 3,93 & 4,10 & 3,97 & 3,93 & 3,90 & 4,09 & 4,03 & 3,98 \\
\hline $\mathrm{Fe}$ & 0,01 & 0,00 & 0,00 & 0,00 & 0,01 & 0,00 & 0,01 & 0,00 & 0,00 & 0,00 & 0,00 & 0,00 & 0,00 & 0,00 & 0,00 & 0,00 & 0,00 & 0,00 & 0,00 & 0,00 & 0,00 & 0,00 & 0,00 \\
\hline $\mathrm{Ti}$ & 0,00 & 0,00 & 0,00 & 0,00 & 0,00 & 0,00 & 0,00 & 0,00 & 0,00 & 0,00 & 0,00 & 0,00 & 0,00 & 0,00 & 0,00 & 0,00 & 0,00 & 0,00 & 0,00 & 0,00 & 0,00 & 0,00 & 0,00 \\
\hline $\mathrm{Mg}$ & 0,00 & 0,00 & 0,00 & 0,00 & 0,00 & 0,00 & 0,00 & 0,00 & 0,00 & 0,00 & 0,00 & 0,00 & 0,00 & 0,00 & 0,00 & 0,00 & 0,00 & 0,00 & 0,00 & 0,00 & 0,00 & 0,00 & 0,00 \\
\hline $\mathrm{Na}$ & 3,92 & 3,75 & 3,72 & 3,74 & 3,66 & 3,64 & 3,56 & 3,85 & 3,73 & 3,81 & 3,77 & 3,67 & 3,72 & 3,77 & 3,78 & 3,57 & 3,54 & 3,95 & 3,90 & 3,79 & 3,47 & 3,81 & 3,88 \\
\hline $\mathrm{Ca}$ & 0,00 & 0,00 & 0,00 & 0,00 & 0,04 & 0,00 & 0,04 & 0,00 & 0,00 & 0,00 & 0,00 & 0,01 & 0,01 & 0,00 & 0,01 & 0,00 & 0,03 & 0,01 & 0,00 & 0,00 & 0,02 & 0,02 & 0,00 \\
\hline K & 0,02 & 0,02 & 0,03 & 0,03 & 0,02 & 0,03 & 0,02 & 0,02 & 0,02 & 0,02 & 0,03 & 0,03 & 0,08 & 0,02 & 0,03 & 0,03 & 0,01 & 0,02 & 0,02 & 0,02 & 0,02 & 0,02 & 0,02 \\
\hline $\mathrm{Mn}$ & 0,00 & 0,00 & 0,00 & 0,00 & 0,00 & 0,00 & 0,00 & 0,00 & 0,00 & 0,00 & 0,00 & 0,00 & 0,00 & 0,00 & 0,00 & 0,00 & 0,00 & 0,00 & 0,00 & 0,00 & 0,00 & 0,00 & 0,00 \\
\hline P & 0,00 & 0,00 & 0,03 & 0,03 & 0,10 & 0,00 & 0,07 & 0,01 & 0,02 & 0,01 & 0,03 & 0,06 & 0,04 & 0,04 & 0,03 & 0,00 & 0,10 & 0,03 & 0,03 & 0,00 & 0,04 & 0,03 & 0,02 \\
\hline Ba & 0,00 & 0,01 & 0,00 & 0,00 & 0,00 & 0,00 & 0,00 & 0,00 & 0,00 & 0,00 & 0,00 & 0,00 & 0,00 & 0,00 & 0,00 & 0,00 & 0,00 & 0,01 & 0,00 & 0,01 & 0,00 & 0,00 & 0,00 \\
\hline Sr & 0,00 & 0,00 & 0,00 & 0,00 & 0,00 & 0,00 & 0,00 & 0,00 & 0,00 & 0,00 & 0,00 & 0,00 & 0,00 & 0,00 & 0,00 & 0,00 & 0,00 & 0,00 & 0,00 & 0,00 & 0,00 & 0,00 & 0,00 \\
\hline $\mathrm{Zn}$ & 0,00 & 0,00 & 0,00 & 0,00 & 0,00 & 0,00 & 0,00 & 0,00 & 0,00 & 0,00 & 0,00 & 0,00 & 0,00 & 0,00 & 0,00 & 0,01 & 0,00 & 0,00 & 0,00 & 0,01 & 0,01 & 0,00 & 0,01 \\
\hline As & 0,00 & 0,00 & 0,00 & 0,00 & 0,00 & 0,00 & 0,00 & 0,00 & 0,00 & 0,00 & 0,00 & 0,00 & 0,00 & 0,00 & 0,00 & 0,00 & 0,00 & 0,00 & 0,01 & 0,00 & 0,00 & 0,00 & 0,00 \\
\hline $\mathrm{Rb}$ & 0,00 & 0,00 & 0,00 & 0,00 & 0,00 & 0,00 & 0,00 & 0,00 & 0,00 & 0,00 & 0,00 & 0,00 & 0,00 & 0,00 & 0,00 & 0,00 & 0,00 & 0,00 & 0,00 & 0,00 & 0,00 & 0,00 & 0,00 \\
\hline$\%$ mol or & 0,6 & 0,7 & 0,8 & 0,7 & 0,4 & 0,7 & 0,5 & 0,6 & 0,5 & 0,5 & 0,8 & 0,8 & 2,1 & 0,5 & 0,8 & 0,7 & 0,3 & 0,6 & 0,5 & 0,4 & 0,6 & 0,6 & 0,5 \\
\hline$\%$ mol $A b$ & 99,2 & 99,3 & 99,1 & 99,1 & 98,4 & 99,2 & 98,3 & 99,4 & 99,4 & 99,4 & 99,2 & 99,0 & 97,5 & 99,3 & 99,0 & 99,3 & 98,8 & 99,3 & 99,4 & 99,6 & 98,7 & 98,9 & 99,4 \\
\hline$\%$ mol $A n$ & 0,2 & 0,2 & 0,1 & 0,2 & 1,1 & 0,2 & 1,3 & 0,1 & 0,2 & 0,1 & 0,0 & 0,3 & 0,4 & 0,2 & 0,3 & 0,0 & 0,9 & 0,1 & 0,1 & 0,0 & 0,7 & 0,5 & 0,0 \\
\hline
\end{tabular}


Plagioclasa (continuación)

Anexo III. Análisis de microsonda electrónica

Carrasquera

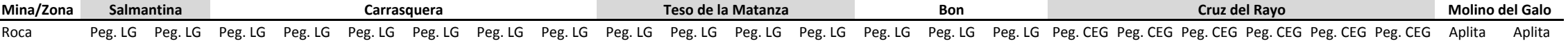

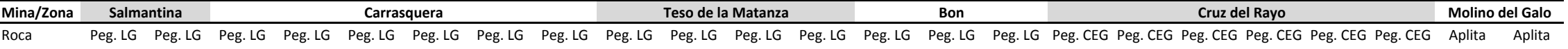

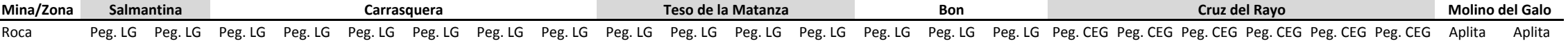

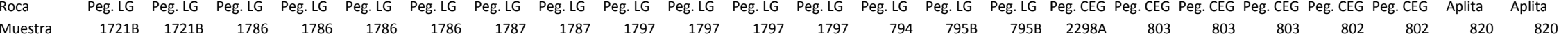

$\begin{array}{lrrrrrrrrrrrrrrrrrrrrrrr}\text { Análisis } & 8.1 & 8.2 & 2.4 & 2.6 & 3.2 & 8.2 & 1.2 & 3.4 & 4.2 & 4.3 & 5.2 & 5.3 & 1.1 & 2.1 & 4.2 & 4.1 & 4.5 & 6.1 & 6.2 & 2.1 & 3.1 & 2.3 & 3.3 \\ \mathrm{SiO}_{2} & 68,65 & 68,43 & 68,07 & 67,58 & 65,61 & 66,80 & 69,20 & 68,74 & 68,62 & 68,74 & 68,37 & 68,76 & 67,69 & 67,87 & 69,67 & 70,17 & 68,98 & 69,20 & 67,85 & 68,93 & 67,93 & 67,07 & 66,97\end{array}$

$\begin{array}{rrrrrrrrrrrrrrrrrrrrrrrrr}\mathrm{P}_{2} \mathrm{O}_{5} & 0,26 & 0,28 & 0,57 & 0,59 & 0,88 & 0,68 & 0,23 & 0,24 & 0,08 & 0,03 & 0,73 & 0,66 & 0,83 & 0,67 & 0,17 & 0,17 & 0,24 & 0,35 & 0,80 & 0,55 & 0,80 & 0,69 & 0,66\end{array}$

$\begin{array}{lllllllllllllllllllllllll}\mathrm{Al}_{2} \mathrm{O}_{3} & 20,05 & 19,80 & 20,06 & 20,25 & 20,52 & 20,31 & 19,52 & 19,37 & 19,12 & 19,10 & 19,67 & 19,76 & 19,76 & 19,97 & 19,23 & 19,23 & 19,34 & 19,16 & 19,40 & 19,80 & 19,92 & 19,98 & 20,39\end{array}$

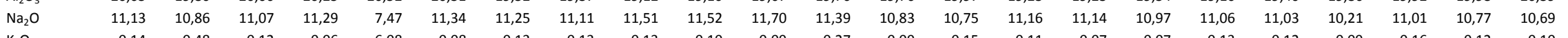

$\begin{array}{llllllllllllllllllllllllllll}\mathrm{K}_{2} \mathrm{O} & 0,14 & 0,48 & 0,12 & 0,06 & 6,08 & 0,08 & 0,13 & 0,13 & 0,13 & 0,10 & 0,09 & 0,27 & 0,09 & 0,15 & 0,11 & 0,07 & 0,07 & 0,13 & 0,12 & 0,09 & 0,16 & 0,12 & 0,10 \\ \mathrm{CaO} & 0,06 & 0,03 & 0,08 & 0,05 & 0,01 & 0,06 & 0,06 & 0,03 & 0,02 & 0,02 & 0,01 & 0,03 & 0,37 & 0,53 & 0,01 & 0,02 & 0,01 & 0,03 & 0,16 & 0,14 & 0,25 & 0,26 & 0,28\end{array}$

$\begin{array}{llllllllllllllllllllllll}\mathrm{MgO} & 0,00 & 0,03 & 0,01 & 0,01 & 0,02 & 0,00 & 0,01 & 0,02 & 0,02 & 0,00 & 0,00 & 0,00 & 0,00 & 0,00 & 0,00 & 0,00 & 0,02 & 0,00 & 0,01 & 0,00 & 0,02 & 0,01 & 0,01\end{array}$

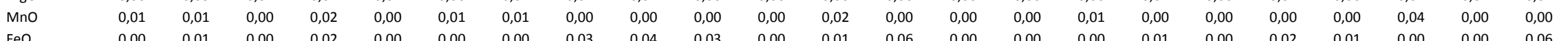

$\begin{array}{llllllllllllllllllllllll}\mathrm{FeO} & 0,00 & 0,01 & 0,00 & 0,02 & 0,00 & 0,00 & 0,00 & 0,03 & 0,04 & 0,03 & 0,00 & 0,01 & 0,06 & 0,00 & 0,00 & 0,00 & 0,01 & 0,00 & 0,02 & 0,01 & 0,00 & 0,00 & 0,06 \\ \mathrm{TiO}_{2} & 0,01 & 0,00 & 0,02 & 0,00 & 0,00 & 0,02 & 0,01 & 0,00 & 0,00 & 0,00 & 0,00 & 0,00 & 0,00 & 0,00 & 0,01 & 0,00 & 0,02 & 0,00 & 0,00 & 0,00 & 0,00 & 0,00 & 0,00\end{array}$

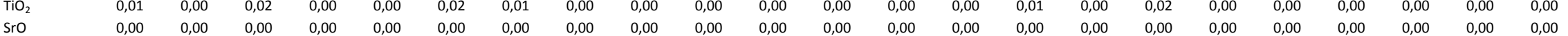

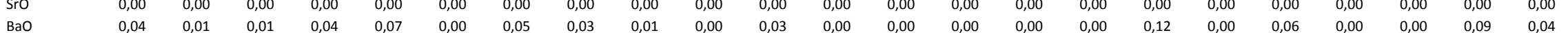

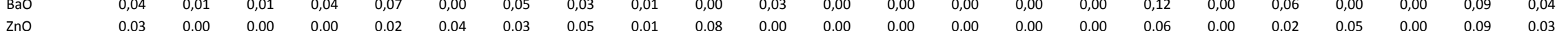

$\begin{array}{lllllllllllllllllllllllll}\mathrm{ZnO} & 0,03 & 0,00 & 0,00 & 0,00 & 0,02 & 0,04 & 0,03 & 0,05 & 0,01 & 0,08 & 0,00 & 0,00 & 0,00 & 0,00 & 0,00 & 0,00 & 0,06 & 0,00 & 0,02 & 0,05 & 0,00 & 0,09 & 0,03 \\ \mathrm{As}_{2} \mathrm{O}_{3} & 0,03 & 0,02 & 0,00 & 0,00 & 0,02 & 0,00 & 0,00 & 0,01 & 0,01 & 0,00 & 0,00 & 0,01 & 0,00 & 0,03 & 0,04 & 0,00 & 0,00 & 0,01 & 0,02 & 0,00 & 0,00 & 0,00 & 0,01\end{array}$

$\begin{array}{llllllllllllllllllllllll}\mathrm{Rb}_{2} \mathrm{O} & 0,00 & 0,00 & 0,00 & 0,00 & 0,01 & 0,00 & 0,00 & 0,00 & 0,00 & 0,00 & 0,00 & 0,00 & 0,02 & 0,02 & 0,02 & 0,02 & 0,02 & 0,02 & 0,02 & 0,02 & 0,02 & 0,02 & 0,02\end{array}$

$\begin{array}{llllllllllllllllllllllllll}\mathrm{Cl} & 0,00 & 0,00 & 0,00 & 0,00 & 0,00 & 0,00 & 0,01 & 0,01 & 0,01 & 0,01 & 0,00 & 0,01 & 0,02 & 0,00 & 0,00 & 0,00 & 0,00 & 0,01 & 0,01 & 0,00 & 0,01 & 0,01 & 0,00 \\ \mathrm{~F} & 0,00 & 0,00 & 0,08 & 0,00 & 0,00 & 0,00 & 0,00 & 0,00 & 0,01 & 0,00 & 0,00 & 0,00 & 0,04 & 0,00 & 0,03 & 0,00 & 0,01 & 0,04 & 0,04 & 0,02 & 0,00 & 0,00 & 0,00\end{array}$

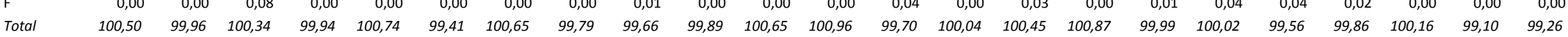

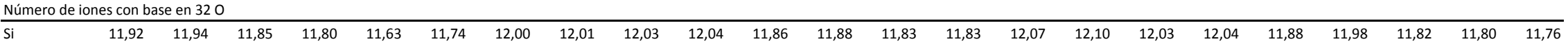

\begin{tabular}{|c|c|c|c|c|c|c|c|c|c|c|c|c|c|c|c|c|c|c|c|c|c|c|c|}
\hline Si & 11,92 & 11,94 & 11,85 & 11,80 & 11,63 & 11,74 & 12,00 & 12,00 & 12,03 & 12,04 & 11,86 & 11,88 & 11,83 & 11,83 & 12,07 & 12,10 & 12,03 & 12,04 & 11,88 & 11,98 & 11,82 & 11,80 & 11,76 \\
\hline Al & 4,10 & 4,07 & 4,12 & 4,17 & 4,29 & 4,20 & 3,99 & 3,99 & 3,95 & 3,94 & 4,02 & 4,03 & 4,07 & 4,10 & 3,93 & 3,91 & 3,98 & 3,93 & 4,00 & 4,05 & 4,09 & 4,14 & 4,22 \\
\hline $\mathrm{Fe}$ & 0,00 & 0,00 & 0,00 & 0,00 & 0,00 & 0,00 & 0,00 & 0,00 & 0,01 & 0,00 & 0,00 & 0,00 & 0,01 & 0,00 & 0,00 & 0,00 & 0,00 & 0,00 & 0,00 & 0,00 & 0,00 & 0,00 & 0,01 \\
\hline $\mathrm{Ti}$ & 0,00 & 0,00 & 0,00 & 0,00 & 0,00 & 0,00 & 0,00 & 0,00 & 0,00 & 0,00 & 0,00 & 0,00 & 0,00 & 0,00 & 0,00 & 0,00 & 0,00 & 0,00 & 0,00 & 0,00 & 0,00 & 0,00 & 0,00 \\
\hline $\mathrm{Mg}$ & 0,00 & 0,01 & 0,00 & 0,00 & 0,01 & 0,00 & 0,00 & 0,00 & 0,01 & 0,00 & 0,00 & 0,00 & 0,00 & 0,00 & 0,00 & 0,00 & 0,00 & 0,00 & 0,00 & 0,00 & 0,00 & 0,00 & 0,00 \\
\hline $\mathrm{Na}$ & 3,74 & 3,68 & 3,74 & 3,82 & 2,57 & 3,86 & 3,78 & 3,76 & 3,91 & 3,91 & 3,93 & 3,82 & 3,67 & 3,63 & 3,75 & 3,72 & 3,71 & 3,73 & 3,75 & 3,44 & 3,71 & 3,67 & 3,64 \\
\hline K & 0,03 & 0,11 & 0,03 & 0,01 & 1,37 & 0,02 & 0,03 & 0,03 & 0,03 & 0,02 & 0,02 & 0,06 & 0,02 & 0,03 & 0,02 & 0,01 & 0,02 & 0,03 & 0,03 & 0,02 & 0,04 & 0,03 & 0,02 \\
\hline $\mathrm{Mn}$ & 0,00 & 0,00 & 0,00 & 0,00 & 0,00 & 0,00 & 0,00 & 0,00 & 0,00 & 0,00 & 0,00 & 0,00 & 0,00 & 0,00 & 0,00 & 0,00 & 0,00 & 0,00 & 0,00 & 0,00 & 0,01 & 0,00 & 0,00 \\
\hline $\mathrm{P}$ & 0,04 & 0,04 & 0,08 & 0,09 & 0,13 & 0,10 & 0,03 & 0,04 & 0,01 & 0,00 & 0,11 & 0,10 & 0,12 & 0,10 & 0,02 & 0,02 & 0,04 & 0,05 & 0,12 & 0,08 & 0,12 & 0,10 & 0,10 \\
\hline $\mathrm{Ba}$ & 0,00 & 0,00 & 0,00 & 0,00 & 0,01 & 0,00 & 0,00 & 0,00 & 0,00 & 0,00 & 0,00 & 0,00 & 0,00 & 0,00 & 0,00 & 0,00 & 0,01 & 0,00 & 0,00 & 0,00 & 0,00 & 0,01 & 0,00 \\
\hline $\mathrm{Sr}$ & 0,00 & 0,00 & 0,00 & 0,00 & 0,00 & 0,00 & 0,00 & 0,00 & 0,00 & 0,00 & 0,00 & 0,00 & 0,00 & 0,00 & 0,00 & 0,00 & 0,00 & 0,00 & 0,00 & 0,00 & 0,00 & 0,00 & 0,00 \\
\hline As & 0,00 & 0,00 & 0,00 & 0,00 & 0,00 & 0,00 & 0,00 & 0,00 & 0,00 & 0,00 & 0,00 & 0,00 & 0,00 & 0,00 & 0,00 & 0,00 & 0,00 & 0,00 & 0,00 & 0,00 & 0,00 & 0,00 & 0,00 \\
\hline $\mathrm{Rb}$ & 0,00 & 0,00 & 0,00 & 0,00 & 0,00 & 0,00 & 0,00 & 0,00 & 0,00 & 0,00 & 0,00 & 0,00 & 0,00 & 0,00 & 0,00 & 0,00 & 0,00 & 0,00 & 0,00 & 0,00 & 0,00 & 0,00 & 0,00 \\
\hline$\%$ mol or & 0,8 & 2,8 & 0,8 & 0,4 & 34,9 & 0,5 & 0,8 & 0,8 & 0,7 & 0,6 & 0,6 & 1,5 & 0,5 & 0,9 & 0,6 & 0,4 & 0,7 & 0,8 & 0,8 & 0,6 & 1,0 & 0,69 & 0,61 \\
\hline$\%$ mol $A b$ & 98,9 & 97,0 & 98,8 & 99,2 & 65,0 & 99,1 & 98,9 & 98,9 & 98,9 & 99,2 & 99,4 & 98,3 & 97,4 & 96,5 & 99,3 & 99,5 & 99,3 & 99,1 & 98,3 & 98,6 & 97,7 & 98,02 & 97,98 \\
\hline$\%$ mol $A n$ & 0,3 & 0,1 & 0,4 & 0,5 & 0,2 & 0,3 & 0,4 & 0,4 & 0,4 & 0,2 & 0,1 & 0,3 & 2,1 & 2,6 & 0,0 & 0,1 & 0,2 & 0,2 & 1,0 & 0,8 & 1,5 & 1,29 & 1,41 \\
\hline
\end{tabular}


Plagioclasa (continuación)

\begin{tabular}{|c|c|c|c|c|c|}
\hline Mina/Zona & & & a Canalita & & \\
\hline Roca & Peg. CEG & Peg. CEG & $\begin{array}{l}\text { Peg. CEG } \\
\text {. }\end{array}$ & Peg. CEG & Peg. CEG \\
\hline Muestra & 1066 & 1066 & 1066 & 1066 & 817 \\
\hline Análisis & 2.1 & 3.3 & 5.1 & 6.3 & 3.2 \\
\hline $\mathrm{SiO}_{2}$ & 69,21 & 68,57 & 68,36 & 69,07 & 68,57 \\
\hline $\mathrm{P}_{2} \mathrm{O}_{5}$ & 0,48 & 0,66 & 0,66 & 0,02 & 0,00 \\
\hline $\mathrm{Al}_{2} \mathrm{O}_{3}$ & 19,44 & 19,81 & 19,58 & 19,52 & 19,33 \\
\hline $\mathrm{Na}_{2} \mathrm{O}$ & 11,30 & 10,90 & 11,19 & 11,02 & 10,98 \\
\hline $\mathrm{K}_{2} \mathrm{O}$ & 0,08 & 0,12 & 0,08 & 0,04 & 0,06 \\
\hline $\mathrm{CaO}$ & 0,12 & 0,20 & 0,19 & 0,44 & 0,00 \\
\hline $\mathrm{MgO}$ & 0,00 & 0,00 & 0,01 & 0,00 & 0,00 \\
\hline $\mathrm{MnO}$ & 0,01 & 0,00 & 0,00 & 0,02 & 0,01 \\
\hline $\mathrm{FeO}$ & 0,03 & 0,00 & 0,00 & 0,02 & 0,00 \\
\hline $\mathrm{TiO}_{2}$ & 0,00 & 0,00 & 0,03 & 0,03 & 0,00 \\
\hline Sro & 0,00 & 0,00 & 0,00 & 0,00 & 0,00 \\
\hline $\mathrm{BaO}$ & 0,01 & 0,00 & 0,00 & 0,00 & 0,05 \\
\hline $\mathrm{ZnO}$ & 0,00 & 0,00 & 0,00 & 0,03 & 0,00 \\
\hline $\mathrm{As}_{2} \mathrm{O}_{3}$ & 0,00 & 0,01 & 0,00 & 0,00 & 0,00 \\
\hline $\mathrm{Rb}_{2} \mathrm{O}$ & 0,02 & 0,02 & 0,02 & 0,02 & 0,03 \\
\hline $\mathrm{Cl}$ & 0,00 & 0,00 & 0,02 & 0,01 & 0,00 \\
\hline $\mathrm{F}$ & 0,03 & 0,00 & 0,00 & 0,00 & 0,00 \\
\hline Total & 100,72 & 100,30 & 100,13 & 100,23 & 99,02 \\
\hline Número de i & iones con b & ase en $32 \mathrm{C}$ & & & \\
\hline $\mathrm{Si}$ & 11,97 & 11,90 & 11,90 & 12,02 & 12,05 \\
\hline Al & 3,96 & 4,05 & 4,02 & 4,00 & 4,00 \\
\hline $\mathrm{Fe}$ & 0,00 & 0,00 & 0,00 & 0,00 & 0,00 \\
\hline $\mathrm{Ti}$ & 0,00 & 0,00 & 0,00 & 0,00 & 0,00 \\
\hline $\mathrm{Mg}$ & 0,00 & 0,00 & 0,00 & 0,00 & 0,00 \\
\hline $\mathrm{Na}$ & 3,79 & 3,67 & 3,77 & 3,72 & 3,74 \\
\hline $\mathrm{Ca}$ & 0,02 & 0,04 & 0,04 & 0,08 & 0,00 \\
\hline K & 0,02 & 0,03 & 0,02 & 0,01 & 0,01 \\
\hline $\mathrm{Mn}$ & 0,00 & 0,00 & 0,00 & 0,00 & 0,00 \\
\hline P & 0,07 & 0,10 & 0,10 & 0,00 & 0,00 \\
\hline Ba & 0,00 & 0,00 & 0,00 & 0,00 & 0,00 \\
\hline $\mathrm{Sr}$ & 0,00 & 0,00 & 0,00 & 0,00 & 0,00 \\
\hline $\mathrm{Zn}$ & 0,00 & 0,00 & 0,00 & 0,00 & 0,00 \\
\hline As & 0,00 & 0,00 & 0,00 & 0,00 & 0,00 \\
\hline $\mathrm{Rb}$ & 0,00 & 0,00 & 0,00 & 0,00 & 0,00 \\
\hline$\% \mathrm{~mol}$ Or & 0,44 & 0,69 & 0,46 & 0,21 & 0,35 \\
\hline$\% \mathrm{~mol} A b$ & 98,99 & 98,31 & 98,62 & 97,63 & 99,65 \\
\hline$\% \mathrm{~mol} A n$ & 0,57 & 0,99 & 0,92 & 2,16 & 0,00 \\
\hline
\end{tabular}

Anexo III. Análisis de microsonda electrónica

\begin{tabular}{|c|c|c|c|c|c|c|c|c|c|c|c|c|c|c|c|c|}
\hline ina/Zona & \multicolumn{3}{|c|}{ San Martín de Trevejo } & \multicolumn{12}{|c|}{ Horia } & \multirow{2}{*}{$\begin{array}{c}\text { Salam. } \\
\text { LG }\end{array}$} \\
\hline & MP & MP & MP & GE & GE & GE & GE & GE & GE & GE & GE & GE & GE & GE & GE & \\
\hline lestra & 807 & 807 & 807 & $1682 \mathrm{~A}$ & $1682 \mathrm{~A}$ & $1682 \mathrm{~A}$ & $1682 \mathrm{~A}$ & $1682 \mathrm{~A}$ & $1682 \mathrm{~A}$ & $1682 \mathrm{~A}$ & $1682 A$ & 1770 & 1770 & 1770 & 1770 & $1690 \mathrm{~B}$ \\
\hline álisis & 1.2 & 2.2 & 3.3 & 1.8 & 1.9 & 4.2 & 4.5 & 6.4 & 6.5 & 7.4 & 9.4 & 1.2 & 1.3 & 1.4 & 3.2 & 1.3 \\
\hline & 47,06 & 47,23 & 46,56 & 47,73 & 47,16 & 47,96 & 47,78 & 45,87 & 47,89 & 49,09 & 46,03 & 48,20 & 49,50 & 47,38 & 46,97 & 44,50 \\
\hline & 0,04 & 0,01 & 0,06 & 0,00 & 0,06 & 0,00 & 0,00 & 0,02 & 0,01 & 0,01 & 0,07 & 0,02 & 0,03 & 0,01 & 0,03 & 0,05 \\
\hline & 35,15 & 35,41 & 34,11 & 34,11 & 35,96 & 33,46 & 31,48 & 36,65 & 33,46 & 28,40 & 36,13 & 32,76 & 34,30 & 31,51 & 36,63 & 33,93 \\
\hline & 0,40 & 0,36 & 0,31 & 0,27 & 0,67 & 0,15 & 0,15 & 0,24 & 0,19 & 1,66 & 0,64 & 0,30 & 0,06 & 0,19 & 0,76 & 0,47 \\
\hline & 10,72 & 10,69 & 10,66 & 10,30 & 9,76 & 10,47 & 10,45 & 10,53 & 10,42 & 8,11 & 10,20 & 10,34 & 9,47 & 10,07 & 9,66 & 10,32 \\
\hline & 0,00 & 0,00 & 0,01 & 0,01 & 0,00 & 0,00 & 0,00 & 0,01 & 0,01 & 0,71 & 0,00 & 0,00 & 0,02 & 0,00 & 0,00 & 0,01 \\
\hline & 0,57 & 0,51 & 0,71 & 1,24 & 0,97 & 1,44 & 1,56 & 0,83 & 1,66 & 0,98 & 0,85 & 2,17 & 1,05 & 2,22 & 0,66 & 0,54 \\
\hline & 0,00 & 0,01 & 0,03 & 0,04 & 0,01 & 0,04 & 0,05 & 0,03 & 0,03 & 0,02 & 0,02 & 0,10 & 0,01 & 0,09 & 0,01 & 0,00 \\
\hline & 0,81 & 0,70 & 1,49 & 1,92 & 1,60 & 2,78 & 2,92 & 1,59 & 2,58 & 1,87 & 1,46 & 2,12 & 0,97 & 1,53 & 1,76 & 3,11 \\
\hline & 1,37 & 0,90 & 0,94 & 1,96 & 1,06 & 0,63 & 0,58 & 0,88 & 0,58 & 0,18 & 0,85 & 0,85 & 0,08 & 0,83 & 0,34 & 0,28 \\
\hline D* & 0,01 & 0,00 & 0,00 & 0,13 & 0,09 & 0,13 & 0,15 & 0,03 & 0,12 & 0,00 & 0,07 & 0,36 & 0,06 & 0,32 & 0,14 & 0,35 \\
\hline & 0,07 & 0,00 & 0,10 & 0,02 & 0,05 & 0,05 & 0,05 & 0,10 & 0,07 & 0,03 & 0,01 & 0,03 & 0,06 & 0,04 & 0,00 & 0,04 \\
\hline & 0,00 & 0,00 & 0,00 & 0,00 & 0,00 & 0,00 & 0,00 & 0,00 & 0,00 & 0,00 & 0,00 & 0,00 & 0,00 & 0,00 & 0,00 & 0,00 \\
\hline & 0,01 & 0,00 & 0,00 & 0,01 & 0,02 & 0,01 & 0,01 & 0,03 & 0,01 & 0,11 & 0,02 & 0,00 & 0,05 & 0,00 & 0,00 & 0,01 \\
\hline & 0,20 & 0,15 & 0,12 & 0,57 & 0,44 & 0,57 & 0,62 & 0,23 & 0,54 & 0,11 & 0,37 & 1,26 & 0,35 & 1,16 & 0,58 & 1,24 \\
\hline & 96,35 & 95,93 & 95,05 & 98,08 & 97,67 & 97,45 & 95,54 & 96,93 & 97,34 & 91,20 & 96,55 & 97,99 & 95,88 & 94,90 & 97,54 & 94,33 \\
\hline \multicolumn{17}{|c|}{ Vúmero de iones con base en 220} \\
\hline & 6,20 & 6,23 & 6,24 & 6,23 & 6,15 & 6,33 & 6,45 & 6,04 & 6,32 & 6,79 & 6,08 & 6,37 & 6,49 & 6,44 & 6,15 & 6,17 \\
\hline & 1,80 & 1,77 & 1,76 & 1,77 & 1,85 & 1,67 & 1,55 & 1,96 & 1,68 & 1,21 & 1,92 & 1,63 & 1,51 & 1,56 & 1,85 & 1,83 \\
\hline & 8,00 & 8,00 & 8,00 & 8,00 & 8,00 & 8,00 & 8,00 & 8,00 & 8,00 & 8,00 & 8,00 & 8,00 & 8,00 & 8,00 & 8,00 & 8,00 \\
\hline & 3,66 & 3,74 & 3,62 & 3,49 & 3,67 & 3,53 & 3,45 & 3,72 & 3,52 & 3,42 & 3,71 & 3,48 & 3,78 & 3,49 & 3,80 & 3,71 \\
\hline & 0,09 & 0,08 & 0,17 & 0,21 & 0,17 & 0,31 & 0,33 & 0,17 & 0,28 & 0,22 & 0,16 & 0,23 & 0,11 & 0,17 & 0,19 & 0,36 \\
\hline & 0,14 & 0,09 & 0,09 & 0,19 & 0,10 & 0,06 & 0,06 & 0,09 & 0,06 & 0,02 & 0,08 & 0,08 & 0,01 & 0,09 & 0,03 & 0,03 \\
\hline & 0,11 & 0,10 & 0,14 & 0,24 & 0,19 & 0,28 & 0,31 & 0,16 & 0,33 & 0,20 & 0,17 & 0,43 & 0,21 & 0,45 & 0,13 & 0,11 \\
\hline & 0,00 & 0,00 & 0,00 & 0,00 & 0,00 & 0,00 & 0,01 & 0,00 & 0,00 & 0,00 & 0,00 & 0,01 & 0,00 & 0,01 & 0,00 & 0,00 \\
\hline & 0,00 & 0,00 & 0,01 & 0,00 & 0,01 & 0,00 & 0,00 & 0,00 & 0,00 & 0,00 & 0,01 & 0,00 & 0,00 & 0,00 & 0,00 & 0,01 \\
\hline & 0,01 & 0,00 & 0,00 & 0,07 & 0,05 & 0,07 & 0,08 & 0,01 & 0,06 & 0,00 & 0,04 & 0,19 & 0,03 & 0,18 & 0,07 & 0,19 \\
\hline & 4,01 & 4,01 & 4,03 & 4,20 & 4,19 & 4,26 & 4,24 & 4,16 & 4,26 & 3,86 & 4,17 & 4,43 & 4,14 & 4,38 & 4,23 & 4,41 \\
\hline & 0,00 & 0,00 & 0,00 & 0,00 & 0,00 & 0,00 & 0,00 & 0,00 & 0,00 & 0,11 & 0,00 & 0,00 & 0,00 & 0,00 & 0,00 & 0,00 \\
\hline & 0,10 & 0,09 & 0,08 & 0,07 & 0,17 & 0,04 & 0,04 & 0,06 & 0,05 & 0,45 & 0,16 & 0,08 & 0,01 & 0,05 & 0,19 & 0,13 \\
\hline & 1,80 & 1,80 & 1,82 & 1,72 & 1,62 & 1,76 & 1,80 & 1,77 & 1,75 & 1,43 & 1,72 & 1,74 & 1,58 & 1,75 & 1,61 & 1,83 \\
\hline & 1,91 & 1,89 & 1,90 & 1,79 & 1,79 & 1,80 & 1,84 & 1,83 & 1,80 & 1,98 & 1,88 & 1,82 & 1,60 & 1,80 & 1,83 & 1,95 \\
\hline & 0,08 & 0,06 & 0,05 & 0,24 & 0,18 & 0,24 & 0,27 & 0,10 & 0,22 & 0,05 & 0,15 & 0,53 & 0,14 & 0,50 & 0,24 & 0,54 \\
\hline & 0,00 & 0,00 & 0,00 & 0,00 & 0,00 & 0,00 & 0,00 & 0,01 & 0,00 & 0,03 & 0,00 & 0,00 & 0,01 & 0,00 & 0,00 & 0,00 \\
\hline$(\mathrm{e}+\mathrm{Mg})$ & 0,44 & 0,44 & 0,54 & 0,46 & 0,48 & 0,52 & 0,51 & 0,52 & 0,47 & 0,52 & 0,49 & 0,35 & 0,34 & 0,28 & 0,60 & 0,76 \\
\hline \multicolumn{17}{|c|}{ razas en ppm } \\
\hline & 64 & 0 & 0 & 621 & 424 & 621 & 699 & 118 & 568 & 0 & 320 & 1652 & 289 & 1497 & 631 & 1617 \\
\hline & 29 & 117 & 105 & 335 & 55 & 0 & 210 & 20 & 263 & 100 & 0 & 405 & 100 & 769 & 263 & 370 \\
\hline & 0 & 282 & 80 & 0 & 0 & 0 & 0 & 0 & 0 & 133 & 0 & 151 & 465 & 1293 & 178 & 0 \\
\hline
\end{tabular}

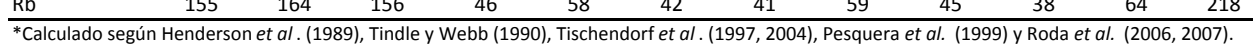


Moscovita (continuación)

Anexo III. Análisis de microsonda electrónica

\begin{tabular}{|c|c|c|c|c|c|c|c|c|c|c|c|c|c|c|c|c|c|c|c|c|c|c|c|}
\hline \multirow{2}{*}{$\begin{array}{l}\text { Mina/Zona } \\
\text { Roca }\end{array}$} & \multicolumn{2}{|c|}{ Salmantina } & \multicolumn{6}{|c|}{ Carrasquera } & \multicolumn{3}{|c|}{ Profunda } & \multicolumn{8}{|c|}{ Teso de la matanza } & \multicolumn{4}{|c|}{ Salmantina } \\
\hline & LG & LG & LG & LG & LG & LG & LG & LG & LG & LG & LG & LG & LG & LG & LG & LG & LG & LG & LG & $A B$ & $A B$ & $A B$ & $A B$ \\
\hline Muestra & $1690 B$ & $1690 B$ & 1781 & 1781 & 1781 & 1779 & 1779 & 1779 & $788 \mathrm{~A}$ & $788 \mathrm{~A}$ & $788 \mathrm{~A}$ & 1788 & 1788 & 1788 & $1791 \mathrm{~A}$ & $1791 \mathrm{~A}$ & $1791 \mathrm{~A}$ & $1791 \mathrm{~A}$ & 1794 & 1684 & 1684 & 1684 & 1685 \\
\hline Análisis & 4.3 & 5.2 & 2.2 & 3.3 & 4.3 & 1.1 & 1.2 & 2.2 & 1.2 & 4.3 & 7.1 & 3.4 & 4.3 & 5.3 & 1.3 & 2.5 & 3.3 & 4.3 & 1.2 & 2.3 & 4.1 & 7.2 & 1.3 \\
\hline $\mathrm{SiO}_{2}$ & 47,32 & 48,08 & 47,44 & 46,17 & 45,77 & 46,33 & 46,41 & 45,77 & 46,51 & 46,66 & 46,64 & 46,15 & 46,46 & 46,10 & 45,35 & 45,70 & 47,45 & 48,63 & 46,72 & 48,32 & 45,87 & 47,62 & 46,15 \\
\hline $\mathrm{P}_{2} \mathrm{O}_{5}$ & 0,03 & 0,07 & 0,00 & 0,04 & 0,32 & 0,05 & 0,00 & 0,05 & 0,06 & 0,04 & 0,09 & 0,04 & 0,01 & 0,01 & 0,06 & 0,05 & 0,00 & 0,26 & 0,05 & 0,03 & 0,08 & 0,01 & 0,03 \\
\hline $\mathrm{Al}_{2} \mathrm{O}_{3}$ & 33,86 & 32,16 & 34,67 & 34,08 & 33,02 & 34,64 & 34,99 & 36,07 & 33,90 & 35,74 & 34,52 & 33,07 & 33,07 & 34,01 & 32,83 & 35,86 & 34,85 & 33,44 & 33,27 & 33,27 & 34,69 & 34,19 & 32,29 \\
\hline $\mathrm{Na}_{2} \mathrm{O}$ & 0,39 & 0,20 & 0,14 & 0,27 & 0,10 & 0,59 & 0,17 & 0,33 & 0,18 & 0,25 & 0,69 & 0,25 & 0,32 & 0,36 & 0,33 & 0,40 & 0,18 & 0,08 & 0,34 & 0,35 & 0,27 & 0,17 & 0,31 \\
\hline $\mathrm{K}_{2} \mathrm{O}$ & 10,48 & 10,62 & 10,89 & 10,51 & 7,82 & 9,44 & 10,67 & 10,28 & 10,10 & 9,60 & 10,06 & 10,15 & 10,18 & 10,40 & 10,16 & 10,19 & 10,52 & 8,68 & 10,53 & 10,12 & 10,68 & 10,62 & 10,25 \\
\hline $\mathrm{CaO}$ & 0,00 & 0,03 & 0,00 & 0,00 & 0,02 & 0,01 & 0,00 & 0,00 & 0,00 & 0,00 & 0,00 & 0,02 & 0,00 & 0,00 & 0,01 & 0,00 & 0,00 & 0,01 & 0,00 & 0,00 & 0,00 & 0,00 & 0,01 \\
\hline $\mathrm{MgO}$ & 0,51 & 0,74 & 0,74 & 0,67 & 0,27 & 0,13 & 0,23 & 0,18 & 0,39 & 0,08 & 0,14 & 0,61 & 0,69 & 0,48 & 0,63 & 0,45 & 0,95 & 0,72 & 0,53 & 0,45 & 0,37 & 0,46 & 0,62 \\
\hline $\mathrm{MnO}$ & 0,06 & 0,06 & 0,05 & 0,07 & 0,05 & 0,10 & 0,10 & 0,11 & 0,12 & 0,09 & 0,10 & 0,04 & 0,04 & 0,06 & 0,13 & 0,05 & 0,09 & 0,09 & 0,11 & 0,11 & 0,09 & 0,06 & 0,10 \\
\hline $\mathrm{FeO}$ & 3,28 & 3,12 & 1,82 & 3,43 & 6,27 & 3,14 & 2,39 & 2,13 & 2,81 & 1,18 & 2,57 & 3,67 & 3,64 & 3,54 & 3,45 & 2,53 & 1,38 & 2,76 & 3,09 & 3,28 & 2,49 & 2,16 & 4,56 \\
\hline $\mathrm{TiO}_{2}$ & 0,38 & 0,37 & 0,37 & 0,26 & 0,15 & 0,11 & 0,06 & 0,16 & 0,22 & 0,02 & 0,11 & 0,33 & 0,38 & 0,13 & 0,49 & 0,03 & 0,37 & 0,15 & 0,45 & 0,29 & 0,18 & 0,26 & 0,35 \\
\hline $\mathrm{Li}_{2} \mathrm{O}^{*}$ & 0,32 & 0,25 & 0,30 & 0,39 & 0,20 & 0,18 & 0,26 & 0,26 & 0,27 & 0,09 & 0,23 & 0,35 & 0,39 & 0,39 & 0,36 & 0,25 & 0,19 & 0,08 & 0,31 & 0,36 & 0,29 & 0,29 & 0,53 \\
\hline $\mathrm{ZnO}$ & 0,03 & 0,07 & 0,08 & 0,09 & 0,10 & 0,22 & 0,06 & 0,09 & 0,07 & 0,00 & 0,11 & 0,01 & 0,09 & 0,00 & 0,21 & 0,07 & 0,06 & 0,11 & 0,04 & 0,00 & 0,07 & 0,07 & 0,01 \\
\hline $\mathrm{As}_{2} \mathrm{O}_{3}$ & 0,00 & 0,00 & 0,00 & 0,00 & 0,00 & 0,00 & 0,00 & 0,00 & 0,00 & 0,00 & 0,00 & 0,00 & 0,00 & 0,00 & 0,00 & 0,00 & 0,00 & 0,23 & 0,00 & 0,00 & 0,00 & 0,00 & 0,00 \\
\hline $\mathrm{Cl}$ & 0,02 & 0,02 & 0,00 & 0,01 & 0,02 & 0,02 & 0,01 & 0,00 & 0,00 & 0,00 & 0,01 & 0,00 & 0,01 & 0,02 & 0,01 & 0,01 & 0,02 & 0,00 & 0,00 & 0,00 & 0,00 & 0,02 & 0,00 \\
\hline $\mathrm{F}$ & 1,17 & 0,95 & 1,10 & 1,36 & 0,77 & 0,71 & 0,98 & 0,96 & 1,00 & 0,43 & 0,89 & 1,25 & 1,38 & 1,39 & 1,27 & 0,93 & 0,74 & 0,39 & 1,12 & 1,29 & 1,05 & 1,05 & 1,81 \\
\hline Total & 97,36 & 96,34 & 97,16 & 96,80 & 94,58 & 95,37 & 95,93 & 96,01 & 95,23 & 94,13 & 95,81 & 95,43 & 96,08 & 96,31 & 94,76 & 96,22 & 96,49 & 95,49 & 96,12 & 97,32 & 95,68 & 96,54 & 96,27 \\
\hline \multicolumn{24}{|c|}{ Número de iones con base en 220} \\
\hline Si & 6,33 & 6,47 & 6,31 & 6,25 & 6,26 & 6,25 & 6,26 & 6,15 & 6,31 & 6,27 & 6,28 & 6,31 & 6,33 & 6,27 & 6,27 & 6,14 & 6,29 & 6,44 & 6,33 & 6,45 & 6,22 & 6,37 & 6,35 \\
\hline $\mathrm{Al}^{\mathrm{IV}}$ & 1,67 & 1,53 & 1,69 & 1,75 & 1,74 & 1,75 & 1,74 & 1,85 & 1,69 & 1,73 & 1,72 & 1,69 & 1,67 & 1,73 & 1,73 & 1,86 & 1,71 & 1,56 & 1,67 & 1,55 & 1,78 & 1,63 & 1,65 \\
\hline$\Sigma z$ & 8,00 & 8,00 & 8,00 & 8,00 & 8,00 & 8,00 & 8,00 & 8,00 & 8,00 & 8,00 & 8,00 & 8,00 & 8,00 & 8,00 & 8,00 & 8,00 & 8,00 & 8,00 & 8,00 & 8,00 & 8,00 & 8,00 & 8,00 \\
\hline $\mathrm{Al}^{\mathrm{V} \mathrm{V}^{\mathrm{V}}}$ & 3,66 & 3,57 & 3,74 & 3,68 & 3,58 & 3,76 & 3,82 & 3,86 & 3,74 & 3,93 & 3,76 & 3,64 & 3,63 & 3,71 & 3,61 & 3,82 & 3,74 & 3,66 & 3,64 & 3,68 & 3,76 & 3,75 & 3,59 \\
\hline $\mathrm{Fe}^{2+}$ & 0,37 & 0,35 & 0,20 & 0,39 & 0,72 & 0,35 & 0,27 & 0,24 & 0,32 & 0,13 & 0,29 & 0,42 & 0,41 & 0,40 & 0,40 & 0,28 & 0,15 & 0,31 & 0,35 & 0,37 & 0,28 & 0,24 & 0,52 \\
\hline $\mathrm{Ti}$ & 0,04 & 0,04 & 0,04 & 0,03 & 0,02 & 0,01 & 0,01 & 0,02 & 0,02 & 0,00 & 0,01 & 0,03 & 0,04 & 0,01 & 0,05 & 0,00 & 0,04 & 0,02 & 0,05 & 0,03 & 0,02 & 0,03 & 0,04 \\
\hline Mg & 0,10 & 0,15 & 0,15 & 0,14 & 0,05 & 0,03 & 0,05 & 0,04 & 0,08 & 0,02 & 0,03 & 0,12 & 0,14 & 0,10 & 0,13 & 0,09 & 0,19 & 0,14 & 0,11 & 0,09 & 0,07 & 0,09 & 0,13 \\
\hline $\mathrm{Mn}$ & 0,01 & 0,01 & 0,01 & 0,01 & $0, c$ & 0,01 & 0,01 & 0,01 & 0,01 & 0,01 & 0,01 & 0,00 & 0,00 & 0,01 & 0,02 & 0,01 & 0,01 & 0,01 & 0,01 & 0,01 & 0,01 & 0,01 & 0,01 \\
\hline 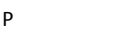 & 0,00 & 0,01 & 0,00 & 0,00 & 0,04 & 0,01 & 0,00 & 0,01 & 0,01 & 0,00 & 0,01 & 0,01 & 0,00 & 0,00 & 0,01 & 0,01 & 0,00 & 0,03 & 0,01 & 0,00 & 0,01 & 0,00 & 0,00 \\
\hline Li* & 0,17 & 0,14 & 0,16 & 0,21 & 0,11 & 0,10 & 0,14 & 0,14 & 0,15 & 0,05 & 0,13 & 0,19 & 0,21 & 0,22 & 0,20 & 0,13 & 0,10 & 0,04 & 0,17 & 0,19 & 0,16 & 0,15 & 0,29 \\
\hline$\Sigma Y$ & 4,35 & 4,26 & 4,30 & 4,45 & 4,5 & 4,26 & 4,29 & 4,31 & 4,33 & 4,15 & 4,24 & 4,42 & 4,45 & 4,45 & 4,41 & 4,34 & 4,23 & 4,21 & 4,33 & 4,37 & 4,31 & 4,28 & 4,59 \\
\hline $\mathrm{Ca}$ & 0,00 & 0,00 & 0,00 & 0,00 & 0,00 & 0,00 & 0,00 & 0,00 & 0,00 & 0,00 & 0,00 & 0,00 & 0,00 & 0,00 & 0,00 & 0,00 & 0,00 & 0,00 & 0,00 & 0,00 & 0,00 & 0,00 & 0,00 \\
\hline $\mathrm{Na}$ & 0,10 & 0,05 & 0,04 & 0,07 & 0,03 & 0,15 & 0,05 & 0,09 & 0,05 & 0,06 & 0,18 & 0,07 & 0,09 & 0,10 & 0,09 & 0,10 & 0,05 & 0,02 & 0,09 & 0,09 & 0,07 & 0,04 & 0,08 \\
\hline K & 1,79 & 1,82 & 1,85 & 1,81 & & 1,63 & 1,83 & 1,76 & 1,75 & 1,65 & 1,73 & 1,77 & 1,77 & 1,80 & 1,79 & 1,75 & 1,78 & 1,47 & 1,82 & 1,72 & 1,85 & 1,81 & 1,80 \\
\hline$\Sigma x$ & 1,89 & 1,88 & 1,88 & 1,88 & 1,40 & 1,78 & 1,88 & 1,85 & 1,80 & 1,71 & 1,91 & 1,84 & 1,85 & 1,90 & 1,88 & 1,85 & 1,83 & 1,49 & 1,91 & 1,81 & 1,92 & 1,86 & 1,88 \\
\hline$F$ & 0,49 & 0,40 & 0,46 & 0,58 & 0,33 & 0,30 & 0,42 & 0,41 & 0,43 & 0,18 & 0,38 & 0,54 & 0,59 & 0,60 & 0,55 & 0,40 & 0,31 & 0,17 & 0,48 & 0,54 & 0,45 & 0,44 & 0,79 \\
\hline $\mathrm{Cl}$ & 0,00 & 0,00 & 0,00 & 0,00 & & 0,00 & 0,00 & 0,00 & 0,00 & 0,00 & 0,00 & 0,00 & 0,00 & 0,00 & 0,00 & 0,00 & 0,00 & 0,00 & 0,00 & 0,00 & 0,00 & 0,00 & 0,00 \\
\hline $\mathrm{Fe} /(\mathrm{Fe}+\mathrm{Mg})$ & 0,78 & 0,70 & 0,58 & 0,74 & 0,93 & 0,93 & 0,85 & 0,87 & 0,80 & 0,89 & 0,91 & 0,77 & 0,75 & 0,81 & 0,75 & 0,76 & 0,45 & 0,68 & 0,77 & 0,80 & 0,79 & 0,73 & 0,81 \\
\hline \multicolumn{24}{|c|}{ Trazas en ppm } \\
\hline Li* & 1509 & 1178 & 1400 & 1800 & 913 & 832 & 1226 & 1205 & 1264 & 419 & 1091 & 1633 & 1819 & 1834 & 1658 & 1158 & 867 & 358 & 1441 & 1684 & 1329 & 1336 & 2465 \\
\hline Sn & 207 & 309 & 222 & 0 & 517 & 310 & 367 & 718 & 532 & 202 & 888 & 353 & 158 & 717 & 578 & 252 & 710 & 0 & 177 & 200 & 0 & 0 & 582 \\
\hline 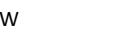 & 0 & 98 & 753 & 1146 & 0 & 1127 & 739 & 0 & 0 & 0 & 0 & 0 & 0 & 232 & 0 & 592 & 0 & 822 & 425 & 0 & 106 & 0 & 815 \\
\hline $\mathrm{Rb}$ & 39 & 80 & 84 & 83 & 54 & 102 & 66 & 109 & 189 & 209 & 289 & 84 & 91 & 101 & 138 & 73 & 69 & 59 & 207 & 89 & 76 & 86 & 93 \\
\hline
\end{tabular}


Anexo III. Análisis de microsonda electrónica

\begin{tabular}{|c|c|c|c|c|c|c|c|c|c|c|c|c|c|c|c|c|c|c|c|c|c|c|c|}
\hline \multirow{2}{*}{$\begin{array}{l}\text { Mina/Zona } \\
\text { Roca }\end{array}$} & \multicolumn{3}{|c|}{ Salmantina } & \multicolumn{5}{|c|}{ Carrasquera } & \multicolumn{5}{|c|}{ Profunda } & \multicolumn{6}{|c|}{ Teso de la Matanza } & \multicolumn{4}{|c|}{ Horia } \\
\hline & $A B$ & $A B$ & AB & AB & $A B$ & $A B$ & $A B$ & $A B$ & $A B$ & $A B$ & $A B$ & $A B$ & $A B$ & $A B$ & $A B$ & $A B$ & $A B$ & $A B$ & $A B$ & Peg. GE & Peg. GE & $\begin{array}{l}\text { Peg. GE } \\
\end{array}$ & Peg. GE \\
\hline Muestra & 1685 & 1685 & 1685 & 1777 & 1777 & 1777 & 1778 & 1778 & $783 B$ & $783 \mathrm{~B}$ & $781 \mathrm{~B}$ & $781 \mathrm{~B}$ & $781 B$ & 1790 & 1790 & 1790 & 1790 & 1790 & 1790 & $1769 \mathrm{~A}$ & 1769A & $1769 \mathrm{C}$ & $1769 \mathrm{C}$ \\
\hline Análisis & 2.5 & 3.3 & 4.2 & 2.3 & 4.4 & 5.4 & 1.4 & 3.2 & 2.1 & 3.3 & 2.2 & 3.3 & 5.2 & 1.4 & 3.2 & 4.1 & 5.2 & 7.3 & 8.2 & 1.1 & 2.4 & 1.1 & 1.2 \\
\hline $\mathrm{SiO}_{2}$ & 45,27 & 48,22 & 44,94 & 47,71 & 47,65 & 47,51 & 44,61 & 44,81 & 47,31 & 47,29 & 46,24 & 46,17 & 47,77 & 45,61 & 46,81 & 46,61 & 46,57 & 46,13 & 46,85 & 45,62 & 45,82 & 44,56 & 45,34 \\
\hline $\mathrm{P}_{2} \mathrm{O}_{5}$ & 0,04 & 0,00 & 0,05 & 0,08 & 0,06 & 0,05 & 0,04 & 0,19 & 0,05 & 0,05 & 0,21 & 0,05 & 0,04 & 0,06 & 0,06 & 0,05 & 0,06 & 0,04 & 0,03 & 0,08 & 0,03 & 0,15 & 0,12 \\
\hline $\mathrm{Al}_{2} \mathrm{O}_{3}$ & 33,50 & 31,80 & 32,82 & 33,93 & 34,07 & 35,05 & 33,44 & 35,08 & 32,76 & 32,52 & 34,94 & 34,84 & 34,62 & 36,40 & 35,60 & 35,59 & 35,64 & 36,04 & 35,79 & 35,47 & 36,35 & 34,17 & 36,42 \\
\hline $\mathrm{Na}_{2} \mathrm{O}$ & 0,24 & 0,13 & 0,35 & 0,45 & 0,32 & 0,28 & 0,17 & 0,53 & 0,17 & 0,29 & 0,44 & 0,47 & 0,24 & 0,19 & 0,41 & 0,26 & 0,36 & 0,55 & 0,23 & 0,54 & 0,23 & 0,64 & 0,30 \\
\hline $\mathrm{K}_{2} \mathrm{O}$ & 10,48 & 10,51 & 10,28 & 10,26 & 10,54 & 10,63 & 10,73 & 10,06 & 10,91 & 10,56 & 10,33 & 10,48 & 10,56 & 10,62 & 10,15 & 10,53 & 10,44 & 10,17 & 10,34 & 9,67 & 10,58 & 9,64 & 10,47 \\
\hline $\mathrm{CaO}$ & 0,00 & 0,00 & 0,00 & 0,00 & 0,00 & 0,00 & 0,00 & 0,01 & 0,00 & 0,01 & 0,01 & 0,00 & 0,01 & 0,00 & 0,03 & 0,00 & 0,00 & 0,00 & 0,00 & 0,00 & 0,01 & 0,01 & 0,00 \\
\hline $\mathrm{MgO}$ & 0,55 & 0,61 & 0,58 & 0,29 & 0,30 & 0,29 & 0,30 & 0,41 & 0,64 & 0,61 & 0,17 & 0,16 & 0,46 & 0,12 & 0,13 & 0,11 & 0,12 & 0,12 & 0,12 & 0,19 & 0,32 & 0,61 & 0,48 \\
\hline $\mathrm{MnO}$ & 0,09 & 0,15 & 0,15 & 0,08 & 0,10 & 0,06 & 0,06 & 0,09 & 0,08 & 0,02 & 0,07 & 0,05 & 0,08 & 0,06 & 0,05 & 0,07 & 0,07 & 0,11 & 0,07 & 0,08 & 0,05 & 0,05 & 0,04 \\
\hline $\mathrm{FeO}$ & 3,83 & 4,49 & 4,23 & 2,44 & 2,75 & 2,45 & 2,95 & 2,28 & 2,61 & 3,74 & 2,28 & 1,90 & 1,74 & 1,92 & 2,35 & 2,46 & 2,14 & 2,11 & 2,20 & 2,78 & 2,52 & 2,90 & 2,44 \\
\hline $\mathrm{TiO}_{2}$ & 0,24 & 0,22 & 0,30 & 0,07 & 0,09 & 0,11 & 0,17 & 0,17 & 0,07 & 0,38 & 0,11 & 0,12 & 0,16 & 0,08 & 0,06 & 0,07 & 0,07 & 0,05 & 0,08 & 0,06 & 0,25 & 0,21 & 0,12 \\
\hline $\mathrm{Li}_{2} \mathrm{O}^{*}$ & 0,41 & 0,49 & 0,45 & 0,36 & 0,48 & 0,34 & 0,49 & 0,44 & 0,28 & 0,37 & 0,16 & 0,20 & 0,28 & 0,20 & 0,19 & 0,27 & 0,14 & 0,21 & 0,21 & 0,09 & 0,20 & 0,25 & 0,25 \\
\hline $\mathrm{ZnO}$ & 0,09 & 0,00 & 0,07 & 0,05 & 0,02 & 0,09 & 0,06 & 0,06 & 0,04 & 0,13 & 0,12 & 0,10 & 0,00 & 0,07 & 0,02 & 0,08 & 0,14 & 0,07 & 0,11 & 0,00 & 0,00 & 0,04 & 0,03 \\
\hline $\mathrm{As}_{2} \mathrm{O}_{3}$ & 0,00 & 0,00 & 0,00 & 0,00 & 0,00 & 0,00 & 0,00 & 0,00 & 0,00 & 0,00 & 0,00 & 0,00 & 0,00 & 0,00 & 0,02 & 0,00 & 0,00 & 0,00 & 0,02 & 0,00 & 0,00 & 0,00 & 0,00 \\
\hline $\mathrm{Cl}$ & 0,00 & 0,01 & 0,01 & 0,00 & 0,01 & 0,01 & 0,00 & 0,01 & 0,01 & 0,01 & 0,00 & 0,00 & 0,00 & 0,00 & 0,01 & 0,01 & 0,00 & 0,01 & 0,01 & 0,00 & 0,00 & 0,01 & 0,00 \\
\hline $\mathrm{F}$ & 1,44 & 1,69 & 1,56 & 1,28 & 1,66 & 1,21 & 1,67 & 1,54 & 1,03 & 1,31 & 0,64 & 0,78 & 1,02 & 0,79 & 0,75 & 1,00 & 0,60 & 0,80 & 0,81 & 0,44 & 0,77 & 0,92 & 0,94 \\
\hline Total & 95,58 & 97,64 & 95,14 & 96,54 & 97,37 & 97,55 & 93,99 & 95,06 & 95,56 & 96,75 & 95,50 & 95,01 & 96,58 & 95,80 & 96,34 & 96,71 & 96,12 & 96,09 & 96,59 & 94,86 & 96,82 & 93,77 & 96,57 \\
\hline \multicolumn{24}{|c|}{ Número de iones con base en 220} \\
\hline Si & 6,23 & 6,51 & 6,24 & 6,40 & 6,39 & 6,31 & 6,25 & 6,15 & 6,42 & 6,40 & 6,22 & 6,25 & 6,36 & 6,13 & 6,24 & 6,23 & 6,22 & 6,17 & 6,24 & 6,15 & 6,10 & 6,15 & 6,07 \\
\hline $\mathrm{Al}^{\mathrm{iV}}$ & 1,77 & 1,49 & 1,76 & 1,60 & 1,61 & 1,69 & 1,75 & 1,85 & 1,58 & 1,60 & 1,78 & 1,75 & 1,64 & 1,87 & 1,76 & 1,77 & 1,78 & 1,83 & 1,76 & 1,85 & 1,90 & 1,85 & 1,93 \\
\hline$\Sigma z$ & 8,00 & 8,00 & 8,00 & 8,00 & 8,00 & 8,00 & 8,00 & 8,00 & 8,00 & 8,00 & 8,00 & 8,00 & 8,00 & 8,00 & 8,00 & 8,00 & 8,00 & 8,00 & 8,00 & 8,00 & 8,00 & 8,00 & 8,00 \\
\hline $\mathrm{Al}^{\mathrm{vI}}$ & 3,66 & 3,57 & 3,62 & 3,77 & 3,78 & 3,80 & 3,77 & 3,82 & 3,66 & 3,58 & 3,76 & 3,81 & 3,79 & 3,89 & 3,83 & 3,83 & 3,82 & 3,86 & 3,85 & 3,79 & 3,81 & 3,71 & 3,82 \\
\hline $\mathrm{Fe}^{2+}$ & 0,44 & 0,51 & 0,49 & 0,27 & 0,31 & 0,27 & 0,35 & 0,26 & 0,30 & 0,42 & 0,26 & 0,21 & 0,19 & 0,22 & 0,26 & 0,27 & 0,24 & 0,24 & 0,24 & 0,31 & 0,28 & 0,33 & 0,27 \\
\hline $\mathrm{Ti}$ & 0,02 & 0,02 & 0,03 & 0,01 & 0,01 & 0,01 & 0,02 & 0,02 & 0,01 & 0,04 & 0,01 & 0,01 & 0,02 & 0,01 & 0,01 & 0,01 & 0,01 & 0,00 & 0,01 & 0,01 & 0,03 & 0,02 & 0,01 \\
\hline $\mathrm{Mg}$ & 0,11 & 0,12 & 0,12 & 0,06 & 0,06 & 0,06 & 0,06 & 0,08 & 0,13 & 0,12 & 0,03 & 0,03 & 0,09 & 0,02 & 0,03 & 0,02 & 0,02 & 0,02 & 0,02 & 0,04 & 0,06 & 0,13 & 0,10 \\
\hline $\mathrm{Mn}$ & 0,01 & 0,02 & 0,02 & 0,01 & 0,01 & 0,01 & 0,01 & 0,01 & 0,01 & 0,00 & 0,01 & 0,01 & 0,01 & 0,01 & 0,01 & 0,01 & 0,01 & 0,01 & 0,01 & 0,01 & 0,01 & 0,01 & 0,00 \\
\hline$P$ & 0,00 & 0,00 & 0,01 & 0,01 & 0,01 & 0,01 & 0,00 & 0,02 & 0,01 & 0,01 & 0,02 & 0,01 & 0,01 & 0,01 & 0,01 & 0,01 & 0,01 & 0,00 & 0,00 & 0,01 & 0,00 & 0,02 & 0,01 \\
\hline Li* & 0,23 & 0,27 & 0,25 & 0,20 & 0,26 & 0,18 & 0,27 & & 0,15 & 0,20 & 0,08 & & 0,15 & 0,11 & 0,10 & 0,15 & 0,08 & 0,11 & 0,11 & 0,05 & 0,11 & 0,14 & 0,14 \\
\hline$\Sigma Y$ & 4,49 & 4,51 & 4,54 & 4,32 & 4,43 & 4,33 & 4,48 & 4,46 & 4,27 & 4,38 & 4,18 & 4,19 & 4,26 & 4,26 & 4,24 & 4,30 & 4,18 & 4,25 & 4,25 & 4,22 & 4,30 & 4,35 & 4,35 \\
\hline $\mathrm{Ca}$ & 0,00 & 0,00 & 0,00 & 0,00 & 0,00 & 0,00 & 0,00 & 0,00 & 0,00 & 0,00 & 0,00 & 0,00 & 0,00 & 0,00 & 0,00 & 0,00 & 0,00 & 0,00 & 0,00 & 0,00 & 0,00 & 0,00 & 0,00 \\
\hline $\mathrm{Na}$ & 0,06 & 0,04 & 0,09 & 0,12 & 0,08 & 0,07 & 0,05 & 0,14 & 0,05 & 0,08 & 0,12 & 0,12 & 0,06 & 0,05 & 0,11 & 0,07 & 0,09 & 0,14 & 0,06 & 0,14 & 0,06 & 0,17 & 0,08 \\
\hline K & 1,84 & 1,81 & 1,82 & 1,76 & 1,80 & 1,80 & 1,92 & 1,76 & 1,89 & 1,82 & 1,77 & 1,81 & 1,79 & 1,82 & 1,73 & 1,80 & 1,78 & 1,74 & 1,76 & 1,66 & 1,80 & 1,70 & 1,79 \\
\hline$\Sigma x$ & 1,90 & 1,85 & 1,92 & 1,87 & 1,89 & 1,87 & 1,96 & 1,90 & 1,94 & 1,90 & 1,89 & 1,94 & 1,86 & 1,87 & 1,84 & 1,86 & 1,87 & 1,88 & 1,82 & 1,81 & 1,86 & 1,87 & 1,87 \\
\hline$F$ & 0,62 & 0,72 & 0,69 & 0,54 & 0,70 & 0,51 & 0,74 & 0,67 & 0,44 & 0,56 & 0,27 & 0,33 & 0,43 & 0,34 & 0,32 & 0,42 & 0,25 & 0,34 & 0,34 & 0,19 & 0,33 & 0,40 & 0,40 \\
\hline $\mathrm{Cl}$ & 0,00 & 0,00 & 0,00 & 0,00 & 0,00 & 0,00 & 0,00 & 0,00 & 0,00 & 0,00 & 0,00 & 0,00 & 0,00 & 0,00 & 0,00 & 0,00 & 0,00 & 0,00 & 0,00 & 0,00 & 0,00 & 0,00 & 0,00 \\
\hline $\mathrm{Fe} /(\mathrm{Fe}+\mathrm{Mg})$ & 0,80 & 0,80 & 0,80 & 0,83 & 0,84 & 0,83 & 0,85 & 0,76 & 0,70 & 0,77 & 0,88 & 0,87 & 0,68 & 0,90 & 0,91 & 0,93 & 0,91 & 0,91 & 0,91 & 0,89 & 0,81 & 0,73 & $\overline{0,74}$ \\
\hline \multicolumn{24}{|c|}{ Trazas en ppm } \\
\hline $\mathrm{Li}^{*}$ & 1907 & 2287 & 2097 & 1681 & 2236 & 1567 & 2259 & 2060 & 1298 & 1718 & 724 & 927 & 1287 & 951 & 889 & 1259 & 665 & 955 & 972 & 423 & 919 & 1146 & 1176 \\
\hline Sn & 594 & 432 & 342 & 480 & 1020 & 83 & 549 & 19 & 412 & 153 & 654 & 87 & 279 & 410 & 397 & 0 & 0 & 0 & 193 & 557 & 100 & 391 & 116 \\
\hline w & 0 & 0 & 0 & 0 & 0 & 0 & 0 & 0 & 144 & 122 & 289 & 0 & 1021 & 0 & 708 & 1491 & 0 & 0 & 0 & 40 & 0 & 581 & 0 \\
\hline $\mathrm{Rb}$ & 102 & 100 & 99 & 82 & 116 & 91 & 115 & 55 & 218 & 274 & 251 & 262 & 209 & 140 & 134 & 157 & 115 & 145 & 146 & 136 & 86 & 83 & 35 \\
\hline
\end{tabular}


Moscovita (continuación)

Anexo III. Análisis de microsonda electrónica Mina/Zona Horia

Mari Carmen

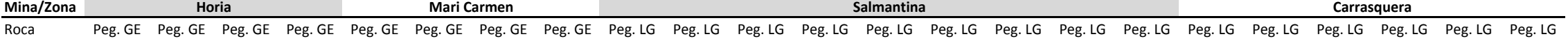

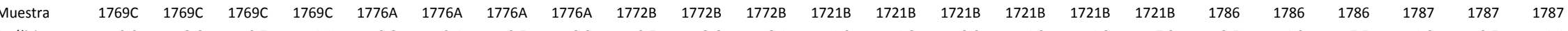

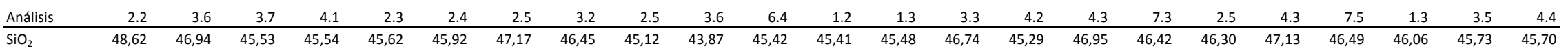
$\begin{array}{rrrrrrrrrrrrrrrrrrrrrrrr}\mathrm{P}_{2} \mathrm{O}_{5} & 0,00 & 0,05 & 0,03 & 0,10 & 0,07 & 0,23 & 0,03 & 0,11 & 0,08 & 0,03 & 0,02 & 0,02 & 0,01 & 0,03 & 0,04 & 0,00 & 0,06 & 0,11 & 0,06 & 0,05 & 0,48 & 0,01 & 0,06 \\ & 35,54 & 34,03 & 36,39 & 35,68 & 36,56 & 34,71 & 35,97 & 37,23 & 34,73 & 34,61 & 35,23 & 30,67 & 30,60 & 32,37 & 32,23 & 25,03 & 32,10 & 33,96 & 34,31 & 34,87 & 34,88 & 34,40 & 33,89\end{array}$ $\begin{array}{lrrrrrrrrrrrrrrrrrrrrrrr}\mathrm{Al}_{2} \mathrm{O}_{3} & 35,54 & 34,03 & 36,39 & 35,68 & 36,56 & 34,71 & 35,97 & 37,23 & 34,73 & 34,61 & 35,23 & 30,67 & 30,60 & 32,37 & 32,23 & 25,03 & 32,10 & 33,96 & 34,31 & 34,87 & 34,88 & 34,40 & 33,89\end{array}$ $\begin{array}{lrrrrrrrrrrrrrrrrrrrrrrrrr}\mathrm{Na}_{2} \mathrm{O} & 0,15 & 0,17 & 0,17 & 0,62 & 0,36 & 0,16 & 0,23 & 0,62 & 0,65 & 0,47 & 0,38 & 0,24 & 0,15 & 0,20 & 0,27 & 0,09 & 0,26 & 0,28 & 0,23 & 0,17 & 0,49 & 0,40 & 0,39 \\ \mathrm{~K}_{2} \mathrm{O} & 10,21 & 9,68 & 10,46 & 9,92 & 10,03 & 9,57 & 10,04 & 10,01 & 10,10 & 10,18 & 10,30 & 10,02 & 9,72 & 10,34 & 10,27 & 10,11 & 10,32 & 10,53 & 9,69 & 10,45 & 9,89 & 10,23 & 9,99\end{array}$

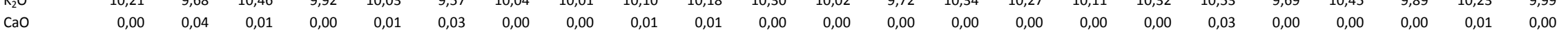
$\begin{array}{lllllllllllllllllllllllll}\mathrm{MgO} & 0,50 & 0,88 & 0,23 & 0,54 & 0,46 & 0,61 & 0,43 & 0,46 & 0,11 & 0,20 & 0,06 & 0,81 & 0,76 & 0,64 & 0,61 & 0,95 & 0,62 & 0,33 & 0,35 & 0,34 & 0,27 & 0,32 & 0,33 \\ \mathrm{MnO} & 0,04 & 0,04 & 0,06 & 0,06 & 0,02 & 0,04 & 0,03 & 0,05 & 0,10 & 0,08 & 0,06 & 0,16 & 0,14 & 0,10 & 0,13 & 0,15 & 0,11 & 0,09 & 0,06 & 0,08 & 0,09 & 0,12 & 0,16\end{array}$ $\begin{array}{llllllllllllllllllllllllll}\mathrm{MnO} & 0,04 & 0,04 & 0,06 & 0,06 & 0,02 & 0,04 & 0,03 & 0,05 & 0,10 & 0,08 & 0,06 & 0,16 & 0,14 & 0,10 & 0,13 & 0,15 & 0,11 & 0,09 & 0,06 & 0,08 & 0,09 & 0,12 & 0,16 \\ \mathrm{FeO} & 2,18 & 2,90 & 2,41 & 3,10 & 1,78 & 4,02 & 1,61 & 1,54 & 2,88 & 2,98 & 1,42 & 6,70 & 7,05 & 4,63 & 5,67 & 8,84 & 5,05 & 3,43 & 2,93 & 2,63 & 3,13 & 3,77 & 3,92\end{array}$ $\begin{array}{lllllllllllllllllllllllll} & \mathrm{FeO} & 2,18 & 2,90 & 2,41 & 3,10 & 1,78 & 4,02 & 1,61 & 1,54 & 2,88 & 2,98 & 1,42 & 6,70 & 7,05 & 4,63 & 5,67 & 8,84 & 5,05 & 3,43 & 2,93 & 2,63 & 3,13 & 3,77 & 3,92 \\ \mathrm{TiO}_{2} & 0,00 & 0,26 & 0,05 & 0,17 & 0,25 & 0,12 & 0,03 & 0,14 & 0,13 & 0,14 & 0,01 & 0,14 & 0,22 & 0,15 & 0,20 & 0,10 & 0,17 & 0,10 & 0,01 & 0,05 & 0,04 & 0,11 & 0,12\end{array}$ $\begin{array}{llllllllllllllllllllllllll}\mathrm{Ti}_{2} & 0,00 & 0,26 & 0,05 & 0,17 & 0,25 & 0,12 & 0,03 & 0,14 & 0,13 & 0,14 & 0,01 & 0,14 & 0,22 & 0,15 & 0,20 & 0,10 & 0,17 & 0,10 & 0,01 & 0,05 & 0,04 & 0,11 & 0,12 \\ \mathrm{Li}_{2} \mathrm{O}^{*} & 0,16 & 0,27 & 0,16 & 0,22 & 0,15 & 0,20 & 0,18 & 0,21 & 0,44 & 0,42 & 0,29 & 0,72 & 0,53 & 0,52 & 0,58 & 1,43 & 0,54 & 0,42 & 0,30 & 0,28 & 0,33 & 0,38 & 0,47\end{array}$

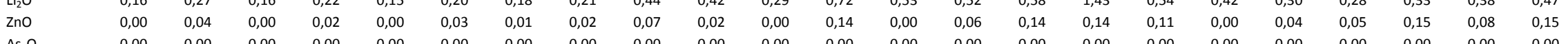
$\begin{array}{lllllllllllllllllllllllllll}\mathrm{As}_{2} \mathrm{O}_{3} & 0,00 & 0,00 & 0,00 & 0,00 & 0,00 & 0,00 & 0,00 & 0,00 & 0,00 & 0,00 & 0,00 & 0,00 & 0,00 & 0,00 & 0,00 & 0,00 & 0,00 & 0,00 & 0,00 & 0,00 & 0,00 & 0,00 & 0,00\end{array}$ $\begin{array}{lllllllllllllllllllllllll}\mathrm{Cl} & 0,00 & 0,01 & 0,01 & 0,00 & 0,00 & 0,01 & 0,01 & 0,00 & 0,00 & 0,00 & 0,00 & 0,00 & 0,00 & 0,00 & 0,01 & 0,01 & 0,01 & 0,03 & 0,00 & 0,00 & 0,01 & 0,02 & 0,01 \\ \mathrm{~F} & 0,66 & 1,01 & 0,67 & 0,83 & 0,62 & 0,76 & 0,70 & 0,82 & 1,54 & 1,48 & 1,06 & 2,40 & 1,80 & 1,79 & 1,96 & 4,62 & 1,85 & 1,46 & 1,10 & 1,04 & 1,19 & 1,35 & 1,62\end{array}$ $\begin{array}{rrrllllllllllllllllllllllll}\text { Total } & 97,80 & 95,90 & 95,91 & 96,47 & 95,69 & 96,08 & 96,15 & 97,33 & 95,34 & 93,87 & 93,81 & 96,43 & 95,72 & 96,83 & 96,58 & 96,50 & 96,87 & 96,46 & 95,86 & 96,18 & 96,53 & 96,36 & 96,14\end{array}$ Número de iones con base en 220

\begin{tabular}{|c|c|c|c|c|c|c|c|c|c|c|c|c|c|c|c|c|c|c|c|c|c|c|c|}
\hline$\overline{\mathrm{Si}}$ & 6,34 & 6,31 & 6,11 & 6,10 & 6,09 & 6,17 & 6,26 & 6,11 & 6,19 & 6,13 & 6,23 & 6,38 & 6,37 & 6,39 & 6,28 & 6,91 & 6,37 & 6,29 & 6,34 & 6,26 & 6,19 & 6,22 & 6,25 \\
\hline $\mathrm{Al}^{\mathrm{IV}}$ & 1,66 & 1,69 & 1,89 & 1,90 & 1,91 & 1,83 & 1,74 & 1,89 & 1,81 & 1,87 & 1,77 & 1,62 & 1,63 & 1,61 & 1,72 & 1,09 & 1,63 & 1,71 & 1,66 & 1,74 & 1,81 & 1,78 & 1,75 \\
\hline$\Sigma z$ & 8,00 & 8,00 & 8,00 & 8,00 & 8,00 & 8,00 & 8,00 & 8,00 & 8,00 & 8,00 & 8,00 & 8,00 & 8,00 & 8,00 & 8,00 & 8,00 & 8,00 & 8,00 & 8,00 & 8,00 & 8,00 & 8,00 & 8,00 \\
\hline $\mathrm{Al}^{\mathrm{V}}$ & 3,81 & 3,70 & 3,86 & 3,74 & 3,85 & 3,67 & 3,88 & 3,88 & 3,81 & 3,82 & 3,93 & 3,46 & 3,42 & 3,60 & 3,55 & 3,25 & 3,56 & 3,72 & 3,79 & 3,79 & 3,72 & 3,73 & 3,72 \\
\hline $\mathrm{Fe}^{2+}$ & 0,24 & 0,33 & 0,27 & 0,35 & 0,20 & 0,45 & 0,18 & 0,17 & 0,33 & 0,35 & 0,16 & 0,79 & 0,83 & 0,53 & 0,66 & 1,09 & 0,58 & 0,39 & 0,33 & 0,30 & 0,35 & 0,43 & 0,45 \\
\hline $\mathrm{Ti}$ & 0,00 & 0,03 & 0,01 & 0,02 & 0,03 & 0,01 & 0,00 & 0,01 & 0,01 & 0,01 & 0,00 & 0,01 & 0,02 & 0,02 & 0,02 & 0,01 & 0,02 & 0,01 & 0,00 & 0,01 & 0,00 & 0,01 & 0,01 \\
\hline $\mathrm{Mg}$ & 0,10 & 0,18 & 0,05 & 0,11 & 0,09 & 0,12 & 0,08 & 0,09 & 0,02 & 0,04 & 0,01 & 0,17 & 0,16 & 0,13 & 0,13 & 0,21 & 0,13 & 0,07 & 0,07 & 0,07 & 0,05 & 0,06 & 0,07 \\
\hline $\mathrm{Mn}$ & 0,00 & 0,00 & 0,01 & 0,01 & 0,00 & 0,00 & 0,00 & 0,01 & 0,01 & 0,01 & 0,01 & 0,02 & 0,02 & 0,01 & 0,02 & 0,02 & 0,01 & 0,01 & 0,01 & 0,01 & 0,01 & 0,01 & 0,02 \\
\hline P & 0,00 & 0,01 & 0,00 & 0,01 & 0,01 & 0,03 & 0,00 & 0,01 & 0,01 & 0,00 & 0,00 & 0,00 & 0,00 & 0,00 & 0,00 & 0,00 & 0,01 & 0,01 & 0,01 & 0,01 & 0,06 & 0,00 & 0,01 \\
\hline Li* & 0,09 & 0,15 & 0,09 & 0,12 & 0,08 & 0,11 & 0,09 & 0,11 & 0,24 & 0,24 & 0,16 & 0,41 & 0,30 & 0,29 & 0,32 & 0,85 & 0,30 & 0,23 & 0,16 & 0,15 & 0,18 & 0,21 & 0,26 \\
\hline$\Sigma Y$ & 4,23 & 4,39 & 4,28 & 4,35 & 4,26 & 4,39 & 4,24 & 4,28 & 4,45 & 4,48 & 4,27 & 4,85 & 4,74 & 4,58 & 4,69 & 5,43 & 4,61 & 4,44 & 4,37 & 4,33 & 4,37 & 4,46 & 4,53 \\
\hline $\mathrm{Ca}$ & 0,00 & 0,01 & 0,00 & 0,00 & 0,00 & 0,00 & 0,00 & 0,00 & 0,00 & 0,00 & 0,00 & 0,00 & 0,00 & 0,00 & 0,00 & 0,00 & 0,00 & 0,00 & 0,00 & 0,00 & 0,00 & 0,00 & 0,00 \\
\hline $\mathrm{Na}$ & 0,04 & 0,04 & 0,05 & 0,16 & 0,09 & 0,04 & 0,06 & 0,16 & 0,17 & 0,13 & 0,10 & 0,06 & 0,04 & 0,05 & 0,07 & 0,03 & 0,07 & 0,07 & 0,06 & 0,05 & 0,13 & 0,11 & 0,10 \\
\hline K & 1,70 & 1,66 & 1,79 & 1,70 & 1,71 & 1,64 & 1,70 & 1,68 & 1,77 & 1,81 & 1,80 & 1,80 & 1,74 & 1,80 & 1,82 & 1,90 & 1,81 & 1,82 & 1,66 & 1,79 & 1,70 & 1,77 & 1,74 \\
\hline$\Sigma x$ & 1,74 & 1,71 & 1,84 & 1,86 & 1,81 & 1,69 & 1,76 & 1,84 & 1,94 & 1,94 & 1,90 & 1,86 & 1,78 & 1,85 & 1,89 & 1,93 & 1,88 & 1,90 & 1,72 & 1,84 & 1,82 & 1,88 & 1,85 \\
\hline$F$ & 0,27 & 0,43 & 0,28 & 0,35 & 0,26 & 0,32 & 0,29 & 0,34 & 0,67 & 0,65 & 0,46 & 1,07 & 0,80 & 0,77 & 0,86 & 2,15 & 0,80 & 0,63 & 0,47 & 0,44 & 0,50 & 0,58 & 0,70 \\
\hline $\mathrm{Cl}$ & 0,00 & 0,00 & 0,00 & 0,00 & 0,00 & 0,00 & 0,00 & 0,00 & 0,00 & 0,00 & 0,00 & 0,00 & 0,00 & 0,00 & 0,00 & 0,00 & 0,00 & 0,01 & 0,00 & 0,00 & 0,00 & 0,00 & 0,00 \\
\hline $\mathrm{Fe} /(\mathrm{Fe}+\mathrm{Mg})$ & 0,71 & 0,65 & 0,86 & 0,76 & 0,69 & 0,79 & 0,68 & 0,65 & 0,93 & 0,90 & 0,93 & 0,82 & 0,84 & 0,80 & 0,84 & 0,84 & 0,82 & 0,85 & 0,82 & 0,81 & 0,87 & 0,87 & 0,87 \\
\hline \multicolumn{24}{|c|}{ Trazas en ppm } \\
\hline Li* & 756 & 1273 & 765 & 1013 & 694 & 906 & 815 & 998 & 2061 & 1965 & 1349 & 3338 & 2455 & 2432 & 2682 & 6640 & 2530 & 1941 & 1406 & 1316 & 1535 & 1783 & 2181 \\
\hline Sn & 0 & 413 & 796 & 202 & 285 & 349 & 234 & 303 & 263 & 362 & 255 & 643 & 417 & 566 & 560 & 326 & 454 & 0 & 63 & 266 & 536 & 187 & 421 \\
\hline w & 0 & 707 & 0 & 0 & 917 & 929 & 831 & 63 & 0 & 738 & 1127 & 0 & 269 & 314 & 251 & 1439 & 566 & 0 & 0 & 1020 & 442 & 324 & 1017 \\
\hline $\mathrm{Rb}$ & 63 & 86 & 70 & 90 & 63 & 66 & 66 & 63 & 100 & 133 & 93 & 166 & 140 & 130 & 132 & 147 & 107 & 105 & 62 & 96 & 80 & 103 & 112 \\
\hline
\end{tabular}


Moscovita (continuación)

Anexo III. Análisis de microsonda electrónica

Cruz del Rayo

Horia Salmantina

\begin{tabular}{lcccccccc}
\hline Mina/Zona & Teso & & & Bon & & Cruz del Rayo & Horia & Salmantina \\
Roca & Peg. LG & Peg. LG & Peg. LG & Peg. LG & Peg. LG & Peg. LG Peg. CEG Peg. CEG Peg. CEG Peg. CEG Peg. CEG Peg. CEG Vena GE Vena GE Vena GE Vena GE Vena LG Vena LG Vena LG Vena LG Vena LG Vena LG Vena LG \\
\hline
\end{tabular}

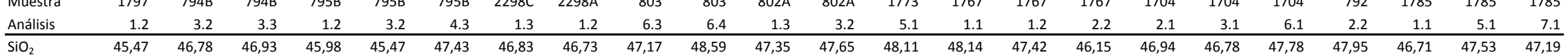

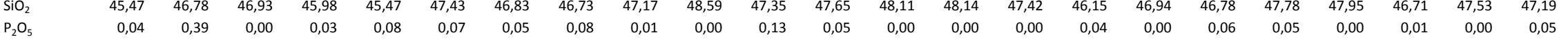

$\begin{array}{lllllllllllllllllllllllllll}\mathrm{Al}_{2} \mathrm{O}_{3} & 34,92 & 35,70 & 34,55 & 33,66 & 32,91 & 34,76 & 36,73 & 36,98 & 36,23 & 34,94 & 34,33 & 34,84 & 30,58 & 30,70 & 29,52 & 34,80 & 35,03 & 34,76 & 34,34 & 29,73 & 35,81 & 32,95 & 35,02\end{array}$

$\begin{array}{llllllllllllllllllllllllll}\mathrm{Na}_{2} \mathrm{O} & 0,47 & 0,91 & 0,90 & 0,72 & 0,55 & 0,63 & 0,48 & 0,96 & 0,22 & 0,22 & 0,25 & 0,41 & 0,22 & 0,18 & 0,26 & 0,49 & 0,37 & 0,30 & 0,31 & 0,13 & 0,34 & 0,14 & 0,29\end{array}$

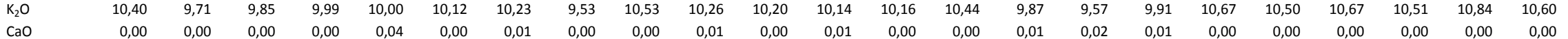

$\begin{array}{llllllllllllllllllllllll}\text { MgO } & 0,29 & 0,73 & 0,97 & 0,46 & 0,47 & 0,14 & 0,00 & 0,26 & 0,01 & 0,00 & 0,01 & 0,00 & 2,95 & 2,23 & 2,16 & 0,69 & 0,29 & 0,28 & 0,37 & 0,80 & 0,17 & 0,31 & 0,13\end{array}$

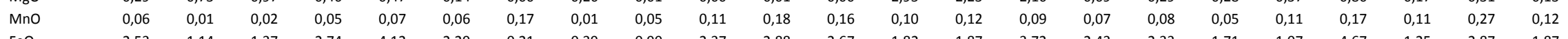

$\begin{array}{lllllllllllllllllllllllll}\mathrm{FeO} & 2,53 & 1,14 & 1,37 & 2,74 & 4,12 & 2,29 & 0,21 & 0,39 & 0,90 & 2,37 & 2,88 & 2,67 & 1,82 & 1,87 & 3,72 & 2,43 & 2,33 & 1,71 & 1,07 & 4,67 & 1,25 & 2,87 & 1,87 \\ \mathrm{TiO}_{2} & 0,00 & 0,05 & 0,92 & 0,19 & 0,16 & 0,08 & 0,01 & 0,00 & 0,00 & 0,00 & 0,17 & 0,07 & 0,85 & 0,78 & 0,81 & 0,66 & 0,11 & 0,10 & 0,13 & 0,48 & 0,09 & 0,08 & 0,05\end{array}$

$\begin{array}{llllllllllllllllllllllll}\mathrm{TiO}_{2} & 0,00 & 0,05 & 0,92 & 0,19 & 0,16 & 0,08 & 0,01 & 0,00 & 0,00 & 0,00 & 0,17 & 0,07 & 0,85 & 0,78 & 0,81 & 0,66 & 0,11 & 0,10 & 0,13 & 0,48 & 0,09 & 0,08 & 0,05 \\ \mathrm{Li}_{2} \mathrm{O}^{*} & 0,46 & 0,02 & 0,08 & 0,22 & 0,23 & 0,15 & 0,11 & 0,00 & 0,02 & 0,33 & 0,03 & 0,07 & 0,47 & 0,37 & 0,27 & 0,18 & 0,20 & 0,20 & 0,11 & 0,22 & 0,12 & 0,30 & 0,21\end{array}$

$\begin{array}{lllllllllllllllllllllllll}\mathrm{Li}_{2} \mathrm{O}^{*} & 0,46 & 0,02 & 0,08 & 0,22 & 0,23 & 0,15 & 0,11 & 0,00 & 0,02 & 0,33 & 0,03 & 0,07 & 0,47 & 0,37 & 0,27 & 0,18 & 0,20 & 0,20 & 0,11 & 0,22 & 0,12 & 0,30 & 0,21 \\ \mathrm{ZnO} & 0,03 & 0,02 & 0,03 & 0,01 & 0,08 & 0,07 & 0,01 & 0,01 & 0,00 & 0,02 & 0,04 & 0,01 & 0,00 & 0,03 & 0,00 & 0,06 & 0,03 & 0,03 & 0,02 & 0,09 & 0,00 & 0,01 & 0,00\end{array}$

$\begin{array}{lllllllllllllllllllllllll}\mathrm{As}_{2} \mathrm{O}_{3} & 0,00 & 0,03 & 0,00 & 0,00 & 0,00 & 0,03 & 0,00 & 0,00 & 0,02 & 0,00 & 0,00 & 0,04 & 0,00 & 0,00 & 0,33 & 0,16 & 0,00 & 0,25 & 0,00 & 0,00 & 0,00 & 0,01 & 0,00\end{array}$

$\begin{array}{llllllllllllllllllllllllll}\mathrm{Cl} & 0,01 & 0,01 & 0,01 & 0,01 & 0,04 & 0,00 & 0,00 & 0,01 & 0,00 & 0,00 & 0,00 & 0,00 & 0,01 & 0,01 & 0,04 & 0,01 & 0,01 & 0,00 & 0,00 & 0,01 & 0,00 & 0,00 & 0,00 \\ \mathrm{~F} & 1,58 & 0,23 & 0,39 & 0,84 & 0,88 & 0,61 & 0,49 & 0,15 & 0,23 & 1,18 & 0,24 & 0,36 & 1,61 & 1,30 & 1,01 & 0,73 & 0,76 & 0,76 & 0,50 & 0,84 & 0,53 & 1,10 & 0,80\end{array}$

$\begin{array}{lrrrrrrrrrrrrrrrrrrrrrrrrrr}\text { F } & 1,58 & 0,23 & 0,39 & 0,84 & 0,88 & 0,61 & 0,49 & 0,15 & 0,23 & 1,18 & 0,24 & 0,36 & 1,61 & 1,30 & 1,01 & 0,73 & 0,76 & 0,76 & 0,50 & 0,84 & 0,53 & 1,10 & 0,80 \\ \text { Total } & 95,60 & 95,68 & 95,89 & 94,59 & 94,75 & 96,20 & 95,17 & 95,11 & 95,37 & 97,56 & 95,74 & 96,45 & 96,27 & 95,87 & 95,34 & 96,02 & 95,76 & 95,64 & 95,14 & 95,42 & 95,52 & 95,98 & 96,03\end{array}$ Número de iones con base en 220

\begin{tabular}{|c|c|c|c|c|c|c|c|c|c|c|c|c|c|c|c|c|c|c|c|c|c|c|c|}
\hline$\overline{\mathrm{Si}}$ & 6,22 & 6,18 & 6,23 & 6,28 & 6,26 & 6,32 & 6,23 & 6,17 & 6,26 & 6,42 & 6,31 & 6,32 & 6,51 & 6,52 & 6,50 & 6,19 & 6,28 & 6,29 & 6,39 & 6,57 & 6,24 & 6,44 & 6,31 \\
\hline $\mathrm{Al}^{\mathrm{V}}$ & 1,78 & 1,82 & 1,77 & 1,72 & 1,74 & 1,68 & 1,77 & 1,83 & 1,74 & 1,58 & 1,69 & 1,68 & 1,49 & 1,48 & 1,50 & 1,81 & 1,72 & 1,71 & 1,61 & 1,43 & 1,76 & 1,56 & 1,69 \\
\hline$\Sigma Z$ & 8,00 & 8,00 & 8,00 & 8,00 & 8,00 & 8,00 & 8,00 & 8,00 & 8,00 & 8,00 & 8,00 & 8,00 & 8,00 & 8,00 & 8,00 & 8,00 & 8,00 & 8,00 & 8,00 & 8,00 & 8,00 & 8,00 & 8,00 \\
\hline $\mathrm{Al}^{\mathrm{V}}$ & 3,85 & 3,75 & 3,64 & 3,70 & 3,60 & 3,77 & 3,98 & 3,93 & 3,92 & 3,85 & 3,71 & 3,76 & 3,38 & 3,43 & 3,27 & 3,69 & 3,81 & 3,79 & 3,80 & 3,37 & 3,87 & 3,70 & 3,83 \\
\hline $\mathrm{Fe}^{2+}$ & 0,29 & 0,13 & 0,15 & 0,31 & 0,47 & 0,26 & 0,02 & 0,04 & 0,10 & 0,26 & 0,32 & 0,30 & 0,21 & 0,21 & 0,43 & 0,27 & 0,26 & 0,19 & 0,12 & 0,53 & 0,14 & 0,33 & 0,21 \\
\hline $\mathrm{Ti}$ & 0,00 & 0,00 & 0,09 & 0,02 & 0,02 & 0,01 & 0,00 & 0,00 & 0,00 & 0,00 & 0,02 & 0,01 & 0,09 & 0,08 & 0,08 & 0,07 & 0,01 & 0,01 & 0,01 & 0,05 & 0,01 & 0,01 & 0,01 \\
\hline $\mathrm{Mg}$ & 0,06 & 0,14 & 0,19 & 0,09 & 0,10 & 0,03 & 0,00 & 0,05 & 0,00 & 0,00 & 0,00 & 0,00 & 0,60 & 0,45 & 0,44 & 0,14 & 0,06 & 0,06 & 0,07 & 0,16 & 0,03 & 0,06 & 0,03 \\
\hline $\mathrm{Mn}$ & 0,01 & 0,00 & 0,00 & 0,01 & 0,01 & 0,01 & 0,02 & 0,00 & 0,01 & 0,01 & 0,02 & 0,02 & 0,01 & 0,01 & 0,01 & 0,01 & 0,01 & 0,01 & 0,01 & 0,02 & 0,01 & 0,03 & 0,01 \\
\hline P & 0,00 & 0,04 & 0,00 & 0,00 & 0,01 & 0,01 & 0,01 & 0,01 & 0,00 & 0,00 & 0,01 & 0,01 & 0,00 & 0,00 & 0,00 & 0,00 & 0,00 & 0,01 & 0,01 & 0,00 & 0,00 & 0,00 & 0,01 \\
\hline Li* & 0,25 & 0,01 & 0,04 & 0,12 & 0,13 & 0,08 & 0,06 & 0,00 & 0,01 & 0,17 & 0,01 & 0,03 & 0,25 & 0,20 & 0,15 & 0,10 & 0,11 & 0,11 & 0,06 & 0,12 & 0,06 & 0,17 & 0,11 \\
\hline$\Sigma Y$ & 4,46 & 4,08 & 4,12 & 4,26 & 4,33 & 4,15 & 4,09 & 4,04 & 4,04 & 4,30 & 4,10 & 4,12 & 4,53 & 4,38 & 4,38 & 4,27 & 4,26 & 4,17 & 4,08 & 4,26 & 4,13 & 4,29 & 4,20 \\
\hline $\mathrm{Ca}$ & 0,00 & 0,00 & 0,00 & 0,00 & 0,01 & 0,00 & 0,00 & 0,00 & 0,00 & 0,00 & 0,00 & 0,00 & 0,00 & 0,00 & 0,00 & 0,00 & 0,00 & 0,00 & 0,00 & 0,00 & 0,00 & 0,00 & 0,00 \\
\hline $\mathrm{Na}$ & 0,12 & 0,23 & 0,23 & 0,19 & 0,15 & 0,16 & 0,12 & 0,24 & 0,06 & 0,06 & 0,06 & 0,11 & 0,06 & 0,05 & 0,07 & 0,13 & 0,10 & 0,08 & 0,08 & 0,03 & 0,09 & 0,04 & 0,08 \\
\hline K & 1,81 & 1,64 & 1,67 & 1,74 & 1,76 & 1,72 & 1,73 & 1,61 & 1,78 & 1,73 & 1,74 & 1,71 & 1,75 & 1,80 & 1,73 & 1,64 & 1,69 & 1,83 & 1,79 & 1,87 & 1,79 & 1,87 & 1,81 \\
\hline$\Sigma x$ & 1,94 & 1,87 & 1,90 & 1,93 & 1,91 & 1,88 & 1,86 & 1,85 & 1,84 & 1,79 & 1,80 & 1,82 & 1,82 & 1,87 & 1,82 & 1,79 & 1,79 & 1,91 & 1,87 & 1,90 & 1,88 & 1,91 & 1,89 \\
\hline$F$ & 0,69 & 0,10 & 0,16 & 0,36 & 0,38 & 0,26 & 0,21 & 0,06 & 0,10 & 0,49 & 0,10 & 0,15 & 0,69 & 0,56 & 0,44 & 0,31 & 0,32 & 0,32 & 0,21 & 0,36 & 0,22 & 0,47 & 0,34 \\
\hline $\mathrm{Cl}$ & 0,00 & 0,00 & 0,00 & 0,00 & 0,01 & 0,00 & 0,00 & 0,00 & 0,00 & 0,00 & 0,00 & 0,00 & 0,00 & 0,00 & 0,01 & 0,00 & 0,00 & 0,00 & 0,00 & 0,00 & 0,00 & 0,00 & 0,00 \\
\hline $\mathrm{Fe} /(\mathrm{Fe}+\mathrm{Mg})$ & 0,83 & 0,47 & 0,44 & 0,77 & 0,83 & 0,90 & 1,00 & 0,45 & 0,99 & 1,00 & 0,99 & 1,00 & 0,26 & 0,32 & 0,49 & 0,67 & 0,82 & 0,77 & 0,62 & 0,77 & 0,80 & 0,84 & 0,89 \\
\hline \multicolumn{24}{|c|}{ Trazas en ppm } \\
\hline Li* & 2128 & 113 & 352 & 1019 & 1078 & 683 & 506 & 0 & 116 & 1523 & 128 & 302 & 2171 & 1707 & 1273 & 850 & 906 & 907 & 517 & 1016 & 557 & 1409 & 965 \\
\hline Sn & 981 & 422 & 398 & 105 & 0 & 330 & 299 & 0 & 0 & 553 & 501 & 278 & 956 & 679 & 858 & 384 & 52 & 106 & 463 & 553 & 64 & 287 & 0 \\
\hline w & 0 & 0 & 461 & 1551 & 0 & 0 & 0 & 573 & 0 & 0 & 2582 & 1243 & 0 & 0 & 0 & 715 & 59 & 0 & 63 & 1611 & 0 & 1160 & 0 \\
\hline $\mathrm{Rb}$ & 123 & 223 & 198 & 231 & 232 & 244 & 376 & 166 & 272 & 294 & 379 & 290 & 769 & 2295 & 2234 & 2675 & 225 & 197 & 211 & 228 & 217 & 232 & 278 \\
\hline
\end{tabular}




\begin{tabular}{|c|c|c|c|c|c|c|c|}
\hline \multirow{2}{*}{$\begin{array}{l}\text { Mina/Zona } \\
\text { Roca }\end{array}$} & \multicolumn{2}{|c|}{ Carrrasquera } & \multicolumn{2}{|c|}{ Molino del Galo } & \multirow{2}{*}{$\begin{array}{c}\text { Canalita } \\
\text { Peg. CEG }\end{array}$} & \multicolumn{2}{|c|}{ Peñaparda } \\
\hline & Vena LG & Vena LG & Aplita & Aplita & & Vena G5 & Vena G5 \\
\hline Muestra & 1785 & 1785 & 820 & 820 & 1066 & $1725 \mathrm{~A}$ & 1725A \\
\hline Análisis & 8.1 & 8.2 & 2.1 & 2.2 & 1.2 & 1.2 & 1.1 \\
\hline $\mathrm{SiO}_{2}$ & 47,18 & 45,61 & 45,44 & 44,64 & 48,05 & 47,99 & 45,82 \\
\hline $\mathrm{P}_{2} \mathrm{O}_{5}$ & 0,00 & 0,07 & 0,08 & 0,19 & 0,03 & 0,08 & 0,14 \\
\hline $\mathrm{Al}_{2} \mathrm{O}_{3}$ & 35,78 & 34,62 & 37,26 & 37,01 & 36,51 & 33,59 & 29,42 \\
\hline $\mathrm{Na}_{2} \mathrm{O}$ & 0,38 & 0,30 & 0,72 & 0,72 & 0,15 & 0,39 & 0,10 \\
\hline $\mathrm{K}_{2} \mathrm{O}$ & 10,57 & 10,48 & 10,72 & 10,56 & 9,87 & 10,76 & 9,96 \\
\hline $\mathrm{CaO}$ & 0,00 & 0,01 & 0,00 & 0,01 & 0,02 & 0,00 & 0,03 \\
\hline MgO & 0,20 & 0,11 & 0,12 & 0,13 & 0,08 & 0,62 & 1,05 \\
\hline $\mathrm{MnO}$ & 0,06 & 0,10 & 0,04 & 0,08 & 0,04 & 0,06 & 09 \\
\hline $\mathrm{FeO}$ & 1,27 & 2,73 & 0,70 & 0,74 & 0,18 & 3,09 & 7,02 \\
\hline $\mathrm{TiO}_{2}$ & 0,11 & 0,05 & 0,00 & 0,01 & 0,00 & 0,24 & 0,27 \\
\hline $\mathrm{Li}_{2} \mathrm{O}^{*}$ & 0,16 & 0,11 & 0,10 & 0,11 & 0,27 & 0,32 & 0,50 \\
\hline $\mathrm{ZnO}$ & 0,00 & 0,04 & 0,00 & 0,02 & 0,02 & 0,11 & 0,00 \\
\hline $\mathrm{As}_{2} \mathrm{O}_{3}$ & 0,01 & 0,11 & 0,00 & 0,00 & 0,00 & 0,00 & 0,11 \\
\hline $\mathrm{Cl}$ & & 0,01 & 00 & 0,01 & 0,02 & 0,01 & 0,04 \\
\hline $\mathrm{F}$ & 0,64 & 0,50 & 0,36 & 0,39 & 0,75 & 0,86 & 1,21 \\
\hline Total & 96,10 & 94,67 & 95,39 & 94,47 & 95,65 & 97,75 & 95,25 \\
\hline \multicolumn{8}{|c|}{ Número de iones con base en 220} \\
\hline Si & 6,27 & 6,20 & 6,06 & 6,02 & 6,34 & 6,36 & 6,40 \\
\hline$A^{i v}$ & 1,73 & 1,80 & 1,94 & 1,98 & 1,66 & 1,64 & 1,60 \\
\hline$\Sigma z$ & 8,00 & 8,00 & 8,00 & 8,00 & 8,00 & 8,00 & 8,00 \\
\hline $\mathrm{Al}^{\mathrm{V}}$ & 3,87 & 3,75 & 3,92 & 3,91 & 4,01 & 3,60 & 3,24 \\
\hline $\mathrm{Fe}^{2+}$ & 0,14 & 0,31 & 0,08 & 0,08 & 0,02 & 0,34 & 0,82 \\
\hline $\mathrm{Ti}$ & 0,01 & 0,01 & 0,00 & 0,00 & 0,00 & 0,02 & 0,03 \\
\hline Mg & & & & 03 & & 0,12 & 0,22 \\
\hline $\mathrm{Mn}$ & 0,01 & 0,01 & 00 & 0,01 & 0,00 & 0,01 & 0,01 \\
\hline$P$ & 0,00 & 0,01 & 0,01 & 0,02 & 0,00 & 0,01 & 0,02 \\
\hline Li* & & & & 06 & 14 & 0,17 & 0,28 \\
\hline$\Sigma Y$ & 4,15 & 4,17 & 4,09 & 4,11 & 4,20 & 4,28 & 4,62 \\
\hline $\mathrm{Ca}$ & 0,00 & 0,00 & 0,00 & 0,00 & 0,00 & 0,00 & 0,00 \\
\hline $\mathrm{Na}$ & & 08 & & 19 & 04 & 0,10 & 0,03 \\
\hline K & 1,79 & 1,82 & 1,82 & 1,82 & 1,66 & 1,82 & 1,77 \\
\hline$\Sigma x$ & 1,89 & 1,90 & 2,01 & 2,01 & 1,70 & 1,92 & 1,81 \\
\hline & 0,27 & 0,22 & 0,15 & 0,17 & 0,31 & 0,36 & 0,53 \\
\hline $\mathrm{Cl}$ & 0,00 & 0,00 & 0,00 & 0,00 & 0,00 & 0,00 & 0,01 \\
\hline $\mathrm{Fe} /(\mathrm{Fe}+\mathrm{N}$ & 0,78 & & 0,77 & 0 & 0,56 & 0,74 & \\
\hline \multicolumn{8}{|c|}{ Trazas en ppm } \\
\hline Li* & 726 & 519 & & 529 & 1238 & 1502 & 2342 \\
\hline & 0 & 553 & $5 \%$ & 469 & 486 & 0 & 386 \\
\hline w & 0 & 1485 & 0 & 0 & 63 & 305 & 0 \\
\hline $\mathrm{Rb}$ & 207 & 240 & 256 & 210 & 239 & 182 & 239 \\
\hline
\end{tabular}

\begin{tabular}{|c|c|c|}
\hline \multicolumn{3}{|l|}{ Lepidolita } \\
\hline Mina/Zona & \multicolumn{2}{|c|}{ Canalita } \\
\hline Roca & Peg. CEG & Peg. CEG \\
\hline Muestra & 1066 & 1066 \\
\hline Análisis & 1.1 & 5.3 \\
\hline$\overline{\mathrm{SiO}_{2}}$ & 53,04 & 52,09 \\
\hline $\mathrm{P}_{2} \mathrm{O}_{5}$ & 0,06 & 0,02 \\
\hline $\mathrm{Al}_{2} \mathrm{O}_{3}$ & 26,41 & 26,71 \\
\hline $\mathrm{Na}_{2} \mathrm{O}$ & 0,45 & 0,33 \\
\hline $\mathrm{K}_{2} \mathrm{O}$ & 9,16 & 9,31 \\
\hline $\mathrm{CaO}$ & 0,00 & 0,01 \\
\hline MgO & 0,01 & 0,01 \\
\hline $\mathrm{MnO}$ & 0,75 & 1,24 \\
\hline $\mathrm{FeO}$ & 0,12 & 0,22 \\
\hline $\mathrm{TiO}_{2}$ & 0,00 & 0,00 \\
\hline $\mathrm{Li}_{2} \mathrm{O}^{*}$ & 5,67 & 5,40 \\
\hline $\mathrm{ZnO}$ & 0,03 & 0,10 \\
\hline $\mathrm{As}_{2} \mathrm{O}_{3}$ & 0,00 & 0,00 \\
\hline $\mathrm{Cl}$ & 0,03 & 0,01 \\
\hline $\mathrm{F}$ & 6,66 & 5,57 \\
\hline Total & 99,56 & 98,68 \\
\hline \multicolumn{3}{|c|}{ Número de iones con base en 22} \\
\hline Si & 7,26 & 7,11 \\
\hline $\mathrm{Al}^{\mathrm{V}}$ & 0,74 & 0,89 \\
\hline$\Sigma Z$ & 8,00 & 8,00 \\
\hline $\mathrm{Al}^{\mathrm{V}}$ & 3,52 & 3,41 \\
\hline $\mathrm{Fe}^{2+}$ & 0,01 & 0,02 \\
\hline $\mathrm{Ti}$ & 0,00 & 0,00 \\
\hline $\mathrm{Mg}$ & 0,00 & 0,00 \\
\hline $\mathrm{Mn}$ & 0,09 & 0,14 \\
\hline $\mathrm{P}$ & 0,01 & 0,00 \\
\hline Li* & 3,12 & 2,96 \\
\hline$\Sigma Y$ & 6,75 & 6,55 \\
\hline $\mathrm{Ca}$ & 0,00 & 0,00 \\
\hline $\mathrm{Na}$ & 0,12 & 0,09 \\
\hline k & 1,60 & 1,62 \\
\hline$\Sigma x$ & 1,72 & 1,71 \\
\hline $\mathrm{F}$ & 2,88 & 2,40 \\
\hline $\mathrm{Cl}$ & 0,01 & 0,00 \\
\hline $\mathrm{Fe} /(\mathrm{Fe}+\mathrm{Mg})$ & 0,89 & 0,90 \\
\hline \multicolumn{3}{|c|}{ Trazas en ppm } \\
\hline Li* & 26337 & 25066 \\
\hline Sn & 614 & 611 \\
\hline w & 145 & 1212 \\
\hline $\mathrm{Rb}$ & 1048 & 1007 \\
\hline
\end{tabular}

\begin{tabular}{|c|c|c|c|c|c|c|c|}
\hline \multicolumn{2}{|c|}{ v. Celadonita } & \multirow{2}{*}{$\frac{\text { Biotita }}{\text { Mina/Zona }}$} & \multirow{2}{*}{\multicolumn{2}{|c|}{$\begin{array}{c}\text { Anexo III. Ar } \\
\text { San Martín }\end{array}$}} & álisis de & nicroso & da ele \\
\hline Mina/Zona & Salm. & & & & \multicolumn{3}{|c|}{ Horia } \\
\hline Roca & LG & Roca & MP & MP & GE & GE & GE \\
\hline Muestra & $1690 \mathrm{~B}$ & Muestra & 807 & 807 & 1682 & 1682 & 1682 \\
\hline Análisis & 1.4 & Análisis & 1.1 & 3.2 & 1.6 & 3.2 & 4.1.1 \\
\hline $\begin{array}{l}\mathrm{SO}_{2} \\
\end{array}$ & 37,02 & $\overline{\mathrm{SiO}_{2}}$ & 35,49 & 35,40 & 33,58 & 33,64 & 33,90 \\
\hline $\mathrm{P}_{2} \mathrm{O}_{5}$ & 0,00 & $\mathrm{P}_{2} \mathrm{O}_{5}$ & 0,05 & 0,04 & 0,03 & 0,01 & 0,01 \\
\hline $\mathrm{Al}_{2} \mathrm{O}_{3}$ & 20,30 & $\mathrm{Al}_{2} \mathrm{O}_{3}$ & 18,10 & 17,79 & 17,85 & 17,87 & 17,52 \\
\hline $\mathrm{Na}_{2} \mathrm{O}$ & 0,08 & $\mathrm{Na}_{2} \mathrm{O}$ & 0,19 & 0,08 & 0,11 & 0,09 & 0,04 \\
\hline $\mathrm{K}_{2} \mathrm{O}$ & 9,26 & $\mathrm{~K}_{2} \mathrm{O}$ & 9,10 & 9,09 & 9,34 & 9,14 & 9,14 \\
\hline $\mathrm{CaO}$ & 0,00 & $\mathrm{CaO}$ & 0,02 & 0,01 & 0,00 & 0,03 & 0,00 \\
\hline MgO & 1,45 & $\mathrm{MgO}$ & 6,91 & 7,26 & 5,78 & 5,71 & 5,19 \\
\hline $\mathrm{MnO}$ & 0,28 & $\mathrm{MnO}$ & 0,21 & 0,26 & 0,20 & 0,24 & 0,27 \\
\hline $\mathrm{FeO}$ & 23,23 & $\mathrm{FeO}$ & 21,68 & 21,79 & 24,62 & 23,53 & 24,85 \\
\hline $\mathrm{TiO}_{2}$ & 1,36 & $\mathrm{TiO}_{2}$ & 3,03 & 2,59 & 2,41 & 2,53 & 3,70 \\
\hline $\mathrm{Li}_{2} \mathrm{O}^{*}$ & 0,51 & $\mathrm{Li}_{2} \mathrm{O}^{*}$ & 0,13 & 0,14 & 0,08 & 0,07 & 0,08 \\
\hline $\mathrm{ZnO}$ & 0,17 & $\mathrm{znO}$ & 0,13 & 0,02 & 0,03 & 0,00 & 0,12 \\
\hline $\mathrm{Cl}$ & 0,01 & $\mathrm{Cl}$ & 0,09 & 0,07 & 0,03 & 0,06 & 0,04 \\
\hline $\mathrm{F}$ & 1,73 & $\mathrm{~F}$ & 0,56 & 0,59 & 0,42 & 0,36 & 0,39 \\
\hline Total & 94,73 & Total & 95,43 & 94,87 & 94,58 & 93,15 & 95,16 \\
\hline \multicolumn{2}{|c|}{$\mathrm{N}^{\circ}$ iones con base $22 \mathrm{O}$} & \multicolumn{6}{|c|}{ Número de iones con base en 220} \\
\hline $\mathrm{Si}$ & 7,93 & $\mathrm{Si}$ & 6,03 & 6,08 & 5,75 & 5,75 & 5,73 \\
\hline $\mathrm{Al}^{\mathrm{V}}$ & 0,07 & $\mathrm{Al}^{\mathrm{V}}$ & 1,97 & 1,92 & 2,25 & 2,25 & 2,27 \\
\hline$\Sigma z$ & 8,00 & $\Sigma z$ & 8,00 & 8,00 & 8,00 & 8,00 & 8,00 \\
\hline $\mathrm{Al}^{\mathrm{VI}}$ & 5,05 & $\mathrm{Al}^{\mathrm{VI}}$ & 1,66 & 1,69 & 1,35 & 1,35 & 1,21 \\
\hline $\mathrm{Fe}^{2+}$ & 4,16 & $\mathrm{Fe}^{2+}$ & 3,08 & 3,13 & 3,52 & 3,36 & 3,51 \\
\hline $\mathrm{Ti}$ & 0,22 & $\mathrm{Ti}$ & 0,39 & 0,33 & 0,31 & 0,33 & 0,47 \\
\hline $\mathrm{Mg}$ & 0,46 & $\mathrm{Mg}$ & 1,75 & 1,86 & 1,48 & 1,46 & 1,31 \\
\hline $\mathrm{Mn}$ & 0,05 & $\mathrm{Mn}$ & 0,03 & 0,04 & 0,03 & 0,03 & 0,04 \\
\hline $\mathrm{P}$ & 0,00 & $\mathrm{P}$ & 0,01 & 0,01 & 0,00 & 0,00 & 0,00 \\
\hline Li* & 0,44 & Li* & 0,09 & 0,10 & 0,06 & 0,05 & 0,05 \\
\hline$\Sigma Y$ & 10,38 & $\Sigma Y$ & 7,01 & 7,16 & 6,75 & 6,58 & 6,59 \\
\hline $\mathrm{Ca}$ & 0,00 & $\mathrm{Ca}$ & 0,00 & 0,00 & 0,00 & 0,01 & 0,00 \\
\hline $\mathrm{Na}$ & 0,03 & $\mathrm{Na}$ & 0,06 & 0,03 & 0,04 & 0,03 & 0,01 \\
\hline k & 2,53 & K & 1,97 & 1,99 & 2,04 & 1,99 & 1,97 \\
\hline$\Sigma x$ & 2,56 & $\Sigma x$ & 2,04 & 2,02 & 2,08 & 2,03 & 1,98 \\
\hline $\mathrm{F}$ & 1,17 & $\mathrm{~F}$ & 0,30 & 0,32 & 0,23 & 0,19 & 0,21 \\
\hline $\mathrm{Cl}$ & 0,00 & $\mathrm{Cl}$ & 0,03 & 0,02 & 0,01 & 0,02 & 0,01 \\
\hline$\overline{\mathrm{Fe} /(\mathrm{Fe}+\mathrm{Mg})}$ & 0,90 & $\mathrm{Fe} /(\mathrm{Fe}+\mathrm{Mg})$ & 0,64 & 0,63 & 0,70 & 0,70 & 0,73 \\
\hline \multicolumn{2}{|c|}{ Trazas en ppm } & \multicolumn{6}{|c|}{ Trazas en ppm } \\
\hline $\mathrm{Li}^{*}$ & 2351 & $\mathrm{Li}$ & 608 & 653 & 393 & 308 & 354 \\
\hline Sn & 158 & Sn & 0 & 37 & 0 & 0 & 0 \\
\hline w & 225 & w & 81 & 0 & 1472 & 0 & 0 \\
\hline $\mathrm{Rb}$ & 226 & $\mathrm{Rb}$ & 166 & 168 & 58 & 82 & 58 \\
\hline
\end{tabular}




\begin{tabular}{|c|c|c|c|c|c|c|c|c|c|c|}
\hline \multicolumn{5}{|l|}{ Mina/Zona } & \multicolumn{5}{|l|}{ Horia } & \multirow{2}{*}{$\frac{\text { Bon }}{\text { Peg. LG }}$} \\
\hline Roca & GE & GE & GE & GE & $\mathrm{GE}$ & GE & GE & GE & GE & \\
\hline Muestra & 1682 & 1682 & 1682 & 1682 & 1682 & 1682 & 1682 & 1682 & 1682 & $794 B$ \\
\hline Análisis & 4.1 .2 & 4.1.3 & 4.1.4 & 4.1.5 & 4.1.6 & 4.1.7 & 4.1.8 & 4.1.9 & 4.1.10 & 5.2 \\
\hline $\mathrm{SiO}_{2}$ & 33,75 & 34,06 & 33,85 & 33,96 & 33,48 & 33,75 & 34,57 & 33,75 & 33,05 & 37,62 \\
\hline $\mathrm{P}_{2} \mathrm{O}_{5}$ & 0,01 & 0,05 & 0,00 & 0,01 & 0,01 & 0,00 & 0,04 & 0,02 & 0,02 & 0,00 \\
\hline $\mathrm{Al}_{2} \mathrm{O}_{3}$ & 17,66 & 17,67 & 17,71 & 17,43 & 17,78 & 18,31 & 17,27 & 17,84 & 19,23 & 17,23 \\
\hline $\mathrm{Na}_{2} \mathrm{O}$ & 0,05 & 0,12 & 0,07 & 0,06 & 0,14 & 0,06 & 0,23 & 0,07 & 0,04 & 0,08 \\
\hline $\mathrm{K}_{2} \mathrm{O}$ & 9,41 & 9,18 & 9,39 & 9,29 & 8,79 & 9,32 & 7,99 & 9,35 & 7,18 & 9,05 \\
\hline $\mathrm{CaO}$ & 0,00 & 0,02 & 0,00 & 0,00 & 0,09 & 0,00 & 0,23 & 0,00 & 0,01 & 0,00 \\
\hline $\mathrm{MgO}$ & 5,22 & 5,25 & 5,29 & 5,39 & 5,18 & 5,31 & 5,20 & 5,45 & 6,80 & 8,82 \\
\hline $\mathrm{MnO}$ & 0,22 & 0,23 & 0,24 & 0,23 & 0,23 & 0,28 & 0,23 & 0,25 & 0,27 & 0,32 \\
\hline $\mathrm{FeO}$ & 24,58 & 24,82 & 24,79 & 24,75 & 24,94 & 25,01 & 24,65 & 24,89 & 26,05 & 19,77 \\
\hline $\mathrm{TiO}_{2}$ & 3,70 & 3,74 & 3,64 & 3,60 & 3,41 & 3,12 & 2,96 & 3,05 & 1,95 & 1,43 \\
\hline $\mathrm{Li}_{2} \mathrm{O}^{*}$ & 0,06 & 0,06 & 0,05 & 0,07 & 0,04 & 0,05 & 0,03 & 0,06 & 0,06 & 0,4452 \\
\hline $\mathrm{ZnO}$ & 0,07 & 0,10 & 0,04 & 0,05 & 0,15 & 0,04 & 0,07 & 0,04 & 0,11 & 0,03 \\
\hline $\mathrm{Cl}$ & 0,03 & 0,04 & 0,03 & 0,02 & 0,05 & 0,03 & 0,05 & 0,02 & 0,02 & 0,00 \\
\hline $\mathrm{F}$ & 0,35 & 0,34 & 0,31 & 0,36 & 0,29 & 0,32 & 0,26 & 0,36 & 0,34 & 1,54 \\
\hline Total & 95,04 & 95,69 & 95,35 & 95,18 & 94,53 & 95,55 & 93,80 & 95,11 & 95,05 & 95,63 \\
\hline \multicolumn{11}{|c|}{ Número de iones con base en 220} \\
\hline Si & 5,66 & 5,67 & 5,63 & 5,69 & 5,60 & 5,60 & 5,75 & 5,67 & 5,49 & 7,48 \\
\hline $\mathrm{Al}^{\mathrm{IV}}$ & 2,34 & 2,33 & 2,37 & 2,31 & 2,40 & 2,40 & 2,25 & 2,33 & 2,51 & 0,52 \\
\hline$\Sigma z$ & 8,00 & 8,00 & 8,00 & 8,00 & 8,00 & 8,00 & 8,00 & 8,00 & 8,00 & 8,00 \\
\hline $\mathrm{Al}^{\mathrm{vI}}$ & 1,15 & 1,14 & 1,10 & 1,14 & 1,11 & 1,19 & 1,13 & 1,20 & 1,26 & 3,52 \\
\hline $\mathrm{Fe}^{2+}$ & 3,45 & 3,45 & 3,45 & 3,47 & 3,49 & 3,47 & 3,43 & 3,50 & 3,62 & 3,29 \\
\hline $\mathrm{Ti}$ & 0,47 & 0,47 & 0,46 & 0,45 & 0,43 & 0,39 & 0,37 & 0,39 & 0,24 & 0,21 \\
\hline Mg & 1,30 & 1,30 & 1,31 & 1,35 & 1,29 & 1,31 & 1,29 & 1,37 & 1,68 & 2,61 \\
\hline $\mathrm{Mn}$ & 0,03 & 0,03 & 0,03 & 0,03 & 0,03 & 0,04 & 0,03 & 0,03 & 0,04 & 0,05 \\
\hline$P$ & 0,00 & 0,01 & 0,00 & 0,00 & 0,00 & 0,00 & 0,01 & 0,00 & 0,00 & 0,00 \\
\hline Li* & 0,04 & 0,04 & 0,03 & 0,04 & 0,03 & 0,04 & 0,02 & 0,04 & 0,04 & 0,36 \\
\hline$\Sigma^{Y}$ & 6,45 & 6,44 & 6,38 & 6,48 & 6,38 & 6,44 & 6,28 & 6,53 & 6,88 & 10,04 \\
\hline $\mathrm{Ca}$ & 0,00 & 0,00 & 0,00 & 0,00 & 0,02 & 0,00 & 0,04 & 0,00 & 0,00 & 0,00 \\
\hline $\mathrm{Na}$ & 0,02 & 0,04 & 0,02 & 0,02 & 0,05 & 0,02 & 0,08 & 0,02 & 0,01 & 0,03 \\
\hline K & 2,01 & 1,95 & 1,99 & 1,99 & 1,88 & 1,97 & 1,69 & 2,00 & 1,52 & 2,29 \\
\hline$\Sigma x$ & 2,03 & 1,99 & 2,01 & 2,01 & 1,94 & 1,99 & 1,81 & 2,02 & 1,54 & 2,32 \\
\hline $\mathrm{F}$ & 0,19 & 0,18 & 0,17 & 0,19 & 0,15 & 0,17 & 0,14 & 0,19 & 0,18 & 0,97 \\
\hline $\mathrm{Cl}$ & 0,01 & 0,01 & 0,01 & 0,00 & 0,01 & 0,01 & 0,01 & 0,01 & 0,00 & 0,00 \\
\hline $\mathrm{Fe} /(\mathrm{Fe}+\mathrm{Mg})$ & 0,73 & 0,73 & 0,72 & 0,72 & 0,73 & 0,73 & 0,73 & 0,72 & 0,68 & 0,56 \\
\hline \multicolumn{11}{|c|}{ Trazas en ppm } \\
\hline $\mathrm{Li}$ & 292 & 280 & 239 & 303 & 206 & 248 & 156 & 300 & 277 & 2068 \\
\hline Sn & 183 & 0 & 0 & 100 & 0 & 0 & 0 & 0 & 147 & 5 \\
\hline N & 0 & 841 & 140 & 108 & 29 & 0 & 0 & 0 & 0 & 0 \\
\hline $\mathrm{Rb}$ & 65 & 61 & 77 & 83 & 73 & 102 & 81 & 82 & 74 & 262 \\
\hline
\end{tabular}

Clorita

Anexo III. Análisis de microsonda electrónica

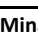

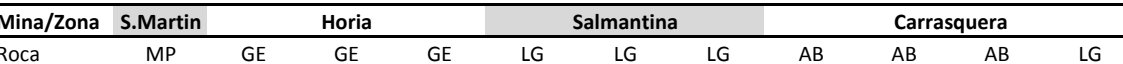

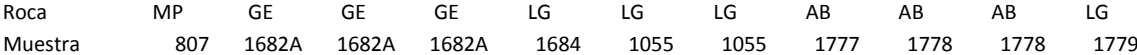

\begin{tabular}{lrrrrrrrrrrr} 
Análisis & 6.1 & 3.1 & 4.3 & 6.3 & 2.1 & 5.6 & 5.10 & 5.1 & 2.1 & 3.1 & 1.3 \\
\hline $\mathrm{SiO}_{2}$ & 26,60 & 25,01 & 26,12 & 24,05 & 31,66 & 37,64 & 35,74 & 39,68 & 32,75 & 30,38 & 45,19
\end{tabular}

$\begin{array}{rrrrrrrrrrrr}\mathrm{ri}_{2} & 26,60 & 25,01 & 26,12 & 24,05 & 31,66 & 37,64 & 35,74 & 39,68 & 32,75 & 30,38 & 45,19 \\ \mathrm{P}_{2} \mathrm{O}_{5} & 0,01 & 0,00 & 0,00 & 0,00 & 1,35 & 1,67 & 3,17 & 0,80 & 0,16 & 0,12 & 1,10\end{array}$

$\begin{array}{rrrrrrrrrrrr}\mathrm{Al}_{2} \mathrm{O}_{3} & 20,77 & 21,29 & 19,63 & 20,81 & 27,15 & 24,17 & 26,58 & 26,12 & 24,95 & 27,65 & 36,18\end{array}$

$\begin{array}{llllllllllll}\mathrm{Na}_{2} \mathrm{O} & 0,01 & 0,06 & 0,02 & 0,06 & 0,05 & 0,03 & 0,02 & 0,07 & 0,14 & 0,12 & 0,03\end{array}$

$\begin{array}{llllllllllll}\mathrm{K}_{2} \mathrm{O} & 0,92 & 0,03 & 0,86 & 0,07 & 0,03 & 0,17 & 0,07 & 0,10 & 0,81 & 0,15 & 0,05\end{array}$

$\begin{array}{llllllllllll}\mathrm{CaO} & 0,02 & 0,07 & 0,06 & 0,04 & 0,02 & 0,23 & 0,21 & 0,18 & 0,09 & 0,11 & 0,03 \\ \mathrm{MgO} & 8,83 & 9,73 & 7,27 & 7,87 & 0,20 & 0,42 & 0,12 & 0,31 & 0,33 & 0,29 & 0,04\end{array}$

$\begin{array}{llllllllllll}\mathrm{MnO} & 0,40 & 0,36 & 0,28 & 0,44 & 0,15 & 0,01 & 0,04 & 0,10 & 0,44 & 0,33 & 0,00\end{array}$

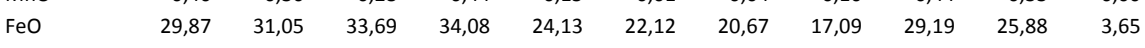

$\begin{array}{llllllllllll}\mathrm{TiO}_{2} & 0,42 & 0,08 & 0,29 & 0,17 & 0,00 & 0,01 & 0,01 & 0,01 & 0,01 & 0,02 & 0,00\end{array}$

\begin{tabular}{llllllllllll} 
& 0,03 & 0,04 & 0,05 & 0,47 & 0,00 & 0,04 & 0,71 & 0,42 & 0,32 & 0,06 \\
\hline$s_{2} O_{3}$ & 0,00 & 0,00 & 0,00 & 0,00 & 0,4 & 0,1 & 0,68 & 0,30 & 0,00 & 0,00 & 0,63
\end{tabular}

$\begin{array}{llllllllllll}\mathrm{As}_{2} \mathrm{O}_{3} & 0,00 & 0,00 & 0,00 & 0,00 & 0,41 & 0,19 & 0,68 & 0,30 & 0,00 & 0,00 & 0,63 \\ \mathrm{Cl} & 0,01 & 0,02 & 0,05 & 0,01 & 0,03 & 0,02 & 0,00 & 0,00 & 0,01 & 0,03 & 0,04 \\ \mathrm{~F} & 0,1 & 0,05 & 0,08 & 0,02 & 0,08 & 0,00 & 0,02 & 0,04 & 0,00 & 0,05 & 0,00\end{array}$

$\begin{array}{llllllllllll}F & 0,19 & 0,05 & 0,08 & 0,02 & 0,08 & 0,00 & 0,02 & 0,04 & 0,00 & 0,05 & 0,09\end{array}$

$\begin{array}{llllllllllll}\text { Total } & 88,06 & 87,75 & 88,33 & 87,65 & 85,75 & 86,71 & 87,35 & 85,49 & 89,30 & 85,50 & 87,04\end{array}$

Número de iones con base en 140

\begin{tabular}{|c|c|c|c|c|c|c|c|c|c|c|c|}
\hline $\mathrm{Si}$ & 2,98 & 2,76 & 2,93 & 2,69 & 3,32 & 3,74 & 3,50 & 3,90 & 3,38 & 3,24 & 3,91 \\
\hline P & 0,00 & 0,00 & 0,00 & 0,00 & 0,12 & 0,14 & 0,26 & 0,07 & 0,01 & 0,01 & 0,08 \\
\hline As & 0,00 & 0,00 & 0,00 & 0,00 & 0,01 & 0,01 & 0,02 & 0,01 & 0,00 & 0,00 & 0,02 \\
\hline $\mathrm{Al}^{\mathrm{IV}}$ & 1,02 & 1,24 & 1,07 & 1,31 & 0,54 & 0,12 & 0,22 & 0,02 & 0,61 & 0,74 & 0,00 \\
\hline$\Sigma z$ & 4,00 & 4,00 & 4,00 & 4,00 & 4,00 & 4,00 & 4,00 & 4,00 & 4,00 & 4,00 & 4,00 \\
\hline $\mathrm{Al}^{\mathrm{VI}}$ & 1,73 & 1,52 & 1,53 & 1,44 & 2,82 & 2,71 & 2,84 & 3,01 & 2,42 & 2,73 & 3,69 \\
\hline $\mathrm{Fe}^{2+}$ & 2,80 & 2,86 & 3,16 & 3,19 & 2,12 & 1,84 & 1,69 & 1,41 & 2,52 & 2,31 & 0,26 \\
\hline $\mathrm{Ti}$ & 0,04 & 0,01 & 0,02 & 0,01 & 0,00 & 0,00 & 0,00 & 0,00 & 0,00 & 0,00 & 0,00 \\
\hline $\mathrm{Mg}$ & 1,48 & 1,60 & 1,22 & 1,31 & 0,03 & 0,06 & 0,02 & 0,05 & 0,05 & 0,05 & 0,01 \\
\hline $\mathrm{Mn}$ & 0,04 & 0,03 & 0,03 & 0,04 & 0,01 & 0,00 & 0,00 & 0,01 & 0,04 & 0,03 & 0,00 \\
\hline vacancias & 0,00 & 0,00 & 0,04 & 0,00 & 1,02 & 1,39 & 1,45 & 1,53 & 0,97 & 0,88 & 2,04 \\
\hline$\Sigma x$ & 6,07 & 6,02 & 6,00 & 6,00 & 6,00 & 6,00 & 6,00 & 6,00 & 6,00 & 6,00 & 6,00 \\
\hline $\mathrm{Ca}$ & 0,00 & 0,01 & 0,01 & 0,00 & 0,00 & 0,02 & 0,02 & 0,02 & 0,01 & 0,01 & 0,00 \\
\hline $\mathrm{Na}$ & 0,00 & 0,01 & 0,01 & 0,01 & 0,01 & 0,01 & 0,00 & 0,01 & 0,03 & 0,02 & 0,01 \\
\hline K & 0,13 & 0,00 & 0,12 & 0,01 & 0,00 & 0,02 & 0,01 & 0,01 & 0,11 & 0,02 & 0,01 \\
\hline Elnterlám. & 0,14 & 0,02 & 0,13 & 0,03 & 0,02 & 0,05 & 0,03 & 0,04 & 0,15 & 0,06 & 0,01 \\
\hline$F$ & 0,14 & 0,04 & 0,06 & 0,02 & 0,05 & 0,00 & 0,01 & 0,02 & 0,00 & 0,03 & 0,05 \\
\hline $\mathrm{Cl}$ & 0,01 & 0,01 & 0,02 & 0,00 & 0,01 & 0,01 & 0,00 & 0,00 & 0,00 & 0,01 & 0,01 \\
\hline $\mathrm{Fe} /(\mathrm{Fe}+\mathrm{Mg})$ & 0,65 & 0,64 & 0,72 & 0,71 & 0,99 & 0,97 & 0,99 & 0,97 & 0,98 & 0,98 & 0,98 \\
\hline
\end{tabular}


Clorita (continuación)

\begin{tabular}{|c|c|c|c|c|c|c|c|c|c|c|c|c|c|c|c|c|c|c|}
\hline \multirow{2}{*}{$\begin{array}{l}\text { Mina/Zona } \\
\text { Roca }\end{array}$} & \multirow{2}{*}{\begin{tabular}{|l|} 
Prof. \\
$A B$
\end{tabular}} & \multicolumn{2}{|c|}{ Profunda } & \multicolumn{3}{|c|}{ Horia } & \multicolumn{2}{|c|}{ Teso } & \multirow{2}{*}{$\begin{array}{l}\text { Horia } \\
\text { Vena GE }\end{array}$} & \multicolumn{4}{|c|}{ Salmantina } & \multicolumn{2}{|c|}{ La Canalita } & \multicolumn{3}{|c|}{ Peñaparda } \\
\hline & & LG & LG & Peg. GE & Peg. GE & Peg. GE & Peg. LG & Peg. LG & & Vena LG & Vena LG & Vena LG & Vena LG & Peg. CEG & Peg. CEG & Vena G5 & Vena G5 & Vena G5 \\
\hline Muestra & $781 B$ & $788 \mathrm{~A}$ & $788 \mathrm{~A}$ & $1769 \mathrm{~A}$ & $1769 \mathrm{~A}$ & $1769 \mathrm{~A}$ & 1797 & 1797 & 1720 & 1693 & 1693 & 1693 & 1693 & 1066 & 1066 & $1725 \mathrm{~A}$ & $1725 \mathrm{~A}$ & $1725 \mathrm{~A}$ \\
\hline Análisis & 1.2 & 2.2 & 2.4 & 4.3 & 3.4 & 5.4 & 6.3 & 7.1 & 5.1 & 1.1 & 2.2 & 2.3 & 2.4 & 4.3 & 5.2 & 3.1 & 2.2 & 3.1 \\
\hline $\mathrm{SiO}_{2}$ & 47,53 & 42,24 & 40,99 & 25,01 & 44,06 & 29,28 & 37,42 & 30,84 & 43,40 & 22,90 & 21,25 & 22,51 & 22,29 & 42,28 & 39,48 & 22,67 & 26,39 & 23,53 \\
\hline $\mathrm{P}_{2} \mathrm{O}_{5}$ & 2,43 & 1,08 & 1,08 & 0,27 & 0,32 & 0,63 & 0,92 & 0,62 & 0,04 & 0,05 & 0,07 & 0,11 & 0,18 & 0,89 & 0,39 & 0,24 & 2,45 & 0,80 \\
\hline $\mathrm{Al}_{2} \mathrm{O}_{3}$ & 32,05 & 30,81 & 33,37 & 22,27 & 33,09 & 26,26 & 30,44 & 25,83 & 28,35 & 20,33 & 21,58 & 19,33 & 19,99 & 33,79 & 41,76 & 20,54 & 17,27 & 19,18 \\
\hline $\mathrm{Na}_{2} \mathrm{O}$ & 0,03 & 0,10 & 0,07 & 0,06 & 0,06 & 0,07 & 0,08 & 0,13 & 0,09 & 0,01 & 0,01 & 0,03 & 0,04 & 0,02 & 0,03 & 0,00 & 0,05 & 0,04 \\
\hline $\mathrm{K}_{2} \mathrm{O}$ & 0,08 & 0,13 & 0,12 & 0,07 & 1,73 & 0,26 & 0,09 & 0,15 & 0,54 & 0,01 & 0,01 & 0,03 & 0,03 & 0,10 & 0,19 & 0,01 & 0,26 & 0,03 \\
\hline $\mathrm{CaO}$ & 0,31 & 0,21 & 0,17 & 0,05 & 0,07 & 0,07 & 0,04 & 0,03 & 0,00 & 0,03 & 0,01 & 0,06 & 0,06 & 0,10 & 0,06 & 0,03 & 0,15 & 0,04 \\
\hline MgO & 0,18 & 0,09 & 0,06 & 4,18 & 1,46 & 3,22 & 2,82 & 0,41 & 1,01 & 0,64 & 0,77 & 0,34 & 0,37 & 1,42 & 0,29 & 0,68 & 0,16 & 0,56 \\
\hline MnO & 0,07 & 0,03 & 0,00 & 0,50 & 0,03 & 0,39 & 0,11 & 0,12 & 0,03 & 0,26 & 0,22 & 0,15 & 0,14 & 0,02 & 0,00 & 0,47 & 0,08 & 0,38 \\
\hline $\mathrm{FeO}$ & 5,34 & 7,56 & 5,64 & 35,04 & 7,14 & 29,15 & 14,09 & 23,68 & 8,99 & 42,42 & 41,84 & 41,76 & 42,22 & 6,62 & 4,42 & 44,02 & 29,51 & 43,97 \\
\hline $\mathrm{TiO}_{2}$ & 0,00 & 0,00 & 0,00 & 0,00 & 0,01 & 0,00 & 0,02 & 0,00 & 0,32 & 0,03 & 0,01 & 0,02 & 0,01 & 0,04 & 0,01 & 0,03 & 0,06 & 0,05 \\
\hline $\mathrm{ZnO}$ & 0,06 & 0,46 & 0,50 & 0,05 & 0,06 & 0,17 & 0,21 & 1,36 & 0,05 & 0,08 & 0,00 & 0,00 & 0,09 & 0,03 & 0,07 & 0,01 & 0,04 & 0,00 \\
\hline $\mathrm{As}_{2} \mathrm{O}_{3}$ & 0,62 & 0,65 & 0,70 & 0,00 & 0,00 & 0,00 & 0,00 & 0,12 & 0,54 & 1,06 & 0,33 & 2,14 & 1,25 & 0,00 & 0,00 & 0,16 & 4,22 & 0,73 \\
\hline $\mathrm{Cl}$ & 0,01 & 0,02 & 0,01 & 0,02 & 0,00 & 0,01 & 0,01 & 0,01 & 0,20 & 0,00 & 0,00 & 0,01 & 0,00 & 0,02 & 0,02 & 0,01 & 0,02 & 0,02 \\
\hline & & 0,05 & 0,05 & 0,05 & 0,16 & 0,04 & 0,00 & 0,00 & 0,45 & 0,07 & 0,00 & 0,11 & 0,00 & 0,03 & 0,06 & 0,13 & 0,00 & 0,01 \\
\hline Total & 88,76 & 83,49 & 82,75 & 87,53 & 88,12 & 89,60 & 86,32 & 83,33 & 84,01 & 87,86 & 86,18 & 86,61 & 86,67 & 85,33 & 86,75 & 88,95 & 80,65 & 89,34 \\
\hline \multicolumn{19}{|c|}{ Número de iones con base en 140} \\
\hline Si & 3,83 & 3,89 & 3,87 & 2,82 & 3,98 & 3,04 & 3,57 & 3,31 & 3,99 & 2,72 & 2,54 & 2,75 & 2,66 & 3,87 & 3,53 & 2,71 & 3,14 & 2,73 \\
\hline & 0,17 & 0,08 & 0,09 & 0,03 & 0,02 & 0,06 & 0,07 & 0,06 & 0,00 & 0,00 & 0,01 & 0,01 & 0,02 & 0,07 & 0,03 & 0,02 & 0,25 & 0,08 \\
\hline As & 0,02 & 0,02 & 0,02 & 0,00 & 0,00 & 0,00 & 0,00 & 0,00 & 0,02 & 0,04 & 0,01 & 0,08 & 0,05 & 0,00 & 0,00 & 0,00 & 0,00 & 0,00 \\
\hline $\mathrm{Al}^{\mathrm{IV}}$ & 0,00 & 0,00 & 0,02 & 1,16 & 0,00 & 0,91 & 0,36 & 0,63 & 0,00 & 1,23 & 1,44 & 1,16 & 1,28 & 0,06 & 0,44 & 1,27 & 0,61 & 1,19 \\
\hline$\Sigma z$ & 4,01 & 4,00 & 4,00 & 4,00 & 4,00 & 4,00 & 4,00 & 4,00 & 4,00 & 4,00 & 4,00 & 4,00 & 4,00 & 4,00 & 4,00 & 4,00 & 4,00 & 4,00 \\
\hline $\mathrm{Al}^{\mathrm{v}}$ & 3,04 & 3,34 & 3,70 & 1,80 & 3,52 & 2,30 & 3,06 & 2,64 & 3,07 & 1,61 & 1,59 & 1,63 & 1,53 & 3,58 & 3,97 & 1,62 & 1,81 & 1,43 \\
\hline $\mathrm{Fe}^{2+}$ & 0,36 & 0,58 & 0,45 & 3,30 & 0,54 & 2,53 & 1,12 & 2,13 & 0,69 & 4,22 & 4,18 & 4,27 & 4,21 & 0,51 & 0,33 & 4,40 & 2,94 & 4,27 \\
\hline $\mathrm{Ti}$ & 0,00 & 0,00 & 0,00 & 0,00 & 0,00 & 0,00 & 0,00 & 0,00 & 0,02 & 0,00 & 0,00 & 0,00 & 0,00 & 0,00 & 0,00 & 0,00 & 0,01 & 0,00 \\
\hline $\mathrm{Mg}$ & 0,02 & $0, \mathrm{C}$ & 0,01 & 0,70 & 0,20 & 0,50 & 0,40 & 0,07 & 0,14 & 0,11 & 0,14 & 0,06 & 0,06 & 0,19 & 0,04 & 0,12 & 0,03 & 0,10 \\
\hline $\mathrm{Mn}$ & 0,00 & 0,00 & 0,00 & 0,05 & 0,00 & 0,03 & 0,01 & 0,01 & 0,00 & 0,03 & 0,02 & 0,02 & 0,01 & 0,00 & 0,00 & 0,05 & 0,01 & 0,04 \\
\hline vacancias & 2,57 & 2,06 & 1,85 & 0,15 & 1,74 & & 1,40 & 1,15 & 2,07 & 0,03 & 0,07 & 0,02 & 0,19 & 1,72 & 1,66 & 0,00 & 1,21 & 0,16 \\
\hline$\Sigma x$ & 6,00 & 6,00 & 6,00 & 6,00 & 6,00 & 6,00 & 6,00 & 6,00 & 6,00 & 6,00 & 6,00 & 6,00 & 6,00 & 6,00 & 6,00 & 6,19 & 6,00 & 6,00 \\
\hline $\mathrm{Ca}$ & 0,03 & 0,02 & 0,02 & 0,01 & 0,01 & 0,01 & 0,00 & 0,00 & 0,00 & 0,00 & 0,00 & 0,01 & 0,01 & 0,01 & 0,01 & 0,00 & 0,02 & 0,01 \\
\hline $\mathrm{Na}$ & 0,00 & & 0,01 & & 0,01 & & & & & 0,00 & & 0,01 & 0,01 & 0,00 & 0,01 & 0,00 & 0,01 & 0,01 \\
\hline & 0,01 & 0,02 & 0,01 & 0,01 & 0,20 & 0,03 & 0,01 & 0,02 & 0,06 & 0,00 & 0,00 & 0,00 & 0,00 & 0,01 & 0,02 & 0,00 & 0,04 & 0,00 \\
\hline terló & 0,04 & 0,05 & 0,04 & 0,03 & 0,22 & 0,06 & 0,03 & 0,05 & 0,08 & 0,01 & 0,00 & 0,02 & 0,02 & 0,02 & 0,03 & 0,01 & 0,07 & 0,02 \\
\hline & 0,05 & 0,03 & 0,03 & 0,04 & 0,09 & $0, c$ & 0,00 & 0,00 & 0,26 & 0,06 & 0,00 & 0,08 & 0,00 & 0,02 & 0,03 & 0,10 & 0,00 & 0,01 \\
\hline & 0,00 & 0,01 & 0,00 & 0,01 & 0,00 & 0,00 & 0,00 & 0,00 & 0,06 & 0,00 & 0,00 & 0,00 & 0,00 & 0,01 & 0,01 & 0,00 & 0,01 & 0,01 \\
\hline & 0,94 & 0,98 & 0,98 & 0,82 & 0,73 & 0,84 & 0,74 & 0,97 & 0,83 & 0,97 & 0,97 & 0,99 & 0,98 & 0,72 & 0,90 & 0,97 & 0,99 & 0,98 \\
\hline
\end{tabular}

Anexo III. Análisis de microsonda electrónica

\begin{tabular}{lrr}
\hline Moca & \multicolumn{2}{c}{ SP Martín } \\
\hline Muestra & 807 & \multicolumn{1}{c}{ MP } \\
Análisis & 2.1 & 4.1 \\
\hline $\mathrm{SiO}_{2}$ & 37,77 & 37,23 \\
$\mathrm{P}_{2} \mathrm{O}_{5}$ & 0,01 & 0,02 \\
$\mathrm{Al}_{2} \mathrm{O}_{3}$ & 61,50 & 61,45 \\
$\mathrm{Na}_{2} \mathrm{O}$ & 0,02 & 0,02 \\
$\mathrm{~K}_{2} \mathrm{O}$ & 0,03 & 0,00 \\
$\mathrm{CaO}$ & 0,03 & 0,01 \\
$\mathrm{MgO}$ & 0,01 & 0,01 \\
$\mathrm{MnO}$ & 0,02 & 0,01 \\
$\mathrm{FeO}$ & 0,28 & 0,26 \\
$\mathrm{TiO}$ & 0,03 & 0,02 \\
$\mathrm{Total}$ & 99,68 & 99,03 \\
$\mathrm{~N}$ de iones con base en & $32 \mathrm{O}$ \\
\hline $\mathrm{Si}$ & 1,02 & 1,01 \\
$\mathrm{Al}$ & 1,96 & 1,97 \\
$\mathrm{P}$ & 0,00 & 0,00 \\
$\mathrm{Na}$ & 0,00 & 0,00 \\
$\mathrm{~K}$ & 0,00 & 0,00 \\
$\mathrm{Ca}$ & 0,00 & 0,00 \\
$\mathrm{Mg}$ & 0,00 & 0,00 \\
$\mathrm{Fe}$ & 0,01 & 0,01 \\
$\mathrm{Mn}$ & 0,00 & 0,00 \\
$\mathrm{Ti}$ & 0,00 & 0,00 \\
\hline
\end{tabular}


Anexo III. Análisis de microsonda electrónica

\begin{tabular}{|c|c|c|c|c|c|c|c|c|c|c|c|c|c|c|c|c|c|c|c|c|c|c|c|}
\hline \multirow{2}{*}{$\begin{array}{l}\text { Mina/Zona } \\
\text { Roca }\end{array}$} & \multicolumn{2}{|c|}{ San Martín } & \multicolumn{2}{|c|}{ Salmantina } & \multirow{2}{*}{$\begin{array}{l}\text { Teso } \\
\text { LG }\end{array}$} & \multicolumn{9}{|c|}{ Salmantina } & \multirow{2}{*}{$\begin{array}{c}\text { Carrasq. } \\
A B\end{array}$} & \multirow{2}{*}{$\begin{array}{l}\text { Prof. } \\
A B\end{array}$} & \multicolumn{2}{|c|}{ Salmantina } & \multirow{2}{*}{$\begin{array}{c}\text { Carrasq. } \\
\text { Peg. LG }\end{array}$} & \multicolumn{4}{|c|}{ Bon } \\
\hline & MP & $\mathrm{MP}$ & LG & LG & & AB & AB & $A B$ & AB & $A B$ & $A B$ & $A B$ & $A B$ & $A B$ & & & Peg. LG & Peg. LG & & Peg. LG & Peg. LG & Peg. LG & Peg. LG \\
\hline Muestra & 807 & 807 & $1690 B$ & 1055 & & 1685 & 1685 & 1685 & 1685 & 1685 & 1685 & 1685 & 825 & 825 & 1777 & $781 \mathrm{~B}$ & $1772 B$ & $1721 \mathrm{~B}$ & 1787 & $794 B$ & $794 B$ & $794 B$ & $794 B$ \\
\hline Análisis & 2.3 & 4.2 & 5.1 & 4.2 & 1.1 & 1.1 & 4.3.1 & 4.3.2 & 4.3 .3 & 4.3 .4 & 4.3 .5 & 4.3 .6 & 2.3 & 4.1 & 1.1 & 4.1 & 2.6 & 7.1 & 2.1 & 3.4 & 4.1 & 5.1 & 5.3 \\
\hline $\mathrm{SiO}_{2}$ & 36,00 & 36,57 & 34,93 & 35,35 & 34,92 & 34,04 & 34,66 & 34,56 & 33,83 & 34,68 & 34,40 & 33,81 & 35,16 & 35,39 & 35,52 & 35,08 & 32,54 & 35,14 & 35,31 & 36,25 & 36,41 & 36,27 & 36,55 \\
\hline $\mathrm{P}_{2} \mathrm{O}_{5}$ & 0,00 & 0,00 & 0,00 & 0,00 & 0,00 & 0,03 & 0,02 & 0,01 & 0,00 & 0,00 & 0,00 & 0,01 & 0,29 & 0,11 & 0,01 & 0,08 & 0,00 & 0,00 & 0,01 & 0,00 & 0,01 & 0,01 & 0,01 \\
\hline $\mathrm{I}_{2} \mathrm{O}_{3}$ & 33,58 & 33,66 & 32,43 & 32,47 & 32,68 & 33,27 & 33,29 & 33,51 & 33,35 & 34,22 & 34,20 & 32,66 & 32,79 & 35,37 & 33,52 & 33,30 & 34,59 & 33,00 & 33,72 & 32,50 & 33,67 & 33,96 & 34,37 \\
\hline $\mathrm{a}_{2} \mathrm{O}$ & 1,77 & 1,75 & 2,05 & 1,85 & 1,93 & 1,86 & 1,90 & 1,86 & 1,81 & 1,50 & 1,33 & 1,91 & 1,54 & 1,66 & 1,87 & 1,81 & 1,99 & 2,08 & 1,65 & 1,94 & 1,83 & 1,84 & 1,91 \\
\hline $\mathrm{K}_{2} \mathrm{O}$ & 0,05 & 0,04 & 0,05 & 0,06 & 0,05 & 0,05 & 0,03 & 0,05 & 0,04 & 0,04 & 0,02 & 0,06 & 0,01 & 0,02 & 0,06 & 0,06 & 0,04 & 0,01 & 0,02 & 0,03 & 0,03 & 0,03 & 0,00 \\
\hline ao & 0,46 & 0,30 & 0,05 & 0,08 & 0,08 & 0,08 & 0,04 & 0,07 & 0,07 & 0,01 & 0,00 & 0,05 & 0,49 & 0,04 & 0,05 & 0,06 & 0,04 & 0,01 & 0,04 & 0,41 & 0,18 & 0,20 & 0,22 \\
\hline go & 4,99 & 4,49 & 1,09 & 1,35 & 1,56 & 1,14 & 1,12 & 1,37 & 1,42 & 0,73 & 0,63 & 1,05 & 0,27 & 0,84 & 0,76 & 0,50 & 0,22 & 0,97 & 0,50 & 4,85 & 3,57 & 3,37 & 4,38 \\
\hline $\mathrm{MnO}$ & 0,04 & 0,08 & 0,09 & 0,14 & 0,15 & 0,22 & 0,18 & 0,22 & 0,16 & 0,18 & 0,23 & 0,24 & 0,11 & 0,14 & 0,13 & 0,12 & 0,14 & 0,09 & 0,19 & 0,06 & 0,07 & 0,11 & 0,01 \\
\hline eO & 7,90 & 8,36 & 14,46 & 14,33 & 13,80 & 13,95 & 13,66 & 14,10 & 14,11 & 13,60 & 13,75 & 14,55 & 15,09 & 13,68 & 14,87 & 15,16 & 12,22 & 14,59 & 14,22 & 9,41 & 10,15 & 10,30 & 8,05 \\
\hline $\mathrm{O}_{2}$ & 0,91 & 0,61 & 0,55 & 0,62 & 0,58 & 0,36 & 0,81 & 0,52 & 0,54 & 0,27 & 0,21 & 0,77 & 0,01 & 0,04 & 0,30 & 0,26 & 0,13 & 0,32 & 0,18 & 0,86 & 0,16 & 0,14 & 0,50 \\
\hline no & 0,10 & 0,10 & 0,22 & 0,20 & 0,25 & 0,13 & 0,33 & 0,22 & 0,19 & 0,16 & 0,18 & 0,19 & 0,09 & 0,21 & 0,21 & 0,21 & 0,36 & 0,20 & 0,29 & 0,04 & 0,04 & 0,15 & 0,14 \\
\hline & 0,01 & 0,01 & 0,00 & 0,01 & 0,01 & 0,01 & 0,00 & 0,01 & 0,01 & 0,02 & 0,00 & 0,00 & 0,00 & 0,00 & 0,00 & 0,00 & 0,00 & 0,01 & 0,01 & 0,00 & 0,00 & 0,01 & 0,00 \\
\hline & 0,21 & 0,13 & 0,4 & 0,45 & 0,35 & 0,37 & 0,37 & 0,39 & 0,45 & 0,3 & 0,26 & 0, & 0,54 & 0,21 & 0,42 & 0,43 & 0,52 & 0,52 & 0,28 & 0,30 & 0,31 & 0,29 & 0,25 \\
\hline${ }_{2} \mathrm{O}^{*}$ & 3,54 & 3,59 & 3,32 & 3,32 & 3,36 & 3,31 & 3,35 & 3,35 & 3,28 & 3,37 & 3,38 & 3,25 & 3,25 & 3,52 & 3,37 & 3,33 & 3,14 & 3,28 & 3,40 & 3,49 & 3,47 & 3,48 & 3,54 \\
\hline $\mathrm{B}_{2} \mathrm{O}_{3}{ }^{*}$ & 10,56 & 10,59 & 10,18 & 10,25 & 10,22 & 10,11 & 10,23 & 10,26 & 10,13 & 10,21 & 10,16 & 10,06 & 10,16 & 10,49 & 10,35 & 10,25 & 9,83 & 10,23 & 10,27 & 10,52 & 10,50 & 10,51 & 10,62 \\
\hline $\mathrm{O}_{2}{ }^{*}$ & 0,17 & 0,22 & 0,07 & 0,03 & 0,04 & 0,01 & 0,08 & 0,00 & 0,00 & 0,05 & 0,02 & 0,00 & 0,20 & 0,12 & 0,05 & 0,06 & 0,12 & 0,03 & 0,10 & 0,10 & 0,06 & 0,12 & 0,21 \\
\hline Total & 100,19 & 100,43 & 99,72 & 100,33 & 99,84 & 98,78 & 99,90 & 100,33 & 99,20 & 99,21 & 98,66 & 98,89 & 99,77 & 101,77 & 101,30 & 100,53 & 95,65 & 100,24 & 100,06 & 100,64 & 100,45 & 100,66 & 100,66 \\
\hline \multicolumn{24}{|c|}{ Número de iones con base en 24.50} \\
\hline$B^{*}$ & 3,00 & 3,00 & 3,00 & 3,00 & 3,00 & 3,00 & 3,00 & 3,00 & 3,00 & 3,00 & 3,00 & 3,00 & 3,00 & 3,00 & 3,00 & 3,00 & 3,00 & 3,00 & 3,00 & 3,00 & 3,00 & 3,00 & 3,00 \\
\hline Si $T$ & 5,93 & 6,00 & 5,97 & 5,9 & 5,94 & 5,85 & 5,89 & 5,85 & 5,81 & 5,90 & 5,89 & 5,84 & 6,00 & 5,86 & 5,97 & 5,95 & 5,75 & 5,97 & 5,98 & 5,99 & 6,00 & 6,00 & 5,98 \\
\hline IT & $0, \mathrm{C}$ & 0,0 & 0,03 & 0,0 & 0,06 & 0,15 & 11 & 0,15 & 9 & 0,10 & & 0,16 & 0 & 4 & 03 & 0,05 & 25 & 03 & 02 & 01 & 00 & 00 & 0,02 \\
\hline Iz & 6,6 & 6,0 & 6,00 & 6,0 & 6,00 & 6,00 & o0 & 6,00 & Do & 6,00 & 6, & 6,00 & 00 & 0 & 6,00 & 6,00 & 6,00 & Do & 00 & Do & 6,00 & 00 & 6,00 \\
\hline $\lg z$ & & & & & & & & & & & & & & & & 0 & 0,00 & 00 & 00 & 0,00 & 00 & 00 & 0,00 \\
\hline Ir & & & & & & & & & & & & & 61 & & 60 & 61 & ,97 & 58 & 0,71 & 0,32 & 0,60 & 0,61 & 0,61 \\
\hline & & & & & & & & & & & & & & & & 15 & 81 & 37 & 2,01 & 1,30 & 1,41 & 42 & 1,10 \\
\hline TiY & 0,1 & 0,0 & $0, \mathrm{C}$ & 0,0 & 0, & 0,0 & 0 & $0, c$ & & $0, \mathrm{C}$ & 03 & 0,10 & & 11 & 0,04 & 0,03 & 0,02 & 0,04 & 0,02 & 0,11 & 0,02 & 0,02 & 0,06 \\
\hline $\operatorname{Mg} Y$ & 1,2 & & 0,2 & & & & & & & & & & 07 & 1 & 19 & 13 & 0,06 & 24 & 0,13 & 1,20 & 0,88 & 83 & 1,07 \\
\hline$Y$ & & & & & & & & & & & & & & & & & & & & & & 01 & 0,00 \\
\hline $\operatorname{Zn} Y$ & $0, \mathrm{C}$ & 0,01 & $0, \mathrm{C}$ & 0, & & 0,0 & 84 & & 22 & & & 0,02 & 01 & 3 & 03 & 03 & 05 & 03 & 0,04 & 0,01 &, 01 & 0,02 & 0,02 \\
\hline ir & & & $0, \mathrm{C}$ & & 0, & & 0 & & & & & $0, \mathrm{C}$ & & 0 & 0,00 & 0 & 0,00 & bo & 0,00 & 0,00 & 0,03 & 00 & 0,00 \\
\hline$i^{*} \gamma$ & & & & & & & & & & & & & & & & & & 2 & D7 & D7 & 0,04 & 08 & 0,14 \\
\hline Ca $X$ & $0, \mathrm{C}$ & & $0, \mathrm{C}$ & & & & 0 , & & & & & & & & 11 & 1 & 0,01 & Do & 0,01 & 0,07 & ,03 & 04 & 0,04 \\
\hline & & & & & & & & & & & & & & & & & 68 & & 0,54 & 0,62 & 0,59 & 59 & 0,61 \\
\hline $\mathrm{K} x$ & & & & & & & & & & & & & & & & 01 & 0,01 & 0,00 & 0,00 & 0,01 & 0,01 & 0,01 & 0,00 \\
\hline Vac. $X$ & 0,3 & 0,3 & 0, & 0, & 0,34 & 0 & 36 & 0 & 38 & & 55 & 0 , & & 5 & 0,37 & 38 & 0,30 & 0,31 & 0,45 & 0,30 & 0,37 & 0,37 & 0,35 \\
\hline & & 0,07 & & & & & & & & & & & & & & 3 & 0,29 & 28 & 0,15 & 0,15 & 0,16 & 0,15 & 0,13 \\
\hline $\mathrm{Cl}$ & 0,00 & 0,0 & 0,00 & $0, c$ & 0,00 & & 0 , & 0, & 00 & $0, \mathrm{C}$ & 0,00 & 0,00 & 0,00 & Do & 0,00 & 0,00 & 0,00 & 0,00 & 0,00 & 0,00 & 0,00 & 0,00 & 0,00 \\
\hline & & & & & & & & & & & & & & & & 77 & 11 & 72 & 3,84 & 3,85 & 3,84 & 3,84 & 3,87 \\
\hline $\mathrm{Fe} /(\mathrm{Fe}+\mathrm{Mg})$ & 0,47 & 0,51 & 0,88 & 0,86 & 0,83 & 0,87 & 0,87 & 0,85 & 0,85 & 0,91 & 0,92 & 0,89 & 0,97 & 0,90 & 0,92 & 0,94 & 0,97 & 0,89 & 0,94 & 0,52 & 0,61 & 0,63 & 0,51 \\
\hline
\end{tabular}

*Calculados por estequiometría 
Turmalina (continuación)

\begin{tabular}{|c|c|c|c|c|c|}
\hline Mina/Zona & Bon & \multicolumn{3}{|c|}{ Cruz del Rayo } & Canalita \\
\hline Roca & Peg. LG & Peg. CEG & eg. CEG & Peg. CEG & Peg. CEG \\
\hline Muestra & $795 \mathrm{~B}$ & $2298 \mathrm{~A}$ & $2298 \mathrm{~A}$ & $2298 \mathrm{~A}$ & 1066 \\
\hline Análisis & 3.1 & 2.1 & 2.2 & 5.1 & 6.2 \\
\hline $\mathrm{SiO}_{2}$ & 35,33 & 35,84 & 37,22 & 34,16 & 36,79 \\
\hline $\mathrm{P}_{2} \mathrm{O}_{5}$ & 0,03 & 0,26 & 0,02 & 1,37 & 0,00 \\
\hline $\mathrm{Al}_{2} \mathrm{O}_{3}$ & 32,41 & 33,66 & 33,86 & 33,54 & 30,05 \\
\hline $\mathrm{Na}_{2} \mathrm{O}$ & 1,89 & 2,02 & 1,63 & 1,67 & 1,67 \\
\hline $\mathrm{K}_{2} \mathrm{O}$ & 0,06 & 0,07 & 0,01 & 0,08 & 0,01 \\
\hline $\mathrm{CaO}$ & 0,06 & 0,06 & 0,37 & 0,03 & 1,20 \\
\hline $\mathrm{MgO}$ & 0,69 & 2,27 & 5,25 & 0,89 & 6,70 \\
\hline $\mathrm{MnO}$ & 0,14 & 0,00 & 0,00 & 0,00 & 0,07 \\
\hline $\mathrm{FeO}$ & 15,38 & 11,50 & 7,27 & 13,74 & 8,00 \\
\hline $\mathrm{TiO}_{2}$ & 0,75 & 0,40 & 0,08 & 0,24 & 1,45 \\
\hline $\mathrm{ZnO}$ & 0,23 & 0,07 & 0,02 & 0,12 & 0,07 \\
\hline $\mathrm{Cl}$ & 0,01 & 0,01 & 0,00 & 0,02 & 0,01 \\
\hline $\mathrm{F}$ & 0,41 & 0,21 & 0,34 & 0,23 & 0,19 \\
\hline $\mathrm{H}_{2} \mathrm{O}^{*}$ & 3,34 & 3,50 & 3,50 & 3,43 & 3,53 \\
\hline $\mathrm{B}_{2} \mathrm{O}_{3}{ }^{*}$ & 10,26 & 10,44 & 10,63 & 10,30 & 10,52 \\
\hline $\mathrm{LiO}_{2}{ }^{*}$ & 0,07 & 0,30 & 0,16 & 0,51 & 0,18 \\
\hline Total & 100,88 & 100,51 & 100,36 & 100,25 & 100,44 \\
\hline \multicolumn{6}{|c|}{ Número de iones con base en 24.50} \\
\hline$B^{*}$ & 3,00 & 3,00 & 3,00 & 3,00 & 3,00 \\
\hline Si $T$ & 5,99 & 5,97 & 6,00 & 5,77 & 6,00 \\
\hline Al $T$ & 0,01 & 0,03 & 0,00 & 0,23 & 0,00 \\
\hline $\mathrm{Al} Z$ & 6,00 & 6,00 & 6,00 & 6,00 & 5,85 \\
\hline $\operatorname{Mg} Z$ & 0,00 & 0,00 & 0,00 & 0,00 & 0,15 \\
\hline AlY $Y$ & 0,46 & 0,57 & 0,52 & 0,44 & 0,00 \\
\hline $\mathrm{FeY} Y$ & 2,18 & 1,60 & 0,99 & 1,94 & 1,11 \\
\hline TiY $Y$ & 0,10 & 0,05 & 0,01 & 0,03 & 0,18 \\
\hline $\operatorname{Mg} Y$ & 0,17 & 0,56 & 1,28 & 0,22 & 1,50 \\
\hline $\mathrm{MnY}$ & 0,02 & 0,00 & 0,00 & 0,00 & 0,01 \\
\hline $\operatorname{Zn} Y$ & 0,03 & 0,01 & 0,00 & 0,02 & 0,01 \\
\hline Sir & 0,00 & 0,00 & 0,09 & 0,00 & 0,08 \\
\hline$L^{*} Y$ & 0,04 & 0,20 & 0,11 & 0,35 & 0,12 \\
\hline $\operatorname{ca} x$ & 0,01 & 0,01 & 0,06 & 0,01 & 0,21 \\
\hline Na $X$ & 0,62 & 0,65 & 0,52 & 0,55 & 0,54 \\
\hline $\mathrm{k} x$ & 0,01 & 0,01 & 0,00 & 0,02 & 0,00 \\
\hline Vac. $X$ & 0,35 & 0,32 & 0,42 & 0,43 & 0,25 \\
\hline$F$ & 0,22 & 0,11 & 0,17 & 0,12 & 0,10 \\
\hline $\mathrm{Cl}$ & 0,00 & 0,00 & 0,00 & 0,01 & 0,00 \\
\hline $\mathrm{OH}^{*}$ & 3,78 & 3,89 & 3,83 & 3,87 & 3,89 \\
\hline $\mathrm{Fe} /(\mathrm{Fe}+\mathrm{Mg})$ & 0,93 & 0,74 & 0,44 & 0,90 & 0,40 \\
\hline
\end{tabular}

Anexo III. Análisis de microsonda electrónica

Gahnita

Mina/Zona

\begin{tabular}{lll} 
Salmantina & Molino del Galo \\
\hline Roca & &
\end{tabular}

$\begin{array}{lllllllllllll}\text { Roca } & \text { AB } & \text { AB } & \text { AB } & \text { AB } & \text { AB } & \text { AB } & \text { AB } & \text { AB } & \text { AB } & \text { Aplita } & \text { Aplita } & \text { Aplita } \\ \text { Muestra } & 825 & 825 & 825 & 825 & 825 & 825 & 825 & 825 & 825 & 820 & 820 & 820\end{array}$

\begin{tabular}{lrrrrrrrrrrrr} 
Muestra & 825 & 825 & 825 & 825 & 825 & 825 & 825 & 825 & 825 & 820 & 820 & 820 \\
Análisis & 1.1 & 1.2 & 2.1 & 2.2 & 3.1 & 3.2 & 3.4 & 3.5 & 3.7 & 1.1 & 1.2 & 1.3 \\
\hline $\mathrm{SiO}_{2}$ & 0,03 & 0,03 & 0,03 & 0,02 & 0,05 & 0,07 & 0,03 & 0,06 & 0,05 & 0,17 & 0,03 & 0,06
\end{tabular}

$\begin{array}{lrrrrrrrrrrrr}\mathrm{Al}_{2} \mathrm{O}_{3} & 53,90 & 53,82 & 54,41 & 54,63 & 54,30 & 53,74 & 54,78 & 52,97 & 53,03 & 0,59 & 0,69 & 0,69\end{array}$

$\begin{array}{lllllllllllll}\mathrm{Na}_{2} \mathrm{O} & 0,58 & 0,57 & 0,52 & 0,48 & 0,42 & 0,48 & 0,49 & 0,53 & 0,46 & 55,64 & 55,97 & 54,94\end{array}$

$\begin{array}{lllllllllllll}\mathrm{K}_{2} \mathrm{O} & 0,01 & 0,00 & 0,02 & 0,01 & 0,02 & 0,03 & 0,02 & 0,01 & 0,00 & 0,02 & 0,00 & 0,02 \\ \mathrm{CaO} & 0,03 & 0,02 & 0,01 & 0,00 & 0,01 & 0,03 & 0,00 & 0,00 & 0,02 & 0,05 & 0,02 & 0,02\end{array}$

$\begin{array}{lllllllllllll}\mathrm{MgO} & 0,01 & 0,05 & 0,11 & 0,09 & 0,04 & 0,02 & 0,02 & 0,04 & 0,10 & 0,09 & 0,08 & 0,03\end{array}$

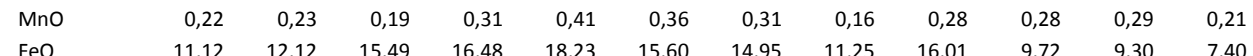

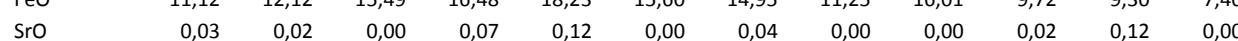

$\begin{array}{llllllllllllll}\text { SnO } & 0,01 & 0,01 & 0,02 & 0,00 & 0,00 & 0,02 & 0,11 & 0,02 & 0,00 & 0,00 & 0,00 & 0,02\end{array}$

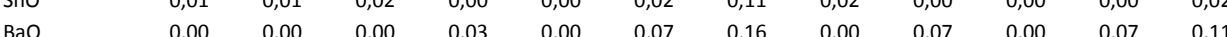

$\begin{array}{lllllllllllll}\text { ZnO } & 29,59 & 28,76 & 25,91 & 25,46 & 22,88 & 25,10 & 25,94 & 29,06 & 24,55 & 30,31 & 31,11 & 33,22\end{array}$

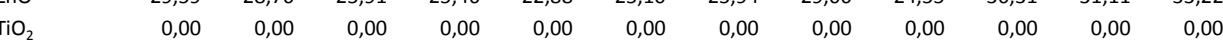

$\begin{array}{rrrrrrrrrrrrr}\mathrm{WO}_{3} & 0,06 & 0,30 & 0,12 & 0,26 & 0,08 & 0,28 & 0,00 & 0,00 & 0,00 & 0,00 & 0,00 & 0,00 \\ \text { Total } & 95,64 & 95,97 & 96,88 & 97,90 & 96,55 & 95,81 & 96,90 & 94,13 & 94,57 & 96,88 & 97,68 & 96,72\end{array}$ Número de iones con base en 40

\begin{tabular}{|c|c|c|c|c|c|c|c|c|c|c|c|c|}
\hline $\mathrm{Zn}$ & 0,69 & 0,67 & 0,59 & 0,58 & 0,52 & 0,58 & 0,59 & 0,68 & 0,57 & 0,69 & 0,70 & 0,76 \\
\hline $\mathrm{Fe}$ & 0,29 & 0,32 & 0,40 & 0,42 & 0,47 & 0,41 & 0,39 & 0,30 & 0,42 & 0,25 & 0,24 & 0,19 \\
\hline $\mathrm{Mg}$ & 0,00 & 0,00 & 0,00 & 0,00 & 0,00 & 0,00 & 0,00 & 0,00 & 0,00 & 0,00 & 0,00 & 0,00 \\
\hline $\mathrm{Mn}$ & 0,01 & 0,01 & 0,00 & 0,01 & 0,01 & 0,01 & 0,01 & 0,00 & 0,01 & 0,01 & 0,01 & 0,01 \\
\hline $\mathrm{Ca}$ & 0,00 & 0,00 & 0,00 & 0,00 & 0,00 & 0,00 & 0,00 & 0,00 & 0,00 & 0,00 & 0,00 & 0,00 \\
\hline $\mathrm{Na}$ & 0,04 & 0,03 & 0,03 & 0,03 & 0,03 & 0,03 & 0,03 & 0,03 & 0,03 & 0,04 & 0,04 & 0,04 \\
\hline K & 0,00 & 0,00 & 0,00 & 0,00 & 0,00 & 0,00 & 0,00 & 0,00 & 0,00 & 0,00 & 0,00 & 0,00 \\
\hline Ba & 0,00 & 0,00 & 0,00 & 0,00 & 0,00 & 0,00 & 0,00 & 0,00 & 0,00 & 0,00 & 0,00 & 0,00 \\
\hline $\mathrm{Sr}$ & 0,00 & 0,00 & 0,00 & 0,00 & 0,00 & 0,00 & 0,00 & 0,00 & 0,00 & 0,00 & 0,00 & 0,00 \\
\hline$\Sigma A$ & 1,02 & 1,03 & 1,04 & 1,04 & 1,04 & 1,03 & 1,02 & 1,02 & 1,04 & 0,99 & 1,00 & 1,00 \\
\hline Si & 0,00 & 0,00 & 0,00 & 0,00 & 0,00 & 0,00 & 0,00 & 0,00 & 0,00 & 0,01 & 0,00 & 0,00 \\
\hline $\mathrm{Al}$ & 2,00 & 1,99 & 1,98 & 1,98 & 1,98 & 1,98 & 2,00 & 1,99 & 1,98 & 2,01 & 2,02 & 2,01 \\
\hline $\mathrm{Ti}$ & 0,00 & 0,00 & 0,00 & 0,00 & 0,00 & 0,00 & 0,00 & 0,00 & 0,00 & 0,00 & 0,00 & 0,00 \\
\hline Sn & 0,00 & 0,00 & 0,00 & 0,00 & 0,00 & 0,00 & 0,00 & 0,00 & 0,00 & 0,00 & 0,00 & 0,00 \\
\hline w & 0,00 & 0,00 & 0,00 & 0,00 & 0,00 & 0,00 & 0,00 & 0,00 & 0,00 & 0,00 & 0,00 & 0,00 \\
\hline$\Sigma B$ & 2,00 & 1,99 & 1,99 & 1,98 & 1,98 & 1,99 & 2,00 & 1,99 & 1,98 & 2,02 & 2,02 & 2,01 \\
\hline$\%$ mol Gh & 70 & 67 & 59 & 57 & 52 & 58 & 60 & 69 & 57 & 72 & 74 & 79 \\
\hline$\% \mathrm{~mol} \mathrm{Hc}$ & 30 & 32 & 40 & 42 & 47 & 41 & 39 & 30 & 42 & 26 & 25 & 20 \\
\hline$\% \mathrm{~mol}$ Spl & 0 & 0 & 0 & 0 & 0 & 0 & 0 & 0 & 0 & 0 & 0 & 0 \\
\hline$\% \mathrm{~mol} G a$ & 1 & 1 & 0 & 1 & 1 & 1 & 1 & 0 & 1 & 1 & 1 & 1 \\
\hline
\end{tabular}

mol $a$ 


\section{Escorodita}

Anexo III. Análisis de microsonda electrónica

\begin{tabular}{|c|c|c|c|c|c|c|c|c|c|c|c|c|c|c|c|c|c|c|c|c|c|c|c|}
\hline \multirow{2}{*}{$\begin{array}{l}\text { Mina/Zona } \\
\text { Roca }\end{array}$} & \multicolumn{5}{|c|}{ Horia } & \multirow{2}{*}{$\begin{array}{l}\text { Mari C. } \\
\text { Vena GE }\end{array}$} & \multicolumn{7}{|c|}{ Salmantina } & \multicolumn{4}{|c|}{ Carrasquera } & \multicolumn{3}{|c|}{ Bon } & \multicolumn{2}{|c|}{ El cruce } & \multirow{2}{*}{$\begin{array}{l}\text { Peñap. } \\
\text { Vena G5 }\end{array}$} \\
\hline & Vena GE & Vena GE & Vena GE & Vena GE & Vena GE & & Vena LG & Vena LG & Vena LG & Vena LG & Vena LG & Vena LG & Vena $L G$ & Vena $L G$ & Vena LG & Vena LG & Vena LG & Vena LG & Vena LG & Vena LG & Vena G2 & Vena G2 & \\
\hline Muestra & 1773 & 1773 & 1773 & 1767 & 1767 & 1720 & 1704 & $835 \mathrm{~A}$ & 833 & 833 & $835 B$ & $835 B$ & $835 \mathrm{~B}$ & 1785 & 1785 & 1785 & 1785 & 792 & 792 & 792 & 801 & 801 & $1725 \mathrm{~B}$ \\
\hline álisis & 4.2 & 4.3 & 5.2 & 1.3 & 2.1 & 4.2 & 3.2 & 1.3 & 3.1 & 4.7 & 1.1 & 1.2 & 3.2 & 1.2 & 5.2 & 5.3 & 7.2 & 1.1 & 1.2 & 2.1 & 1.1 & 2.2 & 1.2 \\
\hline $\mathrm{As}_{2} \mathrm{O}_{5}$ & 44,05 & 43,49 & 45,89 & 47,85 & 41,82 & 41,94 & 44,85 & 40,05 & 31,32 & 30,74 & 25,02 & 22,88 & 31,32 & 50,78 & 50,91 & 50,23 & 51,36 & 37,45 & 42,10 & 53,05 & 49,24 & 45,95 & 48,37 \\
\hline $\mathrm{P}_{2} \mathrm{O}_{5}$ & 0,00 & 0,00 & 0,01 & 1,82 & 0,00 & 2,69 & 3,72 & 10,57 & 19,01 & 18,84 & 10,00 & 25,92 & 18,85 & 0,02 & 0,10 & 0,06 & 0,47 & 4,96 & 14,07 & 2,30 & 0,09 & 3,84 & 4,80 \\
\hline $\mathrm{O}_{3}$ & - & - & - & - & & - & & 0,00 & 0,02 & 0,00 & 0,31 & 0,03 & 0,02 & - & & & & 1,01 & 0,05 & 0,00 & - & - & \\
\hline $\mathrm{Al}_{2} \mathrm{O}_{3}$ & 0,06 & 0,23 & 0,09 & 2,52 & 0,06 & 0,75 & 0,07 & 0,54 & 0,01 & 0,04 & 4,23 & 0,68 & 1,09 & 0,46 & 1,07 & 1,48 & 3,40 & 2,33 & 9,27 & 5,67 & 0,98 & 0,28 & 3,55 \\
\hline $\mathrm{In}_{2} \mathrm{O}_{3}$ & 0,00 & 0,00 & 0,00 & 0,02 & 0,03 & 0,01 & 0,02 & 0,15 & 0,10 & 0,01 & 0,04 & 0,00 & 0,10 & 0,00 & 0,00 & 0,00 & 0,00 & 0,00 & 0,00 & 0,00 & 0,00 & 0,00 & 0,00 \\
\hline $\mathrm{e}_{2} \mathrm{O}_{3}$ & 41,92 & 40,62 & 40,42 & 36,18 & 41,74 & 39,47 & 40,23 & 38,52 & 40,08 & 41,02 & 41,00 & 40,64 & 39,60 & 38,64 & 37,88 & 36,68 & 35,10 & 43,71 & 30,33 & 32,33 & 37,75 & 40,00 & 35,76 \\
\hline $\mathrm{Na}_{2} \mathrm{O}$ & 0,01 & 0,02 & 0,00 & 0,02 & 0,02 & 0,01 & 0,01 & 0,02 & 0,03 & 0,00 & 0,06 & 0,00 & 0,00 & 0,00 & 0,02 & 0,01 & 0,02 & 0,05 & 0,00 & 0,00 & 0,03 & 0,01 & 0,00 \\
\hline $\mathrm{O}$ & 0,02 & 0,00 & 0,02 & 0,01 & 0,03 & 0,00 & 0,02 & 0,00 & 0,03 & 0,01 & 0,05 & 0,00 & 0,00 & 0,02 & 0,00 & 0,04 & 0,01 & 0,03 & 0,00 & 0,00 & 0,02 & 0,03 & 0,00 \\
\hline $\mathrm{aO}$ & 0,01 & 0,03 & 04 & 0,03 & 0,04 & 0,03 & 0,05 & 0,03 & 0,28 & 0,37 & 0,18 & 0,03 & 0,01 & 0,01 & 0,00 & 0,01 & 0,02 & 0,07 & 0,01 & 0,00 & 0,06 & 0,03 & 0,00 \\
\hline no & 0,38 & 0,06 & 0,22 & 0,02 & 0,01 & 0,09 & 0,09 & 0,13 & 0,01 & 0,00 & 0,00 & 0,00 & 0,00 & 0,05 & 0,04 & 0,15 & 0,17 & 0,04 & 0,09 & 0,15 & 0,23 & 0,05 & 0,03 \\
\hline $\mathrm{MgO}$ & & & & 0 & 0,00 & 0,00 & 0,00 & 0,00 & 00 & 00 & 0,00 & 0,00 & 0,00 & 0,00 & 0,00 & 0,00 & 0,00 & 0,00 & 0,00 & 0,00 & 0,00 & 0,00 & 0,00 \\
\hline & 0,00 & .00 & 00 & 0,00 & 0,00 & 0,00 & 0,01 & 0,06 & 0,14 & 0,12 & 0,11 & 0,14 & 0,07 & 0,00 & 0,00 & 0,00 & 0,00 & 0,03 & 0,11 & 0,00 & 0,00 & 0,03 & 0,00 \\
\hline Total & 86,46 & 84,45 & 86,69 & 88,46 & 83,76 & 84,98 & 89,06 & 90,05 & 90,99 & 91,11 & 80,95 & 90,26 & 91,04 & 89,98 & 90,03 & 88,66 & 90,55 & 89,68 & 96,00 & 93,49 & 88,38 & 90,22 & 92,50 \\
\hline \multicolumn{24}{|c|}{ Número de iones con base en 40} \\
\hline & 1,00 & 1,00 & 1,00 & 0,94 & 1,00 & 0,91 & 0,88 & 0,70 & 0,50 & 0,50 & 0,60 & 0,35 & 0,51 & 1,00 & 1,00 & 1,00 & 0,99 & 0,80 & 0,65 & 0,93 & 1,00 & 0,88 & 0,86 \\
\hline & 0,00 & 0,00 & 00 & 0,06 & 0,00 & 0,09 & 0,12 & 0,30 & 0,50 & 0,50 & 0,39 & 0,65 & 0,49 & 0,00 & 0,00 & 0,00 & 0,01 & 0,17 & 0,35 & 0,07 & 0,00 & 0,12 & 0,14 \\
\hline & 0,00 & 0,00 & 0, & 0,00 & 0,00 & 0,0 & 0,00 & 0,00 & 0,00 & 0, & 0,01 & 0,00 & 0,00 & 0,00 & 0,00 & 0,00 & 0,00 & 0,03 & 0,00 & 0,00 & 0,00 & 0,00 & 0,00 \\
\hline an. & 1,00 & 1,00 & 1,00 & 1,00 & 1,00 & 1,00 & 1,00 & 1,00 & 1,00 & 1,00 & 1,00 & 1,00 & 1,00 & 1,00 & 1,00 & 1,00 & 1,00 & 1,00 & 1,00 & 1,00 & 1,00 & 1,00 & 1,00 \\
\hline & 0,00 & 0,01 & 0,00 & 0,12 & 0,00 & 0,04 & 0,00 & 0,03 & 0,00 & 0,00 & 0,38 & 0,07 & 0,08 & 0,02 & 0,05 & 0,07 & 0,15 & 0,14 & 0,50 & 0,24 & 0,04 & 0,01 & 0,14 \\
\hline $\mathrm{Fe}^{3+}$ & 1,37 & 1,34 & 1,27 & 1,09 & 1,44 & 1,35 & 1,29 & 1,38 & 1,84 & 1,92 & 2,36 & 2,56 & 1,82 & 1,10 & 1,07 & 1,05 & 0,98 & 1,68 & 1,04 & 0,88 & 1,10 & 1,10 & 0,92 \\
\hline $\mathrm{Mn}^{3+}$ & 0,00 & 0,00 & 0,00 & 0,00 & 0,00 & 0,00 & 0,00 & 0,01 & 0,00 & & 0,00 & 0,00 & 0,00 & 0,00 & 0,00 & 0,00 & 0,00 & 0,00 & 0,00 & 0,00 & 0,00 & 0,00 & 0,00 \\
\hline hg & 0,00 & 0,00 & & 0,00 & 0 , & 0,00 & 0,00 & 0,00 & 0,00 & 0,00 & 0,00 & 0,00 & 0,00 & 0,00 & 0,00 & 0,00 & 0,00 & 0,00 & 0,00 & 0,00 & 0,00 & 0,00 & 0,00 \\
\hline a & 0,01 & 0,03 & 03 & 0,02 & 0,05 & 0,03 & 0,05 & 0,03 & 0,39 & 0,52 & 0,30 & 0,05 & 0,02 & 0,01 & 0,00 & 0,01 & 0,01 & 0,09 & 0,01 & 0,00 & 0,00 & 0,00 & 0,00 \\
\hline & & & & & & & 0,00 & & & & 01 & 0 & 00 & 0,00 & & 0,00 & 0,00 & 0,00 & 0,00 & 0,00 & 0,00 & 0,00 & 0,00 \\
\hline & & & & & & & & & & & & & & 0,00 & & 00 & 00 & 0,00 & 00 & 0,00 & 0,00 & 0,00 & 0,00 \\
\hline $\mathrm{Zn}$ & 0,01 & 0,00 & 0,01 & 0,00 & 0,00 & 0,00 & 0,00 & 0,00 & 0,00 & 0,00 & 0,00 & 0,00 & 0,00 & 0,00 & 0,00 & 0,00 & 0,00 & 0,00 & 0,00 & 0,00 & 0,01 & 0,00 & 0,00 \\
\hline cat. & & 1,39 & & & 1,49 & 1,43 & 1,35 & 1,46 & 2,24 & 2,45 & 3,06 & 2,68 & 1,92 & 1,13 & 1,1 & 1,13 & 1,15 & 1,91 & 1,55 & 1,12 & 1,16 & 1,12 & 1,06 \\
\hline & 0,00 & 0,00 & 0,00 & 0,00 & 0,00 & 0,00 & 0,00 & 0,01 & 0,03 & 0,02 & 0,03 & 0,04 & 0,01 & 0,00 & 0,00 & 0,00 & 0,00 & 0,01 & 0,02 & 0,00 & 0,00 & 0,00 & 0,00 \\
\hline
\end{tabular}




\begin{tabular}{|c|c|c|c|}
\hline \multicolumn{4}{|l|}{ Escorodita } \\
\hline \multirow{2}{*}{$\begin{array}{l}\text { Mina/Zona } \\
\text { Roca }\end{array}$} & \multicolumn{3}{|c|}{ Peñaparda } \\
\hline & Vena G5 & Vena G5 & Vena G5 \\
\hline Muestra & $1725 B$ & $1725 B$ & $1725 \mathrm{~B}$ \\
\hline Análisis & 1.3 & 2.1 & 2.2 \\
\hline$\overline{\mathrm{As}_{2} \mathrm{O}_{5}}$ & 40,79 & 43,68 & 45,91 \\
\hline $\mathrm{P}_{2} \mathrm{O}_{5}$ & 11,21 & 9,29 & 9,39 \\
\hline \multicolumn{4}{|l|}{$\mathrm{SO}_{3}$} \\
\hline $\mathrm{Al}_{2} \mathrm{O}_{3}$ & 1,23 & 3,52 & 5,92 \\
\hline $\mathrm{Mn}_{2} \mathrm{O}_{3}$ & 0,00 & 0,00 & 0,02 \\
\hline $\mathrm{Fe}_{2} \mathrm{O}_{3}$ & 40,54 & 36,99 & 34,05 \\
\hline $\mathrm{Na}_{2} \mathrm{O}$ & 0,00 & 0,00 & 0,00 \\
\hline $\mathrm{K}_{2} \mathrm{O}$ & 0,00 & 0,00 & 0,00 \\
\hline $\mathrm{CaO}$ & 0,01 & 0,02 & 0,02 \\
\hline $\mathrm{ZnO}$ & 0,00 & 0,06 & 0,20 \\
\hline MgO & 0,00 & 0,00 & 0,00 \\
\hline $\mathrm{F}$ & 0,05 & 0,03 & 0,05 \\
\hline Total & 93,81 & 93,57 & 95,53 \\
\hline \multicolumn{4}{|c|}{ Número de iones con base en 40} \\
\hline As & 0,69 & 0,74 & 0,75 \\
\hline $\mathrm{P}$ & 0,31 & 0,26 & 0,25 \\
\hline $\mathrm{s}$ & 0,00 & 0,00 & 0,00 \\
\hline$\sum a n$. & 1,00 & 1,00 & 1,00 \\
\hline Al & 0,05 & 0,13 & 0,22 \\
\hline $\mathrm{Fe}^{3+}$ & 0,99 & 0,91 & 0,80 \\
\hline $\mathrm{Mn}^{3+}$ & 0,00 & 0,00 & 0,00 \\
\hline Mg & 0,00 & 0,00 & 0,00 \\
\hline $\mathrm{Ca}$ & 0,00 & 0,00 & 0,00 \\
\hline $\mathrm{Na}$ & 0,00 & 0,00 & 0,00 \\
\hline K & 0,00 & 0,00 & 0,00 \\
\hline $\mathrm{Zn}$ & 0,00 & 0,00 & 0,00 \\
\hline$\sum$ cat. & 1,04 & 1,04 & 1,03 \\
\hline $\mathrm{F}$ & 0,01 & 0,00 & 0,01 \\
\hline
\end{tabular}

\begin{tabular}{|c|c|c|c|c|}
\hline \multirow{2}{*}{$\begin{array}{l}\text { Mina/Zona } \\
\text { Roca }\end{array}$} & \multirow{2}{*}{$\frac{\text { Salmant. }}{\text { LG }}$} & \multicolumn{3}{|c|}{ Cruz del Rayo } \\
\hline & & Peg. CEG & Peg. CEG & Peg. CEG \\
\hline Muestra & 1055 & $2298 \mathrm{C}$ & $2298 \mathrm{C}$ & $2298 c$ \\
\hline Análisis & 2.1 & 1.1 & 2.1 & 3.1 \\
\hline$\overline{\mathrm{SiO}_{2}}$ & 68,35 & 66,78 & 66,49 & 66,70 \\
\hline $\mathrm{P}_{2} \mathrm{O}_{5}$ & 0,04 & 0,02 & 0,00 & 0,00 \\
\hline $\mathrm{Al}_{2} \mathrm{O}_{3}$ & 18,05 & 18,02 & 18,08 & 17,85 \\
\hline $\mathrm{Na}_{2} \mathrm{O}$ & 0,29 & 0,79 & 1,12 & 0,88 \\
\hline $\mathrm{K}_{2} \mathrm{O}$ & 0,00 & 0,04 & 0,03 & 0,03 \\
\hline $\mathrm{CaO}$ & 0,00 & 0,00 & 0,00 & 0,02 \\
\hline MgO & 0,02 & 0,00 & 0,01 & 0,00 \\
\hline $\mathrm{MnO}$ & 0,05 & 0,00 & 0,00 & 0,01 \\
\hline $\mathrm{FeO}$ & 0,34 & 0,01 & 0,00 & 0,00 \\
\hline $\mathrm{TiO}_{2}$ & 0,02 & 0,00 & 0,01 & 0,00 \\
\hline $\mathrm{ZnO}$ & 0,04 & 0,01 & 0,06 & 0,01 \\
\hline $\mathrm{F}$ & 0,04 & 0,05 & 0,02 & 0,00 \\
\hline BeO* & 14,22 & 13,89 & 13,83 & 13,88 \\
\hline Total & 101,45 & 99,59 & 99,67 & 99,36 \\
\hline \multicolumn{5}{|c|}{ Número de iones con base en 180} \\
\hline$B e^{*}$ & 3,00 & 3,00 & 3,00 & 3,00 \\
\hline si & 6,00 & 6,00 & 6,00 & 6,00 \\
\hline $\mathrm{Al}$ & 1,87 & 1,91 & 1,92 & 1,89 \\
\hline $\mathrm{Fe}$ & 0,03 & 0,00 & 0,00 & 0,00 \\
\hline $\mathrm{Ti}$ & 0,00 & 0,00 & 0,00 & 0,00 \\
\hline $\mathrm{Mg}$ & 0,00 & 0,00 & 0,00 & 0,00 \\
\hline $\mathrm{Mn}$ & 0,00 & 0,00 & 0,00 & 0,00 \\
\hline $\mathrm{Zn}$ & 0,00 & 0,00 & 0,00 & 0,00 \\
\hline$\Sigma 0$ & 1,90 & 1,91 & 1,93 & 1,89 \\
\hline $\mathrm{Ca}$ & 0,00 & 0,00 & 0,00 & 0,00 \\
\hline $\mathrm{Na}$ & 0,05 & 0,14 & 0,20 & 0,15 \\
\hline K & 0,00 & 0,00 & 0,00 & 0,00 \\
\hline vacancias & 0,95 & 0,86 & 0,80 & 0,84 \\
\hline$\Sigma c$ & 0,05 & 0,14 & 0,20 & 0,16 \\
\hline $\mathrm{F}$ & 0,01 & 0,01 & 0,01 & 0,00 \\
\hline
\end{tabular}

\begin{tabular}{lrr}
\multicolumn{3}{l}{ Topacio } \\
\hline Mina/Zona & \multicolumn{2}{c}{ La Canalita } \\
\hline Roca & Peg. CEG & Peg. CEG \\
Muestra & 1066 & 1066 \\
Análisis & 1.3 & 4.1 \\
\hline $\mathrm{SiO}_{2}$ & 33,65 & 32,17 \\
$\mathrm{P}_{2} \mathrm{O}_{5}$ & 0,22 & 0,44 \\
$\mathrm{Al}_{2} \mathrm{O}_{3}$ & 54,04 & 54,03 \\
$\mathrm{Na}_{2} \mathrm{O}$ & 0,03 & 0,01 \\
$\mathrm{~K}_{2} \mathrm{O}$ & 0,01 & 0,03 \\
$\mathrm{CaO}$ & 0,01 & 0,00 \\
$\mathrm{MgO}$ & 0,01 & 0,00 \\
$\mathrm{MnO}$ & 0,00 & 0,00 \\
$\mathrm{FeO}$ & 0,05 & 0,00 \\
$\mathrm{TiO} \mathrm{O}_{2}$ & 0,00 & 0,00 \\
$\mathrm{ZnO}$ & 0,00 & 0,04 \\
$\mathrm{Rb} \mathrm{O}_{2} \mathrm{O}$ & 0,01 & 0,01 \\
$\mathrm{FeO}$ & 10,83 & 11,02 \\
Total & 88,03 & 86,73 \\
$\mathrm{~N}^{\circ}$ iones con base en 40 & \\
\hline $\mathrm{Si}$ & 0,92 & 0,90 \\
$\mathrm{Al}$ & 1,74 & 1,78 \\
$\mathrm{Ti}$ & 0,00 & 0,00 \\
$\mathrm{Fe}$ & 0,00 & 0,00 \\
$\mathrm{Mn}$ & 0,00 & 0,00 \\
$\mathrm{Zn}$ & 0,00 & 0,00 \\
$\mathrm{Mg}$ & 0,00 & 0,00 \\
$\mathrm{Ca}$ & 0,00 & 0,00 \\
$\mathrm{Na}$ & 0,00 & 0,00 \\
$\mathrm{~K}$ & 0,00 & 0,00 \\
$\mathrm{Rb}$ & 0,00 & 0,00 \\
$\mathrm{P}$ & 0,01 & 0,01 \\
$\mathrm{~F}$ & 0,94 & 0,97 \\
OH* & 1,06 & 1,03 \\
\hline${ }^{*}$ Calculado por estequiometria \\
\end{tabular}


Anexo III. Análisis de microsonda electrónica

\begin{tabular}{|c|c|c|c|c|c|c|}
\hline Asociación & 1 & 1 & 1 & 1 & 1 & 1 \\
\hline Muestra & 1793B & 1793B & 1793B & 1793B & 1793B & $1793 \mathrm{~B}$ \\
\hline Análisis & 2.4 & 2.5 & 2.8 & 2.10 & 2.11 & 2.12 \\
\hline$\overline{\mathrm{P}_{2} \mathrm{O}_{5}}$ & 35,94 & 36,78 & 36,93 & 37,43 & 38,53 & 38,70 \\
\hline $\mathrm{Al}_{2} \mathrm{O}_{3}$ & 0,14 & 0,09 & 0,20 & 0,56 & 0,06 & 0,85 \\
\hline $\mathrm{ZnO}$ & 1,60 & 1,21 & 1,77 & 1,45 & 1,35 & 1,56 \\
\hline $\mathrm{Fe}_{2} \mathrm{O}_{3}{ }^{*}$ & 40,21 & 41,25 & 41,23 & 41,24 & 43,25 & 42,21 \\
\hline $\mathrm{FeO}$ & 10,87 & 12,49 & 13,31 & 11,71 & 10,37 & 8,69 \\
\hline $\mathrm{MnO}$ & 3,11 & 2,92 & 1,28 & 1,81 & 1,51 & 2,24 \\
\hline MgO & 0,06 & 0,03 & 0,04 & 0,05 & 0,03 & 0,03 \\
\hline $\mathrm{CaO}$ & 0,30 & 0,12 & 0,11 & 0,17 & 0,18 & 0,25 \\
\hline $\mathrm{K}_{2} \mathrm{O}$ & 0,04 & 0,03 & 0,01 & 0,04 & 0,05 & 0,03 \\
\hline $\mathrm{Na}_{2} \mathrm{O}$ & 0,04 & 0,00 & 0,00 & 0,00 & 0,00 & 0,01 \\
\hline $\mathrm{F}$ & 0,34 & 0,35 & 0,39 & 0,32 & 0,35 & 0,33 \\
\hline Total & 92,51 & 95,13 & 95,10 & 94,65 & 95,54 & 94,76 \\
\hline \multicolumn{7}{|c|}{ Número de iones con base en $2 \mathrm{P}$} \\
\hline $\begin{array}{l}P \\
P\end{array}$ & 2,00 & 2,00 & 2,00 & 2,00 & 2,00 & 2,00 \\
\hline $\mathrm{Al}$ & 0,01 & 0,01 & 0,02 & 0,04 & 0,00 & 0,06 \\
\hline $\mathrm{Fe}^{3+*}$ & 1,99 & 1,99 & 1,98 & 1,96 & 2,00 & 1,94 \\
\hline ¿triv & 2,00 & 2,00 & 2,00 & 2,00 & 2,00 & 2,00 \\
\hline $\mathrm{Fe}^{2+}$ & 0,60 & 0,67 & 0,71 & 0,62 & 0,53 & 0,44 \\
\hline $\mathrm{Mn}$ & 0,17 & 0,16 & 0,07 & 0,10 & 0,08 & 0,12 \\
\hline $\mathrm{Mg}$ & 0,01 & 0,00 & 0,00 & 0,00 & 0,00 & 0,00 \\
\hline $\mathrm{Ca}$ & 0,02 & 0,01 & 0,01 & 0,01 & 0,01 & 0,02 \\
\hline $\mathrm{Na}$ & 0,00 & 0,00 & 0,00 & 0,00 & 0,00 & 0,00 \\
\hline K & 0,00 & 0,00 & 0,00 & 0,00 & 0,00 & 0,00 \\
\hline $\mathrm{Zn}$ & 0,08 & 0,06 & 0,08 & 0,07 & 0,06 & 0,07 \\
\hline$\sum$ div & 0,88 & 0,90 & 0,88 & 0,80 & 0,69 & 0,65 \\
\hline $\mathrm{F}$ & 0,07 & 0,07 & 0,08 & 0,06 & 0,07 & 0,06 \\
\hline
\end{tabular}

\begin{tabular}{|c|c|c|c|c|c|}
\hline \multicolumn{6}{|l|}{ Keckita } \\
\hline Asociación & 1 & 1 & 1 & 1 & 1 \\
\hline Muestra & 1793B & $1793 B$ & 1793B & $1793 B$ & $1793 \mathrm{~B}$ \\
\hline Análisis & 3.1 & 2.2 & 2.3 & 2.6 & 2.7 \\
\hline $\mathrm{P}_{2} \mathrm{O}_{5}$ & 36,75 & 37,33 & 35,93 & 37,42 & 37,84 \\
\hline $\mathrm{Al}_{2} \mathrm{O}_{3}$ & 0,31 & 0,10 & 0,08 & 1,42 & 0,99 \\
\hline $\mathrm{ZnO}$ & 1,58 & 1,22 & 1,62 & 0,00 & 1,82 \\
\hline $\mathrm{Fe}_{2} \mathrm{O}_{3}$ & 32,19 & 34,16 & 30,14 & 29,68 & 27,65 \\
\hline MnO & 11,83 & 10,99 & 13,92 & 9,16 & 13,17 \\
\hline MgO & 0,65 & 0,65 & 0,69 & 2,23 & 0,92 \\
\hline $\mathrm{CaO}$ & 3,18 & 3,34 & 3,70 & 5,86 & 4,69 \\
\hline $\mathrm{K}_{2} \mathrm{O}$ & 0,02 & 0,01 & 0,00 & 0,04 & 0,04 \\
\hline $\mathrm{Na}_{2} \mathrm{O}$ & 0,52 & 0,80 & 0,42 & 0,20 & 0,59 \\
\hline SrO & 0,00 & 0,00 & 0,00 & 0,00 & 0,12 \\
\hline $\mathrm{BaO}$ & 0,01 & 0,00 & 0,00 & 0,00 & 0,00 \\
\hline $\mathrm{F}$ & 0,46 & 0,51 & 0,31 & 0,37 & 0,47 \\
\hline Total & 87,31 & 88,90 & 86,69 & 86,22 & 88,11 \\
\hline \multicolumn{6}{|c|}{ Número de iones con base en $4 \mathrm{P}$} \\
\hline$P$ & 4,00 & 4,00 & 4,00 & 4,00 & 4,00 \\
\hline $\mathrm{Ca}$ & 0,44 & 0,45 & 0,52 & 0,79 & 0,63 \\
\hline $\mathrm{Sr}$ & 0,00 & 0,00 & 0,00 & 0,00 & 0,01 \\
\hline $\mathrm{Na}$ & 0,13 & 0,20 & 0,11 & 0,05 & 0,14 \\
\hline $\mathrm{Mn}^{2+}$ & 0,43 & 0,35 & 0,37 & 0,16 & 0,22 \\
\hline$\Sigma x$ & 1,00 & 1,00 & 1,00 & 1,00 & 1,00 \\
\hline $\mathrm{Mn}^{2+}$ & 0,86 & 0,83 & 1,00 & 0,82 & 1,00 \\
\hline $\mathrm{Fe}^{3+}$ & 0,14 & 0,17 & 0,00 & 0,18 & 0,00 \\
\hline$\Sigma A$ & 1,00 & 1,00 & 1,00 & 1,00 & 1,00 \\
\hline $\mathrm{Mn}^{2+}$ & 0,00 & 0 & 0,18 & 0 & 0,17 \\
\hline $\mathrm{Fe}^{3+}$ & 1,02 & 1,10 & 1,00 & 0,85 & 0,74 \\
\hline $\mathrm{Zn}$ & 0,15 & 0,11 & 0,16 & 0,00 & 0,17 \\
\hline Mg & 0,12 & 0,12 & 0,14 & 0,42 & 0,17 \\
\hline$\Sigma B$ & 1,29 & 1,33 & 1,47 & 1,27 & 1,25 \\
\hline $\mathrm{Fe}^{3+}$ & 1,95 & 1,98 & 1,99 & 1,79 & 1,85 \\
\hline Al & 0,05 & 0,02 & 0,01 & 0,21 & 0,15 \\
\hline$\Sigma C$ & 2,00 & 2,00 & 2,00 & 2,00 & 2,00 \\
\hline$F$ & 0,19 & 0,21 & 0,13 & 0,15 & 0,19 \\
\hline
\end{tabular}

\begin{tabular}{|c|c|c|c|c|c|c|}
\hline \multicolumn{7}{|l|}{ Mitridatita } \\
\hline Asociación & 1 & 1 & IV & $\mathrm{v}$ & $\mathrm{v}$ & $\mathbf{v}$ \\
\hline $\begin{array}{l}\text { Muestra } \\
\end{array}$ & 1793B & $825 \mathrm{~A}$ & $1772 A$ & $802 \mathrm{~A}$ & $802 \mathrm{~A}$ & $802 \mathrm{~A}$ \\
\hline Análisis & 2.1 & 1.5 & 2.1 & 3.3 & 3.5 & 5.4 \\
\hline $\mathrm{P}_{2} \mathrm{O}_{5}$ & 35,70 & 31,93 & 33,86 & 34,52 & 33,83 & 34,05 \\
\hline $\mathrm{Al}_{2} \mathrm{O}_{3}$ & 3,75 & 1,82 & 0,31 & 0,05 & 0,05 & 0,07 \\
\hline $\mathrm{Fe}_{2} \mathrm{O}_{3}{ }^{*}$ & 32,66 & 32,41 & 37,00 & 38,05 & 37,29 & 36,68 \\
\hline $\mathrm{Mn}_{2} \mathrm{O}_{3}$ & 1,61 & 0,66 & 0,61 & 0,71 & 0,68 & 1,51 \\
\hline $\mathrm{FeO}$ & 4,74 & 5,14 & 0,00 & 0,60 & 0,92 & 2,30 \\
\hline $\mathrm{MgO}$ & 0,00 & 0,04 & 0,00 & 0,00 & 0,05 & 0,01 \\
\hline $\mathrm{ZnO}$ & 0,88 & 0,12 & 1,30 & 0,06 & 0,11 & 0,11 \\
\hline $\mathrm{CaO}$ & 8,38 & 14,60 & 15,88 & 17,72 & 17,55 & 16,49 \\
\hline SrO & 0,00 & 0,00 & 0,00 & 0,00 & 0,13 & 0,18 \\
\hline $\mathrm{BaO}$ & 0,00 & 0,05 & 0,00 & 0,08 & 0,00 & 0,01 \\
\hline $\mathrm{K}_{2} \mathrm{O}$ & 0,14 & 0,02 & 0,01 & 0,04 & 0,03 & 0,05 \\
\hline $\mathrm{Na}_{2} \mathrm{O}$ & 0,30 & 0,01 & 0,09 & 0,00 & 0,01 & 0,07 \\
\hline $\mathrm{F}$ & 0,29 & 0,36 & 0,32 & 0,40 & 0,37 & 0,32 \\
\hline $\mathrm{Cl}$ & 0,02 & 0,03 & 0,03 & 0,00 & 0,00 & 0,00 \\
\hline Total & 88,34 & 87,02 & 89,27 & 92,06 & 90,88 & 91,97 \\
\hline \multicolumn{7}{|c|}{ Número de iones con base en $3 \mathrm{P}$} \\
\hline 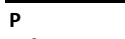 & 3,00 & 3,00 & 3,00 & 3,00 & 3,00 & 3,00 \\
\hline $\mathrm{Fe}^{3+*}$ & 2,44 & 2,71 & 2,91 & 2,99 & 3,02 & 3,07 \\
\hline $\mathrm{Mn}^{3+}$ & 0,12 & 0,06 & 0,05 & 0,06 & 0,05 & 0,12 \\
\hline Al & 0,44 & 0,24 & 0,04 & 0,01 & 0,01 & 0,01 \\
\hline ¿triv & 3,00 & 3,00 & 3,00 & 3,05 & 3,08 & 3,20 \\
\hline $\mathrm{Ca}$ & 0,89 & 1,74 & 1,78 & 1,95 & 1,97 & 1,84 \\
\hline Sr & 0,00 & 0,00 & 0,00 & 0,00 & 0,01 & 0,01 \\
\hline Ba & 0,00 & 0,00 & 0,00 & 0,00 & 0,00 & 0,00 \\
\hline Mg & 0,00 & 0,01 & 0,00 & 0,00 & 0,01 & 0,00 \\
\hline $\mathrm{Na}$ & 0,06 & 0,00 & 0,02 & 0,00 & 0,00 & 0,01 \\
\hline $\mathrm{Zn}$ & 0,06 & 0,01 & 0,10 & 0,00 & 0,01 & 0,01 \\
\hline $\mathrm{Fe}^{2+}$ & 0,39 & 0,48 & 0,00 & 0,00 & 0,00 & 0,00 \\
\hline ¿div & 1,41 & 2,23 & 1,90 & 1,96 & 2,00 & 1,87 \\
\hline $\mathrm{F}$ & 0,09 & 0,13 & 0,10 & 0,13 & 0,12 & 0,11 \\
\hline $\mathrm{Cl}$ & 0,00 & 0,00 & 0,01 & 0,00 & 0,00 & 0,00 \\
\hline
\end{tabular}


Anexo III. Análisis de microsonda electrónica

\begin{tabular}{|c|c|c|c|c|c|c|c|c|}
\hline \multicolumn{9}{|l|}{ rrmanita } \\
\hline Asociación & 1 & IV & IV & IV & IV & IV & IV & $x$ \\
\hline Muestra & $1793 \mathrm{~B}$ & 1772B & 1772B & 1772B & 1797 & 1797 & 1793B & 820 \\
\hline Análisis & 2.1 & 2.1 & 3.1 & 4.1 & 2.1 & 3.2 & 2.1 & 5.3 \\
\hline $\mathrm{P}_{2} \mathrm{O}_{5}$ & 37,16 & 37,52 & 37,70 & 37,48 & 37,68 & 37,80 & 37,16 & 37,50 \\
\hline $\mathrm{Al}_{2} \mathrm{O}_{3}$ & 24,60 & 24,54 & 24,64 & 24,87 & 25,54 & 25,69 & 24,60 & 25,55 \\
\hline $\mathrm{TiO}_{2}$ & 0,00 & 0,00 & 0,02 & 0,01 & 0,01 & 0,01 & 0,00 & 0,13 \\
\hline $\mathrm{MnO}$ & 1,49 & 3,11 & 2,19 & 1,28 & 2,32 & 1,94 & 1,49 & 2,37 \\
\hline $\mathrm{FeO}$ & 21,74 & 23,37 & 21,18 & 25,94 & 20,24 & 21,01 & 21,74 & 19,03 \\
\hline $\mathrm{CaO}$ & 0,22 & 0,16 & 0,13 & 0,08 & 0,04 & 0,06 & 0,22 & 0,40 \\
\hline $\mathrm{MgO}$ & 2,44 & 0,90 & 3,01 & 0,42 & 3,21 & 2,68 & 2,44 & 2,69 \\
\hline $\mathrm{ZnO}$ & 0,07 & 0,03 & 0,00 & 0,12 & 0,04 & 0,07 & 0,07 & 0,07 \\
\hline $\mathrm{K}_{2} \mathrm{O}$ & 0,01 & 0,00 & 0,00 & 0,00 & 0,01 & 0,00 & 0,01 & 0,00 \\
\hline $\mathrm{Na}_{2} \mathrm{O}$ & 0,00 & 0,02 & 0,02 & 0,00 & 0,02 & 0,02 & 0,00 & 0,00 \\
\hline Total & 87,71 & 89,66 & 88,89 & 90,20 & 89,11 & 89,27 & 87,71 & 87,73 \\
\hline \multicolumn{9}{|c|}{ Número de iones con base en $4 \mathrm{P}$} \\
\hline$P$ & 4,00 & 4,00 & 4,00 & 4,00 & 4,00 & 4,00 & 4,00 & 4,00 \\
\hline Al & 3,69 & 3,64 & 3,64 & 3,70 & 3,78 & 3,79 & 3,69 & 3,79 \\
\hline $\mathrm{Zn}$ & 0,01 & 0,00 & 0,00 & 0,01 & 0,00 & 0,01 & 0,01 & 0,01 \\
\hline $\mathrm{Ti}$ & 0,00 & 0,00 & 0,00 & 0,00 & 0,00 & 0,00 & 0,00 & 0,01 \\
\hline Etriv & 3,69 & 3,65 & 3,64 & 3,71 & 3,78 & 3,79 & 3,69 & 3,81 \\
\hline $\mathrm{Fe}^{2+}$ & 2,31 & 2,46 & 2,22 & 2,73 & 2,12 & 2,20 & 2,31 & 2,00 \\
\hline $\mathrm{Mn}^{2+}$ & 0,16 & 0,33 & 0,23 & 0,14 & 0,25 & 0,21 & 0,16 & 0,25 \\
\hline $\mathrm{Mg}$ & 0,46 & 0,17 & 0,56 & 0,08 & 0,60 & 0,50 & 0,46 & 0,51 \\
\hline $\mathrm{Ca}$ & 0,03 & 0,02 & 0,02 & 0,01 & 0,01 & 0,01 & 0,03 & 0,05 \\
\hline $\mathrm{Na}$ & 0,00 & 0,01 & 0,00 & 0,00 & 0,00 & 0,00 & 0,00 & 0,00 \\
\hline $\mathrm{k}$ & 0,00 & 0,00 & 0,00 & 0,00 & 0,00 & 0,00 & 0,00 & 0,00 \\
\hline$\sum$ div & 2,97 & 2,99 & 3,04 & 2,96 & 2,98 & 2,92 & 2,97 & 2,82 \\
\hline
\end{tabular}

\begin{tabular}{|c|c|c|c|c|c|c|c|c|c|c|c|c|c|}
\hline \multicolumn{14}{|c|}{ Eosforita-Childrenita } \\
\hline Asociación & 1 & 1 & II & II & II & IV & IV & IV & IV & IV & IV & IV & IV \\
\hline Muestra & $781 \mathrm{~B}$ & $781 \mathrm{~B}$ & 1055 & 1684 & 1684 & $1772 B$ & 1797 & $1721 \mathrm{~B}$ & 1786 & 1786 & 1786 & 1786 & 178 \\
\hline Análisis & 1.1 & 3.1 & 3.1 & 3.1 & 7.3 & 5.1 & 6.1 & 6.1 & 1.1 & 1.2 & 3.1.1 & 3.1 .2 & 4. \\
\hline $\mathrm{P}_{2} \mathrm{O}_{5}$ & 35,17 & 34,63 & 33,41 & 32,68 & 32,41 & 32,57 & 33,06 & 33,58 & 33,40 & 33,53 & 34,50 & 34,21 & 34,0 \\
\hline $\mathrm{Al}_{2} \mathrm{O}_{3}$ & 21,54 & 22,51 & 22,52 & 22,51 & 22,77 & 22,91 & 22,82 & 23,07 & 22,82 & 22,87 & 21,88 & 21,81 & 23,5 \\
\hline $\mathrm{TiO} 2$ & 0,02 & 0,01 & 0,03 & 0,00 & 0,00 & 0,00 & 0,01 & 0,02 & 0,00 & 0,02 & 0,00 & 0,00 & 0,01 \\
\hline MnO & 22,33 & 24,64 & 13,70 & 16,61 & 17,02 & 13,98 & 23,04 & 8,62 & 12,79 & 16,00 & 16,31 & 14,97 & 16,4 \\
\hline $\mathrm{FeO}$ & 8,55 & 6,32 & 17,15 & 14,53 & 13,73 & 16,74 & 7,47 & 21,00 & 17,58 & 14,31 & 13,30 & 13,27 & 13,9 \\
\hline $\mathrm{CaO}$ & 0,29 & 0,08 & 0,73 & 0,11 & 0,28 & 0,30 & 0,12 & 0,37 & 0,33 & 0,58 & 1,22 & 1,60 & $0,2 c$ \\
\hline MgO & 0,54 & 0,12 & 0,09 & 0,11 & 0,01 & 0,20 & 0,00 & 0,54 & 0,18 & 0,29 & 0,08 & 0,20 & $0,3=$ \\
\hline $\mathrm{ZnO}$ & 0,00 & 0,03 & 0,00 & 0,00 & 0,00 & 0,06 & 0,02 & 0,00 & 0,03 & 0,01 & 0,13 & 0,00 & $0,0 c$ \\
\hline $\mathrm{K}_{2} \mathrm{O}$ & 0,02 & 0,02 & 0,00 & 0,00 & 0,00 & 0,02 & 0,00 & 0,02 & 0,01 & 0,00 & 0,00 & 0,00 & 0,0 \\
\hline $\mathrm{Na}_{2} \mathrm{O}$ & 0,00 & 0,00 & 0,00 & 0,00 & 0,00 & 0,00 & 0,00 & 0,00 & 0,00 & 0,00 & 0,00 &, 00 & 0,00 \\
\hline Total & 88,47 & 88,37 & 87,63 & 86,56 & 86,22 & 86,76 & 86,54 & 87,22 & 87,13 & 87,61 & 87,42 & 86,06 & 88,53 \\
\hline \multicolumn{14}{|c|}{ Número de iones con base en $1 \mathrm{P}$} \\
\hline$P$ & 1,00 & 1,00 & 1,00 & 1,00 & 1,00 & 1,00 & 1,00 & 1,00 & 1,00 & 1,00 & 1,00 & 1,00 & $1, \mathrm{C}$ \\
\hline $\mathrm{Al}$ & 0,85 & 0,91 & 0,94 & 0,96 & 0,98 & 0,98 & 0,96 & 0,96 & 0,95 & 0,95 & 0,88 & 0,89 & $0, \underline{s}$ \\
\hline $\mathrm{Zn}$ & 0,00 & 0,00 & 0,00 & 0,00 & 0,00 & 0,00 & 0,00 & 0,00 & 0,00 & 0,00 & 0,00 & 0,00 & $0, \mathrm{c}$ \\
\hline $\mathrm{Ti}$ & 0,00 & 0,00 & 0,00 & 0,00 & 0,00 & 0,00 & 0,00 & 0,00 & 0,00 & 0,00 & 0,00 & 0,00 & 0,0 \\
\hline$\Sigma$ & 0,85 & 0,91 & 0,94 & 0,96 & 0,98 & 0,98 & 0,96 & 0,96 & 0,95 & 0,95 & 0,89 & 0,89 & \\
\hline $\mathrm{Fe}^{2+}$ & 0,24 & 0,18 & 0,51 & 0,44 & 0,42 & 0,51 & 0,22 & 0,62 & 0,52 & 0,42 & 0,38 & 0,38 & \\
\hline $\mathrm{Mn}^{2+}$ & 0,64 & 0,71 & 0,41 & 0,51 & 0,53 & 0,43 & 0,70 & 0,26 & 0,38 & 0,48 & 0,47 & 0,44 & 0,2 \\
\hline Mg & 0,03 & 0,01 & 0,00 & 0,01 & 0,00 & 0,01 & 0,00 & 0,03 & 0,01 & 0,02 & 0,00 & 0,01 & 0,0 \\
\hline $\mathrm{Ca}$ & 0,01 & 0,00 & 0,03 & 0,00 & 0,01 & 0,01 & 0,00 & 0,01 & 0,01 & 0,02 & 0,04 & 0,06 & 0 , \\
\hline $\mathrm{Na}$ & 0,00 & 0,00 & 0,00 & 0,00 & 0,00 & 0,00 & 0,00 & 0,00 & 0,00 & 0,00 & 0,00 & 0,00 & $0, c$ \\
\hline K & 0,00 & 0,00 & 0,00 & 0,00 & 0,00 & 0,00 & 0,00 & 0,00 & 0,00 & 0,00 & 0,00 & 0,00 & 0,0 \\
\hline$\Sigma$ & 0,91 & 0,90 & 0,95 & 0,96 & 0,96 & 0,96 & 0,93 & 0,92 & 0,93 & 0,94 & 0,90 & 0,89 & \\
\hline
\end{tabular}


Anexo III. Análisis de microsonda electrónica

\begin{tabular}{|c|c|c|c|c|c|c|c|c|c|c|c|c|c|c|c|c|c|c|c|c|c|}
\hline Asociación & IV & IV & IV & IV & IV & IV & IV & IV & IV & IV & IV & IV & IV & IV & IV & IV & IV & IV & IV & IV & $\mathrm{v}$ \\
\hline Muestra & 1786 & 1786 & 1786 & 1786 & 1786 & 1786 & 1786 & 1786 & 1786 & 1786 & 1786 & 1787 & 1787 & 1787 & 1787 & 1787 & 1787 & 1787 & $788 \mathrm{~A}$ & $788 \mathrm{~A}$ & 803 \\
\hline Análisis & 4.4 & 7.1 & 7.2 & 7.6 & 8.1 .1 & 8.1 .2 & 8.1 .2 & 8.1 .4 & 8.1 .5 & 8.1 .6 & 8.1 .7 & 3.1 & 3.2 & 3.3 & 4.1 & 4.2 & 5.1 & 5.2 & 2.1 & 3.1 & 1.1 \\
\hline$\overline{\mathrm{P}_{2} \mathrm{O}_{5}}$ & 33,59 & 33,53 & 34,91 & 35,36 & 32,93 & 33,59 & 33,73 & 32,32 & 33,58 & 34,50 & 33,65 & 33,93 & 33,85 & 33,61 & 33,00 & 33,13 & 33,72 & 33,34 & 33,68 & 34,16 & 35,66 \\
\hline $\mathrm{Al}_{2} \mathrm{O}_{3}$ & 22,74 & 22,59 & 23,69 & 22,67 & 22,56 & 23,01 & 22,46 & 23,14 & 23,63 & 23,10 & 23,49 & 22,85 & 23,21 & 23,24 & 22,66 & 22,89 & 22,22 & 23,24 & 22,39 & 22,91 & 22,44 \\
\hline TiO2 & 0,00 & 0,00 & 0,01 & 0,00 & 0,00 & 0,01 & 0,00 & 0,01 & 0,00 & 0,00 & 0,00 & 0,01 & 0,00 & 0,02 & 0,03 & 0,01 & 0,01 & 0,00 & 0,01 & 0,03 & 0,01 \\
\hline $\mathrm{MnO}$ & 9,28 & 18,74 & 15,86 & 11,60 & 12,11 & 11,70 & 14,60 & 15,22 & 12,37 & 13,52 & 12,67 & 8,75 & 12,74 & 8,09 & 11,59 & 8,55 & 8,81 & 17,97 & 19,68 & 19,12 & 25,83 \\
\hline $\mathrm{FeO}$ & 19,37 & 12,34 & 14,05 & 17,16 & 17,26 & 17,29 & 15,63 & 15,40 & 17,62 & 15,89 & 16,96 & 20,14 & 17,60 & 22,05 & 19,03 & 22,04 & 22,68 & 12,51 & 11,23 & 12,02 & 5,14 \\
\hline $\mathrm{CaO}$ & 0,53 & 0,77 & 1,32 & 1,97 & 2,28 & 1,29 & 0,10 & 0,41 & 0,95 & 0,75 & 1,16 & 0,70 & 0,24 & 1,25 & 0,20 & 0,42 & 0,16 & 1,14 & 0,23 & 0,11 & 0,35 \\
\hline $\mathrm{MgO}$ & 0,93 & 0,12 & 0,28 & 0,23 & 0,17 & 0,48 & 0,45 & 0,52 & 0,53 & 0,40 & 0,10 & 1,14 & 0,62 & 0,02 & 0,51 & 0,33 & 0,31 & 0,07 & 0,16 & 0,25 & 0,01 \\
\hline $\mathrm{ZnO}$ & 0,02 & 0,00 & 0,06 & 0,03 & 0,00 & 0,00 & 0,04 & 0,00 & 0,00 & 0,06 & 0,02 & 0,05 & 0,01 & 0,07 & 0,00 & 0,02 & 0,03 & 0,01 & 0,10 & 0,00 & 0,00 \\
\hline $\mathrm{K}_{2} \mathrm{O}$ & 0,00 & 0,00 & 0,01 & 0,00 & 0,02 & 0,02 & 0,00 & 0,01 & 0,00 & 0,05 & 0,01 & 0,00 & 0,00 & 0,03 & 0,01 & 0,30 & 0,00 & 0,00 & 0,00 & 0,02 & 0,00 \\
\hline $\mathrm{Na}_{2} \mathrm{O}$ & 0,00 & 0,00 & 0,00 & 0,00 & 0,00 & 0,00 & 0,00 & 0,00 & 0,00 & 0,00 & 0,00 & 0,00 & 0,00 & 0,02 & 0,00 & 0,00 & 0,00 & 0,00 & 0,00 & 0,00 & 0,03 \\
\hline Total & 86,46 & 88,08 & 90,19 & 89,02 & 87,33 & 87,39 & 87,00 & 87,03 & 88,69 & 88,28 & 88,06 & 87,57 & 88,26 & 88,39 & 87,02 & 87,68 & 87,95 & 88,28 & 87,47 & 88,62 & 89,47 \\
\hline \multicolumn{22}{|c|}{ Número de iones con base en $1 \mathrm{P}$} \\
\hline P & 1,00 & 1,00 & 1,00 & 1,00 & 1,00 & 1,00 & 1,00 & 1,00 & 1,00 & 1,00 & 1,00 & 1,00 & 1,00 & 1,00 & 1,00 & 1,00 & 1,00 & 1,00 & 1,00 & 1,00 & 1,00 \\
\hline Al & 0,94 & 0,94 & 0,94 & 0,89 & 0,95 & 0,95 & 0,93 & 1,00 & 0,98 & 0,93 & 0,97 & 0,94 & 0,95 & 0,96 & 0,96 & 0,96 & 0,92 & 0,97 & 0,93 & 0,93 & 0,88 \\
\hline $\mathrm{Zn}$ & 0,00 & 0,00 & 0,00 & 0,00 & 0,00 & 0,00 & 0,00 & 0,00 & 0,00 & 0,00 & 0,00 & 0,00 & 0,00 & 0,00 & 0,00 & 0,00 & 0,00 & 0,00 & 0,00 & 0,00 & 0,00 \\
\hline $\mathrm{Ti}$ & 0,00 & 0,00 & 0,00 & 0,00 & 0,00 & 0,00 & 0,00 & 0,00 & 0,00 & 0,00 & 0,00 & 0,00 & 0,00 & 0,00 & 0,00 & 0,00 & 0,00 & 0,00 & 0,00 & 0,00 & 0,00 \\
\hline$\Sigma$ & 0,94 & 0,94 & 0,95 & 0,89 & 0,95 & 0,95 & 0,93 & 1,00 & 0,98 & 0,93 & 0,97 & 0,94 & 0,95 & 0,97 & 0,96 & 0,96 & 0,92 & 0,97 & 0,93 & 0,93 & 0,88 \\
\hline $\mathrm{Fe}^{2+}$ & 0,57 & 0,36 & 0,40 & 0,48 & 0,52 & 0,51 & 0,46 & 0,47 & 0,52 & 0,45 & 0,50 & 0,59 & 0,51 & 0,65 & 0,57 & 0,66 & 0,66 & 0,37 & 0,33 & 0,35 & 0,14 \\
\hline $\mathrm{Mn}^{2+}$ & 0,28 & 0,56 & 0,45 & 0,33 & 0,37 & 0,35 & 0,43 & 0,47 & 0,37 & 0,39 & 0,38 & 0,26 & 0,38 & 0,24 & 0,35 & 0,26 & 0,26 & 0,54 & 0,58 & 0,56 & 0,72 \\
\hline $\mathrm{Mg}$ & 0,05 & 0,01 & 0,01 & 0,01 & 0,01 & 0,02 & 0,02 & 0,03 & 0,03 & 0,02 & 0,01 & 0,06 & 0,03 & 0,00 & 0,03 & 0,02 & 0,02 & 0,00 & 0,01 & 0,01 & 0,00 \\
\hline $\mathrm{Ca}$ & 0,02 & 0,03 & 0,05 & 0,07 & 0,09 & 0,05 & 0,00 & 0,02 & 0,04 & 0,03 & 0,04 & 0,03 & 0,01 & 0,05 & 0,01 & 0,02 & 0,01 & 0,04 & 0,01 & 0,00 & 0,01 \\
\hline $\mathrm{Na}$ & 0,00 & 0,00 & 0,00 & 0,00 & 0,00 & 0,00 & 0,00 & 0,00 & 0,00 & 0,00 & 0,00 & 0,00 & 0,00 & 0,00 & 0,00 & 0,00 & 0,00 & 0,00 & 0,00 & 0,00 & 0,00 \\
\hline K & 0,00 & 0,00 & 0,00 & 0,00 & 0,00 & 0,00 & 0,00 & 0,00 & 0,00 & 0,00 & 0,00 & 0,00 & 0,00 & 0,00 & 0,00 & 0,01 & 0,00 & 0,00 & 0,00 & 0,00 & 0,00 \\
\hline$\Sigma$ & 0,91 & 0,96 & 0,91 & 0,89 & 0,98 & 0,93 & 0,92 & 0,99 & 0,95 & 0,90 & 0,92 & 0,93 & 0,93 & 0,94 & 0,96 & 0,96 & 0,95 & 0,96 & 0,93 & 0,93 & 0,88 \\
\hline
\end{tabular}


Anexo III. Análisis de microsonda electrónica

\begin{tabular}{|c|c|c|c|c|c|c|c|c|c|c|c|c|c|c|c|c|c|c|c|c|c|c|c|}
\hline Asociación & 1 & 1 & $\mathrm{I}$ & 1 & II & II & II & II & 11 & II & II & II & II & II & II & IIII & IIII & IIII & IIII & IIII & IIII & IIII & III \\
\hline Muestra & $781 B$ & $783 B$ & $1793 \mathrm{~B}$ & 1793B & $1684 \mathrm{~B}$ & $1684 \mathrm{~B}$ & $1684 \mathrm{~B}$ & $1684 \mathrm{~B}$ & $1684 \mathrm{~B}$ & $1684 \mathrm{~B}$ & 1055 & 1055 & 1055 & 1055 & 1055 & $1776 \mathrm{~A}$ & 1776a & $1769 \mathrm{~A}$ & $1769 A$ & $1769 A$ & $1769 \mathrm{C}$ & $1769 \mathrm{C}$ & $1769 \mathrm{C}$ \\
\hline Análisis & 2.3 & 3.1 & 1.2 & 2.3 & 2.2 & 3.1 & 4.2 & 5.1 & 6.2 & 6.3 & 3.3 & 3.2 & 4.3 & 6.3 & 6.4 & 1.1 & 3.1 & 1.4 & 4.4 & 4.5 & 1.3 & 2.1 & 3.5 \\
\hline$\overline{\mathrm{P}_{2} \mathrm{O}_{5}}$ & 40,63 & 41,34 & 40,91 & 40,92 & 42,63 & 41,06 & 41,02 & 41,24 & 43,11 & 40,49 & 42,03 & 41,09 & 40,84 & 42,86 & 41,68 & 41,00 & 41,15 & 41,44 & 40,47 & 40,53 & 39,12 & 41,40 & 42,17 \\
\hline $\mathrm{As}_{2} \mathrm{O}_{3}$ & 0,07 & 0,00 & 0,16 & 0,44 & - & - & - & - & - & - & - & - & - & - & - & 0,01 & 0,00 & 0,00 & 0,05 & 0,24 & 0,01 & 0,00 & 0,02 \\
\hline $\mathrm{SO}_{3}$ & & & - & & - & - & - & - & - & - & - & - & - & - & - & - & & - & - & - & - & - & \\
\hline SrO & 0,04 & 0,06 & 0,05 & 0,17 & 0,40 & 0,09 & 0,00 & 0,84 & 0,24 & 0,07 & 0,00 & 0,24 & 0,06 & 0,00 & 0,00 & 0,03 & 0,01 & 0,56 & 0,04 & 0,06 & 0,08 & 0,00 & 0,19 \\
\hline $\mathrm{BaO}$ & 0,09 & 0,01 & 0,00 & 0,02 & 0,00 & 0,00 & 0,00 & 0,00 & 0,01 & 0,00 & 0,00 & 0,10 & 0,01 & 0,03 & 0,07 & 0,05 & 0,00 & 0,00 & 0,00 & 0,00 & 0,00 & 0,00 & 0,03 \\
\hline $\mathrm{FeO}$ & 0,57 & 0,48 & 0,74 & 1,71 & 1,90 & 0,35 & 0,61 & 1,23 & 1,33 & 0,55 & 0,94 & 0,19 & 0,72 & 0,58 & 0,55 & 0,96 & 0,77 & 0,21 & 1,04 & 2,64 & 5,19 & 1,20 & 0,52 \\
\hline $\mathrm{MnO}$ & 0,72 & 3,97 & 1,61 & 0,51 & 5,57 & 5,12 & 5,08 & 3,88 & 5,54 & 2,81 & 2,96 & 1,42 & 2,76 & 1,97 & 2,16 & 4,97 & 5,26 & 4,76 & 0,02 & 0,03 & 2,04 & 5,88 & 3,02 \\
\hline $\mathrm{MgO}$ & 0,01 & 0,00 & 0,03 & 0,00 & 0,00 & 0,00 & 0,00 & 0,03 & 0,00 & 0,01 & 0,00 & 0,00 & 0,01 & 0,01 & 0,01 & 0,02 & 0,02 & 0,00 & 0,00 & 0,00 & 0,08 & 0,01 & 0,00 \\
\hline $\mathrm{CaO}$ & 55,37 & 51,89 & 52,82 & 51,88 & 48,22 & 51,04 & 51,44 & 50,46 & 47,36 & 51,22 & 53,05 & 55,73 & 53,89 & 52,00 & 51,61 & 49,61 & 48,98 & 50,43 & 51,72 & 48,35 & 42,04 & 49,17 & 51,72 \\
\hline $\mathrm{Na}_{2} \mathrm{O}$ & 0,67 & 0,05 & 0,01 & 0,09 & 0,22 & 0,04 & 0,05 & 0,26 & 0,09 & 0,03 & 0,05 & 0,07 & 0,03 & 0,05 & 0,06 & 0,00 & 0,01 & 0,00 & 0,20 & 0,26 & 0,14 & 0,00 & 0,00 \\
\hline $\mathrm{K}_{2} \mathrm{O}$ & 0,00 & 0,00 & 0,01 & 0,03 & 0,00 & 0,01 & 0,00 & 0,01 & 0,04 & 0,01 & 0,01 & 0,02 & 0,00 & 0,00 & 0,01 & 0,00 & 0,00 & 0,01 & 0,00 & 0,02 & 0,03 & 0,00 & 0,00 \\
\hline $\mathrm{Al}_{2} \mathrm{O}_{3}$ & 0,06 & 0,02 & 0,69 & 0,91 & 0,04 & 0,00 & 0,02 & 0,03 & 0,20 & 1,51 & 0,00 & 0,00 & 0,00 & 0,00 & 0,00 & 0,01 & 0,01 & 0,01 & 0,98 & 2,80 & 2,19 & 0,02 & 0,00 \\
\hline & 2,98 & 3,60 & 0,81 & 2,59 & 0,61 & 3,36 & 3,07 & 2,63 & 0,69 & 1,13 & 3,31 & 2,66 & 3,82 & 3,34 & 3,89 & 3,60 & 3,79 & 3,25 & 4,00 & 4,39 & 3,48 & 2,94 & 2,82 \\
\hline $\mathrm{Cl}$ & 0,03 & 0,00 & 0,57 & 0,17 & 1,41 & 0,00 & 0,00 & 0,09 & 1,92 & 1,00 & 0,00 & 0,01 & 0,00 & 0,00 & 0,00 & 0,02 & 0,02 & 0,00 & 0,08 & 0,07 & 0,14 & 0,02 & 0,01 \\
\hline Total & 99,99 & 99,89 & 97,93 & 98,30 & 100,42 & 99,67 & 100,00 & 99,58 & 99,82 & 98,12 & 100,97 & 100,40 & 100,54 & 99,43 & 98,42 & 98,77 & 98,44 & 99,30 & 96,90 & 97,53 & 93,03 & 99,40 & 99,31 \\
\hline \multicolumn{24}{|c|}{ Número de iones con base en $6(P+A s+S)$} \\
\hline$P$ & 3,00 & 3,00 & 2,99 & 2,98 & 3,00 & 3,00 & 3,00 & 3,00 & 3,00 & 3,00 & 3,00 & 3,00 & 3,00 & 3,00 & 3,00 & 3,00 & 3,00 & 3,00 & 3,00 & 2,99 & 3,00 & 3,00 & 3,00 \\
\hline As & 0,00 & 0,00 & 0,01 & 0,02 & 0,00 & 0,00 & 0,00 & 0,00 & 0,00 & 0,00 & 0,00 & 0,00 & 0,00 & 0,00 & 0,00 & 0,00 & 00 & 0,00 &, 00 & 0,01 &, 00 & 0,00 & 0,00 \\
\hline & 0,00 & 0,00 & 0,00 & 0,00 & 0,00 & 0,00 & 0,00 & 0,00 & 0,00 & 0,00 & 0,00 & 0,00 & 0,00 & 0,00 & 0,00 & 0,00 & 0,00 & 0,00 & 0,00 & 0,00 & 0,00 & 0,00 & 0,00 \\
\hline Ean. & 3,00 & 3,00 & 3,00 & 3,00 & 3,00 & 3,00 & 3,00 & 3,00 & 3,00 & 3,00 & 3,00 & 3,00 & 3,00 & 3,00 & 3,00 & 3,00 & 3,00 & 3,00 & 3,00 & 3,00 & 3,00 & 3,00 & 3,00 \\
\hline $\mathrm{Sr}$ & 0,00 & 0,00 & 0,00 & 0,01 & 0,02 & 0,00 & 0,00 & 0,04 & 0,01 & 0,00 & 0,00 & 0,01 & 0,00 & 0,00 & 0,00 & 0,00 & 0,00 & 0,03 & 0,00 & 0,00 & 0,00 & 0,00 & 0,01 \\
\hline Ba & 0,00 & 0,00 & 0,00 & 0,00 & 0,00 & 0,00 & 0,00 & 0,00 & 0,00 & 0,00 & 0,00 & 0,00 & 0,00 & 0,00 & 0,00 & 0,00 & 0,00 & 0,00 & 0,00 & 0,00 & 0,00 & 0,00 & 0,00 \\
\hline $\mathrm{Fe}^{2+}$ & 0,04 & 0,03 & 0,05 & 0,12 & 0,13 & 0,03 & 0,04 & 0,09 & 0,09 & 0,04 & 0,07 & 0,01 & 0,05 & 0,04 & 0,04 & 0,07 & 0,06 & 0,02 & 0,08 & 0,19 & 0,39 & 0,09 & 0,04 \\
\hline $\mathrm{Mn}^{2+}$ & 0,05 & 0,29 & 0,12 & 0,04 & 0,39 & 0,37 & 0,37 & 0,28 & 0,39 & 0,21 & 0,21 & 0,10 & 0,20 & 0,14 & 0,16 & 0,36 & 0,38 & 0,35 & 0,00 & 0,00 & 0,16 & 0,43 & 0,21 \\
\hline $\mathrm{Mg}$ & 0,00 & 0,00 & 0,00 & 0,00 & 0,00 & 0,00 & 0,00 & 0,00 & 0,00 & 0,00 & 0,00 & 0,00 & 0,00 & 0,00 & 0,00 & 0,00 & 0,00 & 0,00 & 0,00 & 0,00 & 0,01 & 0,00 & 0,00 \\
\hline $\mathrm{Ca}$ & 5,17 & 4,77 & 4,89 & 4,78 & 4,29 & 4,72 & & 4,65 & 4,17 & 4,80 & 4,79 & 5,15 & & 4,61 & 4,70 & 4,59 & & 4,62 & 4,85 & 4,53 & 4,08 & 4,51 & 4,66 \\
\hline $\mathrm{Na}$ & 0,11 & 0,01 & 0,00 & 0,02 & 0,03 & 0,01 & 0,01 & 0,04 & 0,01 & 0,01 & 0,01 & 0,01 & 0,01 & 0,01 & 0,01 & 0,00 & 0,00 & 0,00 & 0,03 & 0,04 & 0,02 & 0,00 & 0,00 \\
\hline K & 0,00 & 0,00 & 0,00 & 0,00 & 0,00 & 0,00 & 0,00 & 0,00 & 0,00 & 0,00 & 0,00 & 0,00 & 0,00 & 0,00 & 0,00 & 0,00 & 0,00 & 0,00 & 0,00 & 0,00 & 0,00 & 0,00 & 0,00 \\
\hline $\mathrm{Al}$ & 0,01 & 0,00 & 0,07 & 0,09 & 0,00 & 0,00 & 0,00 & 0,00 & 0,02 & 0,16 & 0,00 & 0,00 & 0,00 & 0,00 & 0,00 & 0,00 & 0,00 & 0,00 & 0,10 & 0,29 & 0,23 & 0,00 & 0,00 \\
\hline$\sum$ cat. & 5,39 & 5,10 & 5,14 & 5,06 & 4,88 & 5,13 & 5,19 & 5,11 & 4,70 & 5,22 & 5,08 & 5,30 & 5,28 & 4,79 & 4,91 & 5,04 & 4,97 & 5,01 & 5,07 & 5,06 & 4,91 & 5,02 & 4,92 \\
\hline 2 & 0,82 & 0,98 & 0,22 & 0,71 & 0,16 & 0,92 & 0,84 & 0,72 & 0,18 & 0,31 & 0,88 & 0,73 & 1,05 & 0,87 & 1,04 & 0,98 & 1,03 & 0,88 & 1,11 & 1,21 & 1,00 & 0,80 & 0,75 \\
\hline $\mathrm{Cl}$ & 0,00 & 0,00 & 0,08 & 0,02 & 0,20 & 0,00 & 0,00 & 0,01 & 0,27 & 0,15 & 0,00 & 0,00 & 0,00 & 0,00 & 0,00 & 0,00 & 0,00 & 0,00 & 0,01 & 0,01 & 0,02 & 0,00 & 0,00 \\
\hline $\mathrm{OH}^{*}$ & 0,17 & 0,02 & 0,69 & 0,27 & 0,64 & 0,08 & 0,16 & 0,27 & 0,55 & 0,54 & 0,12 & 0,27 & 0,00 & 0,13 & 0,00 & 0,01 & 0,00 & 0,12 & 0,00 & 0,00 & 0,00 & 0,20 & 0,25 \\
\hline
\end{tabular}

"Calculdopor estequon 
Anexo III. Análisis de microsonda electrónica

\begin{tabular}{|c|c|c|c|c|c|c|c|c|c|c|c|c|c|c|c|c|c|c|c|c|c|c|c|}
\hline Asociación & IV & IV & IV & IV & IV & IV & IV & IV & IV & IV & IV & IV & IV & IV & IV & IV & $\mathrm{v}$ & $\mathrm{v}$ & $\mathrm{v}$ & $\mathrm{v}$ & $\mathrm{v}$ & $\mathrm{v}$ & $\mathrm{v}$ \\
\hline Muestra & $1772 A$ & $1772 A$ & $788 \mathrm{~A}$ & $788 \mathrm{~A}$ & $788 \mathrm{~A}$ & $788 \mathrm{~A}$ & $794 B$ & $794 \mathrm{~B}$ & 1721B & $1772 B$ & 1786 & 1786 & 1786 & 1786 & 1797 & 1797 & 803 & 803 & 803 & 803 & 803 & 803 & 803 \\
\hline Análisis & 7.4 & 9.10 & 5.1 & 5.2 & 5.3 & 5.4 & 2.1 & 3.1 & 3.1 & 1.1 & 2.2 & 4.2 & 7.7 & 7.8 & 3.1 & 6.2 & 2.2 & 3.3.1 & 3.3.2 & 3.3 .3 & 3.3.4 & 4.2 & 5.1 \\
\hline $\mathrm{P}_{2} \mathrm{O}_{5}$ & 40,69 & $\begin{array}{ll}40,94 \\
\end{array}$ & 42,00 & 41,66 & 41,31 & 40,64 & 42,18 & 41,88 & 40,42 & 40,57 & 45,46 & 45,73 & 44,59 & 43,97 & 41,78 & 41,39 & 42,90 & 43,50 & 43,05 & 41,54 & 42,60 & 42,69 & 41,23 \\
\hline $\mathrm{As}_{2} \mathrm{O}_{3}$ & 0,00 & 0,00 & 0,00 & 0,12 & 0,04 & 0,07 & 0,04 & 0,04 & 0,00 & 0,02 & 0,00 & 0,00 & 0,00 & 0,00 & 0,00 & 0,07 & 0,00 & 0,00 & 0,00 & 0,00 & 0,04 & 0,00 & 0,02 \\
\hline $\mathrm{SO}_{3}$ & 0,04 & 0,06 & & - & - & - & & & & & & - & & - & & & & & & & - & & \\
\hline SrO & 0,30 & 0,15 & 0,20 & 0,21 & 0,00 & 0,13 & 0,03 & 0,06 & 0,00 & 0,06 & 0,18 & 0,14 & 0,18 & 0,26 & 0,00 & 0,07 & 1,32 & 0,29 & 0,20 & 0,95 & 1,28 & 1,18 & 0,93 \\
\hline $\mathrm{BaO}$ & 0,18 & 0,25 & 0,08 & 0,05 & 0,01 & 0,03 & 0,02 & 0,14 & 0,00 & 0,00 & 0,00 & 0,00 & 0,01 & 0,12 & 0,00 & 0,02 & 0,01 & 0,00 & 0,00 & 0,03 & 0,04 & 0,04 & 0,00 \\
\hline $\mathrm{FeO}$ & 6,21 & 5,93 & 1,23 & 1,28 & 1,39 & 1,83 & 0,46 & 0,50 & 0,55 & 0,49 & 3,32 & 2,73 & 3,66 & 4,31 & 0,58 & 0,39 & 0,03 & 0,16 & 0,10 & 0,03 & 0,13 & 0,00 & 1,11 \\
\hline MnO & 2,46 & 2,61 & 4,19 & 4,17 & 4,50 & 4,08 & 2,32 & 1,20 & 4,13 & 3,82 & 0,39 & 0,54 & 0,59 & 0,59 & 2,49 & 1,20 & 4,70 & 6,34 & 6,44 & 5,58 & 5,47 & 5,49 & 7,60 \\
\hline $\mathrm{MgO}$ & 0,07 & 0,03 & 0,15 & 0,08 & 0,08 & 0,08 & 0,01 & 0,02 & 0,00 & 0,00 & 1,70 & 2,17 & 1,74 & 1,83 & 0,02 & 0,00 & 0,00 & 0,00 & 0,01 & 0,00 & 0,00 & 0,00 & 0,00 \\
\hline $\mathrm{CaO}$ & 41,31 & 41,67 & 51,28 & 50,30 & 50,01 & 49,11 & 51,85 & 53,12 & 52,74 & 51,48 & 46,26 & 46,71 & 46,91 & 46,96 & 52,22 & 53,39 & 50,45 & 49,55 & 49,80 & 50,17 & 50,42 & 51,03 & 47,21 \\
\hline $\mathrm{Na}_{2} \mathrm{O}$ & 0,47 & 0,43 & 0,34 & 0,60 & 0,59 & 0,46 & 0,00 & 0,02 & 0,00 & 0,00 & 0,63 & 0,72 & 0,63 & 0,66 & 0,00 & 0,04 & 0,00 & 0,00 & 0,00 & 0,00 & 0,00 & 0,00 & 0,06 \\
\hline $\mathrm{K}_{2} \mathrm{O}$ & 0,02 & 0,01 & 00 & 0,00 & 0,01 & 0,01 & 0,00 & 0,01 & 0,01 & 0,00 & 0,00 & 0,00 & 0,01 & 0,00 & 0,00 & 0,00 & 0,00 & 0,00 & 0,01 & 0,00 & 0,02 & 0,00 & 0,00 \\
\hline $\mathrm{Al}_{2} \mathrm{O}_{3}$ & 0,84 & 0,68 & 0,02 & 0,55 & 0,39 & 0,56 & 0,01 & 0,01 & 0,01 & 0,02 & 0,21 & 0,08 & 0,43 & 2,86 & 0,00 & 0,81 & 0,00 & 0,03 & 0,00 & 0,00 & 0,01 & 0,00 & 0,02 \\
\hline & 0,71 & 0,68 & 2,54 & 2,21 & 2,49 & 2,32 & 3,51 & 3,66 & 3,92 & 3,82 & 0,78 & 1,04 & 0,81 & 0,84 & 3,33 & 0,92 & 1,11 & 0,87 & 1,10 & 0,96 & 0,93 & 1,08 & 0,89 \\
\hline Cl & 3,17 & 3,40 & 0,02 & 0,02 & 0,05 & 0,03 & 0,02 & 0,01 & 0,00 & 0,00 & 0,00 & 0,00 & 0,01 & 0,00 & 0,00 & 0,50 & 0,00 & 0,01 & 0,00 & 0,01 & 0,01 & 0,01 & 0,01 \\
\hline Total & 95,46 & 95,78 & 100,98 & 100,31 & 99,81 & 98,37 & 98,97 & 99,13 & 100,12 & 98,67 & 98,62 & 99,42 & 99,21 & 102,06 & 99,01 & 98,32 & 100,04 & 100,38 & 100,25 & 98,87 & 100,57 & 101,06 & 98,72 \\
\hline \multicolumn{24}{|c|}{ Número de iones con base en $6(\mathrm{P}+\mathrm{As}+\mathrm{S})$} \\
\hline$P$ & 2,99 & 2,99 & 3,00 & 2,99 & 3,00 & 3,00 & 3,00 & 3,00 & 3,00 & 3,00 & 3,00 & 3,00 & 3,00 & 3,00 & 3,00 & 3,00 & 3,00 & 3,00 & 3,00 & 3,00 & 3,00 & 3,00 & 3,00 \\
\hline As & 0,00 & 0,00 & 0,00 & 0,01 & 0,00 & 0,00 & 0,00 & 0,00 & 0,00 & 0,00 & 0,00 & 0,00 & 0,00 & 0,00 & 0,00 & 0,00 & 0,00 & 0,00 & 0,00 & 0,00 & 0,00 & 0,00 & 0,00 \\
\hline & 0,01 & 0,01 & 0,00 & 0,00 & 0,00 & 0,00 & 0,00 & 0,00 & 0,00 & 0,00 & 0,00 & 0,00 & 0,00 & 0,00 & 0,00 & 0,00 & 0,00 & 0,00 & 0,00 & 0,00 & 0,00 & 0,00 & 0,00 \\
\hline Ean. & 3,00 & 3,00 & 3,00 & 3,00 & 3,00 & 3,00 & 3,00 & 3,00 & 3,00 & 3,00 & 3,00 & 3,00 & 3,00 & 3,00 & 3,00 & 3,00 & 3,00 & 3,00 & 3,00 & 3,00 & 3,00 & 3,00 & 3,00 \\
\hline $\mathrm{Sr}$ & 0,02 & 0,01 & 0,01 & 0,01 & 0,00 & 0,01 & 0,00 & 0,00 & 0,00 & 0,00 & 0,01 & 0,01 & 0,01 & 0,01 & 0,00 & 0,00 & 0,06 & 0,01 & 0,01 & 0,05 & 0,06 & 0,06 & 0,05 \\
\hline Ва & 0,01 & 0,01 & 0,00 & 0,0 & 0,00 & 0,00 & 0,00 & 0,00 & 0,00 & 0,00 & 0,00 & 0,00 & 0,00 & 0,00 & 0,00 & 0,00 & 0,00 & 0,00 & 0,00 & 0,00 & 0,00 & 0,00 & 0,00 \\
\hline $\mathrm{Fe}^{2+}$ & 0,45 & 0,43 & 0,09 & 0,09 & 0,10 & 0,13 & 0,03 & 0,04 & 0,04 & 0,04 & 0,22 & 0,18 & 0,24 & 0,29 & 0,04 & 0,03 & 0,00 & 0,01 & 0,01 & 0,00 & 0,01 & 0,00 & 0,08 \\
\hline $\mathrm{Mn}^{2+}$ & 0,18 & 0,19 & 0,30 & 0,30 & 0,33 & 0,30 & 0,16 & 0,09 & 0,31 & 0,28 & 0,03 & 0,04 & 0,04 & 0,04 & 0,18 & 0,09 & 0,33 & 0,44 & 0,45 & 0,40 & 0,39 & 0,39 & 0,55 \\
\hline Mg & 0,01 & 0,00 & 0,02 & 0,01 & 0,01 & 0,01 & 0,00 & 0,00 & 0,00 & 0,00 & 0,20 & 0,25 & 0,21 & 0,22 & 0,00 & 0,00 & 0,00 & 0,00 & 0,00 & 0,00 & 0,00 & 0,00 & 0,00 \\
\hline $\mathrm{Ca}$ & 3,85 & 3,8 & 4,63 & & & 4,59 & & 4,81 & & & & 3,88 & 3,99 & 4,05 & & & & 4,32 & & 4,59 & 4,49 & 4,54 & 4,35 \\
\hline $\mathrm{Na}$ & 0,08 & 0,07 & 0,06 & 0,10 & 0 , & 0,08 & 0,00 & 0,00 & 0,00 & 0,00 & 0 & 0,11 & 0,10 & 0,10 & 0,00 & 0,01 & 0,00 & 0,00 & 0,00 & 0,00 & 0,00 & 0,00 & 0,01 \\
\hline K & 0,00 & 0,00 & 0,00 & 0,00 & 0,00 & 0,00 & 0,00 & 0,00 & 0,00 & 0,00 & 0,00 & 0,00 & 0,00 & 0,00 & 0,00 & 0,00 & 0,00 & 0,00 & 0,00 & 0,00 & 0,00 & 0,00 & 0,00 \\
\hline $\mathrm{Al}$ & 0,09 & 0,07 & 0,00 & 0,06 & & 0,06 & & & & 0 , & & 0,01 & 0 & 0,27 & & 0,08 & 0,0 & 0,00 & 0,00 & 0,00 & 0,00 & 0,00 & 0,00 \\
\hline Ecat. & 4,69 & 4, & & 5,1 & & & & 4,95 & 5,30 & & & 4,46 & 4, & 5,00 & 4,97 & 5,11 & 4,86 & 4,79 & 4,86 & 5,04 & 4,95 & 4,98 & 5,04 \\
\hline & 0,20 & 0,19 & 0,68 & 0,59 & 0,68 & 0,64 & 0,93 & 0,98 & 1,09 & 1,06 & 0,19 & 0,26 & 0,20 & 0,21 & 0,89 & 0,25 & 0,29 & 0,22 & 0,29 & 0,26 & 0,24 & 0,28 & 0,24 \\
\hline & 0,47 & 0,50 & 0,00 & 0,00 & & 0,00 & & 0,00 & & 0,00 & 0 & 0,00 & 0 & 0,00 & 0,00 & 0,07 & 0,00 & 0,00 & 0,00 & 0,00 & 0,00 & 0,00 & 0,00 \\
\hline $\mathrm{OH}^{*}$ & 0,34 & 0,32 & 0,32 & 0,40 & 0,32 & 0,36 & 0,07 & 0,02 & 0,00 & 0,00 & 0,81 & 0,74 & 0,80 & 0,79 & 0,11 & 0,68 & 0,71 & 0,78 & 0,71 & 0,74 & 0,75 & 0,72 & 0,76 \\
\hline
\end{tabular}


Anexo III. Análisis de microsonda electrónica

\begin{tabular}{|c|c|c|c|c|c|c|c|c|c|c|c|c|c|c|c|c|c|c|c|c|c|c|c|}
\hline Asociación & $\mathrm{v}$ & $\mathrm{v}$ & $\mathrm{v}$ & $\mathrm{v}$ & v & $\mathrm{v}$ & v & $\mathrm{v}$ & $\mathrm{VI}$ & VII & VII & VII & VII & VII & VII & VII & VII & VII & VII & VIII & VIII & VIIII & VIIII \\
\hline Muestra & 803 & 803 & 803 & $802 \mathrm{~A}$ & $802 a$ & $802 a$ & $802 a$ & 802a & $2298 \mathrm{a}$ & 843 & $835 \mathrm{~A}$ & $835 \mathrm{~A}$ & $835 \mathrm{~A}$ & $835 B$ & $835 B$ & $835 B$ & $835 B$ & $835 B$ & $835 B$ & 1693 & 1693 & 833 & 833 \\
\hline Análisis & 5.3 & 5.4 & 5.5 & 1.2 & 1.4 & 2.2 & 3.4 & 4.1 & 1.1 & 3.4 & 2.2 & 2.3 & 3.1 & 2.1 & 4.1 & 4.3 & 5.4 & 5.7 & 5.8 & 2.5 & 2.6 & 1.1 & 1.2 \\
\hline $\mathrm{P}_{2} \mathrm{O}_{5}$ & 42,10 & 40,72 & 42,46 & 39,28 & 42,24 & 32,25 & 39,80 & 42,06 & 42,25 & 43,29 & 41,25 & 41,31 & 41,17 & 41,36 & 40,75 & 41,96 & 41,84 & 41,78 & 41,82 & 42,40 & 40,38 & 40,86 & 41,11 \\
\hline $\mathrm{As}_{2} \mathrm{O}_{3}$ & 0,00 & 0,00 & 0,04 & 0,00 & 0,04 & 0,02 & 0,00 & 0,04 & 0,08 & 0,00 & 0,30 & 0,02 & 0,04 & 0,00 & 0,02 & 0,04 & 0,00 & 0,00 & 0,06 & 0,00 & 0,12 & 0,00 & 0,00 \\
\hline $\mathrm{SO}_{3}$ & & & & & - & & & & & 0,00 & 0,41 & 0,10 & 0,20 & 0,06 & 1,32 & 0,00 & 0,12 & 0,04 & 0,10 & 0,05 & 0,33 & 0,04 & 0,04 \\
\hline SrO & 0,30 & 0,23 & 0,80 & 0,19 & 0,07 & 0,27 & 0,17 & 0,04 & 0,29 & 0,08 & 0,00 & 0,00 & 0,65 & 0,34 & 0,07 & 0,00 & 0,62 & 0,40 & 0,41 & 3,10 & 0,40 & 0,28 & 0,22 \\
\hline $\mathrm{BaO}$ & 0,00 & 0,00 & 0,04 & 0,00 & 0,00 & 0,05 & 0,00 & 0,00 & 0,07 & 0,11 & 0,00 & 0,00 & 0,00 & 0,16 & 0,09 & 0,00 & 0,09 & 0,02 & 0,00 & 0,27 & 0,00 & 0,09 & 0,00 \\
\hline $\mathrm{FeO}$ & 0,40 & 3,00 & 1,01 & 3,41 & 3,31 & 2,13 & 2,98 & 0,22 & 0,56 & 0,19 & 0,57 & 0,04 & 0,01 & 0,07 & 0,02 & 0,03 & 0,08 & 0,01 & 0,00 & 0,15 & 0,59 & 0,03 & 0,03 \\
\hline MnO & 3,85 & 0,86 & 6,79 & 1,72 & 1,67 & 2,63 & 1,20 & 3,82 & 2,16 & 5,26 & 0,85 & 0,90 & 3,03 & 2,18 & 2,07 & 1,24 & 3,88 & 3,19 & 3,51 & 5,36 & 1,63 & 1,56 & 1,91 \\
\hline MgO & 0,00 & 0,00 & 0,00 & 0,00 & 0,00 & 0,40 & 0,02 & 0,02 & 0,02 & 0,00 & 0,00 & 0,00 & 0,00 & 0,00 & 0,02 & 0,00 & 0,00 & 0,00 & 0,01 & 0,01 & 0,01 & 0,00 & 0,00 \\
\hline $\mathrm{CaO}$ & 51,50 & 51,97 & 47,55 & 50,96 & 49,25 & 43,71 & 50,52 & 52,25 & 51,79 & 47,81 & 53,16 & 53,57 & 51,31 & 51,71 & 50,95 & 52,29 & 49,55 & 50,69 & 50,36 & 45,82 & 51,78 & 52,87 & 53,78 \\
\hline $\mathrm{Na}_{2} \mathrm{O}$ & 0,08 & 0,06 & 0,06 & 0,03 & 0,08 & 0,34 & 0,05 & 0,15 & 0,00 & 0,00 & 0,14 & 0,01 & 0,05 & 0,00 & 0,55 & 0,00 & 0,05 & 0,00 & 0,07 & 0,00 & 0,11 & 0,00 & 0,00 \\
\hline $\mathrm{K}_{2} \mathrm{O}$ & 0,00 & 0,02 & 0,02 & 0,00 & 0,02 & 0,01 & 0,03 & 0,01 & 0,00 & 0,00 & 0,00 & 0,00 & 0,00 & 0,00 & 0,00 & 0,00 & 0,00 & 0,00 & 0,01 & 0,01 & 0,01 & 0,02 & 0,00 \\
\hline $\mathrm{Al}_{2} \mathrm{O}_{3}$ & 0,06 & 0,10 & 0,22 & 0,04 & 0,66 & 3,93 & 1,33 & 0,00 & 0,00 & 0,00 & 0,00 & 0,00 & 0,00 & 0,04 & 0,01 & 0,02 & 0,00 & 0,02 & 0,00 & 0,02 & 0,14 & 0,00 & 0,00 \\
\hline & 1,26 & 3,43 & 0,74 & 2,79 & 3,14 & 2,37 & 3,28 & 3,04 & 3,31 & 4,05 & 3,61 & 3,86 & 3,48 & 3,64 & 3,33 & 3,41 & 3,08 & 3,72 & 3,19 & 3,63 & 3,62 & 4,37 & 2,45 \\
\hline $\mathrm{Cl}$ & 1,25 & 0,01 & 0,03 & 0,02 & 0,12 & 0,03 & 0,01 & 0,00 & 0,01 & 0,04 & 0,02 & 0,04 & 0,00 & 0,01 & 0,02 & 0,01 & 0,01 & 0,01 & 0,00 & 0,02 & 0,00 & 0,01 & 0,01 \\
\hline Total & 99,98 & 98,94 & 99,42 & 97,27 & 99,25 & 87,15 & 98,01 & 100,36 & 99,15 & 99,12 & 98,77 & 98,22 & 98,47 & 98,03 & 97,82 & 97,55 & 98,01 & 98,31 & 98,19 & 99,33 & 97,60 & 98,29 & 98,53 \\
\hline \multicolumn{24}{|c|}{ Número de iones con base en $6(\mathrm{P}+\mathrm{As}+\mathrm{S})$} \\
\hline$P$ & 3,00 & 3,00 & 3,00 & 3,00 & 3,00 & 3,00 & 3,00 & 3,00 & 3,00 & 3,00 & 2,92 & 2,98 & 2,97 & 2,99 & 2,80 & 3,00 & 2,98 & 2,99 & 2,98 & 2,99 & 2,94 & 2,99 & 2,99 \\
\hline As & 0,00 & 0,00 & 0,00 & 0,00 & 0,00 & 0,00 & 0,00 & 0,00 & 0,00 & 0,00 & 0,02 & 0,00 & 0,00 & 0,00 & 0,00 & 0,00 & 0,00 & 0,00 & 0,00 & 0,00 & 0,01 & 0,00 & 0,00 \\
\hline & 0,00 & 0,00 & 0,00 & 0,00 & 0,00 & 0,00 & 0,00 & 0,00 & 0,00 & 0,00 & 0,06 & 0,02 & 0,03 & 0,01 & 0,20 & 0,00 & 0,02 & 0,01 & 0,02 & 0,01 & 0,05 & 0,01 & 0,01 \\
\hline Ean. & 3,00 & 3,00 & 3,00 & 3,00 & 3,00 & 3,00 & 3,00 & 3,00 & 3,00 & 3,00 & 3,00 & 3,00 & 3,00 & 3,00 & 3,00 & 3,00 & 3,00 & 3,00 & 3,00 & 3,00 & 3,00 & 3,00 & 3,00 \\
\hline Sr & 0,01 & 0,01 & 0,04 & 0,01 & 0,00 & 0,02 & 0,01 & 0,00 & 0,01 & 0,00 & 0,00 & 0,00 & 0,03 & 0,02 & 0,00 & 0,00 & 0,03 & 0,02 & 0,02 & 0,15 & 0,02 & 0,01 & 0,01 \\
\hline Ва & 0,00 & 0,00 & 0,00 & 0,00 & 0,00 & 0,00 & 0,00 & 0,00 & 0,00 & 0,00 & 0,00 & 0,00 & 0,00 & 0,01 & 0,00 & 0,00 & 0,00 & 0,00 & 0,00 & 0,01 & 0,00 & 0,00 & 0,00 \\
\hline $\mathrm{Fe}^{2+}$ & 0,03 & 0,22 & 0,07 & 0,26 & 0,23 & 0,20 & 0,22 & 0,02 & 0,04 & 0,01 & 0,04 & 0,00 & 0,00 & 0,01 & 0,00 & 0,00 & 0,01 & 0,00 & 0,00 & 0,01 & 0,04 & 0,00 & 0,00 \\
\hline $\mathrm{Mn}^{2+}$ & 0,27 & 0,06 & 0,48 & 0,13 & 0,12 & 0,24 & 0,09 & 0,27 & 0,15 & 0,36 & 0,06 & 0,07 & 0,22 & 0,16 & 0,15 & 0,09 & 0,28 & 0,23 & 0,25 & 0,38 & 0,12 & 0,11 & 0,14 \\
\hline Mg & 0,00 & 0,00 & 0,00 & 0,00 & 0,00 & 0,07 & 0,00 & 0,00 & 0,00 & 0,00 & 0,00 & 0,00 & 0,00 & 0,00 & 0,00 & 0,00 & 0,00 & 0,00 & 0,00 & 0,00 & 0,00 & 0,00 & 0,00 \\
\hline $\mathrm{Ca}$ & 4,64 & 4,85 & 4,25 & 4,93 & & 5,14 & & & & & & 4,92 & & & & & & 4,61 & 4,5 & 4,10 & 4,87 & 4,91 & 4,97 \\
\hline $\mathrm{Na}$ & 0,01 & 0,01 & 0,01 & 0,01 & 0,01 & 0,07 & 0,01 & 0,02 & 0,00 & 0,00 & 0 & 0,00 & 0 & 0,00 & 0,09 & 0,00 & 0,01 & 0,00 & 0,01 & 0,00 & 0,02 & 0,00 & 0,00 \\
\hline K & 0,00 & 0,00 & 0,00 & 0,00 & 0,00 & 0,00 & 0,00 & 0,00 & 0,00 & 0,00 & 0,00 & 0,00 & 0,00 & 0,00 & 0,00 & 0,00 & 0,00 & 0,00 & 0,00 & 0,00 & 0,00 & 0,00 & 0,00 \\
\hline Al & 0,01 & & & & & & & & & 0,00 & & 0,00 & 0 & 0,00 & 0,00 & 0,00 & 0,0 & 0,00 & 0,00 & 0,00 & 0,01 & 0,00 & 0,00 \\
\hline$\sum$ cat. & 4,98 & 5,16 & & 5,34 & & 6,25 & 5, & & & 4,58 & 5 , & 4,99 & 4,99 & 4,94 & 5,00 & 4,82 & 4,82 & 4,86 & 4,86 & 4,66 & 5,09 & 5,05 & 5,12 \\
\hline 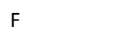 & 0,34 & 0,94 & 0,20 & 0,79 & 0,83 & 0,82 & 0,92 & 0,81 & 0,88 & 1,05 & 0,98 & 1,05 & 0,95 & 0,99 & 0,92 & 0,91 & 0,82 & 1,00 & 0,85 & 0,96 & 1,00 & 1,20 & 0,67 \\
\hline & 0,18 & 0,00 & 0,00 & 0,00 & & 0,01 & & 0,00 & & 0,01 & 0 & 0,01 & 0,00 & 0,00 & 0,00 & 0,00 & 0,00 & 0,00 & 0,00 & 0,00 & 0,00 & 0,00 & 0,00 \\
\hline $\mathrm{OH}^{*}$ & 0,49 & 0,06 & 0,80 & 0,20 & 0,15 & 0,17 & 0,08 & 0,19 & 0,12 & 0,00 & 0,02 & 0,00 & 0,05 & 0,01 & 0,08 & 0,09 & 0,17 & 0,00 & 0,15 & 0,04 & 0,00 & 0,00 & 0,33 \\
\hline
\end{tabular}


Anexo III. Análisis de microsonda electrónica

\begin{tabular}{|c|c|c|c|c|c|c|c|c|c|c|c|c|c|c|c|c|c|c|c|c|c|c|}
\hline Asociación & VIII & VIII & VIII & VIII & VIII & VIIII & VIII & VIII & VIII & VIII & VIII & VIII & VIII & VIII & VIII & VIII & VIII & VIII & $x$ & $x$ & $x$ & $x$ \\
\hline Muestra & 833 & 833 & 833 & 833 & 833 & 833 & 833 & 843 & 1691 & 1691 & 1691 & 1691 & 1691 & 1691 & 1691 & 1710 & 1710 & 1710 & 820 & 820 & 820 & 820 \\
\hline Análisis & 2.1 & 3.4 & 4.2 & 4.3 & 4.4 & 4.5 & 4.6 & 3.4 & 1.2 & 2.3 & 5.1 & 5.2 & 5.3 & 6.2 & 6.3 & 3.1 & 3.2 & 4.1 & 3.1 & 3.2 & 3.4 & 5.4 \\
\hline $\mathrm{P}_{2} \mathrm{O}_{5}$ & 40,69 & 41,15 & 41,69 & 41,50 & 40,99 & 40,97 & 42,33 & 43,29 & 41,57 & \begin{tabular}{ll|}
38,64 \\
\end{tabular} & 39,75 & 39,71 & 38,75 & $\begin{array}{ll}40,14 \\
\end{array}$ & 41,45 & 41,26 & 41,63 & 42,09 & 44,27 & 43,24 & 43,33 & 42,54 \\
\hline $\mathrm{As}_{2} \mathrm{O}_{3}$ & 0,00 & 0,02 & 0,00 & 0,02 & 0,00 & 0,00 & 0,03 & 0,00 & 0,00 & 0,00 & 0,00 & 0,00 & 0,05 & 0,01 & 0,02 & 0,00 & 0,00 & 0,00 & 0,00 & 0,00 & 0,02 & 0,00 \\
\hline $\mathrm{SO}_{3}$ & 0,35 & 0,47 & 0,04 & 0,07 & 0,10 & 0,00 & 0,04 & 0,00 & & - & - & - & & & & - & - & - & 0,26 & 0,03 & 0,00 & 0,03 \\
\hline SrO & 0,52 & 0,12 & 0,30 & 0,29 & 0,27 & 0,51 & 0,20 & 0,08 & 0,29 & 0,15 & 0,28 & 0,12 & 0,23 & 0,15 & 0,17 & 0,39 & 0,13 & 0,69 & 0,32 & 0,94 & 0,80 & 1,01 \\
\hline $\mathrm{BaO}$ & 0,09 & 0,20 & 0,00 & 0,05 & 0,02 & 0,00 & 0,00 & 0,11 & 0,00 & 0,00 & 0,00 & 0,00 & 0,00 & 0,00 & 0,00 & 0,01 & 0,00 & 0,00 & 0,00 & 0,09 & 0,00 & 0,04 \\
\hline $\mathrm{FeO}$ & 0,00 & 0,21 & 0,28 & 0,29 & 0,11 & 0,08 & 0,46 & 0,19 & 0,77 & 0,37 & 1,10 & 0,72 & 0,24 & 1,22 & 1,31 & 0,00 & 0,01 & 0,00 & 0,43 & 0,35 & 0,21 & 0,22 \\
\hline $\mathrm{MnO}$ & 2,38 & 1,62 & 3,14 & 3,56 & 2,63 & 4,07 & 4,00 & 5,26 & 3,41 & 1,14 & 3,59 & 1,65 & 0,96 & 2,14 & 2,18 & 0,77 & 0,24 & 0,36 & 5,12 & 5,02 & 4,72 & 5,96 \\
\hline $\mathrm{MgO}$ & 0,00 & 0,04 & 0,00 & 0,04 & 0,02 & 0,00 & 0,00 & 0,00 & 0,40 & 0,05 & 0,08 & 6,20 & 0,05 & 0,18 & 0,22 & 0,00 & 0,00 & 0,00 & 0,04 & 0,00 & 0,00 & 0,01 \\
\hline $\mathrm{CaO}$ & 52,19 & 51,03 & 50,43 & 49,99 & 51,54 & 50,88 & 49,47 & 47,81 & 50,60 & 54,60 & 51,84 & 46,51 & 54,69 & 53,50 & 53,36 & 52,91 & 54,39 & 55,16 & 48,14 & 48,18 & 49,04 & 47,64 \\
\hline $\mathrm{Na}_{2} \mathrm{O}$ & 0,09 & 0,18 & 0,02 & 0,06 & 0,02 & 0,00 & 0,03 & 0,00 & 0,90 & 1,11 & 0,27 & 0,55 & 1,23 & 0,41 & 0,19 & 0,00 & 0,00 & 0,00 & 0,10 & 0,11 & 0,08 & 0,04 \\
\hline $\mathrm{K}_{2} \mathrm{O}$ & 0, & 0,00 & 01 & 0,01 & 0,02 & 0,01 & 0,00 & 0,00 & 0,00 & 0,00 & 0,01 & 0,01 & 0,01 & 0,01 & 0,00 & 0,00 & 0,01 & 0,00 & 0,00 & 0,00 & 0,00 & 0,03 \\
\hline $\mathrm{Al}_{2} \mathrm{O}_{3}$ & 0,00 & 0,02 & 0,00 & 0,00 & 0,00 & 0,00 & 0,01 & 0,00 & 0,00 & 0,05 & 0,04 & 0,08 & 0,02 & 0,19 & 0,07 & 0,01 & 0,01 & 0,01 & 0,02 & 0,01 & 0,01 & 0,01 \\
\hline & 4,05 & 3,65 & 3,61 & 4,31 & 3,16 & 3,25 & 3,62 & 4,05 & 3,40 & 2,94 & 2,59 & 4,54 & 2,81 & 3,64 & 2,86 & 4,72 & 3,40 & 2,54 & 1,11 & 0,95 & 0,77 & 1,48 \\
\hline $\mathrm{Cl}$ & 0,05 & 0,28 & 0,31 & 0,39 & 0,18 & 0,02 & 0,55 & 0,04 & 0,26 & 0,04 & 0,49 & 0,07 & 0,06 & 0,51 & 0,58 & 0,00 & 0,02 & 0,00 & 0,02 & 0,00 & 0,02 & 0,01 \\
\hline Total & 98,70 & 97,38 & 98,25 & 98,69 & 97,69 & 98,41 & 99,10 & 99,12 & 100,10 & 97,86 & 98,83 & 98,24 & 97,91 & 100,44 & 101,06 & 98,08 & 98,40 & 99,79 & 99,36 & 98,54 & 98,67 & 98,39 \\
\hline \multicolumn{23}{|c|}{ Número de iones con base en $6(\mathrm{P}+\mathrm{As}+\mathrm{S})$} \\
\hline $\mathrm{P}$ & 2,94 & 2,93 & 2,99 & 2,99 & 2,98 & 3,00 & 2,99 & 3,00 & 3,00 & 3,00 & 3,00 & 3,00 & 3,00 & 3,00 & 3,00 & 3,00 & 3,00 & 3,00 & 2,96 & 2,99 & 3,00 & 3,00 \\
\hline As & 0,00 & 0,00 & 0,00 & 0,00 & 0,00 & 0,00 & 0,00 & 0,00 & 0,00 & 0,00 & 0,00 & 0,00 & 0,00 & 0,00 & 0,00 & 0,00 & 0,00 & 0,00 & 0,00 & 0,00 & 0,00 & 0,00 \\
\hline & 0,06 & 0,07 & 0,01 & 0,01 & 0,02 & 0,00 & 0,01 & 0,00 & 0,00 & 0,00 & 0,00 & 0,00 & 0,00 & 0,00 & 0,00 & 0,00 & 0,00 & 0,00 & 0,04 & 0,01 & 0,00 & 0,00 \\
\hline san. & 3,00 & 3,00 & 3,00 & 3,00 & 3,00 & 3,00 & 3,00 & 3,00 & 3,00 & 3,00 & 3,00 & 3,00 & 3,00 & 3,00 & 3,00 & 3,00 & 3,00 & 3,00 & 3,00 & 3,00 & 3,00 & 3,00 \\
\hline Sr & 0,03 & 0,01 & 0,01 & 0,01 & 0,01 & 0,03 & 0,01 & 0,00 & 0,01 & 0,01 & 0,01 & 0,01 & 0,01 & 0,01 & 0,01 & 0,02 & 0,01 & 0,03 & 0,01 & 0,04 & 0,04 & 0,05 \\
\hline Ba & 0,00 & 0,01 & 0,00 & 0,00 & 0,00 & 0,00 & 0,00 & 0,00 & 0,00 & 0,00 & 0,00 & 0,00 & 0,00 & 0,00 & 0,00 & 0,00 & 0,00 & 0,00 & 0,00 & 0,00 & 0,00 & 0,00 \\
\hline $\mathrm{Fe}^{2+}$ & 0,00 & 0,01 & 0,02 & 0,02 & 0,01 & 0,01 & 0,03 & 0,01 & 0,05 & 0,03 & 0,08 & 0,05 & 0,02 & 0,09 & 0,09 & 0,00 & 0,00 & 0,00 & 0,03 & 0,02 & 0,01 & 0,02 \\
\hline $\mathrm{Mn}^{2+}$ & 0,18 & 0,12 & 0,23 & 0,26 & 0,19 & 0,30 & 0,28 & 0,36 & 0,25 & 0,09 & 0,27 & 0,12 & 0,07 & 0,16 & 0,16 & 0,06 & 0,02 & 0,03 & 0,35 & 0,35 & 0,33 & 0,42 \\
\hline Mg & 0,00 & 0,00 & 0,00 & 0,01 & 0,00 & 0,00 & 0,00 & 0,00 & 0,05 & 0,01 & 0,01 & 0,00 & 0,01 & 0,02 & 0,03 & 0,00 & 0,00 & 0,00 & 0,01 & 0,00 & 0,00 & 0,00 \\
\hline $\mathrm{Ca}$ & 4,87 & 4,71 & 4,59 & & 4,77 & & 4,44 & & & & & & & & 4 & 4,87 & 4,96 & 4,97 & 4,13 & 4,23 & 4,30 & 4,25 \\
\hline $\mathrm{Na}$ & 0,02 & 0,03 & 0,00 & 0,01 & 0,00 & 0,00 & 0,01 & 0,00 & 0,15 & 0,20 & 0,05 & 0,10 & 0,22 & 0,07 & 0,03 & 0,00 & 0,00 & 0,00 & 0,02 & 0,02 & 0,01 & 0,01 \\
\hline K & 0,00 & 0,00 & 0,00 & 0,00 & 0,00 & 0,00 & 0,00 & 0,00 & 0,00 & 0,00 & 0,00 & 0,00 & 0,00 & 0,00 & 0,00 & 0,00 & 0,00 & 0,00 & 0,00 & 0,00 & 0,00 & 0,00 \\
\hline $\mathrm{Al}$ & 0,00 & 0,00 & & & & 0,00 & 0,00 & & 0,00 & 0,01 & 0,00 & 0,01 & 0,00 & 0,02 & 0,01 & 0,00 & 0,00 & 0,00 & 0,00 & 0,00 & 0,00 & 0,00 \\
\hline Ecat. & 5,09 & 4,89 & 4,86 & 4,89 & 5,00 & 5,04 & & 4,58 & & 5,70 & 5,38 & 5,33 & & 5,43 & & 4,95 & 4,99 & 5,04 & 4,54 & 4,67 & 4,69 & 4,75 \\
\hline $\mathrm{F}$ & 1,12 & 0,99 & 0,97 & 1,16 & 0,86 & 0,89 & 0,96 & 1,05 & 0,92 & 0,85 & 0,73 & 1,28 & 0,81 & 1,02 & 0,77 & 1,28 & 0,92 & 0,68 & 0,28 & 0,25 & 0,20 & 0,39 \\
\hline $\mathrm{Cl}$ & 0,01 & 0,04 & 0,04 & 0,06 & 0,03 & 0,00 & 0,08 & 0,0 & 0,04 & 0,01 & & 0,01 & 0,01 & 0,08 & 0,08 & 0,00 & 0,00 & 0,00 & 0,00 & 0,00 & 0,00 & 0,0 \\
\hline $\mathrm{OH}^{*}$ & 0,00 & 0,00 & 0,00 & 0,00 & 0,11 & 0,11 & 0,00 & 0,00 & 0,05 & 0,14 & 0,20 & 0,00 & 0,18 & 0,00 & 0,14 & 0,00 & 0,08 & 0,32 & 0,72 & 0,75 & 0,80 & 0,6 \\
\hline
\end{tabular}


Anexo III. Análisis de microsonda electrónica

\begin{tabular}{|c|c|c|c|c|c|c|c|c|c|c|c|c|c|c|c|c|c|c|c|c|c|c|c|}
\hline Asociación & II & II & II & II & IV & VI & VI & VI & VI & IX & IX & IX & IX & IX & IX & $\mathrm{IX}$ & $\mathrm{IX}$ & $\mathrm{IX}$ & $\mathrm{IX}$ & $\mathrm{IX}$ & IX & IX & IX \\
\hline $\begin{array}{l}\text { Muestra } \\
\end{array}$ & 1777 & 1055 & 1055 & 1055 & 1772B & $2298 \mathrm{C}$ & $2298 \mathrm{C}$ & $2298 \mathrm{C}$ & $2298 \mathrm{C}$ & 1066 & 1066 & 1066 & 1066 & 817 & 817 & 817 & 817 & 817 & 817 & 817 & 817 & 817 & 817 \\
\hline Análisis & 4.1 & 5.1 & 5.7 & 5.8 & 6.1 & 1.2 & 2.2 & 3.2 & 3.1 & 2.2 & 3.1 & 3.2 & 4.2 & 1.1 & 1.2 & 1.3 & 1.4 & 2.1 & 2.2 & 2.3 & 2.4 & 2.5 & 2.8 \\
\hline $\mathrm{P}_{2} \mathrm{O}_{5}$ & 52,96 & 53,71 & 52,97 & 55,26 & 50,27 & 51,61 & 54,66 & 52,99 & 56,09 & 54,25 & 51,54 & 52,82 & 49,85 & 52,78 & 53,70 & 53,10 & 53,51 & 52,75 & 53,28 & 53,69 & 52,82 & 53,73 & 53,49 \\
\hline $\mathrm{Al}_{2} \mathrm{O}_{3}$ & 35,45 & 34,71 & 34,80 & 34,91 & 34,97 & 36,01 & 35,51 & 34,90 & 38,57 & 34,46 & 34,99 & 35,11 & 33,07 & 36,13 & 36,03 & 35,33 & 35,68 & 35,35 & 35,91 & 35,32 & 35,63 & 35,47 & 35,34 \\
\hline $\mathrm{MnO}$ & 0,03 & 0,01 & 0,00 & 0,00 & 0,00 & 0,00 & 0,00 & 0,04 & 0,00 & 0,02 & 0,00 & 0,00 & 0,03 & 0,03 & 0,01 & 0,00 & 0,00 & 0,00 & 0,00 & 0,01 & 0,04 & 0,02 & 0,01 \\
\hline $\mathrm{FeO}$ & 0,14 & 0,09 & 0,51 & 0,24 & 0,05 & 0,00 & 0,00 & 0,00 & 0,02 & 0,00 & 0,02 & 0,00 & 0,06 & 0,00 & 0,00 & 0,00 & 0,01 & 0,00 & 0,00 & 0,02 & 0,00 & 0,00 & 0,02 \\
\hline $\mathrm{CaO}$ & 0,01 & 0,01 & 0,00 & 0,02 & 0,06 & 0,02 & 0,00 & 0,02 & 0,10 & 0,02 & 0,01 & 0,02 & 0,11 & 0,00 & 0,00 & 0,01 & 0,00 & 0,00 & 0,03 & 0,00 & 0,01 & 0,00 & 0,00 \\
\hline $\mathrm{ZnO}$ & 0,00 & 0,05 & 0,00 & 0,08 & 0,00 & 0,00 & 0,00 & 0,02 & 0,00 & 0,00 & 0,07 & 0,00 & 0,01 & 0,00 & 0,04 & 0,00 & 0,01 & 0,00 & 0,00 & 0,00 & 0,00 & 0,01 & 0,00 \\
\hline MgO & 0,00 & 0,00 & 0,00 & 0,00 & 0,00 & 0,00 & 0,00 & 0,01 & 0,00 & 0,00 & 0,02 & 0,00 & 0,00 & 0,01 & 0,00 & 0,01 & 0,00 & 0,01 & 0,00 & 0,01 & 0,00 & 0,00 & 0,00 \\
\hline $\mathrm{K}_{2} \mathrm{O}$ & 0,02 & 0,00 & 0,00 & 0,03 & 0,02 & 0,02 & 0,00 & 0,00 & 0,01 & 0,01 & 0,01 & 0,02 & 0,02 & 0,00 & 0,00 & 0,00 & 0,00 & 0,00 & 0,00 & 0,00 & 0,00 & 0,01 & 0,01 \\
\hline $\mathrm{Na}_{2} \mathrm{O}$ & 0,00 & 0,00 & 0,00 & 0,00 & 0,03 & 0,00 & 0,18 & 0,00 & 0,00 & 0,00 & 0,00 & 0,07 & 0,00 & 0,00 & 0,00 & 0,00 & 0,00 & 0,00 & 0,00 & 0,00 & 0,00 & 0,00 & 0,00 \\
\hline $\mathrm{F}$ & 1,52 & 2,69 & 2,21 & 3,52 & 2,79 & 7,37 & 7,07 & 2,25 & 2,05 & 0,01 & 0,01 & 0,02 & 0,05 & 0,01 & 0,00 & 0,00 & 0,04 & 0,00 & 0,00 & 0,01 & 0,00 & 0,01 & 0,03 \\
\hline $\mathrm{Cl}$ & 0,02 & 0,01 & 0,01 & 0,00 & 0,00 & 0,00 & 0,00 & 0,00 & 0,00 & 1,41 & 2,65 & 2,66 & 1,36 & 2,20 & 2,58 & 2,53 & 2,34 & 2,55 & 2,20 & 1,63 & 2,64 & 2,41 & 2,54 \\
\hline Total & 89,51 & 90,15 & 89,58 & 92,58 & 87,02 & 91,92 & 94,45 & 89,29 & 95,98 & 89,59 & 88,21 & 89,60 & 83,98 & 90,23 & 91,27 & 89,90 & 90,60 & 89,59 & 90,49 & 90,00 & 90,03 & 90,65 & 90,38 \\
\hline \multicolumn{24}{|c|}{ Número de iones con base en $1 \mathrm{P}$} \\
\hline 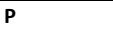 & 1,00 & 1,00 & 1,00 & 1,00 & 1,00 & 1,00 & 1,00 & 1,00 & 1,00 & 1,00 & 1,00 & 1,00 & 1,00 & 1,00 & 1,00 & 1,00 & 1,00 & 1,00 & 1,00 & 1,00 & 1,00 & 1,00 & 1,00 \\
\hline $\mathrm{Al}$ & 0,93 & 0,90 & 0,91 & 0,88 & 0,97 & 0,97 & 0,90 & 0,92 & 0,96 & 0,88 & 0,95 & 0,93 & 0,92 & 0,95 & 0,93 & 0,93 & 0,93 & 0,93 & 0,94 & 0,92 & 0,94 & 0,92 & 0,92 \\
\hline $\mathrm{Zn}$ & 0,00 & 0,00 & 0,00 & 0,00 & 0,00 & 0,00 & 0,00 & 0,00 & 0,00 & 0,00 & 0,00 & 0,00 & 0,00 & 0,00 & 0,00 & 0,00 & 0,00 & 0,00 & 0,00 & 0,00 & 0,00 & 0,00 & 0,00 \\
\hline $\mathrm{Fe}^{2+}$ & 0,00 & 0,00 & 0,01 & 0,00 & 0,00 & 0,00 & 0,00 & 0,00 & 0,00 & 0,00 & 0,00 & 0,00 & 0,00 & 0,00 & 0,00 & 0,00 & 0,00 & 0,00 & 0,00 & 0,00 & 0,00 & 0,00 & 0,00 \\
\hline $\mathrm{Mn}^{2+}$ & 0,00 & 0,00 & 0,00 & 0,00 & 0,00 & 0,00 & 0,00 & 0,00 & 0,00 & 0,00 & 0,00 & 0,00 & 0,00 & 0,00 & 0,00 & 0,00 & 0,00 & 0,00 & 0,00 & 0,00 & 0,00 & 0,00 & 0,00 \\
\hline $\mathrm{Mg}$ & 0,00 & 0,00 & 0,00 & 0,00 & 0,00 & 0,00 & 0,00 & 0,00 & 0,00 & 0,00 & 0,00 & 0,00 & 0,00 & 0,00 & 0,00 & 0,00 & 0,00 & 0,00 & 0,00 & 0,00 & 0,00 & 0,00 & 0,00 \\
\hline Li* & 1,00 & 1,00 & 1,00 & 1,00 & 1,00 & 1,00 & 1,00 & 1,00 & 1,00 & 1,00 & 1,00 & 1,00 & 1,00 & 1,00 & 1,00 & 1,00 & 1,00 & 1,00 & 1,00 & 1,00 & 1,00 & 1,00 & 1,00 \\
\hline $\mathrm{F}$ & 0,11 & 0,19 & 0,16 & 0,24 & 0,21 & 0,53 & 0,48 & 0,16 & 0,14 & 0,10 & 0,19 & 0,19 & 0,10 & 0,16 & 0,18 & 0,18 & 0,16 & 0,18 & 0,15 & 0,11 & 0,19 & 0,17 & 0,18 \\
\hline $\mathrm{Cl}$ & 0,00 & 0,00 & 0,00 & 0,00 & 0,00 & 0,00 & 0,00 & 0,00 & 0,00 & 0,00 & 0,00 & 0,00 & 0,00 & 0,00 & 0,00 & 0,00 & 0,00 & 0,00 & 0,00 & 0,00 & 0,00 & 0,00 & 0,00 \\
\hline $\mathrm{OH}^{*}$ & 0,89 & 0,81 & 0,84 & 0,76 & 0,79 & 0,47 & 0,52 & 0,84 & 0,86 & 0,90 & 0,81 & 0,81 & 0,90 & 0,84 & 0,82 & 0,82 & 0,84 & 0,82 & 0,85 & 0,89 & 0,81 & 0,83 & 0,82 \\
\hline
\end{tabular}

Calculado por estequiometría 
Anexo III. Análisis de microsonda electrónica

\begin{tabular}{|c|c|c|c|c|}
\hline \multicolumn{5}{|c|}{ Ambligonita-Montebrasi } \\
\hline Asociación & $\mathrm{IX}$ & IX & $\mathrm{IX}$ & IX \\
\hline Muestra & 817 & 817 & 817 & 817 \\
\hline Análisis & 2.7 & 2.6 & 3.1 & 4.1 \\
\hline $\mathrm{P}_{2} \mathrm{O}_{5}$ & 52,86 & 52,12 & 53,36 & 52,28 \\
\hline $\mathrm{Al}_{2} \mathrm{O}_{3}$ & 35,24 & 35,78 & 36,14 & 35,22 \\
\hline $\mathrm{MnO}$ & 0,00 & 0,00 & 0,01 & 0,06 \\
\hline $\mathrm{FeO}$ & 0,00 & 0,00 & 0,01 & 0,00 \\
\hline $\mathrm{CaO}$ & 0,00 & 0,00 & 0,02 & 0,49 \\
\hline $\mathrm{ZnO}$ & 0,00 & 0,00 & 0,03 & 0,03 \\
\hline $\mathrm{MgO}$ & 0,00 & 0,00 & 0,00 & 0,01 \\
\hline $\mathrm{K}_{2} \mathrm{O}$ & 0,01 & 0,02 & 0,01 & 0,02 \\
\hline $\mathrm{Na}_{2} \mathrm{O}$ & 0,00 & 0,00 & 0,00 & 0,00 \\
\hline $\mathrm{F}^{2}$ & 0,00 & 0,02 & 0,00 & 0,02 \\
\hline $\mathrm{Cl}$ & 2,27 & 2,39 & 2,52 & 0,98 \\
\hline Total & 89,42 & 89,32 & 91,04 & 88,69 \\
\hline
\end{tabular}

\begin{tabular}{lr} 
Brasilianita & \\
\hline Asociación & \multicolumn{1}{c}{ IX } \\
\hline Muestra & 817 \\
Análisis & 4.2 \\
\hline $\mathrm{P}_{2} \mathrm{O}_{5}$ & 44,19 \\
$\mathrm{Al}_{2} \mathrm{O}_{3}$ & 41,83 \\
$\mathrm{MnO}$ & 0,01 \\
$\mathrm{FeO}$ & 0,03 \\
$\mathrm{CaO}$ & 0,05 \\
$\mathrm{ZnO}$ & 0,01 \\
$\mathrm{MgO}$ & 0,01 \\
$\mathrm{~K}_{2} \mathrm{O}$ & 0,01 \\
$\mathrm{Na}_{2} \mathrm{O}$ & 4,06 \\
$\mathrm{~F}$ & 0,00 \\
$\mathrm{Cl}$ & 1,13 \\
$\mathrm{Total}$ & 90,86 \\
$\mathrm{~N}$ iones con base & $2 \mathrm{P}$ \\
\hline $\mathrm{P}$ & $\mathbf{2 , 0 0}$ \\
$\mathrm{Al}$ & 2,64 \\
$\mathrm{Zn}$ & 0,00 \\
$\mathrm{Fe}$ & 0,00 \\
$\mathrm{Mn}$ & 0,00 \\
$\mathrm{Mg}^{2+}$ & 0,00 \\
$\mathrm{Ca}$ & 0,00 \\
$\mathrm{Na}$ & 0,42 \\
$\mathrm{~K}$ & 0,00 \\
$\mathrm{~F}$ & 0,19 \\
$\mathrm{Cl}$ & 0,00 \\
$\mathrm{OH}^{*}$ & 3,81 \\
\hline${ }^{*}$ Calculado por & \\
estequiometría & \\
&
\end{tabular}

\begin{tabular}{|c|c|c|c|c|c|c|c|c|c|c|c|c|c|}
\hline \multicolumn{14}{|l|}{ Goyazita } \\
\hline Asociación & II & II & VII & VII & VII & VII & VII & VII & VII & VII & VII & VII & VII \\
\hline Muestra & $1684 \mathrm{~A}$ & $1684 \mathrm{~B}$ & $835 \mathrm{~A}$ & $835 \mathrm{~A}$ & $835 \mathrm{~A}$ & $835 \mathrm{~A}$ & $835 B$ & $835 B$ & $835 B$ & $835 B$ & $835 B$ & $835 B$ & $835 B$ \\
\hline Análisis & 6.2 & 4.1 & 2.4 & 2.8 & 3.3 & 3.2 & 5.1 & 5.5 & 5.2 & 5.3 & 5.6 & 6.1 & 6.2 \\
\hline $\mathrm{P}_{2} \mathrm{O}_{5}$ & 31,34 & 30,82 & 31,66 & 31,93 & 30,51 & 27,91 & 28,83 & 27,53 & 32,25 & 26,55 & 25,92 & 26,41 & 26,44 \\
\hline SO3 & - & & 0,73 & 0,36 & 0,61 & 3,98 & 3,33 & 3,70 & 1,14 & 3,71 & 6,35 & 5,67 & 6,22 \\
\hline $\mathrm{Al}_{2} \mathrm{O}_{3}$ & 30,84 & 31,79 & 31,65 & 31,83 & 31,57 & 31,76 & 31,48 & 31,52 & 31,71 & 31,76 & 32,71 & 32,47 & 32,27 \\
\hline MnO & 0,00 & 0,06 & 0,02 & 0,02 & 0,00 & 0,02 & 0,00 & 0,02 & 0,00 & 0,02 & 0,03 & 0,05 & 0,00 \\
\hline $\mathrm{Fe}_{2} \mathrm{O}_{3}$ & 1,51 & 0,58 & 0,00 & 0,04 & 0,00 & 0,01 & 0,01 & 0,06 & 0,00 & 0,05 & 0,03 & 0,45 & 0,00 \\
\hline $\mathrm{CaO}$ & 0,36 & 4,56 & 2,24 & 2,07 & 1,03 & 0,88 & 0,85 & 1,41 & 1,30 & 1,19 & 3,36 & 3,99 & 2,64 \\
\hline $\mathrm{ZnO}$ & 0,09 & 0,00 & 0,00 & 0,00 & 0,00 & 0,00 & 0,00 & 0,09 & 0,00 & 0,00 & 0,00 & 0,03 & 0,00 \\
\hline MgO & 0,03 & 0,06 & 0,00 & 0,02 & 0,00 & 0,00 & 0,01 & 0,06 & 0,00 & 0,09 & 0,00 & 0,01 & 0,00 \\
\hline SrO & 20,36 & 13,30 & 18,14 & 18,78 & 20,30 & 20,17 & 19,63 & 19,62 & 19,01 & 19,13 & 15,53 & 13,90 & 16,44 \\
\hline $\mathrm{BaO}$ & 0,03 & 0,41 & 0,67 & 0,26 & 0,58 & 0,76 & 0,38 & 0,19 & 0,14 & 0,14 & 0,41 & 0,43 & 0,90 \\
\hline $\mathrm{K}_{2} \mathrm{O}$ & 0,04 & 0,00 & 0,00 & 0,01 & 0,02 & 0,01 & 0,01 & 0,26 & 0,00 & 0,13 & 0,01 & 0,03 & 0,03 \\
\hline $\mathrm{Na}_{2} \mathrm{O}$ & 0,00 & 0,00 & 0,00 & 0,00 & 0,00 & 0,00 & 0,00 & 0,02 & 0,00 & 0,01 & 0,00 & 0,01 & 0,00 \\
\hline $\mathrm{F}$ & 0,63 & 0,26 & 2,15 & 1,88 & 2,36 & 1,52 & 1,74 & 1,41 & 2,46 & 1,82 & 1,16 & 0,90 & 1,34 \\
\hline $\mathrm{Cl}$ & 0,00 & 0,01 & 0,02 & 0,01 & 0,01 & 0,01 & 0,00 & 0,02 & 0,02 & 0,00 & 0,01 & 0,01 & 0,02 \\
\hline Total & 84,97 & 81,75 & 86,38 & 86,41 & 86,00 & 86,37 & 85,54 & 85,32 & 87,00 & 83,82 & 85,04 & 83,99 & 85,74 \\
\hline \multicolumn{14}{|c|}{ Número de iones con base en $2(\mathrm{P}+\mathrm{S})$} \\
\hline$P$ & 2,00 & 2,00 & 1,96 & 1,98 & 1,97 & 1,78 & 1,81 & 1,79 & 1,94 & 1,78 & 1,64 & 1,68 & 1,65 \\
\hline $\mathrm{s}$ & 0,00 & 0,00 & 0,04 & 0,02 & 0,03 & 0,22 & 0,19 & 0,21 & 0,06 & 0,22 & 0,36 & 0,32 & 0,35 \\
\hline ¿an. & 2,00 & 2,00 & 2,00 & 2,00 & 2,00 & 2,00 & 2,00 & 2,00 & 2,00 & 2,00 & 2,00 & 2,00 & 2,00 \\
\hline Al & 2,74 & 2,87 & 2,73 & 2,75 & 2,83 & 2,81 & 2,76 & 2,85 & 2,66 & 2,96 & 2,89 & 2,88 & 2,81 \\
\hline $\mathrm{Fe}^{3+}$ & 0,09 & 0,03 & 0,00 & 0,00 & 0,00 & 0,00 & 0,00 & 0,00 & 0,00 & 0,00 & 0,00 & 0,03 & 0,00 \\
\hline Etriv. & 2,83 & 2,91 & 2,73 & 2,75 & 2,83 & 2,81 & 2,76 & 2,85 & 2,66 & 2,97 & 2,89 & 2,90 & 2,81 \\
\hline $\mathrm{Ca}$ & 0,03 & 0,37 & 0,18 & 0,16 & 0,08 & 0,07 & 0,07 & 0,12 & 0,10 & 0,10 & 0,27 & 0,32 & 0,21 \\
\hline $\mathrm{Sr}$ & 0,89 & 0,59 & 0,77 & 0,80 & 0,90 & 0,88 & 0,85 & 0,87 & 0,78 & 0,88 & 0,67 & 0,61 & 0,70 \\
\hline Ba & 0,00 & 0,01 & 0,02 & 0,01 & 0,02 & 0,02 & 0,01 & 0,01 & 0,00 & 0,00 & 0,01 & 0,01 & 0,03 \\
\hline $\mathrm{Mn}^{2+}$ & 0,00 & 0,00 & 0,00 & 0,00 & 0,00 & 0,00 & 0,00 & 0,00 & 0,00 & 0,00 & 0,00 & 0,00 & 0,00 \\
\hline Mg & 0,00 & 0,01 & 0,00 & 0,00 & 0,00 & 0,00 & 0,00 & 0,01 & 0,00 & 0,01 & 0,00 & 0,00 & 0,00 \\
\hline Ediv. & 0,92 & 0,99 & 0,96 & 0,97 & 1,00 & 0,97 & 0,93 & 1,00 & 0,89 & 0,99 & 0,96 & 0,94 & 0,94 \\
\hline $\mathrm{F}$ & 0,15 & 0,06 & 0,50 & 0,44 & 0,57 & 0,36 & 0,41 & 0,34 & 0,55 & 0,46 & 0,27 & 0,21 & 0,31 \\
\hline $\mathrm{Cl}$ & 0,00 & 0,00 & 0,00 & 0,00 & 0,00 & 0,00 & 0,00 & 0,00 & 0,00 & 0,00 & 0,00 & 0,00 & 0,00 \\
\hline$\%$ Gyz & 97 & 60 & 80 & 82 & 90 & 90 & 91 & 88 & 88 & 89 & 71 & 64 & 75 \\
\hline \% Crnd & 3 & 38 & 18 & 17 & 8 & 7 & 7 & 12 & 11 & 10 & 28 & 34 & 22 \\
\hline$\%$ Grcx & 0 & 1 & 2 & 1 & 2 & 2 & 1 & 1 & 0 & 0 & 1 & 1 & 3 \\
\hline
\end{tabular}


Anexo III. Análisis de microsonda electrónica

\begin{tabular}{|c|c|c|c|c|c|c|c|c|c|c|c|c|c|c|c|c|c|c|c|c|c|}
\hline Asociación & II & II & II & II & II & II & II & II & II & IV & IV & IV & IV & IV & IV & IV & IV & IV & VII & VII & VII \\
\hline Muestra & 1055 & 1055 & 1055 & 1055 & 1055 & 1055 & 1055 & 1055 & 1055 & $1772 A$ & $1772 \mathrm{~A}$ & $1772 A$ & $1772 A$ & $1772 A$ & $1772 \mathrm{~A}$ & $1772 A$ & $1772 \mathrm{~A}$ & $1772 A$ & $835 \mathrm{~A}$ & $835 \mathrm{~A}$ & $835 \mathrm{~B}$ \\
\hline Análisis & 4.1 & 4.5 & 5.3 & 5.5 & 5.11 & 6.2 & 6.5 & 7.3 & 7.5 & 4.1 & 4.2 & 4.4 & 4.5 & 6.1 & 7.1 & 7.2 & 9.4 & 9.5 & 1.1 & 1.2 & 3.1 \\
\hline$\overline{\mathrm{P}_{2} \mathrm{O}_{5}}$ & 34,20 & 33,68 & 33,67 & 33,40 & 33,89 & 33,92 & 33,50 & 33,26 & 32,28 & 33,46 & 33,59 & 33,33 & 30,51 & 32,05 & 32,38 & 32,93 & 34,75 & 33,32 & 33,12 & 31,20 & 30,66 \\
\hline $\mathrm{As}_{2} \mathrm{O}_{3}$ & 0,09 & 0,09 & 0,06 & 0,08 & 0,13 & 0,10 & 0,13 & 0,12 & 0,06 & 0,07 & 0,00 & 0,00 & 0,35 & 0,17 & 0,15 & 0,14 & 0,00 & 0,00 & 0,88 & 2,30 & 2,88 \\
\hline $\mathrm{SO}_{3}$ & & & - & & - & & & & & 0,04 & 0,03 & 0,00 & 0,02 & 0,00 & 0,00 & 0,01 & 0,00 & 0,00 & 0,02 & 0,04 & 0,00 \\
\hline $\mathrm{Al}_{2} \mathrm{O}_{3}$ & 3,14 & 1,51 & 4,07 & 3,81 & 4,27 & 1,97 & 0,39 & 0,12 & 0,84 & 0,07 & 0,02 & 0,03 & 0,54 & 0,90 & 0,02 & 0,18 & 0,01 & 0,00 & 2,03 & 0,93 & 0,78 \\
\hline $\mathrm{Fe}_{2} \mathrm{O}_{3}$ * & 46,48 & 48,25 & 44,19 & 44,20 & 44,28 & 47,91 & 49,78 & 49,83 & 47,16 & 50,20 & 50,39 & 49,95 & 45,32 & 46,86 & 48,69 & 49,28 & 52,11 & 49,98 & 47,48 & 48,00 & 48,08 \\
\hline $\mathrm{MnO}$ & 1,32 & 1,34 & 0,63 & 0,59 & 0,65 & 0,70 & 0,73 & 0,93 & 0,91 & 3,11 & 2,74 & 2,58 & 2,02 & 2,09 & 4,23 & 2,67 & 3,23 & 2,79 & 6,26 & 6,25 & 5,80 \\
\hline $\mathrm{FeO}$ & 7,91 & 5,82 & 7,03 & 7,12 & 6,39 & 8,06 & 5,92 & 6,14 & 7,09 & 3,51 & 4,05 & 5,14 & 4,72 & 6,52 & 4,64 & 4,59 & 2,55 & 5,83 & 1,72 & 0,86 & 2,70 \\
\hline $\mathrm{CaO}$ & 0,20 & 0,37 & 0,33 & 0,33 & 0,35 & 0,19 & 0,47 & 0,43 & 0,27 & 0,40 & 0,42 & 0,52 & 0,52 & 0,43 & 0,41 & 0,68 & 0,10 & 0,17 & 0,03 & 0,24 & 0,06 \\
\hline $\mathrm{ZnO}$ & 0,20 & 0,19 & 0,00 & 0,04 & 0,14 & 0,13 & 0,02 & 0,04 & 0,09 & 0,27 & 0,10 & 0,13 & 0,78 & 0,96 & 0,21 & 0,10 & 0,14 & 0,09 & 0,06 & 0,42 & 0,26 \\
\hline $\mathrm{MgO}$ & 0,02 & 0,03 & 0,00 & 0,01 & 0,00 & 0,03 & 0,03 & 0,00 & 0,02 & 0,34 & 0,56 & 0,44 & 0,01 & 0,02 & 0,00 & 0,02 & 0,38 & 0,72 & 0,00 & 0,00 & 0,00 \\
\hline SrO & 0,04 & 0,00 & 0,02 & 0,00 & 0,07 & 0,07 & 0,02 & 0,00 & 0,00 & 0,10 & 0,05 & 0,12 & 0,00 & 0,04 & 0,10 & 0,00 & 0,01 & 0,00 & 0,00 & 0,05 & 0,07 \\
\hline $\mathrm{BaO}$ & 0,05 & 0,07 & 0,00 & 0,01 & 0,00 & 0,00 & 0,12 & 0,00 & 0,00 & 0,00 & 0,14 & 0,20 & 0,00 & 0,30 & 0,25 & 0,23 & 0,00 & 0,00 & 0,00 & 0,00 & 0,00 \\
\hline $\mathrm{K}_{2} \mathrm{O}$ & 0,01 & 0,00 & 0,08 & 0,09 & 0,10 & 0,34 & 0,03 & 0,03 & 0,02 & 0,00 & 0,01 & 0,01 & 0,03 & 0,01 & 0,00 & 0,01 & 0,00 & 0,00 & 0,00 & 0,03 & 0,00 \\
\hline $\mathrm{Na}_{2} \mathrm{O}$ & 0,01 & 0,05 & 0,04 & 0,06 & 0,01 & 0,05 & 0,19 & 0,13 & 0,03 & 0,18 & 0,02 & 0,01 & 0,21 & 0,22 & 0,00 & 0,03 & 0,46 & 0,01 & 0,02 & 0,10 & 0,02 \\
\hline $\mathrm{F}$ & 0,28 & 0,23 & 0,29 & 0,31 & 0,25 & 0,28 & 0,21 & 0,23 & 0,30 & 0,21 & 0,25 & 0,24 & 0,34 & 0,18 & 0,21 & 0,08 & 0,31 & 0,19 & 0,39 & 0,34 & 0,21 \\
\hline Total & 93,83 & 91,54 & 90,31 & 89,94 & 90,42 & 93,65 & 91,45 & 91,14 & 88,94 & 91,86 & 92,24 & 92,60 & 85,24 & 90,66 & 91,20 & 90,91 & 93,92 & 93,01 & 91,84 & 90,60 & 91,44 \\
\hline \multicolumn{22}{|c|}{ Número de iones con base en $3(\mathrm{P}+\mathrm{As}+\mathrm{S})$} \\
\hline $\mathrm{P}$ & 2,99 & 2,99 & 3,00 & 3,00 & 2,99 & 2,99 & 2,99 & 2,99 & 3,00 & 2,99 & 3,00 & 3,00 & 2,97 & 2,99 & 2,99 & 2,99 & 3,00 & 3,00 & 2,94 & 2,84 & 2,80 \\
\hline As & 0,01 & 0,01 & 0,00 & 0,00 & 0,01 & 0,01 & 0,01 & 0,01 & 0,00 & 0,00 & 0,00 & 0,00 & 0,02 & 0,01 & 0,01 & 0,01 & 0,00 & 0,00 & 0,06 & 0,16 & 0,20 \\
\hline s & 0,00 & 0,00 & 0,00 & 0,00 & 0,00 & 0,00 & 0,00 & 0,00 & 0,00 & 0,00 & 0,00 & 0,00 & 0,00 & 0,00 & 0,00 & 0,00 & 0,00 & 0,00 & 0,00 & 0,00 & 0,00 \\
\hline ¿an. & 3,00 & 3,00 & 3,00 & 3,00 & 3,00 & 3,00 & 3,00 & 3,00 & 3,00 & 3,00 & 3,00 & 3,00 & 3,00 & 3,00 & 3,00 & 3,00 & 3,00 & 3,00 & 3,00 & 3,00 & 3,00 \\
\hline $\mathrm{Al}$ & 0,38 & 0,19 & 0,50 & 0,48 & 0,53 & 0,24 & 0,05 & 0,01 & 0,11 & 0,01 & 0,00 & 0,00 & 0,07 & 0,12 & 0,00 & 0,02 & 0,00 & 0,00 & 0,25 & 0,12 & 0,10 \\
\hline $\mathrm{Fe}^{3+*} *$ & 3,62 & 3,81 & 3,50 & 3,52 & 3,47 & 3,76 & 3,95 & 3,99 & 3,89 & 3,99 & 4,00 & 4,00 & 3,93 & 3,88 & 4,00 & 3,98 & 4,00 & 4,00 & 3,75 & 3,88 & 3,90 \\
\hline$\Sigma$ triv. & 4,00 & 4,00 & 4,00 & 4,00 & 4,00 & 4,00 & 4,00 & 4,00 & 4,00 & 4,00 & 4,00 & 4,00 & 4,00 & 4,00 & 4,00 & 4,00 & 4,00 & 4,00 & 4,00 & 4,00 & 4,00 \\
\hline $\mathrm{Fe}^{2+}$ & 0,69 & 0,52 & 0,62 & 0,64 & 0,57 & 0,71 & 0,53 & 0,56 & 0,66 & 0,32 & 0,36 & 0,46 & 0,49 & 0,62 & 0,44 & 0,43 & 0,22 & 0,52 & 0,23 & 0,30 & 0,54 \\
\hline $\mathrm{Mn}^{2+}$ & 0,12 & 0,12 & 0,06 & 0,05 & 0,06 & 0,06 & 0,07 & 0,08 & 0,08 & 0,28 & 0,24 & 0,23 & 0,20 & 0,20 & 0,39 & 0,24 & 0,28 & 0,25 & 0,57 & 0,60 & 0,57 \\
\hline Mg & 0,00 & 0,00 & 0,00 & 0,00 & 0,00 & 0,01 & 0,00 & 0,00 & 0,00 & 0,05 & 0,09 & 0,07 & 0,00 & 0,00 & 0,00 & 0,00 & 0,06 & 0,11 & 0,00 & 0,00 & 0,00 \\
\hline $\mathrm{Ca}$ & 0,02 & 0,04 & 0,04 & 0,04 & 0,04 & 0,02 & 0,05 & 0,05 & 0,03 & 0,05 & 0,05 & 0,06 & 0,06 & 0,05 & 0,05 & 0,08 & 0,01 & 0,02 & 0,00 & 0,03 & 0,01 \\
\hline $\mathrm{Na}$ & 0,00 & 0,01 & 0,01 & 0,01 & 0,00 & 0,01 & 0,04 & 0,03 & 0,01 & 0,04 & 0,00 & 0,00 & 0,05 & 0,05 & 0,00 & 0,01 & 0,09 & 0,00 & 0,00 & 0,02 & 0,01 \\
\hline K & 0,00 & 0,00 & 0,01 & 0,01 & 0,01 & 0,05 & 0,00 & 0,00 & 0,00 & 0,00 & 0,00 & 0,00 & 0,00 & 0,00 & 0,00 & 0,00 & 0,00 & 0,00 & 0,00 & 0,00 & 0,00 \\
\hline $\mathrm{Zn}$ & 0,01 & 0,02 & 0,00 & 0,00 & 0,01 & 0,01 & 0,00 & 0,00 & 0,01 & 0,02 & 0,01 & 0,01 & 0,07 & 0,08 & 0,02 & 0,01 & 0,01 & 0,01 & 0,00 & 0,04 & 0,02 \\
\hline$\sum$ div. & 0,85 & 0,71 & 0,74 & 0,76 & 0,69 & 0,87 & 0,70 & 0,72 & 0,79 & 0,76 & 0,75 & 0,83 & 0,88 & 0,99 & 0,90 & 0,77 & 0,67 & 0,91 & 0,81 & 0,99 & 1,15 \\
\hline & 0,09 & 0,08 & 0,10 & 0,10 & 0,08 & 0,09 & 0,07 & 0,08 & 0,10 & 0,07 & 0,08 & 0,08 & 0,12 & 0,06 & 0,07 & 0,03 & 0,10 & 0,06 & 0,13 & 0,12 & 0,08 \\
\hline
\end{tabular}




\begin{tabular}{|c|c|c|c|c|c|c|c|c|c|}
\hline Asociación & II & II & II & II & II & VII & VII & VII & VII \\
\hline Muestra & 1055 & 1055 & 1055 & 1055 & 1055 & $835 \mathrm{~B}$ & $835 B$ & $835 B$ & $835 \mathrm{~B}$ \\
\hline Análisis & 5.4 & 7.1 & 7.2 & 7.4 & 7.6 & 2.3 & 2.4 & 4.2 & 4.4 \\
\hline $\mathrm{P}_{2} \mathrm{O}_{5}$ & 35,60 & 34,35 & 35,30 & 34,98 & 35,78 & 33,05 & 33,74 & 34,87 & 33,10 \\
\hline $\mathrm{Al}_{2} \mathrm{O}_{3}$ & 4,08 & 1,89 & 5,28 & 5,21 & 4,39 & 0,40 & 0,41 & 0,96 & 0,81 \\
\hline $\mathrm{Fe}_{2} \mathrm{O}_{3} *$ & 43,67 & 45,33 & 41,38 & 41,02 & 43,44 & 42,94 & 42,65 & 44,31 & 42,84 \\
\hline $\mathrm{MnO}$ & 0,69 & 0,13 & 0,17 & 0,10 & 0,16 & 5,06 & 5,15 & 4,13 & 5,22 \\
\hline $\mathrm{FeO}$ & 6,73 & 4,19 & 3,79 & 3,94 & 3,12 & 0,00 & 0,00 & 0,00 & 0,00 \\
\hline $\mathrm{CaO}$ & 0,36 & 0,03 & 0,06 & 0,07 & 0,20 & 0,08 & 0,12 & 0,07 & 0,11 \\
\hline $\mathrm{ZnO}$ & 0,07 & 0,11 & 0,11 & 0,04 & 0,00 & 0,09 & 0,16 & 0,00 & 0,03 \\
\hline MgO & 0,12 & 0,00 & 0,02 & 0,03 & 0,01 & 0,00 & 0,00 & 0,00 & 0,00 \\
\hline $\mathrm{K}_{2} \mathrm{O}$ & 0,07 & 0,03 & 0,00 & 0,04 & 0,00 & 0,00 & 0,00 & 0,00 & 0,00 \\
\hline $\mathrm{Na}_{2} \mathrm{O}$ & 0,03 & 0,00 & 0,00 & 0,00 & 0,00 & 0,00 & 0,00 & 0,00 & 0,00 \\
\hline $\mathrm{F}$ & 0,32 & 0,33 & 0,30 & 0,28 & 0,40 & 0,28 & 0,31 & 0,31 & 0,25 \\
\hline Total & 91,62 & 86,26 & 86,29 & 85,59 & 87,34 & 81,78 & 82,42 & 84,51 & 82,27 \\
\hline \multicolumn{10}{|c|}{ Número de iones con base en $4 \mathrm{P}$} \\
\hline$P$ & 4,00 & 4,00 & 4,00 & 4,00 & 4,00 & 4,00 & 4,00 & 4,00 & 4,00 \\
\hline $\mathrm{Al}$ & 0,64 & 0,31 & 0,83 & 0,83 & 0,68 & 0,07 & 0,07 & 0,15 & 0,14 \\
\hline $\mathrm{Fe}^{3+*}$ & 4,36 & 4,69 & 4,17 & 4,17 & 4,32 & 4,62 & 4,49 & 4,52 & 4,60 \\
\hline Etriv. & 5,00 & 5,00 & 5,00 & 5,00 & 5,00 & 4,69 & 4,56 & 4,67 & 4,74 \\
\hline $\mathrm{Fe}^{2+}$ & 0,75 & 0,48 & 0,42 & 0,45 & 0,34 & 0,00 & 0,00 & 0,00 & 0,00 \\
\hline $\mathrm{Mn}^{2+}$ & 0,08 & 0,01 & 0,02 & 0,01 & 0,02 & 0,61 & 0,61 & 0,47 & 0,63 \\
\hline $\mathrm{Mg}$ & 0,02 & 0,00 & 0,00 & 0,01 & 0,00 & 0,00 & 0,00 & 0,00 & 0,00 \\
\hline $\mathrm{Ca}$ & 0,05 & 0,01 & 0,01 & 0,01 & 0,03 & 0,01 & 0,02 & 0,01 & 0,02 \\
\hline $\mathrm{Na}$ & 0,01 & 0,00 & 0,00 & 0,00 & 0,00 & 0,00 & 0,00 & 0,00 & 0,00 \\
\hline k & 0,01 & 0,01 & 0,00 & 0,01 & 0,00 & 0,00 & 0,00 & 0,00 & 0,00 \\
\hline $\mathrm{Zn}$ & 0,01 & 0,01 & 0,01 & 0,00 & 0,00 & 0,01 & 0,02 & 0,00 & 0,00 \\
\hline$\sum$ div. & 0,93 & 0,52 & 0,47 & 0,48 & 0,39 & 0,63 & 0,65 & 0,48 & 0,65 \\
\hline $\mathrm{F}$ & 0,13 & 0,14 & 0,13 & 0,12 & 0,17 & 0,13 & 0,14 & 0,13 & 0,11 \\
\hline
\end{tabular}

\begin{tabular}{lr}
\multicolumn{2}{l}{ Zwieselita } \\
\hline Asociación & \multicolumn{1}{c}{ III } \\
\hline Muestra & $1769 \mathrm{C}$ \\
Análisis & 1.4 \\
\hline $\mathrm{P}_{2} \mathrm{O}_{5}$ & 33,28 \\
$\mathrm{Al}_{2} \mathrm{O}_{3}$ & 0,04 \\
$\mathrm{MnO}$ & 17,62 \\
$\mathrm{FeO}$ & 36,18 \\
$\mathrm{CaO}$ & 0,57 \\
$\mathrm{ZnO}$ & 0,24 \\
$\mathrm{MgO}$ & 6,98 \\
$\mathrm{~K}_{2} \mathrm{O}$ & 0,00 \\
$\mathrm{Na}{ }_{2} \mathrm{O}$ & 0,00 \\
$\mathrm{~F}$ & 5,04 \\
$\mathrm{Cl}$ & 0,01 \\
$\mathrm{Total}$ & 97,84 \\
$\mathrm{~N}^{\circ}$ iones con base $1 \mathrm{P}$ \\
\hline $\mathrm{P}$ & $\mathbf{1 , 0 0}$ \\
$\mathrm{Al}$ & 0,00 \\
$\mathrm{Zn}$ & 0,01 \\
$\mathrm{Fe}$ & 1,07 \\
$\mathrm{Mn}{ }^{2+}$ & 0,53 \\
$\mathrm{Mg}$ & 0,37 \\
$\mathrm{Ca}$ & 0,02 \\
$\mathrm{Na}$ & 0,00 \\
$\mathrm{~K}$ & 0,00 \\
$\Sigma$ cat. & $\mathbf{2 , 0 0}$ \\
$\mathrm{F}$ & 0,57 \\
$\mathrm{Cl}$ & 0,00 \\
\hline $\mathrm{Fe} /(\mathrm{Fe}+\mathrm{Mn})$ & 0,67 \\
\hline &
\end{tabular}

Anexo III. Análisis de microsonda electrónica

\section{Staněkita}

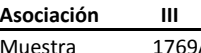

Análisis $\quad 1.3$

$\mathrm{P}_{2} \mathrm{O}_{5}$

$\mathrm{Al}_{2} \mathrm{O}_{3} \quad 0,24$

$\mathrm{TiO}_{2} \quad 0,00$

$\mathrm{Fe}_{2} \mathrm{O}_{3} * \quad 36,00$

$\mathrm{FeO} \quad 15,35$

MgO $\quad 0,87$

MnO $\quad 15,41$

$\begin{array}{ll}\mathrm{ZnO} & 0,01 \\ \mathrm{CaO} & 0,07\end{array}$

$\mathrm{K}_{2} \mathrm{O} \quad 0,03$

$\mathrm{N}^{\circ}$ iones con base $1 \mathrm{P}$

$\mathrm{P}^{3+*} \quad \mathbf{1 , 0 0}$

$\mathrm{e}^{3+*} \quad 0,96$

Al $\quad 0,01$

Striv.

$\mathrm{Fe}^{2+} \quad 0,46$

$\mathrm{Mn}^{2+} \quad 0,46$

$\mathrm{Mg} \quad 0,05$

$\mathrm{Ti} \quad 0,00$

$\begin{array}{ll}\mathrm{Ca} & 0,00 \\ \mathrm{Na} & 0,00\end{array}$

\begin{tabular}{ll}
$\mathrm{Na}$ & 0,00 \\
$\mathrm{~K}$ & 0,00 \\
\hline
\end{tabular}

¿div.

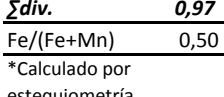

\section{oxenita}

\begin{tabular}{lllll}
\hline Asociación & IV & IV & IV & IV \\
\hline Muestra & $1772 B$ & $1772 B$ & 1786 & 1786
\end{tabular}

\begin{tabular}{llllll} 
Análisis & 23 & 3.2 & 7.3 & 7.4 \\
\hline $\mathrm{P}_{2} \mathrm{O}_{5}$ & 39.96 & 40.60 & 41.44 & 38.83
\end{tabular}

$\begin{array}{lrrrr}\mathrm{An}_{2} \mathrm{O}_{5} & 39,96 & 40,60 & 41,44 & 38,83\end{array}$

$\begin{array}{rrrrr}\mathrm{Al}_{2} \mathrm{O}_{3} & 0,84 & 0,96 & 1,78 & 2,86\end{array}$

$\begin{array}{rrrrr}\mathrm{Fe}_{2} \mathrm{O}_{3} & 20,11 & 21,02 & 14,86 & 14,26\end{array}$

$\begin{array}{rrrrr}\mathrm{MnO} & 3,04 & 2,04 & 0,94 & 1,21\end{array}$

$\begin{array}{lllll}\text { MgO } & 0,73 & 0,67 & 3,08 & 1,83\end{array}$

$\begin{array}{rrrrr}\mathrm{CaO} & 26,31 & 26,49 & 27,42 & 26,53 \\ \mathrm{ZnO} & 0,15 & 0,05 & 0,06 & 0,06\end{array}$

SrO $\quad 0,16 \quad 0,06 \quad 0,01 \quad 0,05$

$\begin{array}{lllll}\mathrm{BaO} & 0,03 & 0,00 & 0,10 & 0,12\end{array}$

$\begin{array}{lllll}\mathrm{K}_{2} \mathrm{O} & 0,02 & 0,04 & 0,01 & 0,02\end{array}$

$\begin{array}{lllll}\mathrm{Na}_{2} \mathrm{O} & 0,00 & 0,00 & 0,07 & 0,06 \\ \mathrm{~F} & 0,67 & 0,71 & 0,57 & 0,59 \\ \mathrm{C} & 0,01 & 0,02 & 0,05 & 0,28\end{array}$

$\begin{array}{lllll}\mathrm{Cl} & 0,61 & 0,71 & 0,57 & 0,59 \\ \mathrm{~F} & 0,02 & 0,05 & 0,28\end{array}$

$\begin{array}{lllll}\text { Total } & 91,74 & 92,37 & 90,13 & 86,45\end{array}$

\begin{tabular}{lllll}
\multicolumn{4}{l}{ Número de iones con base en $4 \mathrm{P}$} \\
\hline $\mathrm{P}$ & $\mathbf{4 , 0 0}$ & $\mathbf{4 , 0 0}$ & $\mathbf{4 , 0 0}$ & $\mathbf{4 , 0 0}$
\end{tabular}

\begin{tabular}{lcccc}
$\mathbf{P}$ & $\mathbf{4 , 0 0}$ & $\mathbf{4 , 0 0}$ & $\mathbf{4 , 0 0}$ & $\mathbf{4 , 0 0}$ \\
$\mathrm{Al}$ & 0,12 & 0,13 & 0,24 & 0,41 \\
$\mathrm{Fe}^{3+}$ & $\mathbf{1 , 7 9}$ & 1,84 & 1,27 & 1,31 \\
$\Sigma$ & $\mathbf{1 , 9}$ & $\mathbf{1 , 9 8}$ & $\mathbf{1 , 5 2}$ & $\mathbf{1 , 7 2}$ \\
$\mathrm{Mn}^{2+}$ & 0,30 & 0,20 & 0,09 & 0,12 \\
$\mathrm{Mg}$ & 0,13 & 0,12 & 0,52 & 0,33 \\
$\mathrm{Ca}$ & 3,33 & 3,30 & 3,35 & 3,46 \\
$\mathrm{Sr}$ & 0,01 & 0,00 & 0,00 & 0,00 \\
$\mathrm{Ba}$ & 0,00 & 0,00 & 0,00 & 0,01 \\
$\Sigma$ & $\mathbf{3 , 7 8}$ & $\mathbf{3 , 6 2}$ & $\mathbf{3 , 9 7}$ & $\mathbf{3 , 9 2}$ \\
$\mathrm{F}$ & 0,25 & 0,26 & 0,20 & 0,23 \\
$\mathrm{Cl}$ & 0,00 & 0,00 & 0,01 & 0,06 \\
\hline
\end{tabular}


Anexo III. Análisis de microsonda electrónica

\begin{tabular}{|c|c|c|c|c|c|c|c|c|c|c|c|}
\hline \multicolumn{12}{|l|}{ Alluaudita } \\
\hline Asociación & IV & IV & IV & IV & IV & IV & IV & $\mathrm{v}$ & $\mathrm{v}$ & $\mathrm{v}$ & $x$ \\
\hline Muestra & 1772B & 1772B & $1772 A$ & $1772 A$ & $1772 A$ & $1772 A$ & $1772 A$ & $802 \mathrm{~A}$ & $802 \mathrm{~A}$ & $802 \mathrm{~A}$ & 820 \\
\hline Análisis & 3.3 & 3.4 & 3.1 & 6.2 & 8.1 & 9.7 & 9.8 & 5.1 & 5.2 & 5.5 & 5.1 \\
\hline $\overrightarrow{\mathrm{P}_{2} \mathrm{O}_{5}}$ & 47,03 & 46,47 & 45,75 & 45,70 & 45,36 & 46,97 & 46,22 & 46,45 & 46,17 & 45,83 & 47,11 \\
\hline $\mathrm{Al}_{2} \mathrm{O}_{3}$ & 0,02 & 0,05 & 0,23 & 0,10 & 0,07 & 0,02 & 0,04 & 0,00 & 0,01 & 0,02 & 0,07 \\
\hline $\mathrm{TiO}_{2}$ & 0,00 & 0,00 & 0,00 & 0,00 & 0,01 & 0,00 & 0,00 & 0,00 & 0,00 & 0,00 & 0,04 \\
\hline $\mathrm{CaO}$ & 0,07 & 0,10 & 1,87 & 0,07 & 2,07 & 0,10 & 0,04 & 0,09 & 0,09 & 0,10 & 0,27 \\
\hline MgO & 0,19 & 0,16 & 0,35 & 0,19 & 1,36 & 0,25 & 0,20 & 0,03 & 0,00 & 0,03 & 3,19 \\
\hline $\mathrm{MnO}$ & 12,48 & 12,04 & 11,68 & 10,72 & 12,81 & 10,53 & 11,86 & 19,80 & 18,55 & 19,30 & 11,61 \\
\hline $\mathrm{FeO}$ & 33,99 & 33,27 & 33,62 & 32,89 & 31,38 & 33,90 & 33,54 & 25,47 & 26,92 & 27,02 & 26,73 \\
\hline $\mathrm{ZnO}$ & 0,00 & 0,12 & 0,01 & 0,06 & 0,02 & 0,30 & 0,24 & 0,02 & 0,00 & 0,00 & 0,01 \\
\hline $\mathrm{K}_{2} \mathrm{O}$ & 0,00 & 0,00 & 0,04 & 0,01 & 0,04 & 0,00 & 0,01 & 0,03 & 0,02 & 0,03 & 0,03 \\
\hline $\mathrm{Na}_{2} \mathrm{O}$ & 5,70 & 5,90 & 4,86 & 5,84 & 4,61 & 6,22 & 5,74 & 6,67 & 6,58 & 6,16 & 7,76 \\
\hline $\mathrm{F}$ & 0,58 & 0,61 & 0,38 & 0,60 & 0,48 & 0,37 & 0,61 & 0,44 & 0,57 & 0,49 & 0,56 \\
\hline Total & 100,07 & 98,72 & 98,79 & 96,17 & 98,22 & 98,66 & 98,50 & 98,98 & 98,90 & 98,99 & 97,37 \\
\hline \multicolumn{12}{|c|}{ Número de iones con base en $3 \mathrm{P}$} \\
\hline $\bar{P}$ & 3,00 & 3,00 & 3,00 & 3,00 & 3,00 & 3,00 & 3,00 & 3,00 & 3,00 & 3,00 & 3,00 \\
\hline $\mathrm{Fe}^{3+*}$ & 2,00 & 2,00 & 1,98 & 1,99 & 1,99 & 2,00 & 2,00 & 1,62 & 1,73 & 1,75 & 1,68 \\
\hline $\mathrm{Mn}^{2+}$ & 0,00 & 0,00 & 0,00 & 0,00 & 0,00 & 0,00 & 0,00 & 0,37 & 0,27 & 0,25 & 0,31 \\
\hline Al & 0,00 & 0,00 & 0,02 & 0,01 & 0,01 & 0,00 & 0,00 & 0,00 & 0,00 & 0,00 & 0,0075 \\
\hline$\Sigma M 2$ & 2,00 & 2,00 & 2,00 & 2,00 & 2,00 & 2,00 & 2,00 & 2,00 & 2,00 & 2,00 & 2,00 \\
\hline $\mathrm{Fe}^{2+}$ & 0,14 & 0,13 & 0,20 & 0,14 & 0,06 & 0,14 & 0,15 & 0,00 & 0,00 & 0,00 & 0,00 \\
\hline $\mathrm{Mg}$ & 0,02 & 0,02 & 0,04 & 0,02 & 0,16 & 0,03 & 0,02 & 0,00 & 0,00 & 0,00 & 0,36 \\
\hline $\mathrm{Mn}^{2+}$ & 0,80 & 0,78 & 0,77 & 0,70 & 0,84 & 0,67 & 0,77 & 0,90 & 0,93 & 1,00 & 0,43 \\
\hline Ca & 0,01 & 0,01 & 0,16 & 0,01 & 0,00 & 0,01 & 0,00 & 0,01 & 0,01 & 0,00 & 0,02 \\
\hline $\mathrm{Na}$ & 0,18 & 0,20 & 0,04 & 0,27 & 0,00 & 0,29 & 0,20 & 0,09 & 0,06 & 0,00 & 0,19 \\
\hline$\sum M 1$ & 1,00 & 1,00 & 1,00 & 1,00 & 1,00 & 1,00 & 1,00 & 1,00 & 1,00 & 1,00 & 1,00 \\
\hline $\mathrm{Mn}$ & 0,00 & 0,00 & 0,00 & 0,00 & 0,01 & 0,00 & 0,00 & 0,00 & 0,00 & 0,02 & 0,00 \\
\hline $\mathrm{Ca}$ & 0,00 & 0,00 & 0,00 & 0,00 & 0,17 & 0,00 & 0,00 & 0,00 & 0,00 & 0,01 & 0,00 \\
\hline $\mathrm{Na}$ & 0,66 & 0,68 & 0,69 & 0,61 & 0,70 & 0,62 & 0,65 & 0,90 & 0,92 & 0,92 & 0,94 \\
\hline$\sum \times 1$ & 0,66 & 0,68 & 0,69 & 0,61 & 0,88 & 0,62 & 0,65 & 0,90 & 0,92 & 0,95 & 0,94 \\
\hline $\mathrm{Na}$ & 0,00 & 0,00 & 0,00 & 0,00 & 0,00 & 0,00 & 0,00 & 0,00 & 0,00 & 0,00 & 0,00 \\
\hline vacancias & 1,00 & 1,00 & 1,00 & 1,00 & 1,00 & 1,00 & 1,00 & 1,00 & 1,00 & 1,00 & 1,00 \\
\hline$\Sigma \times 2$ & 1,00 & 1,00 & 1,00 & 1,00 & 1,00 & 1,00 & 1,00 & 1,00 & 1,00 & 1,00 & 1,00 \\
\hline $\mathrm{Fe} /(\mathrm{Fe}+\mathrm{Mn})$ & 0,73 & 0,73 & 0,74 & 0,75 & 0,71 & 0,76 & 0,74 & 0,56 & 0,59 & 0,58 & 0,70 \\
\hline
\end{tabular}

\begin{tabular}{|c|c|c|c|c|c|c|}
\hline \\
\hline Asociación & VII & VII & VII & VII & VII & VII \\
\hline Muestra & 843 & 843 & 843 & 843 & 843 & 84 \\
\hline Análisis & 1.1 & 1.2 & 1.3 & 1.4 & 1.5 & 2.2 \\
\hline $\mathrm{P}_{2} \mathrm{O}_{5}$ & 37,02 & 36,65 & 36,17 & 40,78 & 39,28 & 39,95 \\
\hline $\mathrm{As}_{2} \mathrm{O}_{3}$ & 0,75 & 0,72 & 0,71 & 2,37 & 3,85 & 3,7 \\
\hline $\mathrm{SO}_{3}$ & 0,02 & 0,02 & 0,00 & 0,02 & 0,00 & $0,0 c$ \\
\hline $\mathrm{Al}_{2} \mathrm{O}_{3}$ & 0,09 & 0,02 & 0,03 & 0,02 & 0,05 & $0,0 \varepsilon$ \\
\hline $\mathrm{Mn}_{2} \mathrm{O}_{3}{ }^{*}$ & 32,52 & 31,45 & 32,65 & 23,68 & 25,17 & 24,8 \\
\hline $\mathrm{MnO}$ & 15,53 & 15,65 & 9,98 & 14,10 & 19,68 & $16,7 \mathrm{C}$ \\
\hline $\mathrm{FeO}$ & 2,79 & 2,36 & 8,03 & 6,70 & 1,20 & 4,16 \\
\hline $\mathrm{CaO}$ & 0,06 & 0,09 & 0,09 & 0,12 & 0,04 & 0,08 \\
\hline $\mathrm{ZnO}$ & 0,06 & 0,04 & 0,00 & 0,09 & 0,00 & 0,02 \\
\hline $\mathrm{MgO}$ & 0,18 & 0,24 & 0,11 & 0,00 & 0,00 & $0,0 c$ \\
\hline $\mathrm{Na}_{2} \mathrm{O}$ & 0,00 & 0,00 & 0,00 & 0,00 & 0,00 & $0,0 c$ \\
\hline $\mathrm{K}_{2} \mathrm{O}$ & 0,00 & 0,00 & 0,00 & 0,00 & 0,00 & $0,0 c$ \\
\hline $\mathrm{F}$ & 0,67 & 0,54 & 0,66 & 0,78 & 0,74 & 1,05 \\
\hline Total & 89,42 & 87,55 & 88,16 & 88,31 & 89,71 & 90,21 \\
\hline \multicolumn{7}{|c|}{ Número de iones con base en $2(P+A s+S)$} \\
\hline $\mathrm{P}$ & 1,97 & 1,97 & 1,97 & 1,92 & 1,87 & $1,8 \varepsilon$ \\
\hline $\mathrm{s}$ & 0,00 & 0,00 & 0,00 & 0,00 & 0,00 & $0,0 c$ \\
\hline As & 0,03 & 0,03 & 0,03 & 0,08 & 0,13 & 0,12 \\
\hline$\Sigma a n$. & 2,00 & 2,00 & 2,00 & 2,00 & 2,00 & 2,00 \\
\hline $\mathrm{Mn}^{3+*}$ & 1,55 & 1,52 & 1,60 & 1,00 & 1,07 & 1,0 \\
\hline $\mathrm{Al}$ & 0,01 & 0,00 & 0,00 & 0,00 & 0,00 & 0,0 \\
\hline Etriv. & 1,56 & 1,52 & 1,60 & 1,00 & 1,08 & 1,05 \\
\hline $\mathrm{Fe}^{2+}$ & 0,15 & 0,13 & 0,44 & 0,32 & 0,06 & 0,2 \\
\hline $\mathrm{Mn}^{2+}$ & 0,83 & 0,84 & 0,54 & 0,66 & 0,94 & $0,7 \mathrm{c}$ \\
\hline $\mathrm{Mg}$ & 0,02 & 0,02 & 0,01 & 0,00 & 0,00 & $0,0 c$ \\
\hline $\mathrm{Ca}$ & 0,00 & 0,01 & 0,01 & 0,01 & 0,00 & 0,0 \\
\hline $\mathrm{Na}$ & 0,00 & 0,00 & 0,00 & 0,00 & 0,00 & 0,0 \\
\hline $\mathrm{k}$ & 0,00 & 0,00 & 0,00 & 0,00 & 0,00 & $0,0 c$ \\
\hline $\mathrm{Zn}$ & 0,00 & 0,00 & 0,00 & 0,00 & 0,00 & 0,00 \\
\hline Ediv. & 1,00 & 1,00 & 1,00 & 1,00 & 1,00 & 1,00 \\
\hline $\mathrm{F}$ & 0,14 & 0,11 & 0,14 & 0,14 & 0,14 & 0,22 \\
\hline
\end{tabular}


Anexo III. Análisis de microsonda electrónica

\begin{tabular}{|c|c|c|c|c|c|c|c|c|c|c|}
\hline Asociación & $\begin{array}{ll}\text { VII } \\
\end{array}$ & $\begin{array}{ll}\mathrm{VII} \\
\end{array}$ & $\begin{array}{ll}\text { VIII } \\
\end{array}$ & VIIII & VIIII & VIIII & VIIII & 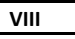 & 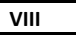 & VIIII \\
\hline Muestra & 843 & 843 & 1183 & 1183 & 1183 & 1183 & 1183 & 1183 & 1691 & 1691 \\
\hline Análisis & 4.1 & 4.2 & 1.1 & 1.2 & 1.4 & 2.5 & 2.8 & 4.9 & 1.3 & 2.1 \\
\hline $\mathrm{P}_{2} \mathrm{O}_{5}$ & 34,00 & 33,73 & 30,87 & 32,28 & 31,11 & 31,30 & 31,75 & 31,55 & 34,31 & 33,40 \\
\hline $\mathrm{Al}_{2} \mathrm{O}_{3}$ & 0,02 & 0,03 & 0,00 & 0,04 & 0,01 & 0,01 & 0,07 & 0,02 & 0,03 & 0,01 \\
\hline $\mathrm{FeO}$ & 10,53 & 10,99 & 20,28 & 20,44 & 20,60 & 17,45 & 19,08 & 16,56 & 21,04 & 17,66 \\
\hline $\mathrm{MnO}$ & 46,54 & 45,75 & 35,69 & 34,21 & 34,07 & 36,49 & 34,69 & 38,39 & 27,83 & 33,59 \\
\hline $\mathrm{CaO}$ & 1,19 & 1,27 & 0,87 & 0,92 & 0,91 & 0,99 & 1,01 & 0,98 & 0,74 & 0,90 \\
\hline $\mathrm{ZnO}$ & 0,20 & 0,00 & - & - & - & - & - & - & 0,06 & 0,01 \\
\hline $\mathrm{MgO}$ & 3,28 & 3,65 & 6,02 & 5,87 & 5,80 & 6,14 & 5,82 & 5,73 & 11,13 & 9,24 \\
\hline $\mathrm{K}_{2} \mathrm{O}$ & 0,00 & 0,00 & 0,00 & 0,00 & 0,00 & 0,00 & 0,00 & 0,01 & 0,00 & 0,00 \\
\hline $\mathrm{Na}_{2} \mathrm{O}$ & 0,00 & 0,00 & 0,00 & 0,00 & 0,00 & 0,00 & 0,00 & 0,00 & 0,00 & 0,00 \\
\hline $\mathrm{F}$ & 4,85 & 5,00 & - & - & - & - & - & - & 5,30 & 5,58 \\
\hline $\mathrm{Cl}$ & 0,00 & 0,01 & - & - & - & - & - & - & 0,00 & 0,01 \\
\hline Total & 98,57 & 98,31 & 93,73 & 93,74 & 92,50 & 92,38 & 92,42 & 93,23 & 98,21 & 98,05 \\
\hline \multicolumn{11}{|c|}{ Número de iones con base en $1 \mathrm{P}$} \\
\hline$P$ & 1,00 & 1,00 & 1,00 & 1,00 & 1,00 & 1,00 & 1,00 & 1,00 & 1,00 & 1,00 \\
\hline $\mathrm{Al}$ & 0,00 & 0,00 & 0,00 & 0,00 & 0,00 & 0,00 & 0,00 & 0,00 & 0,00 & 0,00 \\
\hline $\mathrm{Zn}$ & 0,01 & 0,00 & 0,00 & 0,00 & 0,00 & 0,00 & 0,00 & 0,00 & 0,00 & 0,00 \\
\hline $\mathrm{Fe}^{2+}$ & 0,31 & 0,32 & 0,65 & 0,63 & 0,65 & 0,55 & 0,59 & 0,52 & 0,61 & 0,52 \\
\hline $\mathrm{Mn}^{2+}$ & 1,37 & 1,36 & 1,16 & 1,06 & 1,10 & 1,17 & 1,09 & 1,22 & 0,81 & 1,01 \\
\hline $\mathrm{Mg}$ & 0,17 & 0,19 & 0,34 & 0,32 & 0,33 & 0,35 & 0,32 & 0,32 & 0,57 & 0,49 \\
\hline $\mathrm{Ca}$ & 0,04 & 0,05 & 0,04 & 0,04 & 0,04 & 0,04 & 0,04 & 0,04 & 0,03 & 0,03 \\
\hline $\mathrm{Na}$ & 0,00 & 0,00 & 0,00 & 0,00 & 0,00 & 0,00 & 0,00 & 0,00 & 0,00 & 0,00 \\
\hline K & 0,00 & 0,00 & 0,00 & 0,00 & 0,00 & 0,00 & 0,00 & 0,00 & 0,00 & 0,00 \\
\hline ¿cat. & 1,90 & 1,92 & 2,18 & 2,04 & 2,12 & 2,10 & 2,05 & 2,10 & 2,02 & 2,05 \\
\hline $\mathrm{F}$ & 0,53 & 0,55 & 0,00 & 0,00 & 0,00 & 0,00 & 0,00 & 0,00 & 0,58 & 0,62 \\
\hline $\mathrm{Cl}$ & 0,00 & 0,00 & 0,00 & 0,00 & 0,00 & 0,00 & 0,00 & 0,00 & 0,00 & 0,00 \\
\hline $\mathrm{Fe} /(\mathrm{Fe}+\mathrm{Mn})$ & 0,18 & 0,19 & 0,36 & 0,37 & 0,37 & 0,32 & 0,35 & 0,30 & 0,43 & 0,34 \\
\hline
\end{tabular}

\begin{tabular}{lrrr} 
Isokita & & & \\
\hline Asociación & \multicolumn{1}{l}{ VIII } & \multicolumn{1}{l}{ VIII } & \multicolumn{1}{l}{ VIII } \\
\hline Muestra & 1183 & 1183 & 1183 \\
Análisis & 1.3 & 4.10 & 4.11 \\
\hline $\mathrm{P}_{2} \mathrm{O}_{5}$ & 34,94 & 37,10 & 37,74 \\
$\mathrm{Al}_{2} \mathrm{O}_{3}$ & 0,11 & 0,00 & 0,05 \\
$\mathrm{FeO}$ & 0,87 & 0,90 & 0,37 \\
$\mathrm{MnO}$ & 0,50 & 0,50 & 0,35 \\
$\mathrm{CaO}$ & 29,46 & 31,30 & 31,49 \\
$\mathrm{ZnO}$ & - & - & - \\
$\mathrm{MgO}$ & 18,66 & 20,79 & 21,71 \\
$\mathrm{~K}_{2} \mathrm{O}$ & 0,02 & 0,00 & 0,03 \\
$\mathrm{Na}_{2} \mathrm{O}$ & 0,11 & 0,06 & 0,08 \\
$\mathrm{~F}$ & - & - & - \\
$\mathrm{Cl}$ & - & - & - \\
Total & 84,65 & 90,66 & 91,81 \\
$\mathrm{Número}$ de iones con base en $1 \mathrm{P}$ & \\
\hline $\mathrm{P}$ & $\mathbf{1 , 0 0}$ & $\mathbf{1 , 0 0}$ & $\mathbf{1 , 0 0}$ \\
$\mathrm{Al}$ & 0,00 & 0,00 & 0,00 \\
$\mathrm{Zn}$ & 0,00 & 0,00 & 0,00 \\
$\mathrm{Fe}$ & 0,02 & 0,02 & 0,01 \\
$\mathrm{Mn}{ }^{2+}$ & 0,01 & 0,01 & 0,01 \\
$\mathrm{Mg}$ & 0,94 & 0,99 & 1,01 \\
$\mathrm{Ca}$ & 1,07 & 1,07 & 1,06 \\
$\mathrm{Na}$ & 0,01 & 0,00 & 0,00 \\
$\mathrm{~K}$ & 0,00 & 0,00 & 0,00 \\
$\sum$ cat. & $\mathbf{2 , 0 6}$ & $\mathbf{2 , 1 0}$ & $\mathbf{2 , 1 0}$ \\
$\mathrm{F}$ & 0,00 & 0,00 & 0,00 \\
$\mathrm{Cl}$ & 0,00 & 0,00 & 0,00 \\
\hline & & &
\end{tabular}

\begin{tabular}{lr} 
Heterosita & \\
\hline Asociación & \multicolumn{1}{c}{$\boldsymbol{X}$} \\
\hline Muestra & 820 \\
Análisis & 5.2 \\
\hline $\mathrm{P}_{2} \mathrm{O}_{5}$ & 48,65 \\
$\mathrm{Al}_{2} \mathrm{O}_{3}$ & 0,40 \\
$\mathrm{TiO}_{2}$ & 0,13 \\
$\mathrm{Fe}_{2} \mathrm{O}_{3}$ & 32,11 \\
$\mathrm{Mn}_{2} \mathrm{O}_{3}$ & 14,15 \\
$\mathrm{CaO}$ & 0,07 \\
$\mathrm{MgO}$ & 3,11 \\
$\mathrm{ZnO}$ & 0,31 \\
$\mathrm{~K}_{2} \mathrm{O}$ & 0,03 \\
$\mathrm{Na} \mathrm{O}_{2} \mathrm{O}$ & 0,08 \\
$\mathrm{~F}$ & 0,46 \\
$\mathrm{Total}$ & 99,50 \\
$\mathrm{~N}^{\circ}$ iones con base $1 \mathrm{P}$ \\
\hline $\mathbf{P}$ & $\mathbf{1 , 0 0}$ \\
$\mathrm{Mn}{ }^{3+}$ & 0,26 \\
$\mathrm{Fe}{ }^{3+}$ & 0,59 \\
$\mathrm{Al}$ & 0,01 \\
$\mathrm{Zn}$ & 0,01 \\
$\mathrm{Ti}$ & 0,00 \\
$\mathrm{Mg}$ & 0,11 \\
$\mathbf{\Sigma}$ cat. & $\mathbf{0 , 9 8}$ \\
\hline $\mathrm{Fe} /(\mathrm{Fe}+\mathrm{Mn})$ & 0,69 \\
\hline &
\end{tabular}

\begin{tabular}{|c|c|}
\hline Asociación & $x$ \\
\hline Muestra & $82 C$ \\
\hline Análisis & 5.2 \\
\hline $\mathrm{P}_{2} \mathrm{O}_{5}$ & 48,65 \\
\hline $\mathrm{Al}_{2} \mathrm{O}_{3}$ & 0,40 \\
\hline $\mathrm{TiO}_{2}$ & 0,13 \\
\hline $\mathrm{Fe}_{2} \mathrm{O}_{3}$ & 32,11 \\
\hline $\mathrm{MnO}$ & 12,71 \\
\hline $\mathrm{CaO}$ & 0,07 \\
\hline MgO & 3,11 \\
\hline $\mathrm{ZnO}$ & 0,31 \\
\hline $\mathrm{K}_{2} \mathrm{O}$ & 0,03 \\
\hline $\mathrm{Na}_{2} \mathrm{O}$ & 0,08 \\
\hline $\mathrm{F}$ & 0,46 \\
\hline Total & 98,06 \\
\hline \multicolumn{2}{|c|}{$\mathrm{N}^{\circ}$ iones con base $1 \mathrm{P}$} \\
\hline$P$ & 1,00 \\
\hline $\mathrm{Fe}^{3+}$ & 0,59 \\
\hline $\mathrm{Mn}^{2+}$ & 0,26 \\
\hline Al & 0,01 \\
\hline $\mathrm{Zn}$ & 0,01 \\
\hline $\mathrm{Ti}$ & 0,00 \\
\hline Mg & 0,11 \\
\hline$\sum c a t$. & 0,98 \\
\hline $\mathrm{Li}^{*}$ & 0,99 \\
\hline $\mathrm{Fe} /(\mathrm{Fe}+\mathrm{Mn})$ & 0,69 \\
\hline
\end{tabular}




\begin{tabular}{|c|c|c|c|c|c|c|c|c|c|}
\hline Asociación & VII & VII & VII & VII & VII & VII & VII & VII & VII \\
\hline Muestra & 843 & 843 & 843 & 843 & 843 & 843 & 843 & 843 & 843 \\
\hline Análisis & 1.6 & 1.7 & 2.1 & 3.1 & 3.2 & 3.3 & 4.3 & 4.4 & 4.5 \\
\hline$\overline{\mathrm{P}_{2} \mathrm{O}_{5}}$ & 43,40 & 44,37 & 39,37 & 39,09 & 42,25 & 38,72 & $\begin{array}{ll}44,37 \\
\end{array}$ & 44,05 & 44,48 \\
\hline $\mathrm{As}_{2} \mathrm{O}_{3}$ & 1,12 & 0,62 & 5,97 & 4,68 & 1,54 & 6,14 & 0,31 & 0,17 & 0,19 \\
\hline $\mathrm{SO}_{3}$ & 0,00 & 0,02 & 0,00 & 0,03 & 0,00 & 0,00 & 0,01 & 0,00 & 0,00 \\
\hline $\mathrm{Al}_{2} \mathrm{O}_{3}$ & 0,08 & 0,02 & 0,26 & 0,66 & 0,61 & 0,55 & 0,12 & 0,11 & 0,14 \\
\hline $\mathrm{Mn}_{2} \mathrm{O}_{3}$ & 0,29 & 0,72 & 0,29 & 0,36 & 0,29 & 0,19 & 0,81 & 2,88 & 2,12 \\
\hline $\mathrm{Fe}_{2} \mathrm{O}_{3}$ & 44,61 & 44,36 & 44,12 & 44,45 & 43,80 & 43,37 & 43,35 & 41,76 & 42,94 \\
\hline $\mathrm{CaO}$ & 0,06 & 0,04 & 0,06 & 0,06 & 0,06 & 0,05 & 0,04 & 0,04 & 0,04 \\
\hline $\mathrm{ZnO}$ & 0,00 & 0,04 & 0,00 & 0,00 & 0,00 & 0,00 & 0,00 & 0,00 & 0,02 \\
\hline $\mathrm{MgO}$ & 0,00 & 0,01 & 0,00 & 0,00 & 0,00 & 0,00 & 0,03 & 0,09 & 0,14 \\
\hline $\mathrm{Na}_{2} \mathrm{O}$ & 0,00 & 0,00 & 0,00 & 0,00 & 0,00 & 0,00 & 0,01 & 0,03 & 0,00 \\
\hline $\mathrm{K}_{2} \mathrm{O}$ & 0,01 & 0,00 & 0,00 & 0,01 & 0,00 & 0,01 & 0,00 & 0,01 & 0,01 \\
\hline $\mathrm{F}$ & 0,40 & 0,41 & 0,28 & 0,36 & 0,56 & 0,28 & 0,58 & 0,48 & 0,55 \\
\hline Total & 89,80 & 90,45 & 90,23 & 89,54 & 88,87 & 89,21 & 89,40 & 89,42 & 90,40 \\
\hline \multicolumn{10}{|c|}{ Número de iones con base en $1(\mathrm{P}+\mathrm{As}+\mathrm{S})$} \\
\hline P & 0,98 & 0,99 & 0,90 & 0,92 & 0,97 & 0,90 & 0,99 & 1,00 & 1,00 \\
\hline $\mathrm{s}$ & 0,00 & 0,00 & 0,00 & 0,00 & 0,00 & 0,00 & 0,00 & 0,00 & 0,00 \\
\hline As & 0,02 & 0,01 & 0,10 & 0,08 & 0,03 & 0,10 & 0,01 & 0,00 & 0,00 \\
\hline Ean. & 1,00 & 1,00 & 1,00 & 1,00 & 1,00 & 1,00 & 1,00 & 1,00 & 1,00 \\
\hline Al & 0,00 & 0,00 & 0,01 & 0,02 & 0,02 & 0,02 & 0,00 & 0,00 & 0,00 \\
\hline $\mathrm{Fe}^{3+}$ & 0,91 & 0,89 & 1,00 & 1,01 & 0,92 & 1,00 & 0,87 & 0,84 & 0,86 \\
\hline $\mathrm{Mn}^{3+}$ & 0,01 & 0,01 & 0,01 & 0,01 & 0,01 & 0,00 & 0,02 & 0,06 & 0,04 \\
\hline Mg & 0,00 & 0,00 & 0,00 & 0,00 & 0,00 & 0,00 & 0,00 & 0,00 & 0,01 \\
\hline Сa & 0,04 & 0,02 & 0,04 & 0,04 & 0,04 & 0,04 & 0,02 & 0,02 & 0,02 \\
\hline $\mathrm{Na}$ & 0,00 & 0,00 & 0,00 & 0,00 & 0,00 & 0,00 & 0,00 & 0,00 & 0,00 \\
\hline K & 0,00 & 0,00 & 0,00 & 0,00 & 0,00 & 0,00 & 0,00 & 0,00 & 0,00 \\
\hline $\mathrm{Zn}$ & 0,00 & 0,00 & 0,00 & 0,00 & 0,00 & 0,00 & 0,00 & 0,00 & 0,00 \\
\hline$\sum$ cat. & 0,96 & 0,93 & 1,05 & 1,08 & 0,99 & 1,06 & 0,91 & 0,93 & 0,93 \\
\hline & 0,03 & 0,03 & 0,03 & 0,03 & 0,05 & 0,03 & 0,05 & 0,04 & 0,05 \\
\hline
\end{tabular}


Anexo III. Análisis de microsonda electrónica

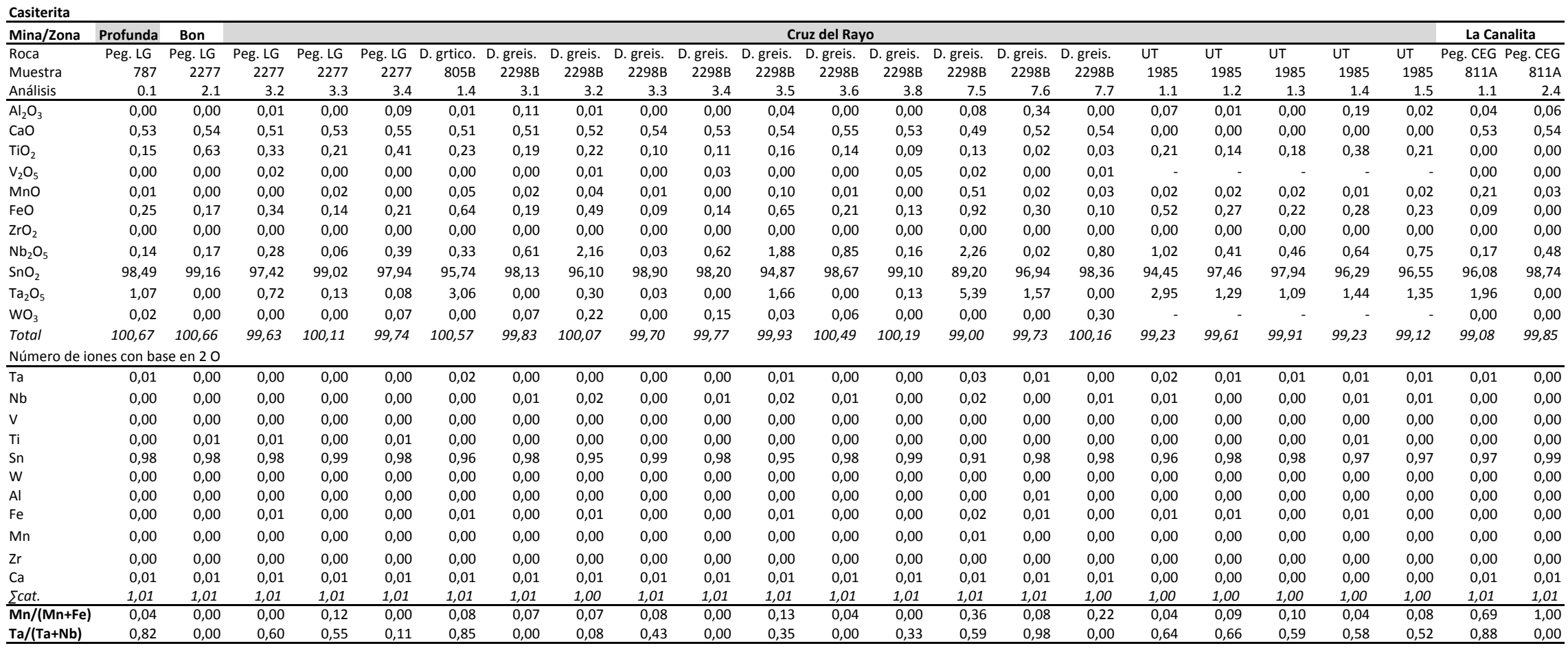


Anexo III. Análisis de microsonda electrónica

\begin{tabular}{|c|c|c|c|c|c|c|c|c|c|c|c|c|c|c|c|c|c|c|c|c|c|c|c|}
\hline \multirow{2}{*}{$\begin{array}{l}\text { Mina/Zona } \\
\text { Roca }\end{array}$} & \multicolumn{9}{|c|}{ La Canalita } & \multicolumn{11}{|c|}{ Horia } & \multicolumn{3}{|c|}{ Mari Carmen } \\
\hline & Peg. CEG & Peg. CEG & Peg. CEG & Peg. CEG & Peg. CEG & Peg. CEG & Peg. CEG & Peg. CEG & Peg. CEG & Vena GE & Vena GE & Vena GE & Vena GE & Vena GE & Vena GE & Vena GE & Vena GE & Vena GE & Vena GE & Vena GE & Vena GE & Vena GE & Vena GE \\
\hline Muestra & $811 \mathrm{~A}$ & $818 \mathrm{~A}$ & $818 \mathrm{~A}$ & $818 \mathrm{~A}$ & $818 \mathrm{~A}$ & $1066 \mathrm{~A}$ & $1066 \mathrm{~A}$ & 1066A & 1066A & 1711 & 1711 & 1711 & 1711 & 1711 & 1711 & 1711 & 1711 & 1711 & 1711 & 1711 & $1775 B$ & $1775 B$ & $1775 \mathrm{~B}$ \\
\hline Análisis & 3.1 & 1.2 & 5.2 & 6.2 & 6.4 & 1.1 & 2.2 & 4.1 & 4.2 & 1.1 & 1.2 & 1.3 & 1.4 & 1.5 & 1.6 & 2.4 & 3.1 & 3.2 & 3.3 & 3.4 & 1.3 & 1.4 & 1.5 \\
\hline $\mathrm{Al}_{2} \mathrm{O}_{3}$ & 0,83 & 0,20 & 0,66 & 0,00 & 0,69 & 0,25 & 0,61 & 0,30 & 0,04 & 0,00 & 0,00 & 0,13 & 0,00 & 0,00 & 0,00 & 0,00 & 0,00 & 0,00 & 0,00 & 0,00 & 0,00 & 0,00 & 0,00 \\
\hline $\mathrm{CaO}$ & 0,46 & 0,54 & 0,55 & 0,55 & 0,55 & 0,49 & 0,53 & 0,51 & 0,54 & 0,57 & 0,54 & 0,55 & 0,54 & 0,57 & 0,50 & 0,57 & 0,55 & 0,55 & 0,54 & 0,54 & 0,55 & 0,55 & 0,55 \\
\hline $\mathrm{O}_{2}$ & 0,00 & 0,00 & 0,00 & 0,00 & 0,00 & 0,09 & 0,03 & 0,11 & 0,10 & 71 & 0,49 & 0,00 & 0,38 & 0,19 & 0,43 & 0,53 & 0,66 & 0,43 & 0,48 & 0,54 & 0,53 & ,41 & 0,47 \\
\hline $\mathrm{V}_{2} \mathrm{O}_{5}$ & 0,01 & 0,00 & 0,04 & 0,02 & 0,00 & 0,01 & 0,00 & 0,06 & 0,02 & 0,03 & 0,01 & 0,00 & 0,03 & 0,00 & 0,00 & 0,00 & 0,03 & 0,00 & 0,03 & 0,03 & 0,02 & 0,00 & 0,00 \\
\hline $\mathrm{MnO}$ & 0,99 & 0,05 & 0,00 & 0,01 & & 1,22 & 0,03 & 0,42 & & 0,02 & & 0,00 & 0,00 & 0,00 & 0,06 & & 0,00 & 0,00 & 0,04 & 0,00 & 0,00 & 0,00 & 0,00 \\
\hline 0 & & 0,04 & 0, & 0,01 & & 0,35 & 0,00 & 0,18 & 0,04 & 03 & 0,00 & 0,39 & 0,00 & 0,20 & 0,00 & 0,04 & 0,04 & 0,00 & 0,07 & 0,02 & 0,00 &, 00 & 0,01 \\
\hline $\mathrm{KO}_{2}$ & 0,00 & 0,00 & 0,00 & 0,00 & 0,00 & 0,00 & 0,00 & 0,00 & 0,00 & 0,00 & 0,00 & 0,00 & 0,00 & 0,00 & 0,00 & 0,00 & 0,00 & 0,00 & 0,00 & 0,00 & 0,00 & 0,00 & 0,00 \\
\hline $\mathrm{Nb}_{2} \mathrm{O}_{5}$ & 4,48 & 0,55 & 0,48 & 0,00 & 0,47 & 2,19 & 0,62 & 2,08 & 0,21 & 0,00 & 0,00 & 0,00 & 0,00 & 0,00 & 0,00 & 0,01 & 0,04 & 0,00 & 0,17 & 0,10 & 0,02 & 0,03 & 0,00 \\
\hline $\mathrm{nO}_{2}$ & 82,73 & 98,01 & 96,20 & 99,88 & 97,11 & 87,04 & 97,94 & 94,02 & 97,43 & 97,95 & 99,17 & 98,79 & 98,34 & 98,77 & 99,42 & 98,07 & 97,43 & 99,07 & 98,57 & 98,13 & 99,59 & 99,03 & 99,72 \\
\hline $\mathrm{Ta}_{2} \mathrm{O}_{5}$ & 9,03 & 0,14 & 0,09 & 0,00 & 0,00 & 8,42 & 0,17 & 2,44 & 1,28 & 0,00 & 0,00 & 0,00 & 0,00 & 0,00 & 0,00 & 0,00 & 0,00 & 0,00 & 0,00 & 0,00 & 0,00 & 0,00 & 0,00 \\
\hline $\mathrm{WO}_{3}$ & 0,00 & 0,54 & 0,37 & 0,11 & 0,28 & 0,00 & 0,07 & 0,18 & 0,11 & 0,11 & 0,02 & 0,02 & 0,00 & 0,08 & 0,00 & 0,03 & 0,44 & 0,00 & 0,00 & 0,00 & 0,01 & 0,00 & 0,00 \\
\hline Total & 98,63 & 100,07 & 98,39 & 100,58 & 99,16 & 100,07 & 100,01 & 100,29 & 99,92 & 99,42 & 100,24 & 99,89 & 99,28 & 99,82 & 100,41 & 99,25 & 99,18 & 100,06 & 99,89 & 99,37 & 100,72 & 100,03 & 100,76 \\
\hline \multicolumn{24}{|c|}{ Número de iones con base en 20} \\
\hline $\mathrm{Ta}$ & 0,06 & 0,00 & 0 , & 0,00 & & 0,05 & & 0,01 & & 00 & & 00 & 00 & 0,00 & 0,00 & 0,00 & 0,00 & 0,00 & 0,00 & , ,00 & 0,00 & 00 & 0,00 \\
\hline ab & 0,05 & 0,01 & & 0,00 & & 0,02 & & & & & & 00 & & 00 & 0 & 0,00 & 0,00 & 0,00 & 0,00 & 0,00 & 0,00 & 0,00 & 0,00 \\
\hline & 0, & 0,00 & 0, & 0, & & 0,00 & & & & & & & & & & 0,00 & & 0,00 & 0,00 & 0,00 & 0,00 & & 0,00 \\
\hline & & & & & & & & & & & & & & & & & & & & & & & \\
\hline & & & & & & & & & & & & & & & & & & & & & & & 99 \\
\hline & & & & & & & & & & & & & & & & 0,0 & & 0,0 & & 0,0 & 0,00 & b & 0,00 \\
\hline & & & & & & & & & & & & & & & & & & ( & & o & & & \\
\hline TE & 0,00 & 0,00 & 0,00 & 0,00 & 0,00 & 0,01 & 0,00 & 0,00 & 0,00 & 0,00 & 0,00 & 0,01 & 0,00 & 0,00 & 0,00 & 0,00 & 0,00 & 0,00 & 0,00 & 0,00 & 0,00 & 0,00 & 0,00 \\
\hline $\mathrm{Mn}$ & 0,02 & 0,00 & 0,00 & 0,00 & 0,00 & 0,02 & 0,00 & 0,01 & 0,00 & 0,00 & 0,00 & 0,00 & 0,00 & 0,00 & 0,00 & 0,00 & 0,00 & 0,00 & 0,00 & 0,00 & 0,00 & 0,00 & 0,00 \\
\hline & & & & & & & & & & & & & & & & & & & & & & & \\
\hline & & & & & & & & & & & & & & & & & & & & & & 0,01 & \\
\hline cat. & & 1,01 & 1,02 & 1,01 & 1,02 & 1,01 & 1,02 & 1,01 & 1,01 & 1,01 & 1,0 & 1,01 & 1,01 & 1,01 & 1,01 & 1,01 & 1,01 & 1,01 & 1,01 & 1,01 & 1,01 & 1,01 & $1,($ \\
\hline & 0,91 & 0,59 & 0,00 & 0,40 & 0,71 & 0,78 & 0,91 & 0,70 & 0,76 & 0,33 & 0,00 & 0,00 & 0,00 & 0,01 & 1,00 & 0,07 & 0,00 & 0,00 & 0,37 & 0,00 & 0,00 & 0,00 & \\
\hline $\mathrm{ra} /(\mathrm{Ta}$ & 0,55 & 0,13 & 0,10 & 0,00 & 0,00 & 0,70 & 0,14 & 0,41 & 0,79 & 0,00 & 0,00 & 0,00 & 0,00 & 0,00 & 0,00 & 0,00 & 0,00 & 0,00 & 0,00 & 0,00 & 0,00 & 0,00 & \\
\hline
\end{tabular}


Anexo III. Análisis de microsonda electrónica

\begin{tabular}{|c|c|c|c|c|c|c|c|c|c|c|c|c|c|c|c|c|c|c|c|}
\hline \multirow{2}{*}{$\begin{array}{l}\text { Mina/Zona } \\
\text { Roca }\end{array}$} & \multicolumn{2}{|c|}{ Mari Carmen } & \multicolumn{7}{|c|}{ Salmantina } & \multicolumn{3}{|c|}{ Carrasquera } & \multicolumn{3}{|c|}{ Teso de la Matanza } & \multicolumn{4}{|c|}{ Bon } \\
\hline & $\begin{array}{l}\text { Vena GE } \\
\end{array}$ & Vena GE & Vena LG & Vena LG & Vena LG & Vena LG & Vena LG & $\begin{array}{l}\text { Vena LG } \\
\end{array}$ & Vena LG & $\begin{array}{l}\text { Vena LG } \\
\text {. }\end{array}$ & Vena LG & $\begin{array}{l}\text { Vena LG } \\
\end{array}$ & Vena LG & Vena LG & Vena LG & Vena LG & Vena LG & Vena LG & Vena LG \\
\hline & $1775 B$ & $1775 B$ & 1691 & & 1691 & 1691 & 1691 & 1691 & 1699 & $1785 \mathrm{~B}$ & $1785 \mathrm{~B}$ & $1785 B$ & 1792 & 1792 & 1792 & 840 & 840 & 840 & 840 \\
\hline Análisis & 1.6 & 1.7 & 6.1 & 6.2 & 6.3 & 6.4 & 6.5 & 6.6 & 4.3 & 1.1 & 1.2 & 2.1 & 1.1 & 1.2 & 2.1 & 1.1 & 1.2 & 4.1 & 6.1 \\
\hline $\mathrm{Al}_{2} \mathrm{O}_{3}$ & 0,00 & 0,00 & 0,00 & 0,00 & 0,01 & 0,00 & 0,00 & 0,00 & 0,00 & 0,00 & 0,00 & 0,00 & 0,00 & 0,00 & 0,00 & 0,00 & 0,00 & 0,00 & 0,00 \\
\hline $\mathrm{CaO}$ & 0,53 & 0,54 & 0,54 & 0,54 & 0,56 & 0,56 & 0,53 & 0,57 & 0,56 & 0,55 & 0,56 & 0,56 & 0,51 & 0,53 & 0,52 & 0,58 & 0,56 & 0,54 & 0,54 \\
\hline $\mathrm{TiO}_{2}$ & 0,45 & 0,73 & 0,36 & 0,59 & 0,37 & 0,40 & 0,60 & 0,14 & 0,00 & 0,00 & 0,00 & 0,03 & 0,28 & 0,27 & 0,15 & 0,41 & 0,56 & 0,34 & 0,49 \\
\hline $\mathrm{V}_{2} \mathrm{O}_{5}$ & 0,00 & 0,03 & 0,03 & 0,00 & 0,00 & 0,03 & 0,00 & 0,00 & 0,03 & 0,00 & 0,01 & 0,01 & 0,03 & 0,03 & 0,00 & 0,01 & 0,00 & 0,00 & 0,04 \\
\hline $\mathrm{MnO}$ & 02 & 0,02 & 0,00 & 0,00 & 0,00 & 02 & 0,00 & 0,00 & 0,00 & 0,01 & Do & 0,00 & 0,00 & 00 & 0,00 & 0,03 & 0,01 &, 00 & 0,01 \\
\hline $\mathrm{FeO}$ & 0,01 & 0,00 & 0,08 & 0,07 & 0,12 & 0,11 & 0,09 & 0,01 & 0,05 & 0,04 & 0,03 & 0,18 & 0,05 & 0,08 & 0,07 & 0,06 & 0,07 & 0,04 & 0,05 \\
\hline $\mathrm{ZrO}_{2}$ & 0,0 & 0,00 & 0,00 & 0,00 & 0,00 & 0, & 0,00 & 0,00 & 0,00 & 0,00 & 0,00 & 0,00 & 0,00 & 0,00 & 0,00 & 0,00 & 0,00 & 0,00 & 0,00 \\
\hline $\mathrm{Nb}_{2} \mathrm{O}_{5}$ & 0,00 & 0,00 & 0,20 & 0,00 & 0,23 & 0,25 & 0,24 & 0,00 & 0,00 & 0,00 & 0,00 & 0,42 & 0,01 & 0,04 & 0,22 & 0,05 & 0,01 & 0,11 & 0,06 \\
\hline $\mathrm{SnO}_{2}$ & 99,94 & 99,00 & 98,87 & 99,29 & 98,51 & 98,79 & 98,83 & 99,55 & 99,64 & 99,90 & 99,75 & 99,05 & 98,72 & 98,84 & 99,05 & 98,06 & 99,47 & 96,40 & 97,99 \\
\hline $\mathrm{a}_{2} \mathrm{O}_{5}$ & 0,00 & 0,00 & 0,00 & 0,00 & 0,00 & 0,00 & 0,00 & 0,00 & 0,00 & 0,00 & 0,00 & 0,00 & 0,00 & 0,00 & 0,00 & 0,00 & 0,00 & 0,00 & 0,00 \\
\hline $\mathrm{WO}_{3}$ & 0,00 & 0,00 & 0,16 & 0,11 & 0,00 & 0,19 & 0,07 & 0,00 & 0,02 & 0,00 & 0,28 & 0,04 & 0,00 & 0,13 & 0,24 & 0,00 & 0,00 & 0,10 & 0,04 \\
\hline Total & 100,95 & 100,33 & 100,23 & 100,59 & 99,81 & 100,34 & 100,35 & 100,28 & 100,30 & 100,50 & 100,63 & 100,28 & 99,61 & 99,91 & 100,25 & 99,19 & 100,68 & 97,54 & 99,23 \\
\hline \multicolumn{20}{|c|}{ Número de iones con base en 20} \\
\hline $\mathrm{Ta}$ & 0,00 & 0,00 & 0,00 & 0,00 & 0,00 & 0,00 & 0,00 & 0,00 & 0,00 & 0,00 & 0,00 & 0,00 & 0,00 & 0,00 & 0,00 & 0,00 & 0,00 & 0,00 & 0,00 \\
\hline $\mathrm{Nb}$ & 0,00 & 0,00 & 0,00 & 0,00 & 0,00 & & 0,00 & 0,00 & 0,00 & 0,00 & & 0,00 & 0,00 & 00 & 0,00 & 0,00 & 0,00 & 0,00 & 0,00 \\
\hline & & 0,00 & & 0,00 & & & 0,00 & 0,00 & & 0,00 & 0,00 & 00 & 0,00 &, 00 & 0,00 & 0,00 & 0,00 & 0,00 & 0,00 \\
\hline & & & & & & & & & & & & & & & & & & 01 & 0,01 \\
\hline & & & & & & & & & & & & & & & & & & & 98 \\
\hline & & & & & & & & & & & & & & & & & & & 0,00 \\
\hline & & & & & & & & & & & & & & & & & & & 0,00 \\
\hline & 0,00 & 0,00 & 0,00 & 0,00 & 0,00 & 0, & 0,00 & 0,00 & 0,00 & 0,00 & 0,00 & 0,00 & 0,00 & 0,00 & 0,00 & 0,00 & 0,00 & 0,00 & 0,00 \\
\hline $\mathrm{Mn}$ & 0,00 & 0,00 & 0,00 & & 0,00 & & 0,00 & 00 & $0, c$ & 0,00 & 0,00 & 00 & 0,00 & 0,00 & 0,00 & 0,00 & 0,00 & 0,00 & 0,00 \\
\hline & 0,0 & & & & $0, \mathrm{C}$ & & 0,0 & & & & & & & 0,00 & 0,00 & 0,00 & 0,00 & 0,00 & 0,00 \\
\hline & & & & & & & & & & & & & & & & & & & 0,01 \\
\hline & & & & & & & & & & & & & & & & & & & \\
\hline & & & & & & & & & & & & & & & & & & 0,00 & 0,21 \\
\hline $\mathrm{Ta} /(\mathrm{Ta}+\mathrm{Nb})$ & 0,00 & 0,00 & 0,00 & 0,00 & 0,00 & 0,00 & 0,00 & 0,00 & 0,00 & 0,00 & 0,00 & 0,00 & 0,00 & 0,00 & 0,00 & 0,00 & 0,00 & 0,00 & 0,00 \\
\hline
\end{tabular}


Anexo III. Análisis de microsonda electrónica

\begin{tabular}{|c|c|c|c|c|c|c|c|c|c|c|c|c|c|c|c|c|c|c|c|c|c|c|c|}
\hline \multirow{2}{*}{$\begin{array}{l}\text { Mina/Zona } \\
\text { Roca }\end{array}$} & \multicolumn{16}{|c|}{ Salmantina } & \multicolumn{5}{|c|}{ Profunda } & \multicolumn{2}{|c|}{ Teso } \\
\hline & Vena LG & Vena LG & Vena LG & Vena LG & Vena LG & Vena LG & Vena LG & Vena LG & Vena LG & Vena LG & Vena LG & Vena LG & Vena LG & Vena LG & Vena LG & Vena LG & Vena LG & Vena LG & Vena LG & Vena LG & Vena LG & Vena LG & Vena LG \\
\hline Muestra & 846 & 846 & 846 & 846 & 846 & 846 & 846 & 846 & 846 & 846 & 846 & 846 & 846 & 846 & 846 & 1691 & $783 B$ & $783 B$ & $783 B$ & $783 \mathrm{~B}$ & $783 B$ & 1790 & 1790 \\
\hline Análisis & 1.1 & 1.2 & 1.3 & 1.4 & 2.1 & 2.3 & 3.1 & 3.2 & 3.3 & 3.4 & 3.5 & 3.6 & 3.7 & 3.8 & 3.9 & 4.1 & 1.1 & 1.2 & 1.3 & 1.4 & 1.5 & 2.1 & 2.2 \\
\hline $\mathrm{O}_{3}$ & 0,00 & 0,00 & 0,00 & 0,00 & 0,00 & 0,00 & 0,00 & 0,00 & 0,00 & 0,00 & 0,00 & 0,00 & 0,00 & 0,00 & 0,00 & 0,00 & 0,00 & 0,00 & 0,00 & 0,00 & 0,00 & 0,00 & 0,00 \\
\hline $\mathrm{CaO}$ & 0,01 & 0,03 & 0,05 & 0,02 & 0,03 & 0,02 & 0,03 & 0,03 & 0,02 & 0,01 & 0,04 & 0,01 & 0,01 & 0,02 & 0,02 & 0,02 & 0,01 & 0,00 & 0,03 & 0,01 & 0,02 & 0,01 & 0,01 \\
\hline $\mathrm{TiO}_{2}$ & 0,02 & 0,07 & 0,01 & 0,00 & 0,06 & 0,08 & 0,06 & 0,00 & 0,00 & 0,00 & 0,03 & 0,04 & 0,07 & 0,03 & 0,01 & 0,02 & 0,03 & 0,00 & 0,00 & 0,00 & 0,00 & 0,02 & 0,01 \\
\hline $\mathrm{I}_{2} \mathrm{O}_{5}$ & 0,02 & 0,00 & 0,00 & 0,00 & 0,00 & 0,00 & 0,00 & 0,01 & 0,00 & 0,00 & 0,00 & 0,00 & 0,00 & 0,00 & 0,00 & 0,00 & 0,00 & 0,01 & 0,01 & 0,00 & 0,00 & 0,00 & 0,00 \\
\hline An & 14,29 & 12,30 & 12,18 & 14,43 & 16,34 & 13,41 & 14,78 & 12,24 & 12,82 & 11,13 & 14,77 & 14,35 & 13,95 & 13,15 & 15,77 & 8,29 & 9,71 & 9,08 & 8,88 & 8,95 & 8,93 & 13,84 & 13,38 \\
\hline 0 & & 10,89 & & 8,79 & 6,95 & 10,11 & 8,20 & 10,85 & 10,10 & 12,02 & 8,66 & 8,85 & 9,29 & 10,12 & 7,06 & 14,59 & 13,42 & 13,91 & 14,16 & 14,06 & 14,13 & 9,36 & 9,98 \\
\hline $\mathrm{rO}_{2}$ & 0,70 & 0,80 & 0,85 & 0,84 & 0,65 & 0,73 & 0,81 & 0,83 & 0,81 & 0,86 & 0,93 & 0,88 & 0,74 & 0,95 & 0,72 & 0,92 & 0,82 & 0,95 & 0,91 & 0,74 & 0,85 & 0,92 & 0,90 \\
\hline $\mathrm{Nb}_{2} \mathrm{O}_{5}$ & 0,26 & 0,30 & 0,16 & 0,44 & 0,11 & 0,47 & 0,37 & 0,46 & 0,12 & 0,20 & 0,10 & 0,19 & 0,35 & 0,21 & 0,12 & 0,49 & 0,17 & 0,07 & 0,04 & 0,17 & 0,16 & 0,35 & 0,33 \\
\hline $\mathrm{nO}_{2}$ & 0,01 & 0,02 & 0,01 & 0,00 & 0,04 & 0,06 & 0,03 & 0,05 & 0,00 & 0,05 & 0,00 & 0,00 & 0,05 & 0,02 & 0,00 & 0,01 & 0,00 & 0,00 & 0,00 & 0,02 & 0,03 & 0,00 & 0,02 \\
\hline $\mathrm{Ta}_{2} \mathrm{O}_{5}$ & 0,00 & 0,13 & 0,00 & 0,00 & 0,00 & 0,01 & 0,11 & 0,00 & 0,04 & 0,00 & 0,00 & 0,00 & 0,00 & 0,00 & 0,04 & 0,00 & 0,00 & 0,00 & 0,00 & 0,00 & 0,00 & 0,00 & 0,07 \\
\hline $\mathrm{WO}_{3}$ & 76,36 & 76,43 & 75,58 & 75,34 & 74,60 & 74,60 & 74,92 & 75,83 & 76,99 & 75,14 & 75,98 & 76,66 & 75,87 & 74,69 & 75,23 & 75,17 & 75,78 & 75,73 & 76,17 & 75,70 & 75,95 & 75,23 & 75,53 \\
\hline & 100,75 & 100,98 & 99,64 & 99,86 & 98,78 & 99,49 & 99,31 & 100,31 & 100,90 & 99,42 & 100,52 & 100,99 & 100,32 & 99,19 & 98,98 & 99,52 & 99,95 & 99,76 & 100,21 & 99,66 & 100,07 & 99,74 & 100,23 \\
\hline \multicolumn{24}{|c|}{ Número de iones con base en 40} \\
\hline $\mathrm{Ta}$ & 0,00 & 0,00 & 0,00 & 0,00 & 0,00 & 0,00 & 0,00 & & 0,00 & 0,00 & 0,00 & 0,00 & 0,00 & 0,00 & 0,00 & 0,00 & 0,00 & 0,00 & 0,00 & 0,00 & 0,00 & 0,00 & 0,00 \\
\hline $\mathrm{Nb}$ & 0,01 & 0,01 & 0,00 & 0,01 & 0,00 & 0,01 & 0,01 & 0, & 0,00 & 0,00 & 0,00 & 0,00 & 0,01 & 0,00 & 0,00 & 0,01 & 0,00 & 0,00 & 0,00 & 0,00 & 0,00 & 0,01 & 0,01 \\
\hline & & & & & & 00 & & & & & & & & & 0,00 & & 0,00 & 0,00 & & 0,00 & 0,00 & 0,00 & 0,00 \\
\hline & & & & & & & & & & & & & & & & & & & & & & & \\
\hline & & & & & & & & & & & & & & & & & & & & & & & 0,00 \\
\hline & & & & & & & & & & & & & & & & & & & & & & & 0,98 \\
\hline & & & & & & 0 & & & & & & & & 0,00 & 0,00 & 0,0 & 0,00 & c & 0,00 & 0,00 & 0,00 & 0,00 & 0,00 \\
\hline & 0,02 & 0,02 & 0,02 & 0,02 & 0,02 & 0,02 & 0,02 & 0,02 & 0,02 & 0,02 & 0,02 & 0,02 & 0,02 & 0,02 & 0,02 & 0,02 & 0,02 & 0,02 & 0,02 & 0,02 & 0,02 & 0,02 & 0,02 \\
\hline $\mathrm{Fe}^{2+}$ & 0,38 & 0,46 & 0,46 & 0,37 & 0,26 & 0,38 & 0,35 & 0,46 & 0,42 & 0,51 & 0,35 & 0,37 & 0,39 & 0,40 & 0,30 & 0,62 & 0,57 & 0,59 & 0,60 & 0,60 & 0,60 & 0,39 & 0,42 \\
\hline $\mathrm{Fe}^{3+*}$ & & & & & & & & & & & & & & & & & & & & & 0,00 & & 0,00 \\
\hline & & & & & & & & & & & & & & & & & & & & & & & \\
\hline & & & & & & & & & & & & & & & & & & & & & & & 0, \\
\hline Ecat. & & 2,00 & & & 2,01 & 2,00 & 2,00 & 2,00 & $2, c$ & 2,00 & 2,00 & 2,00 & 2,00 & 1,99 & 2,00 & 2,00 & 2,00 & 2,00 & 2,00 & 2,00 & 2,00 & 2,00 & 2,0 \\
\hline & 0,61 & 0,53 & 0,53 & 0,62 & 0,70 & 0,57 & 0,65 & 0,53 & 0,56 & 0,48 & 0,63 & 0,62 & 0,60 & 0,57 & 0,69 & 0,37 & 0,42 & 0,40 & 0,39 & 0,39 & 0,39 & 0,60 & 0,58 \\
\hline & 0,00 & 0,20 & 0,00 & 0,00 & 0,00 & 0,01 & 0,15 & 0,00 & 0,15 & 0,00 & 0,00 & 0,00 & 0,00 & 0,00 & 0,16 & 0,00 & 0,02 & 0,00 & 0,00 & 0,00 & 0,00 & 0,00 & \\
\hline
\end{tabular}




\begin{tabular}{|c|c|c|c|c|c|c|c|c|c|c|c|c|c|c|c|c|}
\hline \multirow{2}{*}{$\begin{array}{l}\text { Mina/Zona } \\
\text { Roca }\end{array}$} & \multicolumn{7}{|c|}{ Bon } & \multicolumn{9}{|c|}{ El Jaque } \\
\hline & Vena LG & Vena LG & Vena LG & Vena LG & Vena LG & Vena LG & Vena LG & Vena G6 & Vena G6 & Vena G6 & Vena G6 & Vena G6 & Vena G6 & Vena G6 & Vena G6 & Vena G6 \\
\hline Muestra & 840 & 840 & 840 & 840 & 840 & 840 & 840 & 1069 & 1069 & 1069 & 1069 & 1069 & 1069 & 1069 & 1069 & 1069 \\
\hline Análisis & 2.1 & 3.1 & 3.2 & 5.1 & 5.2 & 5.3 & 6.2 & 2.1 & 2.1.2 & 2.2 & 2.2.2 & 2.3 & 2.3.2 & 4.1 & 4.2 & 4.3 \\
\hline $\mathrm{Al}_{2} \mathrm{O}_{3}$ & 0,00 & 0,00 & 0,00 & 0,00 & 0,00 & 0,00 & 0,00 & & & & & & & & & \\
\hline $\mathrm{CaO}$ & 0,03 & 0,04 & 0,03 & 0,03 & 0,03 & 0,04 & 0,02 & 0,04 & 0,00 & 0,04 & 0,02 & 0,03 & 0,02 & 0,03 & 0,01 & 0,02 \\
\hline $\mathrm{TiO}_{2}$ & 0,01 & 0,00 & 0,00 & 0,02 & 0,01 & 0,00 & 0,03 & - & - & - & - & - & & - & - & - \\
\hline $\mathrm{V}_{2} \mathrm{O}_{5}$ & 0,00 & 0,00 & 0,06 & 0,00 & 0,00 & 0,00 & 0,00 & - & - & & & & & & & \\
\hline $\mathrm{MnO}$ & 11,21 & 15,50 & 3,08 & 16,24 & 1,98 & 16,45 & 16,09 & 2,98 & 3,77 & 3,12 & 3,17 & 4,32 & 3,93 & 10,73 & 3,90 & 4,19 \\
\hline $\mathrm{FeO}$ & 12,23 & 7,71 & 20,22 & 7,15 & 21,50 & 7,04 & 6,78 & 21,68 & 20,13 & 21,53 & 19,95 & 17,24 & 19,54 & 12,83 & 19,24 & 19,39 \\
\hline $\mathrm{ZrO}_{2}$ & 0,88 & 0,71 & 0,95 & 0,74 & 0,89 & 0,59 & 0,86 & - & . & & - & & & & & \\
\hline $\mathrm{Nb}_{2} \mathrm{O}_{5}$ & 0,34 & 0,16 & 0,09 & 0,24 & 0,33 & 0,18 & 0,25 & - & - & - & - & - & - & - & - & . \\
\hline $\mathrm{SnO}_{2}$ & 0,00 & 0,00 & 0,02 & 0,01 & 0,03 & 0,00 & 0,00 & - & - & - & - & - & - & - & - & . \\
\hline $\mathrm{Ta}_{2} \mathrm{O}_{5}$ & 0,00 & 0,00 & 0,03 & 0,10 & 0,00 & 0,00 & 0,00 & - & - & - & - & & & & - & - \\
\hline $\mathrm{WO}_{3}$ & 75,49 & 76,00 & 75,95 & 75,02 & 74,90 & 73,27 & 76,14 & 75,27 & 76,36 & 75,05 & 77,67 & 78,34 & 76,64 & 75,85 & 76,61 & 76,34 \\
\hline Total & 100,19 & 100,12 & 100,43 & 99,56 & 99,67 & 97,56 & 100,16 & 99,971 & 100,265 & 99,738 & 100,811 & 99,925 & 100,136 & 99,446 & 99,760 & 99,932 \\
\hline \multicolumn{17}{|c|}{ Número de iones con base en 40} \\
\hline $\mathrm{Ta}$ & 0,00 & 0,00 & 0,00 & 0,00 & 0,00 & 0,00 & 0,00 & 0,00 & 0,00 & 0,00 & 0,00 & 0,00 & 0,00 & 0,00 & 0,00 & 0,00 \\
\hline $\mathrm{Nb}$ & 0,01 & 0,00 & 0,00 & 0,01 & 0,01 & 0,00 & 0,01 & 0,00 & 0,00 & 0,00 & 0,00 & 0,00 & 0,00 & 0,00 & 0,00 & 0,00 \\
\hline $\mathrm{v}$ & 0,00 & 0,00 & 0,00 & 0,00 & 0,00 & 0,00 & 0,00 & 0,00 & 0,00 & 0,00 & 0,00 & 0,00 & 0,00 & 0,00 & 0,00 & 0,00 \\
\hline $\mathrm{Ti}$ & 0,00 & 0,00 & 0,00 & 0,00 & 0,00 & 0,00 & 0,00 & 0,00 & 0,00 & 0,00 & 0,00 & 0,00 & 0,00 & 0,00 & 0,00 & 0,00 \\
\hline $\mathrm{Sn}$ & 0,00 & 0,00 & 0,00 & 0,00 & 0,00 & 0,00 & 0,00 & 0,00 & 0,00 & 0,00 & 0,00 & 0,00 & 0,00 & 0,00 & 0,00 & 0,00 \\
\hline w & 0,98 & 0,99 & 0,99 & 0,98 & 0,98 & 0,97 & 1,00 & 0,97 & 0,99 & 0,97 & 1,02 & 1,06 & 1,00 & 0,99 & 1,01 & 1,00 \\
\hline Al & 0,00 & 0,00 & 0,00 & 0,00 & 0,00 & 0,00 & 0,00 & 0,00 & 0,00 & 0,00 & 0,00 & 0,00 & 0,00 & 0,00 & 0,00 & 0,00 \\
\hline $\mathrm{Zr}$ & 0,02 & 0,02 & 0,02 & 0,02 & 0,02 & 0,01 & 0,02 & 0,00 & 0,00 & 0,00 & 0,00 & 0,00 & 0,00 & 0,00 & 0,00 & 0,00 \\
\hline $\mathrm{Fe}^{2+}$ & 0,50 & 0,32 & 0,85 & 0,27 & 0,88 & 0,21 & 0,29 & 0,781 & 0,822 & 0,772 & 0,845 & 0,751 & 0,826 & 0,521 & 0,82 & 0,82 \\
\hline $\mathrm{Fe}^{3+*}$ & 0,01 & 0,00 & 0,00 & 0,03 & 0,02 & 0,09 & 0,00 & 0,121 & 0,024 & 0,125 & 0,000 & 0,000 & 0,000 & 0,022 & 0,00 & 0,00 \\
\hline $\mathrm{Mn}$ & 0,48 & 0,66 & 0,13 & 0,69 & 0,08 & 0,71 & 0,69 & 0,13 & 0,16 & 0,13 & 0,14 & 0,19 & 0,17 & 0,46 & 0,17 & 0,18 \\
\hline $\mathrm{Ca}$ & 0,00 & 0,00 & 0,00 & 0,00 & 0,00 & 0,00 & 0,00 & 0,00 & 0,00 & 0,00 & 0,00 & 0,00 & 0,00 & 0,00 & 0,00 & 0,00 \\
\hline$\sum$ cat. & 2,00 & 2,00 & 2,00 & 2,00 & 1,99 & 2,00 & 2,00 & 2,00 & 2,00 & 2,00 & 2,00 & 2,00 & 2,00 & 2,00 & 2,00 & 2,00 \\
\hline$M n /(M n+F e)$ & 0,48 & 0,67 & 0,13 & 0,70 & 0,09 & 0,70 & 0,71 & 0,12 & 0,16 & 0,13 & 0,14 & 0,20 & 0,17 & 0,46 & 0,17 & 0,18 \\
\hline $\mathrm{Ta} /(\mathrm{Ta}+\mathrm{Nb})$ & 0,00 & 0,00 & 0,18 & 0,20 & 0,00 & 0,00 & 0,00 & 0,00 & 0,00 & 0,00 & 0,00 & 0,00 & 0,00 & 0,00 & 0,00 & 0,00 \\
\hline
\end{tabular}

Anexo III. Análisis de microsonda electrónica

\begin{tabular}{|c|c|c|c|c|}
\hline \multirow{2}{*}{$\frac{\text { Mina/Zona }}{\text { Roca }}$} & \multicolumn{4}{|c|}{ Bon } \\
\hline & Peg. LG & Peg. LG & Peg. LG & Peg. LG \\
\hline Muestra & 2277 & 2277 & 2277 & 2277 \\
\hline Análisis & 1.1 & 1.2 & 1.3 & 1.4 \\
\hline $\mathrm{Al}_{2} \mathrm{O}_{3}$ & 0,06 & 1,72 & 0,11 & 0,10 \\
\hline $\mathrm{CaO}$ & 0,02 & 0,06 & 0,04 & 0,03 \\
\hline $\mathrm{TiO}_{2}$ & 90,36 & 87,02 & 85,90 & 88,76 \\
\hline $\mathrm{V}_{2} \mathrm{O}_{5}$ & 0,48 & 0,41 & 0,42 & 0,53 \\
\hline $\mathrm{MnO}$ & 0,01 & 0,00 & 0,00 & 0,00 \\
\hline $\mathrm{FeO}$ & 2,28 & 2,80 & 3,05 & 2,44 \\
\hline $\mathrm{ZrO}_{2}$ & 0,00 & 0,00 & 0,00 & 0,00 \\
\hline $\mathrm{Nb}_{2} \mathrm{O}_{5}$ & 4,38 & 3,72 & 6,44 & 4,87 \\
\hline $\mathrm{SnO}_{2}$ & 1,50 & 0,41 & 1,71 & 1,46 \\
\hline $\mathrm{Ta}_{2} \mathrm{O}_{5}$ & 0,86 & 2,89 & 1,72 & 1,59 \\
\hline $\mathrm{wO}_{3}$ & 0,36 & 0,05 & 0,19 & 0,09 \\
\hline MgO & & - & & \\
\hline $\mathrm{HfO}_{2}$ & - & - & 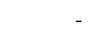 & - \\
\hline $\mathrm{ThO}_{2}$ & - & - & - & \\
\hline $\mathrm{UO}_{2}$ & - & - & & \\
\hline $\mathrm{Bi}_{2} \mathrm{O}_{3}$ & & & & \\
\hline \multirow{2}{*}{\multicolumn{5}{|c|}{ Número de iones con base en 20}} \\
\hline & & & & \\
\hline Ta & 0,00 & 0,01 & 0,01 & 0,01 \\
\hline $\mathrm{Nb}$ & 0,03 & 0,02 & 0,04 & 0,03 \\
\hline $\mathrm{v}$ & 0,00 & 0,00 & 0,00 & 0,00 \\
\hline $\mathrm{Ti}$ & 0,93 & 0,92 & 0,91 & 0,92 \\
\hline Sn & 0,01 & 0,00 & 0,01 & 0,01 \\
\hline w & & & & \\
\hline $\mathrm{Al}$ & 0,00 & 0,03 & 0,00 & 0,00 \\
\hline $\mathrm{Fe}$ & & & 0,04 & 0,03 \\
\hline $\mathrm{Mn}$ & & & 0,00 & 0,00 \\
\hline $\mathrm{zr}$ & 0,00 & 0,00 & 0,00 & 0,00 \\
\hline $\mathrm{Ca}$ & 0,00 & & 0,00 & \\
\hline $\mathrm{Mg}$ & 0,00 & & 0,00 & \\
\hline $\mathrm{Hf}$ & & & 0,00 & 0,00 \\
\hline U & 0,00 & 0,00 & 0,00 & 0,00 \\
\hline Th & 0,00 & 0,00 & 0,00 & 0,00 \\
\hline $\mathrm{Bi}$ & 0,00 & 0,00 & 0,00 & 0,00 \\
\hline & 0,03 & 0,03 & 0,04 & 0,03 \\
\hline $\mathrm{Mn} /(\mathrm{MI}$ & 0,01 & 0,00 & 0,00 & 0,00 \\
\hline $\mathrm{Ta} /(\mathrm{Ta}+\mathrm{Nb})$ & 0,11 & 0,32 & 0,14 & 0,16 \\
\hline
\end{tabular}


Anexo III. Análisis de microsonda electrónica

Rutilo (continuación)

\begin{tabular}{|c|c|c|c|c|c|c|c|c|c|c|c|c|c|c|c|c|c|c|c|c|c|c|c|}
\hline Mina/Zona & Bo & & & Horia & & Mari C & Carmen & & & & & & & & Salma & antina & & & & & & & \\
\hline Roca & Peg. LG & Peg. LG & Vena GE & Vena GE & Vena GE & Vena GE & Vena GE & Vena LG & Vena LG & Vena LG & Vena LG & Vena LG & Vena LG & Vena LG & Vena LG & Vena LG & Vena LG & Vena LG & Vena LG & Vena LG & Vena $L G$ & Vena $L G$ & Vena $L G$ \\
\hline Muestra & 2277 & 2277 & 1711A & 1711A & $1711 \mathrm{~A}$ & . $1775 B$ & $1775 B$ & 846 & 1691 & 1699 & 1699 & 1699 & 1699 & 1699 & $\quad 1699$ & 1699 & $\quad 1699$ & 1699 & 1699 & 1699 & 1699 & 1699 & 1699 \\
\hline Análisis & 2.2 & 3.1 & 1.7 & 1.8 & 1.9 & 1.1 & 1.2 & 2.2 & 3.1 & 1.A.1 & 1.A. 2 & 1.A.3 & 1.A.4 & 1.A. 5 & 1.A.6 & 1.A.7 & 1.B.1 & 1.B. 2 & 1.B13 & 1.B. 4 & 1.B. 5 & 1.B. 6 & 1.B.7 \\
\hline $\mathrm{Al}_{2} \mathrm{O}_{3}$ & 0,11 & 0,14 & 0,11 & 0,09 & 0,29 & 0,54 & 1,33 & 0,07 & 0,12 & 0,25 & 0,10 & 0,12 & 0,13 & 0,12 & 0,11 & 0,11 & 0,14 & 0,07 & 0,09 & 0,08 & 0,05 & 0,91 & 0,06 \\
\hline $\mathrm{CaO}$ & 0,15 & 0,03 & 0,08 & 0,05 & 0,02 & 0,15 & 0,13 & 0,01 & 0,42 & 0,00 & 0,00 & 0,02 & 0,00 & 0,01 & 0,01 & 0,03 & 0,00 & 0,00 & 0,00 & 0,00 & 0,00 & 0,00 & 0,02 \\
\hline $\mathrm{TiO}_{2}$ & 90,59 & 85,37 & 84,11 & 90,64 & 84,59 & 93,01 & 89,63 & 82,12 & 91,98 & 68,38 & 66,26 & 74,36 & 88,78 & 68,19 & 80,61 & 69,52 & 58,67 & 66,59 & 62,44 & 67,64 & 72,83 & 75,48 & 68,44 \\
\hline $\mathrm{V}_{2} \mathrm{O}_{5}$ & 0,53 & 0,42 & 0,69 & 1,13 & 0,92 & 0,33 & 0,44 & 0,67 & 0,39 & & & & & & & & & & & & & & \\
\hline $\mathrm{MnO}$ & 0,04 & 0,01 & 0,05 & 0,01 & 0,00 & 0,02 & 0,01 & 0,07 & 0,03 & 0,00 & 0,01 & 0,02 & 0,02 & 0,02 & 0,00 & 0,00 & 0,54 & 0,03 & 0,03 & 0,00 & 0,00 & 0,00 & 0,03 \\
\hline $\mathrm{FeO}$ & 1,79 & 2,98 & 3,12 & 0,61 & 3,11 & 1,94 & 1,75 & 3,39 & 1,76 & 4,81 & 5,17 & 4,66 & 2,35 & 5,97 & 2,22 & 5,03 & 7,19 & 5,16 & 6,05 & 5,65 & 4,94 & 4,34 & 5,48 \\
\hline $\mathrm{ZrO}_{2}$ & 0,00 & 0,00 & 0,00 & 0,02 & 0,00 & 0,00 & 0,11 & 0,00 & 0,02 & 0,00 & 0,00 & 0,00 & 0,00 & 0,00 & 0,00 & 0,00 & 0,00 & 0,00 & 0,00 & 0,00 & 0,00 & 0,00 & 0,00 \\
\hline $\mathrm{Nb}_{2} \mathrm{O}_{5}$ & 4,07 & 5,59 & 6,10 & 1,91 & 6,13 & 5,82 & 1,60 & 6,23 & 3,46 & 11,84 & 11,75 & 9,20 & 3,08 & 10,71 & 8,69 & 10,86 & 12,68 & 8,52 & 11,14 & 12,95 & 12,64 & 7,48 & 14,27 \\
\hline $\mathrm{SnO}_{2}$ & 1,41 & 1,77 & 2,25 & 4,42 & 2,18 & 3,70 & 1,97 & 1,14 & 1,94 & 0,85 & 0,95 & 1,03 & 0,73 & 0,98 & 0,93 & 0,90 & 2,22 & 0,83 & 1,02 & 1,09 & 1,12 & 0,93 & 1,17 \\
\hline $\mathrm{Ta}_{2} \mathrm{O}_{5}$ & 0,92 & 3,32 & 3,58 & 0,57 & 3,23 & 0,02 & 1,22 & 4,71 & 0,15 & 12,60 & 14,83 & 9,67 & 2,73 & 13,10 & 6,78 & 12,59 & 18,07 & 17,75 & 17,06 & 11,15 & 7,47 & 2,47 & 8,61 \\
\hline $\mathrm{WO}_{3}$ & 0,09 & 0,25 & 0,20 & 0,11 & 0,52 & 1,08 & 0,23 & 0,89 & 0,68 & & & & 0,21 & & & & & & 0,77 & & & 6,79 & 0,50 \\
\hline $\mathrm{MgO}$ & - & - & - & - & & & & & & 0,00 & 0,01 & 0,00 & 0,00 & 0,00 & 0,01 & 0,01 & 0,00 & 0,00 & 0,00 & 0,00 & 0,00 & 0,00 & 0,00 \\
\hline $\mathrm{HfO}_{2}$ & - & - & - & - & - & - & - & - & - & 1,46 & 1,28 & 1,50 & 1,87 & 1,36 & 1,52 & 1,30 & 1,10 & 1,28 & 1,29 & 1,33 & 1,45 & 1,70 & 1,37 \\
\hline $\mathrm{ThO}_{2}$ & - & - & - & - & - & - & - & - & - & 0,02 & 0,00 & 0,00 & 0,01 & 0,00 & 0,00 & 0,01 & 0,00 & 0,00 & 0,00 & 0,01 & 0,00 & 0,01 & 0,01 \\
\hline $\mathrm{UO}_{2}$ & - & - & - & - & - & - & - & - & - & 0,00 & 0,00 & 0,00 & 0,00 & 0,00 & 0,00 & 0,00 & 0,00 & 0,00 & 0,00 & 0,00 & 0,00 & 0,00 & 0,00 \\
\hline $\mathrm{Bi}_{2} \mathrm{O}_{3}$ & - & - & - & - & & - & & & & 0,00 & 0,00 & 0,00 & 0,00 & 0,05 & 0,00 & 0,00 & 0,03 & 0,04 & 0,00 & 0,00 & 0,00 & 0,00 & 0,00 \\
\hline Total & 99,70 & 99,87 & 100,32 & 99,56 & 100,98 & 106,62 & 98,41 & 99,28 & 100,95 & 100,21 & 100,37 & 100,57 & 99,92 & 100,50 & 100,89 & 100,38 & 100,62 & 100,27 & 99,89 & 99,90 & 100,49 & 100,10 & 99,96 \\
\hline Número de io & nes con bas & se en 20 & & & & & & & & & & & & & & & & & & & & & \\
\hline $\mathrm{Ta}$ & 0,00 & 0,01 & 0,01 & 0,00 & 0,01 & 0,00 & 0,00 & 0,02 & 0,00 & 0,05 & 0,06 & 0,04 & 0,01 & 0,05 & 0,03 & 0,05 & 0,08 & 0,08 & 0,07 & 0,05 & 0,03 & 0,01 & 0,04 \\
\hline $\mathrm{Nb}$ & 0,03 & 0,04 & 0,04 & 0, & 0,04 & & & & & 0 , & & & & & & & 0,09 & 0,06 & 0,08 & 0,09 & 0,08 & 0,05 & 0,10 \\
\hline v & 0,00 & 0,00 & 0,01 & 0,01 & 0,01 & 0,00 & 0,00 & 0,01 & 0,00 & 0,00 & 0,00 & 0,00 & 0,00 & 0,00 & 0,00 & 0,00 & 0,00 & 0,00 & 0,00 & 0,00 & 0,00 & 0,00 & 0,00 \\
\hline $\mathrm{Ti}$ & 0,94 & 0,90 & 0,89 & 0,94 & 0,89 & 0,91 & 0,95 & 0,89 & 0,94 & 0,79 & 0,77 & 0,83 & 0,93 & 0,79 & 0,87 & 0,80 & 0,71 & 0,78 & 0,75 & 0,78 & 0,81 & 0,84 & 0,78 \\
\hline Sn & 0, & 0,0 & 0,0 & & 0,01 & & 0,0 & 0 , & 0,01 & 0, & 0,01 & 0 & 0,00 & 0,01 & & 0,01 & 0,02 & 0,01 & 0,01 & 0,01 & 0,01 & 0,01 & 0,01 \\
\hline w & & 0, & 0,00 & & 0, & & & & & 0, & ,00 & & 0,00 & & & & 0,0 & & 0,0 & 0,00 & 0,00 & 0,03 & \\
\hline Al & & & & & & & & & & & & & & & & & & & & & 0,00 & 0,02 & 0,00 \\
\hline $\mathrm{Fe}$ & & & & & & & & & & & & & & & & & 0,10 & & 0,08 & 0,07 & 0,06 & 0,05 & 0,07 \\
\hline $\mathrm{Mn}$ & & 0, & 0,00 & & 0, & & & & & 0 & & & 0,00 & & & & 0,01 & 0,00 & 0,00 & 0,00 & 0,00 & 0,00 & 0,00 \\
\hline & & 0, & & & & & & & & & & & & & & & & & & & & 0,00 & \\
\hline $\mathrm{Ca}$ & & & & & & & & & & & & & & & & & & & & & & 00 & 00 \\
\hline $\mathrm{Mg}$ & & & & & & & & & & & & & & & & & & & & & 0,0 & 0,00 & 0,00 \\
\hline $\mathrm{Hf}$ & 0,00 & 0,00 & 0,00 & $0, \mathrm{C}$ & 0,00 & & 0,00 & 0,00 & 0,00 & 0,01 & 0,01 & 0,01 & 0,01 & 0,01 & 0,01 & 0,01 & 0,01 & 0,01 & 0,01 & 0,01 & 0,01 & 0,01 & 0,01 \\
\hline & 0, & 0,00 & 0,00 & 0, & 0,00 & 0, & 0,00 & 0, & 0,00 & 0,00 & 0,00 & 0,00 & 0,00 & 0,00 & 0,00 & 0,00 & 0,00 & 0,00 & 0,00 & 0,00 & 0,00 & 0,00 & 0,00 \\
\hline & & & & & & & & & & & & & & & & & & & & & & & \\
\hline & & & & & & & & & & & & & & & & & & & & & & 00 & \\
\hline & 0,02 & 0,0 & 1, & & & & & & & 1, & & 1, & & & & & 1,01 & 1,00 & 1,00 & 1,00 & 1,00 & 1,01 & 1,00 \\
\hline $\mathrm{Mn} /(\mathrm{N}$ & 0,02 & 0,00 & 0,02 & 0,01 & 0,00 & 0,01 & 0,00 & 0,02 & 0,02 & 0,00 & 0,00 & 0,00 & 0,01 & 0,00 & 0,00 & 0,00 & 0,07 & 0,01 & 0,01 & 0,00 & 0,00 & 0,00 & 0,01 \\
\hline $\mathrm{Ta} /(\mathrm{Ta}+\mathrm{Nb})$ & 0,12 & 0,26 & 0,26 & 0,15 & 0,24 & 0,00 & 0,31 & 0,31 & 0,03 & 0,39 & 0,43 & 0,39 & 0,35 & 0,42 & 0,32 & 0,41 & 0,46 & 0,56 & 0,48 & 0,34 & 0,26 & 0,17 & 0,27 \\
\hline
\end{tabular}


Anexo III. Análisis de microsonda electrónica

\begin{tabular}{|c|c|c|c|c|c|c|c|c|c|c|c|c|c|c|c|c|c|c|c|c|c|c|c|}
\hline \multirow{2}{*}{$\frac{\text { Mina/Zona }}{\text { Roca }}$} & \multicolumn{23}{|c|}{ Salmantina } \\
\hline & Vena LG & Vena LG & Vena LG & Vena LG & Vena LG & Vena LG & Vena LG & Vena LG & Vena LG & Vena LG & Vena LG & Vena LG & Vena LG & Vena LG & Vena LG & Vena LG & Vena LG & Vena LG & Vena LG & Vena LG & Vena LG & Vena LG & Vena $L G$ \\
\hline Muestra & 1699 & 1699 & 1699 & 1699 & 1699 & 1699 & 1699 & 1699 & 1699 & 1699 & 1699 & 1699 & 1699 & 1699 & 1699 & 1699 & 1699 & 1699 & 1699 & 1699 & 1699 & 1699 & 1699 \\
\hline Análisis & 2.1 & 2.2 & 2.3 & 2.4 & 2.5 & $3.1 \mathrm{a}$ & $3.1 \mathrm{~b}$ & 3.2 & $3.3 a$ & $3.3 \mathrm{~b}$ & 3.4 & 4.1 & 4.2 & 4.3 & 4.4 & 4.5 & 4.6 & 6.1 & 6.2 & 6.3 & 6.4 & 6.5 & 6.6 \\
\hline$\overline{\mathrm{Al}_{2} \mathrm{O}_{3}}$ & 0,06 & 0,11 & 0,08 & 0,07 & 0,08 & 0,09 & 0,15 & 0,66 & 3,34 & 0,23 & 0,10 & 0,07 & 0,07 & 0,08 & 0,02 & 0,04 & 0,08 & 0,16 & 0,31 & 0,08 & 0,09 & 0,05 & 0,08 \\
\hline $\mathrm{CaO}$ & 0,00 & 0,00 & 0,03 & 0,00 & 0,02 & 0,03 & 0,01 & 0,03 & 0,06 & 0,03 & 0,00 & 0,00 & 0,01 & 0,00 & 0,00 & 0,00 & 0,01 & 0,03 & 0,00 & 0,00 & 0,00 & 0,00 & 0,00 \\
\hline $\mathrm{TiO}_{2}$ & 62,35 & 61,27 & 59,47 & 63,27 & 66,54 & 61,23 & 79,53 & 84,36 & 74,43 & 59,08 & 88,21 & 90,58 & 91,38 & 91,53 & 86,52 & 96,77 & 84,32 & 83,63 & 85,87 & 87,11 & 80,67 & 92,37 & 80,53 \\
\hline $\mathrm{V}_{2} \mathrm{O}_{5}$ & & & & & & 0,27 & & & & 0,16 & & & & & & & & & & & & & \\
\hline $\mathrm{MnO}$ & 0,02 & 0,02 & 0,04 & 0,01 & 0,01 & 0,03 & 0,03 & 0,00 & 0,00 & 0,05 & 0,00 & 0,03 & 0,00 & 0,00 & 0,03 & 0,02 & 0,00 & 0,00 & 0,00 & 0,00 & 0,00 & 0,00 & 0,01 \\
\hline $\mathrm{FeO}$ & 5,60 & 6,46 & 5,65 & 6,09 & 5,52 & 7,54 & 3,05 & 1,79 & 2,30 & 9,56 & 2,87 & 2,15 & 1,50 & 2,08 & 2,79 & 0,55 & 3,14 & 1,68 & 1,89 & 1,51 & 3,38 & 0,88 & 2,93 \\
\hline $\mathrm{ZrO}_{2}$ & 0,00 & 0,00 & 0,00 & 0,00 & 0,00 & 0,00 & 0,01 & 0,00 & 0,00 & 0,00 & 0,02 & 0,02 & 0,00 & 0,02 & 0,00 & 0,02 & 0,00 & 0,00 & 0,00 & 0,00 & 0,00 & 0,00 & 0,00 \\
\hline $\mathrm{Nb}_{2} \mathrm{O}_{5}$ & 8,04 & 10,09 & 11,52 & 11,56 & 6,74 & 15,81 & 1,81 & 1,79 & 7,28 & 16,48 & 1,99 & 2,92 & 2,57 & 1,37 & 4,49 & 0,47 & 4,57 & 2,69 & 1,66 & 1,99 & 3,38 & 1,11 & 3,43 \\
\hline $\mathrm{SnO}_{2}$ & 0,78 & 1,00 & 0,88 & 0,98 & 0,95 & 1,39 & 1,00 & 0,84 & 0,33 & 0,89 & 0,88 & 0,85 & 0,66 & 0,73 & 0,53 & 0,06 & 0,74 & 0,10 & 0,12 & 0,19 & 0,85 & 0,23 & 0,70 \\
\hline $\mathrm{Ta}_{2} \mathrm{O}_{5}$ & 21,65 & 20,24 & 21,63 & 17,06 & 19,45 & 12,03 & 10,05 & 7,87 & 11,12 & 11,52 & 3,31 & 1,67 & 1,44 & 1,24 & 3,92 & 1,00 & 5,50 & 9,60 & 5,31 & 7,28 & 9,90 & 3,82 & 11,02 \\
\hline $\mathrm{WO}_{3}$ & 0,11 & & & & & 1,19 & 3,00 & 1,33 & & 1,04 & 0,80 & & 0,33 & 1,27 & & & & 0,35 & 3,10 & & 0,10 & & \\
\hline $\mathrm{MgO}$ & 0,00 & 0,00 & 0,00 & 0,01 & 0,00 & & 0,00 & 0,00 & 0,00 & & 0,00 & 0,00 & 0,00 & 0,01 & 0,02 & 0,00 & 0,00 & 0,00 & 0,00 & 0,00 & 0,00 & 0,02 & 0,01 \\
\hline $\mathrm{HfO}_{2}$ & 1,18 & 1,27 & 1,08 & 1,24 & 1,31 & - & 1,55 & 1,31 & 1,56 & - & 1,88 & 1,77 & 1,85 & 1,82 & 1,74 & 1,98 & 1,71 & 1,65 & 1,64 & 1,76 & 1,62 & 1,87 & 1,58 \\
\hline $\mathrm{ThO}_{2}$ & 0,00 & 0,00 & 0,01 & 0,01 & 0,01 & - & 0,00 & 0,00 & 0,00 & - & 0,00 & 0,00 & 0,00 & 0,00 & 0,00 & 0,00 & 0,00 & 0,02 & 0,00 & 0,00 & 0,00 & 0,00 & 0,00 \\
\hline $\mathrm{UO}_{2}$ & 0,00 & 0,00 & 0,00 & 0,00 & 0,00 & - & 0,00 & 0,00 & 0,00 & - & 0,00 & 0,00 & 0,00 & 0,00 & 0,00 & 0,01 & 0,00 & 0,06 & 0,04 & 0,04 & 0,00 & 0,00 & 0,00 \\
\hline $\mathrm{Bi}_{2} \mathrm{O}_{3}$ & 0,06 & 0,00 & 0,10 & 0,01 & 0,00 & & 0,00 & 0,01 & 0,00 & - & 0,05 & 0,00 & 0,03 & 0,00 & 0,03 & 0,00 & 0,00 & 0,00 & 0,05 & 0,07 & 0,00 & 0,05 & 0,09 \\
\hline \multirow{2}{*}{\multicolumn{9}{|c|}{ Número de iones con base en 20}} & 100,42 & 99,04 & 100,12 & 100,05 & 99,85 & 100,13 & 100,09 & 100,92 & 100,07 & 99,97 & 100,00 & 100,03 & 99,99 & 100,40 & 100,38 \\
\hline & & & 0,10 & 0,07 & 0,08 & 0,05 & 0,04 & 0,03 & 0,05 & 0,05 & 0,01 & 0,01 & 0,01 & 0,00 & & & 0,02 & 0,04 & & & & & 0,04 \\
\hline & & & & & & & & & & & & & & & & & & & & & & & 0,02 \\
\hline V & 0,00 & 0,00 & 0,00 & 0,00 & 0,00 & 0,00 & 0,00 & 0,00 & 0,00 & 0,00 & 0,00 & 0,00 & 0,00 & 0,00 & 0,00 & 0,00 & 0,00 & 0,00 & 0,00 & 0,00 & 0,00 & 0,00 & 0,00 \\
\hline $\mathrm{Ti}$ & 0,76 & 0,74 & 0,72 & 0,75 & 0,79 & 0,72 & 0,88 & 0,91 & 0,84 & 0,71 & 0,93 & & 0,95 & 95 & 0,92 & 98 & 0,91 & 0,91 & 0,92 & 0,93 & 0,89 & 0,96 & 0,89 \\
\hline Sn & 0,01 & 0,01 & 0,01 & & 0,01 & 0, & 0,01 & 0, & 0 & 0 , & & & 0,00 & & 0,00 & 00 & 0,00 & 0,00 & 0,00 & 0,00 & 0,01 & 0,00 & 0,00 \\
\hline & & & & & & & & & & & & & & & & & & & & & & 0,00 & 0,00 \\
\hline & & & & & & & & & & & & & & & & & & & 0, & & 0,00 & 0,00 & 0,00 \\
\hline & & & & & & & & & & & & & & & & & & & & & 0 &, 01 & 0,04 \\
\hline $\mathrm{Mn}$ & & & & & & & & & & & & & & & & & & & & & & & 00 \\
\hline & & & & & & & & & & & & & & & & & & & & & & & 00 \\
\hline & & & & & & & & & & & & & & & & & & & & & & 0,00 & 0,00 \\
\hline $\mathrm{Mg}$ & & 0, & & & & & & & & 0 & & & & & & & 0,0 & 0,00 & 0,0 & 0,00 & 0,00 & 0,00 & 0,00 \\
\hline$H f$ & 0 & & 0,00 & & $0, \mathrm{C}$ & & & & & 0 & & & & & & & & 01 & 0,01 & 0,01 & 0,01 & 0,01 & 0,01 \\
\hline & & & & & & & & & & & & & & & & & & & & & & & \\
\hline & & & & & & & & & & & & & & & & & & & & & & & \\
\hline & & & & & & & & & & & & & & & & & & & & & & & 0,00 \\
\hline$\sum$ cat. & 1,00 & 1,00 & 1,00 & 1,00 & 1,00 & 1,01 & 1,00 & 1,01 & 1,04 & 1,02 & 1,01 & 1,01 & 1,00 & 1,01 & 1,01 & 1,00 & 1,01 & 1,00 & 1,00 & 1,00 & 1,01 & 1,00 & 1,00 \\
\hline & 0,00 & 0,00 & 0,01 & 0,00 & 0,00 & 0,00 & 0,01 & 0,00 & 0,00 & 0,01 & 0,00 & 0,01 & 0,00 & 0,00 & 0,01 & 0,04 & 0,00 & 0,00 & 0,00 & 0,00 & 0,00 & 0,00 & 0,00 \\
\hline $\mathrm{Ta} /(\mathrm{Ta}+$ & 0,62 & 0,55 & 0,53 & 0,47 & 0,63 & 0,31 & 0,77 & 0,73 & 0,48 & 0,30 & 0,50 & 0,26 & 0,25 & 0,35 & 0,34 & 0,56 & 0,42 & 0,68 & 0,66 & 0,69 & 0,64 & 0,67 & 0,6 \\
\hline
\end{tabular}




\begin{tabular}{|c|c|c|c|c|c|c|c|c|}
\hline \multirow{2}{*}{ Mina/Zona } & \multicolumn{8}{|c|}{ Salmantina } \\
\hline & Vena LG & Vena LG & Vena LG & Vena LG & Vena LG & Vena LG & Vena LG & Vena LG \\
\hline Muestra & 1699 & 1699 & 1699 & 1699 & 1699 & 1699 & 1699 & 1699 \\
\hline Análisis & 6.7 & 6.8 & 6.9 & 7.1 & 7.2 & 7.3 & 7.4 & 7.5 \\
\hline $\mathrm{Al}_{2} \mathrm{O}_{3}$ & 0,08 & 0,12 & 0,15 & 0,10 & 0,10 & 0,14 & 0,29 & 0,12 \\
\hline $\mathrm{CaO}$ & 0,02 & 0,04 & 0,01 & 0,04 & 0,00 & 0,02 & 0,00 & 0,00 \\
\hline $\mathrm{TiO}_{2}$ & 89,01 & 85,30 & 91,76 & 73,73 & 53,21 & 79,91 & 74,13 & 77,48 \\
\hline \multicolumn{9}{|l|}{$\mathrm{V}_{2} \mathrm{O}_{5}$} \\
\hline & 0,03 & 0,00 & 0,00 & 0,01 & 0,03 & 0,00 & 0,02 & 0,02 \\
\hline $\mathrm{FeO}$ & 1,45 & 2,98 & 1,47 & 4,93 & 7,56 & 3,30 & 4,94 & 4,29 \\
\hline $\mathrm{ZrO}_{2}$ & 0,00 & 0,00 & 0,00 & 0,00 & 0,00 & 0,00 & 0,00 & 0,00 \\
\hline $\mathrm{Nb}_{2} \mathrm{O}_{5}$ & 2,44 & 2,53 & 1,39 & 9,39 & 11,55 & 5,20 & 8,54 & 6,92 \\
\hline $\mathrm{SnO}_{2}$ & 0,19 & 0,59 & 0,54 & 1,01 & 1,35 & 0,44 & 0,92 & 0,90 \\
\hline $\mathrm{Ta}_{2} \mathrm{O}_{5}$ & 5,56 & 6,84 & 2,57 & 10,06 & 25,59 & 9,27 & 10,59 & 8,85 \\
\hline $\mathrm{WO}_{3}$ & & & & 0,20 & & 0,13 & & \\
\hline MgO & 0,00 & 0,00 & 0,01 & 0,00 & 0,00 & 0,00 & 0,00 & 0,00 \\
\hline $\mathrm{HfO}_{2}$ & 1,69 & 1,71 & 1,89 & 1,41 & 0,99 & 1,50 & 1,45 & 1,58 \\
\hline $\mathrm{ThO}_{2}$ & 0,00 & 0,01 & 0,00 & 0,00 & 0,00 & 0,00 & 0,00 & 0,00 \\
\hline $\mathrm{UO}_{2}$ & 0,00 & 0,00 & 0,00 & 0,00 & 0,00 & 0,00 & 0,00 & 0,00 \\
\hline $\mathrm{Bi}_{2} \mathrm{O}_{3}$ & 0,07 & 0,00 & 0,00 & 0,08 & 0,00 & 0,01 & 0,03 & 0,02 \\
\hline Total & 100,53 & 100,12 & 99,79 & 100,95 & 100,39 & 99,90 & 100,93 & 100,18 \\
\hline \multirow{2}{*}{\multicolumn{9}{|c|}{ Vúmero de iones con base en 20}} \\
\hline Ta & & 0,03 & 0,01 & 0,04 & 0,12 & 0,04 & 0,04 & 0,04 \\
\hline $\mathrm{Nb}$ & 0,02 & 0,02 & 0,01 & 0,06 & 0,09 & 0,03 & 0,06 & 0,05 \\
\hline v & 0,00 & 0,00 & 0,00 & 0,00 & 0,00 & 0,00 & 0,00 & 0,00 \\
\hline $\mathrm{Ti}$ & 0,94 & 0,92 & 0,96 & 0,82 & 0,67 & 0,88 & 0,83 & 0,86 \\
\hline Sn & 0,00 & 0,00 & 0,00 & 0,01 & 0,01 & 0,00 & 0,01 & 0,01 \\
\hline w & 0,00 & 0,00 & 0,00 & 0,00 & 0,00 & 0,00 & 0,00 & 0,00 \\
\hline Al & 0,00 & 0,00 & 0,00 & 0,00 & 0,00 & 0,00 & 0,01 & 0,00 \\
\hline $\mathrm{Fe}$ & 0,02 & 0,04 & 0,02 & 0,06 & 0,11 & 0,04 & 0,06 & 0,05 \\
\hline $\mathrm{Mn}$ & 0,00 & 0,00 & 0,00 & 0,00 & 0,00 & 0,00 & 0,00 & 0,00 \\
\hline $\mathrm{Zr}$ & 0,00 & 0,00 & 0,00 & 0,00 & 0,00 & 0,00 & 0,00 & 0,00 \\
\hline $\mathrm{Ca}$ & 0,00 & 0,00 & 0,00 & 0,00 & 0,00 & 0,00 & 0,00 & 0,00 \\
\hline $\mathrm{Mg}$ & 0,00 & 0,00 & 0,00 & 0,00 & 0,00 & 0,00 & 0,00 & 0,00 \\
\hline $\mathrm{Hf}$ & 0,01 & 0,01 & 0,01 & 0,01 & 0,00 & 0,01 & 0,01 & 0,01 \\
\hline u & 0,00 & 0,00 & 0,00 & 0,00 & 0,00 & 0,00 & 0,00 & 0,00 \\
\hline Th & 0,00 & & & & 00 & 0,00 & 0,00 & 0,00 \\
\hline $\mathrm{Bi}$ & 0,00 & 0,00 & 0,00 & 0,00 & 0,00 & 0,00 & 0,00 & 0,00 \\
\hline Ecat. & 1,00 & 1,01 & 1,01 & 1,01 & 1,00 & 1,00 & 1,01 & 1,01 \\
\hline $\mathrm{Mn} / / \mathrm{n}$ & 0,02 & 0,00 & 0,00 & 0,00 & 0,00 & 0,00 & 0,00 & 0,00 \\
\hline $\mathrm{Ta} /(\mathrm{Ta}+\mathrm{Nb})$ & 0,58 & 0,62 & 0,53 & 0,39 & 0,57 & 0,52 & 0,43 & 0,43 \\
\hline
\end{tabular}

\begin{tabular}{|c|c|c|c|c|c|c|c|c|c|c|}
\hline \multirow{2}{*}{$\frac{\text { Mina/Zona }}{\text { Roca }}$} & \multicolumn{10}{|c|}{ Salmantina } \\
\hline & Vena LG & $\begin{array}{l}\text { Vena LG } \\
\end{array}$ & Vena LG & Vena LG & Vena LG & $\begin{array}{l}\text { Vena LG } \\
\end{array}$ & Vena LG & Vena LG & Vena LG & Vena LG \\
\hline Muestra & 1699 & 1699 & 1699 & 1699 & 1699 & 1699 & 1699 & 1699 & 1699 & 1699 \\
\hline Análisis & 2.1 & 2.2 & 2.3 & 2.4 & 3.2 & 3.3 & 5.1 & 5.2 & 5.3 & 5.4 \\
\hline $\mathrm{Al}_{2} \mathrm{O}_{3}$ & 0,00 & 0,01 & 0,01 & 0,01 & 0,01 & 0,00 & 0,21 & 0,05 & 0,01 & 0,00 \\
\hline $\mathrm{CaO}$ & 0,02 & 0,02 & 0,04 & 0,03 & 0,03 & 0,03 & 0,03 & 0,03 & 0,00 & 0,00 \\
\hline $\mathrm{TiO}_{2}$ & 2,14 & 2,85 & 4,44 & 2,97 & 8,82 & 4,24 & 2,67 & 2,19 & 2,96 & 2,81 \\
\hline $\mathrm{V}_{2} \mathrm{O}_{5}$ & 0,00 & 0,00 & 0,04 & 0,01 & 0,03 & 0,00 & & & & \\
\hline $\mathrm{MnO}$ & 6,47 & 7,35 & 2,61 & 4,50 & 4,25 & 5,04 & 6,20 & 4,19 & 3,25 & 3,61 \\
\hline $\mathrm{FeO}$ & 13,65 & 12,96 & 15,02 & 14,68 & 12,98 & 13,86 & 12,45 & 13,50 & 11,76 & 13,17 \\
\hline $\mathrm{ZrO}_{2}$ & 0,17 & 0,17 & 0,00 & 0,01 & 0,00 & 0,00 & 0,15 & 0,01 & 0,00 & 0,08 \\
\hline $\mathrm{Nb}_{2} \mathrm{O}_{5}$ & 43,83 & 47,67 & 40,36 & 39,47 & 38,30 & 41,93 & 40,41 & 35,39 & 22,07 & 31,28 \\
\hline $\mathrm{SnO}_{2}$ & 0,55 & 0,57 & 1,62 & 1,03 & 0,99 & 1,12 & 0,67 & 0,58 & 0,75 & 0,68 \\
\hline $\mathrm{Ta}_{2} \mathrm{O}_{5}$ & 12,67 & 14,84 & 33,36 & 24,53 & 22,82 & 21,64 & 20,03 & 29,00 & 54,68 & 31,23 \\
\hline $\mathrm{WO}_{3}$ & 20,25 & 12,56 & 2,05 & 9,71 & 9,82 & 10,88 & 16,99 & 14,70 & 4,20 & 17,00 \\
\hline $\mathrm{MgO}$ & & & & -0 & - & 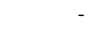 & 0,00 & 0,00 & 0,00 & 0,01 \\
\hline $\mathrm{HfO}_{2}$ & - & - & - & - & - & - & 0,10 & 0,10 & 0,18 & 0,13 \\
\hline $\mathrm{ThO}_{2}$ & - & - & - & - & $\begin{array}{c}- \\
-\end{array}$ & - & 0,00 & 0,01 & 0,00 & 0,00 \\
\hline $\mathrm{UO}_{2}$ & - & - & - & - & - & - & 0,09 & 0,10 & 0,00 & 0,00 \\
\hline $\mathrm{Bi}_{2} \mathrm{O}_{3}$ & - & - & - & - & - & - & 0,00 & 0,20 & 0,06 & 0,10 \\
\hline Total & 99,73 & 99,00 & 99,56 & 96,95 & 98,04 & 98,73 & 100,00 & 100,06 & 99,91 & 100,11 \\
\hline \multicolumn{11}{|c|}{ Número de iones con base en 20} \\
\hline$\overline{T a}$ & 0,07 & 0,08 & 0,20 & & & & 0.12 & & 0,36 & 0,19 \\
\hline $\mathrm{Nb}$ & 0,42 & & & & & & & & 0,24 & 0,32 \\
\hline & 0,00 & 0,00 & 0,00 & 0 , & & 0,00 & 0,00 & 0,00 & 0,00 & 0,00 \\
\hline $\mathrm{Ti}$ & 0,03 & 0,04 & 0,07 & 0,05 & 0,14 & 0,07 & 0,04 & 0,04 & 0,05 & 0,05 \\
\hline $\mathrm{Sr}$ & & & & & & & & & &, 01 \\
\hline w & & & & & & & & & & 10 \\
\hline A & & & & & & & & & & 00 \\
\hline & & & & & & & & & & 25 \\
\hline & & & & & & & & & &, 07 \\
\hline 2 & & & & & & & 0,00 & 00 & 0,00 &, 00 \\
\hline $\mathrm{Ca}$ & & & & & & & & 00 & 0,00 & 00 \\
\hline & & & & & & & & & & 00 \\
\hline & & & & & & & & & & \\
\hline & & & & & & & & & 0,00 & 0,00 \\
\hline Th & & 0, & & & & & 0,00 & 00 & 0,00 & 0,00 \\
\hline $\mathrm{Bi}$ & 0,00 & & & & & & & 00 & 0,00 & 0,00 \\
\hline$\Sigma c c$ & 1,00 & 1, & 1, & & & & & 0,99 & 0,99 & \\
\hline & 0, & & & & & & & 0,24 & 0,22 & 0,22 \\
\hline $\mathrm{Ta} /(\mathrm{Ta}+\mathrm{Nb})$ & 0,15 & 0,16 & 0,33 & 0,27 & 0,26 & 0,24 & 0,23 & 0,33 & 0,60 & 0,38 \\
\hline
\end{tabular}


Anexo III. Análisis de microsonda electrónica

\begin{tabular}{|c|c|c|c|c|c|c|c|c|c|c|c|c|c|c|c|c|c|c|c|c|c|}
\hline \multicolumn{21}{|c|}{ Cruz del Rayo } & \multirow{2}{*}{$\begin{array}{l}\text { Canalita } \\
\text { Peg. CEG }\end{array}$} \\
\hline Roca & D. grtico. & D. grtico. & D. grtico. & D. grtico. & D. grtico. & D. grtico. & D. grtico. & D. grtico. D & D. grtico. D & D. grtico. & D. grtico. & D. grtico. & D. grtico. & D. grtico. & D. grtico. D & D. grtico. & D. grtico. & D. greis, & D. greis. & D. greis. & \\
\hline Muestra & $805 \mathrm{~B}$ & $805 \mathrm{~B}$ & $805 B$ & $805 \mathrm{~B}$ & $805 B$ & $805 B$ & $805 B$ & $805 \mathrm{~B}$ & $805 B$ & $805 B$ & $805 B$ & $3805 B$ & $805 \mathrm{~B}$ & $805 B$ & $805 \mathrm{~B}$ & $805 B$ & $805 B$ & $2298 B$ & $2298 B$ & $2298 B$ & $1066 \mathrm{~A}$ \\
\hline Análisis & 1.2 & 1.3 & 1.5 & 1.6 & 1.7 & 2.1.1 & 2.1 .2 & 2.1 .3 & 2.1.4 & 2.2 & 2.3 & 2.4 & 2.5 & 2.6 & 3.1 & 3.2 & 3.3 & 3.9 & 8.1 & 8.7 & 1.3 \\
\hline $\mathrm{Al}_{2} \mathrm{O}_{3}$ & 0,02 & 0,01 & 0,25 & 0,02 & 0,06 & 0,07 & 0,02 & 0,01 & 0,02 & 0,10 & 0,01 & 0,01 & 0,03 & 0,00 & 0,01 & 0,02 & 0,03 & 0,01 & 0,02 & 0,05 & 0,01 \\
\hline $\mathrm{CaO}$ & 0,04 & 0,03 & 0,08 & 0,04 & 0,03 & 0,02 & 0,04 & 0,01 & 0,04 & 0,03 & 0,03 & 0,02 & 0,04 & 0,02 & 0,04 & 0,02 & 0,03 & 0,01 & 0,03 & 0,02 & 0,10 \\
\hline $\mathrm{TiO}_{2}$ & 2,07 & 1,87 & 1,98 & 1,98 & 1,60 & 3,48 & 3,46 & 3,59 & 3,12 & 2,57 & 2,32 & 4,75 & 4,36 & 4,72 & 4,09 & 3,87 & 3,65 & 2,03 & 1,34 & 1,67 & 0,34 \\
\hline $\mathrm{V}_{2} \mathrm{O}_{5}$ & 0,03 & 0,02 & 0,00 & 0,01 & 0,00 & 0,02 & 0,00 & 0,01 & 0,00 & 0,01 & 0,00 & 0,02 & 0,02 & 0,04 & 0,00 & 0,02 & 0,01 & 0,00 & 0,00 & 0,00 & 0,02 \\
\hline $\mathrm{MnO}$ & 7,19 & 7,19 & 7,16 & 7,27 & 7,06 & 1,15 & 3,86 & 5,56 & 5,56 & 4,48 & 5,43 & 2,50 & 1,88 & 6,38 & 1,23 & 1,60 & 5,05 & 7,44 & 8,81 & 8,26 & 4,72 \\
\hline $\mathrm{FeO}$ & 8,76 & 8,98 & 10,84 & 8,78 & 9,57 & 15,34 & 13,33 & 12,26 & 12,47 & 12,59 & 12,30 & 14,44 & 14,64 & 11,34 & 15,84 & 15,42 & 12,09 & 10,48 & 9,76 & 10,54 & 11,85 \\
\hline $\mathrm{ZrO}_{2}$ & 0,31 & 0,09 & 0,08 & 0,33 & 0,03 & 0,02 & 0,06 & 0,56 & 0,35 & 0,00 & 0,28 & 0,00 & 0,00 & 0,00 & 0,00 & 0,00 & 1,58 & 0,62 & 0,00 & 0,00 & 0,02 \\
\hline $\mathrm{Nb}_{2} \mathrm{O}_{5}$ & 31,25 & 31,09 & 33,71 & 32,09 & 30,34 & 42,68 & 47,13 & 53,12 & 53,75 & 49,10 & 49,39 & 44,15 & 45,56 & 50,87 & 46,38 & 48,01 & 49,42 & 52,08 & 55,07 & 57,92 & 36,31 \\
\hline $\mathrm{SnO}_{2}$ & 1,02 & 0,84 & 0,69 & 0,86 & 1,03 & 2,15 & 1,55 & 1,45 & 1,30 & 1,59 & 0,73 & 1,92 & 2,63 & 1,45 & 1,43 & 1,75 & 1,12 & 0,74 & 0,58 & 0,45 & 0,61 \\
\hline $\mathrm{Ta}_{2} \mathrm{O}_{5}$ & 47,95 & 48,59 & 42,23 & 47,55 & 49,23 & 35,80 & 31,47 & 23,00 & 22,79 & 28,98 & 29,87 & 32,22 & 30,78 & 23,87 & 31,76 & 29,50 & 26,46 & 24,00 & 22,37 & 20,50 & 45,69 \\
\hline $\mathrm{WO}_{3}$ & 0,48 & 0,86 & 2,07 & 0,53 & 0,40 & 0,00 & 0,00 & 0,18 & 0,26 & 0,37 & 0,46 & 0,06 & 0,22 & 1,22 & 0,20 & 0,11 & 0,07 & 0,81 & 1,05 & 0,94 & 0,26 \\
\hline Total & 99,11 & 99,58 & 99,09 & 99,46 & 99,36 & 100,74 & 100,92 & 99,76 & 99,64 & 99,80 & 100,81 & 100,09 & 100,16 & 99,90 & 100,96 & 100,31 & 99,50 & 98,21 & 99,04 & 100,34 & 99,94 \\
\hline \multicolumn{22}{|c|}{ Número de iones con base en 60} \\
\hline $\mathrm{Ta}$ & 0,91 & 0,92 & 0,79 & 0,90 & 0,94 & 0,62 & 0,54 & 0,38 & 0,38 & 0,50 & 0,51 & 0,55 & 0,53 & 0,40 & 0,54 & 0,50 & 0,45 & 0,41 & 0,38 & 0,34 & 0,85 \\
\hline $\mathrm{Nb}$ & 0,99 & 0,98 & 1,05 & 1,01 & 0,96 & 1,24 & 1,34 & 1,47 & 1,49 & 1,40 & 1,40 & 1,26 & 1,30 & 1,41 & 1,31 & 1,36 & 1,40 & 1,49 & 1,55 & 1,59 & 1,13 \\
\hline v & 0,00 & 0,00 & 0,00 & 0,00 & 0,00 & 0,00 & 0,00 & 0,00 & 0,00 & 0,00 & 0,00 & 0,00 & 0,00 & 0,00 & 0,00 & 0,00 & 0,00 & 0,00 & 0,00 & 0,00 & 0,00 \\
\hline $\mathrm{Ti}$ & & 0, & & & & & & & & & & & 0 , & & 0,19 & & 0,17 & 0,10 & 0,06 & 0,08 & 0,02 \\
\hline Sn & 0,03 & 0,03 & 0,02 & 0,03 & & 0, & & & 0,04 & & 0,02 & & 0,07 & 0,04 & 0,04 & 0,0 & 0,03 & 0,02 & 0,02 & 0,01 & 0,02 \\
\hline W & & & & & & 0, & & & & & & & & & & & 0,00 & 01 & 02 & 01 & 0,00 \\
\hline Al & 0,00 & 0,00 & 0,02 & 0,00 & 0,01 & 0,01 & 0,00 & 0,00 & 0,00 & 0,01 & 0,00 & 0,00 & 0,00 & 0,00 & 0,00 & 0,00 & 0,00 & 0,00 & 0,00 & 0,00 & 0,00 \\
\hline$B$ site & 2,05 & 2,04 & 2,01 & 2,05 & 2,03 & 2,10 & 2,08 & 2,07 & 2,06 & 2,08 & 2,05 & 2,10 & 2,11 & 2,08 & 2,09 & 2,09 & 2,06 & 2,03 & 2,02 & 2,03 & 2,02 \\
\hline $\mathrm{Fe}$ & 0,51 & 0,52 & 0,62 & 0,51 & 0,56 & 0,82 & 0,70 & 0,63 & 0,64 & 0,66 & 0,65 & 0,76 & 0,77 & 0,58 & 0,83 & 0,81 & 0,63 & 0,55 & 0,51 & 0,53 & 0,68 \\
\hline $\mathrm{Mn}$ & 0,4 & 0,42 & & 0,43 & & 0,06 & & 0,29 & & & 0,29 & 0,13 & 0,10 & 0,33 & 0,07 & 0,08 & 0,27 & 0,40 & 0,46 & 0,42 & 0,27 \\
\hline $\mathrm{Zr}$ & & & & & & & & & & & & & & & & & & & & & 0,00 \\
\hline & & & & & & & & & & & & & & & & & & 0,00 & 0,00 & 0,00 & 0,01 \\
\hline A site & 0,95 & 0,95 & 1,05 & 0,95 & 0,98 & 0,89 & 0,91 & 0,94 & 0,94 & 0,90 & 0,94 & 0,90 & 0,87 & 0,91 & 0,90 & 0,89 & 0,95 & 0,97 & 0,97 & 0,96 & 0,96 \\
\hline $\mathrm{Mn} /(\mathrm{M}$ & 0,45 & 0,45 & 0,40 & 0,46 & 0,43 & 0,07 & 0,23 & 0,31 & 0,31 & 0,26 & 0,31 & 0,15 & 0,12 & 0,36 & 0,07 & 0,10 & 0,30 & 0,42 & 0,48 & 0,44 & 0,29 \\
\hline $\mathrm{Ta} /(\mathrm{Ta}+\mathrm{Nb})$ & 0,48 & 0,48 & 0,43 & 0,47 & 0,49 & 0,34 & 0,29 & 0,21 & 0,20 & 0,26 & 0,27 & 0,31 & 0,29 & 0,22 & 0,29 & 0,27 & 0,24 & 0,22 & 0,20 & 0,18 & 0,43 \\
\hline
\end{tabular}


Anexo III. Análisis de microsonda electrónica

\begin{tabular}{|c|c|c|c|c|c|c|c|c|c|c|c|c|c|c|c|c|c|c|c|c|c|c|c|}
\hline \multirow{2}{*}{$\begin{array}{l}\text { Mina/Zona } \\
\text { Roca }\end{array}$} & \multicolumn{18}{|c|}{ Cruz del Rayo } & \multicolumn{5}{|c|}{$\begin{array}{l}\text { La Canalita } \\
\end{array}$} \\
\hline & D. greis. & D. greis. & D. greis. & D. greis. & D. greis. & D. greis. & D. greis. & D. greis. & D. greis. & D. greis. & D. greis. & D. greis. & D. greis. & D. greis. & D. greis. & UT & UT & UT & Peg. CEG & Peg. CEG & Peg. CEG & Peg. CEG & Peg. CEG \\
\hline Muestra & $2298 B$ & $2298 B$ & $2298 B$ & $2298 B$ & $2298 B$ & $2298 B$ & $2298 B$ & $2298 B$ & $2298 B$ & $2298 B$ & $2298 B$ & $2298 B$ & $2298 B$ & $2298 B$ & $2298 B$ & 1894 & 1894 & 1894 & - $811 \mathrm{~A}$ & $811 \mathrm{~A}$ & $811 \mathrm{~A}$ & $811 \mathrm{~A}$ & 814-A \\
\hline Análisis & 3.10 & 6.1 & 6.2 & 6.3 & 6.4 & 6.5 & 6.6 & 8.2 & 8.3 & 8.4 & 8.5 & 8.6 & 8.8 & 8.9 & 8.10 & 1.1 & 1.2 & 1.3 & 1.3 & 1.4 & 2.3 & 2.5 & 2.1 \\
\hline $\mathrm{Al}_{2} \mathrm{O}_{3}$ & 0,02 & 0,01 & 0,01 & 0,01 & 0,01 & 0,02 & 0,02 & 0,01 & 0,01 & 0,03 & 0,02 & 0,03 & 0,00 & 0,01 & 0,00 & 0,01 & 0,65 & 0,05 & 0,02 & 0,00 & 0,03 & 0,02 & \\
\hline $\mathrm{CaO}$ & 0,03 & 0,03 & 0,06 & 0,03 & 0,03 & 0,03 & 0,03 & 0,00 & 0,03 & 0,03 & 0,03 & 0,04 & 0,05 & 0,08 & 0,19 & 0,01 & 0,03 & 0,01 & 0,08 & 0,07 & 0,11 & 0,09 & \\
\hline $\mathrm{TiO}_{2}$ & 1,60 & 1,47 & 1,21 & 1,77 & 2,14 & 1,45 & 1,12 & 0,69 & 0,90 & 0,88 & 0,84 & 1,14 & 1,92 & 0,84 & 1,33 & 1,56 & 1,36 & 1,11 & 0,01 & 0,00 & 0,03 & 0,00 & \\
\hline $\mathrm{V}_{2} \mathrm{O}_{5}$ & 0,00 & 0,01 & 0,03 & 0,01 & 0,00 & 0,01 & 0,00 & 0,01 & 0,00 & 0,04 & 0,01 & 0,00 & 0,01 & 0,01 & 0,00 & 0,02 & 0,03 & 0,00 & 0,00 & 0,00 & 0,00 & 0,00 & \\
\hline $\mathrm{MnO}$ & 12,50 & 12,35 & & 12,38 & 11,29 & 11,90 & 12,99 & 9,61 & 13,35 & 14,00 & 14,31 & 14,10 & 14,22 & 14,37 & 13,71 & 10,71 & 14,55 & 14,32 & 16,98 & 16,40 & 14,93 & 16,04 & 13,04 \\
\hline $\mathrm{FeO}$ & 5,56 & 5, & & 31 & 6,50 & & 5,46 & 8,84 & 5,78 & 4,54 & 4,31 & 4,11 & 4,19 & 4,25 & 4,69 & 9,46 & 5,65 & 5,28 & 0,23 & 0,23 & 0,30 & 0,25 & 2,46 \\
\hline $\mathrm{ZrO}_{2}$ & 0,03 & 0,20 & 0,04 & 0,13 & 0,00 & 0,00 & 0,00 & 0,00 & 0,00 & 0,00 & 0,00 & 0,00 & 0,75 & 0,00 & 0,02 & 0,00 & 0,12 & 0,38 & 0,00 & 0,00 & 0,00 & 0,00 & \\
\hline $\mathrm{Nb}_{2} \mathrm{O}_{5}$ & 48,53 & 49,80 & 53,08 & 49,26 & 45,02 & 49,53 & 53,88 & 55,73 & 58,68 & 53,65 & 57,64 & 54,34 & 54,83 & 55,95 & 53,89 & 55,81 & 54,82 & 52,02 & 51,37 & 42,62 & 35,36 & 43,66 & 32,66 \\
\hline $\mathrm{SnO}_{2}$ & 0,48 & 0,42 & 0,37 & 0,44 & 0,48 & 0,48 & 0,40 & 0,25 & 0,30 & 0,25 & 0,28 & 1,08 & 0,37 & 2,18 & 0,45 & 0,54 & 0,26 & 0,31 & 0,21 & 0,21 & 6,57 & 0,38 & \\
\hline $\mathrm{Ta}_{2} \mathrm{O}_{5}$ & 30,41 & 26,62 & 24,88 & 27,54 & 30,91 & 28,12 & 23,71 & 25,02 & 19,09 & 25,52 & 22,72 & 24,53 & 23,33 & 21,32 & 23,09 & 19,74 & 21,33 & 25,13 & 31,67 & 40,42 & 42,19 & 38,87 & 51,3 \\
\hline $\mathrm{WO}_{3}$ & 1,05 & 1,72 & 1,03 & 2,44 & 3,80 & 2,11 & 1,42 & 0,24 & 1,16 & 0,65 & 0,50 & 0,76 & 0,68 & 1,01 & 0,92 & 2,13 & 1,12 & 1,35 & 0,09 & 0,11 & 0,00 & 0,20 & \\
\hline Total & 100,20 & 98,35 & 98,85 & 99,82 & 100,17 & 99,76 & 99,03 & 100,38 & 99,30 & 99,58 & 100,65 & 100,13 & 100,35 & 100,02 & 98,28 & 100,00 & 99,92 & 99,97 & 100,66 & 100,07 & 99,50 & 99,50 & 99,52 \\
\hline \multicolumn{24}{|c|}{ Número de iones con base en 60} \\
\hline $\mathrm{Ta}$ & 0,53 & 0,46 & 0,43 & 0,47 & 0,54 & 0,49 & 0,40 & 0,42 & 0,32 & 0,43 & 0,38 & 0,41 & 0,39 & 0,36 & 0,39 & 0,33 & 0,36 & 0,43 & 0,55 & 0,73 & 0,79 & 0,70 & 0,99 \\
\hline $\mathrm{Nb}$ & 1,39 & 1,44 & 1,51 & 1,41 & 1,31 & 1,42 & 1,53 & 1,56 & 1,62 & 1,52 & 1,59 & 1,52 & 1,52 & 1,56 & 1,53 & 1,54 & 1,53 & 1,48 & 1,47 & 1,28 & 1,10 & 1,31 & 1,04 \\
\hline & 0,00 & & & & & & & & & 0, & & & & 0, & & 0,0 & & 0,00 & & 0,00 & & 0,00 & 0,00 \\
\hline & & & & & & & & & & & & & & & & & & & & & & 0,00 & \\
\hline & & & & & & & & & & & & & & & & & & & & 0,01 & & 0,01 & \\
\hline & & & & & & & & & & & & & & & & & & & & & & 0,00 & \\
\hline & & & & & & & & & & & & 0,00 & & 0,00 & & 0,0 & & 0,0 & 0,00 & 0,00 & & 0,00 & \\
\hline B site & 2,03 & 2,02 & 2,02 & 2,02 & 2,03 & 2,02 & 2,02 & 2,02 & 2,01 & 2,02 & 2,02 & 2,03 & 2,02 & 2,03 & 2,02 & 2,00 & 2,02 & 1,99 & 2,03 & 2,02 & 2,09 & 2,03 & 2,03 \\
\hline $\mathrm{Fe}$ & 0,30 & 0,31 & 0,33 & 0,31 & 0,35 & 0,32 & 0,29 & 0,46 & 0,30 & 0,24 & 0,22 & 0,21 & 0,22 & 0,22 & 0,25 & 0,48 & 0,29 & 0,28 & 0,01 & 0,01 & 0,02 & 0,01 & 0,15 \\
\hline & & & & & & & & & & & & & & & & & & & & & & 0,90 & \\
\hline & & & & & & & & & & & & & & & & & & & & & & 0,00 & \\
\hline & & & & & & & & & & & & & & & & & & & & & & 0,01 & \\
\hline site & 0,97 & 0,98 & & 0, & 0,96 & 0,97 & 0,98 & 0,96 & 0,99 & 0,98 & 0,96 & 0,96 & 0,98 & 0,97 & 0,99 & 1,04 & 1,06 & 1,05 & 0,93 & 0,94 & 0,89 & 0,92 & 0,93 \\
\hline & 0,69 & 0,69 & 0, & 0,68 & 0, & 0,66 & 0,71 & 0,52 & 0,7 & 0,76 & 0,77 & 0,78 & 0,77 & 0,77 & 0,75 & 0,53 & 0,72 & 0,73 & 0,99 & 0,99 & 0,98 & 0,99 & 0,84 \\
\hline $\mathrm{Ta} /(\mathrm{Ta}+\mathrm{Nb})$ & 0,27 & 0,24 & 0,22 & 0,25 & 0,29 & 0,25 & 0,21 & 0,21 & 0,16 & 0,22 & 0,19 & 0,21 & 0,20 & 0,19 & 0,20 & 0,18 & 0,19 & 0,23 & 0,27 & 0,36 & 0,42 & 0,35 & \\
\hline
\end{tabular}




\begin{tabular}{|c|c|c|c|c|c|c|c|c|c|c|c|}
\hline \multirow{2}{*}{$\frac{\text { Mina/Zona }}{\text { Roca }}$} & \multicolumn{11}{|c|}{ La Canalita } \\
\hline & $\begin{array}{l}\text { Peg. CEG } \\
\end{array}$ & $\begin{array}{l}\text { Peg. CEG } \\
\text { Pen }\end{array}$ & 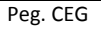 & 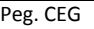 & Peg. CEG & Peg. CEG & Peg. CEG & $\begin{array}{l}\text { Peg. CEG } \\
\text {. }\end{array}$ & eg. CEG & Peg. CEG & Peg. CEG \\
\hline Muestra & 814-A & 814-A & 814-A & $814 B$ & $814 \mathrm{~B}$ & $814 \mathrm{~B}$ & $818 \mathrm{~A}$ & $818 \mathrm{~A}$ & $818 \mathrm{~A}$ & 854 & 854 \\
\hline Análisis & 2.2 & 4.2 & 4.3 & 2.2 & 2.3 & 2.4 & 2.1 & 3.1 & 3.2 & 2.1 & 3.1 \\
\hline $\mathrm{Al}_{2} \mathrm{O}_{3}$ & & & 0,00 & 0,26 & 0,04 & 0,00 & 0,07 & 0,03 & 0,01 & & \\
\hline $\mathrm{CaO}$ & - & - & 0,02 & 0,04 & 0,04 & 0,06 & 0,06 & 0,03 & 0,04 & - & \\
\hline $\mathrm{TiO}_{2}$ & - & - & 0,04 & 0,13 & 0,20 & 0,16 & 0,69 & 0,03 & 0,06 & - & \\
\hline $\mathrm{V}_{2} \mathrm{O}_{5}$ & - & - & 0,00 & 0,00 & 0,00 & 0,00 & 0,00 & 0,02 & 0,00 & & \\
\hline $\mathrm{MnO}$ & 15,51 & 15,43 & 14,62 & 9,74 & 12,25 & 9,90 & 17,81 & 17,84 & 17,88 & 15,74 & 15,44 \\
\hline $\mathrm{FeO}$ & 1,96 & 2,94 & 2,85 & 6,45 & 3,52 & 5,41 & 0,97 & 0,13 & 0,09 & 1,73 & 2,03 \\
\hline $\mathrm{ZrO}_{2}$ & - & & 0,00 & 0,00 & 0,00 & 0,00 & 0,00 & 0,00 & 0,00 & & \\
\hline $\mathrm{Nb}_{2} \mathrm{O}_{5}$ & 61,05 & 59,53 & 60,33 & 32,78 & 34,02 & 35,05 & 59,16 & 54,54 & 52,60 & 60,29 & 59,65 \\
\hline $\mathrm{SnO}_{2}$ & - & & 0,30 & 0,06 & 0,20 & 0,24 & 0,74 & 0,34 & 0,18 & - & \\
\hline $\mathrm{Ta}_{2} \mathrm{O}_{5}$ & 20,40 & 22,04 & 21,38 & 49,71 & 48,21 & 48,63 & 19,39 & 27,92 & 27,44 & 22,30 & 22,48 \\
\hline $\mathrm{WO}_{3}$ & & & 0,16 & 0,00 & 0,62 & 0,55 & 1,97 & 0,53 & 0,75 & & \\
\hline Total & 98,92 & 99,94 & 99,70 & 99,17 & 99,11 & 100,00 & 100,86 & 101,40 & 99,05 & 100,06 & 99,60 \\
\hline \multicolumn{12}{|c|}{ Número de iones con base en 60} \\
\hline Ta & 0,34 & 0,37 & 0,36 & 0,96 & 0,92 & 0,92 & 0,32 & 0,47 & 0,48 & 0,37 & 0,38 \\
\hline $\mathrm{Nb}$ & 1,70 & 1,65 & 1,67 & 1,05 & 1,08 & 1,10 & 1,62 & 1,53 & 1,51 & 1,67 & 1,66 \\
\hline & 0,00 & 0,00 & & 00 & & & 0 & 0,00 & 00 & 0,00 & 0,00 \\
\hline & & 0,00 & & 0 , & & & & 0,0 & & 0,00 & 0,00 \\
\hline & & 0,00 & & & & & & & & 0,00 & 0,00 \\
\hline w & & 0,00 & & & & & & & & 0,00 & 0,00 \\
\hline & & & & & & & & & & & 0,00 \\
\hline B site & 2,04 & 2,02 & 2,04 & 2,03 & 2,03 & 2,04 & 2,02 & 2,02 & 2,01 & 2,04 & 2,04 \\
\hline $\mathrm{Fe}$ & 0,10 & 0,15 & 0,15 & 0,38 & 0,21 & 0,31 & 0,05 & 0,01 & 0,00 & 0,09 & 0,10 \\
\hline $\mathrm{Mn}$ & 0,81 & 0,80 & & 0,58 & & & 91 & 0,94 & 0,96 & 0,82 & 0,80 \\
\hline & & & & & & & & & & & \\
\hline & & & & & & & & & & & 0,00 \\
\hline & 0,91 & 0,95 & 0,9 & & & & 0,96 & 0,95 & 0,97 & 0,90 & 0,91 \\
\hline $\mathrm{Mn} / \mathrm{l}$ & 0,89 & 0,84 & 0,84 & 0,60 & 0,78 & 0,65 & 0,95 & 0,99 & 1,00 & 0,90 & 0,89 \\
\hline $\mathrm{Ta} /(\mathrm{Ta}+\mathrm{Nb})$ & 0,17 & 0,18 & 0,18 & 0,48 & 0,46 & 0,45 & 0,16 & 0,24 & 0,24 & 0,18 & 0,18 \\
\hline
\end{tabular}

\begin{tabular}{|c|c|c|c|c|c|c|c|}
\hline \multirow{2}{*}{$\frac{\text { Mina/Zona }}{\text { Roca }}$} & \multicolumn{7}{|c|}{ La Canalita } \\
\hline & Peg. CEG & Peg. CEG & Peg. CEG & Peg. CEG & Peg. CEG & Peg. CEG & Peg. CEG \\
\hline Muestra & $814 B$ & $814 \mathrm{~B}$ & $814 B$ & $814 \mathrm{~B}$ & $814 \mathrm{~B}$ & $814 \mathrm{~B}$ & $814 \mathrm{~B}$ \\
\hline Análisis & 3.1 & 3.2 & 3.5 & 3.6 & 5.1 & 5.2 & 5.4 \\
\hline $\mathrm{Al}_{2} \mathrm{O}_{3}$ & 0,01 & 0,01 & 0,01 & 0,02 & 0,00 & 0,00 & 0,01 \\
\hline $\mathrm{CaO}$ & 0,62 & 0,49 & 0,03 & 0,36 & 0,01 & 0,01 & 0,02 \\
\hline $\mathrm{TiO}_{2}$ & 0,23 & 0,25 & 0,24 & 0,18 & 0,14 & 0,09 & 0,13 \\
\hline $\mathrm{V}_{2} \mathrm{O}_{5}$ & 0,03 & 0,00 & 0,00 & 0,00 & 0,01 & 0,00 & 0,00 \\
\hline $\mathrm{MnO}$ & 0,42 & 0,52 & 0,46 & 0,57 & 0,55 & 0,50 & 0,55 \\
\hline $\mathrm{FeO}$ & 13,10 & 13,37 & 13,34 & 12,38 & 13,85 & 13,56 & 13,65 \\
\hline $\mathrm{ZrO}_{2}$ & 0,00 & 0,17 & 0,22 & 0,00 & 0,00 & 0,00 & 0,00 \\
\hline $\mathrm{Nb}_{2} \mathrm{O}_{5}$ & 5,88 & 7,36 & 3,97 & 5,76 & 4,95 & 4,41 & 5,72 \\
\hline $\mathrm{SnO}_{2}$ & 0,21 & 0,47 & 0,09 & 0,79 & 0,17 & 0,25 & 0,13 \\
\hline $\mathrm{Ta}_{2} \mathrm{O}_{5}$ & 74,09 & 74,12 & 79,72 & 75,35 & 81,15 & 80,08 & 75,90 \\
\hline $\mathrm{WO}_{3}$ & 0,00 & 0,00 & 0,00 & 0,12 & 0,00 & 0,00 & 0,00 \\
\hline Total & 94,58 & 96,76 & 98,08 & 95,53 & 100,81 & 98,91 & 96,11 \\
\hline \multicolumn{8}{|c|}{ Número de iones con base en 60} \\
\hline $\mathrm{Ta}$ & 1,74 & 1,69 & 1,84 & 1,76 & 1,81 & 1,83 & 1,76 \\
\hline $\mathrm{Nb}$ & 0,23 & 0,28 & 0,15 & 0,22 & 0,18 & 0,17 & 0,22 \\
\hline $\mathrm{v}$ & 0,00 & 0,00 & 0,00 & 0,00 & 0,00 & 0,00 & 0,00 \\
\hline $\mathrm{Ti}$ & 0,01 & 0,02 & 0,02 & 0,01 & 0,01 & 0,01 & 0,01 \\
\hline $\mathrm{Sn}$ & 0,01 & 0,02 & 0,00 & 0,03 & 0,01 & 0,01 & 0,01 \\
\hline w & 0,00 & 0,00 & 0,00 & 0,00 & 0,00 & 0,00 & 0,00 \\
\hline & 0,00 & 0,00 & 0,00 & 0,00 & 0,00 & 0,00 & 0,00 \\
\hline B site & 1,99 & 2,00 & 2,01 & 2,02 & 2,01 & 2,01 & 2,00 \\
\hline $\mathrm{Fe}$ & 0,95 & 0,94 & 0,95 & 0,89 & 0,95 & 0,95 & 0,97 \\
\hline $\mathrm{Mn}$ & 0,03 & 0,04 & 0,03 & 0,04 & 0,04 & 0,04 & 0,04 \\
\hline $\mathrm{Zr}$ & 0,00 & 0,01 & & 0,00 & 0,00 & 0,00 & 0,00 \\
\hline $\mathrm{Ca}$ & 0, & 0,04 & & 0,03 & 00 & 0,00 & 0,00 \\
\hline A site & 1,03 & 1,02 & 0,99 & 0,96 & 0,99 & 0,99 & 1,02 \\
\hline $\mathrm{Mn} /(\mathrm{Mn}+\mathrm{Fe})$ & $\begin{array}{lll}0,03 & & \end{array}$ & 0,04 & 0,03 & 0,04 & 0,04 & 0,04 & 0,04 \\
\hline $\mathrm{Ta} /(\mathrm{Ta}+\mathrm{Nb})$ & 0,88 & 0,86 & 0,92 & 0,89 & 0,91 & 0,92 & 0,89 \\
\hline
\end{tabular}




\section{Tantalita-(Fe)}

\begin{tabular}{|c|c|c|c|c|c|c|c|c|c|c|}
\hline \multirow{2}{*}{$\begin{array}{l}\text { Mina/Zona } \\
\text { Roca }\end{array}$} & \multirow{2}{*}{$\frac{\text { Salmant. }}{L G}$} & \multicolumn{6}{|c|}{ Cruz del Rayo } & \multicolumn{3}{|c|}{ La Canalita } \\
\hline & & D. greis. & UT & UT & UT & UT & UT & Peg. CEG & & eg. CEG \\
\hline Muestra & & $2298 \mathrm{~B}$ & 1895 & 1895 & 1895 & 1895 & 1895 & $1066 \mathrm{~A}$ & $1066 \mathrm{~A}$ & $1066 \mathrm{~A}$ \\
\hline álisis & 5.1 & 7.2 & 2.1 & 2.2 & 2.3 & 2.4 & 2.5 & 1.2 & 1.4 & 2.1 \\
\hline $\mathrm{I}_{2} \mathrm{O}_{3}$ & 0,02 & 0,05 & 0,38 & 0,16 & 0,03 & $\overline{0,49}$ & 0,18 & 0,06 & 0,04 & $\overline{0,02}$ \\
\hline $\mathrm{aO}$ & 0,04 & 0,05 & 0,01 & 0,04 & 0,01 & 0,00 & 0,02 & 0,09 & 0,04 & 0,03 \\
\hline $\mathrm{iO}_{2}$ & 1,83 & 0,93 & 1,36 & 1,06 & 0,37 & 0,44 & 0,76 & 0,35 & 0,62 & 0,40 \\
\hline $\mathrm{V}_{2} \mathrm{O}_{5}$ & 0,03 & 0,01 & & & & & & 0,00 & 0,00 & 0,00 \\
\hline $\mathrm{MnO}$ & 3,10 & 6,48 & 5,98 & 4,77 & 6,59 & 6,47 & 5,07 & 7,74 & 4,63 & 7,43 \\
\hline 20 & 12,53 & 7,80 & 7,34 & 5,94 & 7,85 & 7,30 & 7,45 & 8,43 & 11,19 & 8,62 \\
\hline $\mathrm{ZrO}_{2}$ & 0,00 & 2,25 & 0,00 & 0,00 & 0,00 & 0,00 & 0,00 & 0,00 & 0,00 & 0,00 \\
\hline $\mathrm{Nb}_{2} \mathrm{O}_{5}$ & 24,39 & 23,29 & 13,75 & 12,55 & 19,33 & 22,00 & 15,46 & 28,45 & 27,67 & 26,64 \\
\hline $\mathrm{SnO}_{2}$ & 1,17 & 5,02 & 0,45 & 0,34 & 0,17 & 0,40 & 0,20 & 0,24 & 1,02 & 0,17 \\
\hline $\mathrm{a}_{2} \mathrm{O}_{5}$ & 55,16 & 54,42 & 70,53 & 74,93 & 65,33 & 60,73 & 68,63 & 54,56 & 54,20 & 55,97 \\
\hline $\mathrm{NO}_{3}$ & 0,20 & 0,13 & - & - & & - & - & 0,00 & 0,04 & 0,01 \\
\hline $\mathrm{HfO}_{2}$ & - & & 0,15 & 0,16 & 0,11 & 0,31 & 0,15 & - & - & - \\
\hline $\mathrm{UO}_{2}$ & - & & 0,12 & 0,09 & 0,03 & 0,03 & 0,10 & - & - & \\
\hline $\mathrm{Bi}_{2} \mathrm{O}_{3}$ & - & & 0,00 & 0,00 & 0,02 & 0,04 & 0,00 & - & - & \\
\hline Total & 98,48 & 100,42 & 100,07 & 100,04 & 99,88 & 98,18 & 98,02 & 99,90 & 99,45 & 99,30 \\
\hline \multicolumn{11}{|c|}{ Número de iones con base en 60} \\
\hline Ta & 1,09 & 1,08 & 1,48 & 1,60 & 1,35 & 1,25 & 1,47 & 1,06 & 1,06 & $\overline{1,11}$ \\
\hline & & 0,77 & 0,48 & & & 0,75 & & 0,92 & & 0,88 \\
\hline & & & & & & & & & & 0,00 \\
\hline & & & 0,08 & & & & & & & 0,02 \\
\hline in & 0,04 & 0,16 & 0,02 & 0,01 & 0,01 & 0,01 & 0,01 & 0,01 & 0,03 & 0,01 \\
\hline N & 0,00 & 0,00 & 0,00 & 0,00 & 0,00 & 0,00 & 0,00 & 0,00 & 0,00 & 0,00 \\
\hline & & & & & & & & & & 0,00 \\
\hline & & & 2,10 & & 2,0 & 2,09 & 2,09 & 2,02 & 2,03 & 2,01 \\
\hline & 0,7 & 0,4 & 0,48 & & 0,5 & 0,46 & 0,49 & 0,51 & & 0,52 \\
\hline & & & & & & & & & & 46 \\
\hline & & & & & & & & & & 00 \\
\hline & & & & & & & 0 & & & 0,00 \\
\hline & & 0,0 & & & & 0,01 & 00 & 0,00 & 00 & 0,00 \\
\hline & & & & & & & bo & 0 & 00 & 00 \\
\hline & & & & & & & & & & 00 \\
\hline & & & & & & & & & & \\
\hline & 0,2 & 0,4 & 0,45 & 0,4 & & 0,4 & 0,41 & 0,48 & 0,3 & 0,47 \\
\hline $\mathrm{Ta} /(\mathrm{Ta}+\mathrm{Nb})$ & 0,58 & 0,58 & 0,76 & 0,78 & 0,67 & 0,62 & 0,73 & 0,54 & 0,54 & 0,56 \\
\hline
\end{tabular}

Microlita

\begin{tabular}{|c|c|c|c|c|c|c|c|}
\hline \multirow{2}{*}{$\begin{array}{l}\text { Mina/Zona } \\
\text { Roca }\end{array}$} & \multicolumn{7}{|c|}{ La Canalita } \\
\hline & peg. CEG & peg. CEG & peg. CEG & eg. CEG & peg. CEG & peg. CEG & peg. CEG \\
\hline Muestra & $811 \mathrm{~A}$ & $811 \mathrm{~A}$ & $811 \mathrm{~A}$ & $811 \mathrm{~A}$ & $814 \mathrm{~B}$ & $814 \mathrm{~B}$ & $814 \mathrm{~B}$ \\
\hline Análisis & 1.2 & 1.5 & 2.1 & 2.2 & 3.3 & 3.4 & 5.3 \\
\hline $\mathrm{Al}_{2} \mathrm{O}_{3}$ & 0,00 & 0,00 & 0,00 & 0,00 & 0,06 & 0,09 & 0,05 \\
\hline $\mathrm{CaO}$ & 10,47 & 10,36 & 10,75 & 10,23 & 14,61 & 14,52 & 13,57 \\
\hline $\mathrm{TiO}_{2}$ & 0,00 & 0,00 & 0,00 & 0,00 & 0,22 & 0,19 & 0,05 \\
\hline $\mathrm{V}_{2} \mathrm{O}_{5}$ & 0,00 & 0,00 & 0,00 & 0,02 & 0,01 & 0,06 & 0,00 \\
\hline $\mathrm{MnO}$ & 0,13 & 0,02 & 0,00 & 0,01 & 0,13 & 0,22 & 0,08 \\
\hline $\mathrm{FeO}$ & 0,00 & 0,01 & 0,00 & 0,04 & 0,33 & 0,23 & 0,29 \\
\hline $\mathrm{ZrO}_{2}$ & 0,00 & 0,00 & 0,00 & 0,00 & 0,88 & 0,54 & 0,00 \\
\hline $\mathrm{Nb}_{2} \mathrm{O}_{5}$ & 8,04 & 9,91 & 11,70 & 8,39 & 4,44 & 4,78 & 5,68 \\
\hline $\mathrm{SnO}_{2}$ & 0,05 & 0,05 & 0,07 & 0,09 & 0,39 & 0,32 & 0,30 \\
\hline $\mathrm{Ta}_{2} \mathrm{O}_{5}$ & 73,32 & 70,14 & 69,51 & 73,46 & 76,52 & 77,22 & 75,25 \\
\hline $\mathrm{WO}_{3}$ & 0,53 & 0,14 & 0,16 & 0,10 & 0,00 & 0,00 & 0,00 \\
\hline $\mathrm{UO}_{2}$ & 0,01 & 0,00 & 0,00 & 0,02 & 0,00 & 0,00 & 0,00 \\
\hline $\mathrm{PbO}$ & 0,05 & 0,00 & 0,00 & 0,00 & 0,08 & 0,00 & 0,00 \\
\hline $\mathrm{Na}_{2} \mathrm{O}$ & 6,05 & 5,86 & 6,05 & 5,88 & 0,45 & 0,45 & 0,74 \\
\hline $\mathrm{Sb}_{2} \mathrm{O}_{3}$ & 0,01 & 0,00 & 0,01 & 0,03 & 0,00 & 0,00 & 0,00 \\
\hline $\mathrm{Bi}_{2} \mathrm{O}_{3}$ & 0,00 & 0,00 & 0,00 & 0,00 & 0,00 & 0,02 & 0,00 \\
\hline $\mathrm{F}$ & 1,70 & 1,73 & 1,79 & 1,74 & 0,49 & 0,39 & 0,68 \\
\hline Total & 99,64 & 97,50 & 99,30 & 99,29 & 98,40 & 98,87 & 96,39 \\
\hline \multicolumn{8}{|c|}{ Número de iones con base en $2 B$} \\
\hline Ta & 1,68 & 1,62 & 1,56 & 1,67 & 1,79 & 1,78 & 1,76 \\
\hline $\mathrm{Nb}$ & 0,31 & 0,38 & 0,44 & 0,32 & 0,17 & 0,18 & 0,22 \\
\hline V & 0,00 & 0,00 & 0,00 & 0,00 & 0,00 & 0,00 & 0,00 \\
\hline $\mathrm{Ti}$ & 0,00 & 0,00 & 0,00 & 0,00 & 0,01 & 0,01 & 0,00 \\
\hline Sn & 0,00 & 0,00 & 0,00 & 0,00 & 0,01 & 0,01 & 0,01 \\
\hline w & 0,01 & 0,00 & 0,00 & 0,00 & 0,00 & 0,00 & 0,00 \\
\hline Al & 0,00 & 0,00 & 0,00 & 0 & 0,01 & 0,01 & 0,01 \\
\hline B site & 2,00 & 2,00 & 2,00 & 2,00 & 2,00 & 2,00 & 2,00 \\
\hline $\mathrm{Fe}$ & 0,00 & 0,00 & 0,00 & 0,00 & 0,02 & 0,02 & 0,02 \\
\hline $\mathrm{Mn}$ & 0,01 & 0,00 & 0,00 & 0,00 & 0,01 & 0,02 & 0,01 \\
\hline $\mathrm{Zr}$ & 0,00 & 0,00 & 0,00 & 0,00 & 0,04 & 0,02 & 0,00 \\
\hline $\mathrm{Ca}$ & 0,95 & 0,94 & 0,95 & 0,92 & 1,35 & 1,32 & 1,25 \\
\hline $\mathrm{Hf}$ & 0,00 & 0,00 & 0,00 & & 0,00 & 0,00 & 0,00 \\
\hline $\mathrm{Pb}$ & 0,00 & 0,00 & 0,00 & 0,00 & 0,00 & 0,00 & 0,00 \\
\hline $\mathrm{Na}$ & 0,99 & 0,96 & 0,97 & 0,96 & 0,07 & 0,07 & 0,12 \\
\hline Sb & 0,00 & 0,00 & 0,00 & 0,00 & 0,00 & 0,00 & 0,00 \\
\hline $\mathrm{Bi}$ & 0,00 & 0,00 & 0,00 & 0, & 0,00 & 0,00 & 0,00 \\
\hline A site & 1,94 & 1,90 & 1,92 & & 1,50 & 1,45 & 1,40 \\
\hline $\mathrm{F}$ & 0,45 & 0,46 & 0,47 & 0,46 & 0,13 & 0,10 & 0,19 \\
\hline $\mathrm{Mn} / \mathrm{I}$ & 0,99 & 0,75 & 0,00 & 0,00 & 0,29 & 0,49 & 0,22 \\
\hline $\mathrm{Ta} /(\mathrm{Ta}+\mathrm{Nb})$ & 0,85 & 0,81 & 0,78 & 0,84 & 0,91 & 0,91 & 0,89 \\
\hline
\end{tabular}


Anexo III. Análisis de microsonda electrónica

\begin{tabular}{|c|c|c|}
\hline \multicolumn{3}{|c|}{ Microlita uranifera } \\
\hline Mina/Zona & \multicolumn{2}{|c|}{ La Canalita } \\
\hline Roca & peg. CEG & eg. CEG \\
\hline Muestra & $811 \mathrm{~A}$ & $811 \mathrm{~A}$ \\
\hline Análisis & 4.1 & 4.2 \\
\hline $\mathrm{Al}_{2} \mathrm{O}_{3}$ & 0,00 & 0,05 \\
\hline $\mathrm{CaO}$ & 8,80 & 7,41 \\
\hline $\mathrm{TiO}_{2}$ & 0,00 & 0,02 \\
\hline $\mathrm{V}_{2} \mathrm{O}_{5}$ & 0,00 & 0,02 \\
\hline $\mathrm{MnO}$ & 0,01 & 0,05 \\
\hline $\mathrm{FeO}$ & 0,03 & 0,20 \\
\hline $\mathrm{ZrO}_{2}$ & 0,00 & 0,00 \\
\hline $\mathrm{Nb}_{2} \mathrm{O}_{5}$ & 7,05 & 8,02 \\
\hline $\mathrm{SnO}_{2}$ & 0,14 & 0,19 \\
\hline $\mathrm{Ta}_{2} \mathrm{O}_{5}$ & 74,32 & 70,49 \\
\hline $\mathrm{wO}_{3}$ & 0,00 & 0,07 \\
\hline $\mathrm{vO}_{2}$ & 2,82 & 6,36 \\
\hline $\mathrm{PbO}$ & 0,05 & 0,35 \\
\hline $\mathrm{Na}_{2} \mathrm{O}$ & 4,90 & 0,06 \\
\hline $\mathrm{Sb}_{2} \mathrm{O}_{3}$ & 0,00 & 0,00 \\
\hline $\mathrm{Bi}_{2} \mathrm{O}_{3}$ & 0,00 & 0,00 \\
\hline $\mathrm{F}$ & 1,30 & 0,76 \\
\hline \multirow{2}{*}{\multicolumn{3}{|c|}{$\begin{array}{l}\text { Total } 98,88 \quad 99,12 \\
\text { Número de iones con base en } 2 B\end{array}$}} \\
\hline & & \\
\hline Ta & 1,72 & 1,67 \\
\hline $\mathrm{Nb}$ & 0,27 & 0,32 \\
\hline $\mathrm{v}$ & 0,00 & 0,00 \\
\hline $\mathrm{Ti}$ & 0,00 & 0,00 \\
\hline Sn & 0,01 & 0,01 \\
\hline w & 0,00 & 0,00 \\
\hline Al & 0,00 & 0,01 \\
\hline B site & 2,00 & 2,00 \\
\hline $\mathrm{Fe}$ & 0,00 & 0,01 \\
\hline $\mathrm{Mn}$ & 0,00 & 0,00 \\
\hline $\mathrm{Zr}$ & 0,00 & 0,00 \\
\hline Ca & 0,80 & 0,69 \\
\hline $\mathrm{Hf}$ & 0,05 & 0,12 \\
\hline $\mathrm{Pb}$ & 0,00 & 0,01 \\
\hline $\mathrm{Na}$ & 0,81 & 0,01 \\
\hline sb & 0,00 & 0,00 \\
\hline $\mathrm{Bi}$ & 0,00 & 0,00 \\
\hline A site & 1,67 & 0,85 \\
\hline & 0,35 & 0,21 \\
\hline $\mathrm{Mn} /(\mathrm{Mn}+\mathrm{Fe})$ & 0,23 & 0,19 \\
\hline $\mathrm{Ta} /(\mathrm{Ta}+\mathrm{Nb})$ & 0,86 & 0,84 \\
\hline
\end{tabular}

$\underline{\text { Tantalita-(Mn) }}$

Cruz del Rayo $\quad$ La Canalita

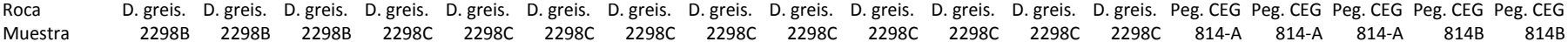

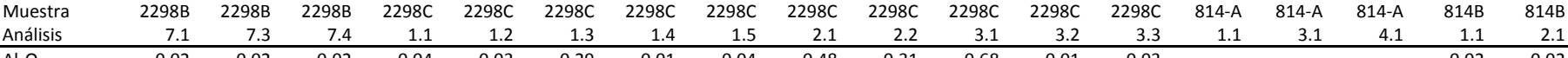

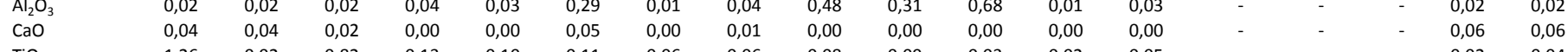

$\begin{array}{lllllllllllllllllll}\mathrm{V}_{2} \mathrm{O}_{5} & 0,04 & 0,00 & 0,04 & - & - & - & - & - & - & - & - & - & - & - & - & - & -03 & 0,03 \\ \mathrm{MnO} & 8,41 & 9,27 & 8,53 & 14,43 & 14,52 & 14,85 & 14,80 & 14,69 & 14,54 & 11,45 & 12,51 & 14,17 & 13,98 & 12,32 & 12,85 & 13,13 & 15,22 & 12,96\end{array}$

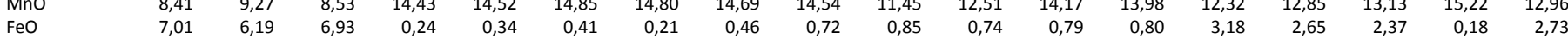

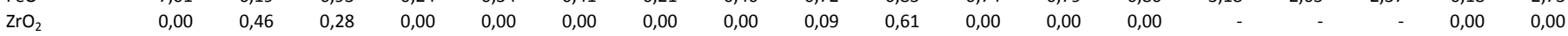

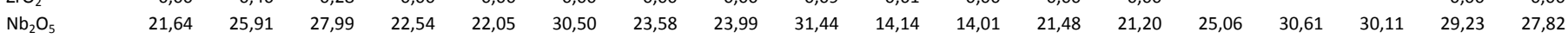

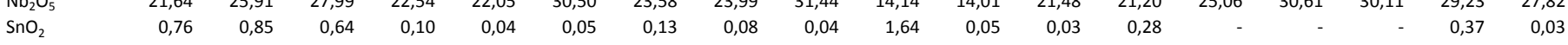

$\begin{array}{lllllllllllllllllll}\mathrm{T}_{2} \mathrm{O}_{5} & 60,33 & 56,81 & 54,96 & 61,38 & 62,12 & 52,75 & 60,11 & 60,15 & 51,39 & 68,31 & 68,43 & 60,31 & 61,52 & 59,91 & 53,44 & 54,32 & 53,18 & 55,77\end{array}$

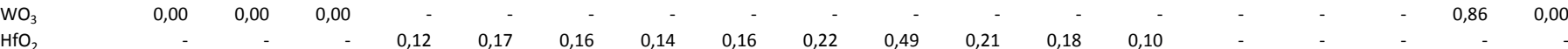

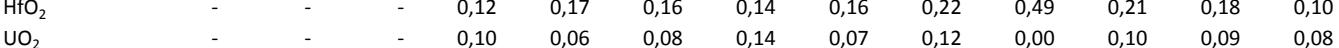

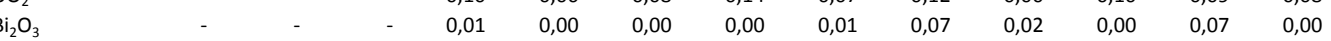

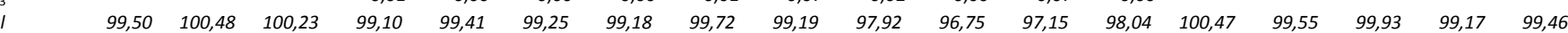

\begin{tabular}{|c|c|c|c|c|c|c|c|c|c|c|c|c|c|c|c|c|c|c|}
\hline Ta & 1,21 & 1,11 & 1,07 & 1,25 & 1,27 & 1,03 & 1,22 & 1,21 & 1,00 & 1,48 & 1,50 & 1,26 & 1,28 & 1,19 & 1,04 & 1,05 & 1,04 & 1,10 \\
\hline $\mathrm{Nb}$ & 0,72 & 0,84 & 0,90 & 0,76 & 0,75 & 0,99 & 0,79 & 0,80 & 1,01 & 0,51 & 0,51 & 0,75 & 0,73 & 0,83 & 0,99 & 0,97 & 0,95 & 0,91 \\
\hline V & 0,00 & 0,00 & 0,00 & 0,00 & 0,00 & 0,00 & 0,00 & 0,00 & 0,00 & 0,00 & 0,00 & 0,00 & 0,00 & 0,00 & 0,00 & 0,00 & 0,00 & 0,00 \\
\hline & 0,07 & 0,05 & 0,04 & 0,01 & 0,01 & 0,01 & 0,00 & 0,00 & 0,00 & 0,01 & 0,00 & 0,00 & 0,00 & 0,00 & 0,00 & 0,00 & 0,00 & 0,00 \\
\hline & 0,03 & 0,03 & 0,02 & 0,00 & 0,00 & 0,00 & 0,00 & 0,00 & 0,00 & 0,06 & 0,00 & 0,00 & 0,01 & 0,00 & 0,00 & 0,00 & 0,01 & 0,00 \\
\hline $\mathrm{W}$ & 0,00 & 0,00 & 0,00 & 0,00 & 0,00 & 0,00 & 0,00 & 0,00 & 0,00 & 0,00 & 0,00 & 0,00 & 0,00 & 0,00 & 0,00 & 0,00 & 0,02 & 0,00 \\
\hline & 0,00 & 0,00 & 0,00 & 0,00 & 0,00 & 0,02 & 0,00 & 0,00 & 0,04 & 0,03 & 0,06 & 0,00 & 0,00 & 0,00 & 0,00 & 0,00 & 0,00 & 0,00 \\
\hline B site & 2,04 & 2,03 & 2,04 & 2,03 & 2,02 & 2,05 & 2,02 & 2,02 & 2,06 & 2,08 & 2,08 & 2,01 & 2,02 & 2,02 & 2,03 & 2,03 & 2,02 & 2,02 \\
\hline $\mathrm{Fe}$ & 0,43 & 0,37 & 0,41 & 0,02 & 0,02 & 0,02 & 0,01 & 0,03 & 0,04 & 0,06 & 0,05 & 0,05 & 0,05 & 0,19 & 0,16 & 0,14 & 0,01 & 0,17 \\
\hline $\mathrm{Mn}$ & 0,53 & 0,57 & 0,52 & 0,92 & 0,92 & 0,90 & 0,93 & 0,92 & 0,88 & 0,77 & 0,86 & 0,92 & 0,90 & 0,76 & 0,78 & 0,79 & 0,93 & 0,80 \\
\hline & 0,00 & 0,02 & 0,01 & 0,00 & 0,00 & 0,00 & 0,00 & 0,00 & 0,00 & 0,02 & 0,00 & 0,00 & 0,00 & 0,00 & 0,00 & 0,00 & 0,00 & 0,00 \\
\hline$c d$ & 0,00 & 0,00 & 0,00 & 0,00 & 0,00 & 0,00 & 0,00 & 0,00 & 0,00 & 0,00 & 0,00 & 0,00 & 0,00 & 0,00 & 0,00 & 0,00 & 0,00 & 0,00 \\
\hline Hf & 0,00 & 0,00 & 0,00 & 0,00 & 0,00 & 0,00 & 0,00 & 0,00 & 0,00 & 0,01 & 0,00 & 0,00 & 0,00 & 0,00 & 0,00 & 0,00 & 0,00 & 0,00 \\
\hline & 0,00 & 0,00 & 0,00 & 0,00 & 0,00 & 0,00 & 0,00 & 0,00 & 0,00 & 0,0 & 0,00 & 0,0 & 0,00 & & $0, \mathrm{C}$ & 0,00 & 0,00 & 0,00 \\
\hline & 0,00 & 0,00 & 0,00 & 0,00 & 0,00 & 0,00 & 0,00 & 0,00 & 0,00 & 0,00 & 0,00 & 0,00 & 0,00 & 0,00 & 0,00 & 0,00 & 0,00 & 0,00 \\
\hline A site & 0,96 & 0,96 & 0,94 & 0,93 & 0,94 & 0,93 & 0,95 & 0,95 & 0,93 & 0,85 & 0,91 & 0,97 & 0,95 & 0,96 & 0,94 & 0,94 & 0,94 & 0,97 \\
\hline & 0,55 & 0,60 & 0,55 & 0,98 & 0,98 & 0,97 & 0,99 & 0,97 & 0,95 & 0,93 & 0,95 & 0,95 & 0,95 & 0,8 & 0,83 & 0,85 & 0,99 & 0,83 \\
\hline $\mathrm{Ta}+1$ & 0,63 & 0,57 & 0,54 & 0,62 & 0,63 & 0,51 & 0,61 & 0,60 & 0,50 & 0,74 & 0,75 & 0,63 & 0,64 & 0,59 & 0,51 & 0,52 & 0,52 & 0,55 \\
\hline
\end{tabular}




\begin{tabular}{|c|c|c|c|c|c|c|c|c|}
\hline \multirow{2}{*}{$\begin{array}{l}\text { Mina/Zona } \\
\text { Roca }\end{array}$} & \multicolumn{8}{|c|}{ La Canalita } \\
\hline & Peg. CEG & eg. CEG & Peg. CEG & Peg. CEG & eg. CEG & Peg. CEG & Peg. CEG & Peg. CEG \\
\hline Muestra & $818 \mathrm{~A}$ & $818 \mathrm{~A}$ & $818 \mathrm{~A}$ & $818 \mathrm{~A}$ & $818 \mathrm{~A}$ & $818 \mathrm{~A}$ & 854 & 854 \\
\hline Análisis & 1.1 & 3.3 & 5.1 & 6.1 & 6.3 & 6.5 & 1.2 & 3.2 \\
\hline $\mathrm{Al}_{2} \mathrm{O}_{3}$ & 0,00 & 0,00 & 0,01 & 0,02 & 0,02 & 0,03 & & 0,00 \\
\hline $\mathrm{CaO}$ & 0,01 & 0,04 & 0,06 & 0,04 & 0,05 & 0,06 & & 0,01 \\
\hline $\mathrm{TiO}_{2}$ & 0,22 & 0,06 & 0,06 & 0,02 & 0,02 & 0,01 & - & 0,00 \\
\hline $\mathrm{V}_{2} \mathrm{O}_{5}$ & 0,00 & 0,00 & 0,01 & 0,00 & 0,06 & 0,03 & & 0,00 \\
\hline MnO & 12,95 & 15,61 & 15,64 & 15,23 & 15,41 & 14,92 & 12,01 & 12,83 \\
\hline $\mathrm{FeO}$ & 2,53 & 0,15 & 0,00 & 0,03 & 0,01 & 0,02 & 3,49 & 2,67 \\
\hline $\mathrm{ZrO}_{2}$ & 0,17 & 0,00 & 0,00 & 0,00 & 0,00 & 0,00 & & 0,00 \\
\hline $\mathrm{Nb}_{2} \mathrm{O}_{5}$ & 31,00 & 29,18 & 30,24 & 30,09 & 29,32 & 29,26 & 27,51 & 31,23 \\
\hline $\mathrm{SnO}_{2}$ & 0,22 & 0,21 & 0,40 & 0,60 & 0,44 & 1,04 & & 0,19 \\
\hline $\mathrm{Ta}_{2} \mathrm{O}_{5}$ & 52,25 & 54,75 & 53,95 & 52,89 & 54,58 & 54,98 & 57,50 & 53,66 \\
\hline $\mathrm{wO}_{3}$ & 0,24 & 0,00 & 0,06 & 0,24 & 0,00 & 0,19 & & 0,00 \\
\hline $\mathrm{HfO}_{2}$ & & & & - & & & & \\
\hline $\mathrm{UO}_{2}$ & - & - & - & - & - & - & - & \\
\hline $\mathrm{Bi}_{2} \mathrm{O}_{3}$ & - & - & - & - & - & - & & \\
\hline Total & 99,60 & 100,00 & 100,41 & 99,15 & 99,91 & 100,55 & 100,51 & 100,59 \\
\hline \multicolumn{9}{|c|}{ Número de iones con base en 60} \\
\hline $\mathrm{Ta}$ & 1,01 & 1,07 & 1,04 & 1,03 & 1,06 & 1,06 & 1,13 & 1,03 \\
\hline $\mathrm{Nb}$ & 1,00 & 0,94 & 0,97 & & 0,95 & & 0,90 & 1,00 \\
\hline V & 0,00 & 0,00 & 0,00 & & 0,00 & 00 & 0,00 & 0,00 \\
\hline $\mathrm{Ti}$ & 0,01 & 0,00 & 0,00 & 0,00 & 0,00 & 0,00 & 0,00 & 0,00 \\
\hline Sn & 0,01 & 0,01 & 0,01 & 0,02 & 0,01 & 0,03 & 0,00 & 0,01 \\
\hline w & 0,00 & 0,00 & 0,00 & 0,00 & 0,00 & 0,00 & 0,00 & 0,00 \\
\hline $\mathrm{Al}$ & 0,00 & 0,00 & 0,00 & 0,00 & 0,00 & 0,00 & 0,00 & 0,00 \\
\hline B site & 2,03 & 2,02 & 2,03 & 2,03 & 2,03 & 2,05 & 2,02 & 2,03 \\
\hline $\mathrm{Fe}$ & 0,15 & 0,01 & 0,00 & 0,00 & 0,00 & 0,00 & 0,21 & 0,16 \\
\hline $\mathrm{Mn}$ & 0,78 & 0,95 & 0,94 & & 0,93 & & 0,73 & 0,77 \\
\hline $\mathrm{Zr}$ & 0,01 & & & & & 00 & 0,00 & 0,00 \\
\hline $\mathrm{Ca}$ & 0,00 & 0,00 & 0,00 & 0,00 & 0,00 & 0,00 & 0,00 & 0,00 \\
\hline $\mathrm{Hf}$ & 0,00 & 0,00 & 0,00 & 0,00 & 0,00 & 0,00 & 0,00 & 0,00 \\
\hline U & 0,00 & 0,00 & & & & & 0,00 &, 00 \\
\hline $\mathrm{Bi}$ & 0,00 & 0, & 0, & & 0 , & & 0,00 & 0,00 \\
\hline A site & 0,94 & 0,96 & 0,94 & 0,93 & 0,94 & 0,91 & 0,94 & 0,92 \\
\hline $\mathrm{Mn} /(\mathrm{M}$ & 0,84 & 0,99 & 1,00 & 1,00 & 1,00 & 1,00 & 0,78 & 0,83 \\
\hline $\mathrm{Ta} /(\mathrm{Ta}+\mathrm{Nb})$ & 0,50 & 0,53 & 0,52 & 0,51 & 0,53 & 0,53 & 0,56 & 0,51 \\
\hline
\end{tabular}

\begin{tabular}{lr}
\multicolumn{2}{l}{ Strüverita } \\
\hline Mina/Zona & Profunda \\
\hline Roca & Peg. LG \\
Muestra & 787 \\
Análisis & 0.2 \\
\hline $\mathrm{Al}_{2} \mathrm{O}_{3}$ & 0,12 \\
$\mathrm{CaO}$ & 0,05 \\
$\mathrm{TOO}_{2}$ & 32,99 \\
$\mathrm{~V}_{2} \mathrm{O}_{5}$ & 0,26 \\
$\mathrm{MnO}$ & 0,10 \\
$\mathrm{FeO}$ & 9,30 \\
$\mathrm{ZrO}_{2}$ & 0,00 \\
$\mathrm{Nb}_{2} \mathrm{O}_{5}$ & 5,19 \\
$\mathrm{SnO}_{2}$ & 5,31 \\
$\mathrm{Ta}_{2} \mathrm{O}_{5}$ & 42,32 \\
$\mathrm{WO} \mathrm{O}_{3}$ & 0,00 \\
$\mathrm{Total}$ & 95,64 \\
$\mathrm{No}^{\circ}$ iones con base 20 \\
\hline $\mathrm{Ta}$ & 0,24 \\
$\mathrm{Nb}$ & 0,05 \\
$\mathrm{~V}$ & 0,00 \\
$\mathrm{Ti}$ & 0,51 \\
$\mathrm{Sn}$ & 0,05 \\
$\mathrm{~W}$ & 0,00 \\
$\mathrm{Al}$ & 0,00 \\
$\mathrm{Fe}$ & 0,16 \\
$\mathrm{Mn}$ & 0,00 \\
$\mathrm{Zr}$ & 0,00 \\
$\mathrm{Ca}$ & 0,00 \\
$\mathrm{\Sigma cat.}$ & 0,16 \\
$\mathrm{Mn} /(\mathrm{Mn}+\mathrm{Fe})$ & 0,01 \\
$\mathrm{Ta} /(\mathrm{Ta}+\mathrm{Nb})$ & 0,83 \\
\hline &
\end{tabular}


Anexo III. Análisis de microsonda electrónica

\begin{tabular}{|c|c|c|c|c|c|c|c|c|c|c|c|c|c|c|c|c|c|c|c|c|c|c|c|}
\hline \multirow{2}{*}{$\begin{array}{l}\text { Mina/Zona } \\
\text { Roca }\end{array}$} & \multicolumn{3}{|c|}{ Horia } & \multicolumn{2}{|c|}{ Teso } & \multicolumn{18}{|c|}{$\begin{array}{cc} & \text { Horia } \\
\end{array}$} \\
\hline & GE & GE & GE & $\mathrm{AB}$ & $\mathrm{AB}$ & Vena GE & Vena GE & Vena GE & Vena GE & Vena GE & Vena GE & Vena GE & Vena GE & Vena GE & $\begin{array}{l}\text { Vena GE } \\
\text { I }\end{array}$ & Vena GE & Vena GE & Vena GE & Vena GE & Vena GE & Vena GE & Vena GE & Vena GE \\
\hline Muestra & $1682 \mathrm{~A}$ & $1682 \mathrm{~B}$ & $1682 \mathrm{~B}$ & 1793 & 1793 & 1767 & 1711D & 1696 & 1696 & 1696 & 1696 & 1773 & 1773 & 1773 & 1773 & 1773 & 1773 & 1773 & 1773 & 1773 & 1773 & 1773 & 1040 \\
\hline Análisis & 8.3 & 6.9 & 8.2 & 1.6 & 1.7 & 2.1 & 1.1 & 1.1 & 1.2 & 2.3 & 3.7 & 1.1 & 1.3 & 2.1 & 2.2 & 2.3 & 3.1 & 3.2 & 3.3 & 4.1 & 4.2 & 4.3 & 2.142 \\
\hline S(\% peso) & 16,72 & 16,89 & 17,60 & 18,58 & 18,89 & 18,82 & 19,06 & 18,75 & 18,08 & 18,60 & 18,38 & 16,91 & 18,27 & 18,16 & 18,57 & 17,31 & 18,17 & 19,35 & 17,84 & 17,75 & 17,90 & 18,34 & 19,18 \\
\hline $\mathrm{Fe}$ & 28,08 & 23,93 & 27,17 & 34,68 & 34,42 & 34,28 & 34,29 & 34,10 & 34,00 & 34,33 & 34,25 & 34,40 & 35,08 & 33,63 & 34,65 & 33,89 & 33,60 & 33,97 & 33,60 & 34,29 & 33,48 & 33,78 & 33,84 \\
\hline $\mathrm{Cu}$ & 0,11 & 0,04 & 0,00 & 0,00 & 0,00 & 0,00 & 0,01 & 0,08 & 0,00 & 0,00 & 0,03 & 0,00 & 0,00 & 0,00 & 0,00 & 0,00 & 0,00 & 0,00 & 0,00 & 0,00 & 0,00 & 0,00 & 0,00 \\
\hline As & 49,12 & 51,07 & 49,63 & 46,60 & 47,65 & 47,41 & 46,92 & 47,08 & 48,01 & 47,48 & 48,04 & 48,70 & 47,45 & 48,22 & 46,78 & 48,78 & 48,23 & 46,64 & 48,54 & 47,97 & 48,61 & 47,87 & 46,18 \\
\hline Co & 4,03 & 4,92 & 4,80 & 0,00 & 0,00 & 0,00 & 0,00 & 0,00 & 0,00 & 0,00 & 0,00 & 0,00 & 0,00 & 0,00 & 0,00 & 0,00 & 0,00 & 0,00 & 0,00 & 0,00 & 0,00 & 0,00 & 0,04 \\
\hline $\mathrm{Zn}$ & 0,00 & 0,06 & 0,00 & & & 0,00 & 0,01 & 0,04 & 0,00 & 0,02 & 0,00 & & 0,00 & & & & & & - & - & - & - & 0,00 \\
\hline $\mathrm{Pb}$ & 0,80 & 0,00 & 0,01 & - & - & 0,00 & 0,00 & 0,00 & 0,08 & 0,14 & 0,00 & - & 0,00 & - & - & - & - & - & - & - & - & & 0,00 \\
\hline $\mathrm{Sb}$ & 0,04 & 0,02 & 0,00 & - & & 0,05 & 0,05 & 0,09 & 0,05 & 0,00 & 0,02 & - & 0,02 & - & & & - & - & - & - & - & & 0,06 \\
\hline $\mathrm{Ni}$ & 0,78 & 2,81 & 0,47 & 0,01 & 0,00 & 0,00 & 0,00 & 0,02 & 0,00 & 0,00 & 0,00 & 0,00 & 0,01 & 0,00 & 0,00 & 0,02 & 0,00 & 0,04 & 0,02 & 0,00 & 0,01 & 0,00 & 0,00 \\
\hline $\mathrm{Ag}$ & 0,05 & 0,00 & 0,03 & & & 0,00 & 0,00 & 0,10 & 0,03 & 0,00 & 0,02 & & 0,00 & & & & & & & & & & 0,00 \\
\hline $\mathrm{Au}$ & 0,07 & 0,00 & 0,03 & - & - & 0,03 & 0,00 & & & 0,00 & & - & & - & & - & - & - & - & - & - & - & 0,00 \\
\hline Sn & 0,01 & 0,00 & 0,00 & - & - & 0,00 & 0,00 & 0,00 & 0,00 & 0,00 & 0,00 & - & 0,00 & - & - & - & - & - & - & - & - & - & 0,00 \\
\hline Se & 0,00 & 0,00 & 0,00 & - & - & 0,00 & 0,00 & 0,00 & 0,00 & 0,00 & 0,00 & - & 0,00 & - & - & - & - & - & - & - & - & - & 0,05 \\
\hline $\mathrm{Te}$ & 0,04 & 0,00 & 0,06 & & & 0,00 & 0,01 & 0,09 & 0,02 & 0,00 & 0,01 & - & 0,04 & - & & - & - & - & - & - & - & - & 0,08 \\
\hline $\mathrm{Bi}$ & 0,00 & 0,00 & 0,00 & - & - & 0,00 & 0,00 & 0,00 & 0,00 & 0,00 & 0,00 & - & 0,00 & - & - & - & - & - & - & - & - & - & 0,00 \\
\hline w & & & & - & - & & & & & & & - & & - & & - & - & & - & - & - & & 0,00 \\
\hline $\mathrm{Cd}$ & 0,00 & 0,02 & 0,05 & - & - & 0,05 & 0,00 & 0,00 & 0,00 & 0,02 & 0,03 & - & 0,00 & - & - & - & - & & - & - & - & - & 0,10 \\
\hline $\mathrm{Hg}$ & & & & & & & & & & & & & & & & & & & - & & & & 0,50 \\
\hline $\mathrm{Mn}$ & 0,01 & 0,00 & 0,01 & & & 0,03 & 0,00 & 0,01 & 0,03 & 0,02 & 0,01 & & 0,01 & - & & & - & & - & - & - & & 0,05 \\
\hline Total & 99,87 & 99,76 & 99,85 & 99,87 & 100,96 & 100,67 & 100,35 & 100,68 & 100,33 & 100,61 & 100,78 & 100,01 & 100,91 & 100,00 & 100,00 & 100,00 & 100,00 & 100,00 & 100,00 & 100,00 & 100,00 & 100,00 & 100,07 \\
\hline 5 & 0,88 & 0,89 & 0,92 & 0,95 & 0,96 & 0,96 & 0,97 & 0,96 & 0,93 & 0,95 & 0,94 & 0,88 & 0,93 & 0,94 & 0,95 & 0,90 & 0,94 & 0,99 & 0,92 & 0,92 & 0,93 & 0,95 & 0,98 \\
\hline As & 1,11 & 1,16 & 1,11 & 1,02 & 1,04 & 1,03 & 1,02 & 1,03 & 1,06 & 1,04 & 1,05 & 1,09 & 1,04 & 1,07 & 1,03 & 1,09 & 1,07 & 1,02 & 1,08 & $\begin{array}{l}1,06 \\
\text { n }\end{array}$ & 1,08 & 1,06 & 1,01 \\
\hline $\mathrm{Fe}$ & 0,85 & 0,73 & 0,82 & 1,02 & 1, & $1, \mathrm{C}$ & & 1,0 & 01 & 1,01 & 1,01 & 1,03 & 1,03 & 1,00 & 1,02 & 1,01 & 1,00 & 0,99 & 1,00 & 1,02 & 1,00 & 1,00 & 0,99 \\
\hline Co & 0,12 & 0,1 & 0, & 0,00 & 0, & & 0 , & 0,0 & 0 & 0,00 & 00 & 0,00 & 0,00 & 0,00 & 0,00 & 0,00 & 0,00 & 0,00 & 0,00 & 0,00 & 0,00 & 0,00 & 0,00 \\
\hline $\mathrm{Ni}$ & 0,02 & 0,0 & , & 0,00 & $0, c$ & 0,0 & 00 & 0,0 & 0,00 & 0,00 & 0,00 & 0,00 & 0,00 & 0,00 & 0,00 & 0,00 & 0,00 & 0,00 & 0,00 & 0,00 & 0,00 & 0,00 & 0,00 \\
\hline $\mathrm{Cu}$ & 0,0 & 0, & & & & & & & & 0,0 & & 0,0 & 0,0 & & 0,00 & 0,00 & & 0,00 & 0,00 & 0,00 & 0,00 & 0,00 & 0,00 \\
\hline $\mathrm{Zn}$ & 0,00 & 0,0 & 0,00 & 0,0 & 0, & & & & & & & & & & & & & 00 & & 0,00 & 0,00 & 0,00 & 0,00 \\
\hline $\mathrm{Pb}$ & 0,0 & & & & & & & & & & & & & & 0,00 & 0,00 & 0,00 & 0,00 & 0,0 & 0,00 & 0,00 & 0,00 & 0,00 \\
\hline $\mathrm{Sb}$ & & & & 0,0 & & & & & & & & 0,00 & 0,00 & 0,00 & 0,00 & 0,00 & 0,00 & 0,00 & 0,00 & 0,00 & 0,00 & 0,00 & 0,00 \\
\hline $\mathrm{Ag}$ & 0,00 & 0,0 & 0,00 & 0,0 & 0,00 & 0,0 & 0,00 & 0,0 & 0,00 & 0,00 & 0,00 & 0,00 & 0,00 & 0,00 & 0,00 & 0,00 & 0,00 & 0,00 & 0,00 & 0,00 & 0,00 & 0,00 & 0,00 \\
\hline $\mathrm{Au}$ & 0,00 & 0,0 & 0,0 & $0, c$ & 0,0 & & & & & & & & & & 0,00 & 0,00 & & 0,00 & & 0,00 & 0,00 & 0,00 & 0,00 \\
\hline Sn & 0,0 & & $0, \mathrm{C}$ & $0, \mathrm{C}$ & 0, & & & & & & & & & & 0,0 & 0,00 & 0,00 & 0,00 & 0,00 & 0,00 & 0,00 & 0,00 & 0,00 \\
\hline Se & 0,00 & 0,00 & 0,00 & 0,00 & 0,00 & 0,00 & 0,00 & 0,00 & 00 & 0,00 & 0,00 & 0,00 & 0,00 & 0,00 & 0,00 & 0,00 & 0,00 & 0,00 & 0,00 & 0,00 & 0,00 & 0,00 & 0,00 \\
\hline $\mathrm{Te}$ & 0,00 & 0,0 & 0,00 & 0,0 & 0,00 & $0, C$ & 00 & & 00 & 0,0 & 00 & $0, C$ & 0,00 & 0,00 & 0,00 & 0,00 & 0,00 & 0,00 & 0,00 & 0,00 & 0,00 & 0,00 & 0,00 \\
\hline & 0,0 & 0,0 & 0,0 & & $0, c$ & & & & & & & & & & & 0,00 & & & & 0,00 & 0,00 & 0,00 & 0,00 \\
\hline & $0, \mathrm{C}$ & & & & & & & & & & & & & & & & & & & & & 00 & \\
\hline $\mathrm{Cd}$ & 0,0 & 0, & & 0,0 & & & & & & & & & & & 0,0 & 0,0 & 0,00 & 0,00 & 0,00 & 0,00 & 0,00 & 0,00 & 0,00 \\
\hline $\mathrm{Hg}$ & 0,00 & 0,00 & 0,00 & 0,00 & 0,00 & 0,00 & 0,00 & 0,00 & 0,00 & 0,00 & 0,00 & 0,00 & 0,00 & 0,00 & 0,00 & 0,00 & 0,00 & 0,00 & 0,00 & 0,00 & 0,00 & 0,00 & 0,00 \\
\hline $\mathrm{Mn}$ & 0,00 & 0,00 & 0,00 & 0,00 & 0,00 & 0,00 & 0,00 & 0,00 & 0,00 & 0,00 & 0,00 & 0,00 & 0,00 & 0,00 & 0,00 & 0,00 & 0,00 & 0,00 & 0,00 & 0,00 & 0,00 & 0,00 & 0,00 \\
\hline
\end{tabular}


Anexo III. Análisis de microsonda electrónica

\begin{tabular}{|c|c|c|c|c|c|c|c|c|c|c|c|c|c|c|c|c|c|c|c|c|c|c|c|}
\hline \multirow{2}{*}{$\begin{array}{l}\text { Mina/Zona } \\
\text { Roca }\end{array}$} & \multicolumn{19}{|c|}{ 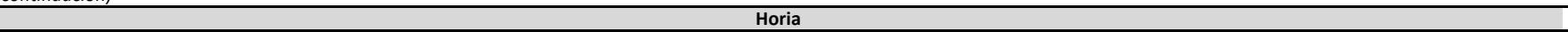 } & \multicolumn{4}{|c|}{ Mari Carmen } \\
\hline & Vena GE & Vena GE & Vena GE & Vena GE & Vena GE & Vena GE & Vena GE & Vena GE & Vena GE & Vena GE & Vena GE & Vena GE & Vena GE & Vena GE & Vena GE & Vena GE & Vena GE & Vena GE & Vena GE & Vena GE & Vena GE & Vena GE & Vena GE \\
\hline Muestra & 1040 & 1041 & 1041 & 1041 & 1041 & 1041 & 1042 & 1042 & 1042 & 1042 & 1043 & 1043 & 1043 & 1043 & 1043 & 1044 & 1044 & 1044 & 1044 & 1047 & 1047 & 1047 & 1047 \\
\hline Análisis & 3.143 & 2.171 & 1.172 & 1.173 & 1.174 & 1.195 & 1.175 & 1.176 & 2.177 & 2.198 & 1.152 & 5.159 & 5.160 .1 & 5.160 .12 & 1.169 & 1.53 & 2.164 & 2.165 & 3.167 & 1.1 & 1.2 & 1.3 & 1.5 \\
\hline S (\% peso) & $\frac{1.14,67}{19,67}$ & $\frac{2.171}{19,20}$ & $\frac{1.172}{19,35}$ & $\frac{1.117}{19,33}$ & $\frac{1.174}{18,95}$ & $\frac{1.153}{19,18}$ & $\frac{1.17,70}{19,7}$ & 19,44 & 19,68 & 18,43 & 18,97 & $\frac{1.157}{19,21}$ & $\frac{1.100 .1}{19,34}$ & $\frac{1.10 .12}{16,84}$ & $\frac{1.107}{19,76}$ & 19,31 & 19,01 & $\frac{2.10,41}{19,4}$ & $\frac{3.10,40}{19,40}$ & $\frac{1.1}{18,20}$ & 19,01 & 19,37 & $\frac{1.5}{18,74}$ \\
\hline $\mathrm{Fe}$ & 34,13 & 31,34 & 34,06 & 33,45 & 34,17 & 33,17 & 33,15 & 33,05 & 32,10 & 34,37 & 33,18 & 33,90 & 33,62 & 34,70 & 34,63 & 34,36 & 35,06 & 33,92 & 34,96 & 33,22 & 33,77 & 33,75 & 33,42 \\
\hline $\mathrm{Cu}$ & 0,00 & 0,00 & 0,05 & 0,11 & 0,11 & 0,00 & 0,00 & 0,00 & 0,08 & 0,00 & 0,00 & 0,00 & 0,04 & 0,14 & 0,03 & 0,00 & 0,00 & 0,03 & 0,04 & 0,03 & 0,00 & 0,00 & 0,00 \\
\hline As & 46,22 & 49,01 & 46,21 & 45,88 & 46,50 & 47,36 & 46,94 & 47,54 & 47,21 & 46,47 & 46,88 & 47,04 & 47,14 & 48,61 & 45,57 & 46,32 & 45,57 & 45,40 & 46,02 & 47,54 & 46,74 & 45,75 & 47,33 \\
\hline Co & 0,09 & 0,00 & 0,05 & 0,01 & 0,01 & 0,01 & 0,00 & 0,09 & 0,01 & 0,09 & 0,11 & 0,03 & 0,01 & 0,04 & 0,01 & 0,04 & 0,02 & 0,01 & 0,01 & 0,02 & 0,05 & 0,04 & 0,02 \\
\hline $\mathrm{Zn}$ & 0,0 & 0,00 & 0,09 & 0,03 & 0,00 & 0,00 & 0,00 & 0,10 & 0,00 & 0,16 & 0,00 & 0,06 & 0,02 & 0,03 & 0,00 & 0,05 & 0,00 & 0,05 & 0,00 & 0,02 & 0,03 & 0,08 & 0,00 \\
\hline $\mathrm{Pb}$ & 0,00 & 0,03 & 0,00 & 0,00 & 0,00 & 0,00 & 0,00 & 0,00 & 0,00 & 0,00 & 0,00 & 0,00 & 0,00 & 0,00 & 0,00 & 0,00 & 0,00 & 0,00 & 0,00 & 0,00 & 0,00 & 0,00 & 0,00 \\
\hline $\mathrm{Sb}$ & 0,01 & 0,02 & 0,02 & 0,02 & 0,03 & 0,00 & 0,04 & 0,04 & 0,00 & 0,00 & 0,03 & 0,04 & 0,00 & 0,00 & 0,04 & 0,06 & 0,00 & 0,02 & 0,01 & 0,00 & 0,02 & 0,05 & 0,00 \\
\hline $\mathrm{Ni}$ & 0,00 & 0,00 & 0,00 & 0,02 & 0,00 & 0,00 & 0,00 & 0,04 & 0,06 & 0,00 & 0,00 & 0,00 & 0,00 & 0,00 & 0,00 & 0,00 & 0,00 & 0,03 & 0,00 & 0,06 & 0,01 & 0,02 & 0,04 \\
\hline $\mathrm{Ag}$ & & 0,00 & 0,00 & 0,07 & 0,03 & 0,01 & 0,04 & 0,0 & & 0,0 & 0,0 & 0,03 & 0,0 & 0,00 & 0,04 & 0,0 & 0,0 & & & 0,04 & & 0,03 & 0,00 \\
\hline $\mathrm{Au}$ & $0, \mathrm{C}$ & 0,00 & 0,00 & 0,64 & 0,00 & 0,02 & oo & 0,00 & 0,00 & 0,00 & 0,07 & 0,00 & 0,00 & 0,00 & 0,00 & 0,03 & 0,05 & 0,04 & 0,14 & 0,00 & 0,00 & 0,00 & 0,00 \\
\hline Sn & 0,02 & 0,00 & 0,04 & 0,04 & 0,01 & 0,02 & 0,04 & 0,06 & 0,06 & 0,02 & 0,02 & 0,04 & 0,02 & 0,05 & 0,08 & 0,01 & 0,03 & 0,03 & 0,00 & 0,03 & 0,00 & 0,03 & 0,06 \\
\hline $\mathrm{Se}$ & 0,00 & 0,03 & 0,18 & 0,00 & 0,04 & 0,03 & 0,00 & 0,30 & 0,22 & 0,06 & 0,06 & 0,09 & 0,00 & 0,21 & 0,10 & 0,00 & 0,14 & 0,15 & 0,00 & 0,03 & 0,01 & 0,00 & 0,01 \\
\hline $\mathrm{Te}$ & 0,00 & 0,00 & 0,00 & 0,03 & 0, & 0,00 & 0,00 & 0,00 & 0,00 & 0,00 & 0,00 & 0,00 & 0,00 & 0,05 & 0,01 & 0,02 & 0,01 & & 0,00 & 0,02 & & 0,00 & 0,00 \\
\hline $\mathrm{Bi}$ & & 0,00 & & & & & 0, & & 0,00 & 0,0 & 0,00 & 0,00 & 0,00 & & 0,00 & & & & & 0,00 & & 0,00 & 0,00 \\
\hline w & 0,08 & 0,14 & 0,12 & 0,10 & 0,15 & 0,09 & 0,00 & 0,05 & 0,00 & 0,03 & 0,01 & 0,00 & 0,06 & 0,13 & 0,02 & 0,11 & 0,00 & 0,06 & 0,00 & 0,06 & 0,01 & 0,00 & 0,00 \\
\hline $\mathrm{Cd}$ & 0,06 & 0,07 & 0,07 & 0,02 & 0,00 & 0,03 & 0,09 & 0,00 & 0,01 & 0,00 & 0,06 & 0,01 & 0,00 & 0,00 & 0,01 & 0,01 & 0,00 & 0,06 & 0,00 & 0,06 & 0,00 & 0,05 & 0,00 \\
\hline $\mathrm{Hg}$ & $0, \mathrm{C}$ & 0,45 & 0 & 0,26 & 0, & 0,06 & 33 & 0,00 & 0,00 & 0,64 & 0,63 & 0,51 & 0,00 & 0,00 & 0,04 & 0,00 & 0,12 & 0,41 & 0,00 & 0,85 & 0,27 & 0,00 & 0,00 \\
\hline $\mathrm{Mn}$ & 0,03 & 0,01 & 0,00 & 0,00 & 0,00 & 0,04 & 0,03 & 0,01 & 0,05 & 0,01 & 0,00 & 0,00 & 0,00 & 0,04 & & & & & & & & & \\
\hline Total & 100,38 & 100,30 & 100,22 & 100,01 & 100,01 & 100,01 & 100,36 & 100,72 & 99,48 & 100,28 & 100,00 & 100,94 & 100,25 & 100,95 & 100,32 & 100,89 & 100,01 & 99,65 & 100,64 & 100,18 & 100,01 & 99,17 & 99,64 \\
\hline c. & $\frac{100,30}{1,00}$ & 0,99 & $\frac{0,92}{0,99}$ & 0,99 & 0,97 & 0,98 & 1,00 & 0,99 & 1,01 & 0,95 & 0,98 & $\frac{0,98}{0,98}$ & 0,99 & 0,87 & 1,00 & 0,98 & 0,97 & 0,99 & 0,98 & 0,94 & 0,97 & 0,99 & $\frac{0,97}{0}$ \\
\hline As & 1,00 & 1,08 & $\begin{array}{l}1,01 \\
\text {. }\end{array}$ & 1,01 & 1,02 & 1,04 & 1,02 & $\begin{array}{l}1,03 \\
\text { n }\end{array}$ & 1,04 & 1,02 & $\begin{array}{l}1,03 \\
\text { n }\end{array}$ & 1,02 & 1,03 & 1,08 & o, & 1,01 & 1,00 & 1,00 & 1,00 & $\begin{array}{l}1,05 \\
\end{array}$ & 1,03 & 1,01 & 1,04 \\
\hline $\mathrm{Fe}$ & 0, & 0,93 & & & & & & & & 1, & & 0,99 & 88 & 1,03 & 1,01 & 1,00 & & 1,00 & 1,02 & 0,99 & 0,99 & 0,99 & 0,99 \\
\hline Co & & & & & & & & & & & & & & $\begin{array}{l}1,03 \\
0,00\end{array}$ & & & 0,0 & & 0 & 0,00 & & o, 00 & 0,00 \\
\hline $\mathrm{Ni}$ & & & & & & & & & & & & & & & & & & & & 0,00 & & 0,00 & 0,00 \\
\hline $\mathrm{Cu}$ & & & & & & & & & & & & & & & & & & & & 0,00 & 0,0 & 0,00 & 0,00 \\
\hline $\mathrm{Zn}$ & & & & & & & & & & & & & & & 0,0 & & 0,0 & & & 0,00 & & 0,00 & 0,00 \\
\hline $\mathrm{Pb}$ & & & & & & & & & & & & & & & & & & & & & 0,0 & 0,00 & 0,00 \\
\hline $\mathrm{sb}$ & 0,0 & 0,00 & 0,00 & $0, c$ & 0, & 0,0 & & o, & & o, & 0 & o, & 0,00 & 0,00 & 0,00 & 0,00 & 0,00 & 0,00 & 0,00 & 0,00 & 0,00 & 0,00 & 0,00 \\
\hline & & & & & & & & & & & & & & & & & & & & & & & 0,00 \\
\hline & & & & & & & & & & & & & & & & & & & & 0,00 & & 0,00 &, 00 \\
\hline $\mathrm{Sn}$ & & 0,00 & 0,00 & 0,00 & 0,00 & 0,00 & & 0,0 & & & 0 , & 0,0 & 0,00 & 0,00 & 0,00 & 0,00 & 0,00 & 0,00 & 0,00 & 0,00 & 0,00 & 0,00 & 0,00 \\
\hline $\mathrm{Se}$ & 0,00 & 0,00 & 0,00 & 0,0 & & 0,0 & & 0,0 & & 0, & 00 & 0, & 0,00 & 0,00 & 0,00 & 0,00 & 0,00 & 0,00 & 0,00 & 0,00 & 0,00 & 0,00 & 0,00 \\
\hline & & & & & & & & & & & & & & & & & & & & & & & \\
\hline & & & & & & & & & & & & & & & & & & & & & & & \\
\hline w & & & & & & & & & & & & & & & & $0, \mathrm{C}$ & 0,0 & & 0,0 & 0,00 & 0,00 & 0,00 & 0,00 \\
\hline $\mathrm{Cd}$ & 0,00 & 0,00 & 0,00 & 0,00 & 0,00 & 0,00 & 0,00 & 0,00 & 0,00 & 0,00 & 0,00 & 0,00 & 0,00 & 0,00 & 0,00 & 0,00 & 0,00 & 0,00 & 0,00 & 0,00 & 0,00 & 0,00 & 0,00 \\
\hline $\mathrm{Hg}$ & 0,00 & 0,00 & 0,00 & 0,00 & 0,00 & 0,00 & 0,00 & 0,00 & 0,00 & 0,01 & 0,01 & 0,00 & 0,00 & 0,00 & 0,00 & 0,00 & 0,00 & 0,00 & 0,00 & 0,01 & 0,00 & 0,00 & 0,00 \\
\hline 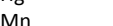 & 000 & 00 & 000 & 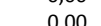 & 000 & 促 & 000 & 000 & 000 & 000 & 000 & 000 & 000 & 000 & 000 & 000 & 000 & 000 & 000 & 000 & 000 & 0 & \\
\hline
\end{tabular}


Anexo III. Análisis de microsonda electrónica

\begin{tabular}{|c|c|c|c|c|c|c|c|c|c|c|c|c|c|c|c|c|c|c|c|c|c|c|c|}
\hline \multirow{2}{*}{$\begin{array}{l}\text { Mina/Zona } \\
\text { Roca }\end{array}$} & \multicolumn{7}{|c|}{ Mari Carmen } & \multicolumn{16}{|c|}{ Salmantina } \\
\hline & Vena GE & Vena GE & Vena GE & Vena GE & Vena GE & Vena GE & Vena GE & Vena LG & Vena LG & Vena LG & Vena LG & Vena LG & Vena LG & Vena LG & 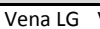 & Vena LG & Vena LG & Vena LG & Vena LG & Vena LG & Vena LG & Vena LG & Vena LG \\
\hline Muestra & 1047 & 1047 & 1047 & 1047 & 1047 & 1720 & 1775 & 1699 & 1690 & 1049 & 1049 & 1049 & 1049 & 1050 & 1050 & 1050 & 1050 & 1050 & 1050 & 1050 & 1050 & 1051 & 1051 \\
\hline Análisis & 1.6 & 1.22 & 1.41 & 2.31 & 3.34 & 5.1 & 1.3 & 4.2 & 6.4 & 1.141 & 3.144 & 4.145 & 4.146 & 177 & 178 & 179 & 180 & $180 \mathrm{~b}$ & 184 & 185 & 186 & 147 & \\
\hline S (\% peso) & 18,93 & 19,37 & 19,37 & 19,47 & $\frac{1.34}{18,98}$ & 19,66 & 18,56 & $\frac{4.2}{19,72}$ & $\begin{array}{r}19,43 \\
193\end{array}$ & $\frac{1.411}{20,10}$ & $\frac{3.144}{20,51}$ & $\frac{4.145}{20,17}$ & $\frac{4.140}{19,96}$ & 19,61 & 19,80 & 20,05 & 19,59 & 20,09 & 20,12 & $\frac{103}{19,96}$ & $\frac{100}{20,20}$ & 20,14 & $\frac{140}{20,42}$ \\
\hline $\mathrm{Fe}$ & 33,77 & 34,50 & 33,88 & 34,16 & 34,52 & 34,56 & 34,42 & 34,70 & 34,79 & 32,63 & 33,56 & 34,50 & 34,46 & 34,07 & 34,32 & 34,32 & 33,50 & 33,64 & 33,61 & 33,47 & 34,47 & 33,50 & 33,55 \\
\hline $\mathrm{Cu}$ & 0,07 & 0,02 & 0,00 & 0,00 & 0,00 & 0,01 & 0,02 & 0,00 & 0,00 & 0,07 & 0,00 & 0,01 & 0,02 & 0,00 & 0,00 & 0,00 & 0,00 & 0,00 & 0,00 & 0,01 & 0,00 & 0,00 & 0,07 \\
\hline As & 46,43 & 45,74 & 47,34 & 46,05 & 45,61 & 45,98 & 46,24 & 45,01 & 45,11 & 45,78 & 45,18 & 44,90 & 45,53 & 45,79 & 45,54 & 45,62 & 45,14 & 45,30 & 44,98 & 46,31 & 45,02 & 44,98 & 45,23 \\
\hline Co & 0,04 & 0,05 & 0,04 & 0,04 & 0,07 & 0,00 & 0,00 & 0,00 & 0,00 & 0,06 & 0,00 & 0,08 & 0,00 & 0,04 & 0,00 & 0,05 & 0,02 & 0,02 & 0,03 & 0,02 & 0,04 & 0,01 & 0,03 \\
\hline $\mathrm{Zn}$ & 0,0 & 0,08 & 0,07 & 0,07 & 0,04 & 0,02 & 0,00 & 0,03 & 0,00 & 0,02 & 0,00 & 0,00 & 0,02 & 0,00 & 0,00 & 0,00 & 0,00 & 0,02 & 0,00 & 0,00 & 0,03 & 0,00 & 0,02 \\
\hline $\mathrm{Pb}$ & 0,00 & 0,00 & 0,00 & 0,00 & 0,00 & 0,00 & 0,00 & 0,00 & 0,00 & 0,00 & 0,00 & 0,00 & 0,00 & 0,00 & 0,00 & 0,00 & 0,00 & 0,00 & 0,00 & 0,00 & 0,00 & 0,00 & 0,00 \\
\hline $\mathrm{Sb}$ & 0,00 & 0,03 & 0,00 & 0,00 & 0,00 & 0,00 & 0,00 & 0,02 & 0,00 & 0,00 & 0,00 & 0,00 & 0,06 & 0,05 & 0,00 & 0,02 & 0,04 & 0,00 & 0,05 & 0,00 & 0,00 & 0,00 & 0,00 \\
\hline $\mathrm{Ni}$ & 0,10 & 0,00 & 0,05 & 0,04 & 0,00 & 0,00 & 0,01 & 0,03 & 0,00 & 0,08 & 0,02 & 0,05 & 0,01 & 0,00 & 0,00 & 0,00 & 0,01 & 0,00 & 0,00 & 0,02 & 0,02 & 0,02 & 0,00 \\
\hline $\mathrm{Ag}$ & 0,0 & 0,08 & 0, & 0,1 & 0,00 & 0,05 & 0,00 & 0,0 & 0,00 & 0,01 & & 0,00 & 0,00 & 0,0 & & 0,0 & 0,00 & & & & & 0,00 & 0,02 \\
\hline Au & , & 0,00 & 0,00 & 0,00 & 0,07 & 0,03 & 04 & 0,08 & 0,00 & 0,00 & 0,00 & 0,00 & 0,00 & 0,00 & 0,18 & 0,00 & 0,00 & 0,00 & 0,00 & 0,00 & o, 00 & 0,00 & on \\
\hline Sn & 0,03 & 0,04 & 0,00 & 0,06 & 0,07 & 0,00 & 0,00 & 0,00 & 0,00 & 0,04 & 0,04 & 0,01 & 0,02 & 0,00 & 0,03 & 0,05 & 0,02 & 0,00 & 0,04 & 0,00 & 0,03 & 0,01 & 0,00 \\
\hline $\mathrm{Se}$ & 0,07 & 0,00 & 0,00 & 0,00 & 0,06 & 0,00 & 0,00 & 0,00 & 0,00 & 0,00 & 0,00 & 0,00 & 0,03 & 0,00 & 0,01 & 0,00 & 0,06 & 0,00 & 0,33 & 0,03 & 0,00 & 0,12 & 0,08 \\
\hline $\mathrm{Te}$ & 0,05 & 0,02 & 0, & 0,00 & 0,00 & 0,00 & 0,00 & 0,00 & 0,02 & 0,01 & 0,00 & 0,02 & 0,00 & 0,02 & & 0,00 & 0,00 & 0,02 & 0,07 & 0,00 & 0,00 & 0,00 & 0,00 \\
\hline $\mathrm{Bi}$ & & 0,00 & & & 0,00 & & 0,00 & & 0,00 & 0,00 & 0,00 & 0,00 & 0,00 & & & & & & 0,00 & & 0,00 & 0,00 & 0,00 \\
\hline w & 0,00 & 0,00 & 0,04 & 0,00 & 0,00 & 0,02 & 0,02 & 0,01 & 0,02 & 0,00 & 0,00 & 0,05 & 0,11 & 0,02 & 0,08 & 0,00 & 0,00 & 0,00 & 0,00 & 0,09 & 0,00 & 0,00 & 0,00 \\
\hline $\mathrm{Cd}$ & 0,00 & 0,00 & 0,00 & 0,01 & 0,01 & 0,02 & 0,00 & 0,00 & 0,02 & 0,00 & 0,00 & 0,00 & 0,08 & 0,00 & 0,00 & 0,07 & 0,00 & 0,04 & 0,00 & 0,03 & 0,07 & 0,03 & 0,05 \\
\hline $\mathrm{Hg}$ & 0,50 & 0,19 & 0,00 & 0,00 & 0,10 & 0,00 & 0,00 & 0,00 & 0,00 & 0,41 & 0,00 & 0,11 & 0,00 & 0,34 & 0,00 & 0,17 & 0,60 & 0,00 & 0,00 & 0,00 & 0,13 & 0,00 & 0,42 \\
\hline $\mathrm{Mn}$ & & & & & & 0,05 & 0,00 & 0,00 & 0,01 & & & & & & & & & & & & & & \\
\hline Total & 100,06 & 100,11 & 100,79 & 100,01 & 99,52 & 100,39 & 99,41 & 99,60 & 99,89 & 99,21 & 99,31 & 99,90 & 100,30 & 99,93 & 99,98 & 100,36 & 99,10 & 99,15 & 99,24 & 100,00 & 100,00 & 98,81 & 99,99 \\
\hline S & $\frac{x}{0,97}$ & $\frac{0,14}{0,99}$ & 0,98 & 0,99 & 0,97 & 1,00 & 0,96 & 1,00 & 1,01 & 1,03 & 1,04 & 1,02 & 1,01 & 1,00 & 1,01 & $\frac{1001}{1,01}$ & 1,01 & 1,02 & 1,03 & 1,01 & 1,02 & 1,03 & 1,03 \\
\hline As & 1,02 & 1,00 & 1,03 & 1,00 & 1,00 & 1,00 & 1, & 0,98 & 0,98 & 1,00 & 0,98 & 0,97 & o, 0 & 1,00 & 0,99 & 0,99 & 0,99 & $\begin{array}{l}0,99 \\
0\end{array}$ & 0,98 & 1,01 & 0,97 & 0,98 & 0,98 \\
\hline $\mathrm{Fe}$ & 0,9 & 1,01 & 0 , & & 2 & 1,0 & & & & 0,96 & & 1,00 & & 1,00 & & 1,00 & 0,99 & & 0,98 & 0,98 & 1,00 & 0,98 & 0,98 \\
\hline Co & & & & & & & & & & & & & & & & & 0 & & 0,0 & & on 0,00 & $\begin{array}{l}0,90 \\
0,00\end{array}$ & $\begin{array}{l}0,00 \\
0,00\end{array}$ \\
\hline $\mathrm{Ni}$ & & 0,0 & & & & & & & & & & & & & & & 0,0 & & 0,0 & & 0,00 & 0,00 & 0,00 \\
\hline $\mathrm{Cu}$ & & & & & & & & & & & & & & & & & & & & 00 & 0,00 & 0,00 & 0,00 \\
\hline $\mathrm{Zn}$ & & 0,00 & & & & & & & & & & & & & & & 0,0 & & & & 0,00 & 0,00 & 0,00 \\
\hline $\mathrm{Pb}$ & & & & & & & & & & & & & & & & & & & & & 0,00 & 0,00 & 0,00 \\
\hline Sb & 0,0 & 0,00 & 0,00 & $0, c$ & 0, & $0, c$ & & 0,0 & 00 & o, & 0 & o, & 0,00 & o, & 0,0 & 0,00 & 0,00 & 0,00 & 0,00 & 0,00 & 0,00 & 0,00 & 0,00 \\
\hline$\Delta$ & & & & & & & & & & & & & & & & & & & & & & & 0,00 \\
\hline & & 0,0 & & & & & & & & & & & & & & & & & & 0,00 & & 0,00 &, 00 \\
\hline $\mathrm{Sn}$ & 0,0 & 0,00 & 0,00 & 0,0 & 0,00 & 0,00 & & 0,00 & & 0,0 & 0 , & & 0,00 & 0,00 & 0,00 & 0,00 & 0,00 & 0,00 & 0,00 & 0,00 & 0,00 & 0,00 & 0,00 \\
\hline $\mathrm{Se}$ & 0,00 & 0,00 & 0,00 & 0,0 & $0, c$ & 0,00 & & 0,0 & 0 & 0,0 & 00 & 0,00 & 0,00 & 0,00 & 0,00 & 0,00 & 0,00 & 0,00 & 0,01 & 0,00 & 0,00 & 0,00 & 0,00 \\
\hline & & & & & & & & & & & & & & & & & & & & & & & \\
\hline & & & & & & & & & & & & & & & & & & & & & & & \\
\hline w & & & & & & & & & & & & & & & & & 0,0 & & 0,00 & 0,00 & 0,00 & 0,00 & 0,00 \\
\hline $\mathrm{Cd}$ & 0,00 & 0,00 & 0,00 & 0,00 & 0,00 & 0,00 & 0,00 & 0,00 & 0,00 & 0,00 & 0,00 & 0,00 & 0,00 & 0,00 & 0,00 & 0,00 & 0,00 & 0,00 & 0,00 & 0,00 & 0,00 & 0,00 & 0,00 \\
\hline $\mathrm{Hg}$ & 0,00 & 0,00 & 0,00 & 0,00 & 0,00 & 0,00 & 0,00 & 0,00 & 0,00 & 0,00 & 0,00 & 0,00 & 0,00 & 0,00 & 0,00 & 0,00 & 0,00 & 0,00 & 0,00 & 0,00 & 0,00 & 0,00 & 0,00 \\
\hline n & 000 & 00 & 000 & 000 & 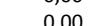 & 促 & 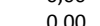 & 000 & 000 & 000 & 000 & 000 & 000 & 000 & 000 & 000 & 000 & 000 & 000 & 000 & 000 & 0 & 000 \\
\hline
\end{tabular}


Anexo III. Análisis de microsonda electrónica

\begin{tabular}{|c|c|c|c|c|c|c|c|c|c|c|c|c|c|c|c|c|c|c|c|c|c|c|c|}
\hline \multirow{2}{*}{$\begin{array}{l}\text { Mina/Zona } \\
\text { Roca }\end{array}$} & \multicolumn{23}{|c|}{ Salmantina } \\
\hline & Vena LG & Vena LG & Vena LG & Vena LG & Vena LG & Vena LG & Vena LG & Vena LG & Vena LG & Vena LG & Vena LG & 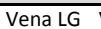 & Vena LG & Vena LG & Vena LG & Vena LG & Vena LG & Vena LG & Vena LG & Vena LG & Vena LG & Vena LG & Vena LG \\
\hline Muestra & 1051 & 1052 & 1052 & 1052 & $1059 \mathrm{~A}$ & $1059 \mathrm{~A}$ & $1059 \mathrm{~A}$ & $1059 B$ & $1059 \mathrm{~B}$ & $1059 \mathrm{~B}$ & $1059 \mathrm{~B}$ & $1059 \mathrm{~B}$ & $1059 \mathrm{~B}$ & $1059 \mathrm{~B}$ & $1059 \mathrm{~B}$ & $1059 \mathrm{~B}$ & $1059 \mathrm{~B}$ & $1059 \mathrm{~B}$ & $1059 \mathrm{~B}$ & $1059 \mathrm{~B}$ & $1059 \mathrm{~B}$ & $1059 \mathrm{~B}$ & $1059 \mathrm{~B}$ \\
\hline Análisis & 149 & 36 & 37 & 38 & 126 & 131 & 137 & 1.1 & 1.2 & 2.13 & 2.15 & 2.16 & 3.2 & 3.1 & 3.4 & 3.6 & 4.20 & 4.21 & 4.22 & 5.25 & 5.26 & 5.28 & 5.29 \\
\hline S (\% peso) & 20,61 & 19,22 & 19,42 & 19,67 & 19,31 & 20,11 & 20,04 & $\frac{1.1}{19,84}$ & 19,86 & 20,39 & 18,25 & 20,37 & 18,67 & $\frac{.1}{18,72}$ & $\begin{array}{r}19,84 \\
\end{array}$ & 20,05 & 20,19 & $\frac{4.21}{19,85}$ & $\frac{4.22}{19,88}$ & $\frac{1.25}{19,08}$ & $\frac{1.20}{19,01}$ & $\frac{1.20}{19,09}$ & $\frac{1.25}{19,59}$ \\
\hline $\mathrm{Fe}$ & 34,04 & 33,80 & 34,27 & 33,31 & 33,36 & 33,89 & 33,40 & 34,15 & 33,89 & 33,26 & 33,90 & 33,41 & 32,25 & 33,65 & 34,01 & 33,28 & 32,86 & 33,06 & 32,40 & 34,90 & 33,06 & 33,68 & 33,69 \\
\hline $\mathrm{Cu}$ & 0,01 & 0,05 & 0,06 & 0,08 & 0,02 & 0,12 & 0,10 & 0,00 & 0,00 & 0,00 & 0,00 & 0,01 & 0,00 & 0,00 & 0,00 & 0,02 & 0,00 & 0,00 & 0,00 & 0,01 & 0,00 & 0,00 & 0,00 \\
\hline As & 45,08 & 46,46 & 45,65 & 46,51 & 46,38 & 46,14 & 45,51 & 46,31 & 46,10 & 45,12 & 47,71 & 45,48 & 48,31 & 47,29 & 45,82 & 46,97 & 46,43 & 47,48 & 47,12 & 45,92 & 46,89 & 46,50 & 46,53 \\
\hline Co & 0,00 & 0,00 & 0,03 & 0,03 & 0,00 & 0,08 & 0,06 & 0,06 & 0,00 & 0,06 & 0,00 & 0,00 & & & 0,04 & 0,06 & 0,05 & 0,00 & 0,00 & 0,00 & 0,00 & 0,00 & 0,00 \\
\hline $\mathrm{Zn}$ & $0, \mathrm{C}$ & 0,03 & 0,07 & 0,03 & 0,29 & 0,02 & 0,00 & 0,00 & 0,00 & 0,02 & 0,00 & 0,00 & 0,03 & 0,00 & 0,29 & 0,03 & 0,00 & 0,05 & 0,00 & 0,00 & 0,05 & 0,06 & 0,04 \\
\hline $\mathrm{Pb}$ & 0,00 & 0,00 & 0,00 & 0,00 & 0,00 & 0,00 & 0,00 & 0,00 & 0,00 & 0,00 & 0,00 & 0,00 & 0,05 & 0,00 & 0,00 & 0,00 & 0,00 & 0,00 & 0,00 & 0,00 & 0,00 & 0,00 & 0,00 \\
\hline $\mathrm{Sb}$ & 0,10 & 0,00 & 0,00 & 0,00 & 0,00 & 0,01 & 0,05 & 0,00 & 0,00 & 0,05 & 0,02 & 0,00 & 0,06 & 0,02 & 0,03 & 0,00 & 0,00 & 0,00 & 0,00 & 0,02 & 0,00 & 0,00 & 0,05 \\
\hline $\mathrm{Ni}$ & 0,00 & 0,01 & 0,05 & 0,01 & 0,00 & 0,05 & 0,08 & 0,00 & 0,06 & 0,02 & 0,00 & 0,03 & & & 0,03 & 0,00 & 0,08 & 0,00 & 0,00 & 0,00 & 0,00 & 0,00 & 0,00 \\
\hline $\mathrm{Ag}$ & 0,0 & 0,00 & 0,00 & 0,02 & 0,00 & 0,01 & 0,00 & 0,00 & 0,00 & 0,0 & & 0,0 & 0,01 & 0,08 & 0,00 & 0,00 & 0,00 & 0,00 & & 0,03 & 0,0 & 0,00 & 0,00 \\
\hline Au & & 0,00 & 0,00 & 0,00 & 0,00 & 0,00 & 57 & 0,04 & 0,00 & 0,00 & 0,02 & 0,00 & 0,15 & 0,19 & 0,02 & 0,02 & 0,05 & 0,00 & 0,06 & 0,00 & 0,33 & 0,10 & 0,00 \\
\hline Sn & 0,02 & 0,05 & 0,00 & 0,03 & 0,12 & 0,03 & 0,00 & 0,00 & 0,00 & 0,00 & 0,00 & 0,00 & 0,00 & 0,00 & 0,02 & 0,03 & 0,00 & 0,02 & 0,00 & 0,00 & 0,00 & 0,10 & 0,00 \\
\hline $\mathrm{Se}$ & 0,00 & 0,10 & 0,15 & 0,00 & 0,12 & 0,00 & 0,00 & 0,04 & 0,00 & 0,00 & 0,00 & 0,04 & 0,02 & 0,00 & 0,00 & 0,00 & 0,00 & 0,00 & 0,00 & 0,00 & 0,00 & 0,00 & 0,07 \\
\hline $\mathrm{Te}$ & 0,00 & 0,00 & 0,00 & 0,07 & 0,00 & 0,00 & 0,00 & 0,00 & 0,04 & 0,00 & 0,00 & 0,00 & 0,10 & 0,00 & 0,00 & 0,00 & 0,00 & 0,00 & 0,00 & 0,00 & 0,07 & 0,13 & 0,00 \\
\hline $\mathrm{Bi}$ & & 0,00 & & & 0,0 & & 0,00 & 0,00 & 0,00 & 0,00 & 0,00 & 0,00 & 0,00 & 0,00 & 0,00 & 0,00 & 0,00 & 0,00 & 0,00 & 0,00 & 0,00 & 0,00 & 0,00 \\
\hline w & 0,00 & 0,00 & 0,00 & 0,00 & 0,00 & 0,00 & 0,01 & & & & & & & & & & & & & & & & \\
\hline $\mathrm{Cd}$ & 0,00 & 0,13 & 0,06 & 0,03 & 0,09 & 0,06 & 0,00 & 0,00 & 0,06 & 0,00 & 0,06 & 0,00 & 0,05 & 0,01 & 0,00 & 0,00 & 0,00 & 0,07 & 0,00 & 0,04 & 0,09 & 0,08 & 0,02 \\
\hline $\mathrm{Hg}$ & 0,00 & 0,17 & 24 & 0,08 & 0,34 & 0,00 & 0,20 & 0,00 & 0,00 & 0,04 & 0,00 & 0,00 & 0,27 & 0,00 & 0,00 & 0,00 & 0,00 & 0,00 & 0,00 & 0,00 & 0,45 & 0,27 & 0,00 \\
\hline $\mathrm{Mn}$ & & 0,00 & $\begin{array}{l}0,03 \\
0,03\end{array}$ & 0,00 & 0,00 & 0,01 & 0,02 & & & & & & & & & & & & & & & & \\
\hline Total & 99,99 & 100,02 & 100,01 & 100,00 & 100,02 & 100,53 & 100,02 & 100,44 & 100,01 & 98,99 & 99,99 & 99,34 & 99,97 & 99,94 & 100,10 & 100,47 & 99,66 & 100,53 & 99,54 & 100,00 & 100,02 & 100,02 & 100,01 \\
\hline S & 1,04 & $\frac{0,02}{0,98}$ & 0,99 & 1,00 & 0,99 & 1,01 & 1,02 & 1,00 & 1,01 & 1,04 & 0,94 & 1,03 & 0,96 & 0,96 & 1,01 & 1,01 & 1,03 & 1,01 & 1,02 & 0,97 & 0,98 & 0,98 & $\frac{1,01}{1,00}$ \\
\hline As & $\begin{array}{l}1,04 \\
0,97\end{array}$ & $\begin{array}{l}1,902 \\
1,02\end{array}$ & $\begin{array}{l}0,99 \\
1,00\end{array}$ & $\begin{array}{l}1,00 \\
1,01\end{array}$ & $\begin{array}{l}0,99 \\
1,02\end{array}$ & $\begin{array}{l}1,01 \\
1,00\end{array}$ & , & $\begin{array}{l}1,00 \\
1,00\end{array}$ & $\begin{array}{l}1,01 \\
1,00\end{array}$ & $\begin{array}{l}1,04 \\
0,98\end{array}$ & $\begin{array}{l}0,94 \\
1,05\end{array}$ & $\begin{array}{l}1,03 \\
0,99\end{array}$ & $\begin{array}{l}0,90 \\
1,07\end{array}$ & $\begin{array}{l}0,90 \\
1,04\end{array}$ & $\begin{array}{l}1,01 \\
0,99\end{array}$ & $\begin{array}{l}1,01 \\
1,02\end{array}$ & $\begin{array}{l}1,03 \\
1,01\end{array}$ & $\begin{array}{l}1,01 \\
1,03\end{array}$ & $\begin{array}{l}1,02 \\
1,03\end{array}$ & $\begin{array}{l}0,911 \\
1,00\end{array}$ & $\begin{array}{l}0,98 \\
1,03\end{array}$ & $\begin{array}{l}0,98 \\
1,02\end{array}$ & $\begin{array}{l}1,00 \\
1,01\end{array}$ \\
\hline $\mathrm{Fe}$ & 0, & 0,99 & & & 0, & & & 0, & 9 & & & & 96 & 0,99 & 0,99 & 0,97 & 0,96 & 0,96 & 0,95 & 1,02 & 0,98 & 0,99 & 0,98 \\
\hline Co & & & & & & & & & & & & & & & 0,00 & 0,00 & 0,00 & 00 & 0,00 & 0,00 & 0,00 & 0,00 & 0,00 \\
\hline $\mathrm{Ni}$ & & 0,0 & & & & & & & & & & & & & & & 0,0 & & 0,00 & 0,00 & 0,00 & 0,00 & 0,00 \\
\hline $\mathrm{Cu}$ & & & & & & & & & & & & & & & & & 0,0 & & 0,00 & 0,00 & 0,00 & 0,00 & 0,00 \\
\hline $\mathrm{Zn}$ & & 0,00 & & & & & & & & & & & & & 0,0 & 0,00 & 0,00 & & 0,00 & 0,00 & 0,00 & 0,00 & 0,00 \\
\hline $\mathrm{Pb}$ & & & & & & & & & & & & & & & & & & & 0,00 & 0,00 & 0,00 & 0,00 & 0,00 \\
\hline $\mathrm{sb}$ & 0,0 & 0,00 & 0,00 & 0,0 & 0, & $0, c$ & & 0,0 & 00 & 0, & & & 0,00 & 0,0 & 0,00 & 0, & 0,00 & 0,00 & 0,00 & 0,00 & 0,00 & 0,00 & 0,00 \\
\hline 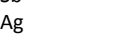 & & 0,0 & & & & & & & & & & & & & & & & & & & & 0,00 & 0,00 \\
\hline & & 0,0 & & & & & & & & & & & & & & & & & & 0,00 & & 0,00 & 0,00 \\
\hline $\mathrm{Sn}$ & 0,0 & 0,00 & 0,00 & 0,00 & 0,00 & 0,00 & & 0,00 & bo & & & & 0,00 & 0,00 & 0,00 & 0,00 & 0,00 & 0,00 & 0,00 & 0,00 & 0,00 & 0,00 & 0,00 \\
\hline $\mathrm{Se}$ & 0,00 & 0,00 & 0,00 & 0,0 & 0, & 0,0 & & 0,0 & bo & 0, & & 0, & 0,00 & 0,00 & 0,00 & 0,00 & 0,00 & 0,00 & 0,00 & 0,00 & 0,00 & 0,00 & 0,00 \\
\hline & & & & & & & & & & & & & & & & & & & & & & & \\
\hline & & & & & & & & & & & & & & & & & & & & & & 00 & \\
\hline w & & & & & & & & & & & & & & & & & 0,0 & & 0,00 & 0,00 & 0,00 & 0,00 & 0,00 \\
\hline $\mathrm{Cd}$ & 0,00 & 0,00 & 0,00 & 0,00 & 0,00 & 0,00 & 0,00 & 0,00 & 0,00 & 0,00 & 0,00 & 0,00 & 0,00 & 0,00 & 0,00 & 0,00 & 0,00 & 0,00 & 0,00 & 0,00 & 0,00 & 0,00 & 0,00 \\
\hline $\mathrm{Hg}$ & 0,00 & 0,00 & 0,00 & 0,00 & 0,00 & 0,00 & 0,00 & 0,00 & 0,00 & 0,00 & 0,00 & 0,00 & 0,00 & 0,00 & 0,00 & 0,00 & 0,00 & 0,00 & 0,00 & 0,00 & 0,00 & 0,00 & 0,00 \\
\hline $\mathrm{Mn}$ & 000 & , & 000 & 000 & 000 & 000 & 000 & 000 & 000 & 000 & 000 & 000 & 000 & 000 & 000 & 000 & 00 & 000 & 000 & 000 & 000 & 000 & 000 \\
\hline
\end{tabular}




\begin{tabular}{|c|c|c|c|c|c|c|c|c|c|c|c|c|c|c|c|c|c|c|c|c|c|c|c|}
\hline \multirow{2}{*}{$\begin{array}{l}\text { Mina/Zona } \\
\text { Roca }\end{array}$} & \multicolumn{23}{|c|}{ Salmantina } \\
\hline & Vena LG & Vena LG & Vena LG & Vena LG & Vena LG & Vena LG & Vena LG & Vena LG & Vena LG & Vena LG & Vena LG & Vena LG & Vena LG & Vena LG & Vena LG & Vena LG & Vena LG & Vena LG & Vena LG & Vena LG & Vena LG & Vena LG & Vena LG \\
\hline Muestra & 1059B & $1059 \mathrm{C}$ & $1059 \mathrm{C}$ & $1059 \mathrm{C}$ & $1059 \mathrm{C}$ & $1059 C$ & $1059 \mathrm{C}$ & $1059 \mathrm{C}$ & 1060 & 1060 & 1159 & 1159 & 1159 & 1159 & 1159 & 1159 & 1159 & 1159 & 1159 & 1159 & 1181 & 1181 & 1181 \\
\hline Análisis & 6.4 & 1.4 & 1.5 & 2.2 & 2.4 & 3.3 & 3.4 & 4.3 & 1.161 & 1.174 & 1.4 & 1.5 & 1.7 & 2.17 & 2.18 & 3.28 & 3.29 & 3.30 & 4.23 & 5.21 & 1.3 & 1.5 & 1.6 \\
\hline S (\% peso) & 20,56 & 20,50 & 20,31 & 19,88 & 19,86 & 18,62 & 16,51 & 19,97 & 19,98 & 19,68 & 19,56 & 19,83 & 20,24 & 19,86 & 20,01 & 19,69 & 20,09 & 19,36 & 19,99 & 19,58 & 20,03 & 19,56 & 20,17 \\
\hline $\mathrm{Fe}$ & 33,30 & 32,84 & 33,76 & 33,25 & 34,36 & 34,68 & 33,64 & 33,99 & 33,75 & 33,58 & 35,32 & 35,17 & 35,35 & 34,28 & 34,29 & 34,73 & 33,87 & 34,29 & 35,07 & 33,82 & 33,92 & 34,06 & 33,53 \\
\hline $\mathrm{Cu}$ & 0,05 & 0,04 & 0,08 & 0,01 & 0,01 & 0,00 & 0,05 & 0,00 & 0,00 & 0,11 & 0,03 & 0,00 & 0,00 & 0,02 & 0,00 & 0,00 & 0,00 & 0,00 & 0,00 & 0,00 & 0,00 & 0,00 & 0,00 \\
\hline As & 44,52 & 44,63 & 44,81 & 45,55 & 45,93 & 46,02 & 49,26 & 46,24 & 46,14 & 46,56 & 45,00 & 44,61 & 44,19 & 46,31 & 46,44 & 45,46 & 45,93 & 45,22 & 45,60 & 45,97 & 46,00 & 46,20 & 46,07 \\
\hline Co & & 0,01 & 0,05 & 0,05 & 0,06 & 0,05 & 0,01 & 0,00 & 0,00 & 0,01 & 0,00 & 0,00 & 0,04 & 0,03 & 0,03 & 0,00 & 0,01 & 0,00 & 0,00 & 0,00 & 0,00 & 0,00 & 0,00 \\
\hline $\mathrm{Zn}$ & 0,02 & 0,82 & 0,00 & 0,00 & 0,07 & 0,02 & 0,01 & 0,02 & 0,00 & 0,00 & 0,00 & 0,00 & 0,04 & 0,00 & 0,00 & 0,00 & 0,00 & 0,00 & 0,00 & 0,00 & - & - & \\
\hline $\mathrm{Pb}$ & 0,00 & 0,05 & 0,00 & 0,00 & 0,06 & 0,00 & 0,00 & 0,00 & 00 & 0,00 & 0,00 & 0,00 & 0,00 & 0,00 & 0,00 & 0,00 & 0,05 & 00 & 0,11 & 0,04 & - & - & \\
\hline Sb & 0,00 & 0,00 & 0,00 & 0,06 & 0,00 & 0,00 & 0,06 & 0,00 & 0,05 & 0,03 & 0,00 & 0,0 & 0,00 & 0,00 & 0,03 & 0,00 & 0,00 & 0,01 & & 0,02 & - & - & \\
\hline $\mathrm{Ni}$ & & 0,00 & 0,01 & 0,00 & 0,05 & 0,00 & 0,00 & 0,04 & 0,00 & 0,00 & 0,00 & $0, \mathrm{C}$ & 0,00 & 0,03 & 0,01 & 0,00 & 0,00 & 0,03 & 0,02 & 0,00 & 0,00 & 0,01 & 0,01 \\
\hline $\mathrm{Ag}$ & 0,03 & 0,00 & 0,00 & 0,00 & 0,00 & 0,00 & 0,00 & 0,00 & 0,08 & 0,03 & 0,00 & 0,00 & 0,00 & 0,01 & 0,04 & 0,06 & 0,06 & 0,00 & 0,00 & 0,00 & - & - & \\
\hline $\mathrm{Au}$ & 0,52 & 0,50 & 0,24 & 0,73 & 0,00 & 0,10 & 0,31 & 0,00 & 0,00 & 0,00 & 0,00 & 0,00 & 0,00 & 0,00 & 0,00 & 0,00 & 0,07 & 0,06 & 0,00 & 0,06 & - & - & \\
\hline Sn & 0,00 & 0,00 & 0,05 & 0,06 & 15 & 0,02 & 0 , & 0,0 & & & 0,00 & & 0,00 & & 0,02 & 0,00 & 0,00 & 0,02 & 0,00 & 0,00 & - & - & \\
\hline Se & 0,00 & 0,00 & $0, C$ & 0,00 & 0,00 & 0,05 & 09 & 0,00 & 0,00 & 0,04 & 0,00 & & 0,00 & 0,10 & 0,00 & 0,00 & 0,00 & 0,00 & 0,10 & 0,00 & - & - & \\
\hline $\mathrm{Te}$ & 0,01 & 0,09 & 0,00 & 0,13 & 0,10 & 0,00 & 0,00 & 0,00 & 0,00 & 0,00 & 0,00 & 0,00 & 0,00 & 0,00 & 0,00 & 0,07 & 0,00 & 0,06 & 0,00 & 0,00 & - & - & \\
\hline $\mathrm{Bi}$ & 0,00 & 0,06 & 0,09 & 0,00 & 0,36 & 0,29 & 0,07 & 0,34 & 0,00 & 0,00 & 0,00 & 0,00 & 0,00 & 0,00 & 0,00 & 0,00 & 0,00 & 0,98 & 0,00 & 0,00 & - & - & \\
\hline W & & & & & & & & & 0,01 & 0,15 & & & & & & & & & & & & - & \\
\hline $\mathrm{Cd}$ & 0,00 & 0,10 & 0,09 & 0,00 & 0,06 & 0,00 & 0,07 & 0,03 & & & 0,00 & & 0,00 & 0,03 & 0,00 & 0,00 & 0,02 & 0,01 & 0,00 & 0,00 & - & - & \\
\hline $\mathrm{Hg}$ & 0,27 & 0,30 & 0,53 & 0,28 & 0,37 & 0,00 & 0,04 & 0,07 & & 0,0 & 0,10 & 0,08 & 0,16 & 0,03 & 0,00 & 0,00 & 0,08 & 0,00 & 0,00 & 0,00 & - & - & \\
\hline $\mathrm{Mn}$ & & & & & & & & & 0,04 & 0,00 & & & & & & & & & & & - & - & \\
\hline Total & 99,28 & 99,93 & 100,02 & 99,99 & 101,43 & 99,84 & 100,13 & 100,75 & 100,15 & 100,20 & 100,00 & 100,01 & 100,01 & 100,69 & 100,85 & 100,01 & 100,18 & 100,02 & 100,88 & 99,49 & 99,95 & 99,83 & 99,78 \\
\hline $\mathrm{s}$ & 1,05 & 1,04 & 1,03 & 1,02 & 1,00 & 0,96 & 0,87 & 1,01 & 1,01 & 1,00 & 0,99 & 1,00 & 1,02 & 1,00 & 1,01 & 1,00 & 1,02 & 0,99 & 1,00 & 1,00 & 1,02 & 1,00 & 1,02 \\
\hline As & & 0,97 & & & & & & & & & & & & & & & & & & & 1,00 & 1,01 & 1,00 \\
\hline $\mathrm{Fe}$ & & 0,96 & & & & & & & & & & & & & 0,99 & 1,01 & & & & 0,99 & 0,99 & 1,00 & 0,98 \\
\hline Co & & 0,00 & & & & & & & & & Do & & 00 & & 0,00 & 0,00 & 0,00 & 0,00 & 0,00 & 0,00 & 0,00 & 0,00 & 0,00 \\
\hline $\mathrm{Ni}$ & & 0,00 & & & & & & & & & & & & & 10 & 0, & 0,0 & & 0,00 & 0,00 & 0,00 & 0,00 & 0,00 \\
\hline $\mathrm{Cu}$ & & 0,0 & & & & & & & & & & & & & & & 0,0 & 0,00 & 0,00 & 0,00 & 0,00 & 0,00 & 0,00 \\
\hline & & & & & & & & & & & & & & & & & & & & & & 0,00 & 0,00 \\
\hline $\mathrm{Pb}$ & & & & & & & & & & & & & & & & & & & & & & 00 & 0,00 \\
\hline $\mathrm{sb}$ & & 0,0 & & & & & & & & & & & & & & & & & & & 0 & 0,00 & 0,00 \\
\hline $\mathrm{Ag}$ & & & & & & & & & & & & & & & & & & & & & 0,00 & 0,00 & 0,00 \\
\hline $\mathrm{Au}$ & 0,00 & 0,00 & 0,00 & 0,01 & 0,00 & 0,00 & 0,00 & 0,00 & 0,00 & 0,0 & 0,00 & 0,00 & 0,00 & 0,00 & 0,00 & 0,00 & 0,00 & 0,00 & 0,00 & 0,00 & 0,00 & 0,00 & 0,00 \\
\hline Sn & 0,0 & 0,00 & 0,0 & & & & & & & & & & & & & & & & & 0,00 & 0,00 & 0,00 & 0,00 \\
\hline & & & & & & & & & & & & & & & & & & & & & 0 & 0,00 & 0,00 \\
\hline $\mathrm{Te}$ & & 0,0 & & & & & & & & & & & & & & & & 0,00 & 0,0 & 0,00 & 0,00 & 0,00 & 0,00 \\
\hline $\mathrm{Bi}$ & 0,00 & 0,00 & 0,00 & 0,00 & 0,00 & 0,00 & 0,00 & 0,00 & 00 & 0,0 & 0,00 & 0,00 & 0,00 & 0,00 & 0,00 & 0,00 & 0,00 & 0,01 & 0,00 & 0,00 & 0,00 & 0,00 & 0,00 \\
\hline & & & & & & & & & & & & & & & & & & & & & & 0,00 & \\
\hline $\mathrm{Cd}$ & & & & & & & & & & & & & & & & & & & & & & 0 & \\
\hline $\mathrm{Hg}$ & & 0,00 & & 0,0 & & & & & & & & & & & 0,0 & $0, \mathrm{C}$ & 0,0 & 0,00 & 0,0 & 0,00 & 0,00 & 0,00 & 00 \\
\hline $\mathrm{Mn}$ & 0,00 & 0,00 & 0,00 & 0,00 & 0,00 & 0,00 & 0,00 & 0,00 & 0,00 & 0,00 & 0,00 & 0,00 & 0,00 & 0,00 & 0,00 & 0,00 & 0,00 & 0,00 & 0,00 & 0,00 & 0,00 & 0,00 & 0,00 \\
\hline
\end{tabular}


Anexo III. Análisis de microsonda electrónica

Arsenopirita (continuación)

\begin{tabular}{|c|c|c|c|c|c|c|c|c|c|c|c|c|c|c|c|c|c|c|c|c|c|c|c|}
\hline \multirow{3}{*}{$\begin{array}{l}\text { Mina/Zona } \\
\text { Roca } \\
\text { Muestra }\end{array}$} & \multirow{2}{*}{\multicolumn{12}{|c|}{ Salmantina }} & \multirow{2}{*}{\multicolumn{2}{|c|}{ Carrasq. Profunda }} & \multicolumn{9}{|c|}{ Teso de la Matanza } \\
\hline & & & & & & & & & & & & & & & Vena LG & Vena LG & Vena LG & Vena LG & Vena LG & Vena LG & 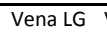 & 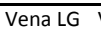 & Vena LG \\
\hline & 1181 & 1181 & 1181 & 1181 & 1181 & 1181 & 1181 & 1181 & 1181 & 1181 & 1181 & 1181 & 1785 & 781 & 1061 & 1061 & 1173 & 1173 & 1173 & 1173 & $1174 \mathrm{~A}$ & $1174 \mathrm{~A}$ & $1174 \mathrm{~A}$ \\
\hline Análisis & 1.7 & 1.9 & 1.12 & 1.17 & 3.4 & 3.5 & 3.6 & 3.19 & 3.25 & 3.25.3 & 4.1 & 4.6 & 3.18 & 5.18 & 1.23 & 2.30 & 1.6 & 1.12 & 2.2 & 3.13 & 4.17 & 4.19 & 5.22 \\
\hline$S(\%$ peso) & 20,08 & 19,76 & 20,23 & 20,75 & 19,96 & 19,75 & 20,18 & 20,34 & 20,20 & 20,34 & 20,00 & 20,14 & 18,81 & 20,04 & 20,62 & 21,05 & 20,72 & 20,84 & 20,28 & 20,26 & 20,40 & 20,21 & 20,36 \\
\hline $\mathrm{Fe}$ & 34,06 & 33,72 & 35,12 & 35,20 & 33,12 & 33,70 & 34,50 & 34,04 & 34,63 & 33,14 & 34,96 & 34,71 & 34,32 & 34,81 & 32,96 & 31,83 & 34,26 & 35,39 & 35,14 & 35,17 & 34,59 & 34,46 & 34,55 \\
\hline $\mathrm{Cu}$ & 0,00 & 0,00 & 0,00 & 0,00 & 0,00 & 0,00 & 0,00 & 0,00 & 0,00 & 0,00 & 0,00 & 0,00 & 0,01 & 0,02 & 0,02 & 0,00 & 0,03 & 0,00 & 0,00 & 0,00 & 0,00 & 0,00 & 0,00 \\
\hline As & 45,67 & 43,76 & 44,57 & 44,53 & 46,15 & 46,36 & 46,73 & 45,03 & 43,84 & 45,14 & 44,92 & 44,80 & 46,54 & 44,80 & 45,49 & 45,97 & 44,00 & 44,20 & 45,02 & 45,13 & 44,46 & 44,44 & 43,89 \\
\hline Co & 0,00 & 0,00 & 0,00 & 0,04 & 0,00 & 0,00 & 0,00 & 0,09 & 0,00 & 0,04 & 0,03 & 0,00 & 0,00 & 0,00 & 0,01 & 0,08 & 0,06 & 0,08 & 0,01 & 0,09 & 0,00 & 0,00 & 0,05 \\
\hline $\mathrm{Zn}$ & & 2,54 & 0,67 & 0,05 & & & & 1,36 & 1,06 & 0,08 & 0,14 & 0,00 & 0,00 & 0,00 & 0,00 & 0,09 & 0,00 & 0,03 & 0,00 & 0,00 & 0,00 & 0,02 & 0,01 \\
\hline$b$ & - & 0,01 & 0,00 & 0,00 & - & - & - & 0,00 & 0,00 & 0,00 & 0,00 & 0,01 & & & 0,0 & & 0,00 & & & & & & 0,00 \\
\hline Sb & - & 0,02 & 0,00 & 0,00 & - & - & - & 0,03 & 0,00 & 0,02 & 0,00 & 0,00 & 0,06 & 0,00 & 0,00 & 0,00 & 0,00 & 0,00 & 0,00 & 0,04 & 0,00 & 0,00 & 0,00 \\
\hline $\mathrm{Ni}$ & 0,10 & 0,02 & 0,00 & 0,00 & 0,04 & 0,00 & 0,00 & 0,00 & 0,00 & 0,02 & 0,01 & 0,01 & 00 & 0,00 & 0,05 & 0,02 & 0,00 & 0,01 & 00 & 0,00 & 0,04 & 0,00 & 0,04 \\
\hline $\mathrm{Ag}$ & & 0,12 & 0,02 & 0,00 & & & & 0,08 & 0,01 & 0,01 & 0,00 & 0,03 & 0,01 & 0,01 & 0,00 & 0,02 & 0,00 & 0,02 & 0,02 & 0,00 & 0,00 & 0,00 & 0,00 \\
\hline & - & 0,00 & 0,00 & 0,00 & - & - & - & 0,00 & 0,00 & 0,00 & 0,00 & 0,00 & 0,02 & & 0,00 & 0,00 & 0,00 & & & 0,00 & 0,00 & 0,00 & 0,00 \\
\hline & - & 0,00 & 0,04 & & - & - & - & 0,00 & 0,06 & 0,07 & 0,00 & 0,00 & & & 0,0 & & 0, & & & & 0,00 & & 0,04 \\
\hline $\mathrm{Se}$ & - & 0,03 & 0,00 & 0,12 & - & - & - & 0,00 & 0,23 & 0,24 & 0,00 & 0,00 & 0 , & 0,00 & 0,00 & 0,10 & 0,08 & 0,00 & 04 & 0,07 & 0,00 & 0,26 & 0,00 \\
\hline $\mathrm{Te}$ & & 0,00 & 0,00 & 0,00 & - & - & & 0,00 & 0,00 & 0,00 & 0,00 & 0,00 & 03 & 0,02 & 0,00 & 0,08 & 0,00 & 0,00 & 0,00 & 0,17 & 0,00 & 0,00 & 0,00 \\
\hline Bi & - & 0,00 & 0,00 & 0,00 & - & - & & 0,00 & 0,00 & 0,67 & 0,00 & 0,00 & 0,00 & 0,00 & 0,00 & 0,00 & 0,00 & 0,00 & 0,39 & 0,00 & 0,00 & 0,00 & 0,00 \\
\hline & - & & & & - & - & & & & & & & & & 0,08 & 0,16 & & & & & & & \\
\hline & - & 0,13 & 0,05 & 0,00 & - & - & - & 0,00 & 0,00 & 0,03 & 0,08 & 0,02 & & 0,03 & 0,02 & 0,10 & 0,10 & 02 & 0,00 & 0,00 & 0,00 & 0,00 & , ,09 \\
\hline $\mathrm{Hg}$ & - & & & & - & - & & & & & & & & 0,0 & 0,00 & 0,00 & & & & & & - & \\
\hline $\mathrm{Mn}$ & & & & & & - & & & & & & & 0,03 & 0,00 & & 0,00 & & & & & & & \\
\hline Total & 99,91 & 100,08 & 100,71 & 100,77 & 99,27 & 99,81 & 101,41 & 100,98 & 100,03 & 99,78 & 100,13 & 99,73 & 99,85 & 99,81 & 99,31 & 99,50 & 99,25 & 100,60 & 100,93 & 100,95 & 99,49 & 99,40 & 99,02 \\
\hline c & 1,02 & 1,00 & 1,01 & 1,04 & 1,02 & $\frac{1,01}{1,01}$ & 1,01 & $\frac{101,02}{1,02}$ & 1,02 & 1,03 & 1,01 & 1,02 & 0,96 & & 1,05 & 1,07 & 1,05 & 1,04 & $\frac{102}{1,02}$ & 1,01 & 1,03 & 1,03 & 1,03 \\
\hline & 0,9 & 0 & & & & & & & & & & 0,97 & & & & & & & & & & 0,96 & 0,95 \\
\hline $\mathrm{Fe}$ & 0,99 & 0,98 & 1,01 & 1,01 & & & & 0,98 & 1,00 & 0,97 & 1,01 & 1,01 & & & 0,96 & 0,93 & 0,99 & & & 1,01 & 1,00 & 1,00 & 1,01 \\
\hline$c$ & 0,00 & & & & & & & & & 00 & 00 & 00 & & & & 0,0 & & & & & & 0,00 & 0,00 \\
\hline & & & & & & & & & & & 0 & 0,00 & & & & 0,00 & & & & 0,00 & & 0,00 & 0,00 \\
\hline & 0,0 & & & & & & & 0,0 & $0, \mathrm{C}$ & 0,0 & 0 & 0,00 & & & 0,00 & 0,0 & 0,00 & 0,0 & & 0,00 & 0,00 & 0,00 & 0,00 \\
\hline & & & & & & & & & & & & & & & & & & & & & & & 0,00 \\
\hline & & & & & & & & & & & & & & & & & & & & & & & 00 \\
\hline $\mathrm{Sk}$ & & & & & & & & & & & & & & & & & & & & & & 0,00 & 0,00 \\
\hline & & & & & & & & & & & & & & & & & & & & & & 0,00 & 0,00 \\
\hline Al & 0,00 & 0,00 & 0,00 & 0,00 & & 0,00 & & 0,00 & 0,00 & 0,00 & 0,00 & 0,00 & & 0,00 & 0,00 & 0,0 & 0,00 & 0,00 & 0,00 & 0,00 & 0,00 & 0,00 & 0,00 \\
\hline & 0,00 & & & & & & & & & & & & & & & & & & & & & 0,00 & 0,00 \\
\hline se & & & & & & & & & & & & & & & & & & & & & 10 & 0,01 & 0,00 \\
\hline Te & 0,00 & 0,00 & & 0,00 & & & & 0,0 & & 0,0 & & 0,00 & & & & & & & & 0,0 & 0,00 & 0,00 & 0,00 \\
\hline $\mathrm{Bi}$ & 0,00 & 0,00 & 0,00 & & & 0,0 & & 0,00 & 0,00 & 0,0 & 0, & 0,00 & & 0,0 & 0,00 & 0,0 & 0,00 & 0,0 & 00 & 0,00 & 0,00 & 0,00 & 0,00 \\
\hline & & & & & & & & & & & & & & & & & & & & & & & 0,00 \\
\hline & & & & & & & & & & & & & & & & & & & & & & & \\
\hline & 0,00 & 0,00 & 0,00 & 0,00 & 0,00 & & 0,00 & 0,00 & & & 0,00 & 00 & 0,00 & & 0,00 & &, 0 & & &, 0 &, 00 & 0,00 & \\
\hline & 000 & 00 & 00 & 000 & 0 & 000 & 000 & 000 & 00 & 000 & 000 & 00 & 000 & 000 & 000 & 000 & 00 & 000 & 0,00 & 年, & 00 & . & \\
\hline
\end{tabular}


Anexo III. Análisis de microsonda electrónica

\begin{tabular}{|c|c|c|c|c|c|c|c|c|c|c|c|c|c|c|c|c|c|c|c|c|c|c|c|}
\hline \multirow{2}{*}{$\begin{array}{l}\text { Mina/Zona } \\
\text { Roca }\end{array}$} & \multicolumn{10}{|c|}{ Teso de la Matanza } & \multicolumn{11}{|c|}{$\begin{array}{c}\text { Bon } \\
\end{array}$} & \multicolumn{2}{|c|}{ El Jaque } \\
\hline & Vena LG & Vena LG & Vena LG & Vena LG & Vena LG & Vena LG & Vena LG & Vena LG & Vena LG & Vena LG & Vena LG & Vena LG & Vena LG & Vena LG & Vena LG & Vena LG & Vena LG & Vena LG & Vena LG & Vena LG & Vena LG & Vena G6 & Vena G6 \\
\hline Muestra & $1174 \mathrm{~A}$ & $1174 \mathrm{~A}$ & $1174 \mathrm{~A}$ & 1174B & $1174 \mathrm{~B}$ & 1174B & 1174B & 1174B & 1174B & 1174B & 1057 & 1057 & 1057 & 1057 & 1057 & 1057 & 1057 & 1057 & 1057 & 1058 & 1058 & 1068 & 1069 \\
\hline Análisis & 5.26 & 6.53 & 6.54 & 1.22 & 3.4 & 3.6 & 5.8 & 5.9 & 4.14 & 4.17 & 1.4 & 1.5 & 1.6 & 1.7 & 1.8 & 2.1 & 2.2 & 2.3 & 4.21 & 1.146 & 4.149 & 1.66 & 1.118 \\
\hline $\mathrm{S}(\%$ peso) & 20,23 & 20,19 & 20,15 & 20,42 & 20,39 & 20,19 & 20,20 & 20,05 & 20,60 & 20,33 & 19,20 & 19,58 & 18,80 & 19,38 & 20,57 & 19,33 & 19,71 & 20,00 & 20,31 & 20,06 & 20,46 & 19,86 & 20,49 \\
\hline $\mathrm{Fe}$ & 34,23 & 34,69 & 34,75 & 34,89 & 34,70 & 33,54 & 35,00 & 34,88 & 34,01 & 35,00 & 33,15 & 33,46 & 33,28 & 33,60 & 33,68 & 34,29 & 34,26 & 33,39 & 33,81 & 33,17 & 32,83 & 33,46 & 32,61 \\
\hline $\mathrm{Cu}$ & 0,00 & 0,00 & 0,00 & 0,00 & 0,00 & 0,00 & 0,00 & 1,20 & 0,00 & 0,03 & 0,00 & 0,00 & 0,00 & 0,00 & 0,00 & 0,00 & 0,00 & 0,00 & 0,05 & 0,03 & 0,00 & 0,02 & 0,00 \\
\hline As & 44,28 & 44,47 & 44,79 & 45,05 & 44,45 & 44,27 & 44,72 & 43,59 & 44,81 & 44,51 & 45,63 & 44,65 & 47,49 & 45,96 & 45,21 & 45,99 & 46,71 & 46,30 & 46,41 & 46,60 & 45,91 & 46,22 & 45,45 \\
\hline Co & 0,06 & 0,07 & 0,00 & 0,00 & 0,00 & 0,09 & 0,02 & 0,00 & 0,00 & 0,05 & 0,00 & 0,00 & 0,05 & 0,00 & 0,00 & 0,00 & 0,00 & 0,00 & 0,00 & 0,03 & 0,08 & 0,02 & 0,07 \\
\hline $\mathrm{Zn}$ & 0,03 & 0,03 & 0,00 & 0,02 & 0,03 & 0,00 & 0,04 & 0,00 & 0,07 & 0,03 & - & - & 0,02 & - & - & - & - & - & 0,00 & 0,03 & 0,00 & 0,00 & 0,03 \\
\hline $\mathrm{Pb}$ & 0,00 & 0,00 & 0,0 & 0,00 & 0,00 & 0,00 & 0,00 & 0,00 & 0,00 & 0,00 & - & - & 0,00 & - & - & - & - & - & 0,00 & 0,00 & 0,00 & 0,00 & 0,00 \\
\hline $\mathrm{sb}$ & 0,00 & 0,00 & 0,00 & 0,00 & 0,00 & 0,00 & 0,00 & 0,00 & 0,00 & 0,00 & - & & 0,03 & & & & - & . & 0,04 & 0,03 & 0,00 & 0,05 & 0,05 \\
\hline $\mathrm{Ni}$ & 0,04 & 0,00 & 0,07 & 0,01 & 0,00 & 0,02 & 0,03 & 0,03 & 0,01 & 0,00 & 0,02 & 0,09 & 0,02 & 0,02 & 0,01 & 0,03 & 0,01 & 0,03 & 0,03 & 0,03 & 0,02 & 0,09 & 0,01 \\
\hline $\mathrm{Ag}$ & 0,00 & 0,00 & 0,00 & 0,08 & 0, & 0,56 & 0,00 & 0,00 & 0,06 & 0,05 & . & 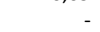 & 0,00 & . & & - & - & - & 0,00 & 0,00 & 0,02 & 0,0 & 0,00 \\
\hline $\mathrm{Au}$ & 0, & 0,00 & 0, & 0,00 & 11 & 0,00 & 0,00 & 0,00 & 0,00 & 0,00 & - & - & 0,00 & - & - & - & - & - & 0,00 & 0,00 & 0,00 & 0,00 & 0,42 \\
\hline Sn & 0,01 & 0,00 & 0,07 & 0,01 & 0,04 & 0,10 & 0,07 & 0,02 & 0,00 & 0,03 & - & - & 0,06 & - & & - & - & - & 0,01 & 0,03 & 0,00 & 0,00 & 0,06 \\
\hline $\mathrm{Se}$ & 0,07 & 0,00 & 0,11 & 0,10 & 0,09 & 0,00 & 0,22 & 0,19 & 0,28 & 0,12 & - & - & 0,00 & - & & - & - & - & 0,00 & 0,00 & 0,00 & 0,10 & 0,00 \\
\hline $\mathrm{Te}$ & 0,08 & 0,00 & 0,03 & 0,13 & 0,02 & 0,02 & 0,00 & 0,00 & 0,00 & 0,00 & - & - & 0,00 & - & - & - & - & - & 0,00 & 0,00 & 0,00 & 0,07 & 0,10 \\
\hline $\mathrm{Bi}$ & 0,00 & 0,00 & 0,00 & 0,00 & 0,00 & 1,19 & 0,00 & 0,00 & 0,00 & 0,00 & - & - & 0,00 & - & - & - & - & - & 0,00 & 0,00 & 0,00 & 0,00 & 0,00 \\
\hline w & & & & & & & & & & & - & - & 0,00 & - & - & - & - & - & 0,00 & 0,00 & 0,00 & 0,00 & 0,71 \\
\hline $\mathrm{Cd}$ & 0,00 & 0,00 & 0,09 & 0,00 & 0,13 & 0,00 & 0,02 & 0,02 & 0,16 & 0,00 & - & - & 0,04 & - & & - & - & - & 0,09 & 0,01 & 0,07 & 0,07 & 0,02 \\
\hline $\mathrm{Hg}$ & & & & & & & & & & & - & - & 0,22 & - & - & - & - & - & 0,00 & 0,00 & 0,48 & 0,00 & 0,00 \\
\hline $\mathrm{Mn}$ & & & & & & . & & . & . & . & - & - & & - & - & - & . & - & & 0,02 & 0,01 & 0,01 & 0,01 \\
\hline Total & 99,04 & 99,44 & 100,05 & 100,70 & 99,86 & 99,97 & 100,33 & 99,97 & 99,99 & 100,15 & 98,00 & 97,78 & 100,01 & 98,96 & 99,47 & 99,64 & 100,69 & 99,72 & 100,75 & 100,04 & 99,86 & 100,02 & 100,01 \\
\hline solus & 1,03 & $\frac{1,02}{1,02}$ & 1,02 & $\frac{10,7}{1,02}$ & 1,03 & 1,03 & $\frac{100,02}{1,02}$ & 1,01 & 1,04 & 1,02 & 1,00 & 1,01 & 0,97 & 1,00 & 1,04 & 0,99 & 1,00 & 1,02 & 1,02 & 1,02 & 1,04 & 1,01 & $\frac{1,01}{1,04}$ \\
\hline As & 0,96 & 0,96 & 0,97 & 0,97 & 0,96 & 0,97 & 0,96 & 0,94 & 0,97 & 0,96 & 1,01 & 0,99 & 1,04 & 1,01 & 0,98 & 1,01 & 1,01 & 1,01 & 1,00 & 1,01 & 1,00 & 1,01 & 0,99 \\
\hline $\mathrm{Fe}$ & 1,00 & 1,01 & & 1,00 & & 0,98 & 1,01 & 1,01 & 98 & 1,01 & 99 & 0,99 & & 0,99 & 0,98 & 1,01 & 0,99 & 0,97 & & & & 0,98 & 0,95 \\
\hline Co & & & & & & & po & & & & & 0 , & & 00 & 0,00 & bo & 0,00 & 0,00 & & & & & 0,00 \\
\hline $\mathrm{Ni}$ & & & & & & & & & & & & & & & & 0,00 & & 0,00 & & & & & 0,00 \\
\hline $\mathrm{Cu}$ & 0,00 & & & & & & 0,00 & 0,03 & & & & 0,00 & & 0,00 & & 0,00 & & 0,00 & & & & & 0,00 \\
\hline$Z_{I}$ & & & & & & & 00 & & & & & & & & & & & 0,00 & & & & & 0,00 \\
\hline $\mathrm{Pb}$ & & & & & & & & & & & & & & & & & 0,00 & 0,00 & & & & & 0,00 \\
\hline $\mathrm{sb}$ & 0,0 & 0,00 & 0 & 0,00 & 0, & 0,0 & 0,00 & 0,00 & 00 & 0,00 & 00 & 0,00 & 0,00 & 0,00 & 0,00 & 0,00 & 0,00 & 0,00 & 0,00 & 0,00 & 0,00 & 0,00 & 0,00 \\
\hline $\mathrm{Ag}$ & & & & & & & & & & & & & & & & & & & & & & & 0,00 \\
\hline Au & & & & & & & & 0,0 & & & & 0, & & 0,00 & & 0,00 & & 0,00 & & & & & 0,00 \\
\hline $\mathrm{Sn}$ & 0,00 & 0,00 & 0, & 0,00 & 0,00 & 0,00 & 0,00 & 0,00 & 0,00 & & & 0,00 & 0,00 & 0,00 & 0,00 & 0,00 & 0,00 & 0,00 & 0,00 & 0,00 & 0,00 & 0,00 & 0,00 \\
\hline $\mathrm{Se}$ & 0,0 & 0,00 & & 0,00 & 0, & 0,00 & 0,00 & 0,00 & 0, & $0, c$ & & 0,00 & 00 & 0,00 & 0,00 & 0,00 & 0,00 & 0,00 & 0,00 & 0,00 & 0,00 & 0,00 & 0,00 \\
\hline & & & & & & & & & & & & & & & & & & & & & & & \\
\hline & & & & & & & & & & & & & & & & & & & & & & & \\
\hline & & & & & & & & & & & & & & & & & 00 & 0,00 & 00 & & & 0,0 & 0,01 \\
\hline $\mathrm{Cd}$ & 0,00 & 0,00 & 0,00 & 0,00 & 0,00 & 0,00 & 0,00 & 0,00 & 0,00 & 0,00 & 0,00 & 0,00 & 0,00 & 0,00 & 0,00 & 0,00 & 0,00 & 0,00 & 0,00 & 0,00 & 0,00 & 0,00 & 0,00 \\
\hline $\mathrm{Hg}$ & 0,00 & 0,00 & 0,00 & 0,00 & 0,00 & 0,00 & 0,00 & 0,00 & 0,00 & 0,00 & 0,00 & 0,00 & 0,00 & 0,00 & 0,00 & 0,00 & 0,00 & 0,00 & 0,00 & 0,00 & 0,00 & 0,00 & 0,00 \\
\hline $\mathrm{Mn}$ & 000 & , & 000 & 000 & 0 & 000 & 000 & 000 & 000 & 000 & 000 & 000 & 000 & 000 & 000 & 000 & 000 & 000 & 000 & 000 & 000 & 000 & 000 \\
\hline
\end{tabular}


Anexo III. Análisis de microsonda electrónica

\begin{tabular}{|c|c|c|c|c|c|c|c|c|c|c|c|c|c|c|c|c|c|c|c|c|c|c|c|}
\hline \multirow{2}{*}{$\begin{array}{l}\text { Mina/Zona } \\
\text { Roca }\end{array}$} & \multicolumn{4}{|c|}{ El Jaque } & \multicolumn{19}{|c|}{ El Cruce } \\
\hline & Vena G6 & Vena G6 & Vena G6 & Vena G6 & Vena G2 & Vena G2 & Vena G2 & Vena G2 & Vena G2 & Vena G2 & Vena G2 & Vena G2 & Vena G2 & Vena G2 & Vena G2 & Vena G2 & Vena G2 & Vena G2 & Vena G2 & Vena $G 2$ & Vena G2 & Vena G2 & Vena G2 \\
\hline Muestra & 1069 & 1068 & 1068 & 1069 & 1064 & 1065 & 1065 & 1065 & 1065 & 1065 & 1065 & 1065 & 1065 & 1065 & 1065 & 1065 & 1065 & 1065 & 1065 & 1065 & 1065 & 1065 & 1065 \\
\hline Análisis & 1.120 & 2.67 & 3.68 & 3.99 & 5.60 & 1.1 & 1.2 & 1.6 & 1.7 & 1.8 & 1.9 & 1.76 & 2.1 & 2.2 & 2.3 & 2.4 & 2.5 & $2.5 \mathrm{~b}$ & 2.6 & 2.7 & 2.10 & 2.11 & 3.1 \\
\hline S (\% peso) & 20,77 & 21,44 & 20,23 & 20,44 & 19,73 & 21,32 & 19,87 & 19,78 & 21,16 & 20,46 & 21,29 & 19,30 & 20,82 & 20,06 & 20,02 & 21,32 & 20,55 & 20,17 & 20,04 & 20,72 & 20,44 & 20,93 & 20,34 \\
\hline $\mathrm{Fe}$ & 34,16 & 34,23 & 34,23 & 34,08 & 34,13 & 35,18 & 34,12 & 34,34 & 34,59 & 33,89 & 34,39 & 33,53 & 34,62 & 33,77 & 33,77 & 33,65 & 33,41 & 34,15 & 33,57 & 33,78 & 33,94 & 33,75 & 33,23 \\
\hline $\mathrm{Cu}$ & 0,00 & 0,03 & 0,01 & 0,07 & 0,13 & 0,00 & 0,00 & 0,00 & 0,00 & 0,00 & 0,00 & 0,00 & 0,00 & 0,00 & 0,00 & 0,00 & 0,00 & 0,01 & 0,00 & 0,00 & 0,00 & 0,00 & 0,00 \\
\hline As & 44,52 & 44,84 & 45,09 & 44,11 & 44,43 & 44,53 & 46,77 & 46,20 & 44,58 & 46,01 & 45,42 & 46,13 & 45,66 & 46,44 & 46,13 & 44,63 & 45,25 & 44,67 & 46,29 & 45,01 & 45,67 & 44,65 & 44,87 \\
\hline Co & 0,08 & 0,03 & 0,00 & 0,07 & 0,04 & 0,00 & 0,00 & 0,00 & 0,00 & 0,00 & 0,00 & 0,05 & 0,00 & 0,00 & 0,00 & 0,00 & 0,00 & 0,02 & 0,00 & 0,00 & 0,00 & 0,00 & 0,00 \\
\hline $\mathrm{Zn}$ & 0,00 & 0,09 & 0,02 & 0,99 & 0,91 & - & - & - & - & - & - & 0,03 & - & & & & - & 0,02 & - & - & - & - & \\
\hline $\mathrm{Pb}$ & 0,00 & 0,00 & 0,00 & 0,0 & 0,00 & - & - & - & - & - & - & 0,00 & - & - & & & - & 0,00 & - & - & - & - & \\
\hline Sb & 0,0 & 0,05 & 0,00 & 0,0 & 0,21 & - & - & - & - & - & - & 0,19 & 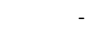 & & & & - & 0,12 & - & - & - & - & \\
\hline $\mathrm{Ni}$ & 0,03 & 0,05 & 0,03 & 0,02 & 0,00 & 0,00 & 0,00 & 0,01 & 0,01 & 0,00 & 0,00 & 0,02 & 0,00 & 0,04 & 0,00 & 0,00 & 0,07 & 0,06 & 0,00 & 0,01 & 0,02 & 0,04 & 0,00 \\
\hline $\mathrm{Ag}$ & 0,00 & 0,00 & 0,00 & 0,00 & 0,00 & - & - & 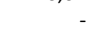 & - & - & - & 0,00 & - & - & - & - & - & 0,04 & - & 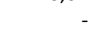 & - & 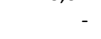 & \\
\hline $\mathrm{Au}$ & 0,00 & 0,00 & 0,00 & 0,00 & 0,00 & - & - & - & - & - & - & 0,00 & - & - & - & - & - & 0,00 & - & - & - & - & \\
\hline Sn & 0,00 & 0,04 & 0,04 & & & - & - & - & - & - & - & 0,0 & - & - & & - & - & 0,03 & - & - & - & - & \\
\hline Se & & 0,05 & & & & - & - & - & - & - & - & 0,01 & - & - & - & - & - & 0,09 & - & - & - & - & \\
\hline $\mathrm{Te}$ & 0 & 0,00 & 00 & & 0,00 & - & - & - & - & - & - & 0,00 & - & - & - & - & - & 0,00 & - & - & - & - & \\
\hline $\mathrm{Bi}$ & 0,00 & 0,00 & 0,00 & 0,00 & 0,00 & - & - & - & - & - & - & 0,00 & - & - & & - & - & 0,16 & - & - & - & - & \\
\hline & & & & & & - & - & - & - & - & - & 0,0 & - & - & - & - & - & & - & - & - & - & \\
\hline $\mathrm{Cd}$ & & & & & & - & - & - & - & - & - & & 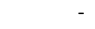 & - & & & & 0,07 & - & - & - & - & \\
\hline $\mathrm{Hg}$ & & & & & & - & - & - & - & - & - & & - & - & - & - & - & 0,39 & - & - & - & - & \\
\hline $\mathrm{Mn}$ & 0,00 & 0,00 & 0,02 & 0,02 & 0,00 & - & - & - & - & - & - & 0,00 & - & - & & - & - & & - & - & - & & \\
\hline Total & 100,02 & 100,94 & 100,00 & 100,03 & 100,08 & 101,03 & 100,76 & 100,33 & 100,34 & 100,36 & 101,10 & 100,02 & 101,10 & 100,31 & 99,92 & 99,60 & 99,28 & 100,00 & 99,90 & 99,52 & 100,07 & 99,37 & 98,44 \\
\hline $\mathrm{s}$ & 1,05 & 1,06 & 1,02 & 1,03 & 1,00 & 1,05 & 1,00 & 1,00 & 1,05 & 1,02 & 1,05 & 0,99 & 1,03 & 1,01 & 1,01 & 1,07 & 1,04 & 1,02 & 1,01 & 1,04 & 1,03 & 1,05 & 1,04 \\
\hline As & & & & & & & & & & & & & & & & & & & & 0,97 & 0,98 & 0,96 & 0,98 \\
\hline $\mathrm{Fe}$ & & 0,98 & & & & & 88 & & & & & & & 0, & 0,98 & 0,97 & 0,97 & 0,99 & 0,97 & 0,97 & 0,98 & 0,97 & 0,97 \\
\hline Co & & 0,00 & & & & & & & & & & & & & 0,00 & 0,00 & 0,00 & 0,00 & 0,00 & 0,00 & 0,00 & 0,00 & 0,00 \\
\hline $\mathrm{Ni}$ & & 0,00 & & & & & & & & & & & & $0, \mathrm{C}$ & 0,00 & 0,00 & 0,00 & 0,00 & 0,00 & 0,00 & 0,00 & 0,00 & 0,00 \\
\hline & & & & & & & & & & & & & & 0, & 0,00 & 00 & 0,00 & 0,00 & 0,00 & 0,00 & 0,00 & 0,00 & 0,00 \\
\hline & & & & & & & & & & & & & & & & & & & & 000 & & 0,00 & 0,00 \\
\hline $\mathrm{Pb}$ & & 0,0 & & & & & & & & & & & & & & & & & & 00 & & 00 & 0,00 \\
\hline $\mathrm{Sb}$ & & & & & & & & & & & & & & & & & & & & 0,00 & 00 & 0,00 & 0,00 \\
\hline $\mathrm{Ag}$ & & & & & & & & & & & & & & & & & 0,00 & & 0,00 & 0,00 & 0,00 & 0,00 & 0,00 \\
\hline $\mathrm{Au}$ & 0,00 & 0,00 & 0,00 & 0,00 & 0,00 & 0,00 & 0,00 & 0,00 & 0,00 & 0,00 & 0,00 & 0,00 & 0,00 & 0,00 & 0,00 & 0,00 & 0,00 & 0,00 & 0,00 & 0,00 & 0,00 & 0,00 & 0,00 \\
\hline Sn & 0,00 & 0,00 & 0,0 & & & & & & & & & & & & 0,00 & 0,00 & 0,00 & 0,00 & 0,00 & 0,00 & 0,00 & 0,00 & 0,00 \\
\hline & & & & & & & & & & & & & & & & & 0,0 & & 0,0 & 0,01 & 0,01 & 0,01 & 0,01 \\
\hline $\mathrm{Te}$ & & & & & & & & & & & & & & & 0,00 & 0,00 & 0,00 & 0,00 & 0,00 & 0,00 & 0,00 & 0,00 & 0,00 \\
\hline $\mathrm{Bi}$ & 0,00 & 0,00 & 0,00 & 0,00 & 0,00 & 0,00 & 0,00 & 0,00 & 0,00 & 0,00 & 0,00 & 0,00 & 0,00 & 0,00 & 0,00 & 0,00 & 0,00 & 0,00 & 0,00 & 0,00 & 0,00 & 0,00 & 0,00 \\
\hline & & & & & & & & & & & & & & & & & & & & 0,00 & 0,00 & 0,00 & \\
\hline $\mathrm{Cd}$ & 0 , & & & & & & & & & & & & & & & & & & & & & bo & Do \\
\hline $\mathrm{Hg}$ & 0,00 & 0,00 & & & & & & & & & & & & & 0,00 & 0,0 & 0,00 & 0,00 & 0,00 & 0,00 & 0,00 & 0,00 & 0,00 \\
\hline $\mathrm{Mn}$ & 0,00 & 0,00 & 0,00 & 0,00 & 0,00 & 0,00 & 0,00 & 0,00 & 0,00 & 0,00 & 0,00 & 0,00 & 0,00 & 0,00 & 0,00 & 0,00 & 0,00 & 0,00 & 0,00 & 0,00 & 0,00 & 0,00 & 0,00 \\
\hline
\end{tabular}


Anexo III. Análisis de microsonda electrónica

\begin{tabular}{|c|c|c|c|c|c|c|c|}
\hline \multirow{2}{*}{$\begin{array}{l}\text { Mina/Zona } \\
\text { Roca }\end{array}$} & \multicolumn{3}{|c|}{ 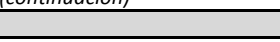 } & \multicolumn{4}{|l|}{ El Cruce } \\
\hline & Vena G2 & Vena G2 & Vena G2 & Vena G2 & Vena G2 & Vena G2 & Vena G2 \\
\hline Muestra & 1065 & 1065 & 1065 & 1065 & 1065 & 1065 & 1065 \\
\hline Análisis & 3.2 & 3.3 & 3.4 & 3.5 & 3.6 & 4.6 & 5.1 \\
\hline S(\% peso) & 19,93 & 20,61 & 20,25 & 21,17 & 20,40 & 20,66 & 19,65 \\
\hline $\mathrm{Fe}$ & 33,50 & 33,69 & 33,54 & 34,55 & 33,88 & 34,35 & 34,02 \\
\hline $\mathrm{Cu}$ & 0,00 & 0,00 & 0,00 & 0,00 & 0,00 & 0,15 & 0,02 \\
\hline As & 45,40 & 44,99 & 45,59 & 44,01 & 45,34 & 44,44 & 44,59 \\
\hline Co & 0,00 & 0,00 & 0,00 & 0,00 & 0,00 & 0,02 & 0,06 \\
\hline $\mathrm{Zn}$ & - & - & - & - & - & 0,03 & 0,05 \\
\hline $\mathrm{Pb}$ & - & - & - & - & & 0,00 & 0,00 \\
\hline $\mathrm{sb}$ & - & & & & & 0,14 & 0,40 \\
\hline $\mathrm{Ni}$ & 0,10 & 0,02 & 0,00 & 0,00 & 0,07 & 0,00 & 0,00 \\
\hline $\mathrm{Ag}$ & - & & - & - & - & 0,00 & 0,06 \\
\hline $\mathrm{Au}$ & - & - & - & - & - & 0,00 & 0,21 \\
\hline Sn & - & - & - & - & & 0,02 & 0,04 \\
\hline Se & - & - & - & - & & 0,00 & 0,35 \\
\hline $\mathrm{Te}$ & - & - & - & - & & 0,00 & 0,06 \\
\hline $\mathrm{Bi}$ & - & - & - & - & & 0,00 & 0,00 \\
\hline w & - & - & - & - & - & & \\
\hline $\mathrm{Cd}$ & - & - & - & - & & 0,10 & 0,05 \\
\hline $\mathrm{Hg}$ & - & - & - & - & - & 0,00 & 0,46 \\
\hline $\mathrm{Mn}$ & - & - & - & - & - & & \\
\hline Total & 98,93 & 99,31 & 99,38 & 99,73 & 99,69 & 99,90 & 100,03 \\
\hline S & 1,01 & 1,04 & 1,02 & 1,06 & 1,03 & 1,04 & 1,00 \\
\hline As & 0,99 & 0,97 & 0,99 & 0,94 & 0,98 & 0,96 & 0,97 \\
\hline & 0 , & 0,97 & 0,97 & 99 & 0,98 & 0,99 & 1,00 \\
\hline Co & & 0 & & & 0,00 & 0,00 & 0,00 \\
\hline $\mathrm{Ni}$ & & 0 & & & 0,00 & 0,00 & \\
\hline $\mathrm{Cu}$ & 0,00 & 0,00 & 0,00 & 00 & 0,00 & 0,00 & 0,00 \\
\hline $\mathrm{Zn}$ & & & & & 0,00 & 0,00 & 0,0 \\
\hline $\mathrm{Pb}$ & & & & & 0 & 0,00 & 0,0 \\
\hline $\mathrm{Sb}$ & 0,00 & 0,00 & 0,00 & 0,00 & 0,00 & 0,00 & 0,01 \\
\hline $\mathrm{Ag}$ & & & & & & & \\
\hline $\mathrm{Au}$ & 0,00 & 0, & 0,00 & & 0,00 & 0,00 & \\
\hline Sn & 0,00 & 0,00 & 0,00 & 0,00 & 0,00 & 0,00 & 0,00 \\
\hline $\mathrm{Se}$ & 0,01 & 11 & 0,01 & 01 & 0,01 & 0,00 & $0, \mathrm{C}$ \\
\hline $\mathrm{Te}$ & & & & & & & \\
\hline $\mathrm{Bi}$ & 0,0 & & & & & & \\
\hline$w$ & & 0, & & 00 & 0,00 & 0,00 & 0,00 \\
\hline $\mathrm{Cd}$ & 0,00 & 0,00 & 0,00 & 0,00 & 0,00 & 0,00 & 0,00 \\
\hline $\mathrm{Hg}$ & 0,00 & 0,00 & 0,00 & 0,00 & 0,00 & 0,00 & 0,00 \\
\hline $\mathrm{Mn}$ & 0,00 & 0,00 & 0,00 & 0,00 & 0,00 & 0,00 & 0,00 \\
\hline
\end{tabular}

\begin{tabular}{|c|c|c|c|c|c|c|c|c|c|c|c|c|c|c|}
\hline \multirow{2}{*}{$\frac{\overline{M i n a / Z o n a}}{\mathrm{Roca}}$} & \multicolumn{11}{|c|}{ Horia } & \multirow{2}{*}{$\begin{array}{l}\text { Mari C. } \\
\text { Vena GE }\end{array}$} & \multicolumn{2}{|c|}{ Salmantina } \\
\hline & GE & Vena GE & Vena GE & Vena GE & Vena GE & Vena GE & Vena GE & Vena GE & Vena GE & Vena GE & Vena GE & & Vena LG & Vena LG \\
\hline Muestra & $1682 \mathrm{~A}$ & 1711D & $1773 A$ & $1773 A$ & $1773 A$ & $1773 \mathrm{~A}$ & 1773A & $1773 \mathrm{~A}$ & 1773A & $1773 A$ & $1773 A$ & 1720 & $1059 \mathrm{~A}$ & $1059 \mathrm{~A}$ \\
\hline Análisis & 1.2 & 1.9 & 3.1 & 1.1 & 1.2 & 1.3 & 1.4 & 1.5 & 1.6 & 1.7 & 1.8 & 3.1 & 127 & 129 \\
\hline S(\% peso) & 33,82 & 33,50 & 32,35 & 33,55 & 33,70 & 32,30 & 32,89 & 33,07 & 33,29 & 32,62 & 33,16 & 32,88 & 32,43 & 32,47 \\
\hline $\mathrm{Fe}$ & 9,07 & 10,37 & 10,44 & 9,72 & 11,34 & 10,53 & 9,05 & 11,01 & 8,32 & 9,52 & 9,70 & 10,12 & 12,26 & 12,27 \\
\hline $\mathrm{Cu}$ & 0,06 & 0,00 & 0,03 & 0,00 & 0,15 & 0,00 & 0,05 & 0,00 & 0,14 & 0,16 & 0,00 & 0,04 & 0,03 & 0,00 \\
\hline As & 0,00 & 0,00 & 0,04 & - & - & - & 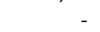 & & & & & 0,01 & 0,03 & 0,00 \\
\hline Co & 0,00 & 0,00 & 0,00 & - & - & - & - & - & - & - & - & 0,00 & 0,06 & 0,00 \\
\hline $\mathrm{Zn}$ & 56,68 & 53,56 & 53,58 & 54,67 & 53,48 & 53,84 & 54,70 & 53,94 & 57,11 & 56,30 & 57,16 & 54,20 & 53,60 & 53,99 \\
\hline $\mathrm{Pb}$ & 0,00 & 0,03 & 0,17 & & - & & - & & & & & 0,00 & 0,00 & 0,00 \\
\hline sb & 0,03 & 0,03 & 0,00 & - & - & - & - & - & & - & & 0,00 & 0,01 & 0,02 \\
\hline $\mathrm{Ni}$ & 0,00 & 0,00 & 0,00 & - & - & - & - & - & - & - & & 0,00 & 0,00 & 0,00 \\
\hline $\mathrm{Ag}$ & 0,00 & 0,01 & 0,03 & - & - & - & - & - & - & - & - & 0,00 & 0,03 & 0,00 \\
\hline $\mathrm{Au}$ & 0,00 & 0,00 & 0,00 & - & - & - & - & - & 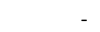 & 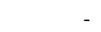 & & 0,00 & 0,00 & 0,00 \\
\hline Sn & 0,00 & 0,00 & 0,00 & 0,03 & 0,00 & 0,01 & 0,01 & 0,00 & 0,00 & 0,00 & 0,00 & 0,00 & 0,00 & 0,00 \\
\hline & 0,03 & 0,02 & 0,01 & 0,07 & 0,00 & 0,09 & 0,00 & 0,00 & 0,00 & 0,02 & 0,01 & 0,00 & 0,02 & 0,00 \\
\hline $\mathrm{Te}$ & 0,07 & 0,06 & 0,00 & - & - & - & - & & & & & 0,00 & 0,00 & 0,11 \\
\hline $\mathrm{Bi}$ & 0,00 & 0,00 & 0,00 & - & - & - & - & 0,13 & & & & 0,00 & 0,00 & 0,00 \\
\hline w & & & & - & - & - & - & & - & - & - & 0,03 & 0,14 & 0,07 \\
\hline $\mathrm{Cd}$ & 0,12 & 1,71 & 2,04 & 1,60 & 1,35 & 1,52 & 1,53 & 1,43 & 1,44 & 1,22 & 1,47 & 1,29 & 0,66 & 0,65 \\
\hline $\mathrm{Hg}$ & & & & & & & & & & & & 0,00 & 0,00 & 0,00 \\
\hline $\mathrm{Mn}$ & 0,04 & 0,52 & 0,34 & 0,34 & 0,50 & 0,43 & 0,29 & 0,47 & 0,07 & 0,02 & 0,14 & 0,59 & 0,41 & 0,45 \\
\hline In & & & & 0,00 & 0,05 & 0,00 & 0,20 & 0,07 & 0,02 & 0,00 & 0,03 & & & \\
\hline Total & 99,92 & 99,79 & 99,03 & 99,97 & 100,57 & 98,72 & 98,73 & 100,12 & 100,39 & 99,86 & 101,67 & 99,16 & 99,68 & 100,01 \\
\hline $\mathrm{S}$ & 1,01 & 1,01 & 0,99 & 1,01 & 1,00 & 0,99 & 1,00 & 0,99 & 1,00 & 0,99 & 0,99 & 1,00 & 0,98 & 0,98 \\
\hline $\mathrm{Fe}$ & 0,16 & 0,18 & & & 0,19 & & 0,16 & & 0,14 & 0,17 & 0,17 & & 0,21 & 0,21 \\
\hline $\mathrm{Zn}$ & 0,83 & 0,79 & 0,80 & 0,80 & 0,78 & 81 & 0,82 & 0,80 & 0,84 & 0,83 & 0,83 & & 0,79 & 0,80 \\
\hline $\mathrm{Cu}$ & 0,00 & 0,00 & 0,00 & 0,00 & 0,00 & 0,00 & 0,00 & 0,00 & 0,00 & 0,00 & 0,00 & 0,00 & 0,00 & 0,00 \\
\hline $\mathrm{Cd}$ & 0,00 & 0,01 & 0,02 & 01 & 0,01 & & 0,01 & 01 & 0,01 & 0,01 & 0,01 & 0,01 & 0,01 & 0,01 \\
\hline $\mathrm{Mn}$ & 0,00 & 0,01 & 0,01 & 01 & 0,01 & & 0, & 01 & 0,00 & 0,00 & 0,00 & 0,01 & 0,01 & 0,01 \\
\hline As & 0,00 & 0,00 & 0,0 & 0, & 0,00 & & 0, & & 0,00 & 0,00 & 0,00 & 0,00 & 0,00 & 0,00 \\
\hline Co & 0,00 & 0,00 & 0,00 & 0,00 & 0,00 & 0,00 & 0,00 & 0,00 & 0,00 & 0,00 & 0,00 & 0,00 & 0,00 & 0,00 \\
\hline $\mathrm{Pb}$ & 0,00 & 0,00 & 0,00 & 0,00 & 0,00 & & 0,00 & 00 & 0,00 & 0,00 & 0,00 & 0,00 & 0,00 & 0,00 \\
\hline $\mathrm{Sb}$ & 0,00 & 0,00 & 0,00 & 0,00 & 0,00 & 0,00 & 0,00 & 0,00 & 0,00 & 0,00 & 0,00 & 0,00 & 0,00 & 0,00 \\
\hline $\mathrm{Ni}$ & 0,00 & 0,00 & 0,00 & 0,00 & 0,00 & 0,00 & 0,00 & 0,00 & 0,00 & 0,00 & 0,00 & 0,00 & 0,00 & 0,00 \\
\hline $\mathrm{Ag}$ & 0,00 & 0,00 & 0,00 & 0,00 & 0,00 & & 0,00 & & 0,00 & 0,00 & 0,00 & & 0,00 & 0,00 \\
\hline $\mathrm{Au}$ & 0,0 & & & & & & & & & bo & 0,00 & 00 & 0,00 & 0,00 \\
\hline Sn & 0,00 & 0,00 & 0,00 & 0,00 & 0,00 & 0,00 & 0,00 & 0,00 & 0,00 & 0,00 & 0,00 & 0,00 & 0,00 & 0,00 \\
\hline Se & 0,00 & 0,00 & 0,00 & 0,00 & 0,00 & 00 & 0,00 & 00 & 0,00 & 0,00 & 0,00 & 0,00 & 0,00 & 0,00 \\
\hline $\mathrm{Te}$ & 0,00 & 0,00 & 0,00 & & 0,0 & & 0, & & & & & & & \\
\hline $\mathrm{Bi}$ & 0,00 & 0,00 & $0, \mathrm{C}$ & & 0,0 & & 0, & & 0, & & 0,00 & & 0,00 & 0,00 \\
\hline W & 0,00 & 0, & 0, & & & & & & & 0,00 & & 00 & 0,00 & 0,00 \\
\hline $\mathrm{Hg}$ & 0,00 & 0,00 & 0,00 & 0, & 0, & 0, & 0,00 & 00 & 0,00 & 0,00 & 0,00 & 0,00 & 0,00 & 0,00 \\
\hline In & 0,00 & 0,00 & 0,00 & 0,00 & 0,00 & 0,00 & 0,00 & 0,00 & 0,00 & 0,00 & 0,00 & 0,00 & 0,00 & 0,00 \\
\hline$X_{\mathrm{Fes}}$ & 15,78 & 18,47 & 18,58 & 17,23 & 19,88 & 18,63 & 16,22 & 19,28 & 14,57 & 16,52 & 16,57 & 17,93 & 21,12 & 21,01 \\
\hline$X_{2 n s}$ & 84,22 & 81,53 & 81,42 & 82,77 & 80,12 & 81,37 & 83,78 & 80,72 & 85,43 & 83,48 & 83,43 & 82,07 & 78,88 & 78,99 \\
\hline
\end{tabular}




\begin{tabular}{|c|c|c|c|c|c|c|c|c|c|c|c|c|c|c|c|c|c|c|c|c|c|c|c|}
\hline \multirow{2}{*}{$\begin{array}{l}\text { Mina/Zona } \\
\text { Roca }\end{array}$} & \multicolumn{23}{|c|}{ Salmantina } \\
\hline & Vena LG & $\begin{array}{l}\text { Vena LG } \\
\end{array}$ & Vena LG & Vena LG & Vena LG & Vena LG & Vena LG & Vena LG & Vena LG & Vena LG & Vena LG & Vena LG & Vena LG & Vena LG & $\begin{array}{l}\text { Vena LG } \\
\end{array}$ & Vena LG & Vena LG & Vena LG & Vena LG & Vena LG & Vena LG & Vena LG & $\overline{\text { Vena } L G}$ \\
\hline Muestra & 1059A & $1059 \mathrm{~B}$ & $1059 \mathrm{~B}$ & $1059 B$ & 1181 & 1181 & 1181 & 1181 & 1181 & 1181 & 1181 & 1181 & 1181 & 1181 & 1181 & 1181 & 1181 & 1181 & 1181 & 1181 & 1181 & 1181 & 1181 \\
\hline Análisis & 135 & 3.3 & 3.5 & 3.7 & 1.10 & 1.13 & 1.16 & 2.4 & 2.5 & 2.6 & 3.20 & 3.24 & 4.6 & 4.7 & 4.8 & 4.9 & 5.3 & 5.4 & 5.5 & 6.2 & 6.4 & 7.1 & 2.6 \\
\hline S(\% peso) & 32,11 & 31,41 & 33,42 & 32,95 & 33,28 & 33,04 & 33,24 & 33,10 & 32,82 & 32,98 & 32,67 & 33,38 & 33,72 & 32,97 & 33,12 & 32,76 & 32,93 & 32,51 & 33,22 & 32,97 & 33,50 & 33,27 & 32,96 \\
\hline $\mathrm{Fe}$ & 12,60 & 13,16 & 13,33 & 12,97 & 6,61 & 8,34 & 8,68 & 8,71 & 8,07 & 9,11 & 7,33 & 7,70 & 9,11 & 7,89 & 8,24 & 8,75 & 8,91 & 8,56 & 8,25 & 8,75 & 8,51 & 8,89 & 8,78 \\
\hline $\mathrm{Cu}$ & 0,05 & 0,00 & 0,00 & 0,00 & 0,01 & 0,03 & 0,00 & 0,06 & 0,04 & 0,12 & 0,00 & 0,00 & 0,13 & 0,12 & 0,00 & 0,12 & 0,02 & 0,11 & 0,01 & 0,00 & 0,14 & 0,05 & 0,04 \\
\hline As & 0 & 0,02 & 0,00 & 0,00 & 0,01 & 0,00 & 0,27 & - & - & - & 0,10 & 0,00 & - & - & - & - & - & - & - & - & - & - & . \\
\hline Co & 0,01 & 0,06 & 0,00 & 0,00 & 0,01 & 0,00 & 0,02 & - & - & - & 0,00 & 0,00 & & & & & & & - & - & - & & \\
\hline $\mathrm{Zn}$ & 53,43 & 54,42 & 52,80 & 53,52 & 59,60 & 57,19 & 57,27 & 58,13 & 58,30 & 58,15 & 58,87 & 59,21 & 58,06 & 59,44 & 59,74 & 58,68 & 58,45 & 58,86 & 58,33 & 58,45 & 58,79 & 58,76 & 57,81 \\
\hline $\mathrm{Pb}$ & 0,00 & 0,00 & 0,00 & 0,00 & 0,00 & 0,00 & 0,00 & & & & 0,00 & 0,00 & & & & & & & & & & & \\
\hline $\mathrm{Sb}$ & 0,00 & 0,00 & 0,00 & & 0,00 & & 0,0 & - & - & - & & 0,0 & - & & & & - & & - & - & - & - & \\
\hline & $0, \mathrm{C}$ & 0,00 & 0,01 & 0,0 & 0,00 & & 0,00 & - & - & - & 0,06 & & - & - & - & - & - & - & - & - & - & - & \\
\hline $\mathrm{Ag}$ & 0,00 & 0,00 & 0,00 & 0,00 & 0,00 & $0, \mathrm{C}$ & 0,00 & - & - & - & 0,04 & 0,01 & - & - & - & - & - & - & - & - & - & - & \\
\hline $\mathrm{Au}$ & 0,00 & 0,00 & 0,00 & 0,05 & 0,00 & 0,00 & 0,00 & 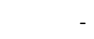 & - & 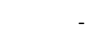 & 0,00 & 0,00 & & & & & & & & 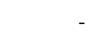 & & & \\
\hline n & 0,00 & 0,03 & 0,00 & 0,00 & 0,07 & 0,00 & 0,00 & 0,00 & 0,06 & 0,02 & 0,00 & 0,02 & 0,07 & 0,00 & 0,00 & 0,01 & 0,00 & 0,23 & 0,00 & 0,12 & 0,03 & 0,00 & 0,00 \\
\hline Se & 0,04 & 0,11 & 0,03 & 0,00 & 0,00 & 0,34 & 0,08 & 0,00 & 0,00 & 0,06 & 0,08 & & 0,00 & 0,02 & 0,00 & 0,05 & 0,00 & 0,00 & 0,09 & 0,00 & 0,00 & 0,00 & 0,05 \\
\hline Te & & 0,08 & 0,01 & 0,00 & 0,03 & 0,09 & 0,00 & - & - & - & 0,00 & 0,00 & - & - & - & - & - & - & - & - & - & - & - \\
\hline & 0,04 & 0,00 & 0,00 & 0,00 & 0,19 & 0,00 & 0,00 & - & - & - & 0,00 & 0,46 & - & & & & - & - & - & - & - & & \\
\hline W & 0,03 & & & & & & & & & & & & & & & & & & & & & & \\
\hline & & 0,68 & 0,41 & 0,48 & 1,05 & 0,97 & 1,03 & 0,76 & 0,79 & 0,79 & 0,87 & 0,00 & 0,65 & 0,59 & 0,66 & 0,78 & 0,79 & 0,81 & 0,61 & 0,76 & 0,69 & 0,82 & 0,76 \\
\hline $\mathrm{Hg}$ & 0,65 & 0,00 & 0,00 & 0,00 & & - & 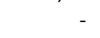 & & & & 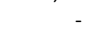 & & & & & & & & & & - & & \\
\hline $\mathrm{Mn}$ & 0,26 & & & & & - & - & 0,22 & 0,11 & 0,14 & - & - & 0,16 & 0,09 & 0,19 & 0,11 & 0,03 & 0,01 & 0,20 & 0,15 & 0,23 & 0,12 & 0,17 \\
\hline & & & & & & & & 0,00 & 0,03 & 0,02 & - & & 0,20 & 0,02 & 0,10 & 0,00 & 0,00 & 0,04 & 0,00 & 0,00 & 0,03 & 0,00 & 0,00 \\
\hline Total & 100,02 & 99,97 & 100,00 & 99,98 & 100,85 & 100,03 & 100,59 & 100,99 & 100,22 & 101,38 & 100,02 & 100,88 & 102,10 & 101,13 & 102,05 & 101,26 & 101,13 & 101,12 & 100,70 & 101,20 & 101,91 & 101,91 & 100,56 \\
\hline $\mathrm{s}$ & 0,97 & 0,95 & 1,00 & 0,99 & 1,00 & 1,00 & 1,00 & 0,99 & 0,99 & 0,98 & 0,99 & 1,00 & 0,99 & 0,98 & 0,98 & 0,98 & 0,98 & 0,98 & 0,99 & 0,98 & 0,99 & 0,99 & 0,99 \\
\hline $\mathrm{Fe}$ & 0,22 & 0,23 & 0,23 & & 0,11 & & & & 0,14 & & & & & & 0,14 & & & & & 0,15 & 0,14 & 0,15 & 0,15 \\
\hline & 0,79 & & 0,77 & & 0, & & & & 86 & 0,85 & 0,87 & & 0,84 & 0,87 & 0,87 & 0,86 & 0,86 & 0,87 & 0,86 & 0,86 & 0,85 & 0,85 & 0,85 \\
\hline $\mathrm{Cu}$ & 0,0 & 0,00 & $0, \mathrm{C}$ & & 0, & & & & & & & & 0,00 & $0, \mathrm{c}$ & 0,00 & 0,00 & 0,00 & & 0,00 & 0,00 & 0,00 & 0,00 & 0,00 \\
\hline $\mathrm{Cd}$ & & & & & & & & & & & & & & & & & & & 0,01 & 0,01 & 0,01 & 0,01 & 0,01 \\
\hline & & & & & & & & & & & & & & & & & & & & 00 & & 00 & 0,00 \\
\hline & & & & & & & & & & & & & & & & & & & & 00 & & 00 & 0,00 \\
\hline & 0,00 & 0,0 & 0,00 & & 0,00 & & & & & & & & & & 0,0 & & & & & 0,00 & & 0,00 & 0,00 \\
\hline & & & & & & & & & & & & & & & & & & & 0,0 & 0,00 & 0,00 & 0,00 & 0,00 \\
\hline & 0,0 & 0,0 & 0,00 & $0, \mathrm{C}$ & 0,0 & & 0 & 0,0 & 00 & 0,0 & 0,00 & & 0,00 & 0,00 & 0,00 & 0,00 & 0,00 & 0,00 & 0,00 & 0,00 & 0,00 & 0,00 & 0,00 \\
\hline & 0,00 & 0,0 & 0,0 & & $0, \mathrm{C}$ & & & & & & & & & & 0,00 & 0,00 & 0,0 & 0,00 & 0,00 & 0,00 & 0,00 & 0,00 & 0,00 \\
\hline & & & & & & & & & & & & & & & & & & & & 0,00 & & 0,00 & 0,00 \\
\hline & & & & & & & & & & & & & & & & & & & 0,0 & 00 & 0,00 & 0,00 & 0,00 \\
\hline $\mathrm{Sr}$ & 0,00 & 0,00 & 0,00 & 0,00 & 0,00 & 0,00 & 0,00 & 0,00 & 0,00 & 0,00 & 0,00 & $0,0 c$ & 0,00 & 0,00 & 0,00 & 0,00 & 0,00 & 0,00 & 0,00 & 0,00 & 0,00 & 0,00 & 0,00 \\
\hline & & 0,00 & & & & & & & & & & & & & & & & & & 00 & 0,00 & 00 & 0,00 \\
\hline & & & & & & & & & & & & & & & & & & & & & & bo & \\
\hline & & & & & & & & & & & & & & & & & & & & Do & ) & 0,00 & 0 \\
\hline & & & & 0,0 & & & & & & & & & & & & & 0,0 & & 0,0 & 0,00 & 0,00 & 0,00 & 0,00 \\
\hline $\mathrm{Hg}$ & 0,00 & 0,00 & 0,00 & 0,00 & 0,00 & 0,00 & 0,00 & 0,00 & 0,00 & 0,00 & 0,00 & 0,0 & 0,00 & 0,00 & 0,00 & 0,00 & 0,00 & 0,00 & 0,00 & 0,00 & 0,00 & 0,00 & 0,00 \\
\hline In & 0,00 & 0,00 & 0,00 & 0,00 & 0,00 & 0,00 & 0,00 & 0,00 & 0,00 & 0,00 & 0,00 & 0,00 & 0,00 & 0,00 & 0,00 & 0,00 & 0,00 & 0,00 & 0,00 & 0,00 & 0,00 & 0,00 & 0,00 \\
\hline$X_{\mathrm{Fes}}$ & 21,63 & 22,06 & 22,81 & 22,10 & 11,48 & 14,58 & 15,07 & 14,92 & 13,94 & 15,50 & 12,72 & 13,21 & 15,52 & 13,45 & 13,90 & 14,86 & 15,14 & 14,55 & 14,20 & 14,91 & \begin{tabular}{ll|}
14,49 \\
\end{tabular} & 15,04 & 15,09 \\
\hline$x_{\text {Zns }}$ & 78,37 & 77,94 & 77,19 & 77,90 & 88,52 & 85,42 & 84,93 & 85,08 & 86,06 & 84,50 & 87,28 & 86,79 & 84,48 & 86,55 & 86,10 & 85,14 & 84,86 & 85,45 & 85,80 & 85,09 & 85,51 & 84,96 & 84,91 \\
\hline
\end{tabular}


Anexo III. Análisis de microsonda electrónica

Esfalerita (continuación)

\begin{tabular}{|c|c|c|c|c|c|c|c|c|c|c|c|c|c|c|c|c|}
\hline $\begin{array}{l}\text { Mina/Zona } \\
\end{array}$ & $\mathrm{Ca}$ & & & Teso de la & Matanza & & & Bon & & & & El Jaque & & & EIC & ruce \\
\hline Roca & Vena LG & Vena LG & Vena LG & Vena LG & Vena LG & Vena LG & Vena LG & Vena LG & Vena LG & Vena G6 & Vena G6 & Vena G6 & Vena G6 & Vena G6 & Vena G2 & Vena G2 \\
\hline Muestra & 1785 & 1785 & 1174 & 1174 & 1174 & 1174 & 1057 & 1057 & 1057 & 1069 & 1069 & 1069 & 1069 & 1069 & $\begin{array}{l}9 \\
1064\end{array}$ & 1064 \\
\hline Análisis & 1.4 & 3.7 & 8.42 & 8.44 & 10.59 & 10.63 & 2.10 & 2.13 & 2.14 & 1.3 & 1.3.1 & 2.3 & 3.100 & 3.101 & 5.59 & 5.62 \\
\hline S (\% peso) & 32,34 & 32,93 & 31,98 & 31,94 & 33,37 & 33,05 & 32,62 & 32,05 & 31,85 & 32,79 & 33,42 & 32,37 & 33,16 & 32,98 & 33,34 & 32,97 \\
\hline $\mathrm{Fe}$ & 6,20 & 8,43 & 7,48 & 7,62 & 6,57 & 6,59 & 5,81 & 5,67 & 6,47 & 7,73 & 7,47 & 7,80 & 8,53 & 8,51 & 8,41 & 7,77 \\
\hline $\mathrm{Cu}$ & 0,28 & 0,06 & 0,00 & 0,00 & 0,05 & 0,11 & 0,00 & 0,11 & 0,00 & 0,09 & 0,04 & 0,08 & 0,19 & 0,08 & 0,01 & 0,13 \\
\hline As & 1,33 & 0,02 & 0,00 & 0,05 & 0,00 & 0,00 & 0,26 & 0,00 & 0,00 & 0,00 & 0,13 & 0,01 & 0,05 & 0,09 & 0,00 & 0,07 \\
\hline Co & 0,00 & 0,00 & 0,03 & 0,03 & 0,00 & 0,03 & 0,04 & 0,00 & 0,00 & 0,02 & 0,04 & 0,00 & 0,01 & 0,00 & 0,05 & 0,00 \\
\hline $\mathrm{Zn}$ & 58,06 & 56,36 & 56,82 & 57,29 & 59,15 & 59,03 & 58,78 & 56,75 & 58,22 & 56,52 & 56,84 & 56,12 & 56,07 & 56,74 & 57,02 & 57,54 \\
\hline $\mathrm{Pb}$ & 0,00 & 0,00 & 0,00 & 0,00 & 0,00 & 0,00 & 0,00 & 0,00 & 0,00 & 0,00 & 0,00 & 0,00 & 0,00 & 0,00 & 0,00 & 0,00 \\
\hline $\mathrm{Sb}$ & 00 & 0,00 & 0,00 & 00 & 0,00 & 0,00 & 0,00 & 0,00 & 0,04 & 0,00 & 0,02 & 0,07 & 0,00 & 0,06 & 0,06 & 0,00 \\
\hline $\mathrm{Ni}$ & 0,00 & 0, & 0,06 & 00 & 0,01 & 0,00 & 0,00 & 0,03 & 0,02 & 0,00 & 0,06 & 0,00 & 0,00 & 0,00 & 0,00 & 0,06 \\
\hline $\mathrm{Ag}$ & 05 & & 0,00 & & 0, & 0,02 & 0,00 & 00 & 0,10 & 0,16 & 0,00 & 09 & 0,01 &, 00 & 0,00 & 0,06 \\
\hline $\mathrm{Au}$ & 0,00 & 0,00 & 0,00 & 0,00 & 0,00 & 0,00 & 0,00 & 0,00 & 0,00 & 0,00 & 0,00 &, 00 & 0,00 & 0,00 & 0,00 & 0,00 \\
\hline Sn & 0,01 & 0,00 & 0,00 & 0,00 & 0,01 & 0,04 & 0,00 & 0,00 & 0,03 & 0,18 & 0,00 & 0,00 & 0,03 & 0,01 & 0,01 & 0,03 \\
\hline Se & 0,01 & 0,07 & 0,16 & 0,09 & 0,00 & 0,00 & 0,00 & 0,09 & 0,00 & 0,00 & 0,11 & & 0,00 & 0,00 & & 0,00 \\
\hline $\mathrm{Te}$ & & & 0,00 & & & 0,00 & 0,06 & & 0,00 & 0,00 & & & & & & 0 , \\
\hline $\mathrm{Bi}$ & 00 & 0,00 & 0,20 & 0,39 & 0,00 & 0,00 & 0,00 & 26 & 0,28 & 0,00 & 0,00 & 0,00 & 0,00 &, 00 & 0,00 & 0,00 \\
\hline w & 0,00 & 0,00 & & & & & 0,05 & 0,14 & 0,03 & & & & 0,11 & 0,17 & 0,13 & 0,09 \\
\hline $\mathrm{Cd}$ & 0,79 & 1,28 & 0,52 & 0,82 & 1,37 & 1,17 & 0,77 & 1,03 & 0,93 & 0,07 & 0,15 & 0,06 & 0,16 & 0,25 & 0,23 & 0,28 \\
\hline $\mathrm{Hg}$ & 0,00 & 0,00 & & & & & 0,00 & 0,30 & 0,22 & 0,13 & 0,12 & 0,00 & 0,09 & 0,00 & 0,00 & 0,15 \\
\hline $\mathrm{Mn}$ & 0,23 & 0,13 & - & - & & & & - & - & & - & & 0,07 & ,01 & 0,14 & 0,06 \\
\hline In & & & & & & & & & & & & & & & & \\
\hline Total & 99,30 & 99,28 & 97,24 & 98,27 & 100,53 & 100,03 & 98,39 & 96,57 & 98,19 & 97,69 & 98,38 & 96,60 & 98,51 & 98,91 & 99,41 & 99,23 \\
\hline & 0,99 & 1,00 & 0,99 & 0,99 & 1,00 & 1,00 & 1,00 & 1,01 & 0,99 & 1,01 & 1,02 & 1,00 & 1,01 & 1,00 & 1,00 & 1,00 \\
\hline & & & & & & 0,11 & 0,10 & & & 0,14 & & & & & & 0,14 \\
\hline & & & & & & & & & & & & & & & & \\
\hline $\mathrm{Cu}$ & 0,00 & 00 & 0,00 & 0, & 0,00 & 0,00 & 0,00 & 0 & 0,00 & 0,00 & 0,00 & 0,00 & 0,00 & 0,00 & 0,00 & 0,00 \\
\hline & 0 & & & & & 0 & 0,01 & & 01 &, 00 & 00 & & & & & 0,00 \\
\hline & & & & & & & 0 , & & & 00 & & & & & & 0,00 \\
\hline & & & & & & & & & & 00 & & & & 0 & & 0,00 \\
\hline & & & & & & & & & & 00 & & & & & & 0 \\
\hline $\mathrm{Pb}$ & & & & & & & 0,00 & & & 0,00 & & & & & & \\
\hline sb & & & & & & 0 & 0,00 & & & 00 & & & & & & 0,00 \\
\hline $\mathrm{Ni}$ & 0,00 & 0,00 & 0,00 & 0,00 & 0, & 0,00 & 0,00 & 0,00 & 0,00 & 0,00 & 0,00 & 0,00 & 0,00 & 0,00 & 0,00 & 0,00 \\
\hline $\mathrm{Ag}$ & & & & & & & & & & & & & & & & \\
\hline a & & & & & & & & & & & & & & & & \\
\hline Sn & & & & & & & & & & 00 & & & & & & 0,00 \\
\hline $\mathrm{Se}$ & 0,00 & 0, & 0,00 & 0,00 & 0, & 00 & 0,00 & 00 & 0,00 & 0,00 & 0,00 & c & 0,00 & 0,00 & 0,00 & 0,00 \\
\hline Te & & 0,00 & 0 , & 0,00 & 0 , & 0,00 & 0 , & 00 & 0 , & 00 & & & 0,00 & & 00 & 0,00 \\
\hline & & 0,00 & & & & & & & & & & & & & & \\
\hline & & & & & & & & & & & & & & & & \\
\hline & & & & & & & & & & & & & & & & 0,00 \\
\hline $\ln$ & 0,00 & 0,00 & 0,00 & 0,00 & 0,00 & 0,00 & 0,00 & 0,00 & 0,00 & 0,00 & 0,00 & 0,00 & 0,00 & 0,00 & 0,00 & 0,00 \\
\hline es & 11,11 & 14,90 & 13,35 & 13,47 & 11,50 & 11,56 & 10,36 & 10,46 & 11,51 & 13,80 & 13,33 & 13,99 & 15,12 & 14,93 & 14,72 & 13,65 \\
\hline$X_{\text {ZnS }}$ & 88,89 & 85,10 & 86,65 & 86,53 & 88,50 & 88,44 & 89,64 & 89,54 & 88,49 & 86,20 & 86,67 & 86,01 & 84,88 & 85,07 & 85,28 & 86,35 \\
\hline
\end{tabular}

\begin{tabular}{|c|c|c|c|c|c|}
\hline \multicolumn{3}{|l|}{$\frac{\text { Pirita }}{\text { Mina/Zona }}$} & & & \\
\hline $\begin{array}{l}\text { IIIna/Lona } \\
\text { Roca }\end{array}$ & $\mathrm{GE}$ & Vena GE & $\begin{array}{c}\text { Morlad } \\
\text { Vena GE }\end{array}$ & Vena GE & Vena GE \\
\hline Muestra & $1682 \mathrm{~A}$ & 1773 & 1773 & 1773 & 1773 \\
\hline Análisis & 3.1 & 1.3 & 1.4 & 1.5 & 2.2 \\
\hline S(\% peso) & 52,83 & 50,94 & 47,48 & 50,59 & 52,93 \\
\hline $\mathrm{Fe}$ & 47,50 & 46,91 & 47,29 & 47,83 & 47,25 \\
\hline $\mathrm{Cu}$ & 0,00 & 0,00 & 0,00 & 0,00 & 0,03 \\
\hline As & 0,00 & 1,47 & 0,13 & 0,41 & 0,00 \\
\hline Co & 0,00 & 0,00 & 0,00 & 0,00 & 0,00 \\
\hline $\mathrm{Zn}$ & 0,08 & - & - & - & 0,43 \\
\hline $\mathrm{Pb}$ & 0,00 & - & - & & 0,00 \\
\hline Sb & 0,00 & & & & 0,02 \\
\hline $\mathrm{Ni}$ & 0,00 & 0,03 & 0,00 & 0,00 & 0,00 \\
\hline $\mathrm{Ag}$ & 0,00 & & & & 0,00 \\
\hline $\mathrm{Au}$ & 0,00 & - & - & - & 0,02 \\
\hline Sn & 0,00 & - & - & & 0,00 \\
\hline Se & 0,02 & - & - & & 0,04 \\
\hline $\mathrm{Te}$ & 0,00 & - & - & & 0,00 \\
\hline $\mathrm{Bi}$ & 0,00 & - & - & - & 0,00 \\
\hline w & & - & - & & \\
\hline $\mathrm{Cd}$ & 0,00 & - & - & - & 0,00 \\
\hline $\mathrm{Hg}$ & & & & & \\
\hline Total & 100,42 & 99,35 & 94,90 & 98,83 & 100,73 \\
\hline $\mathrm{s}$ & 1,98 & 1,95 & 1,91 & 1,94 & 1,98 \\
\hline $\mathrm{Fe}$ & 1,02 & 1,03 & 1,09 & 1,05 & 1,01 \\
\hline $\mathrm{Cu}$ & 0,00 & 0,00 & 0,00 & 0,00 & 0,00 \\
\hline As & 0,00 & 0,02 & 0,00 & 0,01 & 0,00 \\
\hline Co & 0,00 & 0,00 & 0,00 & 0,00 & 0,00 \\
\hline $\mathrm{Zn}$ & 0,00 & 0,00 & 0,00 & 0,00 & 0,01 \\
\hline $\mathrm{Pb}$ & 0,00 & 0,00 & 0,00 & 0,00 & 0,00 \\
\hline $\mathrm{Sb}$ & 0,00 & 0,00 & 0,00 & 0,00 & 0,00 \\
\hline $\mathrm{Ni}$ & 0,00 & 0,00 & 0,00 & 0,00 & 0,00 \\
\hline $\mathrm{Ag}$ & 0,00 & 0,00 & 0,00 & 0,00 & 0,00 \\
\hline $\mathrm{Au}$ & 0,00 & 0,00 & 0,00 & 0,00 & 0,00 \\
\hline Sn & 0,00 & 0,00 & 0,00 & 0,00 & 0,00 \\
\hline Se & 0,00 & 0,00 & 0,00 & 0,00 & 0,00 \\
\hline Te & 0,00 & 0,00 & 0,00 & 0,00 & 0,00 \\
\hline $\mathrm{Bi}$ & 0,00 & 0,00 & 0,00 & 0,00 & 0,00 \\
\hline w & 0,00 & 0,00 & 0,00 & 0,00 & 0,00 \\
\hline $\mathrm{Cd}$ & 0,00 & 0,00 & 0,00 & 0,00 & 0,00 \\
\hline $\mathrm{Hg}$ & 0,00 & 0,00 & 0,00 & 0,00 & 0,00 \\
\hline
\end{tabular}


Anexo III. Análisis de microsonda electrónica

\begin{tabular}{|c|c|c|c|c|c|c|c|c|c|c|c|c|c|c|c|c|c|c|c|c|c|c|c|}
\hline \multirow{2}{*}{$\begin{array}{l}\text { Mina/Zona } \\
\text { Roca }\end{array}$} & \multicolumn{10}{|c|}{ Horia } & \multicolumn{8}{|c|}{$\begin{array}{c}\text { Mari Carmen } \\
\end{array}$} & \multicolumn{5}{|c|}{ Salmantina } \\
\hline & Vena GE & Vena GE & Vena GE & Vena GE & Vena GE & Vena GE & Vena GE & 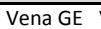 & 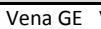 & 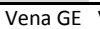 & Vena GE & Vena GE & Vena GE & Vena GE & \begin{tabular}{|l|l} 
Vena GE \\
\end{tabular} & Vena GE & Vena GE & Vena GE & Vena LG & Vena LG & Vena LG & Vena LG & Vena LG \\
\hline Muestra & 1773 & 1773 & 1773 & 1773 & 1773 & 1773 & 1043 & 1043 & 1043 & 1044 & 1046 & 1048 & 1048 & 1048 & 1720 & 1720 & 1775 & 1775 & 1699 & 1690 & 1051 & 1051 & 1051 \\
\hline Análisis & 2.4 & 2.5 & 3.4 & 3.5 & 4.4 & 4.5 & 3.174 & 3.175 & 3.176 & 1.53 & 1.73 & 1.109 & 1.110 & 1.115 & 5.2 & 5.3 & 1.4 & 2.2 & 1.1 & 3.2 & 150 & 151 & 152 \\
\hline S(\% peso) & 51,99 & 45,69 & 50,86 & 52,17 & 51,05 & 49,44 & 53,69 & 54,24 & 53,98 & 53,90 & 53,59 & 51,26 & 53,40 & 50,66 & 53,88 & 52,77 & 53,84 & 53,32 & 52,67 & 53,86 & 54,06 & 54,15 & 54,18 \\
\hline $\mathrm{Fe}$ & 47,66 & 41,63 & 46,70 & 47,29 & 47,58 & 47,76 & 44,90 & 45,01 & 45,38 & 47,13 & 47,01 & 46,22 & 46,59 & 44,45 & 45,89 & 45,83 & 46,06 & 46,02 & 46,16 & 45,76 & 44,76 & 46,61 & 44,72 \\
\hline $\mathrm{Cu}$ & 0,00 & 0,00 & 0,00 & 0,00 & 0,00 & 0,00 & 0,20 & 0,21 & 0,16 & 0,00 & 0,00 & 0,00 & 0,03 & 0,00 & 0,01 & 0,04 & 0,04 & 0,00 & 0,04 & 0,02 & 0,06 & 0,01 & 0,02 \\
\hline As & 0,06 & 0,03 & 0,01 & 0,10 & 0,00 & 0,00 & 0,60 & 0,38 & 0,30 & 0,32 & 0,07 & 2,29 & 0,06 & 3,02 & 0,38 & 0,14 & 0,30 & 0,17 & 0,05 & 0,04 & 0,10 & 0,07 & 0,08 \\
\hline Co & 0,00 & 0,00 & 0,00 & 0,00 & 0,00 & 0,00 & 0,05 & 0,04 & 0,03 & 0,07 & 0,03 & 0,04 & 0,05 & 0,05 & 0,00 & 0,00 & 0,00 & 0,00 & 0,00 & 0,00 & 0,04 & 0,04 & 0,09 \\
\hline $\mathrm{Zn}$ & & & & & & & 0,03 & 0,04 & 0,00 & 0,00 & 0,00 & 0,30 & 0,86 & 0,32 & 0,00 & 0,00 & 0,05 & 0,00 & 0,05 & 0,03 & 0,00 & 0,01 & 0,02 \\
\hline $\mathrm{Pb}$ & - & - & - & - & - & - & 0,00 & 0,00 & 0,00 & 0,00 & 0,00 & 0,00 & 0,00 & 0,00 & 0,00 & 0,00 & 0,00 & 0,00 & 0,00 & 0,00 & 0,00 & 0,00 & 0,00 \\
\hline $\mathrm{Sb}$ & - & & & - & & - & 0,00 & 0,04 & 0,00 & 0,00 & 0,00 & 0,03 & 0,10 & 0,02 & 0,00 & 0,02 & 0,05 & 0,00 & 0,00 & 0,00 & 0,00 & 0,06 & 0,01 \\
\hline $\mathrm{Ni}$ & 0,00 & 0,00 & 0,00 & 0,00 & 0,00 & 0,04 & 0,00 & 0,00 & 0,00 & 0,02 & 0,00 & 0,00 & 0,00 & 0,05 & 0,00 & 0,00 & 0,00 & 0,03 & 0,00 & 0,01 & 0,24 & 0,07 & 0,16 \\
\hline $\mathrm{Ag}$ & & & & & & & 0,00 & 0,03 & & 0,02 & 0,09 & 0,02 & 0,00 & & & 0,04 & 0,00 & 0,00 & 0,03 & 0,01 & & 0,00 & 0,04 \\
\hline $\mathrm{Au}$ & - & - & - & - & - & - & 0,04 & 0,22 & 0,00 & 0,10 & 0,00 & 0,00 & 0,00 & 0,00 & 0,06 & 0,06 & 0,00 & 0,00 & 0,02 & 0,00 & & 0,00 & 0,00 \\
\hline Sn & - & - & - & - & - & - & 0,03 & 0,09 & 0,01 & 0,02 & 0,00 & 0,00 & 0,09 & 0,05 & 0,00 & 0,00 & 0,00 & 0,02 & 0,00 & 0,00 & 0,02 & 0,03 & 0,00 \\
\hline Se & - & - & - & - & - & - & 0,32 & 0,11 & 0,07 & 0,00 & 0,00 & 0,09 & 0,00 & 0,08 & 0,03 & 0,03 & 0,05 & 0,04 & 0,03 & 0,03 & 0,10 & 0,04 & 0,00 \\
\hline $\mathrm{Te}$ & - & & - & & & - & 0,03 & 0,01 & 0,01 & 0,00 & 0,06 & 0,00 & 0,00 & 0,10 & 0,01 & 0,03 & 0,00 & 0,00 & 0,05 & 0,02 & 0,00 & 0,00 & 0,00 \\
\hline $\mathrm{Bi}$ & - & - & - & - & - & - & 0,11 & 0,12 & 0,15 & 0,00 & 0,00 & 0,38 & 0,14 & & 0,00 & 0,00 & 0,00 & 0,00 & 0,00 & 0,00 & 0,00 & 0,00 & 0,00 \\
\hline W & - & - & - & - & - & - & 0,01 & 0,10 & 0,11 & 0,08 & 0,01 & 0,00 & 0,00 & 0,17 & 0,01 & 0,00 & 0,00 & 0,10 & 0,05 & 0,00 & 0,09 & 0,05 & 0,26 \\
\hline $\mathrm{Cd}$ & - & - & - & - & - & - & 0,01 & 0,00 & 0,00 & 0,12 & 0,00 & 0,05 & 0,01 & 0,00 & 0,00 & 0,03 & 0,00 & 0,00 & 0,00 & 0,02 & 0,01 & 0,00 & 0,03 \\
\hline $\mathrm{Hg}$ & & & & & & & 0,47 & 0,00 & 0,00 & 0,08 & 0,20 & 0,43 & 0,00 & 0,03 & 0,00 & 0,14 & 0,10 & 0,10 & 0,00 & 0,08 & 0,49 & 0,15 & 0,00 \\
\hline Total & 99,71 & 87,35 & 97,57 & 99,56 & 98,63 & 97,24 & 100,47 & 100,64 & 100,21 & 101,87 & 101,05 & 101,11 & 101,32 & 99,18 & 100,27 & 99,14 & 100,50 & 99,80 & 99,15 & 99,88 & 100,03 & 101,29 & 99,60 \\
\hline S & 1,96 & 1,97 & 1,96 & 1,97 & 1,95 & 1,93 & $\frac{r(0,47}{2,01}$ & $\frac{10,02}{2,02}$ & $\frac{10,21}{2,02}$ & 1,99 & $\frac{1010}{1,99}$ & 1,94 & 1,98 & 1,95 & 2,01 & 2,00 & 2,01 & 2,00 & 1,99 & 2,01 & 2,02 & $\frac{10,2}{2,00}$ & 2,03 \\
\hline $\mathrm{Fe}$ & & & & & & & & & & & & & & & & 1,00 & & & 1,00 & & & 0,99 & 0,96 \\
\hline $\mathrm{Cu}$ & 0,00 & 0,00 & 0,00 & 0,00 & 0,00 & 0,00 & 0,00 & 0,00 & 0,00 & 0,00 & 0,00 & 0,00 & 0,00 & 0,00 & 0,00 & 0,00 & 0,00 & 0,00 & 0,00 & 0,00 & 0,00 & 0,00 & 0,00 \\
\hline As & 0 & 0,00 & & 0,0 & 0 & 0,0 & & 0,0 & & & 00 & $0, \mathrm{C}$ & 00 & 0, & 01 & 0,00 & 0,00 & 0,00 & 0,00 & 0,00 & 0,00 & 0,00 & 00 \\
\hline Co & $0, C$ & 0,00 & 0 & 0,00 & 0 & 0,0 & & 0,0 & & & & 0,00 & & 0,0 & 0 & 0,00 & 0,00 & 0,00 & 0,00 & 0,00 & 0,00 & 0,00 & 0,00 \\
\hline $\mathrm{Zn}$ & 0,0 & 0,00 & 0,00 & 0,00 & 0,00 & 0,00 & 0,00 & 0,0 & 0,00 & 0,0 & 0,00 & 0,01 & 0,02 & $0, C$ & 0,00 & 0,00 & 0,00 & 0,00 & 0,00 & 0,00 & 0,00 & 0,00 & 0,00 \\
\hline $\mathrm{Pb}$ & 0,00 & 0,0 & $0, C$ & & & & & & & & & & & & & & & & & & & 0,00 & 0,00 \\
\hline Sb & 0,00 & 0,0 & $0, \mathrm{C}$ & $0, \mathrm{C}$ & & $0, \mathrm{C}$ & & & & & & & & & & & & & & & & 0,00 & 0 \\
\hline $\mathrm{Ni}$ & & & & & & & & & & & & & & & & & & & 0,00 & & & 0,00 & 0,00 \\
\hline $\mathrm{Ag}$ & 0,0 & 0,00 & 0,00 & 0,00 & 0,00 & 0,00 & 0,00 & 0,00 & 0,00 & 0,00 & 0,00 & 0,00 & 0,00 & 0,00 & 0,00 & 0,00 & 0,00 & 0,00 & 0,00 & 0,00 & 0,00 & 0,00 & 0,00 \\
\hline $\mathrm{Au}$ & 0,00 & 0,00 & 0,00 & 0,00 & 0,00 & 0,00 & 0,00 & 0,00 & 0,00 & 0,00 & 0,00 & 0,00 & 0,00 & 0,00 & 0,00 & 0,00 & 0,00 & 0,00 & 0,00 & 0,00 & 0,00 & 0,00 & 0,00 \\
\hline Sn & 0,00 & 0,00 & 0,00 & & 0,00 & & & & & & & & & & & & & & & & & 00 & 0,00 \\
\hline Se & & 0,0 & & & & & & & & & & & & & & 0,00 & 0,00 & 0,00 & 0,00 & 0,00 & 0,00 & 0,00 & 0,00 \\
\hline $\mathrm{Te}$ & 0,00 & 0,00 & 0,00 & 0,00 & 0,00 & 0,00 & 0,00 & 0,00 & 0,00 & 0,00 & 0,00 & 0,00 & 0,00 & 0,00 & 0,00 & 0,00 & 0,00 & 0,00 & 0,00 & 0,00 & 0,00 & 0,00 & 0,00 \\
\hline $\mathrm{Bi}$ & 0,00 & 0,00 & 0,00 & 0,00 & 0,00 & 0,00 & 0,00 & 0,00 & 00 & $0, C$ & 0,00 & 0,00 & 0,00 & 0,00 & 0,00 & 0,00 & 0,00 & 0,00 & 0,00 & 0,00 & 0,00 & 0,00 & 0,00 \\
\hline w & 0,00 & 0,00 & 0,00 & & 0,00 & & & & & & & & & & & & & & & 0,00 & & 00 & 0,00 \\
\hline $\mathrm{Cd}$ & & & & & & & & & & & & & & & & & & & & & & & \\
\hline $\mathrm{Hg}$ & 0,00 & 0,00 & 0,00 & 0,00 & 0,00 & 0,00 & 0,00 & 0,00 & 0,00 & 0,00 & 0,00 & 0,00 & 0,00 & 0,00 & 0,00 & 0,00 & 0,00 & 0,00 & 0,00 & 0,00 & 0,00 & 0,00 & 0,00 \\
\hline
\end{tabular}


Anexo III. Análisis de microsonda electrónica

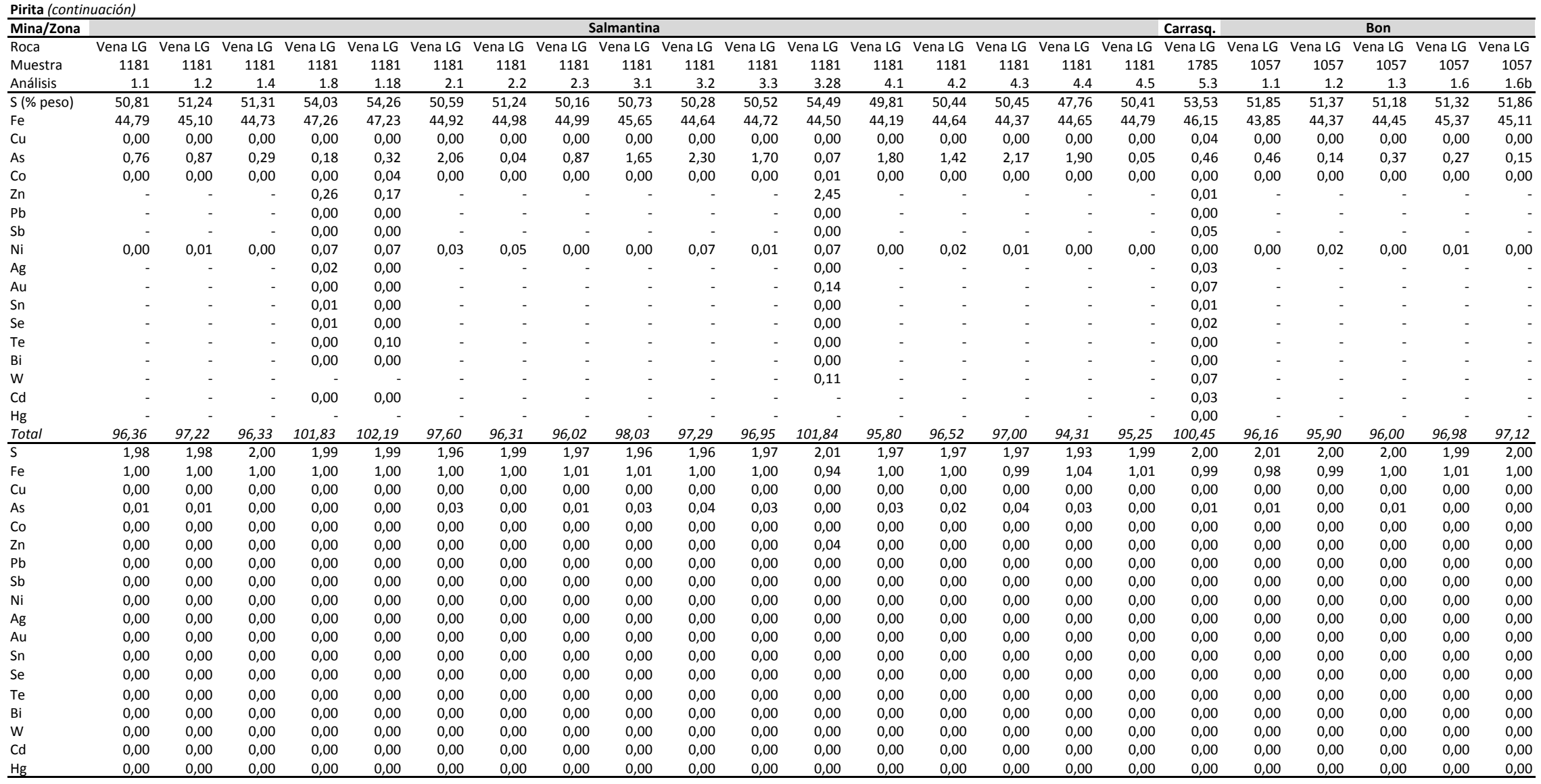


Anexo III. Análisis de microsonda electrónica

\begin{tabular}{|c|c|c|c|c|c|c|c|c|c|c|c|c|c|c|c|c|c|c|c|c|c|c|c|}
\hline \multirow{2}{*}{$\begin{array}{l}\text { Mina/Zona } \\
\text { Roca }\end{array}$} & \multicolumn{7}{|c|}{ Bon } & \multirow{2}{*}{\multicolumn{16}{|c|}{ ElCruce }} \\
\hline & Vena LG & Vena LG & Vena LG & Vena LG & Vena LG & Vena LG & Vena LG & Vena G2 & $\begin{array}{lll}\text { Vena } \mathrm{G} 2 \\
\mathrm{n}\end{array}$ & Vena G2 & Vena G2 & Vena G2 & Vena G2 & Vena G2 & Vena G2 & & & & & & & & \\
\hline Muestra & 1057 & 1057 & 1057 & 1057 & 1057 & 1057 & 1057 & 1064 & 1064 & 1064 & 1064 & 1065 & 1065 & 1065 & 1065 & 1065 & 1065 & 1065 & 1065 & 1065 & 1065 & 1065 & 1065 \\
\hline Análisis & 1.7 & $1.7 \mathrm{~b}$ & 2.4 & 2.5 & 2.6 & 2.9 & 2.15 & 1.53 & 1.55 & 3.55 & 4.58 & 1.1 & 1.3 & 1.4 & 1.5 & 2.2 & 2.8 & 2.9 & 2.12 & 2.78 & 4.1 & 4.2 & 4.5 \\
\hline S(\% peso) & 52,49 & 51,81 & 51,60 & 51,49 & 51,11 & 52,93 & 52,04 & 53,03 & 53,63 & 52,80 & 53,24 & 53,72 & 50,76 & 51,41 & 51,12 & 53,43 & 51,60 & 51,50 & 52,13 & 53,03 & 50,48 & 48,51 & 53,62 \\
\hline $\mathrm{Fe}$ & 46,56 & 45,54 & 45,64 & 44,78 & 45,33 & 45,78 & 45,91 & 46,16 & 47,24 & 46,30 & 47,11 & 46,82 & 45,47 & 45,50 & 45,40 & 46,35 & 45,33 & 44,67 & 44,42 & 44,59 & 45,92 & 45,81 & 46,06 \\
\hline $\mathrm{Cu}$ & 0,03 & 0,00 & 0,00 & 0,00 & 0,00 & 0,00 & 0,00 & 0,09 & 0,15 & 0,00 & 0,00 & 0,07 & 0,00 & 0,00 & 0,00 & 0,01 & 0,00 & 0,00 & 0,00 & 0,11 & 0,00 & 0,00 & 0,00 \\
\hline As & 0,48 & 0,35 & 0,26 & 0,46 & 0,19 & 0,26 & 0,79 & 0,16 & 0,00 & 0,00 & 0,10 & 0,26 & 0,34 & 0,14 & 0,47 & 0,29 & 0,34 & 0,13 & 0,00 & 0,25 & 0,06 & 0,00 & 0,26 \\
\hline Co & 0,05 & 0,00 & 0,00 & 0,00 & 0,00 & 0,01 & 0,06 & 0,05 & 0,00 & 0,04 & 0,05 & 0,03 & 0,00 & 0,00 & 0,00 & 0,08 & 0,00 & 0,00 & 0,00 & 0,03 & 0,00 & 0,00 & 0,09 \\
\hline $\mathrm{Zn}$ & 0,07 & & & & & 0,26 & 0,24 & 0,17 & 0,03 & 0,07 & 0,00 & 0,00 & & & & 0,06 & & - & - & 0,06 & - & & 0,14 \\
\hline $\mathrm{Pb}$ & 0,00 & - & - & - & - & 0,00 & 0,00 & 0,00 & 0,00 & 0,00 & 0,00 & 0,00 & - & - & - & 0,00 & - & - & - & 0,00 & - & & 0,42 \\
\hline $\mathrm{Sb}$ & 0,00 & & - & - & & 0,02 & 0,00 & 0,06 & 0,05 & 0,00 & 0,00 & 0,03 & - & - & & 0,00 & - & - & - & 0,05 & - & - & 0,00 \\
\hline $\mathrm{Ni}$ & 0,03 & 0,00 & 0,00 & 0,00 & 0,00 & 0,00 & 0,02 & 0,00 & 0,02 & 0,07 & 0,00 & 0,01 & 0,03 & 0,00 & 0,00 & 0,05 & 0,00 & 0,01 & 0,00 & 0,02 & 0,00 & 0,00 & 0,00 \\
\hline $\mathrm{Ag}$ & 0,02 & & & & & 0,00 & 0,03 & 0,01 & 0,09 & 0,00 & 0,00 & 0,00 & & & & 0,00 & & & & 0,19 & - & & 0,04 \\
\hline $\mathrm{Au}$ & & - & - & - & - & 0,00 & 0,15 & 0,00 & 0,00 & 0,00 & 0,22 & 0,18 & - & - & & 0,00 & - & - & - & 0,00 & - & - & 0,04 \\
\hline Sn & 0,05 & - & - & - & - & 0,04 & 0,03 & 0,06 & 0,09 & 0,00 & 0,07 & 0,11 & - & - & & 0,00 & - & - & - & 0,00 & - & - & 0,00 \\
\hline Se & 0,00 & - & - & - & - & 0,00 & 0,03 & 0,00 & 0,08 & 0,01 & 0,21 & 0,00 & - & - & & 0,22 & - & - & - & 0,00 & - & - & 0,17 \\
\hline $\mathrm{Te}$ & 0,00 & & - & & & 0,01 & 0,11 & 0,04 & 0,00 & 0,00 & 0,06 & 0,00 & - & - & & 0,00 & - & - & - & 0,07 & - & & 0,05 \\
\hline $\mathrm{Bi}$ & 0,23 & - & - & - & - & 0,00 & 0,00 & 0,59 & 0,00 & 0,26 & 0,06 & 0,67 & - & - & & 0,03 & - & & - & 0,46 & - & - & 0,46 \\
\hline W & 0,0 & - & - & - & - & 0,16 & 0,00 & 0,13 & 0,05 & 0,03 & 0,21 & & - & - & - & & - & - & - & 0,03 & - & - & \\
\hline $\mathrm{Cd}$ & 0,02 & - & - & - & - & 0,01 & 0,00 & 0,07 & 0,00 & $0, \mathrm{C}$ & 0,02 & 0,00 & - & - & - & 0,00 & - & - & - & 0,02 & - & - & 0,00 \\
\hline $\mathrm{Hg}$ & 0,00 & & & & & 0,00 & 0,00 & 0,43 & 0,32 & 0,20 & 0,16 & 0,00 & & & & 0,04 & & & & 0,05 & & & 0,00 \\
\hline Total & 100,03 & 97,70 & 97,50 & 96,73 & 96,63 & 99,47 & 99,41 & 101,04 & 101,74 & 99,77 & 101,48 & 101,90 & 96,60 & 97,05 & 96,99 & 100,56 & 97,27 & 96,31 & 96,55 & 98,96 & 96,46 & 94,32 & 101,35 \\
\hline S & 1,98 & 1,99 & 1,99 & 2,00 & 1,99 & 2,00 & 1,98 & $\begin{array}{r}10,97 \\
\end{array}$ & $\frac{101,7}{1,99}$ & 1,99 & $\frac{101,40}{1,98}$ & 1,99 & 1,98 & 1,99 & 1,98 & 1,99 & 1,99 & 2,00 & 2,01 & 2,01 & 1,97 & 1,95 & 2,00 \\
\hline $\mathrm{Fe}$ & & 1,00 & & & & & & & & & & & 1,02 & 1,01 & & 0,99 & 1,00 & 1,00 & 0,99 & & 1,03 & 1,05 & 0,99 \\
\hline $\mathrm{Cu}$ & 0,00 & 0,00 & 0,00 & 0,00 & 0,00 & 0,00 & 0,00 & 0,00 & 0,00 & 0,00 & 0,00 & 0,00 & 0,00 & 0,00 & 0,00 & 0,00 & 0,00 & 0,00 & 0,00 & 0,00 & 0,00 & 0,00 & 0,00 \\
\hline As & & 0,01 & $0, \mathrm{C}$ & 0,0 & 0 & 0,0 & & 0,0 & Do & 0,0 & 00 & 0,00 & 0,01 & 0,00 & 0,01 & 0,00 & 0,01 & 0,00 & 0,00 & 0,00 & 0,00 & 0,00 & 0,00 \\
\hline Co & & 0,00 & $0, C$ & 0,00 & 0 & 0,0 & & 0,0 & & 0,00 & & 0,00 & 0,00 & 0,00 & 0,00 & 0,00 & 0,00 & 0,00 & 0,00 & 0,00 & 0,00 & 0,00 & 0,00 \\
\hline $\mathrm{Zn}$ & 0,0 & 0,00 & 0,00 & 0,00 & 0,00 & 0,00 & 0,00 & 0,00 & 0,00 & 0,00 & 0,00 & 0,00 & 0,00 & 0,00 & 0,00 & 0,00 & 0,00 & 0,00 & 0,00 & 0,00 & 0,00 & 0,00 & 0,00 \\
\hline $\mathrm{Pb}$ & 0,00 & $0,0 c$ & 0,00 & & 0,00 & & & & & & & & 0,00 & 0,00 & 0,00 & 0,00 & 0,00 & 0,00 & 0,00 & 0,00 & 0,00 & 0,00 & 0,00 \\
\hline Sb & 0,0 & 0,00 & 0,00 & $0, \mathrm{C}$ & 0, & 0,0 & & & & 0, & & & & $0, \mathrm{c}$ & & & & & 0,0 & 0,00 & 0,00 & 0,00 & 0,00 \\
\hline $\mathrm{Ni}$ & & & & & & & & & & & & & & & & $0, C$ & 0,00 & 0,0 & 0,00 & 0 & 0,00 & 0,00 & 0,00 \\
\hline $\mathrm{Ag}$ & $0, C$ & 0,00 & 0,00 & 0,00 & 0,00 & 0,00 & 0,00 & 0,00 & 0,00 & 0,00 & 0,00 & 0,00 & 0,00 & 0,00 & 0,00 & 0,00 & 0,00 & 0,00 & 0,00 & 0,00 & 0,00 & 0,00 & 0,00 \\
\hline $\mathrm{Au}$ & 0,00 & 0,00 & 0,00 & 0,00 & 0,00 & 0,00 & 0,00 & 0,00 & 0,00 & 0,00 & 0,00 & 0,00 & 0,00 & 0,00 & 0,00 & 0,00 & 0,00 & 0,00 & 0,00 & 0,00 & 0,00 & 0,00 & 0,00 \\
\hline Sn & 0,00 & 0,00 & 0,00 & $0, c$ & 0,00 & & & & & & & & & 0,00 & 0,00 & & & 0,00 & 0,00 & 0,00 & 0,00 & 0,00 & 0,00 \\
\hline Se & $0, \mathrm{C}$ & 0,00 & 0 , & & 0, & $0, \mathrm{C}$ & & 0, & & $0, C$ & & & & & 0,0 & 0,00 & 0,00 & 0,00 & 0,00 & 0,00 & 0,00 & 0,00 & 0,00 \\
\hline $\mathrm{Te}$ & 0,00 & 0,00 & 0,00 & 0,00 & 0,00 & 0,00 & 0,00 & 0,00 & 0,00 & 0,00 & 0,00 & 0,00 & 0,00 & 0,00 & 0,00 & 0,00 & 0,00 & 0,00 & 0,00 & 0,00 & 0,00 & 0,00 & 0,00 \\
\hline $\mathrm{Bi}$ & 0,00 & 0,00 & 0,00 & 0,00 & 0,00 & 0,00 & 0,00 & 0,00 & 0,00 & 0,00 & 0,00 & 0,00 & 0,00 & 0,00 & 0,00 & 0,00 & 0,00 & 0,00 & 0,00 & 0,00 & 0,00 & 0,00 & 0,00 \\
\hline w & 0,00 & 0,00 & 0,00 & & 0,00 & & & & & & & & 0,00 & 0,00 & & & & 0,00 & 0,00 & 0,00 & 0,00 & 0,00 & 0,00 \\
\hline $\mathrm{Cd}$ & & 0,0 & & & & & & & & & & & & & & & & & 0,00 & & 0,00 & & \\
\hline $\mathrm{Hg}$ & 0,00 & 0,00 & 0,00 & 0,00 & 0,00 & 0,00 & 0,00 & 0,00 & 0,00 & 0,00 & 0,00 & 0,00 & 0,00 & 0,00 & 0,00 & 0,00 & 0,00 & 0,00 & 0,00 & 0,00 & 0,00 & 0,00 & 0,00 \\
\hline
\end{tabular}


Anexo III. Análisis de microsonda electrónica

\begin{tabular}{|c|c|c|c|c|}
\hline \multirow{2}{*}{$\begin{array}{l}\text { Mina/Zona } \\
\text { Roca }\end{array}$} & \multicolumn{4}{|c|}{$\begin{array}{l}\text { El Cruce } \\
\end{array}$} \\
\hline & Vena G2 & Vena G2 & Vena G2 & Vena $\mathrm{G} 2$ \\
\hline Muestra & 1065 & 1065 & 1065 & 1065 \\
\hline Análisis & 4.8 & 4.88 & 9.2 & 9.3 \\
\hline S(\% peso) & 53,97 & 52,90 & 50,77 & 52,35 \\
\hline $\mathrm{Fe}$ & 47,18 & 47,74 & 45,69 & 47,10 \\
\hline $\mathrm{Cu}$ & 0,00 & 0,00 & 0,02 & 0,00 \\
\hline As & 0,06 & 0,03 & 0,02 & 0,24 \\
\hline Co & 0,02 & 0,03 & 0,02 & 0,01 \\
\hline $\mathrm{Zn}$ & 0,00 & 0,00 & 0,06 & 0,04 \\
\hline $\mathrm{Pb}$ & 0,00 & 0,00 & 0,00 & 0,00 \\
\hline sb & 0,00 & 0,04 & 0,00 & 0,05 \\
\hline $\mathrm{Ni}$ & 0,00 & 0,05 & 0,00 & 0,00 \\
\hline Ag & 0,05 & 0,00 & 0,00 & 0,00 \\
\hline $\mathrm{Au}$ & 0,08 & 0,00 & 0,00 & 0,00 \\
\hline Sn & 0,02 & 0,03 & 0,06 & 0,07 \\
\hline Se & 0,00 & 0,16 & 0,05 & 0,22 \\
\hline Te & 0,00 & 0,01 & 0,06 & 0,11 \\
\hline Bi & 1,03 & 0,44 & 0,46 & 0,00 \\
\hline w & & 0,00 & & \\
\hline $\mathrm{cd}$ & 0,00 & 0,00 & 0,00 & 0,00 \\
\hline $\mathrm{Hg}$ & 0,00 & 0,08 & 0,00 & 0,11 \\
\hline Total & 102,41 & 101,51 & 97,21 & 100,31 \\
\hline $\mathrm{s}$ & 1,99 & 1,97 & 1,97 & 1,97 \\
\hline $\mathrm{Fe}$ & 1,00 & 1,02 & 1,02 & 1,02 \\
\hline Cu & 0,00 & 0,00 & 0,00 & 0,00 \\
\hline As & 0,00 & 0,00 & 0,00 & 0,00 \\
\hline Co & 0,00 & 0,00 & 0,00 & 0,00 \\
\hline $\mathrm{Zn}$ & 0,00 & 0,00 & 0,00 & 0,00 \\
\hline $\mathrm{Pb}$ & 0,00 & 0,00 & 0,00 & 0,00 \\
\hline Sb & 0,00 & 0,00 & 0,00 & 0,00 \\
\hline $\mathrm{Ni}$ & 0,00 & 0,00 & 0,00 & 0,00 \\
\hline $\mathrm{Ag}$ & 0,00 & 0,00 & 0,00 & 0,00 \\
\hline $\mathrm{Au}$ & 0,00 & 0,00 & 0,00 & 0,00 \\
\hline Sn & 0,00 & 0,00 & 0,00 & 0,00 \\
\hline Se & 0,00 & 0,00 & 0,00 & 0,00 \\
\hline $\mathrm{Te}$ & 0,00 & 0,00 & 0,00 & 0,00 \\
\hline $\mathrm{Bi}$ & 0,01 & 0,00 & 0,00 & 0,00 \\
\hline w & 0,01 & 0,00 & 0,00 & 0,00 \\
\hline $\mathrm{Cd}$ & 0,00 & 0,00 & 0,00 & 0,00 \\
\hline & 0,00 & 0,00 & 0,00 & 0,00 \\
\hline
\end{tabular}

\begin{tabular}{lrr} 
Marcasita & & \\
\hline Mina/Zona & \multicolumn{2}{c}{ El Cruce } \\
\hline Roca & Vena G2 & Vena G2 \\
Muestra & 1064 & 1064 \\
Análisis & 1.52 & 1.54 \\
\hline S (\% peso) & 52,86 & 53,09 \\
Fe & 47,24 & 45,17 \\
Cu & 0,00 & 0,00 \\
As & 0,12 & 0,04 \\
Co & 0,05 & 0,00 \\
Zn & 0,09 & 0,00 \\
Pb & 0,00 & 0,00 \\
Sb & 0,00 & 0,03 \\
Ni & 0,03 & 0,09 \\
Ag & 0,00 & 0,00 \\
Au & 0,06 & 0,17 \\
Sn & 0,06 & 0,04 \\
Se & 0,18 & 0,05 \\
Te & 0,00 & 0,00 \\
Bi & 0,27 & 0,00 \\
W & 0,07 & 0,17 \\
Cd & 0,00 & 0,06 \\
Hg & 0,13 & 0,47 \\
Total & 101,16 & 9,38 \\
S & 1,97 & 2,01 \\
Fe & 1,01 & 0,98 \\
Cu & 0,00 & 0,00 \\
As & 0,00 & 0,00 \\
Co & 0,00 & 0,00 \\
Zn & 0,00 & 0,00 \\
Pb & 0,00 & 0,00 \\
Sb & 0,00 & 0,00 \\
Ni & 0,00 & 0,00 \\
Ag & 0,00 & 0,00 \\
Au & 0,00 & 0,00 \\
Sn & 0,00 & 0,00 \\
Se & 0,00 & 0,00 \\
Te & 0,00 & 0,00 \\
Bi & 0,00 & 0,00 \\
W & 0,00 & 0,00 \\
Cd & 0,00 & 0,00 \\
Hg & 0,00 & 0,00 \\
\hline & &
\end{tabular}

\begin{tabular}{|c|c|c|c|c|c|c|c|c|c|c|c|c|}
\hline \multirow{2}{*}{$\begin{array}{l}\text { Pirrotita } \\
\text { Mina/Zona } \\
\text { Roca }\end{array}$} & \multirow{2}{*}{\multicolumn{4}{|c|}{ Horia }} & \multirow{2}{*}{\multicolumn{2}{|c|}{ M Carmen }} & \multirow{2}{*}{\multicolumn{6}{|c|}{ Salmantina }} \\
\hline & & & & & & & Vena LG & & & & & Vena LG \\
\hline Muestra & $1682 \mathrm{~A}$ & $1773 \mathrm{~A}$ & 1711D & $1711 \mathrm{D}$ & 1720 & 1048 & $\quad 1059 \mathrm{~A}$ & $1059 \mathrm{~B}$ & $1059 \mathrm{~B}$ & $1059 \mathrm{~B}$ & $1059 \mathrm{~B}$ & $1059 \mathrm{~B}$ \\
\hline Análisis & 8.1 & 3.4 & 2.1 & 2.3 & 3.3 & 1.115 & 136 & 3.8 & 4.17 & 4.18 & 4.19 & 4.23 \\
\hline$S(\%$ peso) & 38,52 & 38,44 & 38,81 & 37,96 & 39,54 & 39,61 & 37,85 & 39,16 & 39,44 & 39,45 & 39,11 & 40,16 \\
\hline $\mathrm{Fe}$ & 59,19 & 56,16 & 55,88 & 60,54 & 58,26 & 56,29 & 57,92 & 61,07 & 57,96 & 58,69 & 58,69 & 57,48 \\
\hline $\mathrm{Cu}$ & 0,01 & 0,07 & 0,02 & 0,04 & 0,00 & 0,00 & 0,00 & 0,00 & 0,02 & 0,00 & 0,00 & 0,04 \\
\hline As & 0,08 & 0,08 & 0,08 & 0,06 & 0,07 & 0,14 & 0,11 & 0,17 & 0,13 & 0,18 & 0,18 & 0,02 \\
\hline Co & 0,00 & 0,00 & 0,00 & 0,00 & 0,00 & 0,04 & 0,10 & 0,01 & 0,10 & 0,11 & 0,02 & 0,03 \\
\hline $\mathrm{Zn}$ & 0,01 & 3,61 & 3,65 & 1,42 & 1,24 & 2,88 & 1,17 & 0,62 & 0,00 & 0,00 & 0,00 & 0,00 \\
\hline $\mathrm{Pb}$ & 0,11 & 0,00 & 0,00 & 0,00 & 0,00 & 0,00 & 0,00 & 0,00 & 0,00 & 0,00 & 0,00 & 0,00 \\
\hline Sb & 0,00 & 0,00 & 0,06 & 0,04 & 0,02 & 0,04 & 0,03 & 0,00 & 0,00 & 0,00 & 0,01 & 0,00 \\
\hline $\mathrm{Ni}$ & 0,15 & 0,02 & 0,00 & 0,01 & 0,00 & 0,02 & 0,03 & 0,02 & 0,11 & 0,00 & 0,07 & 0,03 \\
\hline $\mathrm{Ag}$ & 0,00 & 0,07 & 0,02 & 0,02 & 0,05 & 0,03 & 0,00 & 0,00 & 0,06 & 0,02 & 0,00 & 0,00 \\
\hline $\mathrm{Au}$ & 0,00 & 0,01 & 0,00 & 0,05 & 0,06 & 0,00 & 0,00 & 0,00 & 0,04 & 0,04 & 0,00 & 0,02 \\
\hline Sn & 0,00 & 0,00 & 0,00 & 0,00 & 0,00 & 0,02 & 0,06 & 0,00 & 0,00 & 0,00 & 0,00 & 0,00 \\
\hline Se & 0,05 & 0,04 & 0,04 & 0,03 & 0,03 & 0,10 & 0,09 & 0,00 & 0,00 & 0,00 & 0,00 & 0,05 \\
\hline $\mathrm{Te}$ & 0,06 & 0,00 & 0,00 & 0,00 & 0,05 & 0,00 & 0,00 & 0,00 & 0,01 & 0,00 & 0,00 & 0,00 \\
\hline $\mathrm{Bi}$ & 0,00 & 1,07 & 0,00 & 0,00 & 0,00 & 0,00 & 0,00 & 0,00 & 0,00 & 0,09 & 0,08 & 0,00 \\
\hline w & & & & & 0,06 & 0,19 & 0,19 & & & & & \\
\hline $\mathrm{Cd}$ & 0,00 & 0,08 & 0,11 & 0,01 & 0,00 & 0,04 & 0,00 & 0,00 & 0,04 & 0,00 & 0,05 & 0,00 \\
\hline $\mathrm{Hg}$ & & & & & 0,00 & 0,16 & 0,01 & 0,00 & 0,00 & 0,00 & 0,00 & 0,14 \\
\hline $\mathrm{Mn}$ & 0,04 & 0,02 & 0,07 & 0,02 & 0,03 & 0,02 & 0,01 & & & & & \\
\hline Total & 98,22 & 99,66 & 98,75 & 100,21 & 99,40 & 99,58 & 97,56 & 101,05 & 97,90 & 98,58 & 98,21 & 97,98 \\
\hline $\mathrm{s}$ & 1,00 & 1,00 & 1,00 & 1,00 & 1,00 & 1,00 & 1,00 & 1,00 & 1,00 & 1,00 & 1,00 & 1,00 \\
\hline $\mathrm{Fe}$ & 0,88 & 0,84 & 0,83 & 0,92 & 0,85 & 0,82 & 0,88 & 0,90 & 0,84 & 0,85 & 0,86 & 0,82 \\
\hline $\mathrm{Cu}$ & 0,00 & 0,00 & 0,00 & 0,00 & 0,00 & 0,00 & 0,00 & 0,00 & 0,00 & 0,00 & 0,00 & 0,00 \\
\hline As & 0,00 & 0,00 & 0,00 & 0,00 & 0,00 & 0,00 & 0,00 & 0,00 & 0,00 & 0,00 & 0,00 & 0,00 \\
\hline Co & 0,00 & 0,00 & 0,00 & 0,00 & 0,00 & 0,00 & 0,00 & 0,00 & 0,00 & 0,00 & 0,00 & 0,00 \\
\hline $\mathrm{Zn}$ & 0,00 & 0,05 & 0,05 & 0,02 & 0,02 & 0,04 & 0,02 & 0,01 & 0,00 & 0,00 & 0,00 & 0,00 \\
\hline $\mathrm{Pb}$ & 0,00 & 0,00 & 0,00 & 0,00 & 0,00 & 0,00 & 0,00 & 0,00 & 0,00 & 0,00 & 0,00 & 0,00 \\
\hline $\mathrm{Sb}$ & 0,00 & 0,00 & 00 & 0,0 & 0,00 & 0,00 & 0,00 & 0,00 & 0,00 & 0,00 & 0,00 & 0,00 \\
\hline $\mathrm{Ni}$ & 0,00 & 0,00 & 0,00 & 0,00 & 0,00 & 0,00 & 0,00 & 0,00 & 0,00 & 0,00 & 0,00 & 0,00 \\
\hline $\mathrm{Ag}$ & 0,00 & 0,00 & 0,00 & 0,00 & 0,00 & 0,00 & 0,00 & 0,00 & 0,00 & 0,00 & 0,00 & 0,00 \\
\hline Au & 0,00 & 0,00 & 0,00 & 0,00 & 0,00 & 0,00 & 0,00 & 0,00 & 0,00 & 0,00 & 0,00 & 0,00 \\
\hline Sn & 0,00 & 0,00 & 0,00 & 0,00 & 0,00 & $0, c$ & 0,00 & 0,00 & 0,00 & 0,00 & 0,00 & 0,00 \\
\hline $\mathrm{Se}$ & 0,00 & 0,00 & 0,00 & 0,00 & 0,00 & 0,00 & 0,00 & 0,00 & 0,00 & 0,00 & 0,00 & 0,00 \\
\hline $\mathrm{Te}$ & 0,00 & 0,00 & 0,00 & 0,00 & 0,00 & 0,00 & 0,00 & 0,00 & 0,00 & 0,00 & 0,00 & 0,00 \\
\hline $\mathrm{Bi}$ & 0,00 & 0,00 & 0,00 & 0,00 & 0,00 & 0,00 & 0,00 & 0,00 & 0,00 & 0,00 & 0,00 & 0,00 \\
\hline w & 0,00 & 0,00 & 0, & 0,00 & & & & 0,00 & & 0,00 & 0,00 & 0,00 \\
\hline $\mathrm{Cd}$ & 0,00 & 0,00 & 0,00 & 0,00 & 0,00 & 0,00 & 0,00 & 0,00 & 0,00 & 0,00 & 0,00 & 0,00 \\
\hline
\end{tabular}


Anexo III. Análisis de microsonda electrónica

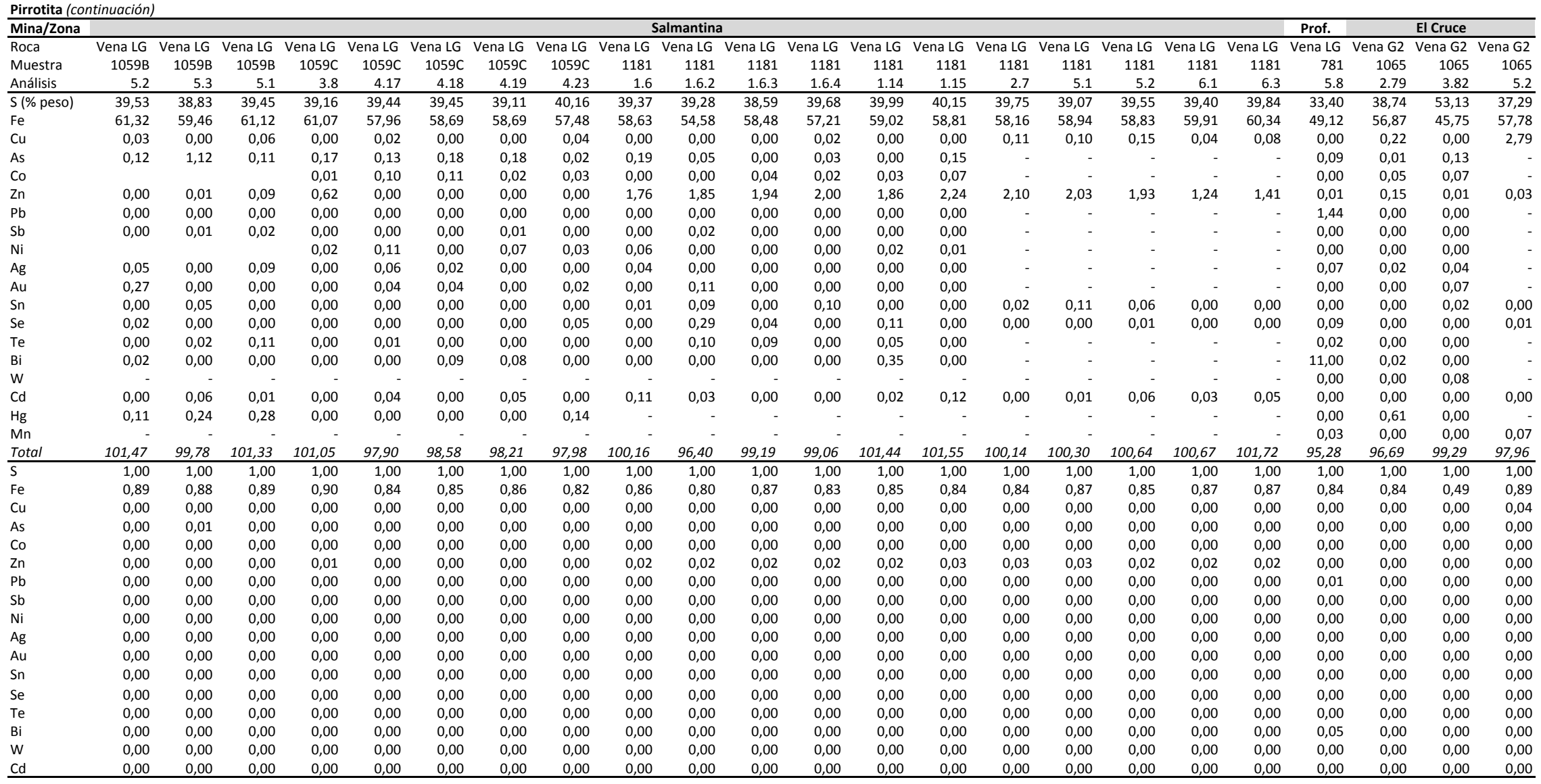


Anexo III. Análisis de microsonda electrónica

\begin{tabular}{|c|c|c|c|}
\hline \multirow{2}{*}{\multicolumn{4}{|c|}{ Pirrotita (continuación) }} \\
\hline & & El Cruce & \\
\hline Roca & Vena G2 & Vena G2 & Vena G2 \\
\hline Muestra & 1065 & 1065 & 1065 \\
\hline Análisis & 6.1 & 6.2 & 6.3 \\
\hline S(\% peso) & 38,88 & 38,54 & 39,37 \\
\hline $\mathrm{Fe}$ & 59,89 & 60,56 & 59,78 \\
\hline $\mathrm{Cu}$ & 0,00 & 0,08 & 0,00 \\
\hline As & & - & \\
\hline Co & & & \\
\hline $\mathrm{Zn}$ & 0,11 & 0,06 & 0,00 \\
\hline $\mathrm{Pb}$ & & & \\
\hline Sb & - & - & - \\
\hline $\mathrm{Ni}$ & - & - & - \\
\hline $\mathrm{Ag}$ & - & - & - \\
\hline $\mathrm{Au}$ & & & \\
\hline Sn & 0,00 & 0,00 & 0,05 \\
\hline Se & 0,00 & 0,00 & 0,02 \\
\hline Te & - & - & - \\
\hline $\mathrm{Bi}$ & - & - & - \\
\hline w & & & \\
\hline $\mathrm{cd}$ & 0,00 & 0,02 & 0,00 \\
\hline $\mathrm{Hg}$ & & & \\
\hline $\mathrm{Mn}$ & 0,03 & 0,00 & 0,00 \\
\hline Total & 98,91 & 99,26 & 99,23 \\
\hline $\bar{s}$ & 1,00 & 1,00 & 1,00 \\
\hline $\mathrm{Fe}$ & 0,88 & 0,90 & 0,87 \\
\hline $\mathrm{Cu}$ & 0,00 & 0,00 & 0,00 \\
\hline As & 0,00 & 0,00 & 0,00 \\
\hline Co & 0,00 & 0,00 & 0,00 \\
\hline $\mathrm{Zn}$ & 0,00 & 0,00 & 0,00 \\
\hline $\mathrm{Pb}$ & 0,00 & 0,00 & 0,00 \\
\hline sb & 0,00 & 0,00 & 0,00 \\
\hline $\mathrm{Ni}$ & 0,00 & 0,00 & 0,00 \\
\hline $\mathrm{Ag}$ & 0,00 & 0,00 & 0,00 \\
\hline $\mathrm{Au}$ & 0,00 & 0,00 & 0,00 \\
\hline Sn & 0,00 & 0,00 & 0,00 \\
\hline $\mathrm{Se}$ & 0,00 & 0,00 & 0,00 \\
\hline $\mathrm{Te}$ & 0,00 & 0,00 & 0,00 \\
\hline $\mathrm{Bi}$ & 0,00 & 0,00 & 0,00 \\
\hline w & 0,00 & 0,00 & 0,00 \\
\hline $\mathrm{Cd}$ & 0,00 & 0,00 & 0,00 \\
\hline
\end{tabular}

Calcopirita

\begin{tabular}{|c|c|c|c|c|c|c|c|c|c|c|c|c|c|c|c|c|c|c|}
\hline \multirow{3}{*}{$\begin{array}{l}\text { Mina/Zona } \\
\text { Roca }\end{array}$} & \multicolumn{10}{|c|}{ Horia } & \multicolumn{2}{|c|}{ Mari Carmen } & \multicolumn{2}{|c|}{ Profunda Carrasq. } & \multicolumn{4}{|c|}{$\begin{array}{l}\text { Teso de la Matanza } \\
\end{array}$} \\
\hline & GE & GE & $\mathrm{GE}$ & GE & Vena GE & Vena GE & Vena GE & Vena GE & Vena GE & Vena GE & Vena GE & Vena GE & Vena LG & Vena LG & Vena LG & Vena LG & Vena LG & Vena LG \\
\hline & $1682 \mathrm{~A}$ & $1682 \mathrm{~A}$ & $1682 \mathrm{~A}$ & $1682 \mathrm{~A}$ & 1711D & 1711D & 1711D & 1773 & 1044 & 1044 & 1048 & 1720 & 781 & 1785 & 1174 & 1174 & 1174 & 1174 \\
\hline Análisis & 1.1 & 5.1 & 6.1 & 8.2 & 1.5 & 1.8 & 2.2 & 3.2 & 3.166 & 3.168 & 2.112 & 2.1 & 5.16 & 3.1 & 3.13 & 3.14 & 5.23 & 5.25 \\
\hline $\mathrm{S}(\%$ peso) & 34,15 & 34,68 & 34,22 & 32,95 & 32,10 & 32,22 & 33,89 & 33,95 & 35,01 & 34,80 & 33,13 & 34,75 & 34,98 & 34,33 & 35,14 & 33,74 & 34,40 & 34,27 \\
\hline $\mathrm{Fe}$ & 29,07 & 29,36 & 29,48 & 31,98 & 28,15 & 28,10 & 29,36 & 29,79 & 29,27 & 30,02 & 26,16 & 29,65 & 30,05 & 29,57 & 28,75 & 28,24 & 28,90 & 28,69 \\
\hline $\mathrm{Cu}$ & 34,64 & 34,80 & 35,31 & 30,06 & 33,08 & 29,56 & 33,15 & 34,90 & 33,74 & 33,59 & 33,47 & 35,84 & 34,02 & 35,87 & 34,10 & 34,20 & 34,32 & 34,34 \\
\hline As & 0,01 & 0,01 & 0,01 & 1,06 & 0,03 & 2,28 & 0,01 & 0,07 & 0,05 & 0,00 & 0,09 & 0,06 & 0,08 & 0,06 & 0,00 & 0,04 & 0,04 & 0,02 \\
\hline Co & 0,00 & 0,00 & 0,00 & 0,00 & 0,00 & 0,00 & 0,00 & 0,00 & 0,01 & 0,01 & 0,04 & 0,00 & 0,00 & 0,00 & 0,00 & 0,00 & 0,00 & 0,01 \\
\hline $\mathrm{Zn}$ & 0,01 & 0,19 & 0,00 & 0,00 & 0,00 & 0,00 & 1,24 & 1,73 & 0,00 & 0,00 & 6,52 & 0,01 & 0,03 & 0,04 & 0,05 & 0,06 & 0,00 & 0,51 \\
\hline $\mathrm{Pb}$ & 0,12 & 0,00 & 0,00 & 0,19 & 0,00 & 0,00 & 0,00 & 0,00 & 0,00 & 0,00 & 0,00 & 0,00 & 0,00 & 0,00 & 0,00 & 0,00 & 0,00 & 0,00 \\
\hline sb & 0,06 & 0,00 & 0,04 & 0,02 & 0,05 & 0,03 & 0,00 & 0,00 & 0,00 & 0,03 & 0,01 & 0,00 & 0,01 & 0,03 & 0,00 & 0,00 & 0,01 & 0,05 \\
\hline $\mathrm{ji}$ & 0,00 & 0,00 & 0,00 & 0,01 & 0,00 & 0,00 & 0,00 & 0,00 & 0,00 & 0,02 & 0,03 & 0,02 & 0,00 & 0,00 & 0,02 & 0,02 & 0,01 & 0,00 \\
\hline $\mathrm{Ag}$ & 0,01 & 0,03 & 0,00 & 0,05 & 0,02 & 0,65 & 01 & 0,00 & 0,00 & 0,03 & & & 0,00 & 0,00 & & 00 & & 0,09 \\
\hline $\mathrm{Au}$ & 0,00 & 0,03 & 0,02 & 0,03 & 0,01 & 0,00 & 0,00 & 0,00 & 17 & 04 & 0,00 & 0,00 & 0,00 & 0,00 & 0,00 & 0,00 & 0,00 & 0,00 \\
\hline Sn & 0,00 & 0,01 & 0,00 & 0,00 & 0,00 & 0,00 & 0,00 & 0,00 & 0,08 & 0,03 & 0,01 & 0,00 & 0,00 & 0,04 & 0,07 & 0,06 & 0,12 & 0,15 \\
\hline $\mathrm{Se}$ & 0,05 & 0,04 & 0,03 & 0,02 & 0,09 & 0,02 & 0,04 & 0,05 & 0,05 & 0,00 & 0,01 & 0,05 & 0,01 & 0,04 & 0,11 & 0,07 & 0,00 & 0,01 \\
\hline & 0,00 & 0,00 & 0,05 & 0,09 & 0,03 & 0,00 & 0,00 & 0,00 & 0,00 & & & & 0,00 & 0,06 & 0,00 & 0,08 & 0,02 & 0,00 \\
\hline $\mathrm{Bi}$ & 0,00 & 0,00 & 0,00 & 0,00 & 5,81 & 3,66 & 0,00 & 0,00 & 0,13 & 0 , & & & 0,00 & 0,00 & 0,63 & 0,19 & 0,98 & 0,58 \\
\hline W & & & & & & & & & 0,02 & 0,03 & 0,00 & 0,02 & 0,00 & 0,03 & & & & \\
\hline $\mathrm{Cd}$ & 0,00 & 0,00 & 0,00 & 0,05 & 0,00 & 0,02 & 0,01 & 0,00 & 0,00 & 0,01 & 0,10 & 0,02 & 0,06 & 0,00 & 0,00 & 0,00 & 0,07 & 0,52 \\
\hline $\mathrm{Hg}$ & & & & & & & & & 0,05 & 0,05 & 0,13 & 0,00 & 0,09 & 0,11 & & - & - & \\
\hline $\mathrm{Mn}$ & 0,00 & 0,01 & 0,02 & 0,00 & 0,00 & 0,00 & 0,04 & 0,00 & & & 0,04 & 0 & 0,04 & 0,04 & & & & \\
\hline Total & 98,12 & 99,17 & 99,17 & 96,51 & 99,38 & 96,55 & 97,74 & 100,49 & 98,56 & 99,08 & 99,95 & 100,45 & 99,37 & 100,24 & 98,95 & 96,68 & 98,87 & 99,25 \\
\hline & 2,00 & 2,00 & 1,98 & 1,97 & 1,95 & 1,98 & 1,99 & 1,95 & 2,03 & 2,01 & 1,94 & 1,99 & 2,01 & 1,97 & 2,03 & 2,00 & 2,01 & 2,00 \\
\hline $\mathrm{Fe}$ & 0,98 & 0,97 & 0,98 & 1,10 & 0,98 & 0,99 & 0,99 & 0,98 & 0,97 & 1,00 & 0,88 & 0,97 & 0,99 & 0,98 & 0,96 & 0,96 & 0,97 & 0,96 \\
\hline & 1, & 1,01 & 1, & 0,90 & 01 & 0,92 & & 1,01 & 0,99 & & & 1 & 0,99 & 1,04 & 1,00 & 1,02 & 1,01 & 1,01 \\
\hline & & 0,0 & & & & & & 0, & & & & & 0,0 & 0,0 & 0,00 & 0,00 & 0,00 & 0,00 \\
\hline & 0,00 & 0,01 & 0,00 & 0,0 & 0,00 & 0,00 & & 0,0 & & & & & 0,0 & 0,0 & 0,00 & 00 & 0,00 & 0,01 \\
\hline io & 0,00 & 0,00 & 0,00 & 0,00 & 0,00 & 0,00 & 00 & & 00 & & & & 0,0 & 0,00 & 0,00 & 00 & 0,00 & 0,00 \\
\hline & & 0, & & & & & & & & & & & & & 0,00 & & 0,00 & 0,00 \\
\hline & & & & 0, & & & & & & & & & 0,0 & 0,00 & 0,00 & 0,00 & 0,00 & 0,00 \\
\hline $\mathrm{Ni}$ & 0,00 & 0,00 & 0,00 & 0,00 & 0,00 & 0,00 & 0,00 & 0,00 & 0,00 & 0,00 & 0,00 & 0,00 & 0,00 & 0,00 & 0,00 & 0,00 & 0,00 & 0,00 \\
\hline & 0,00 & 0,00 & 0,00 & & & & & & & & & & & & & & & 0,00 \\
\hline & 0, & 0,0 & & 0, & & & & & & & & & & & 0,00 & 0,00 & 0,00 & 0,00 \\
\hline Sn & 0,00 & 0,00 & 0,00 & 0,00 & 0,00 & $0, \mathrm{C}$ & 00 & 0, & 0,00 & & 0,0 & 0,00 & 0,00 & 0,00 & 0,00 & 0,00 & 0,00 & 0,00 \\
\hline$c_{0}$ & 0,00 & 0,00 & 0,00 & $0, c$ & 0,00 & 0, & 00 & 0, & 0,00 & 0, & 0,0 & 0,00 & 0,00 & 0,00 & 0,00 & 0,00 & 0,00 & 0,00 \\
\hline & 0, & 0,00 & & & & & & & & & & & & & & & & 0,00 \\
\hline & 0 , & 0, & & & & & & & & & & & & & 0,0 & & 0,01 & 01 \\
\hline N & 0 , & $0,0 c$ & 0,00 & 0,00 & 0 , & $0, C$ & & 0, & & & 0,0 & $0, \mathrm{C}$ & 0,0 & 0,00 & 0,00 & 0,00 & 0,00 & 0,00 \\
\hline $\mathrm{Cd}$ & 0,00 & 0,00 & 0,00 & 0,00 & 0,00 & 0,00 & 0,00 & 0,00 & 0,00 & 0,00 & 0,00 & 0,00 & 0,00 & 0,00 & 0,00 & 0,00 & 0,00 & 0,01 \\
\hline $\mathrm{Hg}$ & 0,00 & 0,00 & 0,00 & 0,00 & 0,00 & 0,00 & 0,00 & 0,00 & 0,00 & 0,00 & 0,00 & 0,00 & 0,00 & 0,00 & 0,00 & 0,00 & 0,00 & 0,00 \\
\hline $\mathrm{Mn}$ & 0,00 & 0,00 & 0,00 & 0,00 & 0,00 & 0,00 & 0,00 & 0,00 & 0,00 & 0,00 & 0,00 & 0,00 & 0,00 & 0,00 & 0,00 & 0,00 & 0,00 & \\
\hline
\end{tabular}


Anexo III. Análisis de microsonda electrónica

\begin{tabular}{|c|c|c|c|c|c|c|c|c|c|c|c|c|c|c|c|c|c|}
\hline \multirow{2}{*}{$\begin{array}{l}\frac{M}{\text { Mina/Zona }} \\
\text { Roca }\end{array}$} & \multicolumn{12}{|c|}{ Teso de la Matanza } & \multicolumn{2}{|l|}{ El Jaque } & \multicolumn{2}{|c|}{$\begin{array}{l}\text { El Cruce } \\
\end{array}$} & \multirow[b]{2}{*}{ Vena G2 } \\
\hline & Vena LG & Vena LG & $\begin{array}{l}\text { Vena LG } \\
\end{array}$ & Vena LG & Vena LG & Vena LG & Vena LG & Vena LG & Vena LG & Vena LG & Vena LG & Vena LG & Vena G6 & Vena G2 & Vena G2 & Vena G2 & \\
\hline Muestra & 1174 & 1174 & 1174 & 1174 & 1174 & 1174 & 1174 & 1179 & 1179 & 1179 & 1179 & 1179 & 1069 & 1065 & 1065 & 1065 & 1065 \\
\hline Análisis & 5.27 & 6.46 & 8.41 .2 & 9.36 & 9.39 & 10.60 & 10.62 & 1.21 & 4.13 & 4.16 & 5.7 & 5.10 & 3.102 & 1.74 & 1.75 & 2.77 & 4.89 \\
\hline S(\% peso) & 33,29 & 35,28 & 34,86 & 35,26 & 35,22 & 35,61 & 35,00 & 35,16 & 35,33 & 34,16 & 35,15 & 35,53 & 34,25 & 33,24 & 33,54 & 34,63 & 33,41 \\
\hline $\mathrm{Fe}$ & 28,83 & 29,80 & 29,54 & 29,56 & 29,11 & 29,14 & 29,10 & 30,76 & 28,67 & 29,90 & 29,73 & 30,37 & 28,02 & 29,03 & 28,17 & 29,63 & 29,26 \\
\hline $\mathrm{Cu}$ & 34,58 & 34,35 & 34,80 & 35,06 & 33,76 & 34,24 & 34,39 & 31,72 & 34,22 & 34,55 & 35,00 & 35,03 & 37,33 & 36,61 & 35,93 & 36,42 & 36,76 \\
\hline As & 0,12 & 0,00 & 0,01 & 0,00 & 0,02 & 0,00 & 0,00 & 0,12 & 0,01 & 0,03 & 0,14 & 0,07 & 0,10 & 0,00 & 0,12 & 0,00 & 0,09 \\
\hline Co & 0,07 & 0,02 & 0,01 & 0,00 & 0,01 & 0,00 & 0,08 & 0,00 & 0,00 & 0,00 & 0,07 & 0,00 & 0,03 & 0,04 & 0,05 & 0,02 & 0,03 \\
\hline $\mathrm{Zn}$ & 0,13 & 0,01 & 0,12 & 0,06 & 0,10 & 0,43 & 0,49 & 0,00 & 0,08 & 0,01 & 0,00 & 0,02 & 0,20 & 0,01 & 0,08 & 0,09 & 0,00 \\
\hline $\mathrm{Pb}$ & 0,95 & 0,00 & 0,00 & 0,00 & 0,00 & 0,00 & 0,00 & 0,00 & 0,00 & 0,08 & 0,00 & 0,00 & 0,00 & 0,00 & 0,00 & 0,00 & 0,00 \\
\hline $\mathrm{Sb}$ & 0,03 & 0,00 & 0,01 & 0,00 & 0,01 & 0,00 & 0,00 & 0,00 & 0,00 & 0,00 & 0,00 & 0,00 & 0,02 & 0,02 & 0,02 & 0,01 & 0,00 \\
\hline $\mathrm{Ni}$ & 0,05 & 0,03 & 0,00 & 0,02 & 0,00 & 0,05 & 0,02 & 0,00 & 0,03 & 0,04 & 0,01 & 0,04 & 0,02 & 0,07 & 0,02 & 0,00 & 0,00 \\
\hline $\mathrm{Ag}$ & 0,53 & 0,00 & 0,00 & 0,04 & 0,04 & 0,00 & 0,00 & 0,18 & 0,00 & 0,08 & 0,03 & 0,00 & 0,30 & 0,00 & 0,00 & 0,05 & 0,00 \\
\hline $\mathrm{Au}$ & 0,06 & 0,00 & 0,00 & 0,00 & 0,08 & 0,00 & 0,00 & 0,00 & 0,00 & 0,00 & 0,00 & 0,00 & 0,00 & 0,00 & 0,28 & 0,00 & 0,00 \\
\hline Sn & 0,23 & 0,05 & 0,01 & 0,02 & 0,00 & 0,08 & 0,00 & 0,06 & 0,07 & 0,08 & 0,13 & 0,13 & 0,04 & 0,09 & 0,00 & 0,00 & 0,01 \\
\hline $\mathrm{Se}$ & 0,37 & 0,15 & 0,22 & 0,00 & 0,00 & 0,17 & 0,04 & 0,17 & 0,00 & 0,00 & 0,23 & 0,00 & 0,00 & 0,00 & 0,20 & 0,00 & 0,11 \\
\hline & 0,00 & 0,11 & 0,02 & 0,00 & 0,00 & 0,00 & 0,00 & 0,00 & 0,03 & 0,00 & 0,00 & & & & & & 0,00 \\
\hline $\mathrm{Bi}$ & 0,58 & 0,00 & 0,00 & 0,16 & 0,63 & 0,00 & 0,13 & 0,65 & 0,64 & 0,87 & 0,00 & 0,34 & 0,00 & 0,07 & 0,00 & 0,00 & 0,23 \\
\hline W & & & & & & & 0,00 & & & & & & 0,08 & 0,00 & 0,00 & 0,00 & 0,00 \\
\hline $\mathrm{Cd}$ & 0,19 & 0,08 & 0,00 & 0,00 & 0,00 & 0,00 & & 0,00 & 0,00 & 0,00 & 0,06 & 0,00 & 0,03 & 0,06 & 0,00 & 0,00 & 0,00 \\
\hline $\mathrm{Hg}$ & & & & & & & 0,20 & & & & & & 0,02 & 0,00 & 0,00 & 0,00 & 0,00 \\
\hline $\mathrm{Mn}$ & & & & & & & & & & & & & 0,00 & 0,01 & 0,00 & 0,00 & 0,01 \\
\hline Total & 100,01 & 99,88 & 99,61 & 100,17 & 98,97 & 99,71 & 99,43 & 98,82 & 99,08 & 99,80 & 100,55 & 101,53 & 100,44 & 99,25 & 98,43 & 100,88 & 99,91 \\
\hline s & 1,95 & 2,02 & 2,00 & $\frac{101}{2,01}$ & 2,04 & 2,04 & 2,02 & 2,03 & 2,04 & 1,98 & 2,00 & $\frac{}{2,01}$ & 1,97 & 1,94 & 1,97 & 1,98 & 1,94 \\
\hline $\mathrm{Fe}$ & 0,97 & 0,98 & 0,98 & 0,97 & 0,97 & 0,96 & 0,96 & 1,02 & 0,95 & 1,00 & 0,97 & 0,99 & 0,93 & 0,97 & 0,95 & 0,97 & 0,98 \\
\hline $\mathrm{Cu}$ & 1,02 & & & 1,01 & 0,99 & & 1,00 & 0,93 & 1,00 & 1,01 & 1,01 & 1,00 & & 1,08 & & 1,05 & 1,08 \\
\hline As & & & & & & & & & & & & & & & & & 0,00 \\
\hline $\mathrm{Zn}$ & 0, & $0, \mathrm{C}$ & & $0,0 c$ & & & & 0,00 & 0, & s & 0,00 & & & & & 0,00 & 0,00 \\
\hline Co & 0,00 & 0,00 & $0,0 c$ & 0,00 & 0,00 & 0,00 & 0,00 & 0,00 & 0,00 & 00 & 0,00 & 0,00 & 0,00 & 0,00 & 0,00 & 0,00 & 0,00 \\
\hline $\mathrm{Pb}$ & & & & & & & & & & & & & & & & 0,00 & 0,00 \\
\hline sb & & & & & & & & 00 & 0,00 & 00 & 0,00 & 0,00 & 0,00 & 0,00 & 0,00 & 0,00 & 0,00 \\
\hline $\mathrm{Ni}$ & 0,00 & 0,00 & 0,00 & 0,00 & 0,00 & 0,00 & 0,00 & 0,00 & 0,00 & 0,00 & 0,00 & 0,00 & 0,00 & 0,00 & 0,00 & 0,00 & 0,00 \\
\hline $\mathrm{Ag}$ & 0,01 & 0,00 & & & & & & 0,00 & 0,00 & 0,00 & & & & & 0,00 & 0,00 & 0,00 \\
\hline $\mathrm{Au}$ & & 0 & & & & & & & & & 0 & & & & 0,00 & 0,00 & 0,00 \\
\hline Sn & 0,00 & 0,00 & 0,00 & 0,00 & 0,00 & 0,00 & 0,00 & 0,00 & 0,00 & 0,00 & 0,00 & 0,00 & 0,00 & 0,00 & 0,00 & 0,00 & 0,00 \\
\hline $\mathrm{Se}$ & & & & & & & & & & & & & & & & & \\
\hline Te & & & & & & & & & & & & & & & & & \\
\hline $\mathrm{Bi}$ & & & & & & & & & & & & & & & &, 00 & 0,00 \\
\hline w & 0,00 & 0,00 & 0,00 & 0,00 & 0,00 & 0,00 & 0,00 & 0,00 & 0,00 & 0,00 & 0,00 & 0,00 & 0,00 & 0,00 & 0,00 & 0,00 & 0,00 \\
\hline $\mathrm{Cd}$ & 0,00 & 0,00 & 0,00 & 0,00 & 0,00 & 0,00 & 0,00 & 0,00 & 0,00 & 0,00 & 0,00 & 0,00 & 0,00 & 0,00 & 0,00 & 0,00 & 0,00 \\
\hline $\mathrm{Hg}$ & 0,00 & 0,00 & 0 & 0,00 & 0,00 & 0,00 & 0,00 & 0,00 & 0,00 & 0,00 & 0,00 & 0,00 & 0,00 & 0,00 & 0,00 & 0,00 & 0,00 \\
\hline $\mathrm{Mr}$ & 0,00 & 0,00 & 0,00 & 0,00 & 0,00 & 0,00 & 0,00 & 0,00 & 0,00 & 0,00 & 0,00 & 0,00 & 0,00 & 0,00 & 0,00 & 0,00 & 0,00 \\
\hline
\end{tabular}

\begin{tabular}{|c|c|c|c|}
\hline \multicolumn{3}{|l|}{ Molibdenita } & \multirow{3}{*}{$\begin{array}{l}\text { Salmant. } \\
\text { Vena LG }\end{array}$} \\
\hline Mina/Zona & Tes & & \\
\hline Roca & $\mathrm{AB}$ & $A B$ & \\
\hline Muestra & 1793 & 1793 & 1704 \\
\hline Análisis & 2.2 & 2.3 & 1.2 \\
\hline S(\% peso) & 38,86 & 37,14 & 38,24 \\
\hline $\mathrm{Fe}$ & 0,13 & 0,10 & 0,12 \\
\hline $\mathrm{Cu}$ & 0,06 & 0,10 & 0,01 \\
\hline As & 0,01 & 0,09 & 0,00 \\
\hline $\mathrm{Zn}$ & 0,02 & 0,00 & 0,00 \\
\hline $\mathrm{Ni}$ & 0,00 & 0,00 & 0,02 \\
\hline $\mathrm{Ag}$ & 0,03 & 0,00 & 0,00 \\
\hline $\mathrm{Au}$ & 0,04 & 0,00 & 0,11 \\
\hline Sn & 0,01 & 0,02 & 0,00 \\
\hline Se & 0,06 & 0,07 & 0,05 \\
\hline $\mathrm{Bi}$ & 0,00 & 0,00 & 0,00 \\
\hline w & 0,46 & 0,50 & 1,41 \\
\hline $\mathrm{Cd}$ & 0,02 & 0,00 & 0,00 \\
\hline $\mathrm{Hg}$ & 0,12 & 0,04 & 0,24 \\
\hline $\mathrm{Mn}$ & 0,01 & 0,00 & 0,02 \\
\hline Mo & 60,43 & 58,52 & 59,94 \\
\hline Total & 100,26 & 96,59 & 100,15 \\
\hline S & 1,96 & 1,96 & 1,95 \\
\hline Mo & 1,02 & 1,03 & 1,02 \\
\hline $\mathrm{Fe}$ & 0,00 & 0,00 & 0,00 \\
\hline $\mathrm{Cu}$ & 0,00 & 0,00 & 0,00 \\
\hline As & 0,00 & 0,00 & 0,00 \\
\hline $\mathrm{Zn}$ & 0,00 & 0,00 & 0,00 \\
\hline $\mathrm{Ni}$ & 0,00 & 0,00 & 0,00 \\
\hline $\mathrm{Ag}$ & 0,00 & 0,00 & 0,00 \\
\hline $\mathrm{Au}$ & 0,00 & 0,00 & 0,00 \\
\hline Sn & 0,00 & 0,00 & 0,00 \\
\hline Se & 0,00 & 0,00 & 0,00 \\
\hline $\mathrm{Bi}$ & 0,00 & 0,00 & 0,00 \\
\hline w & 0,00 & 0,00 & 0,01 \\
\hline $\mathrm{Cd}$ & 0,00 & 0,00 & 0,00 \\
\hline $\mathrm{Hg}$ & 0,00 & 0,00 & 0,00 \\
\hline $\mathrm{Mn}$ & 0,00 & 0,00 & 0,00 \\
\hline
\end{tabular}


Anexo III. Análisis de microsonda electrónica

\begin{tabular}{|c|c|c|c|c|c|c|}
\hline \multirow{2}{*}{$\begin{array}{l}\text { Mina/Zona } \\
\text { Roca }\end{array}$} & \multicolumn{6}{|c|}{ Teso de la Matanza } \\
\hline & $A B$ & $A B$ & $\mathrm{AB}$ & $\mathrm{AB}$ & $A B$ & $A B$ \\
\hline Muestra & 1793 & 1793 & 1793 & 1793 & 1793 & 1793 \\
\hline Análisis & 1.1 & 1.1.1. & 1.2 & 1.3 & 1.4 & 1.5 \\
\hline $\mathrm{S}(\%$ peso) & 1,59 & 1,74 & 1,74 & 1,93 & 2,03 & 1,54 \\
\hline $\mathrm{Fe}$ & 28,04 & 28,77 & 28,75 & 29,00 & 29,08 & 27,97 \\
\hline $\mathrm{Cu}$ & 0,00 & 0,00 & 0,00 & 0,00 & 0,00 & 0,00 \\
\hline As & 69,14 & 70,92 & 70,87 & 70,04 & 70,09 & 68,95 \\
\hline Co & 0,00 & 0,00 & 0,00 & 0,00 & 0,00 & 0,00 \\
\hline $\mathrm{Zn}$ & 0,03 & & - & - & - & \\
\hline $\mathrm{Pb}$ & & & - & - & - & \\
\hline Sb & 0,00 & - & - & - & - & \\
\hline $\mathrm{Ni}$ & 0,03 & 0,03 & 0,00 & 0,00 & 0,00 & 0,02 \\
\hline $\mathrm{Ag}$ & 0,00 & & & & & \\
\hline $\mathrm{Au}$ & 0,10 & - & - & - & & \\
\hline Total & 98,94 & 101,46 & 101,36 & 100,97 & 101,20 & 98,48 \\
\hline $\mathrm{s}$ & 0,10 & 0,11 & 0,11 & 0,12 & 0,12 & 0,10 \\
\hline As & 1,87 & 1,87 & 1,87 & 1,85 & 1,85 & 1,88 \\
\hline $\mathrm{Fe}$ & 1,02 & 1,02 & 1,02 & 1,03 & 1,03 & 1,02 \\
\hline $\mathrm{Cu}$ & 0,00 & 0,00 & 0,00 & 0,00 & 0,00 & 0,00 \\
\hline Co & 0,00 & 0,00 & 0,00 & 0,00 & 0,00 & 0,00 \\
\hline $\mathrm{Zn}$ & 0,00 & 0,00 & 0,00 & 0,00 & 0,00 & 0,00 \\
\hline $\mathrm{Pb}$ & 0,00 & 0,00 & 0,00 & 0,00 & 0,00 & 0,00 \\
\hline sb & 0,00 & 0,00 & 0,00 & 0,00 & 0,00 & 0,00 \\
\hline $\mathrm{Ni}$ & 0,00 & 0,00 & 0,00 & 0,00 & 0,00 & 0,00 \\
\hline $\mathrm{Ag}$ & 0,00 & 0,00 & 0,00 & 0,00 & 0,00 & 0,00 \\
\hline $\mathrm{Au}$ & 0,00 & 0,00 & 0,00 & 0,00 & 0,00 & 0,00 \\
\hline
\end{tabular}

\begin{tabular}{|c|c|c|c|c|c|c|c|c|c|c|c|c|c|}
\hline \multirow{2}{*}{$\begin{array}{l}\text { Mina/Zona } \\
\text { Roca }\end{array}$} & \multicolumn{7}{|c|}{ Horia } & \multicolumn{3}{|c|}{ Mari Carmen } & \multicolumn{3}{|c|}{ Salmantina } \\
\hline & Vena GE & Vena GE & Vena GE & Vena GE & Vena GE & Vena GE & Vena GE & Vena GE & Vena GE & Vena GE & Vena LG & Vena LG & Vena $L G$ \\
\hline Muestra & 1767 & 1767 & 1767 & 1696 & $1773 \mathrm{~A}$ & 1040 & 1040 & 1047 & 1047 & 1775 & 1699 & 1059A & $1059 \mathrm{~B}$ \\
\hline Análisis & 2.1 & 2.3 & 2.5 & 3.6 & 1.1 & 1.138 & 1.140 & 1.25 & 1.26 & 1.1 & 5.4 & 4.1 & 3.2 \\
\hline $\begin{array}{l}\text { S(\% peso) } \\
\end{array}$ & 0,04 & 0,02 & 0,08 & 0,05 & 0,05 & 0,03 & 0,07 & 0,37 & 0,61 & 0,03 & 0,07 & 0,17 & 0,09 \\
\hline $\mathrm{Fe}$ & 0,00 & 0,00 & 0,00 & 1,06 & 0,35 & 1,08 & 1,84 & 0,46 & 0,85 & 1,28 & 0,48 & 2,73 & 2,04 \\
\hline $\mathrm{Cu}$ & 0,00 & 0,03 & 0,00 & 0,04 & 0,02 & 0,00 & 0,08 & 0,00 & 0,04 & 0,01 & 0,03 & 0,01 & 0,12 \\
\hline As & 0,10 & 0,00 & 0,00 & 0,00 & 0,00 & 0,40 & 0,63 & 0,12 & 0,00 & 0,00 & 0,00 & 0,68 & 0,28 \\
\hline Co & 0,00 & 0,01 & 0,00 & 0,00 & 0,00 & 0,09 & 0,03 & 0,00 & 0,00 & 0,00 & 0,00 & 0,02 & \\
\hline $\mathrm{Zn}$ & 0,02 & 0,05 & 0,01 & 0,01 & 0,00 & 0,02 & 0,08 & 0,18 & 0,05 & 0,00 & 0,06 & 0,00 & 0,09 \\
\hline $\mathrm{Pb}$ & 0,00 & 0,00 & 0,00 & 0,00 & 0,00 & 0,05 & 0,32 & 0,66 & 0,64 & 0,00 & 0,00 & 0,04 & 0,23 \\
\hline sb & 0,00 & 0,01 & 0,00 & 0,04 & 0,10 & 0,22 & 0,15 & 0,07 & 0,00 & 0,04 & 0,00 & 0,20 & 0,00 \\
\hline $\mathrm{Ni}$ & 0,01 & 0,03 & 0,01 & 0,04 & 0,01 & 0,06 & 0,03 & 0,03 & 0,00 & 0,02 & 0,00 & 0,00 & \\
\hline & 0,00 & 0,00 & & 0,00 & $0, \mathrm{C}$ & & & & & & 0,01 & 0,13 & 0,16 \\
\hline $\mathrm{Au}$ & & & 0,21 & 00 & 0,00 & 0,00 & 0,00 & 0,00 & & 0,00 & 0,00 & 0,64 & 0,07 \\
\hline Sn & 0,00 & 0,00 & 0,01 & 0,00 & 0,00 & 0,07 & 0,00 & 0,00 & 0,08 & 0,00 & 0,00 & 0,03 & 0,00 \\
\hline Se & 0,07 & 0,07 & 0,07 & 0,08 & 0,07 & 0,03 & 0,00 & 0,25 & 0,10 & 0,10 & 0,08 & 0,00 & 0,00 \\
\hline Te & 0,04 & 0,00 & 0,00 & 0,00 & 0,04 & 0,00 & 0,17 & 0,00 & 0,00 & 0,13 & 0,06 & 0,00 & 0,05 \\
\hline $\mathrm{Bi}$ & 87,50 & 92,66 & 86,10 & 99,61 & 97,99 & 97,13 & 96,81 & 97,96 & 95,60 & 97,25 & 99,24 & 89,43 & 97,18 \\
\hline W & & & & & & 0,10 & 0,04 & 0,13 & 0,08 & 0,10 & 0,04 & & \\
\hline Cd & 0,00 & 0,00 & 0,00 & 0,00 & 0,00 & 0,19 & 0,19 & 0,08 & 0,15 & 0,00 & 0,00 & 0,06 & 0,12 \\
\hline Total & 87,78 & 92,95 & 86,52 & 100,94 & 98,63 & 99,47 & 100,49 & 100,31 & 98,19 & 98,97 & 100,06 & 94,13 & 100,43 \\
\hline $\mathrm{s}$ & 0,00 & 0,00 & 0,01 & 0,00 & 0,00 & 0,00 & 0,00 & 0,02 & 0,04 & 0,00 & 0,00 & 0,01 & 0,01 \\
\hline $\mathrm{Bi}$ & & & & & & & & & & & & & 0,90 \\
\hline $\mathrm{Fe}$ & 0 , & 0 , & & & 0,01 & & & 02 & & & 0,02 & 10 & 0,07 \\
\hline Cu & 0,00 & 0,00 & 0,00 & 0,00 & 0,00 & 0,00 & 0,00 & 0,00 & 0,00 & 0,00 & 0,00 & 0,00 & 0,00 \\
\hline As & & & & & $0, \mathrm{C}$ & & & 00 & & 00 & 0,00 & , 02 & 0,01 \\
\hline Co & & 0, & & 0 , & $0, \mathrm{C}$ & 00 & 0, & 0,00 & & 0,00 & 0,00 & 0,00 & 0,00 \\
\hline $\mathrm{Zn}$ & 0,00 & 0,00 & 0, & & $0, \mathrm{C}$ & 0,00 & 0, & 0,01 & & ,00 & 0,00 & 0,00 & 0,00 \\
\hline $\mathrm{Pb}$ & 0,00 & 0, & 0,0 & & $0, \mathrm{C}$ & & 0, & 01 & & 00 & 00 & 0,00 & 0,00 \\
\hline $\mathrm{Sb}$ & & & & & & & & & & & 00 & & 0,00 \\
\hline $\mathrm{Ni}$ & & & & & & & & & & ,00 & 00 & , 00 & 0,00 \\
\hline $\mathrm{Ag}$ & 0,00 & 0,00 & 0,0 & 0,00 & 0,00 & 0,00 & 0, & 0,00 & 00 & 0,00 & 0,00 & 0,00 & 0,00 \\
\hline $\mathrm{Au}$ & 0,00 & 0,00 & 0,00 & 0,00 & 0,00 & 0,00 & 0,00 & 0,00 & 0,00 & 0,00 & 0,00 & 0,01 & 0,00 \\
\hline Sn & 0,0 & 0, & 0, & & & & & & & & 00 & 00 & 00 \\
\hline Se & 0,00 & 0, & & & & 00 & 0, & 0,01 & 0 , & 0,00 & 0,00 & 0,00 & 0,00 \\
\hline Te & 0,00 & 0,00 & 0,00 & 0,00 & 0,00 & 0,00 & 0,00 & 0,00 & 0,00 & 0,00 & 0,00 & 0,00 & 0,00 \\
\hline W & 0,00 & 0,00 & 0,00 & 0,00 & 0,00 & 0,00 & 0,00 & 0,00 & & 0,00 & 0,00 & 0,00 & 0,00 \\
\hline $\mathrm{Cd}$ & 0,00 & 0,00 & 0, & & 0 , & & & & & 00 & 00 & 0,00 & 00 \\
\hline $\mathrm{Hg}$ & 0,00 & & & & & & & & & 0,00 & & & 0,00 \\
\hline $\mathrm{Mn}$ & 0,00 & 0,00 & 0,00 & 0,00 & 0,00 & 0,00 & 0,00 & 0,00 & 0,00 & 0,00 & 0,00 & 0,00 & 0,00 \\
\hline
\end{tabular}


Bi nativo (continuación)

\begin{tabular}{lrrrrrrrrrrrrrrr}
\multicolumn{10}{c}{ Bi nativo (continuación) } \\
\hline Mina/Zona
\end{tabular}

Anexo III. Análisis de microsonda electrónica

\begin{tabular}{|c|c|c|c|c|c|c|}
\hline \multicolumn{7}{|l|}{ Zialena } \\
\hline Roca & Vena GE & & Vena LG & $\begin{array}{c}\text { Salma } \\
\text { Vena } L G\end{array}$ & $\begin{array}{l}\text { antina } \\
\text { Vena LG }\end{array}$ & Vena LG \\
\hline Muestra & 1047 & 1047 & 1159 & 1159 & 845 & 845 \\
\hline Análisis & 2.32 & 2.98 & 1.5 & 2.12 & 5.6 & 5.7 \\
\hline $\mathrm{S}$ (\% peso) & 12,35 & $\begin{array}{ll}13,17 \\
\end{array}$ & 13,82 & 13,54 & 13,94 & 13,95 \\
\hline $\mathrm{Fe}$ & 0,99 & 0,71 & 1,00 & 1,00 & 0,00 & 0,12 \\
\hline $\mathrm{Cu}$ & 0,00 & 0,01 & 0,13 & 0,00 & 0,06 & 0,19 \\
\hline As & 1,68 & 0,13 & 0,06 & 0,00 & 0,03 & 0,07 \\
\hline Co & 0,00 & 0,00 & 0,00 & 0,00 & 0,00 & 0,00 \\
\hline $\mathrm{Zn}$ & 0,11 & 0,06 & 0,03 & 0,00 & 0,02 & 0,14 \\
\hline $\mathrm{Pb}$ & 69,82 & 78,60 & 77,55 & 78,54 & 83,03 & 82,55 \\
\hline $\mathrm{Sb}$ & 0,05 & 0,00 & 0,07 & 0,01 & 0,00 & 0,00 \\
\hline $\mathrm{Ni}$ & 0,05 & 0,01 & 0,00 & 0,00 & 0,00 & 0,00 \\
\hline $\mathrm{Ag}$ & 0,61 & 0,25 & 2,96 & 1,44 & 0,72 & 1,01 \\
\hline $\mathrm{Au}$ & 0,00 & 0,00 & 0,00 & 0,00 & 0,00 & 0,00 \\
\hline Sn & 0,06 & 0,02 & 0,00 & 0,05 & 0,00 & 0,00 \\
\hline Se & 0,28 & 0,03 & 0,06 & 0,00 & 0,15 & 0,05 \\
\hline Te & & 0,06 & 0,00 & 0,00 & 0,00 & 0,00 \\
\hline $\mathrm{Bi}$ & 12,97 & 5,91 & 4,32 & 4,44 & 2,07 & 1,95 \\
\hline $\mathrm{Cd}$ & 0,00 & 0,14 & 0,00 & 0,00 & 0,03 & 0,03 \\
\hline $\mathrm{Hg}$ & 0,52 & 0,00 & 0,00 & 0,00 & 0,00 & 0,00 \\
\hline Total & 99,50 & 99,11 & 100,00 & 99,02 & 100,04 & 100,04 \\
\hline $\mathrm{s}$ & 1,83 & 1,96 & 1,97 & 1,98 & 2,03 & 2,02 \\
\hline $\mathrm{Pb}$ & 1,61 & 1,81 & 1,71 & 1,77 & 1,87 & 1,85 \\
\hline $\mathrm{Ag}$ & 0,03 & 0,01 & 0,13 & 0,06 & 0,03 & 0,04 \\
\hline $\mathrm{Bi}$ & 0,30 & 0,13 & 0,09 & 0,10 & 0,05 & 0,04 \\
\hline $\mathrm{Fe}$ & 0,08 & 0,06 & 0,08 & 0,08 & 0,00 & 0,01 \\
\hline $\mathrm{Cu}$ & 0,00 & 0,00 & 0,01 & 0,00 & 0,00 & 0,01 \\
\hline As & 0,11 & 0,01 & 0,00 & 0,00 & 0,00 & $0,0 \mathrm{c}$ \\
\hline Co & 0,00 & 0,00 & 0,00 & 0,00 & 0,00 & 0,00 \\
\hline $\mathrm{Zn}$ & 0,01 & 0,00 & 0,00 & 0,00 & 0,00 & 0,01 \\
\hline $\mathrm{Sb}$ & 0,00 & 0,00 & 0,00 & 0,00 & 0,00 & 0,00 \\
\hline $\mathrm{Ni}$ & 0,00 & 0,00 & 0,00 & 0,00 & 0,00 & 0,00 \\
\hline $\mathrm{Au}$ & 0,00 & 0,00 & 0,00 & 0,00 & 0,00 & 0,00 \\
\hline Sn & 0,00 & 0,00 & 0,00 & 0,00 & 0,00 & 0,00 \\
\hline Se & 0,02 & 0,00 & 0,00 & 0,00 & 0,01 & $0,0 c$ \\
\hline Te & 0,00 & 0,00 & 0,00 & 0,00 & 0,00 & 0,00 \\
\hline $\mathrm{Cd}$ & 0,00 & 0,01 & 0,00 & 0,00 & 0,00 & 0,00 \\
\hline $\mathrm{Hg}$ & 0,01 & 0,00 & 0,00 & 0,00 & 0,00 & 0,00 \\
\hline
\end{tabular}


Anexo III. Análisis de microsonda electrónica

\begin{tabular}{|c|c|c|c|c|c|c|c|c|c|c|c|c|c|c|c|c|c|c|c|c|c|c|c|}
\hline \multirow{3}{*}{$\begin{array}{l}\text { Mina/Zona } \\
\text { Roca } \\
\text { Muestra }\end{array}$} & \multirow{2}{*}{$\begin{array}{c}\text { Salm. } \\
\text { Vena LG }\end{array}$} & \multirow{2}{*}{$\begin{array}{c}\text { Prof. } \\
\text { Vena LG }\end{array}$} & \multicolumn{2}{|c|}{ Teso } & \multicolumn{2}{|c|}{ El Jaque } & \multicolumn{11}{|c|}{ El Cruce } & \multicolumn{6}{|c|}{ Peñaparda } \\
\hline & & & Vena LG & Vena LG & Vena G6 & Vena G6 & Vena G2 & Vena G2 & Vena G2 & Vena G2 & Vena G2 & Vena G2 & Vena G2 & Vena G2 & Vena G2 & Vena G2 & Vena G2 & Vena G5 & Vena G5 & Vena G5 & Vena G5 & Vena G5 & Vena G5 \\
\hline & & & 1173 & 1173 & 1069 & 1069 & 1065 & 1065 & 1065 & 1065 & 1065 & 1065 & 1065 & 1065 & 1065 & 1065 & 1065 & 798 & 798 & 798 & 798 & 798 & 798 \\
\hline Análisis & 5.10 & 5.10 & 6.1 & 9.6 & 2.1 & 2.2 & 2.3 & 2.4 & 2.80 & 4.1 & 4.2 & 4.3 & 4.4 & 4.7 & 4.86 & 4.87 & 8.1 & 2.1 & $2.1 \mathrm{~b}$ & 2.2 & 3.1 & $3.1 \mathrm{~b}$ & 4.1 \\
\hline S(\% peso) & 12,93 & 13,92 & 13,34 & 13,51 & 14,27 & 14,15 & 13,49 & 13,80 & 13,85 & 13,86 & 13,52 & 13,49 & 13,55 & 14,34 & 13,40 & 13,70 & 13,77 & 14,21 & 14,04 & 13,12 & 13,95 & 12,21 & $\overline{13,24}$ \\
\hline $\mathrm{Fe}$ & 0,00 & 1,66 & 0,15 & 0,06 & 1,15 & 0,50 & 2,74 & 1,00 & 2,91 & 1,49 & 1,65 & 1,65 & 1,61 & 0,68 & 0,53 & 1,28 & 1,11 & 0,44 & 0,47 & 0,35 & 0,29 & 0,24 & 0,62 \\
\hline $\mathrm{Cu}$ & 0,00 & 0,42 & 0,27 & 0,00 & 0,59 & 0,34 & 0,13 & 0,03 & 0,45 & 0,03 & 0,00 & 0,03 & 0,11 & 0,12 & 0,01 & 0,00 & 0,12 & 0,26 & 0,39 & 0,00 & 0,31 & 0,16 & 0,01 \\
\hline As & 0,05 & 0,10 & 0,11 & 0,01 & 0,05 & 0,19 & 0,11 & 0,17 & 0,00 & 0,11 & 0,11 & 0,07 & 0,21 & 0,01 & 0,00 & 0,00 & 0,19 & 0,00 & 0,00 & 0,01 & 0,00 & 0,00 & 0,04 \\
\hline Co & & 0,00 & & & 0,07 & 0,03 & 0,00 & 0,05 & 0,05 & 0,02 & 0,05 & 0,00 & 0,00 & 0,02 & 0,03 & 0,04 & 0,03 & & & & & & \\
\hline $\mathrm{Zn}$ & 0,00 & 0,00 & 0,00 & 0,00 & 0,06 & 0,04 & 0,04 & 0,07 & 0,29 & 0,11 & 0,00 & 0,18 & 0,12 & 0,00 & 0,05 & 0,03 & 0,08 & 0,00 & 0,00 & 0,10 & 0,00 & 0,00 & 0,00 \\
\hline $\mathrm{Pb}$ & 83,40 & 83,59 & 82,57 & 85,19 & 76,24 & 77,74 & 79,00 & 81,05 & 82,16 & 80,84 & 79,45 & 78,57 & 79,82 & 82,40 & 82,45 & 81,86 & 80,72 & 74,97 & 79,07 & 79,32 & 81,86 & 81,28 & 81,73 \\
\hline Sb & 0,04 & 0,00 & 0,00 & 0,00 & 0,00 & 0,14 & 0,07 & 0,12 & 0,00 & 0,12 & 0,11 & 0,08 & 0,03 & 0,14 & 0,03 & 0,04 & 0,01 & 0,00 & 0,00 & 0,00 & 0,00 & 0,00 & 0,00 \\
\hline $\mathrm{Ni}$ & & 0,00 & & & 0,00 & 0,02 & 0,02 & 0,04 & 0,01 & 0,03 & 0,00 & 0,04 & 0,00 & 0,00 & 0,04 & 0,10 & 0,00 & & & & & & \\
\hline $\mathrm{Ag}$ & 0,77 & 0,37 & 0,52 & 0,40 & 2,56 & 2,49 & 1,88 & 1,64 & 0,29 & 1,08 & 1,36 & 1,29 & 1,31 & 1,31 & 1,09 & 1,03 & 1,57 & 3,45 & 2,07 & 2,65 & 1,36 & 1,39 & 1,21 \\
\hline $\mathrm{Au}$ & & 0,00 & & & 0,00 & 0,37 & 0,00 & 0,55 & 0,00 & 0,21 & 0,19 & 0,38 & 0,48 & 0,35 & 0,00 & 0,00 & 0,00 & & & & & & \\
\hline Sn & & 0,19 & - & - & & 0,09 & 0,00 & 0,00 & 0,05 & 0,09 & 0,06 & 0,01 & 0,00 & 0,01 & 0,00 & 0,08 & 0,00 & & & & & & \\
\hline $\mathrm{Se}$ & 0,03 & 0,12 & 0,03 & 0,05 & 0,62 & 0,00 & 0,00 & 0,13 & 0,00 & 0,14 & 0,06 & 0,43 & 0,18 & 0,24 & 0,00 & 0,07 & 0,00 & 0,11 & 0,07 & 0,10 & 0,15 & 0,00 & 0,07 \\
\hline $\mathrm{Te}$ & & 0,02 & & & 0,02 & 0,30 & 0,08 & 0,03 & 0,00 & 0,00 & 0,18 & 0,18 & 0,03 & 0,00 & 0,00 & 0,19 & 0,00 & & & & & & \\
\hline $\mathrm{Bi}$ & 2,20 & 0,00 & 2,92 & 1,23 & 4,48 & 3,47 & 2,56 & 2,32 & 0,00 & 1,79 & 2,49 & 3,06 & 2,09 & 1,27 & 1,52 & 0,90 & 2,63 & 6,61 & 4,12 & 4,24 & 2,83 & 3,70 & 2,99 \\
\hline Co & 0,07 & & 0,20 & 0,00 & & & 0,00 & 0,00 & 0,00 & 0,00 & 0,00 & 0,00 & 0,00 & 0,00 & 0,14 & 0,19 & 0,00 & 0,09 & 0,00 & 0,02 & 0,09 & 0,20 & 0,00 \\
\hline $\mathrm{Hg}$ & 0,00 & 0,00 & 0,00 & 0,00 & & 0,22 & & 0,00 & & 0,00 & 0,00 & 0,04 & 0,23 & 0,00 & 0,43 & 0,57 & 0,00 & 0,00 & 0,00 & 0,00 & 0,00 & 0,00 & 0,00 \\
\hline Total & 99,48 & 100,39 & 100,12 & 100,46 & 100,16 & 100,10 & 100,27 & 100,99 & 100,06 & 99,91 & 99,24 & 99,48 & 99,76 & 100,90 & 99,70 & 100,09 & 100,22 & 100,15 & 100,23 & 99,91 & 100,83 & 99,18 & 99,91 \\
\hline S & 1,95 & 1,97 & 1,97 & 2,00 & 1,98 & 2,00 & 1,90 & 1,96 & 1,93 & 1,97 & 1,95 & 1,93 & 1,94 & 2,02 & 1,97 & 1,96 & 1,97 & 2,01 & 2,00 & 1,93 & 2,00 & 1,88 & 1,95 \\
\hline $\mathrm{Pb}$ & 1,95 & 33 & 1,89 & 1,95 & 1,64 & & 1,72 & 1,79 & 1,77 & 1,78 & 1,77 & & 1,77 & & 1,88 & 1,82 & 1,79 & 1,64 & 1,75 & & 1,82 & 1,93 & 1,87 \\
\hline $\mathrm{Ag}$ & 0,03 & & 0,02 & 0,02 & & & & 0,0 & 0,01 & 0,05 & 0,06 & & 0,06 & & 0,05 & 0,0 & 0,0 & 0,14 & 0,09 & & 0,06 & 0,06 & 0,05 \\
\hline $\mathrm{Bi}$ & 0,05 & & 0,07 & 0,03 & & & & & & & $0, \mathrm{C}$ & & & & & 0,0 & & 0,14 & 0,09 & & 0,06 & 0,09 & 0,07 \\
\hline $\mathrm{Fe}$ & 0,00 & 0 , & 0,01 & 0,01 & & 0,04 & & 0,08 & 0,2 & & 0 , & & 0 , & 0,05 & 0 , & 0,1 & & 0,04 & 0,04 & 0,03 & 0,02 & 0,02 & 0,05 \\
\hline $\mathrm{Cu}$ & 0,00 & & & & & & & & & & & & & & $0, \mathrm{C}$ & & & 0,02 & 0,03 & & 0,02 & 0,01 & 0,00 \\
\hline As & 0,00 & & 0,0 & 0, & & & & & 0,0 & & 0,01 & & 0,01 & 0,00 & 0,00 & 0,00 & 0,01 & 0,00 & 0,00 & 0,00 & 0,00 & 0,00 & 0,00 \\
\hline Co & 0,00 & $0, \mathrm{C}$ & 0,00 & 0,00 & & 0,00 & $0, \mathrm{C}$ & 0,00 & 0,00 & 0,00 & 0,00 & 0,00 & 0,00 & 0,00 & 0,00 & 0,00 & 0,00 & 0,00 & 0,00 & 0,00 & 0,00 & 0,00 & 0,00 \\
\hline $\mathrm{Zn}$ & 0,00 & & & & & & & & & & & & & & & & & & & & & 0,00 & 0,00 \\
\hline $\mathrm{Sb}$ & & & & & & & & & & & & & & & & & & & & & & 0,0 & 0,00 \\
\hline $\mathrm{Ni}$ & & & & & & & & & & & & & & & & 0,0 & & 0,00 & 0,00 & 0,00 & 0,00 & 0,00 & 0,00 \\
\hline $\mathrm{Au}$ & 0,00 & 0,00 & 0,00 & 0,00 & 0,00 & 0,01 & 0,00 & 0,01 & 0,00 & 0,00 & 0,00 & 0,01 & 0,01 & 0,01 & 0,00 & 0,00 & 0,00 & 0,00 & 0,00 & 0,00 & 0,00 & 0,00 & 0,00 \\
\hline Sn & 0,00 & 0,01 & 0,00 & 0,00 & 0,00 & 0,00 & 0,00 & 0,00 & 0,00 & 0,00 & 0,00 & 0,00 & 0,00 & 0,00 & 0,00 & 0,00 & 0,00 & 0,00 & 0,00 & 0,00 & 0,00 & 0,00 & 0,00 \\
\hline $\mathrm{Se}$ & 0,00 & & 0,00 & 0,00 & & & & & 0,00 & & 0,00 & & & & 0,00 & 0,00 & & 0,01 & 0,00 & 0,01 & 0,01 & 0,00 & 0,00 \\
\hline $\mathrm{Te}$ & 0,00 & 0,00 & 0,0 & 0, & & & & & & 0,0 & 0,01 & 0,01 & 0,00 & 0,00 & 0,00 & 0,01 & 0,00 & 0,00 & 0,00 & 0,00 & 0,00 & 0,00 & 0,00 \\
\hline $\mathrm{Cd}$ & 0,00 & 0,00 & 0,01 & 0,00 & 0,00 & 0,00 & 0,00 & 0,00 & 0,00 & 0,00 & 0,00 & 0,00 & 0,00 & 0,00 & 0,01 & 0,01 & 0,00 & 0,00 & 0,00 & 0,00 & 0,00 & 0,01 & 0,00 \\
\hline $\mathrm{Hg}$ & 0,00 & 0,00 & 0,00 & 0,00 & 0,00 & 0,01 & 0,00 & 0,00 & 0,00 & 0,00 & 0,00 & 0,00 & 0,01 & 0,00 & 0,01 & 0,01 & 0,00 & 0,00 & 0,00 & 0,00 & 0,00 & 0,00 & 0,00 \\
\hline
\end{tabular}


Anexo III. Análisis de microsonda electrónica

Matildita

\begin{tabular}{|c|c|c|c|c|c|c|c|c|c|c|c|c|c|c|c|c|c|c|c|c|c|}
\hline \multirow{2}{*}{$\begin{array}{l}\text { Mina/Zona } \\
\text { Roca }\end{array}$} & \multicolumn{6}{|c|}{ Salmantina } & \multicolumn{8}{|c|}{$\begin{array}{l}\text { Profunda } \\
\end{array}$} & \multicolumn{7}{|c|}{$\begin{array}{l}\text { Teso de la matanza } \\
\end{array}$} \\
\hline & Vena LG & Vena LG & Vena LG & Vena LG & Vena LG & Vena LG & Vena LG & Vena LG & Vena LG & Vena LG & Vena LG & Vena LG & Vena LG & Vena LG & Vena LG & Vena LG & Vena LG & Vena LG & Vena LG & Vena LG & Vena LG \\
\hline Muestra & 1699 & 1699 & 1699 & 1699 & $835 B$ & 1159 & $781 \mathrm{~B}$ & $781 \mathrm{~B}$ & $781 \mathrm{~B}$ & $781 \mathrm{~B}$ & 783 & 783 & 783 & 783 & 1174 & 1174 & 1174 & 1179 & 1179 & 1179 & 1179 \\
\hline Análisis & 5.1 & 5.2 & 5.5 & 5.8 & 5.2 & 1.1 & 5.1 & 5.11 & 5.14 & 5.17 & 2.1 & 3.3 & 3.4 & 3.7 & 1.3 & 1.4 & 1.10 & 1.19 & 1.24 & 1.25 & \\
\hline$S(\%$ peso) & 16,96 & 16,37 & 15,89 & 16,93 & 16,99 & 15,72 & 16,85 & 16,99 & 17,23 & 15,29 & 16,80 & 16,70 & 18,11 & 17,57 & 17,58 & 17,40 & 19,43 & 16,70 & 16,36 & 16,56 & 17,20 \\
\hline $\mathrm{Fe}$ & 0,90 & 0,84 & 1,02 & 0,40 & 0,00 & 1,22 & 1,47 & 0,92 & 0,79 & 0,65 & 0,50 & 0,22 & 0,08 & 0,20 & 0,00 & 0,04 & 0,00 & 0,03 & 0,06 & 0,06 & 0,00 \\
\hline $\mathrm{Cu}$ & 0,01 & $0, \mathrm{C}$ & 0,02 & 01 & 0,00 & 0,00 & 0,01 & 0,02 & 0,00 & 0,04 & 0,00 & 0,00 & 0,14 & 0,00 & 0,26 & 0,18 & 0,39 & 0,04 & 0,00 & 0,00 & 0,07 \\
\hline As & 0 , & 0,00 & 0,00 & 0,00 & 0,00 & 0,00 & 0,00 & 0,00 & 0,00 & 0,00 & 0,00 & 0,00 & 0,00 & 0,00 & 0,00 & 0,00 & 0,00 & 0,06 & 0,12 & 0,31 & 0,00 \\
\hline Co & 0,00 & 0,00 & 0,00 & 0,00 & & 0,01 & 0,00 & 0,00 & 0,00 & 0,00 & & & & & & & & 0,00 & & 00 & \\
\hline $\mathrm{Zn}$ & 0,01 & & 0,05 & & 0,23 & 00 & 0,02 & 0,00 & 0,01 & 0,00 & 0,00 & 0,09 & 0,06 & 0,05 & 0,00 & 0,00 & 0,03 & 0,00 & 0,00 & 0,03 & 0,20 \\
\hline $\mathrm{pb}$ & 0,00 & & 00 & 00 & 0,00 & 0,00 & 0,00 & 0,00 & 0,00 & 0,00 & 0,00 & 0,00 & 0,11 & 0,07 & 0,00 & 0,00 & 0,00 & 15 & 0,14 & 0,97 & 1,10 \\
\hline Sb & 0,00 & 0,01 & 0,00 & 0,07 & 0,03 & 0,12 & 0,14 & 0,13 & 0,00 & 0,17 & 0,02 & 0,12 & 0,00 & 0,08 & 0,00 & 0,01 & 0,00 & 0,13 & 0,09 & 0,02 & 0,00 \\
\hline & & & & 0,02 & & 0,05 & 0,03 & 0,03 & 0,00 & 0,01 & & & & & & & & & 0,02 & 0,04 & \\
\hline $\mathrm{Ag}$ & 30,19 & 27,76 & & 28,42 & 27,84 & 25,46 & 29,35 & 29,01 & 29,68 & 25,92 & 28,13 & 28,27 & 28,53 & 28,67 & 27,94 & 28,72 & 27,04 & 27,53 & 26,53 & 26,41 & 29,2 \\
\hline $\mathrm{Au}$ & & & & & & & & 0,00 & 0,10 & 0,06 & & - & & & & & - & 0,00 & 0,00 & 0,00 & \\
\hline Sn & 00 & 0 & & 0,00 & & 0,00 & 0,00 & 0,00 & 0,00 & 0,00 & - & & & & & & & 0,00 & 0,00 & 0,04 & \\
\hline Se & 06 & 44 & 08 & 0,05 & 0,01 & 0,00 & 0,12 & 0,11 & 0,11 & 0,10 & 0,11 & 0,11 & 0,05 & 0,09 & 0,00 & 0,08 & 0,16 & 0,04 & 0,00 & 0,27 & 0,20 \\
\hline & & & & 04 & & 00 & 0,00 & 0,00 & & 00 & & & & & & & & & 0,00 & 0,00 & \\
\hline & & & & 53,35 & 54,88 & 56,80 & 52,50 & 51,91 & 52,25 & 57,99 & 54,43 & 54,44 & 53,25 & 54,00 & 54,79 & 54,31 & 52,94 & 54,90 & 56,36 & 54,80 & 52,87 \\
\hline $\mathrm{Cd}$ & 00 & & & & 0,00 & 0,20 & 0,00 & 0,00 & 0,00 & 0,00 & 0,00 & 0,00 & 0,00 & 0,00 & 0,00 & 0,00 & 0,00 & 0,32 & 0,29 & 0,30 & 0,00 \\
\hline n & & & & & 0,03 & 00 & 0,04 & 0,00 & 0,00 & 05 & 0,00 & 0,05 & 0,01 & 0,00 & 0,00 & 0,02 & 0,00 & 00 & 0,00 & 0,00 & 0,00 \\
\hline Total & 100,54 & 99,75 & 99,15 & 99,48 & 100,00 & 99,60 & 100,55 & 99,12 & 100,17 & 100,30 & 99,99 & 100,01 & 100,34 & 100,73 & 100,57 & 100,77 & 99,99 & 100,02 & 100,01 & 99,79 & 100,91 \\
\hline & 1,97 & 1,95 & 1,94 & & 2,01 & 1,92 & 1,95 & $\frac{1,12}{1,99}$ & 1,99 & 1,89 & 1,99 & 1,98 & 2,07 & 2,03 & 2,04 & 2,02 & $\begin{array}{r}2,17 \\
\end{array}$ & 1,99 & 1,97 & 1,98 & 2,00 \\
\hline & & & & & & & & & & & & & & & & & 0,90 & & & 0.94 & 1,01 \\
\hline & 0 & & & & 1,0 & & 0,93 & 0 , & & & 0,99 & , & 0,94 & , & 0,98 & & 0,91 & & ,04 & 01 & \\
\hline & & & & & & & & & & & 0,03 & 01 & 0,01 & & 0,00 & 0,00 & 0,00 & & 0,00 & 00 & 0,00 \\
\hline & & & & & & & & & & & & & & & 0,00 & 0,00 & 0,00 & & 0,00 & 0,02 & 0,02 \\
\hline & & & & & & & & & & & 0 , & & & & 0,02 & 01 & 0,02 & & 0,00 & 0,00 & \\
\hline & & & & & & & & & & & & & & & & &, 00 & & & 0,02 & 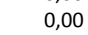 \\
\hline & & & & & & & & & & & & & & & & & & & & & \\
\hline & & & & & & & & & & & & & & & & & & & & & 0,01 \\
\hline & & & & & & & & & & & & & & & 0,0 & 00 & 0,00 & & 0,00 & 0,00 & 0,00 \\
\hline & & & & & & & 0,00 & 0,00 & 0,00 & & 0,00 & 00 & 0,00 & & 0,00 & 0,00 & 0,00 &, 01 & 0,00 & 0,00 & 0,00 \\
\hline & & & & & & & & & & & & & & & & & & & & & \\
\hline & & & & & & & & & & & & & & & & & & & & & \\
\hline $\mathrm{Se}$ & 0,00 & 0,00 & 0,00 & 0, & 0,00 & 0,00 & 0,01 & 0,01 & 0,01 & 00 & 0,01 & 0,01 & 0,0 & 0,00 & 0,00 & 0,00 & 0,01 & 0,00 & 0,00 & 0,01 & 0,01 \\
\hline & & & & & & & & 0,00 & & & 0,00 & 00 & 0,0 & & 0,00 & 0,00 & 0,00 & & 0,00 & 0,00 & 0,00 \\
\hline & & & & & & & & & & & & & & & & & & & & 0,01 & \\
\hline & 0,00 & 0,00 & 0,00 & 0,00 & 0,00 & 0,00 & 0,00 & 0,00 & 0,00 & 0,00 & 0,00 & 0,00 & 0,00 & 0,00 & 0,00 & 0,00 & 0,00 & 0,00 & 0,00 & 0,00 & \\
\hline
\end{tabular}


Anexo III. Análisis de microsonda electrónica

\begin{tabular}{|c|c|c|c|c|c|c|c|c|c|c|c|c|c|c|c|c|c|c|c|c|c|c|c|}
\hline \multicolumn{24}{|l|}{ Bismutinita } \\
\hline Mina/Zona & Hor & & & Mari C: & armen & & & & & Salmar & ntina & & & & & & & & arrasquera & & & & \\
\hline Roca & Vena GE & 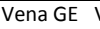 & Vena GE & Vena GE & Vena GE & Vena GE & Vena LG & Vena LG & Vena LG & Vena LG & Vena LG & $\begin{array}{l}\text { Vena LG } \\
\end{array}$ & $\begin{array}{ll}\text { Vena LG } \\
\end{array}$ & Vena LG & Vena LG & Vena LG & 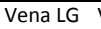 & Vena LG & $\begin{array}{ll}\text { Vena } L G \\
\end{array}$ & Vena LG & Vena LG & Vena LG & Vena LG \\
\hline Muestra & 1696 & 1696 & 1047 & 1047 & 1047 & $1775 \mathrm{~A}$ & 1153 & 1153 & 1153 & 833 & 1704 & 1704 & 1699 & 1699 & 1782 & 1782 & 1782 & 1782 & 1782 & 1782 & 1785B & $1785 B$ & 1785B \\
\hline Análisis & 4.1 & 4.3 & 1.1 & 1.2 & 1.3 & 2.1 & 1.2 & 2.3 & 3.2 & 2.1 & 3.1 & 6.1 & 4.1 & 5.3 & 1.2 & 1.4 & 1.5 & 2.1 & 3.1 & 3.3 & 2.5 & 2.7 & 3.6 \\
\hline (\% peso) & 18,13 & 18,00 & 18,73 & 18,52 & 18,41 & 18,74 & 17,88 & 15,85 & 15,66 & 18,25 & 15,32 & 18,86 & 18,98 & 19,06 & 17,26 & 16,08 & 18,47 & 18,80 & 18,94 & 18,21 & 19,20 & 18,94 & 18,97 \\
\hline $\mathrm{Fe}$ & 0,11 & 1,42 & 0,34 & 0,38 & 0,49 & 0,26 & 0,03 & 2,31 & 2,66 & 0,00 & 1,79 & 0,10 & 0,89 & 0,28 & 0,00 & 0,00 & 0,00 & 0,00 & 0,00 & 0,00 & 0,06 & 0,00 & 0,10 \\
\hline $\mathrm{Cu}$ & & 0,3 & 0,00 & 0,09 & 0,02 & 0,41 & 0,15 & 0,44 & 0,64 & 0,18 & 0,11 & 0,04 & 0,03 & 0,08 & 0,22 & 0,15 & 1,27 & 0,48 & 0,04 & 0,08 & 0,36 & 0,06 & 0,09 \\
\hline As & 0,00 & 0,15 & 0,20 & 0,00 & 0,03 & 0,00 & 0,05 & 0,89 & 0,99 & 0,00 & 3,64 & 0,00 & 0,00 & 0,00 & 0,92 & 0,87 & 0,00 & 0,00 & 0,00 & 0,00 & 0,00 & 0,00 & 0,00 \\
\hline co & 0,00 & 0,00 & 0,05 & 0,04 & 0,02 & 0,00 & 0,00 & 0,00 & 0,00 & - & 0,00 & 0,03 & 0,00 & 0,00 & 0,07 & 0,00 & 0,00 & 0,08 & & & & - & \\
\hline & 0,00 & 0,00 & 0,05 & 0,04 & 0,02 & 0,00 & 0,00 & 0,00 & 0,00 & & 0,00 & 0,03 & 0,00 & 0,00 & 0,02 & 0,00 & 0,06 & 0,00 & 0,04 & 0,00 & 0,02 & 0,01 & 0,00 \\
\hline $\mathrm{Pb}$ & 0,04 & 0,00 & 0,09 & 0,01 & 0,00 & 0,02 & 0,15 & 0,08 & 0,00 & 0,14 & 0,01 & 0,00 & 0,01 & 0,00 & 0,02 & 0,00 & 0,02 & 0,00 & 0,00 & 0,01 & 0,03 & 0,03 & 0,04 \\
\hline i & 0,00 & 0,00 & 0,14 & 0,09 & 0,12 & 0,01 & 0,04 & 0,00 & 0,00 & & 0,01 & 0,00 & 0,00 & 0,00 & 0,01 & 0,02 & 0,05 & 0,00 & & & & & \\
\hline $\mathrm{Se}$ & & & & & & & 0,03 & 0,08 & 0,08 & & & & & & & 0,03 & & & 0,00 & 0,00 & 0,10 & 0,00 & 0,00 \\
\hline & 0,08 & 0,06 & 0,08 & 0,0 & 0,00 & 0,09 & 0,05 & 0,15 & 0,22 & 0,01 & 0,00 & 0,09 & 0,08 & 0,08 & 0,06 & 0,12 & 0,14 & 0,06 & 0,09 & 0,06 & 0,04 & 0,06 & 0,10 \\
\hline $\mathrm{Cd}$ & 80,63 & 79,10 & 81,01 & 79,92 & 79,48 & 80,32 & 81,89 & 75,82 & 76,05 & 81,16 & 79,03 & 81,51 & 79,79 & 81,16 & 81,24 & 82,77 & 70,28 & 80,47 & 81,13 & 80,93 & 79,70 & 81,25 & 80,24 \\
\hline $\mathrm{Hg}$ & & & 0,05 & 0,11 & 0,00 & 0,00 & & & & & 0,00 & 0,00 & 0,01 & 0,11 & 0,04 & 0,00 & 0,05 & 0,00 & 0,05 & 0,00 & 0,08 & 0,00 & 0,00 \\
\hline & 0,00 & 0,00 & 0,04 & 0,16 & 0,10 & 0,00 & 0,08 & 0,49 & 0,07 & 0,00 & 0,00 & & 0,00 & & 0,00 & & 0,00 & & & & 0,00 & 0,00 & 0,00 \\
\hline $\mathrm{Hg}$ & & & 0,18 & 0,00 & 0,31 & 0,00 & 0,00 & 0,00 & 14 & 0,00 & 0,00 & & 0,00 & & & & & & & & & 0,05 & 0,04 \\
\hline $\mathrm{Mn}$ & 0,02 & 0,02 & & & & 0,00 & & & & & 0,02 & 0,03 & 0,00 & 0,02 & 0,01 & 0,02 & 0,03 & 0,05 & 0,00 & 0,03 & 0,00 & 0,04 & 0,02 \\
\hline Total & 99,35 & 99,18 & 101,04 & 99,35 & 99,00 & 99,85 & 100,35 & 96,10 & 96,50 & 99,74 & 99,93 & 100,73 & 99,79 & 100,82 & 99,88 & 100,10 & 90,47 & 99,94 & 100,45 & 99,36 & 99,60 & 100,45 & 99,60 \\
\hline$s$ & 11,80 & 11,45 & 11,82 & & 11,85 & 11,89 & 11,59 & 10,57 & 10,44 & 11,82 & 10,17 & 11,96 & 11,93 & 12,00 & 11,37 & 10,96 & 12,30 & 11,90 & 11,99 & 11,82 & 12,08 & 12,02 & 12,04 \\
\hline $\mathrm{Fe}$ & & & & & & & & & & & & & & 0,10 & & 0,00 & & & & 0,00 & 0,02 & 0,00 & 0,04 \\
\hline & & & & & & & & & & & & & & & & & & & & &, 1 & 0,02 & 0,03 \\
\hline & & 0,04 & 0,05 & & 0,01 & & 0, & 0,25 & & & & $0, \mathrm{C}$ & & 0,00 & 0,26 & 0,25 & 0,00 & & 0,0 & 0,00 & 0,00 & 0,00 & 0,00 \\
\hline & & 0,00 & & & & & & & & & & & & & & & & & & 0,00 & 0,01 & 0,00 & 0,00 \\
\hline & & & & & & & & & & & & & & & & & & & & 0,00 & 0,01 & 0,01 & 0,01 \\
\hline & & & & & & & 0, & & & & & & & & & & 0,0 & & 0,0 & 0,00 & 0,00 & 0,00 & 0,00 \\
\hline & & & & & & & & & & & & & & & & & & & & & & & \\
\hline & & & & & & & & & & & & & & & & & & & & & & 00 & 00 \\
\hline & & & & & & & & & & & & & & & & & & & & & & 0,02 & 03 \\
\hline & & & & & 7,85 & & 8,14 & 7,7 & & & & & & & 8,2 & 8,65 & 7,1 & 7,82 & 7,8 & 8,06 & 7,69 & 7,91 & 7,81 \\
\hline & & 0,00 & 0,00 & & 0,00 & & 0,00 & 0,00 & 0,00 & $0, c$ & & & 0,0 & 0, & 0,0 & 0,00 & 0,00 & 0,00 & 0,00 & 0,00 & 0,00 & 0,00 & 0,00 \\
\hline & & & 0,00 & & & & & & & & & & & & & & & & & & & 00 & \\
\hline & & & & & & & & & & & & & & & & & & & & & & & \\
\hline $\mathrm{Mn}$ & & & & & & & & & & & & & & & & & 0,00 & & 0,00 & 0,00 & 0,00 & 0,00 & 0,00 \\
\hline$n_{\text {aik }}$ & 0,21 & 2,78 & 0,00 & 0,37 & 0,06 & 1,65 & 1,33 & 5,41 & 4,93 & 0,71 & 0,45 & 0,18 & 0,12 & 0,32 & 0,90 & 0,66 & 5,34 & 1,93 & 0,17 & 0,31 & 1,44 & 0,24 & 0,35 \\
\hline & 8 & & 0 & & . & & 0 & & & 2 & 402 & 364 & 42 & & 1838 & 1351 & & & & & & & \\
\hline & 175 & & 0 & & 0 & & & & & 0 & & & & 08 & & 188 & & & & 0 & & & 44 \\
\hline Te pp & 0 & 156 & 0 & & 3040 & & 2570 & 0 & 760 & 0 & 0 & 774 & 0 & 0 & 278 & 0 & 977 & 233 & 86 & 918 & 364 & 0 & \\
\hline sb ppm & 0 & 0 & 1060 & 90 & 430 & 763 & 770 & 0 & 0 & 0 & 327 & 0 & 688 & 512 & 1150 & 800 & 0 & 5313 & 3625 & 3291 & 2359 & 621 & 1833 \\
\hline
\end{tabular}


Bismutinita (continuación)

\begin{tabular}{|c|c|c|c|c|c|c|c|c|c|c|c|c|c|c|c|c|c|c|c|c|c|c|c|}
\hline \multirow{3}{*}{$\begin{array}{l}\text { Mina/Zona } \\
\text { Roca } \\
\text { Muestra }\end{array}$} & \multicolumn{2}{|c|}{ Carrasquera } & \multicolumn{2}{|c|}{$\begin{array}{l}\text { Profunda } \\
\end{array}$} & \multicolumn{19}{|c|}{ Teso de la Matanza } \\
\hline & $\begin{array}{l}\text { Vena LG } \\
\end{array}$ & Vena LG & Vena LG & Vena LG & Vena LG & Vena LG & Vena LG & Vena LG & Vena LG & Vena LG & Vena LG & Vena LG & Vena LG & Vena LG & Vena LG & Vena LG & Vena LG & Vena LG & Vena LG & Vena LG & Vena LG & Vena LG & Vena LG \\
\hline & $1785 \mathrm{~B}$ & $1785 \mathrm{~B}$ & $781 \mathrm{~B}$ & 781B & 1173 & 1173 & 1173 & 1774 & 1774 & 1774 & 1774 & 1774 & 1774 & 1774 & 1774 & 1774 & 1774 & 1174B & $1174 \mathrm{~B}$ & $1174 \mathrm{~B}$ & $1174 B$ & $1174 B$ & $1174 B$ \\
\hline Análisis & 5.1 & 5.2 & 5.4 & 5.5 & 1.1 & 3.5 & 4.1 & 1.5 & 2.10 & 2.11 & 3.16 & 2.4 & 4.4 & 4.5 & 4.6 & 9.35 & 9.38 & 1.1 & 1.4 & 1.7 & 1.9 & 2.2 & 2.3 \\
\hline $\mathrm{S}(\%$ peso) & 18,93 & 18,78 & 18,84 & 18,92 & 21,34 & 21,05 & 5,11 & 18,43 & 18,93 & 17,35 & 19,00 & 19,60 & 19,75 & 20,64 & 20,72 & 18,96 & 19,15 & 21,77 & 20,41 & 21,18 & 22,07 & 21,04 & 21,12 \\
\hline $\mathrm{Fe}$ & 0,00 & 0,38 & 0,78 & 0,87 & 0,00 & 0,00 & 0,00 & 0,08 & 0,01 & 0,04 & 0,01 & 0,14 & 0,00 & 0,00 & 0,00 & 0,17 & 0,07 & 0,01 & 0,01 & 0,06 & 0,00 & 0,00 & 0,00 \\
\hline $\mathrm{Cu}$ & 0,13 & 0,09 & 0,06 & 0,23 & 0,31 & 0,00 & 0,15 & 0,03 & 0,14 & 0,18 & 0,09 & 1,65 & 0,34 & 0,40 & 0,40 & 0,54 & 0,28 & 0,32 & 0,54 & 0,29 & 0,22 & 0,58 & 0,23 \\
\hline As & 0,00 & 0,00 & 0,00 & 0,00 & 0,00 & 0,00 & 0,00 & 0,01 & 0,00 & 0,12 & 0,02 & 0,00 & 0,00 & 0,00 & 0,00 & 0,00 & 0,00 & 0,00 & 0,00 & 0,00 & 0,00 & 0,00 & 0,00 \\
\hline Co & & & 0,00 & 0,01 & & & & & & & & & & & & & & & & 0,00 & 0,00 & 0,00 & 0,02 \\
\hline $\mathrm{Zn}$ & 0,01 & 0,00 & 0,00 & 0,00 & & & & 0,07 & 0,00 & 0,00 & 0,08 & & & & 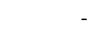 & 0,00 & 0,01 & & & & & & \\
\hline $\mathrm{Pb}$ & 0,00 & 0,03 & 0,09 & 0,03 & 0,10 & 0,00 & 0,04 & 0,02 & 0,09 & 0,00 & 0,00 & 0,00 & 0,12 & 0,00 & 0,42 & 0,05 & 0,04 & 0,00 & 0,00 & 0,12 & 0,19 & 0,00 & 0,10 \\
\hline $\mathrm{N}$ & & & 0,00 & 0,00 & & & & & & & & & & & & & & & & 0,00 & 0,03 & 0,00 & 0,00 \\
\hline Se & 0,00 & 0,00 & 0,00 & 0,02 & & & & 0,00 & 0,11 & 0,00 & 0,00 & & & & & 0,04 & 0,16 & & & & & & \\
\hline & 0,06 & 0 , & 0,07 & 0,14 & 0,08 & 0,04 & 0,01 & 0,12 & 0,00 & 0,00 & 0,00 & 0,07 & 0,12 & 0,08 & 0,00 & 0,00 & 0,10 & 0,04 & 0,04 & 0,06 & 0,11 & 0,00 & 0,02 \\
\hline $\mathrm{Cd}$ & 80,70 & 80,01 & 79,66 & 79,92 & 78,98 & 77,77 & 85,55 & 81,06 & 82,38 & 80,48 & 81,16 & 74,11 & 81,64 & 77,95 & 79,61 & 82,91 & 82,01 & 77,29 & 76,30 & 78,26 & 77,17 & 78,72 & 79,07 \\
\hline & & & & 0,06 & & & & 0,00 & 0,00 & 0,00 & 0,00 & & & & & & & & & & & & \\
\hline & & & & & 0,00 & 0,00 & 0,00 & 21 & & 0 & 0,05 & 0,00 & 0,03 & 0,00 & 0,00 & 0,00 & 0,00 & 0,00 & 0,00 & 0,00 & 0,00 & 0,00 & 0,00 \\
\hline & & & & 0 , & 0,00 & 0,09 & 0,03 & 0,00 & 0,00 & 0,00 & 0,00 & 0,00 & 0,00 & 0,05 & 0,09 & - & 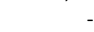 & 0,00 & 0,00 & 0,22 & 0,15 & 0,02 & 0,00 \\
\hline $\mathrm{Mn}$ & 0 & 0,04 & 0,01 & 0,02 & & - & & 0,00 & 0,00 & 0,00 & 0,00 & & & - & & - & & & & & & - & \\
\hline Total & 99,82 & 99,47 & 99,55 & 100,21 & 100,81 & 98,95 & 90,88 & 100,02 & 101,71 & 98,23 & 100,42 & 95,58 & 102,00 & 99,12 & 101,23 & 102,66 & 101,83 & 99,44 & 97,30 & 100,18 & 99,93 & 100,36 & 100,56 \\
\hline & & 11,93 & 11,91 & $\frac{1}{11,86}$ & 12,63 & 12,75 & 5,12 & 11,67 & 11,91 & 11,55 & 11,99 & 12,01 & 12,09 & 12,54 & 12,37 & 11,77 & 11,91 & 12,86 & 12,54 & 12,60 & 12,85 & 12,51 & 12,59 \\
\hline & & & & & & 0,00 & & 0,03 & & 0,01 & 0,00 & 0,05 & 0,00 & & 0,00 & 0,06 & 0,02 & 0,00 & & & 0,00 & 0,00 & 0,00 \\
\hline & & & & & 0,09 & 00 & 0,08 & 01 & & 06 & 0,03 & 0,51 & 0,1 & 12 & 0,12 & 0,17 & 0,09 & & 17 & & 0,06 & 0,17 & 0,07 \\
\hline As & 0,0 & & & & 0,00 & 00 & $0, \mathrm{C}$ & 00 & 0,00 & 0,03 & 0,01 & 0,00 & 0,00 & 00 & 0,00 & 0,00 & 0,00 & 0,00 & 0,00 & 0,00 & 0,00 & 0,00 & 0,00 \\
\hline & & & & & & & & & & 00 & & 00 & & & 0, & 00 & 0,00 & 0,00 & 00 & & 0,00 & 0,00 & 0,00 \\
\hline & & & & & & 0 & 0, & 01 & & 00 & 0, & 0,00 & 04 & 0,00 & 12 & 0,01 & 0,01 & 0,00 & 0,00 & 0,03 & 0,05 & 0,00 & 0,03 \\
\hline & & & & & & & & & & & & & & & & & & & & & 0,05 & 0,06 & 0,05 \\
\hline & & & & & & & & & & & & & & & & & & & & &, 00 & 0,00 & 0,00 \\
\hline$S$ & & & & & & & & & & & & 0,00 & & & 0,00 & 0,0 & 0,03 & 0,0 & 0,00 & & 0,00 & 0,00 & 0,00 \\
\hline & & & & & & & & & & & & & & & & & & 0,0 & & & 0,03 & 0,00 & 0,00 \\
\hline & & & & & & 7,23 & 13,14 & 87 & & 22 & 7,86 & 6,97 & 7,6 & 7,2 & 7,29 & 7,90 & 7,82 & 7,0 & 7,20 & 7,15 & 6,90 & 7,18 & 7,23 \\
\hline & 0,0 & & & & 0,00 & 0,00 & $0, C$ & 0,00 & 0, & 0,00 & 0,0 & 0,00 & 0,00 & 0,00 & 0,00 & 0,0 & 0,00 & 0,0 & 0,00 & 0,00 & 0,00 & 0,00 & 0,00 \\
\hline & & & & & & 0, & & & & & & & & & & & & & & &, 00 & & 0,00 \\
\hline & & & & & & & & & & & & & & & & & & & & & & & 0,00 \\
\hline $\mathrm{Mn}$ & & & & & & & & & & 0,00 & & 0,00 & & 0,00 & & 0,00 & 0,00 & 0,00 & 0,00 & 0,00 & 0,00 & 0,00 & 0,00 \\
\hline & 0,50 & 0,37 & 0,26 & 0,89 & 1,47 & 0,07 & 11,58 & 0,46 & 0,56 & 1,51 & 0,66 & 10,99 & 1,51 & 1,79 & 1,82 & 2,73 & 2,01 & 1,44 & 2,70 & 1,55 & 1,45 & 2,93 & 1,55 \\
\hline & & & 178 & 292 & 0 & 90 & 26400 & 17540 & 620 & 0 & 510 & 1320 & 1040 & 0 & 1960 & 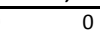 & 410 & & & & & 2870 & 1020 \\
\hline & & 186 & 64 & & 0 & 0 & 0 & & 0 & & 0 & & 0 & & 0 & & & & & & & 0 & 0 \\
\hline Te ppm & 646 & 0 & 0 & 50 & 0 & 0 & 0 & 110 & 0 & 350 & 0 & 0 & 0 & 0 & 0 & 0 & 0 & & 0 & 0 & 0 & 0 & \\
\hline Sb ppm & 2119 & 2361 & 368 & 899 & 2200 & 0 & 0 & 0 & 1390 & 1840 & 2520 & 3060 & 1990 & 1640 & 2160 & 1660 & 580 & 0 & 1970 & 2440 & 2610 & 1720 & 580 \\
\hline
\end{tabular}




\begin{tabular}{|c|c|c|c|c|c|c|c|c|c|c|}
\hline \multirow{2}{*}{$\begin{array}{l}\text { Mina/Zona } \\
\text { Roca }\end{array}$} & \multicolumn{10}{|c|}{ Teso de la Matanza } \\
\hline & Vena LG & Vena LG & Vena LG & Vena LG & Vena LG & Vena LG & $\begin{array}{l}\text { Vena LG } \\
\end{array}$ & Vena LG & Vena LG & Vena LG \\
\hline Muestra & $1174 \mathrm{~B}$ & $1174 B$ & $1174 B$ & $1174 B$ & $1174 \mathrm{~B}$ & $1174 \mathrm{~B}$ & $1174 \mathrm{~B}$ & 1179 & 1179 & 1179 \\
\hline Análisis & 3.2 & 3.5 & 4.2 & 5.1 & 5.4 & 8.3 & 8.9 & 1.2 & 1.3 & 3.2 \\
\hline $\mathrm{S}(\%$ peso) & 21,78 & 21,69 & 20,63 & 20,45 & 20,67 & 20,34 & 20,93 & 18,66 & 19,11 & 17,52 \\
\hline $\mathrm{Fe}$ & 0,00 & 0,00 & 0,01 & 0,01 & 0,05 & 0,00 & 0,05 & 0,42 & 0,38 & 1,13 \\
\hline $\mathrm{Cu}$ & 0,24 & 0,06 & 0,35 & 0,08 & 0,26 & 0,00 & 0,89 & 0,69 & 0,90 & 0,10 \\
\hline As & 0,00 & 0,00 & 0,00 & 0,00 & 0,00 & 0,00 & 0,00 & 0,00 & 0,00 & 1,53 \\
\hline Co & 0,00 & 0,06 & 0,00 & 0,04 & 0,00 & 0,02 & 0,01 & 0,00 & 0,01 & 0,00 \\
\hline $\mathrm{Zn}$ & & & & & & & & & & 0,00 \\
\hline $\mathrm{Pb}$ & 0,28 & 0,13 & 0,27 & 0,00 & 0,06 & 0,06 & 0,00 & 0,23 & 0,00 & 0,67 \\
\hline $\mathrm{Ni}$ & 0,00 & 0,00 & 0,00 & 0,01 & 0,01 & 0,00 & 0,01 & 0,03 & 0,00 & 0,05 \\
\hline Se & & & & & & & & & & 0,06 \\
\hline $\mathrm{Bi}$ & 0,00 & 0,05 & 0,05 & 0,00 & 0,13 & 0,02 & 0,04 & 0,09 & 0,10 & 0,11 \\
\hline $\mathrm{cd}$ & 79,27 & 79,02 & 78,26 & 77,79 & 78,02 & 80,02 & 75,39 & 78,25 & 77,08 & 73,48 \\
\hline $\mathrm{Hg}$ & & & & & & & & & & \\
\hline $\mathrm{Cd}$ & 0,02 & 0,00 & 0,00 & 0,00 & 0,00 & 0,00 & 0,00 & 0,00 & 0,00 & 0,09 \\
\hline $\mathrm{Hg}$ & 0,15 & 0,28 & 0,00 & 0,16 & 0,00 & 0,11 & 0,00 & 0,05 & 0,00 & \\
\hline $\mathrm{Mn}$ & & & & & & & & & & \\
\hline Total & 101,75 & 101,28 & 99,57 & 98,53 & 99,20 & 100,57 & 97,32 & 98,41 & 97,58 & 94,74 \\
\hline $\mathrm{s}$ & 12,68 & 12,77 & 12,46 & 12,58 & 12,51 & 12,45 & 12,57 & 11,76 & 11,97 & 11,36 \\
\hline $\mathrm{Fe}$ & 0,00 & 0,00 & 0,00 & 0,00 & 0,02 & 0,00 & 0,02 & 0,15 & 0,14 & 0,42 \\
\hline $\mathrm{Cu}$ & 0,07 & 0,02 & 0,11 & 0,02 & 0,08 & 0,00 & 0,27 & 0,22 & 0,28 & 0,03 \\
\hline As & 0,00 & 0,00 & 0,00 & 0,00 & 0,00 & 0,00 & 0,00 & 0,00 & 0,00 & 0,42 \\
\hline Co & 0,00 & 0,00 & 0,00 & 0,00 & & & 0,00 & 0,00 & 0,00 & 0,00 \\
\hline $\mathrm{Zn}$ & 0,08 & 0,04 & 0,08 & 0,00 & 0,02 & 0,02 & 0,00 & 0,07 & 0,00 & 0,21 \\
\hline $\mathrm{Pb}$ & 0,02 & 0,00 & 0,04 & 0,03 & 0,06 & 0,00 & 0,15 & 0,14 & 0,15 & 0,05 \\
\hline $\mathrm{Ni}$ & 0,00 & 0,00 & 0,00 & 0,00 & 0,00 & 0,00 & 0,00 & 0,00 & 0,00 & 0,00 \\
\hline Sn & 0,00 & 0,00 & 0,00 & 0,00 & 0,00 & 0,00 & 0,00 & 0,00 & 0,00 & 0,01 \\
\hline Se & 0,00 & 0,01 & 0,01 & 0,00 & 0,03 & 00 & 0,01 & 0,02 & 0,03 & 0,03 \\
\hline $\mathrm{Bi}$ & 7,08 & 7,14 & 7,25 & 7,34 & 7,24 & 7,51 & 6,95 & 7,57 & 7,41 & 7,31 \\
\hline w & 0,00 & 0,00 & 0,00 & 0,00 & 0,00 & 0,00 & 0,00 & 0,00 & 0,00 & 0,00 \\
\hline $\mathrm{Cd}$ & 0,00 & 0,00 & 0,00 & 0,00 & 0,00 & 0,00 & 0,00 & 0,00 & 0,00 & 0,02 \\
\hline $\mathrm{Hg}$ & 0,01 & 0,03 & 0,00 & 0,02 & 0,00 & 0,01 & 0,00 & 0,00 & 0,00 & 0,00 \\
\hline $\mathrm{Mn}$ & 0,00 & 0,00 & 0,00 & 0,00 & 0,00 & 0,00 & 0,00 & 0,00 & 0,00 & 0,00 \\
\hline$n_{\text {aik }}$ & 1,19 & 0,28 & 1,88 & 0,64 & 1,70 & 0,06 & 5,24 & 4,47 & 5,42 & 1,07 \\
\hline Ag ppm & 1800 & 0 & 1000 & 0 & 1950 & 0 & 0 & 2270 & 760 & 6440 \\
\hline Au ppm & 0 & 0 & 0 & 0 & 0 & 0 & 0 & 0 & 0 & 0 \\
\hline Te ppm & 0 & 0 & 0 & 0 & 0 & 0 & 0 & 0 & 0 & 140 \\
\hline Sb ppm & 440 & 0 & 1660 & 0 & 600 & 0 & 2480 & 970 & 900 & 0 \\
\hline
\end{tabular}

\section{Argentita}

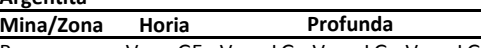

Roca Vena GE Vena LG Vena LG VenaLG $\begin{array}{llll}696 & 783 & 783 & 783\end{array}$ \begin{tabular}{lrrrr} 
Análisis & 3.5 & 4.1 & 4.2 & 4.3 \\
\hline $\mathrm{S}(\%$ peso) & 13,33 & 14,02 & 15,99 & 7,71
\end{tabular} $\begin{array}{lllll}\mathrm{Fe} & 0,05 & 0,16 & 0,37 & 0,36\end{array}$ $\begin{array}{lllll}\mathrm{Cu} & 0,03 & 0,00 & 0,05 & 0,21 \\ \mathrm{As} & 0,01 & 0,11 & 0,18 & 0,21\end{array}$ $\begin{array}{lllll}\mathrm{Zn} & 0,00 & 0,11 & 0,10 & 0,00 \\ \mathrm{~Pb} & 0,00 & 0,00 & 0,00 & 0,02\end{array}$

$\begin{array}{lllll}\mathrm{Pb} & 0,00 & 0,00 & 0,00 & 0,02 \\ \mathrm{Sb} & 1,54 & 0,00 & 0,00 & 0,00\end{array}$

$\begin{array}{rrrrr}\mathrm{Sb} & 1,54 & 0,00 & 0,00 & 0,00 \\ \mathrm{Ag} & 80,60 & 86,11 & 87,01 & 92,47\end{array}$

$\begin{array}{rrrrr}\mathrm{Se} & 0,00 & 0,03 & 0,01 & 0,07 \\ \mathrm{Bi} & 0,87 & 0,00 & 0,00 & 0,00\end{array}$

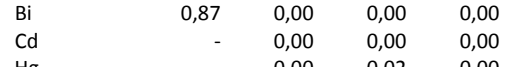

Te $\quad 0,00$
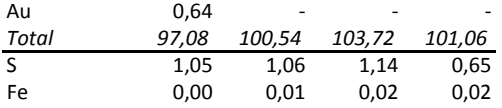

$\begin{array}{lllll}\mathrm{Cu} & 0,00 & 0,00 & 0,00 & 0,01\end{array}$

$\begin{array}{lllll}\text { As } & 0,00 & 0,00 & 0,01 & 0,01 \\ \mathrm{Zn} & 0,00 & 0,00 & 0,00 & 0,00\end{array}$

$\begin{array}{lllll}\mathrm{Pb} & 0,00 & 0,00 & 0,00 & 0,00\end{array}$

$\begin{array}{lllll}\mathrm{Sb} & 0,03 & 0,00 & 0,00 & 0,00 \\ \mathrm{Ag} & 1,89 & 1,93 & 1,84 & 2,31 \\ \mathrm{~S} & 0,00 & 0,00 & 0,00 & 0,00\end{array}$

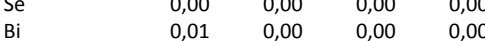

$\begin{array}{lllll}\mathrm{Cd} & 0,00 & 0,00 & 0,00 & 0,00 \\ \mathrm{H} & 0,00 & 0,00 & 0,00 & 0,00\end{array}$

\begin{tabular}{lllll}
$\mathrm{Hg}$ & 0,00 & 0,00 & 0,00 & 0,00 \\
$\mathrm{Te}$ & 0,00 & 0,00 & 0,00 & 0,00 \\
\hline
\end{tabular}

\begin{tabular}{lllll}
$\mathrm{Au}$ & 0,01 & 0,00 & 0,00 & 0,00 \\
\hline
\end{tabular} 


\begin{tabular}{|c|c|c|c|c|c|c|c|c|c|c|c|c|c|c|c|c|c|c|}
\hline \multicolumn{2}{|l|}{ Mina/Zona } & \multicolumn{3}{|c|}{ Salmantina } & \multicolumn{14}{|c|}{ Teso de la Matanza } \\
\hline Roca & $\begin{array}{ll}\text { Vena LG } \\
\end{array}$ & Vena LG & Vena LG & Vena LG & Vena LG & Vena LG & Vena LG & Vena LG & $\begin{array}{l}\text { Vena LG } \\
\end{array}$ & Vena LG & Vena LG & $\begin{array}{ll}\text { Vena LG } \\
\end{array}$ & $\begin{array}{l}\text { Vena LG } \\
\end{array}$ & Vena LG & Vena LG & Vena LG & Vena LG & Vena LG \\
\hline Muestra & 845 & 845 & 845 & 845 & 1773 & 1773 & 1773 & 1773 & 1773 & 1774 & 1774 & 1774 & $1785 B$ & $1785 B$ & $1785 B$ & $1785 B$ & $1785 B$ & $1785 \mathrm{~B}$ \\
\hline Análisis & 1.1 & 1.2 & 1.3 & 1.4 & 1.7 & 1.8 & 1.9 & 1.10 & $1.10 \mathrm{~b}$ & 6.47 & 6.48 & 6.49 & 1.1 & 1.3 & 1.5 & 2.1 & 4.6 & 4.7 \\
\hline S(\% peso) & 28,24 & 28,52 & 28,30 & 28,69 & 29,52 & 29,22 & 27,73 & 29,12 & 28,99 & 29,52 & 29,83 & 29,82 & 29,63 & 30,00 & 27,64 & 30,07 & 29,22 & 29,34 \\
\hline $\mathrm{Fe}$ & 10,53 & 10,95 & 10,40 & 11,05 & 9,81 & 10,36 & 14,26 & 9,49 & 9,75 & 12,67 & 12,09 & 12,70 & 11,72 & 10,57 & 11,66 & 11,68 & 11,47 & 11,42 \\
\hline $\mathrm{Cu}$ & 28,10 & 27,94 & 28,37 & 28,17 & 27,18 & 26,36 & 23,78 & 27,65 & 28,69 & 29,01 & 29,32 & 29,39 & 28,66 & 25,22 & 26,52 & 27,39 & 28,39 & 27,97 \\
\hline As & & & & & 0,00 & 0,00 & 1,19 & 0,00 & 0,00 & 0,15 & 0,04 & 0,00 & 0,00 & 0,00 & 3,53 & 0,00 & 0,00 & 0,00 \\
\hline Co & & & & & 0,04 & 0,00 & 0,00 & 0,12 & 0,03 & 0,01 & 0,09 & 0,00 & 0,00 & 0,00 & 0,00 & 0,00 & 0,00 & 0,00 \\
\hline $\mathrm{Zn}$ & 2,51 & 2,37 & 2,83 & 3,77 & 4,44 & 4,25 & 3,73 & 4,24 & 4,14 & 1,08 & 1,00 & 1,05 & 1,56 & 9,46 & 2,17 & 3,09 & 1,96 & 2,76 \\
\hline Sb & & & & & 0,07 & 0,05 & 0,03 & 0,00 & 0,01 & 0,00 & 0,00 & 0,00 & 0,00 & 0,00 & 0,00 & 0,00 & 0,00 & 0,00 \\
\hline $\mathrm{Ni}$ & - & & & & 0,00 & 0,01 & 0,00 & 0,00 & 0,00 & 0,05 & 0,04 & 0,00 & 0,01 & 0,01 & 0,00 & 0,00 & 0,00 & 0,00 \\
\hline $\mathrm{Ag}$ & - & & - & - & 0,00 & 0,00 & 0,00 & 0,00 & 0,00 & 0,06 & 0,00 & 0,00 & 0,02 & 0,02 & 0,02 & 0,00 & 0,22 & 0,01 \\
\hline $\mathrm{Au}$ & & & & & 0,00 & 0,00 & 0,00 & 0,00 & 0,00 & 0,00 & 0,24 & 0,00 & 0,00 & 0,00 & 0,00 & 0,03 & 0,00 & 0,01 \\
\hline Sn & 26,65 & 27,71 & 26,06 & 26,70 & 27,90 & 27,55 & 23,69 & 27,68 & 28,20 & 28,06 & 28,28 & 28,25 & 27,23 & 24,05 & 27,22 & 27,21 & 27,34 & 28,30 \\
\hline Se & 0,02 & 0,00 & 0,07 & 0,00 & 0,43 & 0,00 & 0,00 & 0,00 & 0,00 & 0,22 & 0,33 & 0,00 & 0,16 & 0,14 & 0,07 & 0,15 & 0,17 & 0,13 \\
\hline $\mathrm{Bi}$ & & & & & 0,00 & 0,00 & 0,11 & 0,00 & 0,00 & 0,00 & 0,00 & 0,00 & 0,00 & 0,00 & 0,00 & 0,00 & 0,00 & 0,00 \\
\hline w & & & & & 0,00 & 0,00 & 0,00 & 0,00 & 0,00 & 0,00 & 0,00 & 0,00 & 0,03 & 0,00 & 0,00 & 0,02 & 0,08 & 0,00 \\
\hline $\mathrm{Cd}$ & 0,12 & 0,05 & 0,12 & 0,09 & 0,50 & 0,36 & 0,34 & 0,35 & 0,36 & 0,17 & 0,11 & 0,13 & 0,20 & 0,29 & 0,16 & 0,15 & 0,15 & 0,17 \\
\hline $\mathrm{Mn}$ & 0,13 & 0,07 & 0,04 & 0,07 & 0,00 & 0,00 & 0,00 & 0,00 & 0,00 & 0,00 & 0,00 & 0,00 & 0,04 & 0,10 & 0,07 & 0,04 & 0,05 & 0,06 \\
\hline in & 0,00 & 0,19 & 0,10 & 0,08 & & & & & & & & & & & & & & \\
\hline Total & 96,287 & 97,804 & 96,295 & 98,612 & 99,89 & 98,17 & 94,85 & 98,65 & 100,16 & 100,98 & 101,37 & 101,35 & 99,26 & 99,86 & 99,07 & 99,84 & 99,03 & 100,18 \\
\hline $\mathrm{s}$ & 3,96 & 3,96 & 3,96 & 3,93 & 4,01 & 4,02 & 3,91 & 4,00 & 3,94 & 3,95 & 3,98 & 3,97 & 4,01 & 3,99 & 3,83 & 4,04 & 3,98 & 3,97 \\
\hline $\mathrm{Fe}$ & 0,85 & 0,87 & 0,84 & 0,87 & 0,76 & $0, \varepsilon$ & & & 0,76 & 0,97 & 0,93 & 0, & 0,91 & 0,81 & 0,93 & 0,90 & 0,90 & 0,89 \\
\hline $\mathrm{Cu}$ & 1,99 & 1,96 & 2,00 & 1,95 & 1,86 & 1,83 & 1,69 & 1,92 & 1,97 & 1,96 & 1,97 & 1,97 & 1,96 & 1,69 & 1,85 & 1,86 & 1,95 & 1,91 \\
\hline As & 0,00 & 0,00 & 0,00 & 0,00 & 00 & 0,0 & 0,07 & 0,00 & 0,00 & 0,01 & 0,00 & 0,00 & 0,00 & 0,00 & 0,21 & 0,00 & 0,00 & 0,00 \\
\hline Co & 0,00 & & 0,00 & 0,0 & & & & & & 10 & & & 0,00 & 0,00 & 0,00 & 0,00 & 0,00 & 0,00 \\
\hline $\mathrm{Zn}$ & 0,17 & 0,16 & 0,19 & 0,25 & 30 & 0,2 & 26 & & 0,28 & 0,07 & 0,07 & 77 & 0,10 & 0,62 & 0,15 & 0,20 & 0,13 & 0,18 \\
\hline sb & 0,00 & 0,00 & 0,00 & 0,00 & 0,00 & $0, \mathrm{c}$ & 0,00 & & 0,00 & 0,0 & 0,00 & 0, & 0,00 & 0,00 & 0,0 & 0,00 & 0,00 & 0,00 \\
\hline $\mathrm{Ni}$ & 0,00 & 0,00 & 0,00 & 0,00 & & & & & 0,00 & 0,0 & & & & 0,00 & & 0,00 & 0,00 & 0,00 \\
\hline $\mathrm{Ag}$ & & & & & & & & & & & & & 0,00 & 0,00 & 0,00 & 0,00 & 0,01 & 0,00 \\
\hline $\mathrm{Au}$ & 0,00 & 0,00 & 0,00 & 0,00 & 0,00 & 0,00 & 0,00 & 0,00 & 0,00 & 0,00 & 0,01 & 0,00 & 0,00 & 0,00 & 0,00 & 0,00 & 0,00 & 0,00 \\
\hline Sn & 1,01 & 1,04 & 0,99 & 0,99 & 1,02 & 1,02 & 0,90 & 1,03 & 1,04 & 1,01 & 1,02 & 1,02 & 1,00 & 0,86 & 1,02 & 0,99 & 1,01 & 1,03 \\
\hline $\mathrm{Se}$ & 0,00 & 0,00 & 0,00 & 0,00 & 0,02 & & & & 0,00 & 0,0 & & & & & & 0,01 & & 0,01 \\
\hline $\mathrm{Bi}$ & 0,00 & 0,0 & & $0, \mathrm{C}$ & & & & & & $0, c$ & & & 00 & bo & 0,00 & 0,00 & 0,00 & 0,00 \\
\hline w & 0,00 & 0,00 & 0,00 & 0,00 & 0,00 & 0,00 & 0,00 & 0,00 & 0,00 & 0,00 & 0,00 & 0,00 & 0,00 & 0,00 & 0,00 & 0,00 & 0,00 & 0,00 \\
\hline $\mathrm{Cd}$ & 0,00 & 0,00 & 0,00 & 0,00 & & 0,01 & & 0,01 & & 0,01 & 0,00 & 0,01 & & 0,01 & & 0,01 & 0,01 & 0,01 \\
\hline $\mathrm{Mn}$ & 0,01 & & 0,00 & & & & & 0,00 & 0,0 & 0,00 & & & & 0,01 & & 0,00 & 0,00 & 0,00 \\
\hline & 0,00 & 0,01 & 0,00 & 0,00 & 0,00 & 0,00 & 0,00 & 0,00 & 0,00 & 0,00 & 0,00 & 0,00 & 0,00 & 0,00 & 0,00 & 0,00 & 0,00 & 0,00 \\
\hline
\end{tabular}


Anexo III. Análisis de microsonda electrónica

\begin{tabular}{|c|c|c|c|c|c|c|c|c|c|c|c|c|c|c|c|c|c|c|}
\hline \multicolumn{4}{|l|}{ Pavonita } & \multirow{2}{*}{\multicolumn{15}{|c|}{$\begin{array}{c}\text { Teso de la Matanza } \\
\end{array}$}} \\
\hline Mina/Zona & & Horia & & & & & & & & & & & & & & & & \\
\hline Roca & Vena GE & Vena GE & Vena GE & Vena LG & Vena LG & Vena LG & Vena LG & Vena LG & Vena LG & Vena LG & & Vena LG & Vena LG & Vena LG & Vena LG & Vena LG & Vena LG & Vena LG \\
\hline Muestra & 1711D & 1696 & 1773A & $1174 \mathrm{~B}$ & $1174 \mathrm{~B}$ & $1174 \mathrm{~B}$ & $1174 \mathrm{~B}$ & $1174 \mathrm{~B}$ & $1174 \mathrm{~B}$ & $1174 \mathrm{~B}$ & $1174 \mathrm{~B}$ & $1174 \mathrm{~B}$ & $1174 \mathrm{~B}$ & 1174 & 1174 & 1174 & 1174 & 1179 \\
\hline Análisis & 1.3 & 2.1 & 3.3 & 1.2 & 2.4 & 5.2 & 5.3 & 6.7 & 6.9 & 7.1 & 8.1 & 8.2 & 8.11 & 1.9 & 1.11 & 2.2 & 3.1 & 1.1 \\
\hline $\mathrm{S}(\%$ peso) & 18,18 & 17,51 & 18,44 & 20,27 & 19,97 & 20,20 & 20,11 & 21,10 & 21,01 & 20,00 & 19,52 & 19,59 & 20,27 & 18,71 & 19,38 & 18,76 & 18,94 & 18,61 \\
\hline $\mathrm{Fe}$ & 0,00 & 0,00 & 0,00 & 0,00 & 0,10 & 0,13 & 0,05 & 0,00 & 0,09 & 0,26 & 0,08 & 0,21 & 0,04 & 0,29 & 0,21 & 0,59 & 0,05 & 0,48 \\
\hline $\mathrm{Cu}$ & 0,14 & 0,28 & 0, & 1,19 & 0,84 & 0,57 & 0,54 & 1,79 & 1,95 & 0,26 & 08 & 0,62 & 1,23 & 0,12 & 0,16 & 1,11 & 0,56 & 0,17 \\
\hline As & 0,00 & 0,00 & 0,00 & 0,00 & 0,00 & 0,00 & 0,00 & 0,00 & 0,00 & 0,00 & 0,00 & 0,00 & 0,00 & 0,00 & 0,00 & 0,00 & 0,00 & 0,00 \\
\hline $\mathrm{Zn}$ & 0,04 & 0,04 & 0,00 & 0,00 & 0,00 & 0,00 & 0,08 & 0,00 & 0,08 & 0,05 & 0,04 & 0,00 & 0,18 & 0,00 & 0,09 & 0,00 & 0,00 & 0,08 \\
\hline $\mathrm{Pb}$ & 1,53 & & & & & 2,44 & & 9,47 & 7,45 & & & & & & & 9,47 & & 5,50 \\
\hline Sb & 0,00 & & & 0,01 & & 0,04 & & 0,11 & 0,15 & 0,00 & & 0,00 & 00 & 0,06 & 0,01 & & 0,02 & 0,05 \\
\hline $\mathrm{Ag}$ & 11,10 & 12,31 & 10,89 & 11,20 & 11,42 & 10,42 & 10,53 & 8,36 & 9,05 & 10,97 & 10,03 & 11,47 & 10,73 & 10,72 & 11,12 & 8,40 & 10,54 & 9,42 \\
\hline Se & 0,18 & 0,07 & 0,10 & 0,07 & 0,03 & 0,06 & 0,03 & 0,04 & 0,09 & 0,00 & 0,06 & 0,04 & 0,11 & 0,06 & 0,13 & 0,11 & 0,09 & 0,09 \\
\hline & 68,33 & 69,15 & 69,21 & 67,01 & 65,54 & 65,65 & 64,59 & 59,52 & 61,53 & 64,77 & 63,31 & 65,52 & 67,07 & 66,60 & 66,32 & 61,81 & 66,86 & 66,05 \\
\hline & 0,32 & 0,00 & 0,58 & 0,01 & & & & 0,00 & & & & & & & & & & 0,66 \\
\hline $\mathrm{Hg}$ & & & & 0,00 & 0,00 & 0,11 & 0,03 & 0,00 & 0,00 & 0,00 & 0,25 & 0,00 & 0,06 & 0,00 & 0,00 & 0,00 & 0,00 & 0,00 \\
\hline Total & 99,81 & 99,86 & 99,71 & 101,95 & 100,54 & 99,80 & 98,59 & 100,39 & 101,43 & 99,36 & 96,27 & 99,99 & 101,86 & 98,92 & 99,68 & 100,65 & 100,00 & 101,11 \\
\hline S(\% at.) & 20 & 20 & 20 & 20 & 20 & 20 & 20 & 20 & 20 & 20 & 20 & 20 & 20 & 20 & 20 & 20 & 20 & 20 \\
\hline $\mathrm{Pb}$ & 0,27 & 0,09 & 0,04 & 0,38 & 0,46 & 0,44 & 0,47 & 1,73 & 1,33 & 0,53 & 0,54 & 0,45 & 0,36 & 0,39 & 0,39 & 1,66 & 0,48 & 0,94 \\
\hline $\mathrm{Ag}$ & 3,72 & 4,08 & 4,24 & 3,75 & & & & 2,94 & & & & & & & & & & 3,11 \\
\hline $\mathrm{Bi}$ & 11,81 & 11,85 & 11,88 & 11,60 & 11,51 & 11,62 & 11,63 & 10,81 & 10,91 & 11,51 & 11,69 & 11,52 & 11,56 & 11,6 & 11,64 & 10,72 & 11,65 & 11,25 \\
\hline $\mathrm{Cu}$ & 0,08 & 0,16 & & 0,68 & & 0,33 & & $\begin{array}{r}1,07 \\
\end{array}$ & 1,14 & 0,15 & & $\begin{array}{r}0,36 \\
\end{array}$ & $\begin{array}{r}0,70 \\
0\end{array}$ & $\begin{array}{r}0,07 \\
\end{array}$ & 0,09 & 0,63 & $\begin{array}{r}0,32 \\
0,32\end{array}$ & 0,09 \\
\hline $\mathrm{Fe}$ & 0,00 & & & & & & & 0,00 & 06 & & & 0,14 & 0,03 & 0,19 & 0,14 & 0,38 & 0,03 & 0,30 \\
\hline $\mathrm{Zn}$ & 0,02 & 0,02 & 0,00 & 0,00 & 0,00 & 0,00 & 0,04 & 0,00 & 0,04 & 0,03 & 0,02 & 0,00 & 0,10 & 0,00 & 0,05 & 0,00 & 0,00 & 0,04 \\
\hline Sb & 0,00 & & & & & & & & & & & & & & & & & 0,02 \\
\hline $\mathrm{Cd}$ & 0,10 & 0, & & 0, & 0, & $0, \mathrm{C}$ & 0, & 0,00 & $0, \mathrm{c}$ & $0, C$ & & 0,00 & & & 0,02 & 0,08 & 0,07 & 0,21 \\
\hline $\mathrm{Hg}$ & 0,00 & 0,00 & 0,00 & 0,00 & 0,00 & 0,02 & 0,01 & 0,00 & 0,00 & 0,00 & 0,05 & 0,00 & 0,01 & 0,00 & 0,00 & 0,00 & 0,00 & 0,00 \\
\hline$N_{p}$ & 4,9 & 5,3 & 4,6 & 5,2 & 5,4 & 4,9 & 5,0 & 5,1 & 5,1 & 5,2 & 4,8 & 5,4 & 5,0 & 4,9 & 5,1 & 4,9 & 4,9 & 4,6 \\
\hline & 470 & 1078 & & & & & & & & & & & & & & & & \\
\hline
\end{tabular}

\begin{tabular}{lrr} 
Mummeita & \multicolumn{2}{c}{} \\
\hline Mina/Zona & \multicolumn{2}{c}{ Teso } \\
\hline Roca & Vena LG & Vena $L G$ \\
Muestra & $1174 \mathrm{~B}$ & $1174 \mathrm{~B}$ \\
Análisis & 6.3 & 6.4 \\
\hline $\mathrm{S}$ (\% peso) & 19,64 & 18,89 \\
$\mathrm{Fe}$ & 0,10 & 0,14 \\
$\mathrm{Cu}$ & 1,61 & 1,57 \\
$\mathrm{As}$ & 0,00 & 0,00 \\
$\mathrm{Zn}$ & 0,19 & 0,12 \\
$\mathrm{~Pb}$ & 12,56 & 12,02 \\
$\mathrm{Sb}$ & 0,23 & 0,19 \\
$\mathrm{Ag}$ & 12,31 & 11,53 \\
$\mathrm{Se}$ & 0,15 & 0,06 \\
$\mathrm{Bi}$ & 55,46 & 55,75 \\
$\mathrm{Cd}$ & 0,00 & 0,00 \\
$\mathrm{Hg}$ & 0,33 & 0,21 \\
Total & 102,58 & 100,48 \\
\hline $\mathrm{S}$ (\% at.) & 28,00 & 26,00 \\
$\mathrm{~Pb}$ & 3,16 & 2,84 \\
$\mathrm{Ag}$ & 5,95 & 5,23 \\
$\mathrm{Bi}$ & 13,84 & 13,05 \\
$\mathrm{Cu}$ & 1,32 & 1,21 \\
$\mathrm{Fe}$ & 0,09 & 0,12 \\
$\mathrm{Zn}$ & 0,15 & 0,09 \\
$\mathrm{Sb}$ & 0,10 & 0,08 \\
$\mathrm{Cd}$ & 0,00 & 0,00 \\
$\mathrm{Hg}$ & 0,09 & 0,05 \\
\hline $\mathrm{Ng}_{\mathrm{P}}$ & $\mathbf{8 , 9}$ & $\mathbf{8 , 0}$ \\
\hline Au ppm & - & - \\
\hline & &
\end{tabular}




\begin{tabular}{|c|c|c|c|c|c|c|c|}
\hline \multirow{2}{*}{$\begin{array}{l}\text { Benjaminita } \\
\text { Mina/Zona }\end{array}$} & Salmant. & \multicolumn{6}{|c|}{ Teso de la Matanza } \\
\hline & Vena LG & Vena LG & Vena LG & Vena LG & Vena LG & Vena LG & Vena LG \\
\hline Muestra & $1690 \mathrm{~B}$ & $1174 B$ & $1174 \mathrm{~B}$ & $1174 B$ & 1174 & 1174 & 1174 \\
\hline Análisis & 6.3 & 6.5 & 6.6 & 9.4 & 1.7 & 1.8 & 2.7 \\
\hline $\mathrm{S}(\%$ peso) & 17,73 & 19,17 & 19,87 & 19,55 & 18,57 & 18,84 & 18,69 \\
\hline $\mathrm{Fe}$ & 0,00 & 0,00 & 0,92 & 0,12 & 0,67 & 0,14 & 0,14 \\
\hline $\mathrm{Cu}$ & 0,01 & 1,76 & 0,20 & 0,45 & 0,23 & 0,64 & 1,71 \\
\hline As & 0,00 & 0,00 & 0,00 & 0,00 & 0,00 & 0,00 & 0,00 \\
\hline $\mathrm{Zn}$ & 0,00 & 0,00 & 0,00 & 0,08 & 0,00 & 0,05 & 0,06 \\
\hline $\mathrm{Pb}$ & 13,35 & 10,54 & 6,42 & 3,40 & 9,56 & 3,54 & 6,27 \\
\hline sb & 0,00 & 0,28 & 0,26 & 0,02 & 0,31 & 0,05 & 0,07 \\
\hline Ag & 10,16 & 11,24 & 12,48 & 13,94 & 11,79 & 12,84 & 11,93 \\
\hline Se & 0,12 & 0,17 & 0,12 & 0,09 & 0,08 & 0,12 & 0,06 \\
\hline $\mathrm{Bi}$ & 58,06 & 58,14 & 60,36 & 64,43 & 59,23 & 62,49 & 59,15 \\
\hline $\mathrm{cd}$ & 0,00 & 0,00 & 0,00 & 0,00 & 0,00 & 0,07 & 0,20 \\
\hline $\mathrm{Hg}$ & & 0,00 & 0,00 & 0,00 & 0,00 & 0,01 & 0,00 \\
\hline Total & 99,43 & 101,30 & 100,63 & 102,08 & 100,44 & 98,79 & 98,28 \\
\hline $\mathrm{S}$ (\% at.) & 24 & 24 & 24 & 24 & 24 & 24 & 24 \\
\hline $\mathrm{Pb}$ & 2,92 & 2,27 & 1,37 & 0,71 & 2,03 & 0,77 & 1,37 \\
\hline $\mathrm{Ag}$ & 4,27 & 4,65 & 5,11 & 5,63 & 4,82 & 5,34 & 5,01 \\
\hline $\mathrm{Bi}$ & 12,60 & 12,40 & 12,75 & 13,43 & 12,50 & 13,42 & 12,81 \\
\hline $\mathrm{Cu}$ & 0,01 & 1,23 & 0,14 & 0,31 & 0,16 & 0,45 & 1,22 \\
\hline $\mathrm{Fe}$ & 0,00 & 0,00 & 0,73 & 0,10 & 0,53 & 0,11 & 0,11 \\
\hline $\mathrm{Zn}$ & 0,00 & 0,00 & 0,00 & 0,06 & 0,00 & 0,03 & 0,04 \\
\hline $\mathrm{Sb}$ & 0,00 & 0,10 & 0,09 & 0,01 & 0,11 & 0,02 & 0,03 \\
\hline $\mathrm{Cd}$ & 0,00 & 0,00 & 0,00 & 0,00 & 0,00 & 0,03 & 0,08 \\
\hline $\mathrm{Hg}$ & 0,00 & 0,00 & 0,00 & 0,00 & 0,00 & 0,00 & 0,00 \\
\hline$\frac{N_{P}}{N_{p}}$ & 6,5 & 7,2 & 7,0 & 7,2 & 7,0 & 6,8 & 7,2 \\
\hline$\overline{\text { Au ppm }}$ & & & & - & & - & 1059 \\
\hline
\end{tabular}

\begin{tabular}{|c|c|c|c|c|c|c|c|}
\hline \multirow{2}{*}{$\begin{array}{l}\text { Mina/Zona } \\
\text { Roca }\end{array}$} & \multirow{2}{*}{$\begin{array}{l}\text { Horia } \\
\text { Vena GE }\end{array}$} & \multirow{2}{*}{$\begin{array}{l}\text { Carrasq. } \\
\text { Vena LG }\end{array}$} & \multicolumn{5}{|c|}{ Teso de la Matanza } \\
\hline & & & Vena LG & Vena LG & Vena LG & Vena LG & Vena LG \\
\hline & & 1785 & $1174 B$ & $1174 \mathrm{~B}$ & $1174 \mathrm{~B}$ & 1174 & 1174 \\
\hline Análisis & 1.2 & 3.5 & 2.5 & 8.6 & 8.8 & 2.1 & 3.3 \\
\hline S(\% peso) & 17,48 & 18,64 & 20,12 & 21,06 & 20,47 & 18,42 & 18,70 \\
\hline $\mathrm{Fe}$ & 0,00 & 0,66 & 0,00 & 0,00 & 0,09 & 0,47 & 0,00 \\
\hline $\mathrm{Cu}$ & 0,07 & 0,65 & 0,86 & 0,90 & 0,67 & 0,94 & 0,39 \\
\hline As & 0,00 & 0,00 & 0,00 & 0,00 & 0,00 & 0,00 & 0,00 \\
\hline $\mathrm{Zn}$ & 0,00 & 0,03 & 0,13 & 0,15 & 0,09 & 0,00 & 0,00 \\
\hline $\mathrm{Pb}$ & 0,25 & 0,00 & 2,50 & 2,06 & 1,98 & 9,57 & 2,31 \\
\hline $\mathrm{sb}$ & 0,00 & 0,02 & 0,00 & 0,03 & 0,05 & 0,10 & 0,00 \\
\hline $\mathrm{Ag}$ & 12,69 & 12,09 & 11,64 & 11,83 & 11,98 & 9,94 & 11,84 \\
\hline Se & 0,22 & 0,10 & 0,02 & 0,11 & 0,08 & 0,07 & 0,05 \\
\hline $\mathrm{Bi}$ & 68,86 & 65,44 & 65,68 & 66,33 & 65,92 & 63,53 & 65,77 \\
\hline $\mathrm{Cd}$ & 0,00 & 2,03 & 0,00 & 0,07 & 0,00 & 0,17 & 0,18 \\
\hline $\mathrm{Hg}$ & & 0,00 & 0,00 & 0,00 & 0,06 & 0,02 & 0,00 \\
\hline Total & 99,57 & 99,66 & 100,94 & 102,54 & 101,38 & 103,24 & 99,24 \\
\hline S (\% at.) & 22 & 22 & 22 & 22 & 22 & 22 & 22 \\
\hline $\mathrm{Pb}$ & 0,05 & 0,00 & 0,49 & 0,40 & 0,38 & 1,79 & 0,45 \\
\hline $\mathrm{Ag}$ & 4,67 & 4,39 & 4,35 & 4,38 & 4,46 & 3,57 & 4,45 \\
\hline $\mathrm{Bi}$ & 13,06 & 12,26 & 12,66 & 12,66 & 12,68 & 11,78 & 12,75 \\
\hline $\mathrm{Cu}$ & 0,04 & 0,40 & 0,54 & 0,56 & 0,42 & 0,57 & 0,25 \\
\hline $\mathrm{Fe}$ & 0,00 & 0,47 & 0,00 & 0,00 & 0,07 & 0,33 & 0,00 \\
\hline $\mathrm{Zn}$ & 0,00 & 0,02 & 0,08 & 0,09 & 0,05 & 0,00 & 0,00 \\
\hline $\mathrm{Sb}$ & 0,00 & 0,01 & 0,00 & 0,01 & 0,02 & 0,03 & 0,00 \\
\hline $\mathrm{Cd}$ & 0,00 & 0,71 & 0,00 & 0,03 & 0,00 & 0,06 & 0,07 \\
\hline $\mathrm{Hg}$ & 0,00 & 0,00 & 0,00 & 0,00 & 0,01 & 0,00 & 0,00 \\
\hline $\mathrm{N}_{\mathbf{p}}$ & 5,5 & 5,9 & 5,5 & 5,6 & 5,6 & 5,5 & 5,6 \\
\hline Au ppm & & & & & & & 0, \\
\hline
\end{tabular}

Anexo III. Análisis de microsonda electrónica

\begin{tabular}{|c|c|c|c|c|}
\hline na/Zona & & Salm & Intina & \\
\hline oca & Vena LG & Vena LG & Vena LG & Vena LG \\
\hline lestra & 833 & 833 & 833 & 845 \\
\hline álisis & 1.1 & 3.1 & 4.1 & 5.12 \\
\hline \% peso) & 17,98 & 17,52 & 16,49 & 17,92 \\
\hline & 0,99 & 0,05 & 0,00 & 0,03 \\
\hline & 0,29 & 0,00 & 0,25 & 0,33 \\
\hline & 0,00 & 0,00 & 0,00 & 0,00 \\
\hline & 0,25 & 0,00 & 0,18 & 0,12 \\
\hline & 18,52 & 19,17 & 18,48 & 20,57 \\
\hline & 0,41 & 0,11 & 0,33 & 0,37 \\
\hline & 10,01 & & 9,64 & 9,43 \\
\hline & 0,06 & 0,06 & 0,06 & 0,09 \\
\hline & 53,15 & 53,66 & 54,32 & 53,28 \\
\hline & 0,00 & 0,00 & 0,00 & 0,00 \\
\hline & 0,00 & 0,00 & 0,00 & 0,09 \\
\hline & 101,66 & 99,94 & 99,74 & 102,22 \\
\hline (\% at.) & 54,58 & 55,47 & 53,41 & 55,19 \\
\hline & 1,72 & 0,09 & 0,00 & 0,05 \\
\hline & 0,44 & 0,00 & 0,42 & 0,51 \\
\hline & 0,00 & & ,00 & 0,00 \\
\hline & 0,37 & 0,00 & 0,28 & 0,18 \\
\hline & 8,70 & 9,39 & 9,26 & 9,80 \\
\hline & 0,33 & 0,09 & 0,28 & 0,30 \\
\hline & 9,03 & & 9,28 & 8,63 \\
\hline & 0,08 & 0,08 & 0,07 & 0,11 \\
\hline & 24,75 & 26,06 & 27,00 & 25,18 \\
\hline & 0,00 & 0, & 0,00 & 0,00 \\
\hline & 0,00 & & ,00 & \\
\hline$\%$ & 0,95 & 0,96 & 0,98 & 0,92 \\
\hline & 1,21 & 1,02 & 1,10 & 1,12 \\
\hline mula & & & & \\
\hline & 6,54 & 6,12 & 6,26 & 6,4 \\
\hline & 1,11 & & 1,05 & \\
\hline & 1,21 & 1,02 & 1,10 & 1,1 \\
\hline & 3,21 & 3,02 & 3,10 & 3,12 \\
\hline & 4,5 & 4,1 & 4,3 & \\
\hline
\end{tabular}


Anexo III. Análisis de microsonda electrónica

\begin{tabular}{|c|c|c|c|c|c|c|c|c|c|c|c|c|c|c|c|c|c|c|c|c|c|c|c|}
\hline \multirow{2}{*}{$\frac{\text { Mina/Zona }}{\text { Roca }}$} & \multicolumn{4}{|c|}{ Salmantina } & \multicolumn{4}{|c|}{ Profunda } & \multicolumn{15}{|c|}{ Teso de la Matanza } \\
\hline & Vena LG & Vena LG & Vena LG & Vena LG & Vena LG & Vena LG & Vena LG & Vena LG & Vena LG & Vena LG & Vena LG & Vena LG & Vena LG & Vena LG & Vena LG & Vena LG & Vena LG & Vena LG & Vena LG & Vena LG & Vena LG & Vena LG & Vena LG \\
\hline Muestra & 845 & 845 & 845 & 845 & 783 & 783 & 783 & 783 & 1174 & 1174 & 1174 & 1174 & 1174 & 1174 & 1174 & 1174 & 1174 & 1174 & 1174 & 1174 & 1174 & 1174 & 1174 \\
\hline Análisis & 5.13 & 5.16 & 5.19 & 5.20 & 3.2 & 3.5 & 3.6 & 3.10 & 1.1 & 1.6 & 1.10 & 1.12 & 2.3 & 2.5 & 2.6 & 2.8 & 2.9 & 2.10 & 3.2 & 3.4 & 4.1 & 4.2 & 4.3 \\
\hline \% peso) & 17,44 & 16,66 & 16,70 & 17,85 & 16,99 & 17,95 & 18,51 & 17,02 & 17,56 & 17,84 & 17,91 & 18,25 & 17,47 & 17,19 & 17,79 & 17,70 & 17,38 & 17,57 & 18,04 & 17,66 & 17,84 & 18,21 & 18,01 \\
\hline $\mathrm{Fe}$ & 0,04 & 0,04 & 0,00 & 0,00 & 0,05 & 0,31 & 0,04 & 0,12 & 0,02 & 0,10 & 0,05 & 0,00 & 0,18 & 0,03 & 0,03 & 0,64 & 0,03 & 0,02 & 0,00 & 0,00 & 0,00 & 0,01 & 0,00 \\
\hline cu & 0,04 & 0,19 & & 0,37 & 0,05 & 0,03 & 0,07 & 0,20 & 0,36 & 0,24 & 0,32 & 0,00 & 0,51 & 0,20 & 0,77 & 0,31 & 0,02 & 0,50 & 0,30 & 0,53 & 0,50 & 0,21 & 0,52 \\
\hline & 0,00 & & & & & & & & & 0, & & 0,00 & 00 & 0,00 & & & & & 0,0 & & & & 0,00 \\
\hline & & & & & 0,19 & & 0,00 & 0,12 & 0,00 & 0,00 & 0,07 & 0,14 & 0,00 & 0,00 & 00 & 0,00 & 0,00 & 0,05 & 0,10 & 0,04 & 0,08 & 0,00 & 0,17 \\
\hline & 22,34 & 22,36 & 21,43 & 20,90 & 19,05 & 18,36 & 18,61 & 19,18 & 19,88 & 20,23 & 17,78 & 17,99 & 20,66 & 29,46 & 21,05 & 18,39 & 19,09 & 20,38 & 18,66 & 17,86 & 18,88 & 18,81 & 18,88 \\
\hline & & & & 0,27 & 0,17 & 0,14 & 0,20 & 0,20 & 0,26 & 0,28 & 0,29 & 0,22 & 0,59 & 0,31 & 0,67 & 0,35 & 0,19 & 0,31 & 0,33 & 0,12 & 0,37 & 0,31 & 0,31 \\
\hline & & & & & 47 & & 10,23 & & 55 & 8,97 & 29 & 8,56 & 8,30 & 6,13 & & 9,80 & 890 & 8,57 & 9,08 & 8,70 & 9,53 & 8,89 & 8,27 \\
\hline & & & & & & & & & & & & & & & & & & & & & & & 0,00 \\
\hline & & & & & 53,79 & & 54,60 & 54,57 & 52,49 & 51,19 & 52,99 & 55,15 & 53,08 & 47,16 & 51,01 & 54,12 & 53,38 & 51,81 & 54,22 & 54,53 & 51,45 & 54,07 & 52,95 \\
\hline $\mathrm{Cd}$ & & & & & & & & 0,00 & 0,00 & 0,00 & 0,00 & 0,00 & 0,00 & 0,00 & 0,00 & & 0,00 & 0,00 & 0,00 & 0,00 & 0,00 & 0,00 & 0,00 \\
\hline $\mathrm{Hg}$ & 0,00 & 00 & 1 & 0,00 & 0,00 & 0,00 & 0,00 & 0,16 & 0,00 & 0,00 & 0,27 & 0,04 & 0,00 & 0,00 & 0,00 & 0,00 & 0,00 & 0,00 & 0,00 & 0,00 & 0,00 & 0,12 & 0,00 \\
\hline Total & 100,53 & 99,03 & 101,93 & 97,96 & 99,82 & 100,96 & 102,31 & 100,25 & 99,31 & 98,86 & 99,02 & 100,46 & 100,88 & 100,64 & 99,89 & 101,31 & 99,04 & 99,29 & 100,73 & 99,53 & 98,72 & 100,77 & 99,11 \\
\hline & & & & & & & & & & 56,19 & & 56,64 & 54,88 & 55,32 & & & & 55, & 55,97 & & 55,91 & 56,32 & 56,38 \\
\hline & & & & & & & & & & & & 0,00 & 0,32 & 0,06 & & & & 0,04 & 0,00 & 0,00 & & & 0,00 \\
\hline u & & & & & & & & & 58 & & & 00 & 80 & 0,32 & & & & 0,80 & 0,47 & 0,85 & 79 & 0,32 & 0,81 \\
\hline & & & & & & & & & & & & 0, & 00 & 0,00 & & & & 0,00 & 00 & 0,00 & 00 & 0,00 & 0,00 \\
\hline & & & & & 30 & & 0 & 0,19 & bo & 0, & & 0 , & 0,00 & 0,00 & & & & 0,08 & 0,14 & 0,06 & 0,13 & 0,00 & 0,26 \\
\hline & & & & & & & & & & & & & 10,04 & 14,67 & & & & & & & & & 9,15 \\
\hline & & & & & & & & & & & & & & 0,27 & & & & & & & & 0,25 & 0,26 \\
\hline & & & & & & & & & & & & & & & & & & & & & & & 7,70 \\
\hline & & & & & & & & & & & & & & & & & & & & & & 0,19 & 0,00 \\
\hline $\mathrm{Bi}$ & 25,03 & 25,14 & 26,80 & 24,79 & 26,43 & 26,24 & 25,44 & 26,81 & 25,52 & 24,74 & 25,47 & 26,26 & 25,58 & 23,29 & 24,45 & 25,64 & 26,19 & 25,14 & 25,81 & 26,37 & 24,74 & 25,66 & 25,43 \\
\hline $\mathrm{Cd}$ & & & & & & & & & & & & 0,00 & & 0,00 & & & & 0,00 & 0,00 & 0,00 & 0,00 & 0,00 & 0,00 \\
\hline $\mathrm{Hg}$ & & & & & & & & & & & & & & & & & & & & & & 06 & 0,00 \\
\hline $\mathrm{mol} \%$ & 0,87 & & & 0, & 6 & & 0,97 & & 93 & 0,91 & 0 & 1,04 & 0,93 & 0,67 & 0,89 & 0,97 & 0,97 & 0,91 & 0,98 & 1,00 & 0,93 & 0,98 & 0,97 \\
\hline & 0,96 & 1,08 & 0,92 & 0,91 & 1,04 & 0,90 & 1,15 & 0,93 & 1,03 & 1,08 & 1,11 & 0,85 & 0,98 & 0,71 & 1,15 & 1,15 & 0,95 & 1,07 & 1,03 & 1,03 & 1,26 & 0,97 & 0,99 \\
\hline & & & & & & & & & & & & & & & & & & & $6, \mathrm{C}$ & & & 5,98 & 6,05 \\
\hline & & & & & & & & & & & & & & & & & & & & & & 1,03 & 1,06 \\
\hline $\mathrm{Ag}$ & 0,9 & 1,08 & & 0,91 & 1,04 & & 1,15 & 0,9 & 1,03 & 1, & 1,11 & 0,85 & 0,98 & 0,71 & 1,1 & 1,15 & 0,95 & 1,07 & 1,03 & 1,03 & 1,26 & 0,97 & 0,99 \\
\hline $\mathrm{AB}$ & 2,96 & $\begin{array}{l}1,00 \\
3,08\end{array}$ & 2,92 & 2,91 & $\begin{array}{l}1,04 \\
3,04\end{array}$ & $\begin{array}{l}2,90 \\
2,90\end{array}$ & 3,15 & 2,93 & $\begin{array}{l}3,03 \\
3,03\end{array}$ & $\begin{array}{l}3,0 \\
3,08\end{array}$ & $\begin{array}{l}1,11 \\
3,11\end{array}$ & $\begin{array}{l}2,00 \\
2,85\end{array}$ & 2,98 & 2,71 & $\begin{array}{l}1,1 \\
3,15\end{array}$ & $\begin{array}{l}1,15 \\
3,15\end{array}$ & $\begin{array}{l}2,95 \\
2,95\end{array}$ & $\begin{array}{l}3,07 \\
3,07\end{array}$ & $\begin{array}{l}3,03 \\
3,03\end{array}$ & $\begin{array}{l}3,03 \\
3,03\end{array}$ & $\begin{array}{l}3,20 \\
3,26\end{array}$ & 2,97 & 2,99 \\
\hline $\bar{N}_{T_{1}}$ & 4,2 & 4,5 & 4,0 & 4,0 & 4,2 & 3,8 & 4,4 & 3,9 & 4,2 & 4,4 & 4,3 & 3,6 & 4,1 & 4,1 & 4,6 & 4,4 & 4,0 & 4,3 & 4,1 & 4,1 & 4,7 & 4,0 & , \\
\hline & & & & & & & & & & & & & & & & & & & & & & & \\
\hline
\end{tabular}


Anexo III. Análisis de microsonda electrónica

\begin{tabular}{|c|c|c|c|c|c|c|c|c|c|c|c|c|c|c|c|c|c|c|c|c|c|c|c|}
\hline \multirow{2}{*}{$\begin{array}{l}\text { Mina/Zona } \\
\text { Roca }\end{array}$} & \multicolumn{23}{|c|}{ Teso de la Matanza } \\
\hline & Vena LG & Vena LG & $\begin{array}{l}\text { Vena } L G \\
\text { L }\end{array}$ & Vena LG & Vena LG & Vena LG & $\begin{array}{l}\text { Vena LG } \\
\text { L }\end{array}$ & $\begin{array}{l}\text { Vena LG } \\
\end{array}$ & $\begin{array}{l}\text { Vena } L G \\
\end{array}$ & Vena LG & Vena LG & $\begin{array}{l}\text { Vena LG } \\
\end{array}$ & 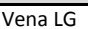 & Vena LG & Vena LG & Vena LG & Vena LG & Vena LG & $\begin{array}{l}\text { Vena LG } \\
\end{array}$ & Vena LG & Vena LG & Vena LG & Vena LG \\
\hline Muestra & 1179 & $1174 \mathrm{~B}$ & $1174 \mathrm{~B}$ & $1174 B$ & $1174 \mathrm{~B}$ & $1174 \mathrm{~B}$ & $1174 \mathrm{~B}$ & $1174 \mathrm{~B}$ & $1174 B$ & $1174 B$ & $1174 \mathrm{~B}$ & $1174 \mathrm{~B}$ & $1174 \mathrm{~B}$ & $1174 \mathrm{~B}$ & $1174 \mathrm{~B}$ & $1174 \mathrm{~B}$ & $1174 \mathrm{~B}$ & $1174 \mathrm{~B}$ & $1174 \mathrm{~B}$ & 1174B & $1174 \mathrm{~B}$ & $1174 \mathrm{~B}$ & $1174 \mathrm{~B}$ \\
\hline Análisis & 1.4 & 1.5 & 1.6 & 1.8 & 1.11 & 1.12 & 1.13 & 1.14 & 2.1 & 3.1 & 3.4 & 4.1 & 5.5 & 5.7 & 5.8 & 5.9 & 5.10 & 5.11 & 5.12 & 5.13 & 5.14 & 5.15 & 6.1 \\
\hline S(\% peso) & 17,27 & 19,48 & 19,42 & 19,41 & 20,12 & 19,78 & 20,74 & 20,91 & 19,46 & 20,09 & 19,85 & 20,03 & 17,89 & 18,22 & 18,50 & 18,51 & 18,28 & 19,34 & 19,21 & 18,99 & 18,46 & 18,22 & 17,96 \\
\hline $\mathrm{Fe}$ & 0,08 & 0,00 & 0,10 & 0,00 & 0,00 & 0,00 & 0,00 & 0,00 & 0,00 & 0,02 & 0,01 & 0,04 & 0,01 & 0,00 & 0,00 & 0,07 & 0,00 & 0,00 & 0,00 & 0,00 & 0,00 & 0,10 & 0,00 \\
\hline $\mathrm{Cu}$ & 0,55 & 0,40 & 0,27 & 0,25 & & 0,17 & 0,26 & 0,22 & 0,33 & 0,41 & 0,33 & 0,00 & 0,46 & 0,19 & 0,22 & 0,09 & 0,31 & 0,08 & 0,18 & 0,08 & 0,08 & 0,39 & 0,22 \\
\hline & & 0, & & 0,00 & & 0,0 & & $0,0 c$ & 0, & 0,00 & & 0,0 & 0,00 & $0, c$ & & & & & & $0, \mathrm{c}$ & 0,00 & 00 & 00 \\
\hline$n$ & & 0,00 & & 0,15 & & 0,05 & & 0,00 & 20 & 0,00 & 0, & 0,24 & 0,10 & 0,00 & 0,00 & 0,00 & 0,00 & 0,03 & 0,07 & 0,00 & 0,00 & 0,00 & 0,08 \\
\hline $\mathrm{Pb}$ & 18,32 & 20,13 & 19,82 & 19,61 & 19,72 & 19,54 & 19,48 & 19,57 & 18,10 & 17,46 & 17,96 & 18,41 & 20,70 & 24,73 & 21,58 & 21,34 & 26,83 & 27,79 & 20,77 & 20,87 & 21,55 & 21,26 & 19,28 \\
\hline $\mathrm{Sb}$ & 0,26 & 0,27 & 0,22 & 0,11 & 0,28 & 0,37 & 0,29 & 0,33 & 0,05 & 0,09 & 0,10 & 0,15 & 0,34 & 0,22 & 0,32 & 0,26 & 0,20 & 0,19 & 0,35 & 0,19 & 0,27 & 0,36 & 0,27 \\
\hline & 8,83 & 70 & & 9,72 & & 8,74 & 99 & 8,79 & 9,26 & 9,36 & 9,16 & 900 & 8,97 & 7,55 & 8,63 & 7,85 & 7,33 & 7,39 & 7,91 & 8,16 & 8,56 & 8,23 & 9,84 \\
\hline & & & & & & & & & & & & & & & & & & & & & 0,08 & & 0,02 \\
\hline & 55,34 & 51,08 & & 52,60 & & 53,08 & 50,92 & 53,19 & 52,94 & 55,01 & 51,65 & 54,15 & 52,08 & 47,00 & 51,85 & 52,66 & 48,66 & 45,39 & 52,53 & 52,22 & 51,29 & 52,81 & 52,78 \\
\hline $\mathrm{Cd}$ & & & & & & & & 0,00 & 0,00 & 0,00 & & & 0,00 & 0,00 & 0,00 & 0,00 & 0,00 & 0,00 & 0,00 & 0,00 & 0,00 & 0,00 & 0,00 \\
\hline $\mathrm{Hg}$ & 0,00 & 0,02 & 0,00 & 0,16 & 0,00 & 0,00 & 0 & 0,00 & 0,07 & 0,00 & 0,14 & 0,00 & 0,04 & 0,00 & 0,00 & 0,13 & 0,00 & 0,00 & 0,00 & 0,00 & 0,00 & 0,23 & 0,00 \\
\hline Total & 100,87 & 100,09 & 102,36 & 102,05 & 102,20 & 101,73 & 100,42 & 103,06 & 100,55 & 102,44 & 99,21 & 102,07 & 100,66 & 98,01 & 101,18 & 100,97 & 101,68 & 100,30 & 101,02 & 100,57 & 100,28 & 101,71 & 100,44 \\
\hline$\%$ at & & 58,50 & 57,73 & 57,64 & & 58,60 & & 59,86 & 58,12 & 58,65 & 59,25 & 58,80 & & 57,48 & 56,77 & 57,08 & 56,57 & 58,70 & 58,12 & 57,95 & 57,06 & 56,08 & 55,79 \\
\hline & & & & & & & & & & 0,03 & & & & 0,00 & 0,00 & & & & 0,00 & 0,00 & 0,00 & 0,18 & 0,00 \\
\hline $\mathrm{Cu}$ & 0,87 & 1 & & & & & & & 50 & 0,60 & & & & 31 & 35 & 14 & & 0,11 & 27 & 0,12 & 0,12 & 0,60 & 0,35 \\
\hline & & & & & & & & & 0 & 0,00 & & & & & & 00 & & 0,0 & & & 00 & 0,00 & 0,00 \\
\hline & & & & & & & & & & & & & & & 0,00 & & & & & 0,00 & 0,00 & 0,00 & 0,11 \\
\hline & & & & & & & & & & & & & & 12,07 & 10,25 & 10, & & & & 9,86 & 10,31 & 10,13 & 9,27 \\
\hline & 0,22 & 0 , & & & & & & & & 0,07 & & & & 0,18 & 0,25 & & & & & & 0,22 & 029 & 22 \\
\hline$A \varepsilon_{\varepsilon}$ & & & & & & & & & & & & & & & & & & & & & & & , 09 \\
\hline & & & & & & & & & & & & & & & & & & & & & & & 0,02 \\
\hline Bi & 26,77 & 23,54 & 24,41 & 23,97 & 23,19 & 24,13 & 22,73 & 23,36 & 24,26 & 24,64 & 23,65 & 24,39 & 24,84 & 22,75 & 24,41 & 24,92 & 23,11 & 21,14 & 24,38 & 24,45 & 24,33 & 24,94 & 25,15 \\
\hline $\mathrm{Cd}$ & 0,00 & 0,00 & & & & & & & & & & & & 0,00 & & & & & & 0,00 & 0,00 & 0,00 & 0,00 \\
\hline & & & & & & & & & & & & & & & & & & & & & & 11 & 0,00 \\
\hline $\mathrm{mol} \%$ & 1,00 & 91 & 0,94 & & 0,91 & & 0, & & 0,97 & 1,01 & 0, & 1,00 & 0,90 & 0,77 & 0,89 & 0,92 & 0,75 & 0,70 & 0,93 & 0,92 & 0,89 & 0,91 & 0,94 \\
\hline $\begin{array}{l}x \\
\text { Férmula }\end{array}$ & 1,03 & 1,09 & 1,02 & 1,18 & 1,25 & 0,96 & 1,05 & 0,99 & 1,12 & 1,09 & 1,14 & 0,94 & 1,12 & 0,95 & 1,00 & 0,83 & 0,90 & 0,94 & 0,86 & 0,88 & 0,97 & 0,95 & 1,18 \\
\hline & & & & & & & & & & & & & & & & & & & & & & 09 & 6,53 \\
\hline & & & & & & & & & & & & & & & & & & & & & & 8 & 1,16 \\
\hline & 1,03 & 1,09 & 1,02 & & & 0,9 & & 0,99 & 1,12 & 1,0 & & 0,94 & 1,12 & 0,9 & 1,00 & 0,83 & 0,90 & 0,94 & 0,86 & 0,88 & 0,97 & 0,95 & 1,18 \\
\hline Bi & 3,03 & $\begin{array}{l}3,09 \\
3,09\end{array}$ & $\begin{array}{l}1,062 \\
3,02\end{array}$ & $\begin{array}{l}1,10 \\
3,18\end{array}$ & $\begin{array}{l}1,25 \\
3,25\end{array}$ & 2,96 & 3,05 & 2,99 & $\begin{array}{l}1,112 \\
3,12\end{array}$ & $\begin{array}{l}1,09 \\
3,09\end{array}$ & $\begin{array}{l}1,14 \\
3,14\end{array}$ & 2,94 & $\begin{array}{l}1,12 \\
3,12\end{array}$ & 2,95 & $\begin{array}{l}3,00 \\
3,00\end{array}$ & 2,83 & 2,90 & $\begin{array}{l}0,74 \\
2,94\end{array}$ & 2,86 & $\begin{array}{l}2,00 \\
2,88\end{array}$ & 2,97 & 2,95 & $\begin{array}{l}1,10 \\
3,18\end{array}$ \\
\hline & 4,1 & 4,4 & 4,2 & 4,6 & 4,7 & 4,0 & 4,3 & 4,1 & 4,3 & 4,2 & 4,4 & 3,9 & 4,5 & 4,5 & 4,2 & 3,8 & 4,4 & 4,7 & 3,8 & 3,9 & 4,2 & 4,1 & \\
\hline Au ppm & & & & & & & & & & & & 1400 & & & & & & & & & & & \\
\hline
\end{tabular}


Anexo III. Análisis de microsonda electrónica

\begin{tabular}{|c|c|c|c|c|c|c|c|c|c|c|c|c|c|c|c|c|c|c|c|c|c|c|c|}
\hline \multirow{2}{*}{$\begin{array}{l}\text { Mina/Zona } \\
\text { Roca }\end{array}$} & \multicolumn{23}{|c|}{ Teso de la Matanza } \\
\hline & Vena LG & Vena LG & 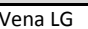 & Vena LG & Vena LG & Vena LG & 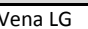 & $\begin{array}{l}\text { Vena LG } \\
\end{array}$ & 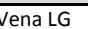 & Vena LG & Vena LG & Vena LG & Vena LG & Vena LG & Vena LG & Vena LG & Vena LG & Vena LG & Vena LG & Vena LG & Vena LG & Vena LG & Vena LG \\
\hline Muestra & $1174 \mathrm{~B}$ & 1174B & $1174 \mathrm{~B}$ & $1174 \mathrm{~B}$ & $1174 \mathrm{~B}$ & 1174B & $1174 \mathrm{~B}$ & $1174 \mathrm{~B}$ & $1174 B$ & $1174 \mathrm{~B}$ & $1174 \mathrm{~B}$ & $1174 \mathrm{~B}$ & $1174 \mathrm{~B}$ & $1174 \mathrm{~A}$ & 1173 & 1173 & 1173 & 1173 & 1173 & 1173 & 1173 & 1173 & 1173 \\
\hline Análisis & 6.2 & 6.8 & 6.10 & 6.11 & 6.12 & 7.2 & 7.3 & 8.4 & 8.5 & 8.7 & 8.10 & 9.2 & 9.3 & 1.15 & 1.1 & $1.1 \mathrm{~b}$ & 1.2 & 1.3 & 1.4 & 1.5 & 1.6 & 1.7 & 1.8 \\
\hline S(\% peso) & 19,25 & 20,28 & 19,49 & 20,81 & 20,65 & 18,43 & 18,30 & 18,55 & 18,60 & 20,13 & 18,94 & 18,36 & 19,00 & 19,55 & 19,50 & 16,62 & 17,17 & 17,25 & 16,89 & 17,76 & 17,45 & 17,63 & 17,38 \\
\hline $\mathrm{Fe}$ & 0,00 & 0,07 & 0,18 & 0,41 & 0,08 & 0,08 & 0,00 & 0,00 & 0,00 & 0,00 & 0,00 & 0,00 & 0,03 & 0,13 & 0,12 & 0,18 & 0,53 & 0,04 & 0,19 & 0,42 & 0,19 & 0,36 & 0,30 \\
\hline $\mathrm{Cu}$ & 0,15 & 1,08 & 0,72 & 0,79 & & 0,28 & 0,03 & 0,22 & 0,05 & 0,30 & 0,39 & 0,21 & 0,25 & 0,15 & 0,24 & 0,11 & 0,19 & 0,35 & 0,03 & 0,12 & 0,00 & 0,23 & 0,34 \\
\hline & & 0, & & 0,00 & & 0,00 & & 0,0 & $0, \mathrm{C}$ & 0,00 & $0, \mathrm{C}$ & 0,0 & 0,00 & & & & & & & & ,00 & 00 & 00 \\
\hline$n$ & 0,15 & 0,17 & & 0, & & 0,00 & 6 & 0,00 & 21 & 0,16 & 0, & 0,00 & 0,00 & 0,00 & 0,00 & 0,00 & 0,17 & 0,10 & 0,00 & 0,00 & 0,17 & 0,27 & 0,00 \\
\hline $\mathrm{Pb}$ & 18,70 & 19,53 & 20,12 & 19,45 & 18,60 & 19,14 & 19,21 & 18,56 & 18,34 & 18,52 & 18,52 & 18,94 & 18,78 & 18,26 & 25,84 & 22,42 & 27,53 & 23,81 & 28,20 & 23,14 & 24,05 & 27,80 & 24,66 \\
\hline Sb & 0,66 & 0,57 & 0,60 & 0,56 & 0,60 & 0,24 & 0,28 & 0,14 & 0,17 & 0,27 & 0,15 & 0,26 & 0,19 & 0,23 & 0,47 & 0,53 & 0,48 & 0,51 & 0,36 & 0,58 & 0,44 & 0,37 & 0,52 \\
\hline & 9,46 & 77 & 8,3 & 8,60 & 4 & 9,29 & 3 & 9,84 & 94 & 10,23 & 9,32 & 9,51 & 9,35 & 9,03 & 6,49 & 8,06 & 6,91 & 7,57 & 7,49 & 8,06 & 7,85 & 6,73 & 7,52 \\
\hline & & & & & & & & & & & & & & & & & & & & & 0,07 & & 0,08 \\
\hline & 52,48 & 55,16 & & 51,01 & & 54,32 & 52,96 & 52,96 & 52,18 & 53,02 & 54,06 & 54,97 & 53,47 & 55,80 & 48,80 & 52,08 & 47,13 & 51,28 & 47,57 & 51,14 & 49,69 & 46,05 & 49,32 \\
\hline $\mathrm{Cd}$ & & & & & & & & 0,00 & 0,00 & 0,00 & & & 0,00 & 0,00 & 0,00 & 0,00 & 0,12 & 0,00 & 0,04 & 0,00 & 0,02 & 0,00 & 0,00 \\
\hline $\mathrm{Hg}$ & 0,06 & 0,00 & 0,00 & 0,00 & 0,00 & 0,05 & 0 & 0,00 & 0,00 & 0,00 & 0,10 & 0,06 & 0,00 & 0,00 & 0,00 & 0,00 & 0,00 & 0,00 & 0,17 & 0,00 & 0,00 & 0,00 & 0,00 \\
\hline Total & 101,02 & 105,70 & 102,88 & 101,74 & 102,79 & 101,90 & 100,44 & 100,41 & 98,56 & 102,66 & 101,53 & 102,31 & 101,15 & 103,29 & 101,55 & 100,03 & 100,31 & 100,95 & 101,06 & 101,31 & 99,93 & 99,51 & 100,12 \\
\hline$\%$ at.) & & 57,58 & 57,48 & 59,41 & & 56,23 & & 56,77 & 57,58 & 58,38 & 57,14 & 56,09 & 57,37 & 57,69 & 58,62 & 53,98 & 54,69 & 54,84 & 54,34 & 55,37 & 55,45 & 55,83 & $\frac{55,16}{55}$ \\
\hline & & & & & & & & & 0,00 & 0,00 & & & 0,05 & & & & & 0,08 & 0,35 & 0,76 & 0,35 &, 66 & 0,54 \\
\hline $\mathrm{Cu}$ & 0,23 & 1, & & 1, & & & & & 8 & 0,44 & & & & 23 & 37 & 18 & & 0,56 & 05 & 0,19 & 0,00 & 0,37 & 0,55 \\
\hline & & & & & & & & & 0 & 00 & & & & & & & & 0,00 & 00 & & 0,00 & 0,00 & 0,00 \\
\hline & & 3 & & & & & & & & & & & & & 0,00 & & 26 & & 0,00 & & 0,26 & 0,41 & 0,00 \\
\hline & & & & & & & & & & & & & & & 12,02 & & $\begin{array}{l}0,205 \\
13,57\end{array}$ & & 14,04 & 11,16 & 11,83 & $\begin{array}{r}13,41 \\
13,62\end{array}$ & 12,11 \\
\hline & 0,52 & & & & & & & & & & & & & & 0,37 & & & & 0,31 & & 0,37 & 0,31 & 0,43 \\
\hline$A \xi$ & & & & & & & & & & & & & & & & & & & & & 7,41 & 5,33 & 7,09 \\
\hline & 0,1 & & & & & & & & & & & & & & & & & & & & 0,09 & 0,09 & 0,10 \\
\hline $\mathrm{Bi}$ & 24,12 & 24,03 & 24,17 & 22,34 & 23,17 & 25,43 & 25,10 & 24,87 & 24,78 & 23,59 & 25,02 & 25,76 & 24,77 & 25,26 & 22,51 & 25,95 & 23,03 & 25,01 & 23,48 & 24,46 & 24,23 & 22,37 & 24,02 \\
\hline $\mathrm{Cd}$ & 0,00 & & & & & & & & & & & & & & 0,00 & & & & 0,04 & 0,00 & 0,02 & 0,00 & 0,00 \\
\hline & & & & & & & & & & & & & & & & & & & & & & 00 & \\
\hline $\mathrm{mol} \%$ & 0,96 & 96 & 0,94 & & & & & & 0,97 & 0,95 & 0,97 & 0,98 & 0,96 & 1,02 & 0,77 & 0,89 & 0,72 & 0,84 & 0,71 & 0,86 & 0,82 & 0,70 & 0,80 \\
\hline $\begin{array}{l}x \\
\text { Férmula }\end{array}$ & 1,08 & 1,15 & 1,03 & 1,18 & 1,19 & 1,06 & 1,06 & 1,18 & 1,00 & 1,27 & 1,11 & 1,05 & 1,09 & 0,94 & 0,74 & 0,86 & 0,83 & 0,87 & 0,87 & 0,89 & 0,86 & 0,84 & 0,91 \\
\hline & & & & & & & & & & & & & & & & & & & & & & & 6,26 \\
\hline & & & & & & & & & & & & & & & & & & & & & & 1,70 & 1,44 \\
\hline & 1,08 & 1,15 & 1,03 & & & 1,06 & & 1,18 & 1,00 & & & & 1,0 & 0,94 & 0,74 & 0,86 & 0,8 & 0,87 & 0,87 & 0,89 & 0,86 & 0,84 & 0,91 \\
\hline $\mathrm{Bi}$ & $\begin{array}{l}1,00 \\
3,08\end{array}$ & 3,15 & $\begin{array}{l}3,03 \\
3,03\end{array}$ & $\begin{array}{l}1,10 \\
3,18\end{array}$ & $\begin{array}{l}1,17 \\
3,19\end{array}$ & $\begin{array}{l}3,06 \\
3,06\end{array}$ & $\begin{array}{l}1,00 \\
3,06\end{array}$ & $\begin{array}{l}1,10 \\
3,18\end{array}$ & 3,00 & $\begin{array}{l}1,27 \\
3,27\end{array}$ & $\begin{array}{l}1,11 \\
3,11\end{array}$ & $\begin{array}{l}3,05 \\
3,05\end{array}$ & $\begin{array}{l}3,09 \\
3,09\end{array}$ & 2,94 & 2,74 & $\begin{array}{l}2,00 \\
2,86\end{array}$ & $\begin{array}{l}2,83 \\
2,83\end{array}$ & 2,87 & $\begin{array}{l}2,811 \\
2,87\end{array}$ & $\begin{array}{l}2,89 \\
2,89\end{array}$ & $\begin{array}{l}2,00 \\
2,86\end{array}$ & $\begin{array}{l}0,044 \\
2,84\end{array}$ & 2,91 \\
\hline & 4,2 & 4,4 & 4,2 & 4,6 & 4,5 & 4,2 & 4,2 & 4,5 & 4,1 & 4,7 & 4,3 & 4,2 & 4,3 & 3,8 & 3,9 & 3,9 & 4,3 & 4,1 & 4,4 & 4,1 & 4,1 & 4,4 & \\
\hline Au ppm & & & & & & & & & & & & & & 1991 & & & & & & & & & \\
\hline
\end{tabular}


Anexo III. Análisis de microsonda electrónica

\begin{tabular}{|c|c|c|c|c|c|c|c|c|c|c|c|c|c|c|c|c|c|c|c|c|c|c|c|}
\hline \multirow{2}{*}{$\begin{array}{l}\text { Mina/Zona } \\
\text { Roca }\end{array}$} & \multicolumn{23}{|c|}{ Teso de la Matanza } \\
\hline & $\begin{array}{l}\text { Vena LG } \\
\end{array}$ & Vena LG & Vena LG & Vena LG & Vena LG & Vena LG & Vena LG & Vena LG & Vena LG & Vena LG & Vena LG & Vena LG & Vena LG & Vena LG & Vena LG & Vena LG & Vena LG & Vena LG & $\begin{array}{l}\text { Vena LG } \\
\end{array}$ & Vena LG & Vena LG & Vena LG & Vena LG \\
\hline Muestra & 1173 & 1173 & 1173 & 1173 & 1173 & 1173 & 1173 & 1173 & 1173 & 1173 & 1173 & 1173 & 1173 & 1173 & 1173 & 1173 & 1173 & 1173 & 1173 & 1173 & 1173 & 1173 & 1173 \\
\hline Análisis & 1.9 & 2.1 & $2.1 \mathrm{~b}$ & 2.2 & 2.3 & 3.1 & 3.2 & 3.3 & 3.4 & 3.5 & 3.6 & 3.7 & 3.8 & 3.9 & 3.10 & 3.11 & 3.12 & 3.13 & 3.14 & 3.15 & 3.16 & 3.17 & 3.18 \\
\hline S(\% peso) & 18,33 & 17,85 & 18,06 & $\begin{array}{l}18,04 \\
\end{array}$ & 17,75 & 18,24 & 18,22 & 17,85 & 17,99 & 18,12 & 17,69 & 16,91 & 17,71 & 17,85 & 17,26 & 17,79 & 17,44 & 17,72 & 17,29 & 17,71 & 17,26 & 17,56 & 17,44 \\
\hline $\mathrm{Fe}$ & 0,13 & 0,30 & 0,00 & 0,16 & 0,21 & 0,04 & 0,05 & 0,00 & 0,12 & 0,19 & 0,09 & 0,00 & 0,02 & 0,02 & 0,01 & 0,06 & 0,00 & 0,08 & 0,04 & 0,13 & 0,11 & 0,00 & 0,06 \\
\hline Cu & 0,04 & 0,39 & 0,25 & 0,27 & 0,27 & 0,26 & 0,05 & 0,21 & 0,18 & 0,39 & 0,23 & 0,49 & 0,38 & 0,20 & 0,14 & 0,21 & 0,15 & 0,27 & 0,31 & 0,35 & 0,34 & 0,40 & 0,22 \\
\hline & & 0, & & 0,00 & & 0,00 & & 0,0 & & 0,00 & & 0,0 & 0,00 & & 0,00 & & & & & &, 00 & 00 & \\
\hline$n$ & & 00 & & 0,13 & & 0,10 & & 0,12 & 17 & 0,05 & 0, & 0,00 & 0,21 & 0,17 & 0,00 & 0,11 & 0,00 & 0,00 & 0,00 & 0,06 & 0,00 & 0,00 & 0,07 \\
\hline $\mathrm{Pb}$ & 21,10 & 28,12 & 24,60 & 22,32 & 26,00 & 24,86 & 20,79 & 28,81 & 22,00 & 28,54 & 21,51 & 21,52 & 21,58 & 21,29 & 21,75 & 21,54 & 28,30 & 21,96 & 29,16 & 21,05 & 27,31 & 22,14 & 21,45 \\
\hline Sb & 0,50 & 0,41 & 0,41 & 0,51 & 0,44 & 0,54 & 0,61 & 0,38 & 0,55 & 0,37 & 0,75 & 0,60 & 0,57 & 0,61 & 0,62 & 0,71 & 0,44 & 0,59 & 0,44 & 0,61 & 0,43 & 0,61 & 0,65 \\
\hline & 8,35 & 79 & & 8, & & 7,54 & 3 & 6,11 & 37 & 6,05 & 7,41 & 825 & 9,56 & 9,01 & 8,84 & 8,87 & 6,57 & 8,67 & 5,99 & 8,83 & 6,86 & 8,44 & 8,75 \\
\hline & & & & & & & & & & & & & & & & & & & & & & & 0,06 \\
\hline & 52,36 & 45,51 & & 51,19 & & 49,88 & & 47,72 & 52,94 & 47,13 & 50,30 & 49,87 & 52,29 & 51,08 & 51,10 & 50,90 & 46,34 & 51,64 & 46,13 & 52,26 & 46,77 & 54,43 & 50,98 \\
\hline $\mathrm{Cd}$ & & & & & & 0,00 & & 0,00 & 0,06 & 0,07 & & & 0,01 & 0,00 & 0,02 & 0,03 & 0,00 & 0,00 & 0,00 & 0,02 & 0,00 & 0,00 & 0,00 \\
\hline $\mathrm{Hg}$ & 0,06 & 0,00 & 0,00 & 0,00 & 0,00 & 0,00 & 0,00 & 0,00 & 0,11 & 0,00 & 0,17 & 0,00 & 0,08 & 0,00 & 0,00 & 0,08 & 0,00 & 0,00 & 0,00 & 0,00 & 0,03 & 0,42 & 0,00 \\
\hline Total & 100,87 & 99,45 & 99,71 & 101,40 & 100,56 & 101,49 & 100,36 & 101,20 & 102,52 & 100,90 & 98,20 & 97,65 & 102,49 & 100,30 & 99,74 & 100,40 & 99,33 & 101,03 & 99,40 & 101,03 & 99,16 & 104,09 & 99,69 \\
\hline$\%$ at & & 56,29 & & 55,70 & & 56,40 & & 56,29 & 55,46 & 56,60 & & & 54,63 & & 55,08 & 55,58 & 56,06 & & 55,82 & 55,24 & 55,55 & 54,34 & 55,26 \\
\hline & & & & & & & & 0,00 & & 0,34 & & & & & & & & & 0,07 & 0,23 & 0,20 & 0,00 & 0,11 \\
\hline $\mathrm{Cu}$ & & 0, & & & & & & & 8 & 61 & & & & 31 & & 33 & & 0,43 & 50 & 0,55 & 0,55 & 0,63 & 0,35 \\
\hline & & & & & & & & & & & & & & & & & & & & 0,00 & & 0,00 & 0,00 \\
\hline & & & & & & & & & & & & & & & & & 0,00 & & 0,00 & & 0,00 & 0,00 & 0,12 \\
\hline $\mathrm{Pb}$ & & 13,72 & 11,95 & 10,67 & & 11,90 & & $\begin{array}{l}14,06 \\
14,0\end{array}$ & 10,50 & 13,80 & 10,62 & 10,8 & 10,30 & 10,28 & 10,74 & 10,4 & 14,08 & & 14,57 & 10,16 & 13,60 & 10,60 & $\begin{array}{r}0,12 \\
10,52\end{array}$ \\
\hline sb & 0,41 & & & 0,42 & & & & 0,31 & 0,45 & 0,30 & & & & & & & & & & 0,50 & 0,36 & $\begin{array}{r}0,49 \\
\end{array}$ & 0,55 \\
\hline$A \varepsilon$ & & & & & & & & & & & & & & & & & & & & & & 7,76 & 3,24 \\
\hline & & & & & & & & & & & & & & & & & & & & & & 0,12 & 0,08 \\
\hline $\mathrm{Bi}$ & 24,84 & 22,02 & 23,56 & 24,25 & 23,14 & 23,67 & 24,62 & 23,09 & 25,04 & 22,59 & 24,62 & 24,88 & 24,75 & 24,46 & 25,02 & 24,40 & 22,85 & 24,76 & 22,85 & 25,01 & 23,09 & 25,84 & 24,78 \\
\hline $\mathrm{Cd}$ & & & & & & & & & & & & & & & & & & & & 0,02 & 0,00 & 0,00 & 0,00 \\
\hline & & & & & & & & & & & & & & & & & & & & & & 21 & 00 \\
\hline $\mathrm{mol} \%$ & 0,92 & 70 & 0,80 & & 0,7 & & & & 0,90 & 69 & 0, & 0 & 0,89 & 0,89 & 0,88 & 0,88 & 0,70 & 0,88 & 0,67 & 0,91 & 0,72 & 0,91 & 0,89 \\
\hline $\begin{array}{l}x \\
\text { Férmula }\end{array}$ & 0,88 & 0,91 & 0,89 & 1,03 & 0,90 & 0,87 & 0,97 & 0,70 & 0,91 & 0,75 & 0,83 & 1,06 & 1,18 & 1,06 & 1,02 & 1,04 & 0,78 & 1,01 & 0,74 & 1,04 & 0,87 & 0,94 & 1,03 \\
\hline & & & & & & & & & & & & & & & & & & & & & & 6,05 & 6,31 \\
\hline & & & & & & & & & & & & & & & & & & & & & & 18 & 1,26 \\
\hline & 0,88 & 0,91 & 0,8 & 1,03 & & & 0,97 & & 0,91 & 0,7 & & & 1,18 & 1,0 & 1,02 & 1,04 & 0,7 & 1,01 & 0,74 & 1,04 & 0,87 & 0,94 & 1,03 \\
\hline Bi & $\begin{array}{l}2,00 \\
2,88\end{array}$ & 2,91 & $\begin{array}{l}2,89 \\
2,89\end{array}$ & $\begin{array}{l}1,03 \\
3,03\end{array}$ & 2,90 & 2,87 & 2,97 & 2,70 & 2,91 & 2,75 & $\begin{array}{l}2,00 \\
2,83\end{array}$ & $\begin{array}{l}3,00 \\
3,06\end{array}$ & $\begin{array}{l}1,10 \\
3,18\end{array}$ & $\begin{array}{l}3,006 \\
3,06\end{array}$ & $\begin{array}{l}3,02 \\
3,02\end{array}$ & $\begin{array}{l}3,04 \\
3,04\end{array}$ & 2,78 & $\begin{array}{l}1,01 \\
3,01\end{array}$ & 2,74 & $\begin{array}{l}3,04 \\
3,04\end{array}$ & $\begin{array}{l}2,01 \\
2,87\end{array}$ & 2,94 & $\begin{array}{l}1,03 \\
3,03\end{array}$ \\
\hline & 3,9 & 4,6 & 4,2 & 4,4 & 4,3 & 4,2 & 4,1 & 4,0 & 4,0 & 4,2 & 3,8 & 4,4 & 4,7 & 4,4 & 4,3 & 4,4 & 4,2 & 4,3 & 4,2 & 4,3 & 4,4 & 4,1 & \\
\hline Au ppm & & & & & 1163 & & & & & & & & & & & & & & & & & & \\
\hline
\end{tabular}




\begin{tabular}{|c|c|c|c|c|c|c|c|c|c|c|c|c|c|c|c|}
\hline \multirow{2}{*}{$\begin{array}{l}\text { Mina/Zona } \\
\text { Roca }\end{array}$} & \multicolumn{15}{|c|}{$\begin{array}{ll}\text { Teso de la Matanza } \\
\end{array}$} \\
\hline & Vena LG & Vena LG & Vena LG & Vena LG & Vena LG & Vena LG & Vena LG & Vena LG & Vena LG & Vena LG & Vena LG & Vena LG & Vena LG & Vena LG & Vena LG \\
\hline & 1173 & 1173 & 1173 & 1173 & 1173 & 1173 & 1173 & 1173 & 1173 & 1173 & 1173 & 1173 & 1173 & 1173 & 1173 \\
\hline Análisis & 3.19 & 3.20 & 3.21 & 4.2 & 5.1 & 5.2 & 6.2 & 7.2 & 7.3 & 7.4 & 8.2 & 9.4 & 9.7 & 9.8 & 9.11 \\
\hline $\mathrm{S}(\%$ peso) & 17,80 & 16,93 & 17,91 & 17,66 & 17,62 & 18,24 & 16,85 & 17,82 & 17,70 & 17,46 & 17,25 & 17,99 & 17,58 & 17,69 & 17,56 \\
\hline $\mathrm{Fe}$ & 0,00 & 0,10 & 0,00 & 0,01 & 0,12 & 0,45 & 0,01 & 0,08 & 0,02 & 0,00 & 0,41 & 0,08 & 0,11 & 0,00 & 0,02 \\
\hline $\mathrm{Cu}$ & 0,29 & 0,14 & 0,38 & 0,05 & 0,14 & 0,13 & 0,39 & 0,17 & 0,08 & 0,14 & 0,35 & 0,06 & 0,48 & 0,36 & 0,28 \\
\hline As & 0,00 & 0,00 & 0,00 & 0,00 & 0,00 & 0,00 & 0,00 & 0,00 & 0,00 & 0,00 & 0,00 & 0,00 & 0,00 & 0,00 & 0,00 \\
\hline $\mathrm{Zn}$ & 0,00 & 0,27 & 0,13 & 0,06 & 0,04 & 0,02 & 0,00 & 0,00 & 0,00 & 0,15 & 0,00 & 0,07 & 0,00 & 0,00 & 0,02 \\
\hline $\mathrm{Pb}$ & 27,52 & 29,16 & 22,00 & 20,75 & 25,68 & 23,98 & 28,12 & 20,91 & 21,12 & 28,72 & 20,48 & 19,92 & 20,08 & 20,32 & 20,22 \\
\hline $\mathrm{Sb}$ & 0,46 & 0,36 & 0,58 & 0,19 & 0,52 & 0,48 & 0,47 & 0,58 & 0,59 & 0,50 & 0,62 & 0,73 & 0,74 & 0,75 & 0,66 \\
\hline $\mathrm{Ag}$ & 7,00 & 6,39 & 7,91 & 8,67 & 6,46 & 7,05 & 6,63 & 9,03 & 7,94 & 6,14 & 8,43 & 10,16 & 9,11 & 8,76 & 9,43 \\
\hline Se & 0,02 & 0,03 & 0,05 & 0,12 & 0,04 & 0,01 & 0,03 & 0,03 & 0,03 & 0,06 & 0,06 & 0,00 & 0,04 & 0,05 & 0,02 \\
\hline $\mathrm{Bi}$ & 49,06 & 46,01 & 50,14 & 52,63 & 48,70 & 50,96 & 46,76 & 50,64 & 52,72 & 46,69 & 50,75 & 54,17 & 53,03 & 52,94 & 51,86 \\
\hline c & 0,01 & 0,00 & & 0,03 & 0,00 & 0,02 & 0,13 & 0,00 & 0,02 & 0,01 & 0,01 & 0,00 & 0,00 & 0,00 & 0,09 \\
\hline $\mathrm{Hg}$ & 0,00 & 0,00 & 0,00 & 0,04 & 0,00 & 0,00 & & 0,00 & 0,16 & 0,05 & 0,00 & 0,00 & 0,00 & 0,00 & 0,00 \\
\hline Total & 102,15 & 99,39 & 99,10 & 100,20 & 99,32 & 101,33 & 99,39 & 99,26 & 100,38 & 99,91 & 98,36 & 103,18 & 101,16 & 100,87 & 100,14 \\
\hline $\begin{array}{l}\text { (\% at.) } \\
\text { (a) }\end{array}$ & 55,73 & 55,02 & 56,34 & 55,72 & 56,29 & 56,41 & 54,85 & 56,03 & 55,89 & 55,96 & 55,09 & 55,00 & 54,87 & 55,35 & 55,20 \\
\hline $\mathrm{Fe}$ & 0,00 & 0,19 & 0,00 & 0,02 & 0,22 & 0,80 & 0,01 & 0,14 & 0,04 & 0,00 & 0,75 & 0,14 & 0,19 & 0,00 & 0,03 \\
\hline $\mathrm{Cu}$ & & 0,23 & & 0,07 & & 0,20 & & & & 0,22 & 0,57 & 0,09 & 0,75 & 0,57 & 0,45 \\
\hline As & 0,00 & 0,00 & & 0,00 & 0,00 & 0,00 & & 0,00 & 0,00 & 0,00 & 0,00 & 0,00 & 0,00 & 0,00 & 0,00 \\
\hline $\mathrm{Zn}$ & 0,00 & 0,43 & 0,19 & 0,09 & 0,06 & 0,03 & 0,00 & 0,00 & 0,00 & 0,23 & 0,00 & 0,11 & 0,00 & 0,00 & 0,02 \\
\hline $\mathrm{Pb}$ & 13,33 & 14,67 & 10,71 & 10,13 & 12,70 & 11,48 & 14,17 & 10,17 & 10,32 & 14,25 & 10,12 & 9,43 & 9,70 & 9,84 & 9,84 \\
\hline $\mathrm{sb}$ & 0,38 & 0,31 & 0,48 & 0,15 & 0,44 & 0,39 & 0,40 & 0,48 & $\begin{array}{r}0,49 \\
\end{array}$ & 0,42 & 0,52 & 0,59 & 0,60 & 0,62 & 0,54 \\
\hline $\mathrm{Ag}$ & 6,51 & 6 , & & 8 & & 6, & & & & 5,85 & 8,00 & 9,23 & 8,45 & 8,15 & 8,81 \\
\hline Se & 0,03 & 0,04 & 0,06 & 0,15 & 0,05 & 0,01 & 0,04 & 0,04 & 0,04 & 0,08 & 0,07 & 0,00 & 0,04 & 0,06 & 0,02 \\
\hline $\mathrm{Bi}$ & 23,57 & 22,94 & 24,20 & 25,48 & 23,87 & 24,18 & 23,35 & 24,43 & 25,54 & 22,96 & 24,87 & 25,41 & 25,39 & 25,41 & 25,01 \\
\hline $\mathrm{Cd}$ & 0,01 & 0,00 & 0,00 & 0,03 & & 0,02 & & 0,00 & 0,02 & 0,01 & 0,01 & 0,00 & 0,00 & 0,00 & 0,08 \\
\hline $\mathrm{Hg}$ & & & & 0 & & & & & & 0,03 & & 0,00 & 0,00 & 0,00 & \\
\hline mol\% & 0,74 & 0,67 & 0,87 & 0,92 & 0,77 & 0,84 & 0,70 & 0,89 & 0,93 & 0,68 & 0,91 & 0,95 & 0,93 & 0,94 & 0,91 \\
\hline $\begin{array}{l}x \\
\text { Fórmula }\end{array}$ & 0,82 & 0,76 & 0,96 & 0,94 & 0,71 & 0,75 & 0,84 & 1,08 & 0,82 & 0,70 & 1,02 & 1,12 & 1,10 & 1,01 & 1,14 \\
\hline $\mathrm{s}$ & 6,21 & 6,26 & 6,20 & 6,05 & 5,83 & 5,78 & 6,40 & 6,41 & 5,76 & 6,05 & 6,24 & 6,36 & 6,35 & 6,15 & 6,49 \\
\hline $\mathrm{Pb}$ & 1,57 & 1,74 & & 1,1 & & 1,29 & & & & & & & & & 1,22 \\
\hline $\mathrm{Ag}$ & $0, \varepsilon$ & 0 , & & & & & & & & & & & & 1,01 & $\begin{array}{l}1,14 \\
\text {. }\end{array}$ \\
\hline $\mathrm{Bi}$ & 2,82 & 2,76 & 2,96 & 2,94 & 2,71 & 2,75 & 2,84 & 3,08 & 2,82 & 2,70 & 3,02 & 3,12 & 3,10 & 3,01 & 3,14 \\
\hline${ }_{\mathrm{N}}^{\mathrm{L}}$ & 4,2 & 4,3 & 4,2 & 4,0 & 3,8 & 3,8 & 4,4 & \begin{tabular}{|l|}
4,4 \\
\end{tabular} & 3,8 & 4,0 & 4,2 & 4,4 & 4,3 & 4,2 & \\
\hline & & & & - & - & - & - & - & - & - & & & & & \\
\hline
\end{tabular}

Anexo III. Análisis de microsonda electrónica

\begin{tabular}{|c|c|c|c|c|c|c|}
\hline \multirow{2}{*}{$\frac{\text { Mina/Zona }}{\text { Roca }}$} & \multicolumn{6}{|c|}{ Salmantina } \\
\hline & Vena LG & Vena LG & Vena LG & Vena LG & Vena LG & $\begin{array}{l}\text { Vena LG } \\
\end{array}$ \\
\hline Muestra & 845 & 845 & 845 & 845 & 1059 & 1159 \\
\hline Análisis & 1.1 & 4.3 & 5.4 & 5.9 & 2.3 & 1.2 \\
\hline S(\% peso) & 17,38 & 17,29 & 16,91 & 17,39 & 14,27 & 16,94 \\
\hline $\mathrm{Fe}$ & 0,42 & 0,00 & 0,09 & 0,00 & 0,00 & 0,59 \\
\hline $\mathrm{Cu}$ & 0,38 & 0,78 & 1,72 & 0,45 & 0,05 & 0,06 \\
\hline As & 0,00 & 0,00 & 0,00 & 0,00 & 0,00 & 0,00 \\
\hline $\mathrm{Zn}$ & 0,15 & 0,18 & 0,00 & 0,07 & 0,06 & 0,24 \\
\hline $\mathrm{Pb}$ & 26,49 & 28,30 & 30,40 & 27,01 & 38,44 & 26,26 \\
\hline Sb & 0,25 & 0,00 & 0,53 & 0,02 & 0,07 & 0,38 \\
\hline $\mathrm{Ag}$ & 9,47 & 9,23 & 7,59 & 9,94 & 7,39 & 11,00 \\
\hline Se & 0,07 & 0,08 & 0,49 & 0,01 & 0,56 & 0,04 \\
\hline $\mathrm{Bi}$ & 43,58 & 44,53 & 45,72 & 45,30 & 38,68 & 46,64 \\
\hline $\mathrm{Cd}$ & 0,00 & 0,05 & 0,51 & 0,00 & 0,00 & 0,00 \\
\hline $\mathrm{Hg}$ & 0,08 & 0,14 & 0,09 & 0,15 & 0,00 & 0,00 \\
\hline Total & 98,25 & 100,58 & 104,06 & 100,35 & 99,52 & 102,16 \\
\hline 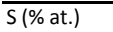 & 55,02 & 54,38 & 52,34 & 54,73 & 49,64 & 52,88 \\
\hline $\mathrm{Fe}$ & 0,76 & 0,00 & 0,17 & 0,00 & 0,00 & 1,05 \\
\hline $\mathrm{Cu}$ & 0,60 & 1,23 & 2,69 & 0,71 & 0,09 & 0,09 \\
\hline As & 0,00 & 0,00 & 0,00 & 0,00 & 0,00 & 0,00 \\
\hline $\mathrm{Zn}$ & 0,24 & 0,27 & 0,00 & 0,11 & 0,10 & 0,37 \\
\hline $\mathrm{Pb}$ & 12,98 & 13,77 & 14,56 & 13,16 & 20,69 & 12,69 \\
\hline sb & 0,20 & 0,00 & 0,43 & 0,02 & 0,06 & 0,32 \\
\hline $\mathrm{Ag}$ & 8,91 & 8,63 & 6,98 & 9,30 & 7,64 & 10,21 \\
\hline Se & 0,08 & 0,11 & 0,62 & 0,02 & 0,79 & 0,06 \\
\hline $\mathrm{Bi}$ & 21,17 & 21,49 & 21,71 & 21,87 & 20,64 & 22,34 \\
\hline $\mathrm{Cd}$ & 0,00 & 0,05 & 0,45 & 0,00 & 0,00 & 0,00 \\
\hline $\mathrm{Hg}$ & 0,04 & 0,07 & 0,05 & 0,08 & 0,00 & 0,00 \\
\hline $\mathrm{mol} \%$ & 0,73 & 0,71 & 0,69 & 0,73 & 0,52 & 0,76 \\
\hline $\begin{array}{l}x \\
\text { Fórmula }\end{array}$ & 1,61 & 1,70 & 1,55 & 1,69 & 1,19 & 1,67 \\
\hline $\mathrm{s}$ & 8,40 & 8,77 & 8,51 & 8,59 & 8,57 & 8,39 \\
\hline $\mathrm{Pb}$ & 2,19 & 2,38 & 2,41 & 2,22 & 3,19 & 2,05 \\
\hline $\mathrm{Ag}$ & 1,61 & 1,70 & 1,55 & 1,69 & 1,19 & 1,67 \\
\hline $\mathrm{Bi}$ & 3,61 & 3,70 & 3,55 & 3,69 & 3,19 & 3,67 \\
\hline$\underline{N_{L}}$ & 6,40 & 6,77 & 6,51 & 6,59 & 6,57 & 6,39 \\
\hline Auppn & & & & & 4274 & \\
\hline
\end{tabular}


Anexo III. Análisis de microsonda electrónica

\begin{tabular}{|c|c|c|c|c|c|c|c|c|c|}
\hline \multirow{2}{*}{$\begin{array}{l}\text { Mina/Zona } \\
\text { Roca }\end{array}$} & \multicolumn{5}{|c|}{ Salmantina } & \multicolumn{3}{|c|}{ Teso de la Matanza } & \multirow{2}{*}{$\begin{array}{l}\text { Bon } \\
\text { Vena } L G\end{array}$} \\
\hline & Vena LG & Vena LG & Vena LG & Vena LG & Vena LG & Vena LG & Vena LG & Vena LG & \\
\hline Muestra & 1159 & 1159 & 1159 & 1159 & 1159 & 1173 & 1173 & 1173 & 1057 \\
\hline Análisis & 1.3 & 1.4 & 1.7 & 1.11 & 1.13 & 7.1 & 9.3 & 9.5 & 2.12 \\
\hline$s(\%$ peso) & 17,02 & 16,89 & 16,30 & 17,07 & 17,40 & 16,75 & 16,16 & 16,44 & 16,691 \\
\hline $\mathrm{Fe}$ & 0,61 & 0,60 & 0,57 & 0,26 & 0,17 & 0,11 & 0,00 & 0,10 & 0,644 \\
\hline $\mathrm{Cu}$ & 0,00 & 0,20 & 0,15 & 0,00 & 0,00 & 0,22 & 0,25 & 0,30 & 0,066 \\
\hline As & 0,00 & 0,00 & 0, & 0,00 & 0,00 & 0,00 & 0,00 & 0,00 & 0,256 \\
\hline $\mathrm{Zn}$ & 0,14 & 0,00 & 0,00 & 0,00 & 0,10 & 0,02 & 0,00 & 0,20 & 0,000 \\
\hline $\mathrm{Pb}$ & 25,40 & 25,75 & 26,17 & 29,47 & 27,90 & 36,44 & 39,01 & 36,87 & 28,627 \\
\hline $\mathrm{Sb}$ & 0,49 & 0,38 & & 0,34 & 0,41 & $0.09-2-1$ & 0,19 & 0,21 & 0,000 \\
\hline $\mathrm{Ag}$ & 11,51 & 10,71 & 11,32 & 10,45 & 10,33 & 7,34 & 6,68 & 7,53 & 10,106 \\
\hline $\mathrm{Se}$ & 0,07 & 0,05 & 0,09 & 0,00 & 0,09 & 0,06 & 0,13 & 0,00 & 0,033 \\
\hline $\mathrm{Bi}$ & 46,67 & 45,23 & 43,85 & 42,13 & 43,60 & 38,10 & 37,60 & 38,18 & 42,884 \\
\hline $\mathrm{Cd}$ & 0,00 & 0,00 & 0,00 & 0,00 & 0,00 & 0,02 & 0,00 & 0,10 & 0,204 \\
\hline $\mathrm{Hg}$ & 0,00 & 0,00 & 0,00 & 0,07 & 0,00 & 0,00 & 0,00 & 0,12 & 0,000 \\
\hline Total & 101,91 & 99,80 & 98,86 & 99,79 & 100,00 & 99,16 & 100,02 & 100,05 & 99,51 \\
\hline $\mathrm{S}$ (\% at.) & 53,01 & 53,52 & 52,60 & 54,29 & 54,77 & 54,64 & 53,55 & 53,63 & 53,34 \\
\hline $\mathrm{Fe}$ & 1,08 & 1,08 & 1,05 & 0,48 & 0,31 & 0,20 & 0,00 & 0,19 & 1,18 \\
\hline $\mathrm{Cu}$ & 0,00 & 0,32 & 0, & 0,00 & 00 & 0,36 & 0,41 & 0,50 & 0,11 \\
\hline As & 0,00 & 0,00 & & & & & & 0,00 & 0,35 \\
\hline $\mathrm{Zn}$ & 0,2 & 0,00 & & 0,00 & & & & & \\
\hline $\mathrm{Pb}$ & 12,24 & 12,63 & 13,07 & 14,51 & 13,59 & 18,39 & 20,00 & 18,61 & 14,16 \\
\hline $\mathrm{Sb}$ & 0,40 & 0,32 & 0,35 & 0,28 & 0,34 & 0,08 & 0,16 & 0,18 & 0,00 \\
\hline $\mathrm{Ag}$ & 10 & 10,09 & & 88 & & & 6 & 7,30 & 9,60 \\
\hline $\mathrm{Se}$ & 0,08 & 0,06 & & 0,00 & 0,12 & 0,08 & 0,18 & 0,00 & 0,04 \\
\hline $\mathrm{Bi}$ & 22,30 & 21,99 & 21,71 & 20,56 & 21,06 & 19,07 & 19,12 & 19,11 & 21,03 \\
\hline $\mathrm{Cd}$ & 0,00 & 0,00 & & & & & & 0,09 & 0,19 \\
\hline $\mathrm{Hg}$ & 0,00 & 0,00 & 0,00 & 0,00 & 0 & 0,00 & 0 & , 06 & 0,00 \\
\hline $\mathrm{mol} \%$ & 0,77 & 0,76 & & 0,69 & & 0,54 & 0,50 & 0,55 & 0,69 \\
\hline $\begin{array}{l}x \\
\text { Fórmu }\end{array}$ & 1,77 & 1,75 & 2,03 & 1,80 & 1,65 & 1,28 & 1,14 & 1,36 & 1,71 \\
\hline$\frac{\text { Form }}{\mathrm{s}}$ & 8,57 & 8,62 & 9,44 & 25 & 8,61 & 8,72 & 8,53 & 8,97 & 8,96 \\
\hline $\mathrm{Pb}$ & 2,03 & 2,12 & 2 & 65 & 2,32 & & & 3,26 & 2,53 \\
\hline $\mathrm{Ag}$ & 1,77 & 1,75 & & & & & & & \\
\hline $\mathrm{Bi}$ & 3,77 & 3,75 & 4,03 & 3,80 & 3,65 & 3,28 & 3,14 & 3,36 & 3,71 \\
\hline$N_{L}$ & 6,57 & 6,62 & 7,44 & 7,25 & 6,61 & 6,72 & 6,53 & 6,97 & 6,96 \\
\hline
\end{tabular}

Vikingita

\begin{tabular}{|c|c|c|c|c|c|c|c|c|c|c|c|c|}
\hline \multirow{2}{*}{$\frac{\text { Mina/Zona }}{\text { Roca }}$} & \multicolumn{12}{|c|}{ Salmantina } \\
\hline & $\begin{array}{l}\text { Vena LG } \\
\end{array}$ & Vena LG & Vena LG & Vena LG & Vena LG & Vena LG & Vena LG & Vena LG & Vena LG & Vena LG & Vena LG & $\begin{array}{l}\text { Vena LG } \\
\end{array}$ \\
\hline & & 845 & 845 & 845 & 845 & 845 & 845 & 845 & 845 & 845 & 845 & 845 \\
\hline Análisis & 1.1 & 2.1 & 2.2 & 3.1 & 4.1 & 4.2 & $4.2 \mathrm{~b}$ & 5.1 & 5.3 & 5.5 & 5.8 & 5.11 \\
\hline $\mathrm{S}$ (\% peso) & 17,38 & 16,36 & 16,64 & 16,90 & 16,44 & 16,17 & 16,76 & 16,62 & 16,51 & 17,05 & 16,70 & $\begin{array}{l}17,04 \\
\end{array}$ \\
\hline $\mathrm{Fe}$ & 0,42 & 0,00 & 0,00 & 0,19 & 0,00 & 0,02 & 0,02 & 0,00 & 0,11 & 0,00 & 0,00 & 0,00 \\
\hline $\mathrm{Cu}$ & 0,38 & 0,08 & 0,30 & 0,50 & 0,05 & 0,22 & 0,05 & 0,40 & 0,25 & 0,41 & 0,25 & 0,16 \\
\hline As & 0,00 & 0,00 & 0,00 & 0,00 & 0,00 & 0,00 & 0,00 & 0,00 & 0,00 & 0,00 & 0,00 & 0,00 \\
\hline $\mathrm{Zn}$ & 0,15 & 0,12 & 0,00 & 0,00 & 0,02 & 0,18 & 0,00 & 0,00 & 0,10 & 0,12 & 0,00 & 0,00 \\
\hline $\mathrm{Pb}$ & 26,49 & 27,02 & 28,55 & 26,58 & 27,20 & 26,76 & 28,08 & 30,94 & 31,31 & 31,47 & 28,72 & 25,89 \\
\hline $\mathrm{Sb}$ & 0,25 & 0,13 & 0,25 & 0,20 & 0,16 & 0,17 & 0,11 & 0,18 & 0,20 & 0,08 & 0,11 & 0,20 \\
\hline $\mathrm{Ag}$ & 9,47 & 9,62 & 8,91 & 9,27 & 10,57 & 9,32 & 9,06 & 8,27 & 7,66 & 8,00 & 8,31 & 9,80 \\
\hline Se & 0,07 & 0,09 & 0,03 & 0,07 & 0,03 & 0,09 & 0,02 & 0,06 & 0,03 & 0,01 & 0,02 & 0,00 \\
\hline $\mathrm{Bi}$ & 43,58 & 44,85 & 43,46 & 44,76 & 47,82 & 47,96 & 42,42 & 44,31 & 43,72 & 44,17 & 45,65 & 46,20 \\
\hline $\mathrm{Cd}$ & 0,00 & 0,00 & 0,00 & 0,00 & 0,00 & 0,04 & 0,00 & 0,00 & 0,02 & 0,00 & 0,00 & 0,00 \\
\hline $\mathrm{Hg}$ & 0,08 & 0,00 & 0,00 & 0,00 & 0,04 & 0,00 & 0,00 & 0,00 & 0,00 & 0,00 & 0,00 & 0,00 \\
\hline Total & 98,25 & 98,28 & 98,14 & 98,48 & 102,33 & 100,93 & 96,52 & 100,78 & 99,91 & 101,31 & 99,77 & 99,30 \\
\hline S(\% at.) & 55,02 & 53,72 & 54,37 & 54,37 & 52,66 & 52,60 & 55,17 & 53,72 & 53,87 & 54,36 & 54,25 & 54,64 \\
\hline $\mathrm{Fe}$ & 0,76 & 0,00 & 0,00 & 0,35 & 0,00 & 0,04 & 0,04 & 0,00 & 0,20 & 0,00 & 0,00 & 0,00 \\
\hline $\mathrm{Cu}$ & 0,60 & 0,13 & 0,50 & 0,82 & 0,09 & 0,36 & 0,08 & 0,66 & 0,41 & 0,65 & 0,41 & 0,26 \\
\hline As & 0,00 & 0,00 & 0,00 & 0,00 & 0,00 & 0,00 & 0,00 & 0,00 & 0,00 & 0,00 & 0,00 & 0,00 \\
\hline $\mathrm{Zn}$ & 0,24 & 0,20 & 0,00 & 0,00 & 0,03 & 0,29 & 0,00 & 0,00 & 0,17 & 0,18 & 0,00 & 0,00 \\
\hline $\mathrm{Pb}$ & 12,98 & 13,73 & 14,44 & 13,23 & 13,48 & 13,47 & 14,30 & 15,48 & 15,81 & 15,53 & 14,44 & 12,85 \\
\hline $\mathrm{Sb}$ & 0,20 & 0,11 & 0,22 & 0,17 & 0,14 & 0,14 & 0,10 & 0,15 & 0,17 & 0,07 & 0,09 & 0,17 \\
\hline $\mathrm{Ag}$ & 8,91 & 9,39 & 8,65 & 8,87 & 10,06 & 9,01 & 8,86 & 7,95 & 7,43 & 7,58 & 8,02 & 9,34 \\
\hline $\mathrm{Se}$ & 0,08 & 0,12 & 0,04 & 0,09 & 0,04 & 0,12 & 0,03 & 0,08 & 0,04 & 0,01 & 0,03 & 0,00 \\
\hline $\mathrm{Bi}$ & 21,17 & 22,60 & 21,79 & 22,10 & 23,50 & 23,94 & 21,42 & 21,97 & 21,89 & 21,61 & 22,75 & 22,73 \\
\hline $\mathrm{Cd}$ & 0,00 & 0,00 & 0,00 & 0,00 & 0,00 & 0,03 & 0,00 & 0,00 & 0,02 & 0,00 & 0,00 & 0,00 \\
\hline $\mathrm{Hg}$ & 0,04 & 0,00 & 0,00 & 0,00 & 0,00 & 0,00 & 0,00 & 0,00 & 0,00 & 0,00 & 0,00 & 0,00 \\
\hline mol\% & 0,73 & 0,73 & 0,70 & 0,74 & 0,75 & 0,75 & 0,69 & 0,66 & 0,64 & 0,65 & 0,70 & 0,76 \\
\hline & 1,61 & 1,44 & 1,43 & 1,54 & 1,51 & 1,27 & 1,42 & 1,27 & 1,10 & 1,23 & 1,17 & 1,44 \\
\hline $\begin{array}{l}\text { Fórmula } \\
\text { S }\end{array}$ & 8.40 & 797 & 810 & 8.18 & 801 & 739 & 812 & 783 & 7.43 & 776 & 734 & 7,82 \\
\hline $\mathrm{Pb}$ & 2,19 & 2,08 & 2,25 & 2,10 & 2,00 & $\begin{array}{l},, 39 \\
1,84\end{array}$ & $\begin{array}{l}8,12 \\
2,28\end{array}$ & $\begin{array}{r}, 283 \\
2,29\end{array}$ & $\begin{array}{l},, 43 \\
2,23\end{array}$ & $\begin{array}{l}, 1,10 \\
2,31\end{array}$ & $\begin{array}{l}, 354 \\
2,00\end{array}$ & $\begin{array}{l}1,82 \\
1,93\end{array}$ \\
\hline $\mathrm{Ag}$ & 161 & 144 & 143 & 154 & 151 & 127 & 142 & 127 & 110 & 123 & 117 & 144 \\
\hline $\mathrm{Bi}$ & 3,61 & 3,44 & 3,43 & 3,54 & 3,51 & 3,27 & 3,42 & 3,27 & 3,10 & 3,23 & 3,17 & 3,44 \\
\hline$N_{L}$ & 6,4 & 6,0 & 6,1 & 6,2 & 6,0 & 5,4 & 6,1 & 5,8 & 5,4 & 5,8 & 5,3 & 5,8 \\
\hline
\end{tabular}




\begin{tabular}{|c|c|c|c|c|c|c|c|c|c|c|c|c|c|c|c|c|c|c|c|c|}
\hline \multirow{2}{*}{$\begin{array}{l}\text { Mina/Zona } \\
\text { Roca }\end{array}$} & \multicolumn{11}{|c|}{ Salmantina } & \multicolumn{9}{|c|}{ Teso de la Matanza } \\
\hline & Vena LG & Vena LG & Vena LG & Vena LG & Vena LG & Vena LG & Vena LG & Vena LG & Vena LG & Vena LG & Vena LG & Vena LG & Vena LG & Vena LG & Vena LG & Vena LG & Vena LG & Vena LG & Vena LG & Vena LG \\
\hline Muestra & 845 & 845 & 845 & 845 & 845 & 845 & 845 & 845 & 1159 & 1159 & 1159 & 1173 & 1173 & 1173 & 1173 & 1173 & 1173 & 1173 & 1173 & $1174 \mathrm{~B}$ \\
\hline Análisis & 5.14 & 5.15 & 5.17 & 5.18 & 5.22 & 5.23 & 6.1 & 7.1 & 1.12 & 1.15 & 2.16 & 6.3 & 8.1 & 8.3 & 8.4 & 9.1 & 9.2 & 9.9 & 9.10 & \\
\hline $\mathrm{S}(\%$ peso) & 16,29 & 16,55 & 16,06 & 16,02 & 16,77 & 17,04 & 16,27 & 16,48 & 17,24 & 17,91 & 16,42 & 17,29 & 16,83 & 16,52 & $\begin{array}{ll}16,63 \\
\end{array}$ & 16,49 & 16,25 & 16,93 & 16,86 & 17,88 \\
\hline $\mathrm{Fe}$ & 0,00 & 0,09 & 0,12 & 0,00 & 0,00 & 0,01 & 0,09 & 0,02 & 0,32 & 0,83 & 0,76 & 0,79 & 0,56 & 0,48 & 0,31 & 0,03 & 0,00 & 0,08 & 0,08 & \\
\hline $\mathrm{Cu}$ & 0,39 & 0,27 & 0,3 & 0,21 & 16 & 0,40 & 0, & 0,06 & 0,21 & 0,13 & 0,01 & 0,40 & 0,23 & 0,38 & 0,24 & 0,2 & 0,28 & 0,02 & 0,19 & 0, \\
\hline As & 0,00 & 0,00 & 0,00 & 0,00 & 0,0 & 0,00 & 0,00 & 0,00 & 0,00 & 0,00 & 0,00 & 0,00 & 0,00 & 0,00 & 00 & 0,00 & 0,00 & 0,01 & 0,00 & \\
\hline $\mathrm{Zn}$ & 0,07 & 0,02 & 0,00 & 0,06 & 0,20 & 0,00 & 0,01 & 0,00 & 0,21 & 0,25 & 0,00 & 0,00 & 0,00 & 0,20 & 0,00 & 0,00 & 0,00 & 0,00 & 0,10 & 0,03 \\
\hline $\mathrm{Pb}$ & 30,86 & 29,90 & 31,87 & 31,54 & 29,22 & 28,39 & 26,80 & 27,23 & 27,12 & 25,87 & 24,29 & 25,09 & 32,07 & 36,31 & 27,49 & 31,60 & 30,92 & 33,11 & 31,91 & 30,40 \\
\hline & & & & & & & & 0,09 & & 0,47 & & & & & & & & & & \\
\hline & & & & 7,72 & & & 10,61 & & & 9,14 & & 9,48 & & 6,87 & & & & 8,10 & 8,74 & \\
\hline Se & 0,09 & 0,09 & 0,06 & 0,08 & 0,7 & 0,05 & 0,01 & 0,09 & 0,09 & 0,04 & 0,00 & 0,08 & 0,04 & 0,06 & 0,04 & 0,04 & 0,03 & 0,01 & 0,09 & 0,07 \\
\hline $\mathrm{Bi}$ & 41,96 & 45,15 & 42,28 & 44,26 & 43,87 & 45,02 & 47,41 & 46,13 & 47,00 & 45,43 & 47,03 & 47,74 & 42,91 & 40,82 & 46,69 & 43,01 & 43,52 & 41,04 & 42,47 & 43,93 \\
\hline & & 0,13 & & 0,04 & 0,00 & 0,00 & 0,00 & 0,00 & 0,00 & 0,00 & 0,07 & 0,00 & 0,00 & 0,02 & 0,00 & 0,06 & 0,02 & 0,04 & 0,03 & \\
\hline & 0,00 & & & & & & & 0,00 & & 0,00 & & 0,24 & & 0,00 & & & 0,01 & 0,00 & 0,00 & \\
\hline & 97,13 & 100,96 & 97,85 & 100,04 & & & 101,45 & 99,99 & 102,03 & 100,06 & 99,65 & 101,42 & 100,22 & 101,93 & 100,49 & 100,3 & 99,76 & 99,62 & 100,88 & 100,25 \\
\hline$S$ (\% at.) & 54,32 & 53,44 & 53,78 & 53,05 & 54,05 & 54,69 & 52,43 & 53,49 & 53,94 & 55,28 & 52,76 & 53,82 & 54,17 & 53,10 & 53,56 & 53,57 & 53,36 & 54,77 & 53,94 & $56,2 \mathrm{C}$ \\
\hline $\mathrm{Fe}$ & 0,00 & 0,17 & 0,23 & 0,00 & 0,00 & 0,02 & 0,16 & 0,04 & 0,57 & 1,46 & 1,41 & 1,42 & 1,03 & 0,88 & 0,57 & 0,05 & 0,00 & 0,16 & 0,15 & \\
\hline & 66 & & & 0 , & & & & & & & & & & & & & & 0,03 & 30 & \\
\hline & & & & & & & & & & & & & & & & & & & & \\
\hline & & & & & & & & & & & & & & & & & & & & \\
\hline $\mathrm{Pb}$ & 15,93 & 14,94 & 16,52 & 16,16 & 14,57 & 14,10 & 13,37 & 13,68 & 13,13 & 12,36 & 12,08 & 12,09 & 15,97 & 18,06 & 13,70 & 15,89 & 15,71 & 16,58 & 15,80 & 14, \\
\hline & & & & & & & & & & & & 0,25 & & & & & & & 0,35 & \\
\hline & & & & & & & & & & & & & & & & & & 7,79 & 8,31 & \\
\hline Se & 0,12 & 0,12 & 0,0 & 0,11 & & & 0, & & & 0,05 & & 0,10 & & 0,07 & & 0, & 0,03 & 0,01 & 0,11 & \\
\hline $\mathrm{Bi}$ & 21,47 & 22,37 & 21,72 & 22,49 & 21,69 & 22,17 & 23,44 & 22,97 & 22,58 & 21,51 & 23,31 & 22,80 & 21,19 & 20,13 & 23,07 & 21,44 & 21,93 & 20,37 & 20,85 & 21,2 \\
\hline & & & & & & & & & & & & & & & & & & 0,03 & 0,03 & \\
\hline & 0,00 & & & & & & & & & & & & & & & & & & 00 & \\
\hline mol\% & 0,64 & & & & & & & & & & & & & & & & 66 & 0,60 & 0,64 & \\
\hline $\begin{array}{l}x \\
\text { Fórmula }\end{array}$ & 1,15 & 1,24 & 1,06 & 1,09 & 1,48 & 1,33 & 1,64 & 1,44 & 1,26 & 1,29 & 1, & 1,38 & 1,04 & 1,09 & 1,18 & 1,34 & 1,27 & 1,22 & 1,37 & \\
\hline s & 7,63 & & 7,44 & & & & & & 7,39 & 7, & & 7,53 & 7,34 & 7,92 & 7,2 & & 7,85 & 8,04 & 8,25 & \\
\hline & & & & & & & & & & & & & & & & & & & & \\
\hline & & & & & & & & & & & & & & & & & & & & \\
\hline & 3,15 & 3,24 & 3,06 & 3,09 & 3,48 & 3,33 & 3,64 & 3,44 & 3,26 & 3,29 & 3,44 & 3,38 & 3,04 & 3,09 & 3,18 & 3,34 & 3,27 & 3,22 & 3,37 & \\
\hline$N_{L}$ & 5,6 & 5,7 & 5,4 & 5,4 & 6,3 & 5,8 & 6,36 & 5,9 & 5,4 & 5,4 & 5,6 & 5,5 & 5,3 & 5,9 & 5,2 & 6,1 & 5,8 & 6,0 & 6,2 & \\
\hline
\end{tabular}




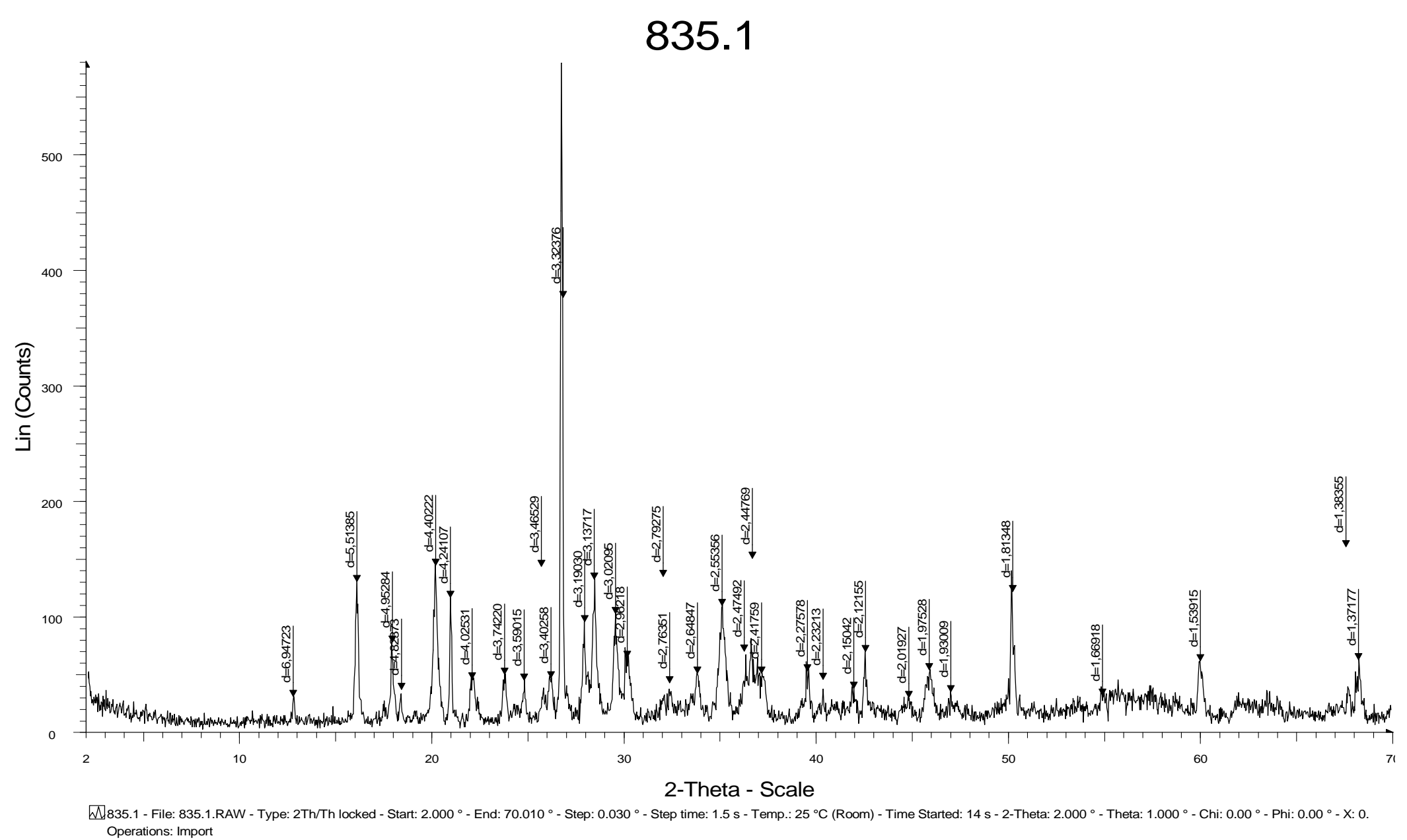




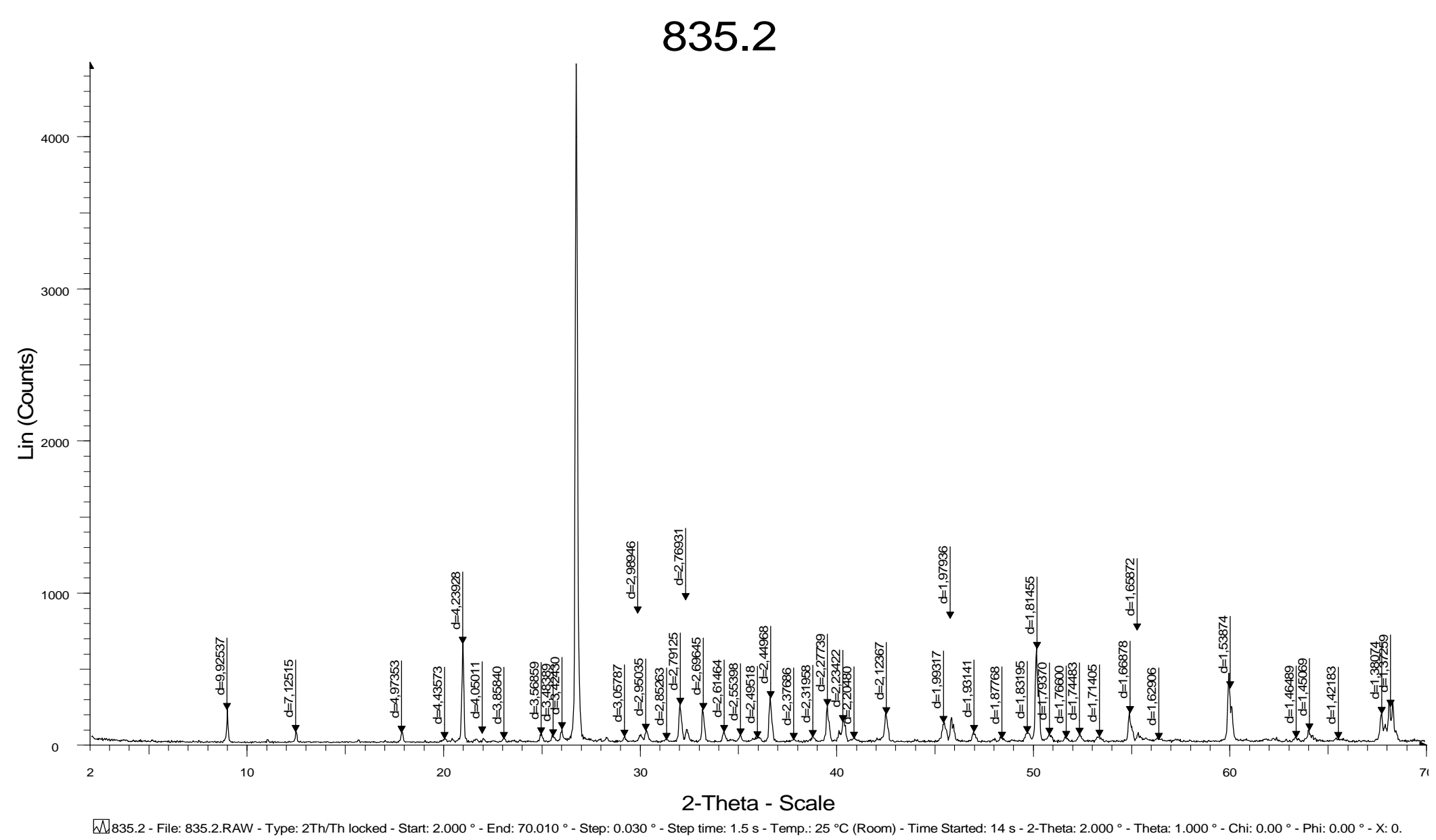

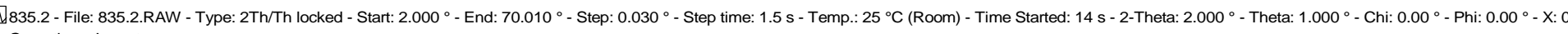




\section{2}

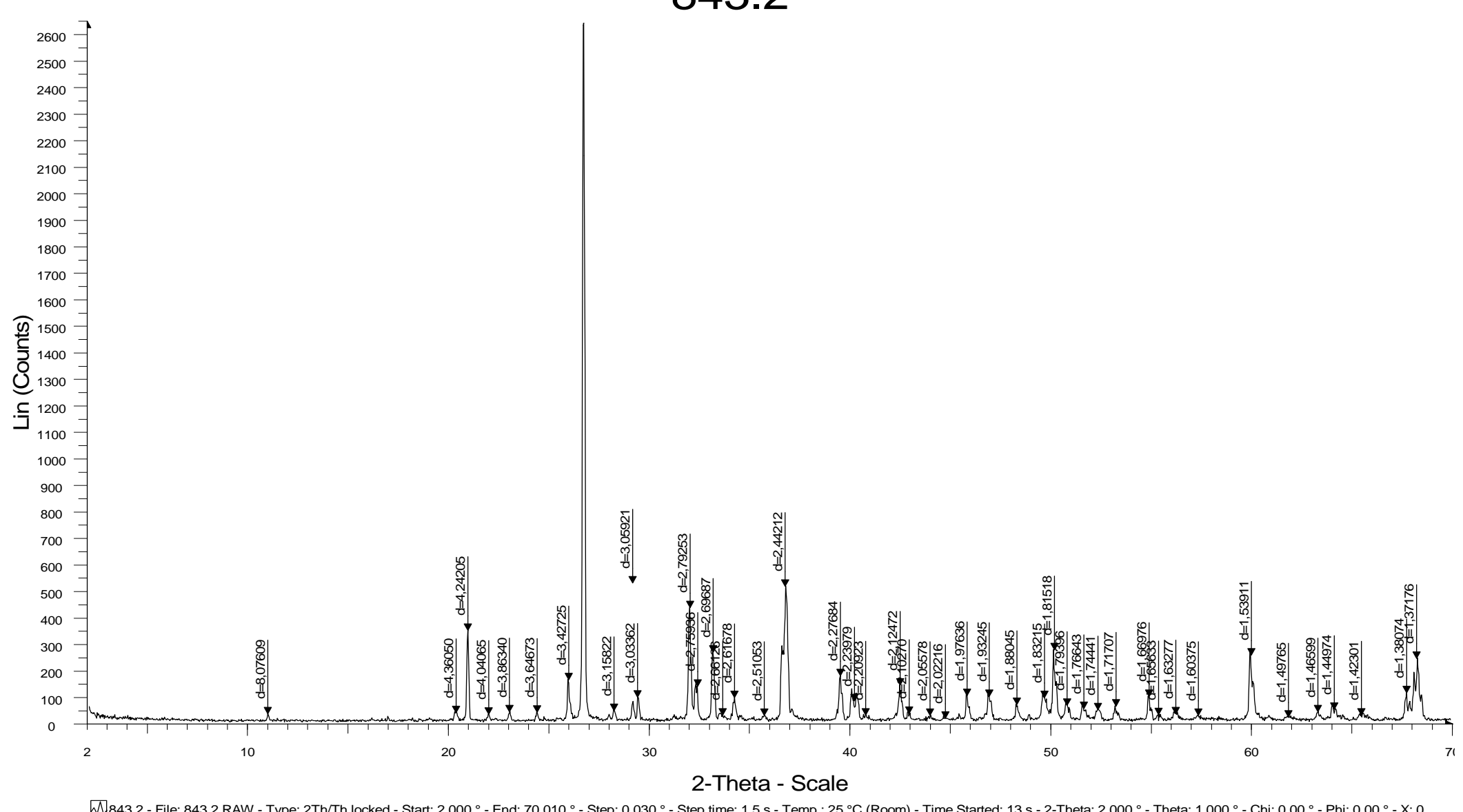

W843.2 - File: 843.2.RAW - Type: 2 Th/Th locked - Start: $2.000^{\circ}$ - End: $70.010^{\circ}$ - Step: $0.030^{\circ}$ - Step time: $1.5 \mathrm{~s}$ - Temp.: $25^{\circ} \mathrm{C}$ (Room) - Time Started: $13 \mathrm{~s}$ - 2-Theta: $2.000^{\circ}-$ Theta: $_{1.000^{\circ}}$ - Chi: $0.00^{\circ}$ - Phi: $0.00^{\circ}$ - X: 0. Operations: Import 


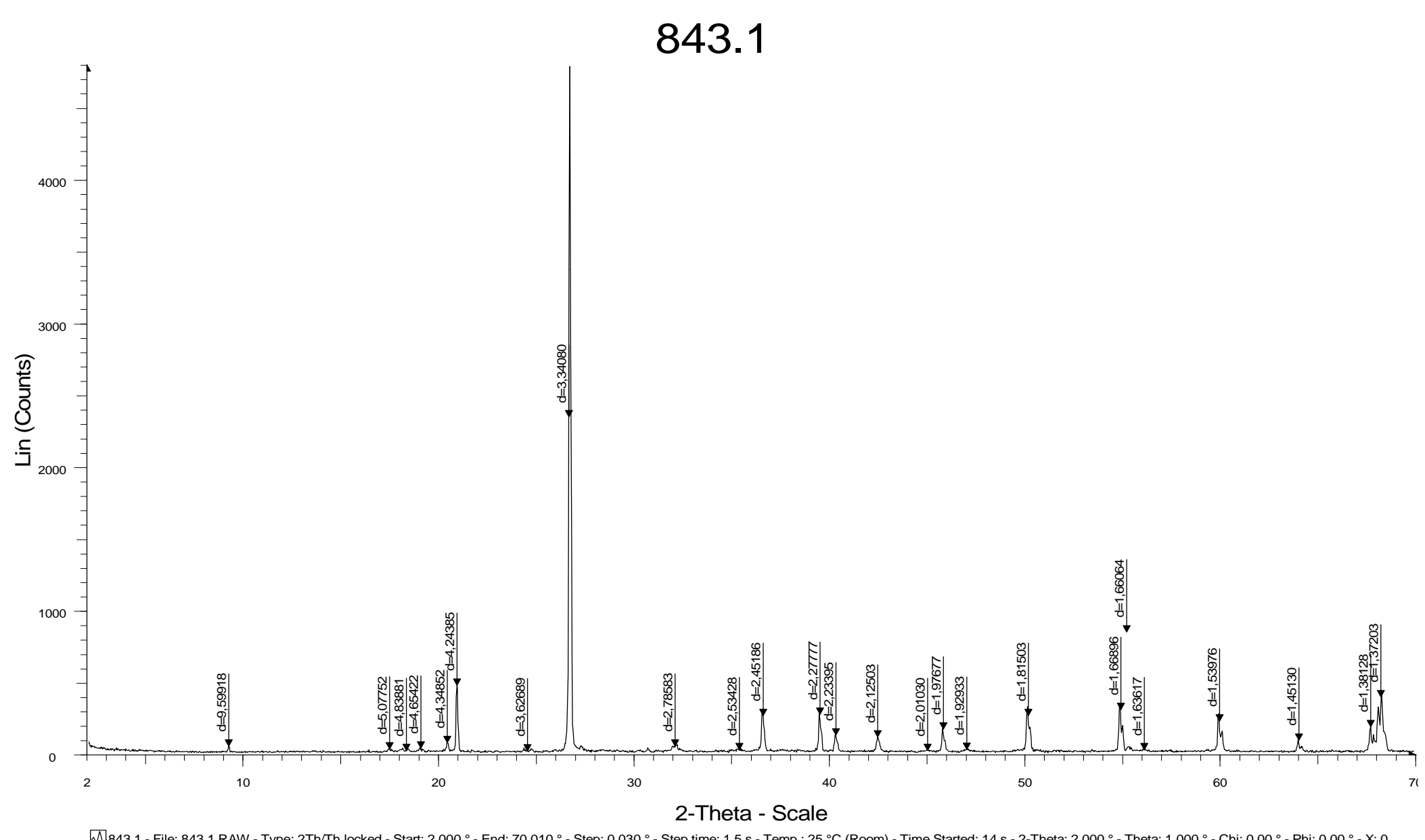

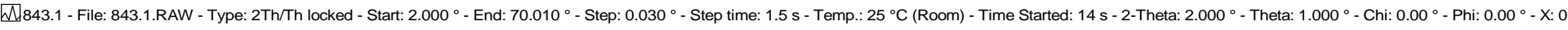
Operations: Import 


\section{2}

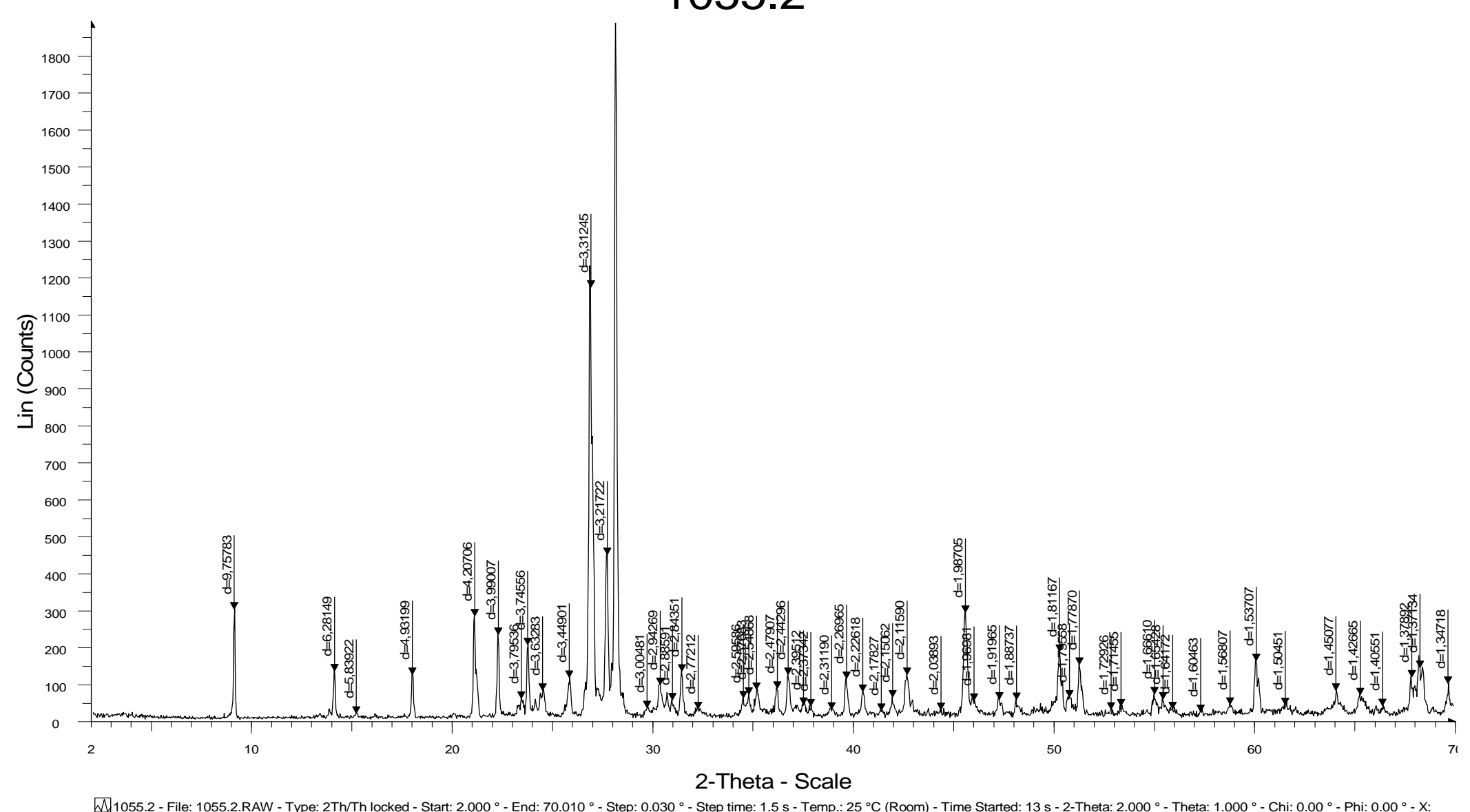

W1055.2 - File: 1055.2.RAW - Type: 2 Th/Th locked - Start: $2.000^{\circ}$ - End: $70.010^{\circ}$ - Step: $0.030^{\circ}$ - Step time: $1.5 \mathrm{~s}$ - Temp.: $25^{\circ} \mathrm{C}$ (Room) - Time Started: $13 \mathrm{~s}$ - 2-Theta: $2.000^{\circ}$ - Theta: $1.000^{\circ}$ - Chi: $0.00^{\circ}$ - Phi: $0.00^{\circ}$ - X: Operations: Import 


\section{0}

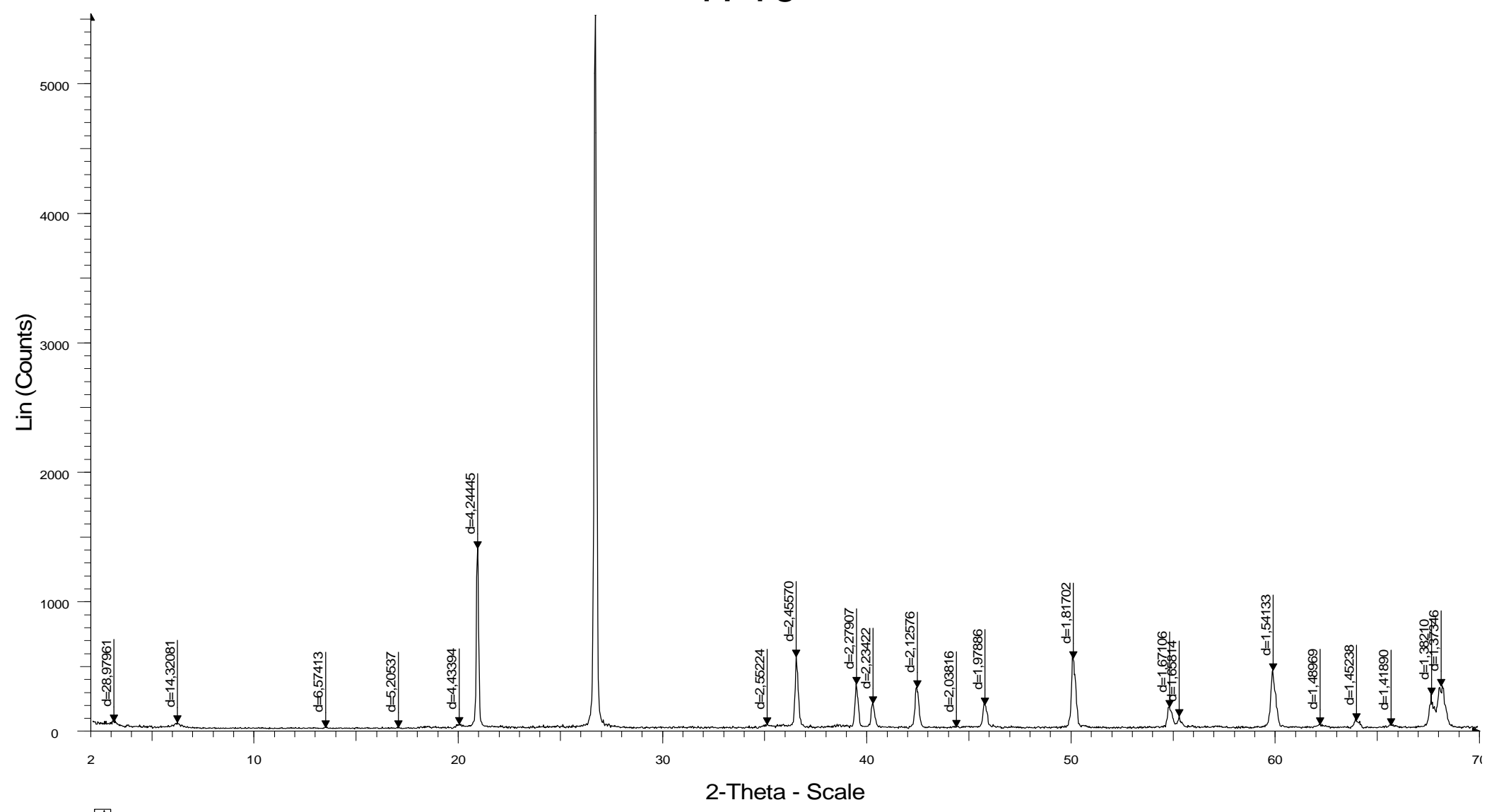

ه1710 - File: 1710. RAW - Type: 2 Th/Th locked - Start: $2.000^{\circ}$ - End: $70.010^{\circ}$ - Step: $0.030^{\circ}$ - Step time: 1.5 s - Temp.: $25^{\circ}$ C (Room) - Time Started: 11 s - 2-Theta: $2.000^{\circ}$ - Theta: $1.000^{\circ}$ - Chi: $0.00^{\circ}$ - Phi: $0.00^{\circ}$ - X: 0.0 Operations: Import 
Anexo V. Análisis químico

Análisis químico de micas

\begin{tabular}{|c|c|c|c|c|c|c|c|c|c|c|c|}
\hline Muestra & 1769 & 1766 & 789 & 795 & 802 & 1787 & 1796 & 1894 & 2298 & 817 & 819 \\
\hline \multicolumn{12}{|c|}{ Elementos mayores (\% en pesc } \\
\hline $\mathrm{Al}_{2} \mathrm{O}_{3}$ & 30,44 & 33,58 & 34,97 & 32,37 & 35,06 & 34,36 & 34,06 & 35,42 & 36,97 & 27,67 & 28,60 \\
\hline $\mathrm{CaO}$ & 0,05 & 0,03 & 0,02 & 0,01 & 0,02 & 0,03 & - & - & 0,03 & - & 0,01 \\
\hline $\mathrm{Fe}_{2} \mathrm{O}_{3}$ & 0,41 & 0,40 & 2,24 & 3,12 & 1,22 & 3,31 & 1,90 & 1,08 & 0,77 & 0,17 & 0,21 \\
\hline $\mathrm{FeO}$ & 2,05 & 1,81 & - & - & - & - & - & - & - & - & - \\
\hline $\mathrm{K}_{2} \mathrm{O}$ & 8,87 & 8,92 & 10,65 & 10,47 & 9,70 & 10,40 & 9,41 & 9,62 & 9,75 & 8,40 & 8,95 \\
\hline $\mathrm{MgO}$ & 0,60 & 0,39 & 0,09 & 0,25 & 0,01 & 0,20 & 0,12 & - & 0,01 & - & - \\
\hline $\mathrm{MnO}$ & 0,05 & 0,06 & 0,11 & 0,09 & 0,19 & 0,08 & 0,05 & 0,19 & 0,16 & 0,58 & 0,52 \\
\hline $\mathrm{Na}_{2} \mathrm{O}$ & 0,02 & 0,08 & 0,66 & 0,68 & 0,83 & 0,55 & 0,67 & 0,79 & 0,92 & 0,47 & 0,41 \\
\hline $\mathrm{P}_{2} \mathrm{O}_{5}$ & 0,07 & 0,08 & 0,06 & 0,05 & 0,10 & 0,15 & 0,11 & 0,08 & 0,16 & 0,07 & 0,03 \\
\hline $\mathrm{SiO}_{2}$ & 50,48 & 47,25 & 46,38 & 46,84 & 46,52 & 46,76 & 47,67 & 46,29 & 46,23 & 50,35 & 48,46 \\
\hline $\mathrm{TiO}_{2}$ & 0,28 & 0,20 & 0,06 & 0,14 & 0,03 & 0,15 & 0,17 & 0,04 & 0,03 & - & - \\
\hline $\mathrm{Li}_{2} \mathrm{O}$ & 0,21 & 0,11 & 0,09 & 0,27 & 0,05 & 0,35 & 0,17 & 0,15 & 0,06 & 3,37 & 3,63 \\
\hline M.V. & 5,76 & 6,27 & 4,40 & 5,65 & 5,47 & 3,55 & 5,50 & 5,34 & 3,40 & 6,00 & 6,32 \\
\hline \multicolumn{12}{|c|}{ Elementos menores (ppm) } \\
\hline $\mathrm{Cr}$ & 6,3 & 3,0 & - & - & - & - & - & - & - & - & - \\
\hline $\mathrm{Cu}$ & - & - & 25,0 & - & 17,0 & - & 15,0 & - & 16,0 & 15,0 & - \\
\hline $\mathrm{Nb}$ & 101,0 & 157,0 & 152,0 & 120,0 & 130,0 & 157,0 & 129,0 & 106,0 & 100,0 & 66,0 & 85,0 \\
\hline $\mathrm{Ni}$ & 115,0 & 110,0 & - & - & - & - & - & - & - & - & - \\
\hline $\mathrm{Pb}$ & 4,8 & 1,1 & 60,0 & 44,0 & 51,0 & 45,0 & - & 46,0 & 42,0 & 21,0 & 67,0 \\
\hline $\mathrm{Ce}$ & 17,7 & 13,4 & - & - & - & - & - & - & - & - & - \\
\hline $\mathrm{Zn}$ & 64,3 & 27,2 & 484,0 & 275,0 & 455,0 & 363,0 & 249,0 & 397,0 & 307,0 & 275,0 & 192,0 \\
\hline W & 55,0 & 49,2 & - & - & - & - & - & - & - & - & - \\
\hline Sn & 175,8 & 276,4 & - & - & - & - & - & - & - & - & - \\
\hline
\end{tabular}



Anexo VI. Microtermometría de inclusiones fluidas

Inclusiones fluidas de tipo |

\begin{tabular}{|c|c|c|c|c|c|c|c|c|c|c|}
\hline Muestra & Min. & IF & $\begin{array}{c}\text { Tamaño } \\
(\mu \mathrm{m})\end{array}$ & $\mathrm{F}$ & $\mathrm{Te}$ & Tmhh & Tmice & Tmcla & Th & $\begin{array}{c}\text { Sal. (\% } \\
\text { eq. } \mathrm{NaCl})\end{array}$ \\
\hline 1174 & Qtz & $4-A-6$ & & & & & & & 257,0 & \\
\hline 1174 & Qtz & $4-B-7$ & 8 & 0,8 & & $-21,6$ & $-3,5$ & & 240,8 & 5,7 \\
\hline 1174 & Qtz & $4-B-8$ & 8 & 0,5 & & & & & 235,0 & \\
\hline 1174 & Qtz & $4-B-9$ & 10 & 0,8 & & $-26,5$ & $-3,0$ & & 242,2 & 5,0 \\
\hline 1174 & Qtz & 4-B-16 & 12 & 0,8 & & $-28,0$ & $-4,5$ & & 332,0 & 7,2 \\
\hline 1174 & Qtz & 4-B-18 & 10 & 0,8 & & $-26,7$ & $-3,6$ & & 275,8 & 5,9 \\
\hline 1174 & Qtz & 7-B-19 & 10 & 0,9 & & $-29,0$ & $-4,0$ & & 232,0 & 6,4 \\
\hline 1174 & Qtz & 7-B-22 & 10 & 0,8 & & $-26,0$ & $-3,0$ & & 273,0 & 5,0 \\
\hline 1174 & Qtz & 7-B-23 & 12 & 0,8 & $-47,0$ & $-28,9$ & $-3,7$ & & 254,0 & 6,0 \\
\hline 1174 & Qtz & 7-B-24 & 10 & 0,8 & & $-25,0$ & $-2,5$ & & 265,0 & 4,2 \\
\hline 1174 & Qtz & $7-C-26$ & 18 & 0,8 & $-49,0$ & $-27,7$ & $-3,7$ & & 220,0 & 6,0 \\
\hline 1174 & Qtz & 7-C-30 & 10 & 0,8 & & & & & 233,0 & \\
\hline 1040 & Qtz & $1-B^{\prime}-5$ & 12 & 0,7 & & $-24,4$ & $-3,2$ & & 309,7 & 5,3 \\
\hline 1040 & Qtz & $1-B^{\prime}-1$ & 7 & 0,7 & $-50,0$ & $-21,0$ & $-6,6$ & & 317,0 & 10,0 \\
\hline 1040 & Qtz & $1-B^{\prime}-2$ & $10 \times 20$ & 0,95 & & & $-2,5$ & & 233,2 & 4,2 \\
\hline 1040 & Qtz & $1-B^{\prime}-3$ & 8 & 0,7 & $-47,0$ & $-21,0$ & $-6,7$ & & 251,0 & 10,1 \\
\hline 1040 & Qtz & $1-B^{\prime}-4$ & 10 & 0,9 & & & & & 300,0 & \\
\hline 1040 & Qtz & $1-B-2$ & 15 & 0,7 & & & & & 284,6 & \\
\hline 1057 & Qtz & 1-B-1 & 12 & 0,7 & & $-23,4$ & $-3,0$ & & 264,1 & 5,0 \\
\hline 1057 & Qtz & 2-B-1 & 10 & 0,7 & & & $-3,2$ & & 281,0 & 5,3 \\
\hline 1057 & Qtz & $2-B-2$ & 10 & 0,5 & & $-23,2$ & $-3,5$ & & 249,0 & 5,7 \\
\hline 1057 & Qtz & $2-B-1^{\prime}$ & 7 & 0,7 & & & & & 326,0 & \\
\hline 1057 & Qtz & 2-B-1" & 8 & 0,7 & & & & & 317,0 & \\
\hline 1057 & Qtz & $2-C-1$ & 10 & 0,5 & & & & & & \\
\hline 1057 & Qtz & $2-C-2$ & 12 & 0,7 & & & $-2,6$ & & 263,0 & 4,3 \\
\hline 1057 & Qtz & $2-C-3$ & 15 & 0,7 & & & & & & \\
\hline 1057 & Qtz & $2-C-4$ & 8 & 0,7 & & & & & & \\
\hline 1057 & Qtz & $2-C-5$ & 10 & 0,5 & & & & & 263,0 & \\
\hline 1057 & Qtz & 2-D-1 & 10 & 0,7 & $-51,0$ & $-22,0$ & $-2,5$ & & 230,0 & 4,2 \\
\hline 1057 & Qtz & $2-D-2$ & 12 & 0,7 & $-51,0$ & $-22,0$ & $-1,4$ & & 242,0 & 2,4 \\
\hline 1057 & Qtz & $2-D-3$ & 8 & 0,9 & & & & & 244,0 & \\
\hline 1057 & Qtz & $2-D-5$ & 10 & 0,7 & & & & & 248,0 & \\
\hline 1057 & Qtz & 3-B-1 & 10 & 0,8 & & & $-4,6$ & & 298,6 & 7,3 \\
\hline 1057 & Qtz & $3-B-4$ & 7 & 0,7 & & $-26,0$ & $-4,9$ & & 291,8 & 7,7 \\
\hline 1057 & Qtz & $3-B-5$ & 10 & 0,75 & & $-21,7$ & $-5,3$ & & 309,2 & 8,3 \\
\hline 1057 & Qtz & $3-A-3$ & 8 & 0,85 & $-47,6$ & $-22,8$ & $-1,4$ & & 237,3 & 2,4 \\
\hline 1057 & Qtz & $3-A-4$ & 10 & 0,8 & & $-23,2$ & $-3,7$ & & 229,7 & 6,0 \\
\hline 1057 & Qtz & $3-A-5$ & 10 & 0,7 & & & $-4,2$ & & 227,6 & 6,7 \\
\hline 1057 & Qtz & $3-A-6$ & 10 & 0,7 & & $-22,8$ & $-4,0$ & & 232,1 & 6,4 \\
\hline 1057 & Qtz & $3-A-7$ & 10 & & & & & & 227,4 & \\
\hline 1057 & Qtz & $3-A-8$ & 8 & & & & & & 230,7 & \\
\hline 1057 & Qtz & $3-A-9$ & 10 & & & & & & 236,4 & \\
\hline 1057 & Qtz & $3-A-10$ & 8 & & & & & & 243,2 & \\
\hline 1059 & Qtz & 2-B-1 & 8 & 0,85 & & $-21,8$ & $-2,4$ & & 279,6 & 4,0 \\
\hline 1059 & Qtz & $2-B-2$ & 7 & 0,9 & & & $-1,9$ & & 233,1 & 3,2 \\
\hline 1059 & Qtz & $2-B-3$ & 7 & 0,7 & & & & & 264,1 & \\
\hline 1059 & Qtz & 2-B-4 & $14 \times 6$ & 0,85 & & $-23,9$ & $-4,2$ & & 288,4 & 6,7 \\
\hline 1059 & Qtz & $2-B-5$ & 8 & 0,85 & & & $-2,4$ & & 219,6 & 4,0 \\
\hline 1059 & Qtz & $2-B-6$ & 6 & 0,7 & & & $-4,5$ & & 224,8 & 7,2 \\
\hline 1059 & Qtz & $2-B-6^{\prime}$ & & & & & & & 254,7 & \\
\hline 1059 & Qtz & $2-B-7$ & 8 & 0,8 & & $-22,7$ & $-4,6$ & & 289,8 & 7,3 \\
\hline 1059 & Qtz & 2-B-9 & 7 & 0,75 & & $-24,2$ & $-3,7$ & & 266,4 & 6,0 \\
\hline 1059 & Qtz & 2-B-11 & 10 & 0,75 & & $-22,7$ & $-2,8$ & & 262,3 & 4,6 \\
\hline 1059 & Qtz & $3-A-2$ & 12 & 0,9 & & $-24,1$ & $-4,0$ & & 268,7 & 6,4 \\
\hline 1059 & Qtz & $3-A-3$ & 9 & 0,8 & $-49,7$ & $-23,3$ & $-3,8$ & & 227,0 & 6,2 \\
\hline 1894 & Cst & $A-4-1$ & 13 & 0,80 & & $-21,0$ & $-2,7$ & & 274,0 & 4,5 \\
\hline 1894 & Cst & $A-4-2$ & 12 & 0,60 & & & $-2,4$ & & 270,0 & 4,0 \\
\hline 1894 & Cst & $A-5-3$ & 18 & 0,80 & & & & & 270,0 & 0,0 \\
\hline 1894 & Cst & A-7-10 & 8 & 0,75 & & & $-3,6$ & & 278,0 & 5,9 \\
\hline 1894 & Cst & A-7-11 & 8 & 0,75 & & & $-2,9$ & & 265,0 & 4,8 \\
\hline 1894 & Qtz & A-3-1 & 6 & 0,70 & $-47,0$ & $-26,0$ & $-4,7$ & & 345,0 & 7,4 \\
\hline 1894 & Qtz & $A-3-2$ & 8 & 0,80 & & $-21,5$ & $-4,2$ & & 258,0 & 6,7 \\
\hline 1894 & Qtz & $A-3-3$ & 8 & 0,60 & & & $-4,0$ & & 282,0 & 6,4 \\
\hline 1894 & Qtz & $A-3-4$ & 8 & 0,70 & & & $-5,0$ & & 304,0 & 7,9 \\
\hline 1894 & Qtz & A-3-5 & 5 & & & & & & 258,0 & \\
\hline
\end{tabular}


Anexo VI. Microtermometría de inclusiones fluidas

Inclusiones fluidas de tipo I (continuación)

\begin{tabular}{|c|c|c|c|c|c|c|c|c|c|}
\hline Muestra & Min. & IF & $\begin{array}{c}\text { Tamaño } \\
(\mu \mathrm{m})\end{array}$ & $\mathrm{F}$ & $\mathrm{Te}$ & Tmhh & Tmice & Th & $\begin{array}{c}\text { Sal. (\% } \\
\text { eq. NaCl }\end{array}$ \\
\hline 1894 & Qtz & A-3-6 & 6 & & & & & 282,0 & \\
\hline 1894 & Qtz & $A-2-7$ & 18 & 0,75 & & $-24,0$ & $-4,1$ & 257,0 & 6,6 \\
\hline 1894 & Qtz & $A-2-8$ & 10 & & & & & 307,0 & \\
\hline 1894 & Qtz & A-2-9 & 12 & & & & & 391,0 & \\
\hline 1894 & Qtz & A-2-12 & 6 & 0,75 & & $-24,2$ & $-8,3$ & 340,0 & 12,0 \\
\hline 1894 & Qtz & A-2-13 & 6 & 0,70 & & & $-5,6$ & 302,0 & 8,7 \\
\hline 1894 & Qtz & A-2-14 & 10 & 0,70 & & & $-5,9$ & 310,0 & 9,1 \\
\hline 1894 & Qtz & A-2-15 & 6 & 0,80 & & $-21,0$ & $-5,5$ & 270,0 & 8,5 \\
\hline 1894 & Qtz & A-2-16 & 6 & 0,75 & & & $-5,6$ & 318,0 & 8,7 \\
\hline 1894 & Qtz & A-2-17 & 8 & 0,65 & & $-22,5$ & $-7,5$ & 314,0 & 11,1 \\
\hline 1894 & Qtz & A-2-18 & 6 & 0,60 & & & & 324,0 & \\
\hline 1894 & Qtz & A-2-19 & 11 & 0,70 & $-49,0$ & $-22,4$ & $-5,8$ & 340,0 & 8,9 \\
\hline
\end{tabular}

Inclusiones fluidas de tipo lla

\begin{tabular}{|c|c|c|c|c|c|c|c|c|c|c|}
\hline Muestra & Min. & IF & $\begin{array}{c}\text { Tamaño } \\
(\mu \mathrm{m})\end{array}$ & $\mathrm{F}$ & $\mathrm{Te}$ & Tmhh & Tmice & Tmcla & Th & $\begin{array}{c}\text { Sal. (\% } \\
\text { eq. } \mathrm{NaCl})\end{array}$ \\
\hline 1174 & Qtz & $4-A-3$ & 17 & 0,9 & & $-25,6$ & $-3,9$ & 8,5 & 215,0 & 3,0 \\
\hline 1174 & Qtz & $4-A-4$ & $12 \times 16$ & 0,9 & & $-28,0$ & $-3,6$ & 8,8 & 215,0 & 2,4 \\
\hline 1174 & Qtz & 4-B-11 & 10 & 0,7 & & $-27,8$ & $-3,8$ & 9,4 & 270,0 & 1,2 \\
\hline 1174 & Qtz & 4-B-12 & $14 \times 10$ & 0,8 & $-51,0$ & $-26,7$ & $-3,6$ & 8,5 & 233,0 & 3,0 \\
\hline 1174 & Qtz & 4-B-13 & 6 & 0,8 & & $-24,0$ & $-3,3$ & 8,0 & 254,0 & 3,9 \\
\hline 1174 & Qtz & 4-B-15 & 14 & 0,8 & $-48,0$ & $-26,8$ & $-4,2$ & 5,3 & 295,5 & 8,6 \\
\hline 1174 & Qtz & 7-B-21 & 10 & 0,8 & & $-27,6$ & $-3,3$ & 8,5 & 256,6 & 3,0 \\
\hline 1174 & Qtz & 7-B-25 & 8 & 0,8 & $-49,0$ & $-27,9$ & $-3,7$ & 7,7 & 264,7 & 4,5 \\
\hline 1174 & Qtz & $7-C-27$ & 16 & 0,85 & $-51,0$ & $-29,0$ & $-3,3$ & 8,4 & 224,7 & 3,2 \\
\hline 1040 & Qtz & $1-B^{\prime}-4$ & 12 & 0,7 & & $-21,0$ & & 8,9 & 310,6 & 2,2 \\
\hline 1040 & Qtz & $1-B^{\prime}-6$ & 12 & 0,7 & & & & 8,8 & 323,0 & 2,4 \\
\hline 1040 & Qtz & $1-B^{\prime}-13$ & 8 & 0,7 & & & & 8,4 & 282,0 & 3,2 \\
\hline 1040 & Qtz & $1-B^{\prime}-14$ & 12 & 0,7 & & $-22,0$ & & 8,6 & 298,0 & 2,8 \\
\hline 1040 & Qtz & 2-B-3 & $8 \times 15$ & 0,7 & $-49,0$ & $-28,0$ & & 9,4 & 274,6 & 1,2 \\
\hline 1040 & Qtz & $2-B-4$ & 10 & 0,7 & & $-21,9$ & & 7,5 & 280,0 & 4,9 \\
\hline 1040 & Qtz & 2-B-1 & 10 & 0,7 & & & & 6,2 & 298,8 & 7,1 \\
\hline 1040 & Qtz & 2-B-2 & 15 & 0,7 & $-48,5$ & $-21,4$ & & 8,2 & 303,2 & 3,6 \\
\hline 1040 & Qtz & 2-B-1' & 8 & 0,7 & & $-23,3$ & & 6,8 & 288,0 & 6,1 \\
\hline 1040 & Qtz & 2-B-2' & 10 & 0,7 & & & & & 282,0 & \\
\hline 1040 & Qtz & $2-B-3$ & 6 & 0,7 & & & & & 280,0 & \\
\hline 1040 & Qtz & $2-C-1$ & 18 & 0,8 & $-49,5$ & $-24,5$ & $-4,8$ & 7,8 & 255,0 & 4,3 \\
\hline 1040 & Qtz & $2-C-4$ & 12 & 0,8 & & $-20,8$ & $-4,3$ & 8,8 & 259,2 & 2,4 \\
\hline 1040 & Qtz & $2-C-8$ & 20 & & $-47,0$ & $-25,5$ & $-4,9$ & 7,7 & 263,2 & 4,5 \\
\hline 1040 & Qtz & $3-A-2$ & & 0,8 & $-47,9$ & $-24,9$ & $-5,2$ & 4,0 & 291,7 & 10,6 \\
\hline 1040 & Qtz & $3-A-4$ & & & & & & & 290,0 & \\
\hline 1040 & Qtz & $3-A-5$ & & & & & & & 286,7 & \\
\hline 1057 & Qtz & $3-B-2$ & 10 & 0,75 & & $-22,0$ & $-4,8$ & 7,4 & 303,4 & 5,1 \\
\hline 1057 & Qtz & $3-B-3$ & 25 & 0,8 & & $-28,0$ & -4 & 5,0 & 304,1 & 9,1 \\
\hline 1057 & Qtz & $3-A-1$ & 16 & 0,6 & & $-22,7$ & $-5,2$ & 9,2 & 283,6 & 1,6 \\
\hline 1057 & Qtz & $3-A-2$ & 12 & 0,7 & $-47,8$ & $-25,3$ & $-3,2$ & 5,1 & 290,5 & 8,9 \\
\hline 1059 & Qtz & $2-B-8$ & 11 & 0,7 & & $-22,8$ & $-3,9$ & 8,0 & 313,2 & 3,9 \\
\hline 1059 & Qtz & 2-B-12 & 8 & 0,75 & & $-24,6$ & -3 & 8,6 & 242,3 & 2,8 \\
\hline 1059 & Qtz & 1-B-1 & 12 & 0,7 & & $-23,7$ & $-4,2$ & 6,8 & 297,3 & 6,1 \\
\hline 1059 & Qtz & 1-B-2 & 12 & 0,7 & & $-23,6$ & $-4,1$ & 7,6 & 297,3 & 4,7 \\
\hline 1059 & Qtz & 1-B-3 & 11 & 0,7 & & $-25,2$ & $-4,2$ & 7,2 & 294,6 & 5,4 \\
\hline 1059 & Qtz & 1-B-4 & & & & & & & 282,7 & \\
\hline 1059 & Qtz & 1-B-5 & & & & & & & 294,7 & \\
\hline 1059 & Qtz & 1-B-6 & & & & & & & 265,0 & \\
\hline 1059 & Qtz & 1-B-7 & & & & & & & 289,9 & \\
\hline 1059 & Qtz & 1-B-8 & & & & & & & 305,8 & \\
\hline
\end{tabular}


Anexo VI. Microtermometría de inclusiones fluidas

Inclusiones fluidas de tipo Ilb

\begin{tabular}{|c|c|c|c|c|c|c|c|c|c|c|}
\hline Muestra & Min. & IF & $\begin{array}{c}\text { Tamaño } \\
\text { ( } \mu \mathrm{m})\end{array}$ & $F$ & $\mathrm{Te}$ & Tmhh & Tmice & Tmcla & Th & $\begin{array}{c}\text { Sal. (\% } \\
\text { eq. } \mathrm{NaCl})\end{array}$ \\
\hline 1174 & Qtz & $4-A-1$ & 14 & 0,8 & $-49,0$ & $-29,0$ & $-4,5$ & 11,5 & 251,5 & 7,2 \\
\hline 1174 & Qtz & $4-A-2$ & 16 & 0,75 & & $-28,5$ & $-4,2$ & 11,5 & 268,8 & 6,7 \\
\hline 1174 & Qtz & $4-A-5$ & 16 & 0,7 & & $-28,0$ & $-3,9$ & 10,5 & 292,4 & 6,3 \\
\hline 1174 & Qtz & 4-B-10 & 12 & 0,8 & & $-26,5$ & $-4,1$ & 11,7 & 284,0 & 6,6 \\
\hline 1174 & Qtz & 4-B-14 & 12 & 0,8 & $-48,0$ & $-28,0$ & $-3,9$ & 11,0 & 294,4 & 6,3 \\
\hline 1174 & Qtz & 4-B-17 & 10 & 0,8 & & $-29,5$ & $-4,0$ & 12,5 & 275,0 & 6,4 \\
\hline 1174 & Qtz & 7-B-20 & 28 & 0,8 & $-49,2$ & $-30,8$ & $-3,3$ & 12,7 & 270,0 & 5,4 \\
\hline 1174 & Qtz & $7-C-28$ & 8 & 0,8 & & $-28,4$ & $-4,5$ & 11,0 & 253,5 & 7,2 \\
\hline 1174 & Qtz & 7-C-29 & 8 & 0,85 & & $-23,0$ & $-4,0$ & 11,0 & 241,5 & 6,4 \\
\hline 1174 & Qtz & 7-C-31 & 8 & 0,6 & & & & & 258,1 & \\
\hline 1040 & Qtz & $1-B^{\prime}-2$ & 10 & 0,5 & & & & 16,5 & 295,0 & 5,0 \\
\hline 1040 & Qtz & 2-B-1 & 10 & 0,7 & & & & 10,4 & 286,8 & \\
\hline 1040 & Qtz & $2-C-2$ & 12 & 0,75 & & $-23,0$ & $-5,0$ & 11,0 & 263,6 & 7,9 \\
\hline 1040 & Qtz & $2-C-3$ & 14 & 0,7 & & $-22,6$ & $-4,2$ & 11,2 & 251,8 & 6,7 \\
\hline 1040 & Qtz & $2-C-5$ & 12 & 0,7 & & $-23,8$ & $-4,5$ & 10,2 & 256,7 & 7,2 \\
\hline 1040 & Qtz & $2-C-6$ & 12 & 0,7 & & $-21,7$ & $-6,2$ & 10,0 & 256,6 & 9,5 \\
\hline 1040 & Qtz & $3-A-1$ & & 0,7 & & $-25,9$ & $-5,4$ & 12,7 & & 8,4 \\
\hline 1059 & Qtz & 2-B-10 & 9 & 0,75 & & & $-2,1$ & 11,5 & 266,0 & 3,5 \\
\hline 1059 & Qtz & $3-A-1$ & 12 & 0,7 & & $-26,1$ & $-4,5$ & 11,5 & 287,0 & 7,2 \\
\hline 1059 & Qtz & $3-A-4$ & 12 & 0,8 & & $-28,7$ & $-4,9$ & 14,3 & 288,6 & 7,7 \\
\hline 1059 & Qtz & 3-A-1' & 8 & 0,7 & & $-28,0$ & $-7,0$ & 11,9 & 339,7 & 10,5 \\
\hline 1059 & Qtz & $3-A-2^{\prime}$ & 12 & 0,8 & & & $-4,0$ & 11,6 & 284,8 & 6,4 \\
\hline 1059 & Qtz & $3-A-3$ & 8 & 0,55 & & $-25,0$ & $-2,0$ & 11,2 & 367,6 & 3,4 \\
\hline 1059 & Qtz & $3-A-4$ & 5 & 0,5 & & & $-1,9$ & 11,2 & 384,7 & 3,2 \\
\hline 1059 & Qtz & $3-A-5$ & & & & & & & 294,7 & \\
\hline 1059 & Qtz & $3-A-6$ & & & & & & & 295,0 & \\
\hline
\end{tabular}


